Danilo Vicensotto Bernardo

\title{
AFINIDADES MORFOLÓGICAS INTRA E EXTRA-CONTINENTAIS DOS PALEOÍNDIOS DE LAGOA SANTA: UMA NOVA ABORDAGEM
}

EXEMPLAR REVISADO

São Paulo

2007 
Danilo Vicensotto Bernardo

\section{AFINIDADES MORFOLÓGICAS INTRA E EXTRA-CONTINENTAIS DOS PALEOÍNDIOS DE LAGOA SANTA: UMA NOVA ABORDAGEM}

Dissertação apresentada ao Departamento de Genética e Biologia Evolutiva do Instituto de Biociências da Universidade de São Paulo, para a obtenção do título de Mestre em Ciências, na Área de Genética e Biologia Evolutiva.

Orientador: Walter Alves Neves 
Ficha Catalográfica

Bernardo, Danilo Vicensotto

Afinidades morfológicas intra e extra-continentais dos Paleoíndios de Lagoa Santa: uma nova abordagem.

333 páginas

Dissertação (Mestrado) - Instituto de Biociências da Universidade de São Paulo. Departamento de Genética e Biologia Evolutiva.

1. Craniometria

2. Análise Multivariada

3. Paleoamericanos

I. Universidade de São Paulo. Instituto de Biociências.

Departamento de Genética e Biologia Evolutiva.

Comissão Julgadora

Prof. Doutor (a)

Prof. Doutor (a)

Sabine Eggers

Astolfo G. de M. Araujo

Prof. Doutor

Walter Alves Neves 
À memória de meu pai, que se foi no início desta minha história. 


\section{Agradecimentos}

Ao meu orientador, Prof. Dr. Walter Neves, pelo companheirismo, compreensão e, principalmente, por seu exemplo como cientista;

Ao Dr. Tsunehiko Hanihara pelo banco de dados utilizado;

Ao Prof. Dr. Rui Murrieta, pela infindável ajuda nos momentos de maior dúvida e dificuldade acadêmica;

Aos Drs. Mark Hubbe e Maria Mercedes Martinez Okumura, pela iniciação nas análises quantitativas e a inestimável ajuda para a solução de várias dúvidas estatísticas, arqueológicas e craniomorfológicas;

Ao Prof. Dr. Renato Kipnis pelas sempre valiosas opiniões, no campo e no laboratório;

Aos colegas de laboratório, em especial meus amigos Pedro Jeca e Max Ernani, minha amiga Cassiana, Marcos, Helbert, André, Elver, Alex, Papito, Dani, Emil e Vitor;

Aos professores que tive contato durante essa pesquisa;

Ao Sr. Helder R. S. Souza, técnico acadêmico da secretaria de pósgraduação do IBUSP, pela sua gentileza e orientação nos momentos de dúvidas protocolares;

À FAPESP pelo fundamental apoio financeiro através da concessão da bolsa (Processo FAPESP 05/52273-4);

À minha mãe e minha irmã, pelo amor fundamental;

Ao pessoal do time de futsal da Biologia, em especial aos grandes amigos que fiz nesses anos: Jeca, Pedrinho, Vaquero, Gaúcho, Vander, Confusão e Magal;

E à Tatiana, o amor da minha vida, que veio fazer o meu mundo melhor. 


\section{Índice}

LISTA DE FIGURAS............................................................................................ VIII

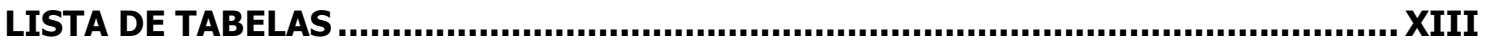

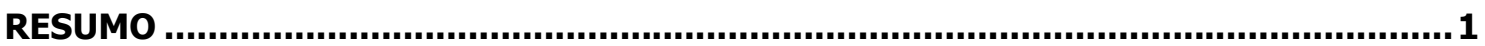

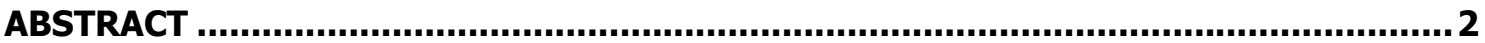

CAPÍTULO 1 - INTRODUÇÃO ............................................................................. 3

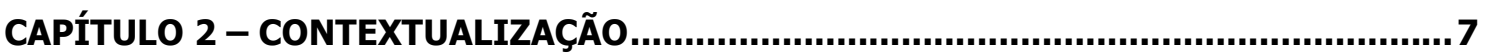

2.1 - As origens do homem americano: contribuições da Genética e da Biologia Molecular...................................................................................................................... 8

2.2 - Os primeiros americanos: Evidências Arqueológicas...................................... 14

2.3 - Os primeiros americanos à luz da Antropologia Biológica................................ 20

2.4 - Modelos de colonização do Novo Mundo …................................................... 30

CAPÍTULO 3 - MATERIAL E MÉTODOS..................................................................41

3.1 - 0 banco de dados.......................................................................................... 41

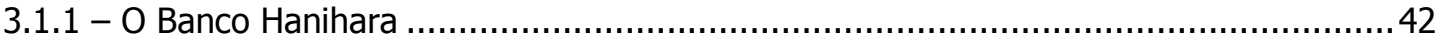

3.1.2 - O Banco de Dados de Walter Neves ................................................................48

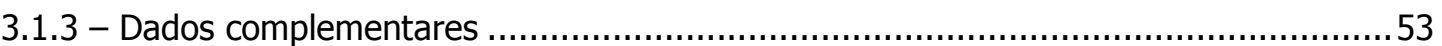

3.2 - A Estatística Multivariada ........................................................................... 53

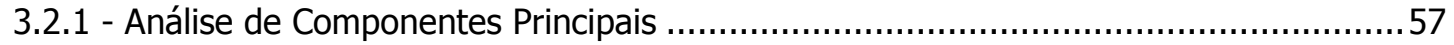

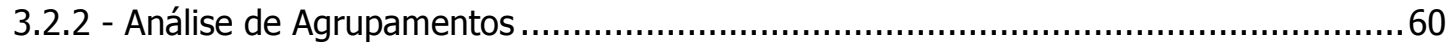

3.2.3 - Distância Euclidiana.....................................................................................62

3.2.4 - Distância Generalizada de Mahalanobis e Escalonamento Multidimensional ...............63

3.3 - Novo e Velho Mundo: Contextualização Progressiva......................................65

3.3.1 - Primeiro nível: Investigação das afinidades biológicas intra-continentais ..................66

3.3.2 - Segundo nível: Investigação das afinidades biológicas extra-continentais ................75

3.3.2.1 - Primeiro nível de inclusão das Afinidades Biológicas Extra-Continentais.................75

3.3.2.2 - Segundo nível de inclusão das Afinidades Biológicas Extra-Continentais .................78

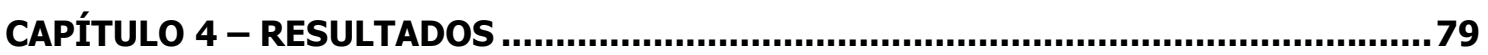

4.1 - Investigação das Afinidades Biológicas Intra-Continentais.............................79

4.1.1 - Parcela Masculina, Tamanho e Forma ............................................................ 79

4.1.2 - Parcela Masculina, Forma Apenas........................................................................... 96

4.1.3 - Parcela Feminina, Tamanho e Forma ............................................................. 116

4.1.4 - Parcela Feminina, Forma Apenas ................................................................ 134 
4.2 - Investigação das Afinidades Biológicas Extra-Continentais.

4.2.1 - Primeiro nível de inclusão das Afinidades Biológicas Extra-Continentais.

4.2.2 - Segundo nível de inclusão das Afinidades Biológicas Extra-Continentais... 167

4.2.2.1 - Parcela Masculina, Tamanho e Forma ..................................................... 167

4.2.2.2 - Parcela Masculina, Apenas Forma ......................................................... 185

4.2.2.3 - Parcela Feminina, Tamanho e Forma ...................................................... 203

4.2.2.4 - Parcela Feminina, forma apenas ....................................................... 219

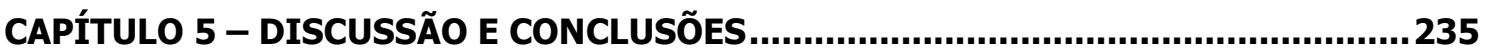

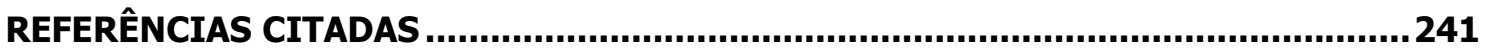

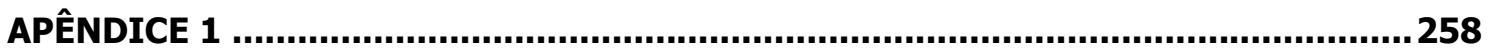

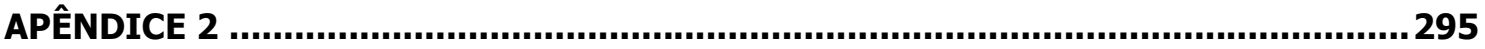




\section{Lista de Figuras}

Figura

Pág.

Figura 3.1 - Distribuição geográfica das séries do banco de dados Howells

Figura 3.2 - Distribuição geográfica das séries do banco de dados Hanihara

Figura 3.3 - Medidas craniométricas do protocolo Howells (1973) utilizadas neste trabalho. Vista lateral esquerda.

Figura 3.4 - Medidas do protocolo Howells (1973) utilizadas neste trabalho. Vista inferior (base do crânio).

Figura 3.5 - Medidas craniométricas do protocolo Howells (1973) utilizadas neste trabalho. Vista frontal.

Figura 3.6 - Localização geográfica da região cárstica de Lagoa Santa, MG, Brasil.

Figura 3.7 - Localização geográfica da Colômbia. A área circundada pela linha tracejada corresponde à região da Sabana de Bogotá, de onde se localizam os sítios que originaram os crânios utilizados neste estudo.

Figura 3.8 - Elipses de Distância de Mahalanobis

Figura 4.1 - Gráfico de decaímento da porcentagem de variância condensada em cada Componente Principal. Parcela masculina, forma e tamanho (76 séries, 23 variáveis craniométricas).

Figura 4.2 - Gráfico bidimensional do morfo-espaço formado pelos CP 1 x CP 2. Parcela masculina, forma e tamanho (77 séries, 23 variáveis craniométricas).

Figura 4.3 - Gráfico bidimensional do morfo-espaço formado pelos CP 1 × CP 3. Parcela masculina, forma e tamanho (77 séries, 23 variáveis craniométricas).

Figura 4.4 - Gráfico bidimensional do morfo-espaço formado pelos CP $2 \times$ CP 3. Parcela masculina, forma e tamanho (77 séries, 23 variáveis craniométricas).

Figura 4.5 - Dendrograma gerado sobre matriz de Distância Euclidiana calculada a partir dos sete primeiros componentes principais - Método de Ward. Parcela masculina, forma e tamanho (76 séries, 23 variáveis craniométricas).

Figura 4.6 - Dendrograma gerado sobre matriz de Distância Euclidiana calculada a partir dos sete primeiros componentes principais - Método de Ligação Simples. Parcela masculina, forma e tamanho (76 séries, 23 variáveis craniométricas).

Figura 4.7 - Dendrograma gerado sobre matriz de Distância Euclidiana calculada a partir dos sete primeiros componentes principais - Método de Ligação Completa. Parcela masculina, forma e tamanho (76 séries, 23 variáveis craniométricas).

Figura 4.8 - Dendrograma gerado sobre matriz de Distância Euclidiana calculada a partir dos sete primeiros componentes principais - Método da Média dos Grupos. Parcela masculina, forma e tamanho (76 séries, 23 variáveis craniométricas).

Figura 4.9 - Dendrograma gerado sobre matriz de Distância de Mahalanobis - Método de Ward. Parcela masculina, forma e tamanho.

Figura 4.10 - Dendrograma gerado sobre matriz de Distância de Mahalanobis - Método de Ligação Simples. Parcela masculina, forma e tamanho.

Figura 4.11 - Dendrograma gerado sobre matriz de Distância de Mahalanobis - Método de Ligação Completa. Parcela masculina, forma e tamanho.

Figura 4.12 - Dendrograma gerado sobre matriz de Distância de Mahalanobis - Método da Média dos Grupos. Parcela masculina, forma e tamanho.

Figura 4.13 - Gráfico bidimensional da relação ortogonal entre as dimensões $1 \times 2$. Parcela masculina, forma e tamanho ( 28 grupos, 23 variáveis craniométricas).

Figura 4.14 - Gráfico bidimensional da relação ortogonal entre as dimensões $1 \times 3$. Parcela masculina, forma e tamanho (28 grupos, 23 variáveis craniométricas).

Figura 4.15 - Gráfico bidimensional da relação ortogonal entre as dimensões $2 \times 3$. Parcela masculina, forma e tamanho (28 grupos, 23 variáveis craniométricas).

Figura 4.16 - Gráfico de decaímento da porcentagem de variância condensada em cada Componente Principal. Parcela masculina, forma apenas (76 séries, 23 variáveis craniométricas).

Figura 4.17 - Gráfico bidimensional do morfo-espaço formado pelos CP 1 x CP 2. Parcela masculina, forma apenas ( 77 séries, 23 variáveis craniométricas).

Figura 4.18 - Gráfico bidimensional do morfo-espaço formado pelos CP 1 × CP 3. Parcela masculina, forma apenas ( 77 séries, 23 variáveis craniométricas).

Figura 4.19 - Gráfico bidimensional do morfo-espaço formado pelos CP 1 × CP 3. Parcela masculina, forma apenas ( 77 séries, 23 variáveis craniométricas).

Figura 4.20 - Dendrograma gerado sobre matriz de Distância Euclidiana calculada a partir dos seis primeiros componentes principais - Método de Ward. Parcela masculina, forma apenas (76 séries, 23 variáveis craniométricas).

Figura 4.21 - Dendrograma gerado sobre matriz de Distância Euclidiana calculada a partir dos seis primeiros componentes principais - Método da Ligação Simples. Parcela masculina, forma apenas (76 séries, 23 variáveis craniométricas).

Figura 4.22 - Dendrograma gerado sobre matriz de Distância Euclidiana calculada a partir dos seis primeiros componentes principais - Método da Ligação Completa. Parcela masculina, forma apenas (76 séries, 23 variáveis craniométricas).

Figura 4.23 - Dendrograma gerado sobre matriz de Distância Euclidiana calculada a partir dos seis primeiros componentes principais - Método da Média dos Grupos. Parcela masculina, forma apenas (76 séries, 23 variáveis craniométricas). 
Figura 4.24 - Dendrograma gerado sobre matriz de Distância de Mahalanobis - Método de Ward. Parcela masculina, forma apenas.

Figura 4.25 - Dendrograma gerado sobre matriz de Distância de Mahalanobis - Método de Ligação Simples. Parcela masculina, forma apenas.

Figura 4.26 - Dendrograma gerado sobre matriz de Distância de Mahalanobis - Método de Ligação Completa. Parcela masculina, forma apenas.

Figura 4.27 - Dendrograma gerado sobre matriz de Distância de Mahalanobis - Método da Média dos Grupos. Parcela masculina, forma apenas.

Figura 4.28 - Gráfico bidimensional da relação ortogonal entre as dimensões $1 \times 2$. Parcela masculina, forma apenas (28 grupos, 23 variáveis craniométricas).

Figura 4.29 - Gráfico bidimensional da relação ortogonal entre as dimensões 1 x 3. Parcela masculina, forma apenas (28 grupos, 23 variáveis craniométricas).

Figura 4.30 - Gráfico bidimensional da relação ortogonal entre as dimensões 2 × 3. Parcela masculina, forma apenas (28 grupos, 23 variáveis craniométricas).

Figura 4.31 - Gráfico de decaímento da porcentagem de variância condensada em cada Componente Principal. Parcela feminina, forma e tamanho (69 séries, 23 variáveis craniométricas).

Figura 4.32 - Gráfico bidimensional do morfo-espaço formado pelos CP 1 × CP 2. Parcela feminina, forma e tamanho (69 séries, 23 variáveis craniométricas).

Figura 4.33 - Gráfico bidimensional do morfo-espaço formado pelos CP 1 x CP 3. Parcela feminina, forma e tamanho (69 séries, 23 variáveis craniométricas).

Figura 4.34 - Gráfico bidimensional do morfo-espaço formado pelos CP 2 × CP 3. Parcela feminina, forma e tamanho (69 séries, 23 variáveis craniométricas).

Figura 4.35 - Dendrograma gerado sobre matriz de Distância Euclidiana calculada a partir dos seis primeiros componentes principais - Método de Ward. Parcela feminina, forma e tamanho (69 séries, 23 variáveis craniométricas).

Figura 4.36 - Dendrograma gerado sobre matriz de Distância Euclidiana calculada a partir dos seis primeiros componentes principais - Método de Ligação Simples. Parcela feminina, forma e tamanho (69 séries, 23 variáveis craniométricas).

Figura 4.37 - Dendrograma gerado sobre matriz de Distância Euclidiana calculada a partir dos seis primeiros componentes principais - Método de Ligação Completa. Parcela feminina, forma e tamanho (69 séries, 23 variáveis craniométricas).

Figura 4.38 - Dendrograma gerado sobre matriz de Distância Euclidiana calculada a partir dos seis primeiros componentes principais - Método da Média dos Grupos. Parcela feminina, forma e tamanho (69 séries, 23 variáveis craniométricas).

Figura 4.39 - Dendrograma gerado sobre matriz de Distâncias de Mahalanobis - Método de Ward. Parcela feminina, forma e tamanho.

Figura 4.40 - Dendrograma gerado sobre matriz de Distâncias de Mahalanobis - Método de Ligação Simples. Parcela feminina, forma e tamanho.

Figura 4.41 - Dendrograma gerado sobre matriz de Distâncias de Mahalanobis - Método de Ligação Completa. Parcela feminina, forma e tamanho.

Figura 4.42 - Dendrograma gerado sobre matriz de Distâncias de Mahalanobis - Método da Média dos Grupos. Parcela feminina, forma e tamanho.

Figura 4.43 - Gráfico bidimensional da relação ortogonal entre as dimensões 1 × 2. Parcela feminina, forma e tamanho (22 grupos, 23 variáveis craniométricas).

Figura 4.44 - Gráfico bidimensional da relação ortogonal entre as dimensões $1 \times 3$. Parcela feminina, forma e tamanho (22 grupos, 23 variáveis craniométricas).

Figura 4.45 - Gráfico bidimensional da relação ortogonal entre as dimensões $2 \times 3$. Parcela feminina, forma e tamanho (22 grupos, 23 variáveis craniométricas).

Figura 4.46 - Gráfico de decaímento da porcentagem de variância condensada em cada Componente Principal. Parcela feminina, forma apenas ( 76 séries, 23 variáveis craniométricas).

Figura 4.47 - Gráfico bidimensional do morfo-espaço formado pelos CP 1 x CP 2. Parcela feminina, forma apenas ( 69 séries, 23 variáveis craniométricas).

Figura 4.48 - Gráfico bidimensional do morfo-espaço formado pelos CP 1 × CP 3. Parcela feminina, forma apenas ( 69 séries, 23 variáveis craniométricas).

Figura 4.49 - Gráfico bidimensional do morfo-espaço formado pelos CP 2 × CP 3. Parcela feminina, forma apenas (69 séries, 23 variáveis craniométricas).

Figura 4.50 - Dendrograma gerado sobre matriz de Distâncias Euclidianas calculadas a partir dos seis primeiros componentes principais - Método de Ward. Parcela feminina, apenas forma (69 séries, 23 variáveis craniométricas).

Figura 4.51 - Dendrograma gerado sobre matriz de Distâncias Euclidianas calculadas a partir dos seis primeiros componentes principais - Método de Ligação Simples. Parcela feminina, apenas forma (69 séries, 23 variáveis craniométricas).

Figura 4.52 - Dendrograma gerado sobre matriz de Distâncias Euclidianas calculadas a partir dos seis primeiros componentes principais - Método de Ligação Completa. Parcela feminina, apenas forma (69 séries, 23 variáveis craniométricas).

Figura 4.53 - Dendrograma gerado sobre matriz de Distâncias Euclidianas calculadas a partir dos seis primeiros componentes principais - Método da Média dos Grupos. Parcela feminina, apenas forma (69 séries, 23 variáveis craniométricas).

Figura 4.54 - Dendrograma gerado sobre matriz de Distâncias de Mahalanobis - Método de Ward. Parcela feminina, apenas forma.

Figura 4.55 - Dendrograma gerado sobre matriz de Distâncias de Mahalanobis - Método de Ligação Simples. 
Parcela feminina, apenas forma.

Figura 4.56 - Dendrograma gerado sobre matriz de Distância de Mahalanobis - Método de Ligação Completa. Parcela feminina, apenas forma.

Figura 4.57 - Dendrograma gerado sobre matriz de Distância de Mahalanobis - Método da Média dos Grupos. Parcela feminina, apenas forma.

Figura 4.58 - Gráfico bidimensional da relação ortogonal entre as dimensões $1 \times 2$. Parcela feminina, apenas forma (22 grupos, 23 variáveis craniométricas).

Figura 4.59 - Gráfico bidimensional da relação ortogonal entre as dimensões $1 \times 3$. Parcela feminina, apenas forma (22 grupos, 23 variáveis craniométricas).

Figura 4.60 - Gráfico bidimensional da relação ortogonal entre as dimensões $2 \times 3$. Parcela feminina, apenas forma (22 grupos, 23 variáveis craniométricas).

Figura 4.61 - Gráfico bidimensional do morfo-espaço formado pelos CP $1 \times$ CP 2. Parcela masculina, tamanho e forma (análise extra-continental - conjunto Oceania).

Figura 4.62 - Gráfico bidimensional do morfo-espaço formado pelos CP 1 × CP 2. Parcela masculina, forma apenas (análise extra-continental - conjunto Oceania).

Figura 4.63 - Gráfico bidimensional do morfo-espaço formado pelos CP 1 x CP 2. Parcela feminina, tamanho e forma (análise extra-continental - conjunto Oceania).

Figura 4.64 - Gráfico bidimensional do morfo-espaço formado pelos CP 1 x CP 2. Parcela feminina, apenas forma (análise extra-continental - conjunto Oceania).

Figura 4.65 - Gráfico bidimensional do morfo-espaço formado pelos CP 1 x CP 2. Parcela masculina, tamanho e forma (análise extra-continental - conjunto Leste Asiático).

Figura 4.66 - Gráfico bidimensional do morfo-espaço formado pelos CP 1 x CP 2. Parcela masculina, apenas forma (análise extra-continental - conjunto Leste Asiático).

Figura 4.67 - Gráfico bidimensional do morfo-espaço formado pelos CP 1 x CP 2. Parcela feminina, tamanho e forma (análise extra-continental - conjunto Leste Asiático).

Figura 4.68 - Gráfico bidimensional do morfo-espaço formado pelos CP 1 x CP 2. Parcela feminina, apenas forma (análise extra-continental - conjunto Leste Asiático).

Figura 4.69 - Gráfico bidimensional do morfo-espaço formado pelos CP 1 × CP 2. Parcela masculina, tamanho e forma (análise extra-continental - conjunto Sudoeste Asiático).

Figura 4.70 - Gráfico bidimensional do morfo-espaço formado pelos CP 1 x CP 2. Parcela masculina, apenas forma (análise extra-continental - conjunto Sudoeste Asiático).

Figura 4.71 - Gráfico bidimensional do morfo-espaço formado pelos CP 1 x CP 2. Parcela feminina, forma e tamanho (análise extra-continental - conjunto Sudoeste Asiático).

Figura 4.72 - Gráfico bidimensional do morfo-espaço formado pelos CP 1 x CP 2. Parcela feminina, apenas forma (análise extra-continental - conjunto Sudoeste Asiático).

Figura 4.73 - Gráfico bidimensional do morfo-espaço formado pelos CP $1 \times$ CP 2. Parcela masculina, tamanho e forma (análise extra-continental - conjunto Africano).

Figura 4.74 - Gráfico bidimensional do morfo-espaço formado pelos CP 1 x CP 2. Parcela masculina, apenas forma (análise extra-continental - conjunto Africano).

Figura 4.75 - Gráfico bidimensional do morfo-espaço formado pelos CP 1 × CP 2. Parcela feminina, tamanho e forma (análise extra-continental - conjunto Africano).

Figura 4.76 - Gráfico bidimensional do morfo-espaço formado pelos CP 1 x CP 2. Parcela feminina, apenas forma (análise extra-continental - conjunto Africano).

Figura 4.77 - Gráfico bidimensional do morfo-espaço formado pelos CP 1 x CP 2. Parcela masculina, tamanho e forma (análise extra-continental - conjunto Europa).

Figura 4.78 - Gráfico bidimensional do morfo-espaço formado pelos CP 1 x CP 2. Parcela masculina, apenas forma (análise extra-continental - conjunto Europa).

Figura 4.79 - Gráfico bidimensional do morfo-espaço formado pelos CP 1 x CP 2. Parcela feminina, tamanho e forma (análise extra-continental - conjunto Europa).

Figura 4.80 - Gráfico bidimensional do morfo-espaço formado pelos CP $1 \times$ CP 2. Parcela feminina, apenas forma (análise extra-continental - conjunto Europa).

Figura 4.81 - Gráfico de decaímento da porcentagem de variância condensada em cada Componente Principal. Parcela masculina, forma e tamanho (14 séries, 23 variáveis craniométricas).

Figura 4.82 - Gráfico bidimensional do morfo-espaço formado pelos CP $1 \times$ CP 2. Parcela masculina, forma e tamanho (14 séries, 23 variáveis craniométricas).

Figura 4.83 - Gráfico bidimensional do morfo-espaço formado pelos CP 1 × CP 3. Parcela masculina, forma e tamanho (14 séries, 23 variáveis craniométricas).

Figura 4.84 - Gráfico bidimensional do morfo-espaço formado pelos CP $2 \times$ CP 3. Parcela masculina, forma e tamanho (14 séries, 23 variáveis craniométricas).

Figura 4.85 - Dendrograma gerado sobre matriz de Distância Euclidiana calculada a partir dos quatro primeiros Componentes Principais - Método de Ward. Parcela masculina, forma e tamanho (14 séries, 23 variáveis craniométricas).

Figura 4.86 - Dendrograma gerado sobre matriz de Distância Euclidiana calculada a partir dos quatro primeiros Componentes Principais - Método de Ligação Simples. Parcela masculina, forma e tamanho (14 séries, 23 variáveis craniométricas).

Figura 4.87 - Dendrograma gerado sobre matriz de Distância Euclidiana calculada a partir dos quatro primeiros Componentes Principais - Método de Ligação Completa. Parcela masculina, forma e tamanho (14 séries, 23174 variáveis craniométricas).

Figura 4.88 - Dendrograma gerado sobre matriz de Distância Euclidiana calculada a partir dos quatro primeiros Componentes Principais - Método da Média dos Grupos. Parcela masculina, forma e tamanho (14 séries, 23175 variáveis craniométricas). 
Figura 4.89 - Dendrograma gerado sobre matriz de Distância de Mahalanobis - Método de Ward. Parcela masculina, forma e tamanho (4904 indivíduos, 23 variáveis craniométricas).

Figura 4.90 - Dendrograma gerado sobre matriz de Distância de Mahalanobis - Método de Ligação Simples. Parcela masculina, forma e tamanho (4904 indivíduos, 23 variáveis craniométricas).

Figura 4.91 - Dendrograma gerado sobre matriz de Distância de Mahalanobis - Método de Ligação Completa. Parcela masculina, forma e tamanho (4904 indivíduos, 23 variáveis craniométricas).

Figura 4.92 - Dendrograma gerado sobre matriz de Distância de Mahalanobis - Método da Média dos Grupos. Parcela masculina, forma e tamanho (4904 indivíduos, 23 variáveis craniométricas).

Figura 4.93 - Gráfico bidimensional da relação ortogonal entre as dimensões $1 \times 2$. Parcela masculina, forma e tamanho (4904 indivíduos, 23 variáveis craniométricas).

Figura 4.94 - Gráfico bidimensional da relação ortogonal entre as dimensões 1 x 3. Parcela masculina, forma e tamanho (4904 indivíduos, 23 variáveis craniométricas).

Figura 4.95 - Gráfico bidimensional da relação ortogonal entre as dimensões 2 × 3. Parcela masculina, forma e tamanho (4904 indivíduos, 23 variáveis craniométricas).

Figura 4.96 - Gráfico de decaímento da porcentagem de variância condensada em cada Componente Principal. Parcela masculina, apenas forma (14 séries, 23 variáveis craniométricas).

Figura 4.97 - Gráfico bidimensional do morfo-espaço formado pelos CP $1 \times$ CP 2. Parcela masculina, apenas forma (14 séries, 23 variáveis craniométricas).

Figura 4.98 - Gráfico bidimensional do morfo-espaço formado pelos CP 1 x CP 3. Parcela masculina, apenas forma (14 séries, 23 variáveis craniométricas).

Figura 4.99 - Gráfico bidimensional do morfo-espaço formado pelos CP 2 × CP 3. Parcela masculina, apenas forma (14 séries, 23 variáveis craniométricas).

Figura 4.100 - Dendrograma gerado sobre matriz de Distância Euclidiana calculada a partir dos quatro primeiros Componentes Principais - Método de Ward. Parcela masculina, apenas forma (14 séries, 23 variáveis craniométricas).

Figura 4.101 - Dendrograma gerado sobre matriz de Distância Euclidiana calculada a partir dos quatro primeiros Componentes Principais - Método de Ligação Simples. Parcela masculina, apenas forma (14 séries, 23 variáveis craniométricas).

Figura 4.102 - Dendrograma gerado sobre matriz de Distância Euclidiana calculada a partir dos quatro primeiros Componentes Principais - Método de Ligação Completa. Parcela masculina, apenas forma (14 séries, 23 variáveis craniométricas).

Figura 4.103 - Dendrograma gerado sobre matriz de Distância Euclidiana calculada a partir dos quatro primeiros Componentes Principais - Método da Média dos Grupos. Parcela masculina, apenas forma (14 séries, 23 variáveis craniométricas).

Figura 4.104 - Dendrograma gerado sobre matriz de Distância de Mahalanobis - Método de Ward. Parcela masculina, apenas forma (4904 indivíduos, 23 variáveis craniométricas).

Figura 4.105 - Dendrograma gerado sobre matriz de Distância de Mahalanobis - Método de Ligação Simples. Parcela masculina, forma apenas (4904 indivíduos, 23 variáveis craniométricas).

Figura 4.106 - Dendrograma gerado sobre matriz de Distância de Mahalanobis - Método de Ligação Completa. Parcela masculina, apenas forma (4904 indivíduos, 23 variáveis craniométricas).

Figura 4.107 - Dendrograma gerado sobre matriz de Distância de Mahalanobis - Método da Média dos Grupos. Parcela masculina, forma apenas (4904 indivíduos, 23 variáveis craniométricas).

Figura 4.108 - Gráfico bidimensional da relação ortogonal entre as dimensões $1 \times 2$. Parcela masculina, forma apenas (4904 indivíduos, 23 variáveis craniométricas).

Figura 4.109 - Gráfico bidimensional da relação ortogonal entre as dimensões $1 \times 3$. Parcela masculina, forma apenas (4904 indivíduos, 23 variáveis craniométricas).

Figura 4.110 - Gráfico bidimensional da relação ortogonal entre as dimensões $2 \times 3$. Parcela masculina, forma apenas (4904 indivíduos, 23 variáveis craniométricas).

Figura 4.111 - Gráfico de decaímento da porcentagem de variância condensada em cada Componente Principal. Parcela feminina, forma e tamanho (14 séries, 23 variáveis craniométricas).

Figura 4.112 - Gráfico bidimensional do morfo-espaço formado pelos CP 1 × CP 2. Parcela feminina, forma e tamanho (14 séries, 23 variáveis craniométricas).

Figura 4.113 - Gráfico bidimensional do morfo-espaço formado pelos CP 1 x CP 3. Parcela feminina, forma e tamanho (14 séries, 23 variáveis craniométricas).

Figura 4.114 - Gráfico bidimensional do morfo-espaço formado pelos CP $2 \times$ CP 3. Parcela feminina, forma e tamanho (14 séries, 23 variáveis craniométricas).

Figura 4.115 - Dendrograma gerado sobre matriz de Distância Euclidiana calculada a partir dos três primeiros Componentes Principais - Método de Ward. Parcela feminina, forma e tamanho (14 séries, 23 variáveis craniométricas).

Figura 4.116 - Dendrograma gerado sobre matriz de Distância Euclidiana calculada a partir dos três primeiros variáveis craniométricas).

Figura 4.117 - Dendrograma gerado sobre matriz de Distância Euclidiana calculada a partir dos três primeiros Componentes Principais - Método de Ligação Completa. Parcela feminina, forma e tamanho (14 séries, 23 variáveis craniométricas).

Figura 4.118 - Dendrograma gerado sobre matriz de Distância Euclidiana calculada a partir dos três primeiros Componentes Principais - Método da Média dos Grupos. Parcela feminina, forma e tamanho (14 séries, 23 variáveis craniométricas).

Figura 4.119 - Dendrograma gerado sobre matriz de Distância de Mahalanobis - Método de Ward. Parcela feminina, forma e tamanho (1138 indivíduos, 23 variáveis craniométricas).

Figura 4.120 - Dendrograma gerado sobre matriz de Distância de Mahalanobis - Método de Ligação Simples. 
Parcela feminina, forma e tamanho (1138 indivíduos, 23 variáveis craniométricas).

Figura 4.121 - Dendrograma gerado sobre matriz de Distância de Mahalanobis - Método de Ligação Completa. Parcela feminina, forma e tamanho (1138 indivíduos, 23 variáveis craniométricas).

Figura 4.122 - Dendrograma gerado sobre matriz de Distância de Mahalanobis - Método da Média dos Grupos. Parcela feminina, forma e tamanho (1138 indivíduos, 23 variáveis craniométricas).

Figura 4.123 - Gráfico bidimensional da relação ortogonal entre as dimensões $1 \times 2$. Parcela feminina, forma e tamanho (1138 indivíduos, 23 variáveis craniométricas).

Figura 4.124 - Gráfico bidimensional da relação ortogonal entre as dimensões 1 x 3. Parcela feminina, forma e tamanho (1138 indivíduos, 23 variáveis craniométricas).

Figura 4.125 - Gráfico bidimensional da relação ortogonal entre as dimensões 2 × 3. Parcela feminina, forma e tamanho (1138 indivíduos, 23 variáveis craniométricas).

Figura 4.126 - Gráfico de decaímento da porcentagem de variância condensada em cada Componente Principal. Parcela feminina, apenas forma (14 séries, 23 variáveis craniométricas).

Figura 4.127 - Gráfico bidimensional do morfo-espaço formado pelos CP $1 \times$ CP 2. Parcela feminina, forma apenas ( 14 séries, 23 variáveis craniométricas).

Figura 4.128 - Gráfico bidimensional do morfo-espaço formado pelos CP 1 x CP 3. Parcela feminina, apenas forma (14 séries, 23 variáveis craniométricas).

Figura 4.129 - Gráfico bidimensional do morfo-espaço formado pelos CP 2 × CP 3. Parcela feminina, apenas forma e tamanho (14 séries, 23 variáveis craniométricas).

Figura 4.130 - Dendrograma gerado sobre matriz de Distância Euclidiana calculada a partir dos três primeiros Componentes Principais - Método de Ward. Parcela feminina, forma apenas (14 séries, 23 variáveis craniométricas).

Figura 4.131 - Dendrograma gerado sobre matriz de Distância Euclidiana calculada a partir dos três primeiros Componentes Principais - Método de Ligação Simples. Parcela feminina, forma apenas (14 séries, 23 variáveis craniométricas).

Figura 4.132 - Dendrograma gerado sobre matriz de Distância Euclidiana calculada a partir dos três primeiros Componentes Principais - Método de Ligação Completa. Parcela feminina, forma apenas (14 séries, 23 variáveis craniométricas).

Figura 4.133 - Dendrograma gerado sobre matriz de Distância Euclidiana calculada a partir dos três primeiros Componentes Principais - Método da Média dos Grupos. Parcela feminina, forma apenas (14 séries, 23 variáveis craniométricas).

Figura 4.134 - Dendrograma gerado sobre matriz de Distância de Mahalanobis - Método de Ward. Parcela feminina, forma apenas (1138 indivíduos, 23 variáveis craniométricas).

Figura 4.135 - Dendrograma gerado sobre matriz de Distância de Mahalanobis - Método de Ligação Simples. Parcela feminina, forma apenas (1138 indivíduos, 23 variáveis craniométricas).

Figura 4.136 - Dendrograma gerado sobre matriz de Distância de Mahalanobis - Método de Ligação Completa. Parcela feminina, forma apenas (1138 indivíduos, 23 variáveis craniométricas).

Figura 4.137 - Dendrograma gerado sobre matriz de Distância de Mahalanobis - Método da Média dos Grupos. Parcela feminina, forma apenas (1138 indivíduos, 23 variáveis craniométricas).

Figura 4.138 - Gráfico bidimensional da relação ortogonal entre as dimensões $1 \times 2$. Parcela feminina, forma apenas (1138 indivíduos, 23 variáveis craniométricas).

Figura 4.139 - Gráfico bidimensional da relação ortogonal entre as dimensões $1 \times 3$. Parcela feminina, forma apenas (1138 indivíduos, 23 variáveis craniométricas).

Figura 4.140 - Gráfico bidimensional da relação ortogonal entre as dimensões 2 × 3. Parcela feminina, forma apenas (1138 indivíduos, 23 variáveis craniométricas). 


\section{Lista de Tabelas}

Tabela

Tabela 3.1 - Variáveis craniométricas tomadas de acordo com o protocolo estabelecido por Howells (1973, 1989) utilizadas no presente estudo*.

Tabela 3.2 - Exemplo do formato do Banco de Dados organizado por T. Hanihara.

Tabela 3.3 - Identificação dos crânios constituintes da amostra esqueletal paleoíndia de Lagoa Santa.

Tabela 3.4 - Identificação dos crânios constituintes da amostra esqueletal da Sabana de Bogotá utilizada no presente estudo

Tabela 3.5 - Composição das séries esqueletais utilizadas na análise de afinidades intracontinentais (Parcela Masculina).

Tabela 3.6 - Composição das séries esqueletais utilizadas na análise de afinidades intracontinentais (Parcela Feminina).

Tabela 3.7 - Centróides das séries esqueletais utilizadas na análise de afinidades intracontinentais (Parcela Masculina).

Tabela 3.8 - Centróides das séries esqueletais utilizadas na análise de afinidades intracontinentais (Parcela Feminina).

Tabela 3.9 - Composição das séries esqueletais utilizadas nos cálculos de Distâncias de Mahalanobis - Análise intra-continental.

Tabela 3.10 - "Composição das séries esqueletais utilizadas na análise de afinidades extracontinentais, primeiro nível de inclusão.

Tabela 3.11 - "Composição das séries esqueletais utilizadas na análise de afinidades extracontinentais, segundo nível de inclusão.

Tabela 4.1 - Autovalores da matriz de covariância e porcentagens de variância explicada por cada Componente Principal. Parcela masculina, forma e tamanho (76 séries, 23 variáveis craniométricas).

Tabela 4.2 - Fatores de coordenadas de cada série. Parcela masculina, forma e tamanho (76 séries, 2381 variáveis craniométricas).

Tabela 4.3 - Matriz de Distâncias de Mahalanobis. Parcela masculina, forma e tamanho (28 grupos, 23 variáveis craniométricas).

Tabela 4.4 - Configuração final das dimensões calculadas através de escalonamento multidimensional sobre Matriz de Distância baseada em Distâncias de Mahalanobis. Parcela masculina, forma e tamanho (28 grupos, 23 variáveis craniométricas).

Tabela 4.5 - Autovalores da matriz de covariância e porcentagens de variância explicada por cada Componente Principal. Parcela masculina, forma apenas (76 séries, 23 variáveis craniométricas).

Tabela 4.6 - Fatores de coordenadas de cada série. Parcela masculina, forma apenas (76 séries, 23 variáveis craniométricas).

Tabela 4.7 - Matriz de Distâncias de Mahalanobis. Parcela masculina, forma apenas ( 28 grupos, 23 variáveis craniométricas).

Tabela 4.8 - Configuração final das dimensões calculadas através de escalonamento multidimensional sobre Matriz de Distâncias de Mahalanobis. Parcela masculina, forma apenas (28 grupos, 23 variáveis craniométricas).

Tabela 4.9 - Autovalores da matriz de covariância e porcentagens de variância total explicada por cada Componente Principal. Parcela feminina, forma e tamanho (69 séries, 23 variáveis craniométricas).

Tabela 4.10 - Fatores de coordenadas de cada série. Parcela feminina, forma e tamanho (69 séries, 23 variáveis craniométricas).

Tabela 4.11 - Matriz de Distâncias de Mahalanobis. Parcela feminina, forma e tamanho (22 grupos, 23 variáveis craniométricas).

Tabela 4.12 - Configuração final das dimensões calculadas através de escalonamento multidimensional sobre Matriz de Distâncias de Mahalanobis. Parcela feminina, forma e tamanho (22 grupos, 23 variáveis 132 craniométricas).

Tabela 4.13 - Autovalores da matriz de covariância e porcentagens de variância total explicadas por cada Componente Principal. Parcela feminina, forma apenas (69 séries, 23 variáveis craniométricas).

Tabela 4.14 - Fatores de coordenadas de cada série. Parcela feminina, forma apenas (69 séries, 23 variáveis craniométricas).

Tabela 4.15 - Matriz de Distância baseada em Distâncias de Mahalanobis. Parcela feminina, apenas forma (22 grupos, 23 variáveis craniométricas).

Tabela 4.16 - Configuração final das dimensões calculadas através de escalonamento multidimensional sobre Matriz de Distância baseada em Distâncias de Mahalanobis. Parcela feminina, forma e tamanho (22 grupos, 23 variáveis craniométricas).

Tabela 4.17 - Autovalores da matriz de covariância e porcentagens de variância total explicada por cada Componente Principal. Parcela masculina, forma e tamanho (14 séries, 23 variáveis craniométricas).

Tabela 4.18 - Fatores de coordenadas de cada série. Parcela masculina, forma e tamanho (14 séries, 23171 variáveis craniométricas).

Tabela 4.19 - Matriz de Distância Euclidiana calculada sobre os quatro primeiros Componentes Principais. Parcela masculina, forma e tamanho (14 séries, 23 variáveis craniométricas).

Tabela 4.20 - Matriz de Distância de Mahalanobis. Parcela masculina, forma e tamanho (4904 indivíduos, 23 variáveis craniométricas).

Tabela 4.21 - Configuração final das dimensões calculadas através de escalonamento multidimensional sobre Matriz de Distância baseada em Distâncias de Mahalanobis. Parcela masculina, forma e tamanho (4904 
indivíduos, 23 variáveis craniométricas).

Tabela 4.22 - Autovalores da matriz de covariância e porcentagens de variância total explicada por cada Componente Principal. Parcela masculina, apenas forma (14 séries, 23 variáveis craniométricas).

Tabela 4.23 - Fatores de coordenadas de cada série. Parcela masculina, apenas forma (14 séries, 23 variáveis craniométricas).

Tabela 4.24 - Matriz de Distância Euclidiana calculada sobre os quatro primeiros Componentes Principais. Parcela masculina, apenas forma (14 séries, 23 variáveis craniométricas).

Tabela 4.25 - Matriz de Distância de Mahalanobis. Parcela masculina, apenas forma (4904 indivíduos, 23 variáveis craniométricas).

Tabela 4.26 - Configuração final das dimensões calculadas através de escalonamento multidimensional sobre Matriz de Distância baseada em Distâncias de Mahalanobis. Parcela masculina, forma apenas (4904 indivíduos, 23 variáveis craniométricas).

Tabela 4.27 - Autovalores da matriz de covariância e porcentagens de variância total explicada por cada Componente Principal. Parcela feminina, forma e tamanho (14 séries, 23 variáveis craniométricas).

Tabela 4.28 - Fatores de coordenadas de cada série. Parcela feminina, forma e tamanho (14 séries, 23 variáveis craniométricas).

Tabela 4.29 - Matriz de Distância Euclidiana calculada sobre os três primeiros Componentes Principais. Parcela feminina, forma e tamanho (14 séries, 23 variáveis craniométricas).

Tabela 4.30 - Matriz de Distância de Mahalanobis. Parcela feminina, forma e tamanho (1138 indivíduos, 23 variáveis craniométricas).

Tabela 4.31 - Configuração final das dimensões calculadas através de escalonamento multidimensional sobre Matriz de Distância baseada em Distâncias de Mahalanobis. Parcela feminina, forma e tamanho (1138 indivíduos, 217 23 variáveis craniométricas).

Tabela 4.32 - Autovalores da matriz de covariância e porcentagens de variância total explicada por cada Componente Principal. Parcela feminina, forma apenas (14 séries, 23 variáveis craniométricas).

Tabela 4.33 - Fatores de coordenadas de cada série. Parcela feminina, forma apenas (14 séries, 23 variáveis craniométricas).

Tabela 4.34 - Matriz de Distância Euclidiana calculada sobre os três primeiros Componentes Principais. Parcela feminina, forma apenas (14 séries, 23 variáveis craniométricas).

Tabela 4.35 - Matriz de Distância de Mahalanobis. Parcela feminina, forma apenas (1138 indivíduos, 23 variáveis craniométricas).

Tabela 4.36 - Configuração final das dimensões calculadas através de escalonamento multidimensional sobre Matriz de Distância baseada em Distâncias de Mahalanobis. Parcela feminina, forma apenas (1138 indivíduos, 23 variáveis craniométricas). 


\section{Resumo}

Afinidades morfológicas intra e extra-continentais dos Paleoíndios de Lagoa Santa:

uma nova abordagem

O presente trabalho propõe-se a analisar as afinidades biológicas através da comparação estatística multivariada dos dados craniométricos dos Paleoíndios de Lagoa Santa com outras séries esqueletais representativas de diversas regiões do mundo, testando, de forma complementar, as relações biológicas primeiramente observadas por Neves \& Pucciarelli (1989).

De acordo com a proposta inicial de Neves e Pucciarelli (1989), que sugere que a ocupação do Novo Mundo se deu a partir da chegada de dois componentes biológicos à América, os Paleoíndios, representantes da primeira leva de colonizadores, apresentam morfologia craniana generalizada, semelhante à observada entre as populações australo-melanésicas e africanas atuais e diametralmente oposta à morfologia especializada, característica dos nativos americanos recentes, todos descendentes da segunda leva de colonizadores.

Para a execução do trabalho proposto foi utilizado, como base de dados comparativa à série Paleoíndia de Lagoa Santa, uma base de dados alternativa ao banco Howells, classicamente utilizado nas investigações bioantropologicas. A base de dados alternativa, numericamente expressiva e contando com populações originárias de 19 grandes regiões geográficas, foi organizada pelo Prof. Tsunehiko Hanihara, do Departamento de Anatomia da Saga Medical School (Saga, Japão), e cedida ao Laboratório de Estudos Evolutivos Humanos para a execução deste trabalho.

Os resultados gerados através das técnicas estatísticas multivariadas empregadas indicaram que a população Paleoíndia de Lagoa Santa, em escala intracontinental, não se associa com as populações indígenas nativas americanas tardias e atuais e, em escala extra-continental, apresentam, de maneira geral, uma morfologia craniana mais semelhante à apresentada por populações de morfologia craniana generalizada.

Palavras-chave: Craniometria; Análise Multivariada; Paleoamericanos 


\section{Abstract}

Intra and Extra-continental Morphological affinities of the Paleoindians of Lagoa Santa: a new approach

The present work proposes the analysis of the biological affinities, through a multivariate statistics comparison, of the Lagoa Santa Paleoindians' craniometric data and other skeletal series, representatives of other regions in the world, testing, in a complementary way, the biological relationships first observed by Neves \& Pucciarelli (1989).

In accordance with Neves and Pucciarelli initial proposal, which suggests that the New World settlement happened with the arrive of two biological components to the America, the Paleoindians, representatives of the first migration wave, who show the generalized cranial morphology, resembling the one observed among the australomelanesian and african current populations, and completely opposite to the specialized morphology of the current native americans, all descendents from the second migration wave.

For the accomplishment of this work it was used, as comparative data base to the Lagoa Santa's Paleoindians series, an alternative data set from that produced by Howells, commonly utilized in physical anthropological studies. The alternative data base, numerically expressive and counting with populations derived from 19 great geographic regions, was organized by the Professor Tsunehiko Hanihara, from the Anatomy Department of Saga Medical School (Saga, Japan), and granted to the Laboratory of Human Evolution Studies (Laboratório de Estudos Evolutivos Humanos LEEH), for the execution of this project.

The results generated through the employee multivariate statistics technics pointed out that the Paleoindian population from Lagoa Santa, in a intra-continental scale, do not associate with the american indigenous populations, neither from the past nor the present and, from the extra-continental scale, they present, in a general manner, a cranial morphology that resembles more that one presented by the populations with the generalized cranial morphology

Key words: Craniometry; Multivariate Analysis; Paleoamericans 


\section{CAPÍTULO 1 - Introdução}

O surgimento do homem no Novo Mundo ocupa, há muito tempo, posição de destaque nas discussões arqueológicas e bioantropológicas entre as principais escolas mundiais. Os debates intensificaram-se a partir da descoberta das mais antigas manifestações culturais do novo continente, as pontas Clovis, no final dos anos 1920 (Figgins, 1927; Fagan, 1987).

Na década de 1950, com o advento das técnicas de datação, o estrato arqueológico dos níveis de cultura Clovis foi datado em 11.400 anos A.P. e sua indústria lítica passou a ser encontrada em sítios de costa a costa da América do Norte, em latitudes desde o sul do Canadá até o centro da América Central (Bradley \& Stanford, 2004).

Sobre esse pano de fundo, pesquisas antropofísicas clássicas, como a idéia do Holótipo Americano, proposta por Hrdlička (1932), associadas às primeiras evidências moleculares das origens genéticas dos primeiros colonizadores americanos reforçaram a idéia de homogeneidade, origem geográfica comum e surgimento de diversidade apenas pós-migratória entre os nativos americanos (Armelagos et al., 1982; Cann, 1994).

Nesse contexto, estagnado durante décadas por dúvidas e deficiências teóricas e metodológicas, foi proposto, por Greenberg, Zegura e Turner II (Greenberg et al., 1986), o modelo de povoamento da América, denominado como Modelo das Três Migrações, de maior sucesso e aceitação tanto nos círculos acadêmico e quanto nos não-especializados.

Com base em estudos genéticos, lingüísticos e odontomorfológicos, os autores argumentaram que todos os nativos americanos provêem de uma única população oriunda no nordeste asiático, migrando para a América em três ondas populacionais (Greenberg et al., 1986).

No entanto, nas últimas décadas, as conclusões sobre a investigação das origens do homem americano apresentou novos cenários devido às interfaces estabelecidas com outras áreas do conhecimento antropológico.

A abordagem genética, através das técnicas de biologia molecular, mostrou, com maior precisão, os diferentes graus de diversidade e de 
variabilidade biológica das populações ameríndias atuais (Szathmary, 1993; Cann, 1994). Os estudos arqueológicos recuaram, de maneira confiável e segura, a temporalidade da presença humana no continente americano para datas anteriores a 11.400 anos A.P. (Meltzer et al., 1997; Dillehay et al. 1997; Kipnis, 1998; Dillehay, 2000). E a antropologia biológica observou que a morfologia craniana dos paleoamericanos parece ser bastante diferente daquela encontrada nos nativos americanos recentes e atuais (Neves \& Pucciarelli, 1989, 1990, 1991). A partir dessas evidências, novas idéias vêm sendo sugeridas em contraposição ao modelo tradicionalmente utilizado para explicar a ocupação da América.

Dentre os novos modelos destaca-se a proposta defendida por Neves e associados, inicialmente divulgada no final dos anos 1980 (Neves \& Pucciarelli, 1989). Baseados nas associações biológicas entre os crânios dos primeiros americanos e os de outras populações mundiais, os autores propuseram que 0 Novo Mundo foi ocupado por dois estoques genéticos distintos, de maneira bastante discordante do pressuposto no modelo ainda predominante.

Desde então, outros pesquisadores vêm, de maneira independente, alcançando os mesmos resultados obtidos por Neves e associados (Powell \& Steele, 1992), fortalecendo a hipótese levantada pelos pesquisadores sulamericanos. Em contrapartida, críticas contundentes à natureza dos fósseis e à metodologia empregadas tornaram-se, também, freqüentes entre os círculos mais conservadores, principalmente entre os norte-americanos, de pesquisadores das origens do homem na América (Brace, 2001; Dillehay, 2000; van Vark et al., 2003).

Parte das críticas aos estudos que utilizam morfologia craniana como marcador antropológico fundamenta-se no fato de as séries contidas no banco de dados Howells, amplamente usado e difundido entre os pesquisadores, serem poucas, não contemplando, assim, toda a variabilidade morfológica craniana humana do planeta (Brace, 2001; Dillehay, 2000; Roosevelt et al., 2002; Seguchi et al., 2005; van Vark et al., 2003). 
Segundo os críticos, essa insuficiência poderia levar a interpretações equivocadas sobre as relações biológicas entre séries, promovendo, estatisticamente, associações fortuitas entre elas (Williams et al., 2005).

Obviamente, essas críticas recaíram fortemente sobre os trabalhos que demonstraram formalmente a não-associação entre os paleoíndios de Lagoa Santa e as populações nativas americanas tardias. Para esses críticos, o caráter conspícuo dos crânios paleoíndios pode ser explicado pelo fato das comparações efetuadas até o momento terem se baseado apenas em 4 amostras de referência do Novo Mundo (Esquimó, Arikara, Santa Cruz e Peru) (Brace \& Hunt, 1990; Brace et al., 2001; Dillehay, 2000; Seguchi et al., 2005).

Assim, para que o Modelo dos Dois Componentes Biológicos Principais ${ }^{1}$ (Neves e Pucciarelli, 1989; 1991), colha uma maior aceitação entre a comunidade bioantropológica é necessário demonstrar se os resultados obtidos por Neves e colaboradores se mantêm à luz de uma comparação que envolve um grande número de séries, sobretudo oriundas do continente americano.

Sob essas circunstâncias planejou-se e desenvolveu-se o presente trabalho, visando rebater as críticas ao "Modelo dos Dois Componentes Biológicos" no que se refere à pouca expressividade do trabalho de Howells em termos do número de amostras envolvido. O banco Howells (1973, 1989), foi, dessa forma, substituído pelo banco Hanihara (Hanihara, 1993a; Hanihara, 1993b; Hanihara, 1996; Hanihara, 2000), numericamente muito mais expressivo, com amostras amplamente distribuídas pelo planeta, que foi cedido ao Laboratório de Estudos Evolutivos Humanos do Departamento de Genética e Biologia Evolutiva do Instituto de Biociências da Universidade de São Paulo para a realização deste trabalho.

Assim sendo, pretende-se aqui testar a hipótese defendida por Neves e colaboradores (Neves \& Pucciarelli, 1989, 1990, 1991; Munford et al., 1995; Neves et al., 1999a, 1999b, 1999c, 2003, 2004, 2005; González-José et al., 2005; Neves \& Hubbe, 2005) de que o continente americano foi ocupado, entre o final do Pleistoceno e o início do Holoceno, por duas populações asiáticas morfologicamente distintas, apresentando a primeira uma morfologia craniana

\footnotetext{
${ }^{1}$ Sobre o Modelo, veja no capítulo 2 - Modelos de Colonização do Novo Mundo.
} 
mais generalizada (morfologia paleoamericana), similar à encontrada hoje em dia entre os povos africanos sub-saarianos e australo-melanésios, e a segunda uma morfologia especializada, similar à encontrada hoje na maioria dos povos asiáticos e entre os nativos americanos, e conhecida na literatura tradicional como morfologia mongolóide.

Se a hipótese de Neves e colaboradores estiver correta, espera-se que: 1) Quando comparada em escala intracontinental, a amostra paleoíndia estudada apresente grandes diferenças morfológicas em relação aos ameríndios tardios e atuais. 2) Em escala extracontinental, que seja observada uma estreita relação biológica entre a população de Lagoa Santa e as populações australo-melanésicas e africanas atuais. 


\section{CAPÍTULO 2 - Contextualização}

À chegada dos primeiros conquistadores europeus ao Novo Mundo seguiu-se um fato absolutamente fascinante: a presença de seres humanos no continente americano. Esses homens, "desprovidos" de toda a cultura, fé e tecnologia européias suscitaram, logo após os primeiros contatos, questionamentos e idéias entre os pensadores do Velho Mundo. Quem eram aqueles seres de aparência humana e comportamento exótico? Como era sua fé e sua visão de mundo? Quais eram suas origens? (Fagan, 1987, 1999; Diamond, 2003).

De um modo geral, até meados do século XVII todo o pensamento acerca das origens do homem americano tinha um cunho estritamente especulativo, quase sempre associado às explicações de cunho religioso, mítico e folclórico, interpretados a partir da visão etnocêntrica dos relatos dos cronistas dos séculos XVI e XVII (Arensburg \& Nès, 1995; Prous, 2006).

As semelhanças físicas entre os índios americanos e as populações asiáticas começaram a chamar a atenção dos primeiros naturalistas que passaram a especular uma possível relação de ascendência e descendência entre esses povos. Ainda que de maneira incipiente e pouco rigorosa do ponto de vista científico, Thomas Gage, em 1648, observou essas semelhanças físicas e propôs a Ásia como sendo o ponto de partida das populações ameríndias, que teriam chegado ao Novo Mundo através do Estreito de Bering (Fagan, 1987, 1999).

A partir desse ponto, o caráter explicativo da antropologia, e de suas derivações como a antropologia física e a arqueologia, passou a desempenhar papéis determinantes na elucidação da história do povoamento da América, na busca de estabelecer relações biológicas e culturais entre ameríndios e asiáticos (Prous, 2006). Nesse sentido, os primeiros trabalhos abordando a cultura material e as características físicas dos ameríndios constituíram as principais fontes de evidências que geraram idéias sobre a colonização do Novo Mundo (Harper \& Laughlin, 1982; Fagan, 1987, Munford, 1999). 
Contar uma história grandiosa, como o é a colonização prístina do continente americano, é uma tarefa árdua e complexa, que necessita buscar informações em diferentes áreas de conhecimento. Hoje já está muito claro para os pesquisadores envolvidos na questão que o conhecimento da biologia, no mais amplo sentido, da cultura, com todos os seus desdobramentos lingüísticos, sociais e políticos bem como a compreensão de como se deu a dispersão dessas populações ao longo do tempo é a melhor maneira de executar uma aproximação fidedigna de como ocorreu o processo da primeira descoberta do Novo Mundo (Neves et al., 1997; Cavalli-Sforza, 1997, 2000; Cavalli-Sforza et al., 1988; Prous, 2006).

Tendo em vista o exposto é importante analisar e conhecer a evolução ao longo do tempo, de duas das principais fontes de evidências sobre povos pré-históricos: a arqueologia e a antropologia biológica. Somados a essas disciplinas, os estudos de genética e biologia molecular também contribuíram para a compreensão da diversidade das populações ameríndias atuais, gerando, conjuntamente, avanços significativos para as investigações sobre as origens do homem no Novo Mundo.

Neste capítulo, apresentaremos uma breve síntese de como a arqueologia, a biologia molecular e a antropologia biológica contribuíram para os estudos da origem do homem americano.

2.1 - As origens do homem americano: contribuições da Genética e da Biologia Molecular

Desde a descoberta, na década de 1950, da estrutural funcional do código genético, e da possibilidade teórica de se manipular os ácidos nucléicos, ou seus produtos, para testar e estudar a composição genética dos nativos americanos, a Biologia Molecular passou a gozar uma destacada posição nas pesquisas sobre as origens do homem no Novo Mundo. Entretanto, durante muitos anos, o progresso desses estudos foi barrado pelas limitações práticas impostas pelas técnicas desenvolvidas e utilizadas (para uma revisão ver Crawford, 1998; Zegura et al., 2004). 
As primeiras tentativas, que lograram maior êxito, dos geneticistas contribuírem para as discussões sobre a diversidade dos nativos americanos datam do final da década de 1960. Esses estudos iniciais utilizavam ensaios imuno-enzimáticos sobre proteínas (proteínas, imunoglobulinas e complementos de histocompatibilidade) para estabelecer relações biológicas entre os nativos americanos e populações do Velho Mundo.

Empregando sistemas sanguíneos, Matson et al. (1967) sugeriram que, sob o ponto de vista de afinidades por esses marcadores proteícos, as populações nativas da América do Sul eram mais relacionadas às populações polinésias do que às do nordeste asiático.

Empregando um número maior de marcadores polimórficos (análises com 13 e 28 marcadores), Kirk (1979) chegou a resultados contrastantes. Em sua análise, quando utilizou 13 polimorfismos, demonstrou grande afinidade biológica entre nativos sul-americanos e populações do Pacífico Sul. Em contrapartida, na análise feita sobre 28 marcadores, os americanos apresentaram uma relação mais forte com populações asiáticas.

De maneira geral, os trabalhos baseados em polimorfismos protéicos foram marcados por essa oscilação na interpretação dos resultados gerados. Dependendo do conjunto de marcadores utilizados, bem como das populações analisadas, os nativos americanos podiam ser mais relacionados com as populações asiáticas ou com as do Pacífico-Sul.

Um resultado mais enfático foi alcançado por Williams et al. (1985) que estudando a imunoglobulina $\mathrm{G}$ ( $\mathrm{IgG}$ ) de quatro grupos ameríndios observou evidências que apontaram para as populações do Nordeste Asiático como sendo a ascendência comum a todas as populações nativas americanas. De maneira alternativa, Salzano e colaboradores, em uma série de artigos, (Salzano et al., 1985; Salzano \& Callegari-Jacques, 1988, 1991; Callegari-Jacques \& Salzano, 1989) compararam índios sul-americanos a indígenas norte-americanos, esquimós, polinésios e siberianos chegando a resultados que, de acordo com as freqüências apresentadas, não excluía nem asiáticos, nem polinésios como contribuintes para a formação do patrimônio genético dos nativos sulamericanos. 
Fora esses exemplos mais extremos, a grande maioria dos estudos sobre a composição e as afinidades genéticas realizadas sobre os polimorfismos protéicos das populações nativas americanas aponta, predominantemente, para uma maior associação entre americanos e asiáticos do que entre americanos e polinésios. Num trabalho com mais de 40 populações distribuídas por todo 0 mundo, os grupos nativos americanos formam um agrupamento associado às populações do nordeste da Ásia, em oposição a outro agrupamento que associa populações da Oceania e sudeste asiático (Cavalli-Sforza et al., 1988; CavalliSforza, 2000).

Um trabalho grandioso sobre as imunoglobulinas IgG e do sistema HLA comparou a freqüência dos marcadores entre índios sul-americanos, índios norte e centro-americanos, populações siberianas, norte-asiáticas, polinésias, norte-africanas, do sudeste asiático e da Nova Guiné. Os autores (Black et al., 1991) concluíram que a ocupação do continente americano deu-se seguindo, obrigatoriamente, um eixo norte-sul, tendo sua origem no nordeste asiático, uma vez que todos os haplótipos encontrados na América do Sul estavam presentes na América Central e do Norte, e todos os aí presentes também foram encontrados na Sibéria. A obrigatoriedade do sentido e da origem da dispersão se dá, simplesmente, pelo fato da combinação inversa (todos os haplótipos presentes na Sibéria estarem presentes na América do Norte, e os daí também serem encontrados na América do Sul) não ocorrer.

Resultados discordantes foram gerados por Schanfield (1992). Estudando nativos americanos divididos em quatro grupos (sul-americanos, norteamericanos Nadene, norte-americanos não-Nadene e Escaleutas) em comparação com grupos do Velho Mundo, concluiu que a colonização do continente americano ocorreu através de quatro movimentos migratórios, em épocas distintas, observando, ainda, certa afinidade genética entre os nativos sul-americanos e os aborígines australianos.

Apesar de alguns resultados conflitantes, e da instabilidade inerente aos primeiros trabalhos que foram feitos baseados nos polimorfismos protéicos, a visão mais parcimoniosa, e com resultados mais expressivos, desses estudos sugerem que, a partir do nordeste asiático, através de uma ou de poucas ondas 
migratórias, os primeiros americanos chegaram à América e dando início ao processo de colonização do Novo Mundo.

Com o avanço das técnicas de manipulação de ácidos nucléicos, e o advento da técnica de polimerização em cadeia, desenhou-se um novo panorama para as possíveis contribuições que a Genética e a Biologia Molecular poderiam gerar para a questão das origens do homem americano. Os marcadores, a partir daí, passariam a ser os próprios conteúdos genéticos, e não mais apenas seus produtos, como vinham sendo até então. Vislumbrando a possibilidade de se traçar todo o processo evolutivo de um gene, não só as idéias quanto às origens, mas também as relativas às épocas poderiam ser melhores levantadas, estudadas e testadas (Szathmary, 1993; Cann, 1994; Gibbons, 1993, 1996; Templeton, 2002).

A variabilidade do DNAmt foi o marcador antropológico mais popularizado nos estudos microevolutivos sobre as origens do homem na América. Essa popularidade é devida às suas características marcantes, como a herança exclusivamente materna, o fácil acesso a toda sua seqüência e à ausência de recombinação gênica (Merriwether \& Ferrel, 1996; ver Kravsberg et al., 2004 para uma visão contrária). Pena e colaboradores (Pena et al., 1995) propuseram a utilização de estudos da variabilidade do cromossomo $Y$, uma espécie de "antagonista natural" do DNAmt (Pena et al., 1995; Bianchi et al., 1998), para as pesquisas acerca dos eventos demográficos e migratórios de populações humanas no passado.

Classicamente, admitiu-se principalmente que toda a variabilidade de DNAmt entre os nativos americanos poderia ser classificada em quatro haplogrupos bem definidos: A, B, C e D (Schurr et al., 1990).

As análises das freqüências e da diversidade desses haplogrupos sugeriam que a migração ameríndia deveria ter ocorrido em dois momentos. Num primeiro momento, uma grande onda migratória entrou na América, carregando os haplogrupos A, C e D (primeira migração ameríndia, entre 26 e 34 mil anos A.P.), seguida, num segundo momento, de uma onda quantitativamente menor, carregando o haplogrupo B (segunda migração ameríndia, entre 12 e 15 mil anos A.P.). Seguindo esta mesma interpretação, 
os Nadene, portando exclusivamente o haplogrupo A, migraram para o Novo Mundo em um outro fluxo de dispersão, entre 7 e 9 mil anos A.P. (Ward et al., 1991; Torroni et al., 1993a, 1993b, 1994).

Uma interpretação diferente da apresentada por Torroni e colaboradores é a de que, obrigatoriamente, cada haplogrupo teria adentrado o Novo Mundo carregado por ondas migratórias específicas, dado a variabilidade estrita a cada grupo. Esse fluxo migratório, de acordo com os cálculos moleculares apresentados, deveria ter ocorrido entre 21 e 14 mil anos A.P. (Horai et al., 1993).

Entretanto, após o trabalho de Bailliet et al. (1994), essa "tipagem" passou a ser contestada. No trabalho, os autores sugerem que os haplogrupos A, C e D apresentam uma grande variabilidade, obrigando a reclassificação dos haplogrupos em A1, A2, C1, C2, D1 e D2 (conjuntamente com o haplogrupo B, de menor variabilidade) além da adição, ainda, de um novo haplogrupo, denominado $\mathrm{E}^{2}$.

Essa nova classificação, e principalmente a menor diversidade do haplogrupo B, pode explicar os resultados obtidos por Torroni e colaboradores sem, necessariamente, recorrer à mesma interpretação que eles, ou seja, a das migrações diferenciadas (Merriwether \& Ferrell, 1996; Eshleman et al., 2003). Algumas características como freqüências, distribuição, taxas de mutação e, principalmente, a ocorrência de marcadores genéticos exclusivos nas populações americanas indicariam que tanto o modelo proposto por Torroni et al. quanto o defendido por Horai et al. poderiam estar equivocados.

O fato de alguns marcadores (mutações) serem amplamente compartilhados por portadores nativo-americanos dos diferentes haplogrupos sem encontrar o mesmo tipo de ocorrência nos mesmos haplogrupos de populações do Nordeste Asiático fala a favor de um processo comum, ocorrido no Novo Mundo e, consequentemente, advoga a favor de uma única onda migratória dando origem aos Ameríndios, Nadene e Escaleutas (Bonatto \& Salzano, 1997a, 1997b; Eshleman et al., 2003). Esses resultados apontam também um acentuado gargalo populacional quando da chegada dos primeiros

\footnotetext{
${ }^{2} \mathrm{Na}$ literatura especializada, o haplogrupo $\mathrm{E}$ passou a ser denominado $\mathrm{X}$.
} 
americanos, seguido de uma grande expansão demográfica e conseqüente observação de "efeito fundador" nesses haplogrupos, como já havia sido preconizado em outros trabalhos (Forsters et al., 1996; Kolman et al., 1996; Bonatto \& Salzano, 1997a, 1997b; Eshleman et al., 2003).

De acordo com Eshleman et al. (2003), os estudos da variabilidade do DNAmt entre os nativos americanos atuais indicam muito claramente que a colonização do continente americano se deu através de apenas uma onda migratória tendo, como ponto de partida, o Nordeste Asiático. Entretanto, a idade da presença humana no Novo Mundo ainda não são consensuais entre os pesquisadores, uma vez que as estimativas baseadas nos relógios moleculares são instáveis a ponto de, em alguns momentos, indicar idades muito mais antigas do que qualquer datação de vestígios arqueológicos e em outros apontar para antiguidades muito recentes e incompatíveis com o grau de variabilidade apresentada pelos haplótipos no Novo Mundo (Meltzer et al., 1997; Bortolini et al., 2003; Eshleman et al., 2003; Zegura et al., 2004).

Apesar de terem sido iniciados cerca de quinze anos após os estudos de diversidade do DNAmt, os estudos feitos sobre a variabilidade do cromossomo Y entre as populações indígenas americanas já apresentam resultados de considerável destaque.

Os primeiros resultados sobre a variabilidade do cromossomo $\mathrm{Y}$ para as populações nativas americanas sugeriram que um determinado haplótipo principal ocorria com freqüência superior a 0,9 (90\%) (Pena et al., 1995; Santos et al., 1995), indicando um acentuado efeito fundador nessa linhagem no continente americano.

Estudos realizados entre Nadene e Escaleutas também evidenciaram a predominância de um determinado haplótipo Y principal (Underhill et al., 1996), não deixando outras alternativas, sob essa ótica, à apenas uma migração para o Novo Mundo (Bianchi et al., 1998). Entretanto, Karafet et al. (1999), não excluem a possibilidade de, mesmo com essa discrepância em termos de freqüência, de pelo menos duas linhagens do cromossomo $Y$ terem sido trazidas para a América. Essa possibilidade foi, novamente alentada, mesmo que por caminhos diferentes, por Schurr (2004). 
Ao contrário dos polimorfismos de DNAmt, que partiram do Nordeste Asiático para o continente americano, parece que o ponto de saída para o Novo Mundo do haplogrupo Y principal foi a Sibéria Central, uma vez que a linhagem americana apresenta ancestralidade comum aos Ket e aos Altai, populações dessa região geográfica (Santos et al., 1999; Karafet et al., 1999).

Quanto à temporalidade da linhagem $\mathrm{Y}$ na América, Bianchi e colaboradores (1998) destacaram a semelhança dos resultados obtidos através das três fontes de evidências genéticas (os polimorfismos protéicos, a variabilidade de DNAmt e a variabilidade do cromossomo Y) estabelecendo uma antiguidade média de cerca de 22.600 anos A.P. (média de um intervalo com limite inferior de 13.500 anos A.P. e limite superior de 58.700 anos A.P.) para a presença humana no Novo Mundo.

Com os dados brevemente expostos, pode-se dizer que tanto as análises efetuadas sobre os polimorfismos protéicos, quanto as análises de diversidade e variabilidade de linhagens de DNAmt e do cromossomo $\mathrm{Y}$ indicam, de maneira bastante convergente, o mesmo quadro consensual de que todas as populações nativas americanas atuais tiveram como ancestrais populações localizadas no nordeste asiático (Norte e Centro-sul da Sibéria), e adentraram o continente americano numa única leva migratória, realizada em alguma época entre 30 e 10 mil anos A.P. (Zegura et al., 2004; ver Schurr, 2004 para uma defesa de duas migrações).

\section{2 - Os primeiros americanos: Evidências Arqueológicas}

As primeiras discussões sobre a ocupação do continente americano sob o ponto de vista arqueológico, no início do século $X X$, estiveram bastante enviesadas pela visão antropológica da época, de que, pelas características completamente modernas dos primeiros americanos, a chegada do homem ao Novo Mundo ${ }^{3}$ não teria uma antiguidade superior a cerca de 4.000 a.C.

Esse cenário passou a ser contestado em meados dos anos 1920, quando da descoberta de pontas de projéteis associadas a animais extintos do

3 Ver o tópico 2.3 - Os primeiros americanos à luz da Antropologia Biológica, para uma contextualização mais detalhada. 
Pleistoceno, num sítio arqueológico perto de Folsom, no Novo México (EUA). Poucos anos depois, escavações num sítio arqueológico na região de Clovis, também no Novo México, produziu uma série de pontas de lanças, de tipo distinto, associadas a ossos de mamutes. Essas peças arqueológicas passaram a distinguir duas tradições tecnológicas (ou culturais), a Folsom e a Clovis, respectivamente (Figgins, 1927; Fagan, 1987; Fangan, 1999; Bradley \& Stanford, 2004).

Apesar desses materiais não terem sido diretamente datados, suas associações com animais pleistocênicos extintos levou a interpretações que thes atribuíam grande antiguidade. Ainda devido a essa associação, os primeiros modelos qualificavam os primeiros americanos como praticantes de caça de grandes animais (big-game hunters) (Fangan, 1999; Bradley \& Stanford, 2004), reconhecendo Clovis e Folsom como os registros arqueológicos mais antigos da presença de seres humanos na América.

Na década de 1950, com o advento das técnicas de datação, o estrato arqueológico mais antigo do sítio Clovis foi datado em 11.400 anos A.P. e sua indústria lítica passou a ser encontrada em sítios de costa a costa da América do Norte, em latitudes desde o sul do Canadá até o centro da América Central (Bradley \& Stanford, 2004).

Pesquisas arqueológicas desenvolvidas no quarto final do século $X X$, colocaram em cheque a supremacia do modelo Clovis (Lovgren, 2003; Bradley \& Stanford, 2004; Schurr 2004). Datações estabelecidas entre 16.000 e 14.000 mil anos A.P. para os sítios de Meadowcroft, na Pennsylvania (Adovasio et al., 1998), Topper, na Carolina do Sul (Goodyear, 1999) e Cactus Hill, na Virginia (McAvoy et al., 2000), além de algumas ocorrências encontradas no Texas (Collins, 2002), diferem daquelas atribuídas aos sítios associados à cultura Clovis, forçando uma reavaliação sobre os limites temporais da entrada humana no continente americano.

Paralelamente a essas pesquisas, intervenções arqueológicas na América do Sul vêm gerando um crescente número de evidências de antiguidades iguais ou superiores àquelas atribuídas aos sítios Clovis. 
O trabalho emblemático desenvolvido por Tom Dillehay no sítio de Monte Verde, no sul do Chile, apresenta datas que ocupam a faixa entre 11.500 e 12.300 anos A.P. e as pesquisas no sítio de Pedra Pintada, na Amazônia, também indicam uma ocupação pré-Clovis no Novo Mundo (Dillehay, 1997, 1999; Dillehay et al., 1992; Roosevelt et al. 2002, Prous, 2006).

Outras evidências geradas também na América do Sul, sem, entretanto, contar com a mesma aceitação daquelas presentes no sítio do extremo sul chileno, têm sido apresentadas no intuito de questionar a supremacia do modelo Clovis e sugerir uma maior antiguidade para a presença dos humanos na América. Um bom exemplo é o sítio do Boqueirão da Pedra Furada, localizado no Parque Nacional da Serra da Capivara, Piauí, Brazil, amplamente escavado durante os anos 1970 e 1980. As datações sugeridas pela arqueóloga franco-brasileira, Niède Guidon, de estratos arqueológicos contendo artefatos líticos, é de 35.000 anos A.P. (Guidon \& Delibrias, 1996). Entretanto, assim como os supostos artefatos de maior profundidade cronológica de Monte Verde, estes do nordeste brasileiro também têm sua origem antrópica extremamente criticada (Fagan, 1999; Prous, 1997, 2006).

Por fim, sobre as evidências recolhidas na América do Sul, uma série de sítios arqueológicos da transição Pleistoceno/Holoceno (convencionalmente estabelecido em 10.000 anos A.P.) podem ser encontrados de norte a sul no subcontinente.

Destaque deve ser atribuído, como não poderia deixar de ser, ao esqueleto (com ênfase no crânio) exumado em Lapa Vermelha IV, na região cárstica de Lagoa Santa, no Brasil Central, pela missão franco-brasileira, liderada pela arqueóloga Annette Laming-Emperaire, nos anos de 1974 e 1975 (Prous, 1991). O crânio desse espécime, que anos mais tarde passou a ser um elemento chave nas pesquisas sobre a colonização do Novo Mundo, foi encontrado em estrato arqueológico datado entre 11.000 e 11.500 anos (Neves et al., 1999a; Prous, 2006). Apesar da datação indireta, esse fóssil representa uma das mais inquestionáveis provas da presença humana na América do Sul no final do Pleistoceno. 
De qualquer forma, a existência de evidências de presença humana na América do Sul datadas entre 11.500 e 12.300 anos A.P., obriga, indubitavelmente, que a supremacia do modelo Clovis seja colocada em xeque. Estima-se que para se estabelecer no extremo sul do continente com essa profundidade cronológica seria necessário recuar a chegada dos primeiros paleoíndios à América do Norte para, pelo menos, 14.000 anos atrás (Dillehay, 2003). Essa data para a chegada dos primeiros humanos ao Novo Mundo continua sob intenso debate (Schurr, 2004; Waguespack, 2007).

Um grande problema enfrentado pelos modelos de migração repousa, além das evidências e interpretações arqueológicas dos vestígios encontrados no continente americano, na questão paleoecológica. Sob quais condições ambientais os primeiros colonizadores teriam chegado à América (Hoffecker et al., 1993)? Durante a última era glacial, a conformação física da área geográfica que compreende o espaço que se estende desde o centro-nordeste asiático, no vale do Rio Lena, até o centro-norte da América do Norte, na bacia do Rio Mackenzie, era dominada pelo mesmo tipo de paisagem, constituída por um clima extremamente frio e seco. Essa região é denominada Beríngia (Hoffecker et al., 1993, Hoffecker \& Elias, 2003).

Nos períodos de maior diminuição do nível do mar, essa grande extensão de terra era constituída por uma unidade geográfica composta por um mosaico de diferentes biomas, todos eles de clima frio, sendo que apenas alguns deles poderiam oferecer suporte à presença humana. Esse cenário é compatível com o que deve ter sido observado na região durante o Último Máximo Glacial (LGM), entre 21.000 e 18.000 anos A.P. (Pavlov et al., 2001). Nos altitermais, com aumento do nível das águas, a região deveria apresentar uma característica fragmentária, constituindo um cenário preenchido por istmos, tornando possível, pelo menos teoricamente, sua travessia através de cabotagem. Sob essas circunstâncias, admitindo uma performance adequada dos pioneiros americanos, vindos do nordeste asiático, pode-se aceitar que poderiam ter entrado no continente americano mesmo desprovidos de tecnologia de navegação para grandes travessias oceânicas, desde cerca de 60.000 anos A.P. (Fagan, 1999; Hoffecker \& Elias, 2003). 
As controvérsias acerca das origens do homem na América ainda não estão completamente solucionadas (Fangan, 1999; Eshleman et al., 2003; Waguespack, 2007). Com as contribuições advindas da Bioantropologia, tanto nos níveis morfológico quanto molecular, não restam dúvidas de que o ponto de partida dos primeiros americanos foi o nordeste asiático (Neves \& Pucciarelli, 1989; Neves et al., 1999a, 1999b; Schurr, 2004; Zegura et al., 2004). Esse ponto de vista encontra respaldo também nos achados arqueológicos e paleoambientais, que também indicam a obrigatoriedade da passagem dos primeiros habitantes do Novo Mundo pela Beríngia a partir da Sibéria (Fangan, 1999; Eshleman et al., 2003, Prous, 2006) ${ }^{4}$.

No entanto, se, por um lado, parece extremamente consensual o caminho por onde os primeiros americanos chegaram ao Novo Mundo, ainda não existe nenhuma definição sobre quando tal travessia foi feita (Meltzer, 1989). De uma forma geral, a cronologia sobre a colonização da América divide a comunidade arqueológica em dois grandes grupos: os que acreditam numa migração entre 30.000 e 15.000 anos A.P. (com algumas proposições ainda mais arrojadas) e os que defendem uma antiguidade entre 14.000 e 11.400 anos A.P. para a chegada do homem na América (Fagan, 1999; Waguespack, 2007).

Uma das questões que pode enriquecer esse debate é a compreensão dos registros arqueológicos da Beríngia (Hoeffecker et al., 1993). Os modelos que se baseiam em migrações muito antigas, anteriores ao LGM, esbarram na ausência de vestígios humanos na Sibéria. Datações estabelecidas em faixas de 18.000 e 22.000 anos atrás para o nordeste e de 40.000 a 30.000 anos A.P. (ca) para o sudeste da Sibéria não deixavam muitas possibilidades para que a migração pela Beríngia tivesse ocorrido em antiguidades muito superiores há 18.000 anos atrás (Hoeffecker et al., 1993; Goebel et al., 1999). Entretanto, arqueólogos russos, trabalhando numa região central da Sibéria, encontraram ferramentas de pedra e de osso, além de restos de grandes mamíferos, que puderam ser datados em aproximadamente 27 mil anos (Pitulko et al., 2004), aumentando a possibilidade de uma maior antiguidade para a chegada do

\footnotetext{
${ }^{4}$ Para uma visão contrária, propondo uma migração a partir da Europa, ver Bradley \& Stanford, 2004.
} 
homem à América. Os mesmos autores sugerem ainda uma grande semelhança entre os artefatos por eles encontrados na Sibéria Central e aqueles pertencentes à cultura Clovis, na América do Norte.

A favor dos que defendem uma cronologia mais curta, foi também aventada a existência de um Corredor Livre de Gelo (Ice-free corridor) para explicar a rápida dispersão dos primeiros colonizadores por todo o continente. Por essa teoria, a existência de uma faixa de terra ligando o noroeste ao centro-sul da América do Norte, com condições climáticas e, conseqüentemente, oferta de recursos, favoráveis, teria facilitado a penetração das primeiras populações no interior do continente Americano quase completamente coberto por geleiras. Tal corredor apresenta uma boa sintonia com o modelo Clovis-first.

Estudos questionando a idéia de um corredor livre de gelo durante a existência das populações Clovis popularizaram-se no final do século XX. Em estratos arqueológicos datados entre 21 mil e 11,5 mil anos antes do presente na área por onde teria se estendido o corredor, nenhum osso animal foi encontrado, tornando difícil a aceitação da teoria. Em alternativa à idéia, baseado em evidências geológicas e lingüísticas, existe uma corrente de arqueólogos que defende que o processo de colonização, no sentido norte-sul, da América, tenha ocorrido através de uma rota costeira. As datações propostas para essas rotas estariam na faixa cronológica que vai de 16.800 a 14.850 anos antes do presente, constituindo um ponto favorável à corrente que defende uma colonização por volta de 15.000 anos (Fagan, 1999; Fedje, 1999, Dixon, 2001a, 2001b).

Finalmente, após uma revisão crítica e re-datação de algumas amostraschave, Waters \& Stafford Jr (2007), diminuíram a profundidade cronológica da cultura Clovis, atrasando seu início em 450 anos. Mais do que isso, a nova faixa cronológica de 11.050 - 10.800 A.P. antecipa seu término em 100 anos representando um xeque-mate ao modelo Clovis-first, isto é, na aceitação de que a cultura Clovis representaria a mais antiga manifestação humana no Novo Mundo (Waters \& Stafford Jr, 2007). 
A contemporaneidade de sítios Clovis com sítios sul-americanos como Cerro Três Teatas, Cueva Casa del Mineiro e Pietra Museo, na Argentina (com datas de $10.935 \pm 35$ A.P., $10.985 \pm 40$ A.P. e $10960 \pm 45$ A.P., respectivamente), atestam, indubitavelmente, que o modelo Clovis-first não pode mais gozar a supremacia de representar a mais antiga ocupação do Novo Mundo (Walter \& Stafford Jr., 2007). Estima-se que para se estabelecer no extremo sul do continente com essa profundidade cronológica seria necessário recuar a chegada dos primeiros paleoíndios à América do Norte para, pelo menos, 14.000 anos atrás (Dillehay, 2003; Dixon, 2001b). A data para a chegada dos primeiros humanos ao Novo Mundo continua sob intenso debate (Schurr, 2004; Waguespack, 2007).

2.3 - Os primeiros americanos à luz da Antropologia Biológica

Desde os primeiros relatos sobre os nativos americanos, o caráter antropológico da questão das origens do homem americano teve uma posição de destaque. Após as primeiras especulações sobre as semelhanças físicas entre os ameríndios e os mongolóides asiáticos, a incipiente Antropologia Física do século XVIII passou a contribuir significativamente para os debates sobre 0 surgimento do homem americano.

Trabalhos sobre as características cranianas dos nativos americanos, desenvolvidos por J. Winslow, em 1722, G. W. Steller, entre 1728 e 1739 e J. F. Blumenbach, em 1795, já ressaltavam a relação de parentesco entre os ameríndios e os mongolóides (Harper \& Laughlin, 1982).

Já no século XIX a Antropologia Física, com destaque para a craniometria, tornou-se uma das mais importantes ferramentas antropológicas (Stocking Jr, 1988, 2004). O importante trabalho de Samuel Morton intitulado "Crania Americana", publicado em 1839, pode ser considerado o ponto de partida das investigações através de comparações craniométricas, difundindo uma primeira metodologia que iria orientar a primeira geração de antropólogos físicos norte-americanos (Fagan, 1987). Nos resultados apresentados nessa 
publicação, bem como na que se seguiu, "Crania Aegyptiaca", de 1844, Morton tentou demonstrar, através de índices de volume do cérebro, a definição de uma hierarquia racial, chegando, inclusive, a subdividir as populações indígenas entre bárbaras e civilizadas (Fagan, 1987; Gould, 1999, Newmann, 1951).

Seguindo-se aos primeiros trabalhos de craniometria formal, alguns autores desenvolveram os primeiros trabalhos baseados em amplas compilações de natureza diversa, como evidências arqueológicas, lingüísticas e etnológicas para elaborar sobre as origens dos nativos americanos. No entanto, a força com que as teorias racialistas dominavam os estudos antropológicos acabou eclipsando tais estudos (Brace, 1982; Trinkaus, 1982).

Na Europa, o proeminente cientista francês Paul Broca popularizou a utilização do índice craniano, que consiste no quociente entre a largura e o comprimento do crânio. Através da utilização desse índice, Broca estabeleceu a hierarquização de dois tipos raciais ${ }^{5}$ : os dolicocéfalos, referentes a raças superiores e os braquicéfalos, vinculadas às raças inferiores (Brace, 1982; Brace \& Hunt, 1990; Trinkaus, 1982, Gould, 1999).

Este caráter extremamente tipológico e racialista dos primeiros estudos craniométricos encontrou forte apoio na Antropologia Física emergente no início do século XX nos Estados Unidos. Dois dos principais cientistas da Antropologia Física norte-americana da primeira metade do século XX, Ăles Hrdlička (fundador do American Journal of Physical Anthropology ${ }^{6}$ em 1918) e Earnest Hooton (fundador do Departamento de Antropologia da Universidade de Harvard) trabalhando junto ao Departamento de Antropologia do Museu Americano de História Natural (Fagan, 1987; Howells, 1992) participaram incisivamente do debate que mobilizaram a comunidade científica acerca das origens do homem no Novo Mundo e do próprio surgimento dos humanos modernos. Hrdlička, defensor da linearidade na Evolução Humana e adepto ferrenho das teorias racialistas, como as de Broca, disseminou, definitivamente, a abordagem tipológico-classificatória nos estudos físico-antropológicos nos EUA (Brace, 1982; Trinkaus, 1982).

\footnotetext{
${ }^{5} \mathrm{O}$ índice craniano é calculado pela razão entre largura máxima e comprimento máximo do crânio. São Dolicocéfalos, i.e., crânios mais longos e estreitos, aqueles cujo índice não ultrapassa 0,75. Braquicéfalos, crânios mais largos e curtos, são os que apresentam índice craniano superior a 0,80.

${ }^{6}$ Ainda hoje um dos mais importantes, se não o mais, periódico na área da Antropologia Biológica.
} 
Os métodos empregados pela Antropologia Física, mais enfaticamente a craniometria, foram alvos de constantes ataques da facção culturalista da emergente Antropologia norte-americana. Capitaneados por Franz Boas, orientador dos principais nomes das primeiras gerações de antropólogos da América do Norte, que apresentou um trabalho demonstrando a plasticidade morfológica humana em resposta a condições ambientais (Boas, 1912), essa corrente se opunha ferozmente às idéias tipológicas e classificatórias propostas pelos estudos morfo-antropológicos.

Apesar das contestações vindas da Antropologia Cultural, a Antropologia Física, apoiada nos estudos antropométricos, continuou desfrutando de grande popularidade entre outras coisas porque atendia aos anseios discriminatórios e raciais da sociedade que emergia nos Estados Unidos.

No campo acadêmico, principalmente no que se refere à questão das origens do homem americano, a corrente culturalista, mais uma vez representada por Boas, já havia tentado solucionar algumas perguntas através de uma abordagem etnográfica, como ocorreu durante a Jesup North Pacific Expedition, não obtendo, entretanto, resultados satisfatórios ${ }^{7}$, segundo 0 próprio Boas (Castro, 2005). Já os resultados e interpretações apresentados pela corrente física encontravam respaldo em dados arqueológicos e culturais.

Nesse contexto, voltando à Antropologia Física e às origens dos primeiros americanos, Hrdlička debruçou-se sobre as questões da antiguidade e da ancestralidade das primeiras populações ameríndias, com um forte interesse também pelo estudo das rotas migratórias para o continente (Fagan, 1987). Para isso, associou-se a arqueólogos, promovendo expedições ao norte da América do Norte, para agregar informações de cultura material aos dados antropométricos (Hrdlička, 1932).

De acordo com sua visão, que não foi acompanhada por Hooton, todos os ameríndios compunham um único tipo comum e homogêneo, estabelecido a partir de uma série de características físicas distintivas (como cor da pele,

\footnotetext{
${ }^{7}$ A Jesup North Pacific Expedition, idealizada por Boas e financiada por Morris K. Jesup (líder do American Museum of Natural History quando da contratação de Franz Boas em 1896), tratava-se de uma ampla pesquisa coletiva que objetivava investigar as afinidades e as relações culturais entre os povos asiáticos e do noroeste americano. A expedição desenrolou-se entre 1897 e 1902. Mesmo tendo reunido um amplo material etnográfico, a expedição ficou muito aquém do esperado, tanto por escassez de recursos quanto por dificuldades diversas dos pesquisadores.
} 
formato dos olhos, cor e tipo de cabelos e distribuição de pelos sobre o corpo), determinadas características esqueletais (como estatura, capacidade craniana e robustez) e funções fisiológicas (como o batimento cardíaco e o ritmo respiratório). A esse "homótipo americano", Hrdlička associou as populações asiáticas, estabelecendo assim a teoria de origem unicamente asiática dos ameríndios (Hrdlička, 1932).

Toda e qualquer variação observada entre os povos do homótipo americano eram interpretadas por Hrdlička como evidências de diferenciações anteriores à saída do Velho Mundo. Essa suposição encontrou respaldo nas pesquisas arqueológicas realizadas por ele e seus colaboradores, uma vez que, à sua época, nenhuma evidência de ocupação muito antiga havia sido encontrada no Alaska, a porta de entrada do Novo Mundo ${ }^{8}$.

Aliados a essas variações do homótipo padrão, Hrdlička observou também alguns vestígios de variações culturais entre os primeiros ocupantes da América, que dificilmente poderiam ter se diferenciado já no continente americano. A partir dessas evidências, Ăles Hrdlička argumentou que 0 povoamento do Novo Mundo deveria ter ocorrido através de vários fluxos migratórios, cada um deles trazendo populações previamente diferenciadas a partir de um ancestral comum asiático. Essas migrações seriam descontínuas, devido às adversidades da região, o que fortalecia as características diferenciadas antes da partida do Velho Mundo. Segundo suas interpretações, as populações esquimós, por exemplo, eram descendentes da última leva migratória, o que explicaria sua distinção das outras populações ameríndias (Hrdlička, 1912, 1932; Fagan 1987).

As idéias de Ăles Hrdlička suscitaram grande polêmica. Ao mesmo tempo em que boa parte dos antropólogos aceitava a proposta da homogeneidade biológica entre os nativos americanos, uma outra parte considerava inaceitável a idéia de que toda a diversidade observada entre os povos nativos das três Américas deveria estar contida, toda, numa única noção de homótipo americano (Munford, 1999).

\footnotetext{
${ }^{8}$ Ver o item 2.2 - Os primeiros americanos: evidências arqueológicas.
} 
Para alguns, a variabilidade observada entre os nativos americanos só poderia ser explicada como sendo o produto de um processo que envolvesse uma série de fatores, desde diferenças étnicas até polimorfismos culturais, lingüísticos e biológicos atuando sobre populações que já apresentassem diferenças entre si (Rivet, 1943). Essa foi a modelagem alternativa proposta por Paul Rivet. Apesar de reconhecer que restringir às populações do nordeste asiático a condição de fundadoras do continente americano seria a hipótese mais óbvia, acreditava que populações Australianas e Melanésicas também deveriam ter chegado ao Novo Mundo (Munford, 1999; Rivet, 1943; Smith, 1984).

Assim como Hrdlička, Rivet reconheceu os esquimós como uma população diferente dos demais ameríndios. Em suas comparações, o antropólogo francês utilizou crânios fósseis da Europa e da Ásia para estabelecer as afinidades biológicas dos esquimós, concluindo que faziam parte de uma população de distribuição polar, que chegou tardiamente à América (Munford, 1999).

Ao contrário do proposto para os esquimós, que pouco teriam contribuído para a evolução das populações ameríndias, Rivet sugeriu, uma influência bastante significativa das populações de origem australiana. Estudando as características dos fueguinos, de crânio dolicocéfalo, arco sagital pronunciado, região occipital desenvolvida e frontal estreito, caracterizados pelos índices craniano, de altura-largura e facial, observou certas semelhanças gerais entre os nativos patagões e as populações australianas. Ainda segundo ele, semelhanças culturais e lingüísticas também não poderiam ser desprezadas (Rivet, 1968).

De maneira ainda mais pronunciada, Rivet enfatizou a contribuição de populações Melanésicas na formação da biologia dos povos americanos. Segundo ele, a participação melanésica ocupou um espaço muito mais extenso, uma vez que admitiu a influência dessa população na formação dos nativos distribuídos numa longa faixa que ia desde o norte da Argentina à Califórnia. A semelhança morfológica entre essas populações poderia ser atestada através da observação de características como dolicocefalia, face larga e curta, nariz e 
órbitas medianas e fronte estreita, glabela bem marcada e frontal desenvolvido e sem fuga. Assim como no caso dos patagões, comparações de dados etnográficos e lingüísticos também corroboravam suas idéias (Rivet, 1968).

Estudos feitos sobre os achados fósseis exumados por Peter Lund na região de Lagoa Santa, Brasil Central, de antiguidade pré-histórica, também apontaram associação ao tipo melanésico, utilizando para isso as mesmas variáveis cranianas utilizadas nos outros trabalhos com populações recentes (Rivet, 1968).

Em suma, as discussões ao longo do primeiro quarto do século XX giraram em torno do intenso debate acerca da homogeneidade (ou da heterogeneidade) biológica das populações nativas do continente americano. Os antropólogos físicos participavam intensamente desses debates, e cientistas como Juan Comas, José Imbelloni e Ernst Hooton destacavam a grande diversidade de informações e de características morfológicas como sendo um reflexo da pluralidade biológica das origens do homem do Novo Mundo. A tentativa de sistematização e classificação biológica dos nativos americanos continuou sendo o pano de fundo dessas discussões, embora a idéia de um Homótipo Americano já não fizesse mais parte das idéias discutidas a partir dos anos 1940 (Armelagos et al., 1982).

As proposições de Hrdlička eram fundamentalmente embasadas em caracteres relacionados à pigmentação e ao tegumento. Segundo seus críticos, as variações desse tipo de caracteres são dificilmente perceptíveis, reforçando, a priori, a idéia de homogeneidade, sem mencionar suposição de que os caracteres mongolóides teriam natureza dominante, o que, em caso de miscigenação, promoveria a ampla distribuição do caráter. Em contrapartida, ao valorizar-se as características esqueletais, as relações métricas poderiam ser estabelecidas representando uma grande vantagem metodológica à abordagem de Hrdlička (Imbeloni, 1938; Newmann, 1951).

A esses ataques recíprocos somava-se a discordância quanto a um único caminho para a entrada dos colonizadores no Novo Mundo. Segundo as proposições de Imbeloni e Rivet, os colonizadores poderiam ter usado vias marítimas, ou mesmo colonizado a América não apenas no sentido norte-sul, 
mas também do sul para o norte, entrando através da Antártida (Comas, 1976; Imbeloni, 1938; Rivet, 1968).

Um duro golpe sofrido pela idéia da homogeneidade dos nativos americanos foi desferido em 1938, quando o antropólogo argentino José Imbeloni, publicou sua "Tabla Classificatória". Nesse trabalho, através da análise de diversas características como estatura, índice cefálico, proporções entre tórax e membros e entre tórax e cabeça, cor e pilosidade da pele, cor e textura dos cabelos, dimorfismo sexual, tipo de deformação craniana, cor e forma dos olhos, formato do nariz, comprimento da face e diâmetro bizigomático, Imbeloni identificou nove raças americanas: 1) Columbidos, 2) Plánidos, 3) Sonórinos, 4) Pueblos Andinos, 5) Ístimidos, 6) Amazonidos, 7) Pámpidos, 8) Láguidos e 9) Fuéguidos (Imbeloni, 1938), deixando de fora dessa classificação os esquimós, indiretamente não os reconhecendo como um povo americano.

Assim como Rivet, Imbeloni hipotetizou a participação de populações ancestrais da Melanésia e da Austrália na formação da biologia ameríndia. Para ele, os Láguidos, indígenas típicos do Planalto Central brasileiro, mas apresentando também uma distribuição pontual que ia da Amazônia à Califórnia, representados no registro fóssil pelo "Homem de Lagoa Santa" (da Gruta do Sumidouro), tinham ancestrais melanésicos. Essa população distinguia-se das demais populações indígenas por vários aspectos, com destaque para sua morfologia facial (Imbeloni, 1938).

Na América do Sul, numa área que ia da Terra do Fogo até o norte da bacia do Rio São Francisco, Imbeloni encontrava a população que classificava como Fuéguidos. Para ele, essa população apresentava grande dispersão através da costa do Atlântico, na região ocupada pelos índios Botocudos, e algumas populações sambaquieiras seriam suas representantes já extintas. Apresentando crânio dolicocéfalo e face estreita, esses povos eram notadamente distintos dos Láguidos, apresentando forte relação com as populações australóides (Imbeloni, 1938).

Ao contrário do proposto por Rivet, que acreditava que as populações australo-melanésicas deveriam ter uma chegada tardia no Novo Mundo, 
Imbeloni acreditava que a dispersão dos Fuéguidos e do Láguidos era um forte indício de que essas populações teriam sido resultados de migrações mais antigas que as dos outros ameríndios, que os restringiram, por motivos biológicos e culturais, a áreas marginais, cerceando assim sua dispersão (Imbeloni, 1938).

Durante a década de 1940 o pensamento tipológico racial atingiu o seu ponto mais alto. Amparando filosofias totalitaristas na Europa, como o nazifascismo, a classificação tipológica antropométrica foi cooptada por teorias que procuravam eliminar ou subjugar grupos ou pessoas indesejáveis, seja do ponto de vista étnico, seja do ponto de vista sócio-econômico-cultural (Gould, 1999). Esse uso indevido das técnicas antropométricas suscitou, novamente, manifestações contrárias dos antropólogos culturais, apoiados ainda nos trabalhos de Boas, que argumentavam sobre a natureza anti-arquetípica da variabilidade morfológica humana.

Com o surgimento e a popularização das técnicas de manipulação de polimorfismos protéicos $^{9}$ no começo da década de 1960 e a adoção de caracteres cranianos não-métricos, como os trabalhos desenvolvidos por James N. Spuhler, um discípulo de E. Hooton, a craniometria, como marcador antropológico foi praticamente abandonada. Os poucos trabalhos que ainda foram tocados adiante tinham caráter adaptacionista, tentando sempre associar características morfológicas esqueletais e distribuição geográfica. Foi nessa época, em trabalhos como os de Marshall Newmann (1963), que as questões de herdabilidade passaram a inquirir a validade dos estudos antropofísicos (Harper \& Laughlin, 1982; Newmann, 1962).

Sob essa ótica, Newmann confrontou modelos advindos da Antropologia Física que se valiam até então da substituição de populações em detrimento da modificação contínua "in loco" para explicar a variabilidade humana americana. Analisando amostras de todo o continente, Newmann argumentou que uma série de alterações adaptativas poderia explicar convincentemente a variabilidade morfológica observada entre os ameríndios, com uma certa tendência à braquicefalia, observável nos ameríndios nos últimos 8.000 anos.

\footnotetext{
${ }^{9}$ Ver o item 1 - As origens do homem americano: contribuições da Genética e Biologia Molecular.
} 
Paralelamente aos estudos de Newmann, crescia em alguns centros a influência dos estudos sobre genética de populações, para explicar as alterações morfológicas ao longo do tempo (Armelagos et al., 1982; Harper \& Laughlin, 1982; Newmann, 1962).

O debate levantado pelos trabalhos de Newmann e Spuhler, ao invés de tornarem-se referência no sentido de contribuir para a formulação de novas teorias sobre o povoamento da América, foram utilizados para um ataque crítico ao arcabouço teórico sob o qual se apoiavam os estudos antropométricos. Durante cerca de três décadas, desde o trabalho de Imbeloni até o final dos anos 1960, nada advindo da antropologia física havia sido cooptado pelas teorias e interpretações sobre as origens do homem americano. A crença difundida entre os antropólogos, fortalecidos agora pela derrocada da antropologia física, era a de que os restos esqueletais em nada poderiam contribuir para elucidar a história do povoamento do Novo Mundo (Armelagos et al., 1982; Comas, 1964; Genovés, 1967).

No início da década de 1970, W. W. Howells, outro discípulo de E. Hooton, apoiado no avanço de técnicas estatísticas ${ }^{10}$, no surgimento das técnicas estatísticas multivariadas, em ferramentas automáticas de cálculo, e em computadores, publicou uma série de trabalhos seminais, resultados de um esforço hercúleo para o renascimento da craniometria.

Apoiado em duas inovações metodológicas fundamentais, a já citada, estatística multivariada e a releitura crítica de quais medidas cranianas deveriam ser utilizadas, Howells pode, enfim, apresentar uma comparação morfológica entre crânios humanos convincente do ponto de vista populacional e não mais tipológica.

Medindo mais de 3000 crânios, provenientes de populações distribuídas pelos cinco continentes, Howells demonstrou as relações morfológicas entre elas, tendo suas interpretações confirmadas, na maioria dos contextos, tanto pela arqueologia quanto pela biologia molecular. Demonstrou que em termos

\footnotetext{
${ }^{10} \mathrm{Na}$ verdade, as técnicas de estatística multivariada já tinham sua metodologia teórica fundamentada desde a década de 1930, apoiada nos trabalhos de Fisher (Hotelling, 1933). O seu "aparecimento" e popularização somente a partir da década de 1970 deveu-se às limitações práticas impostas pela dificuldade de execução dos complexos cálculos envolvidos nessas técnicas. Essas limitações foram vencidas, sistematicamente, com o advento e desenvolvimentos de computadores e softwares cada vez mais poderosos.
} 
de morfologia craniana, a humanidade pode ser organizada em dois grandes grupos: um grupo associando africanos e australianos, e outro agrupando asiáticos, europeus e índios americanos, com os polinésios ocupando posições ora mais próximas do primeiro cluster, ora mais próximas do segundo (Howells, 1973, 1989). O banco de dados por ele formado é hoje utilizado por todos os pesquisadores dedicados a investigar o parentesco evolutivo entre populações humanas distribuídas pelo planeta.

Nos seus trabalhos, no que diz respeito às populações autóctones do Novo Mundo, Howells observou marcada similaridade morfológica entre as três populações por ele analisadas do continente americano. Mais ainda, Howells observou uma forte associação morfológica dessas populações àquelas do nordeste asiático, identificando assim, do ponto de vista antropométrico, a possível origem geográfica das populações ancestrais dos ameríndios modernos (Howells, 1973, 1989, 1999).

Apesar dos avanços da metodologia sugerida e empregada por Howells, esse campo da antropologia continuou ausente, até o final da década de 1980, das discussões sobre as origens dos povos nativos americanos. A caracterização das populações nativas americanas parecia muito mais apropriada de ser feita pelas abordagens advindas da biologia molecular, cujos marcadores seriam muito mais fidedignos. Nesse vácuo, o modelo inicialmente proposto por Hrdlička predominou sobre os estudos antropofísicos, reforçando a idéia de homogeneidade, origem geográfica comum e surgimento de diversidade apenas pós-migratória entre os nativos americanos (Armelagos et al., 1982; Fagan, 1987; Munford, 1995; Szathmary, 1993).

A Antropologia Biológica, representada pela craniometria comparativa, viria finalmente a contribuir, no final da década de 1980, para a caracterização biológica das populações pré-históricas mais antigas do continente americano (Steele \& Powell, 1993).

Explorando remanescentes ósseos humanos de origem arqueológica, Neves \& Pucciarelli $(1989,1990,1991)$ contribuíram com novas informações para o debate sobre quem eram os primeiros americanos. Aplicando técnicas de estatística multivariada às características métricas de crânios de antiguidade 
Pleisto-holocênica da América do Sul e comparando-os a dados relativos a populações recentes e a fósseis de ampla distribuição global, os autores observaram uma forte associação morfológica entre os primeiros sulamericanos e as populações australo-melanésicas.

Diversos outros trabalhos seguiram as mesmas metodologia e fundamentação teórica. Desde então, a Antropologia Biológica, baseada em diferentes técnicas, acena com a possibilidade de que a morfologia craniana dos paleoamericanos pode ter sido muito diferente da difundida entre os nativos americanos tardios, recentes e atuais (Neves \& Pucciarelli, 1989, 1990, 1991; Powell \& Steele, 1992; Steele \& Powell, 1993; Munford et al., 1995; Neves et al., 1999a, 1999b, 1999c, 2003, 2004, 2005; Powell \& Neves, 1999; Jantz \& Owsley, 2001; Hubbe et al., 2004; González-José et al., 2005; Neves \& Hubbe, 2005, para apenas alguns exemplos). Essa nova investida dos estudos comparativos da morfologia craniana, vem garantindo, nos últimos 15 anos, uma destacada posição à Antropologia Biológica nas pesquisas sobre as origens biológicas primeiros americanos.

\section{4 - Modelos de colonização do Novo Mundo}

Mesmo após o trabalho visionário de Howells (1973) os estudos comparativos da diversidade da morfologia craniana continuaram ausentes das discussões acerca das origens biológicas dos primeiros colonizadores do Novo Mundo. A idéia de homogeneidade, origem geográfica comum e surgimento de diversidade apenas pós-migratória entre os nativos americanos foi tornando-se, cada vez mais, arraigada entre os Antropólogos, materialistas e culturais (Armelagos et al., 1982; Fagan, 1987; Munford, 1995; Szthmary, 1993).

Nesse cenário, um estudo multidisciplinar produzido no início da década de 1980 gerou um novo modelo para a ocupação do Novo Mundo que obteve grande sucesso acadêmico. O Modelo das Três Migrações (MTM), apresentado pelo lingüista Joseph Greenberg, o antropólogo C. G. Turner II e o geneticista Stephen Zegura, apoiou-se nessas três áreas do conhecimento para defender 
que os nativos americanos poderiam ser divididos em três grandes grupos (Ameríndios, distribuídos por todo o continente; Nadenes, localizados no noroeste da América do Norte; Aleutas - esquimós - distribuídos ao longo da linha ártica) originados, todos, no nordeste asiático. Ainda segundo o MTM, esses três grupos teriam chegado ao Novo Mundo através de três ondas migratórias distintas e discretas (Greenberg et al., 1986).

Greenberg adotou, no trabalho de 1986, uma posição contrária à da maioria dos lingüistas da época, que relutavam em classificar a diversidade lingüística do continente americano agrupando-as em grandes conjuntos. Compilando dados relativos à gramática e ao vocabulário das línguas nativas americanas, Greenberg classificou-as em três famílias. Analisando as diferenças e semelhanças ao comparar cerca de 1.900 palavras das línguas nativas, concluiu que as três famílias proviam de um único tronco lingüístico ancestral, do norte asiático. Recorrendo à glotocronologia ${ }^{11}$, mesmo reconhecendo as limitações do método, procurou estabelecer a época de separação dos três grupos lingüísticos e quando cada um teria chegado ao novo continente. Para ele, os proto-ameríndios, ancestrais dos ameríndios modernos, teriam saído da Ásia com destino à América por volta de 11.000 anos atrás. Essa primeira onda migratória teria sido seguida pela dos proto-Nadenes, entre 9.000 e 5.000 anos atrás. Finalmente, entre 5.000 e 2.900 anos atrás, os proto-Escaleutas teriam deixado o nordeste asiático e migrado para o Novo Mundo (Greenberg et al., 1986).

Turner II, por seu turno, utilizou evidências dentárias, comparando características da morfologia dos dentes de populações recentes e préhistóricas do Novo e do Velho Mundo, para argumentar a favor do MTM.

Realizando comparações uni e multivariadas em função dos 17 polimorfismos encontrados na dentição de nativos americanos, asiáticos, europeus e populações do Pacífico, Turner II observou a ocorrência de dois tipos-padrão de dentição: a Sundadontia e a Sinodontia. A Sundadontia estaria presente em todo o sul asiático, ocorrendo entre indonésios, javaneses, atayals e jomoneses do Japão. Na região norte da Ásia, entre os chineses, siberianos,

11 Glotocronologia é o estudo científico das línguas, principalmente seu surgimento e desaparecimento, sob a perspectiva histórico-cronológica. 
mongóis e japoneses (exceto Jomon), ocorreriam características mais complexas, derivadas da Sundadontia, a Sinodontia (Greenberg et al., 1986; Hillson, 1996; Turner II, 1983, 1990; Turner II \& Bird, 1981).

Segundo Turner II, os nativos americanos apresentam, de maneira generalizada, o padrão Sinodonte. Concluiu assim que as populações do Novo Mundo têm como ancestrais aquelas que se desenvolveram no norte/nordeste asiático. Observou ainda que pequenas alterações ocorreram ao longo dos últimos 11.000 anos, o que o levou a classificar o padrão Sinodôntico, em três grupos, os Ameríndios, os Nadene e os Aleutas, cada qual com uma história evolutiva particular. Os Ameríndios, sucessores dos paleoíndios, teriam, sob sua ótica, partido do vale do rio Lena, na Sibéria, cerca de 14.000 anos atrás. Numa região ao sul desse vale, encontrar-se-ia o ponto de partida dos Nadene, que cruzaram a Beríngia há cerca de 10.000 anos. E, finalmente, a partir da bacia do rio Amur, teriam partido os proto-Aleutas, cerca de 5.000 anos atrás (Greenberg et al., 1986; Turner II, 1983). Para ele, essa seria a explicação mais parcimoniosa para a morfologia Sinodôntica ameríndia (Greenberg et al., 1986; Turner II, 1983; Turner II \& Bird, 1981).

Com a intenção de suplementar o modelo, Zegura propôs uma revisão dos dados disponíveis à época acerca da distribuição de genes e de genótipos no Novo Mundo, através do estudo de freqüências de polimorfismos genéticos.

O estudo realizado por Williams e colaboradores (1985), sobre a análise da distribuição de haplótipos de Imunoglobulinas $G$, forneceu indícios para que Zegura, apoiado em informações bibliográficas sobre os Aleutas e alguns povos da América do Sul, confirmasse, do ponto de vista genético, o MTM. A ocorrência de um haplótipo específico entre os Nadene e outro entre os Aleutas, associado às freqüências semelhantes entre outros haplótipos entre os outros ameríndios, refletiriam, a princípio, um povoamento a partir de três ondas migratórias. Além disso, a freqüência desses polimorfismos parecia confirmar a origem dessas populações no Norte Asiático, uma região que disporia de variabilidade genética, proximidade geográfica e história geológica compatível com as proposições do MTM (Greenberg et al., 1986; Cavalli-Sforza, 1997). Contemplou-se assim certa variabilidade entre os nativos americanos, 
em oposição à idéia de homogeneidade de Hrdlička, que perdurara durante quase todo o século XX.

Apesar de uma ampla aceitação, alguns pontos contrários foram levantados em relação ao MTM. Do ponto de vista lingüístico, a metodologia adotada por Greenberg foi bastante exótica em relação àquela adotada por seus pares. Exemplo disso foi o trabalho desenvolvido por Nichols (1990), que apontou a América como sendo uma das regiões de maior diversidade lingüística do planeta, comparada à observada na Austrália, indicando um povoamento bastante antigo, realizado através de várias ondas migratórias (Campbell, 1987; Nichols, 1990; Nichols, 1997).

Segundo a pesquisadora, uma alternativa natural para amalgamar os estudos de cunho lingüístico-arqueológico seria investigar os ambientes e cenários prístinos, de maneira a compreender as áreas de distribuição de recursos, as trajetórias de movimentos e as densidades de línguas e populações humanas, características, segundo ela, fundamentais para a modelação da distribuição étnico-lingüística das populações modernas e atuais (Nichols, 1997).

As análises de morfologia dentária também sofreram críticas quanto à metodologia (Powell, 1993), à disparidade amostral (Szathmary, 1986) e à ocorrência de erros inter e intra-observadores (Haydenbilt, 1996).

Estudando esqueletos Paleoíndios e Arcaicos norte-americanos, Powell (1995) demonstrou não ser possível classificá-los como sinodontes, seguindo-se o método proposto por Turner II (1983). A análise de Haydenblit (1996) mostrou resultados semelhantes aos de Powell, porém para esqueletos tardios da América Central. A dentição dos esqueletos Maya por ela analisados apresenta características muito mais sundadônticas do que sinodônticas. Em estudos realizados com populações esqueletais do período arcaico andino, foi impossível reduzir a variabilidade de todos os indivíduos somente ao padrão sinodôntico, devido à alta freqüência, também, da morfologia sundadôntica (Sutter, 1997).

Análises da dentição de esqueletos paleoíndios do Brasil Central indicaram dificuldade em classificar a morfologia dentária desses espécimes 
tanto como sundadontes quanto como sinodontes (Powell \& Neves, 1998). Entretanto, quando os autores "forçaram" uma classificação, os paleoíndios sulamericanos apresentaram uma dentição mais sundadôntica que sinadôntica, indo de maneira contrária ao proposto por Turner II.

Apesar de todos os autores acima citados terem seguido a metodologia descrita e proposta por Turner II (Turner II, 1983), o autor rebateu as críticas sem alterar em nenhum momento seu modelo, culpando as disparidades encontradas a diferenças de critérios utilizados entre os distintos autores (Turner II, 2002; Turner II, 2006).

Como era de se esperar, pelos poucos elementos disponíveis quando da sua formulação, o MTM também sofreu críticas advindas dos estudos da genética dos nativos americanos. Embora ainda não haja um consenso entre os geneticistas quanto à antiguidade e ao fluxo migratório no processo de povoamento, parece claro que o atual cenário desenhado pelas pesquisas genéticas não é condizente com o proposto pelo MTM (Cann, 1994; Crawford, 1992; Szathmary, 1993; Weiss, 1994; Schurr, 2004) $)^{12}$.

No final da década de 1980, a craniometria comparativa, voltou, finalmente, a contribuir para a caracterização biológica das populações préhistóricas mais antigas do continente americano.

Estudando séries arqueológicas, Neves \& Pucciarelli (1989, 1990, 1991) lançaram novas idéias ao debate sobre quem foram os primeiros americanos. Utilizando técnicas de estatística multivariada sobre medidas tomadas em crânios de cronologia recuada da América do Sul e comparando-os a dados relativos a populações recentes de outras partes do planeta (séries Howells), os autores observaram uma forte associação morfológica entre os paleoíndios americanos e as populações australo-melanésicas (Neves \& Pucciarelli, 1989, 1990, 1991; Steele \& Powell, 1993).

Os resultados gerados por Walter Neves e Héctor Pucciarelli colocaram a história evolutiva das primeiras populações americanas em desacordo ao que era advogado pelo modelo corrente. Para justificar seus resultados, Neves e Pucciarelli propuseram um novo modelo de ocupação para o Novo Mundo, o

\footnotetext{
${ }^{12}$ Ver o tópico 2.1 - As origens do homem americano: contribuições da Genética e Biologia Molecular.
} 


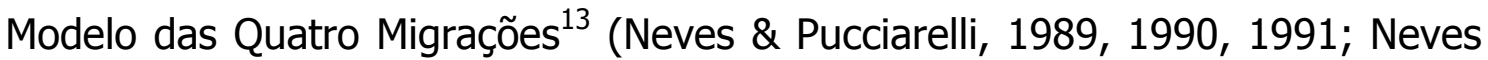
et al., 1996a, 1999).

Revestidos da cautela necessária para evitar ter de lançar mão de complicadas, e pouco prováveis, rotas migratórias que envolvessem, entre outros feitos fantásticos, migrações trans-oceânicas ${ }^{14}$, por exemplo, os dois autores sugeriram que 0 continente americano teria sido colonizado primeiramente por uma população pré-mongolóide, anterior em termos temporais àquela que deu origem aos nativos atuais. Os primeiros americanos teriam afinidades morfológicas acentuadas com aquelas que chegaram ao Pacífico Sul no final do período Pleistoceno (Neves et al., 1996a). Devido às similaridades morfológicas observadas com fósseis de Zhoukoudian, China, Neves \& Pucciarelli defenderam, no novo modelo, que, assim como ocorreu com os ancestrais dos americanos atuais, a Beríngia teria sido também a porta de entrada para os não-mongolóides (Neves \& Pucciarelli, 1991). Outras análises, envolvendo outras amostras da América do Sul, chegaram aos mesmos resultados obtidos inicialmente por Neves e colaboradores (Munford et al., 1995; Munford, 1999; Neves et al., 1996b, 1998).

De maneira independente, também foram feitos estudos craniométricos comparativos com os paleoíndios da América do Norte. Assim como os apresentados pelos pesquisadores sul-americanos, os resultados opuseram-se fortemente ao MTM. Segundo esses estudos, os primeiros norte-americanos apresentariam uma maior similaridade morfológica com europeus e sul-asiáticos do que com as populações mongolóides do nordeste da Ásia (Steele \& Powell, 1992, 1993; Powell \& Steele, 1992). Tais pesquisadores sugeriram que os primeiros americanos seriam representantes de uma população de morfologia generalizada, que ocupou o Velho Mundo no início da dispersão dos humanos modernos (Steele \& Powell, 1992, 1993, 1994; Powell \& Steele, 1992).

\footnotetext{
${ }^{13} \mathrm{O}$ modelo das Quatro Migrações foi rebatizado por seus autores como modelo dos Dois Componentes Biológicos Principais. Essa alteração no nome se deu para uma melhor adequação do modelo às idéias advindas da Biologia Molecular (apenas 1 migração).

${ }^{14}$ A idéia de uma migração trans-pacífica já havia sido alentada por Rivet (1908, 1942). Entretanto, as evidências arqueológicas, que mostram que a ocupação das ilhas polinésicas deu-se tardiamente, aliados à incompatibilidade da tecnologia pré-histórica para uma travessia oceânica refutam, quase que inquestionavelmente, essa teoria (Fagan, 1987, 1998).
} 
Seguindo o método de correção do fator tamanho proposto por Corruccini (1973) e adicionando séries paleoíndias sul-americanas ao banco de dados usado, Neves et al. (1993) replicaram o experimento de Steele \& Powell (1992), observando que, no geral, os crânios norte-americanos associavam-se com os sul-americanos, e ambas as amostras paleoíndias aproximavam-se no morfo-espaço às populações do Pacífico Sul.

Os trabalhos apresentados por Steele \& Powell (1993) e Neves e colaboradores $(1993,1996)$ mostraram que os primeiros americanos, além de não apresentarem morfologia mongolóide e de serem muito similares às populações do Pacífico Sul, associavam-se também a populações africanas subsaarianas.

Martha Lahr (1995) também contribuiu para a investigação das origens dos primeiros americanos, atendo-se à origem e à dispersão das populações mongolóides. Comparando caracteres métricos e não-métricos entre populações do Velho Mundo e as encontradas na Patagônia e na Terra do Fogo, a autora concluiu que os nativos encontrados no extremo sul do continente americano não se associavam morfologicamente às populações tipicamente mongolóides. Essa observação apoiava as idéias de Powell \& Steele, sugerindo que alguns habitantes da América ainda conservavam caracteres ancestrais de uma morfologia humana generalizada (Lahr, 1995, 1996).

Essa proposta é compatível com o modelo Out of África, ou da "Monogênese Africana", amplamente difundido na comunidade paleoantropológica, para explicar a origem e a dispersão do homem moderno (Stringer \& Andrews, 1988). A argumentação proposta por Lahr $(1995,1996)$ é a de que os humanos modernos, saídos da África, teriam se dispersado rapidamente pelo Velho Mundo, alcançando pontos extremos, como a Austrália, por exemplo, mantendo as mesmas características morfológicas da população original. Segundo ela, isso é amparado pela semelhança morfológica entre as populações australianas e africanas modernas. Ambas seriam as que mais se 
assemelhariam à morfologia dos primeiros modernos surgidos na África, por volta de 120.000 anos atrás (Lahr, 1995, 1996) ${ }^{15}$.

A divulgação dos resultados obtidos com o único esqueleto encontrado na Lapa Vermelha IV, batizado popularmente de Luzia, exumado em meados da década de 1970 pela missão franco-brasileira na região de Lagoa Santa, Brasil Central, causou grande impacto na comunidade científica internacional por ser o remanescente ósseo humano mais antigo até hoje encontrado na América ${ }^{16}$. As análises multivariadas efetuadas sobre o crânio de Luzia demonstraram uma clara relação entre esse espécime e populações africanas e australianas, confirmando conclusões anteriores (Neves et al., 1998, 1999).

Procurando diversificar a origem geográfica dos fósseis cujas afinidades biológicas seriam testadas, Powell \& Neves (1998) compararam a morfologia do esqueleto mais antigo da América do Sul (Lapa Vermelha IV) e, o então, mais antigo espécime da América do Norte (Warm Mineral Springs). Os resultados foram convergentes a dos outros trabalhos, apresentando ambos os esqueletos forte associação entre si e com australianos e africanos.

A consistência dessas observações levou, na verdade, a duas hipóteses distintas: ou os paleoíndios representam, de fato, uma migração anterior à entrada da morfologia mongolizada na América, conforme pressuposto originalmente no modelo sugerido por Neves e associados, ou a morfologia mongolóide no Velho e no Novo Mundo representa um caso de convergência adaptativa (Powell \& Neves, 1999).

Contribuindo para esse debate, o estudo das afinidades morfológicas extra-continentais do esqueleto de Palli Aike, vestígio de ocupação paleoíndia tardia no extremo sul do continente, em condições climáticas completamente opostas àquelas encontradas no resto da América do Sul, apresentou as mesmas relações morfológicas observadas nos outros esqueletos paleoíndios (Neves et al., 1999).

De maneira sintética, portanto, paleoíndios provenientes de diferentes regiões do continente americano apresentam, todos, as mesmas similaridades

\footnotetext{
${ }^{15}$ Pesquisas (datação dos remanescentes de Omo Kibish) publicadas posteriormente aos trabalhos de Lahr recuaram a origem da morfologia moderna na África para 200.000 anos atrás.

${ }^{16} \mathrm{O}$ intervalo de 11.500 - 11.000 anos A.P. foi atribuído ao esqueleto por sua posição estratigráfica no sítio, devido à ausência de colágeno no fóssil.
} 
morfológicas, associando-se às populações Africanas e Australianas, quando comparados com a variabilidade morfológica existente no planeta. Tal observação desfavorece a interpretação de que a morfologia dos nativos americanos tardios e atuais seria devida a processos microevolutivos locais convergentes, como os que ocorreram na Ásia, remetendo a melhor explicação para a morfologia paleoíndia ao modelo proposto por Neves \& Pucciarelli (1991).

A partir da publicação de Stringer (1998), uma nova comparação morfológica, envolvendo fósseis de hominíneos modernos de grande antiguidade do Velho Mundo (Williandra Lakes 50 - Austrália; Ngandong - Ásia; UC-101 Zhoukoudian Upper Cave - Ásia e Skhul-Qafzeh - Oriente Médio) e paleoíndios da América do Norte e do Sul (Spirit Cave e Wizard's Beach América do Norte e Santana do Riacho I - América do Sul) e as séries Howells $(1973,1989)$ de referência, foi realizada para adicionar informações ao modelo dos dois componentes biológicos principais. Aplicando análises exploratórias multivariadas aos dados corrigidos estatisticamente em relação ao fator "tamanho", os autores observaram uma associação morfológica que corroborou o esperado pelo modelo dos Dois Componentes Biológicos Principais (DCBP) (Neves et al., 1999c).

Os resultados apresentados nesse trabalho mostraram as séries distribuídas em dois grandes grupos no morfoespaço. Um grupo constituído pelos primeiros humanos modernos (Skhul-Qafzeh), australianos modernos e fósseis, africanos atuais e paleoíndios americanos em contraposição a um outro, constituído por europeus, asiáticos, polinésios e americanos tardios.

Por fim, estudos mais inclusivos contribuíram também para o debate acerca do processo de mongolização ocorrido na América do Sul. Munford et al. (1995), demonstraram que esse processo parece ter ocorrido de forma abrupta, uma vez que nenhuma morfologia intermediária foi observada. Essa substituição populacional deve ter ocorrido quando da chegada da segunda leva migratória ao sub-continente, por volta de 8.000 anos atrás.

Na América do Norte, a publicação de Green et al., (1998) descreveu o crânio de Buhl, de antiguidade Holocênica inicial (cerca de 10.000 anos atrás). 
A descrição do espécime, apesar de desprovida de análises quantitativas, sugeria, segundo os autores, características morfológicas similares àquelas encontradas entre os índios americanos modernos e as populações do nordeste asiático, contrariando assim, ao menos parcialmente, a associação entre paleoíndios e australianos e africanos, conforme defende o modelo DCBP.

Tal conclusão foi corroborada por Neves \& Blum (2000) que compararam quantitativamente o crânio de Buhl, o esqueleto de Lapa Vermelha IV e as séries Howells $(1973,1989)$, concluindo que, na América do Norte, a morfologia mongolóide é quase tão antiga quanto à morfologia generalizada, não sendo possível, portanto, que a primeira pudesse ser derivada da segunda, no continente americano.

O modelo DCBP assume que em algum momento do Holoceno, houve um processo de substituição populacional que excluiu o componente biológico generalizado, uma vez que, atualmente, todas as populações nativas americanas são representadas pela morfologia hoje também dominante na Ásia.

Do ponto de vista de dinâmica populacional é difícil admitir o completo desaparecimento do primeiro componente biológico. Lahr (1995) mostrou em seus trabalhos de morfologia comparada uma certa similaridade morfológica entre os índios históricos da Terra do Fogo e populações Australo-Melanésicas, sugerindo que, de fato, representantes da morfologia não-mongolóide poderiam ter sobrevivido até recentemente na América do Sul, pelo menos em locais muitos extremos e isolados.

Recentemente, um exemplo de sobrevivência tardia da morfologia craniana generalizada foi detectado na Baja California, na América do Norte. Os índios Pericus, isolados geograficamente no sul da Baja California, foram contatados e exterminados pelos colonizadores europeus no século XVI. Análises comparativas efetuadas por Gonzalez-José et al. (2003), mostraram que a morfologia craniana apresentada pelos Pericus era muito mais similar à dos Paleoíndios do que ao dos nativos atuais. Esse exemplo contundente apóia fortemente um dos pressupostos do DCBP, que prevê a sobrevivência da morfologia não-mongolóide, se existir, apenas em grupos altamente periféricos, 
ou isolados (Neves et al., 1991), como é a condição à qual os Pericus foram submetidos.

O modelo DCBP recebeu uma série de críticas da comunidade especializada, principalmente a norte-americana, baseada, geralmente, na argumentação de que os resultados gerados por Neves e associados eram frutos de crânios anômalos, poucos crânios outliers ou ainda sobre crânios isolados. Questionaram também a ineficiência das comparações morfológicas tomando como base apenas o banco de dados Howells $(1973,1989)$, uma vez que são poucas as séries americanas contempladas nesse estudo (Brace, 2001; Dillehay, 2000; Roosevelt et al., 2002; Seguchi et al., 2005; van Vark et al., 2003). Resultados gerados por Neves et al. (2003) e Neves \& Hubbe (2005), a partir de coleções maiores de crânios bem contextualizados arqueologicamente do Brasil Central, rebateram, de maneira apropriada, pelo menos parte das críticas, ratificando a peculiaridade e as afinidades biológicas dos paleoíndios de Lagoa Santa com as populações australianas e africanas.

Estudos comparativos utilizando mais séries planetárias com ampla distribuição geográfica seria de grande utilidade para responder à segunda categoria de críticas, a de que o banco de dados Howells não esgota a variabilidade morfológica craniana do planeta, em especial a do continente americano. 


\section{Capítulo 3 - Material e Métodos}

\section{1 - O banco de dados}

Como já discutido em capítulos anteriores, a Antropologia Biológica ocupa um lugar de destaque nos debates sobre as origens dos primeiros americanos. Nesse contexto, a craniometria mostrou-se, principalmente nas duas últimas décadas, um excelente marcador antropofísico.

Classicamente, os trabalhos exploratórios das afinidades biológicas de diferentes populações a partir de comparações da morfologia craniana foram, e continuam sendo, baseados no Banco de Dados Howells $(1973,1989)$.

De caráter pioneiro, principalmente no que se refere aos métodos e técnicas empregados, as séries Howells abrangem uma distribuição geográfica mundial, sendo representadas por ao menos três grupos humanos de cada grande região do planeta, demonstradas na Figura 3.1.

Figura 3.1 - Distribuição geográfica das séries do banco de dados Howells

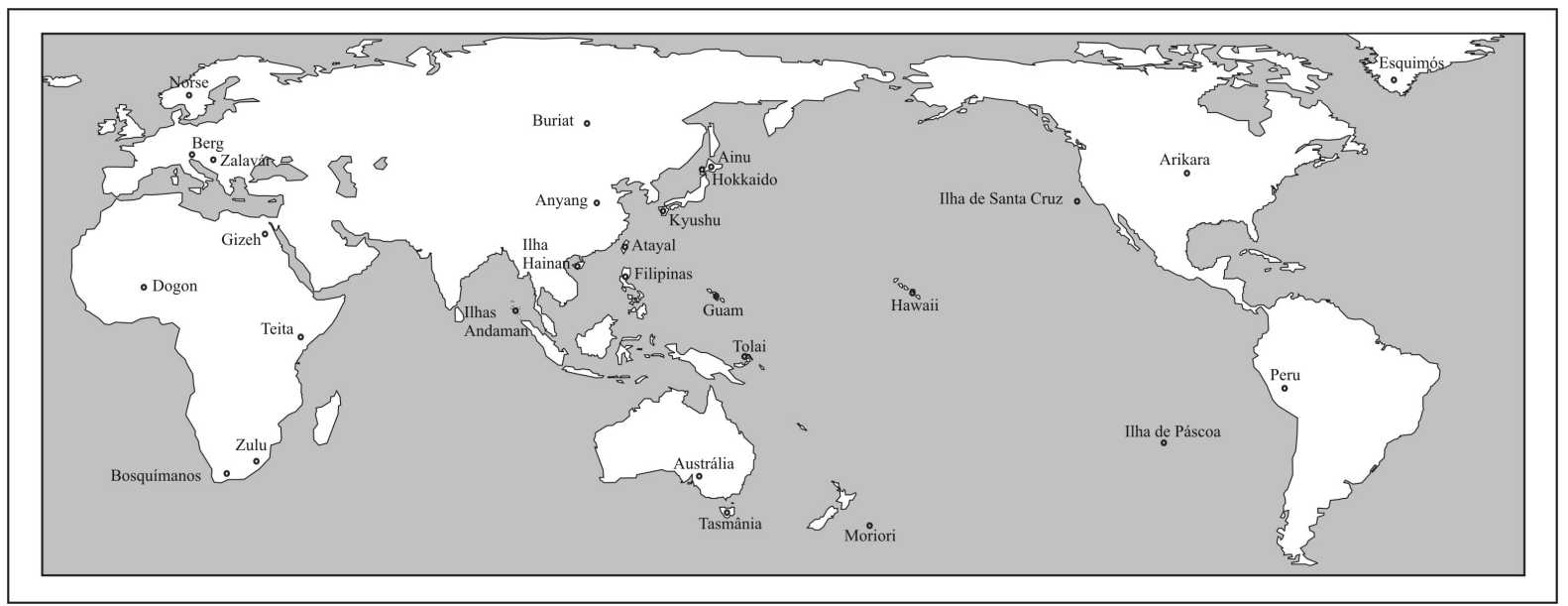

Entretanto, críticas aos estudos comparativos que utilizaram as séries Howells foram feitas recentemente, argumentando que a diversidade morfológica coberta por suas séries seria insuficiente para caracterizar a diversidade craniana atual, sobretudo aquela existente no Novo Mundo (Armelagos et al., 2006; Brace, 2001, 2002; Seguchi et al., 2005). 
Nesse contexto, a adoção de um banco de dados mais inclusivo seria recomendável para ratificar ou não as análises efetuadas com base nos dados Howells.

Para isso, neste trabalho, adotou-se como séries esqueletais comparativas o banco de dados organizado por T. Hanihara, publicado parcialmente em uma série de artigos (Hanihara, 1993a; Hanihara, 1993b; Hanihara, 1996; Hanihara, 2000) desse pesquisador. Constituído por uma amostra de número bastante expressivo, o banco foi cedido pelo Dr. Hanihara para a execução deste trabalho.

\subsection{1 - O Banco Hanihara}

O Banco de Dados organizado pelo Dr. Tsunehiko Hanihara, do Departamento de Anatomia da Saga Medical School (Saga, Japão), é caracterizado por um grande número de amostras, representando 272 séries masculinas e 179 femininas, de 19 regiões geográficas, demonstradas na Figura 3.2.

Figura 3.2 - Distribuição geográfica das séries do banco de dados Hanihara

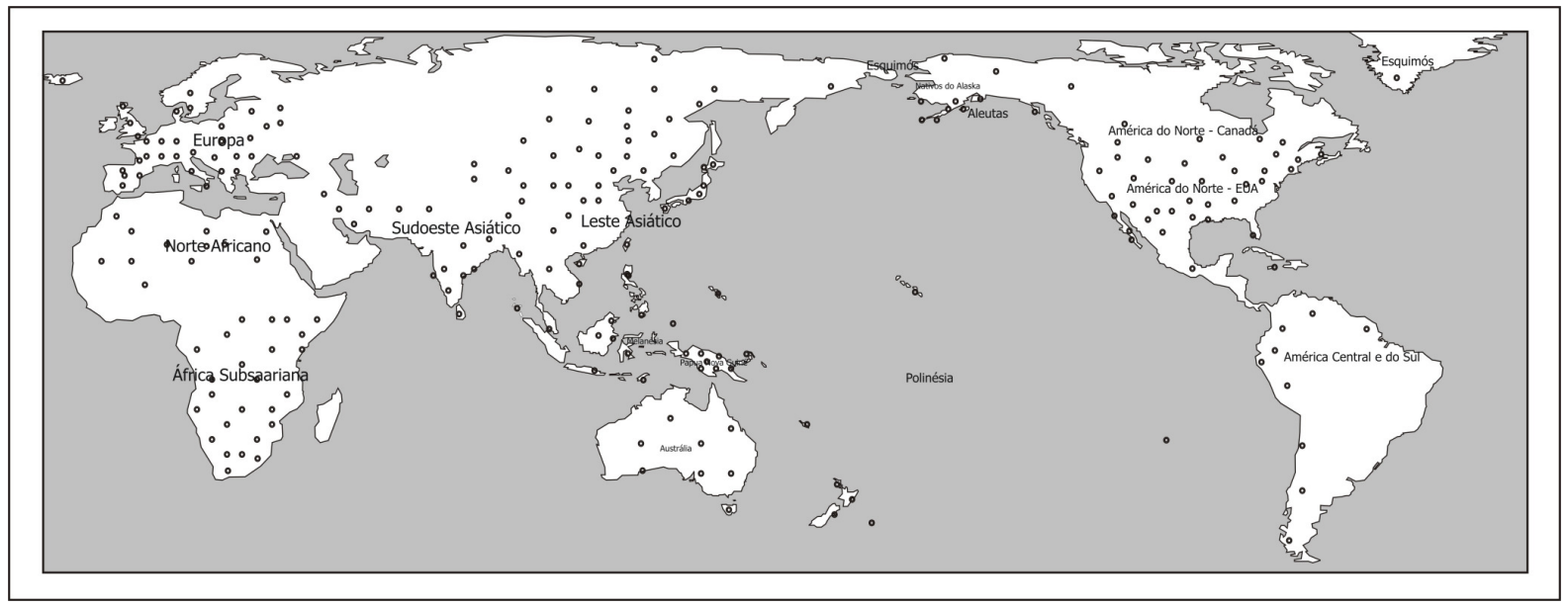

Ao contrário dos bancos organizados por Neves e colaboradores, que seguem, criteriosamente, o protocolo de medidas craniométricas estabelecido 
por Howells (1973), o banco Hanihara, composto por 45 variáveis métricas, foi consolidado a partir de uma combinação de protocolos.

Das 45 medidas que consta no banco Hanihara, 25 são tomadas de maneira idêntica às definidas em Cranial Variation in Man (Howells, 1973). Considerando que a base de dados organizada por Neves e colaboradores segue, rigorosamente, o protocolo estabelecido por Howells, pôde-se definir quais seriam as variáveis que, potencialmente, poderiam ser utilizadas neste trabalho, conforme mostrado na Tabela 3.1 e Figuras 3.3 a 3.5.

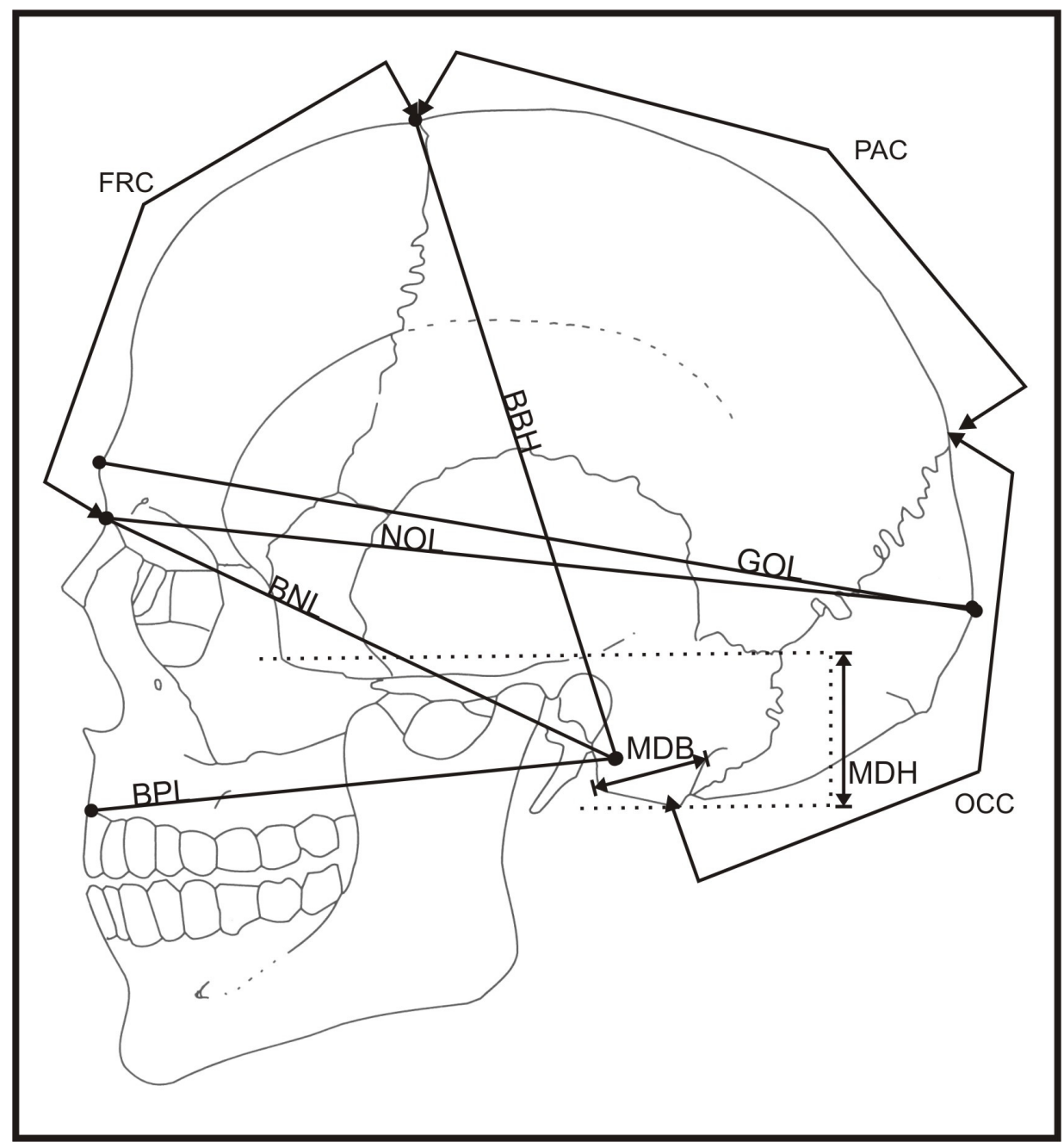

Figura 3.3 - Medidas craniométricas do protocolo Howells (1973) utilizadas neste trabalho. Vista lateral esquerda. 


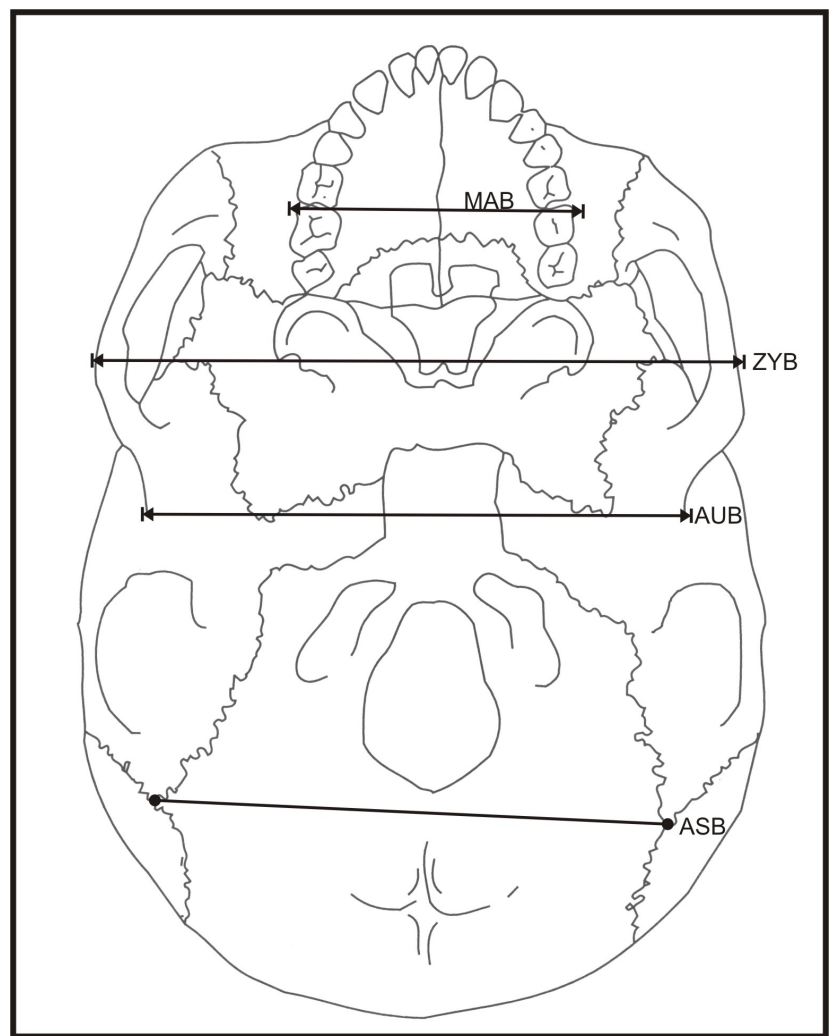

Figura 3.4 - Medidas do protocolo Howells (1973) utilizadas neste trabalho. Vista inferior (base do crânio).

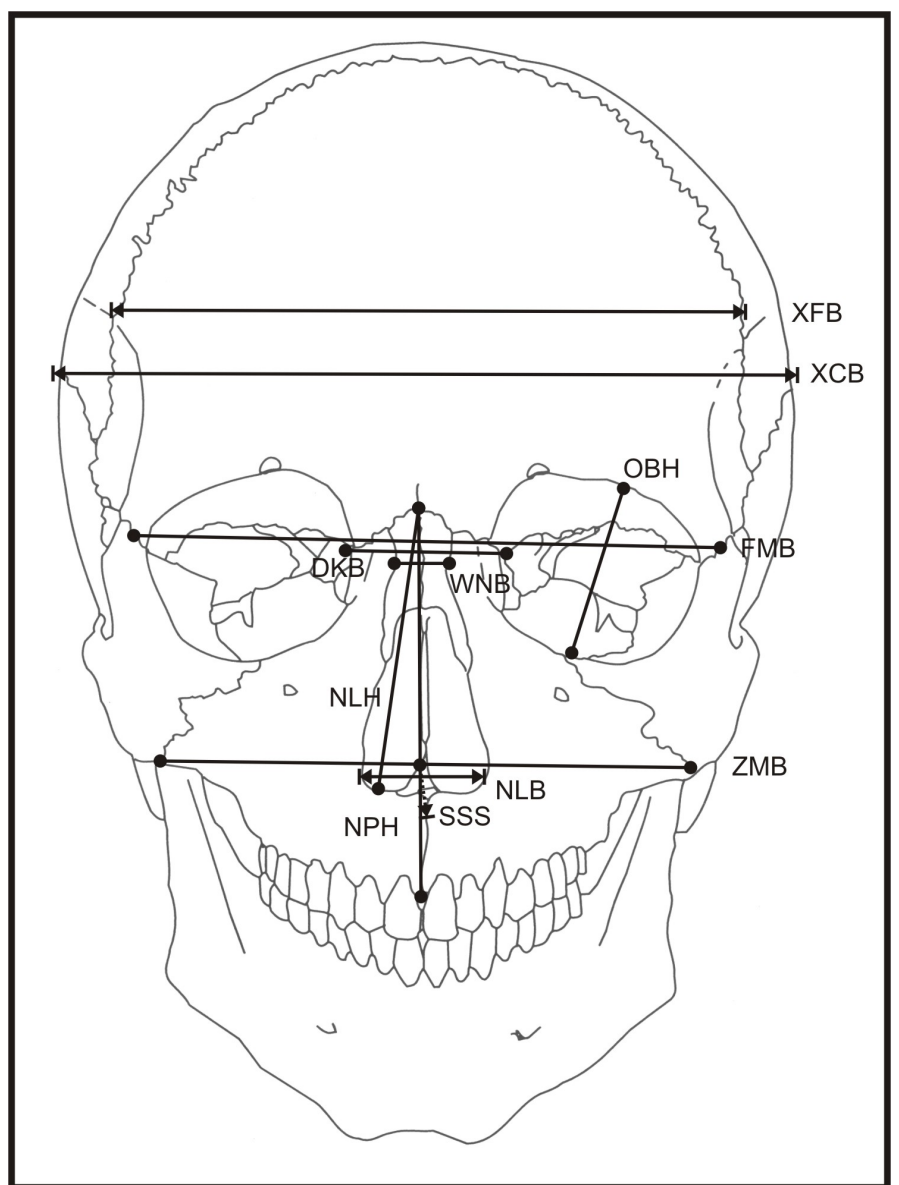

Figura 3.5 - Medidas craniométricas do protocolo Howells (1973) utilizadas neste trabalho. Vista frontal. 
Tabela 3.1 - Variáveis craniométricas tomadas de acordo com o protocolo estabelecido por Howells (1973, 1989) utilizadas no presente estudo*.

\begin{tabular}{|c|c|c|c|}
\hline \multicolumn{2}{|c|}{ Variáveis faciais } & \multicolumn{2}{|c|}{ Variáveis neurocranianas } \\
\hline Descrição & Abreviatura & Descrição & Abreviatura \\
\hline $\begin{array}{l}\text { Comprimento Basion- } \\
\text { Prostion }\end{array}$ & BPL & $\begin{array}{c}\text { Comprimento Glabelo- } \\
\text { Occipital }\end{array}$ & GOL \\
\hline Largura Bizigomática & ZYB & $\begin{array}{c}\text { Comprimento Nasion- } \\
\text { Occipital }\end{array}$ & NOL \\
\hline $\begin{array}{c}\text { Corda simótica (largura } \\
\text { nasal mínima) }\end{array}$ & WNB & $\begin{array}{c}\text { Comprimento Basion- } \\
\text { Nasion }\end{array}$ & BNL \\
\hline Altura nasion-prostion & NPH & Altura Basion-Bregma & BBH \\
\hline Altura nasal & NLH & Largura craniana máxima & XCB \\
\hline Altura orbital & OBH & Largura frontal máxima & XFB \\
\hline Largura nasal & NLB & Largura biauricular & AUB \\
\hline $\begin{array}{l}\text { Largura externa do } \\
\text { palato }\end{array}$ & MAB & Largura bi-asterionica & ASB \\
\hline Largura bimaxilar & ZMB & Altura do mastóide & MDH \\
\hline Bimaxilar subtense ${ }^{* *}$ & SSS & Espessura do mastóide & MDB \\
\hline Distância interorbital & DKB & $\begin{array}{c}\text { Corda frontal } \\
\text { (comprimento nasion- } \\
\text { bregma) } \\
\text { Corda parietal }\end{array}$ & FRC \\
\hline Subtense ${ }^{* *}$ simótico & SIS & $\begin{array}{l}\text { (comprimento bregma- } \\
\text { lambda) } \\
\text { Corda occipital } \\
\text { (comprimento lambda- } \\
\text { opistion) }\end{array}$ & PAC \\
\hline
\end{tabular}

* Foi mantida a nomenclatura original, em inglês, das abreviaturas das variáveis por tratar-se da norma universalmente adotada.

** $\mathrm{O}$ termo subtense é uma medida de projeção. Não existe nenhum termo que o traduza para o português. 
O Banco de Dados foi oferecido ao Laboratório de Estudos Evolutivos Humanos sob a forma de 451 arquivos distintos (um para cada grupo), construídos no modelo apresentado na Tabela 3.2.

Tabela 3.2 - Exemplo do formato do Banco de Dados organizado por T. Hanihara.

\begin{tabular}{|lllllllllll|}
\hline \multicolumn{1}{rr}{35} & & & & & & & & & \\
$1250 \mathrm{FC} 88$ & & & & & & & & & \\
175.00 & 173.00 & 99.00 & 0.00 & 0.00 & 0.00 & 120.00 & 118.00 & 107.00 & 135.00 \\
116.00 & 125.00 & 0.00 & 105.00 & 113.00 & 0.00 & 97.00 & 0.00 & 0.00 & 0.00 \\
63.00 & 25.00 & 44.00 & 40.00 & 33.00 & 26.00 & 47.00 & 47.00 & 59.00 & 35.00 \\
21.00 & 0.00 & 0.00 & 0.00 & 0.00 & 0.00 & 0.00 & 0.00 & 0.00 & 0.00 \\
0.00 & 11.93 & 2.98 & 0.00 & 0.00 & & & & & \\
$1250 \mathrm{FC} 89$ & & & & & & & & & \\
176.00 & 172.00 & 0.00 & 143.00 & 94.00 & 114.00 & 131.00 & 130.00 & 112.00 & 0.00 \\
118.00 & 141.00 & 113.00 & 105.00 & 124.00 & 96.00 & 0.00 & 104.00 & 0.00 & 99.00 \\
71.00 & 20.00 & 43.00 & 39.00 & 36.00 & 24.00 & 50.00 & 50.00 & 66.00 & 30.00 \\
17.00 & 0.00 & 0.00 & 0.00 & 0.00 & 0.00 & 0.00 & 0.00 & 0.00 & 94.80 \\
18.41 & 10.92 & 5.17 & 99.00 & 27.34 & & & & & \\
& 24 & & & & & & & & & \\
175.00 & 173.00 & 93.00 & 147.00 & 79.00 & 115.00 & 128.00 & 127.00 & 115.00 & 123.00 \\
125.00 & 110.00 & 0.00 & 113.00 & 102.00 & 0.00 & 96.00 & 102.00 & 138.00 & 100.00 \\
69.00 & 19.00 & 44.00 & 41.50 & 37.00 & 25.00 & 54.00 & 54.00 & 66.00 & 28.00 \\
18.00 & 0.00 & 0.00 & 0.00 & 0.00 & 0.00 & 0.00 & 0.00 & 0.00 & 98.50 \\
17.60 & 6.87 & 3.61 & 98.50 & 25.04 & & & & & \\
\hline
\end{tabular}

No exemplo, conforme esclarecimentos prestados pelo próprio pesquisador, constam o número de indivíduos presentes no arquivo (3), o número de variáveis craniométricas (45), a identificação de cada um dos espécimes representados (1250FC88; 1250FC89; 24) e as 45 medidas cranianas dispostas seqüencialmente ao longo de cinco linhas de 10 colunas (a última linha utiliza, sempre, apenas 5 colunas). Os valores ausentes ("missingvalues'), comumente encontrados em amostras esqueletais de origem arqueológica, estão preenchidos pelo valor 0.00 , o que é problemático do ponto de vista de tratamento quantitativo.

Após a verificação da uniformidade estrutural de todos os 451 arquivos iniciou-se a sua adequação estrutural.

Cada um dos arquivos teve suas linhas reordenadas manualmente, de modo que todo o banco passou a ser constituído com os indivíduos alinhados nas linhas e as variáveis craniométricas dispostas ao longo das 45 colunas da linha, como é comumente encontrado em outros bancos de dados. É também o 
formato adequado para a aplicação dos pacotes estatísticos computacionais disponíveis.

Seguindo o protocolo de todos os trabalhos realizados no Laboratório de Estudos Evolutivos Humanos (LEEH), todos os dados foram conferidos, um a um, com o auxílio de uma segunda pessoa que não tivesse trabalhado na digitação e estruturação dos dados, de maneira a evitar, a todo custo, erros causados por problemas de digitação e alocação de dados.

Após a conversão de todos os arquivos do formato preexistente para o formato convencionalmente adotado no LEEH, pode-se construir duas grandes planilhas de dados (uma relativa aos homens e outra às mulheres) de maneira que as estatísticas básicas descritivas das séries pudessem ser executadas. Num primeiro momento, a divisão geográfica adotada por Hanihara foi mantida. A re-adequação do formato permite, entre outras coisas, a fácil manipulação de indivíduos e séries para a formação de grupos e/ou subgrupos, o que é de grande utilidade em trabalhos comparativos.

Os dados, representados nos Apêndices 1 e 2, para as séries masculinas e femininas, respectivamente, trazem informações a respeito do número de indivíduos incluídos em cada subconjunto de cada um dos 19 grupos geográficos (Aleutas, Australianos, Canadenses, Centro e Sul-Americanos, Asiáticos do Leste, Esquimós, Europeus, Indianos, Melanésios, Micronésios, Africanos do Norte, Asiáticos do Nordeste, Papuas Nova Guiné, Polinésios, Asiáticos do Sudeste, Africanos Sub-saarianos, Asiáticos do Sudoeste, Bretões e Norte-Americanos) estabelecidos por Hanihara (representado por " $\mathrm{N}$ "), bem como o número de medições tomadas para cada uma das variáveis (" $n$ "). Tal informação também é fornecida em termos percentuais ("\%"), de forma a explicitar a integridade morfológica das amostras analisadas. Por fim, os Apêndices apresentam ainda os valores das médias aritméticas para cada uma das 24 variáveis ${ }^{17}$ utilizadas.

\footnotetext{
17 Originalmente, 25 das 45 variáveis medidas por Hanihara eram idênticas às tomadas pelo protocolo Howells (1973, 1989), adotado pelo LEEH. Entretanto, a variável SIS (Simotic Subtense) é de difícil tomada devido à necessidade de equipamentos especialmente adaptados para tal fim.
} 
A magnitude, geográfica e numérica, do banco de dados consolidado fica patente pela simples observação dos Apêndices 1 e 2. Para alcançar o objetivo comparativo deste trabalho, agregou-se a esse banco, além dos Paleoíndios de Lagoa Santa, outras séries esqueletais, pertencentes ao banco de dados de Neves.

\subsection{2 - O Banco de Dados de Walter Neves}

O Banco de Dados do Laboratório de Estudos Evolutivos Humanos (LEEH) do Departamento de Genética e Biologia Evolutiva do Instituto de Biociências da Universidade de São Paulo, consolidado por Walter Neves e colaboradores nos últimos 20 anos, é composto por dados morfocranianos métricos, não-metricos e odontométricos, além de dados provenientes de análises bioarqueológicas sobre materiais pós-cranianos.

O conjunto de dados métricos cranianos contém séries esqueletais de diferentes populações de distintas cronologias e regiões geográficas. Coleções oriundas de populações arcaicas pré-históricas do sul/sudeste do Brasil (sambaquieiras e do interior), do Brasil Central, da Amazônia e da Colômbia, de populações Paleoíndias do Brasil e da Colômbia além de coleções de nativos recentes do Brasil ditam a tônica do banco de dados do LEEH.

Os dados constituintes do banco foram tomados seguindo-se o protocolo estabelecido por Howells (1973) em Cranial Variation in Man. Como já explicado apenas 25 variáveis das 61 variáveis tomadas por Howells são utilizadas neste trabalho. O banco de dados de Neves contribuiu com as séries Lagoa Santa, o principal objeto de estudo desta pesquisa, e séries paleoíndias e arcaicas da Savana de Bogotá, Colômbia.

\section{A amostra de Lagoa Santa}

A amostra esqueletal referente à população paleoíndia de Lagoa Santa é o maior banco de dados craniométricos existente no planeta para populações paleoíndias americanas, representando, nas palavras de Walter Neves, um enorme "fossil power" pra a antropologia biológica brasileira, no que se refere aos primeiros americanos. Os 
espécimes constituintes desse banco de dados são advindos de estratos arqueológicos do período Paleoíndio tardio (entre 10.000 e 8.000 anos atrás), mais apropriadamente da faixa cronológica entre 8.500 e 8.000 , um período de grande ocupação dos abrigos da região cárstica de Lagoa Santa, no Brasil Central, representada na Figura 3.6 (Araujo et al., 2003).

Figura 3.6 - Localização geográfica da região cárstica de Lagoa Santa, MG, Brasil

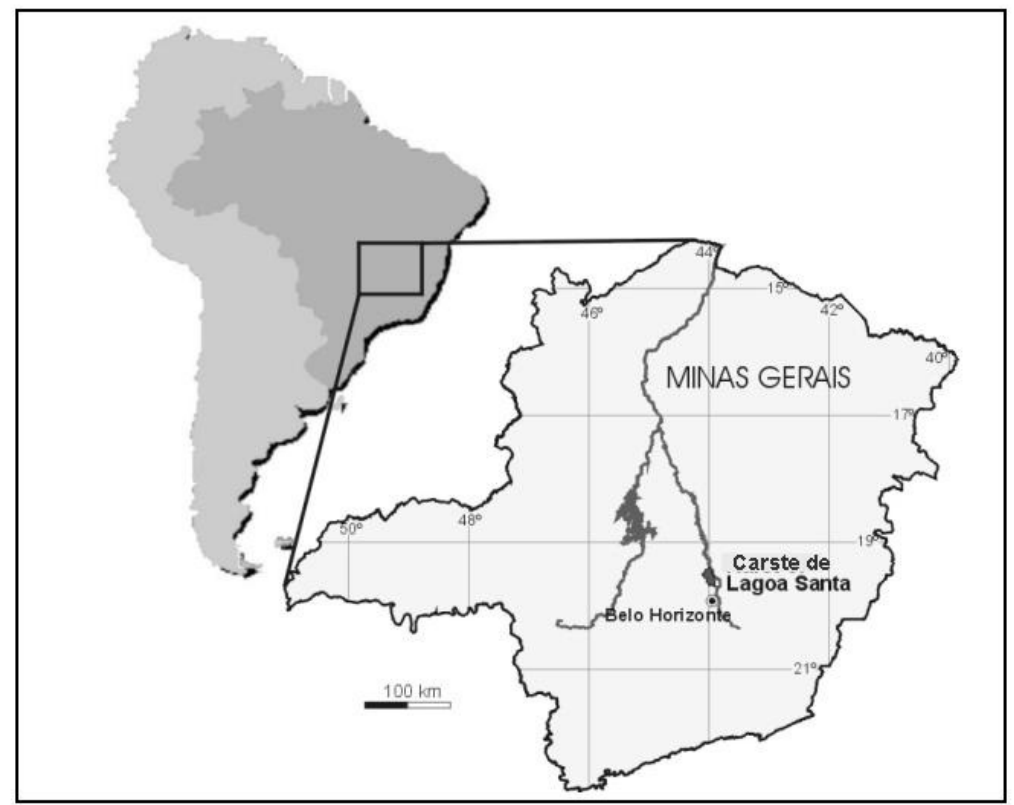

O banco de dados é resultado de um esforço sistemático empregado por Neves e colaboradores ao longo das duas últimas décadas, atacando coleções já institucionalizadas em todo o mundo.

Como consta do trabalho de Neves \& Hubbe (2005), o banco de dados dos Paleoíndios de Lagoa Santa conta, atualmente, com medidas referentes a 81 crânios, distribuídos conforme os Apêndices 3 e 4. Assim como foi feito para os dados do banco Hanihara, as tabelas dos dados de Lagoa Santa apresentam o número de indivíduos analisados $(\mathrm{N})$, bem como o número de medições tomadas para cada uma das variáveis (n). Tal informação também é fornecida em termos percentuais, espelhando a integridade morfológica da amostra. Por fim, os apêndices apresentam ainda os valores das médias aritméticas para cada uma das variáveis utilizadas. Os sítios arqueológicos dos quais esses espécimes provêm, bem como suas respectivas cronologias são apresentados na Tabela 3.3.

Todas as medições foram tomadas por Walter Neves, mantendo rigidez protocolar, eliminando assim possíveis vieses inter-observadores. 
Tabela 3.3 - Identificação dos crânios constituintes da amostra esqueletal paleoíndia de Lagoa Santa.

\begin{tabular}{|c|c|c|c|c|c|}
\hline \multicolumn{3}{|c|}{ Masculinos } & \multicolumn{3}{|c|}{ Femininos } \\
\hline Referência Institucional & Sítio Arqueológico & $\begin{array}{c}\text { Arqueólogo Responsável } \\
\text { pela escavação }\end{array}$ & Referência Institucional & Sítio Arqueológico & $\begin{array}{c}\text { Arqueólogo Responsável } \\
\text { pela escavação }\end{array}$ \\
\hline CONFINS & Lapa Mortuária - caverna & Harold Walter & $\mathrm{HW} \mathrm{s} / \mathrm{n}$ & & Harold Walter \\
\hline HW 002 & - & Harold Walter & HW 001 & - & Harold Walter \\
\hline HW 009 & - & Harold Walter & HW 003 & - & Harold Walter \\
\hline HW 010 & - & Harold Walter & HW 004 & - & Harold Walter \\
\hline HW 013 & - & Harold Walter & HW 005 & - & Harold Walter \\
\hline HW 014 & - & Harold Walter & HW 006 & - & Harold Walter \\
\hline HW 017 & - & Harold Walter & HW 016 & - & Harold Walter \\
\hline HW 019 & - & Harold Walter & HW 018 & - & Harold Walter \\
\hline HW 025 & - & Harold Walter & HW 020 & - & Harold Walter \\
\hline HW 027 & - & Harold Walter & HW 021 & - & Harold Walter \\
\hline HW 030 & - & Harold Walter & HW 029 & - & Harold Walter \\
\hline HW AN 74 & - & Harold Walter & Lund-2302 & Escrivânia 3 & Lund \\
\hline MN 1319 & Cerca Grande 5 & Hurt \& Blasi & MN 1325 & Cerca Grande 6 & Hurt \& Blasi \\
\hline MN 1332 & Cerca Grande 2 & Hurt \& Blasi & MN 1353 & Cerca Grande 6 & Hurt \& Blasi \\
\hline MN 1334 & Cerca Grande 5 & Hurt \& Blasi & MN 1383 & Cerca Grande 6 & Hurt \& Blasi \\
\hline MN 1355 & Cerca Grande 6 & Hurt \& Blasi & MN 1388 & Cerca Grande 7 & Hurt \& Blasi \\
\hline MN 1357 & Cerca Grande 6 & Hurt \& Blasi & MN 1959 & Lapa Vermelha IV & Emperaire \\
\hline MN 805 & Lapa Mortuária - abrigo & Padberg Drenkpol & MN 806 & Lapa Mortuária - abrigo & Padberg Drenkpol \\
\hline MN 807 & Lapa Mortuária - abrigo & Padberg Drenkpol & MN 809 & Lapa D’água & Padberg Drenkpol \\
\hline MN 907 & Lapa da Amoreira & Padberg Drenkpol & MN 812 & Lapa Mortuária - abrigo & Padberg Drenkpol \\
\hline SR1-1 & Santana do Riacho 1 & Prous & SR1-2 & Santana do Riacho 1 & Prous \\
\hline Sr1-4 & Santana do Riacho 1 & Prous & SR1-3 & Santana do Riacho 1 & Prous \\
\hline $\mathrm{SH}-01$ & Sumidouro & Lund & SR $1-5$ & Santana do Riacho 1 & Prous \\
\hline $\mathrm{SH}-02$ & Sumidouro & Lund & SR $1-6$ & Santana do Riacho 1 & Prous \\
\hline SH-03 & Sumidouro & Lund & $\mathrm{SH}-06$ & Sumidouro & Lund \\
\hline $\mathrm{SH}-04$ & Sumidouro & Lund & SH-07 & Sumidouro & Lund \\
\hline $\mathrm{SH}-05$ & Sumidouro & Lund & $\mathrm{SH}-08$ & Sumidouro & Lund \\
\hline $\mathrm{SH}-09$ & Sumidouro & Lund & $\mathrm{SH}-14$ & Sumidouro & Lund \\
\hline $\mathrm{SH}-10$ & Sumidouro & Lund & $\mathrm{SH}-15$ & Sumidouro & Lund \\
\hline $\mathrm{SH}-11$ & Sumidouro & Lund & $\mathrm{SH}-17$ & Sumidouro & Lund \\
\hline $\mathrm{SH}-13$ & Sumidouro & Lund & WN-02 & Sumidouro & Lund \\
\hline $\mathrm{SH}-16$ & Sumidouro & Lund & WN-03 & Sumidouro & Lund \\
\hline WN-01 & Sumidouro & Lund & WN-07 & Sumidouro & Lund \\
\hline WN-04 & Sumidouro & Lund & WN-09 & Sumidouro & Lund \\
\hline WN-05 & Sumidouro & Lund & WN-12 & Sumidouro & Lund \\
\hline WN-06 & Sumidouro & Lund & WN-13 & Sumidouro & Lund \\
\hline WN-08 & Sumidouro & Lund & WN-14 & Sumidouro & Lund \\
\hline WN-10 & Sumidouro & Lund & WN-15 & Sumidouro & Lund \\
\hline WN-11 & Sumidouro & Lund & & & \\
\hline MN 629 & Lapa de Carrancas & Bastos d'Ávila & & & \\
\hline MN 630 & Lapa de Carrancas & Bastos d'Ávila & & & \\
\hline
\end{tabular}




\section{A amostra Colombiana}

Ao lado da região de Lagoa Santa, outra área de destacada importância arqueológica para a compreensão da colonização prístina do Novo Mundo, que produziu importante coleção osteológica é a região da Sabana de Bogotá, na Colômbia (Figura 3.7) (Neves et al., 2007).

\footnotetext{
Figura 3.7 - Localização geográfica da Colômbia. A área circundada pela linha tracejada corresponde à região da Sabana de Bogotá, de onde se localizam os sítios que originaram os crânios utilizados neste estudo
}

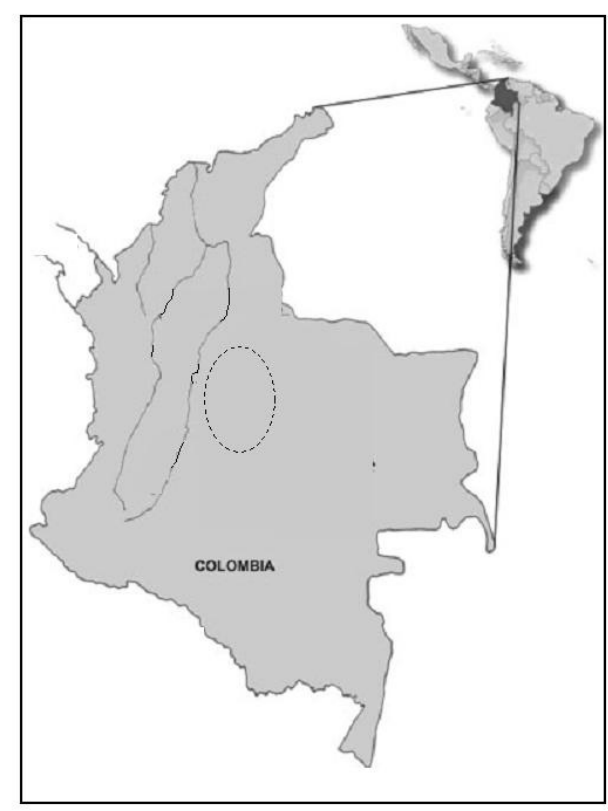

Os crânios originários da Colômbia utilizados neste estudo, contidos no banco de dados de Neves, estão apresentados na Tabela 3.4. 
Tabela 3.4 - Identificação dos crânios constituintes da amostra esqueletal da Sabana de Bogotá utilizada no presente estudo

\begin{tabular}{|c|c|c|c|c|}
\hline \multirow{2}{*}{ Série } & \multicolumn{2}{|c|}{ Masculino } & \multicolumn{2}{|c|}{ Feminino } \\
\hline & Indivíduo & Sítio & Indivíduo & Sítio \\
\hline $\begin{array}{c}\text { Colômbia } \\
\text { Paleoíndio (P) }\end{array}$ & $\begin{array}{l}\text { CHEC } 10 \\
\text { TEQI } 02 \\
\text { TEQI } 03 \\
\text { TEQI } 16 \\
\text { TEQI } 12 \\
\text { TECI } 13\end{array}$ & $\begin{array}{l}\text { Chechua } \\
\text { Tequendama } \\
\text { Tequendama } \\
\text { Tequendama } \\
\text { Tequendama } \\
\text { Tequendama }\end{array}$ & $\begin{array}{l}\text { SU } 45817 \\
\text { GACHA sn } \\
\text { CHEC } 13 \\
\text { CHEC } 08 \\
\text { CHEC } 07 \\
\text { TEQI } 18 \\
\text { TEQII } 01 \\
\text { TEQII } 02 \\
\text { TEQII } 03 \\
\text { TEQII } 04 \\
\text { TEQI } 07\end{array}$ & $\begin{array}{c}\text { Sueva I } \\
\text { Gachala } \\
\text { Checua } \\
\text { Checua } \\
\text { Checua } \\
\text { Tequendama I } \\
\text { Tequendama II } \\
\text { Tequendama II } \\
\text { Tequendama II } \\
\text { Tequendama II } \\
\text { Tequendama I }\end{array}$ \\
\hline Total Paleoíndios & \multicolumn{2}{|c|}{6} & \multicolumn{2}{|c|}{11} \\
\hline $\begin{array}{c}\text { Colômbia Arcaico } \\
\text { (A) }\end{array}$ & $\begin{array}{l}\text { AZ 458-75 } \\
\text { AZ 458-26 } \\
\text { AZ 458-28 } \\
\text { AZ 458-48 } \\
\text { AZ 458-52 } \\
\text { AZ 458-57 } \\
\text { AZ 458-60 } \\
\text { AZ 458-61 } \\
\text { AZ 458-62 } \\
\text { AZ 458-64 } \\
\text { AZ 458-65 } \\
\text { AZ 458-66 } \\
\text { AZ 458-79 } \\
\text { AZ 458-25 } \\
\text { AZ 458-29 } \\
\text { AZ 458-39 } \\
\text { AZ 458-42 } \\
\text { AZ 458-35 } \\
\text { AZ 458-37 } \\
\text { AZ 458-30 } \\
\text { AZ 458-31 } \\
\text { AZ 458-32 } \\
\text { AZ 458-33 } \\
\text { MSQ 1408 } \\
\text { MSQ 1407 }\end{array}$ & $\begin{array}{l}\text { Aguazuque } \\
\text { Aguazuque } \\
\text { Aguazuque } \\
\text { Aguazuque } \\
\text { Aguazuque } \\
\text { Aguazuque } \\
\text { Aguazuque } \\
\text { Aguazuque } \\
\text { Aguazuque } \\
\text { Aguazuque } \\
\text { Aguazuque } \\
\text { Aguazuque } \\
\text { Aguazuque } \\
\text { Aguazuque } \\
\text { Aguazuque } \\
\text { Aguazuque } \\
\text { Aguazuque } \\
\text { Aguazuque } \\
\text { Aguazuque } \\
\text { Aguazuque } \\
\text { Aguazuque } \\
\text { Aguazuque } \\
\text { Aguazuque } \\
\text { Mosquera }\end{array}$ & $\begin{array}{c}\text { CHIA 05 } \\
\text { CHIA 02 } \\
\text { AZ 458-69 } \\
\text { AZ 458-72 } \\
\text { AZ 458-73 } \\
\text { AZ 458-74 } \\
\text { AZ 458-22 } \\
\text { AZ 458-23 } \\
\text { AZ 458-47 } \\
\text { AZ 458-49 } \\
\text { AZ 458-50 } \\
\text { AZ 458-51 } \\
\text { AZ 458-53 } \\
\text { AZ 458-55 } \\
\text { AZ 458-56 } \\
\text { AZ 458-63 } \\
\text { AZ 458-67 } \\
\text { AZ 458-68 } \\
\text { AZ 458-24 } \\
\text { AZ 458-40 } \\
\text { AZ 458-41 } \\
\text { AZ 458-43 } \\
\text { AZ 458-44 } \\
\text { AZ 458-45 } \\
\text { AZ 458-34 } \\
\text { AZ 458-38 } \\
\text { MSQ 1402 } \\
\text { MSQ 1404 } \\
\text { MSQ 1405 } \\
\text { MSO 1410 }\end{array}$ & $\begin{array}{c}\text { Chia III } \\
\text { Chia III } \\
\text { Aguazuque } \\
\text { Aguazuque } \\
\text { Aguazuque } \\
\text { Aguazuque } \\
\text { Aguazuque } \\
\text { Aguazuque } \\
\text { Aguazuque } \\
\text { Aguazuque } \\
\text { Aguazuque } \\
\text { Aguazuque } \\
\text { Aguazuque } \\
\text { Aguazuque } \\
\text { Aguazuque } \\
\text { Aguazuque } \\
\text { Aguazuque } \\
\text { Aguazuque } \\
\text { Aguazuque } \\
\text { Aguazuque } \\
\text { Aguazuque } \\
\text { Aguazuque } \\
\text { Aguazuque } \\
\text { Aguazuque } \\
\text { Aguazuque } \\
\text { Aguazuque } \\
\text { Mosquera } \\
\text { Mosquera } \\
\text { Mosquera } \\
\text { Mosquera }\end{array}$ \\
\hline Total Arcaicos & & & & \\
\hline TOTAL & & & & \\
\hline
\end{tabular}




\subsection{3 - Dados complementares}

Com o intuito de dar mais robustez aos testes realizados, decidiu-se, durante o delineamento desta pesquisa, incluir dados relativos a duas séries brasileiras do arcaico tardio do litoral de Santa Catarina (Tapera e Base Aérea), indubitavelmente associados à morfologia mongolóide (Okumura, 2007).

Esses dados foram obtidos por Maria Mercedes M. Okumura, atualmente associada ao Leverhulme Centre for Human Evolutionary Studies da Cambridge University, durante a coleta de dados para sua tese de doutorado (Okumura, 2007). Dra. Okumura coletou, sistematicamente e após intenso treinamento com seu orientador, Dr. Walter Neves, medidas de mais de 1000 crânios do litoral e interior da região centro-sul do Brasil.

Como foi feito para os dados do banco Hanihara e do banco do LEEH, os apêndices 5 e 6 apresentam o número de indivíduos analisados $(\mathrm{N})$, bem como o número de medições tomadas para cada uma das variáveis (n), e seu respectivo valor relativo, e a média aritmética para cada variável analisada, das séries de Tapera e Base Aérea, para as parcelas masculina e feminina, respectivamente.

Dessa forma, contando com um banco de dados quantitativamente expressivo, consolidado a partir de três bases distintas, porém compatíveis, espera-se esgotar a variabilidade morfológica mundial, sobretudo a americana, tendo em vista que a esmagadora maioria dessa variabilidade ocorre dentro de cada população e não entre populações (Howells, 1973, 1999; Relethford, 1994).

\section{2 - A Estatística Multivariada}

Muito cedo na história da genética, ficou evidente que não há uma correspondência direta, um a um, entre genes e características fenotípicas (Futuyma, 1997). Ao contrário disso, alguns genes podem ter efeitos 
pleiotrópicos $^{18}$ enquanto outras características podem ser derivadas de heranças poligênicas ${ }^{19}$.

Dessa forma, a vantagem seletiva de um gene pode depender de outro, ou outros, genes, complicando a análise dessas interações e, freqüentemente, impossibilitando a visualização de correlações simples entre diferentes variáveis (Stearns \& Hoekstra, 2000; Ridley, 2004).

Essa característica multifatorial dos fenômenos biológicos constantemente desqualifica as análises baseadas, simplesmente, em técnicas estatísticas Uni e Bivariadas, obrigando o pesquisador a modelar métodos e algoritmos de forma que possa observar os efeitos das forças microevolutivas na variação quantitativa entre as populações (Relethford, 1982).

As técnicas univariadas restringem-se às análises e inferências descritivas, que permitem apenas o tratamento de cada variável separadamente, impossibilitando a integração de diferentes medidas de um mesmo fenômeno (Mingoti, 2005). Já as técnicas bivariadas são relativas aos métodos de análise de duas variáveis, podendo ou não estabelecer relações de causa/efeito entre elas, dependendo, sempre, da relação entre essas variáveis, quer através dos coeficientes de correlação linear de Pearson ou Spearman, quer do modelo clássico de regressão linear simples (Reis, 2001).

Pode-se admitir, portanto, que tanto do ponto de vista biológicoevolutivo quanto do ponto de vista estatístico e quantitativo, a inferência da estrutura genética das populações humanas, abordadas através de estudos da morfologia craniana, por exemplo, deve, necessariamente, basear-se em técnicas estatísticas multivariadas (Relethford, 1982; 1994; 2002). Somente por essas técnicas é que se pode examinar e compreender, de forma mais completa e realista, os fenômenos que apresentam correlações naturais múltiplas (Hair et al., 1998).

Não é uma tarefa fácil definir "Estatística Multivariada". De certo modo, o termo refere-se a todos os métodos estatísticos que analisam, simultaneamente, várias medidas em cada indivíduo ou objeto sob investigação

\footnotetext{
${ }^{18}$ Pleiotropia: O efeito fenotípico de um gene em mais de uma característica.

${ }^{19}$ Herança Poligênica: ocorre quando vários genes ou pares de genes atuam conjuntamente na expressão e modulação de uma determinada característica.
} 
(Hair et al., 1998). Inclui os métodos de análise das relações de múltiplas variáveis dependentes e/ou múltiplas variáveis independentes, quer se estabeleçam ou não relações de causa-efeito entre elas, podendo ser aplicados às análises em níveis individuais ou grupais, isto é, possibilita tanto as análises de variação intra quanto inter grupos (Reis, 2001).

Geralmente, quando se medem as características de um ou mais grupos amostrais ou populacionais, essas características estão correlacionadas. $\mathrm{Na}$ existência de correlações entre as variáveis é necessário "destrinchar" a informação por elas fornecida e tornar evidente a estrutura que formam (Reis, 2001). Um dos objetivos da Estatística Multivariada consiste na simplificação dos dados, descrevendo a informação através da redução do número de dimensões, sem prejuízo à maior parcela da variância contida no conjunto de variáveis amostradas (Mingoti, 2005). Assim, através das técnicas multivariadas pode-se, tanto descrever a população ou amostra em estudo quanto inferir as relações e generalizações dos resultados amostrais à população de onde foi extraída a amostra, associando-lhe determinado grau de risco ou incerteza (Reis, 2001).

$\mathrm{Na}$ Antropologia Biológica, mais precisamente nos estudos sobre a variabilidade morfológica craniana, o uso das técnicas estatísticas multivariadas já está bastante difundido, como pode ser notado pela maciça predominância da utilização desses métodos na extensa literatura especializada ${ }^{20}$, desde os trabalhos seminais de Howells ${ }^{21}$.

O ponto de partida para qualquer análise multivariada é definir o problema da pesquisa e os objetivos de análise em termos conceituais. Devese, portanto, modelar e delinear a questão a ser estudada, no nosso caso, as relações morfológicas a serem observadas, em termos conceituais, definindo os conceitos e identificando as relações fundamentais a serem investigadas. Só a partir desse ponto é que deve-se escolher a técnica, ou técnicas, multivariada apropriada. Isto significa que, se o objetivo da pesquisa é a investigação de

\footnotetext{
${ }^{20}$ Para apenas alguns exemplos ver (Relethford, 1982, 1994, 2002; Neves \& Pucciarelli, 1989, 1990, 1991; Powell \& Steele, 1992; Steele \& Powell, 1993; Munford et al., 1995; Neves, 1982; Neves et al., 1999a, 1999b, 1999c, 2003, 2004, 2005, 2007; Powell \& Neves, 1999; Jantz \& Owsley, 2001; Hubbe et al., 2004; González-José et al., 2005; Neves \& Hubbe, 2005)

${ }^{21}$ Ver o capítulo 1, item 3 - Os primeiros americanos à luz da Antropologia Biológica.
} 
relações de dependência ou independência entre casos, os dados devem ser explorados e estruturados de forma que possibilite a aplicação de métodos de dependência ${ }^{22}$. Já, se o objetivo é a investigação das dimensões estruturais ou a similiaridade entre casos, a pesquisa deve recair sobre métodos de interdependência ${ }^{23}$ (Hair et al., 1998).

Após escolher entre um método de dependência ou interdependência, a última decisão é selecionar a técnica estatística mais apropriada, com base nas características das variáveis em estudo e nas particularidades próprias de cada técnica disponível. Questões como tamanho mínimo ou desejado da amostra, tipos permitidos ou exigidos de variáveis (métricas versus não-métricas, por exemplo) e estimação de resultados agregados ou desagregados, entre outras, são as que norteiam as escolhas sobre quais técnicas estatísticas multivariadas são as mais apropriadas para investigar um certo conjunto de dados (Hair et al., 1998; Reis, 2001)

Para o presente trabalho, cujo objetivo é analisar as afinidades da morfologia craniana de populações humanas, distribuídas em níveis intra e extra continentais de escala, a partir de um tamanho amostral quantitativamente expressivo, a decisão recaiu sobre a utilização de quatro tipos de análise:

I) Análise de Componentes Principais;

II) Análise de Agrupamentos com base em Distância Euclidiana;

III) Escalonamento Multidimensional com Base em Distância de Mahalanobis;

IV) Análise de Agrupamentos com base em Distância de Mahalanobis.

Todos os testes estatísticos aqui propostos foram realizados separadamente para as parcelas masculina e feminina. Esta distinção é necessária dada a influência que o dimorfismo sexual pode ter na morfologia

\footnotetext{
${ }^{22}$ Técnica (ou método) de dependência: Técnicas estatísticas diferenciadas por terem uma variável ou um conjunto de variáveis identificado como "variável (eis) dependente $(s)^{y}$ e as variáveis remanescentes como "variáveis independentes". O objetivo é a previsão da (s) variável (eis) dependente (s) pelas variáveis independentes. Um exemplo clássico é a análise de regressão.

${ }^{23}$ Técnica (ou método) de interdependência: Técnicas estatísticas nas quais as variáveis não são divididas em conjuntos dependentes e independentes (por exemplo, a Análise de Componentes Principais), isto é, todas as variáveis são analisadas como um conjunto.
} 
craniana humana. Outra correção necessária é em relação ao tamanho dos crânios. Como "tamanho" é altamente influenciado por condições ambientais imediatas (Corruccini, 1973), é fortemente recomendado que a interpretação das afinidades sejam, também, baseadas em testes que levem em consideração apenas a forma dos crânios. Tal correção foi feita de acordo com o procedimento estabelecido por Darroch \& Mosimann (1985), que consiste em dividir o valor de cada variável em análise pela valor da média geométrica (raiz enésima do produto das $\mathrm{n}$ variáveis medidas) do indivíduo.

Devido a essas correções, os dados matriciais foram configurados de maneira tal que as análises efetuadas possibilitaram, sempre, a geração de 4 topologias distintas para discussão (Parcela Masculina - Tamanho e forma; Parcela Masculina - Apenas Forma; Parcela Feminina - Tamanho e Forma; Parcela Feminina - Apenas Forma). Todos os cálculos e gráficos apresentados neste trabalho foram executados a partir do pacote estatístico STATISTICA 6.0 (Statsoft).

\subsection{1 - Análise de Componentes Principais}

A técnica denominada de Análise de Componentes Principais (ACP) foi introduzida por Karl Pearson (Mingoti, 2005) no trabalho em que discutiu 0 significado matemático e as implicações físicas, estatísticas e biológicas, das configurações de linhas e pontos em sistemas n-dimensionais (Pearson, 1901).

A transição entre a fundamentação teórica e a aplicação prática da técnica foi desenvolvida a partir da publicação do trabalho de Harold Hotelling (1933) sobre a análise de variâncias e covariâncias de dados estatísticos complexos (Reis, 2001).

A ACP, técnica de interdependência, é a abordagem multivariada mais popular na Antropologia Biológica ${ }^{24}$, devido à sua facilidade conceitual e praticidade para 0 estabelecimento de similaridades/dissimilaridades morfológicas entre populações humanas (van Vark \& Schaafsman, 1992). É

\footnotetext{
${ }^{24}$ Como exemplificado no capítulo 1, item 3 - Os primeiros americanos à luz da Antropologia Biológica, apesar de bem fundamentada desde o final dos anos 1930, as técnicas estatísticas multivariadas só puderam ser amplamente aplicadas após o desenvolvimento de computadores e tecnologias capazes de cálculos extensos e complexos.
} 
uma técnica estatística multivariada redutiva, isto é, constrói, a partir dos dados matriciais de correlação ou covariância, vetores de variáveis complexas, que exprimem a informação de mais de uma variável ou dimensão original (Valentin, 2000; Reis, 2001). Basicamente, essa redução é a condensação da informação contida em um grupo de variáveis correlacionadas em eixos ortogonais que expressam porcentagens cumulativas da variância contida na matriz de dados originais. Em outras palavras, cada um dos eixos, os Componentes Principais, resume a informação contida em diversas variáveis de acordo com a correlação ou covariância entre elas (Gower, 1966).

Essa redução permite que as análises executadas a partir da relação ortogonal entre dois Componentes Principais sejam feitas sobre uma alta porcentagem da variabilidade original da amostra, o que fatalmente seria impossível de se fazer através das técnicas bivariadas (Madrigal, 1998; Hair, 1998).

Para o presente estudo decidiu-se extrair os Componentes Principais a partir de matrizes de covariância, uma vez que essas privilegiam as interpretações das relações intergrupais por padronizar a variância original contida na amostra, independentemente dela apresentar ou não uma distribuição normal p-variada (Mingoti, 2005). Permite, pois, que variáveis com variâncias distintas recebam pesos diferenciados na extração de cada componente (James e McCullough 1990; Roseman e Weaver 2004).

A capacidade explanatória dos Componentes Principais é avaliada pela variabilidade expressa (em termos de porcentagem) por cada um dos vetores gerados, sendo essa capacidade extremamente dependente do grau de correlação ou covariância entre as variáveis originais (Mingoti, 2005). Quanto maior a capacidade explanatória dos CPs, melhor é a definição das associações (de similaridade ou dissimilaridade) observáveis no morfo-espaço (Albrecht, 1992; Van Vark \& Schaafsma, 1992).

Neste trabalho, a ACP foi aplicada sobre os centróides hipotéticos, calculados através da média aritmética de cada variável, dentro de cada série. Na ACP a utilização de indivíduos centróides é bastante viável, uma vez que representam a tendência central da dispersão morfológica de cada série 
estudada. $\mathrm{Na}$ análise a partir dos centróides, uma proximidade maior ou menor entre dois pontos no morfo-espaço traduzem uma maior ou menor afinidade morfológica entre os centros hipotéticos das séries (Albrecht, 1992; Van Vark \& Schaafsma, 1992).

Outro fator de decisão em utilizar esses centróides foi tomada tendo em vista as características do banco de dados e a natureza arqueológica de algumas séries em estudo. Em relação ao Banco de Dados, os centróides mostraram-se mais viáveis por diminuir a quantidade de pontos plotados no morfo-espaço, possibilitando uma melhor visualização das afinidades biológicas entre os grupos. Quanto à natureza da amostra arqueológica, a utilização dos centróides é influenciada pela necessidade da técnica de que todos os casos em estudo apresentem-se completos, sem missing-values ${ }^{25}$, o que a natureza fragmentária de crânios arqueológicos raramente permite. Dessa forma, a utilização dos valores centróides evitou a necessidade de substituição das medidas ausentes, mantendo as análises sem a influência de valores estimados. Apenas as variáveis presentes em todas as séries foram utilizadas nos algoritmos de Componentes Principais ${ }^{26}$.

Embora ofereça simples operacionalização e facilite a interpretação das afinidades entre as amostras em estudo, a Análise de Componentes Principais sofre algumas críticas na literatura especializada por não levar em consideração a variância dentro de cada série ou grupo estudado, sendo considerada, por alguns desses críticos, uma forma de transformação de dados e não de análise estatística propriamente dita (Van Vark e Schafsma, 1992).

O fato da ACP não considerar o padrão de variância dentro de cada população não deve ser vista com preocupação neste trabalho. Como algumas das séries utilizadas apresentam pequeno tamanho amostral, principalmente as de origem arqueológica, variações na integridade dos crânios, e também na sua variação morfológica, podem afetar consideravelmente a variância observada, enviesando as técnicas que dependem desse parâmetro estatístico.

\footnotetext{
${ }^{25}$ Embora muito comum mesmo em textos em Língua Portuguesa utilizar-se o termo "missing-values", adotaremos neste trabalho a notação "valores faltantes".

${ }^{26}$ Outras técnicas também necessitam que os casos em estudo estejam completos, sem valores faltantes. Nessas condições, uma das alternativas usuais é a substituição dos valores faltantes. Essa substituição pode ser feita por uma série de técnicas estatísticas, como a regressão linear, a regressão linear múltipla ou a simples substituição pelo valor médio da variável, por exemplo.
} 


\subsection{2 - Análise de Agrupamentos}

A análise de agrupamentos, também conhecida como análise de conglomerados, de classificação, ou de cluster, divide os elementos de uma amostra de acordo com suas características (variáveis). O objetivo dessa divisão, ou agrupamento, é fazer com que elementos de um mesmo grupo sejam semelhantes em relação às variáveis medidas, e os elementos em grupos diferentes, heterogêneos em relação a essas mesmas características (Reis, 2001).

A execução de uma análise de cluster passa, obrigatoriamente, por duas decisões importantes: 1 - a definição de uma medida de distância ou de semelhança entre duas amostras; 2 - a escolha de um critério de agregação ou desagregação das amostras (Reis, 2001).

Neste trabalho adotou-se dois tipos diferentes de medidas de dissimilaridade: distância Euclidiana e distância de Mahalanobis.

Além da escolha da medida de distância, para a análise de agrupamento deve-se também optar pelos critérios de agregação. Basicamente, os vários métodos tentam responder, de formas diferentes, às seguintes questões: a) qual é a distância entre indivíduos do mesmo grupo e entre indivíduos de grupos diferentes? b) qual é a organização (proximidade) entre os indivíduos de um mesmo grupo? c) qual é a densidade dos indivíduos dentro e fora dos grupos? (Reis, 2001).

Neste trabalho empregaram-se 4 diferentes critérios de agregação:

1) Ligação Simples: também conhecida como critério dos vizinhos próximos. Neste método, a similaridade entre dois conglomerados é definida pelos dois elementos mais próximos, ou "parecidos", entre si (Mingoti, 2005), ou seja, encontra os dois elementos separados pela menor distância e os coloca no primeiro agrupamento. Em seguida, a próxima distância mais curta é determinada e um novo elemento se junta aos dois primeiros (Hair et al., 1998). Deste modo, qualquer grupo é 
definido como o conjunto de casos em que qualquer elemento é mais semelhante a pelo menos um outro elemento do mesmo grupo do que a qualquer elemento de outro grupo (Reis, 2001);

2) Ligação Completa: o método da ligação completa é semelhante ao da ligação simples, exceto em que o critério de agrupamento se baseia em distância máxima. Por essa razão, é também chamado de critério dos vizinhos distantes (Hair et al., 1998). A distância máxima entre os indivíduos de cada agregado representa a menor esfera (diâmetro mínimo) que pode incluir todos os indivíduos desse agrupamento (Hair et al., 1998, Mingoti, 2005). Dessa forma, cada grupo passa a ser definido como um conjunto de elementos em que cada um é mais semelhante a todos os elementos do seu grupo do que a qualquer um dos elementos dos outros grupos restantes (Reis, 2001; Mingoti, 2005);

3) Critério das Médias dos Grupos: este critério define a distância entre dois grupos como sendo a média das distâncias entre todos os pares de indivíduos constituídos por elementos dos dois grupos. Esse método é uma alternativa intermediária aos dois critérios apresentados anteriormente. Enquanto que 0 critério dos vizinhos próximos utiliza o menor valor de distância para a inclusão de um novo indivíduo e o dos vizinhos distantes utiliza a maior distância para uma nova inclusão, o critério da média evita valores extremos, utilizando como critério de agregação a distância mínima entre todos os indivíduos de um mesmo grupo.

4) Método de Ward: também conhecido como Mínima Variância. Esse método considera, inicialmente, cada elemento como sendo um único grupo. Em cada passo do algoritmo de agrupamento, calcula-se a soma de quadrados dento de cada grupo formado $(k-1)(k)(k+1)$. Tende a combinar 
agrupamentos dicotômicos ou com pequeno número de observações, além de conglomerados com números próximos de observações (grupos de tamanhos semelhantes) (Hair et al., 1998; Mingoti, 2005).

\subsection{3 - Distância Euclidiana}

A distância Euclidiana entre dois casos é dada pela raiz quadrada da somatória dos quadrados das diferenças entre os dois casos para todas as variáveis analisadas. Tem-se, assim, uma medida média de todos os pontos em relação a um centróide (Mingoti, 2005). No presente trabalho, as distâncias Euclidianas foram calculadas entre os valores dos Componentes Principais (Sokal \& Rohlf, 1969) e não entre os valores das variáveis originais. A Distância Euclidiana calculada a partir dos Componentes Principais é preferível ao invés da distância entre os valores brutos porque no caso dos Componentes Principais não existe correlação entre eles, ou seja, cada vetor expressa características independentes dos demais vetores (Manly, 1994). No entanto, esse recurso matemático apresenta uma séria desvantagem, uma vez que não são todos os Componentes Principais que entram na matriz de cálculo de distâncias ${ }^{27}$.

Por outro lado, se calculadas sobre os dados brutos, as medidas das Distâncias Euclidianas seriam enviesadas pelas variáveis que apresentassem maiores correlações entre si (Sokal \& Rohlf, 1969). Uma maneira de compensar esse viés, além do cálculo das distâncias sobre os Componentes Principais, seria calcular Distâncias Biológicas de Mahalanobis (Mahalanobis, 1936), porém ela é desenvolvida para análises entre indivíduos dentro de populações, de maneira dependente, não sendo possível aplica-la às análises sobre centróides

\footnotetext{
${ }^{27}$ Existem diferentes estratégias para o cálculo de Distâncias Euclidianas a partir dos Componentes Principais. A mais tradicionalmente utilizada é a de escolher-se todos OS CP's mais significativos, isto é, todos os que apresentem autovalores maiores que 1 e/ou expressando mais de $1 \%$ da variância original (Sokal \& Rohlf, 1969). No entanto, como os autovalores que expressam baixa porcentagem da variância normalmente estão correlacionados com resíduos de erros estatísticos (Manly, 1994) decidiu-se, neste trabalho, utilizar a abordagem do "decaímento", que consiste em utilizar como critério de corte o primeiro Componente Principal anterior à segunda queda da expressão dos autovalores, visualizada através do screeplot (Hair et al., 1998; Reis, 2001).
} 
hipotéticos. Dessa forma, decidiu-se, também, montar matrizes de dissimilaridades a partir de Distâncias Generalizadas de Mahalanobis.

\subsection{4 - Distância Generalizada de Mahalanobis e Escalonamento Multidimensional}

A utilização da Distância generalizada de Mahalanobis $\left(D^{2}\right)$ representa uma poderosa ferramenta para se medir a similaridade ou dissimilaridade entre conjuntos de amostras, sendo muito útil para identificar o quanto dois, ou mais, subconjuntos de uma amostra podem associar-se (Clark et al., 1993). Por esse motivo é classicamente utilizada para medir-se distâncias biológicas (Hubbe, 2005; Reis, 2001; Valentin, 2000).

A Distância de Mahalanobis entre dois casos é obtida a partir da soma das diferenças ponderadas pela matriz de covariância entre os dois casos para todas as variáveis analisadas. Dessa forma, a distância de Mahalanobis é uma generalização que leva em conta a correlação entre as variáveis, fazendo com que quanto menor a correlação entre elas, maior o peso dado na soma geral (Mahalanobis, 1936).

É a medida de distância entre dois pontos no espaço definidos por duas ou mais variáveis correlacionadas. Obtida a partir do produto das diferenças entre um mesmo conjunto de variáveis de dois pontos (dependendo do nível de análise, os pontos podem ser grupos ou indivíduos, por exemplo), corrige a projeção das distâncias através da aplicação da matriz de covariância entre as variáveis no algoritmo de cálculo. A fórmula de cálculo da $D^{2}$ desenvolve-se como segue:

$$
D^{2}=(x-m)^{\top} C^{-1}(x-m)
$$

Onde: D²: Distância Generalizada de Mahalanobis

$\mathrm{x}$ : Vetor de dados

m: Vetor-média dos valores das variáveis independentes

$\mathrm{C}^{-1}$ : Matriz inversa da Matriz de Covariância das variáveis independentes

$\mathrm{T}^{\mathrm{S}}$ Indica que o vetor deve ser transposto 
Da fórmula acima, depreende-se que o cálculo da Distância de Mahalanobis é baseado tanto na média quanto na variância das variáveis preditoras, o que algebricamente corrige as distorções causadas pelas projeções dos pontos, como acontece no cálculo de distâncias Euclidianas. Por exemplo, se há duas variáveis que não são correlacionadas entre si, pode-se plotar seus pontos em um gráfico bidimensional. Neste caso, a distância de Mahalanobis entre os pontos é idêntica à Distância Euclidiana. Entretanto, quando as variáveis são correlacionadas, como é comum acontecer entre variáveis de sistemas biológicos, os eixos podem ser não ortogonais, o que torna a distância euclidiana inapropriada (Mahalanobis, 1936; Hair et al., 1998).

Para cada grupo na análise, pode-se determinar a localização do ponto que representa as médias de todas as variáveis no espaço multivariado definido pelas variáveis no modelo. Estes pontos são chamados de centróides. Para cada caso podemos computar as distâncias de Mahalanobis a cada centróide. A probabilidade de um indivíduo pertencer a um grupo é basicamente proporcional à distância de Mahalanobis até o centróide de determinado grupo (não é exatamente proporcional porque assume-se uma distribuição normal multivariada em volta de cada centróide). A Figura 3.8 exemplifica o conceito de Distância de Mahalanobis a partir de um centróide hipotético (no exemplo, o encontro entre os eixos dentro do plano cartesiano).

Figura 3.8 - Elipses de Distância de Mahalanobis

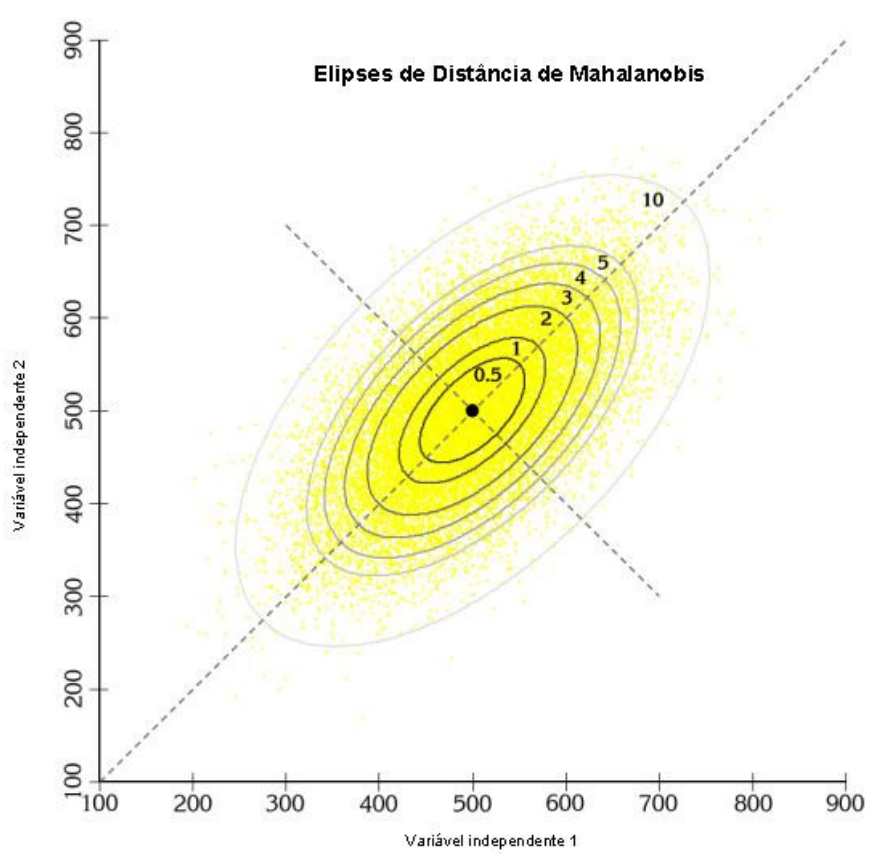


Além de servir para a montagem da matriz de dissimilaridade para a execução das análises de agrupamentos, o cálculo das distâncias de Mahalanobis também foram utilizadas como base para o Escalonamento Multidimensional.

Escalonamento multidimensional (MDS) é a maneira de estabelecer espacialmente as relações de similaridade e dissimilaridades entre dois pontos a partir de uma distância. Basicamente, o MDS distribui os casos de determinada análise de forma que os que apresentem menor distância absoluta se posicionem no espaço multidimensional mais próximos entre si do que com qualquer outro dado analisado (Hair, 1998).

Essa técnica dimensiona as similaridades morfológicas representadas pelas variáveis em estudo em distâncias contidas num espaço multidimensional. Assim, dados dois casos, A e B, considerados mais semelhantes entre si quando comparados com qualquer outro par de casos em análise, o MDS aproximará os pontos A e B de tal forma que a distância entre eles no espaço multidimensional seja menor do que entre quaisquer outros pares de pontos (casos). Dessa forma, o MDS pode ser considerado a técnica de dependência correspondente à Análise de Componentes Principais, de interdependência. Assim como para as ACP's, as topologias resultantes, a partir da relação entre duas dimensões calculadas, exibem a posição relativa de todos os pontos, embora, diferentemente daquelas, exista a necessidade de análises complementares para descrever, predizer e avaliar quais atributos ditam a posição de cada objeto (Hair et al., 1998; Mingoti, 2005; Reis, 2001).

\section{3 - Novo e Velho Mundo: Contextualização Progressiva}

Como exposto nos capítulos anteriores, o presente trabalho foi delineado a partir da necessidade de rebater algumas críticas às investigações clássicas, desenvolvidas por Neves e colaboradores, sobre as afinidades biológicas entre os paleoíndios de Lagoa Santa e outras populações autóctones mundiais (Neves \& Hubbe, 2005). Para tal, decidimos utilizar um novo banco de dados, numericamente mais representativo, na esperança de explorar de maneira mais profunda as associações 
morfológicas entre os Paleoíndios de Lagoa Santa e os nativos americanos e suas relações com outras populações planetárias.

Sem dúvida nenhuma, estudos baseados em amostras quantitativa e qualitativamente expressivas contam com maior robustez estatística, conferindo maior confiabilidade às conclusões obtidas. Em contrapartida, impõem crescente complexidade estatística à análise e interpretação dos dados (Gelman et al., 1998).

Tal paradoxo metodológico tornou-se um ponto central deste trabalho ainda na sua fase de concepção. Se por um lado uma de suas principais virtudes é a expressão numérica do conjunto amostral utilizado, por outro, a mesma grandiosidade quantitativa inviabiliza a aplicação de alguns algoritmos de Estatística Multivariada e, principalmente, prejudica a visualização e a interpretação das relações matematicamente esboçadas.

Dessa forma, para investigar as afinidades biológicas dos Paleoíndios de Lagoa Santa, decidiu-se, seguindo a proposta já explicitada no próprio título do trabalho, utilizar diferentes níveis de escala geográfica, isto é, testar as afinidades morfológicas intra e extra-continentais separadamente. Os resultados obtidos em cada nível da escala podem interpolar-se as análises dos outros níveis, aumentando, progressivamente, a capacidade interpretativa das associações morfológicas observadas. Tal abordagem corresponde à "contextualização progressiva" (Vayda, 1983), estratégia comumente utilizada na Antropologia Ecológica (Hubbe, 2006).

\subsection{1 - Primeiro nível: Investigação das afinidades biológicas intra-continentais}

Para o estudo das afinidades biológicas intra-continentais dos Paleoíndios de Lagoa Santa foram utilizadas as características craniométricas médias das populações de 7 regiões geográficas (Aleutas, Esquimós, Norte-americanos, Centro-sulamericanos, Colombianos e Sul-americanos arcaicos) além da, obviamente, própria amostra de Lagoa Santa.

Foram feitas algumas intervenções no banco original para a montagem da matriz de dados final explorada. Num primeiro momento optou-se por retirar das análises as variáveis consideradas incompatíveis, seja por diferença protocolar na tomada da medida, seja por sua ausência na série Paleoíndia de Lagoa Santa. Tal estratégia foi necessária devido à natureza secundária do banco de dados utilizado, 
uma vez que a uniformidade de protocolos de tomadas de medidas é condição imprescindível para sua consolidação ${ }^{28}$. Outra condição, esta para a aplicação de técnicas multivariadas de interdependência (como a Análise de Componentes Principais, por exemplo) é a ausência de valores faltantes, o que também motivou a retirada das variáveis consideradas incompatíveis. Dessa forma, os testes realizados neste estudo foram executados sobre uma matriz contendo 23 variáveis.

A partir daí, todos as séries que contavam com apenas 1 indivíduo, com exceção ao espécime de Lapa Vermelha IV (o remanescente recuperado na região de Lagoa Santa popularmente conhecido como "Luzia") também foram retiradas da matriz, assim como o foram as que ainda apresentavam valores faltantes, à exceção das séries Paleoíndias de Lagoa Santa. Por fim, as séries de Lagoa Santa que apresentavam valores faltantes em quantidade igual ou superior a $30 \%$ das variáveis foram, também, retiradas da matriz de dados finais.

Embora, em geral, as técnicas estatísticas multivariadas apresentem sensibilidade diferencial ao tipo de substituição de valores faltantes (Mingoti, 2005), decidiu-se aqui, trabalhar com a estratégia mais conservadora possível. Assim, substituiu-se o valor faltante pelo valor médio de todos os indivíduos (sem distinção entre séries e grupos) incluídos na análise para a respectiva variável. Procedendo-se dessa forma, não se forçou a exacerbação de um traço ou característica específica de determinada série. Os mesmos procedimentos foram tomados, separadamente, para os conjuntos de dados das parcelas masculina e feminina.

As Tabelas 3.5 e 3.6 apresentam, a seguir, a configuração final adotada para a análise intra-continental para as parcelas masculina e feminina, respectivamente. Informações como a região geográfica do grupo, bem como o símbolo a ele assignado nas análises, nomes e abreviaturas das séries utilizadas com seus respectivos números (N) amostrais também são fornecidos nas mesmas.

As tabelas 3.7 e 3.8 apresentam, para as parcelas masculina e feminina, respectivamente, a matriz de dados utilizada na investigação das afinidades morfológicas intra-continentais através da Análise de Componentes Principais. Os valores escritos em vermelho correspondem aos valores faltantes substituídos pela média geral, como descrito acima.

\footnotetext{
${ }^{28}$ Neste estudo as variáveis retiradas foram MDH e SIS. Embora, ambas, sejam tomadas de maneira idêntica ao preconizado no protocolo estabelecido por Howells (1973), essas medidas apresentam problemas e vieses na sua utilização. A primeira, $\mathrm{MDH}$, é uma medida que apresenta um alto índice de erro inter-observador, o que é bem crítico devido à natureza do banco de dados empregado para esta investigação. A segunda, SIS, é uma medida que necessita de um equipamento adequado, de difícil acesso, o que também acaba, por vezes, inviabilizando sua tomada.
} 
Tabela 3.5 - Composição das séries esqueletais utilizadas na análise de afinidades intracontinentais (Parcela Masculina).

\begin{tabular}{|c|c|c|c|c|c|c|c|}
\hline Grupo/símbolo & Série & Abreviatura & $\mathrm{N}$ & Grupo/símbolo & Série & Abreviatura & $\mathrm{N}$ \\
\hline \multirow{6}{*}{ Aleuta - O } & Aleuta 1 & Ale 1 & 82 & \multirow{27}{*}{$\begin{array}{l}\text { América do Norte } \\
- \text { EUA - } \triangle \\
\text { (continuação) }\end{array}$} & $\begin{array}{c}\text { EUA - } \\
\text { Delaware }\end{array}$ & ANE - De & 10 \\
\hline & Aleuta 2 & Ale 2 & 45 & & EUA - Florida & ANE - FI & 96 \\
\hline & Aleuta 3 & Ale 3 & 13 & & EUA - Georgia & ANE - Ge & 19 \\
\hline & Aleuta 4 & Ale 4 & 18 & & EUA - Illinois & ANE - II & 118 \\
\hline & Aleuta 5 & Ale 5 & 5 & & EUA - Indiana & ANE - In & 4 \\
\hline & Aleuta 6 & & 16 & & EUA - Kansas & ANE - Ka & 10 \\
\hline \multirow{3}{*}{$\begin{array}{l}\text { América do Norte } \\
\text { - Canadá - } \triangle\end{array}$} & $\begin{array}{l}\text { Canadá - British } \\
\text { Columbia }\end{array}$ & ANC - CB & 78 & & $\begin{array}{l}\text { EUA - } \\
\text { Kentucky }\end{array}$ & ANE - Ke & 37 \\
\hline & Canadá - Central & ANC - C & 3 & & $\begin{array}{l}\text { EUA - } \\
\text { Louisiana }\end{array}$ & ANE - Lo & 8 \\
\hline & $\begin{array}{c}\text { Canadá - Iroques } \\
\text { Ontario }\end{array}$ & ANC - On & 40 & & $\begin{array}{l}\text { EUA - } \\
\text { Maryland }\end{array}$ & ANE - Ma & 54 \\
\hline \multirow{10}{*}{$\begin{array}{c}\text { América Central } \\
\text { e do Sul - } \square\end{array}$} & CSA - Bolívia & ACS - Bo & 9 & & EUA - Michigan & ANE - Mi & 12 \\
\hline & CSA - Caribe & $\mathrm{ACS}-\mathrm{Ca}$ & 13 & & $\begin{array}{l}\text { EUA - } \\
\text { Mississipi }\end{array}$ & ANE - Mp & 3 \\
\hline & CSA - Chile & ACS - Ch & 20 & & EUA - Missouri & ANE - Ms & 10 \\
\hline & CSA - Colômbia & ACS - Co & 20 & & EUA - Montana & ANE - Mo & 15 \\
\hline & CSA - Equador & ACS - Eq & 7 & & $\begin{array}{l}\text { EUA- } \\
\text { Nebraska }\end{array}$ & ANE - Ne & 17 \\
\hline & $\begin{array}{c}\text { CSA - Fueguinos } \\
\text { (Patagonia) }\end{array}$ & ACS - Fu & 57 & & EUA - Nevada & ANE - Nv & 2 \\
\hline & CSA - Guiana & ACS - Gu & 7 & & $\begin{array}{l}\text { EUA - New } \\
\text { Jersey }\end{array}$ & ANE - NJ & 8 \\
\hline & CSA - México & ACS - Me & 73 & & $\begin{array}{l}\text { EUA - Novo } \\
\text { México }\end{array}$ & ANE - NM & 63 \\
\hline & CSA - Peru & ACS - Pe & 223 & & $\begin{array}{l}\text { EUA - Nova } \\
\text { York }\end{array}$ & ANE - NY & 27 \\
\hline & CSA - Venezuela & ACS - Ve & 12 & & $\begin{array}{c}\text { EUA - Nordeste } \\
\text { americano }\end{array}$ & ANE - NE & 9 \\
\hline \multirow{7}{*}{ Esquimó - $\boldsymbol{\Delta}$} & $\begin{array}{c}\text { Esquimó - Alaska } \\
1\end{array}$ & Esq - Al1 & 135 & & EUA - Oregon & ANE - Or & 13 \\
\hline & & Esq - Al2 & 107 & & $\begin{array}{c}\text { EUA - } \\
\text { Tennessee }\end{array}$ & ANE - Te & 10 \\
\hline & $\begin{array}{c}\text { Esquimó - Alaska } \\
3\end{array}$ & Esq - Al3 & 70 & & EUA - Texas & ANE - Tx & 17 \\
\hline & Esquimó - Ásia & Esq - As & 22 & & EUA - Utah & ANE - Ut & 58 \\
\hline & Esquimó - Canadá & Esq - Ca & 30 & & EUA - Virginia & ANE - Vi & 58 \\
\hline & Groelândia & Esq - Gr & 107 & & $\begin{array}{l}\text { EUA - } \\
\text { Washington }\end{array}$ & ANE - Wa & 2 \\
\hline & $\begin{array}{c}\text { Esquimó - } \\
\text { Desconhecido }\end{array}$ & Esq & 10 & & $\begin{array}{c}\text { EUA - } \\
\text { Wisconsin }\end{array}$ & ANE - Wi & 5 \\
\hline \multirow{12}{*}{$\begin{array}{c}\text { América do Norte } \\
- \text { EUA }-\triangle\end{array}$} & EUA - Alabama & ANE - Ab & 5 & & $\begin{array}{c}\text { EUA - } \\
\text { Wyoming }\end{array}$ & ANE - Wy & 3 \\
\hline & $\begin{array}{c}\text { EUA - Nativos do } \\
\text { Alaska }\end{array}$ & ANE - Al & 36 & \multirow{6}{*}{$\begin{array}{c}\text { Paleoíndios de } \\
\text { Lagoa Santa - • }\end{array}$} & $\begin{array}{c}\text { Lapa de } \\
\text { Carrancas }\end{array}$ & LSA - Car & 2 \\
\hline & $\begin{array}{c}\text { EUA - Alaska } \\
\text { (Kodiak) }\end{array}$ & ANE - Al K & 15 & & $\begin{array}{c}\text { Lapa Mortuária } \\
\text { de Confins }\end{array}$ & LSA - Con & 3 \\
\hline & $\begin{array}{c}\text { EUA - Alaska } \\
\text { (Tlingit) }\end{array}$ & ANE - Al T & 35 & & Cerca Grande & LSA - CGr & 5 \\
\hline & EUA - Arizona & ANE - Ar & 41 & & $\begin{array}{c}\text { Coleção Harold } \\
\text { Walter }\end{array}$ & LSA - HW & 11 \\
\hline & EUA - Arkansas & ANE - Ak & 29 & & $\begin{array}{l}\text { Santana do } \\
\text { Riacho }\end{array}$ & LSA - SaR & 2 \\
\hline & EUA - Califórnia 1 & ANE - Ca1 & 61 & & Sumidouro & LSA - Sum & 17 \\
\hline & EUA - Califórnia 2 & ANE - Ca2 & 163 & \multirow{2}{*}{$\begin{array}{c}\text { Arcaicos da } \\
\text { América do Sul - }\end{array}$} & Base Aérea & Base & 20 \\
\hline & EUA - Califórnia 3 & ANE - Ca3 & 5 & & & & 31 \\
\hline & EUA - Colorado & ANE - Co & 6 & \multirow{3}{*}{ Colombianos - O } & $\begin{array}{l}\text { Colômbia } \\
\text { Paleoíndio }\end{array}$ & Col - P & 6 \\
\hline & $\begin{array}{c}\text { EUA - Dakota do } \\
\text { Norte }\end{array}$ & ANE - DN & 15 & & Colômbia & $\mathrm{Col}-\mathrm{A}$ & 26 \\
\hline & $\begin{array}{l}\text { EUA - Dakota do } \\
\text { Sul } 2\end{array}$ & ANE - DS2 & 119 & & Arcaico & $-01-A$ & 20 \\
\hline
\end{tabular}


Após a montagem do conjunto de dados, as análises referentes à parcela masculina dos dados foram conduzidas sobre 2.569 indivíduos enquanto que a feminina sobre 1.787 espécimes.

Tabela 3.6 - Composição das séries esqueletais utilizadas na análise de afinidades intracontinentais (Parcela Feminina).

\begin{tabular}{|c|c|c|c|c|c|c|c|}
\hline Grupo/símbolo & Série & Abreviatura & $\mathrm{N}$ & Grupo/símbolo & Série & Abreviatura & $\mathrm{N}$ \\
\hline \multirow{6}{*}{ Aleuta - $\bigcirc$} & Aleuta 1 & Ale 1 & 57 & \multirow{24}{*}{$\begin{array}{c}\text { América do } \\
\text { Norte - EUA - } \\
\triangle\end{array}$} & EUA - Florida & ANE - FI & 62 \\
\hline & Aleuta 2 & Ale 2 & 42 & & EUA - Georgia & ANE - Ge & 10 \\
\hline & Aleuta 3 & Ale 3 & 13 & & EUA - Illinois & ANE - II & 88 \\
\hline & Aleuta 4 & Ale 4 & 7 & & EUA - Indiana & ANE - In & 2 \\
\hline & Aleuta 5 & Ale 5 & 7 & & EUA - Kansas & ANE - Ka & 11 \\
\hline & Aleuta 6 & Ale 6 & 5 & & EUA - Kentucky & ANE - Ke & 25 \\
\hline \multirow{2}{*}{$\begin{array}{c}\text { América do } \\
\text { Norte }- \\
\text { Canadá }-\triangle\end{array}$} & $\begin{array}{l}\text { Canadá - British } \\
\text { Columbia }\end{array}$ & $A N C-C B$ & 22 & & EUA - Louisiana & ANE - Lo & 2 \\
\hline & $\begin{array}{c}\text { Canada - Iroques } \\
\text { Ontario } \\
\end{array}$ & ANC - On & 6 & & EUA - Maryland & ANE - Ma & 42 \\
\hline \multirow{7}{*}{$\begin{array}{c}\text { América } \\
\text { Central e do } \\
\text { Sul - } \square\end{array}$} & CSA - Argentina & ACS - Ar & 2 & & $\begin{array}{c}\text { EUA - } \\
\text { Massachusetts }\end{array}$ & ANE - Mc & 3 \\
\hline & CSA - Bolívia & ACS - Bo & 6 & & EUA - Michigan & ANE - Mi & 6 \\
\hline & CSA - Chile & ACS - Ch & 20 & & EUA - Missouri & ANE - Ms & 4 \\
\hline & CSA - Equador & ACS - Eq & 2 & & EUA - Montana & ANE - Mo & 7 \\
\hline & $\begin{array}{l}\text { CSA - Fueguinos } \\
\text { (Patagonia) }\end{array}$ & ACS - Fu & 14 & & EUA - Nebraska & ANE - $\mathrm{Ne}$ & 9 \\
\hline & CSA - México & ACS - Me & 43 & & EUA - New Jersey & ANE - NJ & 7 \\
\hline & $\begin{array}{c}\text { CSA - Peru } \\
\text { CSA - Venezuela }\end{array}$ & $\begin{array}{l}\text { ACS - Pe } \\
\text { ACS - Ve }\end{array}$ & $\begin{array}{c}143 \\
2 \\
\end{array}$ & & $\begin{array}{c}\text { EUA - Novo México } \\
\text { EUA - Nova York }\end{array}$ & $\begin{array}{l}\text { ANE - NM } \\
\text { ANE - NY }\end{array}$ & $\begin{array}{l}50 \\
24\end{array}$ \\
\hline \multirow{7}{*}{ Esquimó - $\boldsymbol{\Delta}$} & Esquimó - Alaska & Esq - Al1 & 130 & & EUA - Oklahoma & ANE - Ok & 3 \\
\hline & $\begin{array}{c}\text { Esquimó - Alaska } \\
2\end{array}$ & Esq - Al2 & 104 & & EUA - Oregon & ANE - Or & 3 \\
\hline & $\begin{array}{c}\text { Esquimó - Alaska } \\
3\end{array}$ & Esq - Al3 & 60 & & EUA - Pensilvania & ANE - Pe & 2 \\
\hline & Esquimó - Ásia & Esq - As & 16 & & EUA - Tennessee & ANE - Tn & 13 \\
\hline & Esquimó - Canadá & Esq - Ca & 25 & & EUA - Texas & ANE - Tx & 10 \\
\hline & $\begin{array}{l}\text { Esquimó - } \\
\text { Groelândia }\end{array}$ & Esq - Gr & 57 & & EUA - Utah & ANE - Ut & 40 \\
\hline & $\begin{array}{c}\text { Esquimó - } \\
\text { Desconhecido }\end{array}$ & Esq & 3 & & EUA - Virginia & ANE - Vi & 33 \\
\hline \multirow{13}{*}{$\begin{array}{c}\text { América do } \\
\text { Norte - EUA - } \\
\triangle\end{array}$} & EUA - Alabama & ANE - Ab & 7 & & EUA - Washington & ANE - Wa & 2 \\
\hline & $\begin{array}{c}\text { EUA - Nativos do } \\
\text { Alaska }\end{array}$ & ANE - Al & 29 & & EUA - Wisconsin & ANE - Wi & 5 \\
\hline & $\begin{array}{l}\text { EUA - Alaska } \\
\text { (Kodiak) }\end{array}$ & ANE - Al K & 14 & \multirow{5}{*}{$\begin{array}{c}\text { Paleoíndios de } \\
\text { Lagoa Santa - } \\
\end{array}$} & $\begin{array}{l}\text { Lagoa Santa - } \\
\text { Cerca Grande }\end{array}$ & LSA - CGr & 4 \\
\hline & $\begin{array}{l}\text { EUA - Alaska } \\
\text { (Tlingit) }\end{array}$ & ANE - AI T & 11 & & $\begin{array}{l}\text { Lagoa Santa - Lapa } \\
\text { Vermelha IV }\end{array}$ & LSA - LV IV & 1 \\
\hline & EUA - Arizona & ANE - Ar & 35 & & $\begin{array}{l}\text { Lagoa Santa - } \\
\text { Harold Walter }\end{array}$ & LSA - HW & 11 \\
\hline & EUA - Arkansas & ANE - Ak & 12 & & $\begin{array}{l}\text { Lagoa Santa- } \\
\text { Santana do Riacho }\end{array}$ & LSA - SaR & 4 \\
\hline & EUA - California 1 & ANE - Ca1 & 50 & & $\begin{array}{c}\text { Lagoa Santa - } \\
\text { Sumidouro }\end{array}$ & LSA - Sum & 13 \\
\hline & EUA - California 2 & ANE - Ca2 & 156 & \multirow{3}{*}{$\begin{array}{c}\text { Arcaicos da } \\
\text { América do } \\
\text { Sul - }\end{array}$} & Base Aérea & Base & 17 \\
\hline & EUA - Colorado & ANE - Co & 2 & & Tapera & Tapera & 34 \\
\hline & & & & & & & \\
\hline & $\begin{array}{l}\text { EUA - Dakota do } \\
\text { Norte }\end{array}$ & ANE - DN & 11 & \multirow{3}{*}{$\begin{array}{c}\text { Colombianos } \\
-0\end{array}$} & $\begin{array}{c}\text { Colômbia } \\
\text { Paleoíndio }\end{array}$ & Col - P & 11 \\
\hline & $\begin{array}{l}\text { EUA - Dakota do } \\
\text { Sul }\end{array}$ & ANE & 76 & & Colômbia Arcaico & Col - A & 30 \\
\hline & EUA - Delaware & ANE - De & 10 & & & & \\
\hline
\end{tabular}


Tabela 3.7 - Centróides das séries esqueletais utilizadas na análise de afinidades intracontinentais (Parcela Masculina).

\begin{tabular}{|c|c|c|c|c|c|c|c|c|c|c|c|c|c|c|c|c|c|c|c|c|c|c|c|}
\hline Série & $\mathrm{OL}$ & $\mathrm{DL}$ & BNL & $\mathrm{XCB}$ & XFB & UB & ASB & BBH & FRC & PAC & $\mathrm{OCC}$ & BPL & ZYB & NPH & DKB & $\mathrm{OBH}$ & NLB & $\mathrm{NLH}$ & MAB & MDB & WNB & ZMB & SSS \\
\hline e 1 & 2,114 & 0,449 & 11,449 & 47,076 & 17,300 & 34,196 & 16,474 & 130,065 & 1,744 & 6,60 & 98,150 & 103,169 & 43,716 & 2,468 & 21,437 & 36,056 & 5,80 & 54,114 & 66,163 & 17,813 & 7,646 & \begin{tabular}{|l|l|}
102,7331 \\
\end{tabular} & 20 \\
\hline & & & & & & & & & & & & & & & & & & & & & & & \\
\hline$\hat{1}$ & & & , 192 & ,346 & 515 & 46 & 38 & & & & 17 & 25 & 136 & 42 & ,269 & & 54 & & & & 8,344 & & ,77 \\
\hline & & & & 71 & , & & & & & & & & & & & & & & & & 61 & & 131 \\
\hline 5 & 00 &, 400 & 400 & 3,400 & 3,000 & 0,600 & 1,300 & 50 &, 80 & 8,4 & 97,6 & 8,0 & 3,667 & 00 & bo & 00 & 0 & 0 & 00 & 000 & 02 & 80 & ,388 \\
\hline e 6 & & & & & & & & & & & & & & & & & & & & & & & \\
\hline$N C-C B$ & & & 50 & 54 & 58 & & 95 & & & & & & 75 & & & & & & & & 610 & & \\
\hline$c$. & & & & & & & & & & & & & & 0 & & & & & & & 93 & & \\
\hline$-O n$ & 17 & 556 & ,243 &, 542 &, 378 & 543 &, 361 & 6,250 & & & 543 & 102,067 & 0,679 &, 935 & 22,774 & 5,288 & 39 & 68 & 194 & 378 & 9,142 & 82 & 86 \\
\hline & & & & & & & & & & & & & & & & & & & & & & & \\
\hline & & & 2 & & & & & & & & & & & & 00 & & & & & & & & \\
\hline & & 5 & 5 & & & & & & & & & 100,263 & & & & 0 & & & & & & & \\
\hline & 78 & 667 & 333 & 36 & & 429 & 445 & 4,500 & & & & 15 & 300 & 7,294 &, 444 & 34,816 & & & & & 163 & 100 & 385 \\
\hline & & & & & & & & & & & & & & & & & & & & & & & \\
\hline & & & & & & & & & & & & & & & & & & & & & & & \\
\hline & & & & & & & & & & & & & & & & & & & & & & & 110 \\
\hline Me & & 89 & 0,593 & & 11 & & 57 & j, 147 & & & 119 & ,254 & & 529 & 2,382 & 438 & & & 57 & & 051 & & 696 \\
\hline & & & & & & & & & & & & & & & & & & & & & & & \\
\hline & & & & & & & & & & & & & & & & & & & & & & & \\
\hline & & & 1 & & & & & & & & & & & & & & & & & & & & \\
\hline & & & 849 & & & & & & & & ,977 & & & & & & & & & & 08 & & 136 \\
\hline & & & & & & & & & & & & & & & & & & & & & & & \\
\hline & & & & & & & & & & & & & & & & & & & & & & & \\
\hline & & & & & & & & & & & & & & & & & & & & & & & \\
\hline - $\mathrm{Gr}$ & & & & & & & & & & & & & & & & & & & & & 36 & & 54 \\
\hline & & & & & & & & & & & & & & & & & & & & & & & \\
\hline & & & & & & & & & & & & & & & & & & & & & & & \\
\hline - Al & & & & & & & & & & & & & & & & & & & & & & & \\
\hline & & & & & & & & & & & & & & & & & & & & & & & \\
\hline & & & & & & & & & & & & & & & & & & & & & & & \\
\hline & & & & & & & & & & & & & & & & & & & & & & & \\
\hline Ak & & & & & & & & & & & & & & & & & & & & & & & \\
\hline & & & & & & & & & & & & & & & & & & & & & & & \\
\hline & & & & & & & & & & & & & & & & & & & & & & & \\
\hline & & & & & & & & & & & & & & & & & & & & & & & \\
\hline & & & & & & & & & & & & & & & & & & & & & & & \\
\hline & & & & & & & & & & & & & & & & & & & & & & & \\
\hline & & & & & & & & & & & & & & & & & & & & & & & 521 \\
\hline & & & & & & & & & & & & & & & & & & & & & & & \\
\hline & & & & & & & & & & & & & & & & & & & & & & & \\
\hline & & & & & & & & & & & & & & & & & & & & & & & \\
\hline & & & & & & & & & & & & & & & & & & & & & & & 938 \\
\hline & & & & & & & & & & & & & & & & & & & & & & & \\
\hline & & & & & & & & & & & & & & & & & & & & & & & \\
\hline & & & & & & & & & & & & & & & & & & & & & & & \\
\hline & & & & & & & & & & & & & & & & & & & & & 2 & & \\
\hline & & & & & & & & & & & & & & & & & & & & & & & \\
\hline $\mathrm{Ma}$ & & & & & & & & & & & & & & & & & & & & & 017 & 790 & \\
\hline & & & & & & & & & & & & & & & & & & & & & & & \\
\hline & & & & & & & & & & & & & & & & & & & & & & & \\
\hline
\end{tabular}




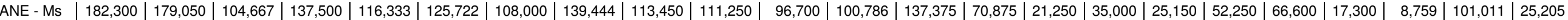

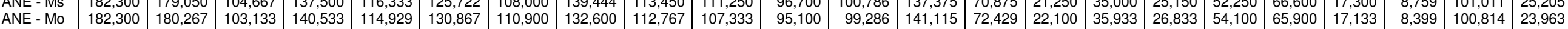

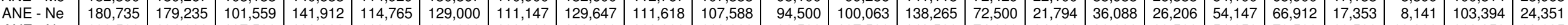

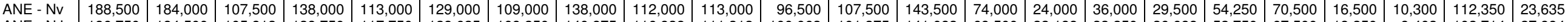

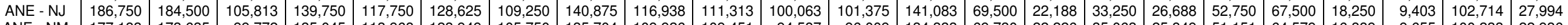

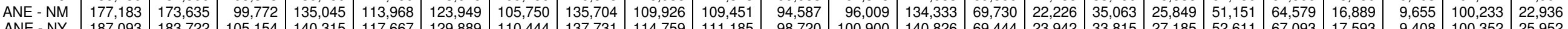

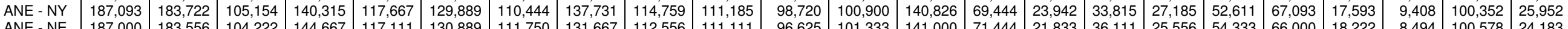

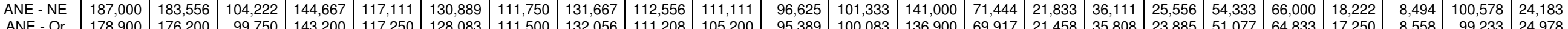

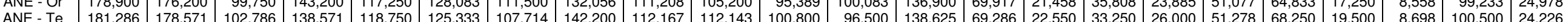

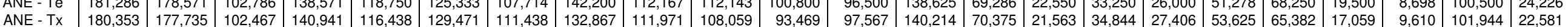

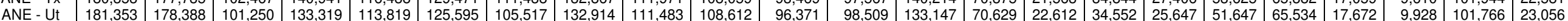

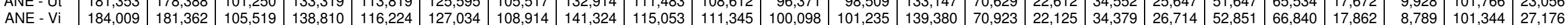

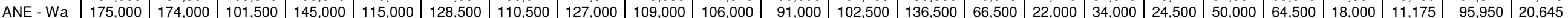

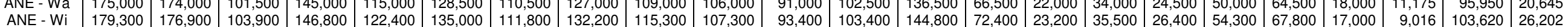

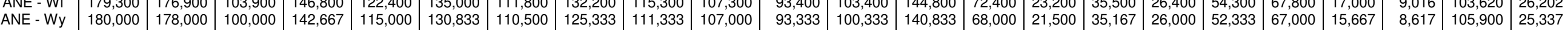

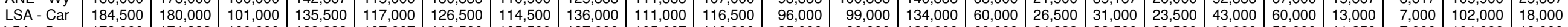

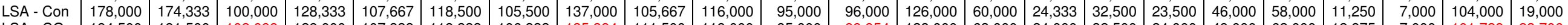

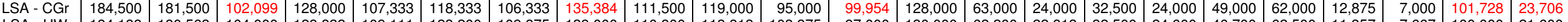

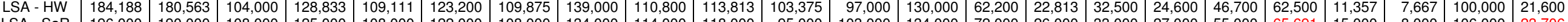

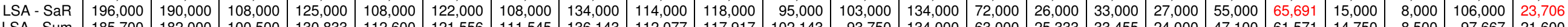

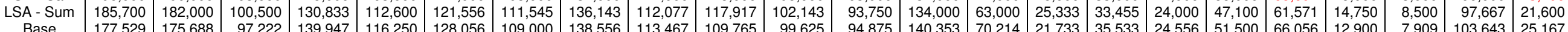

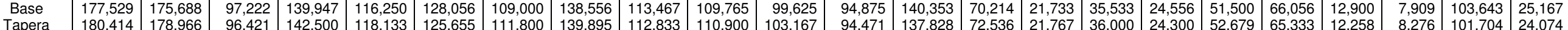

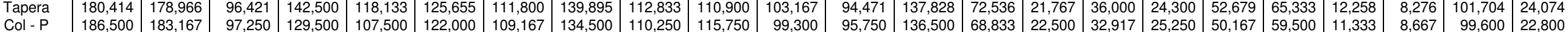

\footnotetext{
* Obs.: Valores em vermelho indicam substituição de valor faltante pela média de todos os valores presentes para a respectiva variável.
}

Tabela 3.8 - Centróides das séries esqueletais utilizadas na análise de afinidades intracontinentais (Parcela Feminina).

\begin{tabular}{|c|c|c|c|c|c|c|c|c|c|c|c|c|c|c|c|c|c|c|c|c|c|c|c|}
\hline Série & GOL & NOL & BNL & $\mathrm{XCB}$ & XFB & AUB & ASB & $\mathrm{BBH}$ & FRC & PAC & OCC & $\mathrm{BF}$ & Z) & $\mathrm{NPH}$ & DK & 0 & NLB & $\mathrm{NLH}$ & $\mathrm{MA}$ & M & W & Z & SSS \\
\hline Ale 1 & 175,795 & 175,080 & 96,918 & 142,605 & 112,673 & 127,688 & 112,063 & 125,179 & 108,330 & 104,054 & 96,918 & 98,390 & 133,956 & 69,764 & 20,327 & 36,093 & 25,182 & 51,782 & 62,973 & 15,375 & 7,755 & 96,871 & 21,454 \\
\hline Ale 2 & 73,881 & 173,024 & 95,095 & 144,321 & 114,202 & 128,881 & 112,571 & 124,060 & 108,536 & 102,845 & 95,583 & 99,200 & 134,868 & 68,725 & 20,250 & 36,250 & 24,964 & 49,786 & 62,573 & 15,683 & 7,578 & 96,002 & 20,442 \\
\hline Ale 3 & 1,808 & 170,808 & 95,269 & 140,455 & 112,200 & 125,208 & 111,577 & 127,154 & 108,000 & 102,846 & 96,538 & 97,167 & 131,429 & 68,625 & 20,731 & & 24,962 & 49,962 & 62,667 & 15,231 & 7,856 & 95,950 & 23,269 \\
\hline Ale 4 & 1,000 & 170,143 & 93,929 & 140167 & 13,500 & & 10,917 & 125,500 & & 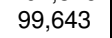 & 97,929 & & 131,500 & & 19,214 & & & & & & & 2,386 & 19,563 \\
\hline $\mathrm{Al}$ & 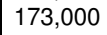 & 172,5 & 93,21 & 3,143 & 750 & & 9,286 & 24,143 & 7,000 & 103,1 & 97,143 & 429 & 3,400 & 7,571 & 2,286 & & & & 1,571 & & 9,440 & & 1,000 \\
\hline Ale 6 & 100 & 170,4 & 95,20 & 144,000 & 1,800 & 800 & 99,000 & 122,200 & 105,400 & 100,4 & 92,800 & 97,400 & 134,800 & 7040 & 19,200 & SOR & 24,000 & 2,600 & 2,500 & 14,600 & 6,564 & & \\
\hline ANC - CB & 3,591 & 172,6 & 97,614 & 136,818 & 11,114 & 122,909 & 07,159 & 128,886 & 110,295 & 101,432 & 97,205 & 99,273 & 130,524 & 886 & 21,523 & 00 & 24,591 & ,705 & 818 & 14,614 & 8,089 & 95,662 & 1,556 \\
\hline ANC - On & 174,167 & 173, & 98,833 & 135 & & 120,167 & 44,667 & 31,000 & & & 96 , & & & 6 & 21,833 & & & 50,833 & & & & & 26,585 \\
\hline ACS - A & 171,000 & 168,0 & 93,500 & 130,000 & 9,000 & 17,250 & 3,000 & 27,500 & 106,000 & 107, & 89,500 & 96,000 & \begin{tabular}{|l|}
127,500 \\
\end{tabular} & 64,500 & 21,000 & 33,500 & 00 & 45,000 & 500 & 14,500 & 8,205 & 94,400 & 20,635 \\
\hline - Bo & 164,917 & 164 & 91,083 & 1 & 0,333 & 15,083 & 33,417 & 26,500 & & & & & 125,000 & 62 & 22,500 & 34,000 & 24,417 & 47,167 & 67 & 14,000 & 10,293 & 92,783 & 21,927 \\
\hline & & & 94,100 & 50 & - & 15625 & 04,150 & 29,175 & & & & & 123,618 & & 20,083 & & 23,350 & & & & & & 21,803 \\
\hline & & & 92 & & & & & & & & & & & & & & & & & & & & \\
\hline - Fu & 178,143 & 176,500 & 97,708 & 136,929 & 112,286 & 124,143 & 107,429 & 133,125 & 112,107 & 107,714 & 98 & 96,292 & \begin{tabular}{|l|}
133,654 \\
\end{tabular} & 68,857 & 20,857 & 34,714 & 24,000 & 49,821 & 2,615 & 16,357 & 8,654 & 95,431 & 23,720 \\
\hline$-\mathrm{Me}$ & 169 & & 94,952 & & & & & & & & & & 126 & & -5 & & & & & & 8, & 94 & 22,057 \\
\hline$A C$ & & & 92 & & & 118 & 106 & 125 & & & & & 125 & & 20,059 & & & & & & & 92 & 21,799 \\
\hline & & & 96,5 & & & & & & & & & & 132 & & & & & & & & & & 25,155 \\
\hline Esq - Al1 & 173,373 & 172,0 & 98,44 & 136,4 & 112,302 & 122 & 107,431 & 129,674 & 10 & & 94 & 97 & 130,513 & 69139 & 20,384 & 39 & 23844 & 51065 & 1,835 & 33 & 5,979 & 96,218 & 19,124 \\
\hline - Al2 & & & & & & & & 132 & & & & & 131,712 & & 19 & & & & & & 5 & 96 & 20,414 \\
\hline Esq - Al3 & 178,842 & 176,542 & 100,623 & 131,5 & 108,991 & 121,2 & 105,457 & 131,289 & 109,356 & 106 & 94 & 97 & 129 & 68,028 & 19,388 & 35,614 & 22,973 & 04 & 16 & 14 & 5 & 94 & 21,054 \\
\hline & & & 98,438 & & & 122 & & & & & & & 131 & 69,500 & & & 24,433 & 51,500 & 62,167 & 14,250 & 5,763 & 93,993 & 19,378 \\
\hline Esq-Ca & 180,520 & 177,640 & 99,560 & 132,659 & 112,130 & 120,188 & 104,260 & 132,980 & 110,917 & 109,063 & 96,4 & 97,020 & $\begin{array}{l}129,184 \\
\end{array}$ & 6806 & 10 & 25 & $|22,460|$ & 50,660 & 60,900 & 15,000 & 5634 & 92,517 & 18,92 \\
\hline
\end{tabular}




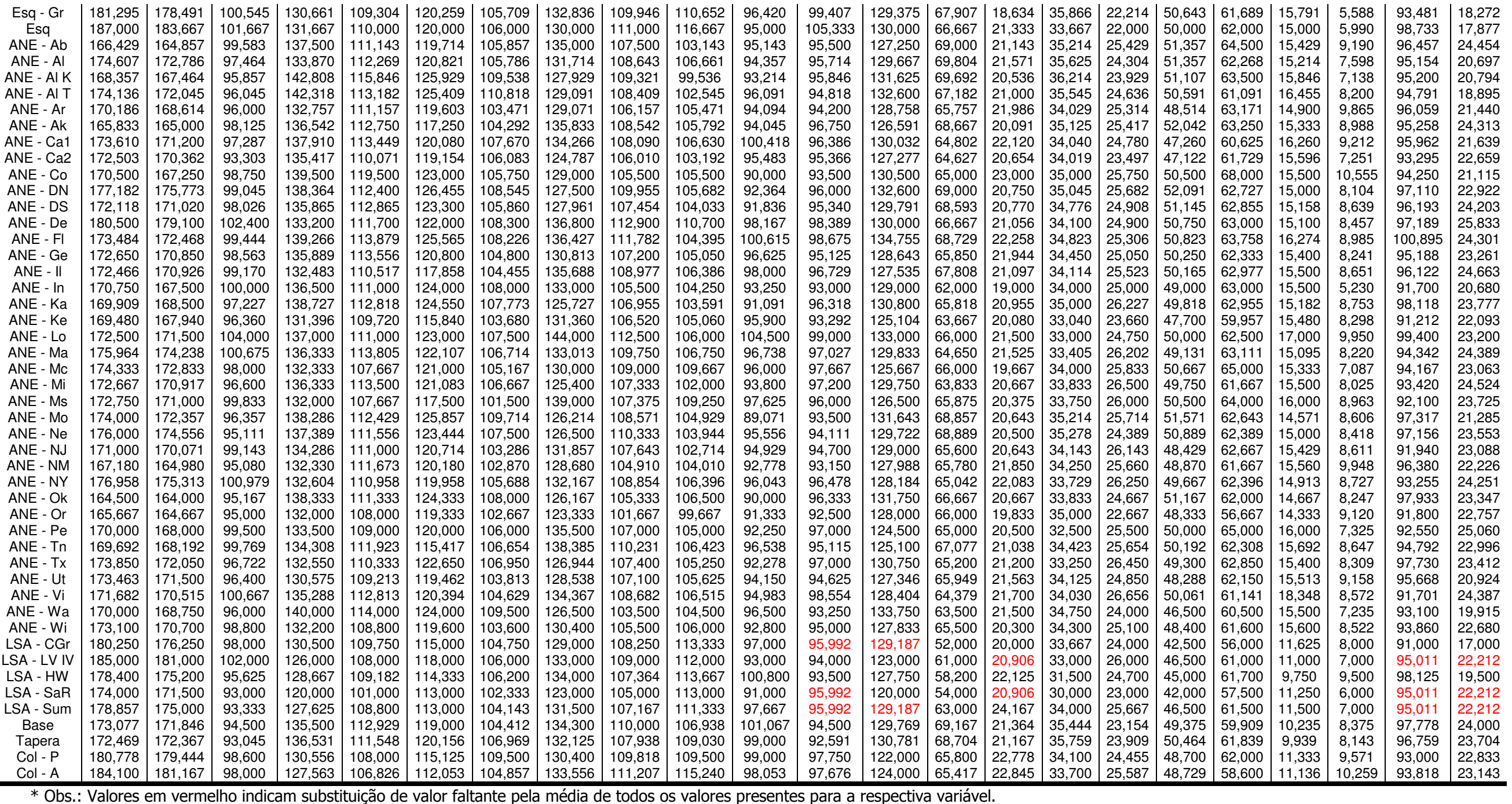


Por fim, para contemplar também a variabilidade interna de cada grupo amostral estudado, decidiu-se estabelecer a relação morfológica entre os grupos através do cálculo da Distância Generalizada de Mahalanobis - D².

Para o cálculo da $D^{2}$, foram necessárias algumas alterações na estrutura geral do conjunto de dados utilizados, apropriados, inicialmente, para as análises de componentes principais. Em suma, essas adequações consistiram em re-agrupar algumas das séries envolvidas na análise proposta, para atender duas condições impostas pela técnica: eliminar séries com apenas um indivíduo e diminuir o número de séries.

Diferentemente do que acontece nas $A C P$ 's, o cálculo de $D^{2}$ é um método de dependência, uma vez que utiliza-se de um algoritmo derivado das funções discriminantes. Por conta disso, é recomendável que grupos contendo número de casos igual ou inferior ao número de variáveis envolvidas na análise não sejam utilizados (Hair et al., 1998, Mingoti, 2005). Como, já extensamente comentado, a representatividade numérica e a integridade morfológica são atributos dificilmente alcançados em bancos de dados arqueológicos, por isso tal recomendação nem sempre pode ser completamente atendida. Entretanto, não há como fugir da limitação da técnica quanto ao número mínimo de casos, i. e., o limite inferior em que se pode executar o cálculo $n=2$. Assim, "séries" contendo apenas um indivíduo não puderam ser utilizadas nesta análise.

Outra condição é originada por uma limitação técnica dos pacotes estatísticos utilizados, que é relativa ao número máximo de grupos que pode ser inserido na análise. O pacote aqui utilizado, o STATISTICA 6.0, permite no máximo de 50 grupos.

Assim sendo, para os cálculos de $D^{2}$ neste trabalho, optou-se por: (1) Com exceção das amostras arqueológicas, eliminou-se todos os indivíduos que apresentaram valores faltantes; (2) Nas amostras de origem arqueológica, indivíduos que apresentaram acima de $30 \%$ de valores faltantes foram retirados da matriz de dados; (3) Os valores faltantes foram substituídos pelo valor da média geral para a variável; (4) Os indivíduos foram agrupados de acordo com sua origem geográfica e etnográfica. Dessa forma, as análises baseadas em 
distância de Mahalanobis foram executadas a partir do banco de dados organizado conforme a Tabela 3.7.

Tabela 3.9 - Composição das séries esqueletais utilizadas nos cálculos de Distâncias de Mahalanobis - Análise intracontinental.

\begin{tabular}{|c|c|c|}
\hline Grupo & Masculino & Feminino \\
\hline Aleuta & 138 & 99 \\
\hline Am. do Norte - Canadá & 69 & 24 \\
\hline CSA - Argentina & - & 2 \\
\hline CSA - Bolívia & 8 & 6 \\
\hline CSA - Caribe & 5 & - \\
\hline CSA - Chile & 16 & 13 \\
\hline CSA - Colômbia & 4 & - \\
\hline CSA - Equador & 2 & - \\
\hline CSA - Fueguinos (Patagônia) & 47 & 11 \\
\hline CSA - Guiana & 4 & - \\
\hline CSA - México & 56 & 35 \\
\hline CSA - Peru & 212 & 140 \\
\hline CSA - Venezuela & 12 & 2 \\
\hline Esquimó - Ásia & 19 & 26 \\
\hline Esquimó - Alaska & 244 & 203 \\
\hline Esquimó - Canadá & 24 & 19 \\
\hline Esquimó - Desconhecido & 8 & - \\
\hline Esquimó - Groelândia & 89 & 39 \\
\hline Am. Do Norte - EUA & 941 & 682 \\
\hline Lagoa Santa - Lapa de Carrancas & 2 & - \\
\hline Lagoa Santa - Lapa Mortuária de Confins & 2 & - \\
\hline Lagoa Santa - Cerca Grande & 2 & 3 \\
\hline Lagoa Santa - Harold Walter & 4 & 6 \\
\hline Lagoa Santa * & 2 & 4 \\
\hline Lagoa Santa - Sumidouro & 9 & 4 \\
\hline Base Aérea & 17 & 8 \\
\hline Tapera & 30 & 27 \\
\hline Colômbia P & 6 & 6 \\
\hline Colômbia A & 12 & 15 \\
\hline Total & 1984 & 1374 \\
\hline
\end{tabular}

Obs: a série Lagoa Santa * refere-se à uma série mista. 
As distâncias de Mahalanobis calculadas neste trabalho foram utilizadas para montar matrizes de distâncias, que por sua vez, fomentaram a execução de Análises de Escalonamento Multidimensional e Análises de Agrupamento.

\subsection{2 - Segundo nível: Investigação das afinidades biológicas extra-continentais}

Como já exposto, a, talvez, principal virtude do presente trabalho - a representatividade dos dados - constituiu, paradoxalmente, um enorme problema para a execução da análise extra-continental. Quando os primeiros testes foram executados o objetivo das análises como ACP e MDS, de condensar a informação e possibilitar sua observação e interpretação através de gráficos, não foi alcançado, pois os centróides representativos das séries analisadas formavam "nuvens densas de pontos" que impossibilitaram a visualização de associações estruturadas.

Para solucionar essa questão, a saída mais econômica seria escolher "sérieschave ${ }^{29 "}$, que melhor representassem a diversidade morfológica craniana planetária, confrontando-as com a série Paleoíndia de Lagoa Santa. No entanto, além da dificuldade de, simplesmente, escolher tais séries, seria extremamente penoso abrir mão, pelo menos numa primeira aproximação, de tentar explorar ao máximo o potencial do banco de dados consolidado.

Dessa forma, a abordagem adotada foi a de estabelecer duas diferentes esferas de inclusão. A primeira para investigar as similaridades morfológicas entre os Paleoíndios e os agrupamentos artificiais estabelecidos por critério geográfico, de acordo com sua localização no Velho Mundo. E uma segunda esfera investigativa, mais global e representativa, agrupando representantes de todas as regiões do Velho Mundo, escolhidas a partir dos resultados obtidos na primeira abordagem, seguindo a proposta de contextualização progressiva.

\subsubsection{1 - Primeiro nível de inclusão das Afinidades Biológicas Extra-Continentais}

Num primeiro nível de inclusão das análises de afinidades extra-continentais dos Paleoíndios investigou-se quais populações mundiais, representadas por seus

\footnotetext{
${ }^{29}$ Seria bastante difícil estabelecer um critério para definir o que seria uma "série-chave" pois essa escolha recairia sobre uma série de atributos como origem geográfica, morfologia craniana, história evolutiva e filiação etnográfica, por exemplo.
} 
centróides, apresentava maior ou menor similaridade morfológica com a população de Lagoa Santa.

Para tanto, utilizou-se a técnica da Análise de Componentes Principais aplicada sobre os cinco conjuntos de dados estabelecidos a partir da localização geográfica de cada série. Por tratar-se de uma abordagem inicial e levando em consideração também a experiência obtida com os resultados da análise intra-continental, decidiu-se investigar essas afinidades a partir das topologias geradas apenas pelos dois primeiros componentes principais.

O cálculo dos centróides de cada série foi realizado, a partir do cálculo do valor médio para cada variável dos indivíduos contidos na amostra. Foram retiradas das análises todas as séries representadas por um único indivíduo (com exceção do espécime I de Lapa Vermelha IV).

A Tabela 3.10 apresenta a configuração final das séries utilizadas para a investigação, num primeiro nível de inclusão, das afinidades biológicas extracontinentais dos Paleoíndios de Lagoa Santa.

Tabela 3.10 - "Composição das séries esqueletais utilizadas na análise de afinidades extracontinentais, primeiro nível de inclusão

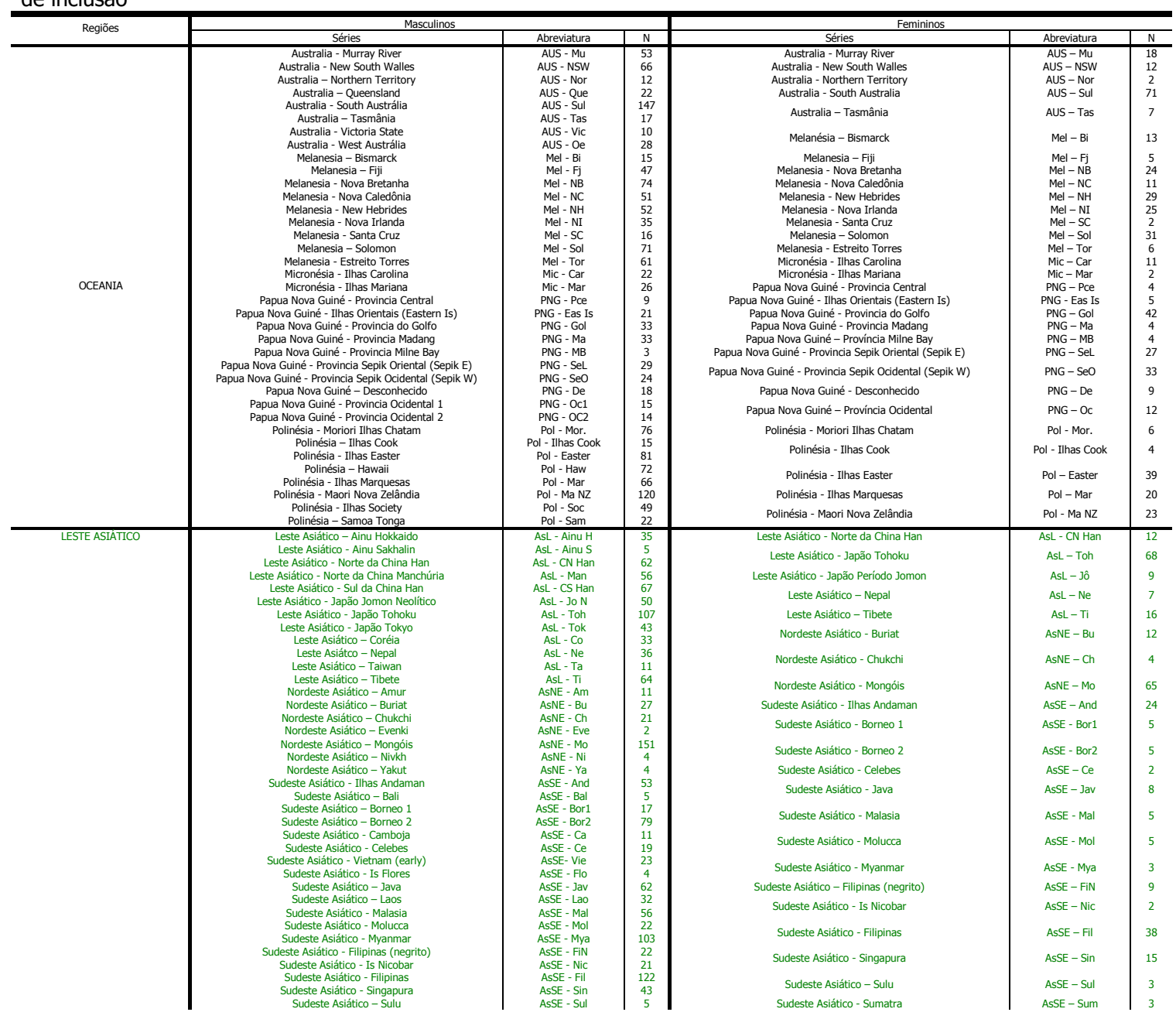




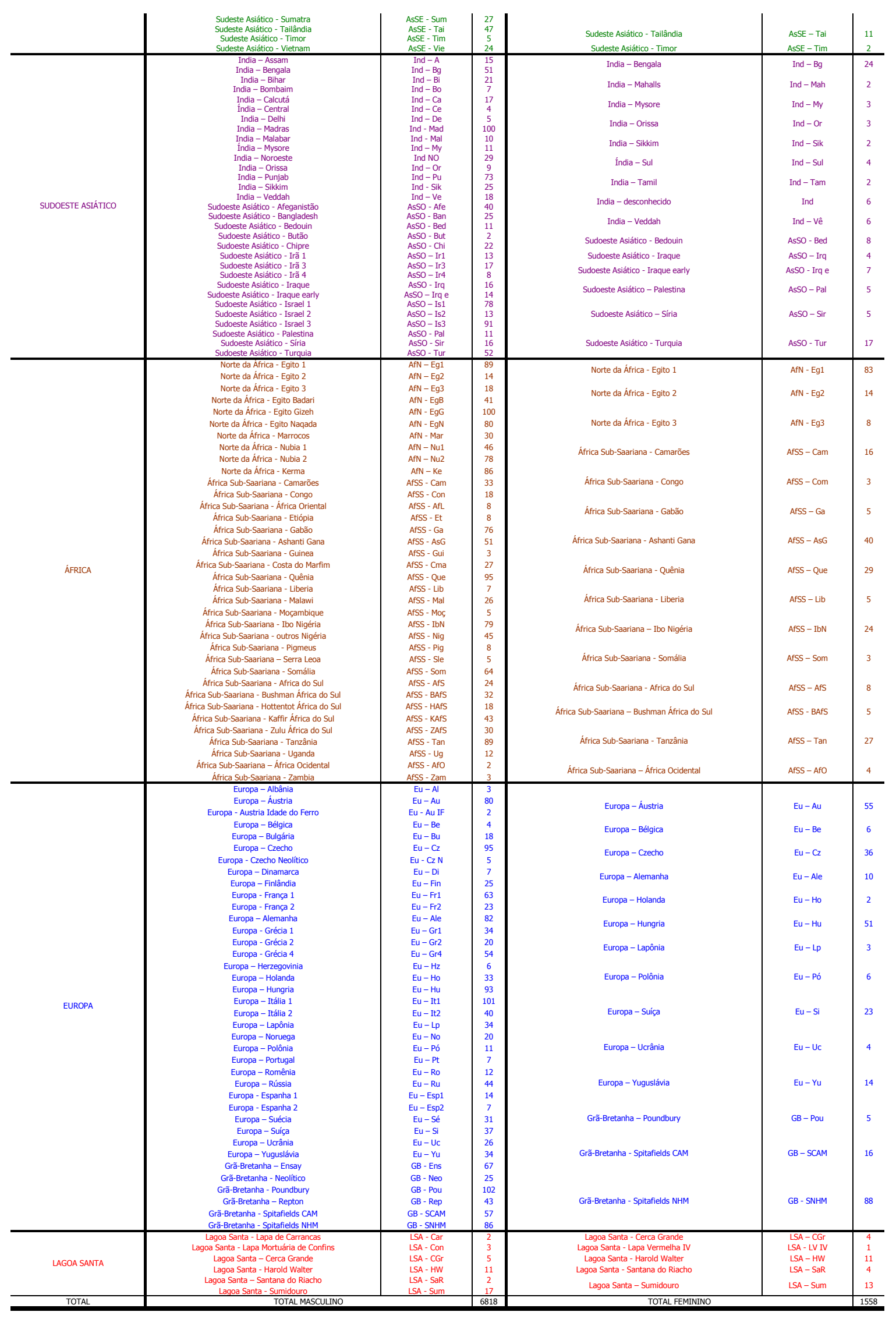


3.3.2.2 - Segundo nível de inclusão das Afinidades Biológicas ExtraContinentais

A proposta para o segundo nível de inclusão das análises de afinidades extra-continentais dos Paleoíndios foi a de investigar quais grupos mundiais, representados de duas maneiras distintas, ora por seus centróides ora por seus indivíduos, apresentam maior ou menor similaridade morfológica com a população de Lagoa Santa.

Para tanto, decidiu-se, diferentemente do que foi feito no primeiro nível de análise extra-continental, utilizar abordagem semelhante à adotada na investigação das afinidades intra-continentais, isto é, combinar técnicas estatísticas multivariadas de dependência e interdependência, procurando maximizar o potencial explicativo do universo amostral utilizado. Dessa forma, os resultados obtidos serão relativos às Análises de Componentes Principais, Análises de Agrupamentos (baseadas em matrizes de Distâncias Euclidianas e de Mahalanobis) e Escalonamento Multidimensional, executados, sempre, para as parcelas masculina e feminina, separadamente, e sobre dados de tamanho e forma e de forma apenas.

A Tabela 3.11, a seguir, apresenta a configuração final das séries agrupadas utilizadas para a investigação do segundo nível de inclusão das afinidades biológicas extra-continentais dos Paleoíndios de Lagoa Santa.

Tabela 3.11 - "Composição das séries esqueletais utilizadas na análise de afinidades extracontinentais, segundo nível de inclusão

\begin{tabular}{c|c|c} 
Grupo inclusão & N masc. & N fem. \\
\hline AUSTRALIA & 355 & 110 \\
LESTE ASIÁTICO & 569 & 113 \\
EUROPA & 1445 & 320 \\
INDIA & 396 & 53 \\
MELANESIA & 422 & 146 \\
NORTE DA ÁFRICA & 582 & 105 \\
NORDESTE ASIÁTICO & 221 & 82 \\
PAPUA NOVA GUINÉ & 199 & 140 \\
POLINÉSIA & 501 & 93 \\
SUDESTE ASIÁTICO & 813 & 140 \\
ÁFRICA SUB-SAARIANA & 817 & 177 \\
SUDOESTE ASIÁTICO & 441 & 47 \\
MICRONÉSIA & 48 & 13 \\
LAGOA SANTA & 43 & 38 \\
\hline Total & 6852 & 1577 \\
\hline
\end{tabular}




\section{Capítulo 4 - Resultados}

4.1 - Investigação das Afinidades Biológicas Intra-Continentais

O primeiro nível de investigação das associações morfológicas cranianas dos Paleoíndios de Lagoa Santa concentra-se nas análises das afinidades intra-continentais. Seguirão, respectivamente, os resultados obtidos através das análises propostas (Análise de Componentes Principais, Análise de Agrupamentos e Escalonamento Multidimensional) para as parcelas masculina e feminina (tamanho e forma e apenas forma, em ambos os casos).

\subsection{1 - Parcela Masculina, Tamanho e Forma}

Os resultados obtidos através da ACP sobre os centróides das séries utilizadas, com base em tamanho e forma, para a parcela masculina são apresentados na Tabela 4.1. O gráfico da Figura 4.1 representa o decaímento dos autovalores dos CPs (screeplot) e sua observação possibilitou a escolha dos CPs utilizados para o Cálculo de Distâncias Euclidianas (Reis, 2001; Mingoti, 2005).

Tabela 4.1 - Autovalores da matriz de covariância e porcentagens de variância explicada por cada Componente Principal. Parcela masculina, forma e tamanho (76 séries, 23 variáveis craniométricas).

\begin{tabular}{c|c|c|c|c}
\hline $\begin{array}{c}\text { Componente } \\
\text { Principal }\end{array}$ & Autovalor & \% Total & $\begin{array}{c}\text { Autovalor } \\
\text { Cumulativo }\end{array}$ & $\%$ Cumulativa \\
\hline 1 & 79,33549 & 39,06624 & 79,3355 & 39,0662 \\
2 & 54,30335 & 26,73996 & 133,6388 & 65,8062 \\
3 & 20,84212 & 10,26304 & 154,4810 & 76,0692 \\
4 & 11,71617 & 5,76926 & 166,1971 & 81,8385 \\
5 & 7,35349 & 3,62099 & 173,5506 & 85,4595 \\
6 & 6,04189 & 2,97514 & 179,5925 & 88,4346 \\
7 & 5,52170 & 2,71899 & 185,1142 & 91,1536 \\
8 & 3,70931 & 1,82653 & 188,8235 & 92,9801 \\
9 & 2,71763 & 1,33821 & 191,5412 & 94,3184 \\
10 & 2,25749 & 1,11163 & 193,7986 & 95,4300 \\
11 & 2,00238 & 0,98601 & 195,8010 & 96,4160 \\
12 & 1,35641 & 0,66792 & 197,1574 & 97,0839 \\
13 & 1,22124 & 0,60136 & 198,3787 & 97,6853 \\
14 & 0,95907 & 0,47226 & 199,3377 & 98,1575 \\
15 & 0,92447 & 0,45523 & 200,2622 & 98,6128 \\
16 & 0,71034 & 0,34979 & 200,9726 & 98,9625 \\
17 & 0,56524 & 0,27833 & 201,5378 & 99,2409 \\
18 & 0,44062 & 0,21697 & 201,9784 & 99,4579 \\
19 & 0,38362 & 0,18890 & 202,3620 & 99,6468 \\
20 & 0,27345 & 0,13465 & 202,6355 & 99,7814 \\
21 & 0,23196 & 0,11422 & 202,8674 & 99,8956 \\
22 & 0,12932 & 0,06368 & 202,9968 & 99,9593 \\
23 & 0,08265 & 0,04070 & 203,0794 & 100,0000 \\
\hline
\end{tabular}


Figura 4.1 - Gráfico de decaímento da porcentagem de variância condensada em cada Componente Principal. Parcela masculina, forma e tamanho (76 séries, 23 variáveis craniométricas).

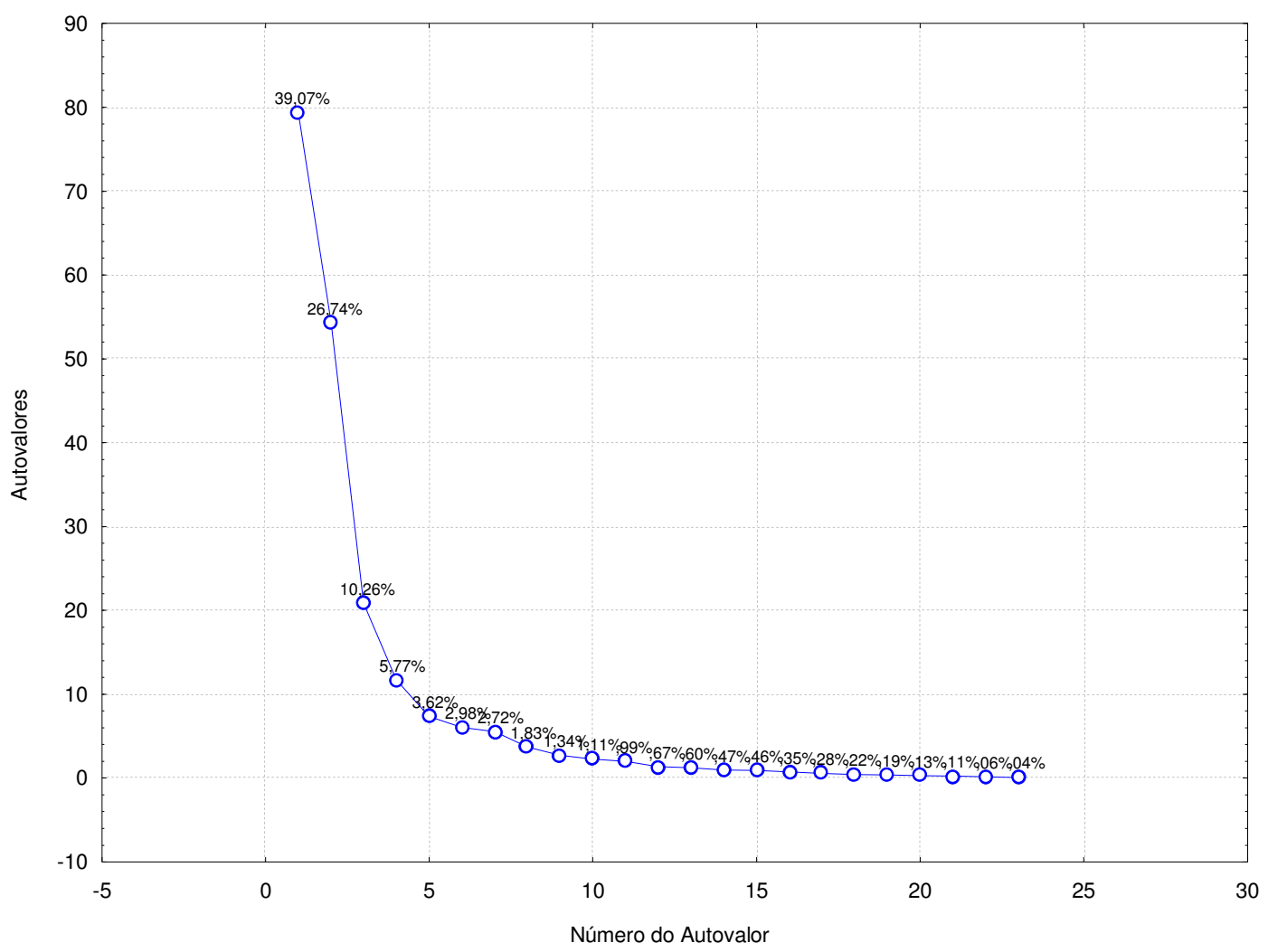

Da análise do screeplot acima depreende-se que ocorre um primeiro platô após o $7^{\circ}$. Componente Principal (2,72\%). Daí, determinou-se, que os sete primeiros fatores seriam os utilizados para o cálculo de Distâncias Euclidianas e posterior montagem de matriz de distâncias para a análise de agrupamentos. Na Tabela 4.2, estão representados os fatores de coordenadas de cada série, extraídas da análise de componentes principais da matriz de covariância.

Já os gráficos das Figuras 4.2, 4.3 e 4.4 são os relativos às comparações dos centróides no morfo-espaço constituído, respectivamente, pelas dimensões formadas pelos CP 1 × CP 2, CP 1 x CP 3 e CP 2 × CP 3. Note que os gráficos apresentam as elipses de dispersão, calculadas com 95\% de confiabilidade, para cada uma das 7 populações arbitrárias estudadas. Os dendrogramas das Figuras 9.5, 9.6, 9.7 e 9.9 apresentam as análises de clusters, sob quatro regras distintas de agrupamento (Ward, Vizinhos Próximos, Vizinhos Distantes e Médias Dentro do Grupo ${ }^{30}$, utilizando-se sempre uma matriz de dados baseadas nas distâncias euclidianas calculadas a partir dos CPs selecionados.

\footnotetext{
${ }^{30} \mathrm{Na}$ literatura especializada poder-se-á encontrar como sinônimos: Vizinhos Próximos = Single Linkage (ou Ligação Simples); Vizinhos Distantes = Complete Linkage (ou Ligação Completa); Médias Dentro do Grupo = (Weighted pairgroup average ou PGMA).
} 
Tabela 4.2 - Fatores de coordenadas de cada série. Parcela masculina, forma e tamanho ( 76 séries, 23 variáveis craniométricas).

\begin{tabular}{|c|c|c|c|c|c|c|c|c|c|c|c|c|c|c|c|c|c|c|c|c|c|c|c|}
\hline & & & & & ator 5 & & & ator 8 & & & & & & & & & & & & & & & \\
\hline & & & & & $\begin{array}{l}-0.902024 \\
0.050224\end{array}$ & & & & & $\begin{array}{l}0.33588 \\
.373020\end{array}$ & & 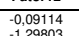 & 0.03265 & $\begin{array}{l}-0.64776 \\
0.52729\end{array}$ & $\begin{array}{l}0,70057 \\
0.2057\end{array}$ & $\begin{array}{l}0.592424 \\
.09271\end{array}$ & 0.21378 & $\begin{array}{l}0.15851 \\
0.18385\end{array}$ & 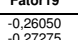 & 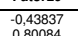 & & & \\
\hline & $\begin{array}{l}-11,1,00 \\
-6.165\end{array}$ & & $\begin{array}{c}7.1 .1992 \\
-6,6378\end{array}$ & $\begin{array}{c}-3.3000 \\
-3,2036 \\
1,2036\end{array}$ & $\begin{array}{l}-0.924282 \\
-4: 90211\end{array}$ & $\begin{array}{l}-1,1725252 \\
0,13207\end{array}$ & 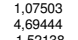 & $\begin{array}{l}-4.42592 \\
-1,50316\end{array}$ & 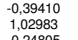 & 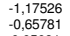 & $\begin{array}{l}0.093767 \\
2,92743 \\
2\end{array}$ & 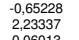 & 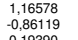 & 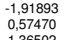 & $\begin{array}{l}-0.411022 \\
0.323292\end{array}$ & $\begin{array}{l}-0.00083 \\
0.747464\end{array}$ & $\begin{array}{l}0.057777 \\
-0.07750\end{array}$ & 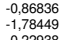 & $\begin{array}{l}0.39712 \\
0.40158\end{array}$ & $\begin{array}{l}0.0545356 \\
.0 .59150\end{array}$ & $\begin{array}{l}0.10448 \\
0.002020\end{array}$ & 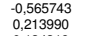 & 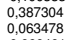 \\
\hline $\begin{array}{l}\text { Ale } 6 \\
\text { ANC CB CB }\end{array}$ & 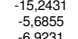 & 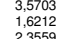 & 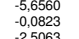 & 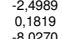 & 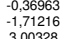 & $\begin{array}{l}-3.24247628 \\
-0.302028\end{array}$ & 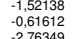 & 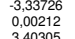 & 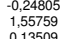 & 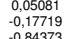 & 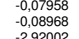 & 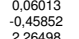 & 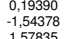 & 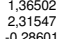 & 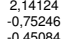 & 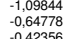 & 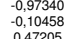 & 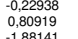 & 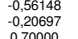 & 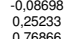 & $\begin{array}{l}0.152029896 \\
-1.26876\end{array}$ & 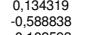 & $\begin{array}{l}-0.060 \\
0.331\end{array}$ \\
\hline & $\begin{array}{l}-6.982 \\
-2.894\end{array}$ & 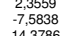 & 年. & 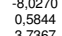 & 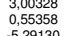 & 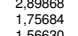 & 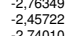 & 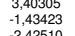 & 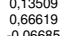 & $-0,84$ & 9200202 & $\begin{array}{l}2.20649098 \\
0.002038\end{array}$ & & 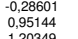 & & 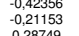 & & & ,. 0.0002 & & & $9^{93}$ & \\
\hline & 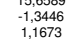 & 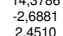 & 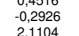 & 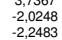 & 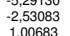 & 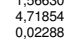 & 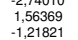 & 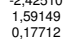 & 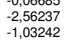 & 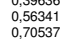 & 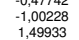 & 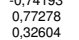 & 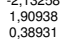 & 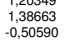 & 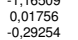 & 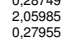 & 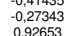 & $\begin{array}{l}0.564 \\
0.564 \\
0.60\end{array}$ & 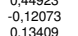 & 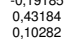 & 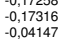 & 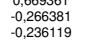 & 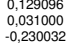 \\
\hline & $\begin{array}{l}1,658 \\
2,5777\end{array}$ & 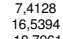 & $\begin{array}{l}0.9190 \\
.2705 \\
\end{array}$ & $\begin{array}{l}-2.126 \\
0.9886 \\
0.98\end{array}$ & 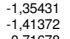 & $\begin{array}{l}1.196538 \\
4,69382\end{array}$ & $\begin{array}{r}\text {.0.02922 } \\
-1,16525\end{array}$ & $\begin{array}{l}0.55566 \\
0.424212\end{array}$ & 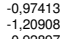 & 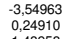 & $\begin{array}{l}2.776233 \\
0.07485\end{array}$ & 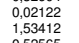 & $\begin{array}{l}0.0606828 \\
0.056828\end{array}$ & 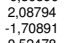 & 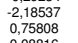 & 12457 & 0.968 & & 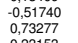 & 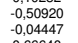 & 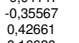 & 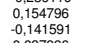 & \\
\hline & 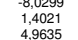 & 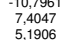 & 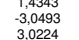 & 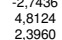 & 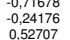 & 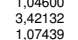 & 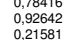 & 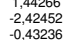 & 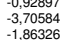 & 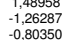 & 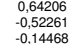 & 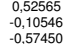 & 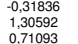 & 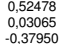 & 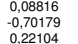 & 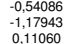 & 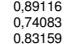 & $\begin{array}{l}-0.7686 \\
0.974 \\
0.2212\end{array}$ & 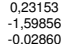 & 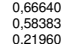 & 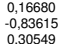 & 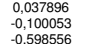 & 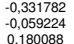 \\
\hline & $\begin{array}{l}4.958 \\
4.78\end{array}$ & $\begin{array}{l}10,459 \\
5,2,258\end{array}$ & & 1.46. & 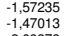 & $\begin{array}{l}-0.01029 \\
2.54834\end{array}$ & $\begin{array}{l}-0.84158 \\
0.073599\end{array}$ & $\begin{aligned}-0.07099 \\
-1,3287\end{aligned}$ & $\begin{array}{l}-0.09055 \\
-1.65255 \\
-1.625\end{array}$ & $\begin{array}{l}0.0 .59 \\
0.14\end{array}$ & & 0,928 & & $-0,74$ & & & & & & & & & \\
\hline & $\begin{array}{l}5.40600 \\
-2.5095 \\
\end{array}$ & 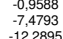 & $\begin{array}{l}0.5 .549 \\
0.77099\end{array}$ & 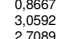 & 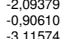 & 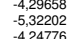 & 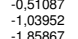 & 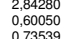 & 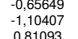 & 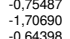 & 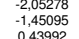 & 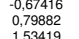 & 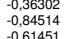 & 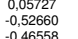 & $\begin{array}{l}-0.1766 \\
-0.7008\end{array}$ & 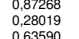 & 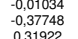 & $\begin{array}{l}-0,07 \\
0.017 \\
0.19\end{array}$ & 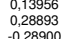 & 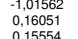 & $\begin{array}{l}0.1120 \\
0.122\end{array}$ & 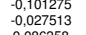 & \\
\hline & $\begin{array}{l}-4.056 \\
2,440 \\
2.40\end{array}$ & 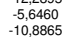 & 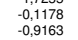 & 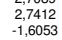 & 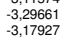 & - 3.45250 & 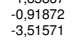 & 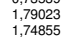 & 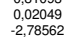 & 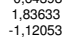 & 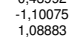 & 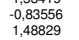 & 0.81866 & $\begin{array}{l}0.07999595 \\
0.042627\end{array}$ & & & & & & & & 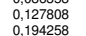 & \\
\hline & 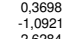 & $\begin{array}{l}-14.5361 \\
-9.5559\end{array}$ & $\begin{array}{l}-1.03933 \\
-1,65552\end{array}$ & 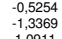 & 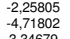 & $\begin{array}{l}5.514048 \\
-1,18980\end{array}$ & 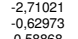 & 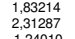 & 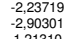 & 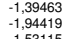 & $\begin{array}{l}1.555158 \\
.565313\end{array}$ & 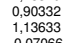 & $\begin{array}{l}-0.477565 \\
-0.03567\end{array}$ & 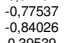 & 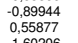 & 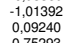 & 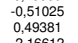 & $\begin{array}{l}0.089 \\
1.9418 \\
1.48\end{array}$ & 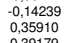 & $\begin{array}{l}-0.008 \\
0.07 \\
0.67\end{array}$ & $\begin{array}{l}-0.018 \\
0.150\end{array}$ & 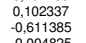 & \\
\hline & 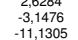 & 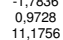 & 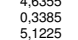 & 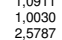 & 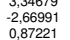 & 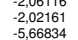 & 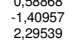 & 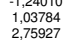 & 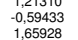 & 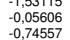 & 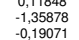 & 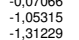 & 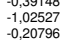 & 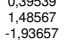 & $\begin{array}{l}-1,701 \\
-0.71 \\
-1.05\end{array}$ & & 0.04 & & 1790 & 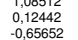 & & 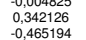 & \\
\hline & 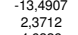 & $\begin{array}{l}.3 .59626 \\
4 ., 9424 \\
4\end{array}$ & $\begin{array}{l}-0.87355 \\
0.16464\end{array}$ & 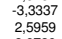 & 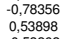 & $\begin{array}{l}1,1,1524 \\
1,29213\end{array}$ & $\begin{array}{l}0.030000 \\
0.80716\end{array}$ & $\begin{array}{l}0.06665 \\
0,1,15064\end{array}$ & $\begin{array}{l}-1.151111 \\
-0,79875\end{array}$ & $\begin{array}{l}0.78637 \\
.1 .862030\end{array}$ & $\begin{array}{l}0.01641 \\
0.98778\end{array}$ & $\begin{array}{l}-5.54646 \\
-1,182837\end{array}$ & $\begin{array}{l}0.8464547 \\
0.52716\end{array}$ & $\begin{array}{l}0.0223535 \\
0.0598851\end{array}$ & 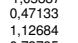 & 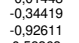 & 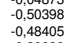 & 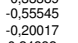 & 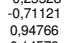 & 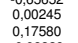 & $\begin{array}{l}-0.62 \\
0.0416 \\
0.416\end{array}$ & 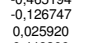 & \\
\hline & 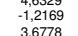 & 5 & 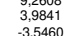 & 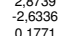 & 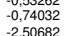 & 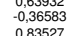 & 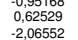 & 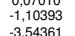 & 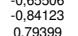 & $\begin{array}{l}0.168 \\
0.164 \\
-1144\end{array}$ & 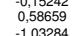 & 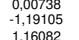 & & 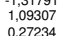 & & & & & 44009 & & & & \\
\hline & 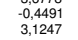 & $\begin{array}{l}8.566505 \\
2 ., 67970\end{array}$ & 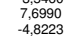 & $\begin{array}{l}0.26737 \\
0 ., 6436\end{array}$ & 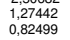 & 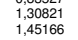 & 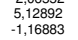 & $\begin{array}{l}0.05104 \\
0.0558873\end{array}$ & 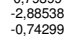 & 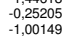 & $\begin{array}{l}2,19966 \\
\text { 2, 1,49598 }\end{array}$ & 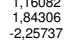 & 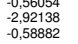 & 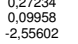 & 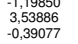 & 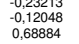 & $\begin{array}{l}0.07 \\
0.07 \\
0.92\end{array}$ & 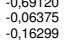 & 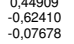 & 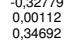 & $\begin{array}{l}0.038 \\
0.022 \\
0.025\end{array}$ & 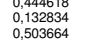 & \\
\hline & -6.58. & 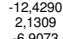 & 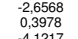 & 资: & $\begin{array}{l}1,439882 \\
0.36222\end{array}$ & 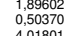 & 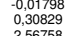 & 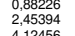 & 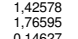 & $\begin{array}{l}0,96 . \\
0.64 . \\
0.64 .\end{array}$ & . 0.075 & 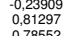 & $\begin{array}{l}0.0186 \\
0.764\end{array}$ & $\begin{array}{l}0.8969 \\
0.038\end{array}$ & & & & & $0175 \%$ & & & & \\
\hline & 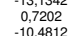 & 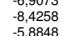 & 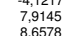 & $\begin{array}{l}0.0380 \\
0.0378\end{array}$ & 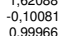 & 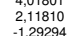 & 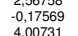 & 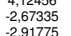 & 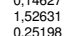 & 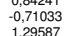 & 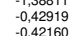 & 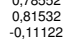 & 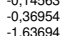 & 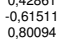 & 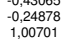 & $\begin{array}{l}0.3681 \\
.4671\end{array}$ & 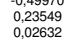 & & 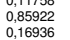 & 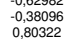 & & $\begin{array}{l}0.09894 \\
0.09589\end{array}$ & \\
\hline & $\begin{array}{l}0.559 \\
3.447 \\
3\end{array}$ & $\begin{array}{l}0.06655 \\
-232424\end{array}$ & $\begin{array}{l}3.8846 \\
7.5226\end{array}$ & 0.16455 & 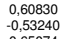 & $\begin{array}{l}.1 .87762 \\
-0.18644\end{array}$ & $\begin{array}{r}-4.44919 \\
0.16079\end{array}$ & 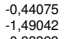 & $\begin{array}{l}-1.11959 \\
0.72291\end{array}$ & 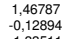 & $\begin{array}{l}1.77262121 \\
0.064899\end{array}$ & 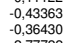 & - 0.6292090 & 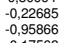 & $\begin{array}{l}0.497 \\
0.31 .12\end{array}$ & $\begin{array}{l}0.22718 \\
0.06127\end{array}$ & $\begin{array}{l}0.727 \\
0.27 \\
0.27\end{array}$ & 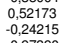 & 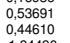 & $\begin{array}{l}\text { o. } 0.42 \\
0.036\end{array}$ & & $\begin{array}{l}\text { o. } 0.0672 \\
0.1572\end{array}$ & \\
\hline E.-ka & 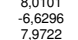 & 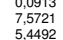 & 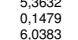 & 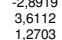 & 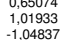 & 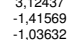 & 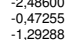 & 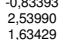 & 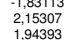 & 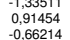 & $\begin{array}{l}-0.05601015 \\
-0.05025\end{array}$ & 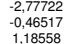 & 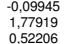 & 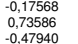 & 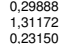 & 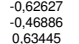 & 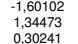 & $\begin{array}{l}-0.07 \\
-0.56 \\
-0.54\end{array}$ & 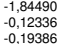 & 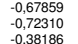 & $\begin{array}{l}0.611 \\
0.0191 \\
0.33\end{array}$ & 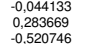 & \\
\hline & 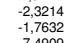 & 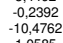 & 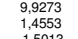 & 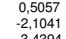 & 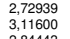 & 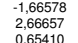 & 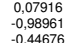 & 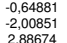 & 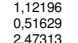 & 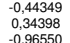 & 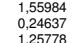 & 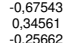 & $\begin{array}{l}0.99894 \\
0.332322\end{array}$ & 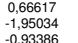 & $\begin{array}{l}-0.171 \\
0.0 .277 \\
0.530\end{array}$ & 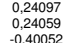 & 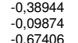 & $\begin{array}{l}0.01 \\
\text { o. } 0.090 \\
-0.09\end{array}$ & $\begin{array}{l}0.067 \\
0.0877 \\
-0.870\end{array}$ & $\begin{array}{l}0,127 \\
0.87 \\
0.45\end{array}$ & $\begin{array}{l}-0.013 \\
0.0209 \\
-0.25\end{array}$ & 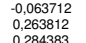 & \\
\hline & $\begin{array}{l}6.1925 \\
\text { 6.2275 }\end{array}$ & 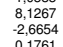 & 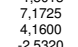 & 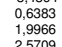 & 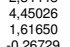 & 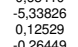 & 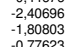 & 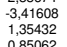 & 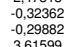 & 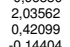 & 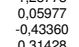 & 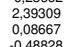 & $\begin{array}{l}2.03 \\
\text { - } 0.035 \\
-0.45\end{array}$ & 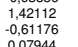 & $\begin{array}{l}-0.99 \\
-0.972 \\
-1.072\end{array}$ & 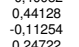 & $\begin{array}{l}1,17 \\
0.119 \\
0.19\end{array}$ & 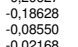 & 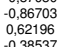 & 0.6 .6 & & 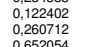 & \\
\hline & 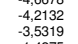 & 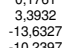 & $\begin{array}{l}-4.4989 \\
-4.442321\end{array}$ & 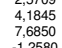 & 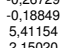 & 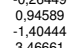 & 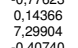 & 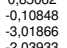 & 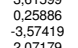 & 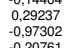 & $\begin{array}{l}\text { i.t7702029 } \\
\text { o.3.32099 }\end{array}$ & 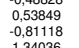 & 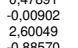 & 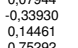 & $\begin{array}{l}0.902 \\
0.092 \\
-0.929\end{array}$ & 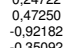 & & 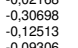 & 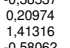 & 0.195477 & & 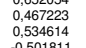 & \\
\hline$=\mathrm{Nm}$ & 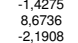 & 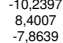 & 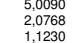 & 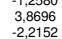 & 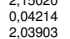 & 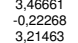 & & 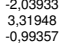 & 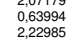 & 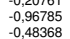 & 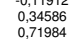 & 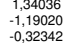 & 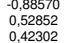 & 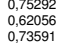 & 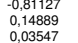 & 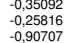 & 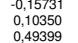 & 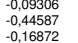 & 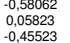 & & & 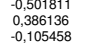 & \\
\hline & 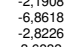 & $\begin{array}{l}-4.4525252 \\
8.2,2726\end{array}$ & 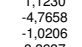 & 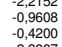 & 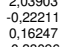 & 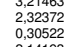 & 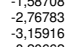 & 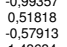 & 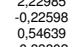 & 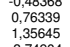 & 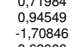 & 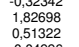 & 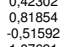 & 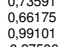 & 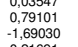 & 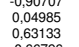 & 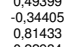 & $\begin{array}{l}-0,46 \\
0 ., 49\end{array}$ & 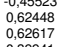 & & & 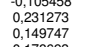 & \\
\hline & 3.6883 & 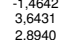 & 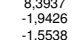 & 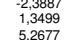 & 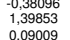 & 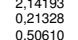 & 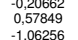 & 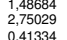 & 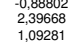 & 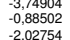 & 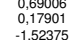 & 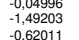 & & 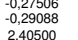 & $\begin{array}{l}0.267 \\
0.355 \\
1.447\end{array}$ & .667 & & $\begin{array}{l}-0,708 \\
0.07\end{array}$ & $\begin{array}{l}\text { o. } 0.3994 \\
\text { o.534 }\end{array}$ & & & & \\
\hline & $\begin{array}{l}1.04048 \\
\text { i. } 24354\end{array}$ & 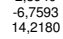 & $\begin{array}{l}6.1360 \\
\text { - } 5.7375\end{array}$ & 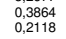 & 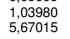 & $\begin{array}{l}.1 .56515 \\
-1,1698988\end{array}$ & -1, 1.10008 & 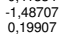 & $\begin{array}{l}0.009511 \\
-0.049354\end{array}$ & $\begin{array}{l}0.672 \\
0.41312\end{array}$ & 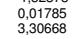 & 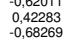 & 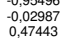 & 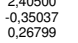 & 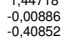 & 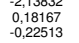 & $\begin{array}{l}.19 \\
-0.16 \\
-1.6\end{array}$ & 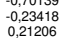 & $1,38 \mathrm{Z}$ & $\begin{array}{l}-0.01 \\
-0.011\end{array}$ & 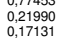 & 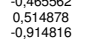 & \\
\hline & 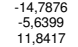 & 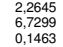 & 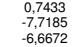 & 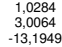 & 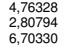 & 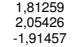 & 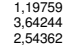 & 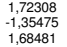 & 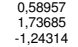 & 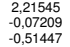 & 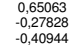 & 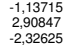 & $\begin{array}{l}.3 .37 \\
-2.35 \\
-2.14\end{array}$ & $\begin{array}{l}0.897979727 \\
0.068772\end{array}$ & 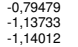 & 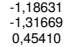 & 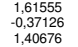 & . 0.0 .34 & $0.239 ;$ & & 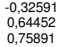 & 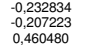 & \\
\hline & 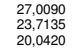 & 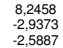 & 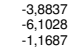 & 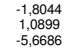 & 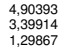 & 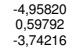 & 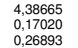 & 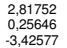 & 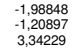 & 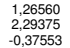 & 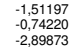 & 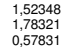 & 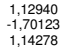 & 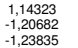 & 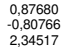 & 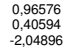 & 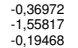 & 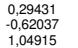 & $\begin{array}{l}-0.4777 \\
\text { - } 1.57 \\
0.577\end{array}$ & 0.24471 & 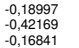 & 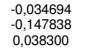 & \\
\hline $\begin{array}{l}\text { Soan } \\
\text { sum }\end{array}$ & 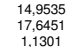 & 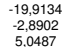 & 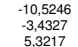 & 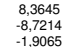 & 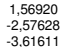 & 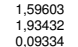 & 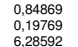 & 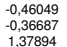 & 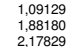 & 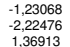 & 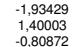 & 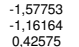 & 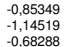 & 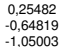 & 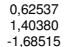 & 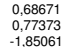 & & 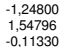 & 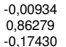 & 5 & 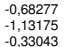 & 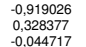 & \\
\hline & 6.565 & $\begin{array}{r}.3 .356656 \\
.3\end{array}$ & $\begin{array}{c}-6.8627 \\
0.627\end{array}$ & 2235 & & 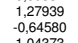 & & 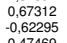 & $\begin{array}{l}-6.62092 \\
\text { o.14279 }\end{array}$ & & & 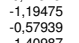 & & & & 10589 & & & & 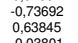 & & & \\
\hline
\end{tabular}


Figura 4.2 - Gráfico bidimensional do morfo-espaço formado pelos CP 1 × CP 2. Parcela masculina, forma e tamanho (77 séries, 23 variáveis craniométricas).

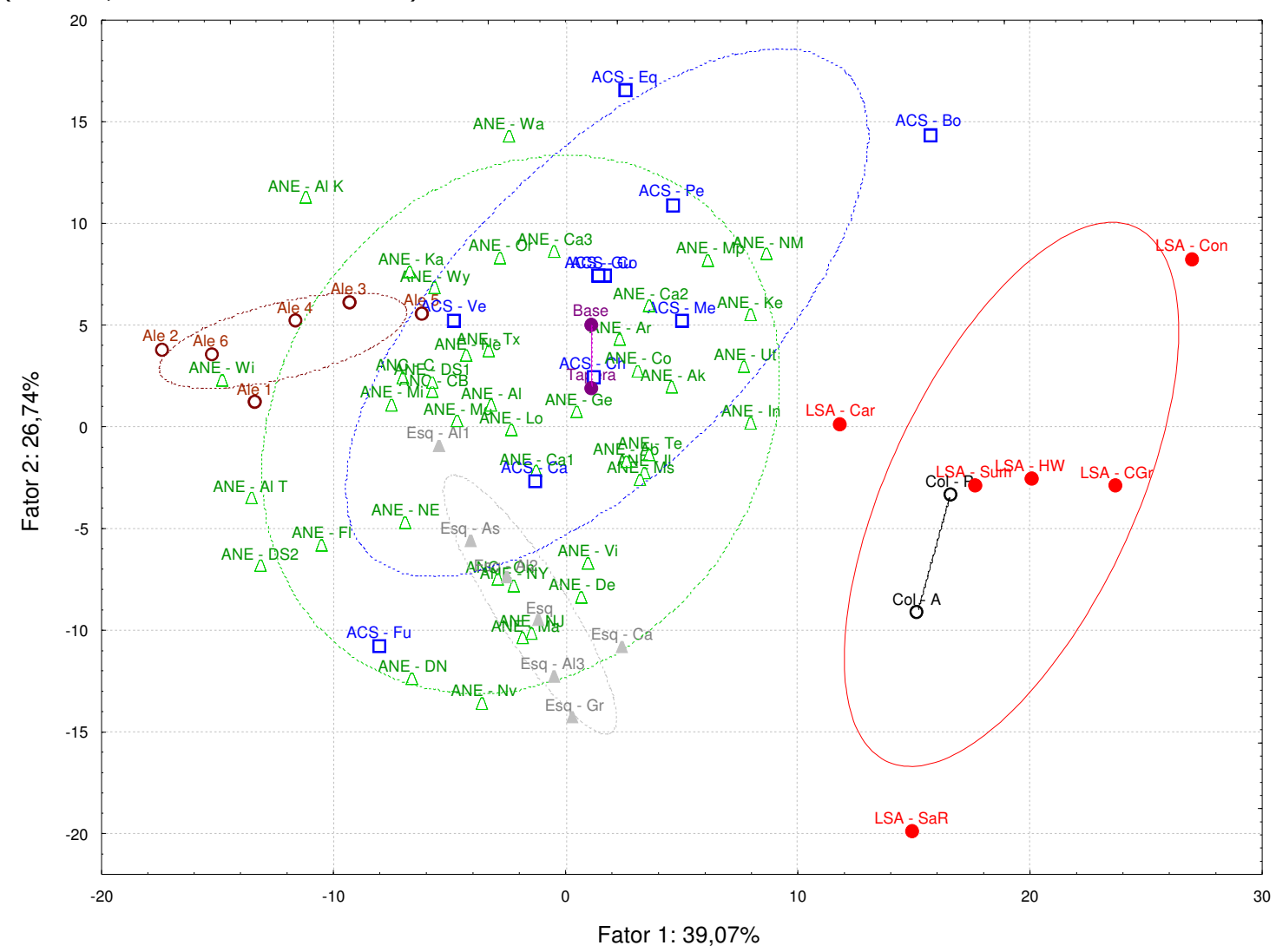

Figura 4.3 - Gráfico bidimensional do morfo-espaço formado pelos CP 1 x CP 3. Parcela masculina, forma e tamanho (77 séries, 23 variáveis craniométricas).

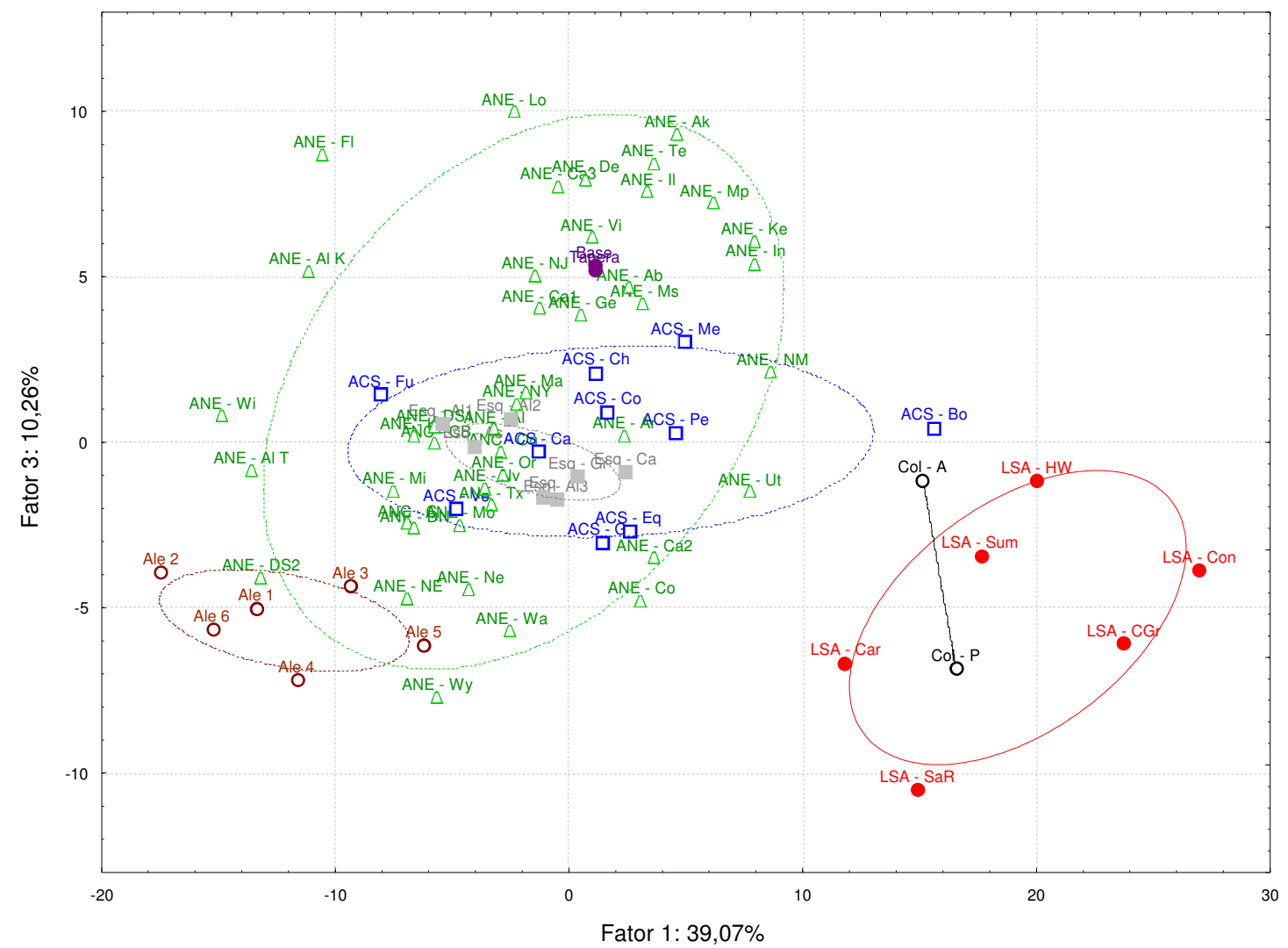


Figura 4.4 - Gráfico bidimensional do morfo-espaço formado pelos CP $2 \times$ CP 3. Parcela masculina, forma e tamanho (77 séries, 23 variáveis craniométricas).

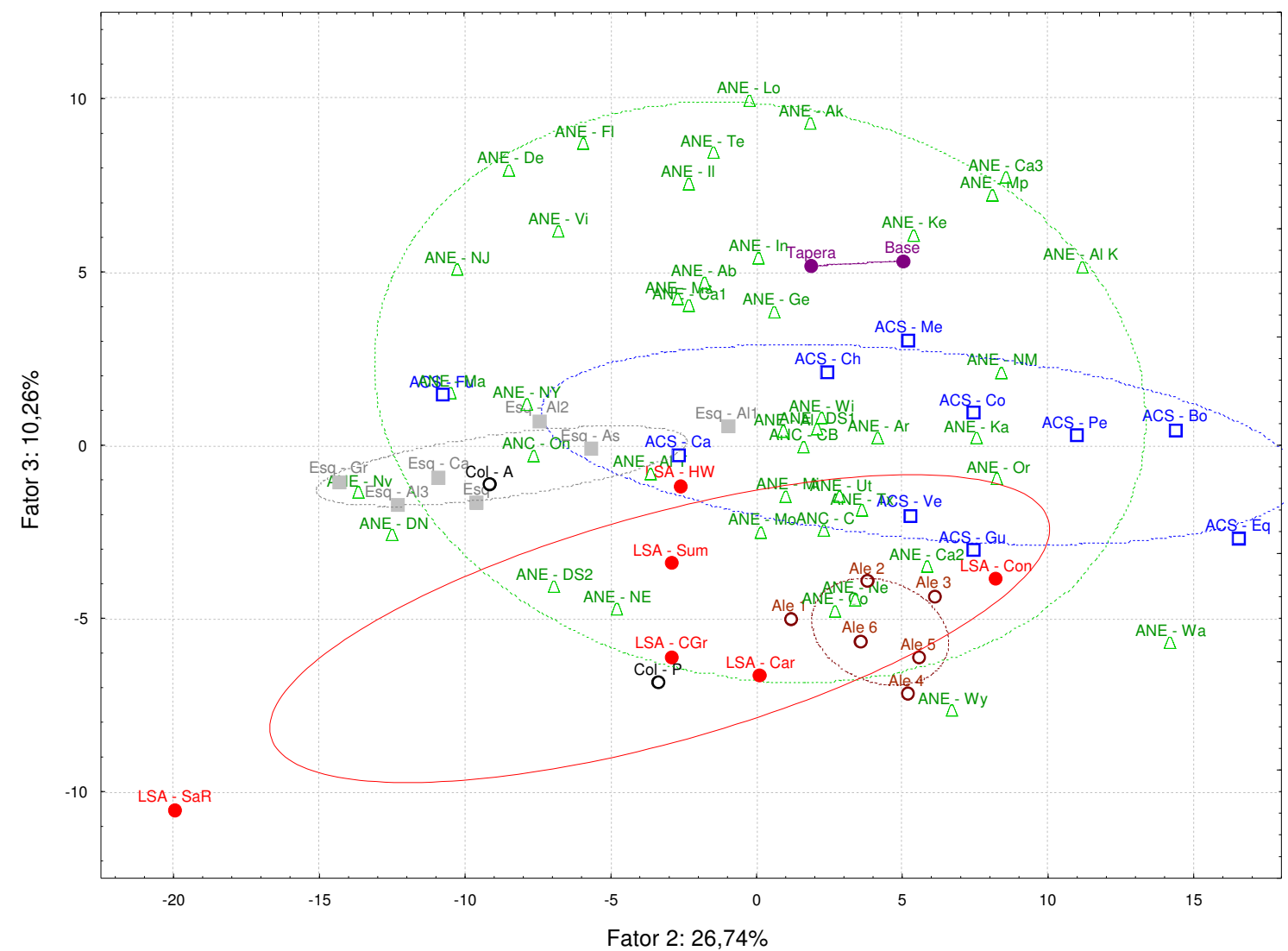

Os gráficos acima indicam forte distinção morfológica dos paleoíndios de Lagoa Santa em relação às outras populações nativas americanas representadas. 0 primeiro gráfico, representando o morfo-espaço formado pelos dois primeiros componentes principais, contendo 65,81 \% da variabilidade amostrada, indica, claramente, esta distinção. As séries representadas neste ensaio distribuem-se, completamente divididas, entre as que são representadas por crânios particularmente mais largos, comuns à morfologia mongolóide, alocadas na região esquerda do gráfico, e aquelas, agregando Lagoa Santa e Colômbia, representadas por crânios mais estreitos, longos e altos, comuns à morfologia australo-melanésica, no extremo direito da figura. 0 mesmo tipo de dispersão pode ser observado no gráfico formado pelos primeiro e terceiro componentes principais, que juntos somam 49,33\% da variabilidade contida na amostra. Os crânios estreitos e longos localizam-se no quadrante direito inferior, enquanto, de maneira completamente oposta, os crânios largos e pouco prognatos alocam-se na região centro-esquerda do gráfico. Já o gráfico representativo da topologia definida pelos segundo e terceiro componentes principais, expressando apenas 37,00 \% da variabilidade contida na amostra não apresenta padrões claros de associação preferencial entre as amostras, mostrando baixa resolução topológica, como esperado. 
Figura 4.5 - Dendrograma gerado sobre matriz de Distância Euclidiana calculada a partir dos sete primeiros componentes principais - Método de Ward. Parcela masculina, forma e tamanho (76 séries, 23 variáveis craniométricas).

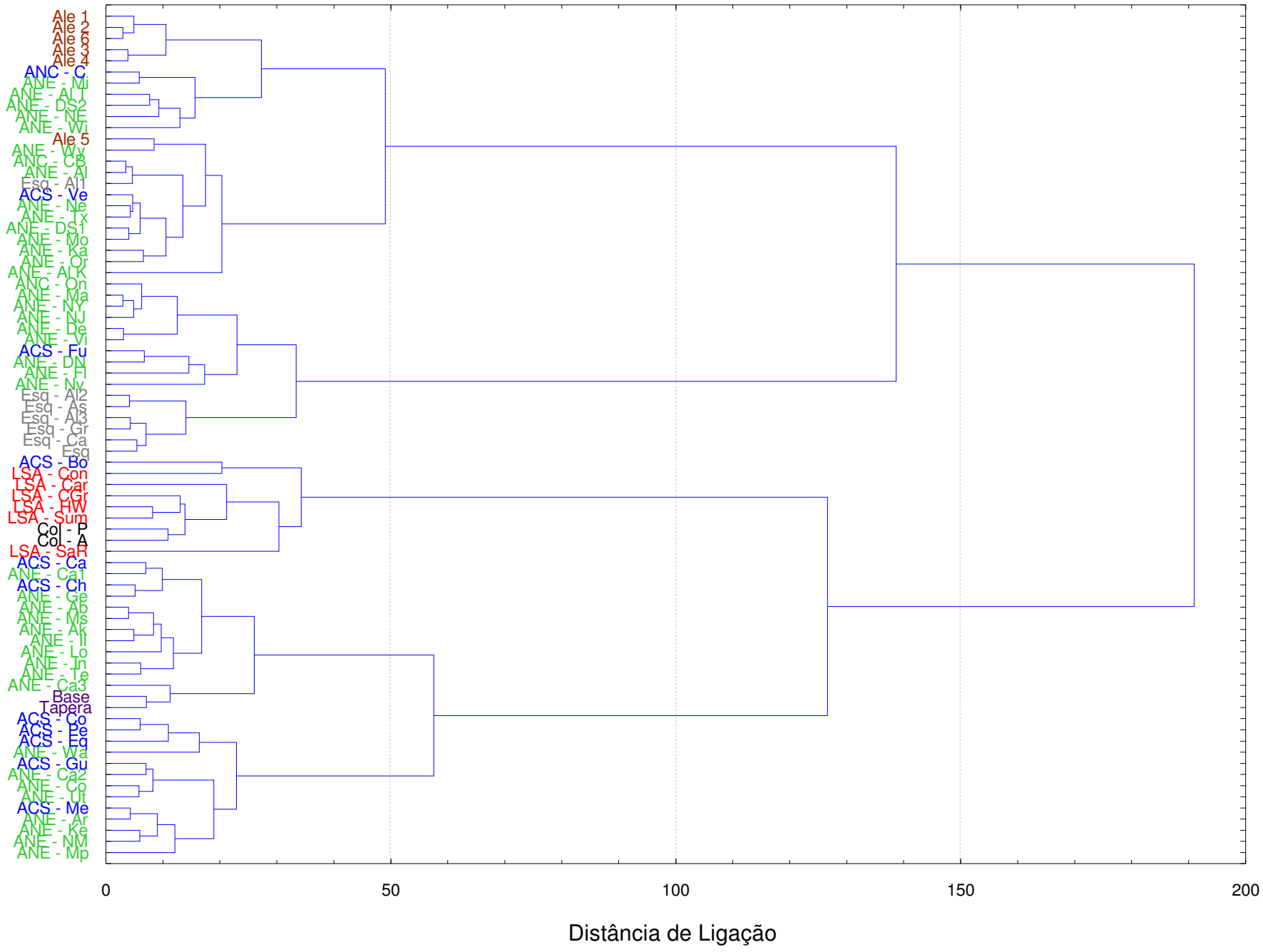


Figura 4.6 - Dendrograma gerado sobre matriz de Distância Euclidiana calculada a partir dos sete primeiros componentes principais - Método de Ligação Simples. Parcela masculina, forma e tamanho (76 séries, 23 variáveis craniométricas).

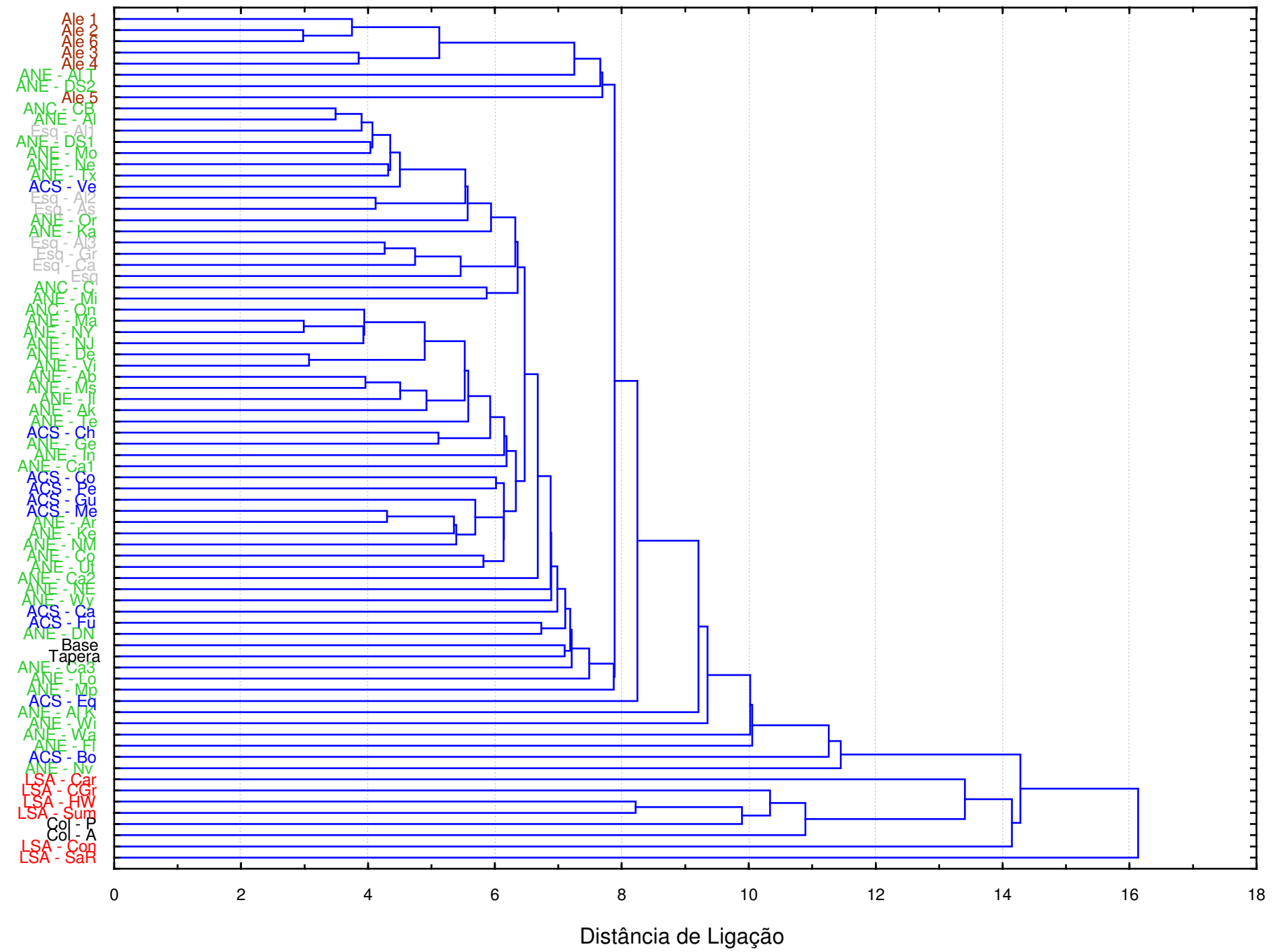


Figura 4.7 - Dendrograma gerado sobre matriz de Distância Euclidiana calculada a partir dos sete primeiros componentes principais - Método de Ligação Completa. Parcela masculina, forma e tamanho (76 séries, 23 variáveis craniométricas).

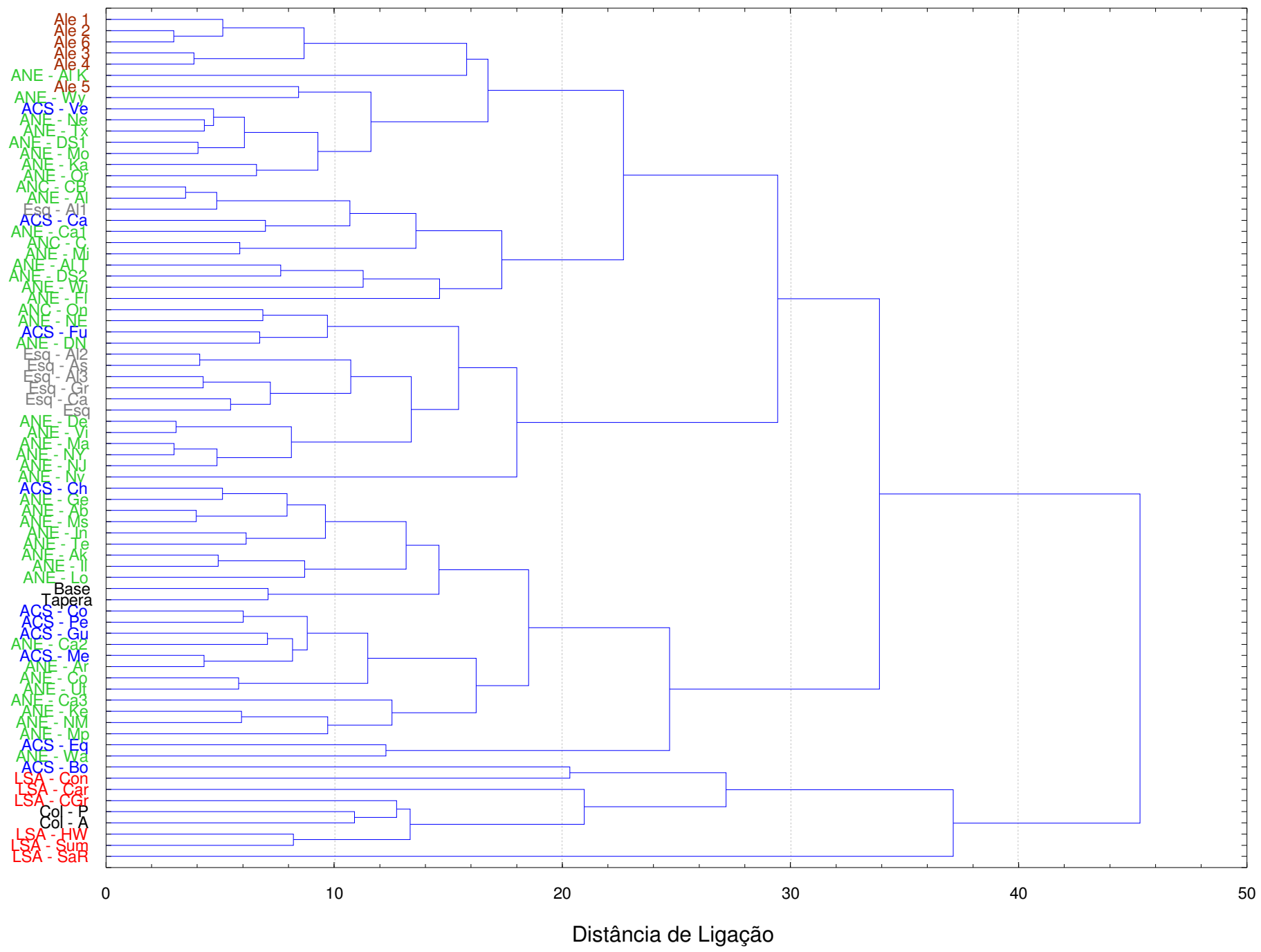


Figura 4.8 - Dendrograma gerado sobre matriz de Distância Euclidiana calculada a partir dos sete primeiros componentes principais - Método da Média dos Grupos. Parcela masculina, forma e tamanho (76 séries, 23 variáveis craniométricas).

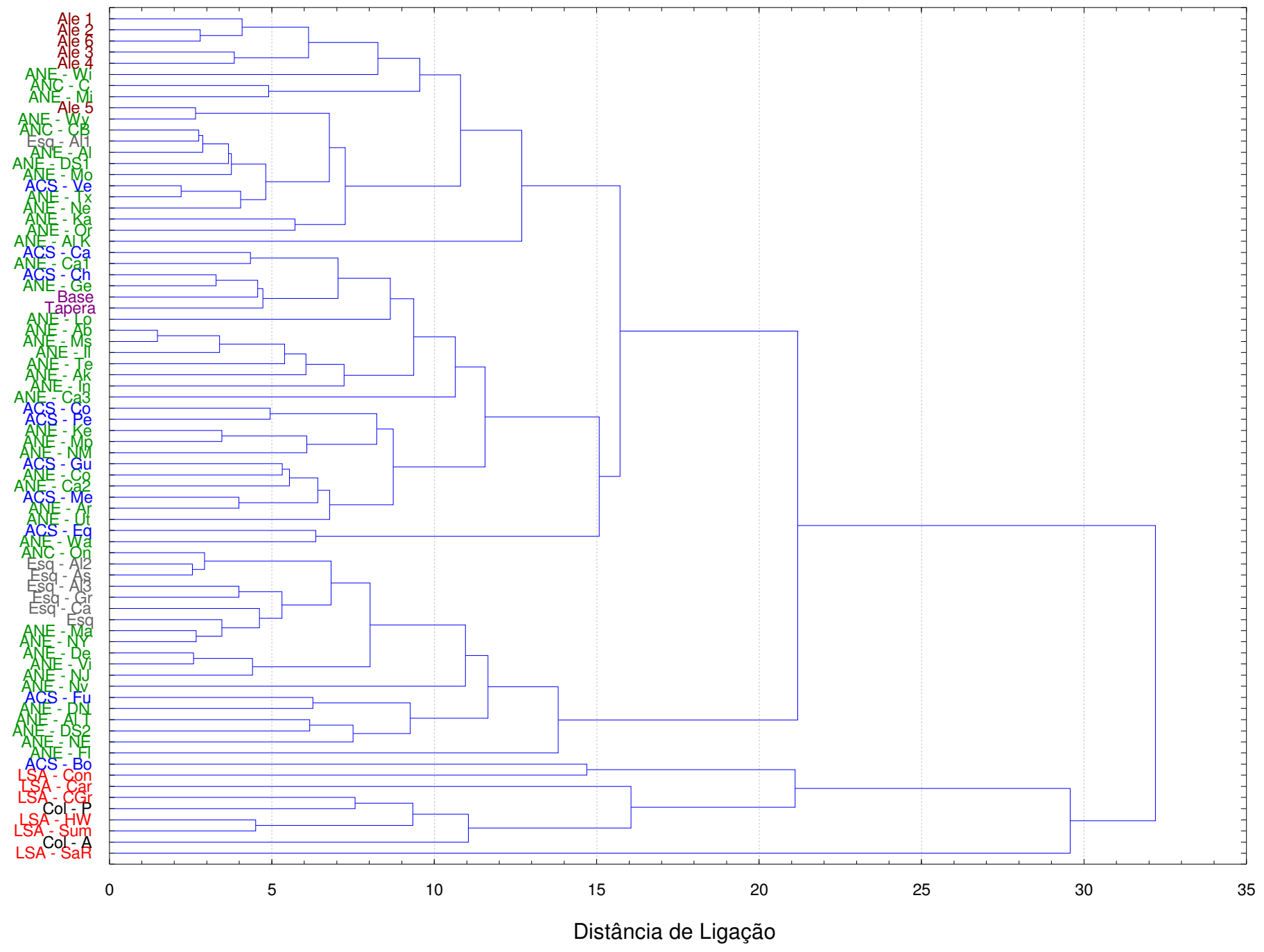


Os dendrogramas das Figuras 4.5 a 4.8 apresentam algumas características comuns, independentes do método de aglomeração utilizado para a análise de agrupamento. Entre essas características, saltam aos olhos a constante associação entre as séries paleoíndias de Lagoa Santa e da Colômbia que, via de regra, formam, em todas as análises, um clusters bem conciso. Da mesma forma que ocorre com Lagoa Santa e Colômbia, as séries representativas dos Aleutas e dos Esquimós também formaram grupos concisos, porém não associados entre si. À exceção do Método de Ward, a análise de agrupamentos baseada em matriz de distâncias euclidianas sobre a parcela masculina, sem correção de tamanho, mostra Lagoa Santa e Colômbia dissociadas das outras populações nativas americanas incluídas no estudo, em especial quando se leva em consideração os métodos dos vizinhos distantes e da média entre os grupos.

Como exposto anteriormente, uma outra maneira de investigar as afinidades biológicas entre populações é a utilização da distância de Mahalanobis para a geração de uma matriz de dissimilaridades.

Os dendrogramas apresentados nas figuras 4.9 a 4.12 foram gerados a partir da utilização desse recurso. Assim como ocorreu na análise feita a partir de distâncias Euclidianas, os agrupamentos mostram-se concisos, com, mais uma vez, destaque para o grupo que agregou as séries de Lagoa Santa. Todos os dendrogramas, exceto o efetuado a partir do método de Ward, confirmam a peculiaridade morfológica do grupo Paleoíndio de Lagoa Santa, mostrando-se sempre agregado à parte dos outros clusters.

A tabela 4.3 apresenta a matriz de distância de Mahalanobis. 
Tabela 4.3 - Matriz de Distâncias de Mahalanobis. Parcela masculina, forma e tamanho (28 grupos, 23 variáveis craniométricas).

\begin{tabular}{|c|c|c|c|c|c|c|c|c|c|c|c|c|c|c|c|c|c|c|c|c|c|c|c|c|c|c|c|c|}
\hline & Aleuta & $\begin{array}{l}\text { Am.do } \\
\text { Norte } \\
\text { Canadá }\end{array}$ & $\begin{array}{l}\text { CSA- } \\
\text { Bolivia }\end{array}$ & $\begin{array}{l}\text { CSA- } \\
\text { Caribe }\end{array}$ & $\begin{array}{l}\text { CSA- } \\
\text { Chile }\end{array}$ & $\begin{array}{l}\text { CSA- } \\
\text { Colómbia }\end{array}$ & $\begin{array}{l}\text { CSA- } \\
\text { Equador }\end{array}$ & $\begin{array}{l}\text { CSA- } \\
\text { Fueguinos } \\
\text { (Patagonia) }\end{array}$ & $\begin{array}{c}\text { CSA- } \\
\text { Guiana }\end{array}$ & $\begin{array}{l}\text { CSA- } \\
\text { México }\end{array}$ & $\begin{array}{l}\text { CSA- } \\
\text { Peru }\end{array}$ & $\begin{array}{l}\text { CSA- } \\
\text { Venezuela }\end{array}$ & $\begin{array}{l}\text { Esquimimó } \\
\text {-Alaska }\end{array}$ & $\begin{array}{l}\text { Esquimó } \\
\text {-Asia }\end{array}$ & $\begin{array}{l}\text { Esquimó } \\
\text { - Canadá }\end{array}$ & $\begin{array}{l}\text { Esquimó- } \\
\text { Desconhecido }\end{array}$ & $\begin{array}{l}\text { Esquimó- } \\
\text { Groelândia }\end{array}$ & $\begin{array}{l}\text { Amdo } \\
\text { Norte- } \\
\text { EUA - }\end{array}$ & $\begin{array}{l}\text { Lagoad } \\
\text { Santa- } \\
\text { Lapa de } \\
\text { Carrancas }\end{array}$ & $\begin{array}{c}\text { Lagoa } \\
\text { Santa- } \\
\text { Lapa } \\
\text { Mortudiala } \\
\text { doffin } \\
\text { Conins }\end{array}$ & $\begin{array}{l}\text { Lagoa } \\
\text { Santa- } \\
\text { Cercad } \\
\text { Grande }\end{array}$ & $\begin{array}{l}\text { Lagoa } \\
\text { Santa- } \\
\text { Harold } \\
\text { Walter }\end{array}$ & $\begin{array}{l}\text { Lagooa } \\
\text { Santa }\end{array}$ & $\begin{array}{l}\text { Laaoaa } \\
\text { Sunta- } \\
\text { Sunidouro }\end{array}$ & $\begin{array}{l}\text { Base } \\
\text { Aérea }\end{array}$ & Tapera & $\begin{array}{l}\text { Colömbia } \\
\text { P }\end{array}$ & $\underset{A}{\text { Colômbia }}$ \\
\hline $\begin{array}{c}\text { Alluta } \\
\text { Am. do Norte }\end{array}$ & 0 & 2,485029 & 4,464492 & $\begin{array}{l}3,855174 \\
\end{array}$ & $\begin{array}{l}3,24643 \\
,\end{array}$ & $\begin{array}{l}3,622017 \\
3\end{array}$ & 4,778205 & 3,195686 & $\begin{array}{l}3,899927 \\
3\end{array}$ & $\begin{array}{l}3,692467 \\
\end{array}$ & 3,109379 & 2,814274 & 3,317831 & 2,945422 & 4,134652 & 4,049304 & 4,36678 & 3,011977 & 6,682477 & 7,574131 & 6,342443 & 6,246365 & 6,388919 & 5,966014 & 4,57102 & 5,02174 & 6,088921 & 5,832063 \\
\hline $\begin{array}{l}\text { Amm do dorte } \\
\text { - Conadad }\end{array}$ & & 0 & 3,582755 & 3,365653 & 1,852061 & 3,129981 & & 56 & 2,951267 & 932 & 2,474142 & 2,271438 & 2,761525 & 2,45945 & 936 & 3,3 & 3,8 & 1,526197 & 235 & 6,708551 & 5,219295 & 5,408749 & 5,488886 & 4,805012 & 3,653832 & 4,289591 & 3336 & 20346 \\
\hline $\begin{array}{l}\text { CSA-Bolivia } \\
\text { CAA-Caribe }\end{array}$ & & & & $\begin{array}{c}3,982775 \\
0\end{array}$ & $\begin{array}{l}3,271139 \\
2,945591\end{array}$ & $\begin{array}{l}4,01631 \\
3,45658 \\
2,928871\end{array}$ & $\begin{array}{l}3,786224 \\
4,405019 \\
3,188006\end{array}$ & $\begin{array}{l}4,386479 \\
3,24596 \\
1927258\end{array}$ & $\begin{array}{l}3,674056 \\
3,22591 \\
2,93553\end{array}$ & $\begin{array}{l}2,988779 \\
2,645971 \\
1,73254\end{array}$ & $\begin{array}{l}2,813804 \\
2,990428 \\
1,580274\end{array}$ & $\begin{array}{l}3,290495 \\
3,068886 \\
2,58808\end{array}$ & $\begin{array}{l}5.0724222 \\
4,13562 \\
3.331082\end{array}$ & $\begin{array}{l}4,608815 \\
3,963458 \\
3,17552\end{array}$ & $\begin{array}{l}5,48846 \\
4,57489 \\
3,570154\end{array}$ & $\begin{array}{r}5,10755 \\
3,92727 \\
3,46257\end{array}$ & $\begin{array}{l}6,030542 \\
4,82367 \\
4146099\end{array}$ & $\begin{array}{l}3,175785 \\
2,81354 \\
1,450997\end{array}$ & $\begin{array}{l}6,856681 \\
6,93958 \\
5,955026\end{array}$ & $\begin{array}{l}7,12344 \\
7,195549 \\
6411663\end{array}$ & $\begin{array}{l}5,442868 \\
5,707537 \\
5149359\end{array}$ & $\begin{array}{l}6,019586 \\
5,884145 \\
5,22856\end{array}$ & $\begin{array}{l}5,905461 \\
5,549345 \\
5500842\end{array}$ & $\begin{array}{l}5,021562 \\
5,567738 \\
4713804\end{array}$ & $\begin{array}{l}3.817032 \\
4,55037 \\
3,693834\end{array}$ & $\begin{array}{l}4,37539 \\
5,003455 \\
445193\end{array}$ & $\begin{array}{l}5,430228 \\
5,717425 \\
5307242\end{array}$ & $\begin{array}{l}4,786334 \\
4,6820212 \\
4285128\end{array}$ \\
\hline $\begin{array}{l}\text { CA } \\
\text { Colómbia }\end{array}$ & & & & & & & 3,708458 & 3,745916 & 3,073864 & 2,551627 & 2,472911 & 2,676368 & 4,035887 & 4,4474 & 4,410017 & 4,042735 & 5,104982 & 2,937978 & 7,05833 & 7,44344 & 6,289764 & 6,670855 & 6,83779 & 6,005272 & 4,634359 & 5,206115 & 6,54264 & 6,401931 \\
\hline $\begin{array}{l}\text { CSA- } \\
\text { Equador }\end{array}$ & & & & & & & 0 & 4,145478 & 3,223138 & 2,728467 & 2,714065 & 3,19158 & 5,134117 & 4,900073 & 5,693317 & 5,176055 & 6,232258 & 3,036789 & 6,921964 & 7,292064 & 5,948868 & 5,924259 & 6,576262 & 5,48661 & 4,402303 & 5,311002 & 6,444439 & 5,664322 \\
\hline $\begin{array}{l}\text { CSAA- } \\
\text { Fueguinos }\end{array}$ & & & & & & & & 0 & 3,579732 & 2,799086 & 2,870724 & $\begin{array}{l}3,088482 \\
\end{array}$ & 2,975489 & 2,731523 & 3,219536 & 3,316004 & 3,690033 & 1,909765 & 6,054418 & 6,773364 & 5,613047 & 5,417647 & 5,709702 & 4,994475 & 3,930293 & 4,41898 & 5,315126 & 4,35246 \\
\hline CSA-Guiana & & & & & & & & & 0 & 2,391211 & $\begin{array}{r}2,98336 \\
1.551969\end{array}$ & $\begin{array}{l}2,243536 \\
\end{array}$ & $\begin{array}{l}4,689389 \\
4,60089\end{array}$ & 4,364883 & 4,9676222 & 4,579634 & 5,546566 & 2,880198 & 7,496897 & 7,560191 & 6,449933 & 6.505326 & 6,148348 & 6,072103 & 4,513971 & 4,996878 & 6,288511 & 5,252054 \\
\hline $\begin{array}{l}\text { CAA-Mexico } \\
\text { CSA-Perru }\end{array}$ & & & & & & & & & & & $\begin{array}{l}1,551969 \\
0\end{array}$ & $\begin{array}{l}2,158687 \\
2,202772\end{array}$ & $\begin{array}{l}\begin{array}{l}3.3882883 \\
3,70292\end{array} \\
3\end{array}$ & 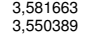 & $\begin{array}{l}\begin{array}{l}4,3966636 \\
4,201678\end{array} \\
4\end{array}$ & $\begin{array}{l}\begin{array}{l}4,4112418 \\
3,856327\end{array} \\
3\end{array}$ & $\begin{array}{l}4,901913 \\
4,780211\end{array}$ & $\begin{array}{l}1,489042 \\
1,753114\end{array}$ & 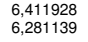 & 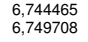 & $\begin{array}{l}5,4009999 \\
55,469962\end{array}$ & $\begin{array}{l}\begin{array}{l}5.545538 \\
5,26115\end{array} \\
\end{array}$ & $\begin{array}{l}5,551823 \\
6,063767\end{array}$ & $\begin{array}{l}5,0404269 \\
4,994657\end{array}$ & 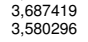 & $\begin{array}{l}\begin{array}{r}4,293641 \\
4,269546\end{array} \\
4\end{array}$ & $\begin{array}{l}5,5,58648 \\
5,443234\end{array}$ & $\begin{array}{l}4,4641031 \\
4,948815\end{array}$ \\
\hline $\begin{array}{c}\text { CSA- } \\
\text { Venezuela }\end{array}$ & & & & & & & & & & & & & 3,893943 & 3,656758 & 4,593978 & 4,159633 & 5,201976 & 2,148182 & 6,97139 & 7,581492 & 6,242273 & 6,286022 & 5,851836 & 5,665143 & 4,155685 & 4,515219 & 6,082611 & 5,548444 \\
\hline $\begin{array}{l}\text { Esquimimó } \\
\text { Alaska }\end{array}$ & & & & & & & & & & & & & 0 & 1,959962 & 1,804821 & 2,148709 & 1,881464 & 3,152007 & 6,486269 & 6,390686 & 5,38113 & 5,482744 & 5,547379 & 5,542727 & 4,754984 & 5,16305 & 6,044211 & 5,687819 \\
\hline $\begin{array}{l}\text { sacuimb } \\
\text { Asia }\end{array}$ & & & & & & & & & & & & & & 0 & 2,857277 & 3,069563 & 2,85406 & 2,884906 & 6,430001 & 6,436421 & 5,361816 & 5,180239 & 5,19361 & 5,450813 & 3,807149 & 4,164594 & 5,165826 & 4,645304 \\
\hline $\begin{array}{l}\text { Esquimó- } \\
\text { Canadá }\end{array}$ & & & & & & & & & & & & & & & 0 & 1,758684 & $\begin{array}{r}1,252633 \\
\end{array}$ & 3,921284 & 6,59705 & 6,340654 & 5,59238 & 5,61929 & 6,221014 & 5,786888 & 5,153242 & 5,372671 & 6,053688 & 5,653982 \\
\hline $\begin{array}{l}\text { Esquilio- } \\
\text { Desconhecido }\end{array}$ & & & & & & & & & & & & & & & & 0 & 2,262475 & 3,823493 & 6,882942 & 6,696224 & 5,730333 & 5,797612 & 6,001644 & 5,73357 & 5,003125 & 5,214611 & 6,146927 & 5,526294 \\
\hline $\begin{array}{l}\text { Esquimó- } \\
\text { Groelândia }\end{array}$ & & & & & & & & & & & & & & & & & 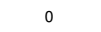 & 4,357394 & 6,677771 & 6,365418 & 5,48952 & 5,509635 & 5,993542 & 5,887014 & 5,609329 & 5,869531 & 6,202826 & 5,750845 \\
\hline $\begin{array}{l}\text { Am. do Norte } \\
\text { - EUA }\end{array}$ & & & & & & & & & & & & & & & & & & 0 & 6,099724 & 6,614523 & 5,135386 & 5,167312 & 5,330264 & 4,661625 & 3,49557 & 4,301036 & 5,344974 & 4,597861 \\
\hline $\begin{array}{l}\text { Lagoa Sanata- } \\
\text { Lapa de } \\
\text { Carrancas }\end{array}$ & & & & & & & & & & & & & & & & & & & 0 & 3,971939 & 3,992041 & 4,291986 & 5,977325 & 2,948277 & 5,9397995 & 6,250656 & 5,36500 & 5,947651 \\
\hline $\begin{array}{l}\text { Morapia } \\
\text { Mortuaria de } \\
\text { Confins }\end{array}$ & & & & & & & & & & & & & & & & & & & & 0 & 3,374411 & 3,9366677 & 6,088327 & 4,314527 & 5,886042 & 6,340234 & 5,161507 & 5,930998 \\
\hline $\begin{array}{l}\text { agoad Santa- - } \\
\text { Cerca Grande }\end{array}$ & & & & & & & & & & & & & & & & & & & & & 0 & 3,416441 & 4,797677 & 2,747396 & 5,23513 & 5,92026 & 4,584007 & 4,963421 \\
\hline$-\mathrm{H}$ & & & & & & & & & & & & & & & & & & & & & & 0 & 4,953552 & 3,31851 & 4,981182 & 5,755485 & 4,432392 & 4,954746 \\
\hline & & & & & & & & & & & & & & & & & & & & & & & 0 & 4,515999 & 6,138702 & 6,294943 & 5,189806 & 5,037709 \\
\hline & & & & & & & & & & & & & & & & & & & & & & & & 0 & 4,726542 & 5,303414 & 4,604381 & 4,870324 \\
\hline $\begin{array}{l}\text { Tapera } \\
\text { Colómbia P }\end{array}$ & & & & & & & & & & & & & & & & & & & & & & & & & & & $\begin{array}{l}4,2,17599 \\
4,17629\end{array}$ & 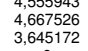 \\
\hline
\end{tabular}


Figura 4.9 - Dendrograma gerado sobre matriz de Distância de Mahalanobis - Método de Ward. Parcela masculina, forma e tamanho.

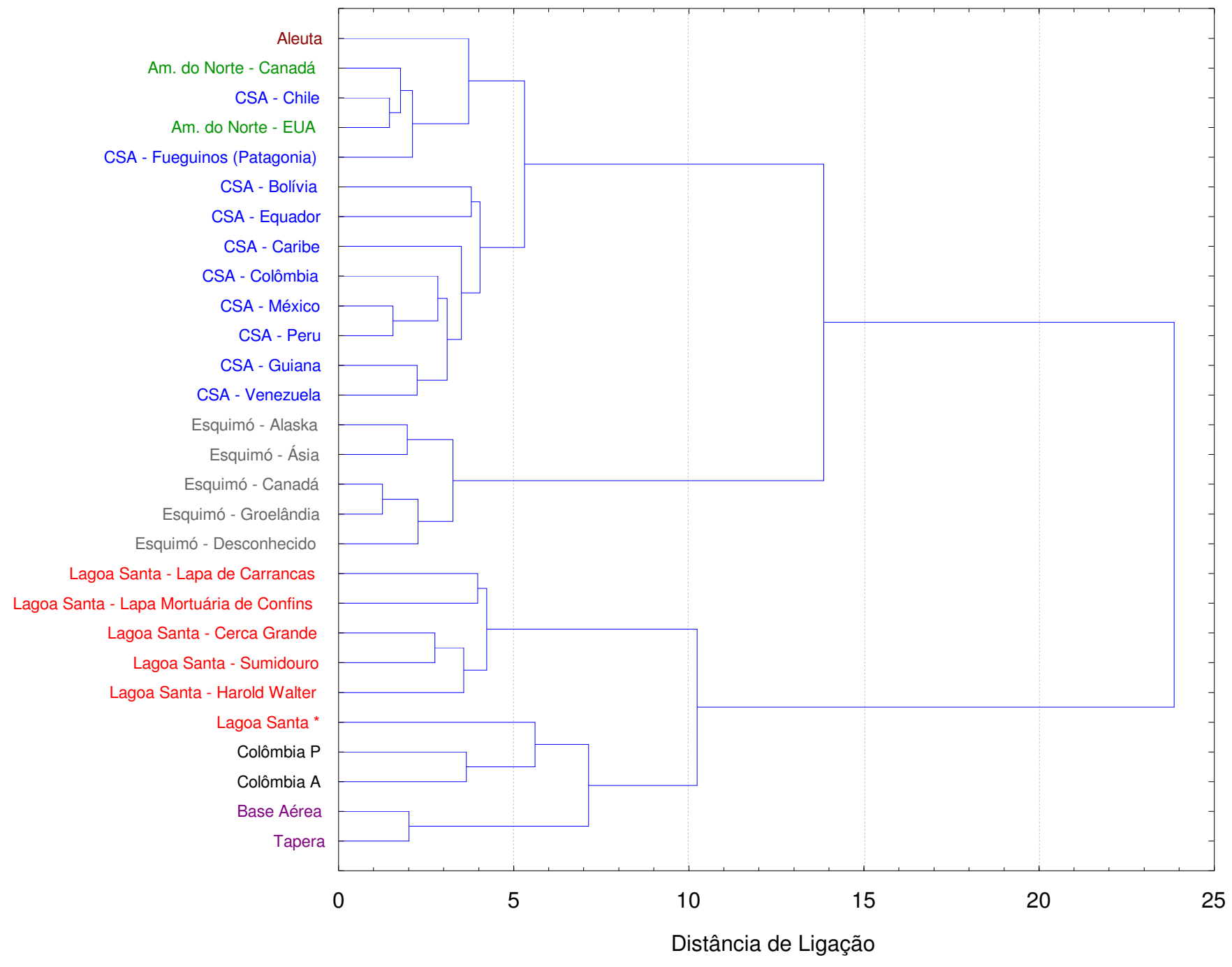


Figura 4.10 - Dendrograma gerado sobre matriz de Distância de Mahalanobis - Método de Ligação Simples. Parcela masculina, forma e tamanho.

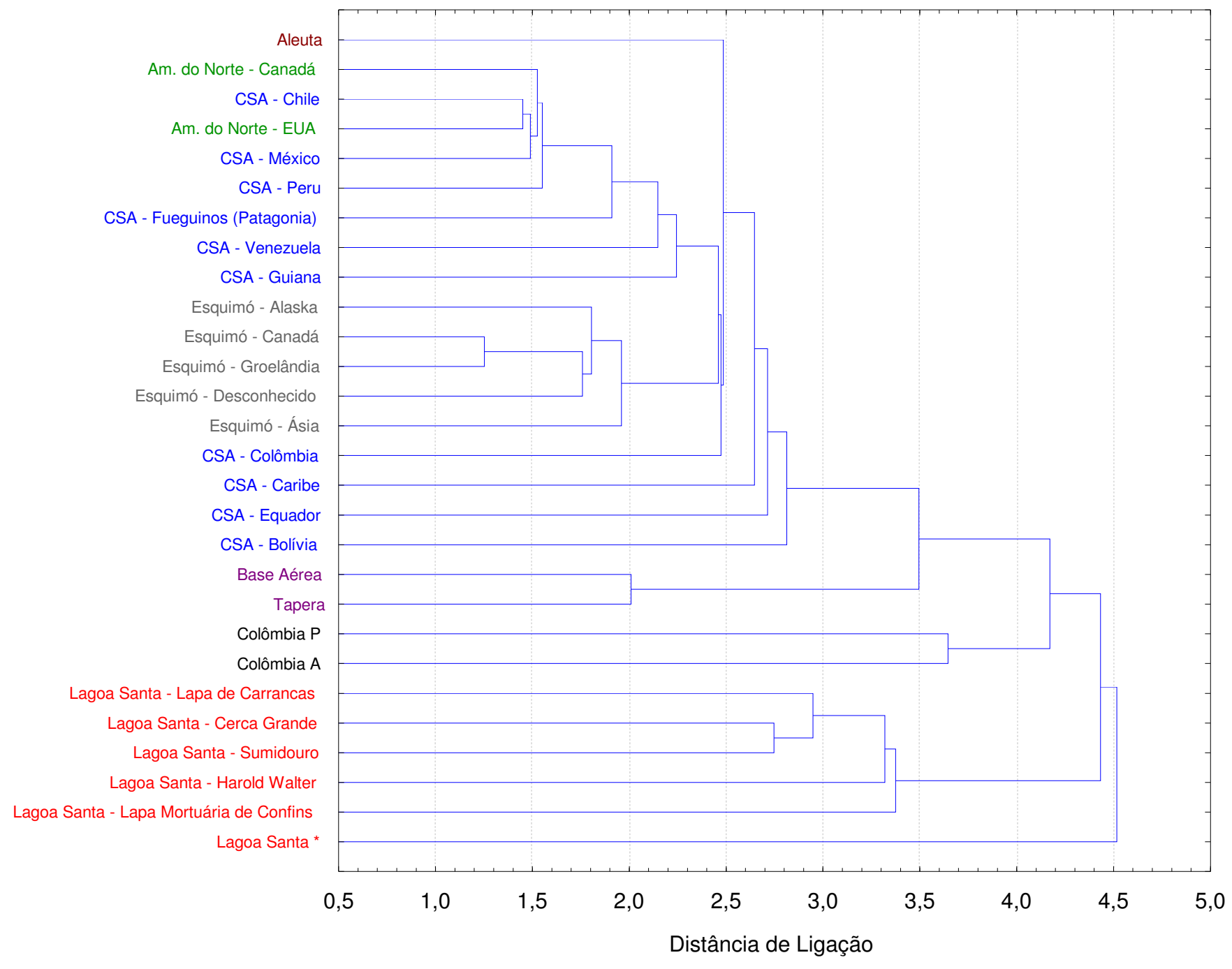


Figura 4.11 - Dendrograma gerado sobre matriz de Distância de Mahalanobis - Método de Ligação Completa. Parcela masculina, forma e tamanho.

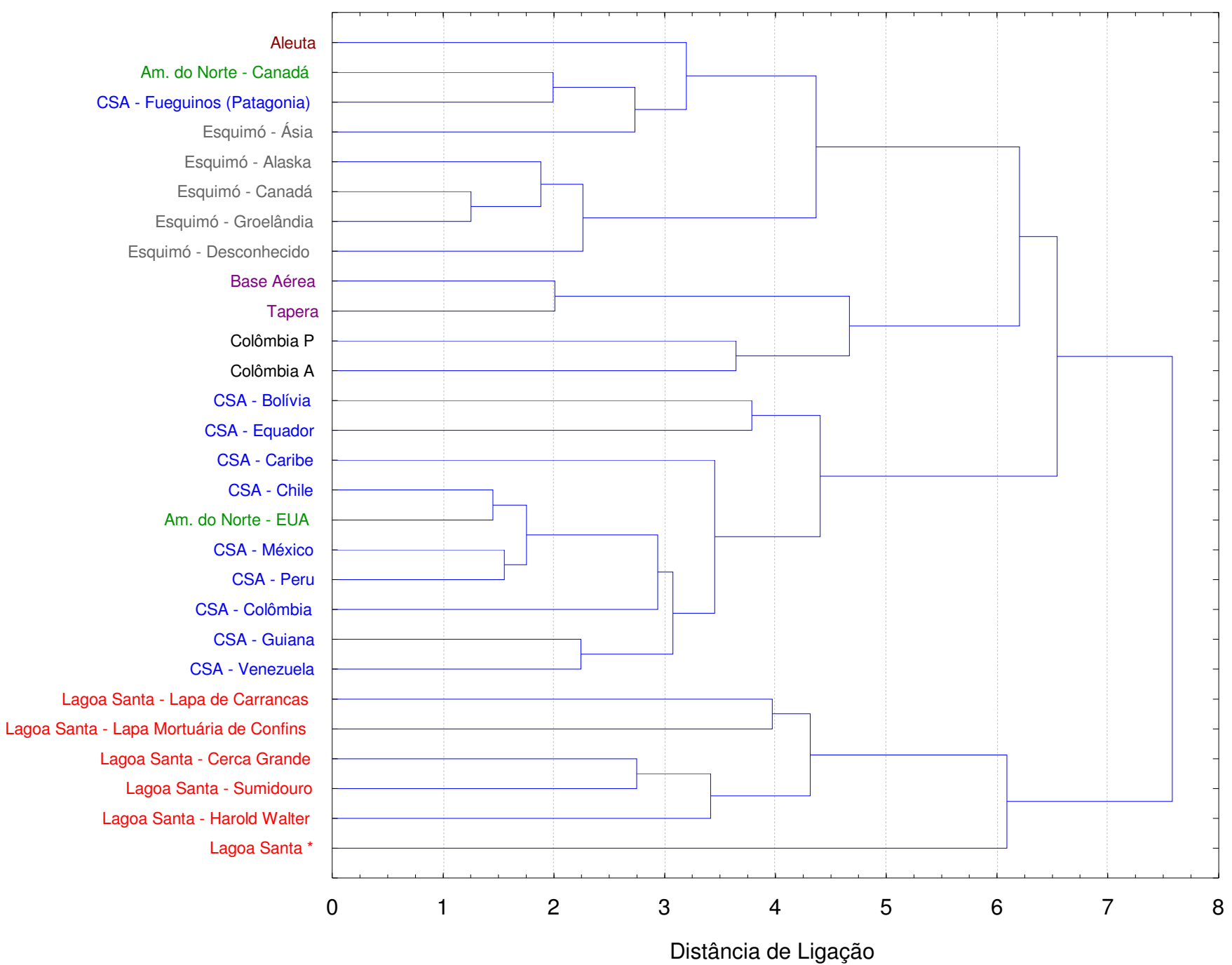


Figura 4.12 - Dendrograma gerado sobre matriz de Distância de Mahalanobis - Método da Média dos Grupos. Parcela masculina, forma e tamanho.

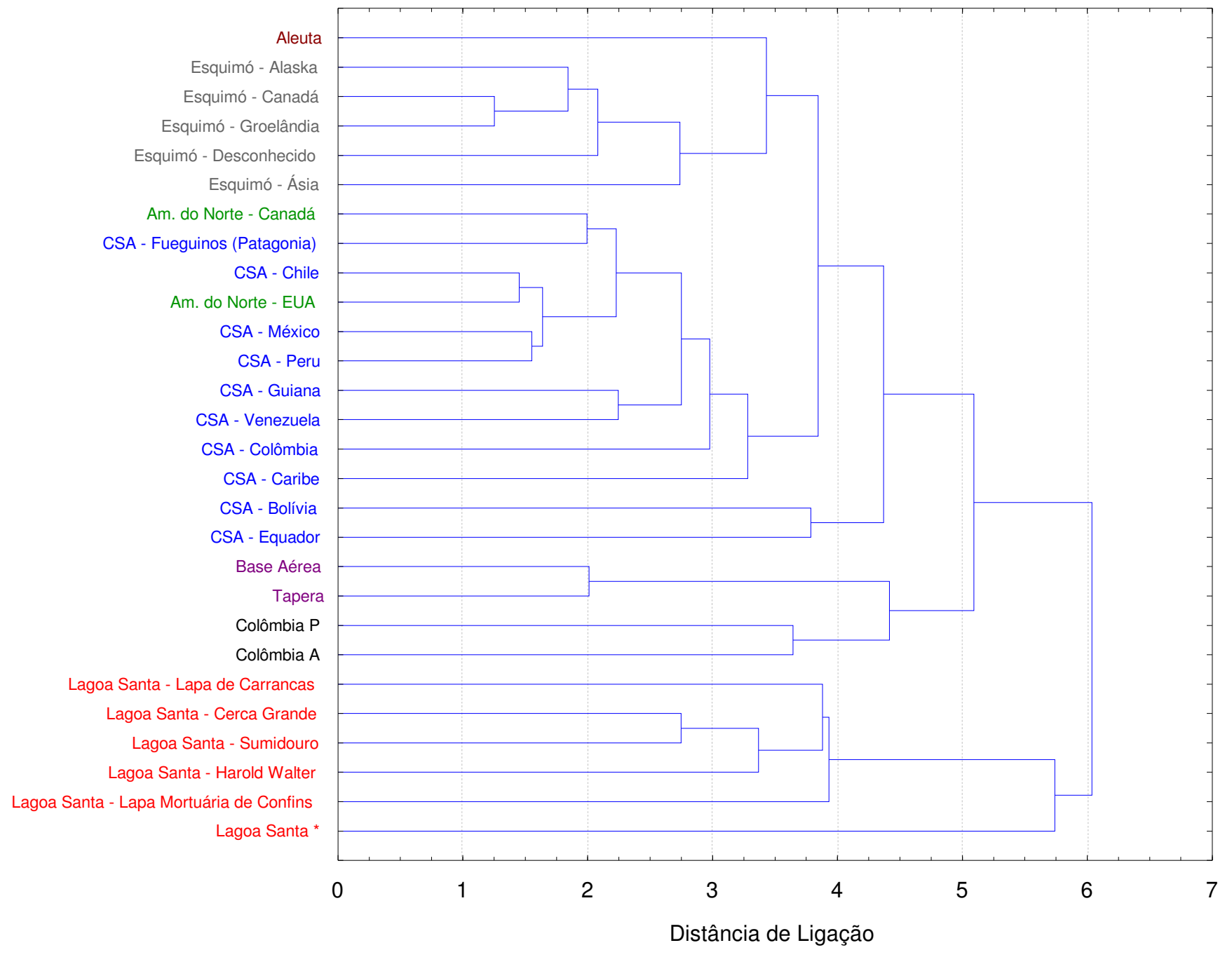


Conforme explicado em Material e Métodos, matrizes de dissimilaridades também podem subsidiar a investigação de afinidades morfológicas através da aplicação, sobre elas, da técnica de Escalonamento Multidimensional (MDS).

A tabela 4.4 fornece o resultado das três primeiras dimensões calculadas a partir da matriz de distância de Mahalanobis para a análise intracontinental, forma e tamanho, da parcela masculina. As figuras 4.13, 4.14 e 4.15 referemse, respectivamente, às topologias resultantes do plano formado pela relação ortogonal entre as dimensões $1 \times 2,1 \times 3$ e $2 \times 3$.

A exemplo do que se observou nas ACP's, as duas primeiras topologias apresentam uma maior resolução. Também, a exemplo do observado nos resultados gerados pelas outras técnicas já apresentadas, nota-se a população paleoíndia de Lagoa Santa fortemente separada das demais populações nativas do continente americano, guardando, ainda, alguma relação espacial com a população Paleoíndia da Colômbia.

Tabela 4.4 - Configuração final das dimensões calculadas através de escalonamento multidimensional sobre Matriz de Distância baseada em Distâncias de Mahalanobis. Parcela masculina, forma e tamanho (28 grupos, 23 variáveis craniométricas).

\begin{tabular}{c|c|c|c}
\hline Grupos & Dimensão 1 & Dimensão 2 & Dimensão 3 \\
\hline Aleuta & $-0,78149$ & $-0,30658$ & $-0,410762$ \\
Am. Do Norte - Canadá & $-0,36362$ & $-0,09199$ & $-0,069847$ \\
CSA - Bolívia & $-0,45761$ & 0,73880 & 0,176703 \\
CSA - Caribe & $-0,57246$ & 0,00350 & 0,531651 \\
CSA - Chile & $-0,32145$ & $-0,050466$ \\
CSA - Colômbia & $-1,04942$ & 0,05319 & $-0,166558$ \\
CSA - Equador & $-0,86687$ & $-0,01050$ & $-0,125387$ \\
CSA - Fueguinos (Patagonia) & $-0,31846$ & 0,64972 & 0,107117 \\
CSA - Guiana & $-0,94280$ & $-0,18917$ & 0,273776 \\
CSA - México & $-0,47248$ & 0,26112 & 0,062775 \\
CSA - Peru & $-0,47733$ & 0,19746 & $-0,120664$ \\
CSA - Venezuela & $-0,79940$ & 0,18091 & 0,008862 \\
Esquim - Alaska & $-0,30725$ & $-0,102616$ \\
Esquim - Ásia & $-0,16850$ & $-0,65524$ & $-0,150021$ \\
Esquim - Canadá & $-0,27647$ & $-0,068643$ \\
Esquim - Desconhecido & $-0,44999$ & $-0,861329$ & 0,101990 \\
Esquim - Groelândia & $-0,16876$ & $-0,056812$ \\
Am. do Norte - EUA & $-0,34736$ & $-1,04680$ & 0,042502 \\
Lagoa Santa - Lapa de Carrancas & 1,65611 & $-0,694848$ \\
Lagoa Santa - Lapa Mortuária de Confins & 1,89703 & 0,07058 & $-0,150577$ \\
Lagoa Santa - Cerca Grande & 1,17575 & 0,04350 & 0,228831 \\
Lagoa Santa - Harold Walter & 1,16621 & $-0,33480$ & $-0,074270$ \\
Lagoa Santa * & 0,80679 & $-0,12055$ & 1,231889 \\
Lagoa Santa - Sumidouro & 1,00711 & $-0,30041$ & $-0,099317$ \\
Base Aérea & 0,02034 & -15166 & $-0,451704$ \\
Tapera & 0,03634 & 0,15867 & $-0,697784$ \\
Colômbia P & 0,93278 & 0,121359 \\
Colômbia A & 0,44327 & 0,69737 & 0,602822 \\
\hline & & 0,87043 & 0,65640 \\
\hline
\end{tabular}


Figura 4.13 - Gráfico bidimensional da relação ortogonal entre as dimensões $1 \times 2$. Parcela masculina, forma e tamanho ( 28 grupos, 23 variáveis craniométricas).

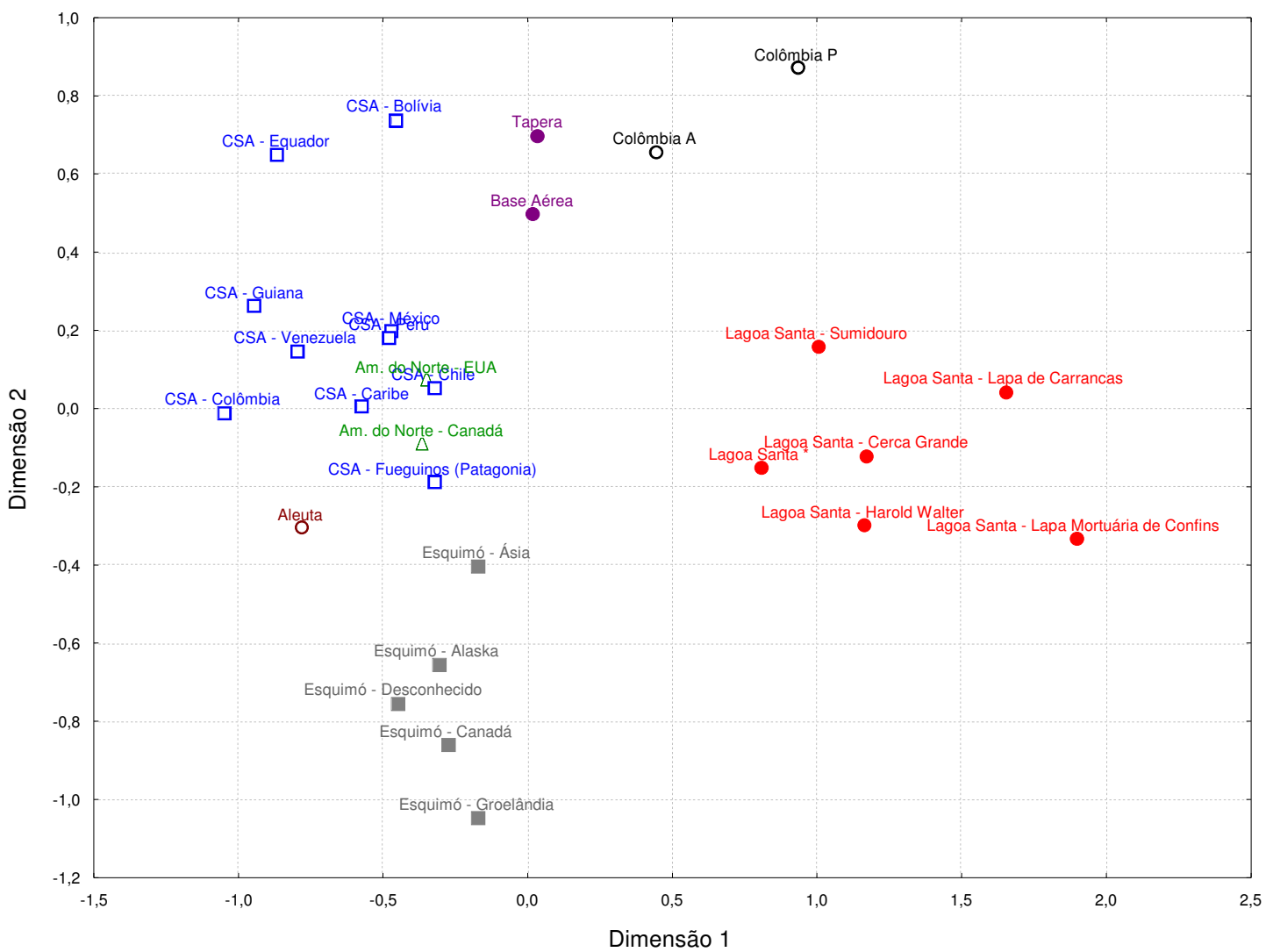

Figura 4.14 - Gráfico bidimensional da relação ortogonal entre as dimensões $1 \times 3$. Parcela masculina, forma e tamanho (28 grupos, 23 variáveis craniométricas).

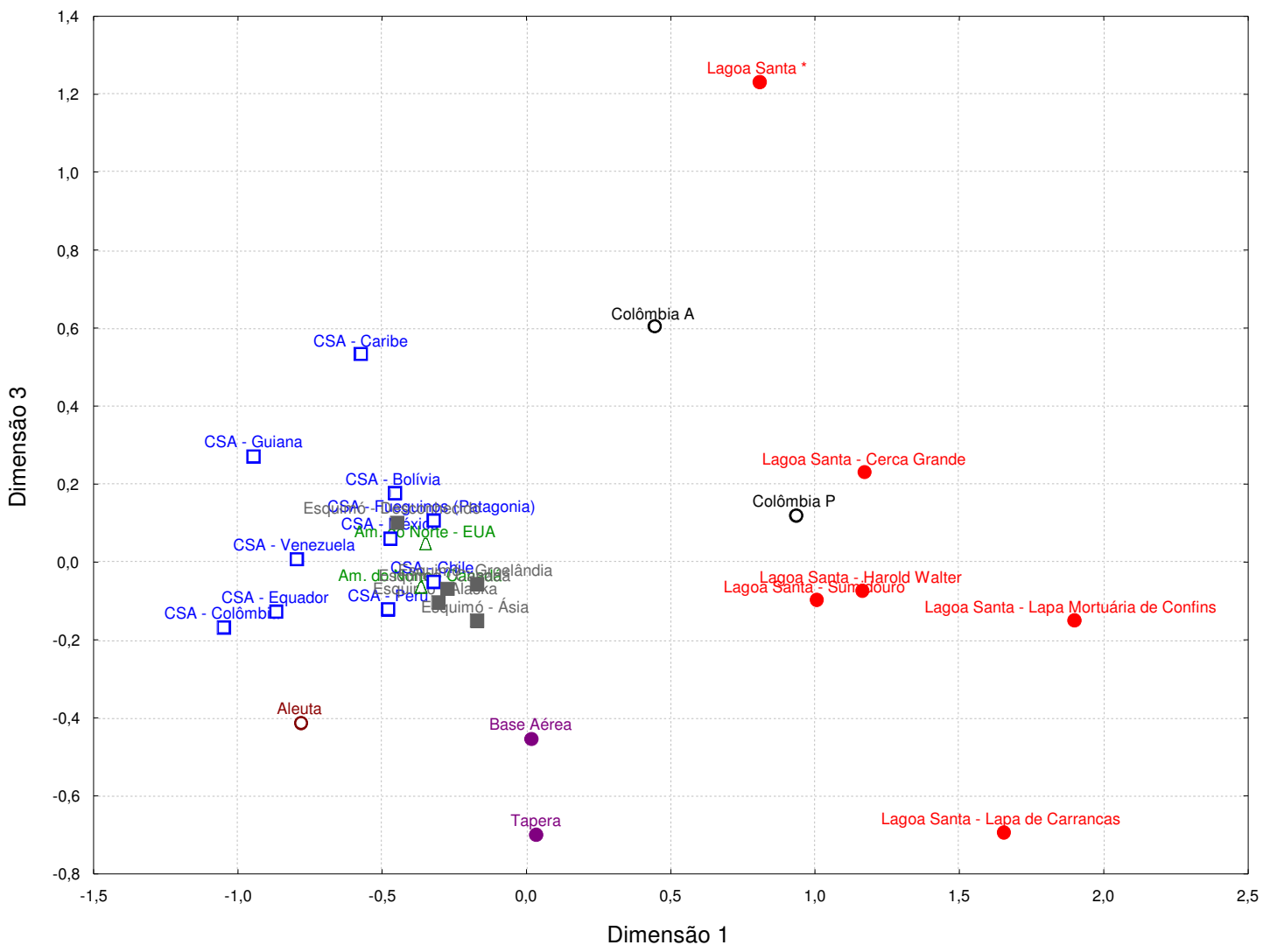


Figura 4.15 - Gráfico bidimensional da relação ortogonal entre as dimensões $2 \times 3$. Parcela masculina, forma e tamanho (28 grupos, 23 variáveis craniométricas).

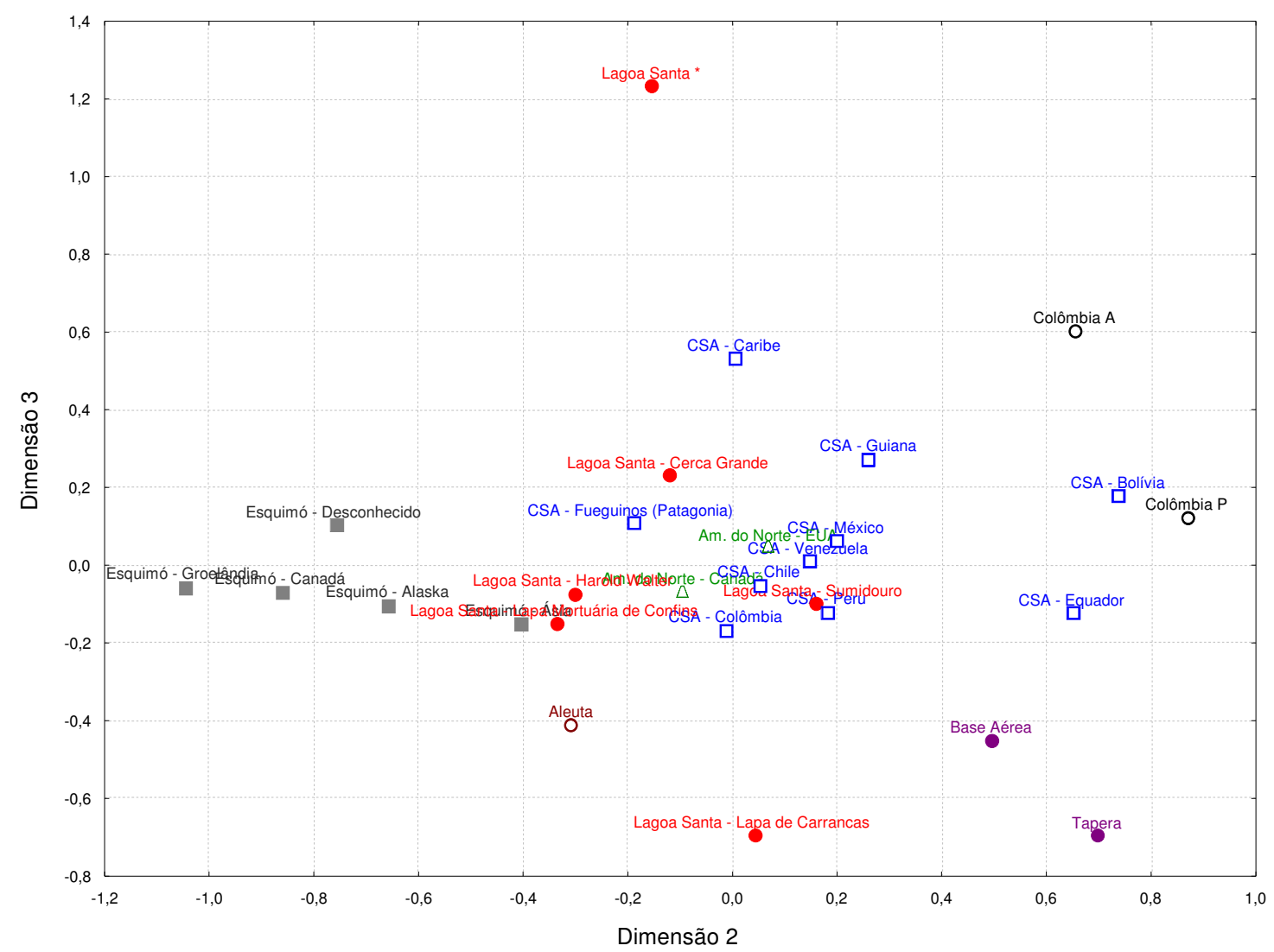

\subsection{2 - Parcela Masculina, Forma Apenas}

A ACP foi realizada sobre as mesmas 23 variáveis, distribuídas em 76 séries, que já haviam sido utilizadas na análise sem correção do fator. A Tabela 4.5 apresenta a síntese dos resultados extraídos da matriz de covariância dos dados estudados. A mesma tabela é representada, graficamente, através da Figura 4.16. A análise desse "screeplot" permitiu a escolha dos Componentes Principais que foram utilizados para o cálculo de Distâncias Euclidianas. 
Tabela 4.5 - Autovalores da matriz de covariância e porcentagens de variância explicada por cada Componente Principal. Parcela masculina, forma apenas ( 76 séries, 23 variáveis craniométricas).

\begin{tabular}{c|c|c|c|c|}
\hline $\begin{array}{c}\text { Componente } \\
\text { Principal }\end{array}$ & Autovalor & $\%$ Total & $\begin{array}{c}\text { Autovalor } \\
\text { Cumulativo }\end{array}$ & $\%$ Cumulativa \\
\hline 1 & 0,018901 & 44,75828 & 0,018901 & 44,7583 \\
2 & 0,009697 & 22,96333 & 0,028599 & 67,7216 \\
3 & 0,004002 & 9,47759 & 0,032601 & 77,1992 \\
4 & 0,002790 & 6,60625 & 0,035391 & 83,8054 \\
5 & 0,001526 & 3,61399 & 0,036917 & 87,4194 \\
6 & 0,001239 & 2,93320 & 0,038156 & 90,3526 \\
7 & 0,000840 & 1,98900 & 0,038996 & 92,3416 \\
8 & 0,000707 & 1,67372 & 0,039703 & 94,0153 \\
9 & 0,000486 & 1,15060 & 0,040188 & 95,1659 \\
10 & 0,000440 & 1,04148 & 0,040628 & 96,2074 \\
11 & 0,000329 & 0,78017 & 0,040958 & 96,9876 \\
12 & 0,000256 & 0,60582 & 0,041214 & 97,5934 \\
13 & 0,000210 & 0,49754 & 0,041424 & 98,0910 \\
14 & 0,000202 & 0,47793 & 0,041626 & 98,5689 \\
15 & 0,000150 & 0,35619 & 0,041776 & 98,9251 \\
16 & 0,000121 & 0,28747 & 0,041897 & 99,2125 \\
17 & 0,000095 & 0,22470 & 0,041992 & 99,4372 \\
18 & 0,000080 & 0,19033 & 0,042073 & 99,6276 \\
19 & 0,000064 & 0,15146 & 0,042137 & 99,7790 \\
20 & 0,000048 & 0,11271 & 0,042184 & 99,8917 \\
21 & 0,000027 & 0,06323 & 0,042211 & 99,9550 \\
22 & 0,000018 & 0,04181 & 0,042229 & 99,9968 \\
23 & 0,000001 & 0,00321 & 0,042230 & 100,0000 \\
\hline
\end{tabular}

Figura 4.16 - Gráfico de decaímento da porcentagem de variância condensada em cada Componente Principal. Parcela masculina, forma apenas (76 séries, 23 variáveis craniométricas).

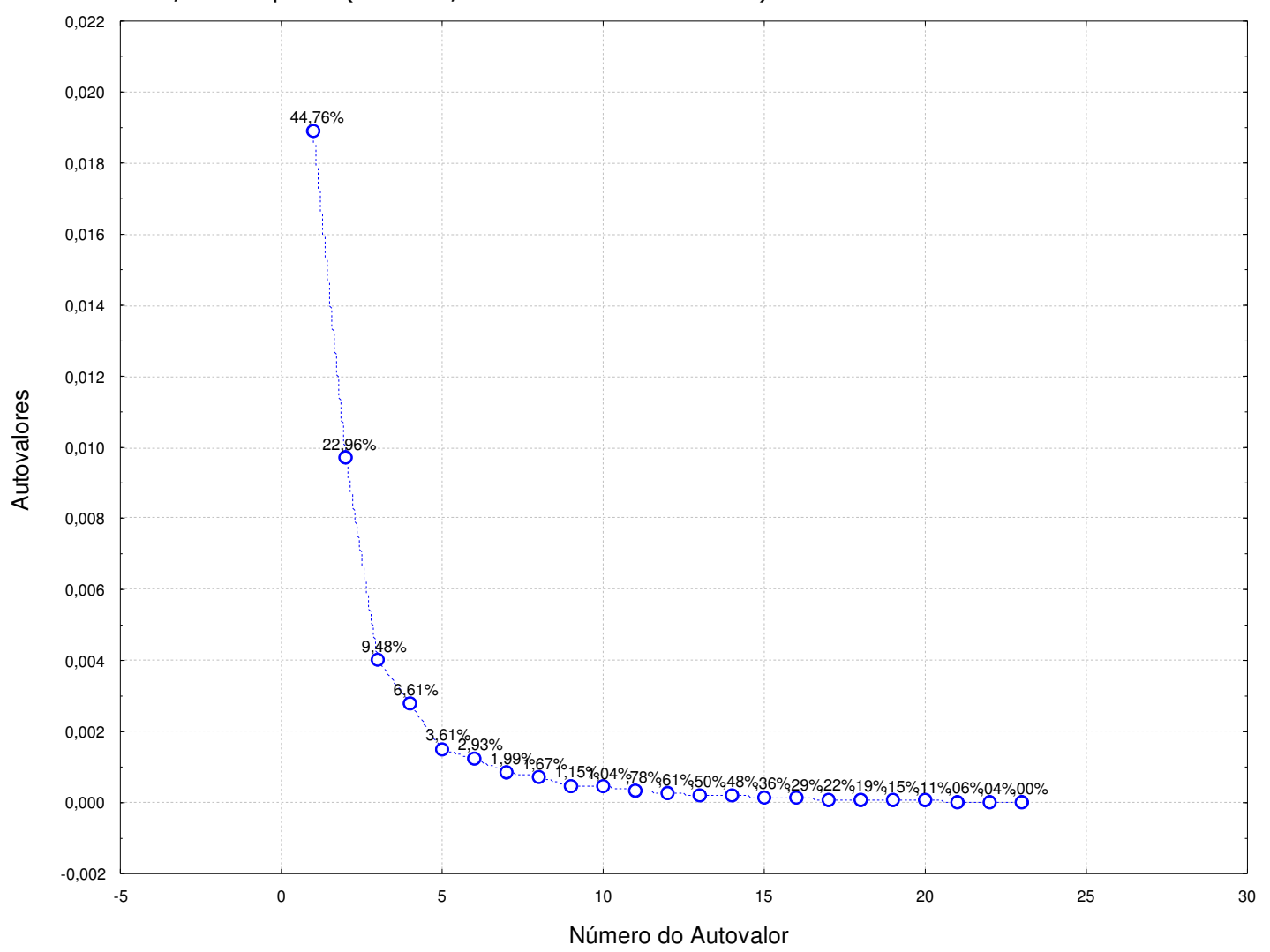


O primeiro platô de estabilização ocorre após o sexto Componente Principal, que representa $2,93 \%$ da variabilidade contida na amostra. Conseqüentemente as distâncias foram calculadas com base nos seis primeiros CP's dessa análise.

A tabela 4.6 apresenta os fatores de coordenadas resultantes dessa ACP. As figuras 4.17, 4.18 e 4.19 apresentam, respectivamente, as topologias resultantes da dispersão dos centróides hipotéticos utilizados nesta análise dentro dos morfo-espaços constituídos pela relação entre os CP 1 x CP 2, CP 1 $x$ CP 3 e CP 2 x CP 3 .

Figura 4.17 - Gráfico bidimensional do morfo-espaço formado pelos CP 1 x CP 2. Parcela masculina, forma apenas (77 séries, 23 variáveis craniométricas).

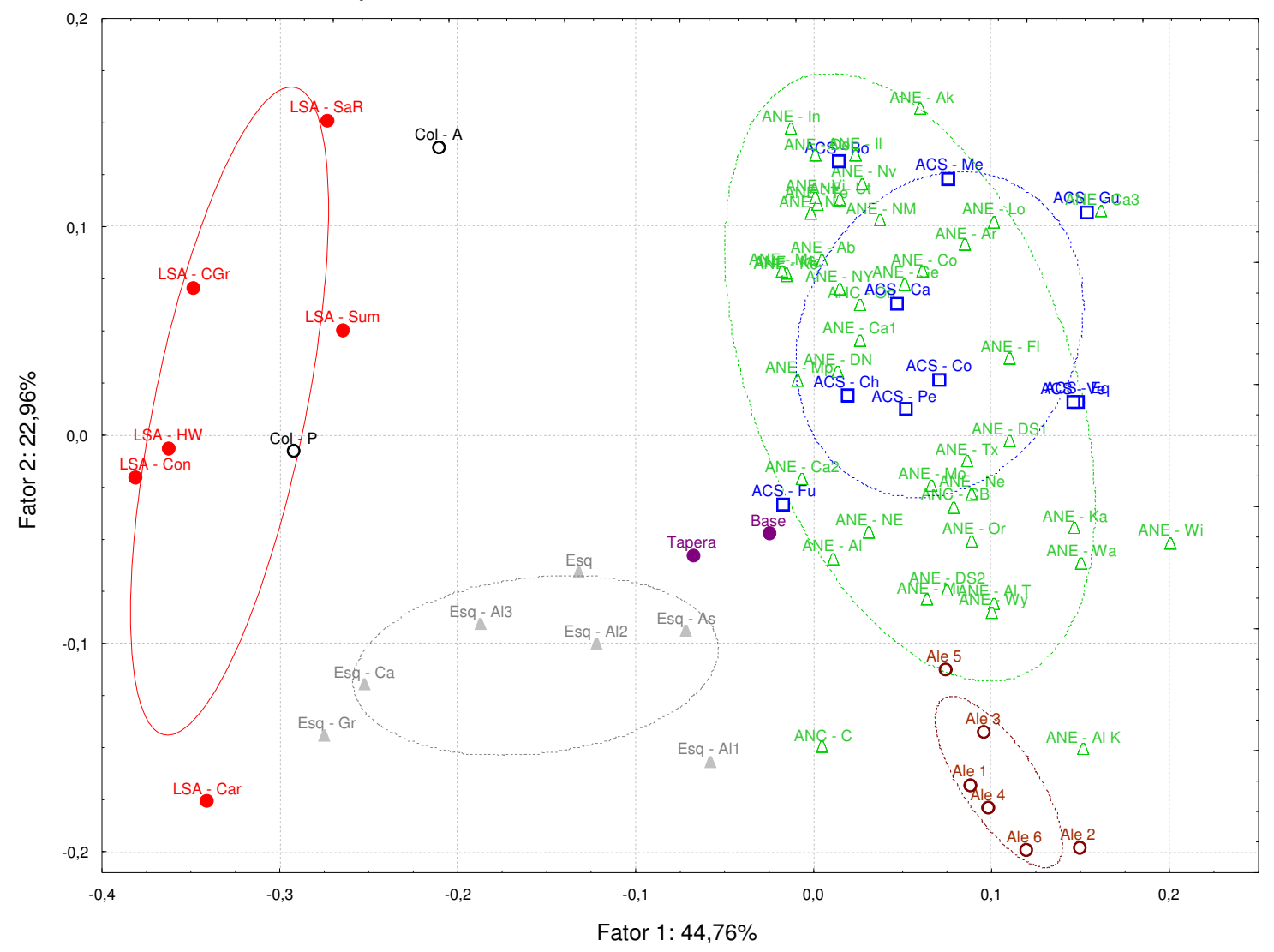


Figura 4.18 - Gráfico bidimensional do morfo-espaço formado pelos CP 1 x CP 3. Parcela masculina, forma apenas (77 séries, 23 variáveis craniométricas).

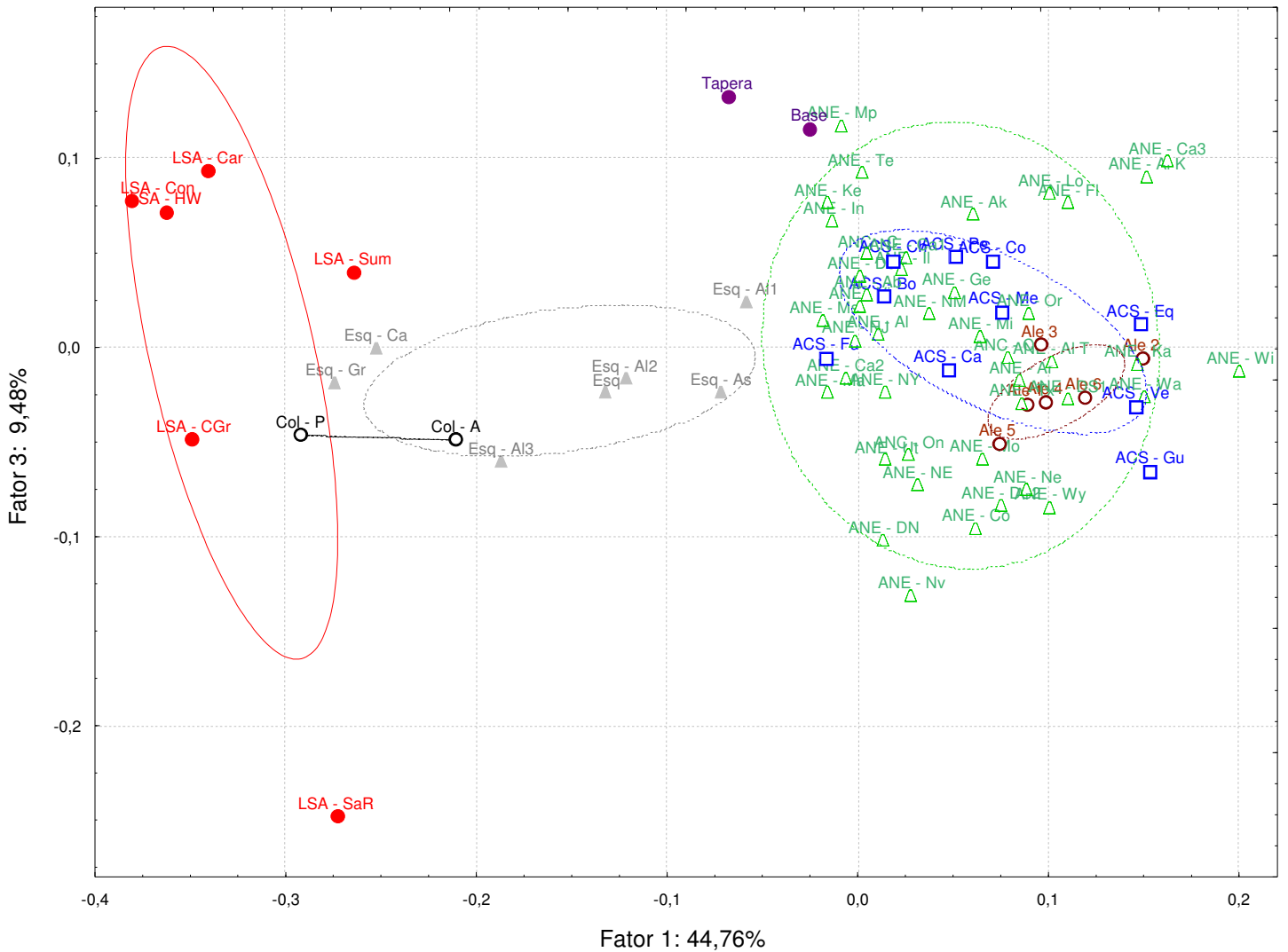

Figura 4.19 - Gráfico bidimensional do morfo-espaço formado pelos CP 1 x CP 3. Parcela masculina, forma apenas (77 séries, 23 variáveis craniométricas).

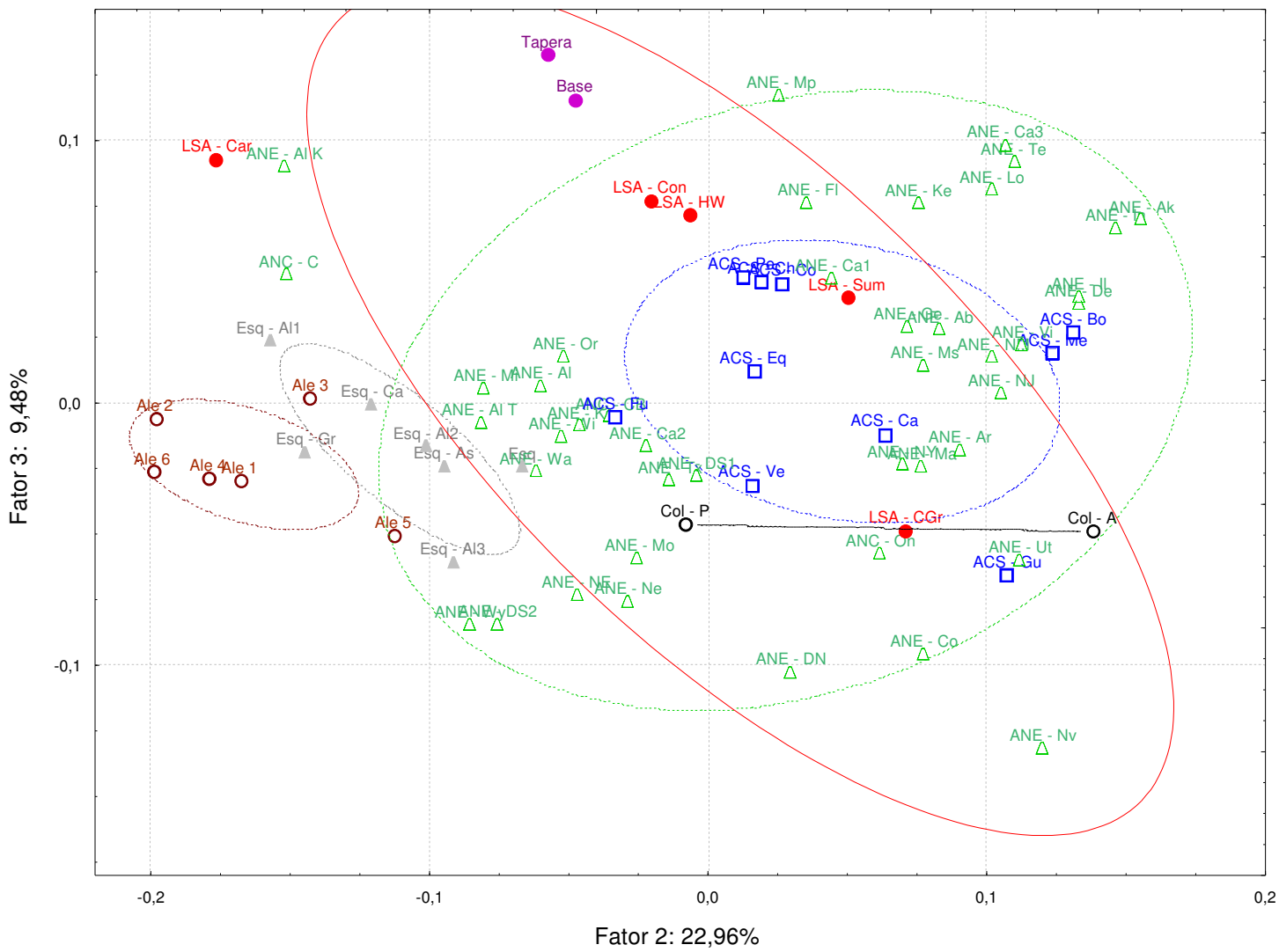



Tabela 4.6 - Fatores de coordenadas de cada série. Parcela masculina, forma apenas (76 séries, 23 variáveis craniométricas).

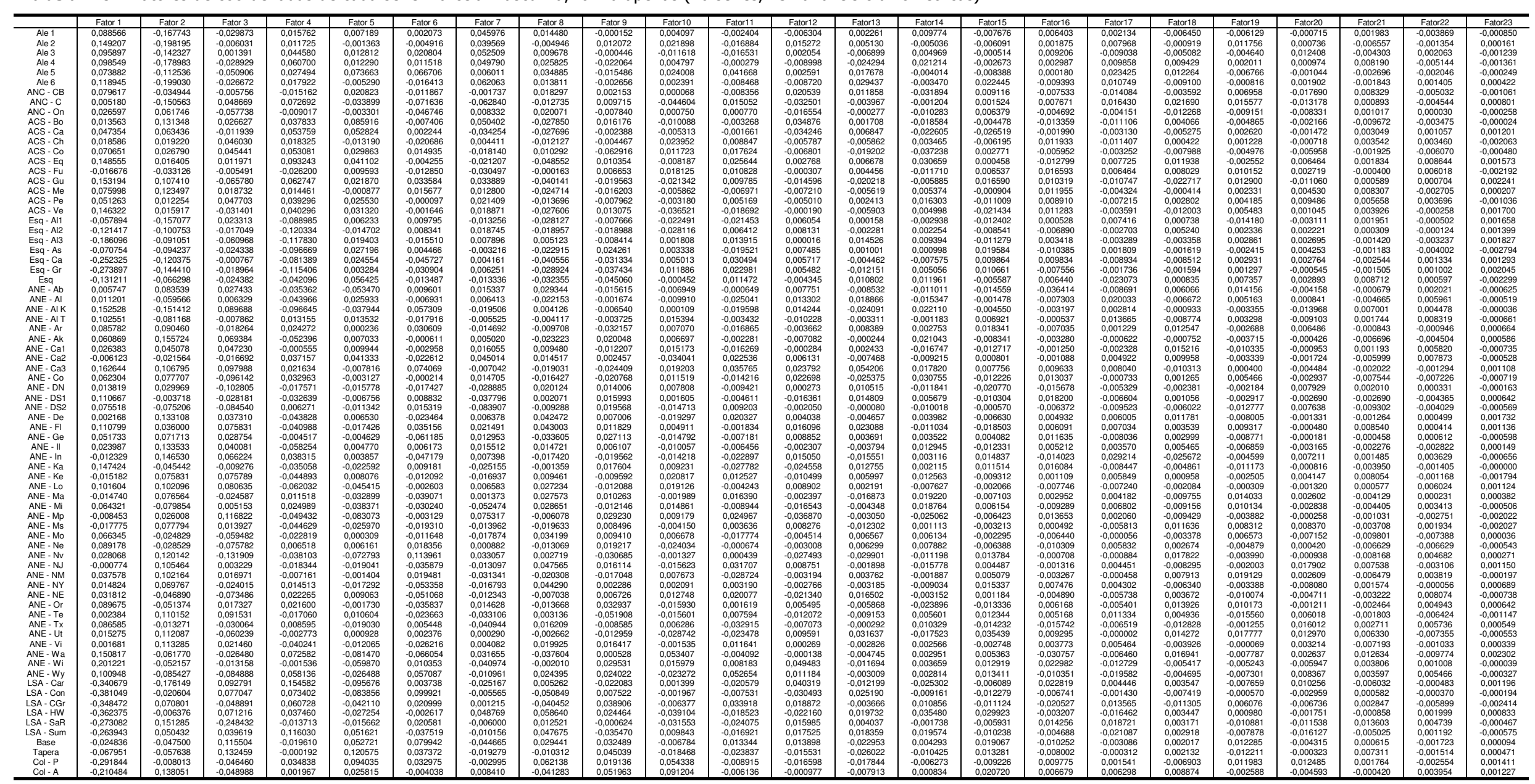


A dissimilaridade morfológica entre os Paleoíndios de Lagoa Santa e as outras populações nativas americanas, com exceção dos Paleoamericanos da Colômbia, fica patente nesta análise, a exemplo do que já foi observado para os dados sem correção do fator tamanho. A primeira topologia, representativa do morfo-espaço constituído pelos componentes principais que condensam $67,72 \%$ da variabilidade contida na amostra, apresenta deslocados na região esquerda do gráfico os crânios de morfologia mais longilínea no eixo sagital, mais estreitos, altos e compridos. À medida que se caminha para a direita no gráfico, e mais enfaticamente para o segundo quadrante cartesiano, encontram-se os crânios de morfologia mais lateralizada, evidenciadas pelas maiores dimensões em largura, da face e do neurocrânio. Interpretação semelhante pode ser dada à topologia formada pela relação entre os primeiro e terceiro componentes principais, agregando $54,24 \%$ da variabilidade original, embora a relação morfológica estabelecida entre os representantes de morfologia mais lateralizada não seja tão estruturada quanto foi no primeiro exemplo. Já a terceira topologia, constituída pelos CP $2 \times$ CP 3 representando apenas $32,44 \%$ da variabilidade contida na amostra original, apresentou um baixo poder de discriminação.

As Figuras 4.20 a 4.23 correspondem aos dendrogramas gerados a partir da matriz de distâncias Euclidianas calculadas a partir dos seis primeiros Componentes Principais, seguindo diferentes critérios de agrupamentos. Embora algumas associações observadas nessas análises de agrupamentos não estejam claras, ou consistentes, pode-se sugerir que, de maneira geral e sintética, todos os quatro agrupamentos caracterizam a 
população Paleoíndia de Lagoa Santa como detentora de uma morfologia única entre as séries americanas, associando-se, constantemente, apenas aos Paleoíndios Colombianos.

Relações semelhantes são observadas nos dendrogramas, apresentados nas figuras 4.24 a 4.27 , gerados a partir das análises de agrupamento sobre matriz de distância de Mahalanobis. Assim como nos resultantes de matrizes Euclidianas, estes indicaram, fortemente, uma característica distintiva dos Paleoamericanos de Lagoa Santa, sempre agregados entre si e marginalizados em relação aos outros americanos. Exatamente, também, como ocorreu com o primeiro tipo de clusters, algumas associações observadas entre as séries Paleoíndias comportaram-se de maneira inconsistente com as demais, sem, entretanto, comprometer a interpretação ditada acima.

Por fim, as figuras 4.28 a 4.30 correspondem às topologias geradas através da técnica de MDS sobre a mesma matriz de distância de Mahalanobis, apresentada na tabela 4.7. Os resultados observados nestes últimos ensaios corroboram os observados nos outros testes até aqui realizados, confirmando, para a parcela masculina dos indivíduos representados, a diferença morfológica entre os Paleoíndios de Lagoa Santa e as outras populações autóctones do continente americano. A tabela 4.8 apresenta a configuração final do cálculo das três primeiras dimensões desse escalonamento. 
Figura 4.20 - Dendrograma gerado sobre matriz de Distância Euclidiana calculada a partir dos seis primeiros componentes principais - Método de Ward. Parcela masculina, forma apenas (76 séries, 23 variáveis craniométricas).

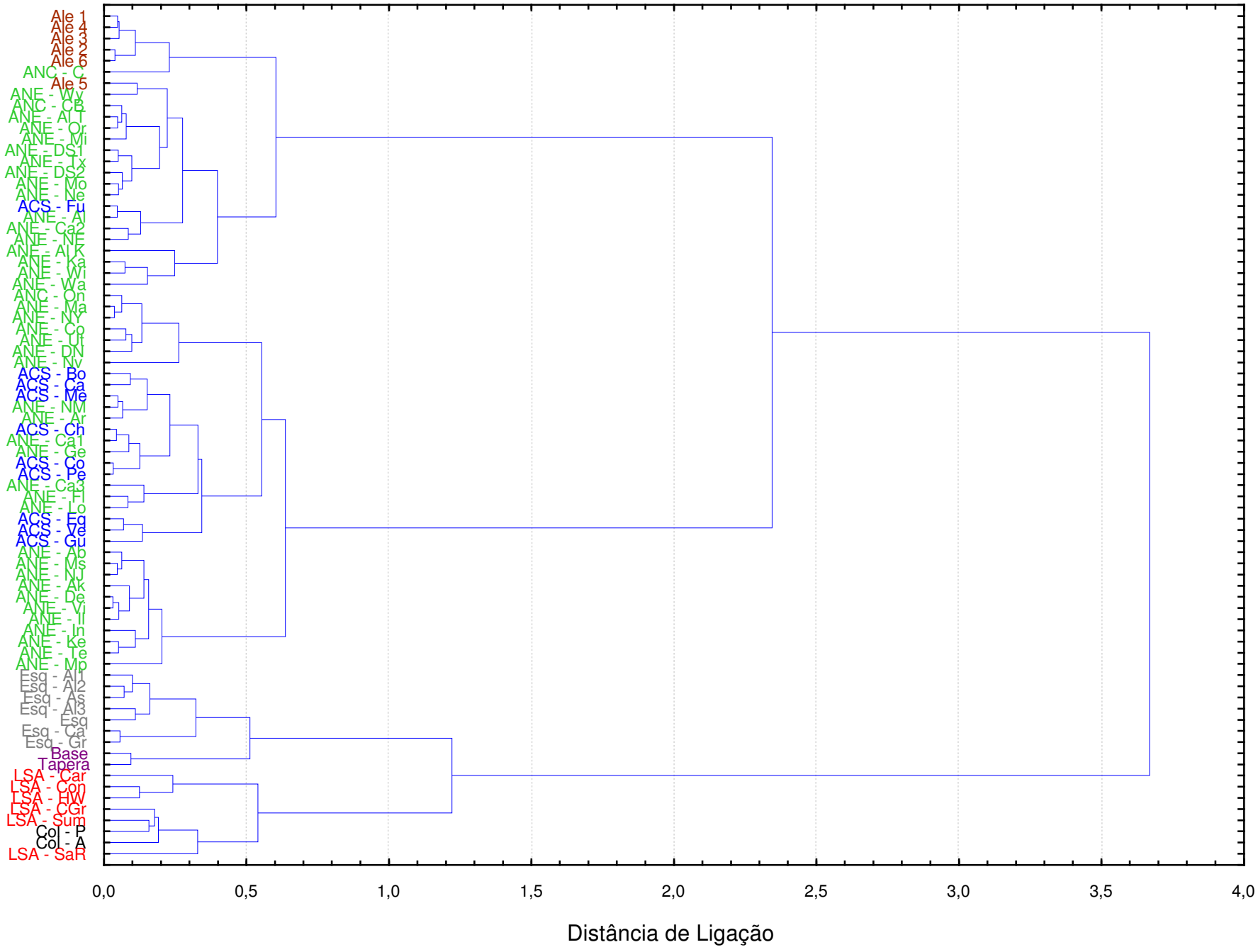


Figura 4.21 - Dendrograma gerado sobre matriz de Distância Euclidiana calculada a partir dos seis primeiros componentes principais - Método da Ligação Simples. Parcela masculina, forma apenas (76 séries, 23 variáveis craniométricas).

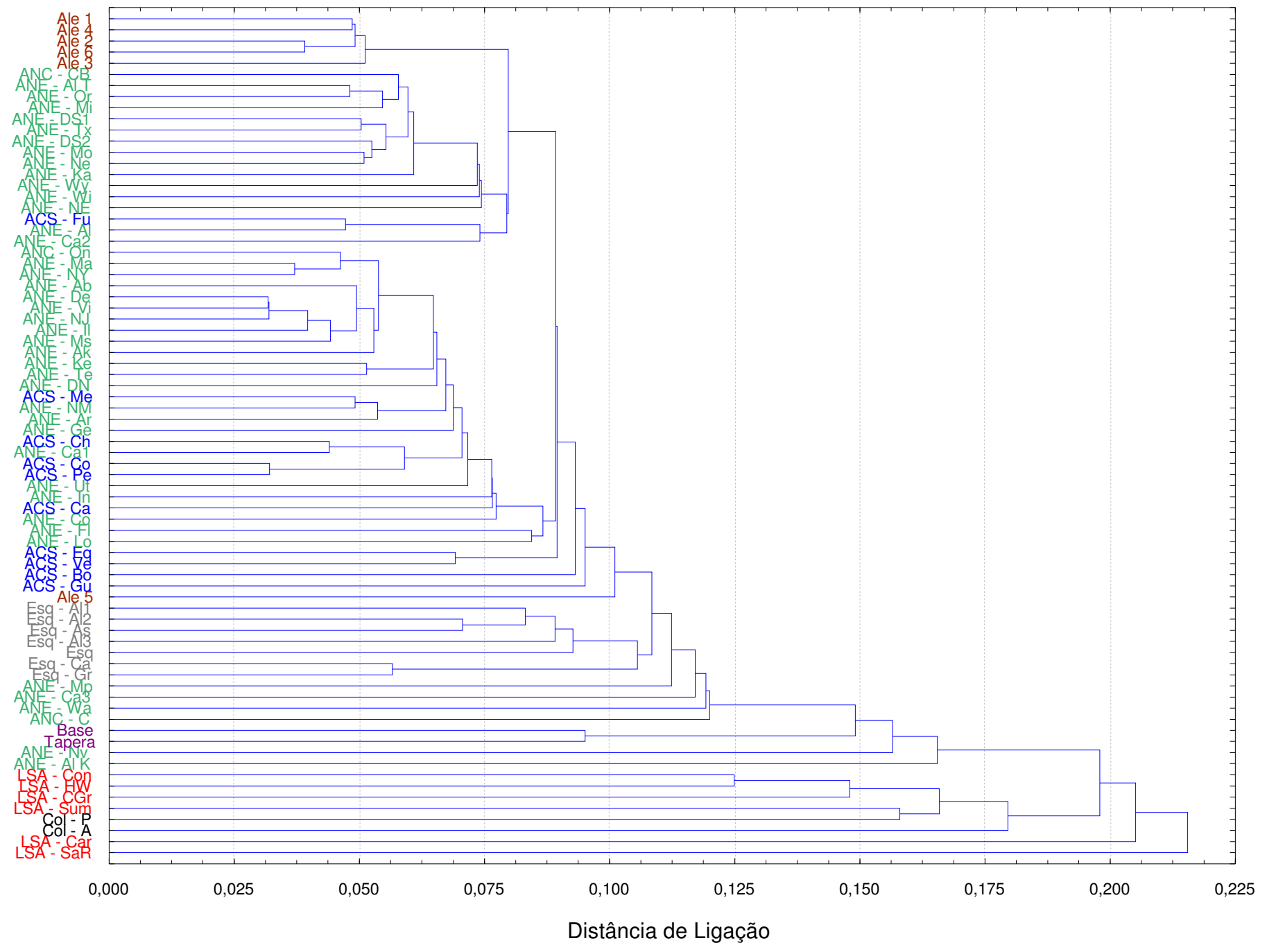


Figura 4.22 - Dendrograma gerado sobre matriz de Distância Euclidiana calculada a partir dos seis primeiros componentes principais - Método da Ligação Completa. Parcela masculina, forma apenas (76 séries, 23 variáveis craniométricas).

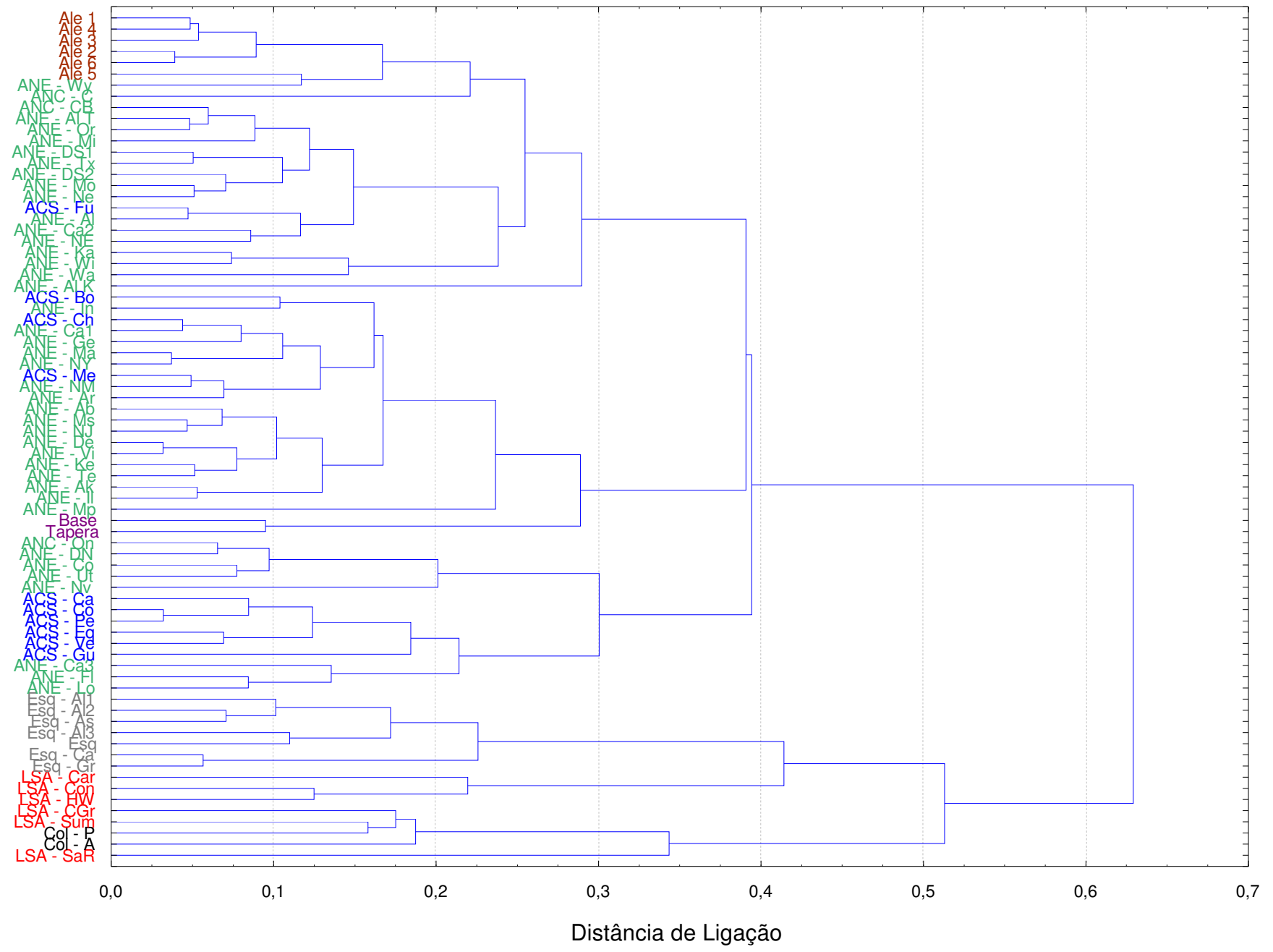


Figura 4.23 - Dendrograma gerado sobre matriz de Distância Euclidiana calculada a partir dos seis primeiros componentes principais - Método da Média dos Grupos. Parcela masculina, forma apenas (76 séries, 23 variáveis craniométricas).

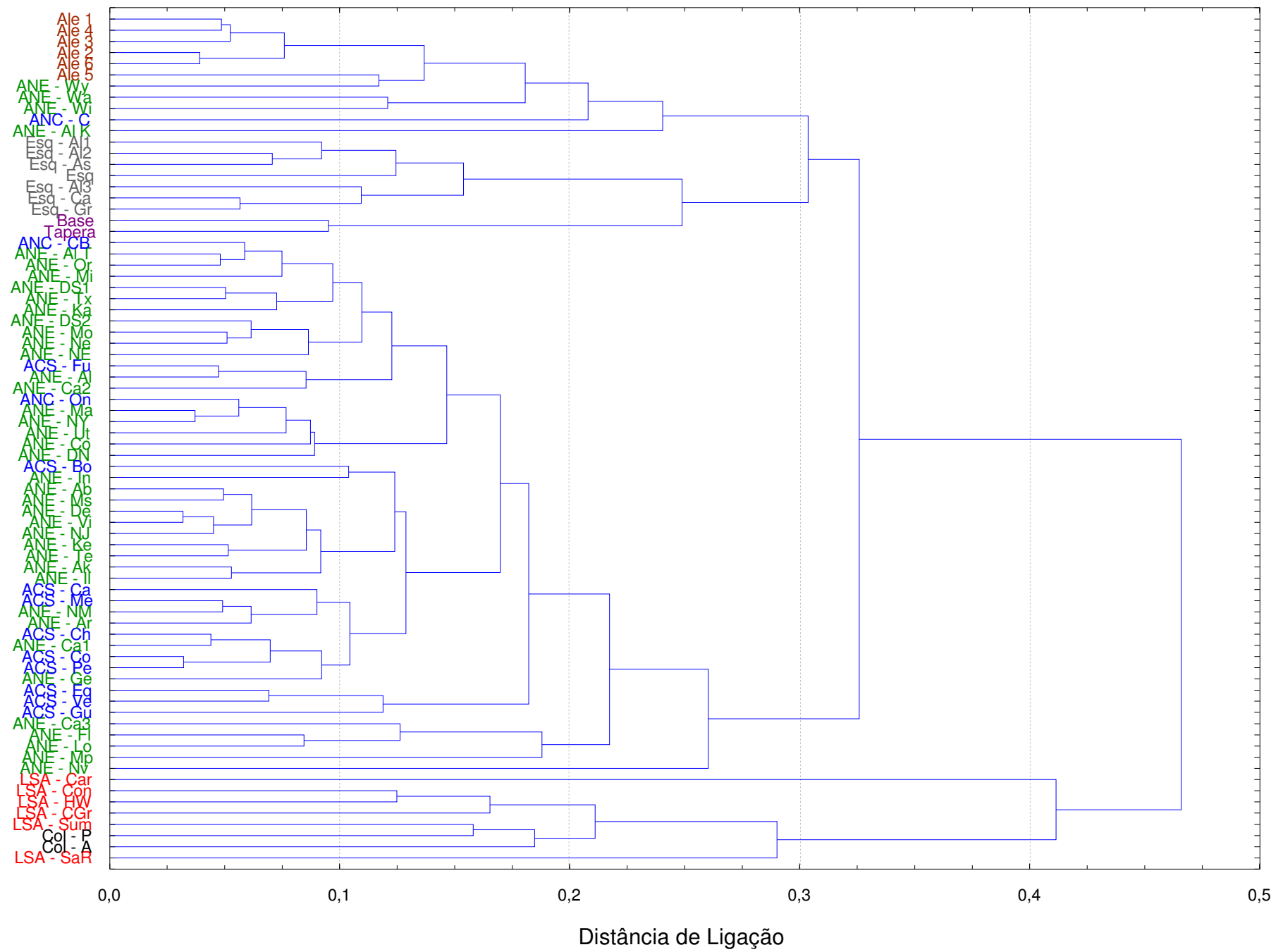


Tabela 4.7 - Matriz de Distâncias de Mahalanobis. Parcela masculina, forma apenas (28 grupos, 23 variáveis craniométricas).

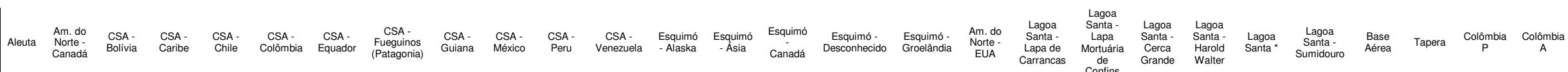

\begin{tabular}{|c|c|c|c|c|c|c|c|c|c|c|c|c|c|c|c|c|c|c|c|c|c|c|c|c|c|c|c|c|c|}
\hline $\begin{array}{c}\text { Aleuta } \\
\text { Am do Norte }\end{array}$ & 0 & 1,608 & & 2,06934 & 1,94060 & 1,79186 & 1,93312 & 2,12993 & 1,81122 & 1,98629 & 1,91617 & 1,68355 & 1,68442 & 1,88717 & 1,75745 & 2,13638 & 2,14000 & 2,20947 & 1,72772 & 2,68684 & 2,85817 & 2,52562 & 2,56048 & 2,56877 & 2,48352 & 2,15672 & 2,27393 & 2,49851 & 2,46559 \\
\hline $\begin{array}{l}\text { Am. do Norte } \\
\text { - Canadà }\end{array}$ & & 0 & & 1,85578 & 1,81198 & 1,35976 & 1,77249 & 1,81754 & 1,38286 & 1,71838 & 1,55370 & 1,51133 & 1,53702 & 1,70532 & 1,57836 & 1,92973 & 1,94155 & 2,04936 & 1,21581 & 2,57761 & 2,70750 & 2,28535 & 2,37641 & 2,36297 & 2,22171 & 1,92106 & 2,11868 & 2,37023 & 2,25247 \\
\hline $\begin{array}{l}\text { CSA-B Boliviva } \\
\text { CSA-Caribe } \\
\text { CSA-Chile }\end{array}$ & & & & 0 & $\begin{array}{c}1,86938 \\
0\end{array}$ & $\begin{array}{l}1,80538 \\
1,64186\end{array}$ & $\begin{array}{l}2,04744 \\
1,81760 \\
1,74489\end{array}$ & $\begin{array}{l}2,03053 \\
1,955088 \\
1,74935\end{array}$ & $\begin{array}{l}2,02402 \\
1,79829 \\
1,31391\end{array}$ & $\begin{array}{l}1,88412 \\
1,77263 \\
1,70604\end{array}$ & $\begin{array}{r}1,77092 \\
1,52929 \\
1,33835\end{array}$ & $\begin{array}{r}1,73696 \\
1,53229 \\
1,18838\end{array}$ & $\begin{array}{l}1,81020 \\
1,71532 \\
1,59824\end{array}$ & $\begin{array}{l}2,24075 \\
2,0,0843 \\
1,87650\end{array}$ & $\begin{array}{l}2,13916 \\
1,986399 \\
1,79435\end{array}$ & $\begin{array}{l}2,33734 \\
2,20378 \\
1,98208\end{array}$ & $\begin{array}{l}2,23400 \\
2,11003 \\
1,97945\end{array}$ & $\begin{array}{l}2,45161 \\
2,30364 \\
2,13610\end{array}$ & $\begin{array}{l}1,78507 \\
1,55737 \\
1,21067\end{array}$ & $\begin{array}{l}2,71197 \\
2,69244 \\
2,54371\end{array}$ & $\begin{array}{l}2,81998 \\
2,7,7324 \\
2,68501\end{array}$ & 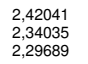 & $\begin{array}{r}2,55977 \\
2,4,4930 \\
2,35103\end{array}$ & $\begin{array}{l}2,47300 \\
2,37928 \\
2,46300 \\
2,460\end{array}$ & $\begin{array}{l}2,29494 \\
2,36952 \\
2,22672\end{array}$ & $\begin{array}{l}1,95309 \\
2,11743 \\
1,93103\end{array}$ & $\begin{array}{l}2,05936 \\
2,25845 \\
2,10723\end{array}$ & $\begin{array}{l}\begin{array}{r}2,37680 \\
2,39133 \\
2,36379\end{array} \\
2.3637\end{array}$ & $\begin{array}{l}2,17730 \\
2,223919 \\
2,14777\end{array}$ \\
\hline $\begin{array}{l}\text { CSA- } \\
\text { Colómbia }\end{array}$ & & & & & & & & 1,96600 & 1,89491 & 1,77535 & 1,65666 & 1,63653 & 1,71034 & 2,03849 & 2,11752 & 2,13384 & 2,06042 & 2,30203 & 1,74933 & 2,75712 & 2,87989 & 2,55834 & 2,66178 & 2,63880 & 2,49864 & 2,17553 & 2,32925 & 2,61266 & 2,58070 \\
\hline $\begin{array}{l}\text { CSA. } \\
\text { Equador } \\
\text { CSA. }\end{array}$ & & & & & & & & 0 & 1,88147 & 1,70525 & 1,61477 & 1,67261 & 1,68556 & 2,24196 & 2,15792 & 2,38370 & 2,26706 & 2,50394 & 1,70024 & 2,68820 & 2,85163 & 2,48383 & 2,50178 & 2,55516 & 2,36451 & 2,11614 & 2,30464 & 2,62551 & 2,39867 \\
\hline $\begin{array}{l}\text { Fueguions } \\
\text { (Patagonia) }\end{array}$ & & & & & & & & & 0 & 1,86607 & 1,58057 & 1,54097 & 1,74193 & 1,77080 & 1,64348 & 1,90096 & 1,97053 & 2,04921 & 1,27864 & 2,52378 & 2,69133 & 2,31869 & 2,33696 & 2,38546 & 2,23547 & 1,97467 & 2,15654 & 2,32147 & 2,16352 \\
\hline $\begin{array}{l}\text { SSA-Guiana } \\
\text { CSA- MExico } \\
\text { CSA-Peru }\end{array}$ & & & & & & & & & & 0 & $\begin{array}{c}1,52240 \\
0\end{array}$ & $\begin{array}{c}1,68557 \\
1,26862 \\
0\end{array}$ & $\begin{array}{l}1,51939 \\
1,45700 \\
1,41009\end{array}$ & $\begin{array}{l}2,177744 \\
1,99422 \\
1,93328\end{array}$ & $\begin{array}{l}2,088999 \\
1,877726 \\
1,85498\end{array}$ & $\begin{array}{l}2,26488 \\
2,12895 \\
2,09171\end{array}$ & $\begin{array}{l}2,19690 \\
2,07121 \\
2,01407\end{array}$ & $\begin{array}{l}2,40009 \\
2,25573 \\
2,23773\end{array}$ & $\begin{array}{l}1,68657 \\
1,22766 \\
1,28484\end{array}$ & $\begin{array}{l}2,79752 \\
2,206168 \\
2,60152\end{array}$ & $\begin{array}{l}2,849002 \\
2,777700 \\
2,76551\end{array}$ & $\begin{array}{l}\begin{array}{l}2,546866 \\
2,359466 \\
2,39323\end{array} \\
2.39\end{array}$ & $\begin{array}{l}2,59375 \\
2,39380 \\
2,39542\end{array}$ & $\begin{array}{l}2,49525 \\
2,36493 \\
2,49094 \\
2\end{array}$ & $\begin{array}{l}2,48428 \\
2,27640 \\
2,28891\end{array}$ & $\begin{array}{l}2,13206 \\
1,95555 \\
1,91825\end{array}$ & $\begin{array}{l}2,26163 \\
2,10714 \\
2,08106\end{array}$ & $\begin{array}{l}2,53799 \\
2,42307 \\
2,41461\end{array}$ & $\begin{array}{l}2,32593 \\
2,19862 \\
2,27055\end{array}$ \\
\hline $\begin{array}{l}\text { CSA- } \\
\text { Venezuela }\end{array}$ & & & & & & & & & & & & & . & 2,01443 & 1,92119 & 2,22027 & 2,14764 & 2,36495 & 1,46807 & 2,70937 & 2,86604 & 2,50984 & 2,56135 & 2,44776 & 2,41620 & 2,07603 & 2,17170 & 2,52372 & 2,40930 \\
\hline $\begin{array}{c}\text { Escuimó- } \\
\text { Alaska }\end{array}$ & & & & & & & & & & & & & & 0 & 1,47356 & 1,38636 & 1,51338 & 1,44248 & 1,80852 & 2,60798 & 2,59707 & 2,33488 & 2,37750 & 2,37896 & 2,37730 & 2,21092 & 2,30376 & 2,47883 & 2,40538 \\
\hline $\begin{array}{l}\text { Escuimó- } \\
\text { Asia }\end{array}$ & & & & & & & & & & & & & & & 0 & 1,79226 & 1,87924 & 1,83104 & 1,69760 & 2,60360 & 2,64661 & 2,30450 & 2,31060 & 2,28796 & 2,35502 & 1,98132 & 2,10411 & 2,31817 & 2,22388 \\
\hline $\begin{array}{l}\text { Esquimó- } \\
\text { Canadá }\end{array}$ & & & & & & & & & & & & & & & & 0 & 1,34017 & 1,14702 & 2,04206 & 2,63638 & 2,56775 & 2,38892 & 2,40360 & 2,52407 & 2,43328 & 2,31173 & 2,36827 & 2,47032 & 2,40393 \\
\hline $\begin{array}{l}\text { Essuimó- } \\
\text { Desconnecido }\end{array}$ & & & & & & & & & & & & & & & & & 0 & 1,51228 & 2,03482 & 2,68977 & 2,61577 & 2,42428 & 2,43649 & 2,49436 & 2,42702 & 2,28378 & 2,33515 & 2,47606 & 2,36764 \\
\hline $\begin{array}{l}\text { Essuqimó- } \\
\text { Groelanndia }\end{array}$ & & & & & & & & & & & & & & & & & & 0 & 2,16061 & 2,65181 & 2,55141 & 2,37438 & 2,37742 & 2,49087 & 2,45864 & 2,41557 & 2,47328 & 2,49144 & 2,41796 \\
\hline $\begin{array}{l}\text { Am. do Norte } \\
\text { EUA }\end{array}$ & & & & & & & & & & & & & & & & & & & 0 & 2,55999 & 2,71099 & 2,29216 & 2,34841 & 2,33727 & 2,20452 & 1,89633 & 2,11346 & 2,36941 & 2,20368 \\
\hline $\begin{array}{l}\text { Lavoda de } \\
\text { Carranas } \\
\text { Lagoa Santa. }\end{array}$ & & & & & & & & & & & & & & & & & & & & 0 & 2,06776 & 2,07340 & 2,12665 & 2,49640 & 1,80107 & 2,54369 & 2,577116 & 2,44220 & 2,50736 \\
\hline $\begin{array}{l}\text { Lapa } \\
\text { Mortuaraia } \\
\text { Contins }\end{array}$ & & & & & & & & & & & & & & & & & & & & & 0 & 2,08583 & 2,13636 & 2,57136 & 2,20020 & 2,57439 & 2,59465 & 2,42806 & 2,48712 \\
\hline $\begin{array}{l}\text { Lagoa Santa- } \\
\text { Cerca Grande }\end{array}$ & & & & & & & & & & & & & & & & & & & & & & 0 & 1,92155 & 2,18839 & 1,67785 & 2,33383 & 2,46965 & 2,26648 & 2,28189 \\
\hline $\begin{array}{l}\text { Lagoa Santa- } \\
\text { Harold Walter }\end{array}$ & & & & & & & & & & & & & & & & & & & & & & & 0 & 2,23606 & 1,85344 & 2,31833 & 2,46333 & 2,23683 & 2,28536 \\
\hline Lagoa Santa" & & & & & & & & & & & & & & & & & & & & & & & & 0 & 2,13662 & 2,51604 & 2,56671 & 2,36111 & 2,31927 \\
\hline 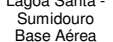 & & & & & & & & & & & & & & & & & & & & & & & & & 0 & $\begin{array}{c}2,22330 \\
0\end{array}$ & $\begin{array}{l}2,34726 \\
1,48433\end{array}$ & $\begin{array}{r}2,22378 \\
2,10362\end{array}$ & $\begin{array}{l}2,25361 \\
2,18516\end{array}$ \\
\hline $\begin{array}{l}\text { Basederea } \\
\text { Topara } \\
\text { Colombiai } \mathrm{P} \\
\text { Colombia }\end{array}$ & & & & & & & & & & & & & & & & & & & & & & & & & & & 48433 & $\begin{array}{l}\begin{array}{l}2,10362 \\
2,04584 \\
0\end{array} \\
0\end{array}$ & $\begin{array}{l}2,1818516 \\
2,1844 \\
1,91387 \\
0\end{array}$ \\
\hline
\end{tabular}


Figura 4.24 - Dendrograma gerado sobre matriz de Distância de Mahalanobis - Método de Ward. Parcela masculina, forma apenas.

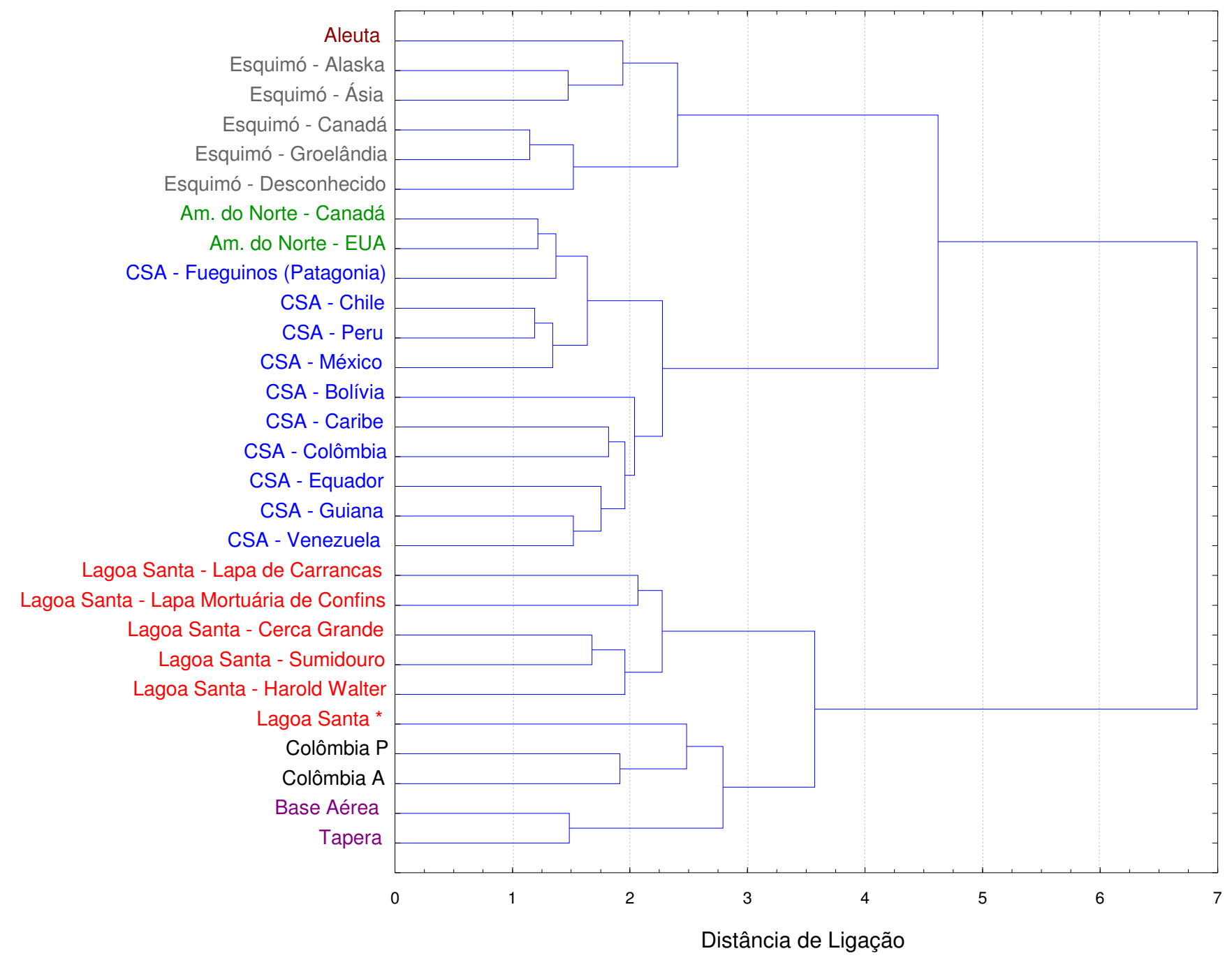


Figura 4.25 - Dendrograma gerado sobre matriz de Distância de Mahalanobis - Método de Ligação Simples. Parcela masculina, forma apenas.

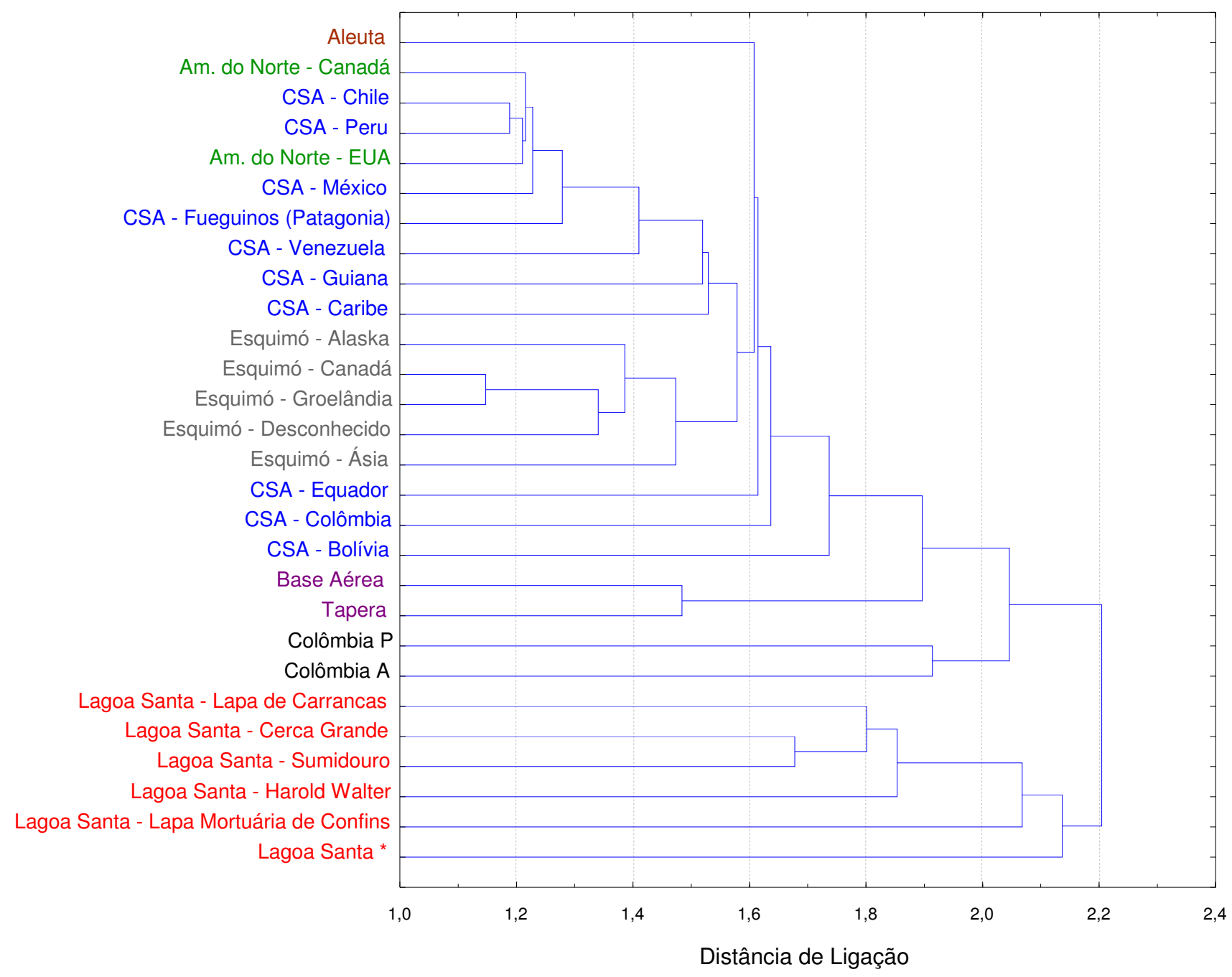


Figura 4.26 - Dendrograma gerado sobre matriz de Distância de Mahalanobis - Método de Ligação Completa. Parcela masculina, forma apenas.

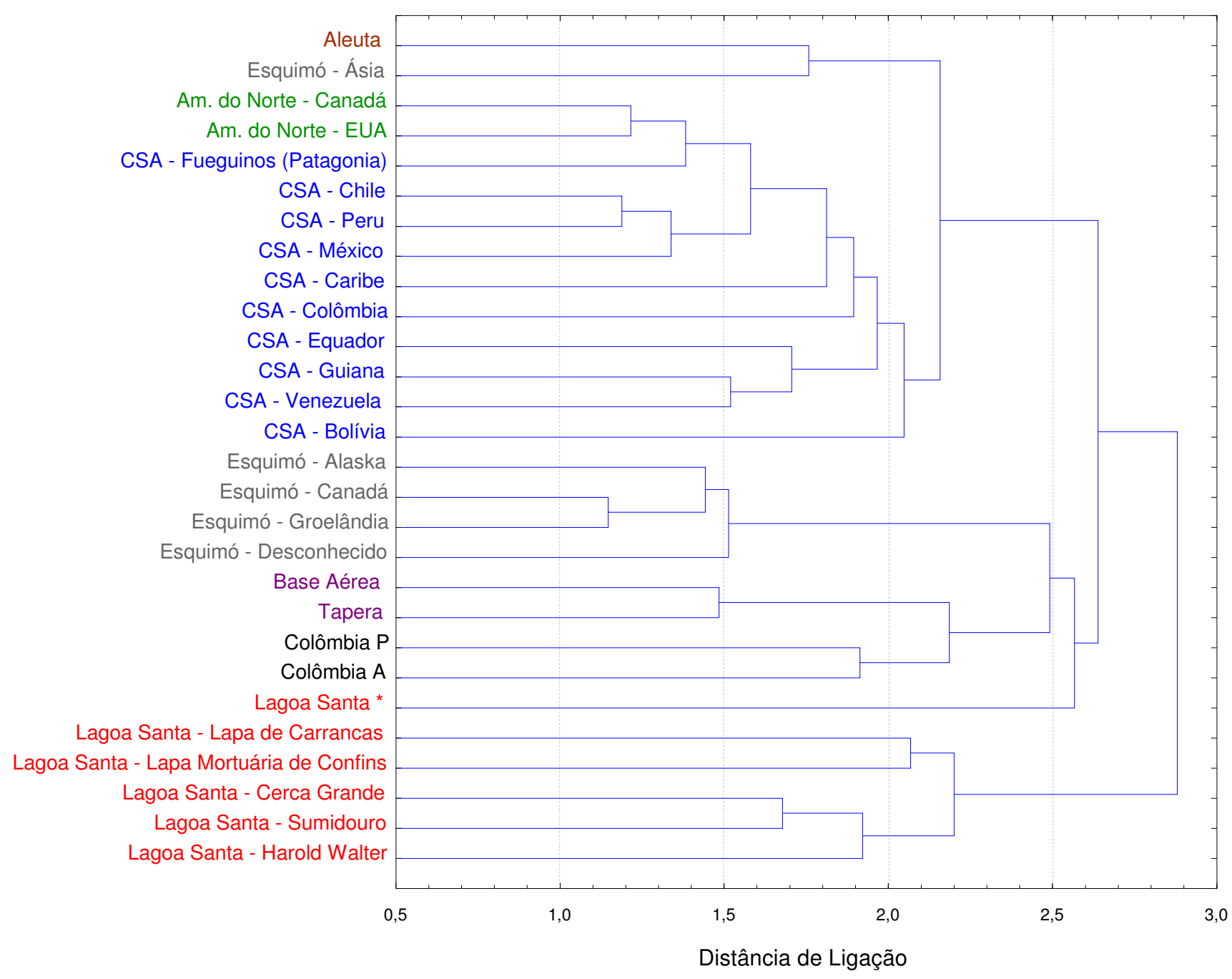


Figura 4.27 - Dendrograma gerado sobre matriz de Distância de Mahalanobis - Método da Média dos Grupos. Parcela masculina, forma apenas.

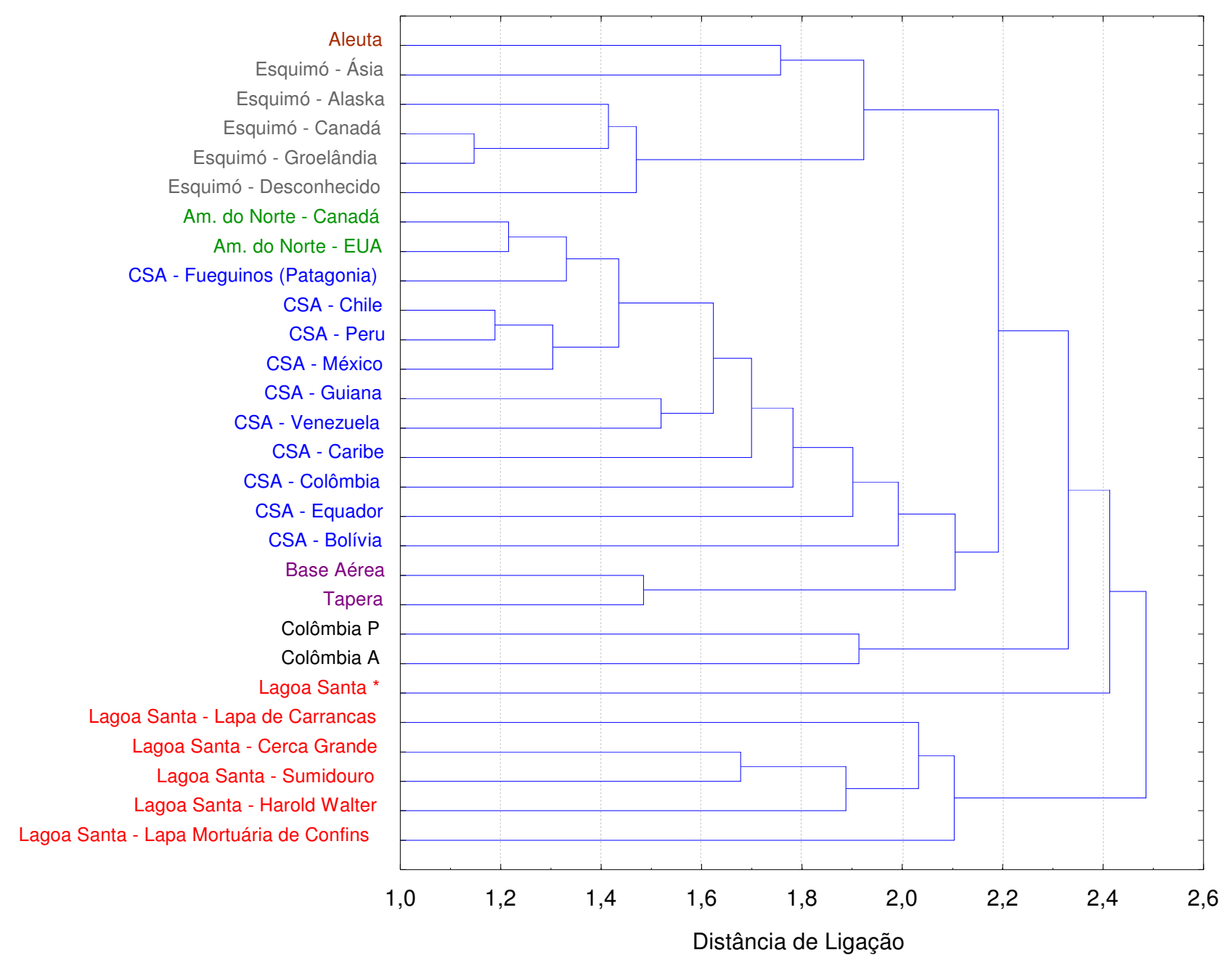



Tabela 4.8 - Configuração final das dimensões calculadas através de escalonamento multidimensional sobre Matriz de Distâncias de Mahalanobis. Parcela masculina, forma apenas (28 grupos, 23 variáveis craniométricas).

\begin{tabular}{c|c|c|c}
\hline Grupo & DIMENSÃO 1 & DIMENSÂO 2 & DIMENSÃO 3 \\
\hline Aleuta & $-0,839890$ & $-0,15639$ & $-0,329042$ \\
Am. do Norte - Canadá & $-0,382851$ & $-0,09486$ & $-0,052074$ \\
CSA - Bolivia & $-0,528401$ & 0,66171 & 0,007621 \\
CSA - Caribe & $-0,510949$ & 0,10241 & 0,430842 \\
CSA - Chile & $-0,377577$ & 0,03436 & 0,010781 \\
CSA - Colômbia & $-0,997089$ & $-0,22699$ & 0,177831 \\
CSA - Equador & $-0,770853$ & 0,34722 & 0,511916 \\
CSA - Fueguinos (Patagonia) & $-0,294306$ & $-0,09057$ & 0,038537 \\
CSA - Guiana & $-0,910000$ & 0,26523 & 0,202415 \\
CSA - México & $-0,478661$ & 0,12396 & 0,146280 \\
CSA - Peru & $-0,552134$ & 0,09028 & 0,029894 \\
CSA - - venezuela & $-0,786468$ & 0,12583 & 0,058836 \\
Esquim - Alaska & $-0,288727$ & $-0,084837$ \\
Esquim - Ásia & $-0,231658$ & $-0,61826$ & $-0,316022$ \\
Esquim - Canadá & $-0,196241$ & $-0,27929$ & $-0,253811$ \\
Esquim - Desconhecido & $-0,311254$ & $-0,83546$ & $-0,117637$ \\
Esquim - Groelândia & $-0,007014$ & $-0,79128$ & $-0,292642$ \\
Am. do Norte - EUA & $-0,392549$ & $-1,01125$ & 0,092328 \\
Lagoa Santa - Lapa de Carrancas & 1,818624 & 0,03956 & 0,240908 \\
Lagoa Santa - Lapa Mortuária de Confins & 1,987145 & 0,13891 & $-0,408434$ \\
Lagoa Santa - Cerca Grande & 1,085391 & $-0,40142$ & 0,378950 \\
Lagoa Santa - Harold Walter & 1,209922 & $-0,17092$ & $-0,059727$ \\
Lagoa Santa * & 0,711047 & $-0,25896$ & 1,231506 \\
Lagoa Santa - Sumidouro & 0,955415 & 0,05346 & 0,376199 \\
Base Area & $-0,135559$ & 0,17288 & $-0,405933$ \\
Tapera & $-0,095513$ & 0,51861 & $-0,765415$ \\
Colombia P & 0,823345 & 0,64527 & $-0,687762$ \\
Colombia A & 0,496803 & 0,72353 & $-0,161506$ \\
\hline & & 0,89242 & \\
\hline & & & \\
\hline
\end{tabular}

Figura 4.28 - Gráfico bidimensional da relação ortogonal entre as dimensões 1 × 2. Parcela masculina, forma apenas (28 grupos, 23 variáveis craniométricas).

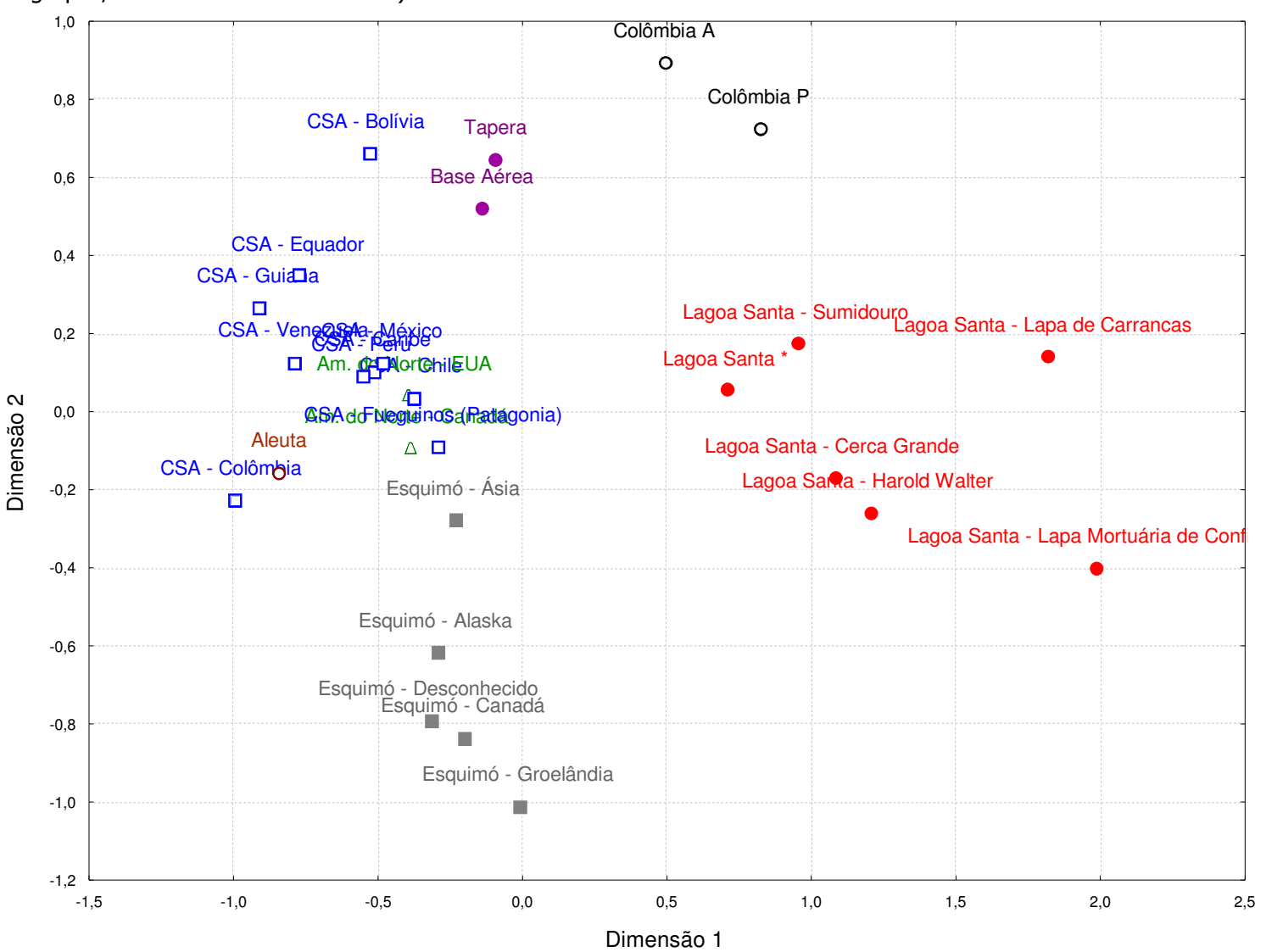


Figura 4.29 - Gráfico bidimensional da relação ortogonal entre as dimensões $1 \times 3$. Parcela masculina, forma apenas (28 grupos, 23 variáveis craniométricas).

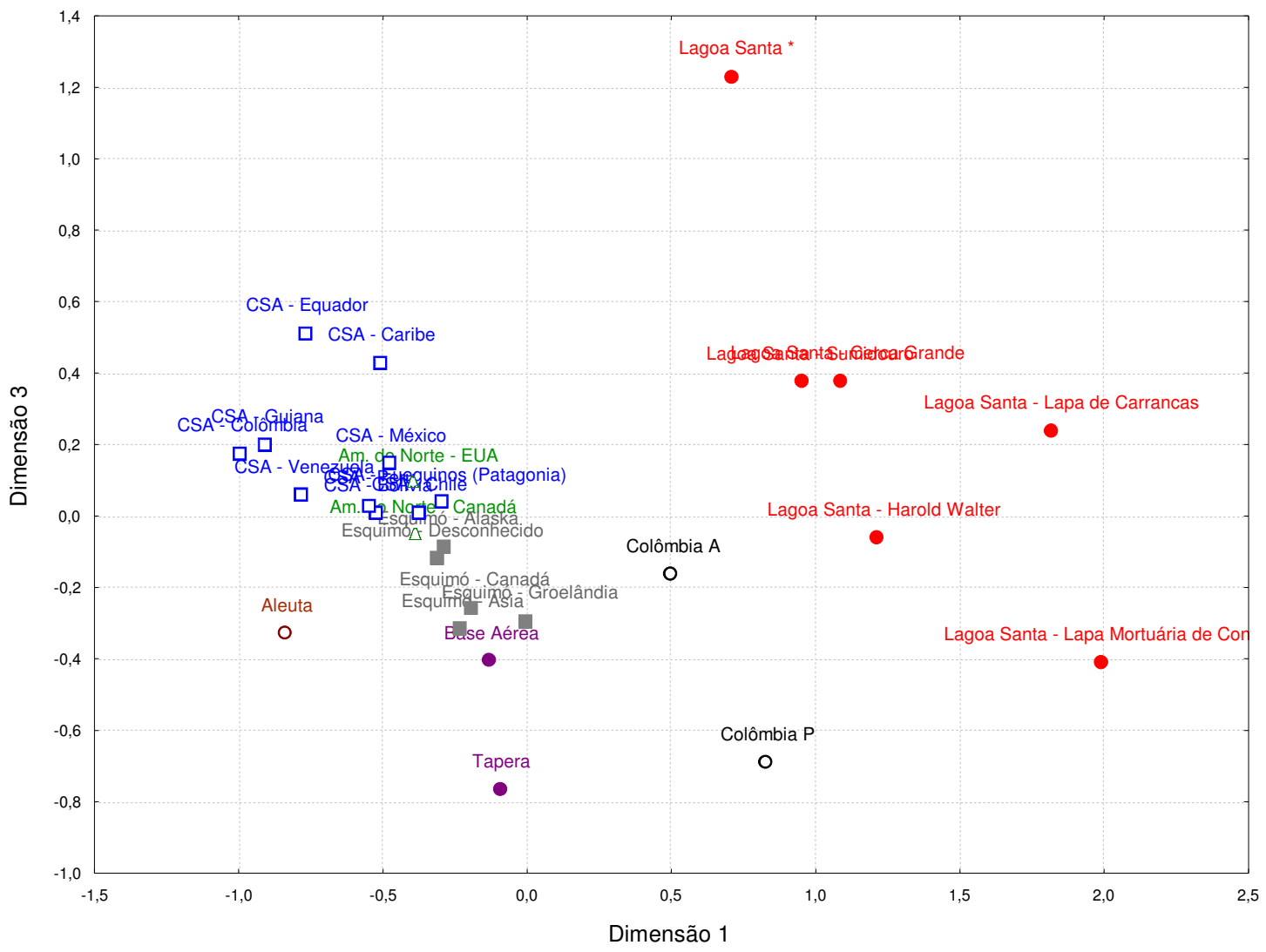

Figura 4.30 - Gráfico bidimensional da relação ortogonal entre as dimensões $2 \times 3$. Parcela masculina, forma apenas (28 grupos, 23 variáveis craniométricas).

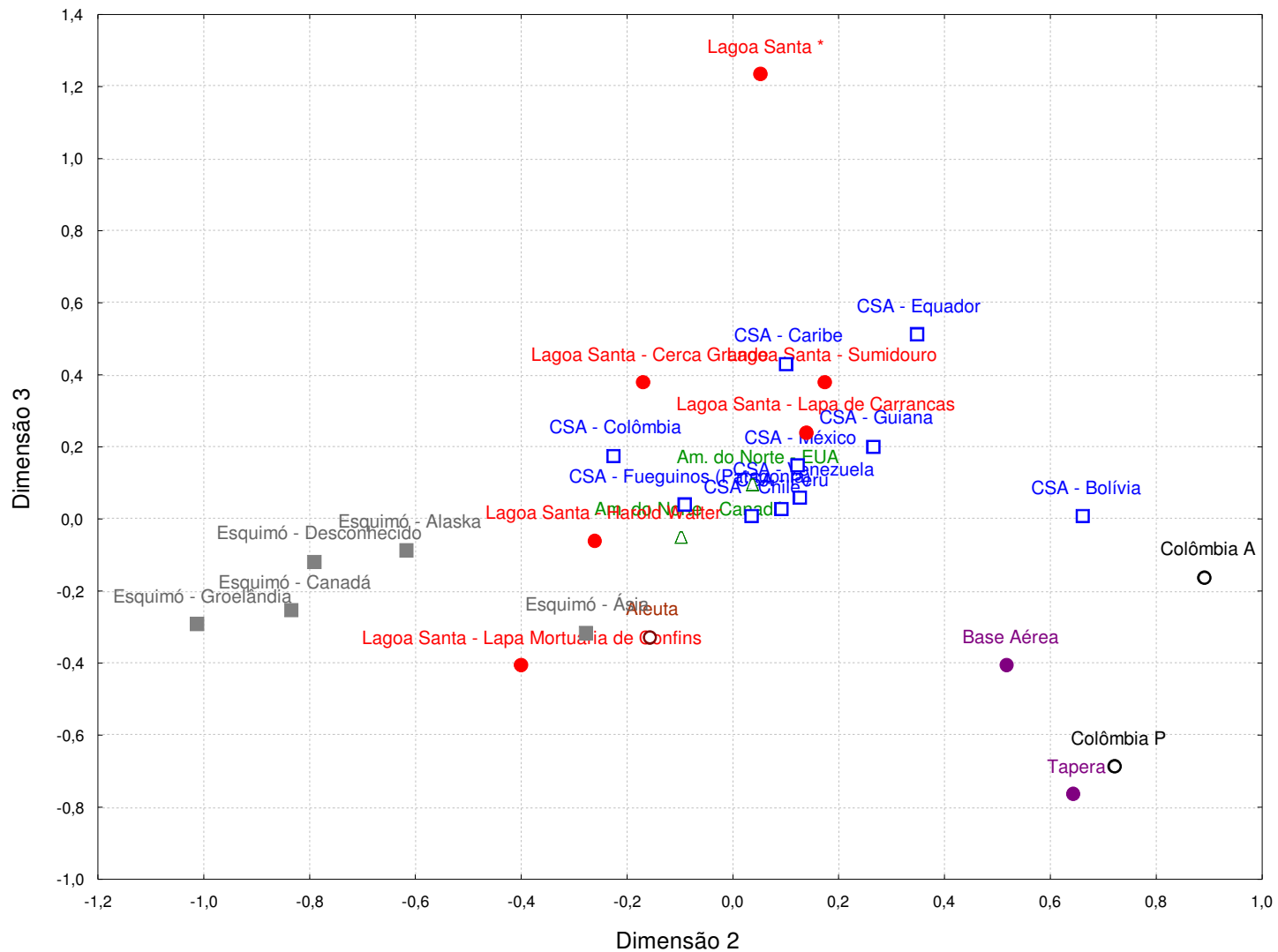




\subsection{3 - Parcela Feminina, Tamanho e Forma}

A investigação das afinidades morfológicas da parcela feminina do banco de dados seguiu a mesma estratégia estabelecida para a da parcela masculina. Na Tabela 4.9 estão apresentados os resultados obtidos através da ACP sobre os centróides das séries, com base em tamanho e forma. A Figura 4.31 representa o decaímento dos autovalores dos CPs (screeplot).

Tabela 4.9 - Autovalores da matriz de covariância e porcentagens de variância total explicada por cada Componente Principal. Parcela feminina, forma e tamanho (69 séries, 23 variáveis craniométricas).

\begin{tabular}{c|c|c|c|c|}
\hline $\begin{array}{c}\text { Componente } \\
\text { Principal }\end{array}$ & Autovalor & $\%$ Total & $\begin{array}{c}\text { Autovalor } \\
\text { Cumulativo }\end{array}$ & $\%$ Cumulativa \\
\hline 1 & 69,98877 & 36,77094 & 69,9888 & 36,7709 \\
2 & 47,83552 & 25,13199 & 117,8243 & 61,9029 \\
3 & 23,82129 & 12,51531 & 141,6456 & 74,4182 \\
4 & 11,11719 & 5,84079 & 152,7628 & 80,2590 \\
5 & 6,96805 & 3,66090 & 159,7308 & 83,9199 \\
6 & 6,43401 & 3,38032 & 166,1648 & 87,3002 \\
7 & 4,46767 & 2,34724 & 170,6325 & 89,6475 \\
8 & 3,88831 & 2,04286 & 174,5208 & 91,6903 \\
9 & 2,94531 & 1,54742 & 177,4661 & 93,2378 \\
10 & 2,75747 & 1,44873 & 180,2236 & 94,6865 \\
11 & 1,93701 & 1,01767 & 182,1606 & 95,7042 \\
12 & 1,81907 & 0,95571 & 183,9797 & 96,6599 \\
13 & 1,58749 & 0,83404 & 185,5672 & 97,4939 \\
14 & 0,98969 & 0,51997 & 186,5569 & 98,0139 \\
15 & 0,96579 & 0,50741 & 187,5227 & 98,5213 \\
16 & 0,75057 & 0,39433 & 188,2732 & 98,9156 \\
17 & 0,60040 & 0,31544 & 188,8736 & 99,2311 \\
18 & 0,50327 & 0,26441 & 189,3769 & 99,4955 \\
19 & 0,30135 & 0,15832 & 189,6783 & 99,6538 \\
20 & 0,25106 & 0,13190 & 189,9293 & 99,7857 \\
21 & 0,20846 & 0,10952 & 190,1378 & 99,8952 \\
22 & 0,13969 & 0,07339 & 190,2775 & 99,9686 \\
23 & 0,05972 & 0,03138 & 190,3372 & 100,0000 \\
\hline
\end{tabular}


Figura 4.31 - Gráfico de decaímento da porcentagem de variância condensada em cada Componente Principal. Parcela feminina, forma e tamanho (69 séries, 23 variáveis craniométricas).

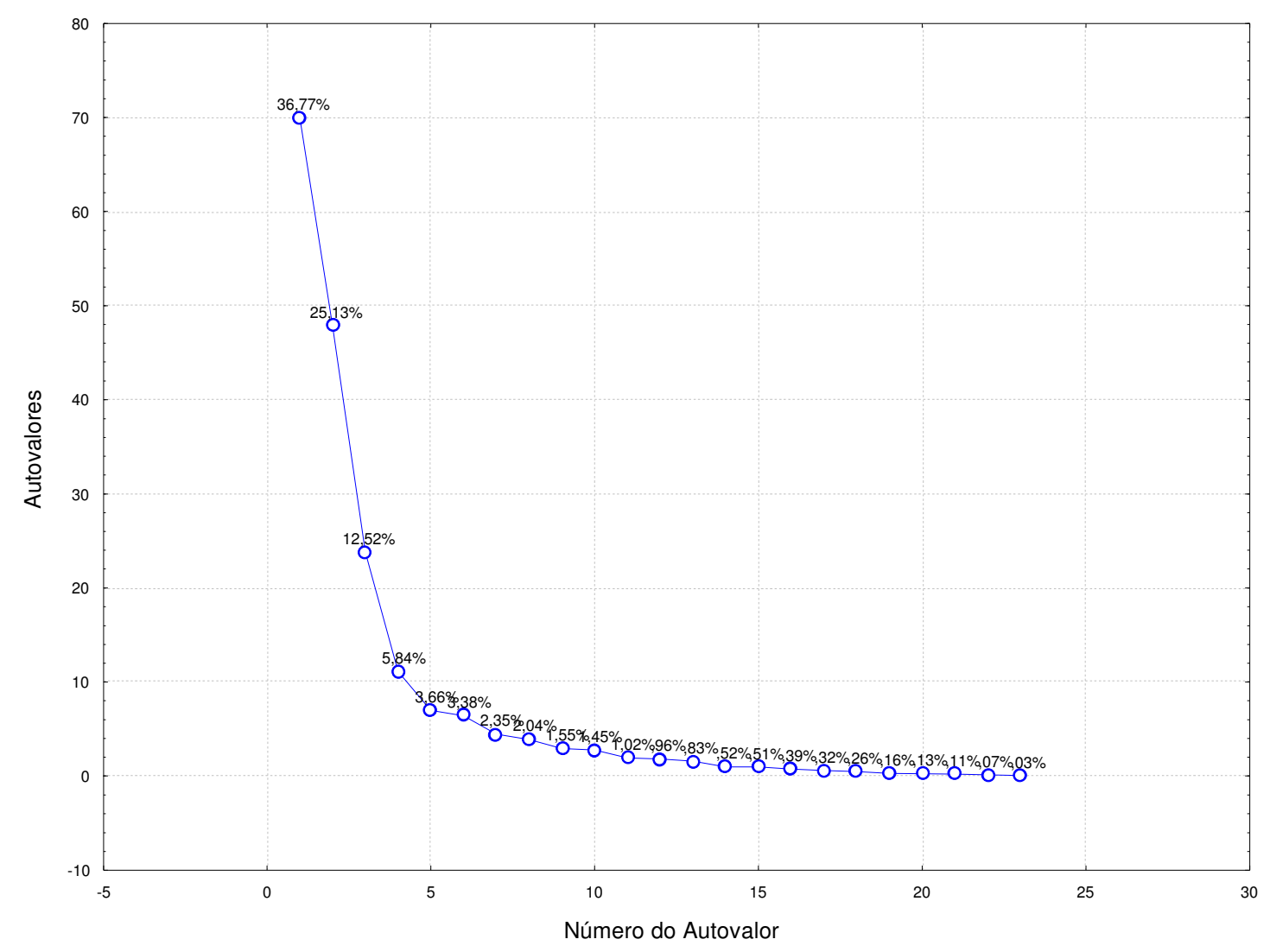

No screeplot acima observa-se o primeiro platô de estabilização após o sexto Componente Principal (3,38\%), o que determinou a escolha dos seis primeiros componentes para o cálculo de Distâncias Euclidianas. Na Tabela 4.10, estão representados os fatores de coordenadas de cada série.

As Figuras 4.32, 4.33 e 4.34 apresentam as relações entre os centróides no morfo-espaço constituído, respectivamente, pelas dimensões formadas pelos CP 1 x CP 2, CP 1 x CP 3 e CP 2 x CP 3. Assim como foi feito para o estudo da parcela masculina, os gráficos apresentam as elipses de dispersão, calculadas com 95\% de confiabilidade, para cada um dos 7 grupos estudados. Os dendrogramas das Figuras 9.35, 9.36, 9.37 e 9.38 apresentam as análises de agrupamento sobre a matriz de Distâncias Euclidianas calculadas a partir dos $\mathrm{CP}$ selecionados. 
Figura 4.32 - Gráfico bidimensional do morfo-espaço formado pelos CP 1 x CP 2. Parcela feminina, forma e tamanho (69 séries, 23 variáveis craniométricas).

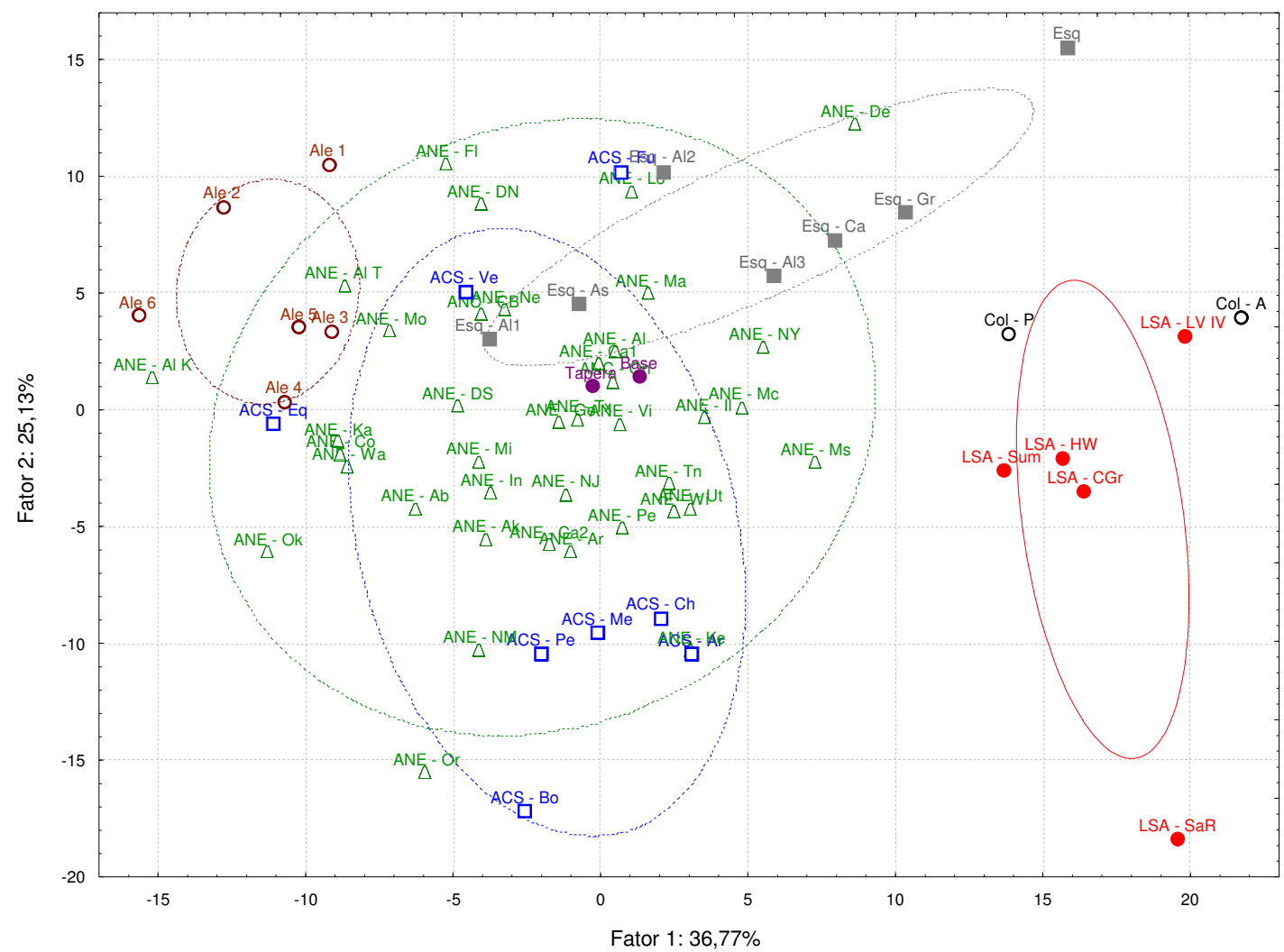

Figura 4.33 - Gráfico bidimensional do morfo-espaço formado pelos CP 1 x CP 3. Parcela feminina, forma e tamanho (69 séries, 23 variáveis craniométricas).

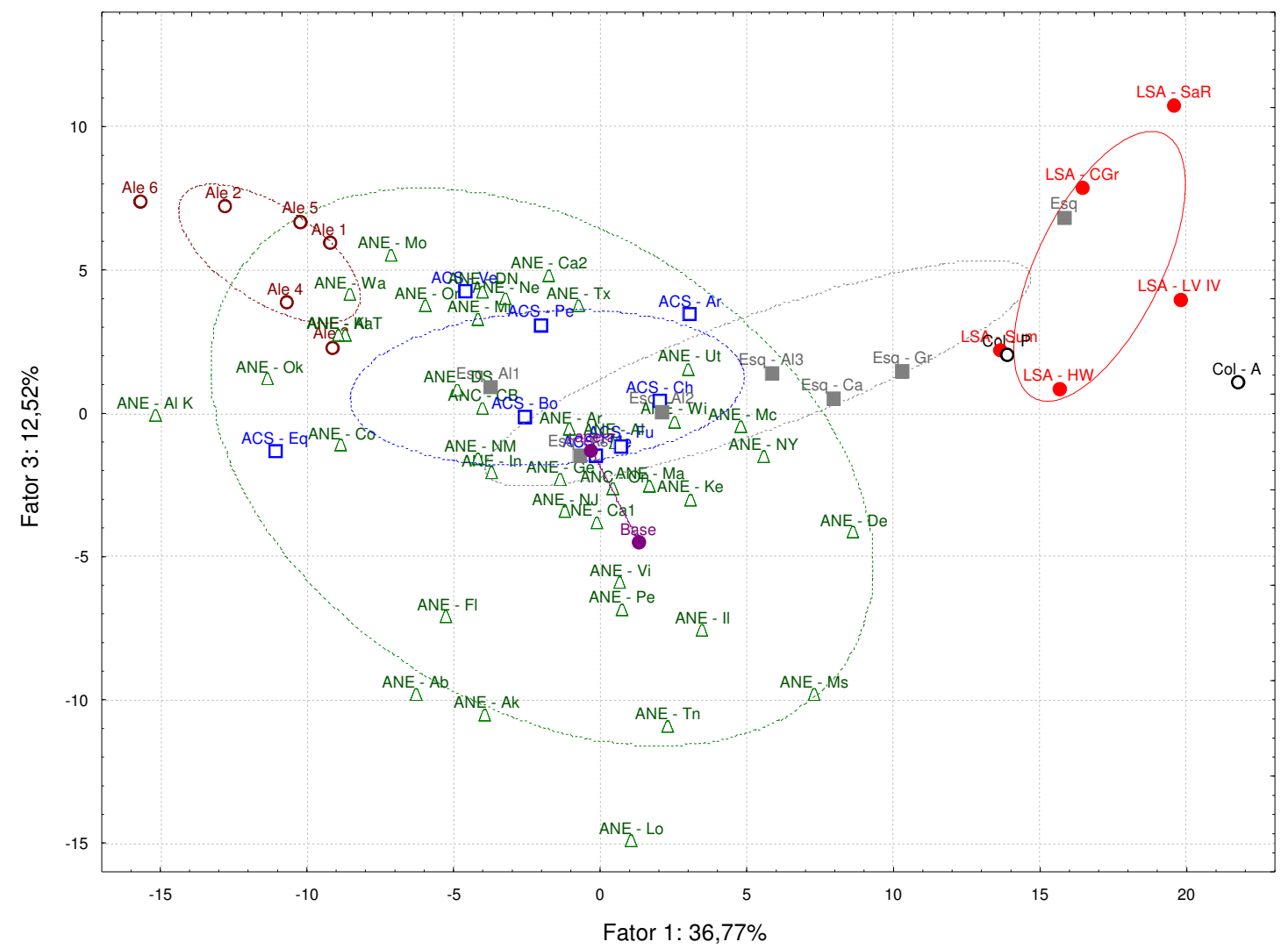


Figura 4.34 - Gráfico bidimensional do morfo-espaço formado pelos CP 2 × CP 3. Parcela feminina, forma e tamanho (69 séries, 23 variáveis craniométricas).

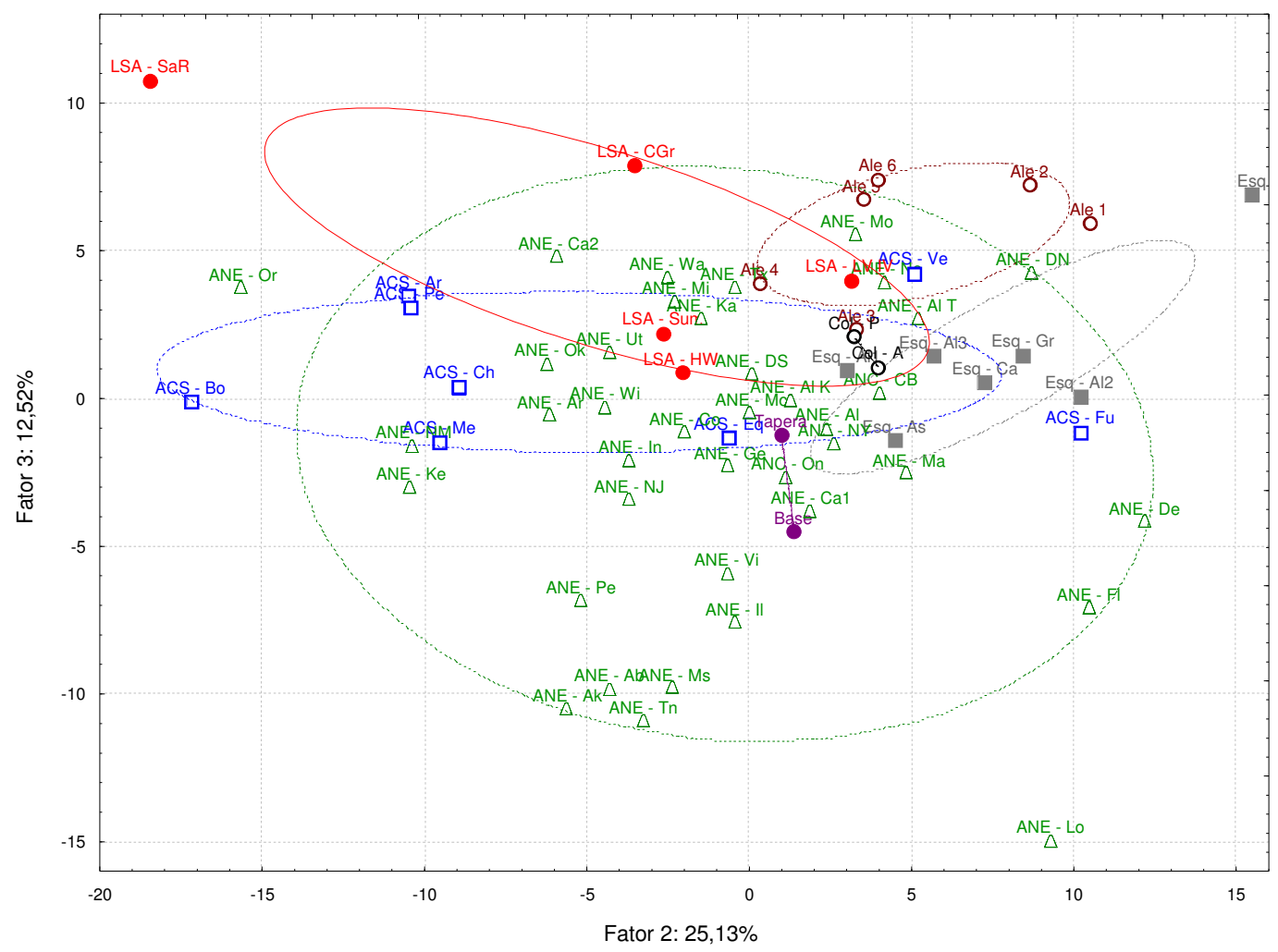

A exemplo do que foi observado na análise sobre forma e tamanho para a parcela masculina, os gráficos, particularmente os entre o CP 1 x CP 2 e o entre o CP 1 e o CP 3, sugerem fortemente que os Paleoíndios de Lagoa Santa não se associam com a outras populações nativas americanas, à exceção dos colombianos antigos.

No primeiro gráfico, representando o morfo-espaço formado pelos dois primeiros componentes principais, expressando $61,90 \%$ da variabilidade original, os centróides da população Paleoíndia de Lagoa Santa encontram-se isolados, juntamente com os Paleocolombianos, na região dos valores positivos extremos do primeiro Componente Principal (eixo das abcissas). Neste ensaio, esta região é ocupada por crânios de morfologia predominantemente estreita, em oposição aos localizados no outro extremo do gráfico, marcados por altos valores relativos às medidas de largura.

O gráfico formado pela relação entre os primeiro e terceiro componentes principais, expressando 49,29\% da variabilidade original amostrada, apresenta as mesmas características, reforçando a singularidade de Lagoa Santa. O último gráfico, referente ao morfo-espaço constituído por CP 2 x CP 3, a exemplo do que se observou nos outros conjuntos de dados, não apresenta estruturação suficiente para discriminar semelhanças e diferenças entre as populações amostradas. 
Tabela 4.10 - Fatores de coordenadas de cada série. Parcela feminina, forma e tamanho (69 séries, 23 variáveis craniométricas).

\begin{tabular}{|c|c|c|c|c|c|c|c|c|c|c|c|c|c|c|c|c|c|c|c|c|c|c|c|}
\hline & & & & & & & & & & & & & & & & & & & & & & 0.551777 & \\
\hline 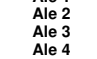 & 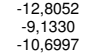 & 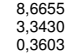 & 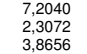 & 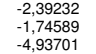 & 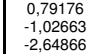 & 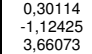 & 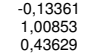 & 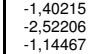 & 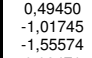 & 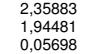 & 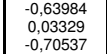 & 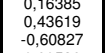 & 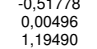 & 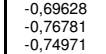 & 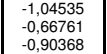 & 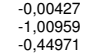 & 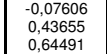 & 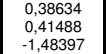 & 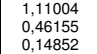 & 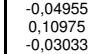 & 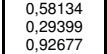 & 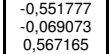 & 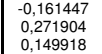 \\
\hline & 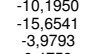 & $\begin{array}{l}3.9995 \\
\text { 3.9.944 } \\
\text { 4.0454 }\end{array}$ & 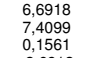 & 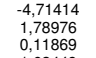 & 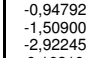 & 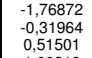 & 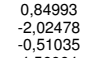 & 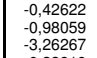 & 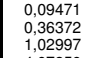 & 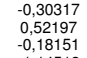 & 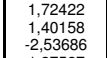 & 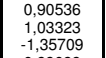 & 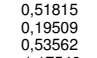 & 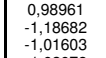 & 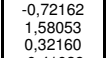 & 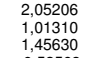 & 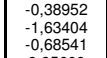 & 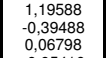 & 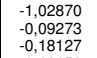 & 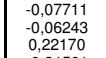 & 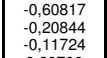 & 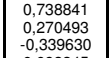 & \\
\hline & & 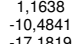 & 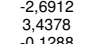 & 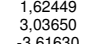 & 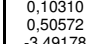 & 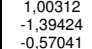 & 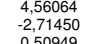 & 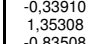 & 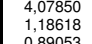 & 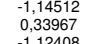 & 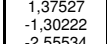 & 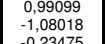 & 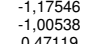 & 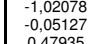 & 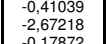 & 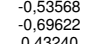 & & 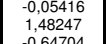 & 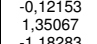 & 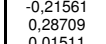 & 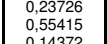 & 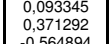 & \\
\hline & & 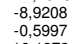 & 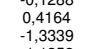 & 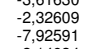 & 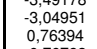 & 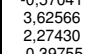 & 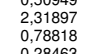 & 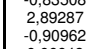 & 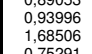 & 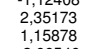 & 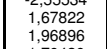 & 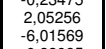 & 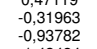 & $\begin{array}{l}0.7 \\
0.7\end{array}$ & 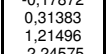 & 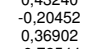 & 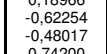 & 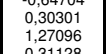 & & 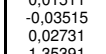 & 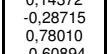 & 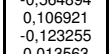 & \\
\hline & 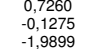 & 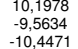 & & 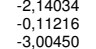 & 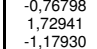 & 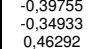 & $\begin{array}{l}0.028 \\
0.022 \\
1.22\end{array}$ & 染9 & 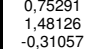 & 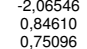 & 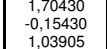 & $\begin{array}{l}0.086 \\
.0 .00 \\
.052\end{array}$ & & & 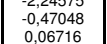 & & & & & & & & \\
\hline & & $\begin{array}{l}50.5 \\
30.06\end{array}$ & 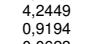 & $\begin{array}{l}4,169898 \\
\text { 202018 }\end{array}$ & 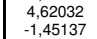 & 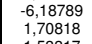 & & 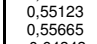 & 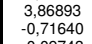 & & & & & & & & & & & & & & \\
\hline & 然 & 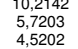 & 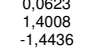 & 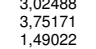 & 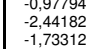 & 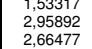 & 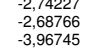 & 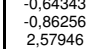 & 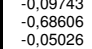 & 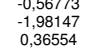 & 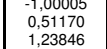 & 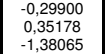 & & $\begin{array}{l}0.6 .0 .0 .0 \\
0.02\end{array}$ & 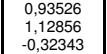 & $\begin{array}{l}-0,64 \\
0.99\end{array}$ & & 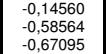 & & & 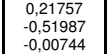 & & \\
\hline & & 8.474. & 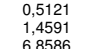 & $\begin{array}{l}2.299 \\
\text { a.495 }\end{array}$ & 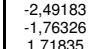 & 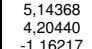 & 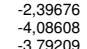 & 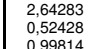 & 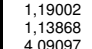 & $\begin{array}{l}0.660 \\
.0 .628\end{array}$ & & & & & & & & & & & & & \\
\hline & & 2.4277 & 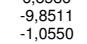 & 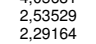 & 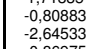 & 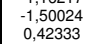 & 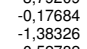 & 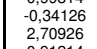 & 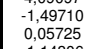 & 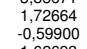 & 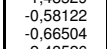 & 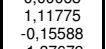 & & $\begin{array}{l}0.50 \\
0.01\end{array}$ & $\mid$ & & & 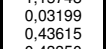 & & & 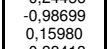 & 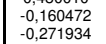 & \\
\hline & 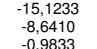 & 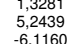 & 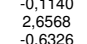 & 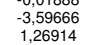 & 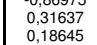 & 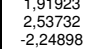 & $\begin{array}{l}0.78 \\
0.78\end{array}$ & 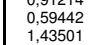 & 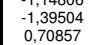 & & .0770966 & 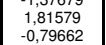 & & & & & & & & & & & \\
\hline & & 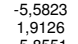 & 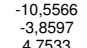 & 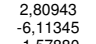 & 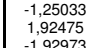 & 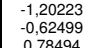 & 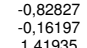 & 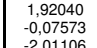 & 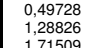 & 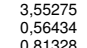 & 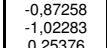 & $\begin{array}{l}0,506 \\
0,779\end{array}$ & $\begin{array}{l}-1,581 \\
0.8361\end{array}$ & $\begin{array}{l}0.0,0.0 \\
\text { i.ti }\end{array}$ & 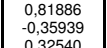 & & & & & & & & \\
\hline & -3.3972 & 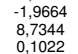 & $\begin{array}{l}2.2428 \\
0.7280\end{array}$ & 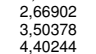 & 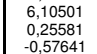 & 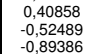 & , 1.408 & 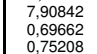 & 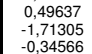 & 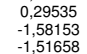 & 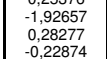 & 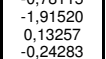 & & $\begin{array}{l}0.8 \\
0.86 \\
0.63\end{array}$ & 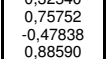 & & & & 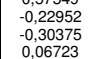 & & 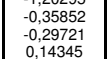 & & \\
\hline & & 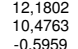 & 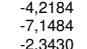 & 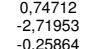 & 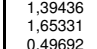 & 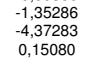 & 2,05 & 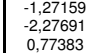 & 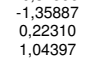 & 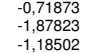 & 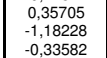 & 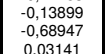 & & $\mid \begin{array}{l}0.73 \\
0.52 \\
0.520\end{array}$ & 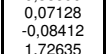 & 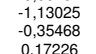 & & & & & & & \\
\hline & $\begin{array}{l}3,5 \\
3 ., 5\end{array}$ & 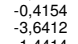 & 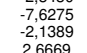 & 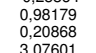 & 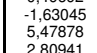 & 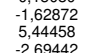 & 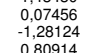 & 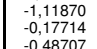 & 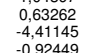 & 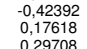 & 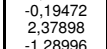 & & & $\begin{array}{l}0.026 \\
0.0100 \\
0.020\end{array}$ & & & 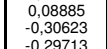 & & & & & & \\
\hline & 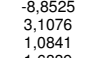 & 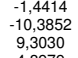 & 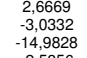 & 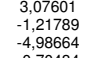 & 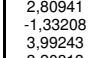 & 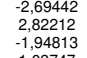 & 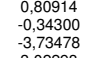 & 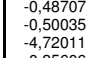 & 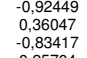 & $\begin{array}{l}.029 \\
-0.096 \\
-1.525\end{array}$ & 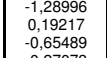 & & & $\begin{array}{l}0.12 \\
0.129\end{array}$ & & & & & & & & & \\
\hline & 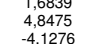 & 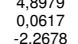 & 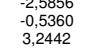 & 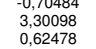 & 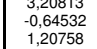 & 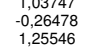 & 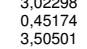 & 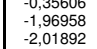 & 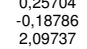 & $\begin{aligned} & 0.62 \\
& 2.092 \\
&-0.62\end{aligned}$ & 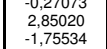 & 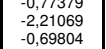 & & 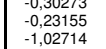 & 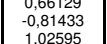 & & & & & & & & \\
\hline & & . & 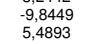 & & 0 & 1.123 & & 10 & & & & & & & & & & & & & & & \\
\hline & & 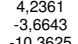 & 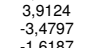 & 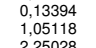 & 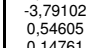 & 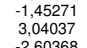 & $\begin{array}{l}2.020 \\
\text {. }\end{array}$ & 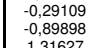 & 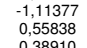 & $\begin{array}{l}-1.43 \\
-2.28 \\
-2.27\end{array}$ & 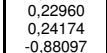 & $\begin{array}{l}-1,04 \\
0.025 \\
0.22\end{array}$ & & 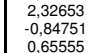 & 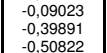 & & 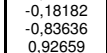 & 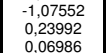 & & & & 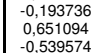 & \\
\hline & & 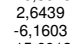 & 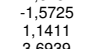 & 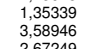 & $\begin{array}{l}0.837979 \\
\text { i. }\end{array}$ & 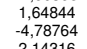 & 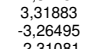 & 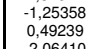 & $\begin{array}{l}0.166 \\
-1,160 \\
-1,16\end{array}$ & $\begin{array}{l}1.94 \\
\text { 3.0. }\end{array}$ & 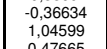 & $\begin{array}{l}0.18 \\
0,124\end{array}$ & & 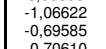 & & & & & & & & & \\
\hline & 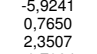 & 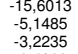 & 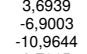 & 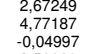 & 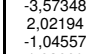 & & 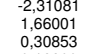 & 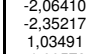 & 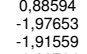 & 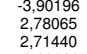 & 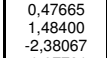 & 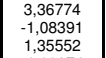 & & $\begin{array}{l}0.770 \\
0.650 \\
0.70\end{array}$ & & & & 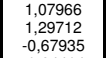 & & & & & \\
\hline & $-0,709$ & 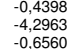 & 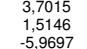 & 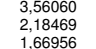 & 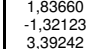 & 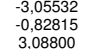 & 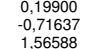 & 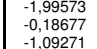 & 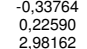 & $\begin{array}{l}-1,6.65 \\
-2.0 .06 \\
0.06\end{array}$ & 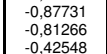 & $\begin{array}{l}-1.0,0.0 \\
0.09\end{array}$ & & $\begin{array}{l}-0.525 \\
0.9300 \\
0.048\end{array}$ & & & & & & & & & \\
\hline & & $\begin{array}{l}-2.51410 \\
4.448\end{array}$ & 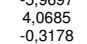 & & 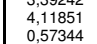 & 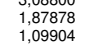 & 步, & & t: & 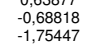 & 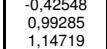 & & & & & & & & & & & & \\
\hline & & 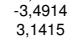 & 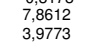 & & $2: 18780$ & 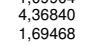 & $\begin{array}{l}2,1,2,0 \\
\text { 2.140 }\end{array}$ & 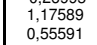 & . & $\begin{array}{l}0 ., 0,1 \\
0.2,2\end{array}$ & & & & & & & & & & & & & \\
\hline & 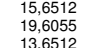 & 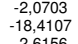 & 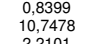 & 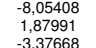 & 2.20043 & 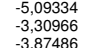 & $\begin{array}{l}-1.1,1.5 \\
-2.52\end{array}$ & 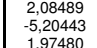 & 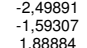 & 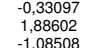 & 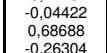 & 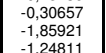 & & & & & & $\begin{array}{l}-0.8 \\
0.04 \\
0.04\end{array}$ & & & & tians: & \\
\hline & & t.3917 & 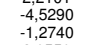 & & & & & & & & & & & & & & & & & & & & \\
\hline & & & & & & & & & & & & & & & & & & & & & & & \\
\hline
\end{tabular}


Figura 4.35 - Dendrograma gerado sobre matriz de Distância Euclidiana calculada a partir dos seis primeiros componentes principais - Método de Ward. Parcela feminina, forma e tamanho (69 séries, 23 variáveis craniométricas).

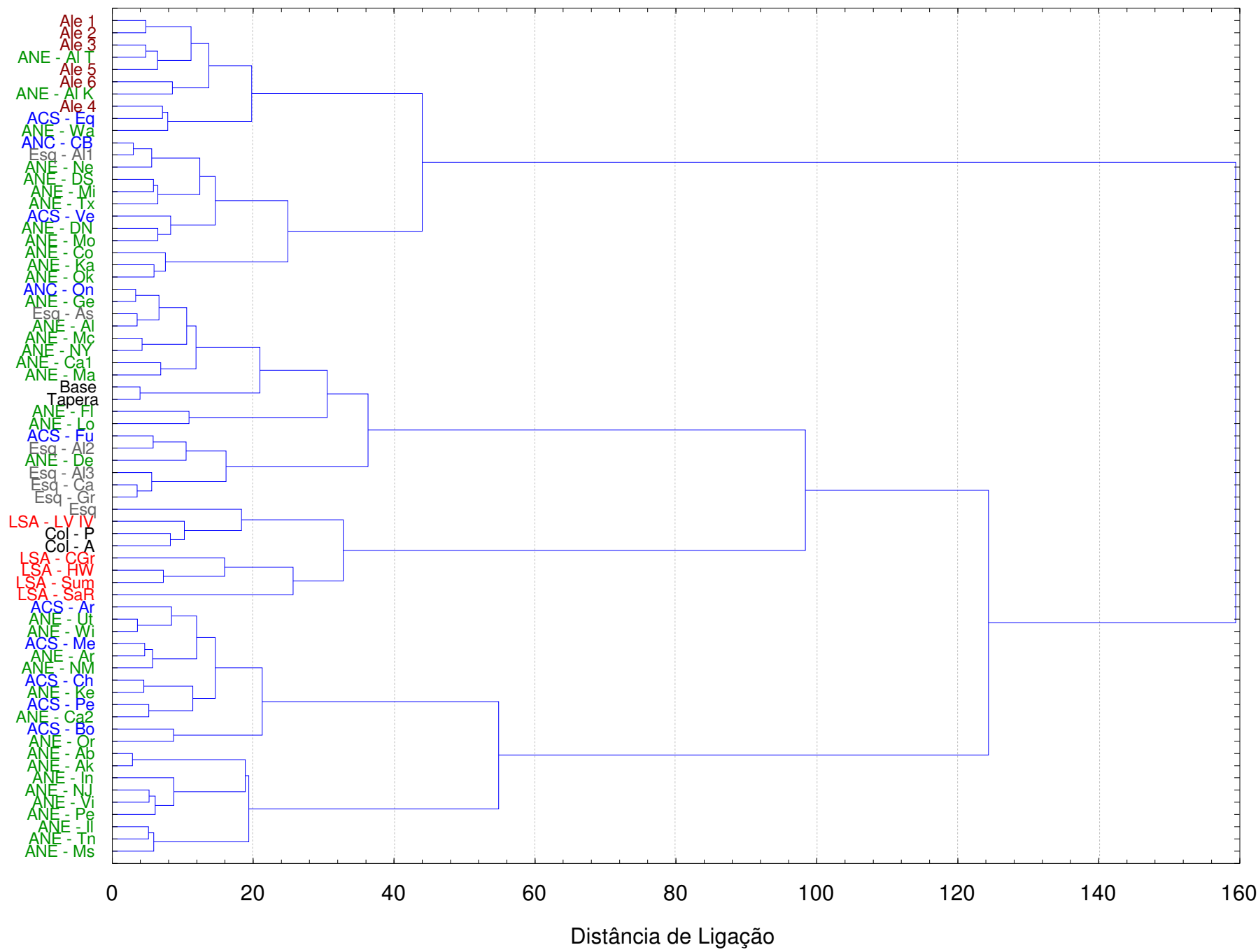


Figura 4.36 - Dendrograma gerado sobre matriz de Distância Euclidiana calculada a partir dos seis primeiros componentes principais - Método de Ligaçã̃o Simples. Parcela feminina, forma e tamanho (69 séries, 23 variáveis craniométricas).

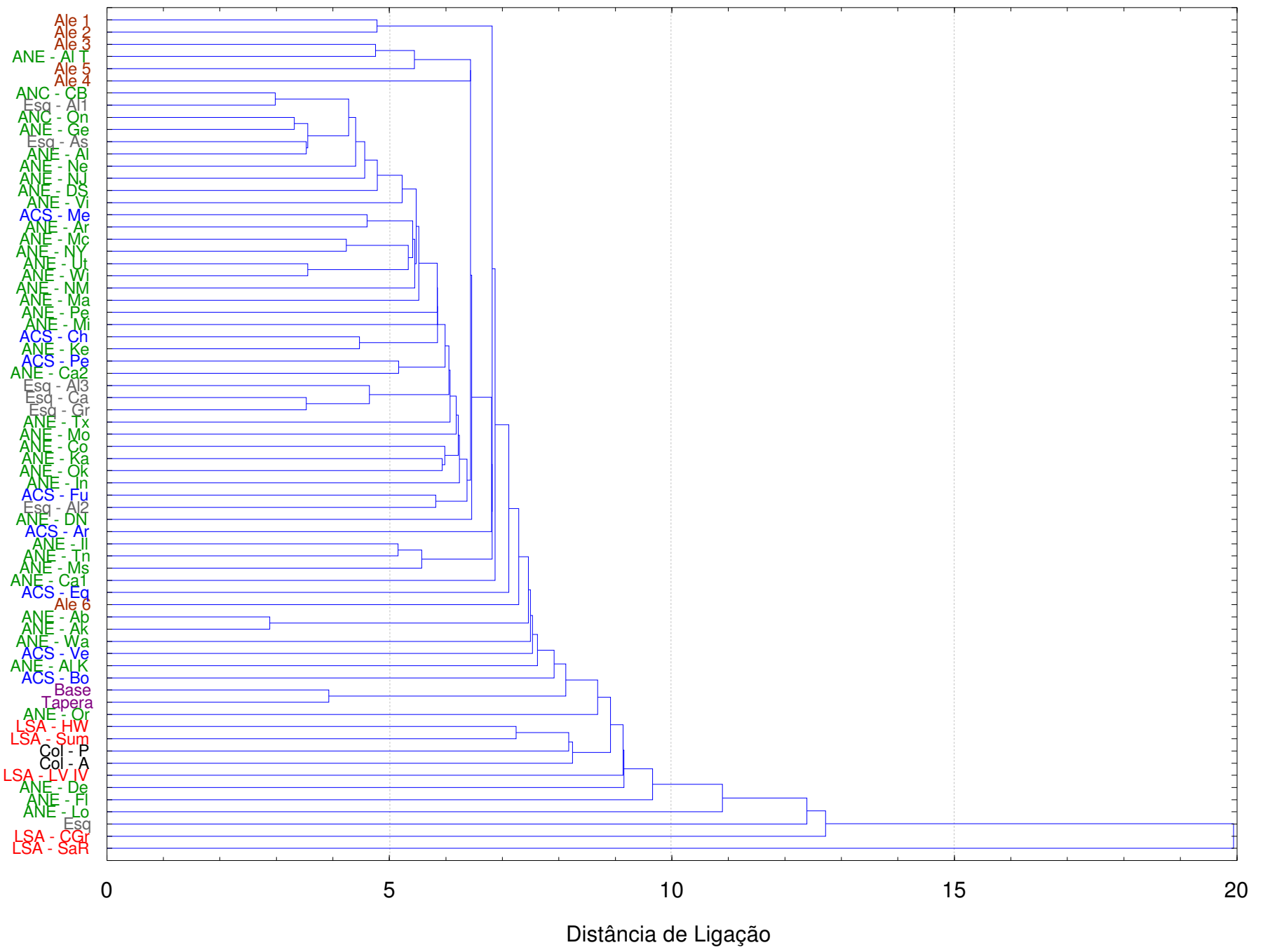


Figura 4.37 - Dendrograma gerado sobre matriz de Distância Euclidiana calculada a partir dos seis primeiros componentes principais - Método de Ligação Completa. Parcela feminina, forma e tamanho (69 séries, 23 variáveis craniométricas).

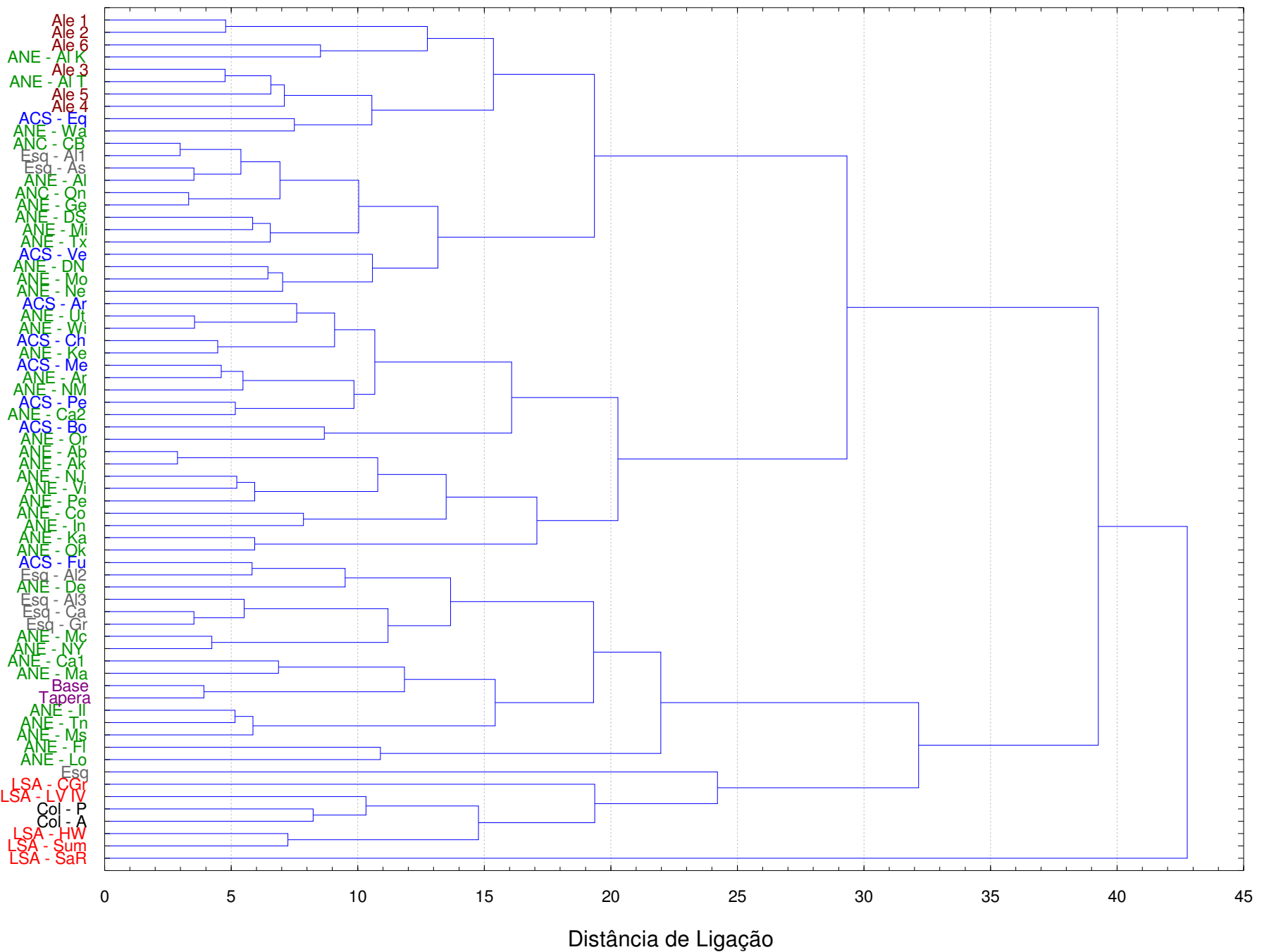


Figura 4.38 - Dendrograma gerado sobre matriz de Distância Euclidiana calculada a partir dos seis primeiros componentes principais - Método da Média dos Grupos. Parcela feminina, forma e tamanho (69 séries, 23 variáveis craniométricas).

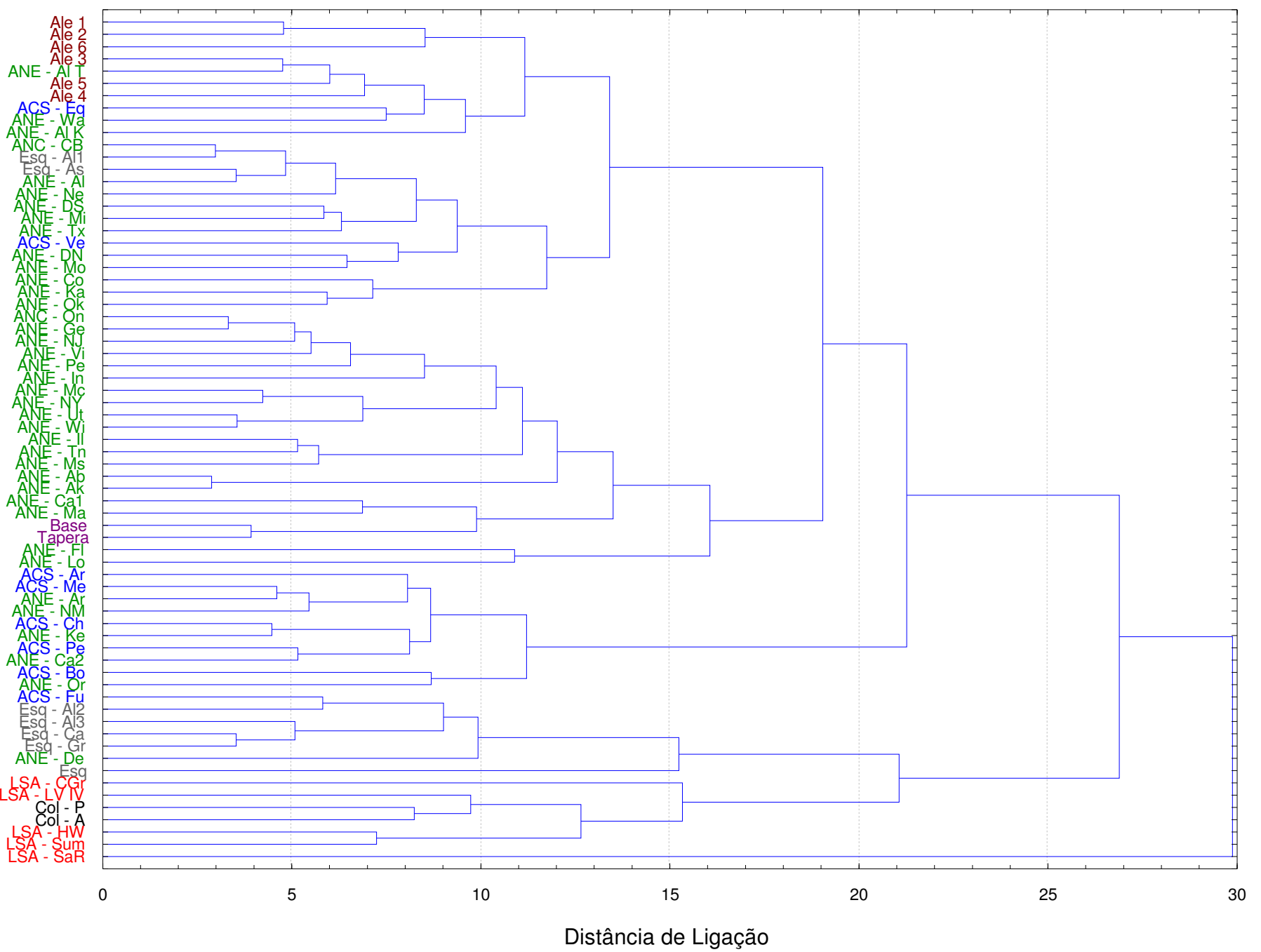


Os dendrogramas apresentados nas Figuras 4.35 a 4.38 reforçam a constatação de uma associação morfológica estreita entre os paleoamericanos, representados pelas séries de Lagoa Santa e da Colômbia. Em contrapartida, as afinidades entre os centróides de Lagoa Santa e as outras populações nativas americanas não estabeleceram-se de maneira consistente, apresentando algumas associações fortuitas e incoerentes entre si. De qualquer maneira, pode-se, ainda assim, visualizar certa singularidade morfológica dos paleoamericanos quando comparados às outras séries americanas.

Testes baseados em Distâncias de Mahalanobis também foram executados para as mulheres. A tabela 4.11 apresenta a matriz de distância montada a partir das distâncias de Mahalanobis utilizada nesses ensaios. Os dendrogramas apresentados nas Figuras 4.39 a 4.42 apresentam resultados semelhantes aos obtidos através dos agrupamentos a partir de distâncias Euclidianas, evidenciando a associação intra grupo das populações amostradas sem, no entanto, solucionar de maneira consistente suas relações interpopulacionais. A exemplo do que ocorreu com os resultados obtidos através do primeiro método, as populações paleoamericanas apresentam certa particularidade morfológica posicionando-se, quase sempre, isoladas das demais. O dendrograma da Figura 4.42, relativo ao agrupamento baseado na média dos grupos, evidencia bem essa interpretação.

A partir da matriz de Distâncias de Mahalanobis aplicou-se também a técnica de Escalonamento Multidimensional (MDS), obtendo-se as topologias apresentadas nas figuras 4.43 a 4.45, referentes, respectivamente, às relações entre as dimensões $1 \times 2,1 \times 3$ e $2 \times 3$. Neste caso, as duas primeiras topologias indicam, claramente, a disassociação entre os Paleoamericanos e as outras populações nativas do Novo Mundo. A topologia formada pelas dimensões 2 × 3 não indica essa separação.

A tabela 4.12 indica a configuração final das dimensões resultantes do MDS. 
Tabela 4.11 - Matriz de Distâncias de Mahalanobis. Parcela feminina, forma e tamanho (22 grupos, 23 variáveis craniométricas).

\begin{tabular}{|c|c|c|c|c|c|c|c|c|c|c|c|c|c|c|c|c|c|c|c|c|c|c|}
\hline & Aleuta & $\begin{array}{l}\text { Am.do } \\
\text { Norte- } \\
\text { Canadá } \\
\end{array}$ & $\begin{array}{l}\text { CSA - } \\
\text { Argentina }\end{array}$ & $\begin{array}{l}\text { CSA- } \\
\text { Bolivia } \\
\end{array}$ & $\begin{array}{l}\text { CSA- } \\
\text { Chile } \\
\end{array}$ & $\begin{array}{l}\text { CSA- } \\
\text { Fueguinos } \\
\text { (Patagonia) }\end{array}$ & $\begin{array}{l}\text { CSA- } \\
\text { México } \\
\end{array}$ & $\begin{array}{l}\text { CSA - } \\
\text { Peru } \\
\end{array}$ & $\begin{array}{l}\text { CSA- } \\
\text { Venezuela }\end{array}$ & $\begin{array}{l}\text { Esquimó - } \\
\text { Alaska } \\
\end{array}$ & $\begin{array}{l}\text { Esquimó - } \\
\text { Assia } \\
\end{array}$ & $\begin{array}{l}\text { Esquimíó- } \\
\text { Canadá } \\
\end{array}$ & $\begin{array}{l}\text { Esquimó- } \\
\text { Groelâandia }\end{array}$ & $\begin{array}{l}\text { Am. do } \\
\text { Norte- } \\
\text { EUA }\end{array}$ & $\begin{array}{l}\text { Lagoa } \\
\text { Santa }\end{array}$ & $\begin{array}{l}\text { Lagoa } \\
\text { Santa- } \\
\text { Cerca } \\
\text { Grande } \\
\end{array}$ & $\begin{array}{l}\text { Lagoa } \\
\text { Santa- } \\
\text { Harold } \\
\text { Walter } \\
\end{array}$ & $\begin{array}{l}\text { Lagoa } \\
\text { Santa- } \\
\text { Sumidouro } \\
\end{array}$ & $\begin{array}{l}\text { Base } \\
\text { Aerea } \\
\end{array}$ & Tapera & $\begin{array}{l}\text { Colômbia } \\
\mathrm{P}\end{array}$ & $\begin{array}{l}\text { Colômbia } \\
\text { A }\end{array}$ \\
\hline \multirow{8}{*}{ 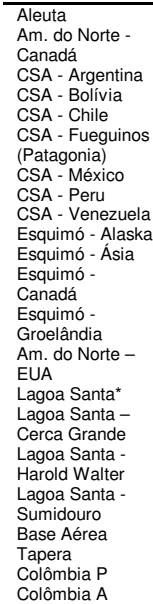 } & & $2,30678^{5}$ & $\begin{array}{r}4,326257 \\
3,639011 \\
0\end{array}$ & $\begin{array}{r}4,487236 \\
3,212445 \\
3,984125 \\
0\end{array}$ & $\begin{array}{r}3,886248 \\
3,223756 \\
3,555742 \\
3,145557 \\
0\end{array}$ & $\begin{array}{l}3,198354 \\
2,559991 \\
3,619156 \\
3,961582 \\
3,214335\end{array}$ & $\begin{array}{l}3,984446 \\
3,105574 \\
3,207572 \\
3,191725 \\
2,674713\end{array}$ & $\begin{array}{r}, 33311 \\
2,986729 \\
3,301624 \\
2,881697 \\
2,138348\end{array}$ & $\begin{array}{l}5,436449 \\
5,638847 \\
6,020982 \\
5,824029 \\
4,832855\end{array}$ & $\begin{array}{l}3,185761 \\
2,743848 \\
4,160695 \\
4,967146 \\
3,990338\end{array}$ & $\begin{array}{r}3,311069 \\
3,06677 \\
4,516968 \\
5,257785 \\
4,433927\end{array}$ & $\begin{array}{l}, 362938 \\
3,721692 \\
4,355266 \\
5,479602 \\
4,229208\end{array}$ & $\begin{array}{r}4,837243 \\
4,33596 \\
4,891935 \\
6,096784 \\
4,965341\end{array}$ & $\begin{array}{l}2,939699 \\
1,894898 \\
2,962673 \\
3,072205 \\
2,318924\end{array}$ & $\begin{array}{l}6,497115 \\
5,670424 \\
5,0852005 \\
5,629055 \\
5,761416\end{array}$ & $\begin{array}{l}6,283158 \\
5,709491 \\
5,184205 \\
6,142627 \\
5,225119\end{array}$ & $\begin{array}{l}7,013724 \\
6,267263 \\
5,995792 \\
5,995027 \\
6,057084\end{array}$ & $\begin{array}{r}6,520534 \\
5,49145 \\
4,98945 \\
5,202319 \\
5,643528\end{array}$ & $\begin{array}{l}, 717465 \\
4,103915 \\
4,711477 \\
4,436956 \\
4,396436\end{array}$ & $\begin{array}{l}4,935003 \\
4,512619 \\
5,273953 \\
4,571818 \\
4,551073\end{array}$ & $\begin{array}{r}, 05231 \\
4,129829 \\
5,025241 \\
4,588939 \\
4,599031\end{array}$ & $\begin{array}{r}6,03332 \\
4,922476 \\
4,82837 \\
4,872695 \\
4,652729\end{array}$ \\
\hline & & & & & & 0 & $\begin{array}{r}2,984275 \\
0\end{array}$ & $\begin{array}{r}2,913314 \\
1,91673 \\
0\end{array}$ & $\begin{array}{r}5,007258 \\
4,384501 \\
4,685199 \\
0\end{array}$ & $\begin{array}{l}3,235806 \\
3,834257 \\
3,817993 \\
5,939868 \\
0\end{array}$ & $\begin{array}{r}3,602841 \\
4,239835 \\
4,314014 \\
6,741676 \\
2,225961 \\
0\end{array}$ & $\begin{array}{l}3,593537 \\
4,230145 \\
4,287969 \\
6,544655 \\
1,861095 \\
2,735752\end{array}$ & $\begin{array}{l}4,336056 \\
4,660455 \\
4,887571 \\
6,810234 \\
2,470295 \\
3,147072\end{array}$ & $\begin{array}{l}1,987351 \\
1,783609 \\
1,787393 \\
4,766116 \\
2,898214 \\
3,520107\end{array}$ & $\begin{array}{l}6,299949 \\
5,684065 \\
5,41501 \\
8,036708 \\
5,458271 \\
5,938843\end{array}$ & $\begin{array}{l}6,0435449 \\
5,411164 \\
5,208114 \\
7,954769 \\
5,791868 \\
5,713326\end{array}$ & $\begin{array}{r}6,623975 \\
6,214983 \\
5,881756 \\
8,237769 \\
6,478686 \\
6,60406\end{array}$ & $\begin{array}{r}6,204639 \\
5,69034 \\
5,526113 \\
8,193325 \\
5,840913 \\
6,120023\end{array}$ & $\begin{array}{l}4,284988 \\
5,172508 \\
4,426148 \\
7,315161 \\
5,030603 \\
4,690447\end{array}$ & $\begin{array}{l}4,916303 \\
5,687312 \\
4,908791 \\
7,150394 \\
5,484926 \\
5,154871\end{array}$ & $\begin{array}{r}4,96348 \\
5,386844 \\
4,739155 \\
7,6054460 \\
4,985437 \\
5,327081\end{array}$ & $\begin{array}{r}5,466833 \\
5,557332 \\
5,156991 \\
7,7111 \\
5,919818 \\
6,00455\end{array}$ \\
\hline & & & & & & & & & & & & 0 & 1,51405 & 3,656037 & 5,533046 & 5,480426 & 6,347659 & 5,789896 & 5,210517 & 5,928219 & 5,204635 & 5,865906 \\
\hline & & & & & & & & & & & & & 0 & 4,396754 & 5,517318 & 5,504088 & 6,366593 & 5,839847 & 5,807182 & 6,470495 & 5,467741 & 6,138927 \\
\hline & & & & & & & & & & & & & & 0 & $\begin{array}{r}5,458278 \\
0\end{array}$ & $\begin{array}{r}5,36949 \\
4,122378\end{array}$ & $\begin{array}{l}6,110062 \\
2,964676\end{array}$ & $\begin{array}{l}5,504932 \\
2,536827\end{array}$ & $\begin{array}{l}4,266647 \\
5,640555\end{array}$ & $\begin{array}{l}4,789137 \\
5,688065\end{array}$ & $\begin{array}{l}4,560003 \\
4,060165\end{array}$ & $\begin{array}{l}5,011641 \\
4,262951\end{array}$ \\
\hline & & & & & & & & & & & & & & & & 0 & 4,02504 & 4,298412 & 5,8212 & 6,249861 & 5,170585 & 4,631434 \\
\hline & & & & & & & & & & & & & & & & & 0 & 2,473408 & 5,389799 & 5,249333 & 4,17948 & 4,14613 \\
\hline & & & & & & & & & & & & & & & & & & 0 & 5,111523 & $\begin{array}{l}5,064516 \\
2,131513 \\
\end{array}$ & $\begin{array}{l}3,3,692777 \\
3,89259 \\
3,939874\end{array}$ & $\begin{array}{r}3,8052721 \\
4,159912 \\
4,123773 \\
3,050054 \\
0\end{array}$ \\
\hline
\end{tabular}


Figura 4.39 - Dendrograma gerado sobre matriz de Distâncias de Mahalanobis - Método de Ward. Parcela feminina, forma e tamanho.

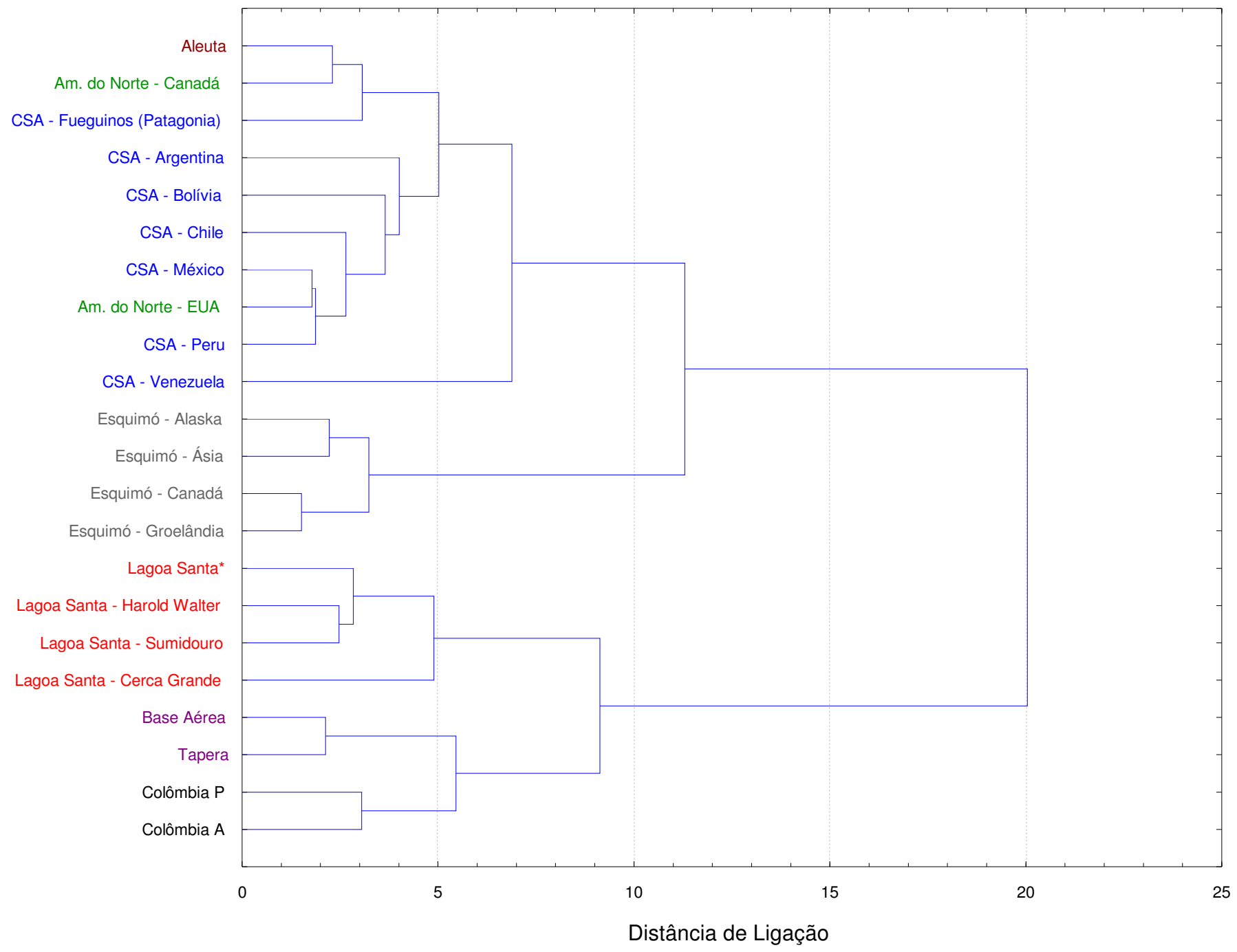


Figura 4.40 - Dendrograma gerado sobre matriz de Distâncias de Mahalanobis - Método de Ligação Simples. Parcela feminina, forma e tamanho.

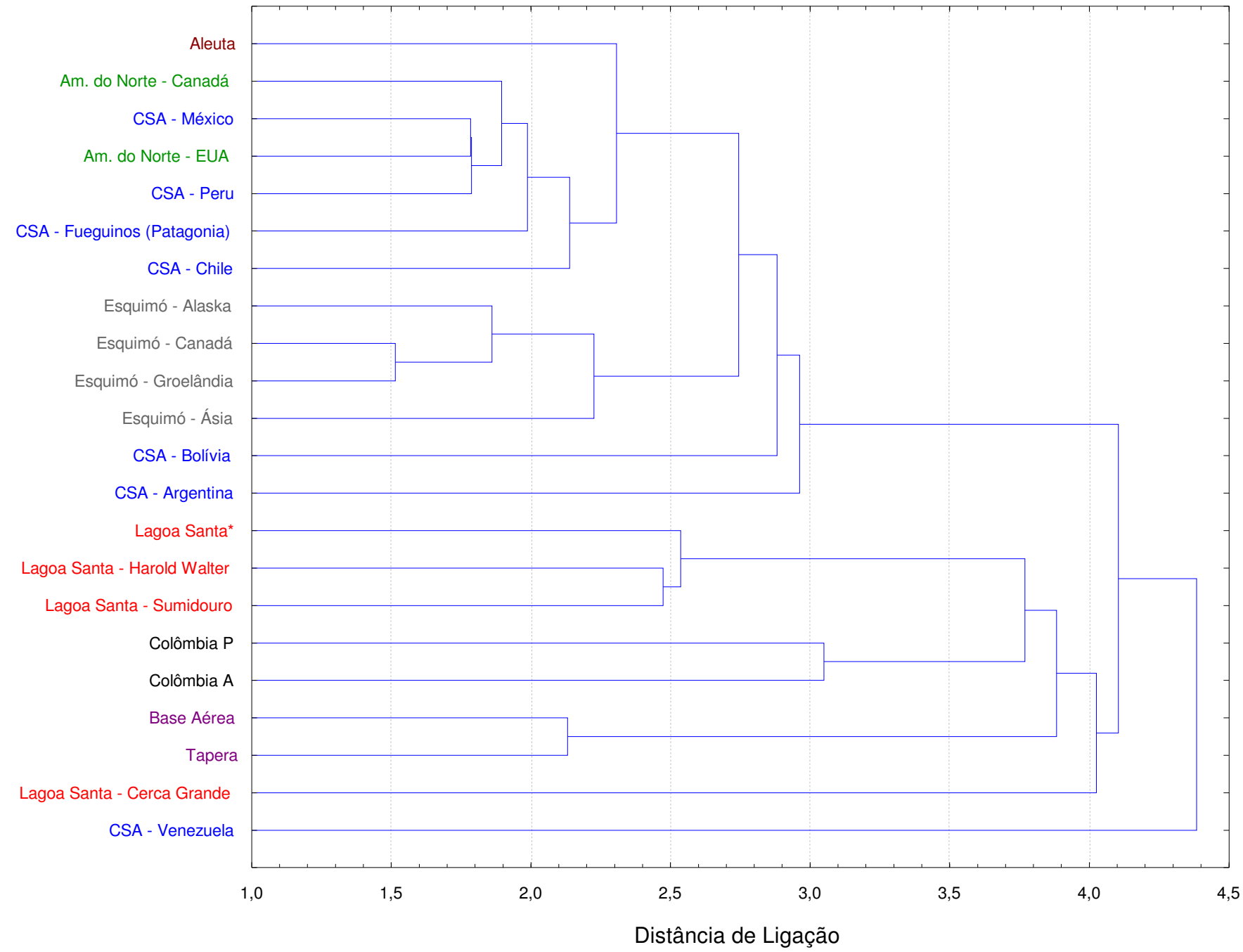


Figura 4.41 - Dendrograma gerado sobre matriz de Distâncias de Mahalanobis - Método de Ligação Completa. Parcela feminina, forma e tamanho.

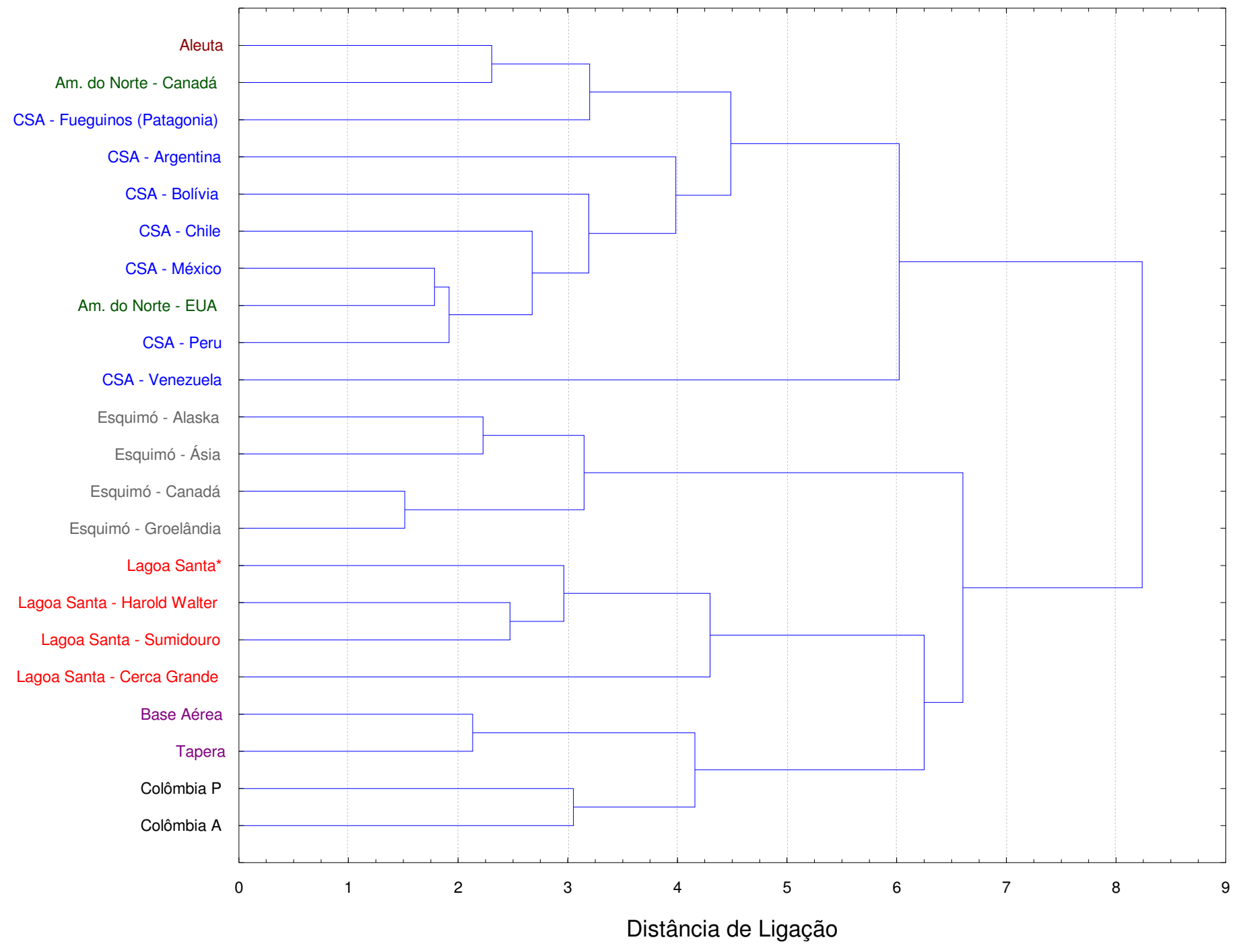


Figura 4.42 - Dendrograma gerado sobre matriz de Distâncias de Mahalanobis - Método da Média dos Grupos. Parcela feminina, forma e tamanho.

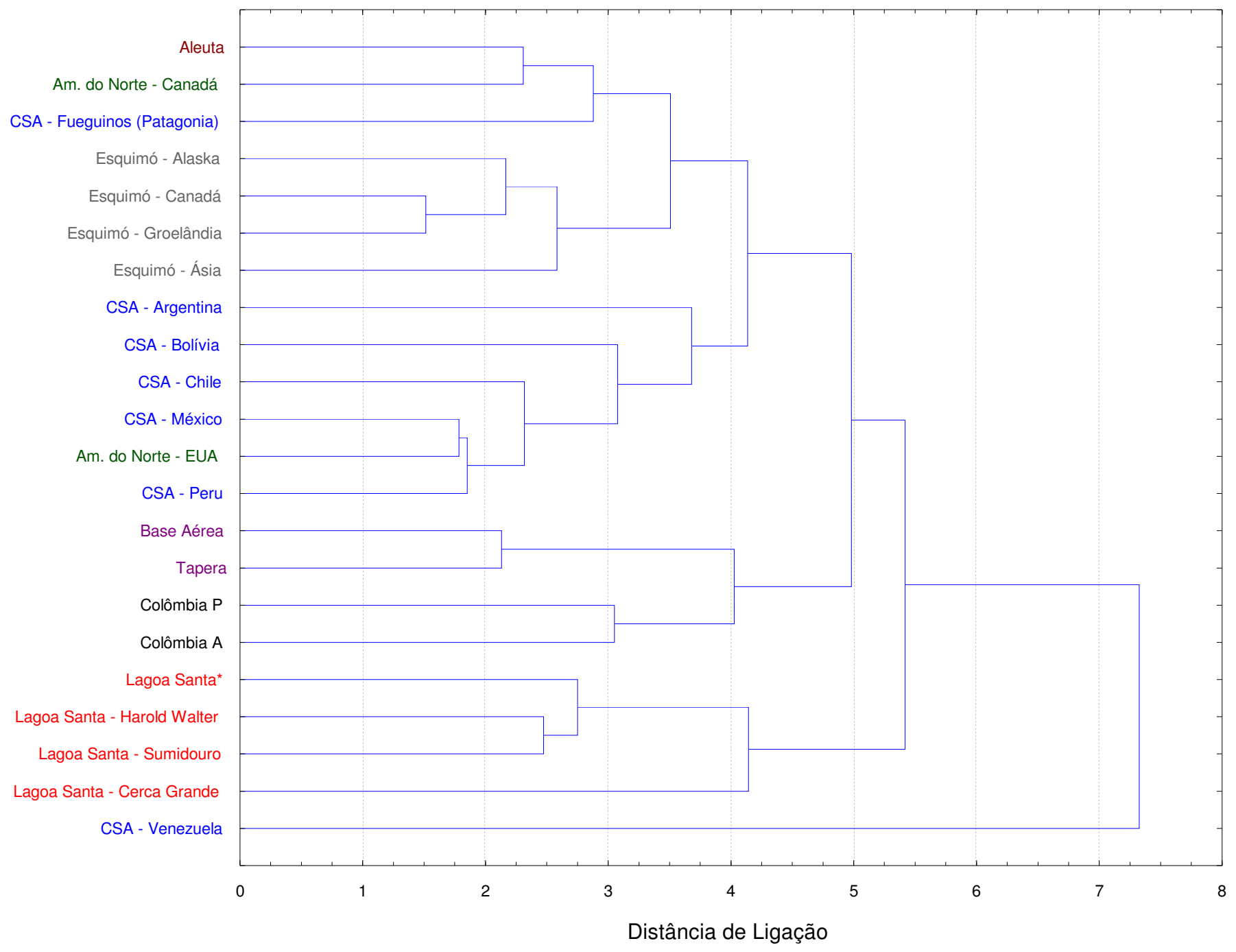



Tabela 4.12 - Configuração final das dimensões calculadas através de escalonamento multidimensional sobre Matriz de Distâncias de Mahalanobis. Parcela feminina, forma e tamanho (22 grupos, 23 variáveis craniométricas).

\begin{tabular}{|c|c|c|c|}
\hline & DIMENSÃO 1 & DIMENSÃO 2 & DIMENSÃO 3 \\
\hline $\begin{array}{c}\text { Aleuta } \\
\text { Am. do Norte - Canadá } \\
\text { CSA - Argentina } \\
\text { CSA - Bolívia } \\
\text { CSA - Chile } \\
\text { CSA - Fueguinos (Patagonia) } \\
\text { CSA - México } \\
\text { CSA - Peru } \\
\text { CSA - Venezuela } \\
\text { Esquimó - Alaska } \\
\text { Esquimó - Ásia } \\
\text { Esquimó - Canadá } \\
\text { Esquimó - Groelândia } \\
\text { Am. do Norte - EUA } \\
\text { Lagoa Santa* } \\
\text { Lagoa Santa - Cerca Grande } \\
\text { Lagoa Santa - Harold Walter } \\
\text { Lagoa Santa - Sumidouro } \\
\text { Base Aérea } \\
\text { Tapera } \\
\text { Colômbia P } \\
\text { Colômbia A }\end{array}$ & $\begin{array}{l}0,72512 \\
0,35043 \\
0,16549 \\
0,23642 \\
0,43229 \\
0,64101 \\
0,58445 \\
0,39897 \\
1,78499 \\
0,45572 \\
0,39994 \\
0,34054 \\
0,21946 \\
0,42214 \\
-1,19948 \\
-0,89119 \\
-1,46065 \\
-1,24790 \\
-0,26104 \\
-0,40196 \\
-0,78246 \\
-0,91228\end{array}$ & $\begin{array}{l}-0,120935 \\
-0,095049 \\
0,160219 \\
-0,640414 \\
-0,308025 \\
0,002149 \\
-0,018902 \\
-0,145257 \\
-0,262070 \\
0,483018 \\
0,460837 \\
0,754533 \\
0,995150 \\
-0,011484 \\
0,433625 \\
0,659329 \\
0,054630 \\
0,051199 \\
-0,707448 \\
-0,878025 \\
-0,290317 \\
-0,576761\end{array}$ & $\begin{array}{c}-0,463097 \\
-0,230255 \\
0,546289 \\
0,412383 \\
0,222147 \\
-0,095771 \\
0,373255 \\
0,275427 \\
0,700624 \\
-0,301734 \\
-0,628711 \\
-0,325830 \\
-0,422281 \\
0,054930 \\
0,095811 \\
0,740675 \\
0,349580 \\
0,079812 \\
-0,540189 \\
-0,581066 \\
-0,336391 \\
0,074392\end{array}$ \\
\hline
\end{tabular}

Figura 4.43 - Gráfico bidimensional da relação ortogonal entre as dimensões $1 \times 2$. Parcela feminina, forma e tamanho (22 grupos, 23 variáveis craniométricas).

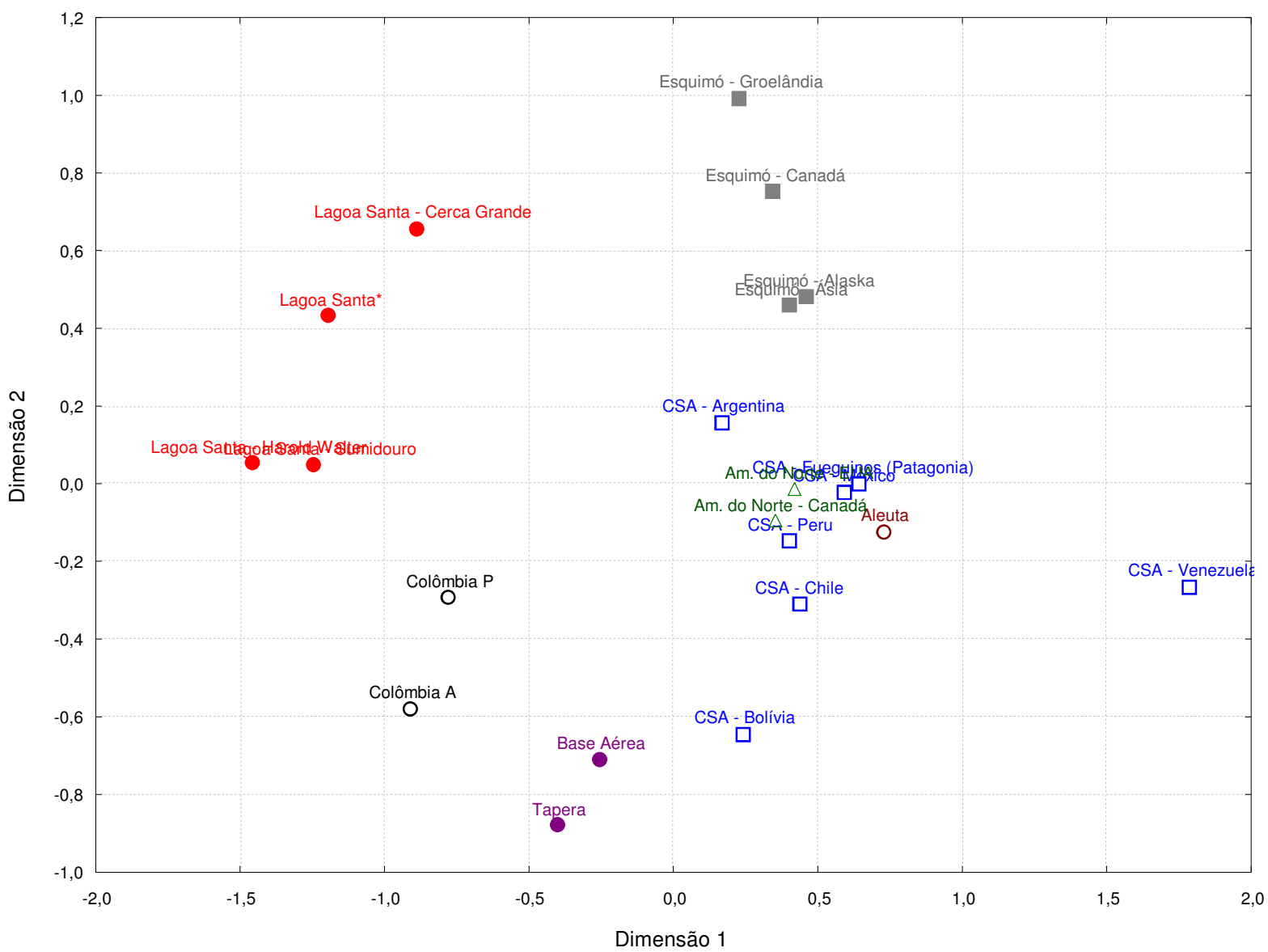


Figura 4.44 - Gráfico bidimensional da relação ortogonal entre as dimensões $1 \times 3$. Parcela feminina, forma e tamanho (22 grupos, 23 variáveis craniométricas).

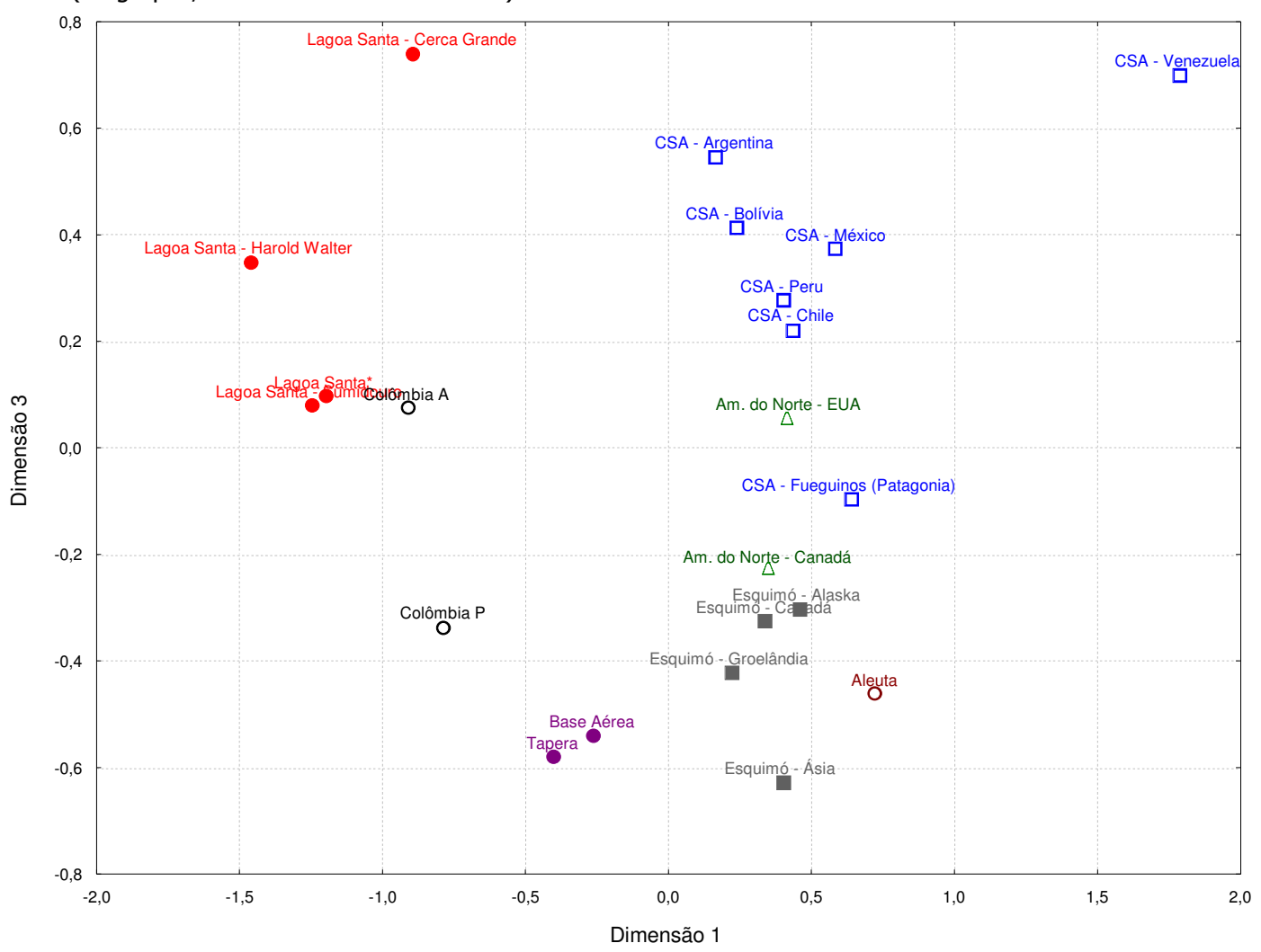

Figura 4.45 - Gráfico bidimensional da relação ortogonal entre as dimensões $2 \times 3$. Parcela feminina, forma e tamanho (22 grupos, 23 variáveis craniométricas).

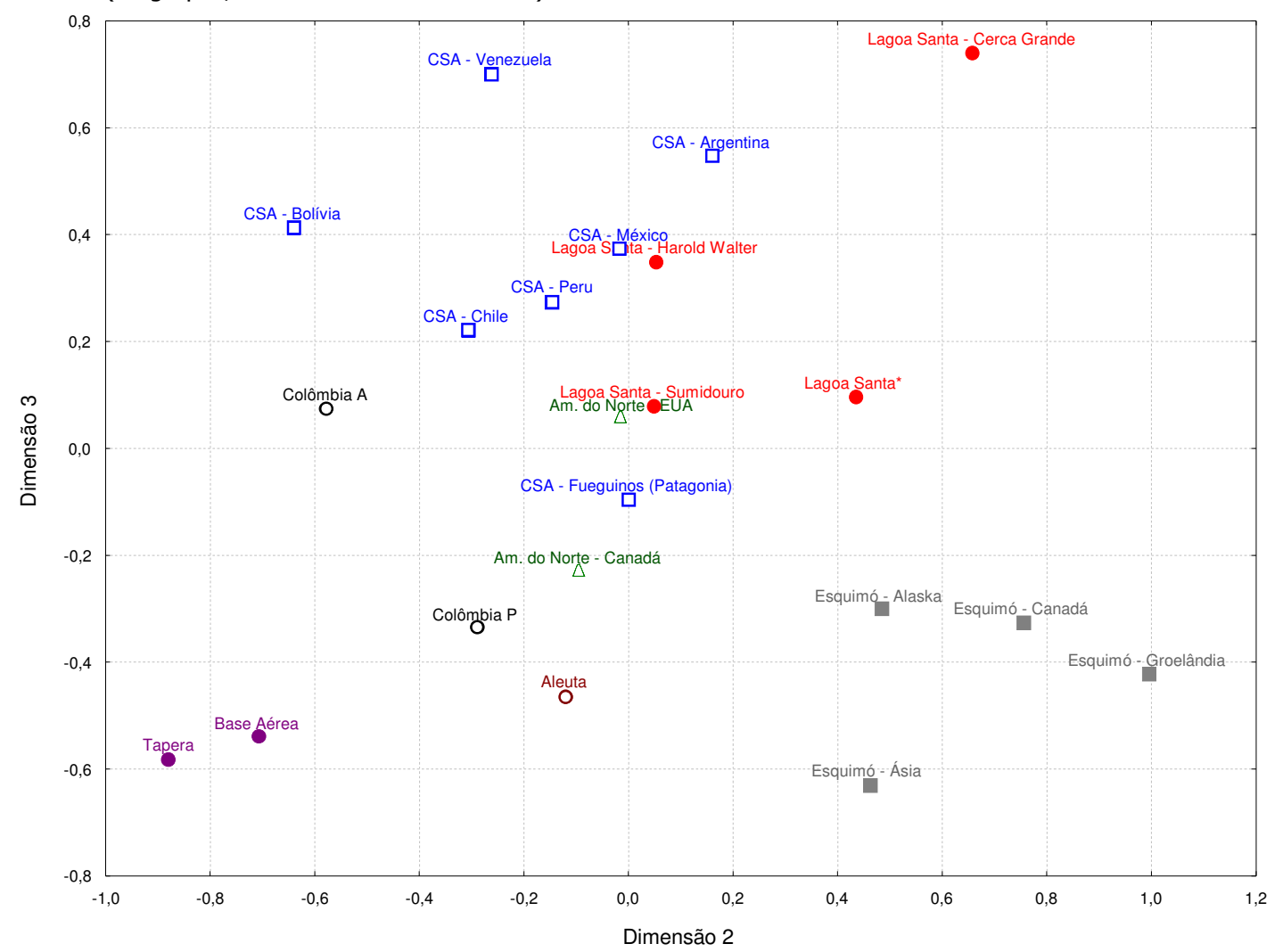




\subsection{4 - Parcela Feminina, Forma Apenas}

A exemplo do que foi feito anteriormente para os dados relativos ao tamanho e forma da parcela Feminina apresentam-se, a seguir, os resultados obtidos nas análises dos dados referentes aos dados corrigidos quanto ao fator tamanho.

A ACP foi realizada sobre as mesmas 23 variáveis, distribuídas nas mesmas 69 séries, como já haviam sido utilizadas na análise sobre tamanho e forma. A Tabela 4.13 apresenta a síntese dos resultados extraídos através da Análise de Componentes Principais da matriz de covariância do conjunto de dados. Sua representação está exibida na Figura 4.46. e sua análise determinou a utilização dos seis primeiros Componentes Principais para o cálculo de Distâncias Euclidianas.

Tabela 4.13 - Autovalores da matriz de covariância e porcentagens de variância total explicadas por cada Componente Principal. Parcela feminina, forma apenas (69 séries, 23 variáveis craniométricas).

\begin{tabular}{c|c|c|c|c|}
\hline $\begin{array}{c}\text { Componente } \\
\text { Principal }\end{array}$ & Autovalor & $\%$ Total & $\begin{array}{c}\text { Autovalor } \\
\text { Cumulativo }\end{array}$ & $\%$ Cumulativa \\
\hline 1 & 0,022733 & 48,10120 & 0,022733 & 48,1012 \\
2 & 0,010481 & 22,17620 & 0,033214 & 70,2774 \\
3 & 0,003509 & 7,42402 & 0,036723 & 77,7014 \\
4 & 0,002677 & 5,66410 & 0,039400 & 83,3655 \\
5 & 0,001752 & 3,70803 & 0,041152 & 87,0736 \\
6 & 0,001338 & 2,83127 & 0,042490 & 89,9048 \\
7 & 0,000924 & 1,95575 & 0,043415 & 91,8606 \\
8 & 0,000747 & 1,58107 & 0,044162 & 93,4417 \\
9 & 0,000648 & 1,37163 & 0,044810 & 94,8133 \\
10 & 0,000472 & 0,99801 & 0,045282 & 95,8113 \\
11 & 0,000428 & 0,90500 & 0,045710 & 96,7163 \\
12 & 0,000374 & 0,79152 & 0,046084 & 97,5078 \\
13 & 0,000273 & 0,57707 & 0,046356 & 98,0849 \\
14 & 0,000225 & 0,47646 & 0,046582 & 98,5613 \\
15 & 0,000180 & 0,38144 & 0,046762 & 98,9428 \\
16 & 0,000145 & 0,30738 & 0,046907 & 99,2501 \\
17 & 0,000115 & 0,24436 & 0,047023 & 99,4945 \\
18 & 0,000080 & 0,16859 & 0,047102 & 99,6631 \\
19 & 0,000058 & 0,12232 & 0,047160 & 99,7854 \\
20 & 0,000047 & 0,10045 & 0,047208 & 99,8859 \\
21 & 0,000039 & 0,08161 & 0,047246 & 99,9675 \\
22 & 0,000014 & 0,02930 & 0,047260 & 99,9968 \\
23 & 0,000002 & 0,00322 & 0,047262 & 100,0000 \\
\hline
\end{tabular}


Figura 4.46 - Gráfico de decaímento da porcentagem de variância condensada em cada Componente Principal. Parcela feminina, forma apenas (76 séries, 23 variáveis craniométricas).

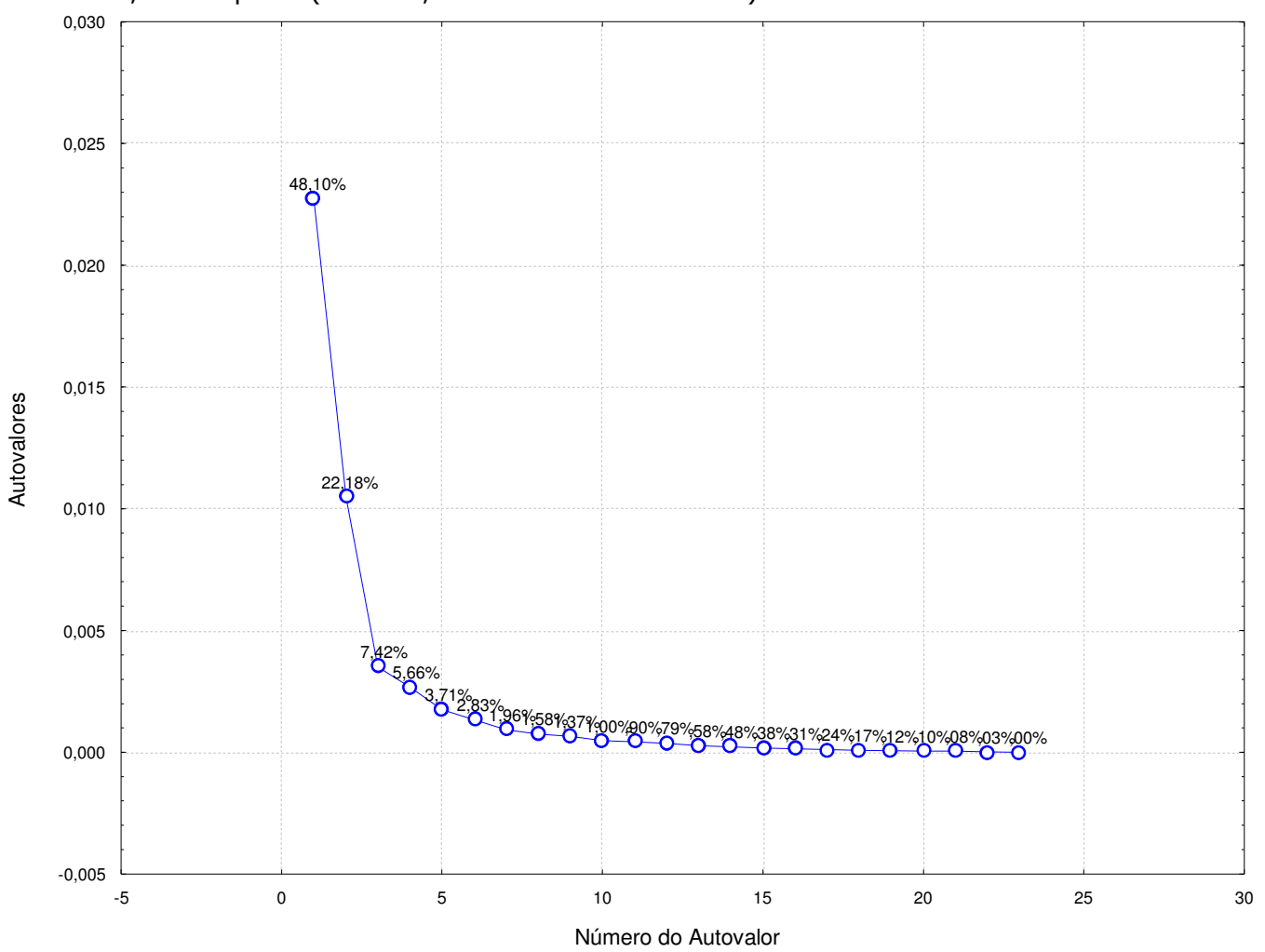

Figura 4.47 - Gráfico bidimensional do morfo-espaço formado pelos CP 1 x CP 2. Parcela feminina, forma apenas (69 séries, 23 variáveis craniométricas).

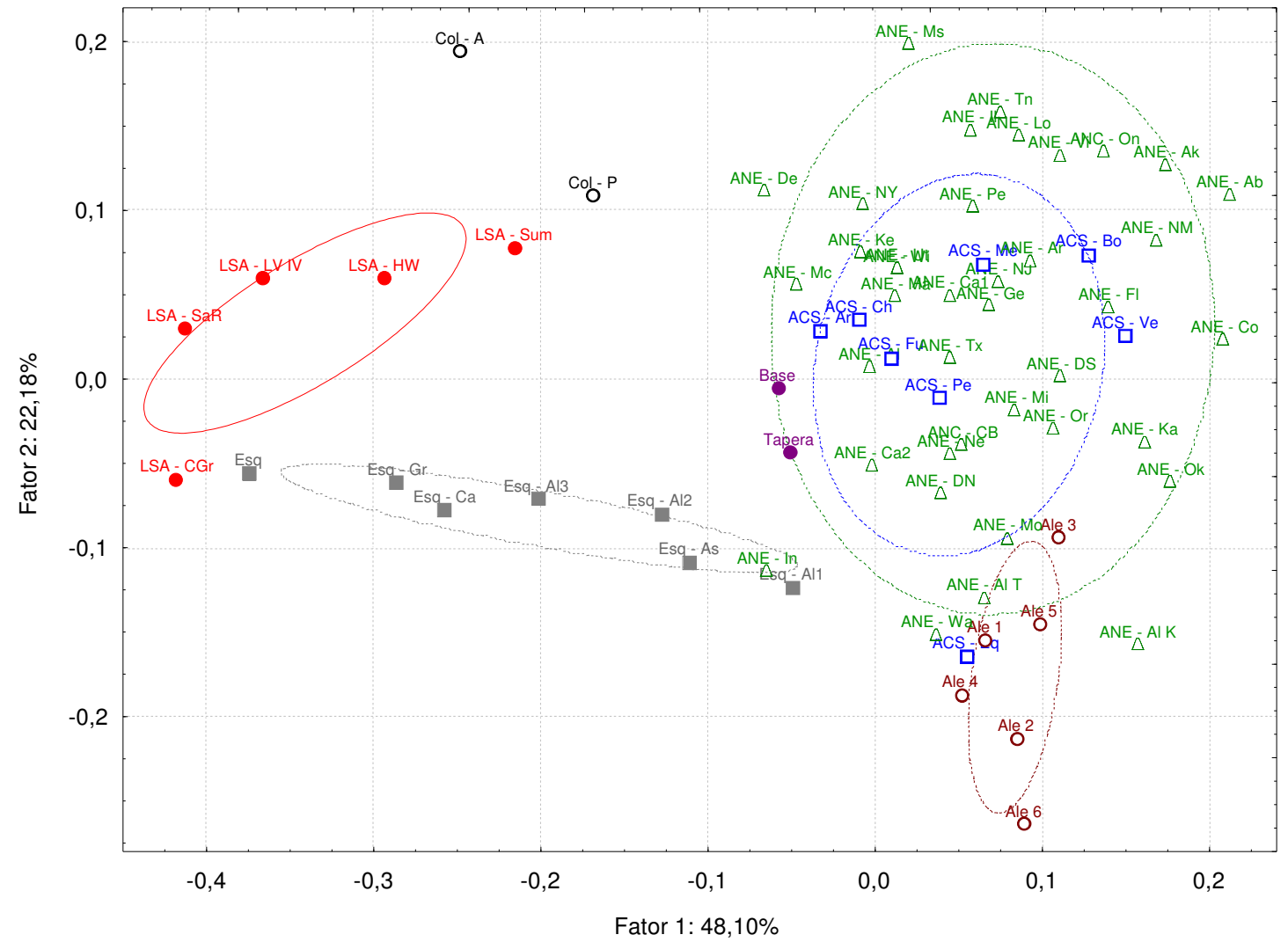


Figura 4.48 - Gráfico bidimensional do morfo-espaço formado pelos CP 1 x CP 3. Parcela feminina, forma apenas (69 séries, 23 variáveis craniométricas).

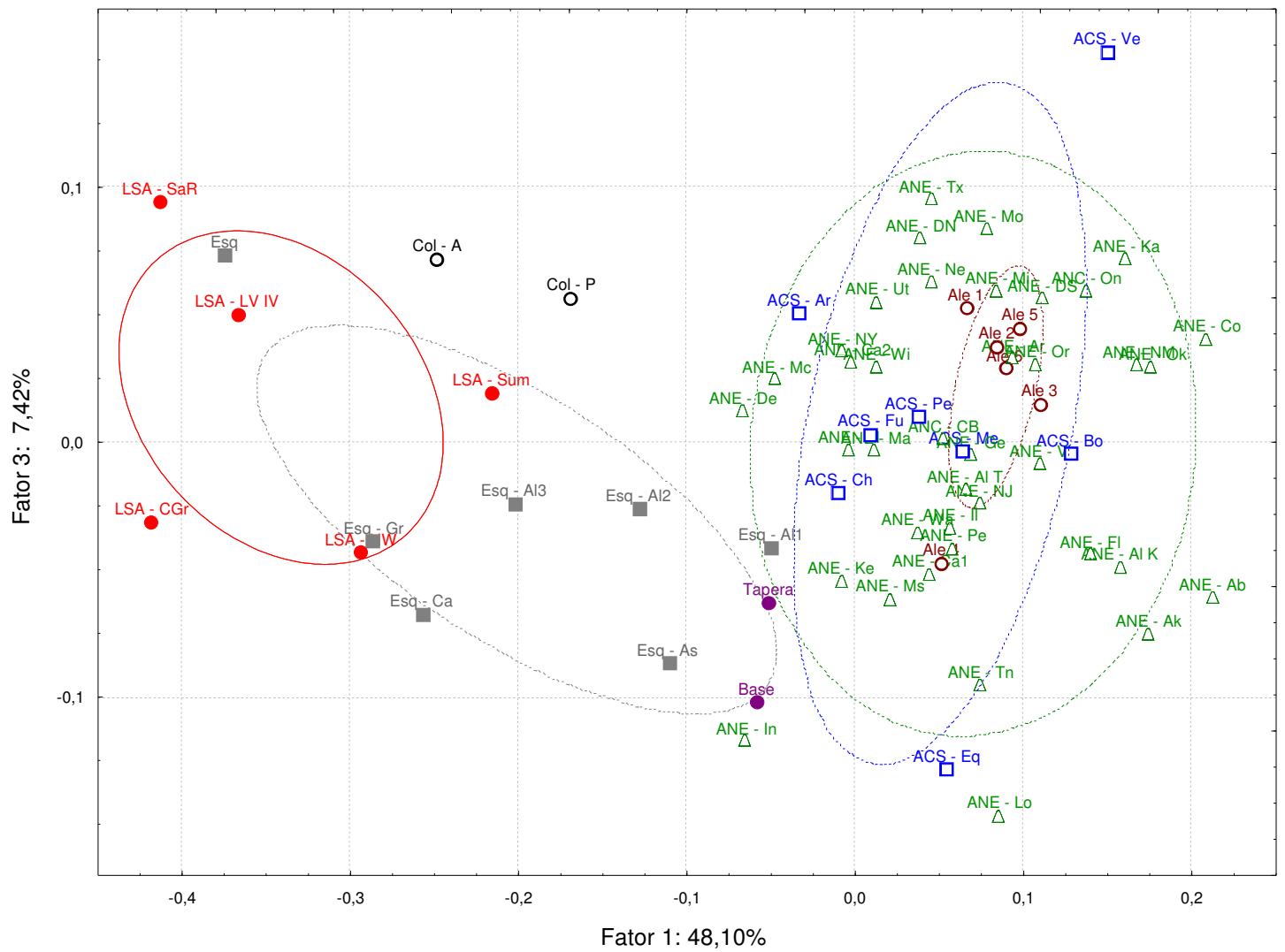

Figura 4.49 - Gráfico bidimensional do morfo-espaço formado pelos CP 2 x CP 3. Parcela feminina, forma apenas (69 séries, 23 variáveis craniométricas).

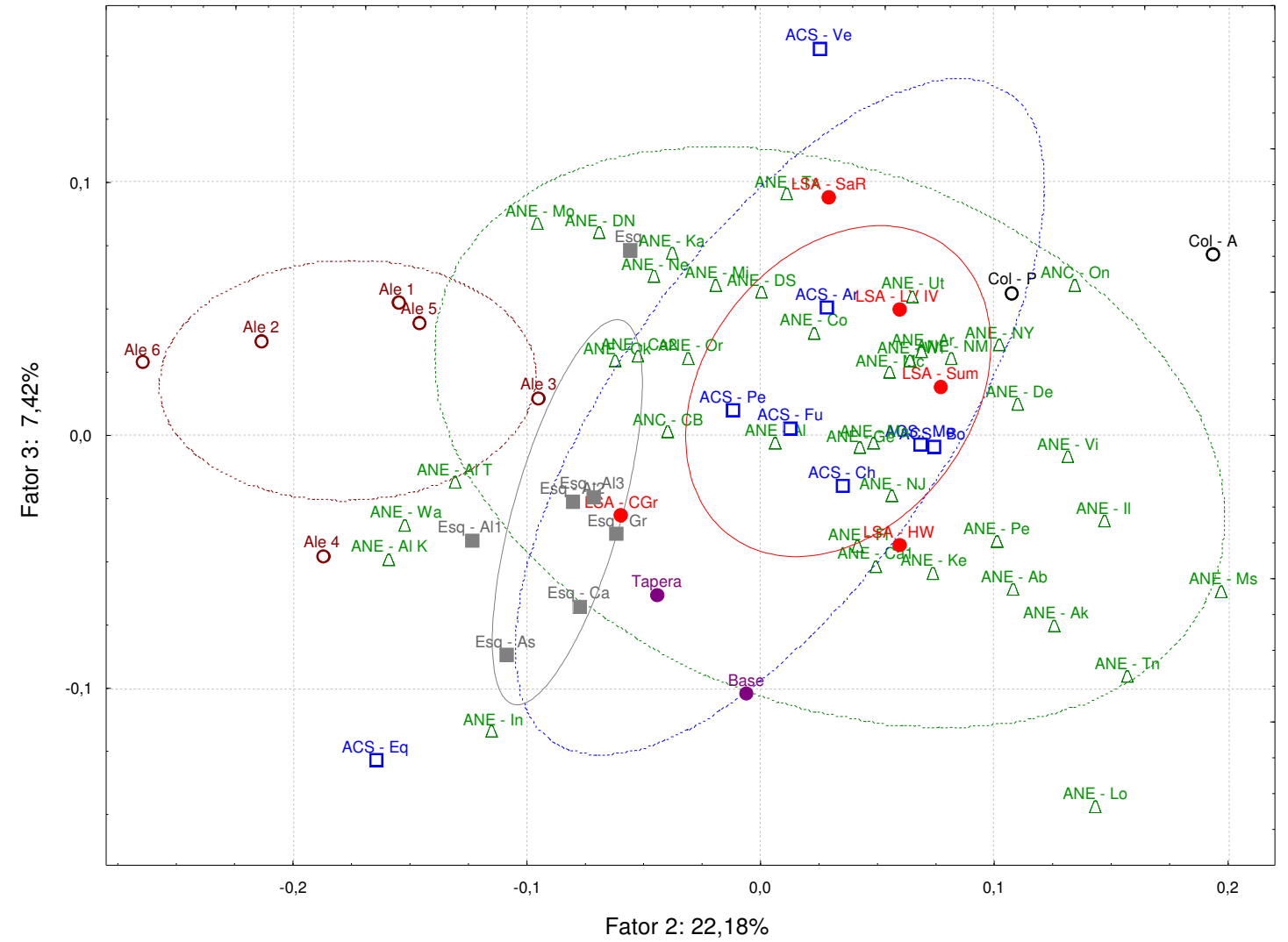


Tabela 4.14 - Fatores de coordenadas de cada série. Parcela feminina, forma apenas (69 séries, 23 variáveis craniométricas).

\begin{tabular}{|c|c|c|c|c|c|c|c|c|c|c|c|c|c|c|c|c|c|c|c|c|c|c|c|}
\hline & tor 1 & Fator 2 & Fator 3 & Fator 4 & Fator 5 & Fator 6 & Fator 7 & ator 8 & tor & Fatorio & ato & ator & Fatorl13 & atort & Fator1 & ator & Fatorr77 & Fato & Fator19 & atort2 & ator21 & Fator 22 & Fatorz3 \\
\hline & & & & & & & & & & & & & & & 81( & & & & & & & & \\
\hline & & & & 0.18802 & & & & & & & 年 & 年 & & & . & & & & & & & 001004 & 0,000867 \\
\hline 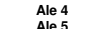 & $\begin{array}{l}0,051539 \\
0,00954\end{array}$ & $\begin{array}{l}-0.0187197 \\
-0.145617\end{array}$ & $\begin{array}{c}-0,0475866 \\
, 04448\end{array}$ & $\begin{array}{l}0,0320057 \\
0,060929\end{array}$ & $\begin{array}{l}-0.049143 \\
\end{array}$ & $\begin{array}{l}-0.044755 \\
-0.0401345\end{array}$ & $\begin{array}{l}-0,0.008970 \\
-0.00937\end{array}$ & $\begin{array}{l}-0,0200694 \\
-0,00252\end{array}$ & 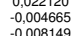 & $\begin{array}{l}-0,0,010498 \\
-0,01098\end{array}$ & $\begin{array}{l}-0,0.053500 \\
0,013141\end{array}$ & $\begin{array}{l}0,0.000625 \\
0.014574\end{array}$ & $\begin{array}{l}-0.0017359 \\
-0,01727\end{array}$ & $\begin{array}{l}0,01015158 \\
0 ., 017517\end{array}$ & $\begin{array}{l}0.0174 \\
0.0090 \\
0.027\end{array}$ & $\begin{array}{l}-0.0040408 \\
-0,01039\end{array}$ & 0.02213 & $\begin{array}{l}0,0003032 \\
0.0069\end{array}$ & $\begin{array}{l}-0.030949 \\
-0.000480\end{array}$ & $\begin{array}{l}0.00317663 \\
0.01393\end{array}$ & 0.00929 & $\begin{array}{l}0.0,0404555 \\
0,001555\end{array}$ & $\begin{array}{c}-0.0,000 \\
-0,0,00\end{array}$ \\
\hline & 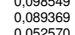 & 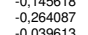 & $\begin{array}{l}0,042848 \\
0,02819\end{array}$ & $\begin{array}{l}-0.0,037329 \\
\end{array}$ & $\begin{aligned}-0.0 .0985067 \\
-0.0080\end{aligned}$ & 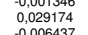 & 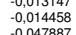 & $\begin{array}{l}0,000202120 \\
0,004220\end{array}$ & 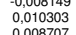 & $\begin{array}{l}0,003606 \\
0,004645\end{array}$ & $\begin{array}{l}-0.0303035 \\
-0,025044\end{array}$ & $\begin{array}{l}0.0 .11962 \\
0,01565\end{array}$ & $\begin{array}{l}-0.0,17452 \\
0,028617\end{array}$ & $\begin{array}{l}-0.0,020966 \\
0,00618\end{array}$ & $\begin{array}{l}-0.027140 \\
-0.020208\end{array}$ & $\begin{array}{l}0,0.0696969 \\
0,01982\end{array}$ & $\begin{array}{l}0.01098390 \\
-0,004917\end{array}$ & $\begin{array}{l}-0.016779 \\
0,005068\end{array}$ & 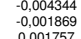 & $\begin{array}{l}-0.0 .08746 \\
-0.002587\end{array}$ & $\begin{array}{l}0,0.073222 \\
0,000585\end{array}$ & $\begin{array}{l}0.0,010163 \\
-0,0,01360\end{array}$ & $\begin{array}{l}-0,0,0008525 \\
0,000053\end{array}$ \\
\hline ANC-O & $\begin{array}{l}0,052570 \\
0,137108\end{array}$ & 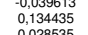 & $\begin{array}{l}0,0.00898272 \\
0,058972\end{array}$ & $\begin{array}{l}-0.0,03379 \\
-0,005240\end{array}$ & $\begin{array}{l}-0.050500 \\
-0,019051\end{array}$ & 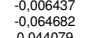 & $\begin{array}{l}-0.04787877 \\
0,000049\end{array}$ & $\begin{array}{l}0.0102727 \\
0,0308303 \\
0\end{array}$ & 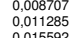 & $\begin{array}{l}-0,0.048111 \\
0,027692\end{array}$ & $\begin{array}{l}0.0422994 \\
-0,020934\end{array}$ & $\begin{array}{l}0.0 .050606 \\
-0,018062\end{array}$ & $\begin{array}{l}0,0,05564 \\
0,013727\end{array}$ & $\begin{array}{l}0.0,014711 \\
0,015733\end{array}$ & $\begin{array}{l}-0,02363778 \\
0.008448\end{array}$ & $\begin{array}{l}0.0 .05073 \\
-0.009468\end{array}$ & $\begin{array}{l}0.002488 \\
-0.00174\end{array}$ & $\begin{array}{l}0.002959 \\
-0.006584\end{array}$ & $\begin{array}{l}0.0,0157 \\
-0.003460\end{array}$ & $\begin{array}{l}-0.0 .000989 \\
0.003163\end{array}$ & $\begin{array}{l}-0.0086261 \\
0,004598\end{array}$ & $\begin{array}{l}0.000928 \\
0.000398\end{array}$ & $\begin{array}{l}0.01018333 \\
-0.003338\end{array}$ \\
\hline & $\begin{array}{l}-0,0,033766 \\
0,127995\end{array}$ & $\begin{array}{l}0.020256535 \\
0.0738212\end{array}$ & $\begin{array}{l}5035359 \\
004814\end{array}$ & .0.0888592 & $\begin{array}{l}0.04041295 \\
-0,047892\end{array}$ & $\begin{array}{l}0.04040079 \\
0.00083\end{array}$ & $\begin{array}{l}0,02025275 \\
0,003242\end{array}$ & $\begin{array}{l}0,0301142 \\
0,013738\end{array}$ & $\begin{array}{l}0.015592 \\
-0,000745\end{array}$ & 0.0176538 & $\begin{array}{l}0,024442 \\
0,03453\end{array}$ & $\begin{array}{l}-0.0,177555 \\
-0,001851\end{array}$ & $\begin{array}{l}-0.0,043803 \\
-0,001986\end{array}$ & $\begin{array}{l}0.0180882 \\
-0,00394\end{array}$ & $\begin{array}{l}0.0,08764 \\
0,001010\end{array}$ & $\begin{array}{c}0.020230303 \\
-0,006667\end{array}$ & $\begin{array}{l}0.02023965 \\
-0,008689\end{array}$ & $\begin{array}{c}0.02021300 \\
-0,007066\end{array}$ & $\begin{array}{l}-0.007301 \\
-0.0058522\end{array}$ & $\begin{array}{l}0.0 .07273 \\
0.004662\end{array}$ & 0159665 & $\begin{array}{l}-0,0,000657 \\
0,009700\end{array}$ & $\begin{array}{l}-0,00038380 \\
0.0,00160\end{array}$ \\
\hline $\begin{array}{l}\text { ACS- Ch } \\
\text { ACS-ES Eq }\end{array}$ & $\begin{array}{l}-0,0,099827 \\
0,054741\end{array}$ & $\begin{array}{l}0.0 .34866 \\
-0.1646456\end{array}$ & $\begin{array}{l}-0,0,020000 \\
-0,0128801\end{array}$ & $\begin{array}{l}0,0,077510 \\
0,076616\end{array}$ & $\begin{array}{l}-0.0,055722 \\
-0,005525\end{array}$ & $\begin{array}{l}-0.053863 \\
-0.026352\end{array}$ & $\begin{array}{l}0.0606281 \\
-0,01390\end{array}$ & $\begin{array}{l}-0,0.02482 \\
-0,011636\end{array}$ & $\begin{array}{l}0,0401141 \\
0,033410\end{array}$ & $\begin{array}{l}-0,0,010941 \\
0,092027\end{array}$ & $\begin{array}{l}-0,0,39343 \\
0,032413\end{array}$ & $\begin{array}{l}-0,0,060773 \\
-0,01132\end{array}$ & $\begin{array}{l}-0.003268 \\
-0.010212\end{array}$ & $\begin{array}{l}-0.0,028055 \\
-0.016641\end{array}$ & $\begin{array}{l}0.0008566 \\
-0.010957\end{array}$ & $\begin{array}{l}0,0.099133 \\
0,003555\end{array}$ & $\begin{array}{l}0,0,05525 \\
0,019049\end{array}$ & $\begin{array}{l}0.0003463 \\
-0,007563\end{array}$ & $\begin{array}{l}-0.001304 \\
-0.000000\end{array}$ & $\begin{array}{l}0.0 .040533 \\
0.0125355\end{array}$ & $\begin{array}{l}-0,0,000777 \\
-0,0,04060\end{array}$ & $\begin{array}{l}0.0,000161 \\
-0.00148\end{array}$ & $\begin{array}{l}0,0014544 \\
0.001383\end{array}$ \\
\hline & $\begin{array}{l}0,0 \\
0,0\end{array}$ & 954 & 003758 & 03025280 & $\begin{array}{l}0.0,034477 \\
0,035855\end{array}$ & & $\begin{array}{l}-0,0,035626 \\
0,00012\end{array}$ & 00131773 & 0,02299 & $\begin{array}{l}0,0,02104 \\
0,010283\end{array}$ & & & $\begin{array}{l}-0,0,0409292 \\
-0.011160\end{array}$ & $\begin{array}{l}-0.00033 \\
-0.0077\end{array}$ & $\begin{array}{l}0,0,015 \\
0,005\end{array}$ & 00346 & & $-0,008$ & & 0097 & $0,002 / 165$ & & $\begin{array}{c}-0.000 \\
0.000\end{array}$ \\
\hline & $\begin{array}{l}0,0,38805 \\
0,150055\end{array}$ & $\begin{array}{l}-0.0,141456 \\
0,025127\end{array}$ & $\begin{array}{l}0,0,09968 \\
0,152866\end{array}$ & $\begin{array}{l}0,0,074250 \\
0,013652\end{array}$ & $\begin{array}{l}0.0,015666 \\
0,039856\end{array}$ & $\begin{array}{l}-0.01421313 \\
0,027555\end{array}$ & $\begin{array}{l}0.0202475 \\
-0,007340\end{array}$ & $\begin{array}{l}-0,0,012771 \\
0,029709\end{array}$ & $\begin{array}{l}0,01011946 \\
0,007920\end{array}$ & $\begin{array}{l}-0,0,01666 \\
0,035810\end{array}$ & $\begin{aligned}-0.0,077661 \\
-0,04481\end{aligned}$ & $\begin{array}{l}0,0,013748 \\
0,050795\end{array}$ & $\begin{array}{l}-0,0,0996565 \\
0,036177\end{array}$ & $\begin{array}{l}-0,0,02096 \\
-0,0209670\end{array}$ & $\begin{array}{l}0,0,019692 \\
0,016013\end{array}$ & $\begin{array}{l}0.0,018300 \\
0,027745\end{array}$ & $\begin{array}{l}-0,0,09973 \\
-0,01213\end{array}$ & $\begin{array}{l}0.0,06987 \\
-0,000280\end{array}$ & $\begin{array}{l}-0,0,00825 \\
0,005100\end{array}$ & $\begin{array}{l}0.0 .0292924 \\
0,0124355\end{array}$ & $\begin{array}{l}0.0,000904 \\
-0.002506\end{array}$ & $\begin{array}{l}-0,0101599 \\
0,000452\end{array}$ & $\begin{array}{l}0.0101088 \\
-0.01010\end{array}$ \\
\hline & $\begin{array}{l}-0.0,492466 \\
-0,0127959\end{array}$ & $\begin{array}{l}-0.1,13616 \\
-0.079958\end{array}$ & 91 & $\begin{array}{l}-0.0,059391 \\
-0,0906595\end{array}$ & $\begin{array}{c}0.0,04480 \\
-0,002638\end{array}$ & $\begin{array}{l}0.01092121 \\
0.0111354\end{array}$ & $\begin{array}{l}0.0,07218 \\
-0,0187717\end{array}$ & $\begin{array}{l}0,0,06597 \\
0,013736\end{array}$ & $\begin{array}{l}-0.0,02744 \\
-0,010138\end{array}$ & $\begin{array}{l}-0,0,023366 \\
-0,0004944\end{array}$ & $\begin{array}{l}0,02028075 \\
0,014972\end{array}$ & $\begin{array}{l}0,0.05555 \\
0,022874\end{array}$ & $\begin{array}{l}0,0,06306 \\
0,0175252\end{array}$ & $\begin{array}{l}-0,0,000406 \\
0,004892\end{array}$ & $\begin{array}{l}0.0505688 \\
0.012970\end{array}$ & $\begin{array}{l}0.004446 \\
0,006487\end{array}$ & $\begin{array}{l}0.03275 \\
0.03394\end{array}$ & $\begin{array}{l}-0,0,020243 \\
0,001978\end{array}$ & $\begin{array}{l}101976 \\
12244\end{array}$ & $\begin{array}{l}5090 \\
5984 \\
\end{array}$ & 30526 & $\begin{array}{l}0.0 .07416 \\
-0.000216\end{array}$ & $\begin{array}{l}-0.0 \\
0.00\end{array}$ \\
\hline g-As & $\begin{array}{l}-0,2,21982 \\
-0,0110649\end{array}$ & $\begin{array}{l}-0.0,17405 \\
-0.0108615\end{array}$ & $\begin{array}{l}-0,0,24132 \\
-0,0887082\end{array}$ & $\begin{array}{l}-0.1,107197 \\
-0.078639\end{array}$ & $\begin{array}{l}-0,0,011203 \\
0,007076\end{array}$ & $\begin{array}{l}-0.0,00260 \\
0,0232029\end{array}$ & $\begin{array}{l}-0,0.0133030 \\
0,034945\end{array}$ & $\begin{array}{l}0,0101369 \\
0,019224\end{array}$ & $\begin{array}{l}-0,0,07757 \\
0,004234\end{array}$ & $\begin{array}{l}0,0.017170 \\
0,014882\end{array}$ & $\begin{array}{l}-0,0.076967 \\
-0,0003847\end{array}$ & $\begin{array}{l}-0,0.0504922 \\
-0.019126\end{array}$ & $\begin{array}{l}0.016619 \\
-0.01781\end{array}$ & $\begin{array}{l}-0,0,03547 \\
0,004829\end{array}$ & $\begin{array}{l}0.0099919 \\
-0.0,07298\end{array}$ & $\begin{array}{l}-0,0,03202 \\
0,006279\end{array}$ & $\begin{array}{l}-0,0,090821 \\
-0,0008969\end{array}$ & $\begin{array}{c}-0,0,07338 \\
0,007022\end{array}$ & $\begin{array}{l}-0.003165 \\
-0.009125\end{array}$ & $\begin{array}{l}-0.0 .060645 \\
-0.001233\end{array}$ & $\begin{array}{l}-0,0,086611 \\
0,000982\end{array}$ & $\begin{array}{l}-0,0,0012525 \\
0,0003118\end{array}$ & $-0,001$ \\
\hline sq-G & $\begin{array}{l}-0,2,275866 \\
-0,2836329\end{array}$ & $\begin{array}{l}-0.0,077729 \\
-0.06651599\end{array}$ & $\begin{array}{l}-0,0,07653 \\
-0,0399999\end{array}$ & $\begin{array}{l}-0.0,02872 \\
-0,0101925\end{array}$ & $\begin{array}{l}-0,0,019147 \\
-0,000326\end{array}$ & $\begin{array}{l}-0.0,07864 \\
-0.0000811\end{array}$ & $\begin{array}{l}0.0307657 \\
0.001499\end{array}$ & $\begin{array}{l}0,0,35940 \\
0,035857\end{array}$ & $\begin{array}{l}-0.0,020240 \\
0,014350\end{array}$ & $\begin{array}{l}0.0,15583 \\
-0,0.03255\end{array}$ & $\begin{array}{l}0,0,06604 \\
-0,010237\end{array}$ & $\begin{array}{l}-0,0,02768 \\
0,019922\end{array}$ & $\begin{array}{l}-0.0,047944 \\
-0.012498\end{array}$ & $\begin{array}{l}-0,0,07141 \\
0,004399\end{array}$ & $\begin{array}{l}0,0.090922 \\
0,010188\end{array}$ & $\begin{array}{l}-0,0.05311 \\
-0.017062\end{array}$ & $\begin{array}{l}-0,0,03547 \\
-0,0.003313\end{array}$ & $\begin{array}{l}-0,0,030607 \\
0,001649\end{array}$ & $\begin{array}{l}-0,0,000033 \\
0,009484\end{array}$ & $\begin{array}{l}0.0 .03927 \\
0.007572\end{array}$ & $\begin{array}{l}0.0,0202844 \\
-0.0090606\end{array}$ & $\begin{array}{l}-0,0,027777 \\
-0,0,00327\end{array}$ & $-0,00$ \\
\hline & 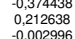 & 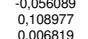 & 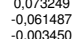 & 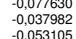 & 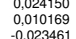 & 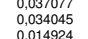 & $\begin{array}{l}0,0.0050790 \\
0,0.0795\end{array}$ & 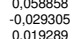 & 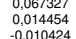 & 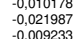 & 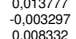 & 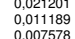 & $\begin{array}{l}0,010686 \\
0.017094\end{array}$ & 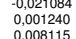 & 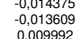 & $\begin{array}{l}0.0 .0303056 \\
0.00047\end{array}$ & 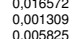 & 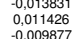 & 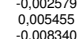 & 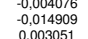 & $\begin{array}{l}D \\
D\end{array}$ & 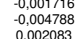 & $\begin{array}{l}0.0 \\
0.0 \\
0.0\end{array}$ \\
\hline${ }_{A \mid}^{A l}$ & $\begin{array}{l}0,15817 \\
0.06444\end{array}$ & $\begin{array}{l}-.0 .1589141 \\
-0.01299935\end{array}$ & $\begin{array}{l}-0,049395 \\
-0,0,19069\end{array}$ & $\begin{array}{l}-0,023735 \\
0.023311\end{array}$ & $\begin{array}{l}0.00036 \\
-0.0143536\end{array}$ & $\begin{array}{l}-0.0 .02885 \\
-0.03737212\end{array}$ & $\begin{array}{l}0.019354 \\
0,01003894\end{array}$ & $\begin{array}{l}-0.019172 \\
-0.0,0190170\end{array}$ & $\begin{array}{l}0.016976 \\
.0 .01010909\end{array}$ & $\begin{array}{l}-0,014307 \\
-0.0,039767\end{array}$ & $\begin{array}{l}0.040995 \\
-0.0101852\end{array}$ & $\begin{array}{l}-0,0004302 \\
0.010190\end{array}$ & $\begin{array}{l}-0,001193 \\
-0.0232303\end{array}$ & $\begin{array}{l}-0.080846 \\
-0.006677\end{array}$ & $\begin{array}{l}0,006752 \\
0,000278\end{array}$ & $\begin{array}{l}0.006390 \\
0,0.0249390\end{array}$ & $\begin{array}{l}0.005954 \\
-0.0000087\end{array}$ & 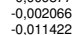 & $\begin{array}{l}0.005029 \\
0.0,010279\end{array}$ & $\begin{array}{l}-0.00516 \\
0.0009936\end{array}$ & 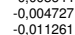 & 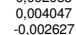 & 0.0 \\
\hline $\begin{array}{l}A N=-A A \\
A N E A K\end{array}$ & 39397 & 26438 & & $\begin{array}{l}.0 .165511 \\
0.040363\end{array}$ & $\begin{array}{l}0,0.09529 \\
0,015688\end{array}$ & $\begin{array}{l}0,029259 \\
0,042547\end{array}$ & $\begin{array}{l}0,01077099 \\
0,037113\end{array}$ & .0.0258921 & $\begin{array}{l}-0,0,020144 \\
0,051570\end{array}$ & 0.00173778 & $\begin{array}{l}0,01014777 \\
0,005015\end{array}$ & $\begin{array}{l}0.0,020208 \\
-0.02020887\end{array}$ & $\begin{array}{l}-0,0,0144079 \\
0,0193959\end{array}$ & $\begin{array}{l}0.0 .03317 \\
-0.0004842\end{array}$ & $\begin{array}{r}-0,01 \\
0.0,003\end{array}$ & $\begin{array}{l}-0,0,010511 \\
0,000744\end{array}$ & 0,001987 & 0.0 & $\begin{array}{l}0.000355 \\
0.0055331\end{array}$ & $\begin{array}{l}-0.000080 \\
0.003619\end{array}$ & $\begin{array}{l}0,0,01785 \\
0,0000740\end{array}$ & $\begin{array}{l}0,0.03030 \\
0.001852\end{array}$ & $\begin{array}{l}-0,000455 \\
0,000700\end{array}$ \\
\hline $\begin{array}{l}\text { Ca1 } \\
\text { Ca2 }\end{array}$ & $\begin{array}{l}0.045216 \\
-0.0014119\end{array}$ & $\begin{array}{l}0.0 .09946 \\
-0.0558189\end{array}$ & .052019 & $\begin{array}{l}0,0,075240 \\
0.0377717\end{array}$ & $\begin{array}{l}-0,0,07309 \\
-0.0303656\end{array}$ & $\begin{array}{l}-0.0 .01766 \\
-0.0227733\end{array}$ & $\begin{array}{l}-0,0,016039 \\
-0,0163898\end{array}$ & $\begin{array}{l}0,024836 \\
-0.0002939\end{array}$ & $\begin{array}{l}0,0.07929 \\
0.0228955\end{array}$ & $\begin{array}{l}-0,0221166 \\
0.01919058\end{array}$ & $\begin{array}{l}-0,040428 \\
0,000448\end{array}$ & $\begin{array}{l}0,0,01687 \\
0,15200\end{array}$ & $\begin{array}{l}0,001727 \\
0,0007788\end{array}$ & $\begin{array}{l}-0,0,013590 \\
-0.005800\end{array}$ & $\begin{array}{l}0,0163777 \\
0.0201754\end{array}$ & $\begin{array}{l}0,0.04246 \\
0.0004641\end{array}$ & $\begin{array}{l}0.0141399 \\
0.0001566\end{array}$ & $\begin{array}{l}0,006890 \\
0,01050576\end{array}$ & $\begin{array}{l}-0.0102828 \\
0.0009862\end{array}$ & $\begin{array}{l}-0,000166 \\
-0.0018098\end{array}$ & $\begin{array}{l}0.003342 \\
-0.001732\end{array}$ & $\begin{array}{l}-0,0002244 \\
-0,0,02080\end{array}$ & $\begin{array}{l}0.00002929 \\
-0.000334\end{array}$ \\
\hline & $\begin{array}{l}0,2,209200 \\
0,039133\end{array}$ & $\begin{array}{l}0.0202905 \\
-0.068561\end{array}$ & $\begin{array}{l}0,0,00084 \\
0,079257\end{array}$ & $\begin{array}{l}0.02011337 \\
-0.047181\end{array}$ & $\begin{array}{c}0.0,04230230 \\
-0,002401\end{array}$ & $\begin{array}{l}-0.0 .016900 \\
-0.0077993 \\
-0.00\end{array}$ & $\begin{array}{l}0,110929 \\
0,007507\end{array}$ & $\begin{array}{l}0.0 .03317 \\
-0.01622424\end{array}$ & $\begin{array}{l}-0.006348 \\
-0.034130\end{array}$ & $\begin{array}{l}0,0,015438 \\
-0,000386\end{array}$ & $\begin{array}{l}0.0,039760 \\
-.0004407\end{array}$ & $\begin{array}{l}0.0,033162 \\
-0.02021091\end{array}$ & $\begin{array}{l}0.0 .09138 \\
-0.011670\end{array}$ & $\begin{array}{l}0.0 .03413 \\
-0.0073715\end{array}$ & $\begin{array}{l}-0.024963 \\
0.0 .01512\end{array}$ & $\begin{array}{l}-0,019564 \\
0,006679\end{array}$ & $\begin{array}{l}0.0060905 \\
0.0050576\end{array}$ & 8028 & $\begin{array}{l}0.0,14452 \\
0.0,017784\end{array}$ & $\begin{array}{r}-0.00055477 \\
-0.0047\end{array}$ & $\begin{array}{l}-0.004754 \\
0,0.0491212\end{array}$ & $\begin{array}{l}-0,0.059390 \\
-0.0000176\end{array}$ & 0,000739 \\
\hline & & $\begin{array}{l}0.021 \\
0912\end{array}$ & 813 & $\begin{array}{l}.04282222 \\
0.022245 \\
\end{array}$ & $\begin{array}{l}0.0042877 \\
-0,008733\end{array}$ & $\begin{array}{l}0.00056562 \\
-0.010592\end{array}$ & $\begin{array}{l}-0.016512 \\
-0,028125\end{array}$ & 0,006502 & $\begin{array}{l}-0.02020242 \\
-0,020700\end{array}$ & 0,008792 & $\begin{array}{l}0.0007166 \\
-0,002825\end{array}$ & 0.016828 & 0,010018 & $\begin{array}{l}-0.009799 \\
-0,011025\end{array}$ & $\begin{array}{l}0,0.001238 \\
0,012329\end{array}$ & & 0.003477 & & & .001792 & & $\begin{array}{l}126 \\
987\end{array}$ & \\
\hline & $\begin{array}{l}0,0139946 \\
0,068836\end{array}$ & $\begin{array}{l}0.04042106 \\
0.042722\end{array}$ & $\begin{array}{l}-0,0,04678 \\
-0,005719\end{array}$ & $\begin{array}{l}0.0,09089 \\
0,007670\end{array}$ & $\begin{array}{l}-0,0,02120101 \\
0,000698\end{array}$ & 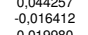 & $\begin{array}{l}-0.060017 \\
0,010125\end{array}$ & $\begin{array}{l}0.015694 \\
0,0104645\end{array}$ & $\begin{array}{l}-0,0,09952 \\
-0,010518\end{array}$ & $\begin{array}{l}0.0032121 \\
0,011519\end{array}$ & $\begin{array}{l}0,019722 \\
0,006308\end{array}$ & $\begin{array}{l}0,0,00078 \\
0,00486\end{array}$ & $\begin{array}{l}-0,0,010193 \\
0,024816\end{array}$ & 13969 & $\begin{array}{l}0.0,024777 \\
-0,0.04283\end{array}$ & $0.0,064324047$ & $\begin{array}{l}0.0000988 \\
0.0001808\end{array}$ & $\begin{array}{l}-0,0,03250 \\
-0,0001297\end{array}$ & $\begin{array}{l}-0,01016292 \\
-0,0,18062\end{array}$ & $\begin{array}{l}-0.004919 \\
0.0008865\end{array}$ & $\begin{array}{l}-0,00022424 \\
0.000321\end{array}$ & $\begin{array}{l}-0,0002866 \\
-0,0,02411\end{array}$ & $\begin{array}{l}0.00054 \\
0.002344\end{array}$ \\
\hline NE-II & $\begin{array}{l}-0.057032 \\
-0.064398\end{array}$ & 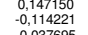 & $\begin{array}{l}-0,0,043566 \\
-0,117939\end{array}$ & $\begin{array}{l}-0.02626944 \\
-0,020371\end{array}$ & $\begin{array}{l}-0.0238611 \\
0,116342\end{array}$ & 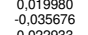 & $\begin{array}{l}-0.0177252 \\
-0,000576\end{array}$ & $\begin{array}{l}0.0003326 \\
-0,054670\end{array}$ & $\begin{array}{l}-0.0,00384 \\
-0,024355\end{array}$ & $\begin{array}{l}0,0.042121 \\
0,004510\end{array}$ & $\begin{array}{l}-0.003306 \\
-0,030125\end{array}$ & $\begin{array}{l}0,0.05584 \\
0,013022\end{array}$ & $\begin{array}{l}0,0,0093952 \\
0,002592\end{array}$ & $\begin{array}{l}0,0.024555 \\
0,014282\end{array}$ & $\begin{array}{l}0.0,07348 \\
0,01081\end{array}$ & $\begin{array}{l}0,0,010652 \\
0,001871\end{array}$ & $\begin{array}{l}-0.0,0639 \\
-0,00064\end{array}$ & $\begin{array}{l}0.0006294 \\
-0,002623\end{array}$ & $\begin{array}{l}-0.000253 \\
-0.00692\end{array}$ & $\begin{array}{l}-0.0 .01847 \\
-0.002919\end{array}$ & $\begin{array}{l}0.0060631 \\
-0.006920 \\
0.0627\end{array}$ & $\begin{array}{l}-0,0,0171714 \\
-0,0,06677\end{array}$ & $\begin{array}{l}0.0000533 \\
-0,00260\end{array}$ \\
\hline & 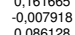 & 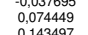 & $0 / 1430$ & 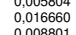 & $\begin{array}{l}0.04038317 \\
0.01717\end{array}$ & & 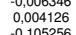 & 0.079688 & 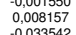 & 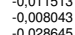 & 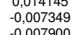 & 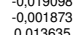 & & 然, 0.000 & $\begin{array}{l}-0,014967 \\
0,01420\end{array}$ & & 0.0005050 & & 6646 & 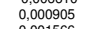 & 00772 & $\begin{array}{l}0,0,0000998 \\
0,0098\end{array}$ & 0.0001648 \\
\hline $\mathrm{NE}-\mathrm{Me}_{\mathrm{Z}}$ & $\begin{array}{l}0.010611286 \\
0.01896\end{array}$ & 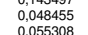 & 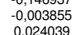 & 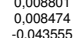 & $\begin{array}{l}0.01025293 \\
0.024353\end{array}$ & 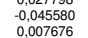 & 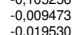 & 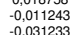 & 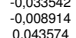 & 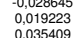 & 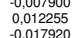 & 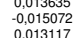 & $\begin{aligned} 0.0 .017517 \\
0.01311\end{aligned}$ & $\begin{array}{l}-0.0,060963 \\
-0.000363\end{array}$ & 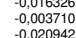 & 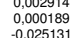 & $\begin{array}{l}0.00039511 \\
0.02011\end{array}$ & 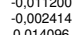 & 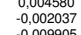 & 0.00025675 & 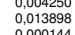 & $\begin{array}{l}-0,0,02009898 \\
0,000092\end{array}$ & , $0.000655^{\circ}$ \\
\hline & 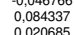 & 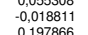 & 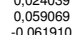 & $\begin{array}{l}0.01039501 \\
.003901\end{array}$ & 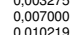 & 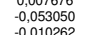 & 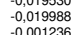 & $\begin{array}{l}0,0.002331 \\
0,0143\end{array}$ & 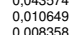 & $\begin{array}{l}0,0.035949 \\
0.0154\end{array}$ & 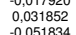 & 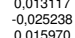 & 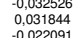 & 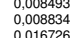 & $\begin{array}{l}-0.0202942 \\
0.0075 \\
0.002232\end{array}$ & 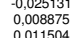 & 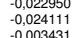 & 996 & 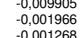 & 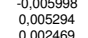 & 44 & 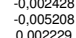 & 紫0 \\
\hline & $\begin{array}{l}0,0,789222 \\
0,0445492\end{array}$ & $\begin{array}{l}-0.094755 \\
-0.0445070\end{array}$ & $\begin{array}{l}0,0.033255 \\
0,0602295\end{array}$ & $\begin{array}{l}-0,0,034324 \\
-0.0075959\end{array}$ & $\begin{array}{l}0.0,013702 \\
-0.0702020\end{array}$ & $\begin{array}{l}0.016660 \\
.0 .0015454\end{array}$ & $\begin{array}{l}0.043952 \\
0.00020230\end{array}$ & $\begin{array}{l}-0,0,07308 \\
-0,020241451\end{array}$ & $\begin{array}{l}-0,0,06561 \\
-0,0203388\end{array}$ & $\begin{array}{l}-0,026083 \\
0,013860\end{array}$ & $\begin{array}{l}-0,000297 \\
0,00071752\end{array}$ & $\begin{array}{l}-0.012567 \\
-0.004627 \\
0.0427\end{array}$ & $\begin{array}{l}-0,0,038181 \\
-0.0164647\end{array}$ & $\begin{array}{l}-0,004588 \\
-0.03030778\end{array}$ & $\begin{array}{l}0,000983 \\
0,005560\end{array}$ & 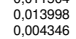 & 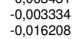 & $\begin{array}{l}-0,010995 \\
0,0009907\end{array}$ & $\begin{array}{l}0,002733 \\
0,002835\end{array}$ & $\begin{array}{l}0.0 .04116 \\
-0.01427275\end{array}$ & 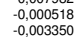 & $\begin{array}{l}0.001348 \\
-0.020230\end{array}$ & 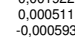 \\
\hline $\begin{array}{l}\text { ANE. } \\
\text { ANEE- }\end{array}$ & $\begin{array}{l}0.074246 \\
0,168129\end{array}$ & 6911 & & 9871 & 0.013700 & & & 0.013345 & $0,0,027566$ & 88 & 0.007477 & & 3490 & 18 & $-0,6$ & 0008091 & & & 0.005 & -0.003174 & $\begin{array}{l}0,0088533 \\
0.0060685\end{array}$ & 0.009396 & \\
\hline & $\begin{array}{c}-0,0,07002 \\
0,0176414\end{array}$ & $\begin{array}{l}0.102599 \\
0.0106518903\end{array}$ & $\begin{array}{l}0.035081 \\
0.0208919\end{array}$ & $\begin{array}{l}-0,017658 \\
0.004940\end{array}$ & $\begin{array}{l}-0,0.04763 \\
0,0707543\end{array}$ & $\begin{array}{l}-0.057261 \\
0.0595564\end{array}$ & $\begin{array}{l}-0,016112 \\
0,0006355\end{array}$ & $\begin{aligned}-0,0.05399 \\
-0.0149398\end{aligned}$ & $\begin{array}{l}0.023671 \\
0.033020\end{array}$ & $\begin{array}{c}0,0,07390 \\
-0,0,2020869\end{array}$ & $\begin{array}{l}0.004984 \\
-0.0202677\end{array}$ & $\begin{array}{l}0.06277 \\
0.038286\end{array}$ & $\begin{array}{l}0.011091 \\
.0 .004710\end{array}$ & $\begin{array}{l}0,01 \\
0,009 \\
0,009\end{array}$ & 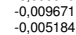 & $\begin{array}{l}0.003278 \\
0.010377568\end{array}$ & 002021 & 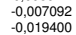 & $\begin{array}{l}-0,000000 \\
0.00031960\end{array}$ & $\begin{array}{l}-0,0028333 \\
0.003547\end{array}$ & $\begin{array}{l}0,04309 \\
0,0032428\end{array}$ & $\begin{array}{l}.020231 \\
0.03233\end{array}$ & \\
\hline & $\begin{array}{l}0,1,176767 \\
0,058784\end{array}$ & $\begin{array}{l}0.0,030156 \\
0,0101404\end{array}$ & $\begin{array}{l}0.0,030128 \\
-0.042147\end{array}$ & $\begin{array}{l}.011973 \\
.060510\end{array}$ & $\begin{array}{l}0.0047701 \\
0.0663373\end{array}$ & $\begin{array}{l}-0.00364 \\
-0.01575758\end{array}$ & $\begin{array}{l}-0.0 .044939 \\
-0.0184474\end{array}$ & $\begin{array}{l}0.0 .04170 \\
-0.0627785\end{array}$ & $\begin{array}{l}.0353544 \\
0.032832\end{array}$ & $\begin{array}{l}-0,0.026747 \\
0,017910\end{array}$ & $\begin{array}{l}-0.0,02801 \\
-0,0008155\end{array}$ & 0,008608 & $\begin{array}{l}.0 .0 .01283 \\
-.0000607\end{array}$ & $\begin{array}{l}0.0 .022924 \\
0,0112022\end{array}$ & $\begin{array}{l}-0,0101055 \\
0.0090951\end{array}$ & $\begin{array}{l}-0,0.91946 \\
0.017999\end{array}$ & $\begin{array}{l}0.0 .17926 \\
0.0183999\end{array}$ & 800 & $\begin{array}{l}0,009800 \\
0,0074756\end{array}$ & $\begin{array}{l}0.0 .01111 \\
0.00003911\end{array}$ & $\begin{array}{l}-0,016 \\
-0,007\end{array}$ & $\begin{array}{l}-0,0,0006707 \\
-0.0,000395\end{array}$ & 654 \\
\hline $\begin{array}{l}\text { E-Tn } \\
\text { E-Tx }\end{array}$ & $\begin{array}{l}0.0755688 \\
0,045509\end{array}$ & $\begin{array}{l}0.1575999 \\
0,0115157\end{array}$ & $\begin{array}{l}-0,0,055639 \\
0,094653\end{array}$ & $\begin{array}{l}-0,019921 \\
-0.007111\end{array}$ & $\begin{array}{l}-0,0.01125 \\
0,025533\end{array}$ & $\begin{array}{l}0.0 .0520202 \\
0,0,025230\end{array}$ & $\begin{array}{c}0.0202724 \\
-0,032934\end{array}$ & $\begin{aligned}-0,0,031980 \\
-0,002961\end{aligned}$ & $\begin{array}{c}0.02026380 \\
-0,0223136\end{array}$ & $\begin{array}{l}-0,0,07770 \\
0,006829\end{array}$ & $\begin{array}{l}0,0101402 \\
0,020004\end{array}$ & $\begin{array}{l}0.0,020247 \\
-0,002279\end{array}$ & $\begin{array}{l}0.0,000514 \\
-0,0009205\end{array}$ & $\begin{array}{l}-0,0,063822 \\
0,014289\end{array}$ & $\begin{array}{l}0,0.016827 \\
0,01093\end{array}$ & $\begin{array}{l}0,0.09585 \\
0,003157\end{array}$ & $\begin{array}{l}-0,0,01092 \\
-0,010405\end{array}$ & 90 & $\begin{array}{c}-0,0.000041 \\
-0,0,000378\end{array}$ & $\begin{array}{l}-0.0 .06034 \\
0.008726\end{array}$ & , 0,008862 & $\begin{array}{l}0,0,03739 \\
-0,0.01272\end{array}$ & 224 \\
\hline $\mathrm{NE}$. & $\begin{array}{l}0,0,133088 \\
0,1110553\end{array}$ & $\begin{array}{l}0.0 .02561 \\
0,1325050\end{array}$ & $\begin{array}{l}0.0,046566 \\
-0,000922\end{array}$ & $\begin{array}{l}-0,0,010037 \\
-0,015121\end{array}$ & $\begin{array}{l}-0,0.013300 \\
0.04490\end{array}$ & $\begin{array}{l}0.0 .09753 \\
-0.062512\end{array}$ & $\begin{array}{l}-0.0202828 \\
-0.01013611\end{array}$ & $\begin{array}{l}0,0,02030 \\
0,0300077\end{array}$ & $\begin{array}{l}0.0,05816 \\
0.028445\end{array}$ & $\begin{array}{l}-0,0,02902 \\
-0.0,04773\end{array}$ & $\begin{array}{l}0.015170 \\
-0,002325\end{array}$ & $\begin{array}{l}0.0242459 \\
-0.03444148\end{array}$ & $\begin{array}{l}-0,0,026537 \\
-0.0003362\end{array}$ & $\begin{array}{l}-0,0.05209 \\
0,0004797\end{array}$ & $\begin{array}{l}-0,003993 \\
0,0005669\end{array}$ & $\begin{array}{l}-0,0.0967 \\
0,0000242\end{array}$ & $\begin{array}{l}0.03171 \\
0,0016169\end{array}$ & 0.008432 & $\begin{array}{l}-0,003261 \\
-0.018201\end{array}$ & $\begin{array}{l}-0,000571 \\
0.0,003838\end{array}$ & $\begin{array}{l}-0,0037780 \\
-0.003784\end{array}$ & $\begin{array}{l}0,002955 \\
0,0029355\end{array}$ & 0 \\
\hline & $\begin{array}{l}0.0,0373363 \\
0.013123\end{array}$ & $\begin{array}{l}0.01515777 \\
0.0654526\end{array}$ & $\begin{array}{l}-0,0,035804 \\
0,020161\end{array}$ & $\begin{array}{l}0.0901338 \\
-0.031480\end{array}$ & $\begin{array}{l}0.04077551 \\
0,025039\end{array}$ & $\begin{array}{l}-0.0,24263 \\
-0.0154 \\
-0.01544\end{array}$ & $\begin{array}{l}0.0003900 \\
-0,001522\end{array}$ & $\begin{array}{l}0.0202091 \\
0,0152182\end{array}$ & $\begin{array}{l}-0,0,01526 \\
-0,0202822\end{array}$ & $\begin{array}{l}-0.019172 \\
-0.001280\end{array}$ & $\begin{array}{l}-0.0,34511 \\
-0,023690\end{array}$ & $\begin{array}{l}0.0 .100866 \\
0,002436\end{array}$ & $\begin{array}{l}0.0191983 \\
-0.000848\end{array}$ & $\begin{array}{l}0.02074822 \\
0,0003222\end{array}$ & $\begin{array}{l}0.0,017 \\
-0,002\end{array}$ & $\begin{array}{l}-0,0.0255151 \\
0,004247\end{array}$ & $\begin{array}{l}0,01018866 \\
0,009737\end{array}$ & $0,00 \mathrm{C}$ & $\begin{array}{l}-0.003210 \\
0,05310\end{array}$ & 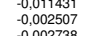 & $\begin{array}{l}0.0,099755 \\
-0,001305\end{array}$ & $\begin{array}{l}0.0,060617 \\
-0,0001977\end{array}$ & 0,0 \\
\hline $\begin{array}{l}\text { LA-CGrir } \\
\text { LSA -LVIV }\end{array}$ & 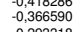 & 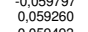 & 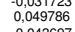 & ofo37 & $\begin{array}{l}.0 .03243840 \\
0.04350\end{array}$ & $\begin{array}{l}-0.0393902 \\
0.03902\end{array}$ & $\begin{array}{l}0,017978 \\
0,017978\end{array}$ & $\begin{array}{l}0.0803039 \\
0.0359\end{array}$ & $\begin{array}{l}-0,0,06541 \\
-10534\end{array}$ & $\begin{array}{l}0,0,04018606 \\
0,001767\end{array}$ & $\begin{array}{l}0,0003021 \\
0.00851\end{array}$ & $\begin{array}{l}-0,0,030356 \\
0,00356\end{array}$ & $\begin{array}{l}0,0,042624 \\
0,012644\end{array}$ & $\begin{array}{l}-0.03592 \\
-0,014992\end{array}$ & $\begin{array}{l}0,0,0206028 \\
0,002098\end{array}$ & $\begin{array}{l}0,0101707 \\
0,0105\end{array}$ & $\begin{array}{l}-0,0,03503 \\
0,016262\end{array}$ & $\begin{array}{l}0,0015961 \\
0,01561\end{array}$ & $\begin{array}{l}0.0 .25998 \\
-0.011839\end{array}$ & $\begin{array}{l}-0.0,072758 \\
0.007600\end{array}$ & $\begin{array}{l}-0,0,093959 \\
0,001006\end{array}$ & $\begin{array}{l}0,0.000283 \\
0,000462\end{array}$ & \\
\hline LSA- HV & $\begin{array}{l}-0,2,233318 \\
-0,041259\end{array}$ & $\begin{array}{l}0.0599993 \\
0,0202641\end{array}$ & $\begin{array}{l}-0,0,036967 \\
0,094023\end{array}$ & $\begin{array}{l}0,0137758 \\
0,067725\end{array}$ & $\begin{array}{l}0.015534 \\
0,074223\end{array}$ & $\begin{array}{l}0.06441919 \\
0.072615\end{array}$ & $\begin{array}{c}-0,0101094 \\
-0,0639303\end{array}$ & $\begin{array}{l}-0.019620 \\
-0,044384\end{array}$ & $\begin{array}{l}-0,0,0334242 \\
0,034224\end{array}$ & $\begin{array}{l}-0.001674 \\
0,013623\end{array}$ & $\begin{array}{l}0,0,01519 \\
0,007702\end{array}$ & $\begin{array}{l}0.0 .066344 \\
-0.028394\end{array}$ & $\begin{array}{l}0.0 .066662 \\
-.000996\end{array}$ & $\begin{array}{l}0.0,035922 \\
-0,015527\end{array}$ & $\begin{array}{l}-0,0,01495 \\
0,01215\end{array}$ & $\begin{array}{l}0.001943 \\
-0,018307\end{array}$ & $\begin{array}{l}-0,0,11 \\
0,006\end{array}$ & $\begin{array}{l}-0,0,060 \\
0,000\end{array}$ & $\begin{array}{l}0.0 .07052 \\
-0.006092\end{array}$ & $\begin{array}{l}0.01010183 \\
-0.007386\end{array}$ & $\begin{array}{l}0.0,111500 \\
-0,0,06576\end{array}$ & $\begin{array}{l}-0,0,015000 \\
0,004715\end{array}$ & \\
\hline & 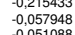 & 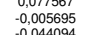 & 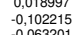 & 9894 & 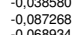 & $\begin{array}{l}0.049495927 \\
0.07029297\end{array}$ & $\begin{array}{l}0,0242498 \\
0,02698\end{array}$ & $\begin{array}{l}0,0201735 \\
0,0021202\end{array}$ & $\begin{array}{l}-0,0,066718 \\
-0,02020\end{array}$ & $\begin{array}{l}0,02025678 \\
0,02232\end{array}$ & $\begin{array}{l}0,01636969 \\
0,006190\end{array}$ & 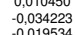 & $\begin{array}{l}0,01013939 \\
0,033003\end{array}$ & $\begin{array}{l}-0,06289 \\
-0,016840\end{array}$ & $\begin{array}{l}0.024216165 \\
-0,001125\end{array}$ & $\begin{array}{l}-0.023348 \\
-0,000024\end{array}$ & $\begin{array}{l}-0,0.0220099 \\
0,010947\end{array}$ & $\begin{array}{l}-0,0.01116813 \\
0,01473\end{array}$ & $\begin{array}{l}-0.0 .0606877 \\
-0.0 .02941\end{array}$ & $\begin{array}{l}-0.0 .0160538 \\
0.004547\end{array}$ & $\begin{array}{l}-0,0,0073844 \\
0,000442\end{array}$ & $\begin{array}{l}-0,0,0303633 \\
-0,004355\end{array}$ & $\begin{array}{l}0.0013499 \\
-0,00088\end{array}$ \\
\hline & & 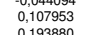 & $\begin{array}{l}0,0.035616 \\
0.056516\end{array}$ & 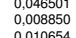 & 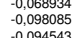 & 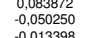 & 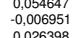 & 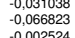 & $\begin{array}{l}-0.0195200 \\
0.03890\end{array}$ & 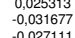 & $\begin{array}{l}-0.038000 \\
0.01022\end{array}$ & $\begin{array}{l}-0.0,019534 \\
0.02673 \\
0.02454\end{array}$ & $\begin{array}{l}0,0.011462 \\
0,01778\end{array}$ & . & 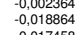 & $\begin{array}{l}0.66717 \\
116714\end{array}$ & $\begin{array}{l}0.030244 \\
115241\end{array}$ & 102 & 0,008353 & 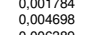 & $\begin{array}{l}0.0,0404636 \\
0,003155\end{array}$ & $\begin{array}{l}0.0,088333 \\
0,003376\end{array}$ & . \\
\hline
\end{tabular}


A tabela 4.14, apresenta os fatores de coordenadas desses Componentes Principais. As figuras 4.47 e 4.48, acima, representando as dispersões dos centróides no morfo-espaço formado pelos CP 1 × CP 2 e CP 1 × CP 3, respectivamente, indicam, com destacada ênfase para primeira das topologias, uma disassociação morfológica entre os Paleoíndios de Lagoa Santa e as outras populações autóctones da América. A primeira topologia, formada pelos primeiro e segundo Componentes Principais, baseada em 70,28\% da variabilidade contida no conjunto original de dados, apresenta os centróides separados, principalmente, devido às medidas relativas ao comprimento do crânio. Os pontos posicionados na extremidade negativa do eixo das abcissas caracterizam-se por crânios estreitos e longos em oposição aos largos e curtos, localizados na região do $2^{\circ}$ quadrante cartesiano do gráfico.

A topologia representada pela Figura 4.48, representando o morfoespaço formado pelos CP 1 × CP 3 também mostra as mesmas relações que a anterior, porém com uma separação menos consistente da população de Lagoa Santa. De qualquer maneira, tanto no primeiro quanto no segundo casos a diferenciação morfológica entre os paleoamericanos (Lagoa Santa e Colômbia) e os demais nativos americanos é incontestável.

A exemplo do que se observou nos ensaios apresentados anteriormente, a topologia formada pelos segundo e terceiro componentes principais, agregando apenas $29,6 \%$ da variabilidade original, não repete a estruturação obtida nas relações com maior porcentagem.

Os dendrogramas apresentados nas figuras 4.50 a 4.53 foram gerados a partir da utilização de uma matriz de distância Euclidiana calculada sobre os seis primeiros Componentes Principais. 

Figura 4.50 - Dendrograma gerado sobre matriz de Distâncias Euclidianas calculadas a partir dos seis primeiros componentes principais - Método de Ward. Parcela feminina, apenas forma (69 séries, 23 variáveis craniométricas).

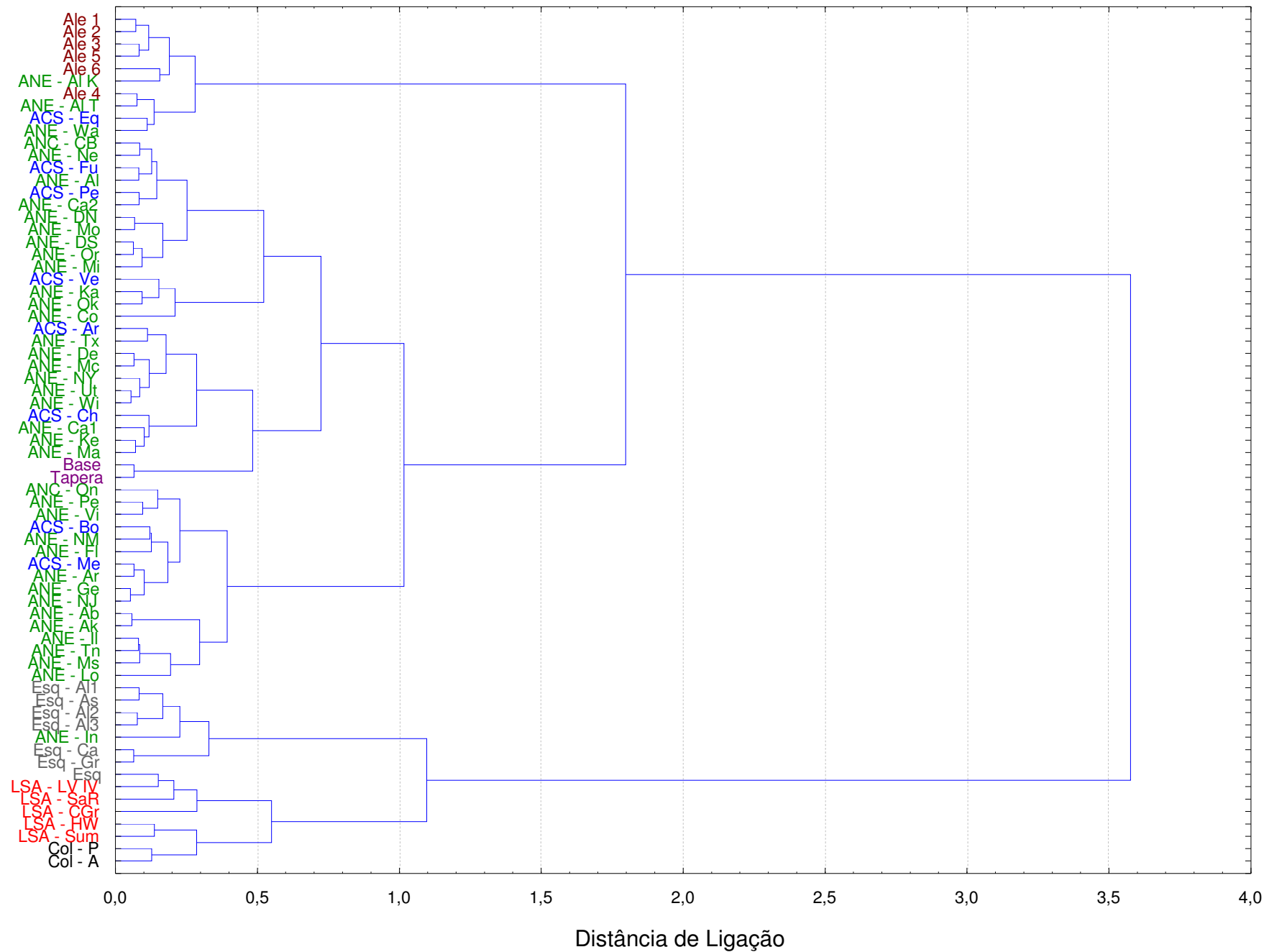


Figura 4.51 - Dendrograma gerado sobre matriz de Distâncias Euclidianas calculadas a partir dos seis primeiros componentes principais - Método de Ligação Simples. Parcela feminina, apenas forma (69 séries, 23 variáveis craniométricas).

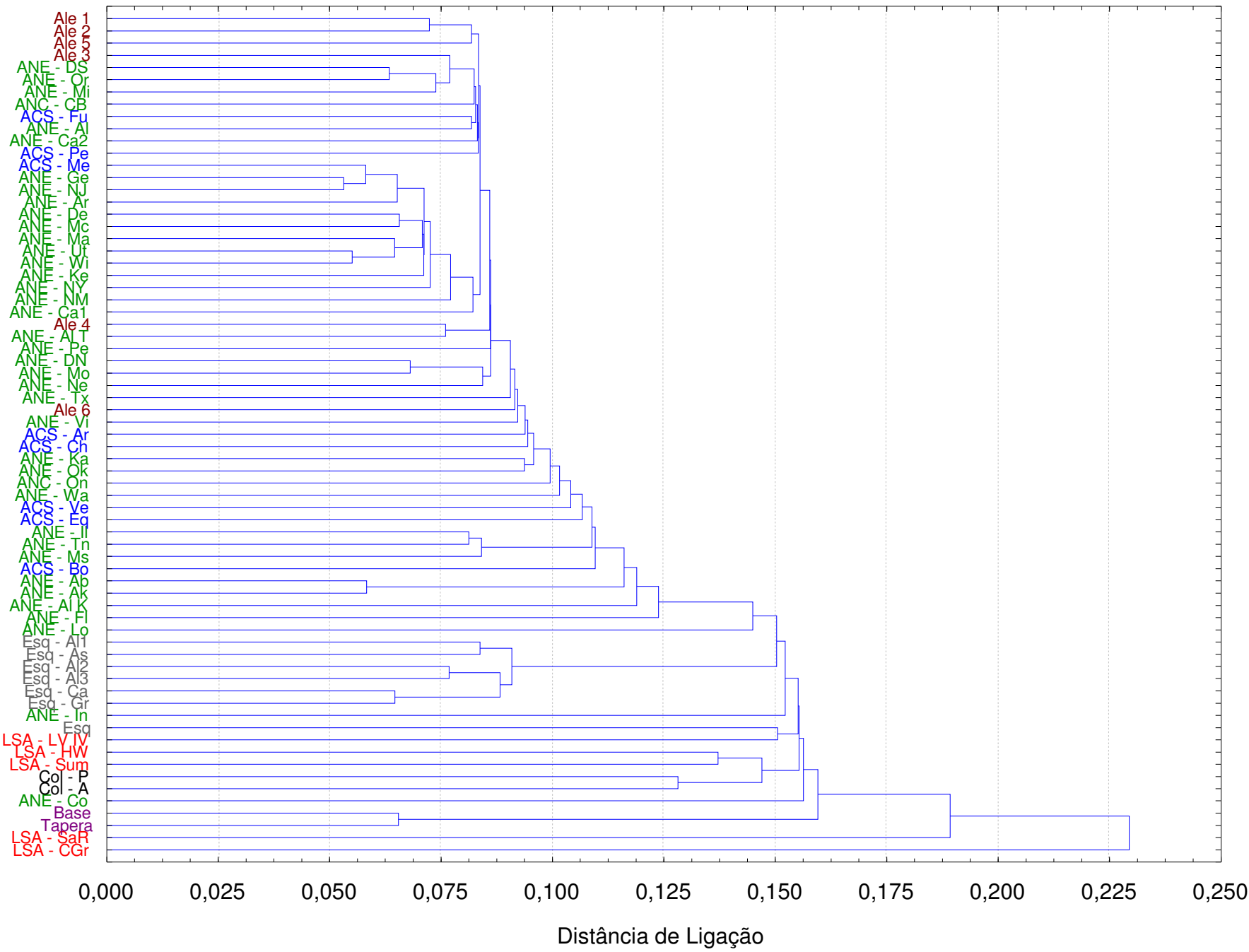


Figura 4.52 - Dendrograma gerado sobre matriz de Distâncias Euclidianas calculadas a partir dos seis primeiros componentes principais - Método de Ligação Completa. Parcela feminina, apenas forma (69 séries, 23 variáveis craniométricas).

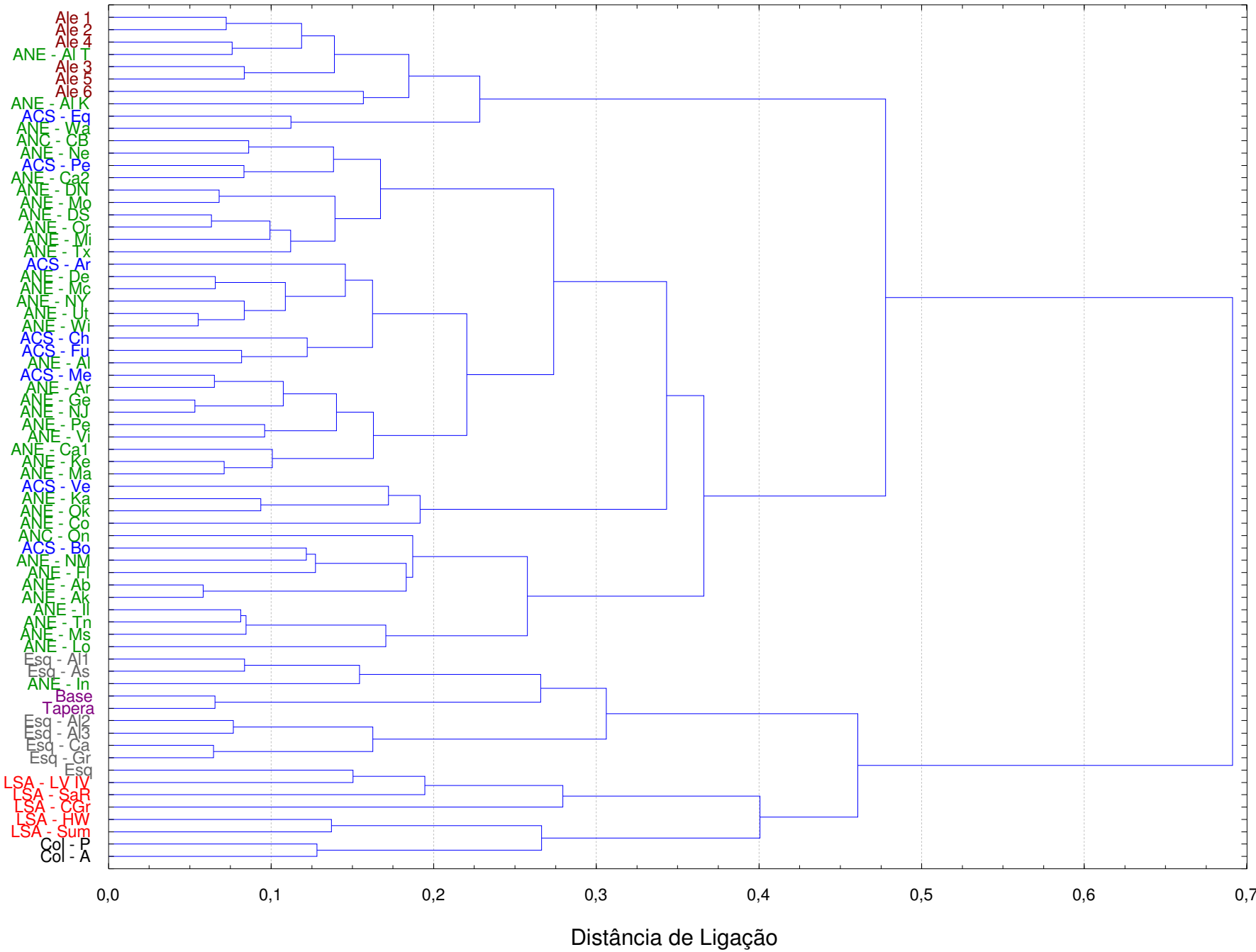


Figura 4.53 - Dendrograma gerado sobre matriz de Distâncias Euclidianas calculadas a partir dos seis primeiros componentes principais - Método da Média dos Grupos. Parcela feminina, apenas forma (69 séries, 23 variáveis craniométricas).

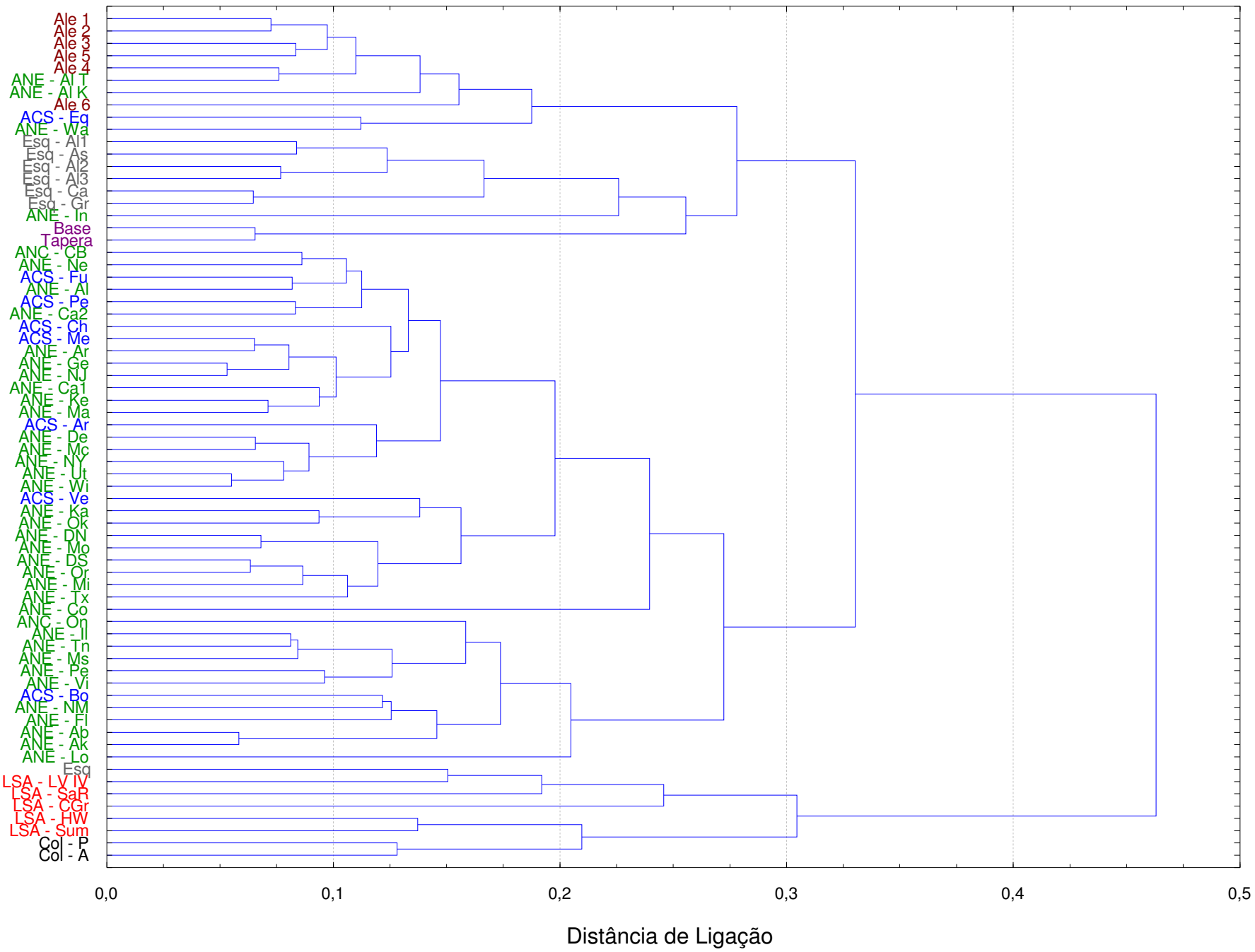


Como ocorreu nas análises de agrupamentos feitas a partir de matriz de distância Euclidiana calculada sobre forma e tamanho da parcela feminina, as figuras 4.50 a 4.53 também reforçam a constatação de uma estreita associação morfológica entre os paleoamericanos, representados pelas séries de Lagoa Santa e da Colômbia. Porém, apresentam algumas associações fortuitas e inconsistentes entre Lagoa Santa e demais populações nativas americanas. De qualquer maneira, pode-se, ainda assim, visualizar, principalmente no dendrograma da Figura 4.53, uma completa dissociação morfológica dos paleoamericanos quando comparados às outras séries americanas.

Os testes estatísticos utilizando Distâncias de Mahalanobis também apresentam incoerência parcial de resultados. Enquanto que os dendrogramas apresentados nas figuras 4.54 a 4.57, indicam uma associação das amostras arqueológicas da América do Sul, as topologias, geradas a partir da aplicação de Escalonamento Multidimensional, reforçam a ocorrência de uma morfologia singular entre os Paleoamericanos. Essas diferenças topológicas podem ser atribuídas à sensibilidade diferencial de cada técnica aplicada ou ainda a características das amostras (número amostral ou viés metodológico, por exemplo), como será discutido no momento apropriado.

A tabela 4.15 apresenta a matriz de Distâncias de Mahalanobis utilizada nesses ensaios enquanto a Tabela 4.16 fornece a configuração final das dimensões resultantes do MDS. 

Tabela 4.15 - Matriz de Distância baseada em Distâncias de Mahalanobis. Parcela feminina, apenas forma (22 grupos, 23 variáveis craniométricas).

\begin{tabular}{|c|c|c|c|c|c|c|c|c|c|c|c|c|c|c|c|c|c|c|c|c|c|c|}
\hline & Aleuta & $\begin{array}{l}\text { Am. do } \\
\text { Norte- } \\
\text { Canadá }\end{array}$ & $\begin{array}{c}\text { CSA- } \\
\text { Argentina }\end{array}$ & $\begin{array}{l}\text { CSA- } \\
\text { Bolivia }\end{array}$ & $\begin{array}{l}\text { CSA- } \\
\text { Chile }\end{array}$ & $\begin{array}{c}\text { CSA- } \\
\text { Fuguinos } \\
\text { (Patagonia) }\end{array}$ & $\begin{array}{l}\text { CSA- } \\
\text { México }\end{array}$ & $\begin{array}{l}\text { CSA- } \\
\text { Peru }\end{array}$ & $\begin{array}{c}\text { CSA- } \\
\text { venezuela }\end{array}$ & $\begin{array}{c}\text { Esquimó- } \\
\text { Alaska }\end{array}$ & $\begin{array}{c}\text { Esquimó- } \\
\text { Asia }\end{array}$ & $\begin{array}{l}\text { Esquimó- } \\
\text { Canadáa }\end{array}$ & $\begin{array}{l}\text { Esquimó- } \\
\text { Groelândia }\end{array}$ & $\begin{array}{l}\text { Am.do } \\
\text { Norte- } \\
\text { EUA }\end{array}$ & $\begin{array}{l}\text { Lagoaa } \\
\text { Santa }\end{array}$ & $\begin{array}{l}\text { Lagoa } \\
\text { Santa- } \\
\text { Cerca } \\
\text { Grande }\end{array}$ & $\begin{array}{l}\text { Lagoa } \\
\text { Santa- } \\
\text { Harold } \\
\text { Walter }\end{array}$ & $\begin{array}{c}\text { Lagoa } \\
\text { Santa- } \\
\text { Sumidouro }\end{array}$ & $\begin{array}{l}\text { Base } \\
\text { Aérea }\end{array}$ & Tapera & $\underset{P}{\text { Colômbia }}$ & $\underset{A}{\text { Colômbia }}$ \\
\hline Aleuta & 0,00000 & 2,19639 & 4,03473 & 3,91757 & 3,53784 & 3,14876 & 3,69837 & 2,82604 & 5,26245 & 3,23782 & 3,42627 & 4,46845 & 5,03880 & 2,74930 & 6,42134 & 6,37181 & $\begin{array}{c}\text { Waler } \\
7,30751\end{array}$ & 6,57145 & 4,72394 & 5,09097 & 5,13923 & 6,25302 \\
\hline $\begin{array}{l}\text { Am.do } \\
\text { Norte- } \\
\text { Canadáa }\end{array}$ & & 0,00000 & 3,54651 & 2,81532 & 3,06596 & 2,49130 & 2,96522 & 2,74699 & 5,46674 & 2,80110 & 3,15779 & 3,85387 & 4,53371 & 1,82963 & 5,72765 & 5,85156 & 6,62216 & 5,62329 & 4,12035 & 4,69520 & 4,26767 & 5,27032 \\
\hline $\begin{array}{c}\text { CSA- } \\
\text { Argentina }\end{array}$ & & & 0,00000 & 4,24720 & 3,70697 & 3,27895 & 3,36883 & 3,41776 & 5,88797 & 4,21150 & 4,56411 & 4,50275 & 5,11589 & 2,98490 & 5,41506 & 5,37441 & 6,59657 & 5,30672 & 4,66630 & 5,51644 & 5,22475 & 5,49821 \\
\hline $\begin{array}{l}\text { CA- } \\
\text { Bolivia }\end{array}$ & & & & 0,00000 & 3,19093 & 3,46854 & 3,14512 & 2,96053 & 5,40700 & 4,61939 & 4,89119 & 5,24146 & 5,87687 & 2,87777 & 5,86997 & 6,17850 & 6,10562 & 5,20984 & 4,00787 & 4,26750 & 4,28227 & 4,93144 \\
\hline $\begin{array}{l}\text { CSA- } \\
\text { Chile }\end{array}$ & & & & & 0,00000 & 2,88664 & 2,68975 & 2,18793 & 4,56361 & 3,85291 & 4,29776 & 4,17493 & 4,96084 & 2,25273 & 6,01735 & 5,34759 & 6,40276 & 5,80731 & 4,25442 & 4,58890 & 4,59774 & 4,99184 \\
\hline $\begin{array}{l}\text { Fueguinos } \\
\text { (Patagonia) }\end{array}$ & & & & & & 0,00000 & 2,71511 & 2,43716 & 4,88690 & 3,35675 & 3,75240 & 3,80016 & 4,64112 & 1,79307 & 6,27540 & 6,16962 & 7,03162 & 6,30981 & 4,32249 & 5,13724 & 5,11655 & 5,82329 \\
\hline $\begin{array}{c}\text { CSA- } \\
\text { México }\end{array}$ & & & & & & & 0,00000 & 1,93055 & 4,14069 & 3,71885 & 4,12198 & 4,20684 & 4,67799 & 1,73233 & 5,89816 & 5,55069 & 6,54572 & 5,84866 & 5,06430 & 5,72671 & 5,39264 & 5,83837 \\
\hline $\begin{array}{l}\text { CSA-Peru } \\
\text { CSA.- }\end{array}$ & & & & & & & & 0,00000 & 4,38365 & 3,65914 & 4,16496 & 4,24807 & 4,90172 & 1,62312 & 5,65888 & 5,32120 & 6,26558 & 5,70164 & 4,25225 & 4,95193 & 4,74711 & 5,51467 \\
\hline $\begin{array}{l}\text { CSA } \\
\text { venezuela }\end{array}$ & & & & & & & & & 0,00000 & 5,80451 & 6,61588 & 6,46011 & 6,77377 & 4,60030 & 7,96822 & 7,95604 & 8,34618 & 8,13624 & 7,15522 & 7,07007 & 7,47287 & 7,72400 \\
\hline $\begin{array}{l}\text { Esquimó- } \\
\text { Alaska- }\end{array}$ & & & & & & & & & & 0,00000 & 2,24580 & 1,91738 & 2,59145 & 2,92044 & 5,46589 & 5,95230 & 6,70253 & 5,92587 & 5,05346 & 5,55880 & 5,02722 & 6,04838 \\
\hline $\begin{array}{l}\text { Esquimó - } \\
\text { Asia }\end{array}$ & & & & & & & & & & & 0,00000 & 2,76367 & 3,23563 & 3,55300 & 5,95296 & 5,87466 & 6,81143 & 6,19285 & 4,73982 & 5,22804 & 5,38124 & 6,11048 \\
\hline $\begin{array}{c}\text { Esquimó- } \\
\text { Canadá }\end{array}$ & & & & & & & & & & & & 0,00000 & 1,56836 & 3,77050 & 5,57618 & 5,66189 & 6,56228 & 5,89092 & 5,27744 & 6,01768 & 5,26475 & 5,98722 \\
\hline $\begin{array}{l}\text { Esquimó- } \\
\text { Groelândia }\end{array}$ & & & & & & & & & & & & & 0,00000 & 4,56857 & 5,53709 & 5,70831 & 6,53049 & 5,92984 & 5,93001 & 6,57089 & 5,53801 & 6,21308 \\
\hline $\begin{array}{l}\text { Norte- } \\
\text { EUA }\end{array}$ & & & & & & & & & & & & & & 0,00000 & 5,61961 & 5,54733 & 6,51526 & 5,69070 & 4,24468 & 4,94740 & 4,67322 & 5,38772 \\
\hline $\begin{array}{l}\text { Lagoa } \\
\text { Santata } \\
\text { Lagoa }\end{array}$ & & & & & & & & & & & & & & & 0,00000 & 4,18373 & 3,24960 & 2,57127 & 5,59587 & 5,76024 & 4,06006 & 4,61128 \\
\hline $\begin{array}{l}\text { Santa- } \\
\text { Cerca } \\
\text { Grande }\end{array}$ & & & & & & & & & & & & & & & & 0,00000 & 4,40641 & 4,44686 & 5,94895 & 6,45817 & 5,34310 & 4,98966 \\
\hline $\begin{array}{l}\text { Santa- } \\
\text { Harold } \\
\text { Walter }\end{array}$ & & & & & & & & & & & & & & & & & 0,00000 & 2,68585 & 5,65564 & 5,38213 & 4,31418 & 4,23885 \\
\hline $\begin{array}{l}\text { Ladod } \\
\text { Sumida- } \\
\text { Sumidouro }\end{array}$ & & & & & & & & & & & & & & & & & & 0,00000 & 5,12681 & 5,10767 & 3,80307 & 4,00761 \\
\hline $\begin{array}{c}\text { Base } \\
\text { Aérea } \\
\text { Capera } \\
\text { Colombiai } \\
\text { Colômbia } \\
\end{array}$ & & & & & & & & & & & & & & & & & & & 0,00000 & $\begin{array}{l}2,27157 \\
0,00000\end{array}$ & $\begin{array}{l}3,93026 \\
3,95711 \\
0,00000\end{array}$ & $\begin{array}{l}4,35493 \\
4,15654 \\
3,10756 \\
0,00000\end{array}$ \\
\hline
\end{tabular}


Figura 4.54 - Dendrograma gerado sobre matriz de Distâncias de Mahalanobis - Método de Ward. Parcela feminina, apenas forma.

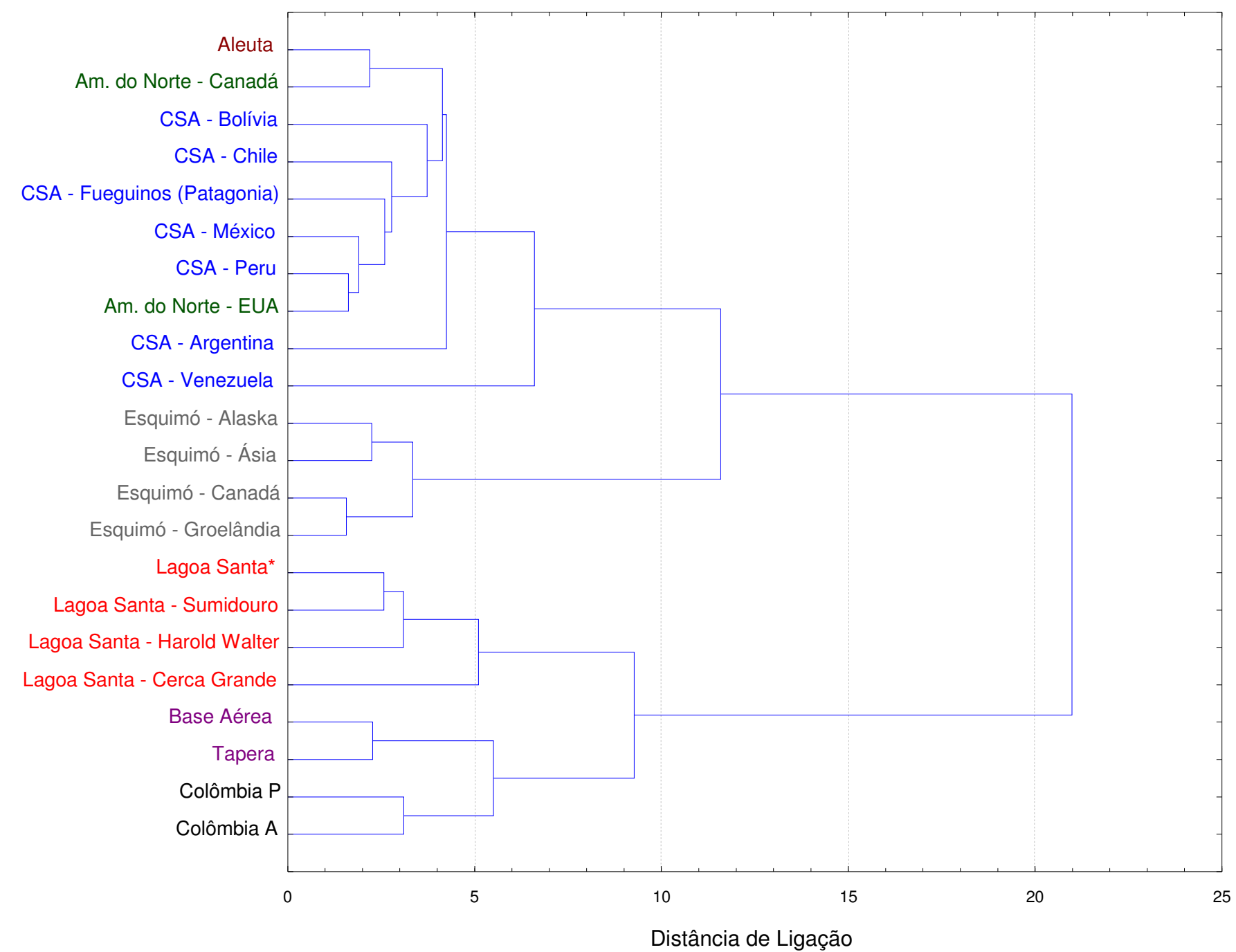


Figura 4.55 - Dendrograma gerado sobre matriz de Distâncias de Mahalanobis - Método de Ligação Simples. Parcela feminina, apenas forma.

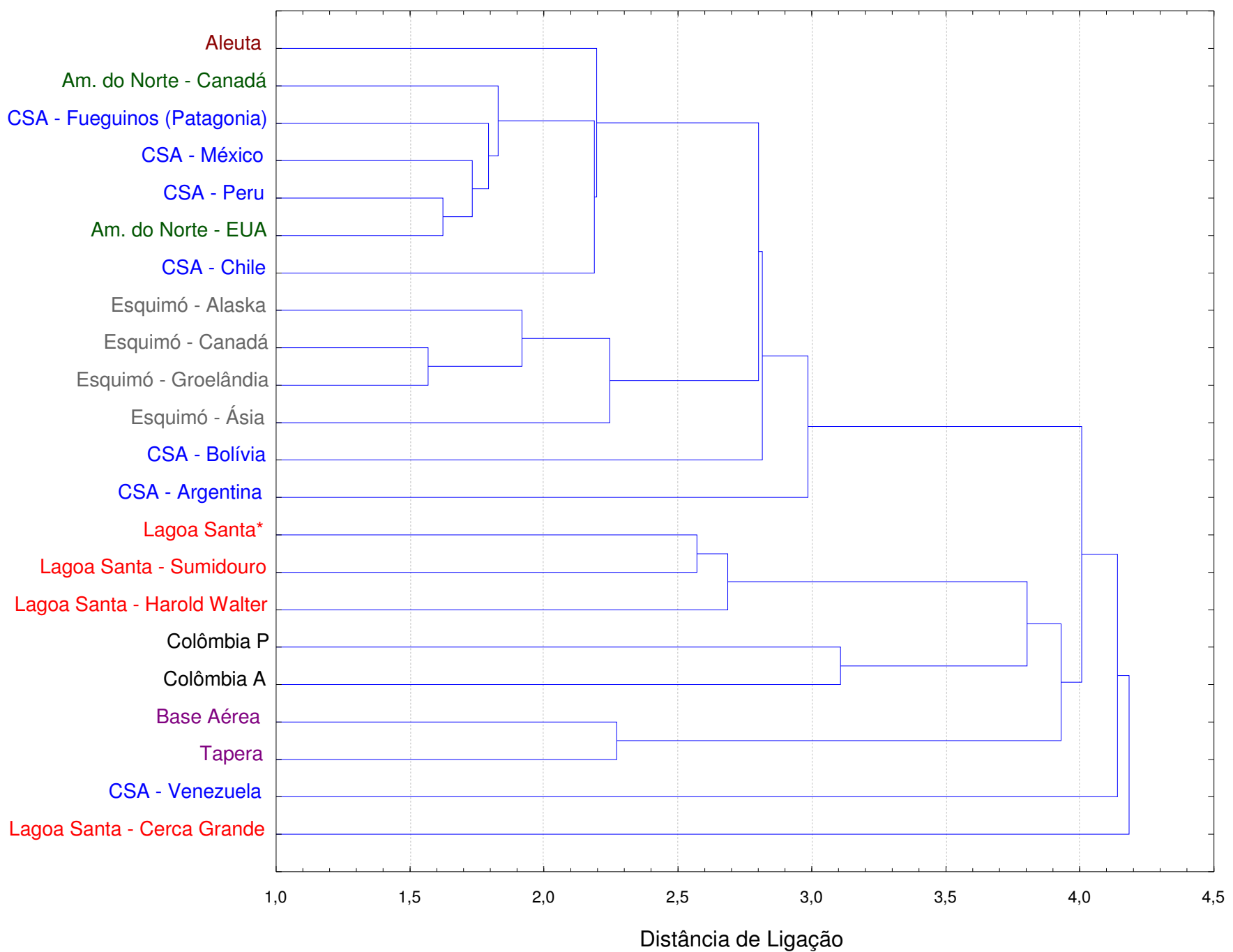


Figura 4.56 - Dendrograma gerado sobre matriz de Distância de Mahalanobis - Método de Ligação Completa. Parcela feminina, apenas forma.

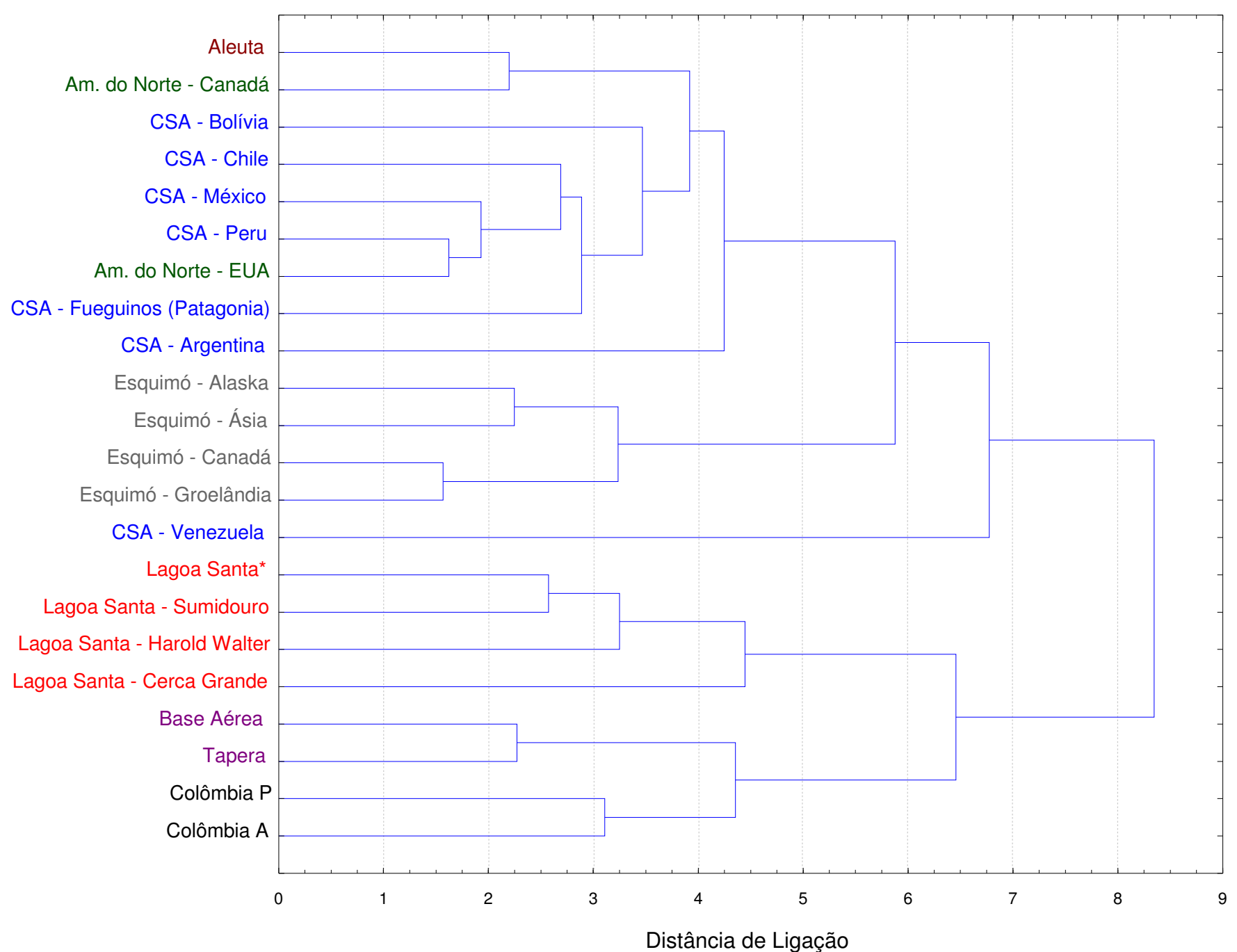


Figura 4.57 - Dendrograma gerado sobre matriz de Distância de Mahalanobis - Método da Média dos Grupos. Parcela feminina, apenas forma.

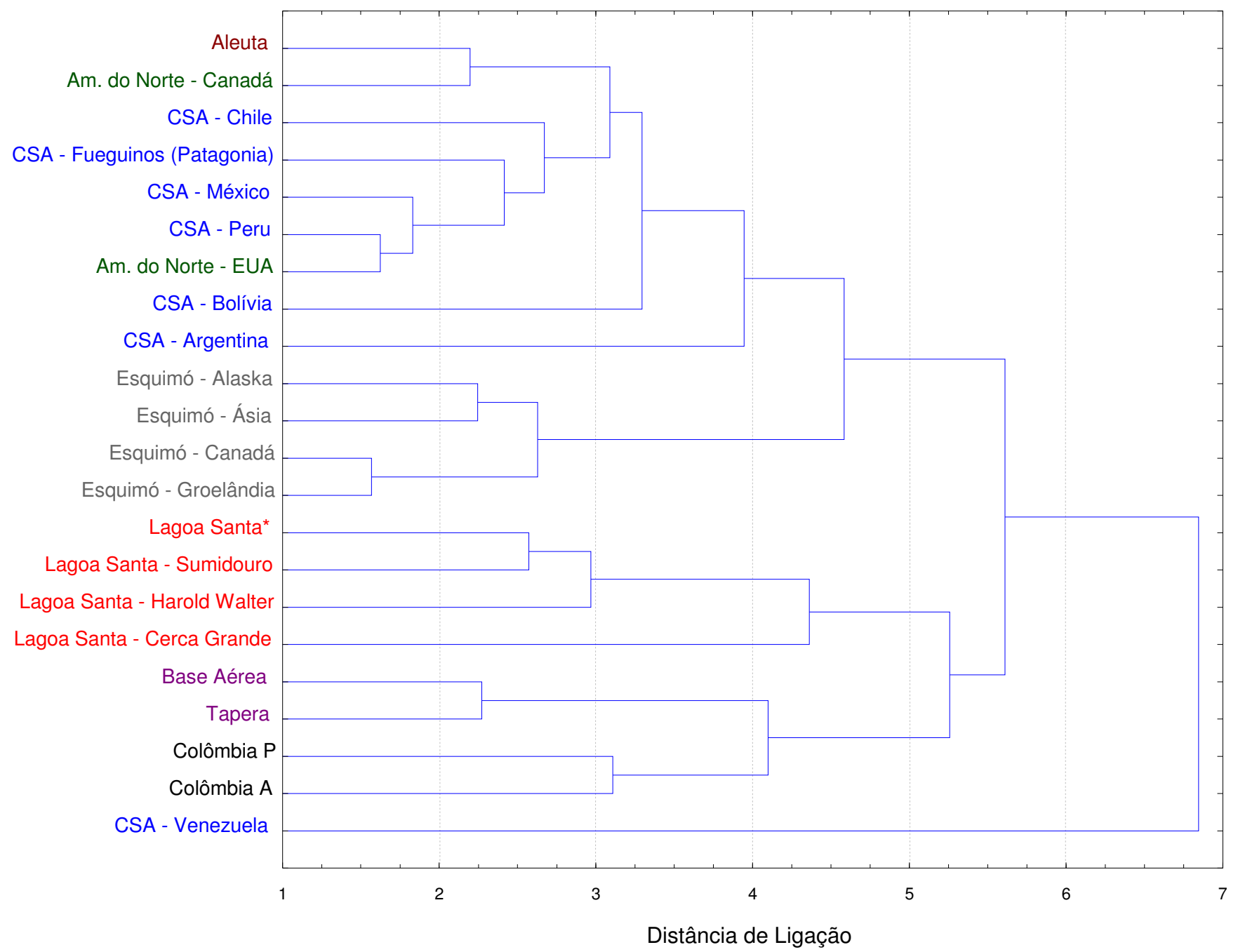


Tabela 4.16 - Configuração final das dimensões calculadas através de escalonamento multidimensional sobre Matriz de Distância baseada em Distâncias de Mahalanobis. Parcela feminina, forma e tamanho (22 grupos, 23 variáveis craniométricas).

\begin{tabular}{c|c|c|c}
\hline & DIMENSÃO 1 & DIMENSÃO 2 & DIMENSÃO 3 \\
\hline Aleuta & 0,75921 & $-0,112672$ & $-0,379991$ \\
Am. do Norte - Canadá & 0,41084 & $-0,015834$ & $-0,208557$ \\
CSA - Argentina & 0,27004 & 0,197236 & 0,583838 \\
CSA - Bolívia & 0,25092 & $-0,613660$ & 0,070545 \\
CSA - Chile & 0,39903 & $-0,255091$ & 0,242837 \\
CSA - Fueguinos (Patagonia) & 0,67437 & 0,043783 & 0,007194 \\
cSA - México & 0,60443 & 0,001015 & 0,325364 \\
CSA - Peru & 0,45597 & $-0,107436$ & 0,186395 \\
cSA - Venezuela & 1,61930 & $-0,444556$ & 0,687040 \\
Esquim - Alaska & 0,42823 & 0,507158 & $-0,287187$ \\
Esquim - Ásia & 0,40504 & 0,464956 & $-0,597341$ \\
Esquim - Canadá & 0,30706 & 0,770753 & $-0,281877$ \\
Esquim - Groelândia & 0,20270 & 1,037010 & $-0,375197$ \\
Am. do Norte - EUA & 0,46771 & $-0,017306$ & 0,036885 \\
Lagoa Santa* & $-1,22069$ & 0,477444 & 0,025388 \\
Lagoa Santa - Cerca Grande & $-0,86537$ & 0,541880 & 0,879323 \\
Lagoa Santa - Harold Walter & $-1,60935$ & 0,037574 & 0,161358 \\
Lagoa Santa - Sumidouro & $-1,25649$ & 0,042501 & 0,078816 \\
Base Aérea & $-0,19295$ & $-0,678025$ & $-0,483005$ \\
Tapera & $-0,39423$ & $-0,913168$ & $-0,535037$ \\
Colômbia P & $-0,74278$ & $-0,320385$ & $-0,318876$ \\
Colômbia A & $-0,97298$ & $-0,643178$ & 0,182086 \\
\hline
\end{tabular}

Figura 4.58 - Gráfico bidimensional da relação ortogonal entre as dimensões $1 \times 2$. Parcela feminina, apenas forma (22 grupos, 23 variáveis craniométricas).

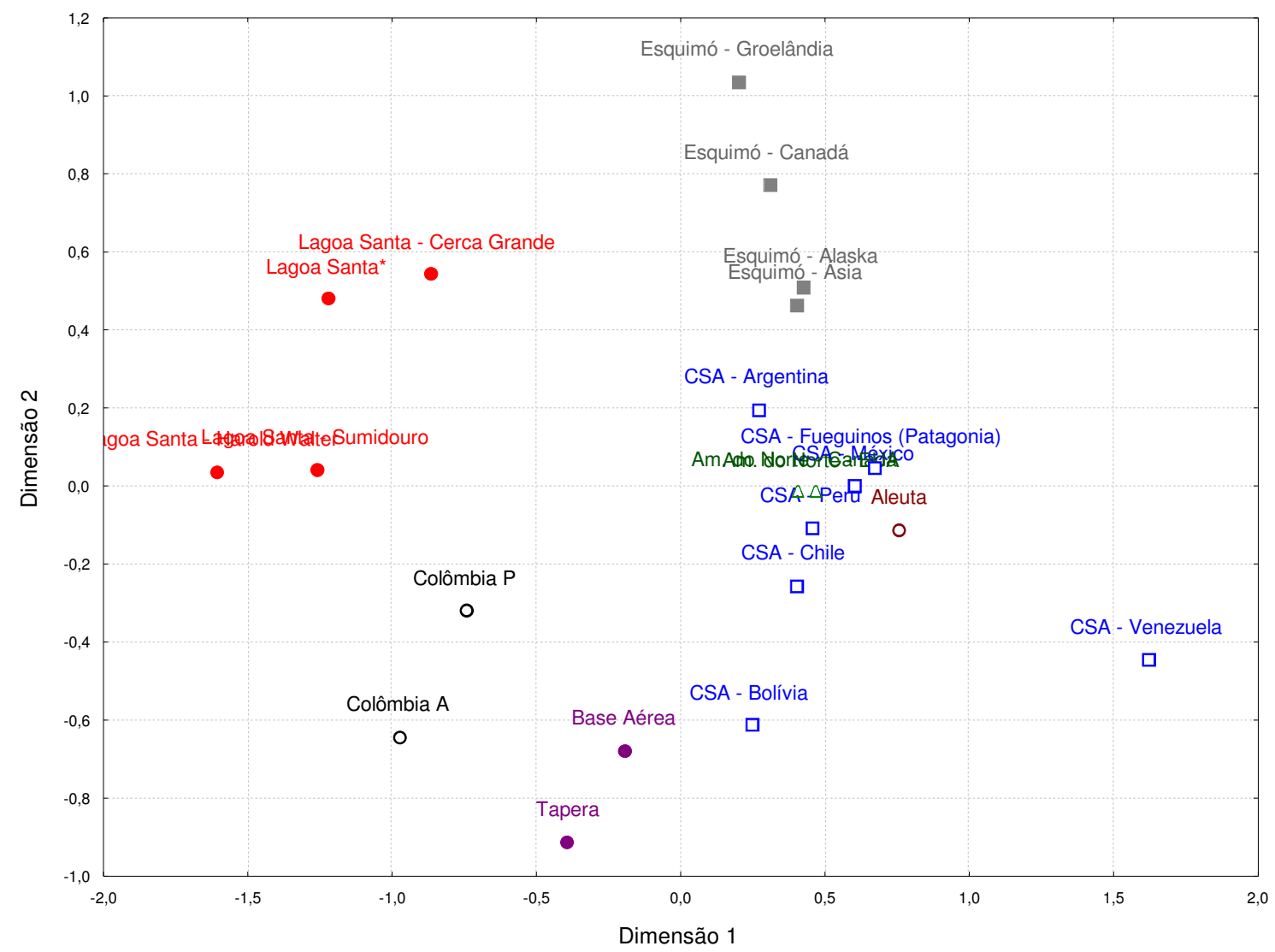


Figura 4.59 - Gráfico bidimensional da relação ortogonal entre as dimensões $1 \times 3$. Parcela feminina, apenas forma (22 grupos, 23 variáveis craniométricas).

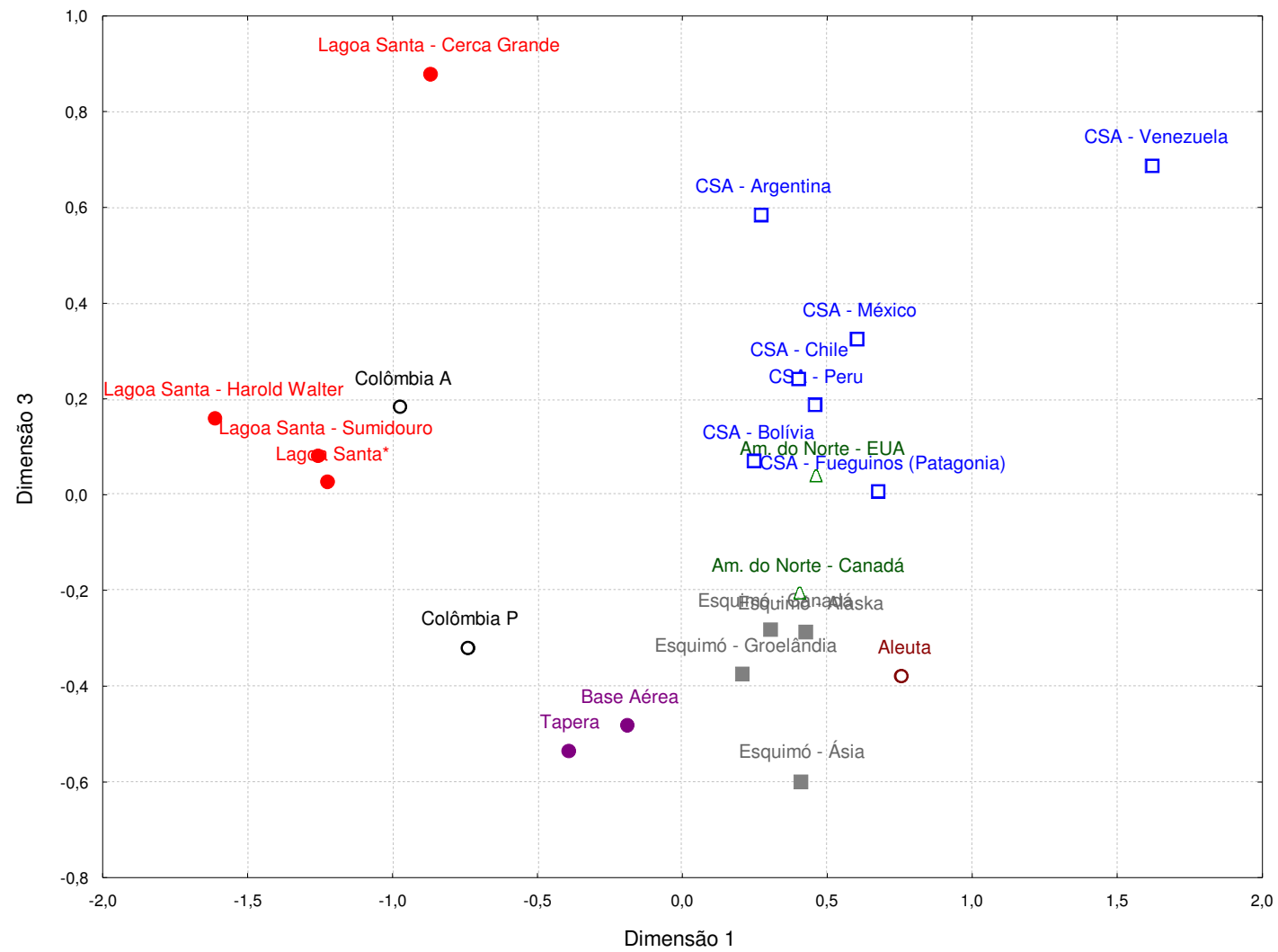

Figura 4.60 - Gráfico bidimensional da relação ortogonal entre as dimensões $2 \times 3$. Parcela feminina, apenas forma (22 grupos, 23 variáveis craniométricas).

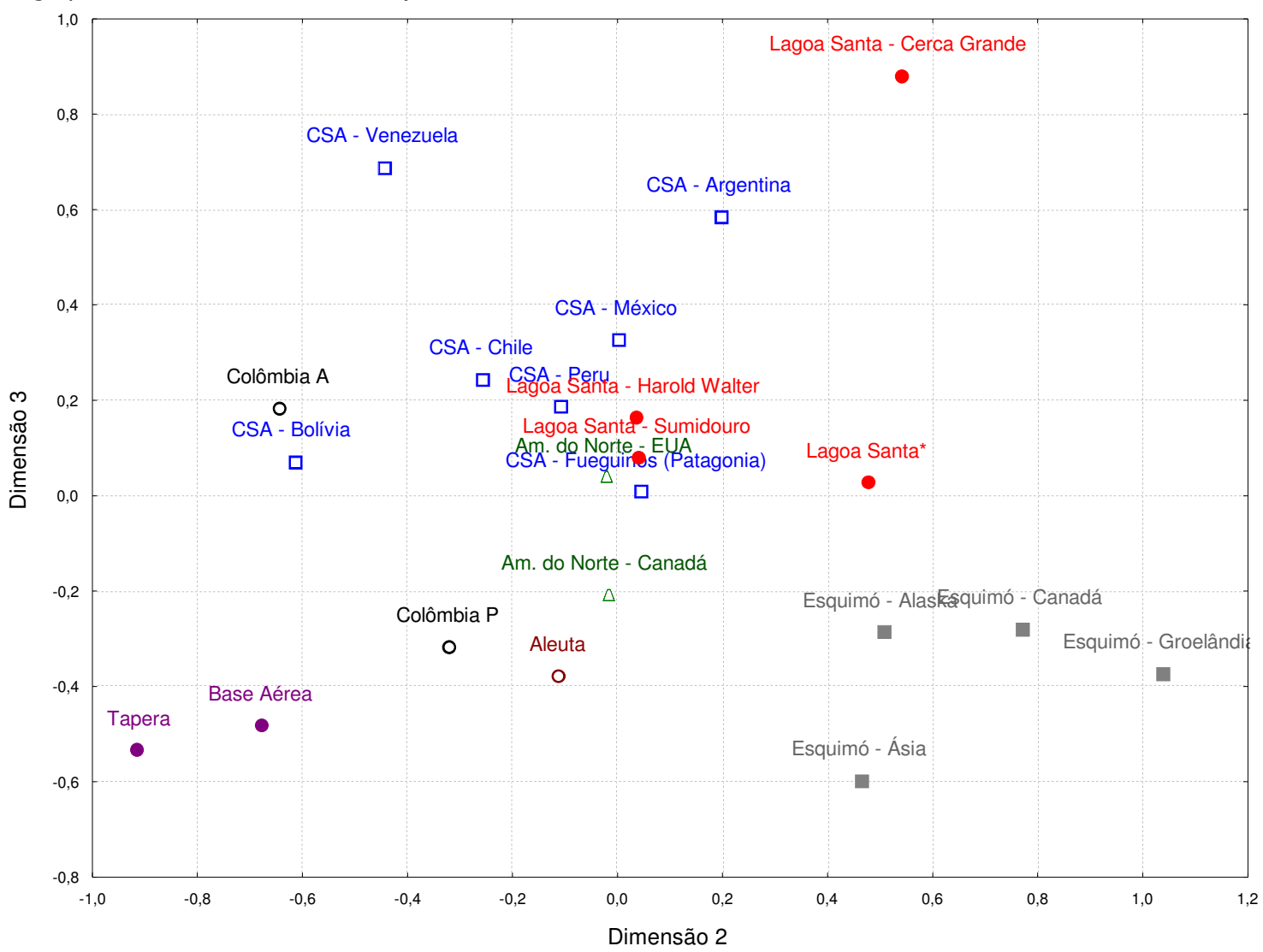


4.2 - Investigação das Afinidades Biológicas Extra-Continentais

4.2.1 - Primeiro nível de inclusão das Afinidades Biológicas Extra-Continentais

Num primeiro nível de inclusão das análises de afinidades extracontinentais dos paleoíndios investigou-se quais populações mundiais, representadas por seus centróides, apresentava maior ou menor similaridade morfológica com a população de Lagoa Santa.

Para tanto, utilizou-se a técnica da Análise de Componentes Principais aplicada sobre os cinco conjuntos de dados estabelecidos a partir da localização geográfica de cada série. Por se tratar de uma abordagem inicial, e levando em consideração também a experiência obtida com os resultados da análise intracontinental, decidiu-se investigar essas afinidades a partir da visualização das topologias geradas apenas pelos dois primeiros componentes principais.

A partir da visualização dessas afinidades, escolheu-se as séries que melhor se encaixaram no segundo nível de inclusão, para uma análise mais detalhada, aplicando-se diferentes técnicas estatísticas multivariadas. Essa escolha recaiu sobre a importância de cada série no teste da hipótese central investigada neste trabalho.

A seguir, as Figuras 4.61 a 4.80 demonstram, respectivamente, os resultados obtidos através dessas ACPs para as parcelas masculina e feminina (tamanho e forma e apenas forma, em todos os casos) para cinco conjuntos de dados propostos (Lagoa Santa x Oceania; Lagoa Santa x Leste Asiático; Lagoa Santa x Sudoeste Asiático; Lagoa Santa x África; Lagoa Santa x Europa). 
Figura 4.61 - Gráfico bidimensional do morfo-espaço formado pelos CP 1 x CP 2. Parcela masculina, tamanho e forma (análise extra-continental - conjunto Oceania).

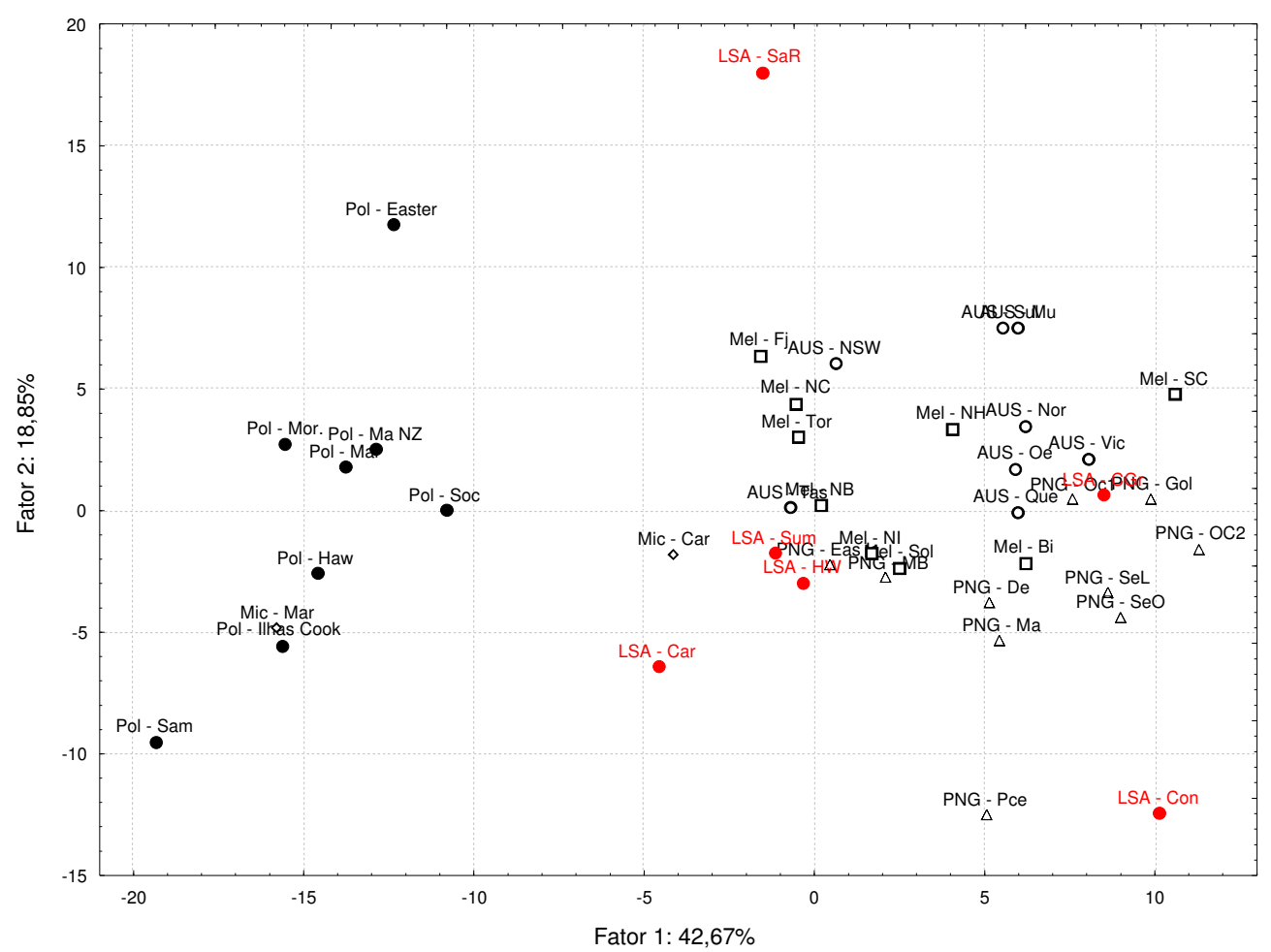

Figura 4.62 - Gráfico bidimensional do morfo-espaço formado pelos CP 1 x CP 2. Parcela masculina, forma apenas (análise extra-continental - conjunto Oceania).

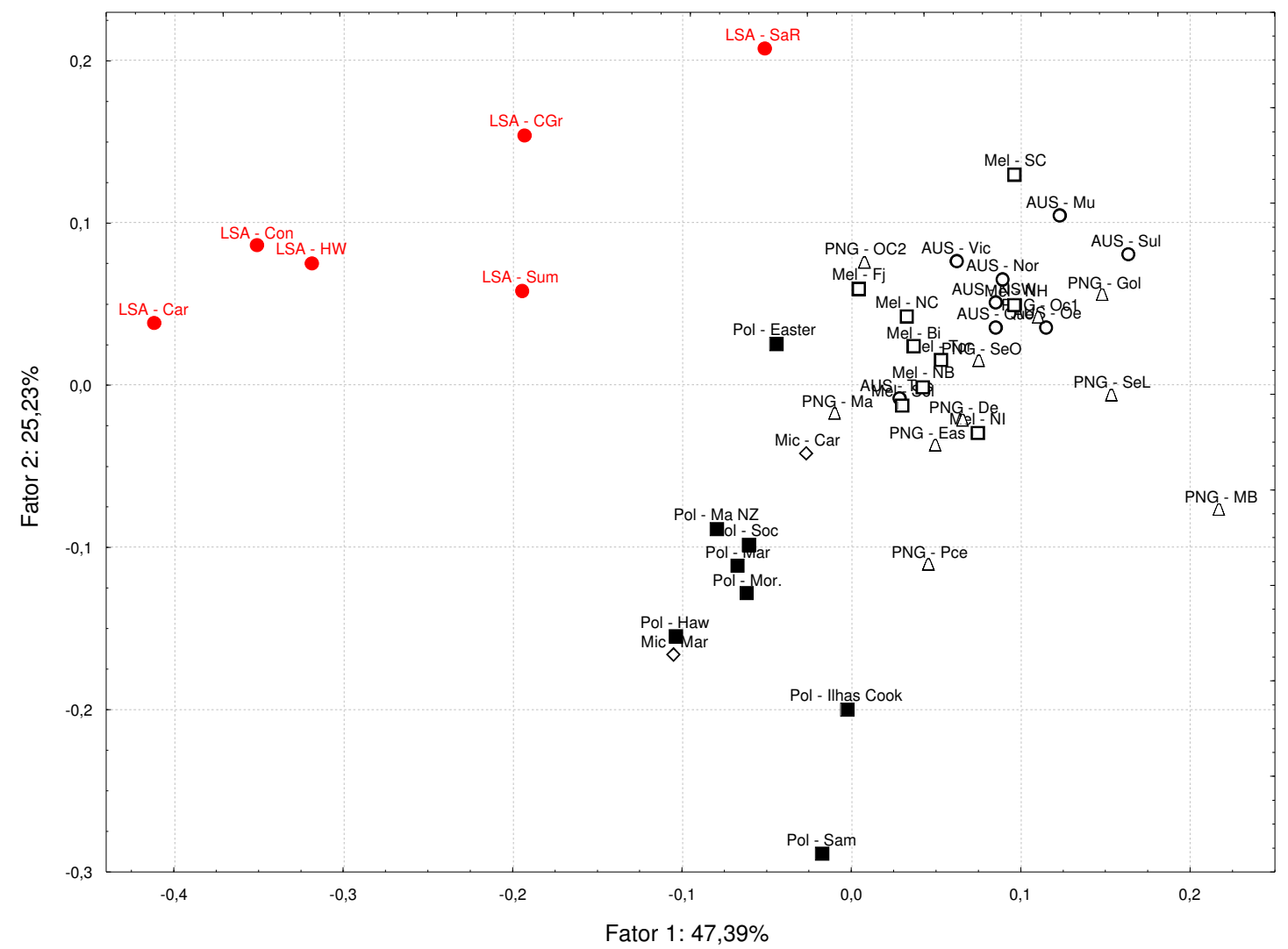


Figura 4.63 - Gráfico bidimensional do morfo-espaço formado pelos CP 1 x CP 2. Parcela feminina, tamanho e forma (análise extra-continental - conjunto Oceania).

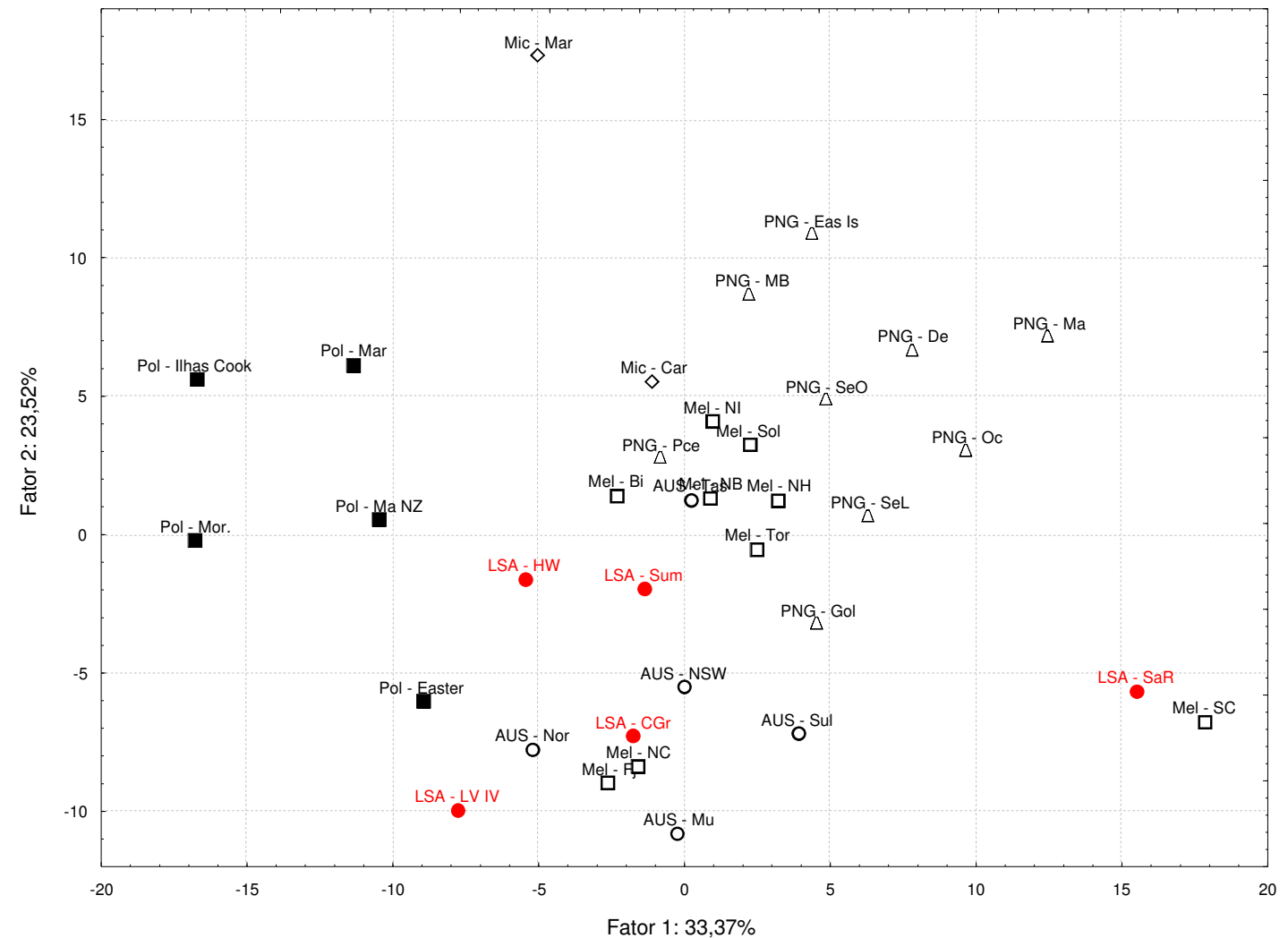

Figura 4.64 - Gráfico bidimensional do morfo-espaço formado pelos CP 1 x CP 2. Parcela feminina, apenas forma (análise extra-continental - conjunto Oceania).

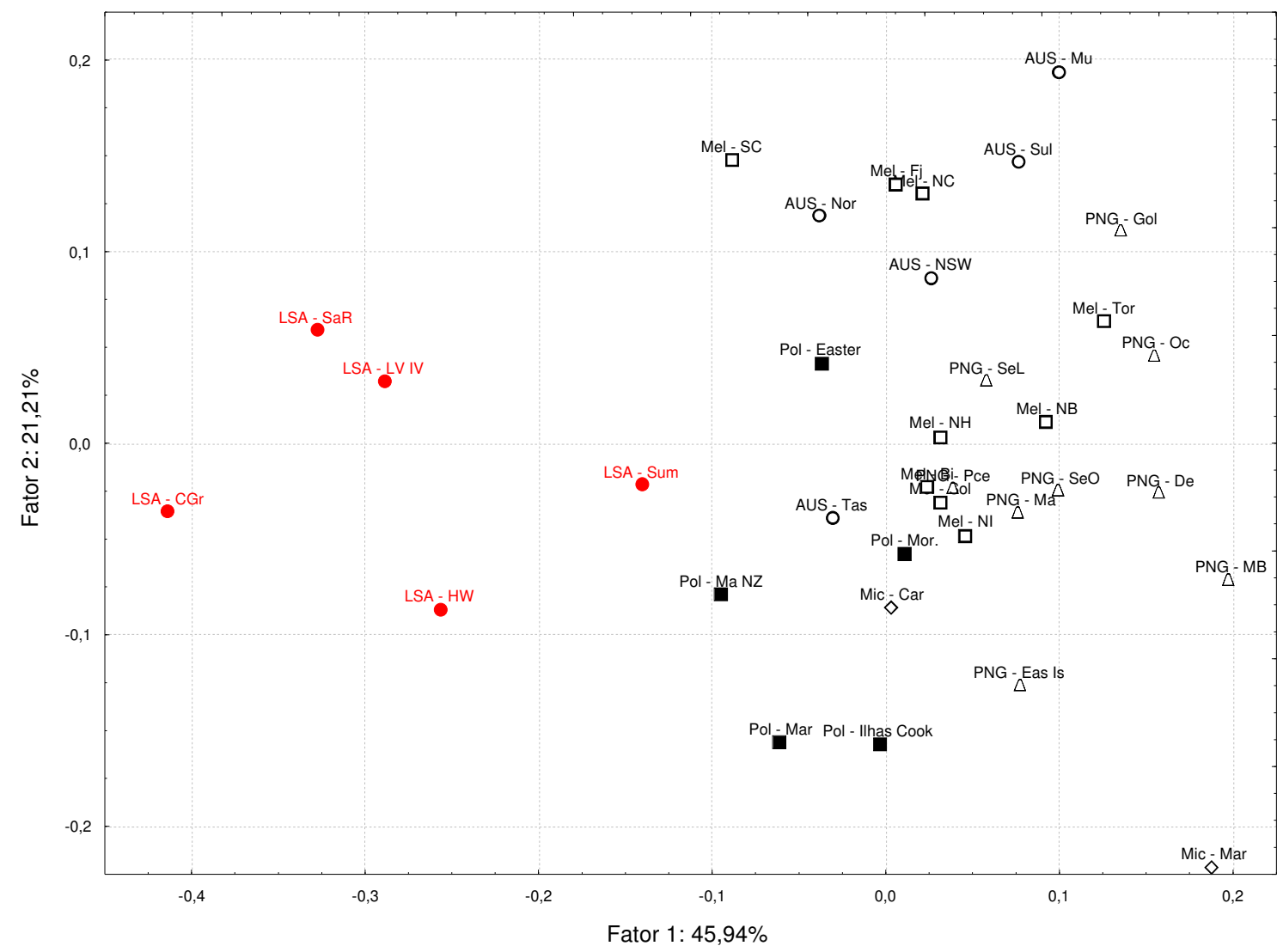


As análises apresentadas nas Figuras 4.61 a 4.64, referentes ao confronto, tanto para as parcelas masculina quanto feminina, entre as séries oriundas da Oceania e a Paleoíndia de Lagoa Santa mostram uma certa integração entre si, mas apenas quando forma e tamanho são levados em consideração. Outra particularidade observada, nas duas análises que apresentaram maior integração entre os Paleoíndios e os povos da Oceania, é a completa separação dos Polinésios, de morfologia notadamente diferente dos demais povos estudados neste conjunto de dados. Para o próximo nível de inclusão, os resultados aqui obtidos abrem a possibilidade de agruparem-se as séries de acordo com suas macro-regiões (um único grupo de australianos, um outro de papuas, polinésios, micronésios e melanésios) de forma a diminuir 0 número de séries e facilitar a visualização das relações morfológicas intergrupais.

As Figuras 4.65 a 4.68 apresentam os gráficos bidimensionais obtidos através da relação ortogonal entre os dois primeiros Componentes Principais extraídos a partir da matriz de covariâncias do estudo sobre as afinidades morfológicas entre os Paleoamericanos e os povos originários do leste asiático. De forma bastante convincente, todas as topologias geradas evidenciam a completa independência morfológica entre os centróides de Lagoa Santa e os do extremo oriente. De maneira geral, principalmente nos gráficos gerados a partir de dados corrigidos quanto ao fator tamanho, as populações asiáticas amostradas mostram boa integração morfológica de acordo com suas regiões de origem (leste asiático, nordeste asiático e sudeste asiático), permitindo, também, seu rearranjo em macro-regiões para o próximo nível de inclusão. 
Figura 4.65 - Gráfico bidimensional do morfo-espaço formado pelos CP 1 x CP 2. Parcela masculina, tamanho e forma (análise extra-continental - conjunto Leste Asiático).

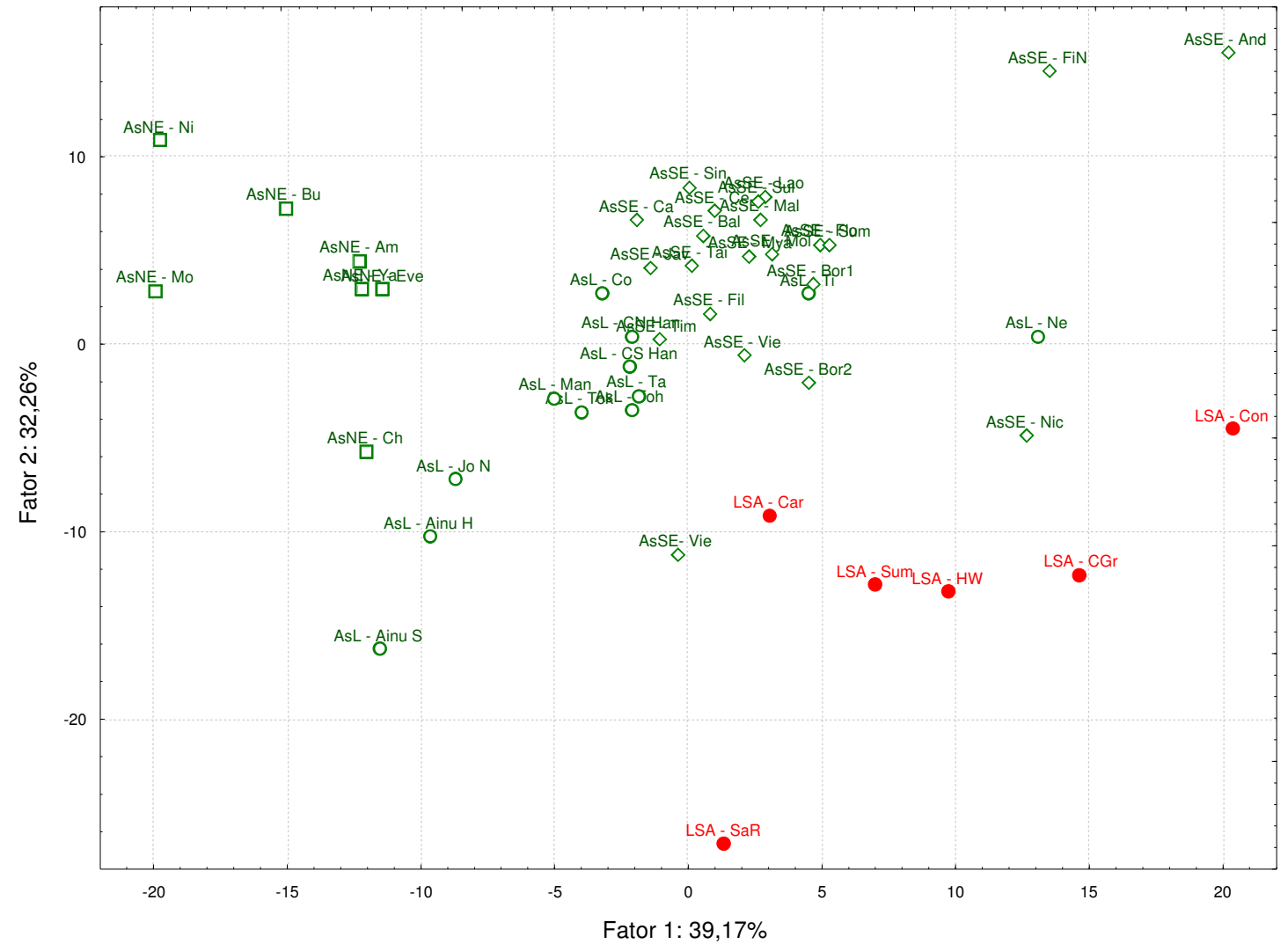

Figura 4.66 - Gráfico bidimensional do morfo-espaço formado pelos CP 1 x CP 2. Parcela masculina, apenas forma (análise extra-continental - conjunto Leste Asiático).

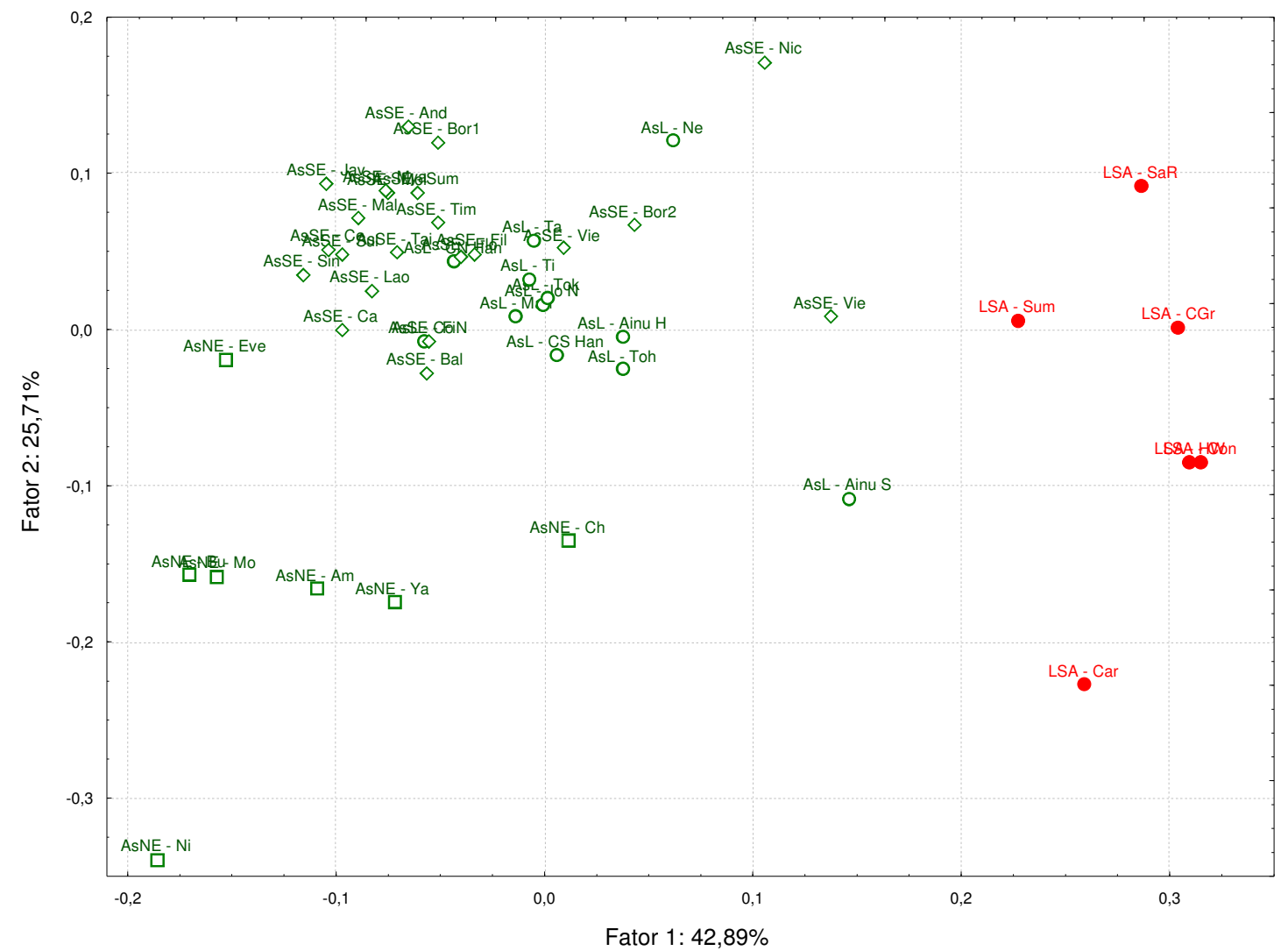


Figura 4.67 - Gráfico bidimensional do morfo-espaço formado pelos CP 1 x CP 2. Parcela feminina, tamanho e forma (análise extra-continental - conjunto Leste Asiático).

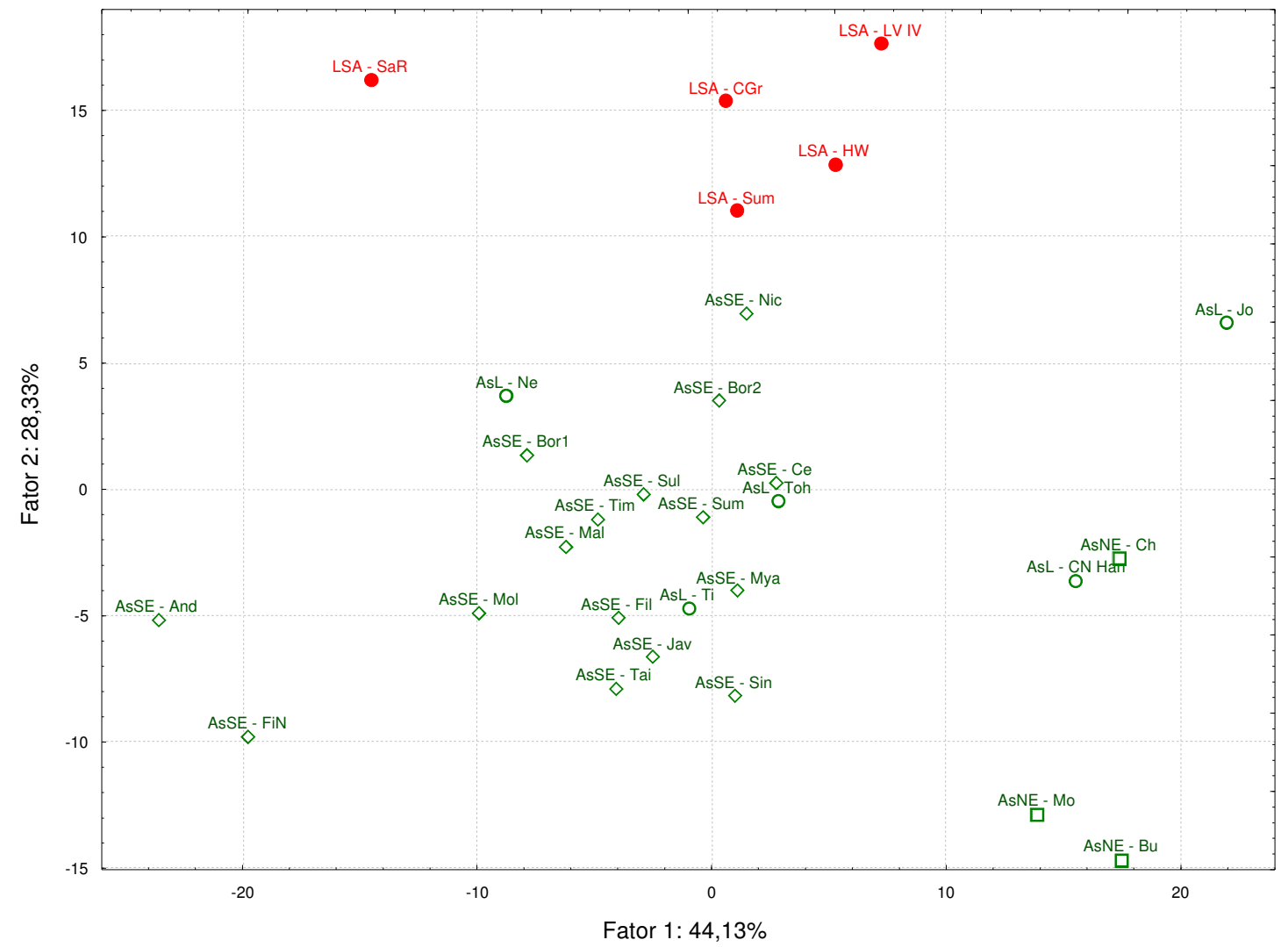

Figura 4.68 - Gráfico bidimensional do morfo-espaço formado pelos CP 1 x CP 2. Parcela feminina, apenas forma (análise extra-continental - conjunto Leste Asiático).

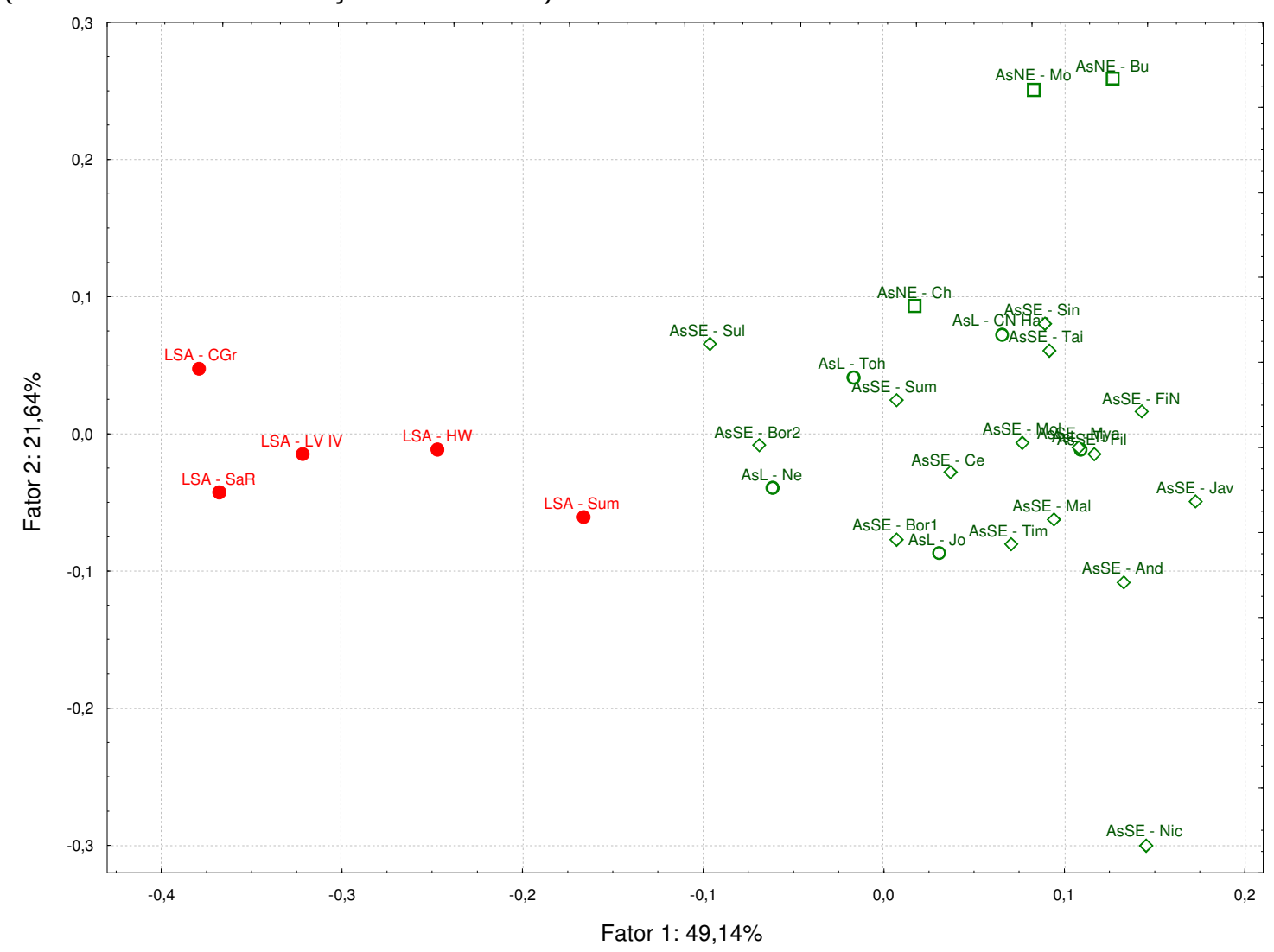


As análises apresentadas nas figuras 4.69 a 4.72 , referem-se ao confronto, tanto para as parcelas masculina quanto feminina, entre as séries do "sudoeste asiático" (congregando populações da Índia, sudoeste asiático e Orientes Médio e Próximo) e as Paleoíndias de Lagoa Santa. Elas não mostram qualquer integração morfológica significativa entre esse últimos e os primeiros. Assim como observado nas análises anteriores, o agrupamento dos dados em macro-regiões também se mostra viável a partir dos resultados obtidos neste primeiro nível de análise.

Figura 4.69 - Gráfico bidimensional do morfo-espaço formado pelos CP 1 x CP 2. Parcela masculina, tamanho e forma (análise extra-continental - conjunto Sudoeste Asiático).

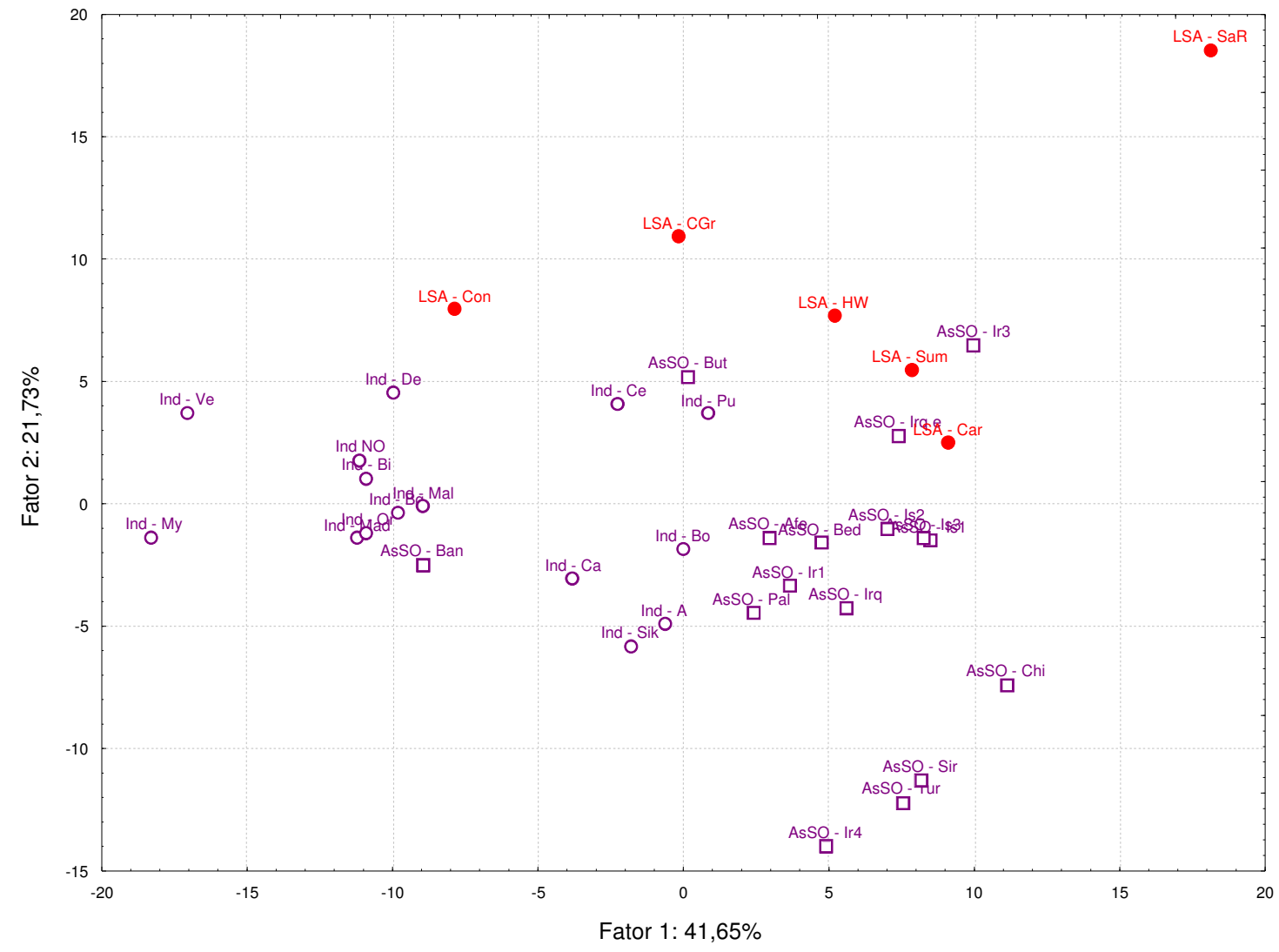


Figura 4.70 - Gráfico bidimensional do morfo-espaço formado pelos CP 1 x CP 2. Parcela masculina, apenas forma (análise extra-continental - conjunto Sudoeste Asiático).

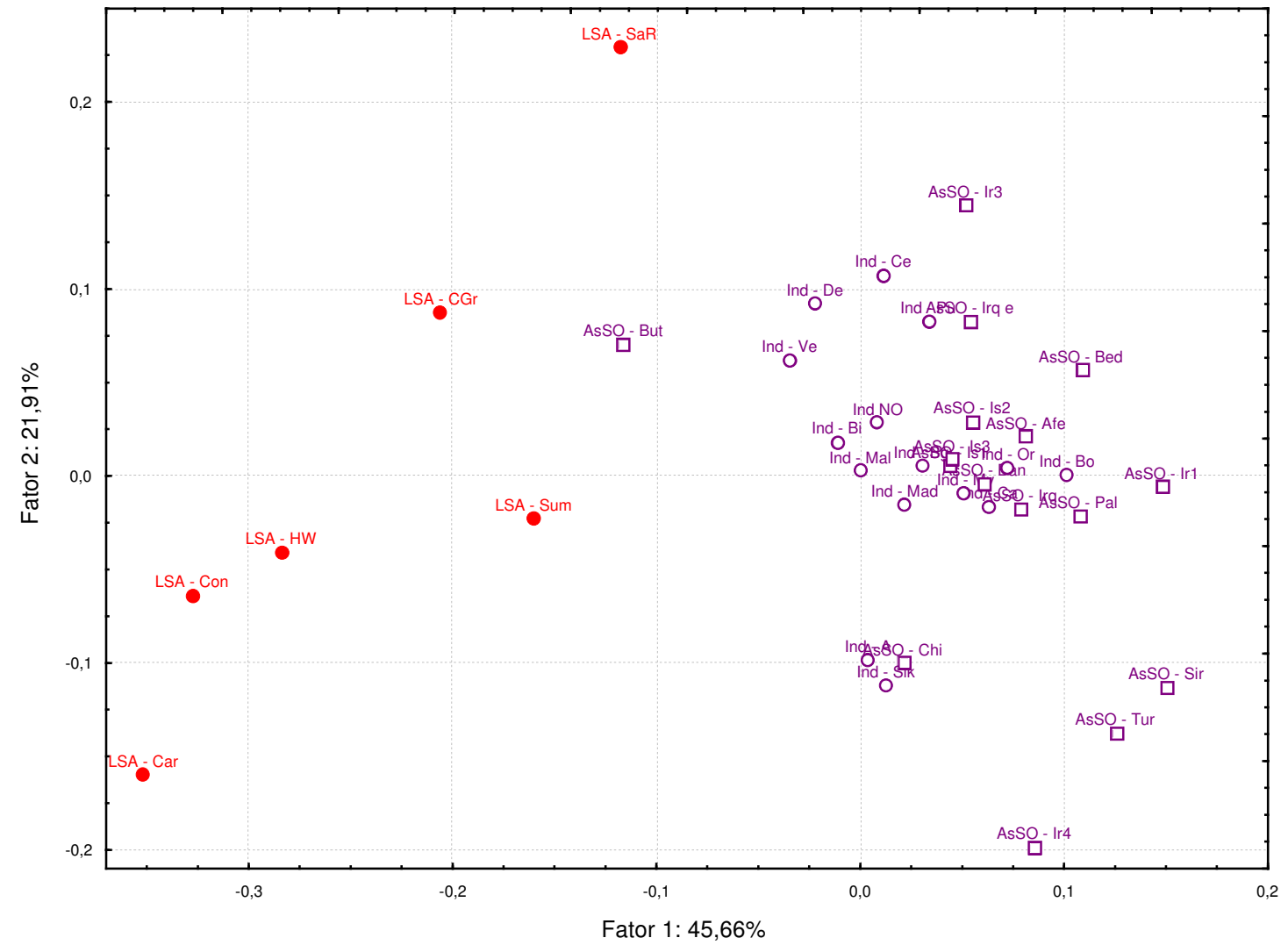

Figura 4.71 - Gráfico bidimensional do morfo-espaço formado pelos CP 1 x CP 2. Parcela feminina, forma e tamanho (análise extra-continental - conjunto Sudoeste Asiático).

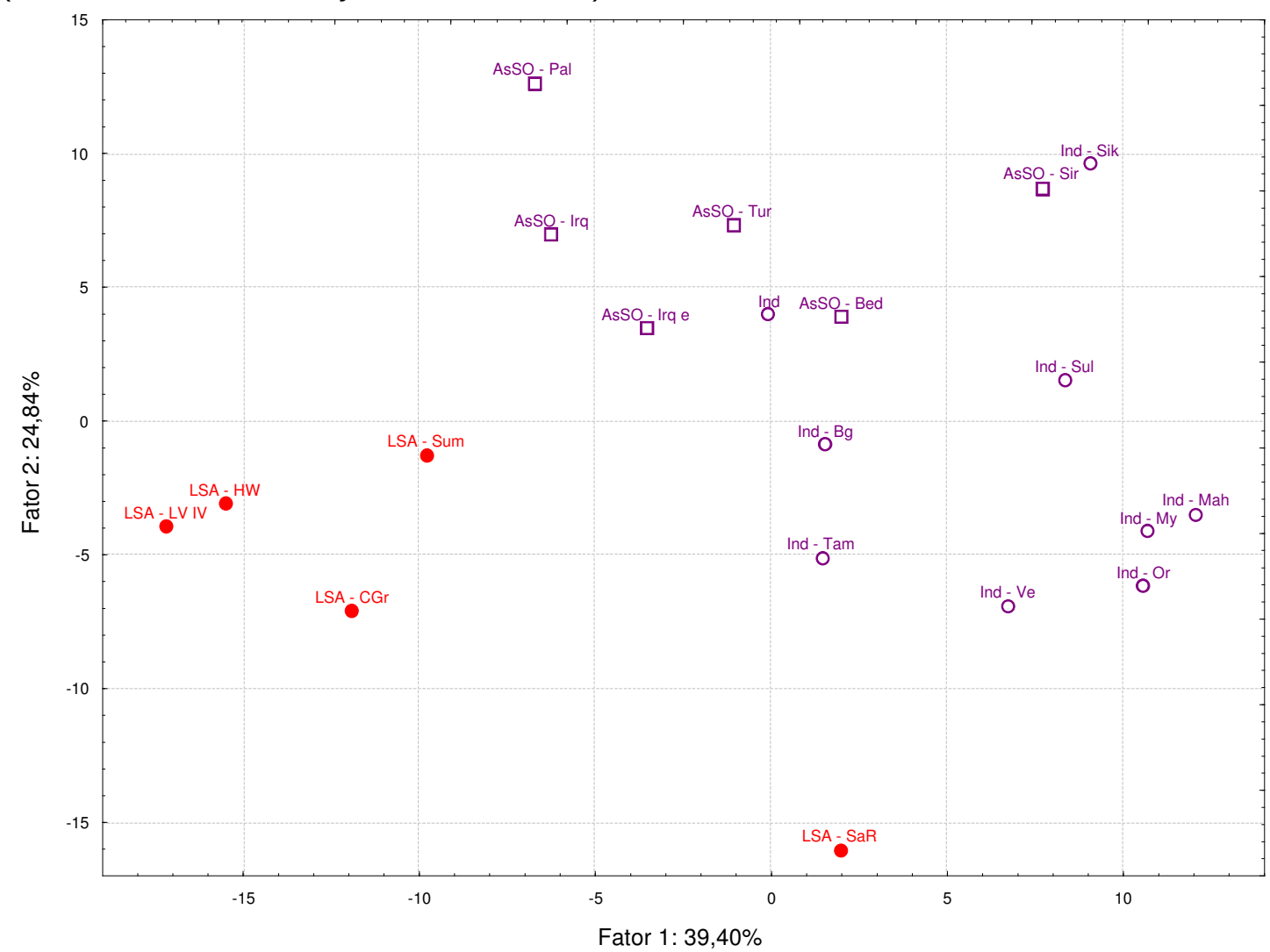


Figura 4.72 - Gráfico bidimensional do morfo-espaço formado pelos CP 1 x CP 2. Parcela feminina, apenas forma (análise extra-continental - conjunto Sudoeste Asiático).

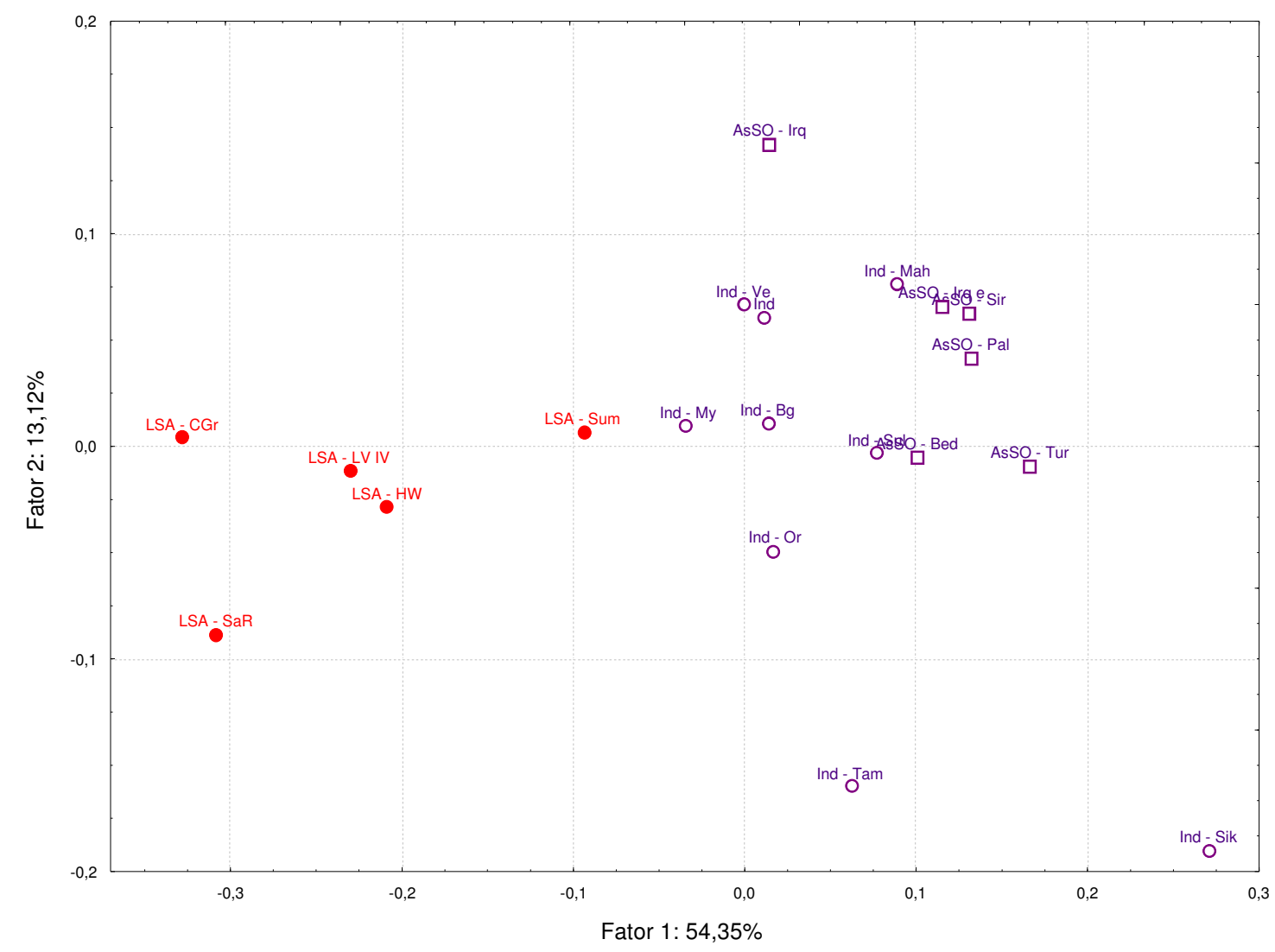

As Figuras 4.73 a 4.76 apresentam os gráficos bidimensionais obtidos através da relação ortogonal entre os dois primeiros Componentes Principais extraídos a partir da matriz de covariâncias do conjunto de dados relativos à comparação entre os Paleoamericanos e os povos originários da África. De maneira geral, exceto para a topologia referente à análise da parcela masculina, tamanho e forma, os gráficos não apresentam relações morfológicas consistentes entre os centróides de Lagoa Santa e os africanos, do norte e do sul, estudados na amostra. A interpretação dos gráficos gerados permite 0 rearranjo dos indivíduos amostrados entre norte e sul africanos. 
Figura 4.73 - Gráfico bidimensional do morfo-espaço formado pelos CP $1 \times$ CP 2. Parcela masculina, tamanho e forma (análise extra-continental - conjunto Africano).

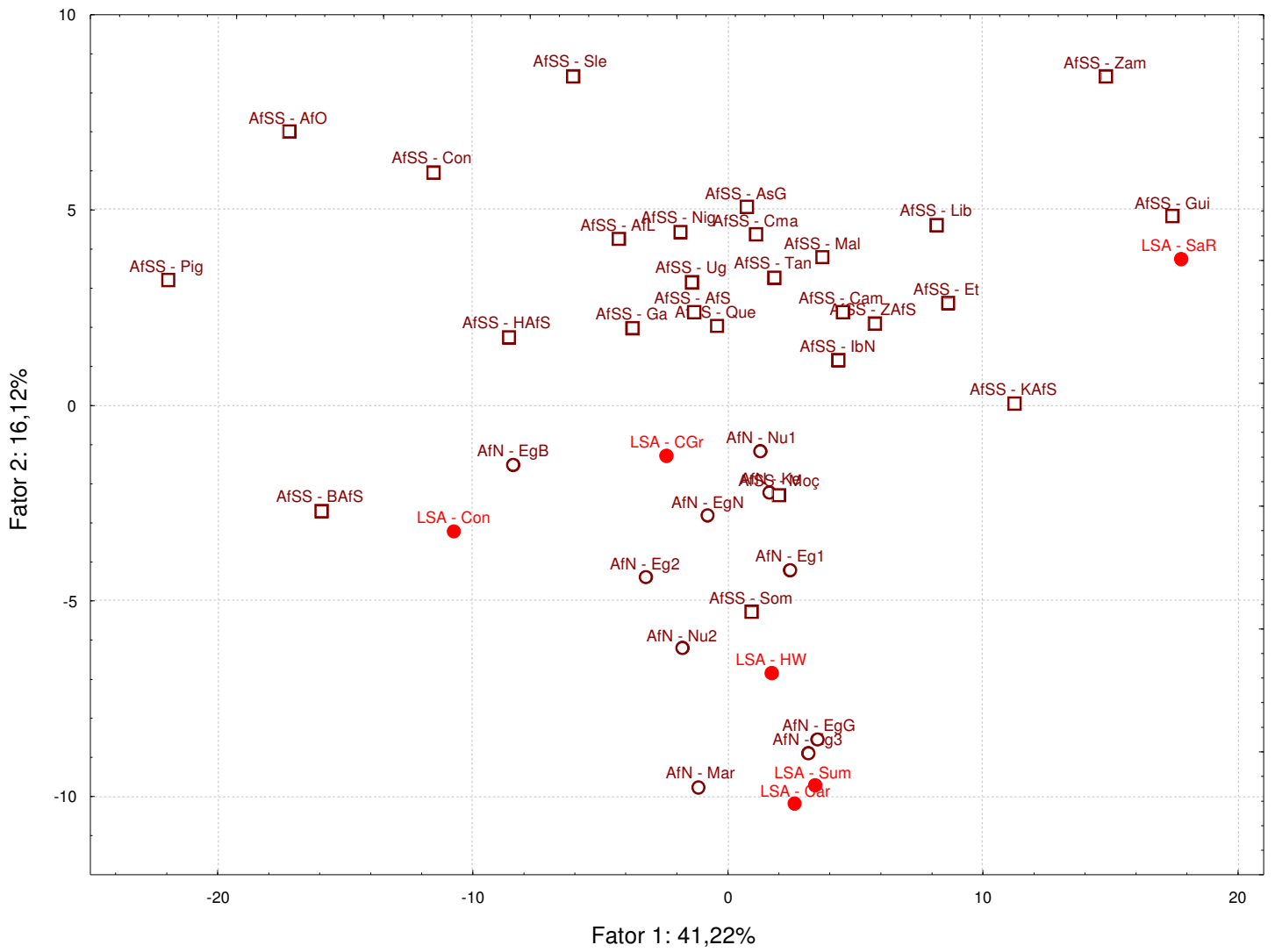

Figura 4.74 - Gráfico bidimensional do morfo-espaço formado pelos CP 1 x CP 2. Parcela masculina, apenas forma (análise extra-continental - conjunto Africano).

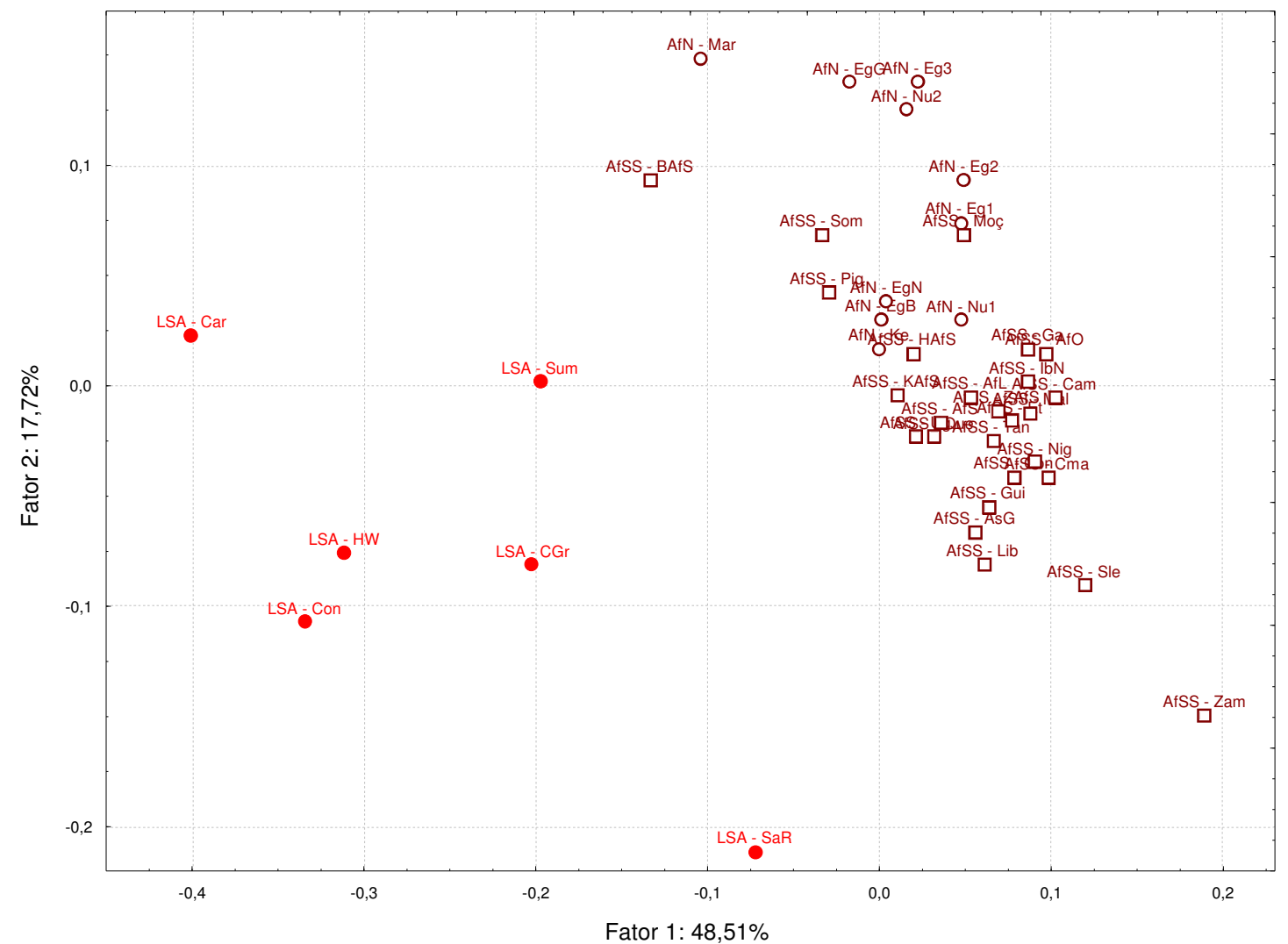


Figura 4.75 - Gráfico bidimensional do morfo-espaço formado pelos CP 1 x CP 2. Parcela feminina, tamanho e forma (análise extra-continental - conjunto Africano).

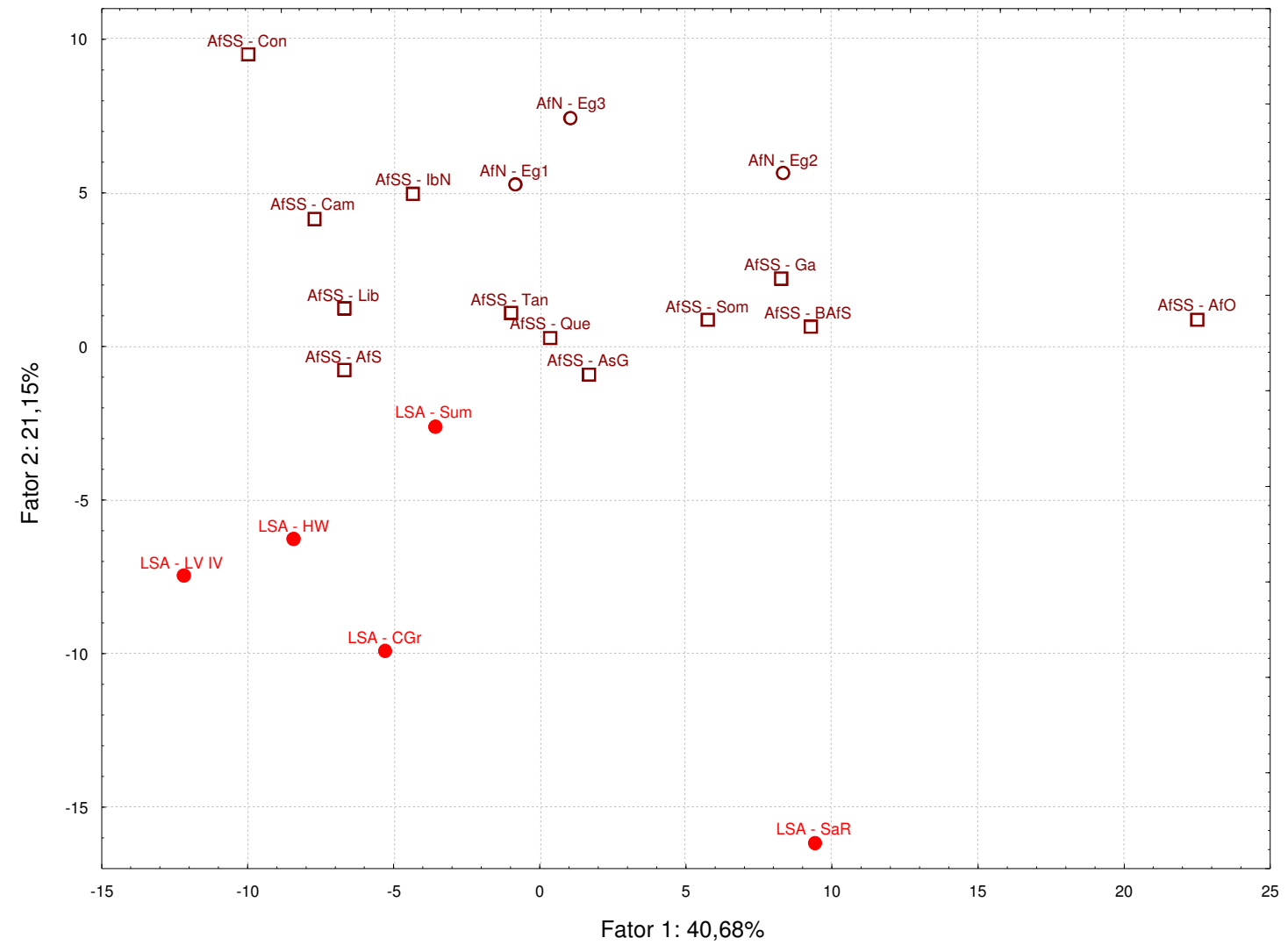

Figura 4.76 - Gráfico bidimensional do morfo-espaço formado pelos CP $1 \times$ CP 2. Parcela feminina, apenas forma (análise extra-continental - conjunto Africano).

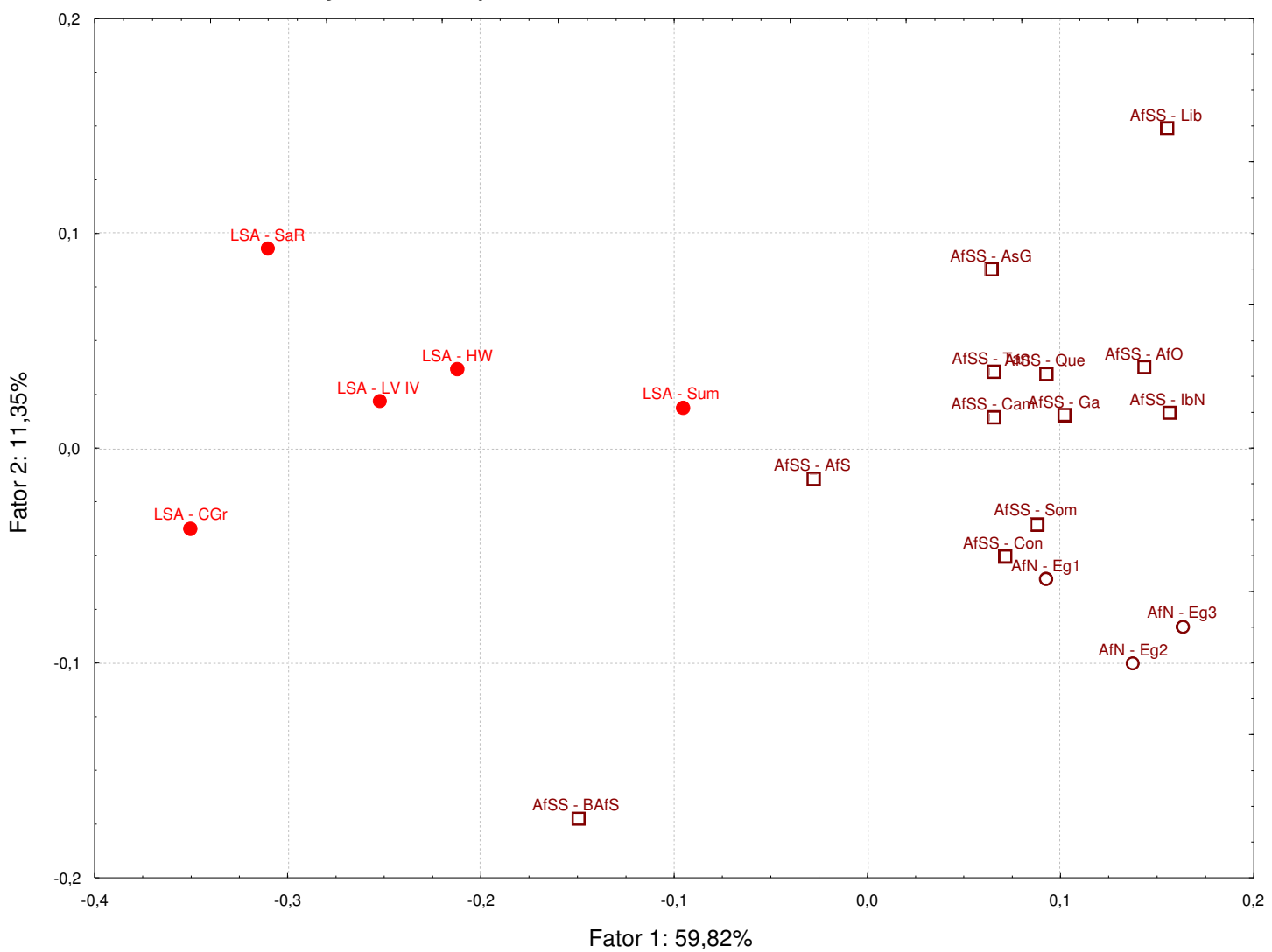


As análises apresentadas nas Figuras 4.77 a 4.80 , referem-se ao confronto com as séries Européias, divididas entre Europa e Grã-Bretanha. A análise dos gráficos gerados a partir da relação entre os dois primeiros Componentes Principais extraídos das matrizes de covariâncias, para as parcelas masculina e feminina, tamanho e forma, e apenas forma, mostram uma completa não-integração morfológica entre os centróides europeus e paleoíndio. De maneira geral, todas as séries européias, tanto as continentais quanto às da Grã-Bretanha, apresentam-se estruturalmente associadas, indicando grande similaridade morfológica entre elas.

Figura 4.77 - Gráfico bidimensional do morfo-espaço formado pelos CP $1 \times$ CP 2. Parcela masculina, tamanho e forma (análise extra-continental - conjunto Europa).

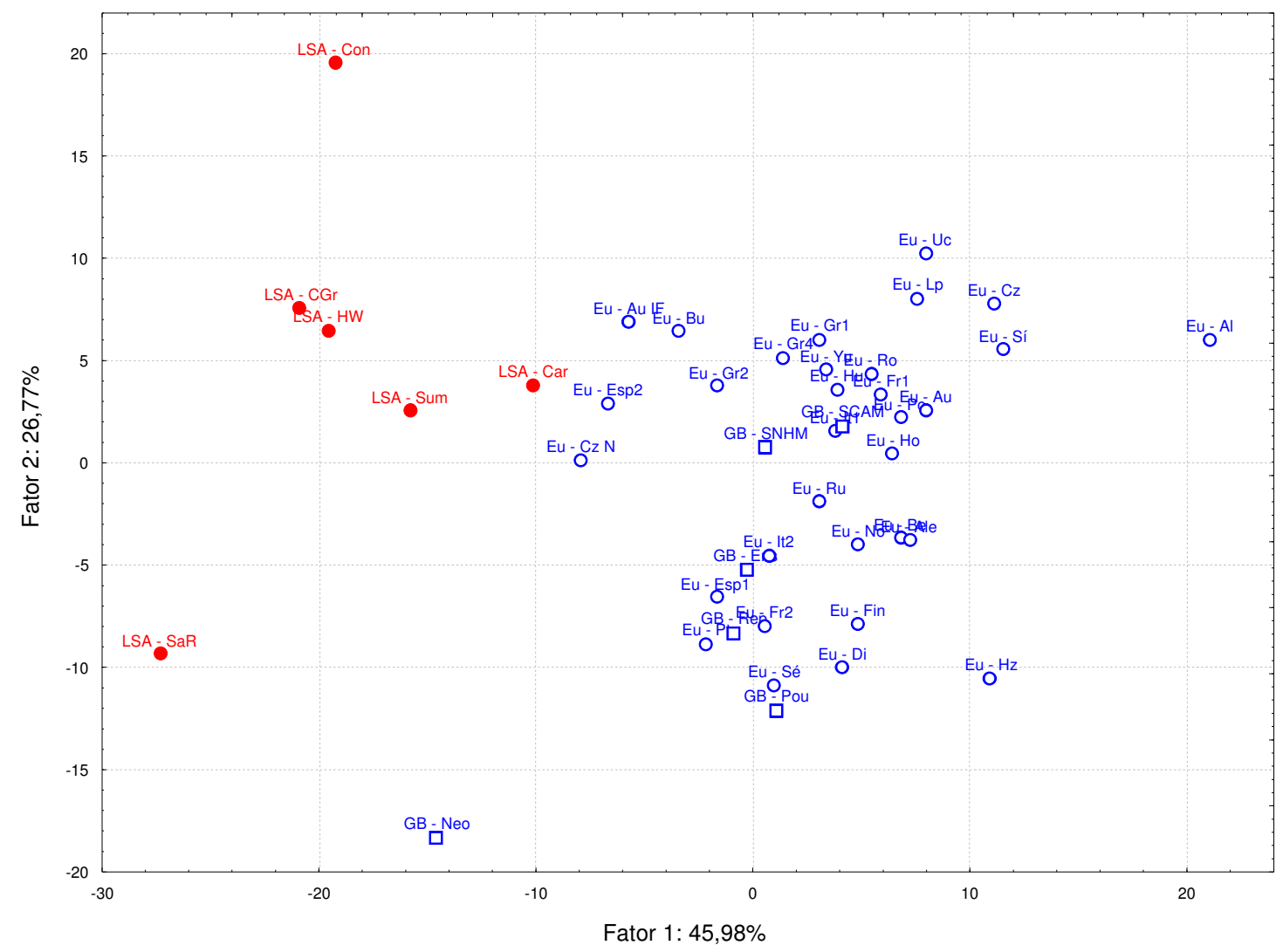


Figura 4.78 - Gráfico bidimensional do morfo-espaço formado pelos CP 1 x CP 2. Parcela masculina, apenas forma (análise extra-continental - conjunto Europa).

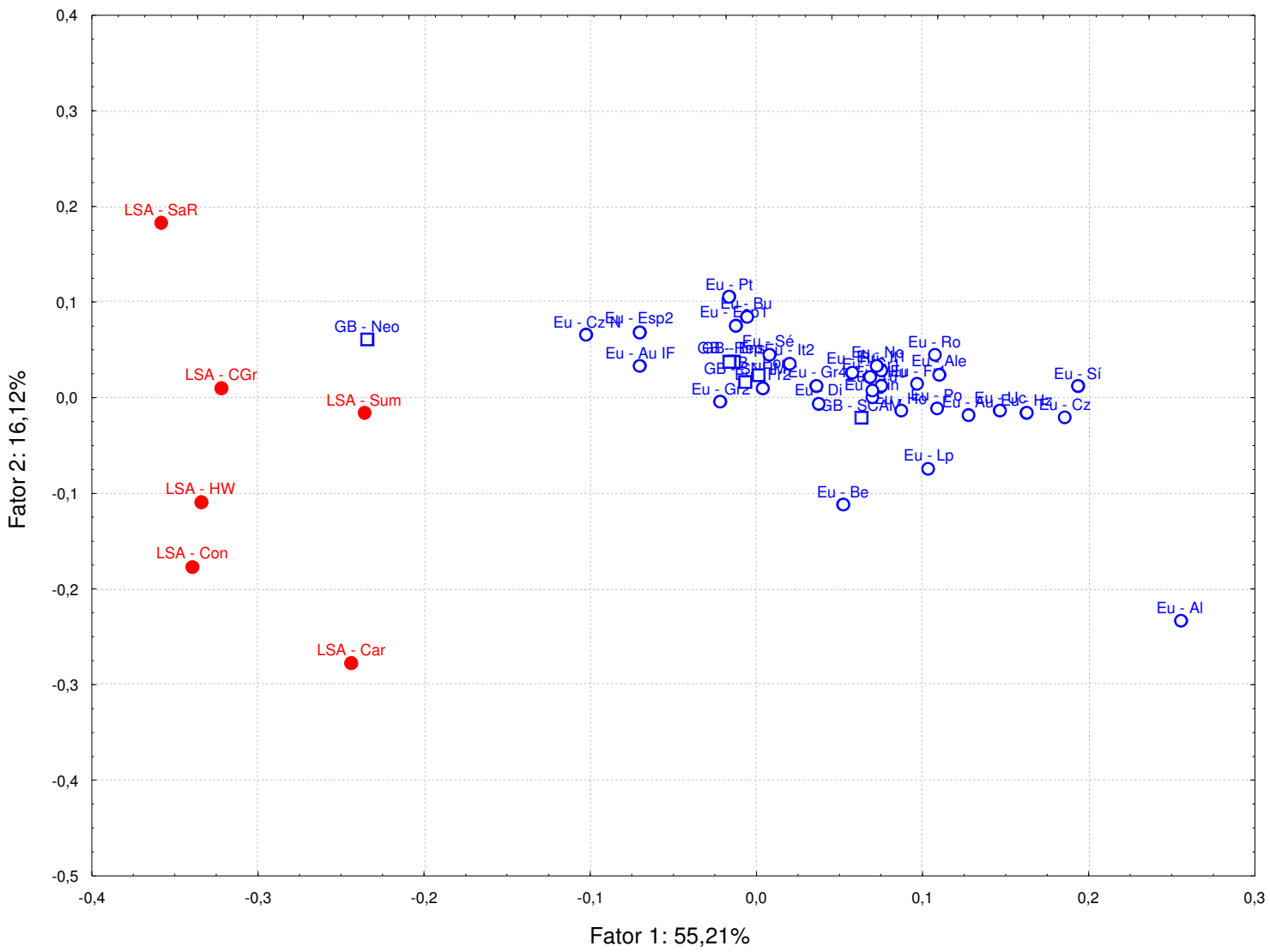

Figura 4.79 - Gráfico bidimensional do morfo-espaço formado pelos CP $1 \times$ CP 2. Parcela feminina, tamanho e forma (análise extra-continental - conjunto Europa).

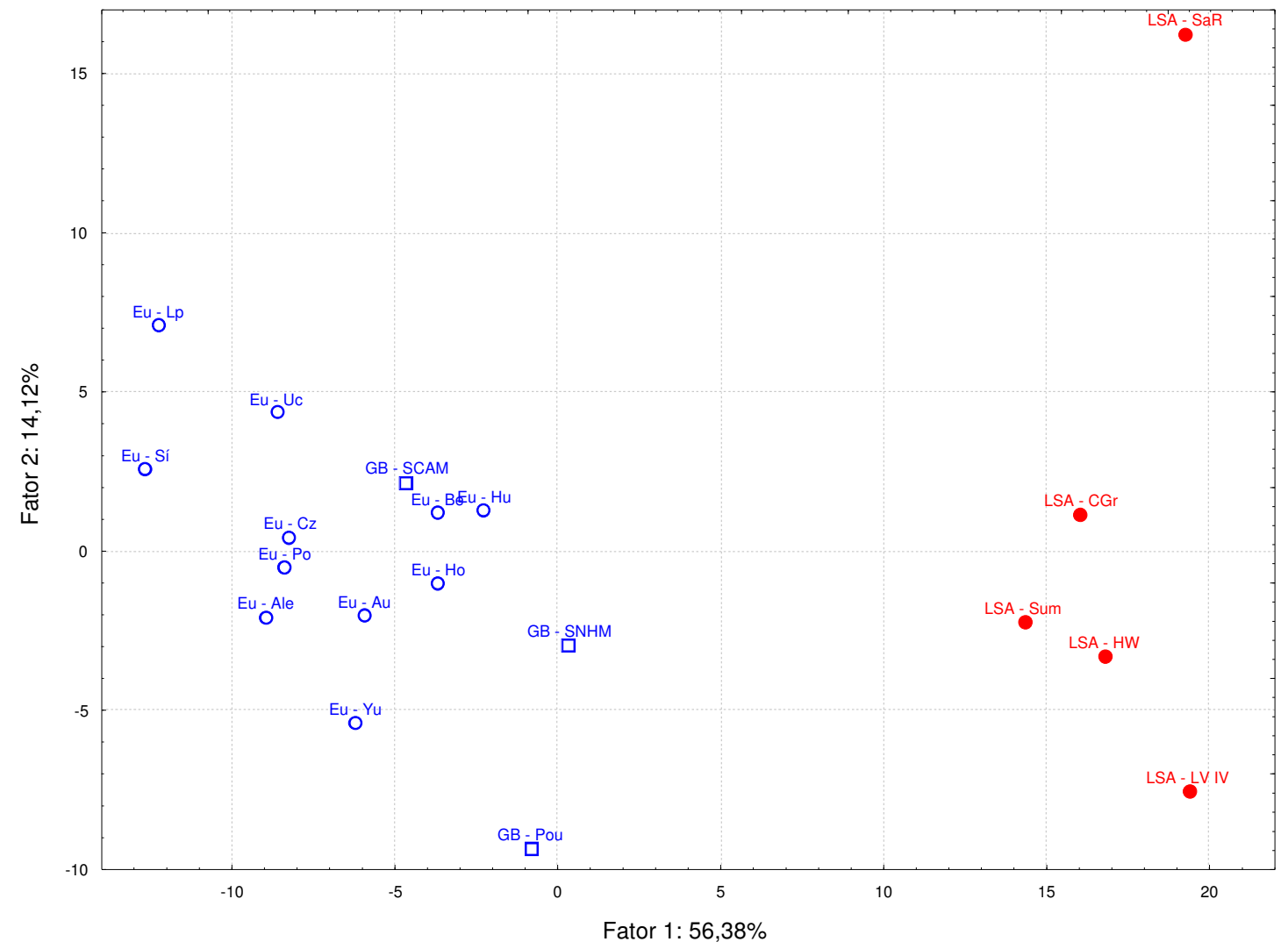


Figura 4.80 - Gráfico bidimensional do morfo-espaço formado pelos CP 1 x CP 2. Parcela feminina, apenas forma (análise extra-continental - conjunto Europa).

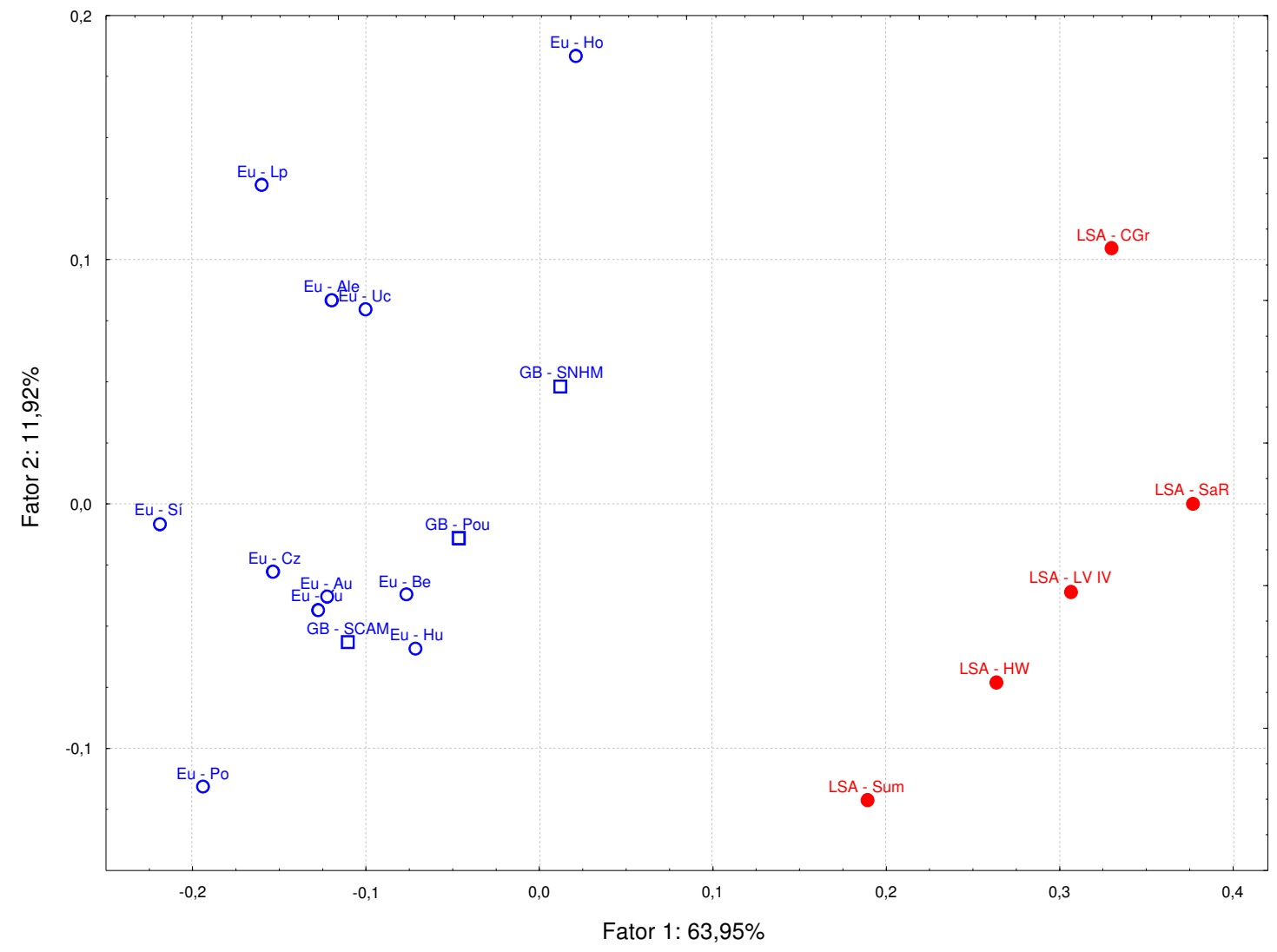

As análises apresentadas anteriormente investigaram as afinidades morfológicas entre os Paleoíndios de Lagoa Santa e as populações autóctones do Velho Mundo. Em termos gerais, a morfologia paleoamericana mostrou-se, como esperado, mais associada às populações de morfologia generalizada, como as africanas e australo-melanésicas, por exemplo, que às de morfologia especializada, como as apresentadas por europeus e asiáticos, embora, em alguns ensaios, tais associações não tenham se mostrado. 
4.2.2 - Segundo nível de inclusão das Afinidades Biológicas Extra-Continentais

A proposta para o segundo nível de inclusão das análises de afinidades extra-continentais dos paleoíndios foi a de investigar quais grupos mundiais, representados de maneiras distintas, ora por seus centróides ora por seus indivíduos, apresentam maior ou menor similaridade morfológica com a população de Lagoa Santa.

Para tanto, decidiu-se, diferentemente do que foi feito no primeiro nível de análise extra-continental, utilizar a mesma abordagem adotada na investigação das afinidades intra-continentais, isto é, combinar técnicas estatísticas multivariadas de dependência e interdependência, procurando maximizar o potencial explicativo do universo amostral utilizado. Dessa forma, os resultados aqui apresentados se referem às Análise de Componentes Principais, Análise de Agrupamentos (baseadas em matrizes de Distâncias Euclidianas e de Mahalanobis) e Escalonamento Multidimensional, executados, sempre, para as parcelas masculina e feminina, separadamente, e sobre dados de tamanho e forma e de forma apenas.

\subsubsection{1 - Parcela Masculina, Tamanho e Forma}

Os resultados obtidos através da ACP sobre os centróides das séries utilizadas, com base em tamanho e forma, para a parcela masculina, são apresentados na Tabela 4.17. O gráfico da Figura 4.81 representa o decaímento dos autovalores dos CPs (screeplot) e a escolha dos 4 primeiros componentes principais para o cálculo de distâncias Euclidianas foi baseado na análises dessa curva. 
Tabela 4.17 - Autovalores da matriz de covariância e porcentagens de variância total explicada por cada Componente Principal. Parcela masculina, forma e tamanho (14 séries, 23 variáveis craniométricas).

\begin{tabular}{c|c|c|c|c}
\hline $\begin{array}{c}\text { Componente } \\
\text { Principal }\end{array}$ & Autovalor & $\%$ Total & $\begin{array}{c}\text { Autovalor } \\
\text { Cumulativo }\end{array}$ & $\%$ Cumulativa \\
\hline 1 & 82,78189 & 52,68117 & 82,7819 & 52,6812 \\
2 & 29,62088 & 18,85029 & 112,4028 & 71,5315 \\
3 & 15,34403 & 9,76471 & 127,7468 & 81,2962 \\
4 & 12,84285 & 8,17300 & 140,5897 & 89,4692 \\
5 & 7,72001 & 4,91290 & 148,3097 & 94,3821 \\
6 & 2,82408 & 1,79720 & 151,1337 & 96,1793 \\
7 & 2,47911 & 1,57767 & 153,6129 & 97,7570 \\
8 & 1,52236 & 0,96881 & 155,1352 & 98,7258 \\
9 & 1,14411 & 0,72809 & 156,2793 & 99,4539 \\
10 & 0,44312 & 0,28199 & 156,7224 & 99,7358 \\
11 & 0,21607 & 0,13750 & 156,9385 & 99,8733 \\
12 & 0,13747 & 0,08748 & 157,0760 & 99,9608 \\
13 & 0,06155 & 0,03917 & 157,1375 & 100,0000 \\
\hline
\end{tabular}

Figura 4.81 - Gráfico de decaímento da porcentagem de variância condensada em cada Componente Principal. Parcela masculina, forma e tamanho (14 séries, 23 variáveis craniométricas).

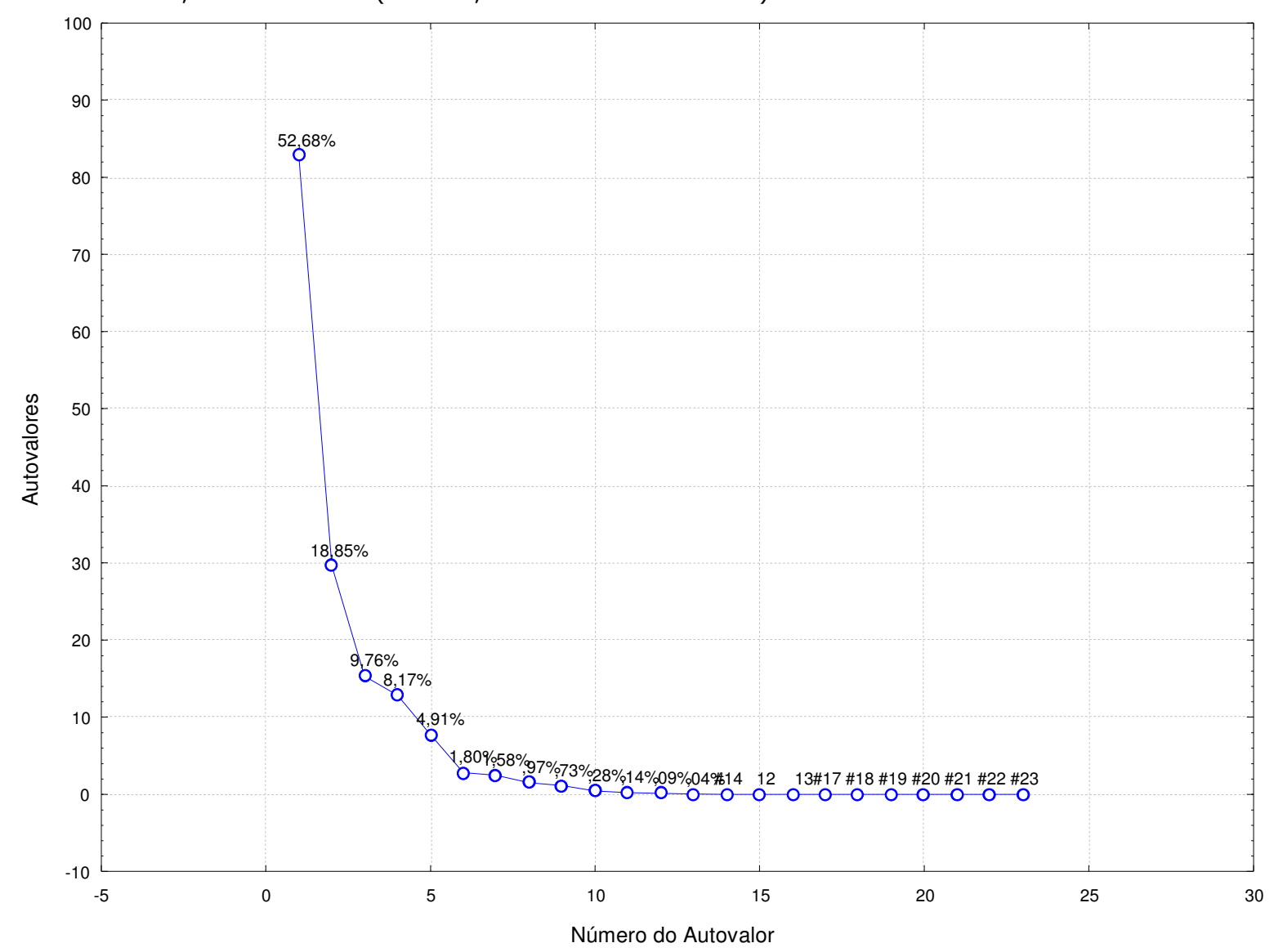

As Tabelas 4.18 e 4.19 indicam, respectivamente, os fatores de coordenadas extraídos pelos Componentes Principais para cada série e a matriz de Distância Euclidiana, calculada sobre os quatro primeiros CPs. 
Os gráficos das Figuras 4.82, 4.83 e 4.84 referem-se às comparações dos centróides no morfo-espaço constituído, respectivamente, pelas dimensões formadas pelos CP 1 × CP 2, CP 1 × CP 3 e CP 2 × CP 3. Os dendrogramas das Figuras 4.85, 4.86, 4.87 e 4.89 apresentam as análises de clusters, sob quatro regras distintas de agrupamento (Ward, Vizinhos Próximos, Vizinhos Distantes e Médias Dentro do Grupo), utilizando-se a matriz de dados baseadas nas distâncias euclidianas calculadas a partir dos CP selecionados.

Figura 4.82 - Gráfico bidimensional do morfo-espaço formado pelos CP $1 \times$ CP 2. Parcela masculina, forma e tamanho (14 séries, 23 variáveis craniométricas).

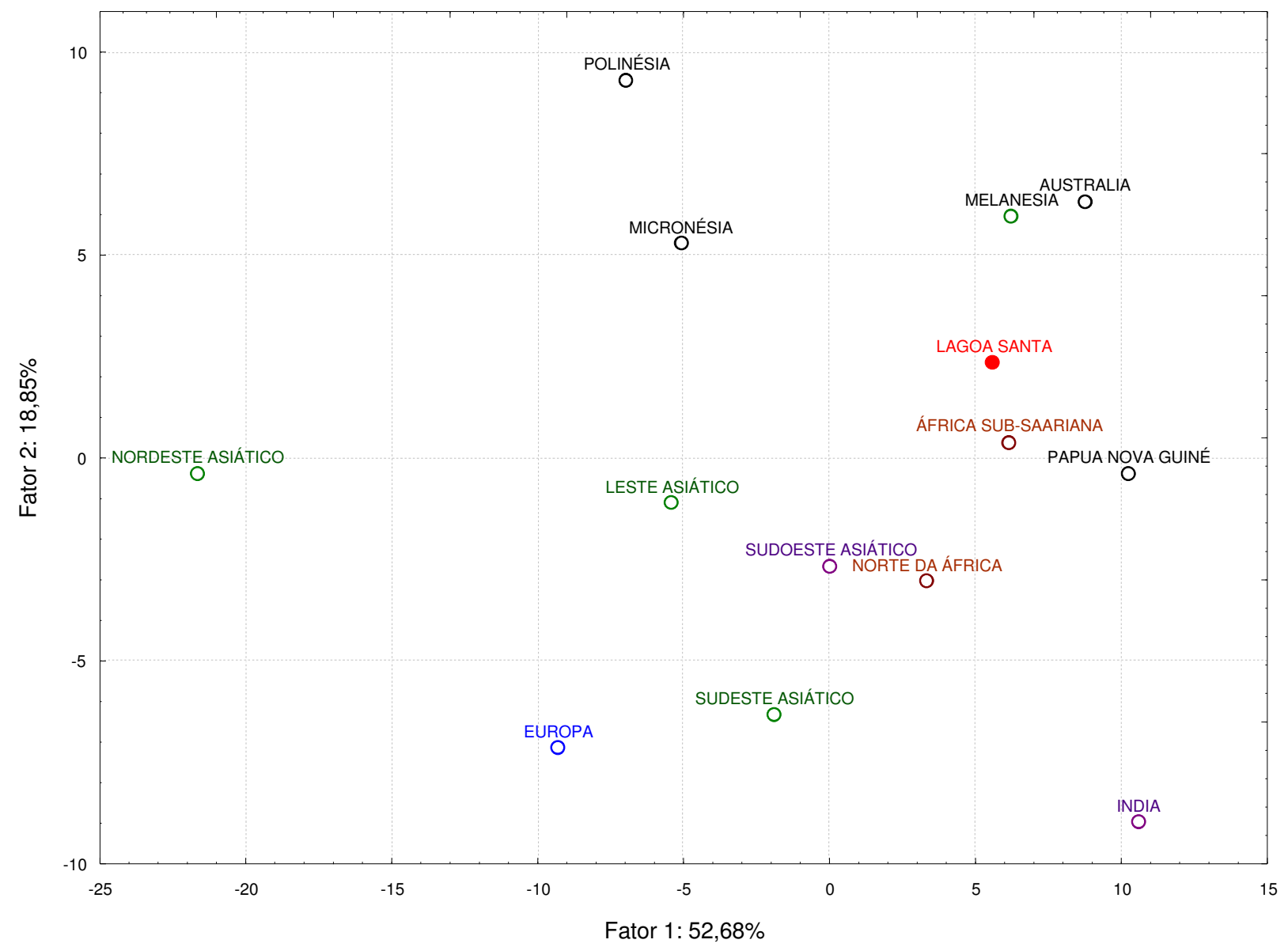


Figura 4.83 - Gráfico bidimensional do morfo-espaço formado pelos CP $1 \times$ CP 3. Parcela masculina, forma e tamanho (14 séries, 23 variáveis craniométricas).

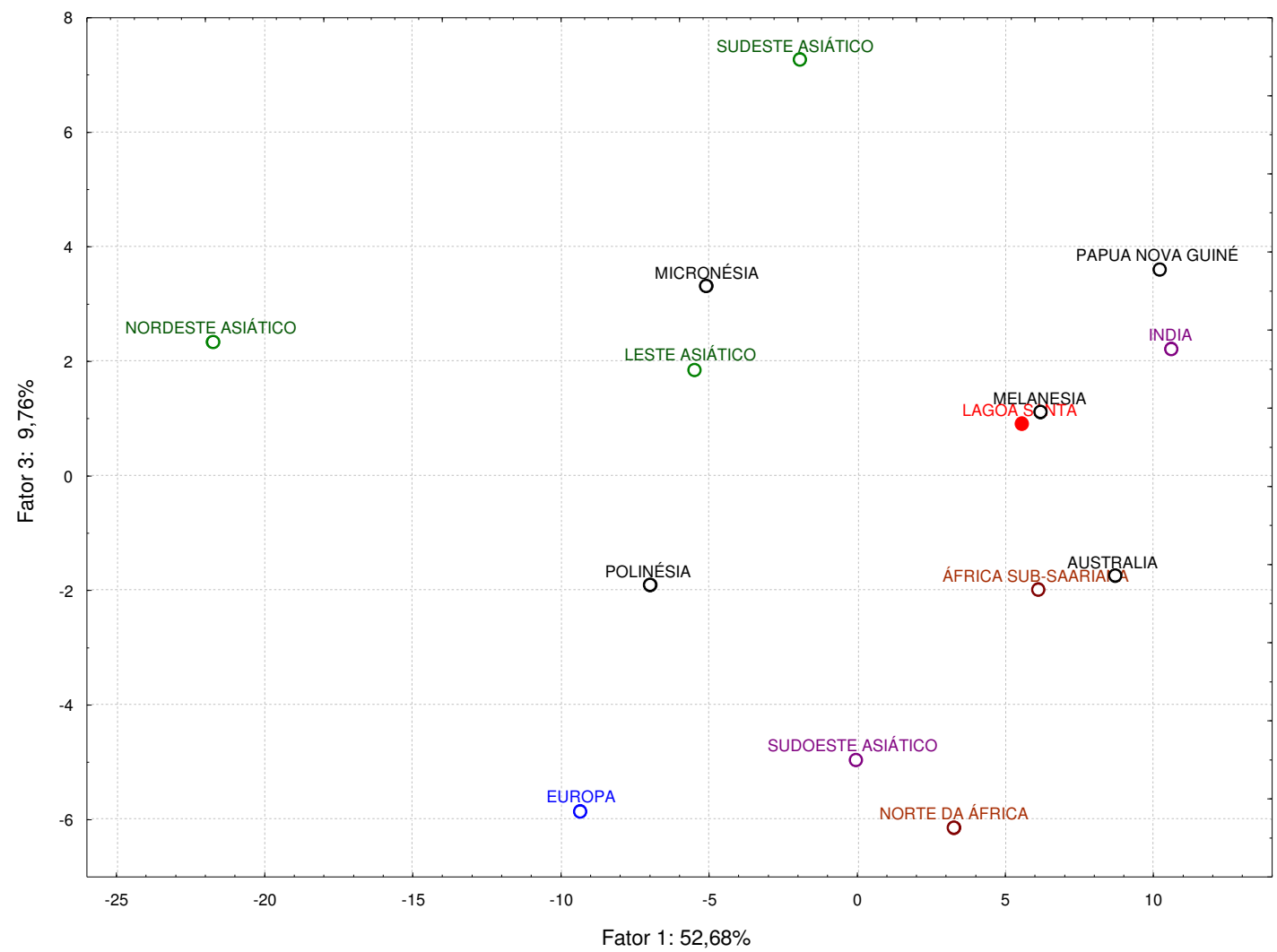

Figura 4.84 - Gráfico bidimensional do morfo-espaço formado pelos CP 2 x CP 3. Parcela masculina, forma e tamanho (14 séries, 23 variáveis craniométricas).

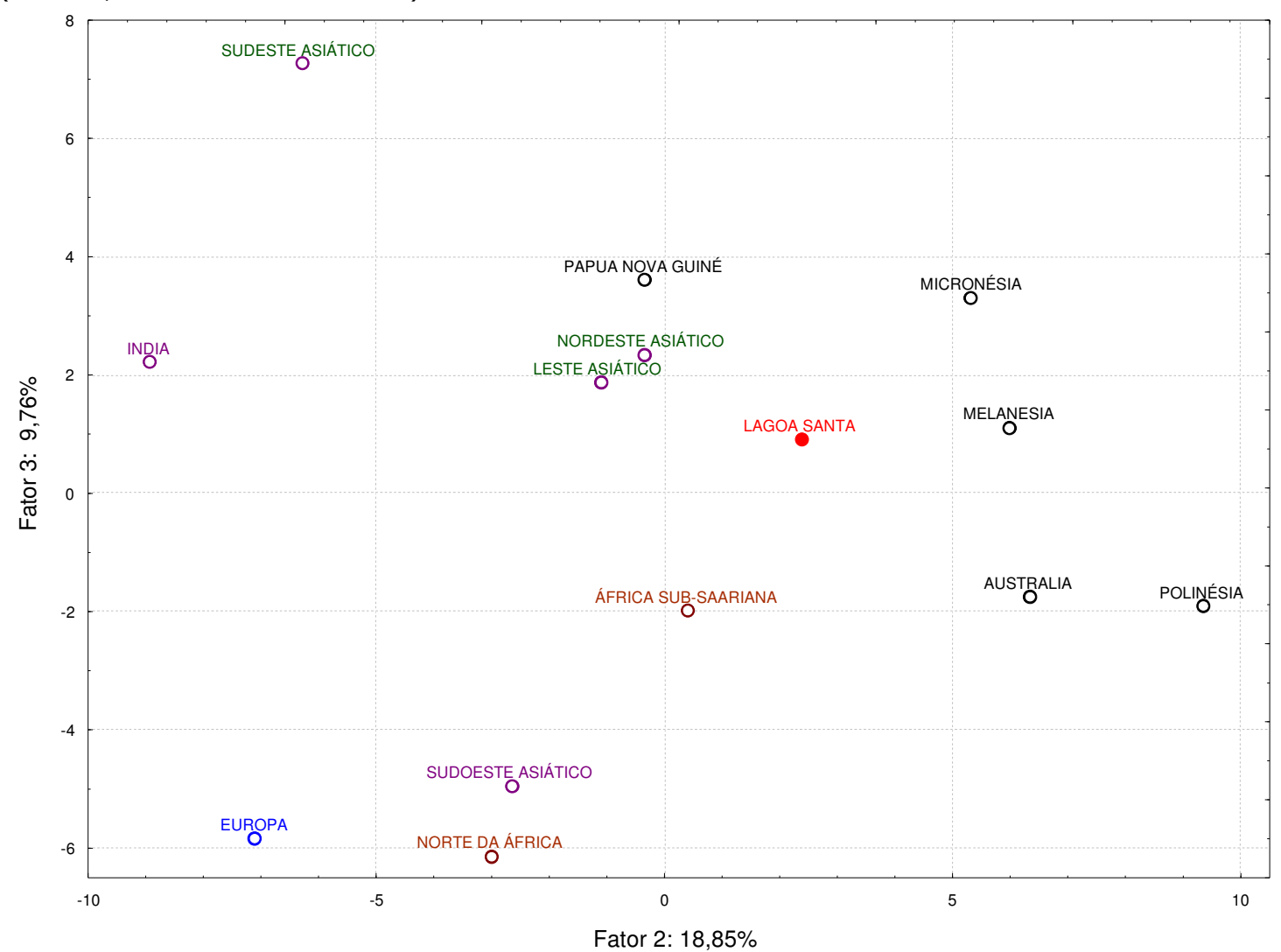


Tabela 4.18 - Fatores de coordenadas de cada série. Parcela masculina, forma e tamanho (14 séries, 23 variáveis craniométricas).

\begin{tabular}{|c|c|c|c|c|c|c|c|c|c|c|c|c|c|}
\hline & Fator 1 & Fator 2 & Fator 3 & Fator 4 & Fator 5 & Fator 6 & Fator 7 & Fator 8 & Fator 9 & Fator10 & Fator11 & Fator12 & Fator13 \\
\hline $\begin{array}{c}\text { AUSTRALIA } \\
\text { LESTE ASITICO } \\
\text { EUROPA } \\
\text { INDIA } \\
\text { MELANESIA } \\
\text { NORTE DA FIICA } \\
\text { NORDESTE ASITICO } \\
\text { PAPUA NOVA GUIN } \\
\text { POLINSIA } \\
\text { SUDESTE ASTICO } \\
\text { FRICA SUB-SAARIANA } \\
\text { SUDDESTE ASIIICO } \\
\text { LAGSA ANTIAO }\end{array}$ & $\begin{array}{l}, 7,7082 \\
-5,4989 \\
-, 93111 \\
10,5737 \\
6,1328 \\
-3,3078 \\
-21,7160 \\
10,174 \\
-7,0153 \\
-1,9591 \\
6,1026 \\
-0,0237 \\
556517\end{array}$ & 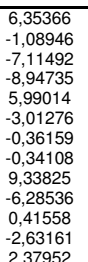 & 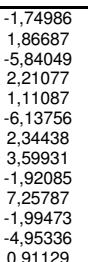 & $\begin{array}{l}5,17192 \\
-1,61959 \\
0 ., 22537 \\
0,12150 \\
2,11103 \\
-1,22993 \\
3,56951 \\
3,59162 \\
-0,95041 \\
0,06492 \\
1,69611 \\
-0,27480 \\
-0,94448\end{array}$ & 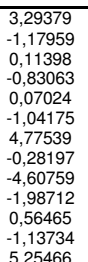 & 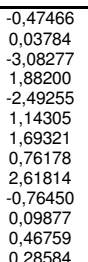 & $\begin{array}{l}-0,17847 \\
0,42638 \\
-1,80564 \\
-1,20393 \\
-0,93929 \\
1,42709 \\
0,019170 \\
-1,7537 \\
-1,29590 \\
1,15256 \\
4,0,0209 \\
-0,34101 \\
-0.61802\end{array}$ & $\begin{array}{l}-1,18597 \\
2,3894 \\
-0,98509 \\
-1,53710 \\
1,44719 \\
1,52136 \\
0 ., 14671 \\
1,24209 \\
-1,05615 \\
-0,49551 \\
-0,85131 \\
0 ., 54325 \\
-0,19223\end{array}$ & 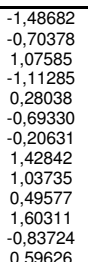 & 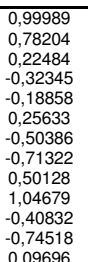 & $\begin{array}{l}, 0,192583 \\
-0,849933 \\
-0,12597 \\
-0,672113 \\
-0,382656 \\
0,613013 \\
0,034627 \\
0,467242 \\
-0,0943410 \\
0,660373 \\
-0,487036 \\
0,323310 \\
0.112228\end{array}$ & $\begin{array}{l}0,288722 \\
0,479897 \\
0,04328 \\
-0,317081 \\
-0,668411 \\
-0,615895 \\
-0,233793 \\
0,344268 \\
-0,081711 \\
-0,044300 \\
0,136579 \\
0,583797\end{array}$ & 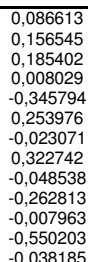 \\
\hline
\end{tabular}

Tabela 4.19 - Matriz de Distância Euclidiana calculada sobre os quatro primeiros Componentes Principais. Parcela masculina, forma e tamanho (14 séries, 23 variáveis craniométricas)

\begin{tabular}{|c|c|c|c|c|c|c|c|c|c|c|c|c|c|c|}
\hline & AUSTRALIA & $\begin{array}{l}\text { LESTE } \\
\text { ASITICO }\end{array}$ & EUROPA & INDIA & MELANESIA & $\begin{array}{l}\text { NORTE DA } \\
\text { FRICA }\end{array}$ & $\begin{array}{c}\text { NORDESTE } \\
\text { ASITICO }\end{array}$ & $\begin{array}{l}\text { PAPUA NOVA } \\
\text { GUIN }\end{array}$ & POLINSIA & $\begin{array}{c}\text { SUDESTE } \\
\text { ASITICO }\end{array}$ & $\begin{array}{l}\text { FRICA SUB- } \\
\text { SAARIANA }\end{array}$ & $\begin{array}{c}\text { SUDOESTE } \\
\text { ASITICO }\end{array}$ & $\begin{array}{l}\text { LAGOA } \\
\text { SANTA }\end{array}$ & MICRONSIA \\
\hline AUSTRALIA & 0,0 & 16,4 & 22,9 & 15,9 & 3,8 & 11,7 & 31,4 & 8,7 & 16,0 & 18,8 & 6,5 & 12,9 & 5,7 & 14,7 \\
\hline $\begin{array}{l}\text { LESTE } \\
\text { ASITICO }\end{array}$ & & 0,0 & 10,5 & 17,9 & 13,7 & 12,0 & 16,2 & 15,8 & 11,2 & 8,3 & 12,3 & 8,9 & 11,6 & 6,6 \\
\hline EUROPA & & & 0,0 & 21,5 & 21,5 & 13,3 & 16,3 & 22,7 & 17,1 & 15,0 & 17,6 & 10,4 & 18,9 & 16,0 \\
\hline INDIA & & & & 0,0 & 15,6 & 12,6 & 33,4 & 8,7 & 25,7 & 13,8 & 11,2 & 14,3 & 12,5 & 21,2 \\
\hline MELANESIA & & & & & 0,0 & 11,9 & 28,6 & 7,9 & 14,0 & 16,0 & 6,4 & 12,2 & 3,7 & 11,5 \\
\hline $\begin{array}{l}\text { NORTE DA } \\
\text { FRICA }\end{array}$ & & & & & & 0,0 & 26,6 & 12,2 & 16,6 & 14,8 & 6,1 & 3,6 & 9,2 & 15,1 \\
\hline $\begin{array}{l}\text { NORDESTE } \\
\text { ASITICO }\end{array}$ & & & & & & & 0,0 & 31,9 & 18,1 & 21,2 & 28,2 & 23,0 & 27,5 & 17,6 \\
\hline $\begin{array}{l}\text { PAPUA NOVA } \\
\text { GUIN }\end{array}$ & & & & & & & & 0,0 & 20,5 & 14,0 & 7,0 & 13,5 & 6,0 & 16,3 \\
\hline POLINSIA & & & & & & & & & 0,0 & 18,8 & 15,9 & 14,2 & 14,7 & 6,9 \\
\hline $\begin{array}{l}\text { SUDESTE } \\
\text { ASITICO }\end{array}$ & & & & & & & & & & 0,0 & 14,0 & 12,9 & 13,1 & 12,6 \\
\hline $\begin{array}{l}\text { FRICA SUB- } \\
\text { SAARIANA }\end{array}$ & & & & & & & & & & & 0,0 & 7,5 & 3,5 & 13,3 \\
\hline $\begin{array}{l}\text { SUDOESTE } \\
\text { ASITICO }\end{array}$ & & & & & & & & & & & & 0,0 & 9,5 & 12,5 \\
\hline $\begin{array}{l}\text { LAGOA } \\
\text { SANTA }\end{array}$ & & & & & & & & & & & & & 0,0 & 11,3 \\
\hline MICRONSIA & & & & & & & & & & & & & & 0,0 \\
\hline
\end{tabular}


Figura 4.85 - Dendrograma gerado sobre matriz de Distância Euclidiana calculada a partir dos quatro primeiros Componentes Principais - Método de Ward. Parcela masculina, forma e tamanho (14 séries, 23 variáveis craniométricas).

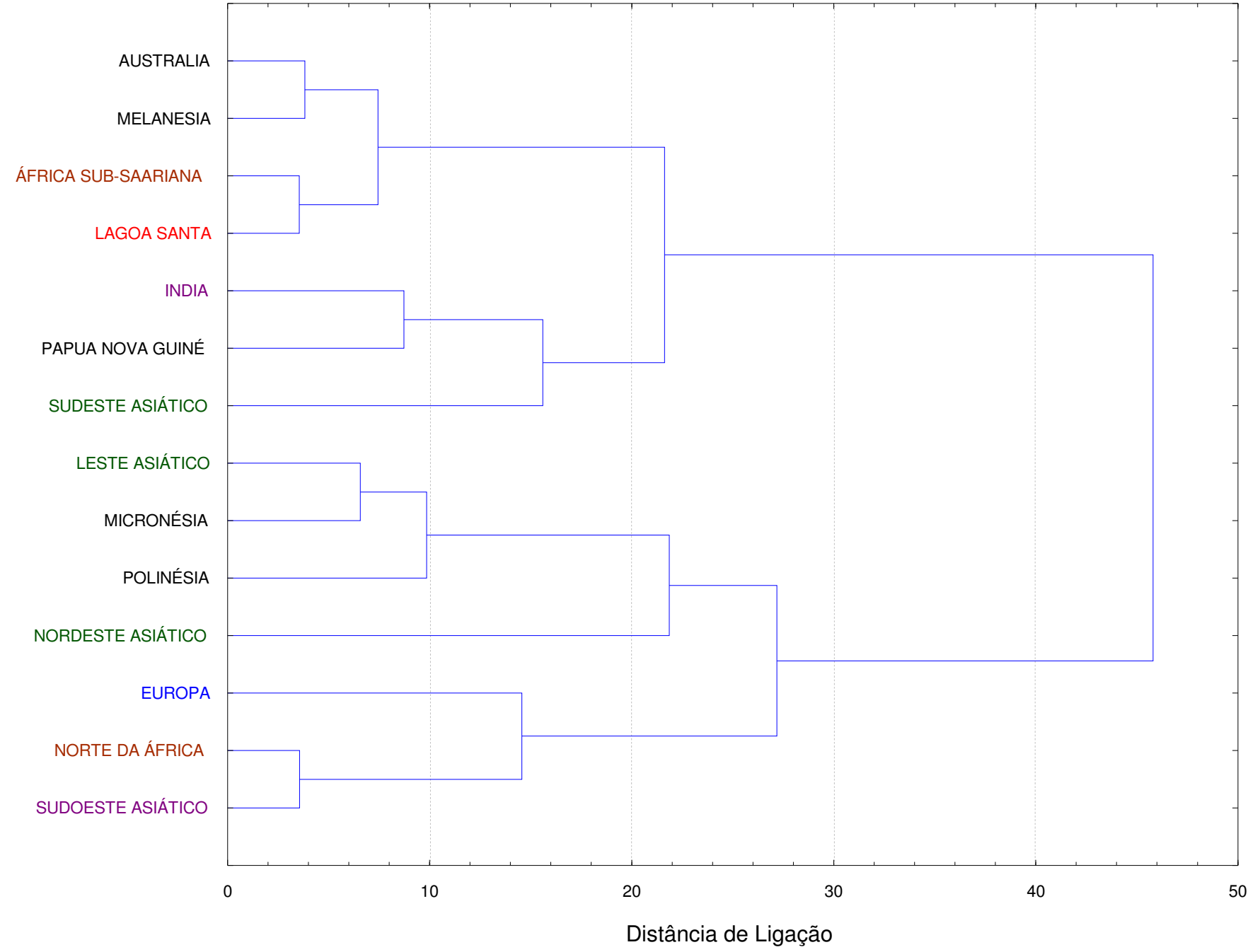


Figura 4.86 - Dendrograma gerado sobre matriz de Distância Euclidiana calculada a partir dos quatro primeiros Componentes Principais - Método de Ligação Simples. Parcela masculina, forma e tamanho (14 séries, 23 variáveis craniométricas).

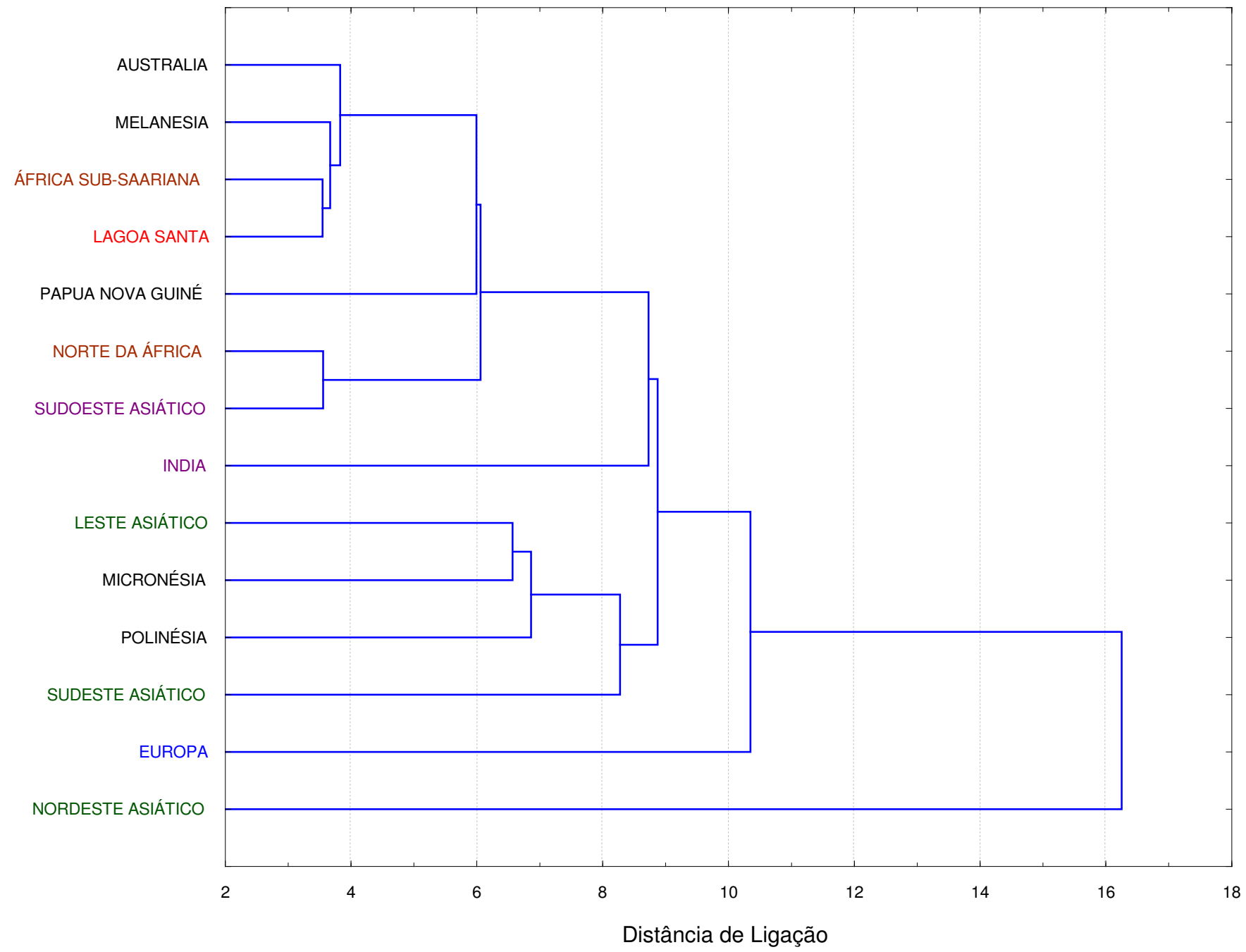


Figura 4.87 - Dendrograma gerado sobre matriz de Distância Euclidiana calculada a partir dos quatro primeiros Componentes Principais - Método de Ligação Completa. Parcela masculina, forma e tamanho (14 séries, 23 variáveis craniométricas).

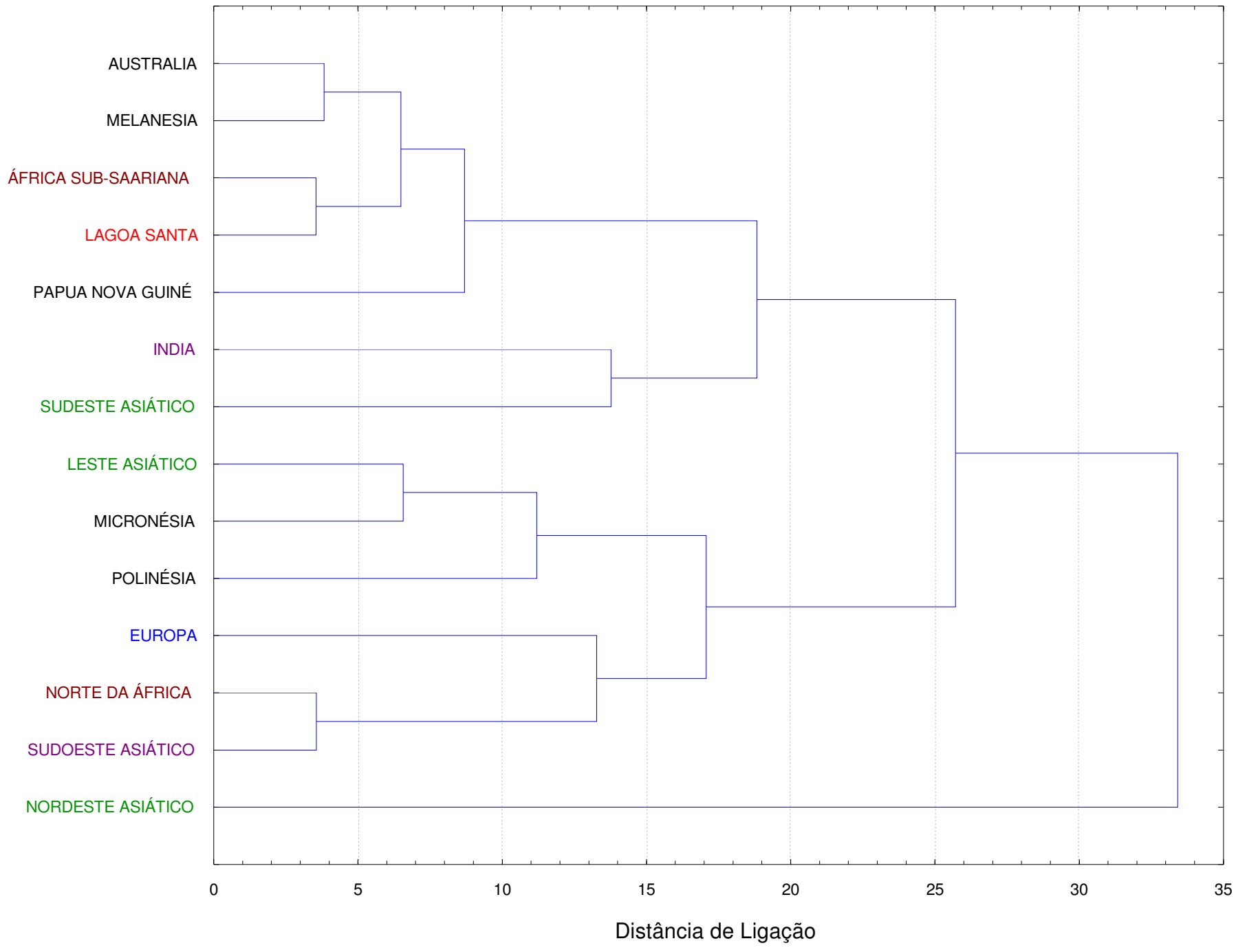


Figura 4.88 - Dendrograma gerado sobre matriz de Distância Euclidiana calculada a partir dos quatro primeiros Componentes Principais - Método da Média dos Grupos. Parcela masculina, forma e tamanho (14 séries, 23 variáveis craniométricas).

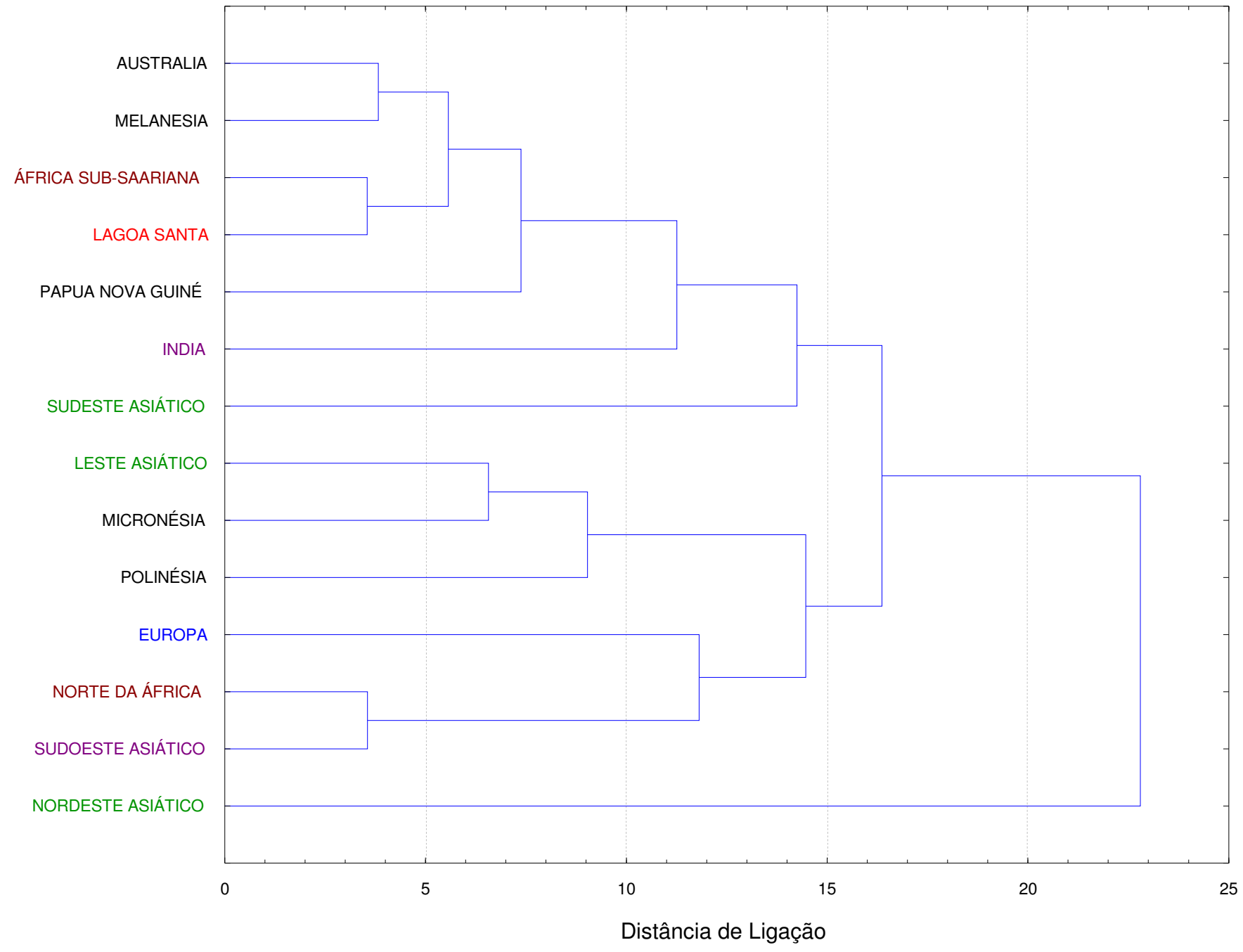



Os gráficos e dendrogramas relativos à investigação das afinidades extra-continentais dos Paleoíndios de Lagoa Santa segundo a parcela masculina não corrigida quanto ao fator tamanho, indicam, indubitavelmente, uma associação morfológica estreita entre a população paleoamericana e as de morfologia generalizada do Velho Mundo (Africanos Subsaarianos e AustraloMelanésicos). A análise das topologias bi-dimensionais geradas pela relação ortogonal entre os três primeiros Componentes Principais sustenta esta posição, uma vez que, nos três gráficos, a população de Lagoa Santa se encontra fortemente associada às australo-melanésicas e africanas subsaarianas, ocupando, juntas, sempre a região do plano dominado pelas projeções vetoriais definidas pelas variáveis que indicam crânios de morfologia mais alta, estreitas, longas e prognatas, em oposição à posição antagônica do morfo-espaço, ocupado, predominantemente, pelos centróides das populações do leste asiático, ostentando morfologia caracterizada por crânios largos e hortognatos.

Os quatro clusters, gerados sob diferentes critérios de agrupamento, confirmam a associação morfológica observada entre os Paleoíndios de Lagoa Santa e os africanos subsaarianos e australo-melanésicos. Embora, em alguns casos específicos, a relação de oposição aos centróides representantes da morfologia especializada asiática, mongolóide, não seja tão clara quanto a observada nos gráficos bi-dimensionais, é evidente a não-associação dos primeiros aos últimos, dando mais robustez à associação observada com os representantes da morfologia generalizada.

$\mathrm{Na}$ tentativa de otimizar o potencial analítico da amostra trabalhada, executou-se também análises de agrupamentos executados a partir de matrizes de Distância de Mahalanobis, através dos mesmos quatro critérios de agregação (Tabela 4.20, Figuras 4.89 a 4.92), que também subsidiou a aplicação da técnica de Escalonamento Multidimensional - MDS (Tabela 4.21, Figuras 4.93 a 4.95). 
Tabela 4.20 - Matriz de Distância de Mahalanobis. Parcela masculina, forma e tamanho (4904 indivíduos, 23 variáveis craniométricas).

\begin{tabular}{|c|c|c|c|c|c|c|c|c|c|c|c|c|c|c|}
\hline & Austrália & $\begin{array}{l}\text { Leste } \\
\text { Asiático }\end{array}$ & Europa & India & Melanésia & $\begin{array}{l}\text { Norte da } \\
\text { África }\end{array}$ & $\begin{array}{l}\text { Nordeste } \\
\text { Asiático }\end{array}$ & $\begin{array}{l}\text { Papua } \\
\text { Nova } \\
\text { Guiné }\end{array}$ & Polinésia & $\begin{array}{l}\text { Sudeste } \\
\text { Asiático }\end{array}$ & $\begin{array}{l}\text { África } \\
\text { Sub- } \\
\text { Saariana }\end{array}$ & $\begin{array}{l}\text { Sudoeste } \\
\text { Asiático }\end{array}$ & Micronésia & $\begin{array}{l}\text { Lagoa } \\
\text { Santa }\end{array}$ \\
\hline Austrália & 0,00000 & 4,37303 & 4,88566 & 3,56291 & 2,01077 & 4,24887 & 5,94510 & 2,35416 & 3,90141 & 4,13007 & 3,58049 & 3,93644 & 3,77701 & 5,65564 \\
\hline Leste Asiático & & 0,00000 & 3,12159 & 2,52531 & 3,45389 & 2,45434 & 2,92871 & 3,15904 & 2,70798 & 1,48869 & 2,98271 & 2,35506 & 2,12017 & 4,31467 \\
\hline Europa & & & 0,00000 & 3,01312 & 4,35884 & 2,43483 & 3,93441 & 4,08867 & 3,95800 & 3,31877 & 3,73728 & 1,80679 & 3,94343 & 5,05205 \\
\hline Índia & & & & 0,00000 & 3,15724 & 1,94425 & 4,70188 & 2,51060 & 3,39675 & 2,27289 & 2,67944 & 1,68545 & 2,73895 & 4,08254 \\
\hline Melanésia & & & & & 0,00000 & 3,70753 & 5,44184 & 1,19832 & 3,19778 & 3,36806 & 3,08929 & 3,34969 & 2,79959 & 5,08214 \\
\hline $\begin{array}{l}\text { Nordeste } \\
\text { Asiático }\end{array}$ & & & & & & & 0,00000 & 5,29319 & 4,14964 & 3,47633 & 4,78589 & 4,14410 & 4,16233 & 5,71582 \\
\hline $\begin{array}{l}\text { Papua Nova } \\
\text { Guiné }\end{array}$ & & & & & & & & 0,00000 & 3,13569 & 2,93576 & 2,62897 & 2,87116 & 2,77416 & 4,95273 \\
\hline Polinésia & & & & & & & & & 0,00000 & 2,96002 & 3,66244 & 3,16630 & 2,29228 & 5,07649 \\
\hline $\begin{array}{l}\text { Sudeste } \\
\text { Asiático }\end{array}$ & & & & & & & & & & 0,00000 & 2,83702 & 2,48227 & 2,03963 & 4,45710 \\
\hline $\begin{array}{l}\text { África } \\
\text { Saariana }\end{array}$ & & & & & & & & & & & 0,00000 & 2,72284 & 3,23671 & 4,57833 \\
\hline
\end{tabular}


Figura 4.89 - Dendrograma gerado sobre matriz de Distância de Mahalanobis - Método de Ward. Parcela masculina, forma e tamanho (4904 indivíduos, 23 variáveis craniométricas).

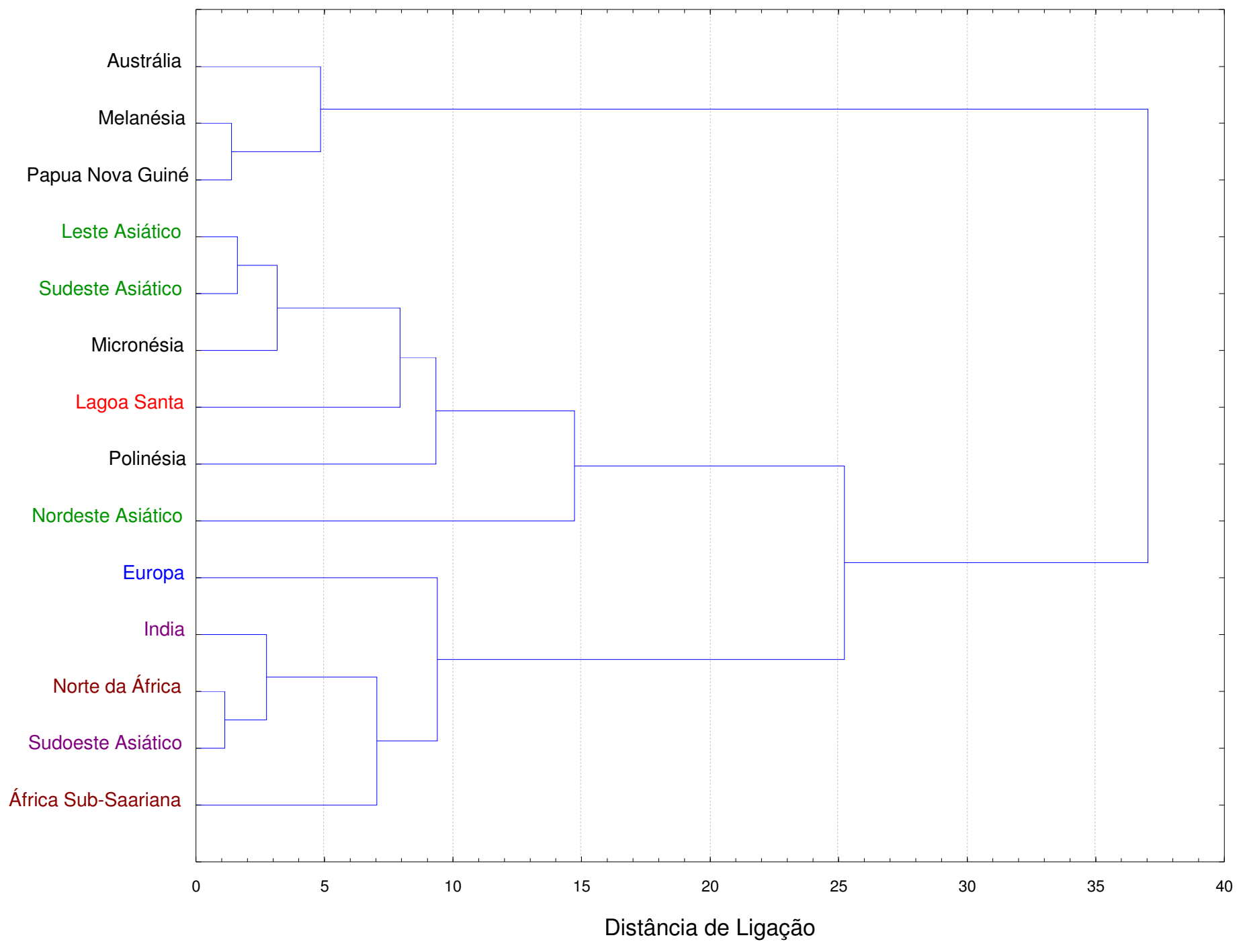


Figura 4.90 - Dendrograma gerado sobre matriz de Distância de Mahalanobis - Método de Ligação Simples. Parcela masculina, forma e tamanho (4904 indivíduos, 23 variáveis craniométricas).

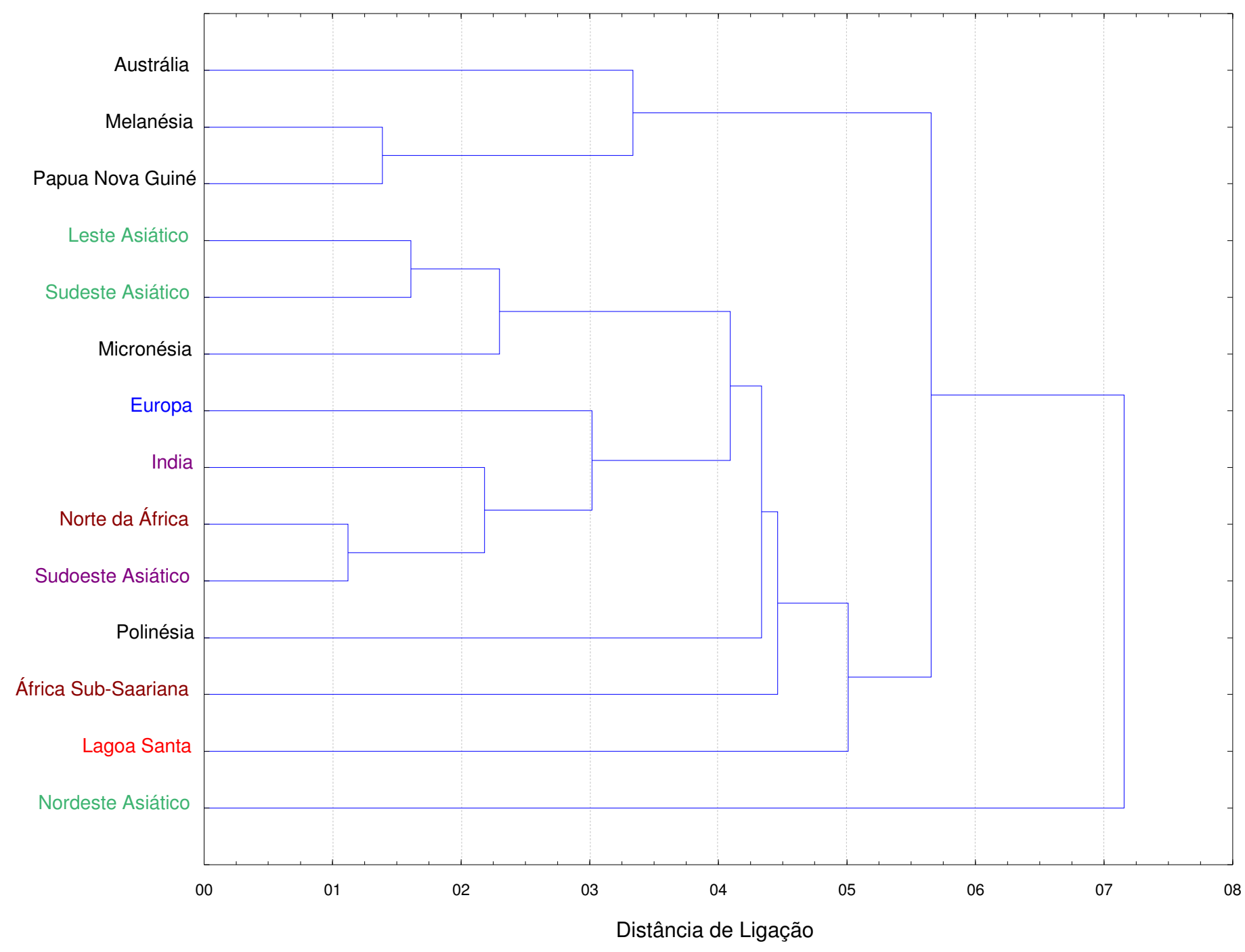


Figura 4.91 - Dendrograma gerado sobre matriz de Distância de Mahalanobis - Método de Ligação Completa. Parcela masculina, forma e tamanho (4904 indivíduos, 23 variáveis craniométricas).

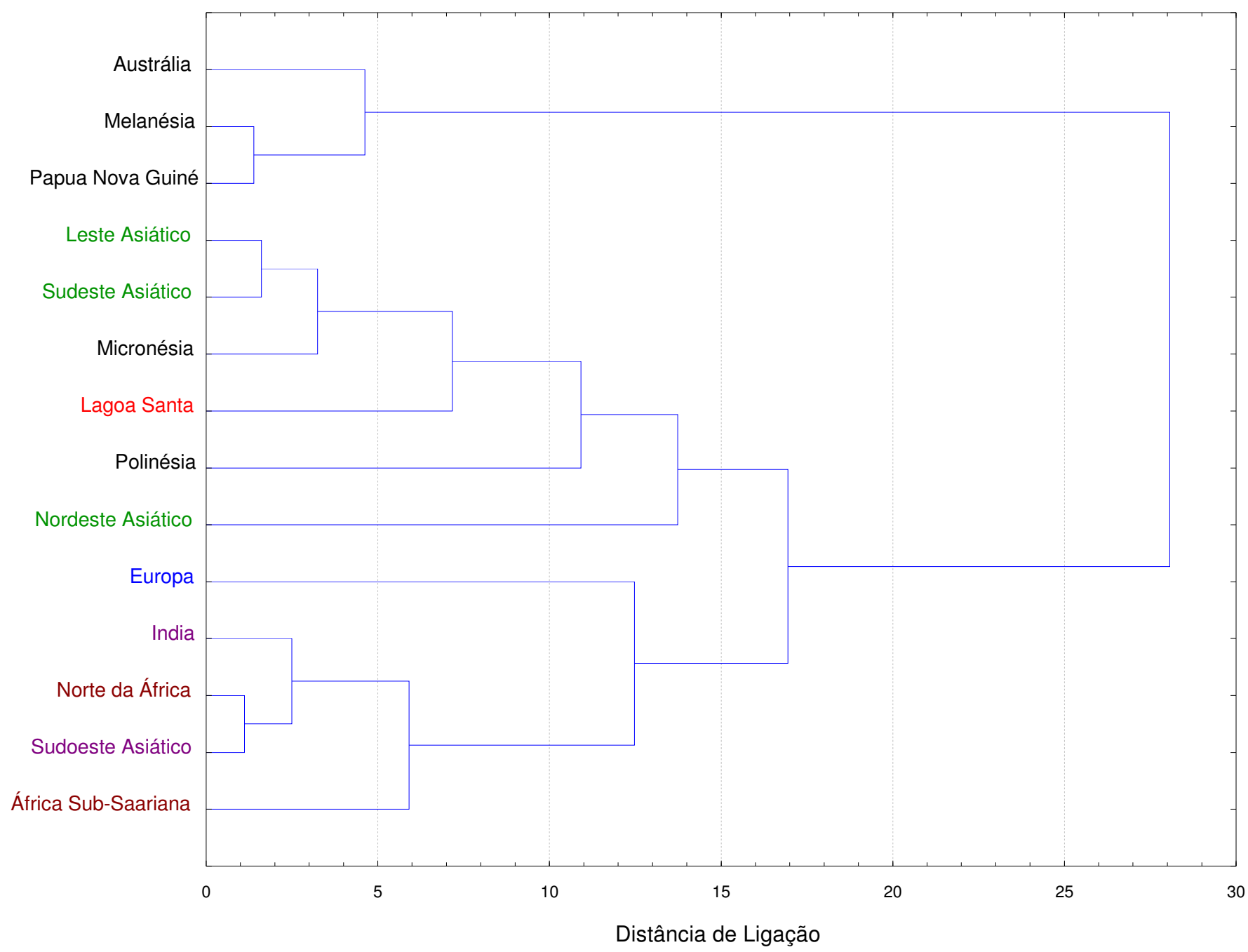


Figura 4.92 - Dendrograma gerado sobre matriz de Distância de Mahalanobis - Método da Média dos Grupos. Parcela masculina, forma e tamanho (4904 indivíduos, 23 variáveis craniométricas).

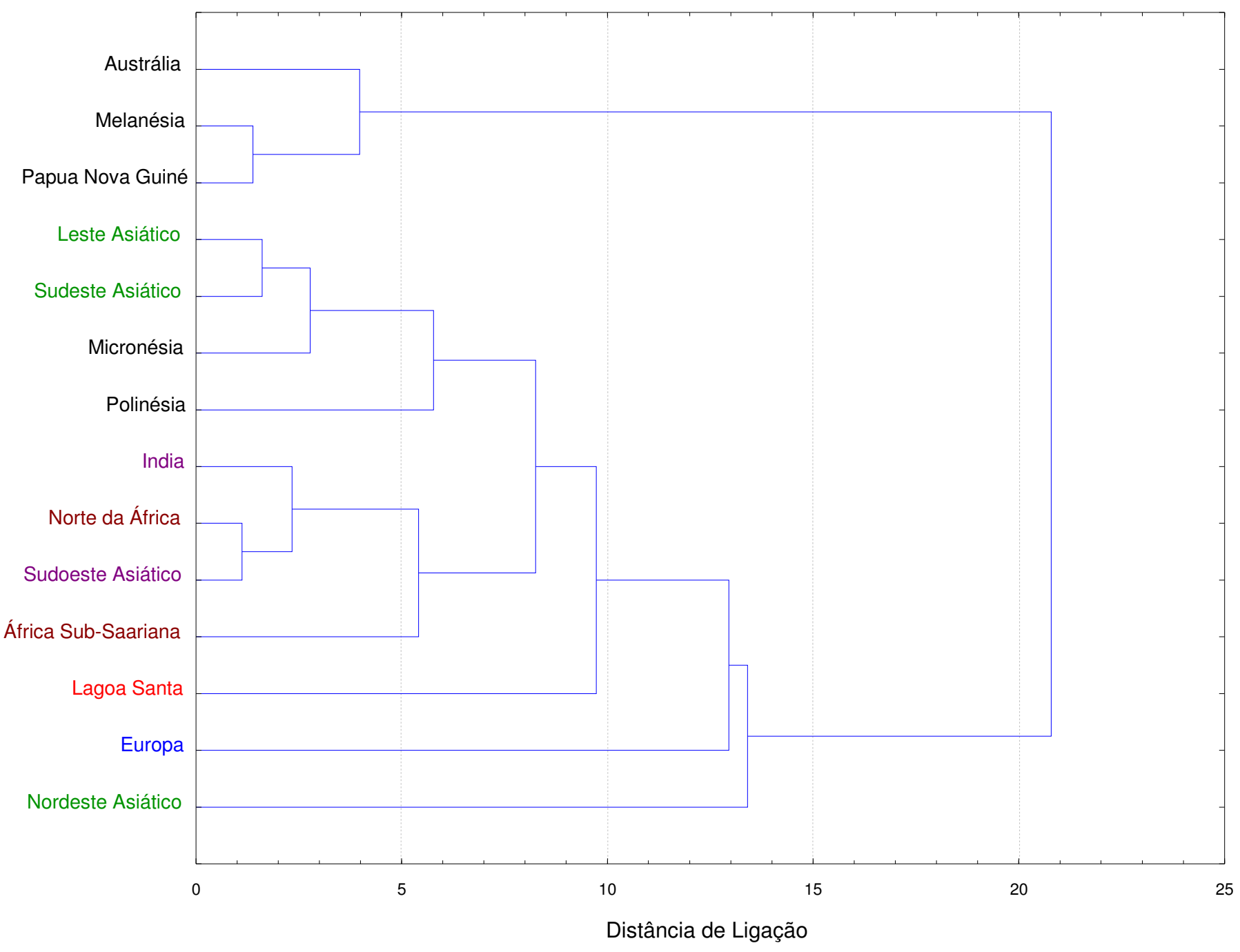


Tabela 4.21 - Configuração final das dimensões calculadas através de escalonamento multidimensional sobre Matriz de Distância baseada em Distâncias de Mahalanobis. Parcela masculina, forma e tamanho (4904 indivíduos, 23 variáveis craniométricas).

\begin{tabular}{l|l|l|l}
\hline & DIMENSÃO 1 & DIMENSÃO 2 & DIMENSÃO 3 \\
\hline Austarria & $-1,58426$ & $-0,07290$ & $-0,292553$ \\
Leste Asiático & 0,39171 & 0,24426 & 0,004504 \\
Europa & 0,91256 & $-1,02035$ & $-0,087525$ \\
Índia & $-0,04148$ & $-0,39884$ & 0,299314 \\
Melanésia & $-1,05552$ & 0,26624 & 0,106388 \\
Norte da África & 0,24259 & $-0,67648$ & 0,182075 \\
Nordeste Asiático & 1,51414 & 0,64053 & $-0,559839$ \\
Papua Nova Guiné & $-0,88599$ & $-0,03977$ & 0,059851 \\
Polinésia & $-0,19103$ & 0,88947 & $-0,211764$ \\
Sudeste Asiático & 0,35219 & 0,08518 & $-0,244898$ \\
África Sub-Saariana & $-0,30422$ & $-0,33026$ & $-0,528544$ \\
Sudoeste Asiático & 0,13643 & $-0,56088$ & 0,127244 \\
Micronésia & $-0,00967$ & 0,46864 & 0,254019 \\
Lagoa Santa & 0,52255 & 0,50515 & 0,891727 \\
\hline
\end{tabular}

Figura 4.93 - Gráfico bidimensional da relação ortogonal entre as dimensões $1 \times 2$. Parcela masculina, forma e tamanho (4904 indivíduos, 23 variáveis craniométricas).

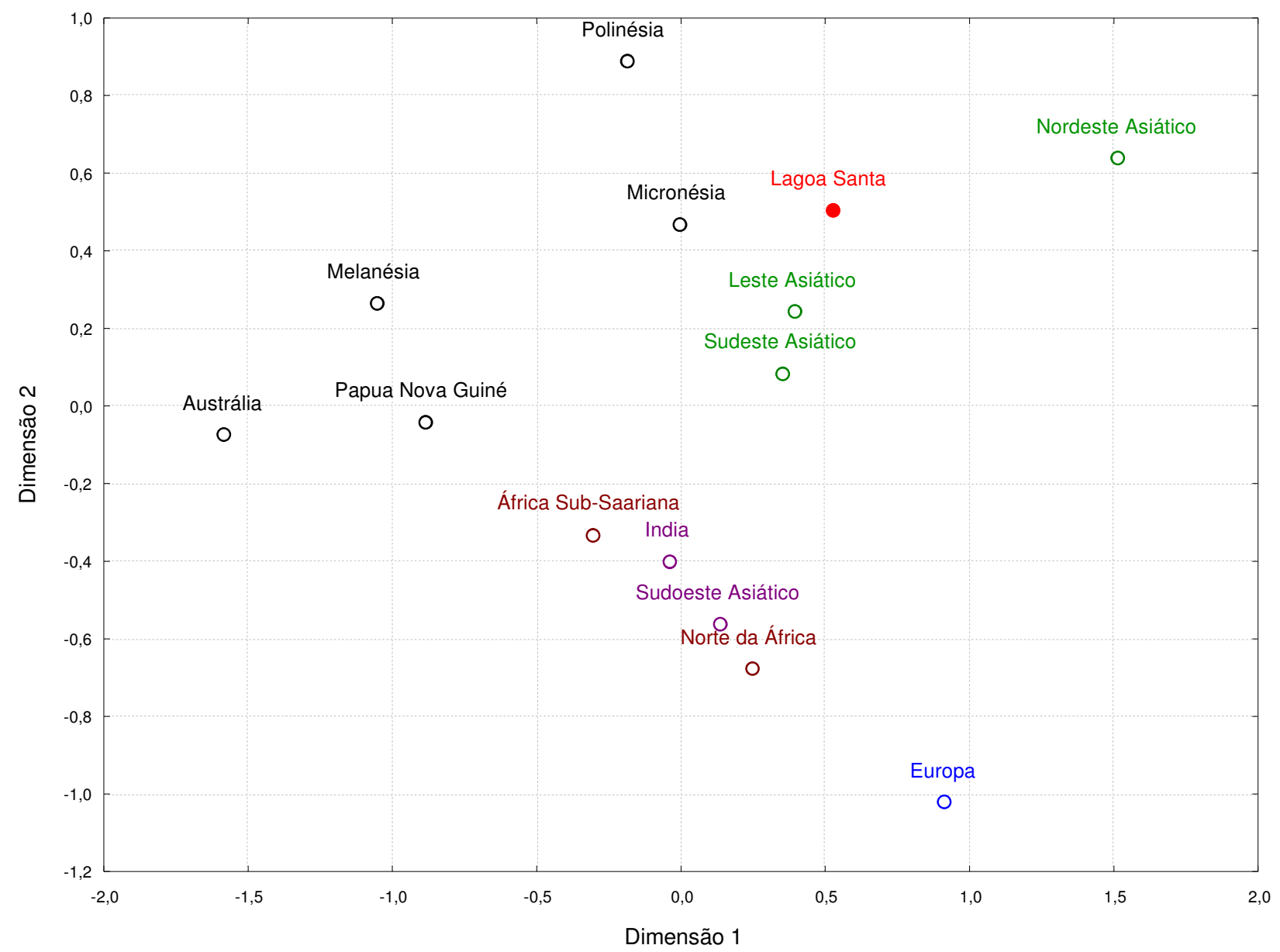


Figura 4.94 - Gráfico bidimensional da relação ortogonal entre as dimensões $1 \times 3$. Parcela masculina, forma e tamanho (4904 indivíduos, 23 variáveis craniométricas).

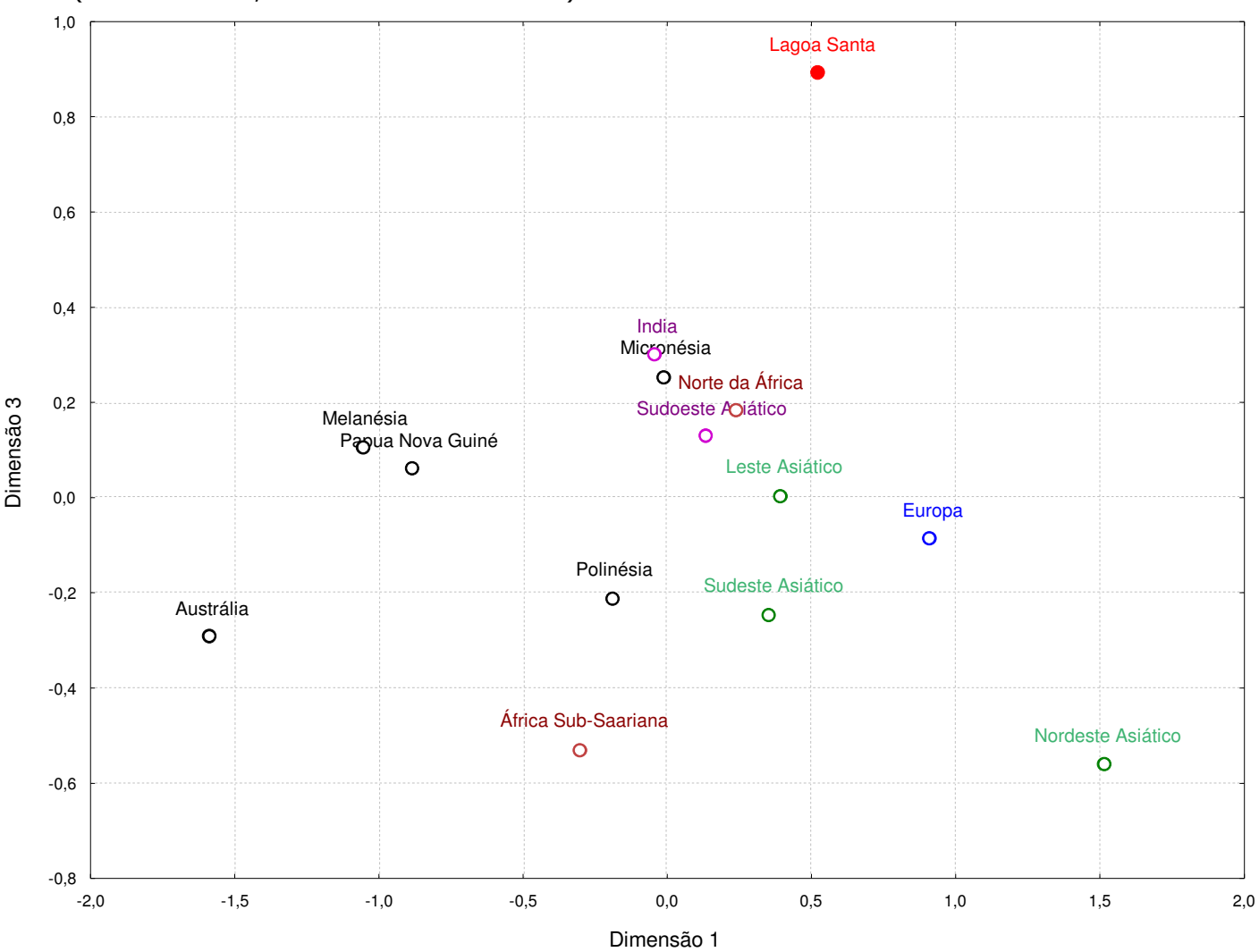

Figura 4.95 - Gráfico bidimensional da relação ortogonal entre as dimensões $2 \times 3$. Parcela masculina, forma e tamanho (4904 indivíduos, 23 variáveis craniométricas).

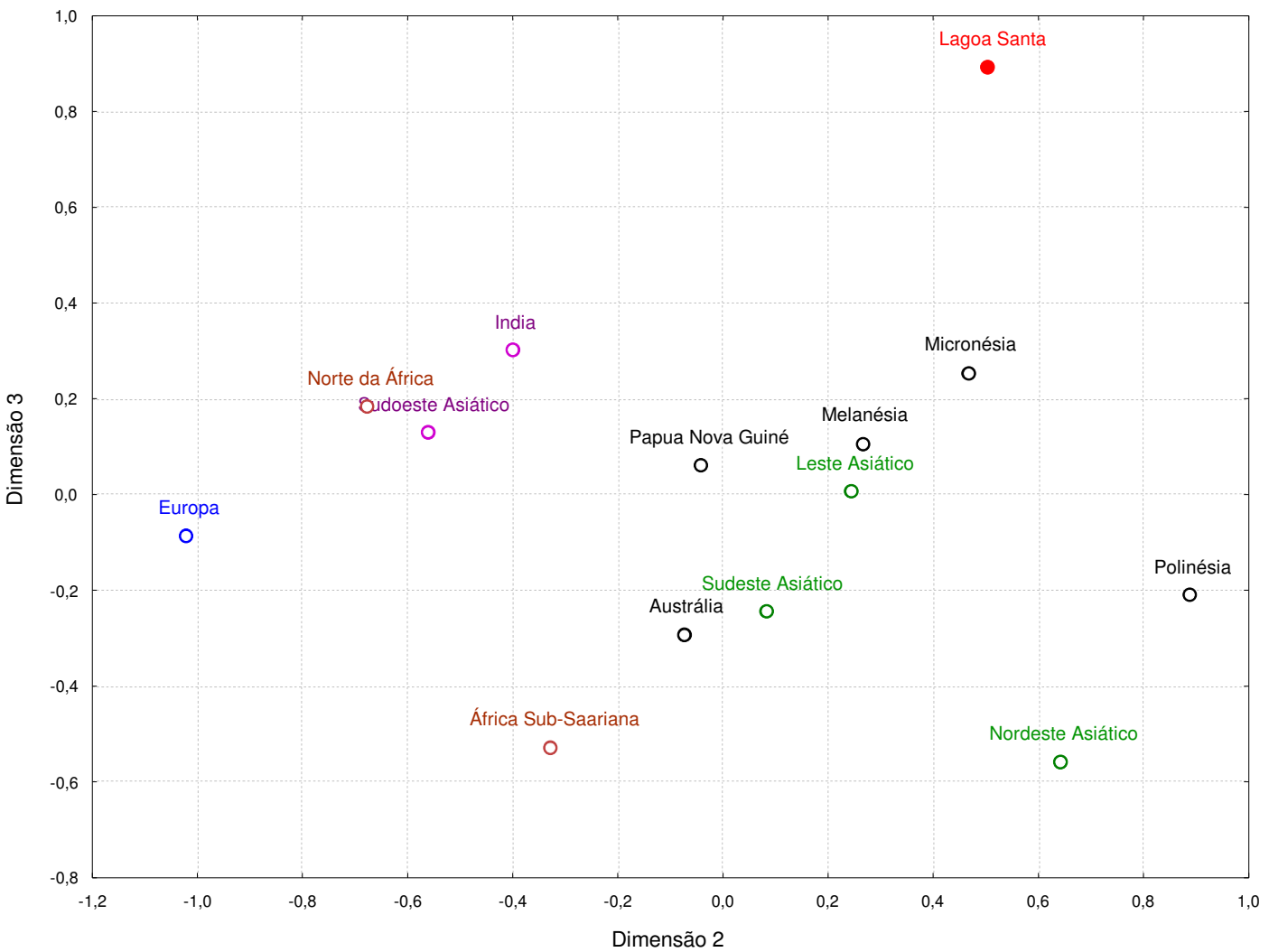


Em oposição aos resultados obtidos pelas Análises de Componentes Principais aplicadas sobre o conjunto de dados relativos à análise de afinidades extra-continentais (parcela masculina, tamanho e forma), representados por seus centróides, as análises baseadas em matriz de Distância de Mahalanobis não apontaram associação morfológica entre os Paleoíndios de Lagoa Santa as populações de morfologia generalizada do Velho Mundo. De maneira geral, tanto nas análises de agrupamento quanto nas de escalonamento multidimensional, a população de Lagoa Santa se apresentou bastante marginal à dispersão dos representantes extra-continentais analisados. Embora, em algumas análises, tenha apresentado algum tipo de associação preferencial, essas não são consistentes o bastante para serem dignas de algum tipo de consideração mais verticalizada.

\subsubsection{2 - Parcela Masculina, Apenas Forma}

Os resultados obtidos através da ACP sobre os centróides das séries analisadas, com base em dados corrigidos quanto ao fator tamanho, para a parcela masculina, são apresentados na Tabela 4.22. O gráfico da Figura 4.96 apresenta o screeplot dos autovalores dos CPs. A escolha dos 4 primeiros componentes principais para o cálculo de distâncias Euclidianas foi baseado na análises dessa curva.

Tabela 4.22 - Autovalores da matriz de covariância e porcentagens de variância total explicada por cada Componente Principal. Parcela masculina, apenas forma (14 séries, 23 variáveis craniométricas).

\begin{tabular}{c|c|c|c|c}
\hline $\begin{array}{c}\text { Componente } \\
\text { Principal }\end{array}$ & Autovalor & $\%$ Total & $\begin{array}{c}\text { Autovalor } \\
\text { Cumulativo }\end{array}$ & $\%$ Cumulativa \\
\hline 1 & 0,008434 & 53,77806 & 0,008434 & 53,7781 \\
2 & 0,002731 & 17,41518 & 0,011166 & 71,1932 \\
3 & 0,001746 & 11,13346 & 0,012912 & 82,3267 \\
4 & 0,001327 & 8,46390 & 0,014239 & 90,7906 \\
5 & 0,000693 & 4,41661 & 0,014932 & 95,2072 \\
6 & 0,000374 & 2,38336 & 0,015306 & 97,5906 \\
7 & 0,000144 & 0,91853 & 0,015450 & 98,5091 \\
8 & 0,000091 & 0,58324 & 0,015541 & 99,0923 \\
9 & 0,000067 & 0,42440 & 0,015608 & 99,5167 \\
10 & 0,000036 & 0,23266 & 0,015644 & 99,7494 \\
11 & 0,000029 & 0,18291 & 0,015673 & 99,9323 \\
12 & 0,000009 & 0,05724 & 0,015682 & 99,9895 \\
13 & 0,000002 & 0,01046 & 0,015683 & 100,0000 \\
\hline
\end{tabular}


Figura 4.96 - Gráfico de decaímento da porcentagem de variância condensada em cada Componente Principal. Parcela masculina, apenas forma (14 séries, 23 variáveis craniométricas).

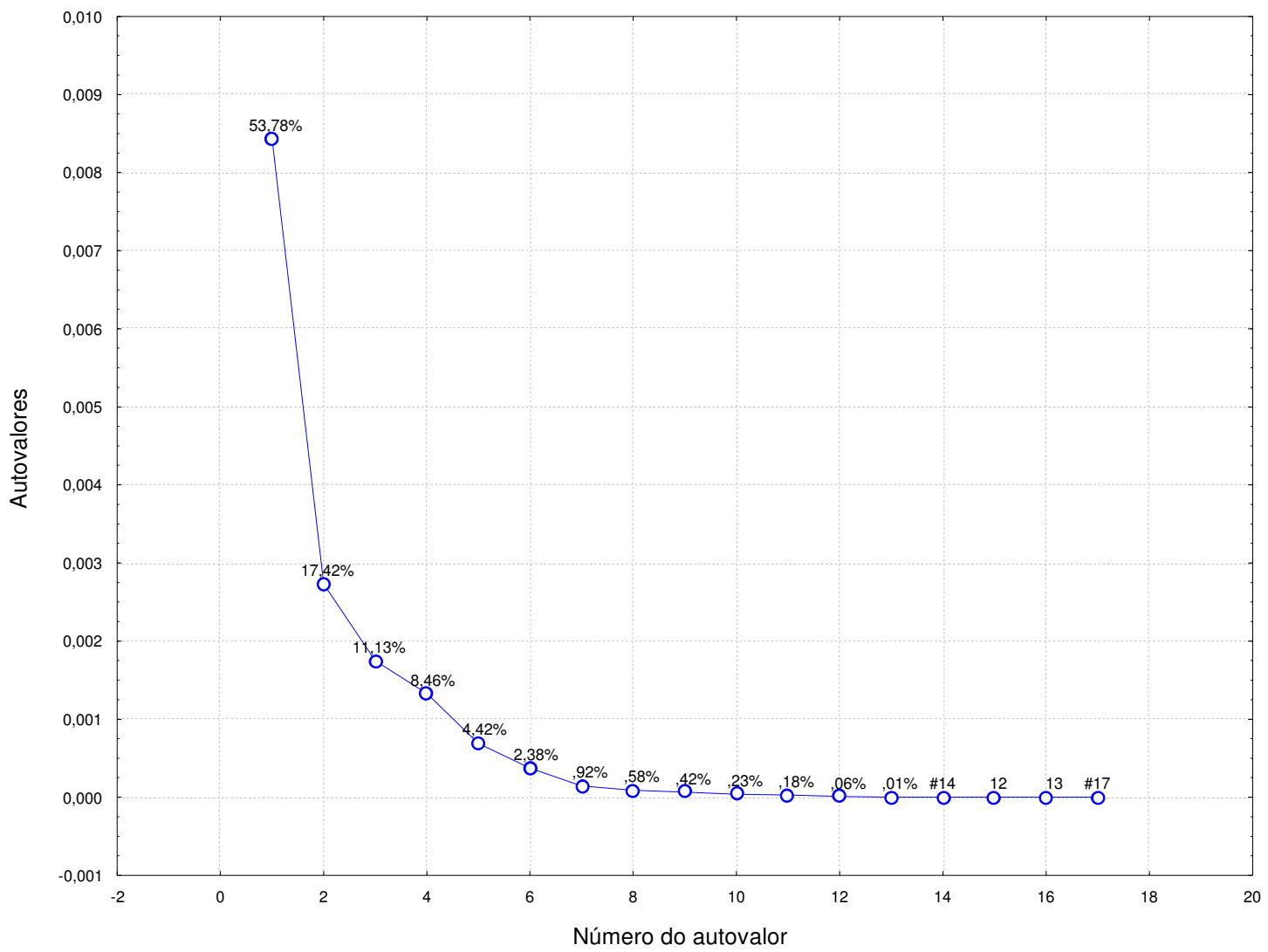

As Tabelas 4.23 e 4.24 indicam, respectivamente, os fatores de coordenadas extraídos pelos Componentes Principais para cada série e a matriz de Distância Euclidiana, calculada sobre os quatro primeiros CPs.

Os gráficos das Figuras 4.97 a 4.99 exibem as relações observadas entre os centróides representativos das séries analisadas posicionados no morfoespaço constituído, respectivamente, pelas dimensões formadas pelos CP $1 \mathrm{x}$ CP 2, CP 1 x CP 3 e CP 2 x CP 3. As Figuras 4.100 a 4.103 apresentam os dendrogramas gerados a partir das análises de clusters, sob as quatro regras distintas de agrupamento utilizadas nesse trabalho, utilizando-se a matriz de dados baseadas nas distâncias euclidianas calculadas a partir dos CP selecionados. 
Figura 4.97 - Gráfico bidimensional do morfo-espaço formado pelos CP 1 x CP 2. Parcela masculina, apenas forma (14 séries, 23 variáveis craniométricas).

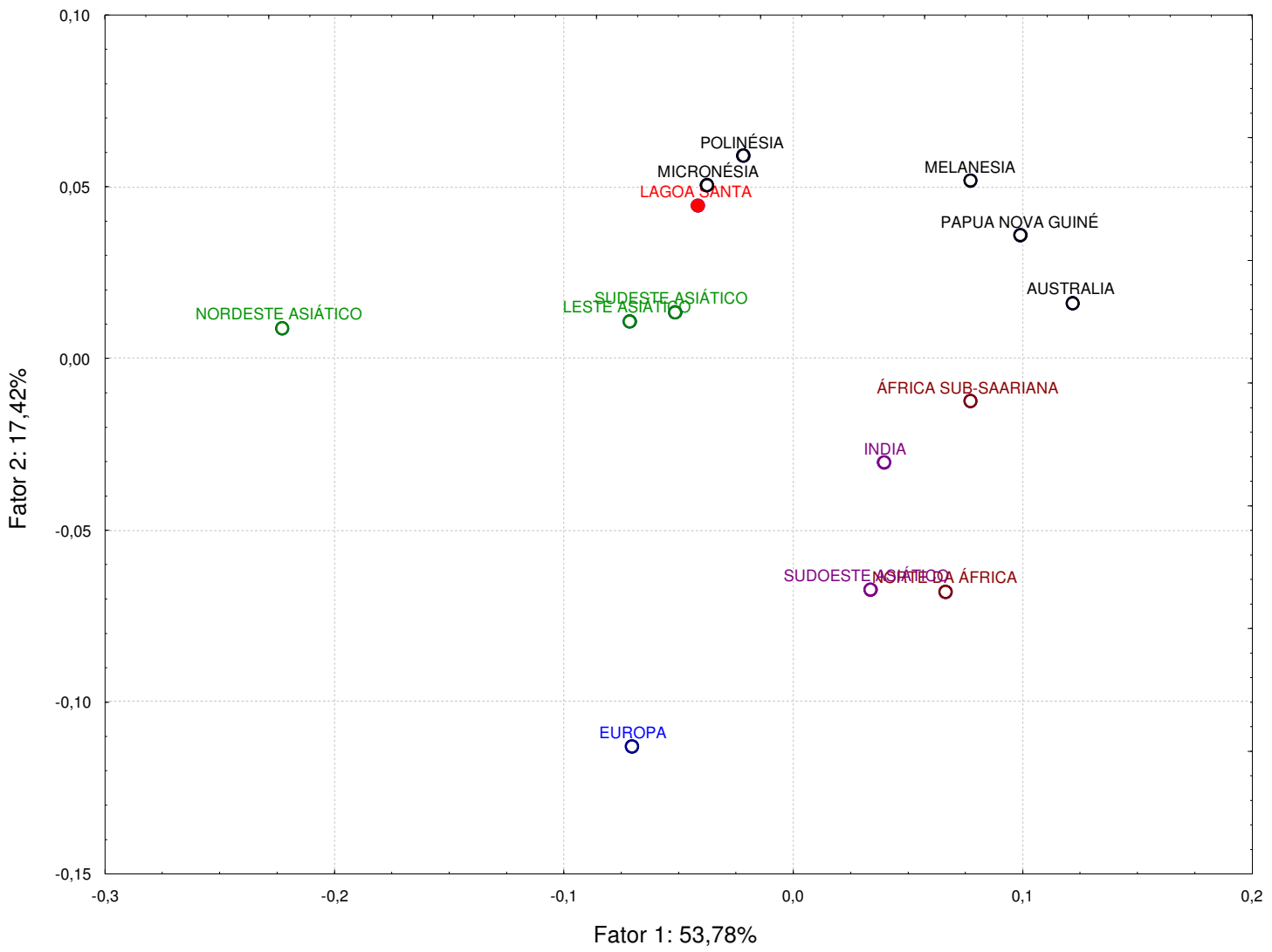

Figura 4.98 - Gráfico bidimensional do morfo-espaço formado pelos CP $1 \times$ CP 3. Parcela masculina, apenas forma (14 séries, 23 variáveis craniométricas).

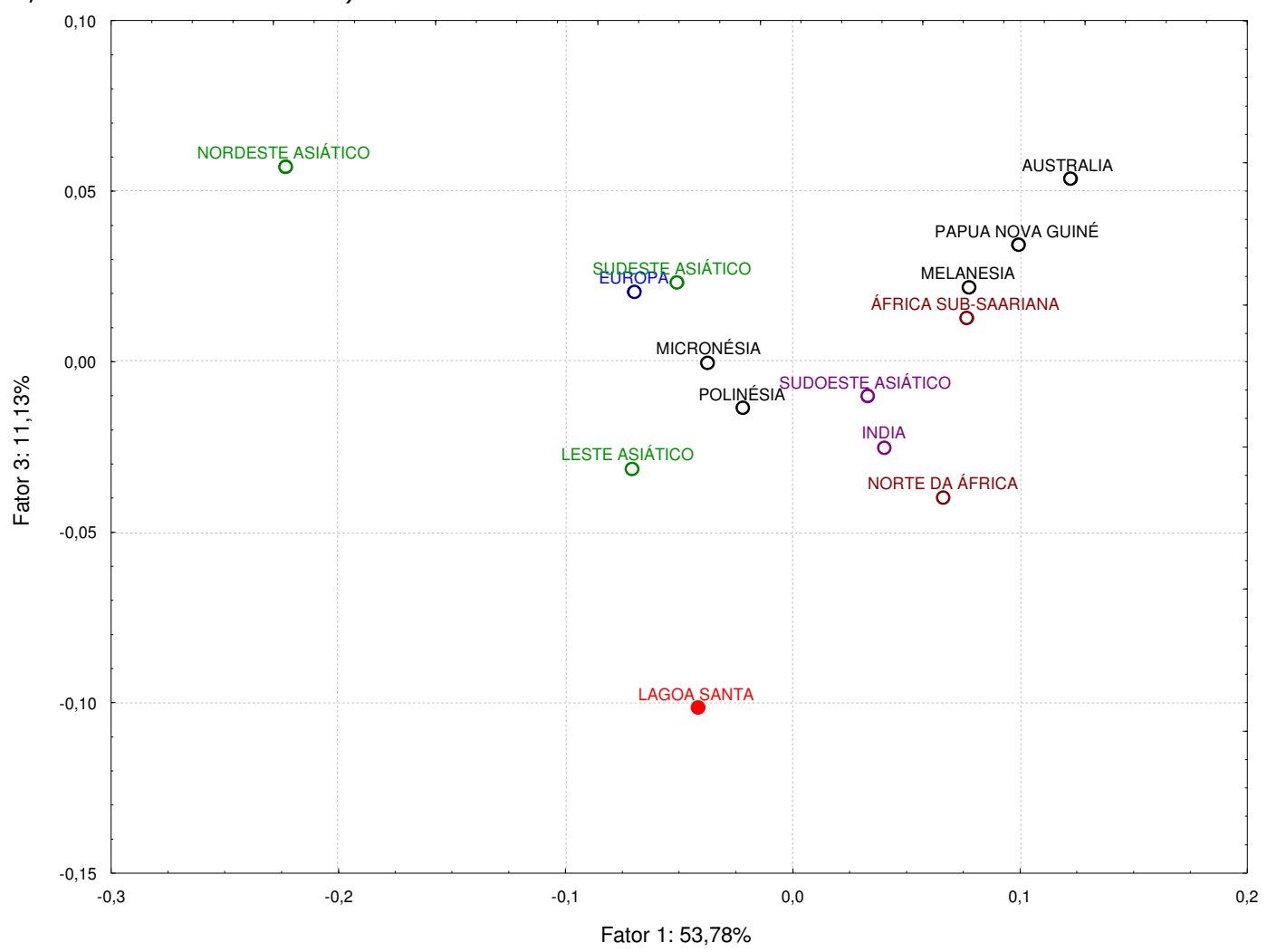


Figura 4.99 - Gráfico bidimensional do morfo-espaço formado pelos CP $2 \times$ CP 3. Parcela masculina, apenas forma (14 séries, 23 variáveis craniométricas).

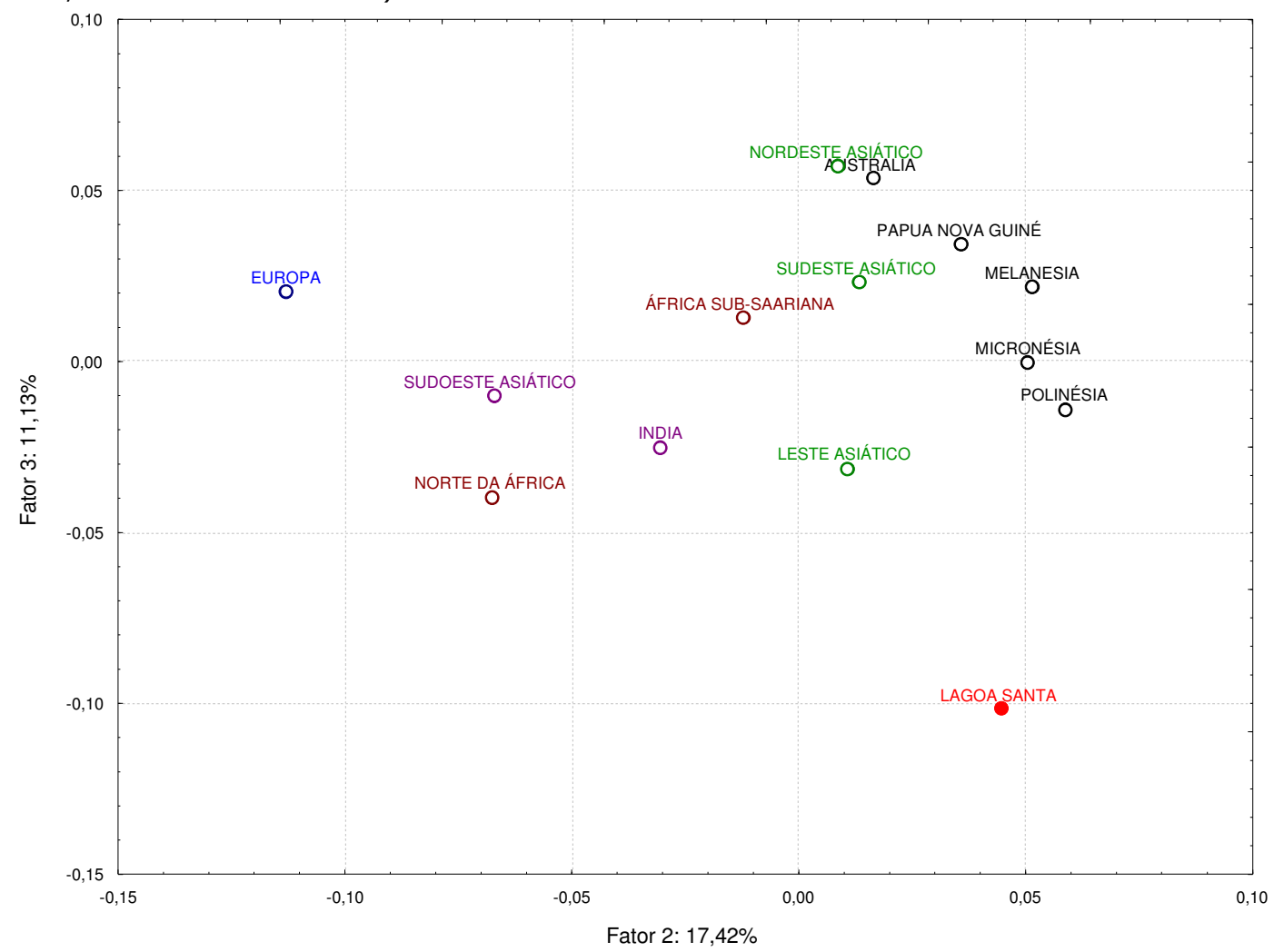

Nas topologias mostradas acima, observa-se, salvo exceção feita à formada pelos CP 1 e CP 2, o posicionamento do centróide da população de Lagoa Santa sempre de maneira marginal à dispersão dos representantes das outras populações do Velho Mundo. De maneira geral, algumas associações apresentam-se de maneira bastante consistente, como se observa entre os grupos de asiáticos e os autralo-melanésicos. 
Tabela 4.23 - Fatores de coordenadas de cada série. Parcela masculina, apenas forma (14 séries, 23 variáveis craniométricas).

\begin{tabular}{|c|c|c|c|c|c|c|c|c|c|c|c|c|c|}
\hline & Fator 1 & Fator 2 & Fator 3 & Fator 4 & Fator 5 & Fator 6 & Fator 7 & Fator 8 & Fator 9 & Fator10 & Fator11 & Fator12 & Fator13 \\
\hline $\begin{array}{c}\text { AUSTRALIA } \\
\text { LESTE ASIATICO } \\
\text { EUROPA } \\
\text { INDIA } \\
\text { MELANESIA } \\
\text { NORTE DA AFRICA } \\
\text { NORDESTE ASIATICO } \\
\text { PAPUA NOVA GUINE } \\
\text { POLINESIA } \\
\text { SUDESTE ASIATICO } \\
\text { AFRICA SUB-SAARIANA } \\
\text { SUDOESTE ASIATICO } \\
\text { LAGOA SANTA }\end{array}$ & \begin{tabular}{|l|}
0,122075 \\
$-0,070811$ \\
$-0,069768$ \\
0,040154 \\
0,077524 \\
0,066559 \\
$-0,222895$ \\
0,099213 \\
$-0,021811$ \\
$-0,051409$ \\
0,076910 \\
0,033359 \\
$-0,041625$ \\
\end{tabular} & \begin{tabular}{|l|}
0,016279 \\
0,010984 \\
$-0,112965$ \\
$-0,030429$ \\
0,051681 \\
$-0,067738$ \\
0,008933 \\
0,035704 \\
0,058752 \\
0,013574 \\
$-0,012455$ \\
$-0,067180$ \\
0,044536 \\
\end{tabular} & \begin{tabular}{|l|}
0,053310 \\
$-0,031273$ \\
0,020475 \\
$-0,025025$ \\
0,021767 \\
$-0,039859$ \\
0,057076 \\
0,034093 \\
$-0,013894$ \\
0,022924 \\
0,012801 \\
$-0,010269$ \\
$-0,101802$ \\
\end{tabular} & $\begin{array}{l}0,053847 \\
-0,018862 \\
0,000855 \\
-0,015244 \\
0,009433 \\
0,005817 \\
0,051689 \\
-0,011024 \\
0,001718 \\
-0,073921 \\
0,008550 \\
-0,006258 \\
0,047938 \\
\end{array}$ & \begin{tabular}{|l|}
$-0,003938$ \\
$-0,009340$ \\
0,013971 \\
$-0,001633$ \\
$-0,009754$ \\
0,000217 \\
$-0,010551$ \\
$-0,010348$ \\
0,081200 \\
$-0,027930$ \\
$-0,010279$ \\
0,012050 \\
$-0,027425$ \\
\end{tabular} & \begin{tabular}{|l|}
$-0,000420$ \\
$-0,005061$ \\
$-0,033170$ \\
0,013698 \\
$-0,029804$ \\
0,013155 \\
0,014974 \\
$-0,015150$ \\
0,007151 \\
0,008661 \\
0,042189 \\
$-0,002680$ \\
$-0,010346$ \\
\end{tabular} & \begin{tabular}{|l|}
0,020041 \\
$-0,015841$ \\
$-0,006150$ \\
0,004104 \\
$-0,015359$ \\
0,002871 \\
0,001341 \\
$-0,006612$ \\
$-0,003580$ \\
0,005150 \\
$-0,019604$ \\
0,010858 \\
0,005277 \\
\end{tabular} & $\begin{array}{l}-0,000345 \\
0,002633 \\
-0,000194 \\
0,013984 \\
0,013135 \\
-0,003906 \\
0,001302 \\
-0,015949 \\
-0,006722 \\
-0,014258 \\
0,003448 \\
-0,002069 \\
-0,006440\end{array}$ & \begin{tabular}{|l|}
0,005602 \\
0,002837 \\
0,004294 \\
$-0,021457$ \\
0,001615 \\
0,006758 \\
$-0,005149$ \\
$-0,011249$ \\
$-0,000453$ \\
0,002168 \\
0,007929 \\
$-0,002348$ \\
0,001003 \\
\end{tabular} & \begin{tabular}{|l|}
0,006495 \\
0,010004 \\
$-0,004751$ \\
0,002359 \\
0,004281 \\
0,004810 \\
$-0,000412$ \\
$-0,007980$ \\
0,001750 \\
0,005922 \\
$-0,007855$ \\
$-0,001189$ \\
$-0,004824$ \\
\end{tabular} & \begin{tabular}{|l|}
0,004597 \\
$-0,003226$ \\
0,006583 \\
0,004622 \\
$-0,001045$ \\
$-0,009919$ \\
$-0,004904$ \\
$-0,006085$ \\
0,002367 \\
0,006386 \\
0,004092 \\
$-0,004375$ \\
0,004542 \\
\end{tabular} & $\begin{array}{l}0,003270 \\
0,006806 \\
0,000796 \\
0,000215 \\
-0,005415 \\
-0,002776 \\
-0,001465 \\
0,002392 \\
-0,000939 \\
-0,003117 \\
0,000481 \\
-0,000846 \\
-0,000795 \\
\end{array}$ & \begin{tabular}{|l|}
0,000213 \\
$-0,000582$ \\
0,001005 \\
0,000837 \\
$-0,000511$ \\
0,002079 \\
0,000049 \\
0,000645 \\
0,000179 \\
$-0,000081$ \\
$-0,000583$ \\
$-0,003675$ \\
$-0,000140$ \\
\end{tabular} \\
\hline
\end{tabular}

Tabela 4.24 - Matriz de Distância Euclidiana calculada sobre os quatro primeiros Componentes Principais. Parcela masculina, apenas forma (14 séries, 23 variáveis craniométricas).

\begin{tabular}{|c|c|c|c|c|c|c|c|c|c|c|c|c|c|c|}
\hline & AUSTRALIA & $\begin{array}{c}\text { LESTE } \\
\text { ASIATICO }\end{array}$ & EUROPA & INDIA & MELANESIA & $\begin{array}{l}\text { NORTE DA } \\
\text { AFRICA }\end{array}$ & $\begin{array}{l}\text { NORDESTE } \\
\text { ASIATICO }\end{array}$ & $\begin{array}{c}\text { PAPUA NOVA } \\
\text { GUINE }\end{array}$ & POLINESIA & $\begin{array}{l}\text { SUDESTE } \\
\text { ASIATICO }\end{array}$ & $\begin{array}{l}\text { AFRICA SUB- } \\
\text { SAARIANA }\end{array}$ & $\begin{array}{l}\text { SUDOESTE } \\
\text { ASIATICO }\end{array}$ & $\begin{array}{l}\text { LAGOA } \\
\text { SANTA }\end{array}$ & MICRONESIA \\
\hline AUSTRALIA & 0,00 & 0,22 & 0,24 & 0,14 & 0,08 & 0,15 & 0,35 & 0,07 & 0,17 & 0,22 & 0,08 & 0,15 & 0,23 & 0,20 \\
\hline $\begin{array}{l}\text { LESTE } \\
\text { ASIATICO }\end{array}$ & & 0,00 & 0,14 & 0,12 & 0,17 & 0,16 & 0,19 & 0,18 & 0,07 & 0,08 & 0,16 & 0,13 & 0,11 & 0,07 \\
\hline EUROPA & & & 0,00 & 0,15 & 0,22 & 0,16 & 0,21 & 0,23 & 0,18 & 0,15 & 0,18 & 0,12 & 0,21 & 0,18 \\
\hline INDIA & & & & 0,00 & 0,10 & 0,05 & 0,29 & 0,11 & 0,11 & 0,13 & 0,06 & 0,04 & 0,15 & 0,12 \\
\hline MELANESIA & & & & & 0,00 & 0,13 & 0,31 & 0,04 & 0,11 & 0,16 & 0,06 & 0,13 & 0,18 & 0,13 \\
\hline $\begin{array}{l}\text { NORTE DA } \\
\text { AFRICA }\end{array}$ & & & & & & 0,00 & 0,32 & 0,13 & 0,16 & 0,18 & 0,08 & 0,05 & 0,17 & 0,17 \\
\hline $\begin{array}{l}\text { NORDESTE } \\
\text { ASIATICO }\end{array}$ & & & & & & & 0,00 & 0,33 & 0,22 & 0,22 & 0,31 & 0,28 & 0,24 & 0,23 \\
\hline $\begin{array}{l}\text { PAPUA NOVA } \\
\text { GUINE }\end{array}$ & & & & & & & & 0,00 & 0,13 & 0,17 & 0,06 & 0,13 & 0,20 & 0,15 \\
\hline POLINESIA & & & & & & & & & 0,00 & 0,10 & 0,12 & 0,14 & 0,10 & 0,06 \\
\hline $\begin{array}{l}\text { SUDESTE } \\
\text { ASIATICO }\end{array}$ & & & & & & & & & & 0,00 & 0,16 & 0,14 & 0,18 & 0,05 \\
\hline $\begin{array}{l}\text { AFRICA SUB- } \\
\text { SAARIANA }\end{array}$ & & & & & & & & & & & 0,00 & 0,08 & 0,18 & 0,15 \\
\hline $\begin{array}{l}\text { SUDOESTE } \\
\text { ASIATICO }\end{array}$ & & & & & & & & & & & & 0,00 & 0,17 & 0,15 \\
\hline $\begin{array}{l}\text { LAGOA } \\
\text { SANTA }\end{array}$ & & & & & & & & & & & & & 0,00 & 0,14 \\
\hline MICRONESIA & & & & & & & & & & & & & & 0,00 \\
\hline
\end{tabular}


Figura 4.100 - Dendrograma gerado sobre matriz de Distância Euclidiana calculada a partir dos quatro primeiros Componentes Principais - Método de Ward. Parcela masculina, apenas forma (14 séries, 23 variáveis craniométricas).

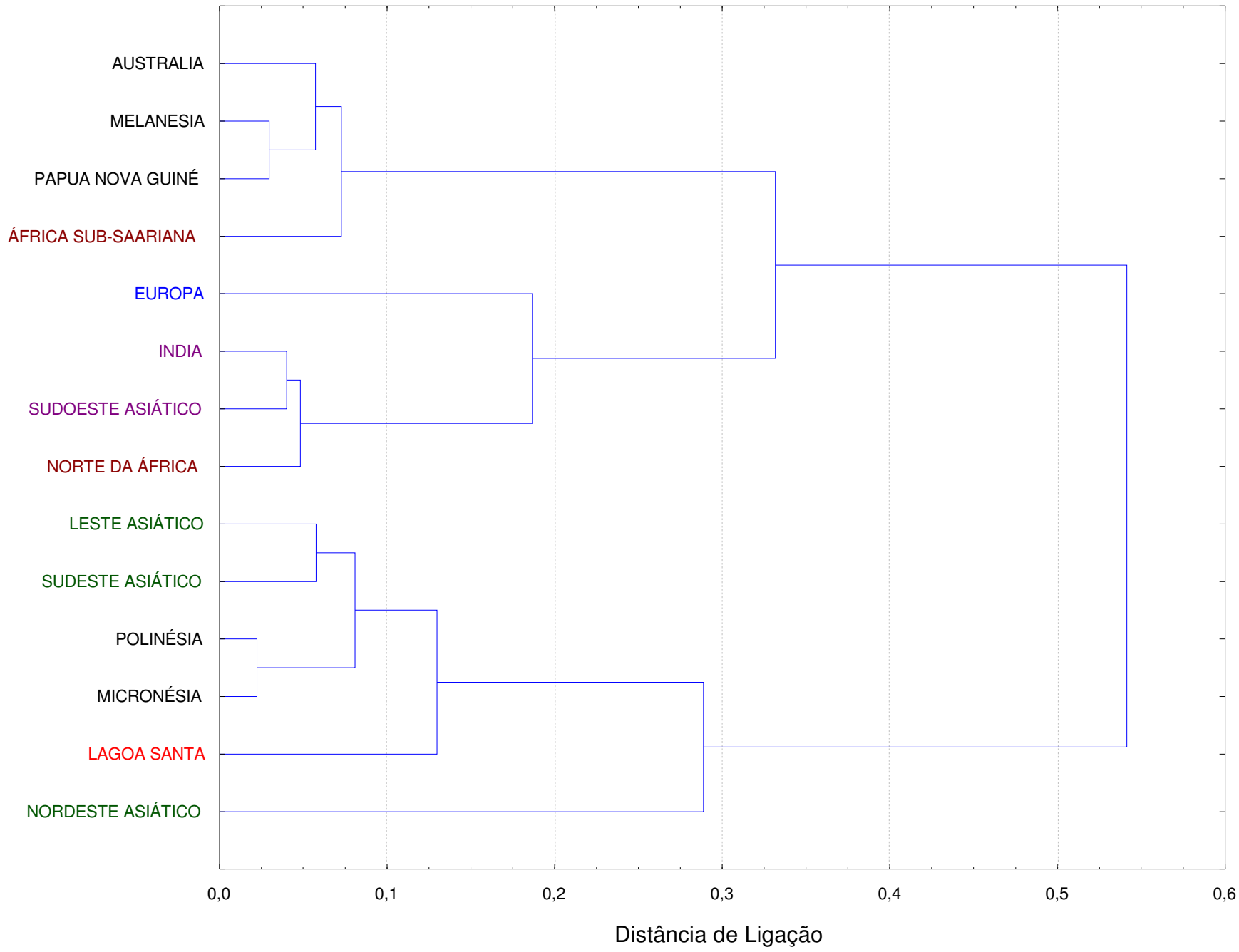


Figura 4.101 - Dendrograma gerado sobre matriz de Distância Euclidiana calculada a partir dos quatro primeiros Componentes Principais - Método de Ligação Simples. Parcela masculina, apenas forma (14 séries, 23 variáveis craniométricas).

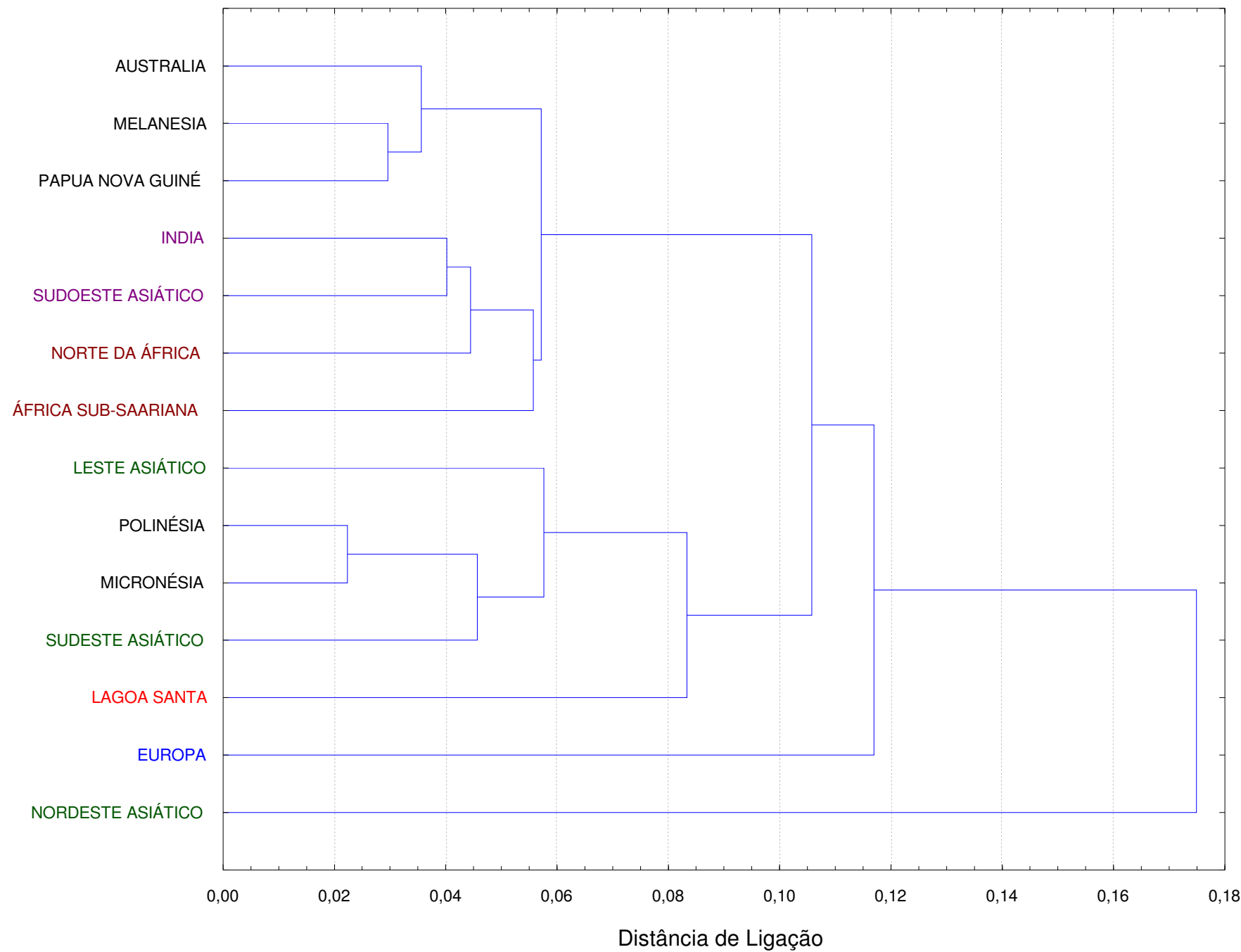


Figura 4.102 - Dendrograma gerado sobre matriz de Distância Euclidiana calculada a partir dos quatro primeiros Componentes Principais - Método de Ligação Completa. Parcela masculina, apenas forma (14 séries, 23 variáveis craniométricas).

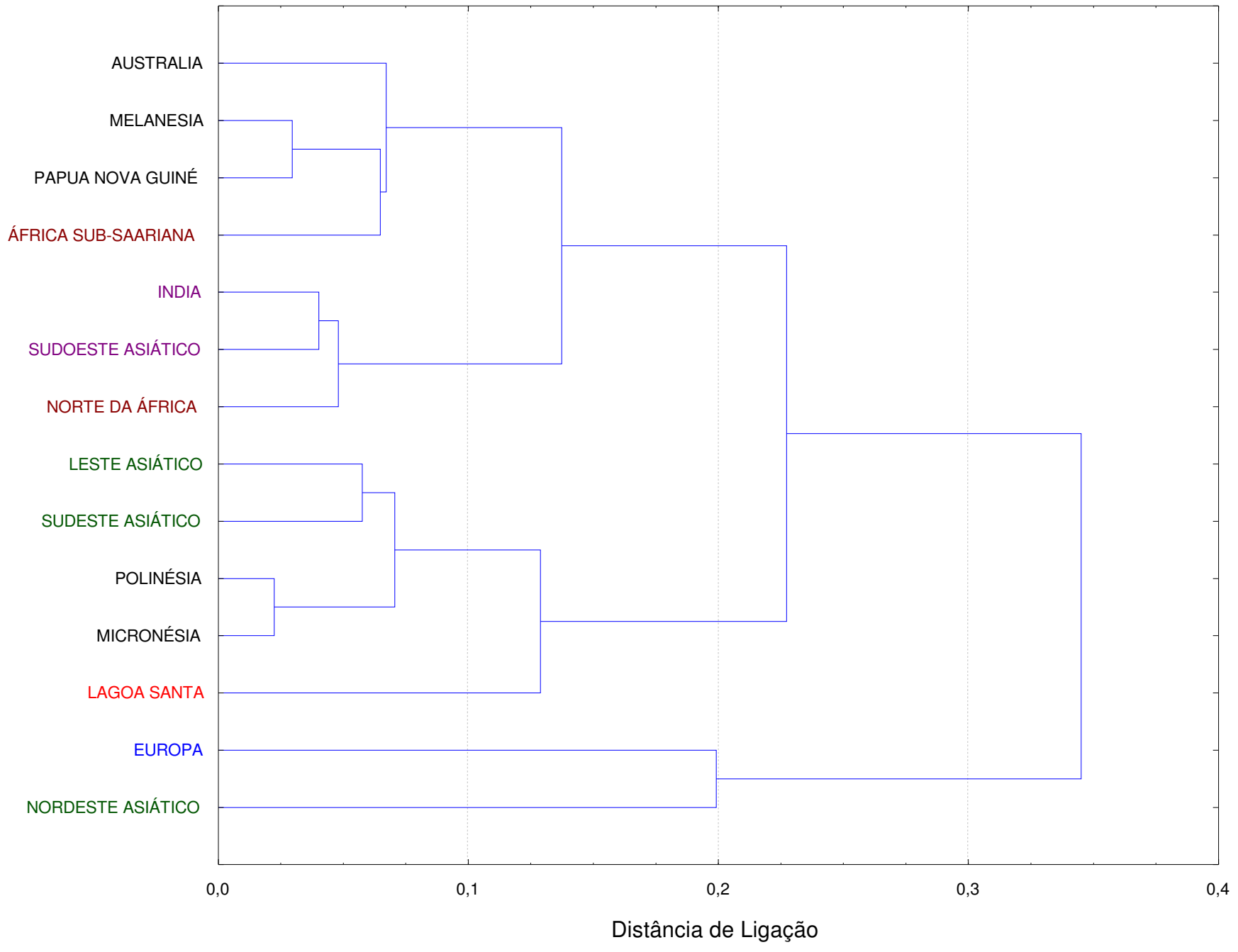


Figura 4.103 - Dendrograma gerado sobre matriz de Distância Euclidiana calculada a partir dos quatro primeiros Componentes Principais - Método da Média dos Grupos. Parcela masculina, apenas forma (14 séries, 23 variáveis craniométricas).

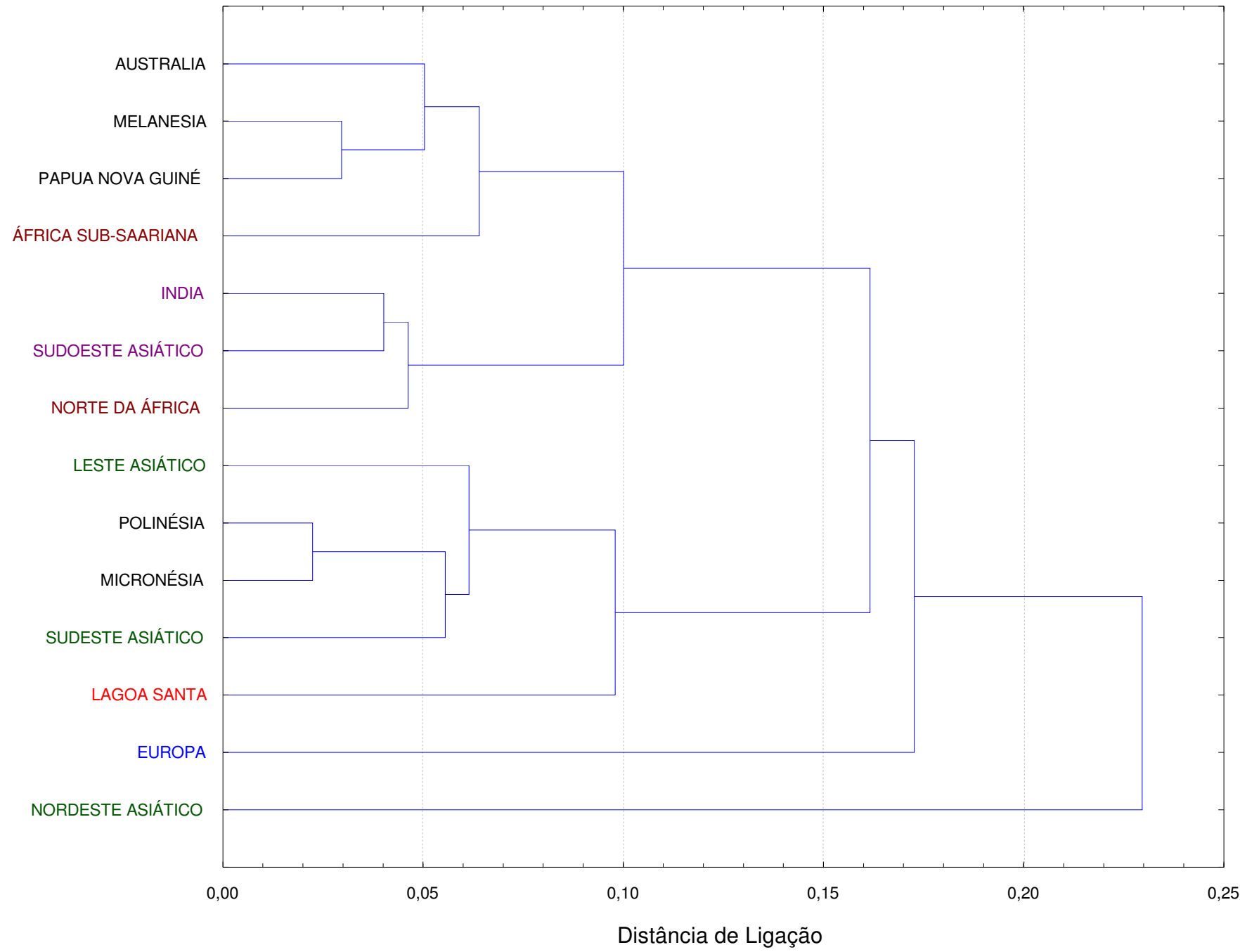



Os dendrogramas relativos à investigação das afinidades extracontinentais dos Paleoíndios de Lagoa Santa segundo a parcela masculina corrigida quanto ao fator tamanho, não indicam com clareza, a exemplo do que se observou nos resultados gerados pela ACP para esse conjunto de dados, quais seriam as associações morfológicas mais consistentes entre os Paleoíndios e populações autóctones do Velho Mundo.

Os quatro clusters, gerados sob diferentes critérios de agrupamento, indicam algumas associações bastante convincentes, como, por exemplo, a observada entre australo-melanésicos e africanos subsaarianos. Por outro lado, os mesmos dendrogramas indicam algumas associações conflitantes, desqualificando em partes a validade desses resultados.

Para explorar o potencial analítico da amostra trabalhada, executou-se também análises de agrupamentos executados a partir de matrizes de Distância de Mahalanobis, através dos mesmos quatro critérios de agregação (Tabela 4.25, Figuras 4.104 a 4.107), que também subsidiou a aplicação da técnica de Escalonamento Multidimensional - MDS (Tabela 4.26, Figuras 4.108 a 4.1110).

A exemplo do que foi observado nas ACPs, realizadas sobre os centróides de cada grupo, as análises executadas a partir da matriz de Distância de Mahalanobis para os dados relativos à análise de afinidades extra-continentais parcela masculina, apenas forma - não apontaram associação morfológica entre os Paleoíndios de Lagoa Santa e as populações de morfologia generalizada do Velho Mundo. De maneira geral, tanto nas análises de agrupamento quanto nas de escalonamento multidimensional, a população de Lagoa Santa se apresentou bastante marginal à dispersão dos representantes extra-continentais analisados. Embora, em algumas análises, tenha apresentado algum tipo de associação preferencial, essas não são qualificadas o suficiente, não cabendo nenhum tipo de consideração mais aprofundada. 
Tabela 4.25 - Matriz de Distância de Mahalanobis. Parcela masculina, apenas forma (4904 indivíduos, 23 variáveis craniométricas).

\begin{tabular}{|c|c|c|c|c|c|c|c|c|c|c|c|c|c|c|}
\hline & Austrália & $\begin{array}{l}\text { Leste } \\
\text { Asiático }\end{array}$ & Europa & Índia & Melanésia & $\begin{array}{l}\text { Norte da } \\
\text { África }\end{array}$ & $\begin{array}{l}\text { Nordeste } \\
\text { Asiático }\end{array}$ & $\begin{array}{l}\text { Papua } \\
\text { Nova } \\
\text { Guiné }\end{array}$ & Polinésia & $\begin{array}{l}\text { Sudeste } \\
\text { Asiático }\end{array}$ & $\begin{array}{c}\text { África } \\
\text { Sub- } \\
\text { Saariana }\end{array}$ & $\begin{array}{l}\text { Sudoeste } \\
\text { Asiático }\end{array}$ & Micronésia & $\begin{array}{l}\text { Lagoa } \\
\text { Santa }\end{array}$ \\
\hline Austrália & 0,00000 & 16,16495 & 19,77028 & 10,89674 & 3,22334 & 14,88485 & 26,96107 & 4,42972 & 10,58058 & 14,94288 & 9,83732 & 12,75284 & 11,55900 & 18,66289 \\
\hline Leste Asiático & & 0,00000 & 9,22360 & 3,59725 & 10,34466 & 5,45273 & 7,13101 & 8,20374 & 5,50273 & 1,45669 & 6,30429 & 5,04580 & 2,22591 & 5,31610 \\
\hline Europa & & & 0,00000 & 6,37720 & 16,99854 & 5,69907 & 13,15032 & 14,80760 & 13,60867 & 10,16043 & 12,36332 & 2,95349 & 12,62194 & 15,15461 \\
\hline Índia & & & & 0,00000 & 8,54846 & 1,94810 & 14,19224 & 5,69728 & 6,10621 & 3,56881 & 4,55946 & 1,52771 & 4,09118 & 7,12743 \\
\hline Melanésia & & & & & 0,00000 & 12,13338 & 23,46821 & 1,08640 & 7,66369 & 10,38901 & 8,05284 & 10,03972 & 6,30202 & 14,68207 \\
\hline Norte da África & & & & & & 0,00000 & 15,75170 & 8,57851 & 9,91363 & 6,43925 & 4,32478 & 1,11562 & 7,51309 & 9,65382 \\
\hline $\begin{array}{l}\text { Nordeste } \\
\text { Asiático }\end{array}$ & & & & & & & 0,00000 & 21,37169 & 14,03206 & 8,68613 & 15,54262 & 13,82082 & 12,27570 & 13,76798 \\
\hline $\begin{array}{l}\text { Papua Nova } \\
\text { Guiné }\end{array}$ & & & & & & & & 0,00000 & 6,50218 & 8,02543 & 5,24636 & 7,22940 & 5,50322 & 13,45922 \\
\hline Polinésia & & & & & & & & & 0,00000 & 7,18806 & 9,71166 & 7,43233 & 4,19302 & 10,38751 \\
\hline $\begin{array}{l}\text { Sudeste } \\
\text { Asiático }\end{array}$ & & & & & & & & & & 0,00000 & 6,00720 & 5,55871 & 2,66652 & 7,41047 \\
\hline $\begin{array}{l}\text { África Sub- } \\
\text { Saariana }\end{array}$ & & & & & & & & & & & 0,00000 & 5,79265 & 6,68318 & 13,67080 \\
\hline $\begin{array}{l}\text { Sudoeste } \\
\text { Asiático }\end{array}$ & & & & & & & & & & & & 0,00000 & 6,25379 & 10,06594 \\
\hline Micronésia & & & & & & & & & & & & & 0,00000 & 5,94752 \\
\hline Lagoa Santa & & & & & & & & & & & & & & 0,00000 \\
\hline
\end{tabular}


Figura 4.104 - Dendrograma gerado sobre matriz de Distância de Mahalanobis - Método de Ward. Parcela masculina, apenas forma (4904 indivíduos, 23 variáveis craniométricas).

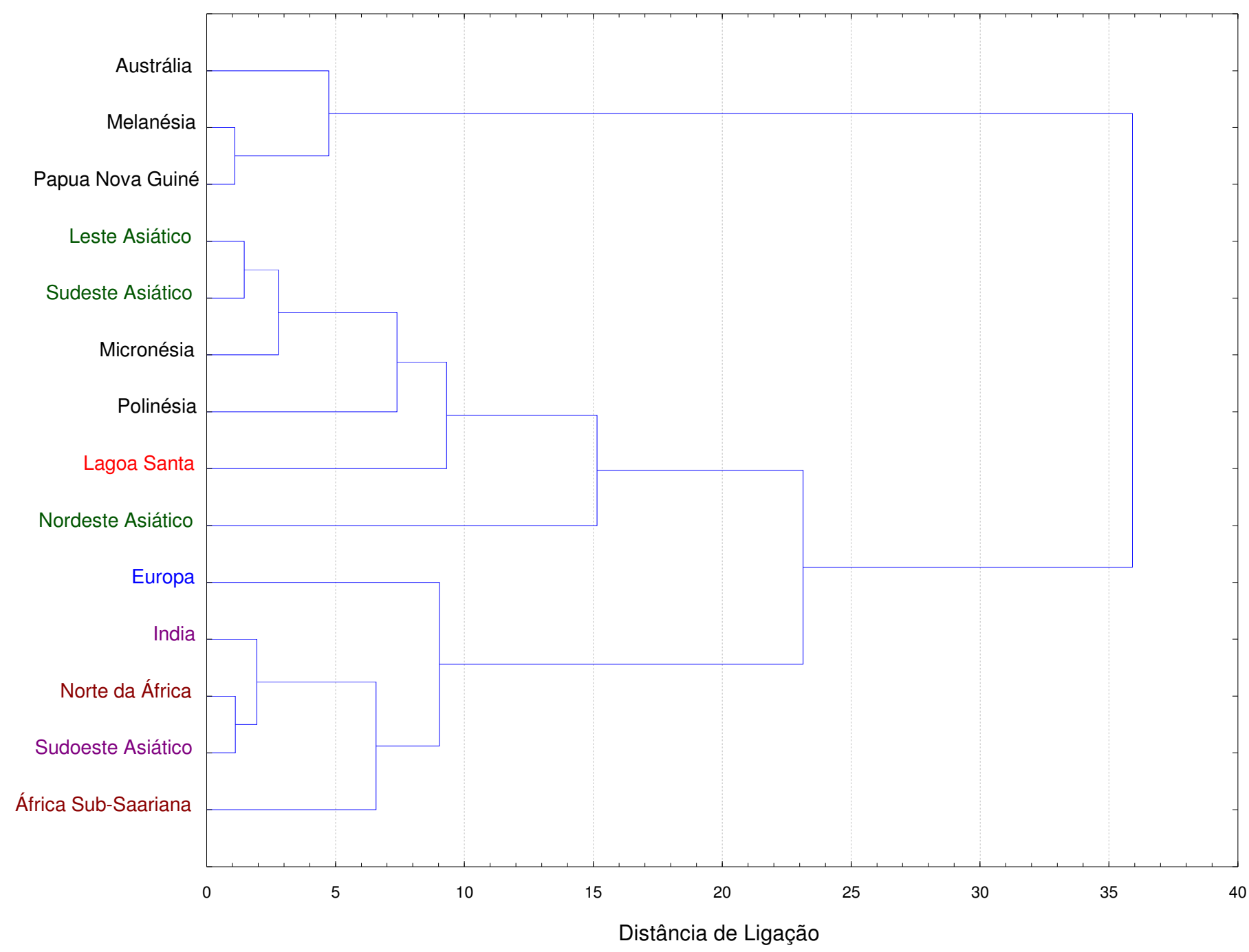


Figura 4.105 - Dendrograma gerado sobre matriz de Distância de Mahalanobis - Método de Ligação Simples. Parcela masculina, forma apenas (4904 indivíduos, 23 variáveis craniométricas).

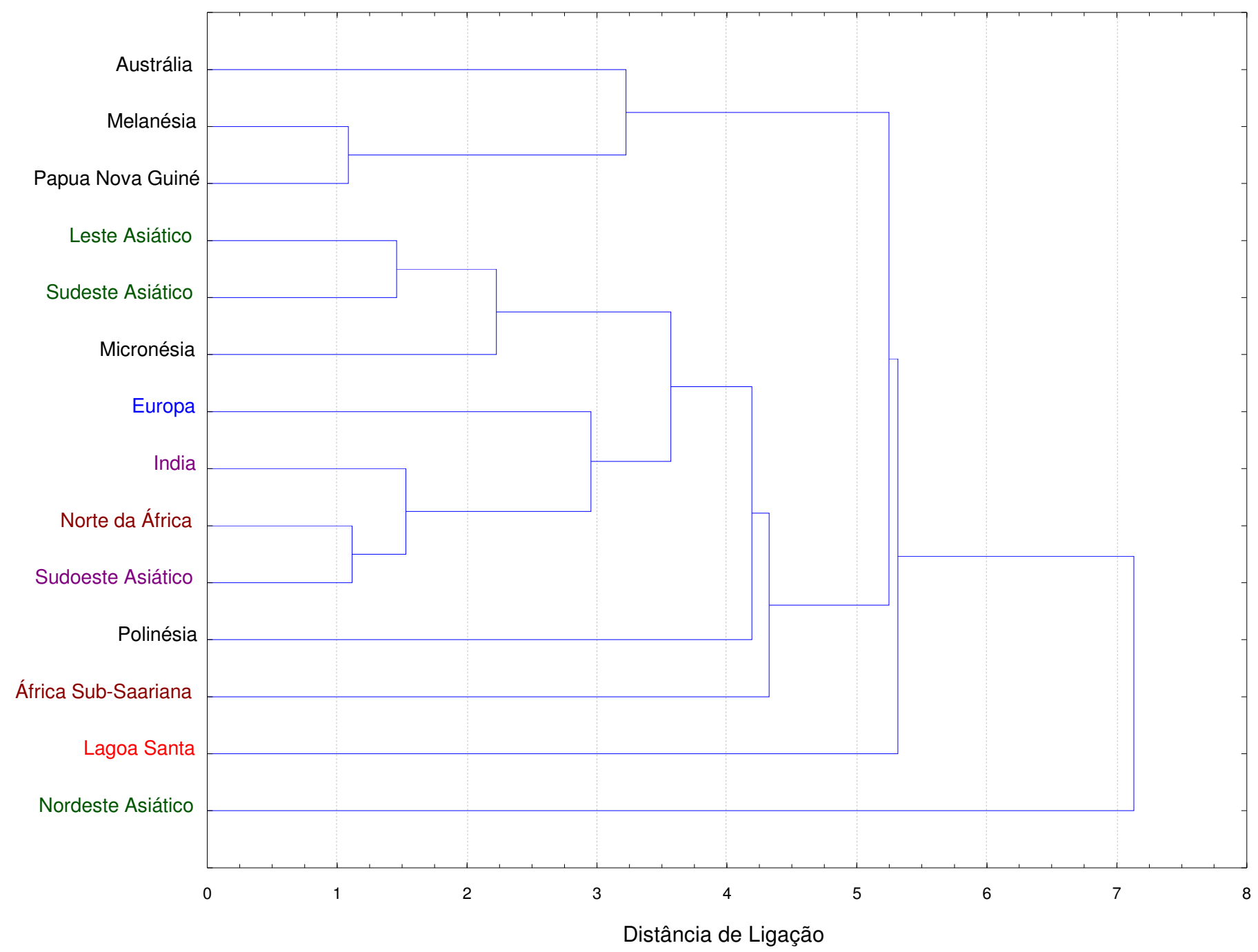


Figura 4.106 - Dendrograma gerado sobre matriz de Distância de Mahalanobis - Método de Ligação Completa. Parcela masculina, apenas forma (4904 indivíduos, 23 variáveis craniométricas).

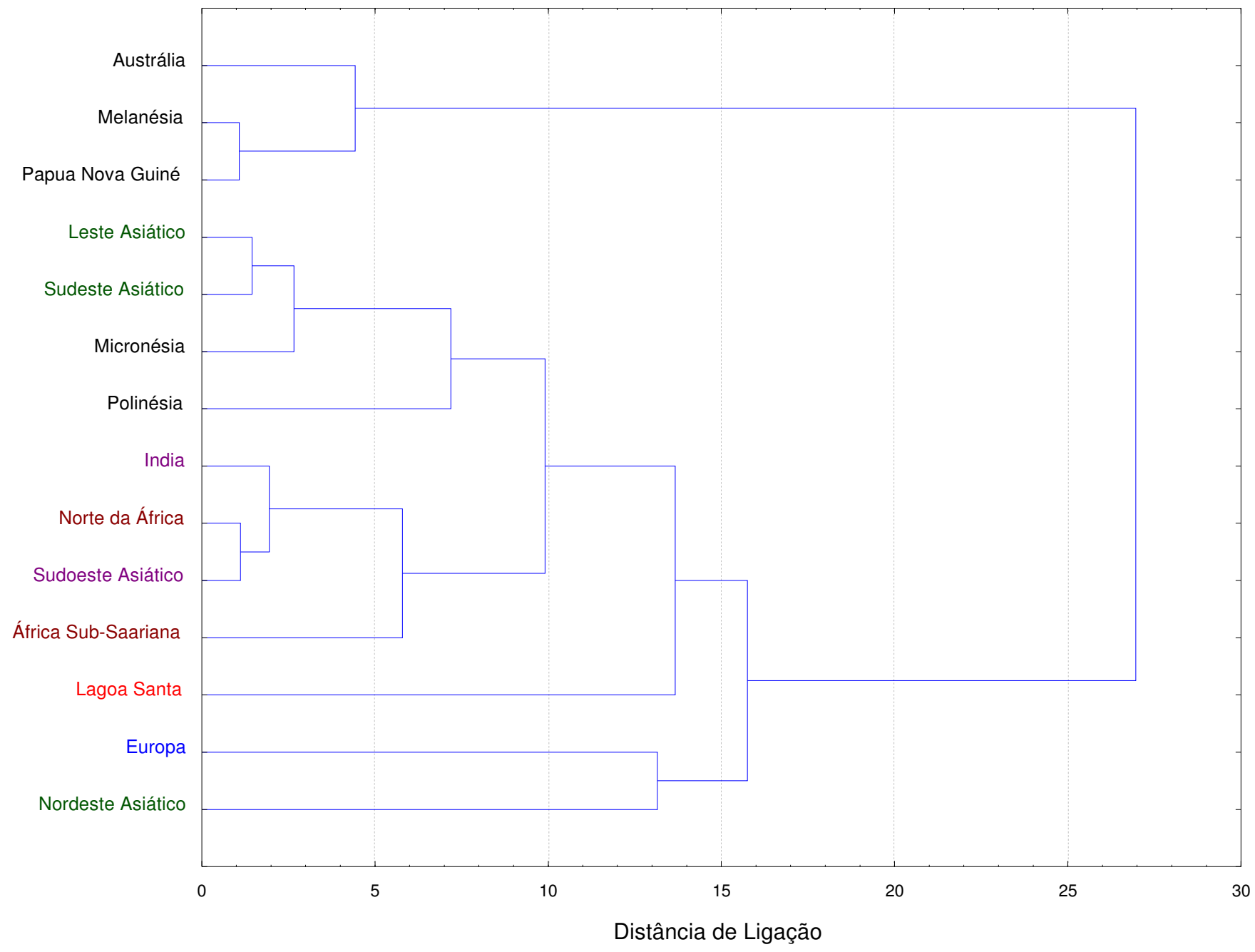


Figura 4.107 - Dendrograma gerado sobre matriz de Distância de Mahalanobis - Método da Média dos Grupos. Parcela masculina, forma apenas (4904 indivíduos, 23 variáveis craniométricas).

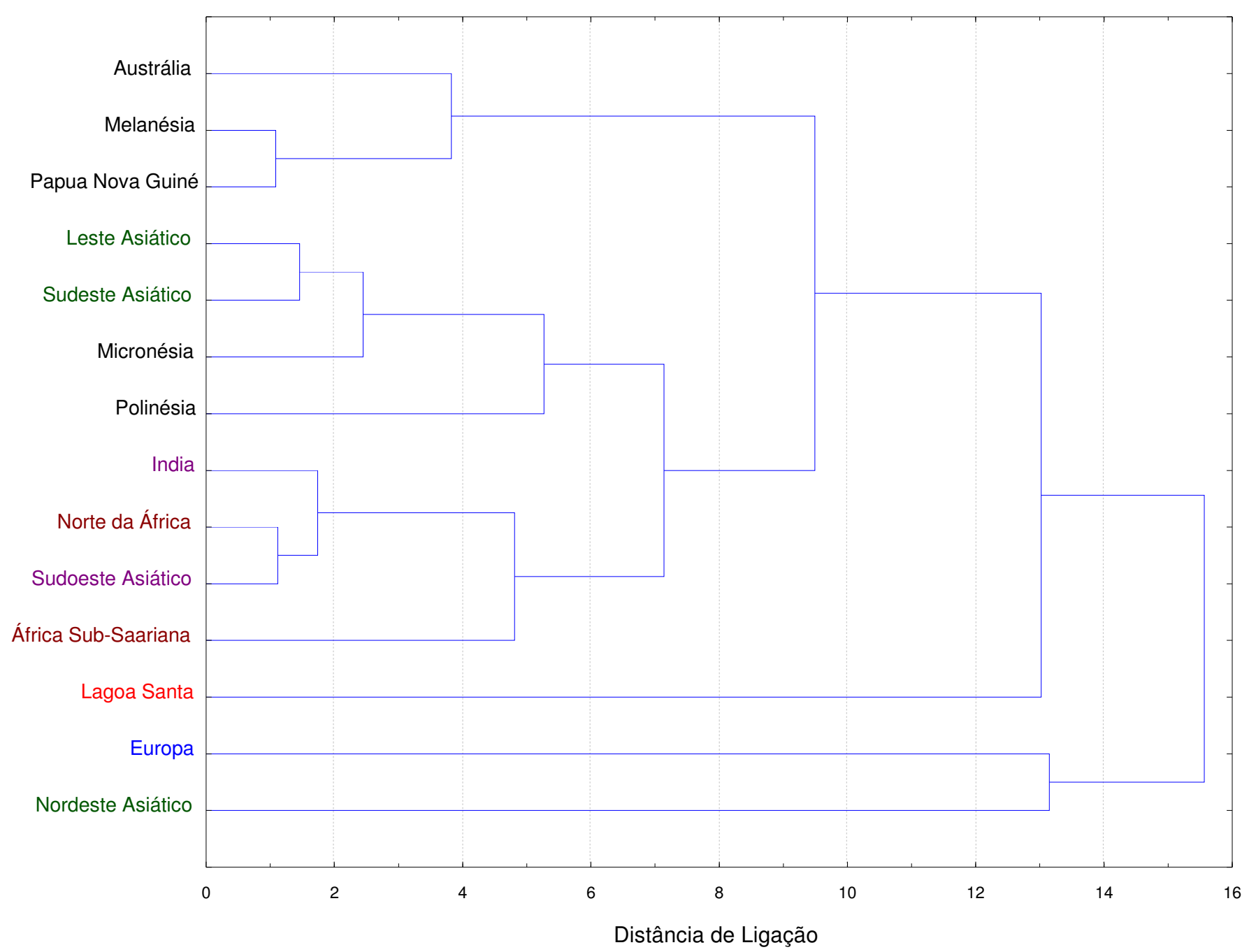


Tabela 4.26 - Configuração final das dimensões calculadas através de escalonamento multidimensional sobre Matriz de Distância baseada em Distâncias de Mahalanobis. Parcela masculina, forma apenas (4904 indivíduos, 23 variáveis craniométricas).

\begin{tabular}{c|c|c|c}
\hline Série & DIMENSÃO 1 & DIMENSÃO 2 & DIMENSÃO 3 \\
\hline Australla & $-1,53843$ & $-0,07006$ & $-0,327627$ \\
Leste Asíático & 0,48205 & 0,23289 & 0,030788 \\
Europa & 0,81578 & $-1,02989$ & $-0,082433$ \\
India & 0,02426 & $-0,22708$ & 0,224763 \\
Melanésia & $-1,14940$ & 0,19379 & 0,218603 \\
Norte da Árrica & 0,15244 & $-0,64195$ & 0,301515 \\
Nordeste Asiático & 1,56151 & 0,51376 & $-0,564091$ \\
Papua Nova Guiné & $-0,83205$ & 0,03202 & 0,140321 \\
Polinésia & $-0,23704$ & 0,76925 & $-0,321166$ \\
Sudeste Asiático & 0,41474 & 0,22623 & $-0,242638$ \\
Árica Sub-Saariana & $-0,36375$ & $-0,32386$ & $-0,575992$ \\
Sudoeste Así́tico & 0,13396 & $-0,58222$ & 0,020017 \\
Micronésia & $-0,02024$ & 0,49478 & 0,168356 \\
Lagoa Santa & 0,55619 & 0,41234 & 1,009585 \\
\hline
\end{tabular}

Figura 4.108 - Gráfico bidimensional da relação ortogonal entre as dimensões $1 \times 2$. Parcela masculina, forma apenas (4904 indivíduos, 23 variáveis craniométricas).

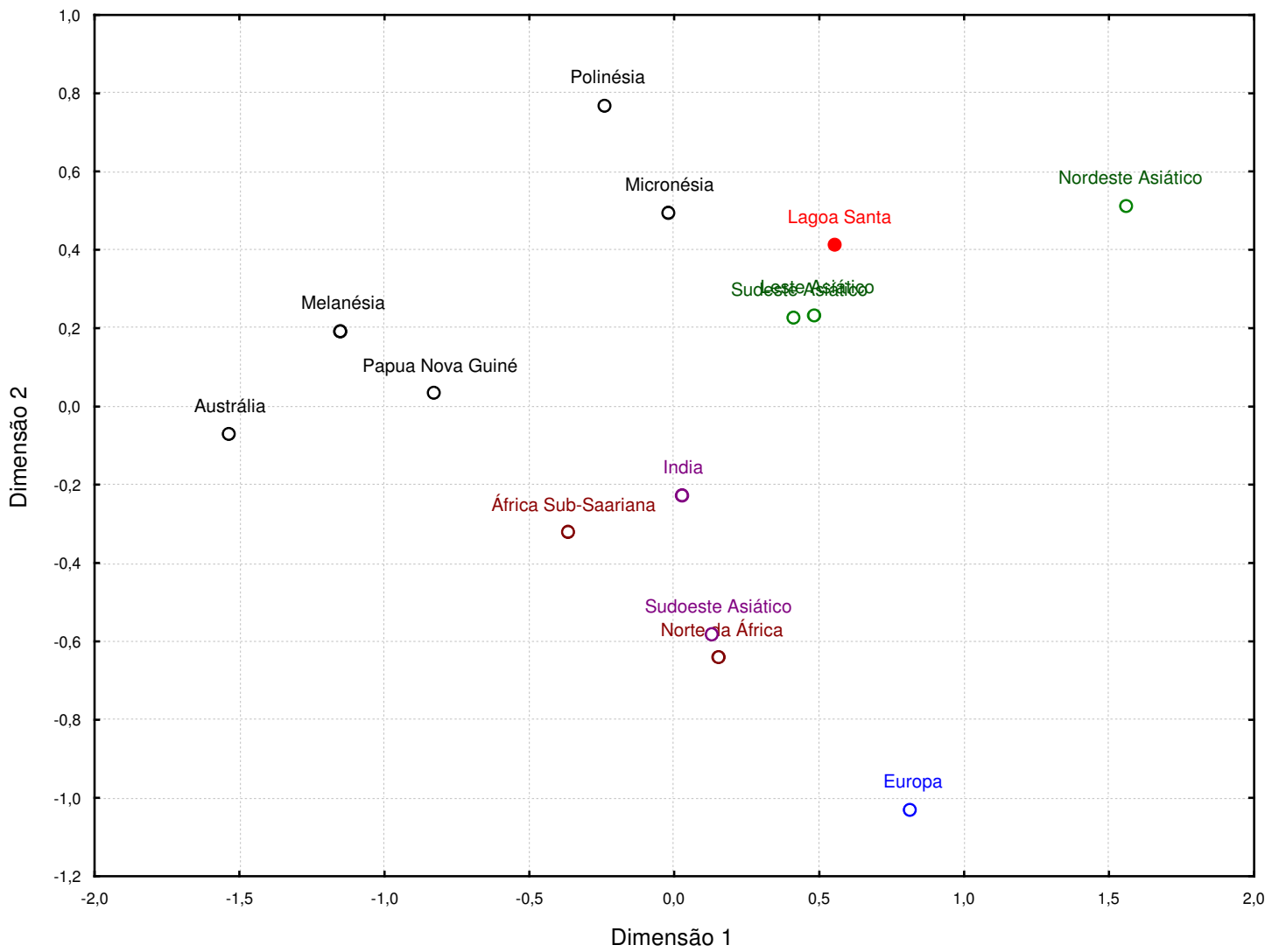


Figura 4.109 - Gráfico bidimensional da relação ortogonal entre as dimensões $1 \times 3$. Parcela masculina, forma apenas (4904 indivíduos, 23 variáveis craniométricas).

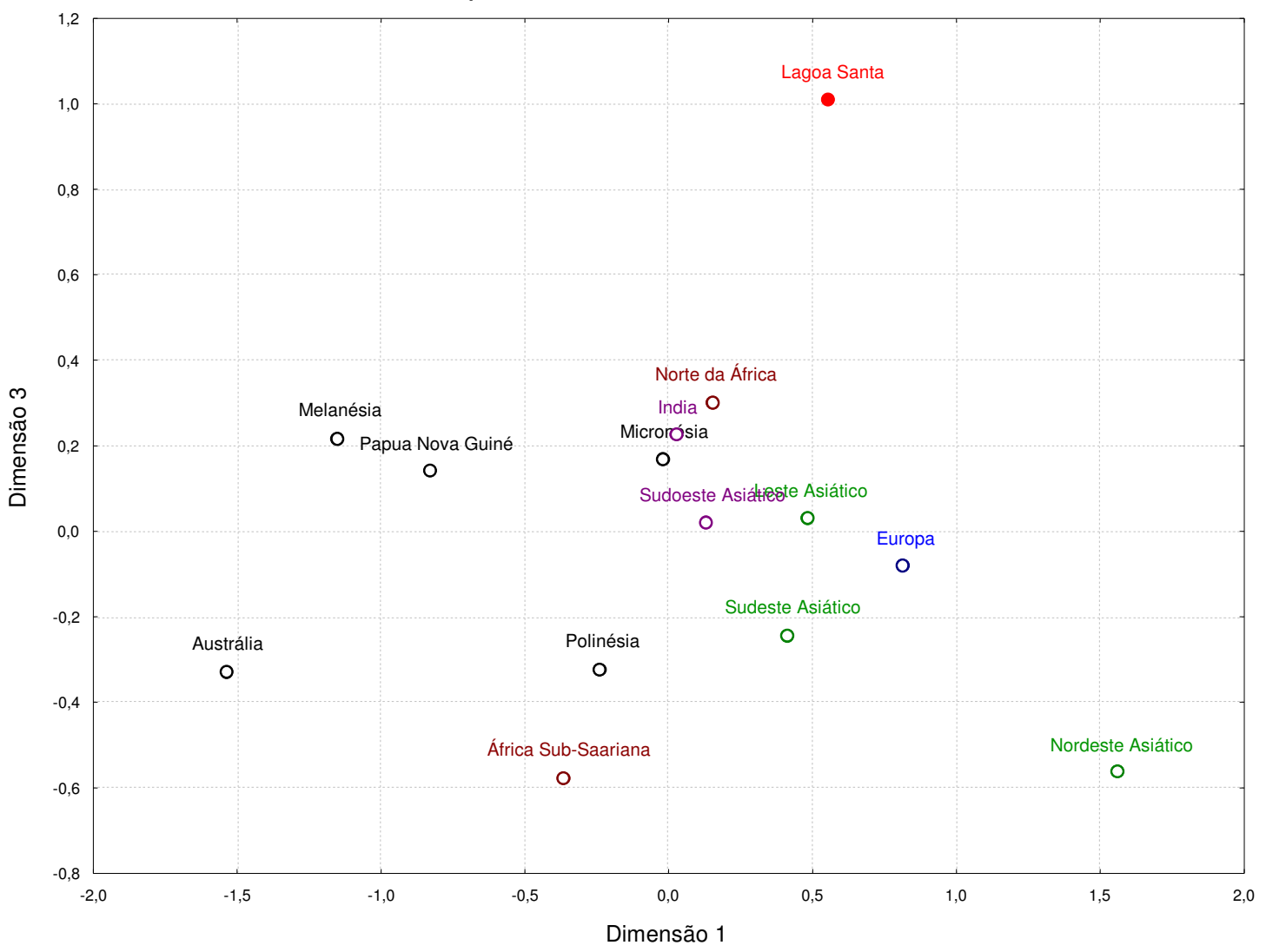

Figura 4.110 - Gráfico bidimensional da relação ortogonal entre as dimensões $2 \times 3$. Parcela masculina, forma apenas (4904 indivíduos, 23 variáveis craniométricas).

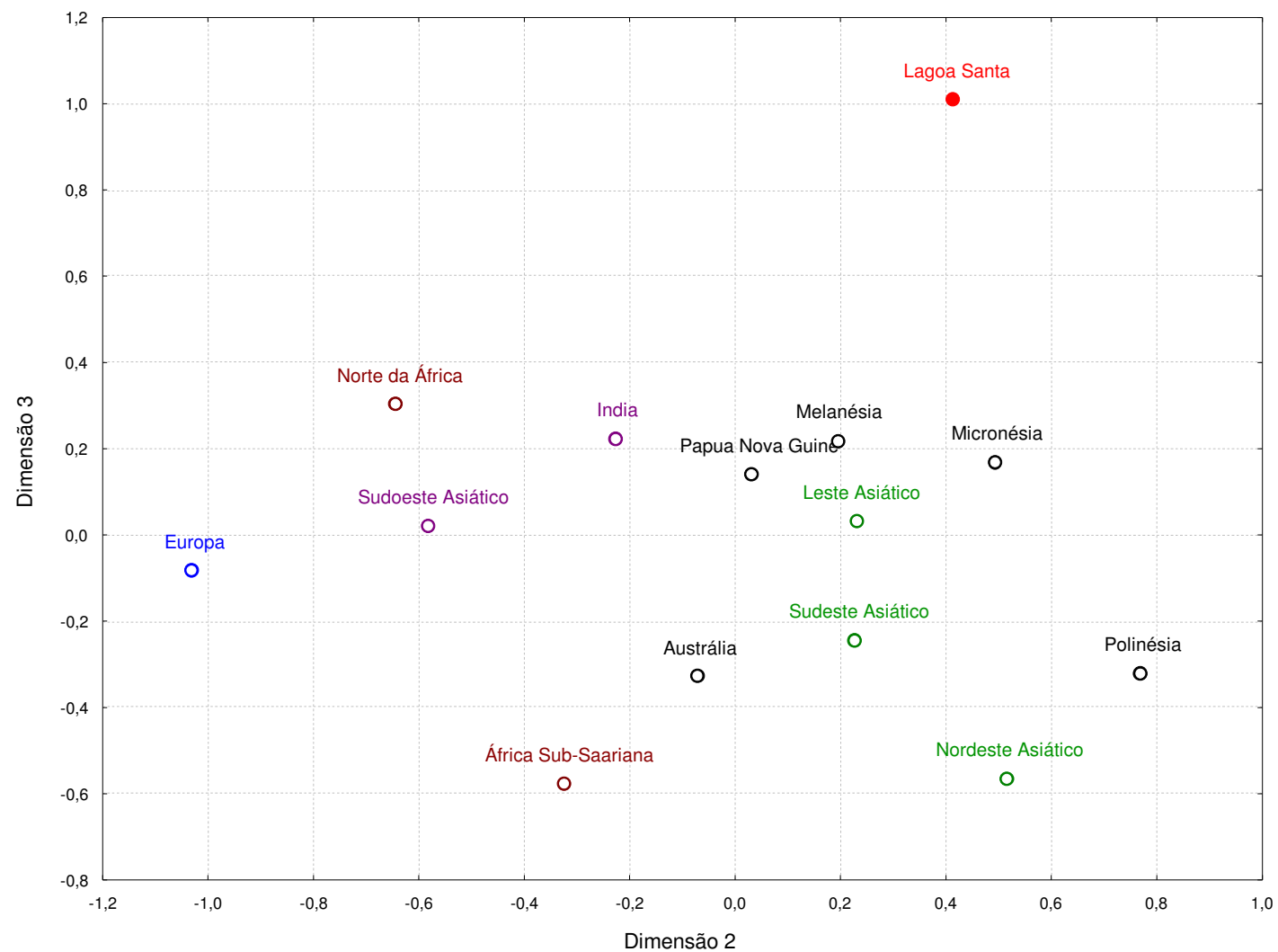




\subsubsection{3 - Parcela Feminina, Tamanho e Forma}

Os resultados obtidos através da ACP sobre os centróides das séries utilizadas, com base em tamanho e forma, para a parcela feminina, são apresentados na Tabela 4.27. O gráfico da Figura 4.111 representa o decaímento dos autovalores dos CPs (screeplot) e a escolha dos 3 primeiros componentes principais para o cálculo de distâncias Euclidianas foi baseado na análises dessa curva.

Tabela 4.27 - Autovalores da matriz de covariância e porcentagens de variância total explicada por cada Componente Principal. Parcela feminina, forma e tamanho (14 séries, 23 variáveis craniométricas).

\begin{tabular}{c|c|c|c|c}
\hline $\begin{array}{c}\text { Componente } \\
\text { Principal }\end{array}$ & Autovalor & $\%$ Total & $\begin{array}{c}\text { Autovalor } \\
\text { Cumulativo }\end{array}$ & $\%$ Cumulativa \\
\hline 1 & 69,38790 & 46,59622 & 69,3879 & 46,5962 \\
2 & 35,39698 & 23,77022 & 104,7849 & 70,3664 \\
3 & 13,94034 & 9,36139 & 118,7252 & 79,7278 \\
4 & 11,64325 & 7,81882 & 130,3685 & 87,5466 \\
5 & 8,82484 & 5,92617 & 139,1933 & 93,4728 \\
6 & 3,43186 & 2,30461 & 142,6252 & 95,7774 \\
7 & 2,18594 & 1,46793 & 144,8111 & 97,2453 \\
8 & 1,78287 & 1,19726 & 146,5940 & 98,4426 \\
9 & 1,14554 & 0,76927 & 147,7395 & 99,2119 \\
10 & 0,64695 & 0,43445 & 148,3865 & 99,6463 \\
11 & 0,25917 & 0,17404 & 148,6457 & 99,8204 \\
12 & 0,20496 & 0,13764 & 148,8506 & 99,9580 \\
13 & 0,06254 & 0,04200 & 148,9132 & 100,0000 \\
\hline
\end{tabular}

Figura 4.111 - Gráfico de decaímento da porcentagem de variância condensada em cada Componente Principal. Parcela feminina, forma e tamanho (14 séries, 23 variáveis craniométricas).

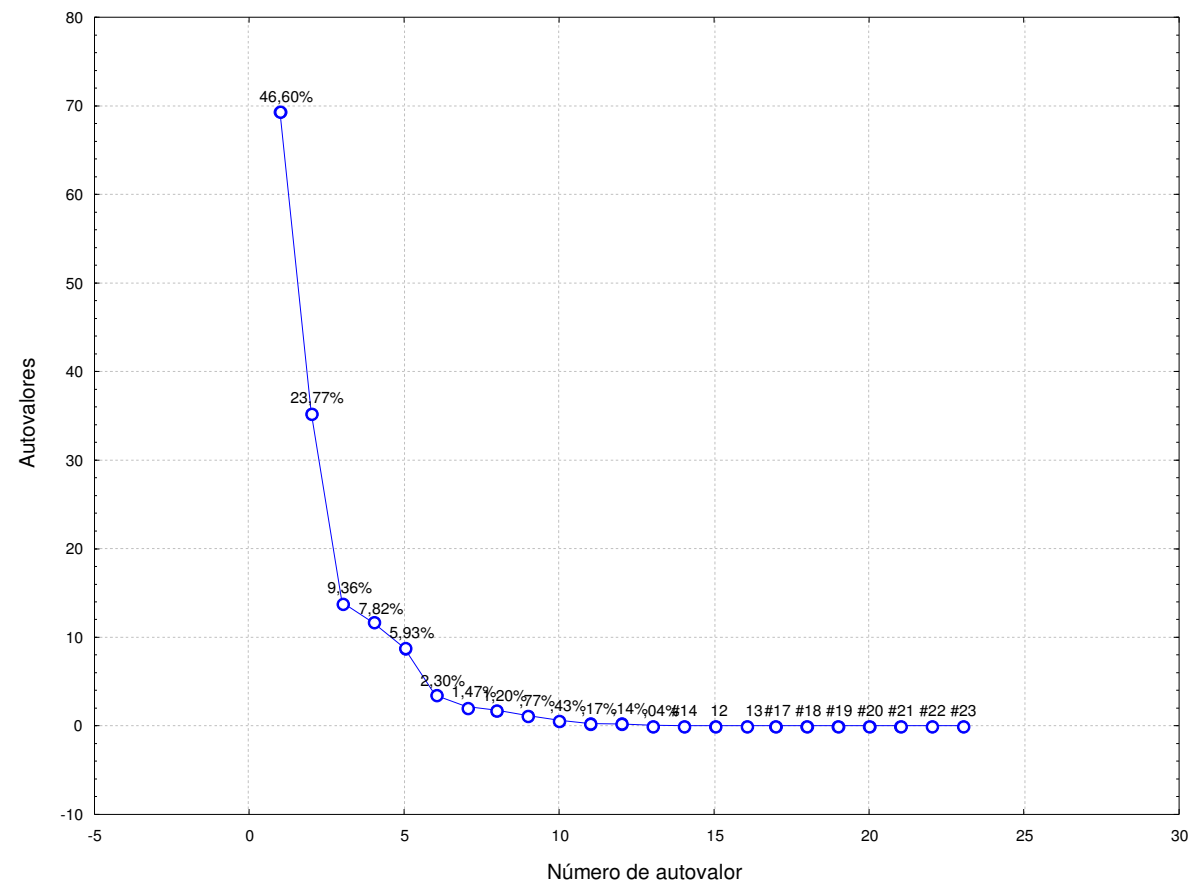


As Tabelas 4.28 e 4.29 indicam, respectivamente, os fatores de coordenadas extraídos pelos Componentes Principais para cada série e a matriz de Distância Euclidiana, calculada sobre os três primeiros CPs.

Os gráficos das Figuras 4.112, 4.113 e 4.114 referem-se às comparações dos centróides no morfo-espaço constituído, respectivamente, pelas relações formadas pelos CP 1 x CP 2, CP 1 x CP 3 e CP 2 x CP 3. Os dendrogramas das Figuras 4.115 a 4.118 apresentam as análises de clusters, sob quatro regras distintas de agrupamento (Ward, Vizinhos Próximos, Vizinhos Distantes e Médias Dentro do Grupo), utilizando-se a matriz de dados baseadas nas distâncias euclidianas calculadas a partir dos CP selecionados.

Figura 4.112 - Gráfico bidimensional do morfo-espaço formado pelos CP 1 x CP 2. Parcela feminina, forma e tamanho (14 séries, 23 variáveis craniométricas).

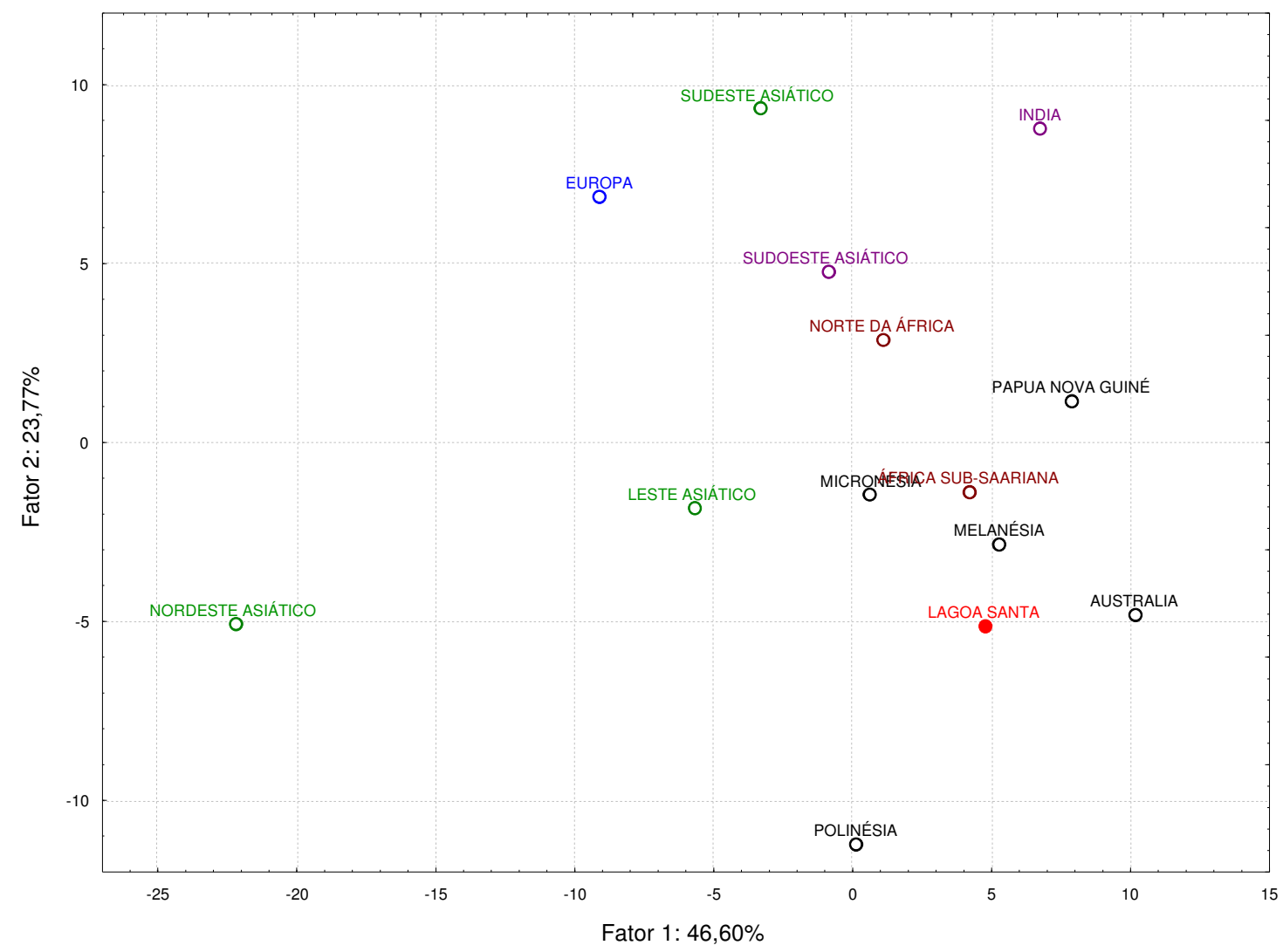


Figura 4.113 - Gráfico bidimensional do morfo-espaço formado pelos CP 1 x CP 3. Parcela feminina, forma e tamanho (14 séries, 23 variáveis craniométricas).

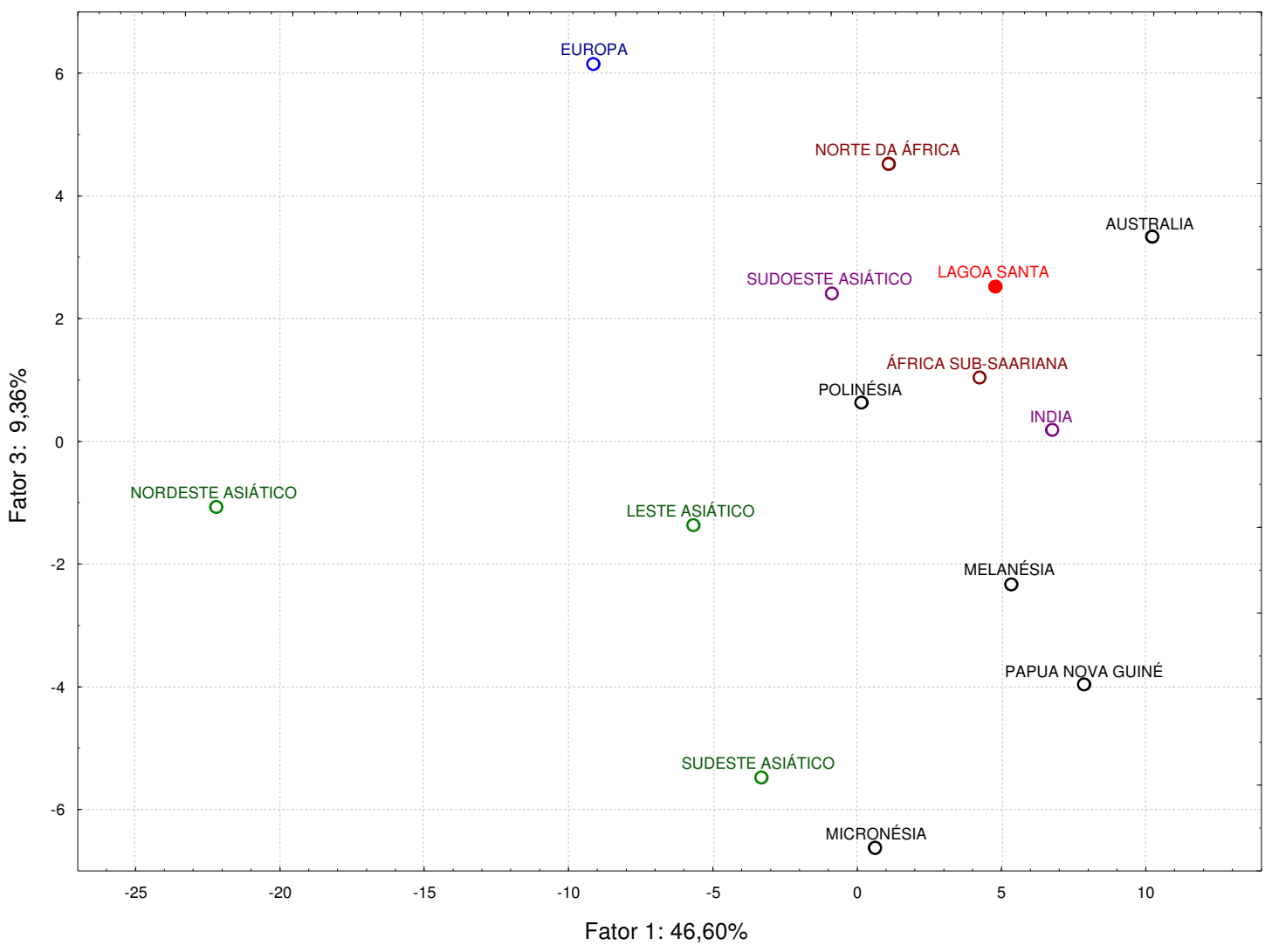

Figura 4.114 - Gráfico bidimensional do morfo-espaço formado pelos CP 2 × CP 3. Parcela feminina, forma e tamanho (14 séries, 23 variáveis craniométricas).

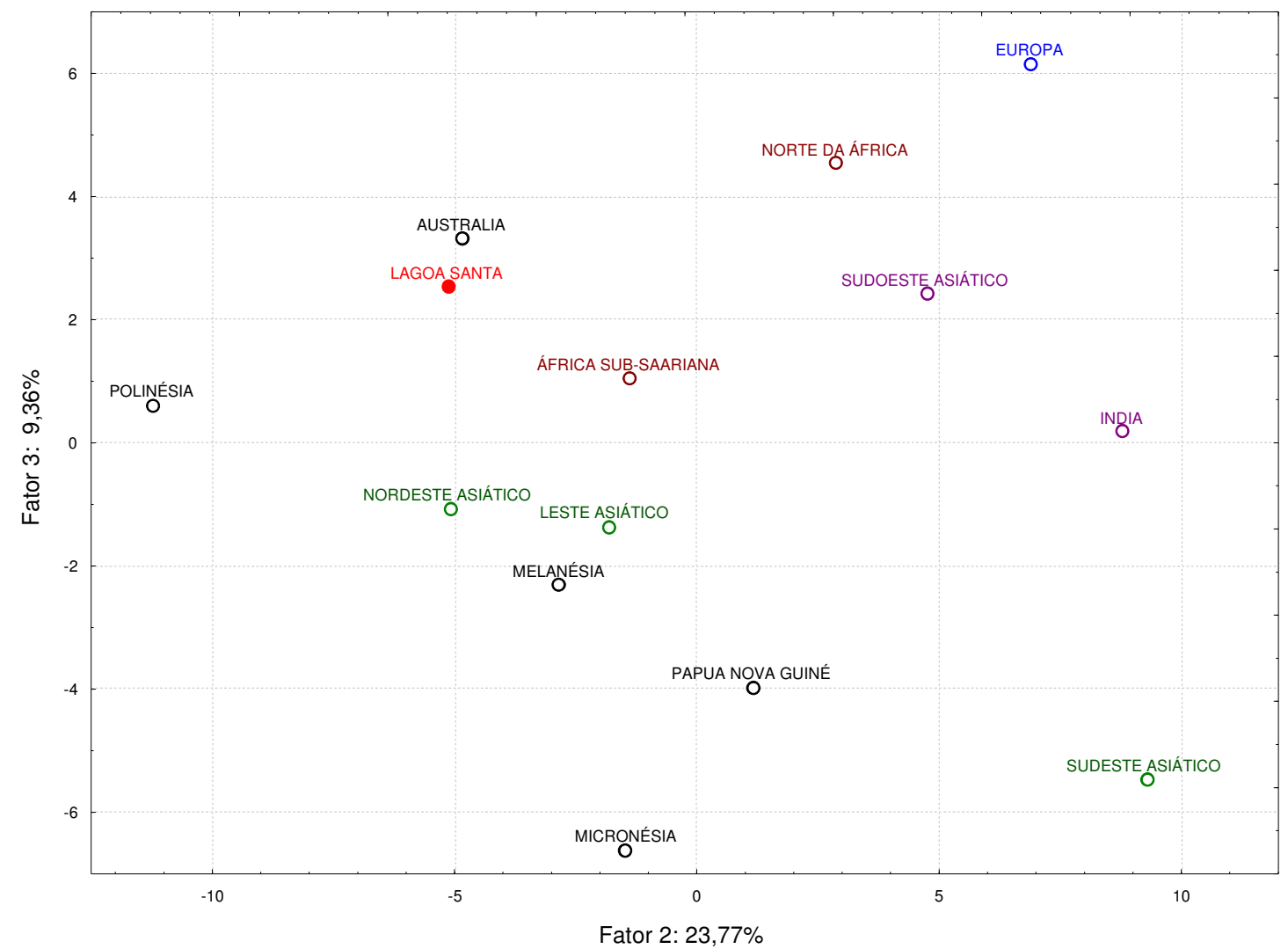


Tabela 4.28 - Fatores de coordenadas de cada série. Parcela feminina, forma e tamanho (14 séries, 23 variáveis craniométricas).

\begin{tabular}{|c|c|c|c|c|c|c|c|c|c|c|c|c|c|}
\hline & Fator 1 & Fator 2 & Fator 3 & Fator 4 & Fator 5 & Fator 6 & Fator 7 & Fator 8 & Fator 9 & Fator10 & Fator11 & Fator12 & Fator13 \\
\hline $\begin{array}{c}\text { AUSTRALIA } \\
\text { LESTE ASIATICO } \\
\text { EUROPA } \\
\text { INDIA } \\
\text { MELANESIA } \\
\text { MICRONESIA } \\
\text { NORTE DA AFRICA } \\
\text { NORDESTE ASIATICO } \\
\text { PAPUA NOVA GUINE } \\
\text { POLINESIA } \\
\text { SUDESTE ASIATICO } \\
\text { AFRICA SUB-SAARIANA } \\
\text { SUDOESTE ASIATICO }\end{array}$ & $\begin{array}{l}10,2221 \\
-5,6364 \\
-9,1026 \\
6,7356 \\
5,3147 \\
0,6376 \\
1,0939 \\
-22,1992 \\
7,9025 \\
0,1490 \\
-3,2898 \\
4,2322 \\
-0,8522 \\
\end{array}$ & $\begin{array}{l}-4,8140 \\
-1,8271 \\
6,8758 \\
8,7681 \\
-2,8328 \\
-1,4831 \\
2,8793 \\
-5,0865 \\
1,1488 \\
-11,2318 \\
9,3123 \\
-1,3650 \\
4,7773\end{array}$ & \begin{tabular}{|l|}
3,31909 \\
$-1,36192$ \\
6,16362 \\
0,17713 \\
$-2,31714$ \\
$-6,61720$ \\
4,52969 \\
$-1,06543$ \\
$-3,97358$ \\
0,61324 \\
$-5,47430$ \\
1,05186 \\
2,42051
\end{tabular} & \begin{tabular}{|l|}
4,8747 \\
$-0,6196$ \\
0,6627 \\
$-1,5810$ \\
1,9345 \\
$-0,6603$ \\
0,7611 \\
0,9826 \\
2,5415 \\
1,0167 \\
$-1,4686$ \\
0,0497 \\
1,7873 \\
\end{tabular} & $\begin{array}{l}-4,54511 \\
2,12225 \\
-0,42339 \\
-0,39997 \\
-1,36753 \\
2,51235 \\
4,67007 \\
-3,83792 \\
-1,14384 \\
5,38483 \\
-0,66038 \\
-2,35949 \\
2,04785\end{array}$ & $\begin{array}{l}0,62134 \\
-0,99735 \\
0,73711 \\
1,86042 \\
-0,72292 \\
-2,15229 \\
-2,88847 \\
-0,52148 \\
-1,05573 \\
3,98492 \\
2,75336 \\
-0,52503 \\
-0,58659\end{array}$ & \begin{tabular}{|l|}
0,67515 \\
0,03857 \\
2,00907 \\
1,01180 \\
1,12224 \\
1,92030 \\
$-1,76074$ \\
$-0,33425$ \\
$-0,13761$ \\
$-0,21005$ \\
$-1,71930$ \\
$-3,37954$ \\
0,31750
\end{tabular} & \begin{tabular}{|l|}
$-1,16635$ \\
0,25514 \\
1,83863 \\
$-2,52100$ \\
2,38111 \\
$-1,35535$ \\
$-0,20240$ \\
$-1,19649$ \\
1,26905 \\
0,13111 \\
0,90767 \\
$-0,16865$ \\
$-0,60675$
\end{tabular} & $\begin{array}{l}0,94762 \\
1,46313 \\
-1,05780 \\
0,38933 \\
0,08032 \\
-1,45859 \\
1,28969 \\
0,38741 \\
0,44689 \\
-0,30383 \\
0,68584 \\
-2,21733 \\
-0,93606\end{array}$ & $\begin{array}{l}1,15663 \\
0,16706 \\
0,53563 \\
-0,82111 \\
-0,21176 \\
1,09524 \\
0,45947 \\
-0,59705 \\
-1,42771 \\
-0,26850 \\
0,99203 \\
0,12848 \\
-1,06805\end{array}$ & \begin{tabular}{|l|}
0,228441 \\
0,745285 \\
$-0,446124$ \\
$-0,345604$ \\
0,276812 \\
$-0,223704$ \\
$-0,540648$ \\
$-0,270080$ \\
$-0,666172$ \\
$-0,242011$ \\
0,214211 \\
0,012786 \\
1,182060
\end{tabular} & \begin{tabular}{|l|}
0,14756 \\
$-1,13275$ \\
$-0,29190$ \\
$-0,40641$ \\
0,13419 \\
0,10986 \\
0,37015 \\
0,26867 \\
$-0,04431$ \\
0,07400 \\
0,42327 \\
$-0,51700$ \\
0,57766
\end{tabular} & \begin{tabular}{|l|l|}
0,176024 \\
0,11973 \\
0,125669 \\
$-0,309117$ \\
$-0,620298$ \\
0,070410 \\
$-0,154172$ \\
$-0,098738$ \\
0,434223 \\
0,015708 \\
0,068405 \\
$-0,081770$ \\
0,147120
\end{tabular} \\
\hline
\end{tabular}

Tabela 4.29 - Matriz de Distância Euclidiana calculada sobre os três primeiros Componentes Principais. Parcela feminina, forma e tamanho (14 séries, 23 variáveis craniométricas).

\begin{tabular}{|c|c|c|c|c|c|c|c|c|c|c|c|c|c|c|}
\hline & Austrália & Leste Asiático & Europa & Índia & Melanésia & Micronésia & Norte da África & $\begin{array}{l}\text { Nordeste } \\
\text { Asiático }\end{array}$ & $\begin{array}{l}\text { Papua Nova } \\
\text { Guiné }\end{array}$ & Polinésia & $\begin{array}{l}\text { Sudeste } \\
\text { Asiático }\end{array}$ & $\begin{array}{l}\text { África Sub- } \\
\text { Saariana }\end{array}$ & $\begin{array}{l}\text { Sudoeste } \\
\text { Asiático }\end{array}$ & Lagoa Santa \\
\hline Austrália & 0,0 & 16,8 & 22,8 & 14,4 & 7,7 & 14,2 & 12,0 & 32,7 & 9,7 & 12,2 & 21,4 & 7,3 & 14,7 & 5,5 \\
\hline Leste Asiático & & 0,0 & 12,0 & 16,4 & 11,0 & 8,2 & 10,1 & 16,9 & 14,1 & 11,2 & 12,1 & 10,2 & 9,0 & 11,6 \\
\hline Europa & & & 0,0 & 17,0 & 19,3 & 18,1 & 11,1 & 19,2 & 20,6 & 21,1 & 13,2 & 16,5 & 9,3 & 18,7 \\
\hline Índia & & & & 0,0 & 12,0 & 13,7 & 9,2 & 32,1 & 8,8 & 21,1 & 11,5 & 10,5 & 8,9 & 14,2 \\
\hline Melanésia & & & & & 0,0 & 6,5 & 9,9 & 27,6 & 5,0 & 10,3 & 15,2 & 3,8 & 10,9 & 5,4 \\
\hline Micronésia & & & & & & 0,0 & 12,0 & 23,8 & 8,2 & 12,1 & 11,5 & 8,5 & 11,1 & 10,7 \\
\hline Norte da África & & & & & & & 0,0 & 25,2 & 11,0 & 14,7 & 12,7 & 6,3 & 3,4 & 9,0 \\
\hline $\begin{array}{l}\text { Nordeste } \\
\text { Asiático }\end{array}$ & & & & & & & & 0,0 & 30,9 & 23,2 & 24,2 & 26,8 & 23,8 & 27,2 \\
\hline $\begin{array}{l}\text { Papua Nova } \\
\text { Guiné }\end{array}$ & & & & & & & & & 0,0 & 15,3 & 13,9 & 6,7 & 11,4 & 9,6 \\
\hline Polinésia & & & & & & & & & & 0,0 & 21,7 & 10,7 & 16,1 & 7,9 \\
\hline $\begin{array}{l}\text { Sudeste } \\
\text { Asiático }\end{array}$ & & & & & & & & & & & 0,0 & 14,6 & 9,4 & 18,4 \\
\hline $\begin{array}{l}\text { África Sub- } \\
\text { Saariana }\end{array}$ & & & & & & & & & & & & 0,0 & 8,1 & 4,1 \\
\hline $\begin{array}{l}\text { Sudoeste } \\
\text { Asiático }\end{array}$ & & & & & & & & & & & & & 0,0 & 11,4 \\
\hline Lagoa Santa & & & & & & & & & & & & & & 0,0 \\
\hline
\end{tabular}


Figura 4.115 - Dendrograma gerado sobre matriz de Distância Euclidiana calculada a partir dos três primeiros Componentes Principais - Método de Ward. Parcela feminina, forma e tamanho (14 séries, 23 variáveis craniométricas).

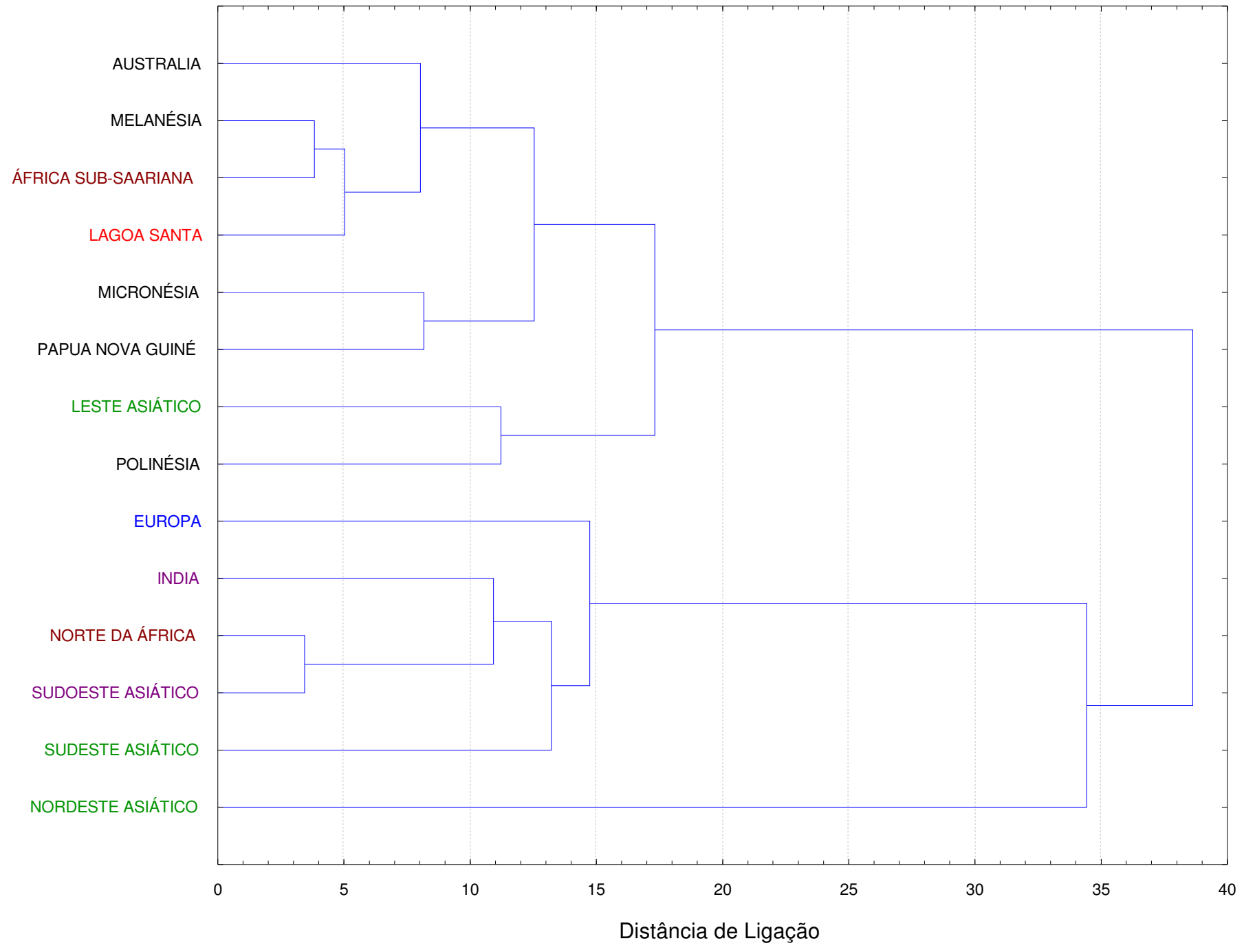


Figura 4.116 - Dendrograma gerado sobre matriz de Distância Euclidiana calculada a partir dos três primeiros Componentes Principais - Método de Ligação Simples. Parcela feminina, forma e tamanho (14 séries, 23 variáveis craniométricas).

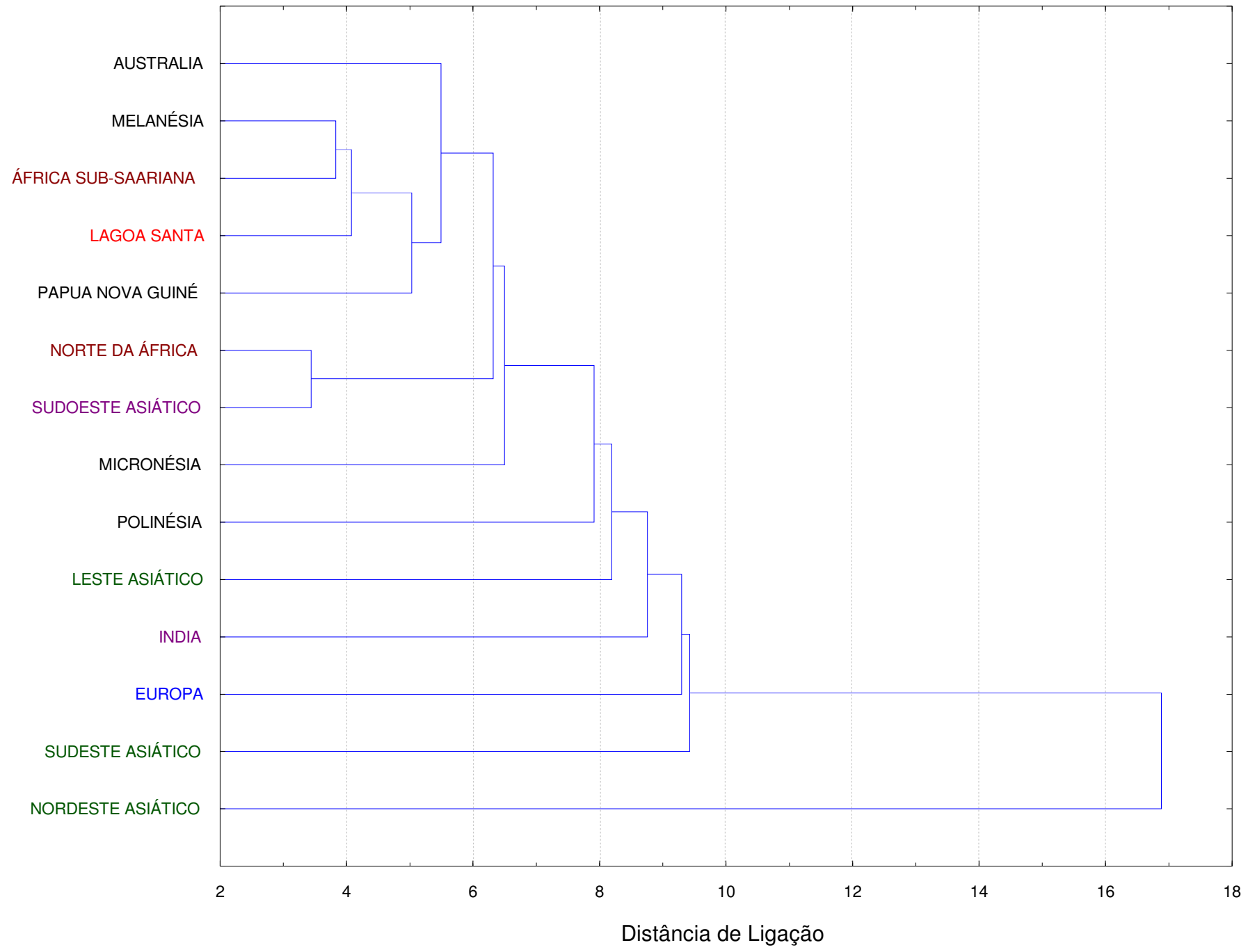


Figura 4.117 - Dendrograma gerado sobre matriz de Distância Euclidiana calculada a partir dos três primeiros Componentes Principais - Método de Ligação Completa. Parcela feminina, forma e tamanho (14 séries, 23 variáveis craniométricas).

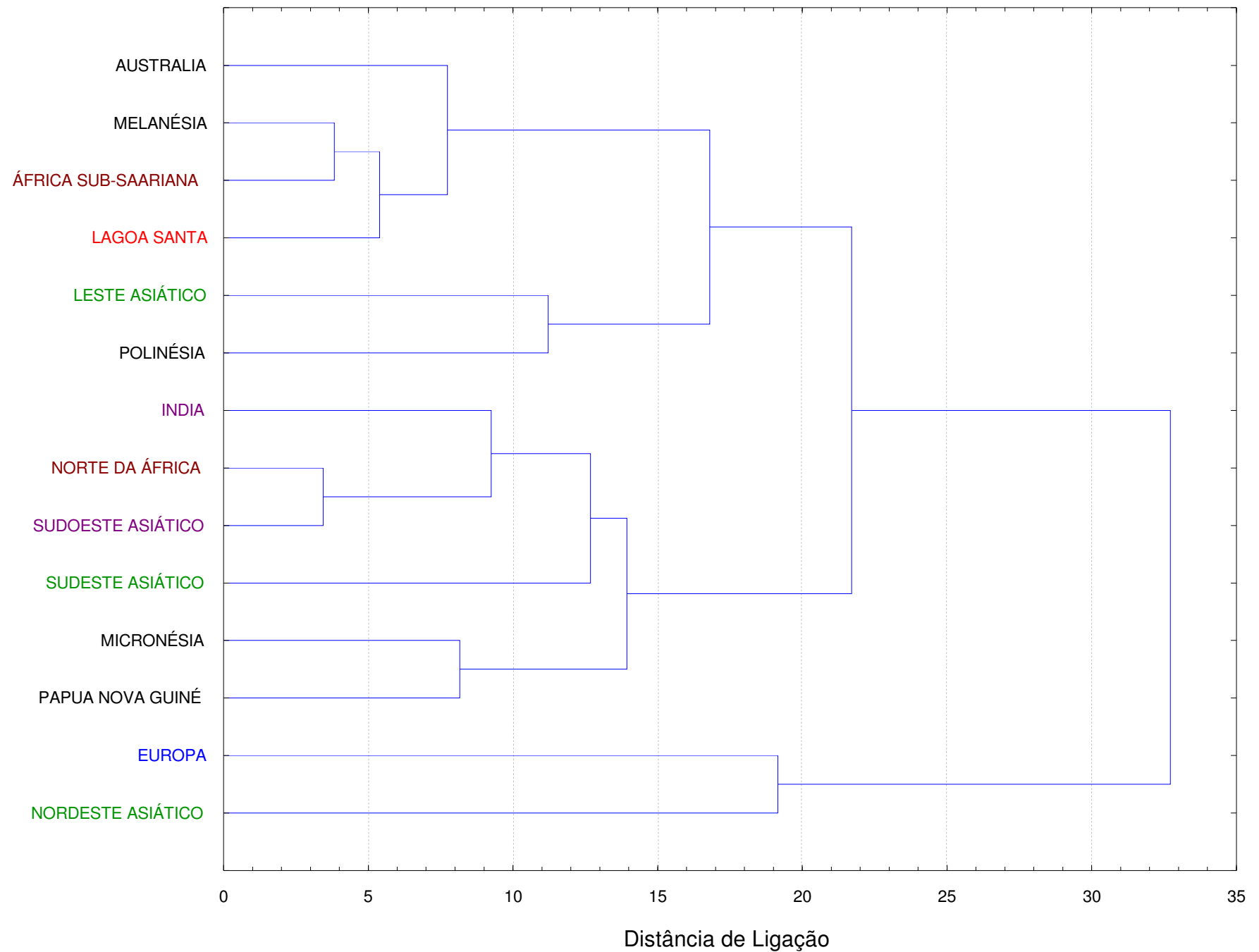


Figura 4.118 - Dendrograma gerado sobre matriz de Distância Euclidiana calculada a partir dos três primeiros Componentes Principais - Método da Média dos Grupos. Parcela feminina, forma e tamanho (14 séries, 23 variáveis craniométricas).

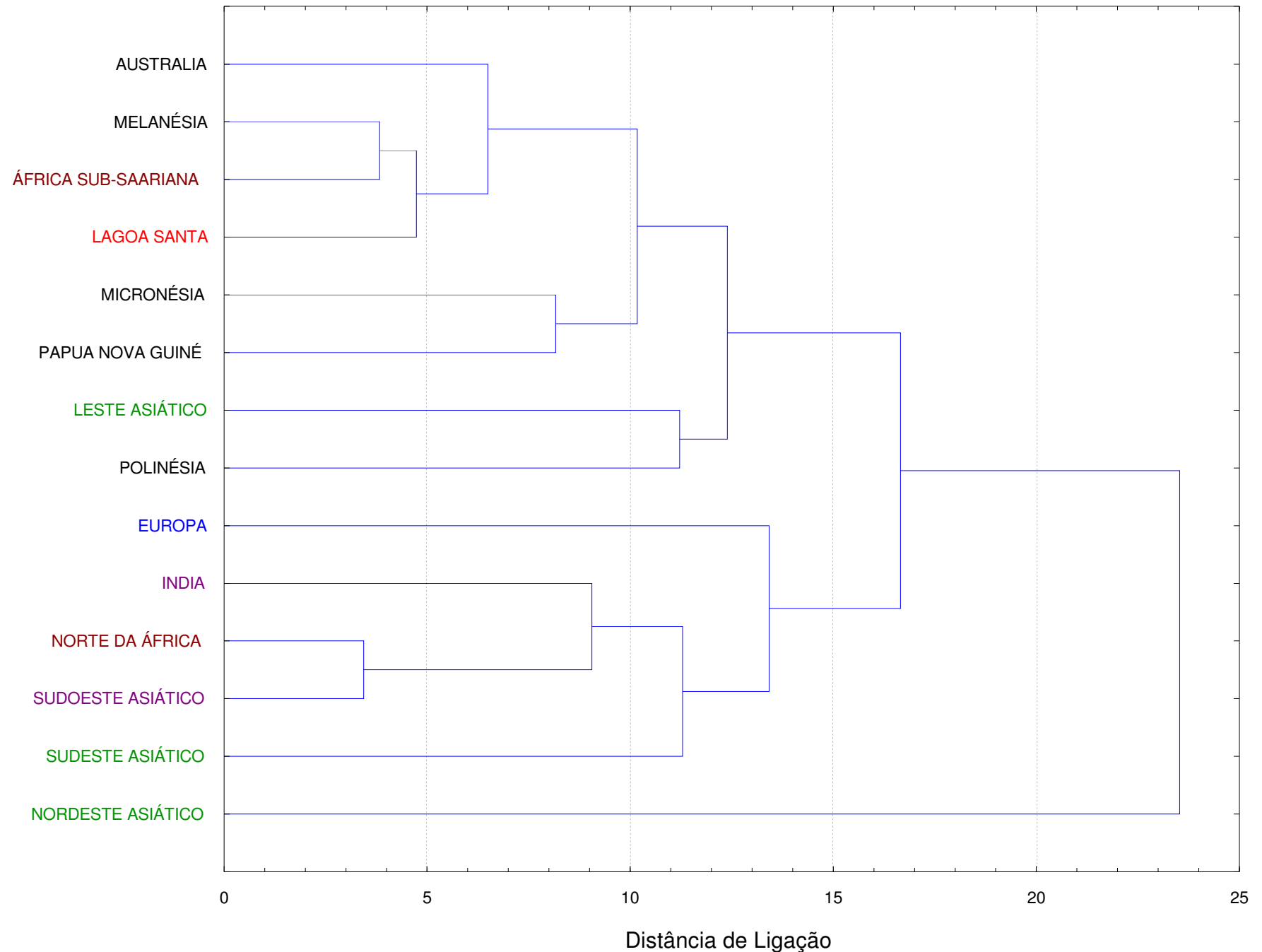


Os gráficos e dendrogramas obtidos a partir da investigação das afinidades extra-continentais dos Paleoíndios de Lagoa Santa da parcela feminina, dados não corrigidos quanto ao fator tamanho, indicam associação morfológica entre a população paleoamericana e as de morfologia generalizada do Velho Mundo (Africanos Subsaarianos e Australo-Melanésicos). Essa constatação pode ser confirmada pela através da análise das topologias bidimensionais geradas pelos três primeiros Componentes Principais, uma vez que, nos três gráficos, observa-se a associação entre a população de Lagoa Santa e às australo-melanésicas e africanas subsaarianas, ocupando, juntas, sempre a região do plano representada pelas projeções vetoriais definidas pelas variáveis que indicam crânios caracterizados por serem altos, estreitos e longos em oposição aos posicionados na região caracterizada por morfologia de crânios largos e hortognatos, sempre ocupados pelos centróides das populações do leste asiático.

Os quatro dendogramas confirmam a associação morfológica observada entre os Paleoíndios de Lagoa Santa e os africanos subsaarianos e australomelanésicos. De maneira bem consistente, a população de Lagoa Santa associou-se, sempre, preferencialmente aos representantes da morfologia generalizada, dando mais robustez à associação observada através da Análise de Componentes Principais.

Como adotado também para os outros conjuntos de dados, executou-se também análises de agrupamentos executados a partir de matrizes de Distância de Mahalanobis, utilizando, também, os mesmos quatro critérios de agregação (Tabela 4.30, Figuras 4.119 a 4.122), que, por fim, também subsidiou a aplicação da técnica de Escalonamento Multidimensional - MDS (Tabela 4.31, Figuras 4.123 a 4.125) para essa matriz de dados.

Os resultados obtidos por essas técnicas corroboram os gerados através das ACPs, embora as associações morfológicas observadas, principalmente entre paleoíndios e australo-melanésicos não tenham apresentado-se de maneira consistente. 
Tabela 4.30 - Matriz de Distância de Mahalanobis. Parcela feminina, forma e tamanho (1138 indivíduos, 23 variáveis craniométricas).

\begin{tabular}{|c|c|c|c|c|c|c|c|c|c|c|c|c|c|c|}
\hline & Austrália & $\begin{array}{c}\text { Leste } \\
\text { Asiático }\end{array}$ & Europa & Índia & Melanésia & Micronésia & $\begin{array}{c}\text { Norte da } \\
\text { África }\end{array}$ & $\begin{array}{l}\text { Nordeste } \\
\text { Asiático }\end{array}$ & $\begin{array}{l}\text { Papua } \\
\text { Nova } \\
\text { Guiné }\end{array}$ & Polinésia & $\begin{array}{l}\text { Sudeste } \\
\text { Asiático }\end{array}$ & $\begin{array}{c}\text { África } \\
\text { Sub- } \\
\text { Saariana }\end{array}$ & $\begin{array}{l}\text { Sudoeste } \\
\text { Asiático }\end{array}$ & $\begin{array}{l}\text { Lagoa } \\
\text { Santa }\end{array}$ \\
\hline Austrália & 0,00000 & 13,67905 & 18,53143 & 11,65128 & 4,42763 & 12,32889 & 18,48927 & 29,33587 & 7,17295 & 10,26901 & 16,00587 & 12,65620 & 16,18287 & 14,78432 \\
\hline Leste Asiático & & 0,00000 & 8,87015 & 6,16194 & 8,08260 & 3,95175 & 7,76349 & 9,37008 & 9,06888 & 4,56008 & 3,50638 & 6,71999 & 6,65547 & 6,38061 \\
\hline Europa & & & 0,00000 & 6,97606 & 15,68810 & 15,90084 & 6,91391 & 14,67576 & 15,55820 & 15,75886 & 9,84013 & 13,09679 & 4,12254 & 18,14985 \\
\hline Índia & & & & 0,00000 & 9,61597 & 7,94889 & 3,73262 & 21,56261 & 7,30252 & 8,77877 & 4,98819 & 8,34640 & 3,78876 & 10,18850 \\
\hline Melanésia & & & & & 0,00000 & 5,76588 & 11,98692 & 25,80953 & 1,48221 & 6,79882 & 10,21655 & 8,07257 & 9,96513 & 12,24802 \\
\hline Micronésia & & & & & & 0,00000 & 10,82344 & 19,51003 & 6,75415 & 6,29684 & 6,64681 & 7,89025 & 9,44200 & 6,67065 \\
\hline Norte da África & & & & & & & 0,00000 & 22,84730 & 9,24963 & 12,55880 & 6,60402 & 6,93887 & 1,48597 & 14,33941 \\
\hline $\begin{array}{l}\text { Nordeste } \\
\text { Asiático }\end{array}$ & & & & & & & & 0,00000 & 28,03588 & 18,81454 & 13,69510 & 16,83414 & 18,65271 & 17,38102 \\
\hline $\begin{array}{l}\text { Papua Nova } \\
\text { Guiné }\end{array}$ & & & & & & & & & 0,00000 & 9,01775 & 8,33085 & 7,40524 & 8,14766 & 13,44469 \\
\hline Polinésia & & & & & & & & & & 0,00000 & 9,83406 & 9,89662 & 10,79555 & 11,54411 \\
\hline $\begin{array}{l}\text { Sudeste } \\
\text { Asiático }\end{array}$ & & & & & & & & & & & 0,00000 & 7,17695 & 6,11289 & 10,23863 \\
\hline $\begin{array}{l}\text { África Sub- } \\
\text { Saariana }\end{array}$ & & & & & & & & & & & & 0,00000 & 5,90881 & 11,17224 \\
\hline $\begin{array}{l}\text { Sudoeste } \\
\text { Asiático }\end{array}$ & & & & & & & & & & & & & 0,00000 & 14,20881 \\
\hline Lagoa Santa & & & & & & & & & & & & & & 0,00000 \\
\hline
\end{tabular}


Figura 4.119 - Dendrograma gerado sobre matriz de Distância de Mahalanobis - Método de Ward. Parcela feminina, forma e tamanho (1138 indivíduos, 23 variáveis craniométricas).

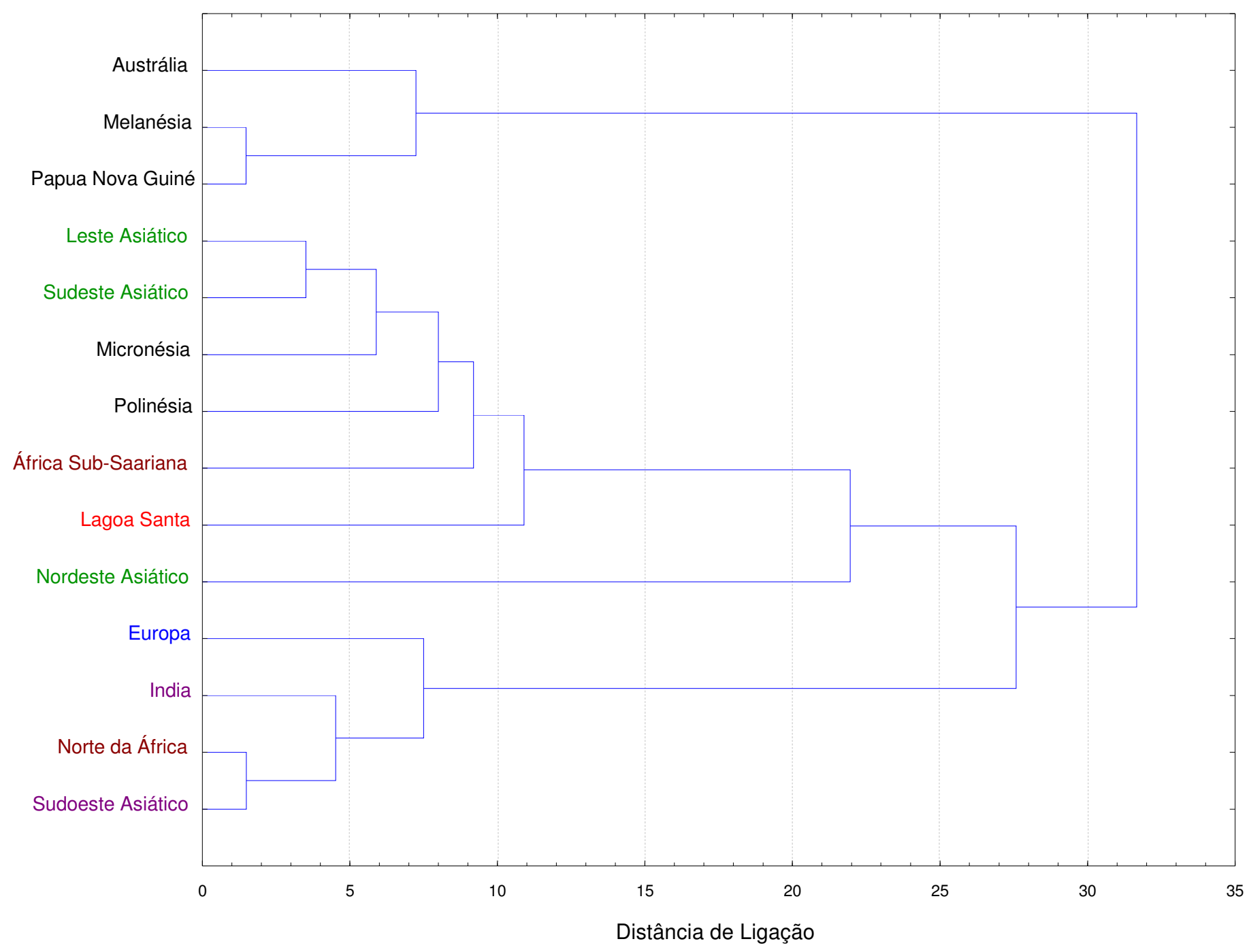


Figura 4.120 - Dendrograma gerado sobre matriz de Distância de Mahalanobis - Método de Ligação Simples. Parcela feminina, forma e tamanho (1138 indivíduos, 23 variáveis craniométricas).

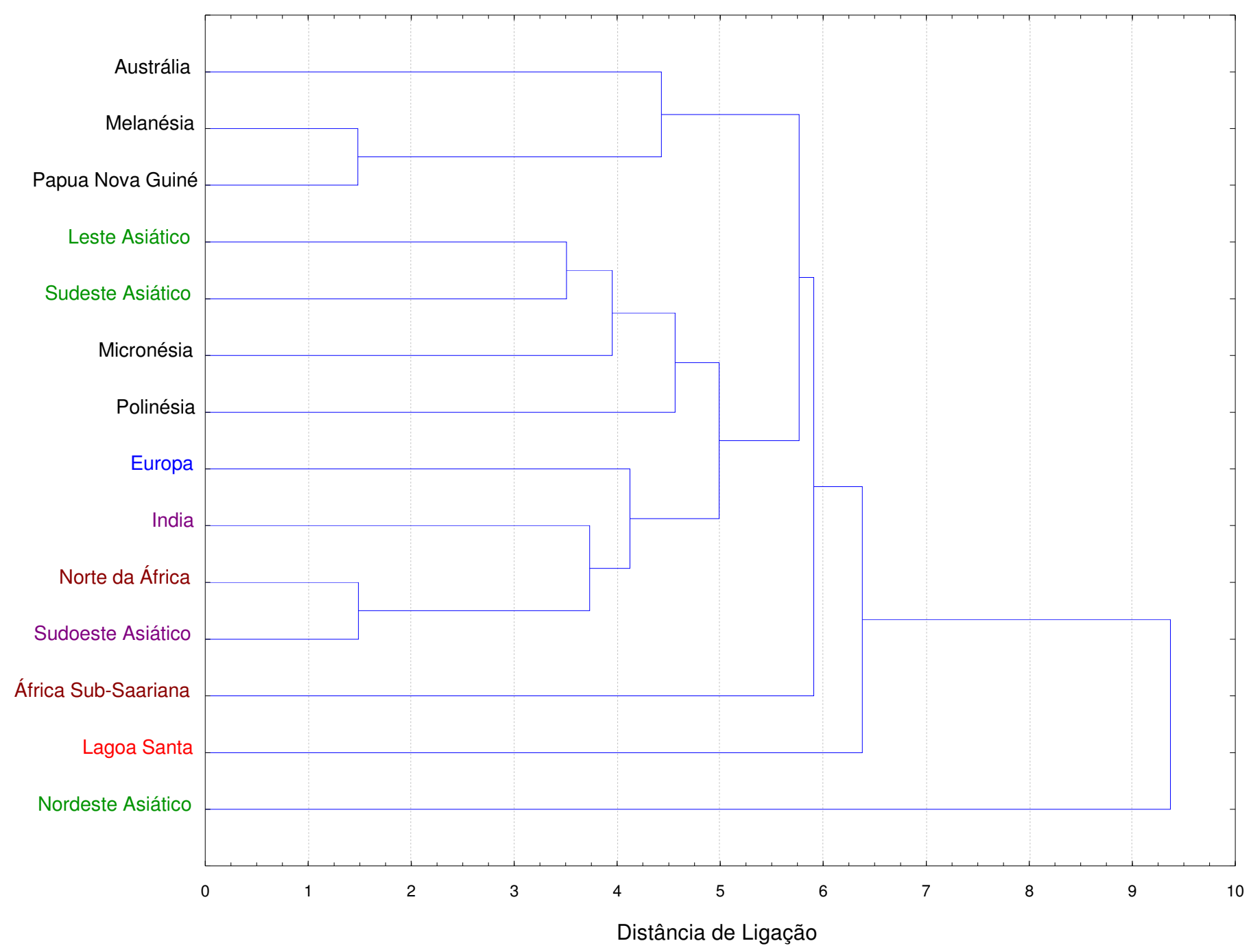


Figura 4.121 - Dendrograma gerado sobre matriz de Distância de Mahalanobis - Método de Ligação Completa. Parcela feminina, forma e tamanho (1138 indivíduos, 23 variáveis craniométricas).

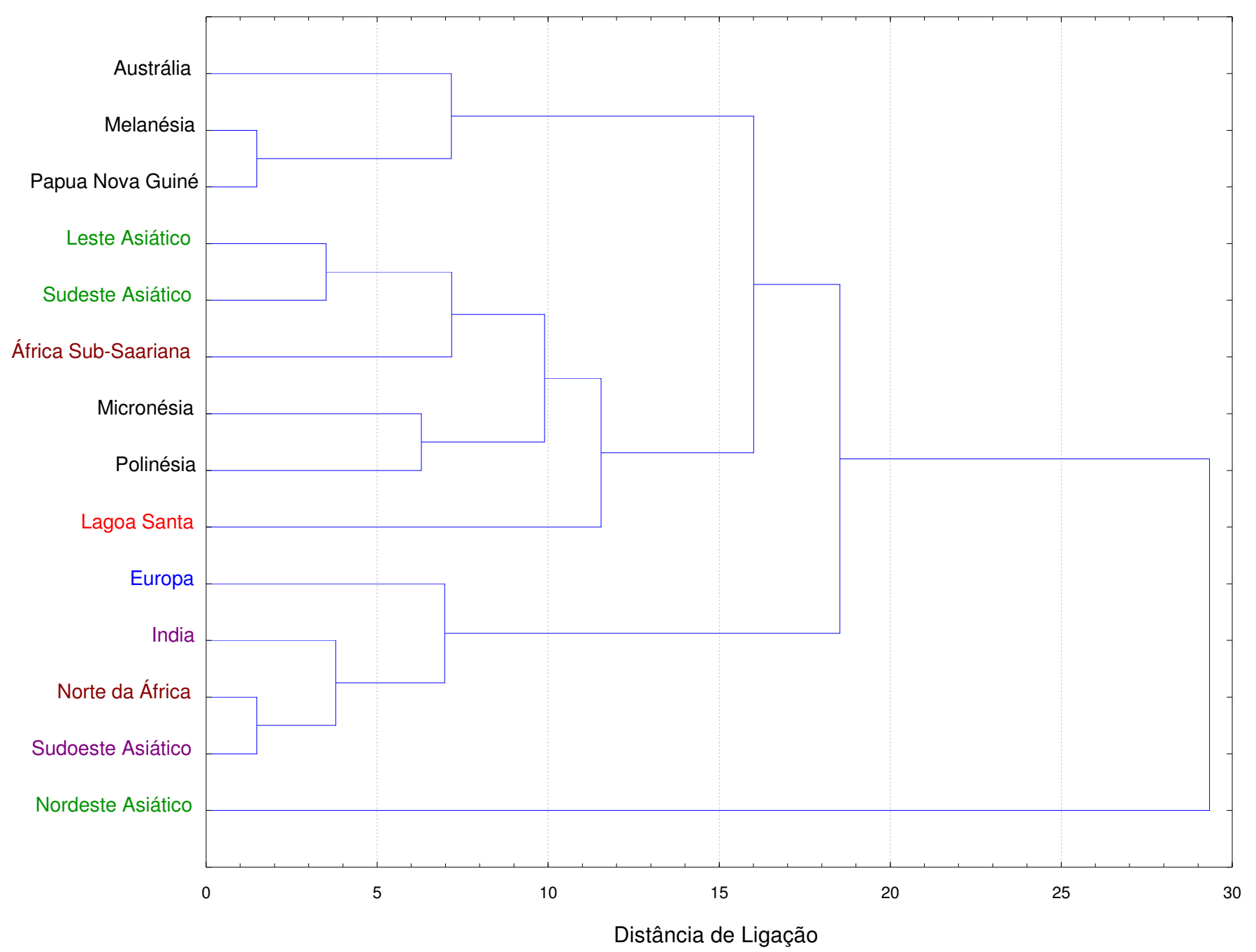


Figura 4.122 - Dendrograma gerado sobre matriz de Distância de Mahalanobis - Método da Média dos Grupos. Parcela feminina, forma e tamanho (1138 indivíduos, 23 variáveis craniométricas).

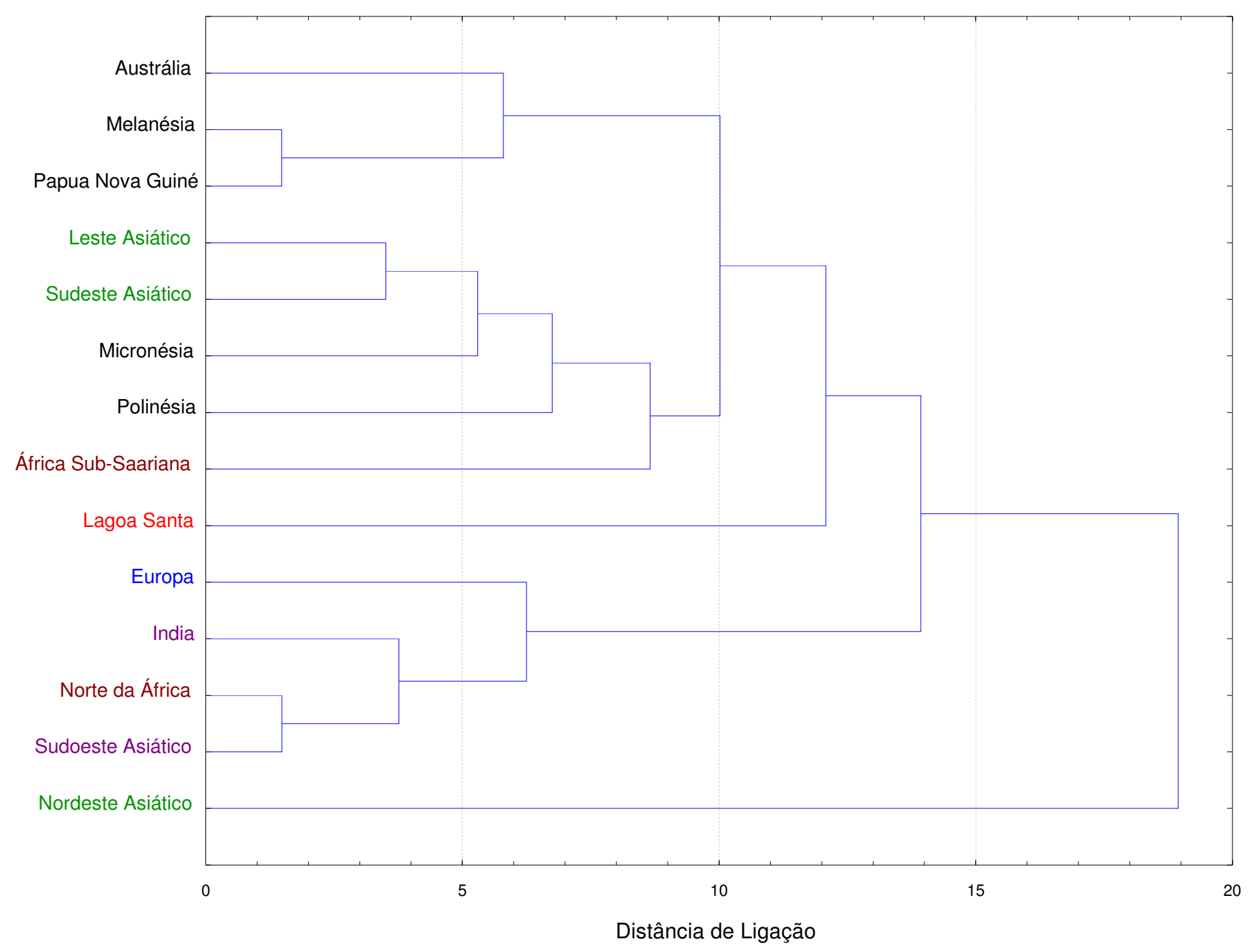


Tabela 4.31 - Configuração final das dimensões calculadas através de escalonamento multidimensional sobre Matriz de Distância baseada em Distâncias de Mahalanobis. Parcela feminina, forma e tamanho (1138 indivíduos, 23 variáveis craniométricas).

\begin{tabular}{c|c|c|c}
\hline & DIMENSÃO 1 & DIMENSÃO 2 & DIMENSÃO 3 \\
\hline Australla & $-1,39546$ & $-0,051413$ & 0,462193 \\
Leste Asiático & 0,31766 & 0,255545 & 0,034003 \\
Europa & 0,69512 & $-0,939463$ & 0,412253 \\
India & 0,03568 & $-0,408511$ & 0,271846 \\
Melanésia & $-0,89700$ & 0,092435 & $-0,024732$ \\
Micronésia & $-0,29020$ & 0,511636 & $-0,091971$ \\
Norte da Árica & 0,30918 & $-0,738188$ & $-0,335311$ \\
Nordeste Asiático & 1,83912 & 0,577555 & 0,256512 \\
Papua Nova Guiné & $-0,84467$ & $-0,197214$ & $-0,177585$ \\
Polinésia & $-0,27947$ & 0,492823 & 0,646645 \\
Sudeste Asiático & 0,41622 & 0,024857 & $-0,226015$ \\
Árrica Sub-Saariana & $-0,11099$ & $-0,101290$ & $-0,729047$ \\
Sudoeste Asiático & 0,20755 & $-0,651474$ & $-0,173832$ \\
Lagoa Santa & $-0,00274$ & 1,132701 & $-0,324962$ \\
\hline
\end{tabular}

Figura 4.123 - Gráfico bidimensional da relação ortogonal entre as dimensões $1 \times 2$. Parcela feminina, forma e tamanho (1138 indivíduos, 23 variáveis craniométricas).

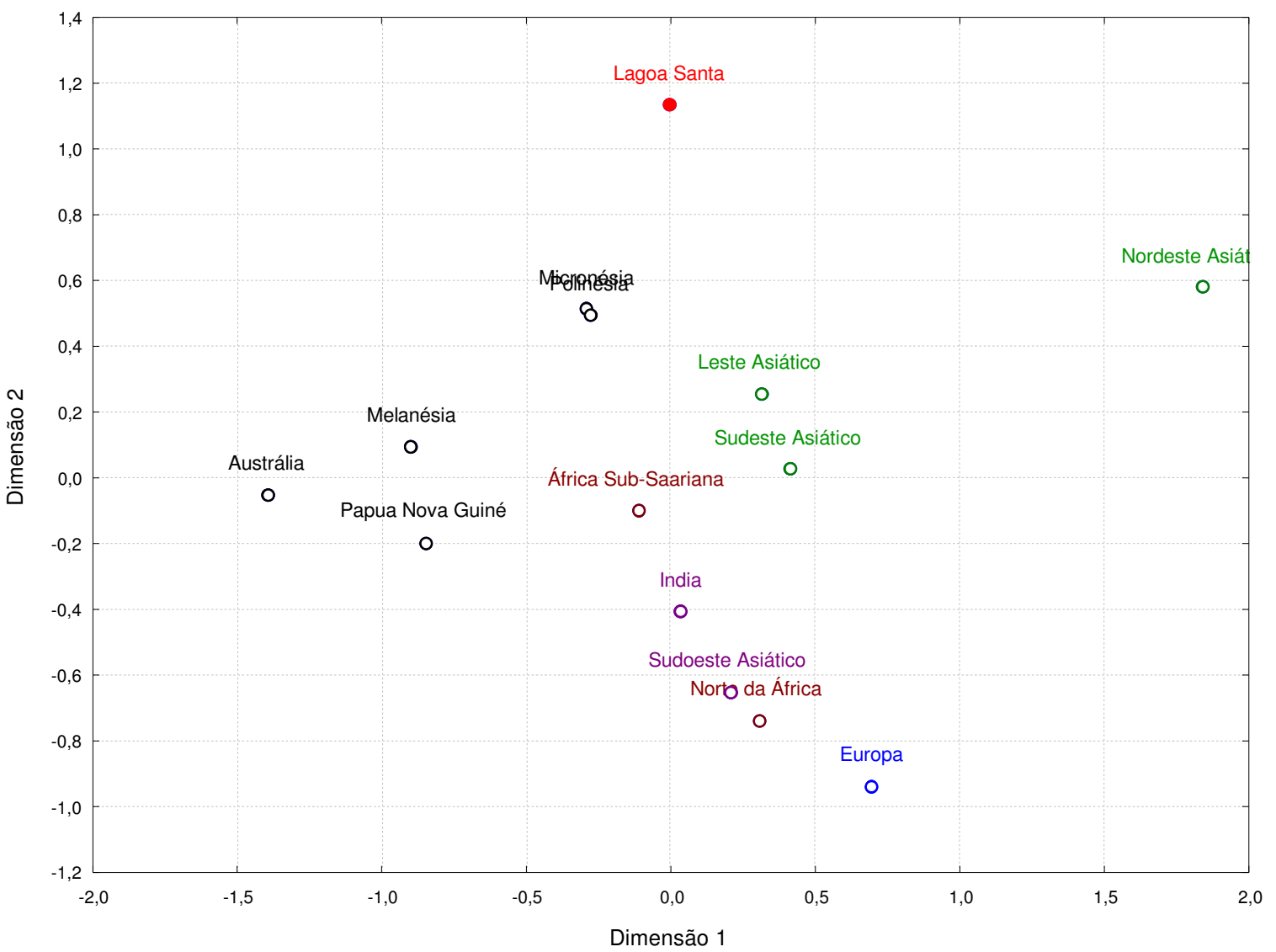


Figura 4.124 - Gráfico bidimensional da relação ortogonal entre as dimensões $1 \times 3$. Parcela feminina, forma e tamanho (1138 indivíduos, 23 variáveis craniométricas).

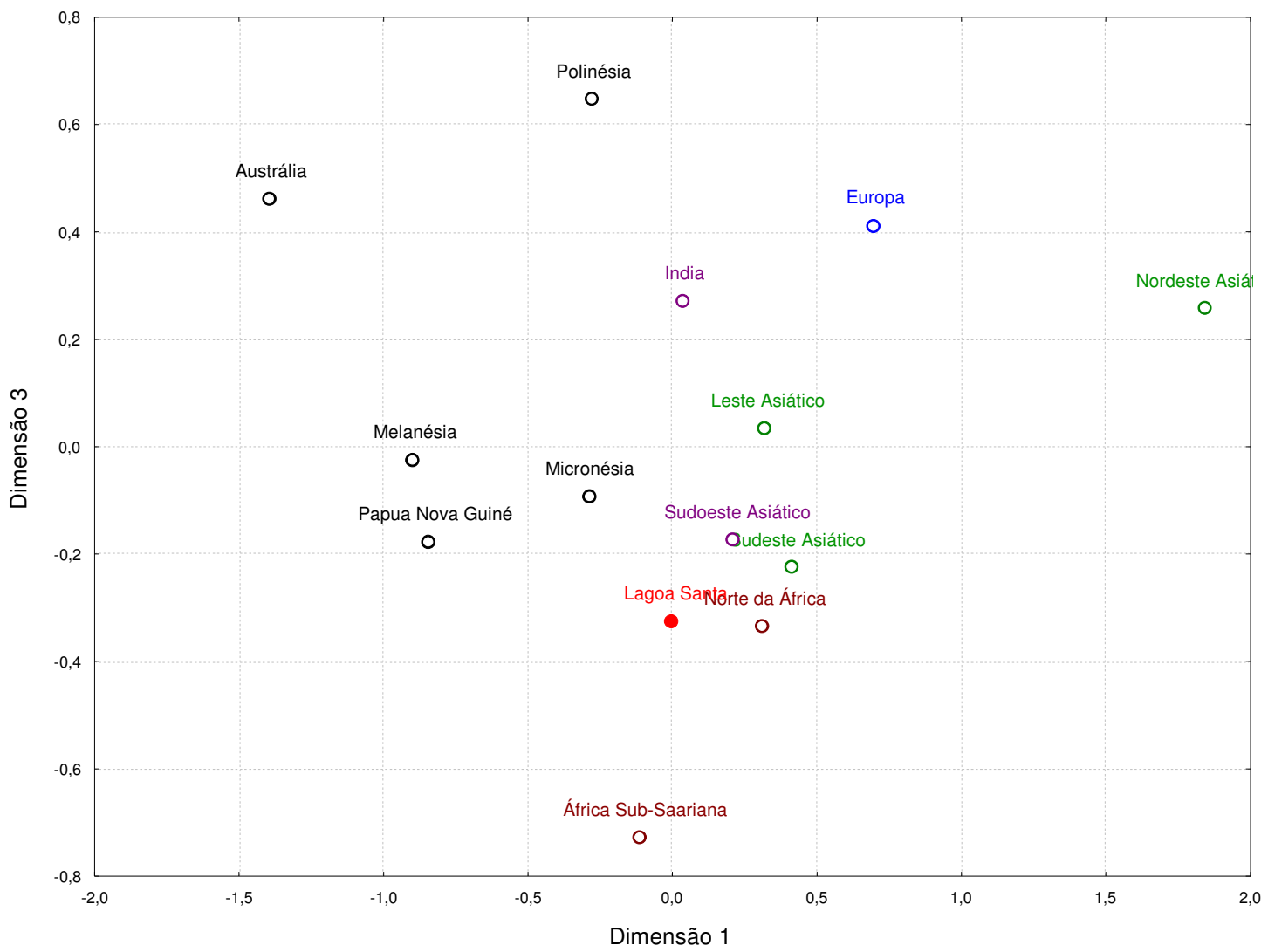

Figura 4.125 - Gráfico bidimensional da relação ortogonal entre as dimensões $2 \times 3$. Parcela feminina, forma e tamanho (1138 indivíduos, 23 variáveis craniométricas).

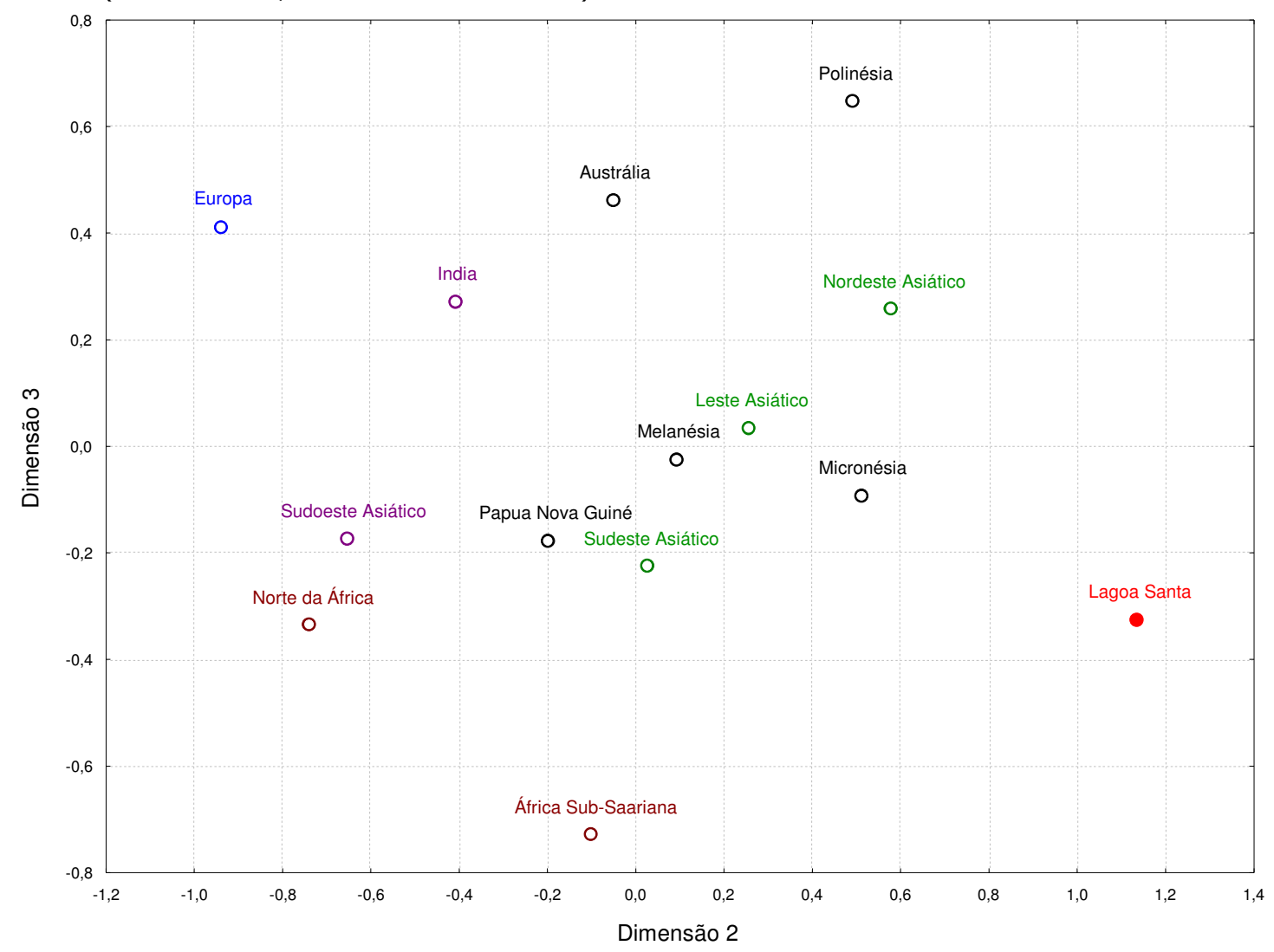


4.2.2.4 - Parcela Feminina, forma apenas

Os resultados obtidos através da ACP sobre os centróides das séries utilizadas, com base em tamanho e forma, para a parcela feminina, são apresentados na Tabela 4.32. O gráfico da Figura 4.126 representa 0 decaímento dos autovalores dos CPs (screeplot). A escolha dos quatro primeiros componentes principais para o cálculo de distâncias Euclidianas foi baseada na análise dessa curva.

Tabela 4.32 - Autovalores da matriz de covariância e porcentagens de variância total explicada por cada Componente Principal. Parcela feminina, forma apenas (14 séries, 23 variáveis craniométricas).

\begin{tabular}{c|c|c|c|c}
\hline $\begin{array}{c}\text { Componente } \\
\text { Principal }\end{array}$ & Autovalor & $\%$ Total & $\begin{array}{c}\text { Autovalor } \\
\text { Cumulativo }\end{array}$ & $\%$ Cumulativa \\
\hline 1 & 0,009535 & 52,81460 & 0,009535 & 52,8146 \\
2 & 0,003349 & 18,54844 & 0,012884 & 71,3630 \\
3 & 0,001926 & 10,66841 & 0,014810 & 82,0315 \\
4 & 0,001639 & 9,07596 & 0,016449 & 91,1074 \\
5 & 0,000814 & 4,50968 & 0,017263 & 95,6171 \\
6 & 0,000365 & 2,02045 & 0,017628 & 97,6375 \\
7 & 0,000191 & 1,05956 & 0,017819 & 98,6971 \\
8 & 0,000100 & 0,55173 & 0,017919 & 99,2488 \\
9 & 0,000053 & 0,29550 & 0,017972 & 99,5443 \\
10 & 0,000037 & 0,20612 & 0,018010 & 99,7504 \\
11 & 0,000027 & 0,15193 & 0,018037 & 99,9024 \\
12 & 0,000016 & 0,09017 & 0,018053 & 99,9925 \\
13 & 0,000001 & 0,00745 & 0,018055 & 100,0000 \\
\hline
\end{tabular}

Figura 4.126 - Gráfico de decaímento da porcentagem de variância condensada em cada Componente Principal. Parcela feminina, apenas forma (14 séries, 23 variáveis craniométricas).

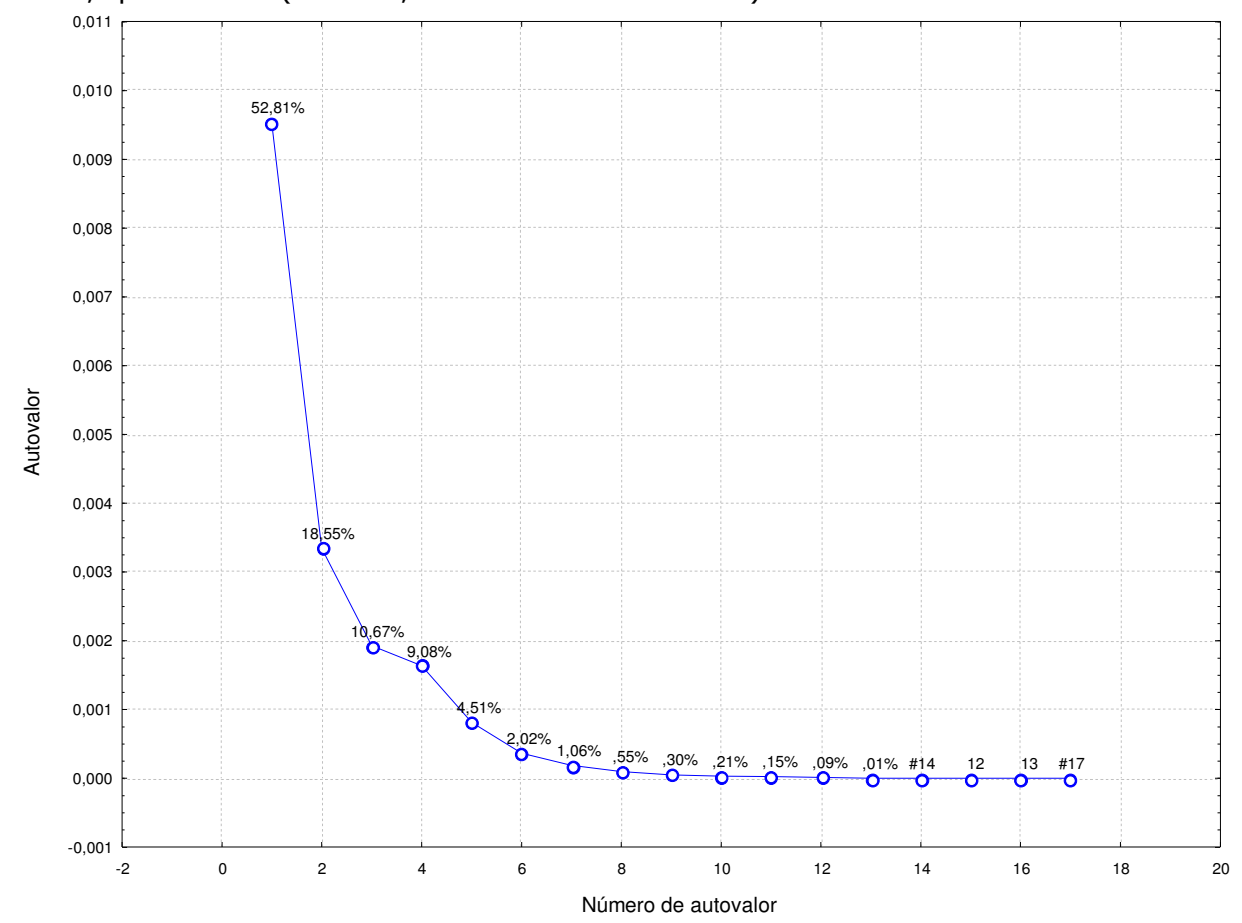


As Tabelas 4.33 e 4.34 indicam, respectivamente, os fatores de coordenadas extraídos pelos Componentes Principais para cada série e a matriz de Distância Euclidiana, calculada sobre os quatro primeiros CPs.

Os gráficos das Figuras 4.127 a 4.129 referem-se às comparações dos centróides no morfo-espaço constituído, respectivamente, pelas relações formadas pelos CP 1 x CP 2, CP 1 x CP 3 e CP 2 x CP 3. Os dendrogramas das Figuras 4.130 a 4.133 apresentam as análises de clusters, sob quatro regras distintas de agrupamento (Ward, Vizinhos Próximos, Vizinhos Distantes e Médias Dentro do Grupo), utilizando-se a matriz de dados baseadas nas distâncias euclidianas calculadas a partir dos CP selecionados.

Figura 4.127 - Gráfico bidimensional do morfo-espaço formado pelos CP 1 x CP 2. Parcela feminina, forma apenas (14 séries, 23 variáveis craniométricas).

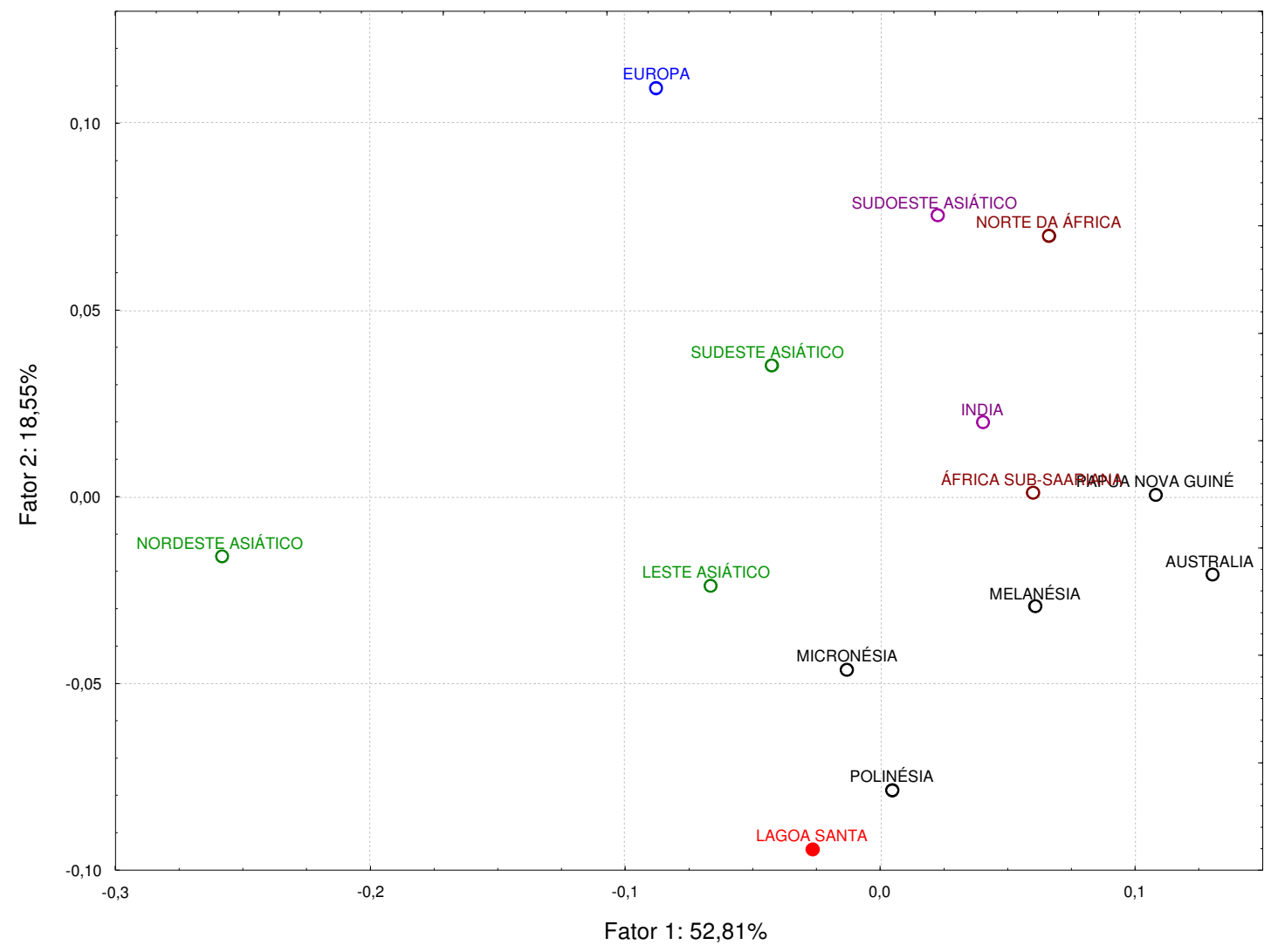


Figura 4.128 - Gráfico bidimensional do morfo-espaço formado pelos CP 1 x CP 3. Parcela feminina, apenas forma (14 séries, 23 variáveis craniométricas).

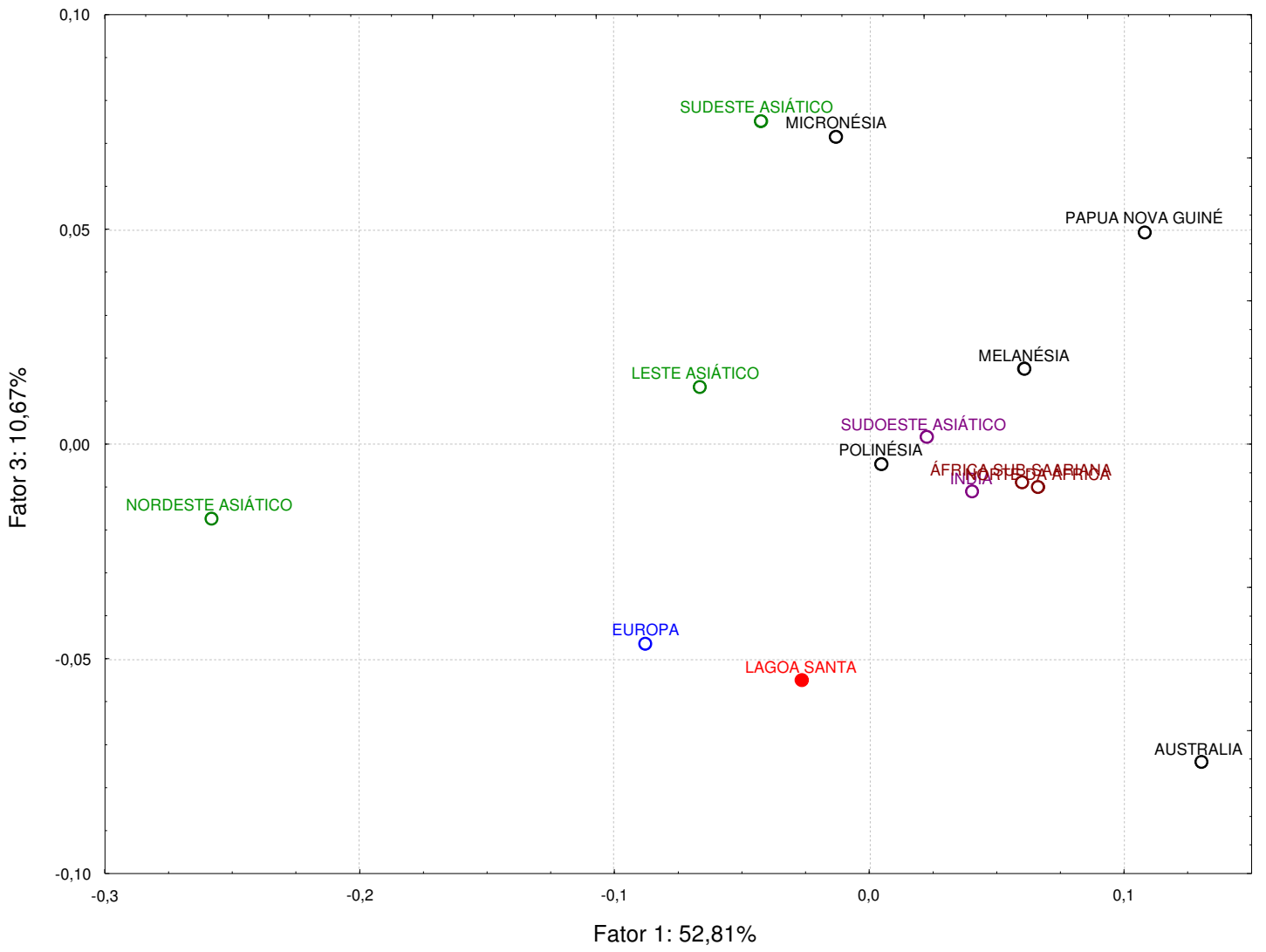

Figura 4.129 - Gráfico bidimensional do morfo-espaço formado pelos CP 2 x CP 3. Parcela feminina, apenas forma e tamanho (14 séries, 23 variáveis craniométricas).

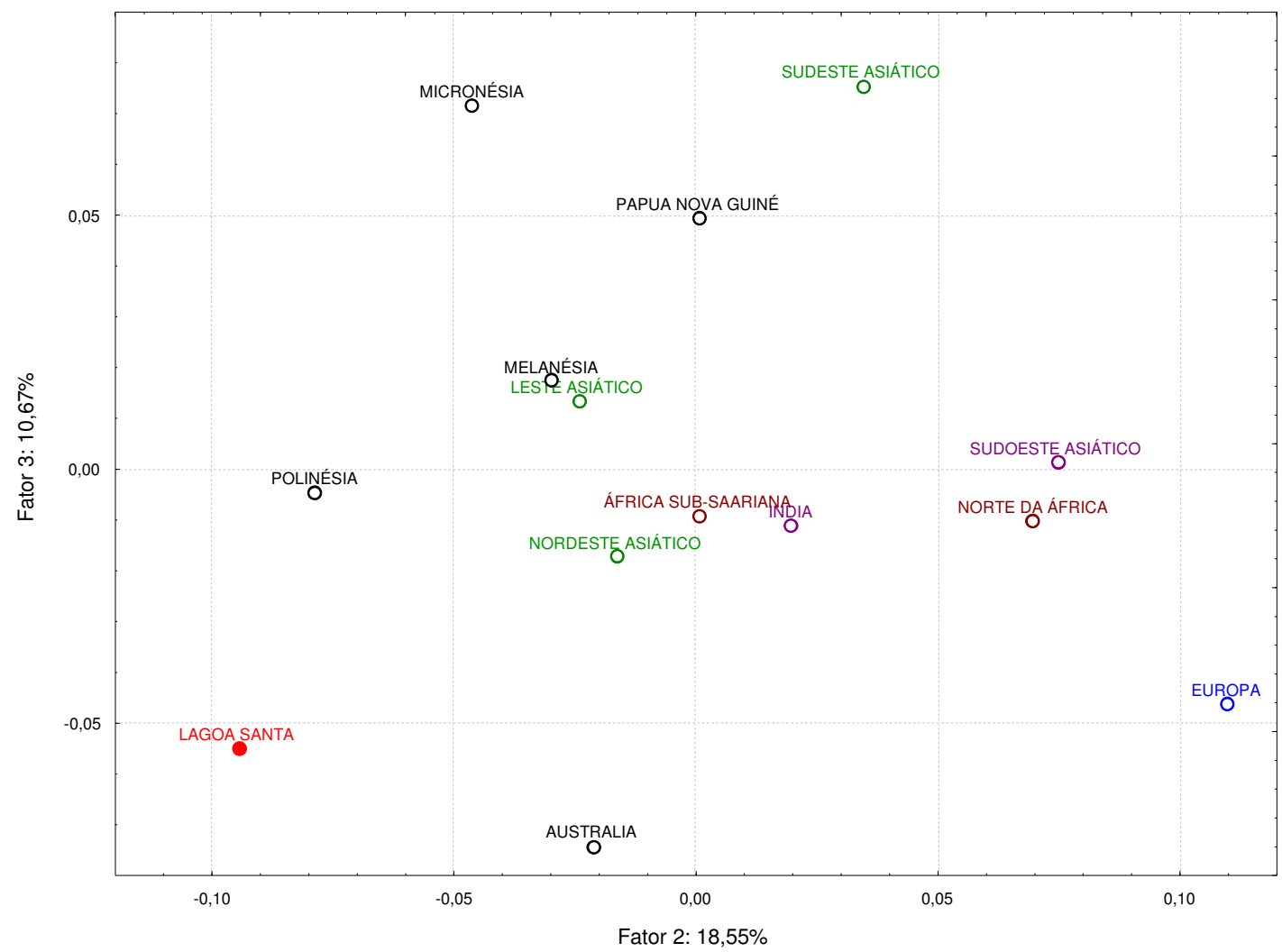


Tabela 4.33 - Fatores de coordenadas de cada série. Parcela feminina, forma apenas (14 séries, 23 variáveis craniométricas).

\begin{tabular}{|c|c|c|c|c|c|c|c|c|c|c|c|c|c|}
\hline & Fator 1 & Fator 2 & Fator 3 & Fator 4 & Fator 5 & Fator 6 & Fator 7 & Fator 8 & Fator 9 & Fator10 & Fator11 & Fator12 & Fator13 \\
\hline $\begin{array}{c}\text { AUSTRALIA } \\
\text { LESTE ASIATICO } \\
\text { EUROPA } \\
\text { INDIA } \\
\text { MELANESIA } \\
\text { MICRONESIA } \\
\text { NORTE DA AFRICA } \\
\text { NORDESTE ASIATICO } \\
\text { PAPUA NOVA GUINE } \\
\text { POLINESIA } \\
\text { SUDESTE ASIATICO }\end{array}$ & \begin{tabular}{|l|}
0,130180 \\
$-0,066752$ \\
$-0,087661$ \\
0,039989 \\
0,061165 \\
$-0,013297$ \\
0,066426 \\
$-0,257906$ \\
0,108424 \\
0,005060 \\
$-0,042611$ \\
\end{tabular} & \begin{tabular}{|l|}
$-0,021078$ \\
$-0,023811$ \\
0,109617 \\
0,019585 \\
$-0,029688$ \\
$-0,046421$ \\
0,069825 \\
$-0,016170$ \\
0,000582 \\
$-0,078591$ \\
0,034895 \\
\end{tabular} & \begin{tabular}{|l|}
$-0,074224$ \\
0,013359 \\
$-0,046352$ \\
$-0,011208$ \\
0,017300 \\
0,071558 \\
$-0,010194$ \\
$-0,017396$ \\
0,049366 \\
$-0,004646$ \\
0,075339
\end{tabular} & \begin{tabular}{|l|}
0,064972 \\
$-0,025592$ \\
$-0,006166$ \\
$-0,030732$ \\
0,037733 \\
$-0,017246$ \\
$-0,056341$ \\
0,059584 \\
0,042055 \\
$-0,029355$ \\
0,004929
\end{tabular} & \begin{tabular}{|l|}
0,007353 \\
0,002299 \\
0,013988 \\
0,004992 \\
$-0,000496$ \\
$-0,001625$ \\
$-0,013359$ \\
$-0,005226$ \\
$-0,013741$ \\
0,079241 \\
$-0,012647$ \\
\end{tabular} & \begin{tabular}{|l|}
0,001531 \\
$-0,011581$ \\
$-0,026847$ \\
0,019144 \\
$-0,031248$ \\
$-0,020861$ \\
0,001659 \\
0,009242 \\
$-0,010109$ \\
0,012693 \\
0,027581 \\
\end{tabular} & \begin{tabular}{|l|}
$-0,003847$ \\
0,011468 \\
$-0,003812$ \\
$-0,008958$ \\
0,012185 \\
$-0,034956$ \\
0,005804 \\
$-0,001105$ \\
0,012688 \\
0,006940 \\
0,016775 \\
\end{tabular} & \begin{tabular}{|l|}
$-0,000478$ \\
$-0,001754$ \\
0,002496 \\
$-0,025173$ \\
0,006590 \\
0,000716 \\
$-0,000827$ \\
$-0,006618$ \\
$-0,013923$ \\
0,004024 \\
0,007468 \\
\end{tabular} & $\begin{array}{l}0,013767 \\
-0,005035 \\
-0,000981 \\
-0,001969 \\
-0,003763 \\
0,006791 \\
0,004361 \\
-0,000407 \\
-0,007089 \\
-0,001884 \\
0,012120\end{array}$ & \begin{tabular}{|l|}
0,000675 \\
0,007561 \\
0,002349 \\
0,001654 \\
0,005449 \\
$-0,000239$ \\
0,006022 \\
$-0,001709$ \\
$-0,007037$ \\
$-0,000778$ \\
0,001258
\end{tabular} & \begin{tabular}{|l|}
0,003061 \\
0,008682 \\
$-0,008867$ \\
$-0,004351$ \\
$-0,002981$ \\
0,000648 \\
0,007907 \\
0,004139 \\
$-0,000634$ \\
$-0,002194$ \\
$-0,005532$ \\
\end{tabular} & \begin{tabular}{|l|}
0,003276 \\
0,009064 \\
0,002285 \\
0,000538 \\
$-0,004968$ \\
$-0,000210$ \\
$-0,007530$ \\
$-0,004553$ \\
0,000326 \\
$-0,002174$ \\
0,002171
\end{tabular} & $\begin{array}{l}0,000100 \\
-0,000244 \\
0,001057 \\
-0,001826 \\
-0,002201 \\
0,000360 \\
0,000942 \\
0,000034 \\
0,001975 \\
0,000876 \\
-0,000237\end{array}$ \\
\hline $\begin{array}{l}\text { AFRICA SUB- } \\
\text { SAARIANA }\end{array}$ & 0,060413 & 0,000777 & $-0,009204$ & 0,026740 & $-0,022575$ & 0,031261 & $-0,016939$ & 0,013287 & $-0,013457$ & 0,006052 & $-0,001283$ & 0,000507 & 0,000488 \\
\hline SUDOESTE ASIATICO & 0,022541 & 0,074990 & 0,001354 & $-0,011445$ & 0,014280 & 0,001450 & $-0,003410$ & 0,010277 & $-0,003419$ & $-0,014795$ & 0,005544 & 0,001130 & $-0,001458$ \\
\hline
\end{tabular}

Tabela 4.34 - Matriz de Distância Euclidiana calculada sobre os três primeiros Componentes Principais. Parcela feminina, forma apenas (14 séries, 23 variáveis craniométricas).

\begin{tabular}{|c|c|c|c|c|c|c|c|c|c|c|c|c|c|c|}
\hline & Austrália & $\begin{array}{c}\text { Leste } \\
\text { Asiático }\end{array}$ & Europa & Índia & Melanésia & Micronésia & $\begin{array}{c}\text { Norte da } \\
\text { África }\end{array}$ & $\begin{array}{l}\text { Nordeste } \\
\text { Asiático }\end{array}$ & $\begin{array}{c}\text { Papua Nova } \\
\text { Guiné }\end{array}$ & Polinésia & $\begin{array}{l}\text { Sudeste } \\
\text { Asiático }\end{array}$ & $\begin{array}{c}\text { África Sub- } \\
\text { Saariana }\end{array}$ & $\begin{array}{c}\text { Sudoeste } \\
\text { Asiático }\end{array}$ & Lagoa Santa \\
\hline Austrália & 0,00 & 0,28 & 0,37 & 0,17 & 0,11 & 0,21 & 0,18 & 0,51 & 0,09 & 0,18 & 0,28 & 0,11 & 0,21 & 0,36 \\
\hline $\begin{array}{l}\text { Leste } \\
\text { Asiático }\end{array}$ & & 0,00 & 0,16 & 0,14 & 0,19 & 0,11 & 0,18 & 0,24 & 0,24 & 0,13 & 0,08 & 0,17 & 0,13 & 0,28 \\
\hline Europa & & & 0,00 & 0,22 & 0,31 & 0,27 & 0,20 & 0,23 & 0,34 & 0,26 & 0,17 & 0,27 & 0,16 & 0,36 \\
\hline Índia & & & & 0,00 & 0,12 & 0,14 & 0,10 & 0,37 & 0,17 & 0,08 & 0,18 & 0,07 & 0,11 & 0,25 \\
\hline Melanésia & & & & & 0,00 & 0,10 & 0,16 & 0,41 & 0,07 & 0,10 & 0,19 & 0,06 & 0,16 & 0,32 \\
\hline Micronésia & & & & & & 0,00 & 0,19 & 0,33 & 0,15 & 0,08 & 0,13 & 0,12 & 0,16 & 0,29 \\
\hline $\begin{array}{l}\text { Norte da } \\
\text { África }\end{array}$ & & & & & & & 0,00 & 0,38 & 0,18 & 0,17 & 0,17 & 0,11 & 0,06 & 0,34 \\
\hline $\begin{array}{l}\text { Nordeste } \\
\text { Asiático }\end{array}$ & & & & & & & & 0,00 & 0,46 & 0,36 & 0,24 & 0,40 & 0,33 & 0,43 \\
\hline $\begin{array}{l}\text { Papua Nova } \\
\text { Guiné }\end{array}$ & & & & & & & & & 0,00 & 0,17 & 0,22 & 0,10 & 0,19 & 0,38 \\
\hline Polinésia & & & & & & & & & & 0,00 & 0,17 & 0,09 & 0,16 & 0,22 \\
\hline $\begin{array}{l}\text { Sudeste } \\
\text { Asiático }\end{array}$ & & & & & & & & & & & 0,00 & 0,17 & 0,12 & 0,36 \\
\hline $\begin{array}{l}\text { África Sub- } \\
\text { Saariana }\end{array}$ & & & & & & & & & & & & 0,00 & 0,12 & 0,30 \\
\hline $\begin{array}{l}\text { Sudoeste } \\
\text { Asiático }\end{array}$ & & & & & & & & & & & & & 0,00 & 0,34 \\
\hline Lagoa Santa & & & & & & & & & & & & & & 0,00 \\
\hline
\end{tabular}


Figura 4.130 - Dendrograma gerado sobre matriz de Distância Euclidiana calculada a partir dos três primeiros Componentes Principais - Método de Ward. Parcela feminina, forma apenas (14 séries, 23 variáveis craniométricas).

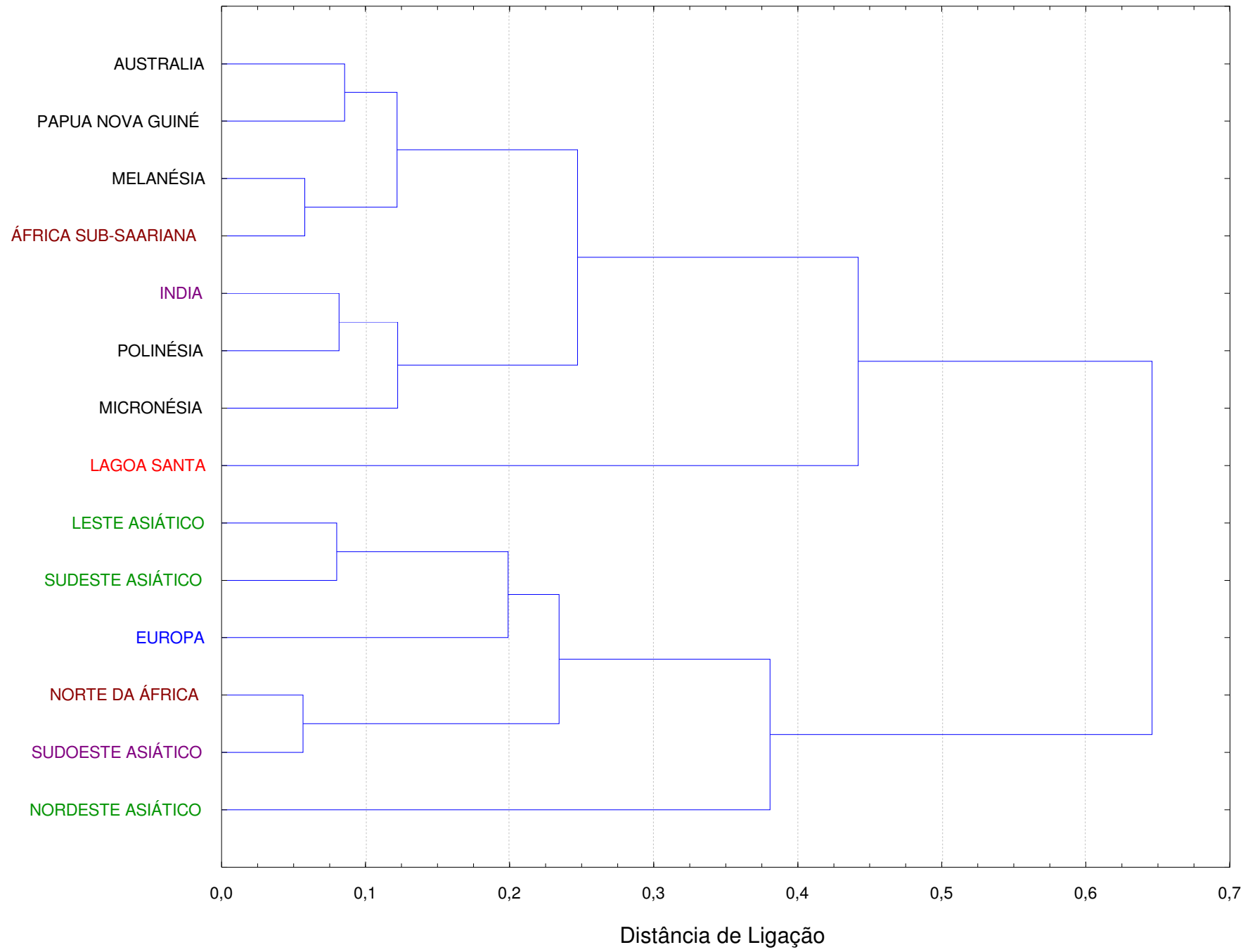


Figura 4.131 - Dendrograma gerado sobre matriz de Distância Euclidiana calculada a partir dos três primeiros Componentes Principais - Método de Ligação Simples. Parcela feminina, forma apenas (14 séries, 23 variáveis craniométricas).

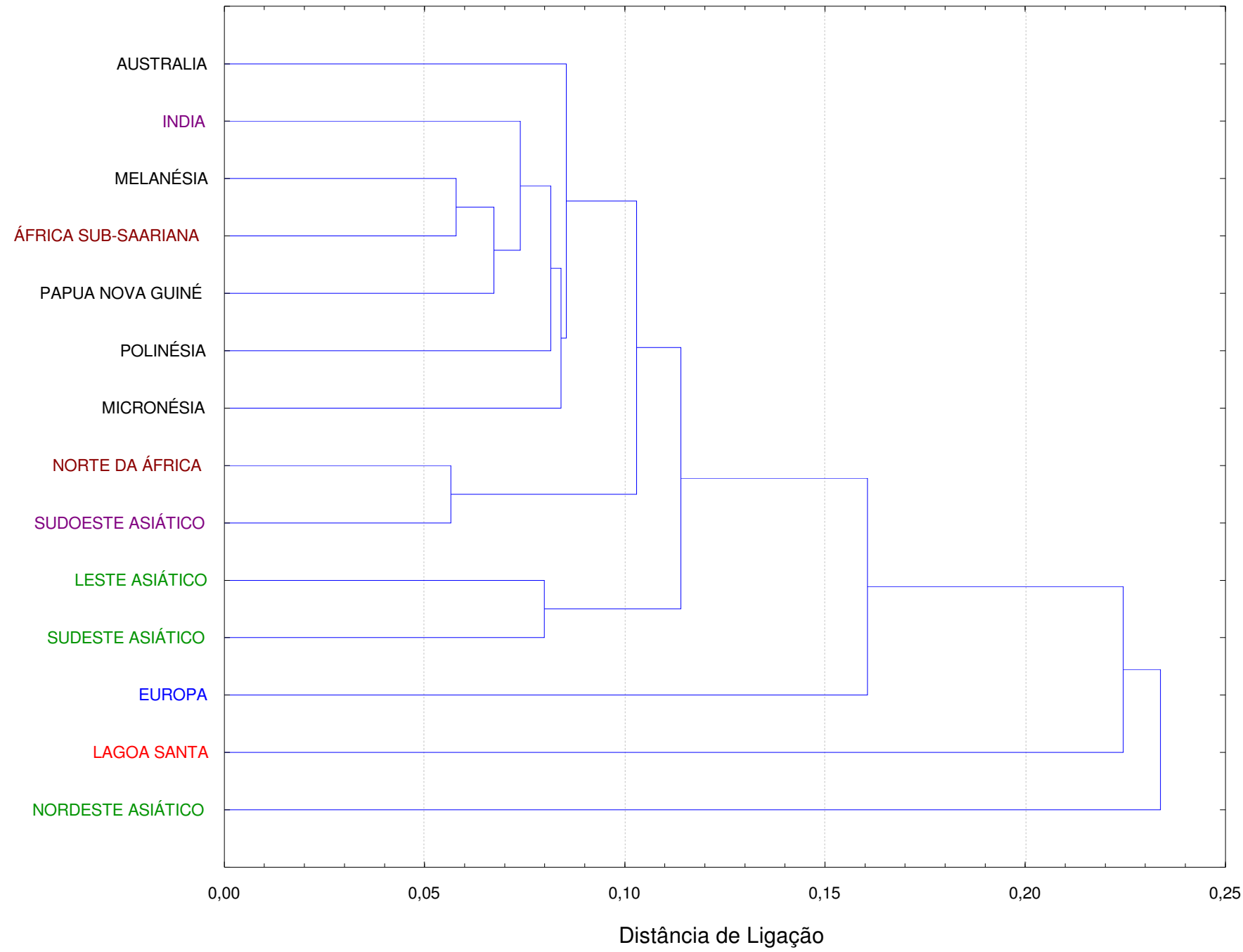


Figura 4.132 - Dendrograma gerado sobre matriz de Distância Euclidiana calculada a partir dos três primeiros Componentes Principais - Método de Ligação Completa. Parcela feminina, forma apenas (14 séries, 23 variáveis craniométricas).

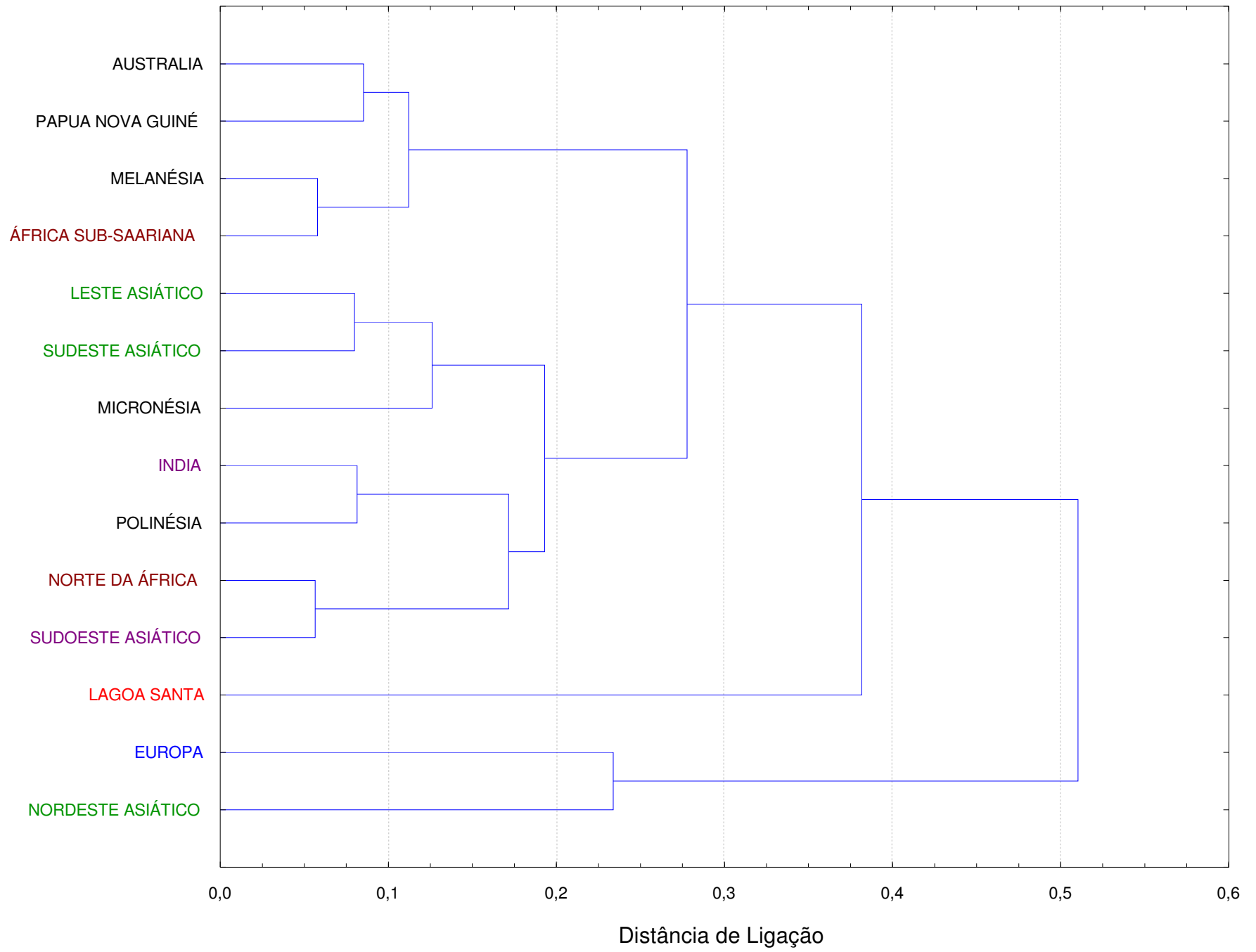


Figura 4.133 - Dendrograma gerado sobre matriz de Distância Euclidiana calculada a partir dos três primeiros Componentes Principais - Método da Média dos Grupos. Parcela feminina, forma apenas (14 séries, 23 variáveis craniométricas).

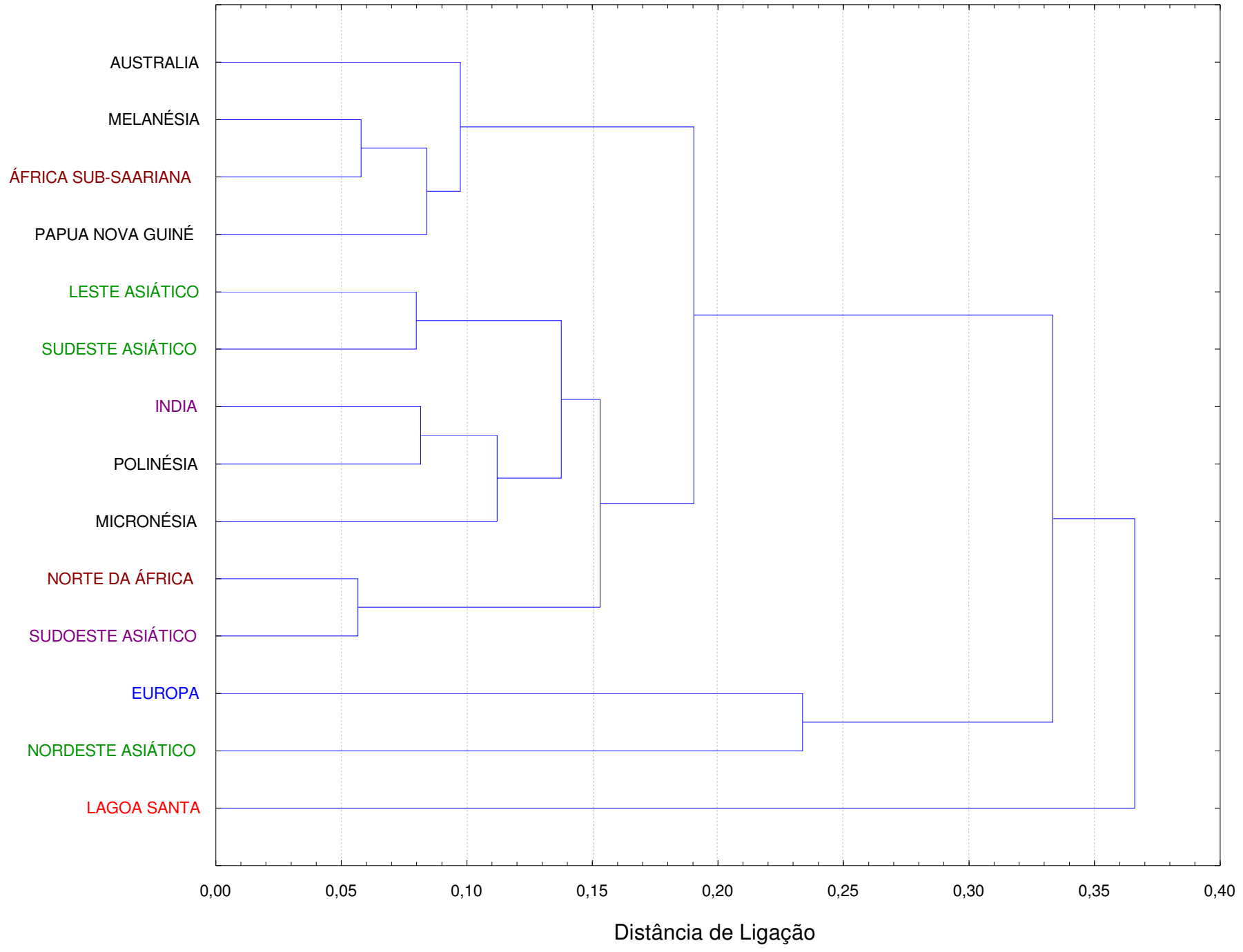


Os gráficos e dendrogramas gerados sobre os dados corrigidos quanto ao fator tamanho da parcela feminina não indicam, claramente, quais associações entre os Paleoíndios de Lagoa Santa e as populações do Velho Mundo ocorrem de maneira preferencial. Alguns desses resultados, como os gráficos das Figuras 4.127 e 4.128 e o dendrograma da Figura 4.130 demonstram a tendência de diferenciação morfológica entre os Paleoíndios de Lagoa Santa e as populações de morfologia mongolóide especializada. Por outro lado, os outros resultados transitam entre associações aparentemente fortuitas, entre séries representantes de morfologias absolutamente distintas, e posicionamento da população paleoíndia de maneira marginal à dispersão dos outros grupos mundiais.

Como adotado também para os outros conjuntos de dados, executou-se análises de agrupamentos a partir de matrizes de Distância de Mahalanobis (Tabela 4.35, Figuras 4.134 a 4.137), e análise por Escalonamento Multidimensional - MDS (Tabela 4.36, Figuras 4.138 a 4.140).

Os resultados gerados através da aplicação dessas técnicas de interdependência não indicaram claras associações morfológicas entre a população de Lagoa Santa e qualquer outra de origem mundial. Nas análises de agrupamentos, por exemplo, o centróide paleoíndio posicionou-se ora de maneira marginal ora inserido em grupos numericamente robustos, dificultando uma precisa interpretação das relações morfológicas analisadas. O mesmo efeito pode ser observado nas análises de Escalonamento Multidimensional, que apresentam a população paleoíndia dispersa dos outros centróides em algumas oportunidades ou associados a grandes grupos em outras. 
Tabela 4.35 - Matriz de Distância de Mahalanobis. Parcela feminina, forma apenas (1138 indivíduos, 23 variáveis craniométricas).

\begin{tabular}{|c|c|c|c|c|c|c|c|c|c|c|c|c|c|c|}
\hline & Austrália & $\begin{array}{l}\text { Leste } \\
\text { Asiático }\end{array}$ & Europa & Índia & Melanésia & Micronésia & $\begin{array}{l}\text { Norte da } \\
\text { África }\end{array}$ & $\begin{array}{c}\text { Nordeste } \\
\text { Asiático }\end{array}$ & $\begin{array}{l}\text { Papua } \\
\text { Nova } \\
\text { Guiné }\end{array}$ & Polinésia & $\begin{array}{l}\text { Sudeste } \\
\text { Asiático }\end{array}$ & $\begin{array}{c}\text { África } \\
\text { Sub- } \\
\text { Saariana } \\
\end{array}$ & $\begin{array}{c}\text { Sudoeste } \\
\text { Asiático }\end{array}$ & $\begin{array}{l}\text { Lagoa } \\
\text { Santa }\end{array}$ \\
\hline Austrália & 0,00000 & 13,22320 & 18,37896 & 10,84713 & 4,24928 & 12,30313 & 18,17917 & 28,25027 & 7,03624 & 9,14245 & 15,56830 & 12,38447 & 15,85092 & 14,65395 \\
\hline Leste Asiático & & 0,00000 & 8,43289 & 4,31537 & 7,95205 & 4,08709 & 7,19132 & 9,50592 & 8,61789 & 4,28630 & 2,26272 & 6,67415 & 6,04171 & 6,32971 \\
\hline Europa & & & 0,00000 & 6,58476 & 15,43592 & 16,15627 & 6,95457 & 13,57645 & 15,59608 & 14,39367 & 9,76829 & 12,84320 & 4,15797 & 18,14273 \\
\hline Índia & & & & 0,00000 & 8,30538 & 7,10022 & 3,34428 & 18,32932 & 6,84046 & 5,37283 & 5,07022 & 6,96209 & 3,41083 & 9,24915 \\
\hline Melanésia & & & & & 0,00000 & 5,92109 & 11,59912 & 25,38877 & 1,28048 & 6,21459 & 9,37016 & 7,99250 & 9,55880 & 12,17476 \\
\hline Micronésia & & & & & & 0,00000 & 10,66903 & 18,89842 & 6,76908 & 5,68384 & 6,14999 & 7,97888 & 9,43167 & 6,87072 \\
\hline Norte da África & & & & & & & 0,00000 & 21,16906 & 9,14503 & 10,95928 & 6,34912 & 6,51521 & 1,48023 & 14,20136 \\
\hline $\begin{array}{c}\text { Nordeste } \\
\text { Asiático }\end{array}$ & & & & & & & & 0,00000 & 26,70275 & 18,95215 & 11,00070 & 16,38905 & 17,19032 & 17,09437 \\
\hline $\begin{array}{l}\text { Papua Nova } \\
\text { Guiné }\end{array}$ & & & & & & & & & 0,00000 & 7,62250 & 8,11138 & 7,14771 & 8,07525 & 13,35316 \\
\hline Polinésia & & & & & & & & & & 0,00000 & 7,23539 & 9,31278 & 9,14386 & 10,82553 \\
\hline $\begin{array}{l}\text { Sudeste } \\
\text { Asiático }\end{array}$ & & & & & & & & & & & 0,00000 & 6,21073 & 5,94277 & 9,80702 \\
\hline $\begin{array}{l}\text { África Sub- } \\
\text { Saariana }\end{array}$ & & & & & & & & & & & & 0,00000 & 5,49255 & 11,13438 \\
\hline $\begin{array}{l}\text { Sudoeste } \\
\text { Asiático }\end{array}$ & & & & & & & & & & & & & 0,00000 & 13,98466 \\
\hline Lagoa Santa & & & & & & & & & & & & & & 0,00000 \\
\hline
\end{tabular}


Figura 4.134 - Dendrograma gerado sobre matriz de Distância de Mahalanobis - Método de Ward. Parcela feminina, forma apenas (1138 indivíduos, 23 variáveis craniométricas).

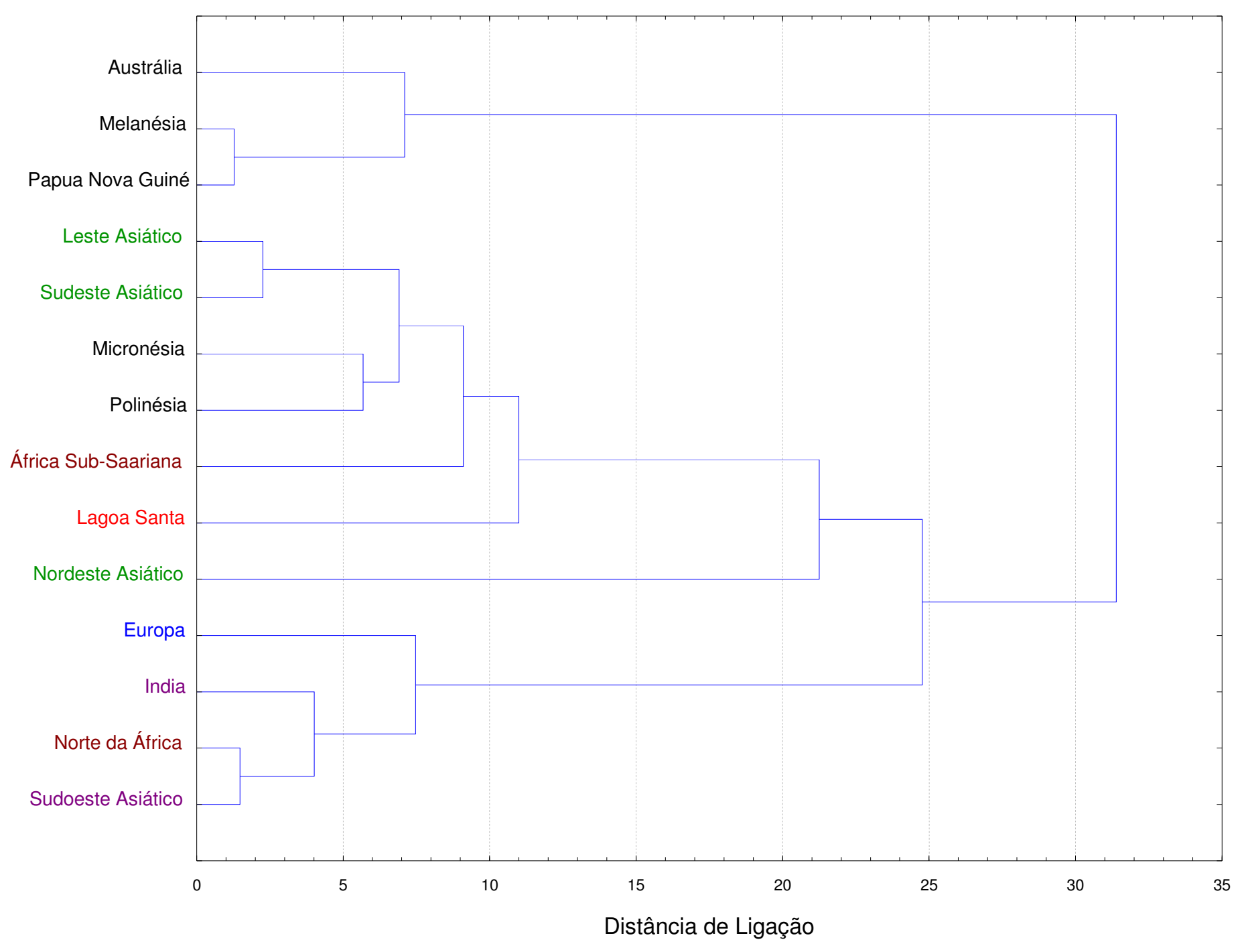


Figura 4.135 - Dendrograma gerado sobre matriz de Distância de Mahalanobis - Método de Ligação Simples. Parcela feminina, forma apenas (1138 indivíduos, 23 variáveis craniométricas).

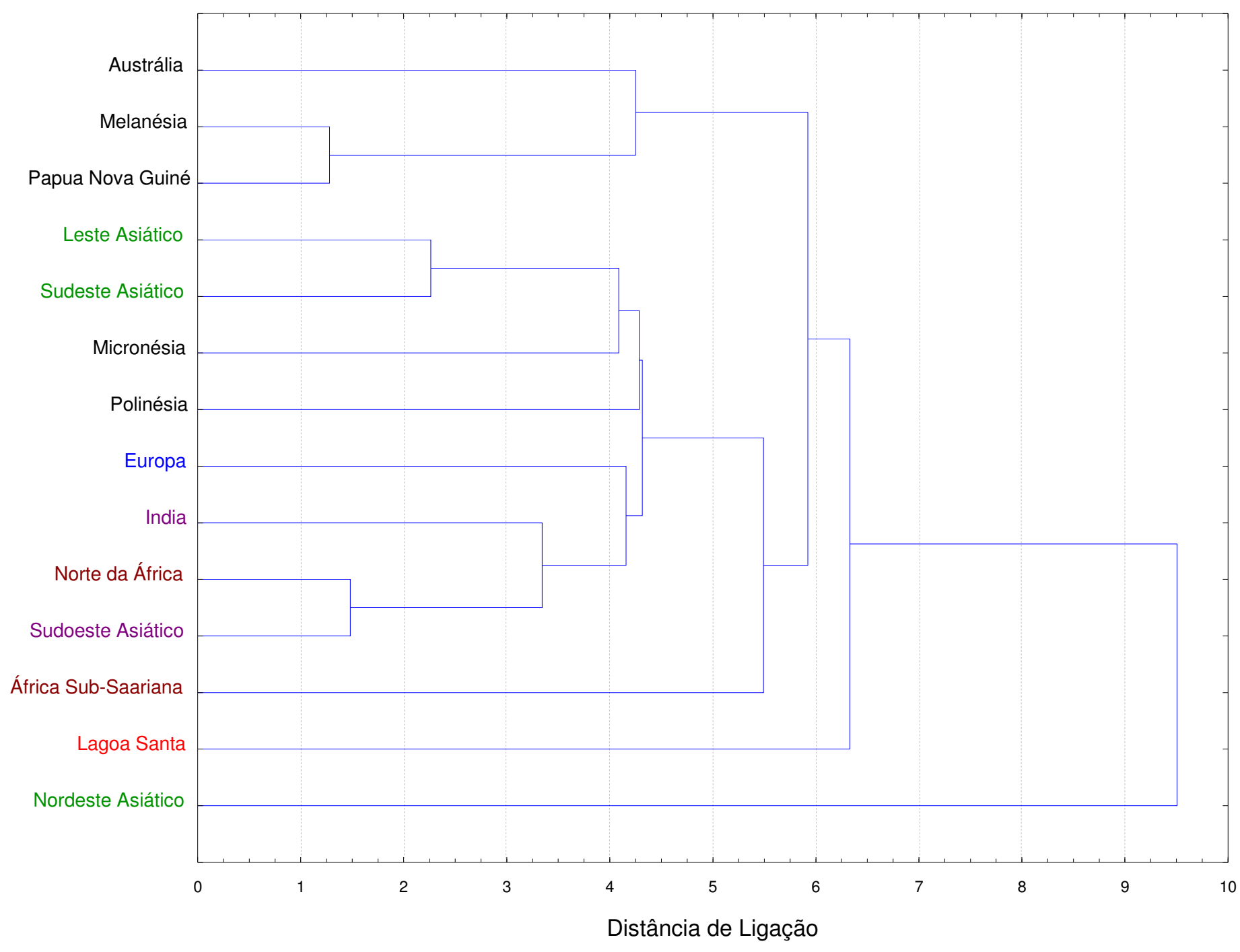


Figura 4.136 - Dendrograma gerado sobre matriz de Distância de Mahalanobis - Método de Ligação Completa. Parcela feminina, forma apenas (1138 indivíduos, 23 variáveis craniométricas).

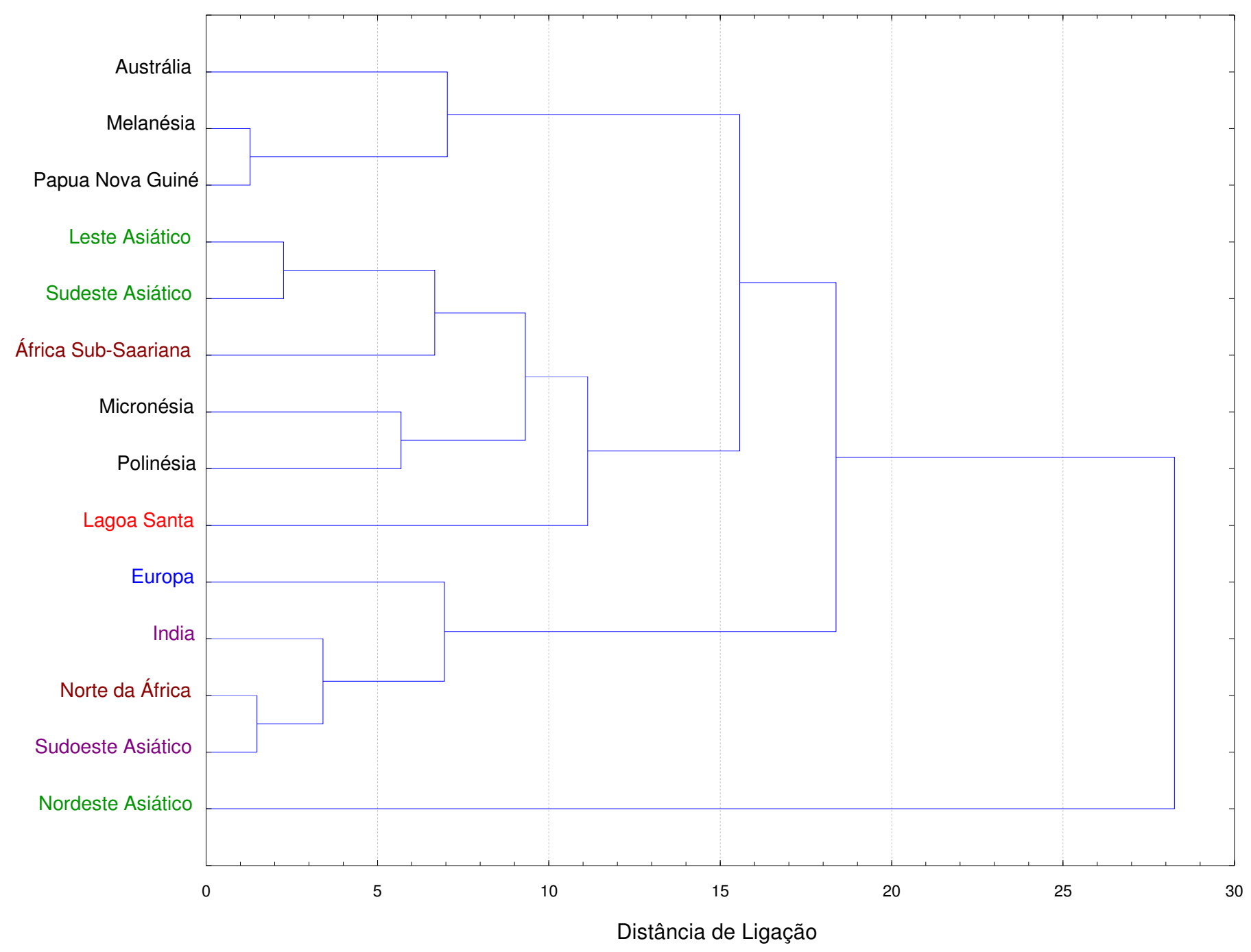


Figura 4.137 - Dendrograma gerado sobre matriz de Distância de Mahalanobis - Método da Média dos Grupos. Parcela feminina, forma apenas (1138 indivíduos, 23 variáveis craniométricas).

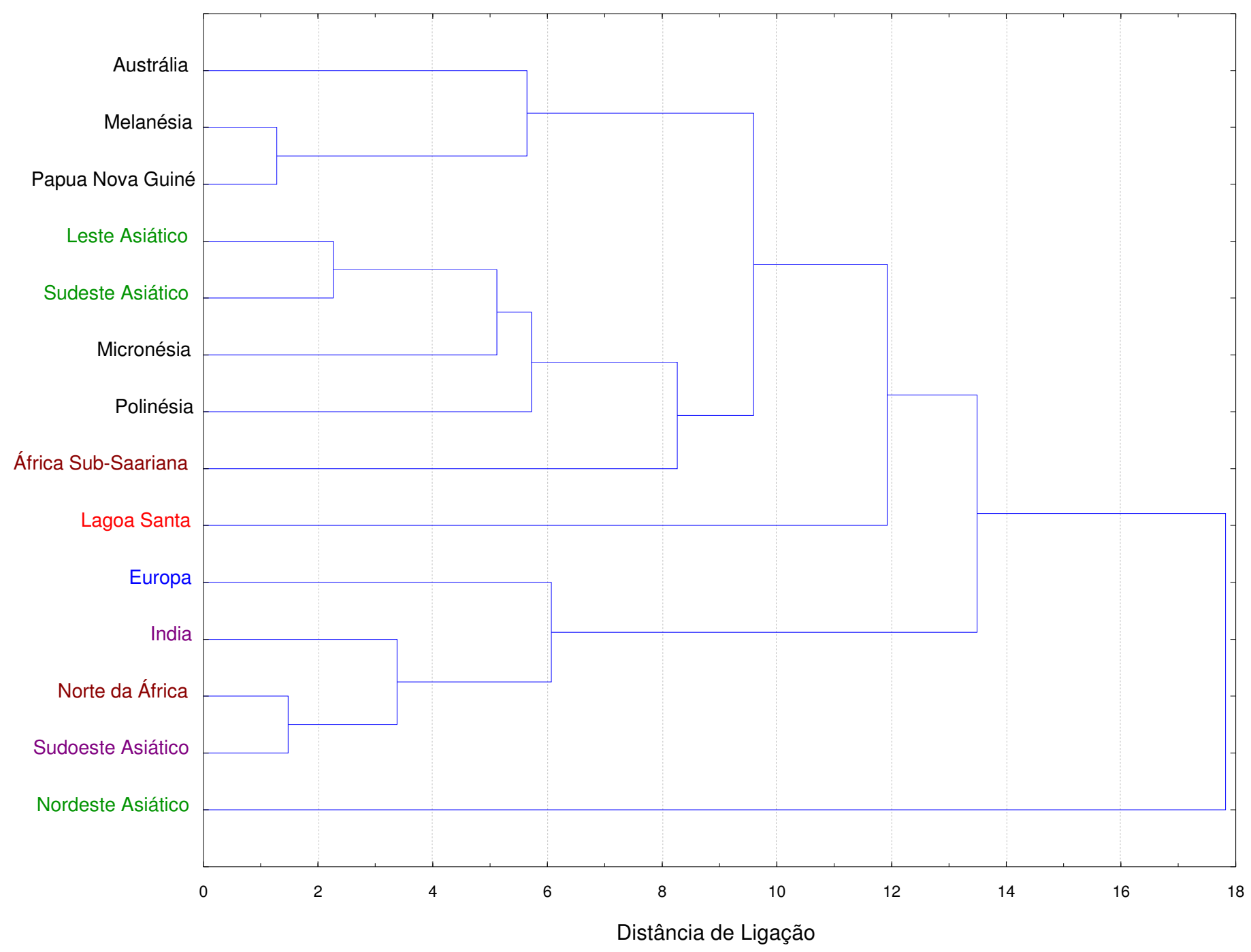


Tabela 4.36 - Configuração final das dimensões calculadas através de escalonamento multidimensional sobre Matriz de Distância baseada em Distâncias de Mahalanobis. Parcela feminina, forma apenas (1138 indivíduos, 23 variáveis craniométricas).

\begin{tabular}{c|c|c|c}
\hline & DIMENSÃO 1 & DIMENSÃO 2 & DIMENSÃO 3 \\
\hline Australla & $-1,46698$ & $-0,031238$ & $-0,413325$ \\
Leste Asítico & 0,30261 & 0,250920 & $-0,058105$ \\
Europa & 0,72676 & $-0,886458$ & $-0,553642$ \\
İndia & $-0,01960$ & $-0,337311$ & $-0,238876$ \\
Melanésia & $-0,90968$ & 0,101021 & 0,143161 \\
Micronésia & $-0,33344$ & 0,565028 & 0,172097 \\
Norte da África & 0,21717 & $-0,772308$ & 0,266870 \\
Nordeste Asiático & 1,84242 & 0,487434 & $-0,083832$ \\
Papua Nova Guiné & $-0,83807$ & $-0,180258$ & 0,294951 \\
Polinésia & $-0,37586$ & 0,268671 & $-0,561834$ \\
Sudeste Asiático & 0,42026 & 0,091301 & 0,222745 \\
Árica Sub-Saariana & 0,01285 & $-0,110349$ & 0,761590 \\
Sudoeste Asiático & 0,28784 & $-0,617943$ & 0,124657 \\
Lagoa Santa & 0,13373 & 1,171491 & $-0,076458$ \\
\hline
\end{tabular}

Figura 4.138 - Gráfico bidimensional da relação ortogonal entre as dimensões $1 \times 2$. Parcela feminina, forma apenas (1138 indivíduos, 23 variáveis craniométricas).

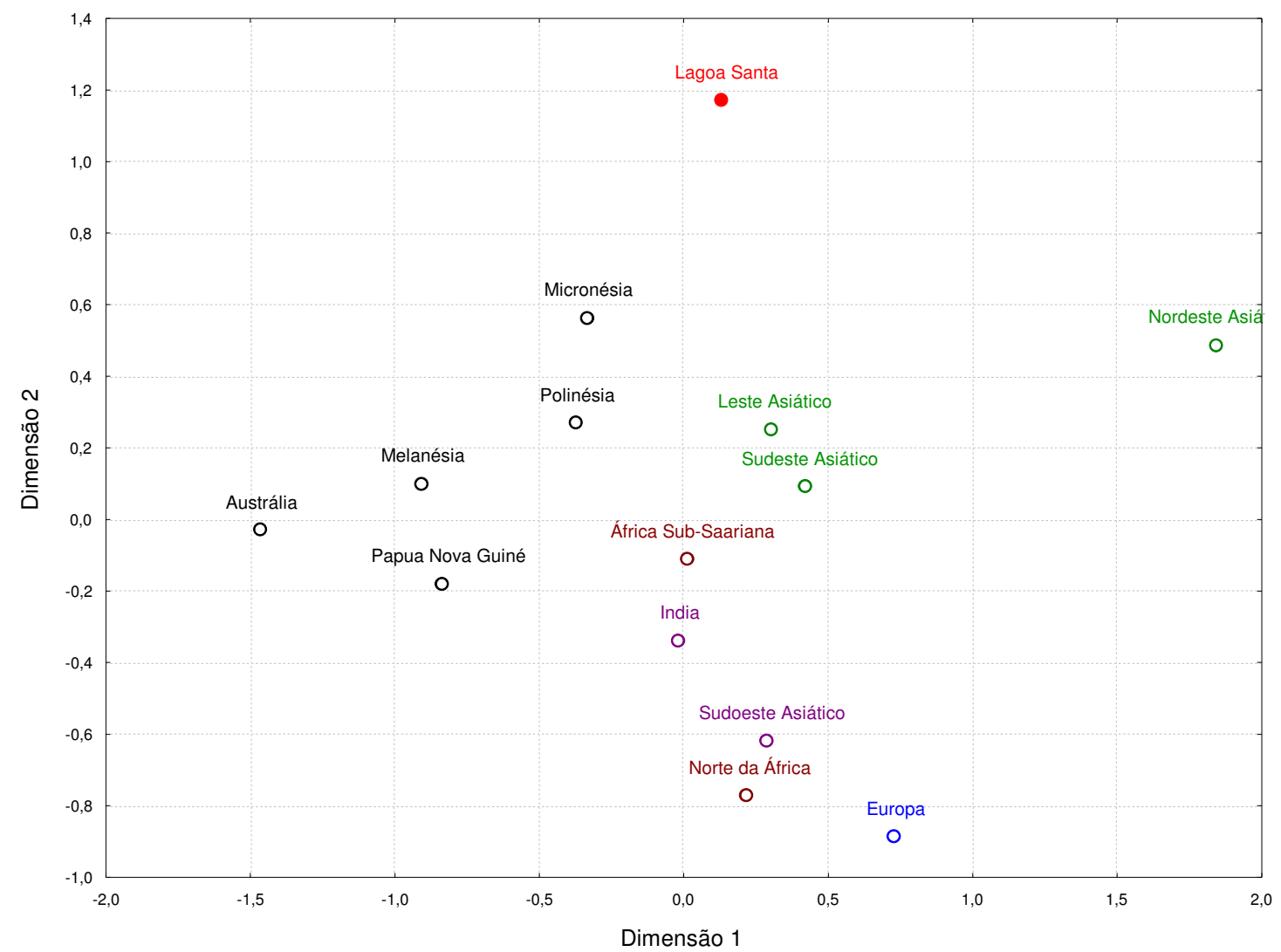


Figura 4.139 - Gráfico bidimensional da relação ortogonal entre as dimensões 1 x 3. Parcela feminina, forma apenas (1138 indivíduos, 23 variáveis craniométricas).

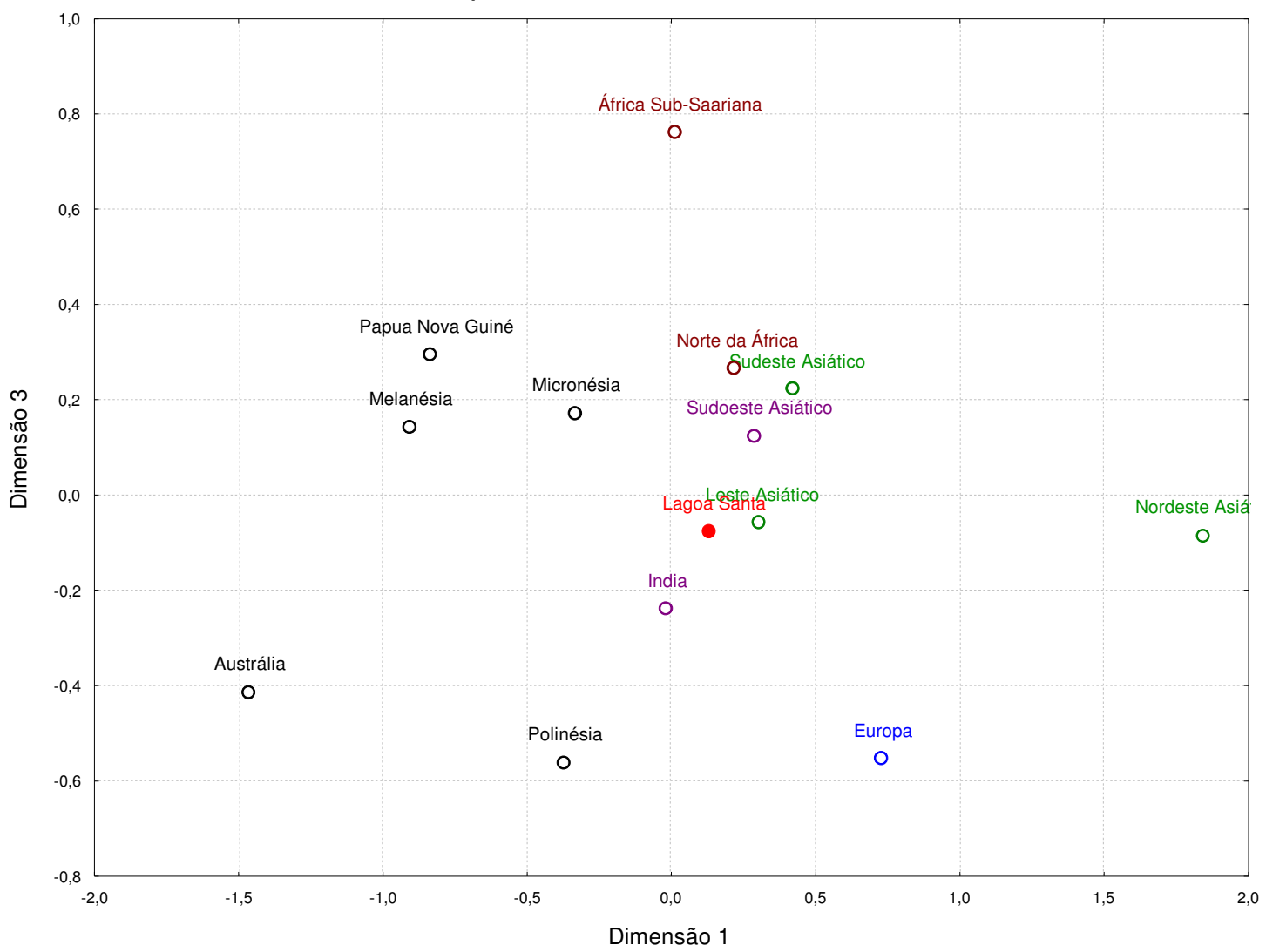

Figura 4.140 - Gráfico bidimensional da relação ortogonal entre as dimensões 2 x 3. Parcela feminina, forma apenas (1138 indivíduos, 23 variáveis craniométricas).

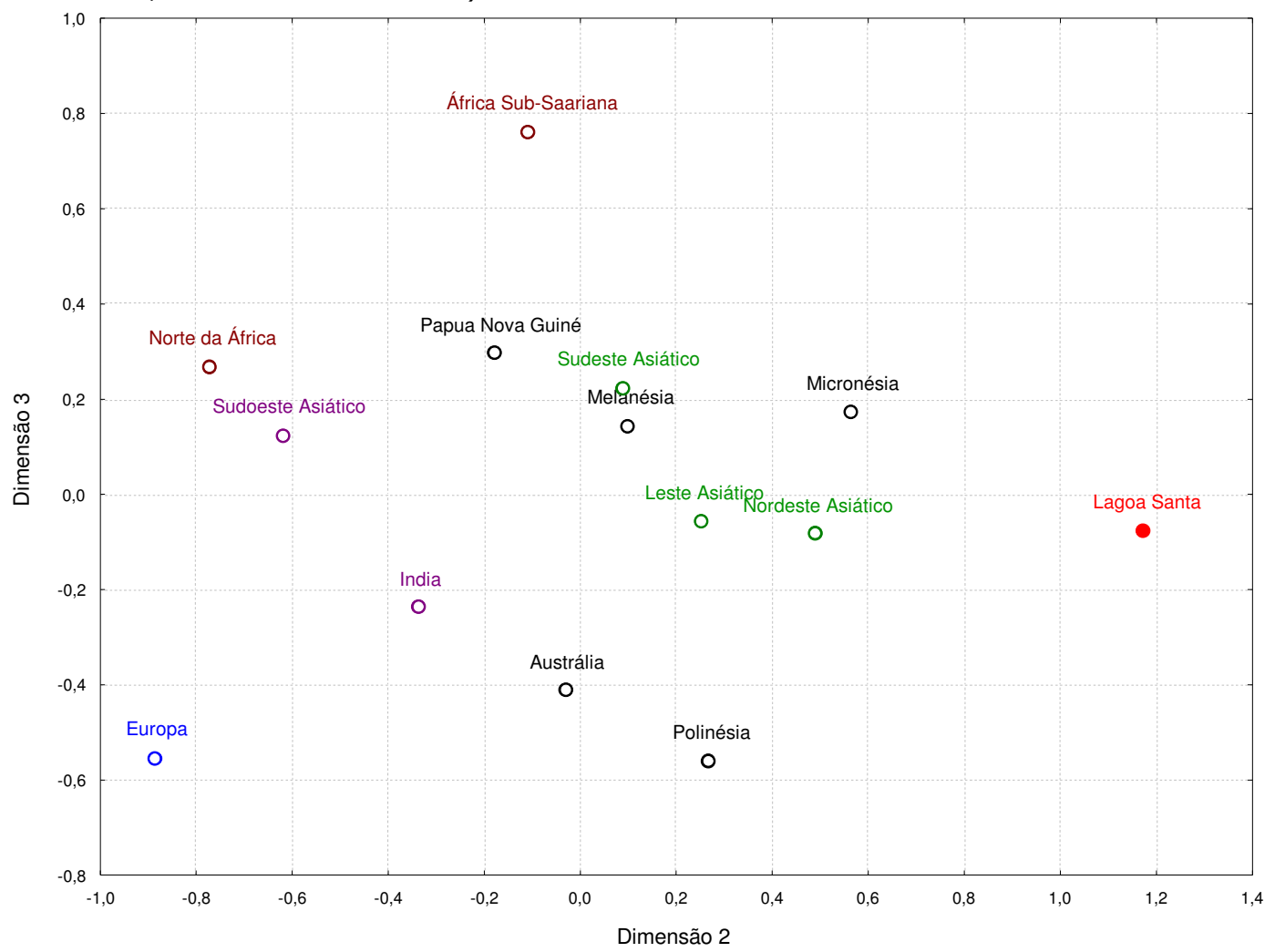




\section{CAPÍTULO 5 - Discussão e conclusões}

A extensa análise multivariada executada neste trabalho permite, num primeiro plano, tirar conclusões de três naturezas distintas: (I) quanto às relações biológicas observadas entre os Paleoíndios de Lagoa Santa e outras populações do planeta; (II) quanto à efetividade das técnicas e estratégias estatísticas utilizadas para testar essas relações; e (III) quanto à contribuição dos resultados aqui gerados para os estudos sobre as origens do homem americano.

Do ponto de vista das afinidades morfológicas propriamente ditas, ficou demonstrado na grande maioria dos resultados gerados, a peculiaridade da morfologia craniana paleoamericana no contexto do Novo Mundo, caracterizada por crânios longos e estreitos, faces baixas, prognatas e pouco lateralizadas e órbitas e nariz relativamente baixos.

Como já extensamente discutido na literatura especializada, essa morfologia, mais generalizada, é similar à encontrada hoje entre os povos africanos sub-saarianos e australo-melanésios, diametralmente distinta da morfologia especializada encontrada hoje na maioria dos povos asiáticos e indígenas americanos, conhecida na literatura tradicional como morfologia mongolóide (Neves et al., 2004, 2005, 2007; Neves \& Hubbe, 2005, para alguns exemplos).

Em escala intra-continental, os Paleoíndios de Lagoa Santa, sempre morfologicamente associados aos paleoamericanos da Colômbia, apresentam forte dissociação morfológica em relação às outras populações nativas americanas utilizadas na análise. Esses resultados são considerados fortemente expressivos e consistentes, uma vez que se repetiram em praticamente todas as análises, para ambos os sexos, tanto para os dados não corrigidos quanto ao fator tamanho como para os que sofreram tal correção (Corruccini, 1973; Darroch \& Mosimann, 1985).

Desprezando-se algumas poucas associações de pequena expressão, claramente devidas às sensibilidades diferenciais das técnicas estatísticas 
empregadas, pode-se afirmar, categoricamente, com base nos resultados obtidos que a morfologia craniana dos paleoíndios de Lagoa Santa não encontra correspondentes entre a esmagadora maioria das populações nativas do continente americano (para algumas exceções ver Gonzalez-José et al., 2003; Atuí, 2005).

Já na escala extra-continental, as afinidades biológicas entre os grupos de Lagoa Santa e os do Velho Mundo não se apresentaram tão nítidas. Os resultados foram menos consistentes, muito mais dependentes da sensibilidade das técnicas estatísticas aplicadas, da natureza dos dados analisados (corrigidos ou não quanto ao fator tamanho) e do tamanho amostral utilizado. Ainda assim, algumas delas mostraram associações morfológicas entre os Paleoíndios de Lagoa Santa e os australo-melanésios e africanos sub-saarianos.

Durante a aplicação dos testes estatísticos notou-se sensibilidade diferencial entre as técnicas empregadas, de acordo com as características do conjunto de dados utilizado.

Tendo em vista que a variabilidade biológica humana reside dentro de cada população (Howells 1973, 1985, 1999; Relethford 1994), seria extremamente apropriado estudar as afinidades morfológicas dos Paleoamericanos através, também, de testes que levassem em consideração as dispersões individuais tanto intra quanto inter-grupos. A enorme quantidade de indivíduos presentes no banco Hanihara impediu, pelo menos num primeiro momento, lançar mão desses testes.

As Análises de Componentes Principais mostraram-se ideais para as investigações de tendências centrais $e$, normalmente, apresentaram associações bastante consistentes em ambos os sexos e independente da correção ou não do fator tamanho.

Para incluir na análise a variabilidade interna de cada série, adotou-se a utilização de Distâncias de Mahalanobis; mas por limitações da própria técnica seus resultados também foram expressos quanto aos centróides de cada série.

De maneira geral, as técnicas baseadas em projeções espaciais (ACP e MDS), que tiveram seus resultados expostos através de gráficos bi- 
dimensionais, mostraram-se mais eficientes, e com melhor resolução, do que as análises baseadas em agrupamentos hierárquicos.

A primeira explicação para tal fenômeno é que pelo estudo envolver algumas amostras arqueológicas, de natureza fragmentária, análises baseadas em distâncias matriciais parecem mostrar-se mais sensíveis à substituição de valores faltantes levando a associações que não refletem a natureza real dos dados estudados (Hair, 1998).

Tal explicação parece ser a mais aceitável, uma vez que, no presente trabalho, associações incoerentes ocorreram, preferencialmente, nos casos em que a matriz de dados original precisou receber, algebricamente, dados para substituir valores faltantes.

A segunda reside na natureza dos dados utilizados. Segundo Reis (2001), não-conformidades das amostras refletem-se no comportamento anômalo de alguns fatores, sejam eles componentes principais, dimensões escalares ou distâncias matriciais.

Dessa forma, num próximo momento será essencial, o emprego de algoritmos de ponta, tais como Distância de Mahalanobis corrigida por herdabilidade (Relethford \& Blangero 1990; Relethford \& Harpending 1994), Distância de Mahalanobis Crânio-a-Crânio com cálculo de Probabilidade Posterior e Tipicalidade (Albrecht 1992; Van Vark \& Schaafsma 1992). Além disso, será igualmente apropriado o emprego de testes de significância baseados em modelos nulos (método de permutação de Monte Carlo, Jacknife ou Bootstrap) para certificar-se que os resultados obtidos são, de fato, reflexos da realidade factorial analisada (Mingoti, 2005; Reis, 2001; Valentin, 2000).

Conforme exposto na contextualização, a arqueologia não deixa mais dúvidas quanto à natureza pré-Clovis do primeiro povoamento da América. Nesse contexto, a entrada na América de duas populações biológicas distintas não encontra oposição formal em termos de profundidade cronológica. Entretanto, as conclusões aqui obtidas através de estudos morfológicos comparativos não coincidem com os modelos postulados pelos estudos da biologia molecular dos nativos americanos. 
Embora, nos últimos anos, uma série de fragilidades nas principais assunções desses estudos, sobretudo quanto à utilização do DNAmt para a recuperação de filogenias, tenham sido levantadas e debatidas (Szathmary, 1993; Gibbons, 1993; Kraytsberg et al., 2004; Templeton, 2002; Strauss, 1999), a maioria dos geneticistas moleculares parece convergir para a idéia que todas as populações nativas americanas atuais tiveram como ancestrais populações localizadas no nordeste asiático (Norte e Centro-sul da Sibéria), e que adentraram o continente americano numa única leva migratória, ocorrida em alguma época entre 30 e 7 mil anos A.P. (Zegura et al., 2004; ver Schurr, 2004 para uma defesa de duas migrações e Kemp et al., 2007 para uma recente colaboração).

Assim, assumindo a legitimidade de ambos os tipos de marcadores, sugere-se as seguintes possibilidades de conciliação:

a) As populações de morfologia generalizada, Paleoíndias, que chegaram primeiro ao Novo Mundo foram parcial ou totalmente substituídas pela população de morfologia especializada, mongolóide, que a sucedeu. Admitindo que nessa substituição a segunda leva não incorporou traços do pacote genético da primeira, os genes e a morfologia das populações nativas americanas tardias e atuais refletem apenas a diversidade biológica da segunda leva de imigrantes;

b) Assumindo a possibilidade de que marcadores moleculares e marcadores morfológicos possuam "assinaturas" evolutivas distintas, isto é, um mesmo conjunto gênico pode abrigar mais de um padrão morfológico, pode-se supor que a mesma população não-mongolóide que entrou na América atravessando o Estreito de Bering pudesse ser a que, sofrendo pressões seletivas diferenciadas, deu origem, na Ásia, à morfologia mongolóide;

c) A segunda leva populacional absorveu os indivíduos da primeira leva, que tiveram seus genes "diluídos" no pool genético que se apresenta atualmente. 
Em síntese, os resultados aqui obtidos permitem conclusões em dois níveis de verossimilhança:

I - Conclusões fortemente verossímeis

a) Em escala intra-continental, a população Paleoíndia de Lagoa Santa não se associa com as populações indígenas nativas americanas tardias e atuais, apresentando, via de regra, uma morfologia craniana completamente distinta dessas últimas;

b) Quando comparada a outras populações autóctones do continente americano, a população de Lagoa Santa associa-se fortemente aos paleoíndios e arcaicos da Colômbia;

II - Conclusões medianamente verossímeis

c) Em escala extra-continental, os Paleoíndios de Lagoa Santa apresentam, de maneira geral, morfologia craniana mais semelhante à apresentada por populações de morfologia craniana generalizada, representadas no banco de dados consolidado por populações de aborígenes australianos, melanésios e africanos;

d) Os resultados obtidos corroboram, pelo menos parcialmente, o modelo proposto por Neves \& Pucciarelli $(1989,1990,1991)$ para o povoamento do Novo Mundo;

II - Conclusões fracamente verossímeis

e) A completa diferenciação morfológica entre as populações paleoíndias e as autóctones americanas recentes leva a crer que, em algum momento durante o Holoceno, ocorreu uma mudança rápida e significativa da 
morfologia dos povos nativos americanos, passando a existir, praticamente, apenas a morfologia mongolóide no Novo Mundo, desaparecendo a morfologia generalizada. 


\section{$\underline{\text { Referências citadas }}$}

Adovasio, J. M., Pedler, D. R., Donahue, J. \& Stuckenrath R. (1998). Two decades of debate on Meadowcroft Rockshelter. North American Archaeology 19(4), 317-341.

Albrecht, G. H. (1992). Assessing the affinities of fossils using canonical variates and generalized distances. Human Evolution 7(4), 49-69.

Araujo, A. G. M., Neves, W. A. \& Pilo, L. B. (2003). Eventos de seca no Holoceno e suas implicações no povoamento pré-histórico do Brasil Central. Anais do IX Congresso da Associação Brasileira de Estudos do Quaternário. ABEQUA, Rio de Janeiro.

Arensburg, B. \& Nès El, M. (1995). On the origin of native Americans: De Acosta versus La Peyrere. Antropología Biológica 3, 1-11.

Armelagos, G. J., Carlson, D. S. \& Van Gerven, D. P. (1982). The theoretical foundations and development of skeletal biology. In: Spencer, F. (ed.). A History of American Physical Anthropology, 1930-1980. New York: Academic Press. 305-328.

Armelagos, G. J. \& Van Gerven, D. P. (2003). A century of skeletal biology and paleopathology: contrasts, contradictions, and conflicts. American Anthropologist 105, 53-64.

Atuí, J. P. V. (2005). Morfologia craniana de ameríndios brasileiros recentes e suas implicações para a questão da ocupação do Novo Mundo: uma análise exploratória. [mestrado] São Paulo: Departamento de Genética e Biologia Evolutiva. Instituto de Biociências. Universidade de São Paulo.

Bailliet, G., Rothhammer, F., Carnese, F. R., Bravi, C. M. \& Biachi, N. O. (1994). Founder mitochondrial haplotypes in Amerindian population. American Journal of Human Genetics 54, 27-33.

Bianchi, N. O., Catanesi, C. I., Baillet, G., Martinéz-Marignac, V. M., Bravi, C. M., Vidal-Rioja, L. B., Herrera, R. J. \& López-Camelo, J. S. (1998). Characterization of an ancestral derived Y-chromosome haplotypes of New 
World native populations. American Journal of Human Genetics 63, 18621871.

Black, F. L., Pandey, J. P. \& Santos, S. E. B. (1991). Evidências baseadas em HLA e IgG sobre as relações intra e inter-continentais das populações nativas da Amazônia. In: Neves, W. A. (org.) Origens, Adaptações e Diversidade Biológica do Homem Nativo da Amazônia. Belém: Museu Paraense Emílio Goeldi.

Boas, F. (1912). New evidence in regard to the instability of human types. American Antiquity. 14, 530-562.

Bonatto, S. L. \& Salzano, F. M. (1997a). Diversity and age of the four major mtDNA haplogroups, and their implications for the peopling of the New World. American Journal of Human Genetics 61, 1413-1423.

Bonatto, S. L. \& Salzano, F. M. (1997b). A single and early migration for the peopling of the Americas supported by mitochondrial DNA sequence data. Proceedings of the National Academy of Science 94, 1966-1971.

Bortolini, M., Salzano, F. M., Thomas, M. G., Stuart, S., Nasanen, S. P. K., Bau, C. H. D., Hutz, M. H., Layrisse, Z., Petzl-Erler, M. L., Tsuneto, L. T., Hill, K., Hurtado, A. M., Castro-de-Guerra, D., Torres, M. M., Groot, H., Michalski, R., Nymadawa, P., Bedoya, G., Bradman, N., Labuda, D. \& Ruiz-Linares, A. (2003). Y-chromosome evidence for differing ancient demographic histories in the Americas. Am. J. Hum. Genet. 73, 524-539.

Brace, C. L. (1982). The roots of the race concept in American physical anthropology. In: Spencer, F. (ed.). A History of American Physical Anthropology, 1930-1980. New York: Academic Press, 11-29.

Brace, C. L. \& Hunt, K. D. (1990). A nonracial craniofacial perspective on human variation: $A$ (ustralia) to $Z$ (uni). American Journal of Physical Anthropology 82, 341-360.

Brace, C. L., Nelson, A. R., Seguchi, N., Oe, H., Sering, L., Qifeng, P., Yongyi, L. \& Tumen, D. (2001). Old World source of the first New World human inhabitants: a comparative craniofacial view. Proceedings of National Academy of Science. 98(17), 10017-10022. 
Bradley, B. \& Stanford, D. (2004). The North American Atlantic ice-edge corridor: a possible Paleolithic route to New World. World Archaeology. 36(4), 459-478.

Callegari-Jacques, S. M. \& Salzano, F. M. (1989). Genetic variation within two linguistic Amerindian groups - relationship with geography and population size. American Journal of Physical Anthropology 79, 313-320.

Campbell, L. (1987). Review of "Language in the Americas" by J. H. Greenberg. Language 64, 591-615.

Cann, R. L. (1994). mtDNA and Native Americans: a southern perspective. American Journal of Human Genetics 55, 7-11.

Castro, C (organização), Boas, F (2005). Franz Boas. Antropologia Cultural. Rio de Janeiro. Jorge Zahar

Cavalli-Sforza, L. L. (1997). Genes, peoples and languages. Proceedings of National Academy of Siences 94, 7719-7724.

Cavalli-Sforza, L. L. (2000). Genes, povos e línguas. São Paulo: Companhia das Letras.

Cavalli-Sforza, L. L., Piazza, A., Menozzi, P. \& Mountains, J. (1988). Reconstruction of human evolution: bringing together genetic, archaeological and linguistic data. Proceedings of the National Academy of Science 85, 60026006.

Clark, J. D., Dunn, J. E. \& Smith, K. G. (1993). A multivariate model of female black bear habitat use for a geographic information system. Journal of Wildlife Management. 57:519-526.

Crawford, M. H. (1992). When two worlds collide. Human Biology 64: 271-279.

Crawford, M. H. (1998). The origins of Native Americans: Evidence from anthropological genetics. England: Cambridge University Press.

Collins, M. B. (2002). The Gault site, Texas, and Clovis research. Athena Review $3(2), 31-41$.

Comas, J. (1976). Manual de Antropologia Física. México: Universidad Nacional Autónoma de Mexico.

Corruccini, R. S. (1973). Size and shape in similarity coefficients based on metric characters. American Journal of Physical Anthropology 38, 743-754. 
Darroch, J. N. \& Mosimann, J. E. (1985). Canonical and principal components of shape. Biometrika 72, 241-252.

Diamond, J. (2003). Armas, Germes e Aço: o Destino das Sociedades Humanas. Rio de Janeiro: Record.

Dillehay, T. D. (1997). Monte Verde: a late Pleistocene settlement in Chile 2: the archaeological context. Washington: Smithsonian Institution Press.

Dillehay, T. D. (1999). The late Pleistocene cultures of South America. Evolutionary Anthropology 7(6), 206-216.

Dillehay, T. D. (2000). The settlement of the Americas. New York: Basic Books.

Dillehay, T. D. (2003). Tracking the first Americans. Nature. 425, 23-24.

Dillehay, T. D., Calderón, G. A., Politis, G. \& Beltrão, M. (1992). Earliest hunters and gatherers of South America. Journal of World Prehistory 6,145-204.

Dixon, E. J. (2001a). Human colonization of the Americas: timing, Technology and process. Quaternary Science Reviews, 20(2001). 277-299.

Dixon, E. J. (2001b). Bones, Boats \& Bison - Archaeology and the First Colonization of Western North America. Albuquerque: University of New Mexico Press.

Eshleman, J. A., Malhi, R. S. \& Smith, D. G. (2003). Mitichondrial DNA studies of Native Americans: Conceptions and Misconceptions of the population prehistory of the Americas. Evolutionary Anthropology. 12, 7-18.

Fagan, B. M. (1987). The great journey. London: Thames and Hudson Ltda.

Fagan, B. M. (1999). World prehistory - a brief introduction. Menlo Park: Longman.

Fedje, D. W. \& Christensen, T. (1999). Modeling paleoshorelines and locating early Holocene coastal site in Haida Gwai. American Antiquity. 64(4), 95-115.

Figgins, J. D. (1927). The antiquity of Man in America. Natural History 27, 229239.

Forster, P., Hardling, R., Torroni, A. \& Bandelt, H. J. (1996). Origin and evolution of Native American mtDNA variation: a reappraisal. American Journal of Human Genetics 59, 935-945.

Futuyma, D. (1997) Evolutionary Biology. USA. Sinauer 
Gelman, A., King, G. \& Liu, C. (1998). Not asked and not answered: multiple imputation for multiple surveys. Journal of the American Statistical Association, 443(93): 846-857.

Genovés, S. T. (1967). Some problems in the physical anthropological study of the peopling of America. Current Anthropology 3, 297-312.

Gibbons, A. (1993). Geneticists trace the DNA trail of the first Americans. Science 259, 312-313.

Gibbons, A. (1996). The Peopling of the Americas. Science 274, 31-33.

Goebel, T. (1999). Pleistocene human colonization of Siberia and peopling of the Americas: an ecological approach. Evolutionary Anthropology. 8(6), 208227.

González-José, R., González-Martin, A., Hernández, M., Pucciarelli, H. M., Sardi, M., Rosales, A. S. \& van de Molen, S. (2003). Craniometric evidence for paleoamerican survival in Baja California. Nature 452, 62-65.

González-José, R., Neves, W. A., Lahr, M. M., González, S., Pucciarelli, H. M., Martinez, M. H. \& Correal, U. (2005). Late Pleistocene/Holocene craniofacial morphology in Mesoamerican Paleoindians: implications for the peopling of the New World. American Journal of Physical Anthropology 128, 772-780.

Goodyear, A. C. III (1999). The Early Holocene occupation of the Southeastern United States: a geoarchaeological summary. In: Bonnichsen, K., L. \& Turnmire, K., L. Corvallis: Cent. Study First Americans.

Gould, S. J. (1999). A Falsa Medida do Homem. São Paulo. Martins Fontes.

Gower, J. C. (1966). Some distance properties of latent roots and vector methods used in multivariate analysis. Biometrika. 53, 325-338.

Green, T. J., Cochran, B., Fenton, T. W., Woods, J. C., Titmus, G. L., Tieszen, L., Davis, M. A. \& Miller, S. J. (1998). The Buhl burial: A Paleoindian woman from Southern Idaho. American Antiquity 63, 437-456.

Greenberg, J. H., Turner II, C. G. \& Zegura, S. L. (1986). The settlement of the Americas: a comparison of linguistic, dental and genetic evidence. Current Anthropology 27, 477-497.

Guidon, N. \& Delibrias, G. (1996). Carbon-14 dates point to man in the Americas 32,000 years ago. Nature. 321, 269-271. 
Hair, J. F. Jr., Anderson, R. E., Tatham, R. L. \& Black, W. C. (1998). Análise Multivariada de Dados. $5^{a}$. edição. São Paulo:Bookman.

Hanihara, T. (1993a). Population prehistory of East Asia and the Pacific as viewed from craniofacial morphology: The basic populations in East Asia, VII. American Journal of Physical Anthropology 91, 173-187.

Hanihara, T. (1993b). Craniofacial features of Southeast Asians and Jomonese: A reconsideration of their microevolution since the late Pleistocene. Anthropol. Sci. 101, 25-46.

Hanihara, T. (1996). Comparison of Craniofacial Features of Major Human Groups. American Journal of Physical Anthropology 99, 389-412.

Hanihara, T. (2000). Frontal and facial flatness of major human populations. American Journal of Physical Anthropology 111, 105-134.

Harper, A. B. \& Laughlin, W. S. (1982). Inquiries into the peopling of the New World: development of ideas and recent advances. In: Spencer, F. (ed.). A History of American Physical Anthropology, 1930-1980, 281-304. New York: Academic Press.

Haydenblit, R. (1996). Dental variation among four Prehispanic Mexican populations. American Journal of Physical Anthropology 100, 225-246.

Hillson, S. (1996). Dental Anthropology. Cambridge: Cambridge University Press.

Hoeffecker, J. F., Powers, W. R. \& Goebel, T. (1993). The colonization of Beringia and the peopling of the New World. Science. 259, 46-53.

Hoeffecker, J. F. \& Elias, S. A. (2003). Environment and archeology in Beringia. Evolutionary Anthropology. 12, 34-49

Horai, S., Kondo, R., Nakagawa-Hattori, Y., Hayashi, S., Sonoda, S. \& Tajima, K. (1993). Peopling of the Americas, founded by four major lineages of DNA. Molecular Biology and Evolution 10, 23-47.

Hotelling, H. (1933). Analysis of a complex of statistical variables into principal components. Journal of Educational Psychology, 24, 417-441.

Howells, W. W. (1973). Cranial variation in man. A study by multivariate analysis of patterns of difference among recent human populations. Papers of 
Peabody Museum of Archaeology and Ethnology. Cambridge: Harvard University Press.

Howells, W. W. (1989). Skull shapes and the map. Craniometric analysis in the dispersion of modern Homo. Papers of Peabody Museum of Archaeology and Ethnology. Cambridge: Harvard University Press.

Howells, W. W. (1999). Who's who in skulls. Papers of Peabody Museum of Archaeology and Ethnology, vol. 82. Cambridge: Harvard University Press.

Hrdlicka, A. (1912). The Skeletal Remains of Early Man in South America. In: Hrdlicka, A. (ed.). Early Man in South America. Bureau of American Ethnology Bulletin 52. Washington: Smithsonian Institution. 153-185.

Hrdlicka, A. (1932). The coming of man from Asia in light of recent discoveries. Proceedings of the American Philosophical Society 71, 393-402.

Hubbe, M., Neves, W. A., Atui, J. P. V., Cartelle, C. \& Silva, M. P. (2004). A new early skeleton from Brazil: further support to the "two main biological components model" for the settlement of the Americas. Current Research in the Pleistocene 21, 77-81.

Hubbe, M. (2006). Análise biocultural dos remanescentes ósseos humanos de Porto do Rio Vermelho 02 (SC-PRV-02) e suas implicações para a colonização da costa brasileira. [doutorado] São Paulo: Departamento de Genética e Biologia Evolutiva. Instituto de Biociências. Universidade de São Paulo.

Imbelloni, J. (1938). Tabla classificatoria de los indios. Regiones biológicas y grupos raciales humanos de América. Physis 12, 229-249.

James, F. C. \& McCullough, C. E. (1990). Multivariate analyses in ecology and systematics: panacea or Pandora's box? Annual Review of Ecology and Systematic. 21, 129-166.

Jantz, R. L. \& Owsley, D. W. (2001). Variation among early North America crania. American Journal of Physical Anthropology 114, 146-155.

Karafet, T. M., Zegura, S. L., Posukh, O., Osipova, L., Bergen, A., Long, J., Goldman, D., Klitz, W., Harihara, S., Knijff, P., Wiebe, V., Griffiths, R. C., Templeton, A. R. \& Hammer, M. F. (1999). Ancestral Asian Source(s) of New World Y-Chromosome Founder Haplotypes. American Journal of Human Genetics 64, 817-831. 
Kemp, B. M., Malhi, R. S., McDonough, J., Bolnick, D. A., Eshleman, J. A., Rickards, O., Martinez-Labarga, C., Johnson, J. R., Lorenz, J. G., Dixon, E. J., Fifield, T. E. Heaton, T. H., Worl, R. \& Smith, D. G. (2007). Remains from Alaska and its implications for the settlement of the Americas. American Journal of Physical Anthropology. 132(4): 605-621.

Kipnis, R. (1998). Early hunter-gatherers in the Americas: perspective from central Brazil. Antiquity 72, 581-592.

Kirk, R. L. (1979) Genetic differentiation in Australia and its bearing on the origin of the first Americans. In: Laughlin, W. S. \& Harper, A. B. (editors). The first Americans: origins, affinities and adaptations. Stuttgart: Gustav Fischer, 211-237.

Kolman, C. J., Sambuughin, N. \& Bermingham, E. (1996). Mitochondrial DNA Analysis of Mongolian Populations and Implications of the Origin of New World Founders. Genetics 142, 1321-1334.

Kraytsberg, Y., Schwartz, M., Brown, T. A., Ebralidse, K., Kunz, W. S., Clayton, D. A., Vissing, J. \& Khrapko, K. (2004). Recombination of human mitochondrial DNA. Science 304, 981.

Lahr, M. M. (1995). Patterns of modern human diversification: implications for Amerindian origins. Yearbook of Physical Anthropology 38, 163-198.

Lahr, M. M. (1996). The origin of modern human diversity. Cambridge: Cambridge University Press.

Lovgren, S. (2003). Who were the first americans? National Geografic News, September 3, 2003. on line version: <http://news.nationalgographic.com/news/2003/09/0903_030903_bajaskull.h tml> acessado em 05/11/2003.

Madrigal, L. (1998). Statistics for anthropology. Cambridge: Cambridge University Press.

Mahalanobis, P. C. (1936). On the generalized distance in statistics. Proceedings of the National Institute of Science of India. 12, 49-55.

Manly, B. F. J. (1994). Multivariate Statistical Methods: a primer. London: Chapman and Hall. 
Matson, G. A., Sutton, H. E., Echeverry, R., Swanson, J. \& Robinson, A. (1967). Distribution of hereditary blood groups among Indians in South America. American Journal of Physical Anthropology 27, 157-193.

McAvoy, J. M., Baker, J. C., Feathers, J. K., Hodges, R. L. \& McWeeney, L. J. (2000). Summary of research at the Cactus Hill archaeological site, Sussex County, Virginia. National Geographic Society.

Meltzer, D. J. (1989). Why don't we know when the first people came to North America? American Antiquity, 54(3): 471-490.

Meltzer, D. J., Grayson, D. K., Ardilla, G., Barker, A. W., Dincauze, D. F., Haynes, C. V., Mena, F., Núñez, L. \& Stanford, D. J. (1997). On the Pleistocene antiquity of Monte Verde, Southern Chile. American Antiquity 62, 659-663.

Merriwether, D. A. \& Ferrell, R. E. (1996). The four founding lineage hypothesis for the New World: A critical reevaluation. Molecular Phylogenetics Evolution 5, 241-246.

Mingoti, S. A. (2005). Análise de dados através de métodos de estatística multivariada - uma abordagem aplicada. Belo Horizonte: Editora UFMG.

Munford, D., Zanini, M. C., \& Neves, W. A. (1995). Human cranial variation in South America: implications for the settlement of the New World. Brazilian Journal of Genetics 18, 673-688.

Munford, D. (1999). Estudo Comparado da Morfologia Craniana de Populações Pré-Históricas da América do Sul: Implicações para a Questão do Povoamento do Novo Mundo. [dissertação] São Paulo: Departamento de Biologia, Instituto de Biociências, Universidade de São Paulo.

Neves, W. A. (1982). Variação métrica nos construtores de sambaquis do sul do Brasil: primeira aproximação multivariada. Revista de Pré-História, 3(4): 83108.

Neves, W. A. \& Pucciarelli, H. M. (1989). Extra-continental biological relationships of early South American human remains: a multivariate analysis. Ciência e Cultura 41, 566-575. 
Neves, W. A. \& Pucciarelli, H. M. (1990). The origin of the first Americans: an analysis based on the cranial morphology of early South American human remains. American Journal of Physical Anthropology 81, 274.

Neves, W. A. \& Pucciarelli, H. M. (1991). Morphological affinities of the first Americans: an exploratory analysis based on early South American human remains. Journal of Human Evolution 21, 261-273.

Neves, W. A. \& Blum, M. (2000). The Buhl burial: A comment on Green et al. American Antiquity 65, 1911-193.

Neves, W. A., Meyer, D. \& Pucciarelli, H. M. (1993). The contribution of the morphology of early South- and North American skeletal remains to the understanding of the peopling of the Americas. American Journal of Physical Anthropology (Supp.) 16, 150-151.

Neves, W. A., Munford, D. \& Zanini, M. C. (1996a). Cranial morphological variation and the colonization of the New World: towards a four-migration model. American Journal of Physical Anthropology (Suppl.) 26, 169.

Neves, W. A., Meyer, D. \& Pucciarelli, H. M. (1996b). Early skeletal remains and the peopling of the Americas. Revista de Antropologia 39, 121-139.

Neves, W.; Zanini, M. C.; Munford, D. \& Pucciarelli, H. M. (1997). O povoamento da América à luz da morfologia craniana. Revista Usp 34, 96105.

Neves, W. A. \& Pucciarelli, H. M. (1998). The Zhoukoudian Upper Cave skull 101 as seen from the Americas. Journal of Human Evolution 34, 219-222.

Neves, W. A.; Powell, J. F. \& Ozolins, E. G. (1999a). Extra-continental morphological affinities of Lapa Vermelha IV, hominid I: a multivariate analysis with progressive numbers of variables. Homo 50, 263-282.

Neves, W. A., Powell, J. F. \& Ozolins, E. G. (1999b). Extra-continental morphological affinities of Palli Aike, Southern Chile. Interciéncia 24, 258-263.

Neves, W. A., Powell, J. F. \& Ozolins, E. G. (1999c). Modern human origins as seen from the peripheries. Journal of Human Evolution 37, 129-133.

Neves, W. A., Prous, A., González-José, R., Kipnis, R. \& Powell, J. (2003). Early human skeletal remains from Santana do Riacho, Brazil: implications for the settlement of the New World. Journal of Human Evolution 45, 19-42. 
Neves, W. A., González-José, R., Hubbe, M., Kipnis, R., Araújo, A. G. M. \& Blasi, O. (2004). Early human skeletal remains from Cerca Grande, Lagoa Santa, Central Brazil, and the origins of the first Americans. World Archaeology 36, 479-501.

Neves, W. A., Hubbe, M., Okumura, M. M. M., González-José, R., Figuti, L., Eggers, S. \& Blasis, P. A. D. (2005). A new early Holocene human skeleton from Brazil: implications for the settlement of the New World. Journal of Human Evolution 48, 403-414.

Neves, W. \& Hubbe, M. (2005). Cranial morphology of early Americans from Lagoa Santa, Brazil: Implications for the settlement of the New World. Proceedings of the National Academy of Science 102, 18309-18314.

Neves, W. A., Hubbe, M. \& Correal, G. (2007). Human skeletal remains from Sabana de Bogotá, Colombia: a case of paleoamerican morphology late survival in South America? American Journal of Physical Anthropology, 133:1080-1098.

Newmann, M. T. (1951). Na historical resume of the concept of differences in Indian type. American Anthropologist 53, 19-36.

Newmann, M. T. (1962). Evolutionary changes in body size and head form in American Indians. American Anthropologist. 64, 237-257.

Newmann, M. T. (1963). Geographic and microgeographic races. Current Anthropology, 4:200-201.

Nichols, J. (1990). Linguistic diversity and the first settlement of the New World. Language 66: 475-521.

Nichols, J. (1997). Modeling ancient population structures and movements in linguistics. Annual Review of Anthropology, 26: 359-384.

Okumura, M. M. M. (2007). Diversidade morfológica craniana, micro-evolução e ocupação pré-histórica da costa brasileira. [doutorado] São Paulo: Departamento de Genética e Biologia Evolutiva. Instituto de Biociências. Universidade de São Paulo.

Pavlov, P., Svendsen, J. I., \& Indrelid, S. (2001). Human Presence in the European Arctic nearly 40,000 years ago. Nature. 413:64-67. 
Pearson, K. (1901). On lines and planes of closest fit to systems of points in the space. Philosophical Magazine, 2:559-572.

Pena, S. D. J., Santos, F. R., Bianchi, N. O., Bravi, C. M., Carnese, F. R., Rothhammer, F., Gerelsaikhan, T., Munkhtuja, B. \& Oyunsurent, T. (1995). A major founder Y-chromosome haplotype in Amerindians. Nature Genetics 11, 15-16.

Pitulko, V. V., Nokolsky, P. A., Girya, E. Y., Basilyan, A. E. \& Tumskoy, V. E. (2004). The Yana RHS site: humans in the Arctic before the last glacial maximum. Science. 303, 52-56.

Powell, J. F. \& Steele, D. G. (1992). A multivariate craniometric analysis of North American paleo-indian remains. Current Research in the Pleistocene 9, 59-62.

Powell, J. F. (1993). Dental evidence for the peopling of the New World: some methodological considerations. Human Biology 65, 799-819.

Powell, J. F. (1995). Dental variation and biological affinity among middle Holocene human populations in North America. [doutorado] Austin: University of Texas.

Powell, J. F. \& Neves, W. A. (1998). Dental diversity of early New World populations: Taking a bite out of the tripartite model. American Journal of Physical Anthropology (Suppl.) 26, 179-180.

Powell, J. F. \& Neves, W. A. (1999). Craniofacial morphology of the first Americans: pattern and process in the peopling of the New World. Yearbook of Physical Anthropology 42, 153-188.

Prous, A. (1991). Arqueologia Brasileira. Brasília: Editora UnB.

Prous, A. (1997). O povoamento da América visto do Brasil: uma perspectiva crítica. Revista USP. 14, 8-21.

Prous, A. (2006). O Brasil antes dos brasileiros - a pré-história do nosso país. Rio de Janeiro: Jorge Zahar Editor.

Reis, E. (2001). Estatística Multivariada Aplicada. Lisboa: Edições Sílabo.

Relethford, J. H. (1982). The use of quantitative traits in the study of human population structure. Yearbook of Physical Anthropology 25, 113-132 
Relethford, J. H. (1994). Craniometric variation among modern human populations. American Journal of Physical Anthropology 95, 53-62.

Relethford, J. H. \& Harpending, H. C. (1994). Craniometric variation, genetic theory, and modern human origins. American Journal of Physical Anthropology. 95(3): 25-38.

Relethford, J. H. (2001). Global analysis of regional differences in craniometric diversity and population substructure. Human Biology 73(5), 629-636.

Relethford, J. H. (2002). Apportionment of global human genetic diversity based on craniometrics and skin color. American Journal of Physical Anthropology 118, 393-398.

Relethford, J. H. \& Blangero, J. (1990). Detection of differential gene flow from patterns of quantitative variation. Human Biology 62, 5-25.

Ridley, M. (2004) Evolução. Rio de Janeiro. Artmed

Rivet, P. (1942). Les Origines de I'Homme Américain. Montreal: Les Éditions l'Arbre.

Rivet, P. (1968). As origens do homem americano. São Paulo: Instituto Progresso Editorial.

Roosevelt, A. C., Douglas, J. \& Brown, L. (2002). The migrations and adaptations of the first Americans: Clovis and pre-Clovis viewed from South America. In: Jablonski, N. G. (ed) The First Americans: the Pleistocene colonization of the New Wolrd. San Francisco: California University Press.

Roseman, C. C. \& Weaver, T. D. (2004). Multivariate apportionment of global human craniometric diversity. American Journal of Physical Anthropology 125, 257-263.

Salzano, F. M., Weimer, T. A., Franco, M. H. L. P., Hutz, M. H., Mestriner, M. A., Simões, A. L. \& Freitas, M. J. M. (1985). Demography and genetics of the Sateré-Mawé and their bearing on the differentiation of the Tupi tribes of South América. Journal of Human Evolution 14, 647-655.

Salzano, F. M. \& Callegari-Jacques, S. M. (1988). A Amazônia como um microcosmo: populações indígenas. In: Neves, W. A. (org.) Biologia e Ecologia Humana na Amazônia: Avaliação e perspectives. Belém: Museu Paraense Emílio Goeldi. 
Salzano, F. M. \& Callegari-Jacques, S. M. (1991). O índio da Amazônia: Uma abordagem microevolucionária. In: Neves, W. A. (org.) Origens, adaptações e diversidade biológica do homem nativo da amazônia. Belém: Museu Paraense Emílio Goeldi.

Santos, F. R., Hutz, M. H., Coimbra, C. E. A., Santos, R. V., Salzano, F. M. \& Pena, S. D. J. (1995). Further evidence for the existence of a major founder $Y$ chromosomal haplotype in Amerindians. Brazilian Journal of Genetics 18, 669672.

Santos, F. R., Pandya, S., Tyler-Smith, C., Pena, S. D. J., Schanfield, M., Leonard, W. R., Osipova, L., Crawford. M. H. \& Mitchell, R. J. (1999). The Central Siberian Origin for Native American Y-chromosomes. American Journal of Human Genetics 64, 619-628.

Schanfield, M. S. (1992). Immunoglobulin allotypes (GM and KM) indicate multiple founding populations of Native Americans: Evidence of at least four migrations to the New World. Human Biology 64, 381-402.

Schurr, T. G., Ballinger, S. W., Gan, Y. Y. Hodge, J. A., Merrewether, D. A., Lawrence, D. N., Knowler, W. C., Weiss, K. M. \& Wallace, D. C. (1990). Amerindian mtDNA have rare Asian mutation at high frequencies, suggesting they derived from four primary maternal lineages. American Journal of Human genetics $46,613-623$.

Schurr, T. G. (2004). The peopling of the New World: Perspectives from molecular anthropology. Annual Rev. Anthropology 33, 551-583.

Seguchi, N., Nelson, A. R., Austin, S. \& Brace, C. L. (2005). Early South Americans in cranifacial metric perspective: Lagoa Santa. American Journal of Physical Anthropology 40 (Suppl.), 187.

Smith, F. H. (1984). Fossil hominids from the Upper Pleistocence of Central Europe and the origin of modern Europeans. In: Smith, F. H. \& Spencer, F. (eds.). The origins of modern humans: a world survey of the fossil evidence. New York: Allan Liss, Inc. 273-299.

Sokal, R. R. \& Rohlf, F. J. (1969). Biometry. San Francisco: W. H. Freeman and Company. 
StatSoft, Inc. (2001). STATISTICA (data analysis software system), version 6.0.4 www.statsoft.com.

Stearns, S. C. \& Hoekstra, R. F. (2000). Evolution: an introduction. Oxford: Oxford University Press.

Steele, D. G. \& Powell, J. F. (1992). Peopling of the Americas: Paleobiological evidence. Human Biology 64, 303-336.

Steele, D. G. \& Powell, J. F. (1993). Paleobiology of the first Americans. Evolutionary Anthropology 2, 138-146.

Stocking Jr., G. W. (editor) (1988). Bones, bodies, behavior: essays in biological anthropology. Madison: The University of Wisconsin Press.

Stocking Jr., G. W. (2004). Franz Boas - A formação da antropologia americana 1883-1911. Rio de Janeiro: Contraponto.

Strauss, E. (1999). MtDNA shows signs of paternal influence. Science. 5449(286), 2436.

Stringer, C. B. (1998). A metrical study of the WL-50 calvaria. Journal of Human Evolution 34, 327-332.

Stringer, C. B. \& Andrews, P. (1988). Genetic and fossil evidence for the origin of modern humans. Science 239, 1263-1268.

Sutter, R. C. (1997). Biological relations among prehistoric northern Chilean populations. A comparative study of dental morphology. American Journal of Physical Anthropology (Suppl.) 24, 224.

Szathmary, E. J. E. (1986). Comments. Current Anthropology 27, 490-491.

Szathmary, E. J. E. (1993). mtDNA and the peopling of the Americas. American Journal of Human Genetics 53, 793-799.

Templeton, A. R. (2002). Out of Africa again and again. Nature 416, 45-51.

Torroni, A., Schurr, T. G., Cabell, M. F., Brown, M. D., Neel, J. V., Larsen, M., Smith, D. G., Vullo, C. M. \& Wallace, D. C. (1993a). Asian affinities and continental radiation of the four founding native American mtDNAs. American Journal of Human Genetics 53, 563-590.

Torroni, A., Sukernik, R. I., Schurr, T. G., Starikovskaya, Y. B., Cabell, M. F., Crawford, M. H., Comuzzie, A. G. \& Wallace, D. C. (1993b). mtDNA variation 
of aboriginal Siberians reviews distant genetic affinities with Native Americans. American Journal of Human Genetics 53, 591-608.

Torroni, A., Neel, J. V., Barrantes, R., Schurr, T. G. \& Wallace, D. C. (1994). Mitochondrial DNA "clock" for the Amerinds and its implications for timing their entry into North America. Proceedings of the National Academy of Science 91, 1158-1162.

Trinkaus, E. (1982). A history of Homo sapiens paleontology in America. In: Spencer, F. (ed.). A History of American Physical Anthropology, 1930-1980. New York: Academic Press, 261-280.

Turner II, C. G. (1983). Dental evidence for the peopling of the Americas. In: Shutler Jr., R. (ed.). Early Man in the New World. Beverly Hills: Sage Publications.

Turner II, C. G. (1990). Major featrures of sundadonty and sinodonty, including suggestions about East Asian microevolution, population history, and late Pleitocene relationships with Australian Aboriginals. American Journal of Physical Anthropology 82, 295-317.

Turner II, C. G. (2002). Teeth, needles, dogs, and Siberia: bioarchaeological evidence for the colonization of the New World. In: Jablonski, N. G. (editor). The first Americans. The Pleistocene colonization of the New World. San Francisco: California Academy of Science, 123-158.

Turner II, C. G. (2006). Dental morphology and the population history of the Pacific Rim and Basin: Commentary on Hirofumi Matsumura and Mark J. Hudson. American Journal of Physical Anthropology 130, 455-461.

Turner II, C. G. \& Bird, J. (1981). Dentition of Chilean Paleo-Indians and peopling of the Americas. Science 212, 1053-1055.

Underhill, P. A., Jin, L., Zemans, R., Oefner, P. J. \& Cavalli-Sforza, L. L. (1996). A precolumbian $\mathrm{Y}$-chromosome specific transition and its implications for human evolutionary history. Proceeding of American Philosophical Society 93, 196-200.

Valentin, J. L. (2000). Ecologia numérica - uma introdução à analise multivariada de dados ecológicos. Rio de Janiero: Editora intersciencia. 
van Vark, G. N. \& Schaafsma, W. (1992). Advances in the quantitative analysis of skeletal morphology. In: Saunders, S. R. \& Katzenberg, M. A. (editors). Skeletal biology of past peoples: research methods. New York: Wiley Liss Inc., 225-257.

van Vark, G. N., Kuizenga, D. \& Williams, F. L., (2003). Kennewick and Luzia: lessons from European upper Paleolithic. American Journal of Physical Anthropology 121, 181-184.

Vayda, A. P. (1983). Progressive contextualization: methods for research in human ecology. Human ecology, 11, 265-281.

Waguespack, N. M. (2007). Why We're Still Arguing About the Pleistocene Occupation of the Americas. Evolutionary Anthropology 16:63-74.

Waters, M. R. \& Stafford Jr., T. W. (2007). Redefining the age of Clovis: implications for the peopling of the Americas. Science. 315: 1122-1126.

Ward, R. H., Frazier, B. L., Dew-Jager, K. \& Paabo, S. (1991). Extensive Mitochondrial diversity within a single Amerindian tribe. Proceedings of the National Academy of Science 88, 8720-8724.

Weiss, K. M. (1994). American origins. Proceeding of the National Academy of Science 91, 833-835.

Williams, F. L., Belcher, R. L. \& Armelagos, G. J. (2005). Forensic misclassifcation of ancient nubian crania: implications for assumptions about human variation. Current Anthropology 46(2), 340-346.

Williams, R. C., Steinberg, A. G., Gershowitz, H., Bennett, P. H., Knowler, W. C., Pettitt, D. J., Butler, W., Baiard, R., Dowda-Rea, L., Burch, T. A., Morse, H. G. \& Smith, A. G. (1985). GM allotypes in Native Americans: evidence for three distant migrations across the Bearing land bridge. American Journal of Physical Anthropology 66, 1-20.

Zegura, S. L., Karafet, T. M., Zhivotovsky, L. A. \& Hammer, M. F. (2004). Highresolution SNPs and microsatellite haplotypes point to a single, recent entry of Native American Y chromosomes into the Americas. Mol. Biol. Evol. 21, 164175. 


\section{Apêndice 1}

Esquema de posicionamento das páginas do Apêndice 1:

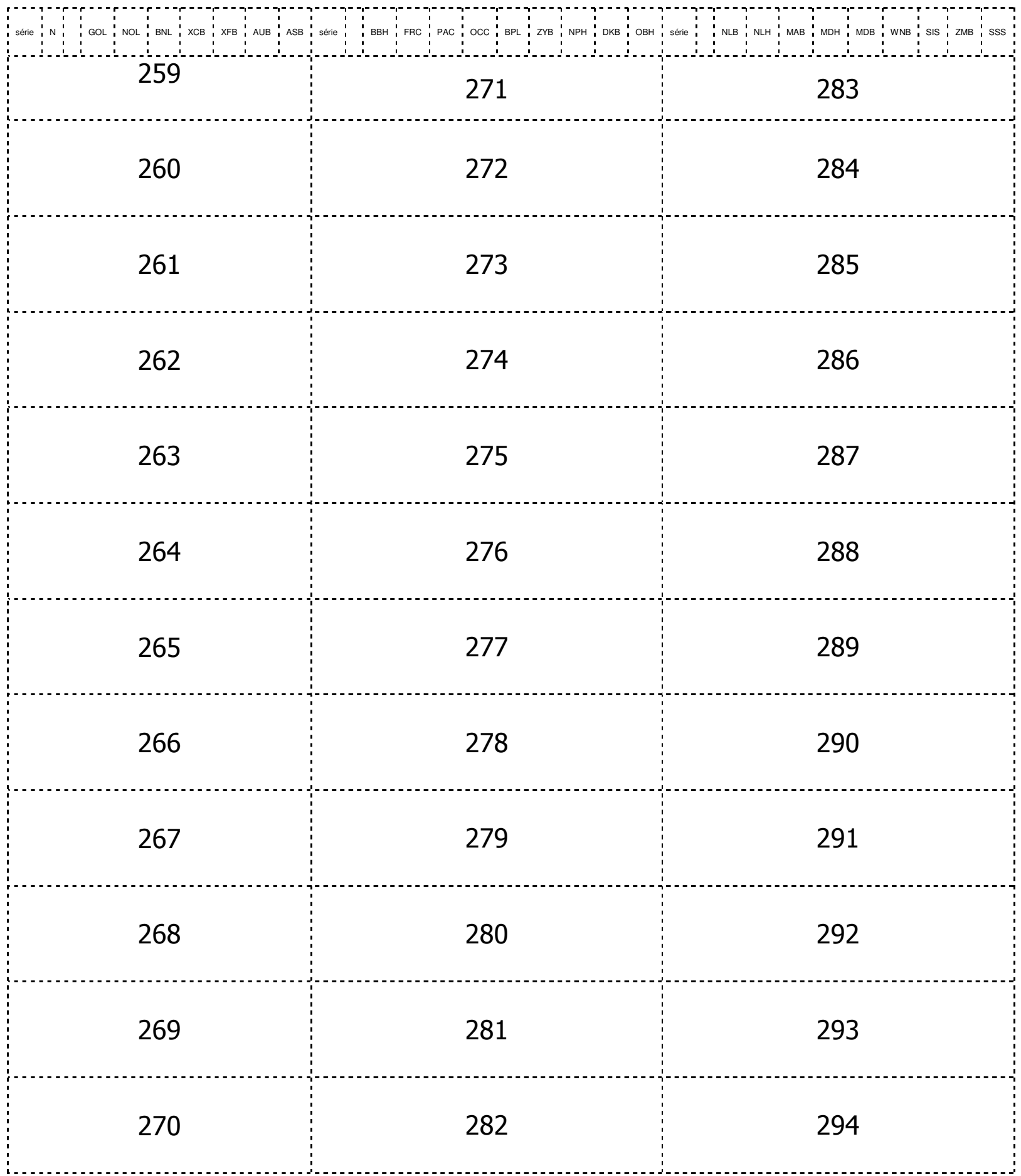


Apêndice 1 - Número de Indivíduos, número de medidas tomadas (absoluta e relativa) e média de cada uma das variáveis utilizáveis do Banco Hanihara - Parcela Masculina.

\begin{tabular}{|c|c|c|c|c|c|c|c|c|c|}
\hline série & $\mathrm{N}$ & & GOL & NOL & BNL & XCB & XFB & AUB & ASB \\
\hline \multirow{3}{*}{ Aleuta 1} & \multirow{3}{*}{82} & $\mathrm{n}$ & 79 & 79 & 78 & 79 & 75 & 79 & 77 \\
\hline & & $\%$ & 96,34 & 96,34 & 95,12 & 96,34 & 91,46 & 96,34 & 93,90 \\
\hline & & média & 182,11 & 180,45 & 101,45 & 147,08 & 117,30 & 134,20 & 116,47 \\
\hline \multirow{3}{*}{ Aleuta 2} & \multirow{3}{*}{45} & $\mathrm{n}$ & 45 & 45 & 45 & 44 & 43 & 45 & 45 \\
\hline & & $\%$ & 100,00 & 100,00 & 100,00 & 97,78 & 95,56 & 100,00 & 100,00 \\
\hline & & média & 180,33 & 178,54 & 100,48 & 150,09 & 119,21 & 136,22 & 116,91 \\
\hline \multirow{3}{*}{ Aleuta 3} & \multirow{3}{*}{13} & $\mathrm{n}$ & 13 & 13 & 13 & 13 & 13 & 13 & 13 \\
\hline & & $\%$ & 100,00 & 100,00 & 100,00 & 100,00 & 100,00 & 100,00 & 100,00 \\
\hline & & média & 179,54 & 177,69 & 99,19 & 145,35 & 117,62 & 131,85 & 116,04 \\
\hline \multirow{3}{*}{ Aleuta 4} & \multirow{3}{*}{18} & $\mathrm{n}$ & 17 & 17 & $\overline{17}$ & 17 & 16 & 17 & $\overline{17}$ \\
\hline & & $\%$ & 94,44 & 94,44 & 94,44 & 94,44 & 88,89 & '94,44 & 94,44 \\
\hline & & média & 180,85 & 178,91 & 98,71 & 146,47 & 116,16 & 133,74 & 117,41 \\
\hline \multirow{3}{*}{ Aleuta 5} & \multirow{3}{*}{5} & $\mathrm{n}$ & 5 & 5 & 5 & 5 & 5 & 5 & 5 \\
\hline & & $\%$ & 100,00 & 100,00 & 100,00 & 100,00 & 100,00 & 100,00 & 100,00 \\
\hline & & média & 180,60 & 178,40 & 96,40 & 143,40 & 113,00 & 130,60 & 111,30 \\
\hline \multirow{3}{*}{ Aleuta 6} & \multirow{3}{*}{16} & $\mathrm{n}$ & 16 & 16 & 16 & 16 & 16 & 16 & 15 \\
\hline & & $\%$ & 100,00 & 100,00 & 100,00 & 100,00 & 100,00 & 100,00 & 93,75 \\
\hline & & média & 181,56 & 179,63 & 101,25 & 149,06 & 117,31 & 136,19 & 115,47 \\
\hline \multirow{3}{*}{$\begin{array}{l}\text { Austrália - } \\
\text { Murray River }\end{array}$} & & $\mathrm{n}$ & 46 & 38 & 14 & 46 & 39 & 34 & 39 \\
\hline & 53 & $\%$ & 86,79 & 71,70 & 26,42 & 86,79 & 73,58 & 64,15 & 73,58 \\
\hline & & média & 188,89 & 182,79 & 100,43 & 129,59 & 110,00 & 118,62 & 108,62 \\
\hline Austrália - & & $n$ & 59 & 58 & 56 & 60 & 61 & 56 & 59 \\
\hline New South & 66 & $\%$ & 89,39 & 87,88 & 84,85 & 90,91 & 92,42 & 84,85 & 89,39 \\
\hline Walles & & média & 187,76 & 182,34 & 101,75 & 132,02 & 111,66 & 118,25 & 108,69 \\
\hline Austrália - & & $\mathrm{n}$ & 12 & 12 & $\overline{12}$ & 12 & 12 & 12 & $\overline{12}$ \\
\hline Território do & 12 & $\%$ & 100,00 & 100,00 & 100,00 & 100,00 & 100,00 & 100,00 & 100,00 \\
\hline & & média & 184,67 & 179,25 & 100,67 & 128,17 & 108,75 & 117,33 & 107,92 \\
\hline & & $\mathrm{n}$ & 22 & 22 & 21 & 22 & 22 & 21 & 21 \\
\hline Ause & 22 & $\%$ & 100,00 & 100,00 & 95,45 & 100,00 & 100,00 & 95,45 & 95,45 \\
\hline & & média & 183,18 & 178,41 & 99,86 & 129,55 & 110,91 & 117,29 & 106,10 \\
\hline & & $\mathrm{n}$ & 127 & 128 & 103 & 127 & 119 & 111 & 125 \\
\hline Austrália - Sul & 147 & $\%$ & 86,39 & 87,07 & 70,07 & 86,39 & 80,95 & 75,51 & 85,03 \\
\hline & & média & 188,55 & 182,95 & 101,62 & 130,03 & 109,43 & 117,62 & 108,74 \\
\hline & & $\mathrm{n}$ & 16 & 16 & 15 & 16 & 17 & 16 & 16 \\
\hline Austrâna- & 17 & $\%$ & 94,12 & 94,12 & 88,24 & 94,12 & 100,00 & 94,12 & 94,12 \\
\hline & & média & 185,50 & 179,38 & 99,23 & 136,44 & 112,82 & 123,38 & 108,88 \\
\hline & & $\mathrm{n}$ & 10 & 10 & $\overline{9}$ & 10 & 10 & 10 & 10 \\
\hline Australla - & 10 & $\%$ & 100,00 & 100,00 & 90,00 & 100,00 & 100,00 & 100,00 & 100,00 \\
\hline & & média & 183,90 & 179,00 & 100,67 & 128,10 & 106,90 & 117,50 & 106,35 \\
\hline & & $\mathrm{n}$ & 28 & 28 & 26 & 28 & 28 & 27 & 27 \\
\hline Australla - & 28 & $\%$ & 100,00 & 100,00 & 92,86 & 100,00 & 100,00 & 96,43 & 96,43 \\
\hline & & média & 184,82 & 180,07 & 99,38 & 130,96 & 110,64 & 117,11 & 106,59 \\
\hline Canadá - & & $\mathrm{n}$ & 52 & 52 & $\overline{76}$ & 52 & 60 & 60 & 57 \\
\hline Columbia & 78 & $\%$ & 66,67 & 66,67 & 97,44 & 66,67 & 76,92 & 76,92 & 73,08 \\
\hline Britânica & & média & 181,45 & 179,54 & 100,75 & 142,15 & 117,76 & 130,16 & 110,39 \\
\hline & & $\mathrm{n}$ & 3 & 3 & 3 & $\overline{3}$ & 3 & 3 & 3 \\
\hline Canada - & 3 & $\%$ & 100,00 & 100,00 & 100,00 & 100,00 & 100,00 & 100,00 & 100,00 \\
\hline & & média & 183,67 & 180,33 & 102,00 & 147,00 & 121,00 & 133,67 & 114,33 \\
\hline Canadá - & & $\mathrm{n}$ & 36 & 36 & 37 & 36 & 37 & 35 & 36 \\
\hline Ontário & 40 & $\%$ & 90,00 & 90,00 & 92,50 & 90,00 & 92,50 & 87,50 & 90,00 \\
\hline (Iroque) & & média & 186,92 & 184,06 & 105,24 & 140,54 & 116,38 & 128,54 & 110,36 \\
\hline América & & $\mathrm{n}$ & 9 & $\overline{9}$ & $\overline{9}$ & $\overline{9}$ & 9 & 9 & $\overline{9}$ \\
\hline Central e do & 9 & $\%$ & 100,00 & 100,00 & 100,00 & 100,00 & 100,00 & 100,00 & 100,00 \\
\hline Sul-Bolívia & & média & 174,39 & 173,22 & 94,83 & 133,33 & 111,39 & 116,89 & 105,83 \\
\hline América & & $\mathrm{n}$ & 9 & 9 & 11 & $\overline{9}$ & 12 & 10 & 11 \\
\hline Central e do & 13 & $\%$ & 69,23 & 69,23 & 84,62 & 69,23 & 92,31 & 76,92 & 84,62 \\
\hline Sul - Caribe & & média & 184,78 & 182,22 & 100,18 & 143,00 & 118,08 & 126,80 & 111,45 \\
\hline América & & $n$ & 20 & 20 & 20 & 20 & 20 & 20 & 19 \\
\hline Central e do & 20 & $\%$ & 100,00 & 100,00 & 100,00 & 100,00 & 100,00 & 100,00 & 95,00 \\
\hline Sul - Chile & & média & 180,30 & 177,28 & 101,93 & 140,73 & 117,05 & 127,10 & 110,18 \\
\hline & & $\mathrm{n}$ & 9 & 9 & 15 & 11 & 13 & 14 & 11 \\
\hline
\end{tabular}




\begin{tabular}{|c|c|c|c|c|c|c|c|c|c|}
\hline & & $n$ & 9 & 9 & 15 & $\overline{11}$ & 13 & 14 & 11 \\
\hline $\begin{array}{c}\text { América } \\
\text { Central e do }\end{array}$ & 20 & média & $\begin{array}{r}45,00 \\
178,78 \\
\end{array}$ & $\begin{array}{r}45,00 \\
176,67\end{array}$ & $\begin{array}{l}75,00 \\
96,53\end{array}$ & $\begin{array}{r}55,00 \\
140,64 \\
\end{array}$ & $\begin{array}{r}65,00 \\
117,23 \\
\end{array}$ & $\begin{array}{r}70,00 \\
125,43 \\
\end{array}$ & $\begin{array}{r}55,00 \\
108,55 \\
\end{array}$ \\
\hline \multirow{3}{*}{$\begin{array}{l}\text { Sul Ancééliấanbia } \\
\text { Central e do } \\
\text { Sul - Equador }\end{array}$} & \multirow{3}{*}{7} & $\mathrm{n}$ & 7 & 7 & 5 & 6 & 6 & 7 & 7 \\
\hline & & $\%$ & 100,00 & 100,00 & 71,43 & 85,71 & 85,71 & 100,00 & 100,00 \\
\hline & & média & 174,29 & 172,00 & 96,00 & 142,67 & 115,50 & 125,21 & 109,14 \\
\hline \multirow{3}{*}{$\begin{array}{l}\text { América Central e } \\
\text { do Sul - Fueguinos } \\
\text { (Patagônia) }\end{array}$} & \multirow{3}{*}{57} & $\mathrm{n}$ & 54 & 54 & 55 & 56 & 55 & 55 & 55 \\
\hline & & $\%$ & 94,74 & 94,74 & 96,49 & 98,25 & 96,49 & 96,49 & 96,49 \\
\hline & & média & 188,26 & 184,12 & 104,52 & 143,70 & 119,53 & 132,65 & 111,70 \\
\hline \multirow{3}{*}{$\begin{array}{c}\text { América } \\
\text { Central e do } \\
\text { Sul - Guiana }\end{array}$} & \multirow{3}{*}{7} & $\mathrm{n}$ & 5 & 5 & 5 & 5 & 5 & 5 & 5 \\
\hline & & $\%$ & 71,43 & 71,43 & 71,43 & 71,43 & 71,43 & 71,43 & 71,43 \\
\hline & & média & 179,00 & 176,60 & 97,20 & 139,40 & 115,40 & 125,20 & 108,80 \\
\hline \multirow{3}{*}{$\begin{array}{c}\text { América } \\
\text { Central e do } \\
\text { Sul - México }\end{array}$} & \multirow{3}{*}{73} & $n$ & 66 & 66 & 70 & 66 & 71 & 68 & 67 \\
\hline & & $\%$ & 90,41 & 90,41 & 95,89 & 90,41 & 97,26 & 93,15 & 91,78 \\
\hline & & média & 178,11 & 175,69 & 100,59 & 137,58 & 115,71 & 124,35 & 108,16 \\
\hline \multirow{3}{*}{$\begin{array}{c}\text { América } \\
\text { Central e do } \\
\text { Sul - Panamá }\end{array}$} & \multirow{3}{*}{1} & $\mathrm{n}$ & 1 & $\overline{1}$ & 1 & 1 & 1 & 1 & 1 \\
\hline & & $\%$ & 100,00 & 100,00 & 100,00 & 100,00 & 100,00 & 100,00 & 100,00 \\
\hline & & média & 180,00 & 178,00 & 103,00 & 155,00 & 121,00 & 137,50 & 113,00 \\
\hline América & & $\mathrm{n}$ & 223 & 223 & 222 & 222 & 223 & 223 & 222 \\
\hline Central e do & 223 & $\%$ & 100,00 & 100,00 & 99,55 & 99,55 & 100,00 & 100,00 & 99,55 \\
\hline Sul - Peru & & média & 176,23 & 173,81 & 98,07 & 139,05 & 114,94 & 124,98 & 110,11 \\
\hline América & & $\mathrm{n}$ & 12 & 12 & 12 & 12 & 12 & 12 & 12 \\
\hline Central e do & 12 & $\%$ & 100,00 & 100,00 & 100,00 & 100,00 & 100,00 & 100,00 & 100,00 \\
\hline Venezuela & & média & 179,75 & 177,96 & 99,42 & 142,83 & 117,92 & 128,04 & 113,67 \\
\hline Leste Asiático & & $n$ & 35 & 35 & 34 & 35 & 35 & 35 & 35 \\
\hline - Ainu & 35 & $\%$ & 100,00 & 100,00 & 97,14 & 100,00 & 100,00 & 100,00 & 100,00 \\
\hline Hokkaido & & média & 187,34 & 183,97 & 105,97 & 142,46 & 118,91 & 124,14 & 110,91 \\
\hline Leste Asiático & & $n$ & 5 & 5 & 5 & 5 & 5 & 5 & 5 \\
\hline - Ainu & 5 & $\%$ & 100,00 & 100,00 & 100,00 & 100,00 & 100,00 & 100,00 & 100,00 \\
\hline Sakhalin & & média & 190,20 & 186,00 & 107,00 & 141,60 & 115,80 & 126,40 & 110,20 \\
\hline Leste Asiático & & $n$ & 61 & 61 & 61 & 62 & 62 & 61 & 62 \\
\hline - Norte da & 62 & $\%$ & 98,39 & 98,39 & 98,39 & 100,00 & 100,00 & 98,39 & 100,00 \\
\hline China (Han) & & média & 180,02 & 177,40 & 98,43 & 141,26 & 116,57 & 123,57 & 108,31 \\
\hline Leste Asiático - & & $n$ & 49 & 55 & 48 & 49 & 56 & 56 & 53 \\
\hline Norte da China & 56 & $\%$ & 87,50 & 98,21 & 85,71 & 87,50 & 100,00 & 100,00 & 94,64 \\
\hline & & média & 181,90 & 178,84 & 100,15 & 139,88 & 115,98 & 124,34 & 108,19 \\
\hline Leste Asiático & & $\mathrm{n}$ & 66 & 66 & 65 & 67 & 67 & 67 & 67 \\
\hline - Sul da China & 67 & $\%$ & 98,51 & 98,51 & 97,01 & 100,00 & 100,00 & 100,00 & 100,00 \\
\hline & & média & 180,53 & 178,05 & 99,38 & 140,30 & 116,72 & 124,43 & 108,27 \\
\hline Leste Asiático - & & $n$ & 33 & 34 & 29 & 35 & 32 & 31 & 32 \\
\hline Japão Jomon & 50 & $\%$ & 66,00 & 68,00 & 58,00 & 70,00 & 64,00 & 62,00 & 64,00 \\
\hline & & média & 184,03 & 180,91 & 103,31 & 142,74 & 119,38 & 126,71 & 112,06 \\
\hline Leste Asiático & & $\mathrm{n}$ & 100 & 100 & 107 & 96 & 97 & 105 & 107 \\
\hline - Japão & 107 & $\%$ & 93,46 & 93,46 & 100,00 & 89,72 & 90,65 & 98,13 & 100,00 \\
\hline Tohoku & & média & 182,15 & 179,39 & 101,57 & 139,26 & 116,35 & 123,24 & 108,59 \\
\hline Leste Asiático & & $\mathrm{n}$ & 43 & 43 & 43 & 43 & 43 & 43 & 43 \\
\hline - Japão & 43 & $\%$ & 100,00 & 100,00 & 100,00 & 100,00 & 100,00 & 100,00 & 100,00 \\
\hline Tóquio & & média & 182,23 & 179,30 & 101,02 & 140,83 & 116,86 & 123,57 & 109,51 \\
\hline & & $n$ & 28 & 28 & 32 & 29 & 28 & 30 & 31 \\
\hline - Coréia & 33 & $\%$ & 84,85 & 84,85 & 96,97 & 87,88 & 84,85 & 90,91 & 93,94 \\
\hline & & média & 178,64 & 174,20 & 99,55 & 141,03 & 116,96 & 125,13 & 108,45 \\
\hline & & $n$ & 34 & 34 & 34 & 34 & 35 & 34 & 34 \\
\hline - Nepal & 36 & $\%$ & 94,44 & 94,44 & 94,44 & 94,44 & 97,22 & 94,44 & 94,44 \\
\hline & & média & 179,09 & 176,29 & 98,12 & 132,38 & 112,26 & 117,29 & 104,94 \\
\hline Leste Asiático & & $\mathrm{n}$ & 11 & 11 & 11 & 11 & 11 & 11 & 11 \\
\hline - Taiwan & 11 & $\%$ & 100,00 & 100,00 & 100,00 & 100,00 & 100,00 & 100,00 & 100,00 \\
\hline & & média & 181,00 & 178,00 & 99,64 & 139,27 & 115,45 & 124,36 & 107,45 \\
\hline & & $\mathrm{n}$ & 56 & 56 & 56 & 56 & 57 & 56 & 56 \\
\hline - Tibet & 64 & $\%$ & 87,50 & 87,50 & 87,50 & 87,50 & 89,06 & 87,50 & 87,50 \\
\hline & & média & 178,46 & 175,86 & 97,80 & 137,27 & 115,56 & 122,09 & 106,61 \\
\hline & & $n$ & 135 & 135 & 134 & 133 & 128 & 135 & 135 \\
\hline Alaska 1 & 135 & $\%$ & 100,00 & 100,00 & 99,26 & 98,52 & 94,81 & 100,00 & 100,00 \\
\hline & & média & 182,07 & 179,18 & 103,32 & 141,52 & 117,66 & 129,55 & 112,07 \\
\hline & & $\mathrm{n}$ & 106 & 106 & 106 & 107 & 107 & 107 & 106 \\
\hline Elacka? & 107 & $\%$ & 99,07 & 99,07 & 99,07 & 100,00 & 100,00 & 100,00 & 99,07 \\
\hline & & média & 185,23 & 181,94 & 105,85 & 137,96 & 115,20 & 128,56 & 110,71 \\
\hline & & $\mathrm{n}$ & 70 & 70 & 68 & 69 & 66 & 64 & 69 \\
\hline Alaska 3 & 70 & $\%$ & 100,00 & 100,00 & 97,14 & 98,57 & 94,29 & 91,43 & 98,57 \\
\hline & & média & 188,70 & 185,41 & 106,47 & 136,08 & 113,45 & 128,72 & 110,35 \\
\hline & & $\mathrm{n}$ & 22 & 22 & 21 & 22 & 22 & 22 & 22 \\
\hline
\end{tabular}




\begin{tabular}{|c|c|c|c|c|c|c|c|c|c|}
\hline \multirow[b]{2}{*}{ Esquimó - } & \multirow[b]{2}{*}{22} & $\mathrm{n}$ & 22 & 22 & 21 & 22 & 22 & 22 & 22 \\
\hline & & média & $18 \theta, 0 \theta$ & 180,00 & 103,88 & 100,00 & 100,00 & $10 \theta, 00$ & 100,00 \\
\hline \multirow{3}{*}{$\begin{array}{l}\text { Assia } \\
\text { Esquilmó - } \\
\text { Canadá }\end{array}$} & \multirow{3}{*}{30} & $\mathrm{n}$ & 30 & 30 & 30 & 30 & 30 & 30 & 30 \\
\hline & & $\%$ & 100,00 & 100,00 & 100,00 & 100,00 & 100,00 & 100,00 & 100,00 \\
\hline & & média & 188,80 & 184,77 & 104,23 & 136,78 & 116,40 & 126,80 & 109,72 \\
\hline \multirow{3}{*}{$\begin{array}{l}\text { Esquimó - } \\
\text { Groelândia }\end{array}$} & \multirow{3}{*}{107} & $\mathrm{n}$ & 103 & 103 & 104 & 103 & 103 & 103 & 104 \\
\hline & & $\%$ & 96,26 & 96,26 & 97,20 & 96,26 & 96,26 & 96,26 & 97,20 \\
\hline & & média & 190,02 & 185,82 & 106,37 & 136,82 & 115,11 & 128,15 & 110,31 \\
\hline \multirow{3}{*}{$\begin{array}{l}\text { Esquimó - } \\
\text { "desconhecido" }\end{array}$} & \multirow{3}{*}{10} & $n$ & 10 & 10 & 10 & 10 & 9 & 10 & 10 \\
\hline & & $\%$ & 100,00 & 100,00 & 100,00 & 100,00 & 90,00 & 100,00 & 100,00 \\
\hline & & média & 187,90 & 184,40 & 103,30 & 138,40 & 117,33 & 128,20 & 111,60 \\
\hline \multirow{3}{*}{$\begin{array}{l}\text { Europa - } \\
\text { Albânia }\end{array}$} & & $n$ & 3 & 3 & 3 & 3 & 3 & 3 & 3 \\
\hline & 3 & $\%$ & 100,00 & 100,00 & 100,00 & 100,00 & 100,00 & 100,00 & 100,00 \\
\hline & & média & 174,33 & 169,67 & 101,33 & 153,33 & 132,67 & 126,83 & 116,50 \\
\hline & & $n$ & 80 & 80 & 80 & 80 & 80 & 80 & 80 \\
\hline Eúustria- & 80 & $\%$ & 100,00 & 100,00 & 100,00 & 100,00 & 100,00 & 100,00 & 100,00 \\
\hline & & média & 179,72 & 176,23 & 100,78 & 146,43 & 124,57 & 125,24 & 112,43 \\
\hline Europa - & & $n$ & 2 & 2 & 1 & 1 & 2 & 1 & 2 \\
\hline Áustria (Idade & 2 & $\%$ & 100,00 & 100,00 & 50,00 & 50,00 & 100,00 & 50,00 & 100,00 \\
\hline & & média & 184,00 & 179,00 & 99,00 & 135,00 & 114,00 & 125,00 & 105,50 \\
\hline & & $n$ & 4 & 4 & 4 & 4 & 4 & 4 & 4 \\
\hline Bélaica & 4 & $\%$ & 100,00 & 100,00 & 100,00 & 100,00 & 100,00 & 100,00 & 100,00 \\
\hline & & média & 184,50 & 181,75 & 100,50 & 147,38 & 126,25 & 125,88 & 115,50 \\
\hline & & $n$ & 17 & 17 & 17 & 17 & 18 & 18 & 18 \\
\hline Europa - & 18 & $\%$ & 94,44 & 94,44 & 94,44 & 94,44 & 100,00 & 100,00 & 100,00 \\
\hline & & média & 180,06 & 177,82 & 100,50 & 137,53 & 118,06 & 119,94 & 108,78 \\
\hline Europa - & & $n$ & 95 & 95 & 94 & 95 & 95 & 95 & 95 \\
\hline "Republica & 95 & $\%$ & 100,00 & 100,00 & 98,95 & 100,00 & 100,00 & 100,00 & 100,00 \\
\hline Tcheca" & & média & 176,12 & 172,65 & 98,83 & 147,17 & 124,44 & 124,27 & 112,30 \\
\hline Europa - & & $n$ & 5 & 5 & 4 & 5 & 5 & 5 & 5 \\
\hline "Republica & 5 & $\%$ & 100,00 & 100,00 & 80,00 & 100,00 & 100,00 & 100,00 & 100,00 \\
\hline Tcheca” Neolítico & & média & 185,60 & 182,60 & 103,25 & 137,90 & 120,00 & 118,00 & 106,60 \\
\hline & & $n$ & 7 & 7 & 7 & 7 & 7 & 7 & 7 \\
\hline Dinamarca & 7 & $\%$ & 100,00 & 100,00 & 100,00 & 100,00 & 100,00 & 100,00 & 100,00 \\
\hline & & média & 188,57 & 185,57 & 101,14 & 147,00 & 123,43 & 127,71 & 114,71 \\
\hline & & $n$ & 25 & 25 & 25 & 25 & 25 & 25 & 25 \\
\hline Finlândia & 25 & $\%$ & 100,00 & 100,00 & 100,00 & 100,00 & 100,00 & 100,00 & 100,00 \\
\hline & & média & 185,24 & 182,12 & 101,56 & 147,00 & 125,52 & 127,56 & 113,36 \\
\hline & & $n$ & 63 & 63 & 60 & 63 & 63 & 62 & 63 \\
\hline Franca 1 & 63 & $\%$ & 100,00 & 100,00 & 95,24 & 100,00 & 100,00 & 98,41 & 100,00 \\
\hline & & média & 180,46 & 177,69 & 98,31 & 144,59 & 123,11 & 122,79 & 111,35 \\
\hline & & $n$ & 20 & 20 & 15 & 19 & 22 & 19 & 19 \\
\hline Franca? & 23 & $\%$ & 86,96 & 86,96 & 65,22 & 82,61 & 95,65 & 82,61 & 82,61 \\
\hline & & média & 187,65 & 184,15 & 101,93 & 143,42 & 123,64 & 126,32 & 114,00 \\
\hline & & $n$ & 79 & 81 & 82 & 76 & 78 & 82 & 80 \\
\hline Alemanha & 82 & $\%$ & 96,34 & 98,78 & 100,00 & 92,68 & 95,12 & 100,00 & 97,56 \\
\hline & & média & 183,76 & 180,37 & 99,45 & 147,04 & 124,49 & 125,53 & 113,63 \\
\hline & & $\mathrm{n}$ & 31 & 31 & 32 & 33 & 34 & 34 & 33 \\
\hline Grécia 1 & 34 & $\%$ & 91,18 & 91,18 & 94,12 & 97,06 & 100,00 & 100,00 & 97,06 \\
\hline & & média & 178,42 & 175,77 & 100,50 & 141,91 & 121,62 & 122,18 & 110,12 \\
\hline & & $n$ & 18 & 18 & 17 & 20 & 19 & 18 & 20 \\
\hline Grécia 2 & 20 & $\%$ & 90,00 & 90,00 & 85,00 & 100,00 & 95,00 & 90,00 & 100,00 \\
\hline & & média & 181,56 & 179,33 & 100,41 & 140,95 & 119,16 & 122,17 & 109,65 \\
\hline & & $n$ & 49 & 49 & 49 & 53 & 53 & 52 & 53 \\
\hline Europa - & 54 & $\%$ & 90,74 & 90,74 & 90,74 & 98,15 & 98,15 & 96,30 & 98,15 \\
\hline & & média & 179,57 & 177,08 & 100,47 & 141,55 & 120,74 & 122,17 & 109,94 \\
\hline & & $n$ & 6 & 5 & 5 & 6 & 6 & 6 & 6 \\
\hline Herzegovinia & 6 & $\%$ & 100,00 & 83,33 & 83,33 & 100,00 & 100,00 & 100,00 & 100,00 \\
\hline & & média & 184,67 & 181,80 & 102,40 & 153,17 & 128,67 & 131,83 & 115,00 \\
\hline & & $n$ & 33 & 33 & 33 & 33 & 33 & 33 & 33 \\
\hline Holanda & 33 & $\%$ & 100,00 & 100,00 & 100,00 & 100,00 & 100,00 & 100,00 & 100,00 \\
\hline & & média & 181,98 & 179,62 & 98,74 & 145,79 & 122,91 & 123,59 & 113,48 \\
\hline & & $n$ & 92 & 92 & 91 & 93 & 93 & 93 & 93 \\
\hline Europa - & 93 & $\%$ & 98,92 & 98,92 & 97,85 & 100,00 & 100,00 & 100,00 & 100,00 \\
\hline & & média & 180,10 & 177,20 & 100,36 & 143,01 & 122,15 & 123,99 & 110,69 \\
\hline & & $\mathrm{n}$ & 100 & 100 & 100 & 99 & 99 & 101 & 100 \\
\hline $\begin{array}{c}\text { Europa - Italla } \\
1\end{array}$ & 101 & $\%$ & 99,01 & 99,01 & 99,01 & 98,02 & 98,02 & 100,00 & 99,01 \\
\hline & & média & 181,10 & 178,06 & 100,87 & 143,47 & 121,96 & 124,28 & 111,54 \\
\hline & & $n$ & 38 & 38 & 30 & 39 & 39 & 37 & 36 \\
\hline & & $\%$ & 95,00 & 95,00 & 75,00 & 97,50 & 97,50 & 92,50 & 90,00 \\
\hline
\end{tabular}




\begin{tabular}{|c|c|c|c|c|c|c|c|c|c|}
\hline & & média & 184,66 & 182,26 & 101,67 & 143,51 & 121,10 & 124,86 & 113,56 \\
\hline \multirow{3}{*}{$\begin{array}{l}\text { Europa - } \\
\text { Lapônia }\end{array}$} & \multirow{3}{*}{34} & $n$ & 31 & 31 & 33 & 33 & 33 & 31 & 33 \\
\hline & & $\%$ & 91,18 & 91,18 & 97,06 & 97,06 & 97,06 & 91,18 & 97,06 \\
\hline & & média & 177,69 & 175,05 & 97,12 & 145,00 & 120,97 & 124,47 & 112,02 \\
\hline \multirow{3}{*}{$\begin{array}{l}\text { Europa - } \\
\text { Noruega }\end{array}$} & \multirow{3}{*}{20} & $\mathrm{n}$ & 19 & 19 & 20 & 19 & 19 & 20 & 20 \\
\hline & & $\%$ & 95,00 & 95,00 & 100,00 & 95,00 & 95,00 & 100,00 & 100,00 \\
\hline & & média & 184,47 & 181,63 & 100,20 & 144,89 & 123,47 & 124,75 & 113,30 \\
\hline \multirow{3}{*}{$\begin{array}{c}\text { Europa - } \\
\text { Polônia }\end{array}$} & \multirow{3}{*}{11} & $n$ & 11 & 11 & 11 & 11 & 11 & 11 & 11 \\
\hline & & $\%$ & 100,00 & 100,00 & 100,00 & 100,00 & 100,00 & 100,00 & 100,00 \\
\hline & & média & 179,32 & 176,18 & 101,00 & 145,91 & 123,36 & 124,77 & 111,68 \\
\hline \multirow{3}{*}{$\begin{array}{l}\text { Europa - } \\
\text { Portugal }\end{array}$} & \multirow{3}{*}{7} & $n$ & 7 & 7 & 7 & 7 & 7 & 7 & 7 \\
\hline & & $\%$ & 100,00 & 100,00 & 100,00 & 100,00 & 100,00 & 100,00 & 100,00 \\
\hline & & média & 188,71 & 186,71 & 101,86 & 144,14 & 121,14 & 122,86 & 109,71 \\
\hline \multirow{3}{*}{$\begin{array}{l}\text { Europa - } \\
\text { Romênia }\end{array}$} & & $n$ & 11 & 11 & 12 & 11 & 12 & 12 & 12 \\
\hline & 12 & $\%$ & 91,67 & 91,67 & 100,00 & 91,67 & 100,00 & 100,00 & 100,00 \\
\hline & & média & 178,36 & 176,36 & 100,50 & 142,73 & 122,17 & 123,92 & 111,17 \\
\hline & & $n$ & 42 & 42 & 42 & 43 & 44 & 44 & 44 \\
\hline Rússia & 44 & $\%$ & 95,45 & 95,45 & 95,45 & 97,73 & 100,00 & 100,00 & 100,00 \\
\hline & & média & 182,83 & 179,86 & 101,45 & 144,12 & 121,68 & 124,75 & 112,82 \\
\hline & & $n$ & 14 & 14 & 14 & 14 & 14 & 14 & 14 \\
\hline Esnapha- & 14 & $\%$ & 100,00 & 100,00 & 100,00 & 100,00 & 100,00 & 100,00 & 100,00 \\
\hline & & média & 187,07 & 184,57 & 103,86 & 142,57 & 122,00 & 121,14 & 113,79 \\
\hline & & $n$ & 7 & 7 & 4 & 6 & 7 & 5 & 5 \\
\hline $\begin{array}{l}\text { Europa - } \\
\text { Espanha? }\end{array}$ & 7 & $\%$ & 100,00 & 100,00 & 57,14 & 85,71 & 100,00 & 71,43 & 71,43 \\
\hline & & média & 182,86 & 180,14 & 100,75 & 138,00 & 118,86 & 117,20 & 110,00 \\
\hline & & $n$ & 31 & 31 & 31 & 31 & 31 & 31 & 31 \\
\hline Suéria - & 31 & $\%$ & 100,00 & 100,00 & 100,00 & 100,00 & 100,00 & 100,00 & 100,00 \\
\hline & & média & 189,23 & 186,35 & 100,74 & 144,52 & 123,68 & 125,55 & 113,13 \\
\hline & & $n$ & 37 & 37 & 37 & 37 & 37 & 37 & 37 \\
\hline Europa - & 37 & $\%$ & 100,00 & 100,00 & 100,00 & 100,00 & 100,00 & 100,00 & 100,00 \\
\hline & & média & 177,53 & 174,23 & 97,45 & 147,28 & 125,03 & 124,36 & 112,32 \\
\hline & & $n$ & 26 & 26 & 26 & 23 & 24 & 25 & 25 \\
\hline Europa - & 26 & $\%$ & 100,00 & 100,00 & 100,00 & 88,46 & 92,31 & 96,15 & 96,15 \\
\hline & & média & 175,50 & 172,44 & 98,23 & 143,89 & 120,83 & 125,48 & 111,48 \\
\hline & & $\mathrm{n}$ & 33 & 33 & 30 & 32 & 34 & 33 & 32 \\
\hline Europa - & 34 & $\%$ & 97,06 & 97,06 & 88,24 & 94,12 & 100,00 & 97,06 & 94,12 \\
\hline & & média & 179,94 & 177,11 & 101,30 & 143,59 & 120,97 & 122,94 & 111,20 \\
\hline & & $\mathrm{n}$ & 13 & 13 & 15 & 14 & 15 & 15 & 14 \\
\hline Índia - Assam & 15 & $\%$ & 86,67 & 86,67 & 100,00 & 93,33 & 100,00 & 100,00 & 93,33 \\
\hline & & média & 178,46 & 175,69 & 96,73 & 135,93 & 114,93 & 121,40 & 106,36 \\
\hline & & $n$ & 49 & 49 & 50 & 49 & 50 & 50 & 49 \\
\hline Rengala & 51 & $\%$ & 96,08 & 96,08 & 98,04 & 96,08 & 98,04 & 98,04 & 96,08 \\
\hline & & média & 177,64 & 174,70 & 99,55 & 131,12 & 112,80 & 115,56 & 103,14 \\
\hline & & $\mathrm{n}$ & 20 & 20 & 21 & 21 & 21 & 21 & 21 \\
\hline Índia - Bihar & 21 & $\%$ & 95,24 & 95,24 & 100,00 & 100,00 & 100,00 & 100,00 & 100,00 \\
\hline & & média & 178,60 & 175,55 & 98,14 & 131,10 & 111,52 & 114,95 & 103,62 \\
\hline & & $n$ & 7 & 7 & 7 & 7 & 7 & 7 & 7 \\
\hline Bombaim & 7 & $\%$ & 100,00 & 100,00 & 100,00 & 100,00 & 100,00 & 100,00 & 100,00 \\
\hline & & média & 180,86 & 177,86 & 101,00 & 134,00 & 115,14 & 118,00 & 107,57 \\
\hline & & $n$ & 17 & 17 & 16 & 17 & 17 & 16 & 17 \\
\hline Índia - Calcutá & 17 & $\%$ & 100,00 & 100,00 & 94,12 & 100,00 & 100,00 & 94,12 & 100,00 \\
\hline & & média & 178,71 & 176,06 & 100,13 & 133,94 & 113,06 & 117,56 & 105,18 \\
\hline & & $n$ & 4 & 4 & 4 & 4 & 4 & 4 & 4 \\
\hline Índia - Central & 4 & $\%$ & 100,00 & 100,00 & 100,00 & 100,00 & 100,00 & 100,00 & 100,00 \\
\hline & & média & 184,00 & 180,25 & 100,00 & 131,25 & 111,25 & 115,75 & 104,50 \\
\hline & & $\bar{n}$ & 5 & 5 & 4 & 5 & 5 & 5 & 5 \\
\hline Índia - Delhi & 5 & $\%$ & 100,00 & 100,00 & 80,00 & 100,00 & 100,00 & 100,00 & 100,00 \\
\hline & & média & 180,60 & 177,60 & 99,75 & 128,80 & 109,40 & 113,40 & 103,20 \\
\hline & & $\mathrm{n}$ & 97 & 97 & 100 & 98 & 100 & 99 & 98 \\
\hline Índia - Madras & 100 & $\%$ & 97,00 & 97,00 & 100,00 & 98,00 & 100,00 & 99,00 & 98,00 \\
\hline & & média & 177,06 & 173,59 & 98,08 & 131,64 & 112,89 & 115,31 & 103,07 \\
\hline & & $n$ & 1 & 1 & 1 & 1 & 1 & 1 & 1 \\
\hline Índia - Mahalls & 1 & $\%$ & 100,00 & 100,00 & 100,00 & 100,00 & 100,00 & 100,00 & 100,00 \\
\hline & & média & 179,00 & 178,00 & 106,00 & 126,00 & 109,00 & 113,00 & 104,00 \\
\hline & & $n$ & 10 & 10 & 10 & 10 & 10 & 10 & 10 \\
\hline Mala - & 10 & $\%$ & 100,00 & 100,00 & 100,00 & 100,00 & 100,00 & 100,00 & 100,00 \\
\hline & & média & 178,60 & 175,70 & 100,10 & 132,90 & 111,90 & 114,20 & 104,70 \\
\hline & & $n$ & 9 & 9 & 11 & 10 & 11 & 11 & 11 \\
\hline Índia - Mysore & 11 & $\%$ & 81,82 & 81,82 & 100,00 & 90,91 & 100,00 & 100,00 & 100,00 \\
\hline & & média & 173,67 & 170,17 & 98,27 & 129,65 & 112,59 & 112,18 & 100,86 \\
\hline
\end{tabular}




\begin{tabular}{|c|c|c|c|c|c|c|c|c|c|}
\hline \multirow{3}{*}{$\begin{array}{l}\text { Índia - } \\
\text { Noroeste }\end{array}$} & \multirow{3}{*}{29} & $\mathrm{n}$ & 28 & 28 & 29 & 29 & 29 & 28 & 29 \\
\hline & & $\%$ & 96,55 & 96,55 & 100,00 & 100,00 & 100,00 & 96,55 & 100,00 \\
\hline & & média & 178,50 & 175,18 & 98,55 & 129,76 & 111,03 & 115,54 & 102,41 \\
\hline \multirow{3}{*}{ Índia - Orissa } & \multirow{3}{*}{9} & $\mathrm{n}$ & 9 & 9 & $\overline{9}$ & 9 & 9 & 9 & 9 \\
\hline & & $\%$ & 100,00 & 100,00 & 100,00 & 100,00 & 100,00 & 100,00 & 100,00 \\
\hline & & média & 176,44 & 172,78 & 98,83 & 129,11 & 111,28 & 116,83 & 102,94 \\
\hline \multirow{3}{*}{ Índia - Pujab } & \multirow{3}{*}{73} & $\mathrm{n}$ & 73 & 73 & $\overline{73}$ & 73 & 73 & 73 & 73 \\
\hline & & $\%$ & 100,00 & 100,00 & 100,00 & 100,00 & 100,00 & 100,00 & 100,00 \\
\hline & & média & 184,07 & 181,19 & 102,77 & 130,68 & 112,56 & 118,07 & 105,85 \\
\hline \multirow{3}{*}{ Índia - Sikkim } & \multirow{3}{*}{25} & $\mathrm{n}$ & 24 & 24 & 25 & 23 & 24 & 23 & 25 \\
\hline & & $\%$ & 96,00 & 96,00 & 100,00 & 92,00 & 96,00 & 92,00 & 100,00 \\
\hline & & média & 177,25 & 174,25 & 98,24 & 135,26 & 115,00 & 122,00 & 107,32 \\
\hline \multirow{3}{*}{ Índia - Veddah } & & $\mathrm{n}$ & 17 & 17 & 17 & 17 & 17 & 17 & 17 \\
\hline & 18 & $\%$ & 94,44 & 94,44 & 94,44 & 94,44 & 94,44 & 94,44 & 94,44 \\
\hline & & média & 177,47 & 174,29 & 98,88 & 127,94 & 109,41 & 112,24 & 98,94 \\
\hline & & $\mathrm{n}$ & 15 & 15 & 15 & 15 & 15 & 15 & 15 \\
\hline Mismarck - & 15 & $\%$ & 100,00 & 100,00 & 100,00 & 100,00 & 100,00 & 100,00 & 100,00 \\
\hline & & média & 181,60 & 177,53 & 100,53 & 130,53 & 109,33 & 117,20 & 107,90 \\
\hline & & $n$ & 45 & 35 & 39 & 45 & 35 & 35 & 36 \\
\hline Theranesla - & 47 & $\%$ & 95,74 & 74,47 & 82,98 & 95,74 & 74,47 & 74,47 & 76,60 \\
\hline & & média & 188,93 & 183,49 & 102,54 & 133,49 & 113,63 & 117,39 & 107,25 \\
\hline & & $n$ & 71 & 71 & 70 & 71 & 71 & 71 & 70 \\
\hline Mielanesia - & 74 & $\%$ & 95,95 & 95,95 & 94,59 & 95,95 & 95,95 & 95,95 & 94,59 \\
\hline & & média & 183,51 & 178,35 & 100,44 & 133,11 & 110,96 & 121,32 & 108,06 \\
\hline Melanésia - & & $\mathrm{n}$ & 47 & 46 & 48 & 47 & 48 & 46 & 47 \\
\hline Nova & 51 & $\%$ & 92,16 & 90,20 & 94,12 & 92,16 & 94,12 & 90,20 & 92,16 \\
\hline Caledônia & & média & 185,88 & 181,73 & 102,32 & 131,52 & 110,98 & 120,27 & 107,81 \\
\hline Melanésia - & & $\mathrm{n}$ & 51 & 51 & 50 & 50 & 51 & 51 & 51 \\
\hline "New & 52 & $\%$ & 98,08 & 98,08 & 96,15 & 96,15 & 98,08 & 98,08 & 98,08 \\
\hline & & média & 184,40 & 180,43 & 99,56 & 131,13 & 109,65 & 119,83 & 107,94 \\
\hline & & $\mathrm{n}$ & 34 & 34 & 34 & 34 & 33 & 33 & 34 \\
\hline Nova Irlanda & 35 & $\%$ & 97,14 & 97,14 & 97,14 & 97,14 & 94,29 & 94,29 & 97,14 \\
\hline & & média & 182,09 & 177,78 & 99,56 & 134,49 & 112,38 & 118,67 & 107,93 \\
\hline & & $\mathrm{n}$ & 16 & 16 & 16 & 16 & 16 & 16 & 16 \\
\hline Mielanesla - & 16 & $\%$ & 100,00 & 100,00 & 100,00 & 100,00 & 100,00 & 100,00 & 100,00 \\
\hline & & média & 185,25 & 181,13 & 99,06 & 127,44 & 107,19 & 114,94 & 105,75 \\
\hline & & $\mathrm{n}$ & 70 & 70 & 66 & 68 & 71 & 70 & 70 \\
\hline Tolomon- & 71 & $\%$ & 98,59 & 98,59 & 92,96 & 95,77 & 100,00 & 98,59 & 98,59 \\
\hline & & média & 182,36 & 177,81 & 100,08 & 132,15 & 110,96 & 119,58 & 107,00 \\
\hline & & $n$ & 56 & 56 & 57 & 55 & 61 & 59 & 57 \\
\hline Estreito Torres & 61 & $\%$ & 91,80 & 91,80 & 93,44 & 90,16 & 100,00 & 96,72 & 93,44 \\
\hline & & média & 184,98 & 180,93 & 101,16 & 133,33 & 112,49 & 120,08 & 109,23 \\
\hline & & $n$ & 22 & 22 & 22 & 22 & 22 & 22 & 22 \\
\hline IVIcronesla - & 22 & $\%$ & 100,00 & 100,00 & 100,00 & 100,00 & 100,00 & 100,00 & 100,00 \\
\hline & & média & 182,48 & 178,91 & 102,91 & 135,18 & 114,41 & 121,48 & 108,14 \\
\hline & & $\mathrm{n}$ & 23 & 23 & 22 & 25 & 25 & 25 & 26 \\
\hline Wicronesla - & 26 & $\%$ & 88,46 & 88,46 & 84,62 & 96,15 & 96,15 & 96,15 & 100,00 \\
\hline & & média & 182,35 & 179,43 & 103,64 & 140,88 & 116,24 & 128,92 & 108,23 \\
\hline & & $n$ & 89 & 89 & 89 & 89 & 88 & 89 & 89 \\
\hline - Egito 1 & 89 & $\%$ & 100,00 & 100,00 & 100,00 & 100,00 & 98,88 & 100,00 & 100,00 \\
\hline & & média & 183,80 & 182,06 & 102,02 & 138,04 & 115,38 & 117,55 & 107,08 \\
\hline & & $\mathrm{n}$ & 14 & 14 & 14 & 14 & 14 & 14 & 14 \\
\hline Norte da Atrica & 14 & $\%$ & 100,00 & 100,00 & 100,00 & 100,00 & 100,00 & 100,00 & 100,00 \\
\hline & & média & 183,18 & 181,29 & 100,18 & 136,68 & 115,43 & 116,11 & 105,79 \\
\hline & & $\mathrm{n}$ & 18 & 18 & 17 & 18 & 17 & 18 & 18 \\
\hline Norte da Arrica & 18 & $\%$ & 100,00 & 100,00 & 94,44 & 100,00 & 94,44 & 100,00 & 100,00 \\
\hline & & média & 183,75 & 182,06 & 100,41 & 139,97 & 116,65 & 122,28 & 109,69 \\
\hline & & $n$ & 41 & 40 & 39 & 41 & 40 & 39 & 41 \\
\hline - Faito Badari & 41 & $\%$ & 100,00 & 97,56 & 95,12 & 100,00 & 97,56 & 95,12 & 100,00 \\
\hline & & média & 182,44 & 179,93 & 99,08 & 132,07 & 112,50 & 113,56 & 103,54 \\
\hline & & $\mathrm{n}$ & 100 & 100 & 100 & 100 & 100 & 100 & 100 \\
\hline - Faito Gizeh & 100 & $\%$ & 100,00 & 100,00 & 100,00 & 100,00 & 100,00 & 100,00 & 100,00 \\
\hline & & média & 185,79 & 183,82 & 101,90 & 140,42 & 118,01 & 119,30 & 108,07 \\
\hline Norte da África & & $\mathrm{n}$ & 80 & 80 & 80 & 79 & 79 & 79 & 79 \\
\hline - Egito & 80 & $\%$ & 100,00 & 100,00 & 100,00 & 98,75 & 98,75 & 98,75 & 98,75 \\
\hline Naqada & & média & 184,56 & 182,20 & 101,73 & 134,63 & 113,58 & 117,03 & 106,71 \\
\hline & & $\mathrm{n}$ & 30 & 30 & 29 & 29 & 30 & 30 & 30 \\
\hline - Marrocos & 30 & $\%$ & 100,00 & 100,00 & 96,67 & 96,67 & 100,00 & 100,00 & 100,00 \\
\hline & & média & 184,43 & 181,73 & 99,86 & 139,60 & 118,08 & 120,33 & 109,27 \\
\hline & & $\mathrm{n}$ & 43 & 43 & 41 & 44 & 45 & 44 & 46 \\
\hline
\end{tabular}




\begin{tabular}{|c|c|c|c|c|c|c|c|c|c|}
\hline \multirow{5}{*}{$\begin{array}{c}\text { Norte da África } \\
\text { Norte dúbią Africa } \\
\text { - Núbia } 2\end{array}$} & \multirow[b]{2}{*}{46} & $n$ & 43 & 43 & 41 & 44 & 45 & 44 & 46 \\
\hline & & média & 183,48 & 183,28 & 189,93 & 195,68 & 194,88 & 195,05 & 100,00 \\
\hline & \multirow{3}{*}{78} & $\mathrm{n}$ & 78 & 78 & 77 & 77 & 78 & 77 & 77 \\
\hline & & $\%$ & 100,00 & 100,00 & 98,72 & 98,72 & 100,00 & 98,72 & 98,72 \\
\hline & & média & 183,21 & 181,03 & 100,75 & 138,95 & 117,19 & 118,43 & 107,68 \\
\hline \multirow{3}{*}{$\begin{array}{c}\text { Norte da África } \\
\text { - Kerma }\end{array}$} & \multirow{3}{*}{86} & $n$ & 86 & 86 & 82 & 86 & 86 & 86 & 86 \\
\hline & & $\%$ & 100,00 & 100,00 & 95,35 & 100,00 & 100,00 & 100,00 & 100,00 \\
\hline & & média & 186,13 & 183,78 & 101,80 & 134,48 & 113,29 & 116,86 & 105,73 \\
\hline \multirow{3}{*}{$\begin{array}{c}\text { Nordeste } \\
\text { Asiático - } \\
\text { Amur }\end{array}$} & \multirow{3}{*}{11} & $\mathrm{n}$ & 10 & 10 & 10 & 10 & 10 & 10 & 10 \\
\hline & & $\%$ & 90,91 & 90,91 & 90,91 & 90,91 & 90,91 & 90,91 & 90,91 \\
\hline & & média & 180,80 & 178,60 & 100,90 & 145,30 & 118,30 & 128,90 & 110,90 \\
\hline \multirow{3}{*}{$\begin{array}{l}\text { Nordeste } \\
\text { Asiático - } \\
\text { Buriat }\end{array}$} & \multirow{3}{*}{27} & $\mathrm{n}$ & 27 & 26 & 26 & 27 & 27 & 27 & 27 \\
\hline & & $\%$ & 100,00 & 96,30 & 96,30 & 100,00 & 100,00 & 100,00 & 100,00 \\
\hline & & média & 179,19 & 176,98 & 98,50 & 148,11 & 122,11 & 130,57 & 113,63 \\
\hline \multirow{3}{*}{$\begin{array}{c}\text { Nordeste } \\
\text { Asiático - } \\
\text { Chukchi }\end{array}$} & \multirow{3}{*}{21} & $\mathrm{n}$ & 21 & 21 & 21 & 21 & 21 & 21 & 21 \\
\hline & & $\%$ & 100,00 & 100,00 & 100,00 & 100,00 & 100,00 & 100,00 & 100,00 \\
\hline & & média & 184,57 & 182,43 & 103,19 & 140,05 & 115,38 & 128,43 & 108,43 \\
\hline \multirow{3}{*}{$\begin{array}{c}\text { Nordeste } \\
\text { Asiático - } \\
\text { Evenki }\end{array}$} & & $\mathrm{n}$ & 2 & 2 & 2 & 2 & 2 & 2 & 2 \\
\hline & 2 & $\%$ & 100,00 & 100,00 & 100,00 & 100,00 & 100,00 & 100,00 & 100,00 \\
\hline & & média & 184,00 & 181,00 & 103,00 & 147,00 & 120,50 & 126,00 & 109,50 \\
\hline Nordeste & & $n$ & 148 & 148 & 148 & 147 & 145 & 147 & 148 \\
\hline Asiático - & 151 & $\%$ & 98,01 & 98,01 & 98,01 & 97,35 & 96,03 & 97,35 & 98,01 \\
\hline Mongóis & & média & 182,42 & 179,58 & 100,44 & 148,95 & 121,90 & 133,01 & 113,94 \\
\hline Nordeste & & $n$ & 1 & 1 & 1 & 1 & 1 & 1 & 1 \\
\hline Asiático - & 1 & $\%$ & 100,00 & 100,00 & 100,00 & 100,00 & 100,00 & 100,00 & 100,00 \\
\hline Neolítico & & média & 193,00 & 188,00 & 102,00 & 139,00 & 110,00 & 127,00 & 117,00 \\
\hline Nordeste & & $\mathrm{n}$ & 4 & 4 & 4 & 4 & 4 & 4 & 4 \\
\hline Asiático - & 4 & $\%$ & 100,00 & 100,00 & 100,00 & 100,00 & 100,00 & 100,00 & 100,00 \\
\hline Nivkh & & média & 178,50 & 176,75 & 100,00 & 152,25 & 122,25 & 133,50 & 114,75 \\
\hline Nordeste & & $n$ & 4 & 4 & $\overline{4}$ & 4 & 4 & 4 & 4 \\
\hline Asiático - & 4 & $\%$ & 100,00 & 100,00 & 100,00 & 100,00 & 100,00 & 100,00 & 100,00 \\
\hline Yakut & & média & 180,50 & 178,00 & 101,25 & 146,75 & 123,25 & 128,75 & 111,00 \\
\hline Papua Nova & & $n$ & 8 & 8 & 9 & 8 & 8 & 8 & 9 \\
\hline Guiné - & 9 & $\%$ & 88,89 & 88,89 & 100,00 & 88,89 & 88,89 & 88,89 & 100,00 \\
\hline $\begin{array}{c}\text { Província } \\
\text { Central }\end{array}$ & & média & 176,25 & 173,63 & 98,78 & 134,75 & 112,38 & 119,63 & 106,22 \\
\hline Papua Nova & & $n$ & 20 & 20 & 19 & 20 & 20 & 20 & 20 \\
\hline Guiné - & 21 & $\%$ & 95,24 & 95,24 & 90,48 & 95,24 & 95,24 & 95,24 & 95,24 \\
\hline Eastern Is & & média & 181,40 & 177,60 & 101,84 & 133,00 & 110,90 & 120,15 & 105,85 \\
\hline Papua Nova & & $n$ & 31 & 31 & 32 & 30 & 32 & 32 & 32 \\
\hline Guiné - & 33 & $\%$ & 93,94 & 93,94 & 96,97 & 90,91 & 96,97 & 96,97 & 96,97 \\
\hline Golfo & & média & 182,58 & 178,77 & 98,81 & 129,17 & 109,50 & 114,22 & 105,50 \\
\hline Papua Nova & & $n$ & 33 & 33 & 31 & 32 & 33 & 33 & 33 \\
\hline Guiné - & 33 & $\%$ & 100,00 & 100,00 & 93,94 & 96,97 & 100,00 & 100,00 & 100,00 \\
\hline Madang & & média & 180,39 & 176,94 & 100,03 & 132,56 & 110,76 & 116,88 & 105,24 \\
\hline Papua Nova & & $n$ & 3 & 3 & 3 & 3 & 3 & 2 & 3 \\
\hline Guiné - & 3 & $\%$ & 100,00 & 100,00 & 100,00 & 100,00 & 100,00 & 66,67 & 100,00 \\
\hline Bay & & média & 180,33 & 177,00 & 100,33 & 132,00 & 112,67 & 116,50 & 106,67 \\
\hline Papua Nova & & $\mathrm{n}$ & 26 & 26 & 26 & 26 & 26 & 26 & 26 \\
\hline Guiné - & 29 & $\%$ & 89,66 & 89,66 & 89,66 & 89,66 & 89,66 & 89,66 & 89,66 \\
\hline $\begin{array}{l}\text { Província } \\
\text { Sepik Oriental }\end{array}$ & & média & 178,21 & 175,42 & 101,15 & 129,44 & 108,73 & 116,15 & 106,00 \\
\hline Papua Nova & & $\mathrm{n}$ & 24 & 24 & 24 & 24 & 24 & 24 & 24 \\
\hline Guiné - & & $\%$ & 100,00 & 100,00 & 100,00 & 100,00 & 100,00 & 100,00 & 100,00 \\
\hline $\begin{array}{l}\text { Província } \\
\text { Sepik }\end{array}$ & 24 & média & & & & & & & \\
\hline Ocidental & & & 179,71 & 176,75 & 99,04 & 130,52 & 109,27 & 115,83 & 104,94 \\
\hline Papua Nova & & $n$ & 16 & 16 & 18 & 16 & 17 & 18 & 16 \\
\hline Guiné - & 18 & $\%$ & 88,89 & 88,89 & 100,00 & 88,89 & 94,44 & 100,00 & 88,89 \\
\hline "desconhecido" & & média & 181,00 & 177,13 & 98,56 & 133,13 & 108,82 & 117,56 & 107,81 \\
\hline Papua Nova & & $n$ & 14 & 14 & 13 & 15 & 15 & 14 & 14 \\
\hline Guiné - & 15 & $\%$ & 93,33 & 93,33 & 86,67 & 100,00 & 100,00 & 93,33 & 93,33 \\
\hline $\begin{array}{l}\text { Província } \\
\text { Ocidental } 1\end{array}$ & & média & 182,86 & 179,21 & 99,15 & 128,87 & 110,60 & 116,71 & 105,93 \\
\hline Papua Nova & & $n$ & 14 & 14 & 10 & 14 & 14 & 14 & 14 \\
\hline Guiné - & 14 & $\%$ & 100,00 & 100,00 & 71,43 & 100,00 & 100,00 & 100,00 & 100,00 \\
\hline $\begin{array}{l}\text { Província } \\
\text { Ocidental } 2\end{array}$ & & média & 181,00 & 176,93 & 100,90 & 127,79 & 108,57 & 114,07 & 106,71 \\
\hline & & $\bar{n}$ & 75 & 74 & $\overline{73}$ & 75 & 75 & 73 & 75 \\
\hline
\end{tabular}




\begin{tabular}{|c|c|c|c|c|c|c|c|c|c|}
\hline & & $\mathrm{n}$ & 75 & 74 & 73 & 75 & 75 & 73 & 75 \\
\hline $\begin{array}{l}\text { Polinésia - } \\
\text { Moriori (llhas }\end{array}$ & 76 & média & $\begin{array}{r}98,68 \\
186,83 \\
\end{array}$ & $\begin{array}{r}97,37 \\
183,98 \\
\end{array}$ & $\begin{array}{r}96,05 \\
104,60 \\
\end{array}$ & $\begin{array}{r}98,68 \\
142,07 \\
\end{array}$ & $\begin{array}{r}98,68 \\
112,89 \\
\end{array}$ & $\begin{array}{r}96,05 \\
127,71 \\
\end{array}$ & $\begin{array}{r}98,68 \\
108,99 \\
\end{array}$ \\
\hline \multirow{3}{*}{$\begin{array}{l}\text { Phatan) } \\
\text { Polinesia - } \\
\text { Ilhas Cook }\end{array}$} & \multirow{3}{*}{15} & $n$ & 14 & 14 & 13 & 13 & 14 & 14 & 14 \\
\hline & & $\%$ & 93,33 & 93,33 & 86,67 & 86,67 & 93,33 & 93,33 & 93,33 \\
\hline & & média & 180,79 & 177,64 & 103,23 & 141,92 & 117,29 & 127,71 & 112,00 \\
\hline \multirow{3}{*}{$\begin{array}{l}\text { Polinésia - } \\
\text { Ilhas Easter }\end{array}$} & \multirow{3}{*}{81} & $n$ & 68 & 68 & 61 & 61 & 59 & 60 & 65 \\
\hline & & $\%$ & 83,95 & 83,95 & 75,31 & 75,31 & 72,84 & 74,07 & 80,25 \\
\hline & & média & 191,98 & 186,54 & 110,98 & 134,75 & 112,59 & 123,26 & 108,05 \\
\hline \multirow{3}{*}{$\begin{array}{l}\text { Polinésia - } \\
\text { Havaí }\end{array}$} & \multirow{3}{*}{72} & $n$ & 71 & 71 & 72 & 72 & 72 & 72 & 72 \\
\hline & & $\%$ & 98,61 & 98,61 & 100,00 & 100,00 & 100,00 & 100,00 & 100,00 \\
\hline & & média & 183,76 & 180,31 & 105,24 & 142,71 & 115,69 & 125,08 & 107,08 \\
\hline \multirow{3}{*}{$\begin{array}{l}\text { Polinésia - } \\
\text { Ilhas } \\
\text { Marquesas }\end{array}$} & \multirow{3}{*}{66} & $\mathrm{n}$ & 65 & 65 & 61 & 65 & 66 & 65 & 65 \\
\hline & & $\%$ & 98,48 & 98,48 & 92,42 & 98,48 & 100,00 & 98,48 & 98,48 \\
\hline & & média & 186,20 & 182,92 & 104,05 & 140,89 & 113,76 & 125,20 & 109,13 \\
\hline \multirow{3}{*}{$\begin{array}{l}\text { Polinésia - } \\
\text { Maori Nova } \\
\text { Zelândia } \\
\end{array}$} & & $n$ & 120 & 120 & 117 & 120 & 119 & 119 & 120 \\
\hline & 120 & $\%$ & 100,00 & 100,00 & 97,50 & 100,00 & 99,17 & 99,17 & 100,00 \\
\hline & & média & 186,89 & 183,15 & 104,35 & 138,63 & 113,13 & 126,37 & 109,06 \\
\hline & & $n$ & 49 & 49 & 45 & 48 & 48 & 47 & 49 \\
\hline Ilhas Society & 49 & $\%$ & 100,00 & 100,00 & 91,84 & 97,96 & 97,96 & 95,92 & 100,00 \\
\hline & & média & 184,84 & 181,53 & 104,53 & 140,01 & 114,67 & 122,96 & 107,88 \\
\hline & & $n$ & 18 & 13 & 19 & 18 & 16 & 15 & 14 \\
\hline Samoa Tonga & 22 & $\%$ & 81,82 & 59,09 & 86,36 & 81,82 & 72,73 & 68,18 & 63,64 \\
\hline & & média & 178,72 & 175,08 & 104,74 & 145,17 & 119,38 & 126,80 & 107,71 \\
\hline Sudeste & & $n$ & 52 & 52 & 52 & 53 & 53 & 52 & 53 \\
\hline Asiático - Ilhas & 53 & $\%$ & 98,11 & 98,11 & 98,11 & 100,00 & 100,00 & 98,11 & 100,00 \\
\hline Andaman & & média & 169,17 & 167,39 & 93,46 & 135,92 & 112,02 & 114,55 & 101,28 \\
\hline & & $n$ & 3 & 3 & 5 & 3 & 5 & 5 & 4 \\
\hline Asiático - Rali & 5 & $\%$ & 60,00 & 60,00 & 100,00 & 60,00 & 100,00 & 100,00 & 80,00 \\
\hline & & média & 177,67 & 173,33 & 99,00 & 142,33 & 115,80 & 124,00 & 108,50 \\
\hline Sudeste & & $n$ & 15 & 15 & 15 & 16 & 16 & 16 & 16 \\
\hline Asiático - & 17 & $\%$ & 88,24 & 88,24 & 88,24 & 94,12 & 94,12 & 94,12 & 94,12 \\
\hline Borneo 1 & & média & 176,87 & 172,73 & 98,53 & 136,56 & 113,44 & 122,56 & 106,56 \\
\hline Sudeste & & $\mathrm{n}$ & 75 & 75 & 70 & 75 & 78 & 74 & 74 \\
\hline Asiático - & 79 & $\%$ & 94,94 & 94,94 & 88,61 & 94,94 & 98,73 & 93,67 & 93,67 \\
\hline Borneo 2 & & média & 179,88 & 176,79 & 99,35 & 136,95 & 115,41 & 121,63 & 107,43 \\
\hline Sudeste & & $n$ & 4 & 4 & 10 & 9 & 11 & 11 & 10 \\
\hline Asiático - & 11 & $\%$ & 36,36 & 36,36 & 90,91 & 81,82 & 100,00 & 100,00 & 90,91 \\
\hline Camboja & & média & 176,00 & 173,25 & 100,40 & 143,22 & 117,91 & 126,36 & 107,20 \\
\hline Sudeste & & $n$ & 19 & 19 & 19 & 18 & 18 & 18 & 18 \\
\hline Asiático - & 19 & $\%$ & 100,00 & 100,00 & 100,00 & 94,74 & 94,74 & 94,74 & 94,74 \\
\hline Celebes & & média & 174,58 & 171,84 & 98,37 & 140,78 & 115,50 & 123,33 & 108,50 \\
\hline Sudeste & & $n$ & 1 & 0 & 0 & 1 & 1 & 1 & 0 \\
\hline Asiático - Laos & 1 & $\%$ & 100,00 & 0,00 & 0,00 & 100,00 & 100,00 & 100,00 & 0,00 \\
\hline (early) & & média & 175,00 & 0,00 & 0,00 & 139,00 & 119,00 & 120,00 & 0,00 \\
\hline Sudeste & & $n$ & 3 & 2 & 0 & 3 & 4 & 2 & 3 \\
\hline Asiático - & 8 & $\%$ & 37,50 & 25,00 & 0,00 & 37,50 & 50,00 & 25,00 & 37,50 \\
\hline Malásia (early) & & média & 186,67 & 182,50 & 0,00 & 137,67 & 113,25 & 121,00 & 111,00 \\
\hline Sudeste & & $\mathrm{n}$ & 16 & 16 & 7 & 15 & 19 & 10 & 10 \\
\hline Asiático - & 23 & $\%$ & 69,57 & 69,57 & 30,43 & 65,22 & 82,61 & 43,48 & 43,48 \\
\hline Vietnam (early) & & média & 186,63 & 183,25 & 101,00 & 138,93 & 114,95 & 120,80 & 108,80 \\
\hline Sudeste & & $n$ & 4 & 4 & 4 & 4 & 4 & 4 & 4 \\
\hline Asiático - & 4 & $\%$ & 100,00 & 100,00 & 100,00 & 100,00 & 100,00 & 100,00 & 100,00 \\
\hline Flores & & média & 176,25 & 172,25 & 99,25 & 136,25 & 118,25 & 125,25 & 104,50 \\
\hline & & $n$ & 61 & 61 & 62 & 60 & 62 & 61 & 61 \\
\hline Asiático - Java & 62 & $\%$ & 98,39 & 98,39 & 100,00 & 96,77 & 100,00 & 98,39 & 98,39 \\
\hline & & média & 176,85 & 173,97 & 100,00 & 141,08 & 118,05 & 123,56 & 106,70 \\
\hline & & $n$ & 17 & 17 & 32 & 23 & 30 & 32 & 30 \\
\hline Asiático - Laos & 32 & $\%$ & 53,13 & 53,13 & 100,00 & 71,88 & 93,75 & 100,00 & 93,75 \\
\hline & & média & 175,53 & 172,00 & 97,06 & 139,00 & 117,47 & 124,16 & 105,37 \\
\hline Sudeste & & $n$ & 47 & 47 & 53 & 47 & 56 & 52 & 49 \\
\hline Asiático - & 56 & $\%$ & 83,93 & 83,93 & 94,64 & 83,93 & 100,00 & 92,86 & 87,50 \\
\hline Malásia & & média & 175,44 & 172,76 & 97,85 & 140,03 & 116,21 & 122,29 & 106,84 \\
\hline Sudeste & & $\mathrm{n}$ & 19 & 19 & 22 & 19 & 22 & 22 & 22 \\
\hline Asiático - & 22 & $\%$ & 86,36 & 86,36 & 100,00 & 86,36 & 100,00 & 100,00 & 100,00 \\
\hline Molucca & & média & 176,79 & 174,63 & 98,00 & 139,50 & 115,09 & 121,32 & 106,32 \\
\hline Sudeste & & $n$ & 88 & 88 & 102 & 89 & 103 & 94 & 91 \\
\hline Asiático - & 103 & $\%$ & 85,44 & 85,44 & 99,03 & 86,41 & 100,00 & 91,26 & 88,35 \\
\hline Myanmar & & média & 176,60 & 173,76 & 98,76 & 139,34 & 116,74 & 122,35 & 106,90 \\
\hline & & $n$ & 21 & 21 & 22 & 22 & 22 & 22 & 22 \\
\hline & & $\%$ & 95,45 & 95,45 & 100,00 & 100,00 & 100,00 & 100,00 & 100,00 \\
\hline
\end{tabular}




\begin{tabular}{|c|c|c|c|c|c|c|c|c|c|}
\hline $\begin{array}{l}\text { Filipinas } \\
\text { (negrito) }\end{array}$ & & média & 171,00 & 168,71 & 95,05 & 137,77 & 114,64 & 119,14 & 102,05 \\
\hline \multirow{3}{*}{$\begin{array}{l}\text { Sudeste } \\
\text { Asiático - } \\
\text { Semang } \\
\text { (negrito) }\end{array}$} & \multirow{3}{*}{1} & $\mathrm{n}$ & 1 & 1 & 1 & 1 & 1 & 1 & 1 \\
\hline & & $\%$ & 100,00 & 100,00 & 100,00 & 100,00 & 100,00 & 100,00 & 100,00 \\
\hline & & média & 166,00 & 161,00 & 96,00 & 130,00 & 109,00 & 115,00 & 98,00 \\
\hline \multirow{3}{*}{$\begin{array}{c}\text { Sudeste } \\
\text { Asiático - Is } \\
\text { Nicobar }\end{array}$} & \multirow{3}{*}{21} & $\mathrm{n}$ & 21 & 20 & 20 & 21 & 20 & 21 & 18 \\
\hline & & $\%$ & 100,00 & 95,24 & 95,24 & 100,00 & 95,24 & 100,00 & 85,71 \\
\hline & & média & 181,76 & 176,90 & 98,15 & 130,86 & 112,05 & 116,60 & 104,42 \\
\hline \multirow{3}{*}{$\begin{array}{c}\text { Sudeste } \\
\text { Asiático - } \\
\text { Filipinas }\end{array}$} & \multirow{3}{*}{122} & $\mathrm{n}$ & 120 & 120 & 119 & 119 & 121 & 119 & 118 \\
\hline & & $\%$ & 98,36 & 98,36 & 97,54 & 97,54 & 99,18 & 97,54 & 96,72 \\
\hline & & média & 178,40 & 175,54 & 99,97 & 139,79 & 115,59 & 123,38 & 107,29 \\
\hline \multirow{3}{*}{$\begin{array}{c}\text { Sudeste } \\
\text { Asiático - } \\
\text { Singapura }\end{array}$} & \multirow{3}{*}{43} & $\mathrm{n}$ & 43 & 43 & 43 & 43 & 43 & 43 & 43 \\
\hline & & $\%$ & 100,00 & 100,00 & 100,00 & 100,00 & 100,00 & 100,00 & 100,00 \\
\hline & & média & 173,71 & 170,84 & 98,77 & 141,86 & 117,85 & 124,60 & 107,63 \\
\hline \multirow{3}{*}{$\begin{array}{c}\text { Sudeste } \\
\text { Asiático - Sulu }\end{array}$} & \multirow{3}{*}{5} & $n$ & 5 & 5 & 5 & 4 & 4 & 4 & 4 \\
\hline & & $\%$ & 100,00 & 100,00 & 100,00 & 80,00 & 80,00 & 80,00 & 80,00 \\
\hline & & média & 175,80 & 172,80 & 100,60 & 140,50 & 117,75 & 122,00 & 106,25 \\
\hline \multirow{3}{*}{$\begin{array}{l}\text { Sudeste } \\
\text { Asiático - } \\
\text { Sumatra }\end{array}$} & & $\mathrm{n}$ & 26 & 26 & 26 & 27 & 27 & 27 & 27 \\
\hline & 27 & $\%$ & 96,30 & 96,30 & 96,30 & 100,00 & 100,00 & 100,00 & 100,00 \\
\hline & & média & 175,46 & 172,85 & 98,96 & 137,96 & 113,00 & 121,37 & 106,30 \\
\hline Sudeste & & $\mathrm{n}$ & 1 & 1 & 1 & 1 & 1 & 1 & 1 \\
\hline Asiático - & 1 & $\%$ & 100,00 & 100,00 & 100,00 & 100,00 & 100,00 & 100,00 & 100,00 \\
\hline Sumbawa & & média & 184,00 & 182,00 & 101,00 & 141,00 & 116,00 & 125,00 & 96,00 \\
\hline Sudeste & & $\mathrm{n}$ & 31 & 31 & 47 & 37 & 45 & 44 & 46 \\
\hline Asiático - & 47 & $\%$ & 65,96 & 65,96 & 100,00 & 78,72 & 95,74 & 93,62 & 97,87 \\
\hline Tailândia & & média & 176,61 & 173,58 & 99,17 & 139,57 & 116,54 & 124,52 & 107,12 \\
\hline Sudeste & & $\mathrm{n}$ & 3 & 3 & 4 & 4 & 5 & 4 & 5 \\
\hline Asiático - & 5 & $\%$ & 60,00 & 60,00 & 80,00 & 80,00 & 100,00 & 80,00 & 100,00 \\
\hline Timor & & média & 183,33 & 179,67 & 97,75 & 140,25 & 116,80 & 123,00 & 107,20 \\
\hline Sudeste & & $n$ & 23 & 23 & 23 & 24 & 24 & 23 & 23 \\
\hline Asiático - & 24 & $\%$ & 95,83 & 95,83 & 95,83 & 100,00 & 100,00 & 95,83 & 95,83 \\
\hline Vietnam & & média & 179,00 & 176,26 & 100,43 & 137,88 & 115,08 & 123,65 & 104,13 \\
\hline África Sub- & & $\mathrm{n}$ & 33 & 33 & 33 & 33 & 33 & 33 & 33 \\
\hline Saariana - & 33 & $\%$ & 100,00 & 100,00 & 100,00 & 100,00 & 100,00 & 100,00 & 100,00 \\
\hline Camarões & & média & 182,85 & 180,62 & 101,91 & 136,05 & 118,35 & 116,82 & 106,48 \\
\hline África Sub- & & $\mathrm{n}$ & 17 & 17 & 14 & 18 & 17 & 17 & 18 \\
\hline Saariana - & 18 & $\%$ & 94,44 & 94,44 & 77,78 & 100,00 & 94,44 & 94,44 & 100,00 \\
\hline Congo & & média & 177,82 & 175,18 & 98,71 & 131,00 & 111,35 & 113,88 & 104,11 \\
\hline África Sub- & & $\mathrm{n}$ & 8 & 8 & 7 & $\overline{8}$ & 8 & 8 & $\overline{7}$ \\
\hline Saariana - & 8 & $\%$ & 100,00 & 100,00 & 87,50 & 100,00 & 100,00 & 100,00 & 87,50 \\
\hline África Oriental & & média & 181,25 & 179,38 & 101,71 & 134,25 & 113,75 & 117,00 & 105,86 \\
\hline África Sub- & & $\mathrm{n}$ & 1 & 1 & 1 & $\overline{1}$ & 1 & 1 & $\overline{1}$ \\
\hline Saariana - & 1 & $\%$ & 100,00 & 100,00 & 100,00 & 100,00 & 100,00 & 100,00 & 100,00 \\
\hline $\begin{array}{c}\text { África } \\
\text { Equatorial }\end{array}$ & & média & 192,00 & 190,00 & 115,00 & 133,00 & 120,00 & 121,00 & 104,50 \\
\hline África Sub- & & $n$ & 8 & 8 & 8 & 8 & 8 & 8 & 8 \\
\hline Saariana - & 8 & $\%$ & 100,00 & 100,00 & 100,00 & 100,00 & 100,00 & 100,00 & 100,00 \\
\hline Etiópia & & média & 188,44 & 185,81 & 104,50 & 134,19 & 116,75 & 118,13 & 110,56 \\
\hline África Sub- & & $\mathrm{n}$ & 76 & 76 & 76 & 75 & 75 & 76 & 76 \\
\hline Saariana - & 76 & $\%$ & 100,00 & 100,00 & 100,00 & 98,68 & 98,68 & 100,00 & 100,00 \\
\hline Gabão & & média & 179,24 & 177,49 & 99,76 & 135,44 & 115,33 & 115,96 & 105,38 \\
\hline África Sub- & & $\mathrm{n}$ & 1 & 1 & 1 & 1 & 1 & 1 & 1 \\
\hline Saariana - & 1 & $\%$ & 100,00 & 100,00 & 100,00 & 100,00 & 100,00 & 100,00 & 100,00 \\
\hline Gâmbia & & média & 180,00 & 179,00 & 96,00 & 127,00 & 111,00 & 111,00 & 110,00 \\
\hline África Sub- & & $\mathrm{n}$ & 51 & 51 & 51 & 51 & 50 & 51 & 51 \\
\hline Saariana - & 51 & $\%$ & 100,00 & 100,00 & 100,00 & 100,00 & 98,04 & 100,00 & 100,00 \\
\hline Ashanti Gana & & média & 183,86 & 181,28 & 102,23 & 131,57 & 112,09 & 114,80 & 105,89 \\
\hline África Sub- & & $n$ & 3 & 3 & 3 & 3 & 3 & 3 & 3 \\
\hline Saariana - & 3 & $\%$ & 100,00 & 100,00 & 100,00 & 100,00 & 100,00 & 100,00 & 100,00 \\
\hline Guinea & & média & 189,33 & 186,67 & 107,33 & 138,00 & 119,67 & 122,50 & 108,67 \\
\hline África Sub- & & $n$ & 26 & 26 & 27 & 25 & 27 & 25 & 25 \\
\hline Saariana - & 27 & $\%$ & 96,30 & 96,30 & 100,00 & 92,59 & 100,00 & 92,59 & 92,59 \\
\hline $\begin{array}{c}\text { Costa do } \\
\text { Marfin }\end{array}$ & & média & 182,42 & 179,65 & 101,56 & 134,12 & 114,52 & 115,72 & 104,40 \\
\hline África Sub- & & $n$ & 94 & 94 & 88 & 94 & 92 & 92 & 93 \\
\hline Saariana - & 95 & $\%$ & 98,95 & 98,95 & 92,63 & 98,95 & 96,84 & 96,84 & 97,89 \\
\hline Quênia & & média & 184,88 & 182,66 & 100,26 & 131,98 & 113,12 & 117,46 & 105,39 \\
\hline África Sub- & & $n$ & 7 & 7 & 7 & 6 & 6 & 7 & 7 \\
\hline Saariana - & 7 & $\%$ & 100,00 & 100,00 & 100,00 & 85,71 & 85,71 & 100,00 & 100,00 \\
\hline Libéria & & média & 186,43 & 183,29 & 102,71 & 132,08 & 115,33 & 116,93 & 105,86 \\
\hline
\end{tabular}




\begin{tabular}{|c|c|c|c|c|c|c|c|c|c|}
\hline \multirow{3}{*}{$\begin{array}{l}\text { África Sub- } \\
\text { Saariana - } \\
\text { Malawi }\end{array}$} & \multirow{3}{*}{26} & $\mathrm{n}$ & 26 & 26 & 26 & 26 & 26 & 26 & 26 \\
\hline & & $\%$ & 100,00 & 100,00 & 100,00 & 100,00 & 100,00 & 100,00 & 100,00 \\
\hline & & média & 184,60 & 182,15 & 102,15 & 135,04 & 116,81 & 116,08 & 105,38 \\
\hline \multirow{3}{*}{$\begin{array}{c}\text { África Sub- } \\
\text { Saariana - } \\
\text { Moçambique }\end{array}$} & \multirow{3}{*}{5} & $n$ & 5 & 5 & 4 & 5 & 5 & 4 & 5 \\
\hline & & $\%$ & 100,00 & 100,00 & 80,00 & 100,00 & 100,00 & 80,00 & 100,00 \\
\hline & & média & 184,10 & 181,80 & 100,75 & 136,40 & 117,20 & 120,25 & 108,40 \\
\hline África Sub- & \multirow{3}{*}{79} & $n$ & 78 & 78 & 75 & 77 & 76 & 75 & 79 \\
\hline \multirow{2}{*}{$\begin{array}{c}\text { Saariana - lbo } \\
\text { Nigéria }\end{array}$} & & $\%$ & 98,73 & 98,73 & 94,94 & 97,47 & 96,20 & 94,94 & 100,00 \\
\hline & & média & 184,37 & 182,00 & 101,76 & 135,86 & 116,86 & 118,16 & 104,96 \\
\hline \multirow{3}{*}{$\begin{array}{c}\text { África Sub- } \\
\text { Saariana - } \\
\text { Nigéria } \\
\text { (outros) }\end{array}$} & \multirow{3}{*}{45} & $\mathrm{n}$ & 43 & 43 & 40 & 45 & 45 & 45 & 44 \\
\hline & & $\%$ & 95,56 & 95,56 & 88,89 & 100,00 & 100,00 & 100,00 & 97,78 \\
\hline & & média & 181,93 & 179,43 & 100,58 & 132,64 & 113,09 & 116,33 & 105,43 \\
\hline África Sub- & \multirow{3}{*}{8} & $n$ & 8 & 8 & $\overline{8}$ & 8 & 7 & 8 & 8 \\
\hline \multirow{2}{*}{$\begin{array}{l}\text { Saariana - } \\
\text { Pigmeus }\end{array}$} & & $\%$ & 100,00 & 100,00 & 100,00 & 100,00 & 87,50 & 100,00 & 100,00 \\
\hline & & média & 177,00 & 175,25 & 94,44 & 131,56 & 109,86 & 110,88 & 104,88 \\
\hline & \multirow{3}{*}{1} & $n$ & 1 & 1 & 1 & 1 & 1 & 1 & 1 \\
\hline Saariana - & & $\%$ & 100,00 & 100,00 & 100,00 & 100,00 & 100,00 & 100,00 & 100,00 \\
\hline & & média & 180,00 & 178,00 & 97,00 & 136,00 & 110,00 & 119,00 & 113,00 \\
\hline Africa Sub- & & $\mathrm{n}$ & 1 & 1 & 0 & 1 & 1 & 0 & 0 \\
\hline Saariana - & 1 & $\%$ & 100,00 & 100,00 & 0,00 & 100,00 & 100,00 & 0,00 & 0,00 \\
\hline Senegal & & média & 184,00 & 181,00 & 0,00 & 136,00 & 115,00 & 0,00 & 0,00 \\
\hline África Sub- & & $\mathrm{n}$ & 4 & 4 & 4 & 5 & 5 & 5 & 5 \\
\hline Saariana - & 5 & $\%$ & 80,00 & 80,00 & 80,00 & 100,00 & 100,00 & 100,00 & 100,00 \\
\hline Serra Leoa & & média & 178,25 & 175,75 & 100,25 & 131,20 & 111,80 & 112,60 & 101,90 \\
\hline África Sub- & & $\mathrm{n}$ & 61 & 61 & 60 & 60 & 61 & 56 & 60 \\
\hline Saariana - & 64 & $\%$ & 95,31 & 95,31 & 93,75 & 93,75 & 95,31 & 87,50 & 93,75 \\
\hline Somália & & média & 185,41 & 183,20 & 101,88 & 135,27 & 114,44 & 116,51 & 107,48 \\
\hline África Sub- & & $\mathrm{n}$ & 24 & 24 & 24 & 24 & 24 & 24 & 24 \\
\hline Saariana - & 24 & $\%$ & 100,00 & 100,00 & 100,00 & 100,00 & 100,00 & 100,00 & 100,00 \\
\hline África do Sul & & média & 183,73 & 181,21 & 100,31 & 134,00 & 113,17 & 115,81 & 105,46 \\
\hline África Sub- & & $n$ & 32 & 32 & 31 & 31 & 32 & 31 & 32 \\
\hline Saariana - & 32 & $\%$ & 100,00 & 100,00 & 96,88 & 96,88 & 100,00 & 96,88 & 100,00 \\
\hline África do Sul & & média & 179,88 & 177,52 & 96,76 & 134,31 & 111,28 & 113,73 & 108,20 \\
\hline África Sub- & & $n$ & 18 & 18 & 17 & 18 & 18 & 18 & 17 \\
\hline Saariana - & 18 & $\%$ & 100,00 & 100,00 & 94,44 & 100,00 & 100,00 & 100,00 & 94,44 \\
\hline África do Sul & & média & 181,50 & 179,44 & 99,29 & 132,89 & 111,33 & 113,78 & 105,76 \\
\hline África Sub- & & $\mathrm{n}$ & 43 & 43 & 43 & 42 & 43 & 42 & 43 \\
\hline Saariana - & 43 & $\%$ & 100,00 & 100,00 & 100,00 & 97,67 & 100,00 & 97,67 & 100,00 \\
\hline $\begin{array}{c}\text { Kafır Atrica do } \\
\text { Sul }\end{array}$ & & média & 189,42 & 186,40 & 103,63 & 136,60 & 117,74 & 119,13 & 108,91 \\
\hline África Sub- & & $n$ & 29 & 29 & 29 & 29 & 30 & 28 & 28 \\
\hline Saariana - & 30 & $\%$ & 96,67 & 96,67 & 96,67 & 96,67 & 100,00 & 93,33 & 93,33 \\
\hline Zulu & & média & 186,31 & 183,97 & 103,10 & 135,76 & 115,23 & 117,43 & 107,07 \\
\hline África Sub- & & $n$ & 86 & 86 & 85 & 85 & 85 & 84 & 85 \\
\hline Saariana - & 89 & $\%$ & 96,63 & 96,63 & 95,51 & 95,51 & 95,51 & 94,38 & 95,51 \\
\hline Tanzânia & & média & 184,48 & 181,96 & 101,31 & 133,71 & 114,02 & 118,43 & 107,92 \\
\hline África Sub- & & $\mathrm{n}$ & 11 & 11 & 11 & 11 & 12 & 11 & 11 \\
\hline Saariana - & 12 & $\%$ & 91,67 & 91,67 & 91,67 & 91,67 & 100,00 & 91,67 & 91,67 \\
\hline Uganda & & média & 184,91 & 182,36 & 99,27 & 132,45 & 113,08 & 114,09 & 107,00 \\
\hline África Sub- & & $n$ & 2 & 2 & 2 & 2 & 2 & 2 & 2 \\
\hline Saariana - & 2 & $\%$ & 100,00 & 100,00 & 100,00 & 100,00 & 100,00 & 100,00 & 100,00 \\
\hline Ocidental & & média & 175,50 & 172,25 & 98,50 & 133,00 & 113,00 & 111,50 & 105,50 \\
\hline África Sub- & & $\mathrm{n}$ & 1 & $\overline{1}$ & $\overline{1}$ & 1 & 1 & 1 & 1 \\
\hline Saariana - & 1 & $\%$ & 100,00 & 100,00 & 100,00 & 100,00 & 100,00 & 100,00 & 100,00 \\
\hline Zaire & & média & 185,00 & 183,00 & 106,00 & 122,00 & 108,00 & 112,00 & 102,00 \\
\hline África Sub- & & $\mathrm{n}$ & 3 & 3 & 3 & 3 & 3 & 3 & 3 \\
\hline Saariana - & 3 & $\%$ & 100,00 & 100,00 & 100,00 & 100,00 & 100,00 & 100,00 & 100,00 \\
\hline Zâmbia & & média & 188,33 & 187,50 & 107,33 & 129,33 & 113,67 & 114,17 & 105,83 \\
\hline África Sub- & & $\mathrm{n}$ & 1 & 1 & 1 & 1 & 1 & 1 & 1 \\
\hline Saariana - & 1 & $\%$ & 100,00 & 100,00 & 100,00 & 100,00 & 100,00 & 100,00 & 100,00 \\
\hline Zimbaue & & média & 189,00 & 187,00 & 104,00 & 133,00 & 116,00 & 113,00 & 108,00 \\
\hline Sudoeste & & $\mathrm{n}$ & 31 & 31 & 39 & 33 & 37 & 36 & 34 \\
\hline Asiático - & 40 & $\%$ & 77,50 & 77,50 & 97,50 & 82,50 & 92,50 & 90,00 & 85,00 \\
\hline Afeganistão & & média & 183,23 & 180,19 & 102,50 & 134,91 & 115,31 & 119,57 & 105,49 \\
\hline Sudoeste & & $n$ & 25 & 25 & 22 & 25 & 25 & 25 & 25 \\
\hline Asiático - & 25 & $\%$ & 100,00 & 100,00 & 88,00 & 100,00 & 100,00 & 100,00 & 100,00 \\
\hline Bangladesh & & média & 178,00 & 175,16 & 99,14 & 132,96 & 114,00 & 114,84 & 102,40 \\
\hline
\end{tabular}




\begin{tabular}{|c|c|c|c|c|c|c|c|c|c|}
\hline \multirow{3}{*}{$\begin{array}{c}\text { Sudoeste } \\
\text { Asiático - } \\
\text { Beduíno }\end{array}$} & \multirow{3}{*}{11} & $\mathrm{n}$ & 11 & 11 & 11 & 11 & 11 & 11 & 11 \\
\hline & & $\%$ & 100,00 & 100,00 & 100,00 & 100,00 & 100,00 & 100,00 & 100,00 \\
\hline & & média & 184,86 & 182,95 & 101,36 & 136,23 & 115,95 & 118,45 & 108,41 \\
\hline Sudoeste & \multirow{3}{*}{2} & $\mathrm{n}$ & 1 & 1 & 1 & 1 & 2 & 2 & 1 \\
\hline \multirow{2}{*}{$\begin{array}{l}\text { Asiático - } \\
\text { Butão }\end{array}$} & & $\%$ & 50,00 & 50,00 & 50,00 & 50,00 & 100,00 & 100,00 & 50,00 \\
\hline & & média & 187,00 & 183,00 & 101,00 & 132,00 & 121,00 & 117,50 & 100,00 \\
\hline Sudoeste & \multirow{3}{*}{22} & $\mathrm{n}$ & 21 & 21 & 19 & 22 & 20 & 21 & 20 \\
\hline \multirow{2}{*}{$\begin{array}{l}\text { Asiático - } \\
\text { Chipre } \\
\end{array}$} & & $\%$ & 95,45 & 95,45 & 86,36 & 100,00 & 90,91 & 95,45 & 90,91 \\
\hline & & média & 184,57 & 182,21 & 100,42 & 142,41 & 119,50 & 123,90 & 110,45 \\
\hline \multirow{3}{*}{$\begin{array}{c}\text { Sudoeste } \\
\text { Asiático - Irã } 1\end{array}$} & \multirow{3}{*}{13} & $\mathrm{n}$ & 6 & 9 & 2 & 7 & 7 & 5 & 10 \\
\hline & & $\%$ & 46,15 & 69,23 & 15,38 & 53,85 & 53,85 & 38,46 & 76,92 \\
\hline & & média & 180,67 & 177,78 & 101,50 & 132,57 & 113,57 & 118,60 & 107,10 \\
\hline & \multirow{3}{*}{12} & $\mathrm{n}$ & 9 & 10 & 2 & 7 & 9 & 3 & 8 \\
\hline Asiático-Irã ? & & $\%$ & 75,00 & 83,33 & 16,67 & 58,33 & 75,00 & 25,00 & 66,67 \\
\hline & & média & 191,22 & 187,60 & 103,50 & 134,43 & 114,78 & 111,33 & 108,38 \\
\hline Sudnecte & & $\mathrm{n}$ & 13 & 13 & 8 & 13 & 14 & 13 & 15 \\
\hline Ascítico - Irã 3 & 17 & $\%$ & 76,47 & 76,47 & 47,06 & 76,47 & 82,35 & 76,47 & 88,24 \\
\hline & & média & 189,62 & 184,62 & 104,75 & 132,38 & 112,29 & 119,08 & 106,53 \\
\hline & & $n$ & 3 & 6 & 2 & 4 & 6 & 6 & 6 \\
\hline Uadoeste & 8 & $\%$ & 37,50 & 75,00 & 25,00 & 50,00 & 75,00 & 75,00 & 75,00 \\
\hline & & média & 175,67 & 172,83 & 105,00 & 143,00 & 115,67 & 123,33 & 109,33 \\
\hline Sudoeste & & $\mathrm{n}$ & 16 & 16 & $\overline{16}$ & 16 & 16 & 16 & 16 \\
\hline Asiático - & 16 & $\%$ & 100,00 & 100,00 & 100,00 & 100,00 & 100,00 & 100,00 & 100,00 \\
\hline Iraque & & média & 182,69 & 180,09 & 103,19 & 137,03 & 116,50 & 118,75 & 107,09 \\
\hline Sudoeste & & $\mathrm{n}$ & 14 & 14 & $\overline{13}$ & 14 & 14 & 13 & 14 \\
\hline Asiático - & 14 & $\%$ & 100,00 & 100,00 & 92,86 & 100,00 & 100,00 & 92,86 & 100,00 \\
\hline Iraque (early) & & média & 187,29 & 184,82 & 101,81 & 134,50 & 115,89 & 117,69 & 106,82 \\
\hline Sudoeste & & $\mathrm{n}$ & 78 & 78 & 76 & 76 & 75 & 78 & 77 \\
\hline Asiático - & 78 & $\%$ & 100,00 & 100,00 & 97,44 & 97,44 & 96,15 & 100,00 & 98,72 \\
\hline Israel 1 & & média & 185,86 & 182,96 & 101,53 & 137,91 & 117,43 & 119,71 & 108,74 \\
\hline Sudoeste & & $\mathrm{n}$ & 13 & 13 & 12 & 13 & 13 & 12 & 13 \\
\hline Asiático - & 13 & $\%$ & 100,00 & 100,00 & 92,31 & 100,00 & 100,00 & 92,31 & 100,00 \\
\hline Israel 2 & & média & 185,62 & 183,08 & 103,42 & 136,77 & 115,69 & 119,17 & 108,31 \\
\hline Sudoeste & & $\mathrm{n}$ & 91 & 91 & 88 & 89 & 88 & 90 & 90 \\
\hline Asiático - & 91 & $\%$ & 100,00 & 100,00 & 96,70 & 97,80 & 96,70 & 98,90 & 98,90 \\
\hline Israel 3 & & média & 185,82 & 182,98 & 101,78 & 137,74 & 117,17 & 119,63 & 108,68 \\
\hline Sudoeste & & $\mathrm{n}$ & 11 & 11 & 11 & 11 & 10 & 11 & 11 \\
\hline Asiático - & 11 & $\%$ & 100,00 & 100,00 & 100,00 & 100,00 & 90,91 & 100,00 & 100,00 \\
\hline Palestina & & média & 181,05 & 178,50 & 100,91 & 136,00 & 114,95 & 118,09 & 108,95 \\
\hline & & $n$ & 16 & 16 & 16 & 16 & 16 & 16 & 16 \\
\hline $\begin{array}{l}\text { Sudoeste } \\
\text { Scióticn }\end{array}$ & 16 & $\%$ & 100,00 & 100,00 & 100,00 & 100,00 & 100,00 & 100,00 & 100,00 \\
\hline & & média & 179,28 & 177,34 & 100,81 & 140,63 & 119,03 & 122,41 & 110,09 \\
\hline Sudoeste & & $\mathrm{n}$ & 48 & 48 & 49 & 50 & 51 & 50 & 50 \\
\hline Asiático - & 52 & $\%$ & 92,31 & 92,31 & 94,23 & 96,15 & 98,08 & 96,15 & 96,15 \\
\hline Turquia & & média & 179,73 & 177,80 & 100,66 & 142,18 & 120,49 & 124,23 & 110,60 \\
\hline Rrõ Dratonho & & $\mathrm{n}$ & 66 & 66 & 64 & 66 & 66 & 66 & 66 \\
\hline Gra-Bretanna & 67 & $\%$ & 98,51 & 98,51 & 95,52 & 98,51 & 98,51 & 98,51 & 98,51 \\
\hline & & média & 188,08 & 184,68 & 99,95 & 143,00 & 122,56 & 121,73 & 111,21 \\
\hline & & $\mathrm{n}$ & 24 & 23 & 14 & 22 & 20 & 20 & 22 \\
\hline Gra-Bretannna & 25 & $\%$ & 96,00 & 92,00 & 56,00 & 88,00 & 80,00 & 80,00 & 88,00 \\
\hline & & média & 197,29 & 194,26 & 105,71 & 138,50 & 118,80 & 121,25 & 113,59 \\
\hline & & $\mathrm{n}$ & 102 & 102 & 100 & 102 & 100 & 99 & 101 \\
\hline - & 102 & $\%$ & 100,00 & 100,00 & 98,04 & 100,00 & 98,04 & 97,06 & 99,02 \\
\hline & & média & 190,27 & 187,32 & 101,62 & 145,70 & 124,33 & 125,77 & 114,07 \\
\hline Grã-Bretank & & $\mathrm{n}$ & 42 & 42 & 35 & 41 & 42 & 38 & 40 \\
\hline Gra-Bretanna & 43 & $\%$ & 97,67 & 97,67 & 81,40 & 95,35 & 97,67 & 88,37 & 93,02 \\
\hline & & média & 188,48 & 185,26 & 102,23 & 143,85 & 121,74 & 124,11 & 114,25 \\
\hline Grã-Bretanha & & $\mathrm{n}$ & 57 & 57 & 57 & 57 & 57 & 57 & 57 \\
\hline - Spitafields & 57 & $\%$ & 100,00 & 100,00 & 100,00 & 100,00 & 100,00 & 100,00 & 100,00 \\
\hline CAM & & média & 181,26 & 178,40 & 100,63 & 143,81 & 124,11 & 123,25 & 111,02 \\
\hline Grã-Bretanha & & $\mathrm{n}$ & 76 & 76 & 77 & $\overline{76}$ & 76 & 78 & 78 \\
\hline - Spitafields & 86 & $\%$ & 88,37 & 88,37 & 89,53 & 88,37 & 88,37 & 90,70 & 90,70 \\
\hline $\mathrm{NHM}$ & & média & 184,47 & 181,71 & 98,64 & 141,74 & 120,62 & 120,15 & 111,53 \\
\hline & & $\mathrm{n}$ & 5 & 5 & 5 & 5 & 5 & 5 & 5 \\
\hline EUA - & 5 & $\%$ & 100,00 & 100,00 & 100,00 & 100,00 & 100,00 & 100,00 & 100,00 \\
\hline & & média & 181,30 & 178,60 & 104,60 & 137,60 & 114,00 & 126,20 & 109,00 \\
\hline & & $\mathrm{n}$ & 36 & 36 & 36 & 35 & 34 & 36 & 36 \\
\hline EUA - nativos & 36 & $\%$ & 100,00 & 100,00 & 100,00 & 97,22 & 94,44 & 100,00 & 100,00 \\
\hline & & média & 181,78 & 178,61 & 101,11 & 141,37 & 116,53 & 128,75 & 110,85 \\
\hline & & $\mathrm{n}$ & 15 & 15 & 15 & 15 & 15 & 15 & 15 \\
\hline
\end{tabular}




\begin{tabular}{|c|c|c|c|c|c|c|c|c|c|}
\hline \multirow{5}{*}{$\begin{array}{c}\text { EUA - Alaska } \\
\text { EUÁ Kodjakk } \\
\text { (Tlingit) }\end{array}$} & \multirow[b]{2}{*}{15} & $\mathrm{n}$ & 15 & 15 & 15 & 15 & 15 & 15 & 15 \\
\hline & & média & 100,00 & 100,00 & 100,00 & 109,00 & 100,00 & $10 Q, 00$ & 100,00 \\
\hline & \multirow{3}{*}{35} & $n$ & 28 & 28 & 32 & 28 & 33 & 29 & 28 \\
\hline & & $\%$ & 80,00 & 80,00 & 91,43 & 80,00 & 94,29 & 82,86 & 80,00 \\
\hline & & média & 184,86 & 181,48 & 102,11 & 148,29 & 119,94 & 134,22 & 114,43 \\
\hline \multirow{3}{*}{ EUA - Arizona } & \multirow{3}{*}{41} & $n$ & 40 & 40 & 41 & 40 & 41 & 40 & 40 \\
\hline & & $\%$ & 97,56 & 97,56 & 100,00 & 97,56 & 100,00 & 97,56 & 97,56 \\
\hline & & média & 179,53 & 176,69 & 100,88 & 138,65 & 115,35 & 126,58 & 107,74 \\
\hline \multirow{3}{*}{$\begin{array}{c}\text { EUA - } \\
\text { Arkansas }\end{array}$} & \multirow{3}{*}{29} & $n$ & 29 & 29 & 27 & 28 & 28 & 29 & 29 \\
\hline & & $\%$ & 100,00 & 100,00 & 93,10 & 96,55 & 96,55 & 100,00 & 100,00 \\
\hline & & média & 177,47 & 175,88 & 103,43 & 138,50 & 115,46 & 123,88 & 106,93 \\
\hline \multirow{3}{*}{$\begin{array}{c}\text { EUA - } \\
\text { Califórnia } 1\end{array}$} & \multirow{3}{*}{61} & $\mathrm{n}$ & 60 & 60 & 59 & 59 & 59 & 59 & 60 \\
\hline & & $\%$ & 98,36 & 98,36 & 96,72 & 96,72 & 96,72 & 96,72 & 98,36 \\
\hline & & média & 182,63 & 179,40 & 102,76 & 141,55 & 117,22 & 127,16 & 111,32 \\
\hline & & $n$ & 163 & 163 & 162 & 162 & 158 & 163 & 163 \\
\hline EUA- & 163 & $\%$ & 100,00 & 100,00 & 99,39 & 99,39 & 96,93 & 100,00 & 100,00 \\
\hline & & média & 181,29 & 178,13 & 98,35 & 138,58 & 113,42 & 124,87 & 110,70 \\
\hline & & $\mathrm{n}$ & 5 & 5 & 5 & 5 & 5 & 5 & 5 \\
\hline Califórnia 3 & 5 & $\%$ & 100,00 & 100,00 & 100,00 & 100,00 & 100,00 & 100,00 & 100,00 \\
\hline & & média & 173,60 & 171,80 & 99,80 & 142,20 & 117,60 & 128,60 & 106,60 \\
\hline EUA - & & $n$ & 1 & 1 & 1 & 1 & 1 & 1 & 1 \\
\hline Carolina do & 1 & $\%$ & 100,00 & 100,00 & 100,00 & 100,00 & 100,00 & 100,00 & 100,00 \\
\hline & & média & 183,00 & 179,50 & 99,00 & 135,00 & 115,00 & 115,00 & 109,00 \\
\hline & & $n$ & 1 & 1 & 1 & 1 & 1 & 1 & 1 \\
\hline$O A-$ & 1 & $\%$ & 100,00 & 100,00 & 100,00 & 100,00 & 100,00 & 100,00 & 100,00 \\
\hline & & média & 185,00 & 184,00 & 102,00 & 148,00 & 123,00 & 134,00 & 111,50 \\
\hline & & $n$ & 6 & 6 & 5 & 6 & 6 & 6 & 5 \\
\hline colorado & 6 & $\%$ & 100,00 & 100,00 & 83,33 & 100,00 & 100,00 & 100,00 & 83,33 \\
\hline & & média & 180,75 & 178,17 & 101,30 & 135,92 & 113,67 & 125,42 & 110,80 \\
\hline & & $n$ & 1 & 1 & 1 & 1 & 1 & 1 & 1 \\
\hline Connecticut & 1 & $\%$ & 100,00 & 100,00 & 100,00 & 100,00 & 100,00 & 100,00 & 100,00 \\
\hline & & média & 190,00 & 187,00 & 101,00 & 136,00 & 116,00 & 126,00 & 108,00 \\
\hline & & $n$ & 15 & 15 & 14 & 15 & 15 & 15 & 15 \\
\hline do Norte & 15 & $\%$ & 100,00 & 100,00 & 93,33 & 100,00 & 100,00 & 100,00 & 100,00 \\
\hline & & média & 189,33 & 186,60 & 107,21 & 141,47 & 116,60 & 130,73 & 112,07 \\
\hline & & $n$ & 119 & 119 & 117 & 119 & 119 & 119 & 118 \\
\hline EUA - Dakota & 119 & $\%$ & 100,00 & 100,00 & 98,32 & 100,00 & 100,00 & 100,00 & 99,16 \\
\hline & & média & 180,39 & 178,09 & 103,51 & 142,02 & 117,27 & 130,70 & 109,67 \\
\hline & & $n$ & 6 & 6 & 6 & 6 & 6 & 6 & 6 \\
\hline do Sul? & 6 & $\%$ & 100,00 & 100,00 & 100,00 & 100,00 & 100,00 & 100,00 & 100,00 \\
\hline & & média & 186,67 & 184,67 & 104,83 & 146,33 & 120,83 & 133,83 & 112,33 \\
\hline & & $n$ & 10 & 10 & 9 & 10 & 10 & 10 & 10 \\
\hline Delaware & 10 & $\%$ & 100,00 & 100,00 & 90,00 & 100,00 & 100,00 & 100,00 & 100,00 \\
\hline & & média & 184,90 & 181,95 & 105,67 & 138,55 & 116,50 & 126,65 & 109,40 \\
\hline & & $n$ & 96 & 96 & 95 & 95 & 96 & 96 & 96 \\
\hline EUA - Flórida & 96 & $\%$ & 100,00 & 100,00 & 98,96 & 98,96 & 100,00 & 100,00 & 100,00 \\
\hline & & média & 181,98 & 179,74 & 104,65 & 145,08 & 119,11 & 133,18 & 112,91 \\
\hline & & $\mathrm{n}$ & 19 & 19 & 14 & 19 & 19 & 19 & 19 \\
\hline EUA - Geórgia & 19 & $\%$ & 100,00 & 100,00 & 73,68 & 100,00 & 100,00 & 100,00 & 100,00 \\
\hline & & média & 180,92 & 178,50 & 103,93 & 140,87 & 118,58 & 126,18 & 109,82 \\
\hline & & $n$ & 1 & 1 & 0 & 1 & 1 & 1 & 1 \\
\hline Shelter \#1 & 1 & $\%$ & 100,00 & 100,00 & 0,00 & 100,00 & 100,00 & 100,00 & 100,00 \\
\hline & & média & 191,00 & 184,50 & 0,00 & 141,00 & 114,00 & 134,00 & 115,50 \\
\hline & & $\mathrm{n}$ & 118 & 118 & 118 & 118 & 118 & 118 & 118 \\
\hline EUA - Illinois & 118 & $\%$ & 100,00 & 100,00 & 100,00 & 100,00 & 100,00 & 100,00 & 100,00 \\
\hline & & média & 180,69 & 178,29 & 104,32 & 137,08 & 114,92 & 124,97 & 108,53 \\
\hline & & $n$ & 4 & 4 & 3 & 4 & 4 & 4 & 4 \\
\hline EUA - Indiana & 4 & $\%$ & 100,00 & 100,00 & 75,00 & 100,00 & 100,00 & 100,00 & 100,00 \\
\hline & & média & 181,25 & 178,38 & 101,00 & 137,50 & 117,00 & 123,00 & 109,25 \\
\hline & & $n$ & 1 & 1 & 1 & 1 & 1 & 1 & 1 \\
\hline EUA - lowa & 1 & $\%$ & 100,00 & 100,00 & 100,00 & 100,00 & 100,00 & 100,00 & 100,00 \\
\hline & & média & 175,00 & 173,00 & 101,50 & 140,00 & 119,00 & 125,00 & 105,00 \\
\hline & & $n$ & 10 & 10 & 10 & 9 & 10 & 9 & 10 \\
\hline EUA - Kansas & 10 & $\%$ & 100,00 & 100,00 & 100,00 & 90,00 & 100,00 & 90,00 & 100,00 \\
\hline & & média & 177,50 & 175,25 & 102,75 & 143,22 & 117,50 & 131,33 & 109,25 \\
\hline & & $n$ & 37 & 37 & 35 & 37 & 37 & 37 & 37 \\
\hline Kentucky & 37 & $\%$ & 100,00 & 100,00 & 94,59 & 100,00 & 100,00 & 100,00 & 100,00 \\
\hline & & média & 177,46 & 174,86 & 101,49 & 136,19 & 113,81 & 123,92 & 106,03 \\
\hline & & $n$ & 8 & 8 & 7 & 8 & 8 & 8 & 8 \\
\hline & & $\%$ & 100,00 & 100,00 & 87,50 & 100,00 & 100,00 & 100,00 & 100,00 \\
\hline
\end{tabular}




\begin{tabular}{|c|c|c|c|c|c|c|c|c|c|}
\hline & & média & 179,00 & 176,13 & 105,14 & 140,81 & 117,63 & 128,25 & 108,13 \\
\hline \multirow{3}{*}{$\begin{array}{l}\text { EUA - } \\
\text { Maryland }\end{array}$} & \multirow{3}{*}{54} & $n$ & 54 & 54 & 49 & 54 & 53 & 54 & 54 \\
\hline & & $\%$ & 100,00 & 100,00 & 90,74 & 100,00 & 98,15 & 100,00 & 100,00 \\
\hline & & média & 187,36 & 184,26 & 106,18 & 139,88 & 116,57 & 129,67 & 112,33 \\
\hline \multirow{3}{*}{$\begin{array}{c}\text { EUA - } \\
\text { Massachusetts }\end{array}$} & \multirow{3}{*}{1} & $n$ & 1 & 1 & 1 & 1 & 1 & 1 & 1 \\
\hline & & $\%$ & 100,00 & 100,00 & 100,00 & 100,00 & 100,00 & 100,00 & 100,00 \\
\hline & & média & 183,00 & 179,00 & 106,00 & 130,00 & 107,00 & 123,00 & 102,00 \\
\hline \multirow{3}{*}{$\begin{array}{l}\text { EUA - } \\
\text { Michigan }\end{array}$} & \multirow{3}{*}{12} & $n$ & 12 & 12 & 12 & 12 & 12 & 12 & 11 \\
\hline & & $\%$ & 100,00 & 100,00 & 100,00 & 100,00 & 100,00 & 100,00 & 91,67 \\
\hline & & média & 182,33 & 179,08 & 103,25 & 144,33 & 118,25 & 133,71 & 112,68 \\
\hline \multirow{3}{*}{$\begin{array}{l}\text { EUA - } \\
\text { Mississipi }\end{array}$} & \multirow{3}{*}{3} & $n$ & 3 & 3 & 2 & 3 & 3 & 3 & 3 \\
\hline & & $\%$ & 100,00 & 100,00 & 66,67 & 100,00 & 100,00 & 100,00 & 100,00 \\
\hline & & média & 175,33 & 173,33 & 103,00 & 139,33 & 113,33 & 124,67 & 106,67 \\
\hline \multirow{3}{*}{$\begin{array}{l}\text { EUA - } \\
\text { Missouri }\end{array}$} & & $n$ & 10 & 10 & 9 & 10 & 9 & 9 & 10 \\
\hline & 10 & $\%$ & 100,00 & 100,00 & 90,00 & 100,00 & 90,00 & 90,00 & 100,00 \\
\hline & & média & 182,30 & 179,05 & 104,67 & 137,50 & 116,33 & 125,72 & 108,00 \\
\hline & & $n$ & 15 & 15 & 15 & 15 & 14 & 15 & 15 \\
\hline Montana & 15 & $\%$ & 100,00 & 100,00 & 100,00 & 100,00 & 93,33 & 100,00 & 100,00 \\
\hline & & média & 182,30 & 180,27 & 103,13 & 140,53 & 114,93 & 130,87 & 110,90 \\
\hline & & $n$ & 17 & 17 & 17 & 17 & 17 & 17 & 17 \\
\hline Nebraska & 17 & $\%$ & 100,00 & 100,00 & 100,00 & 100,00 & 100,00 & 100,00 & 100,00 \\
\hline & & média & 180,74 & 179,24 & 101,56 & 141,91 & 114,76 & 129,00 & 111,15 \\
\hline & & $n$ & 2 & 2 & 2 & 2 & 2 & 2 & 2 \\
\hline EUA - Nevada & 2 & $\%$ & 100,00 & 100,00 & 100,00 & 100,00 & 100,00 & 100,00 & 100,00 \\
\hline & & média & 188,50 & 184,00 & 107,50 & 138,00 & 113,00 & 129,00 & 109,00 \\
\hline EUA - New & & $n$ & 8 & 8 & 8 & 8 & 8 & 8 & 8 \\
\hline Jersey & 8 & $\%$ & 100,00 & 100,00 & 100,00 & 100,00 & 100,00 & 100,00 & 100,00 \\
\hline & & média & 186,75 & 184,50 & 105,81 & 139,75 & 117,75 & 128,63 & 109,25 \\
\hline & & $\mathrm{n}$ & 52 & 52 & 57 & 56 & 62 & 59 & 56 \\
\hline México & 63 & $\%$ & 82,54 & 82,54 & 90,48 & 88,89 & 98,41 & 93,65 & 88,89 \\
\hline & & média & 177,18 & 173,63 & 99,77 & 135,04 & 113,97 & 123,95 & 105,75 \\
\hline & & $n$ & 27 & 27 & 26 & 27 & 27 & 27 & 27 \\
\hline $\begin{array}{l}\text { York } \\
\text { York }\end{array}$ & 27 & $\%$ & 100,00 & 100,00 & 96,30 & 100,00 & 100,00 & 100,00 & 100,00 \\
\hline & & média & 187,09 & 183,72 & 105,15 & 140,31 & 117,67 & 129,89 & 110,44 \\
\hline EUA - & & $n$ & 9 & 9 & 9 & 9 & 9 & 9 & 8 \\
\hline Nordeste & 9 & $\%$ & 100,00 & 100,00 & 100,00 & 100,00 & 100,00 & 100,00 & 88,89 \\
\hline americano & & média & 187,00 & 183,56 & 104,22 & 144,67 & 117,11 & 130,89 & 111,75 \\
\hline & & $n$ & 2 & 2 & 0 & 1 & 2 & 0 & 2 \\
\hline EUA - Ohio & 2 & $\%$ & 100,00 & 100,00 & 0,00 & 50,00 & 100,00 & 0,00 & 100,00 \\
\hline & & média & 183,00 & 180,50 & 0,00 & 144,00 & 114,50 & 0,00 & 106,50 \\
\hline & & $n$ & 10 & 10 & 12 & 10 & 12 & 12 & 10 \\
\hline EUA - Oregon & 13 & $\%$ & 76,92 & 76,92 & 92,31 & 76,92 & 92,31 & 92,31 & 76,92 \\
\hline & & média & 178,90 & 176,20 & 99,75 & 143,20 & 117,25 & 128,08 & 111,50 \\
\hline & & $n$ & 3 & 3 & 4 & 3 & 4 & 4 & 3 \\
\hline Pensilvânia & 4 & $\%$ & 75,00 & 75,00 & 100,00 & 75,00 & 100,00 & 100,00 & 75,00 \\
\hline & & média & 190,00 & 187,00 & 106,50 & 140,00 & 117,50 & 129,25 & 110,00 \\
\hline & & $n$ & 7 & 7 & 7 & 7 & 8 & 9 & 7 \\
\hline Tennesse & 10 & $\%$ & 70,00 & 70,00 & 70,00 & 70,00 & 80,00 & 90,00 & 70,00 \\
\hline & & média & 181,29 & 178,57 & 102,79 & 138,57 & 118,75 & 125,33 & 107,71 \\
\hline & & $\mathrm{n}$ & 17 & 17 & 15 & 17 & 16 & 17 & 16 \\
\hline EUA - Texas & 17 & $\%$ & 100,00 & 100,00 & 88,24 & 100,00 & 94,12 & 100,00 & 94,12 \\
\hline & & média & 180,35 & 177,74 & 102,47 & 140,94 & 116,44 & 129,47 & 111,44 \\
\hline & & $n$ & 58 & 58 & 58 & 58 & 58 & 58 & 58 \\
\hline EUA - Utah & 58 & $\%$ & 100,00 & 100,00 & 100,00 & 100,00 & 100,00 & 100,00 & 100,00 \\
\hline & & média & 181,35 & 178,39 & 101,25 & 133,32 & 113,82 & 125,59 & 105,52 \\
\hline & & $n$ & 58 & 58 & 53 & 58 & 58 & 58 & 58 \\
\hline EUA - Virginia & 58 & $\%$ & 100,00 & 100,00 & 91,38 & 100,00 & 100,00 & 100,00 & 100,00 \\
\hline & & média & 184,01 & 181,36 & 105,52 & 138,81 & 116,22 & 127,03 & 108,91 \\
\hline & & $n$ & 1 & 1 & 1 & 1 & 1 & 1 & 1 \\
\hline Ocidental & 1 & $\%$ & 100,00 & 100,00 & 100,00 & 100,00 & 100,00 & 100,00 & 100,00 \\
\hline & & média & 178,00 & 175,00 & 100,00 & 138,00 & 117,00 & 123,00 & 107,00 \\
\hline & & $n$ & 1 & 1 & 2 & 1 & 2 & 2 & 2 \\
\hline Washington & 2 & $\%$ & 50,00 & 50,00 & 100,00 & 50,00 & 100,00 & 100,00 & 100,00 \\
\hline & & média & 175,00 & 174,00 & 101,50 & 145,00 & 115,00 & 128,50 & 110,50 \\
\hline & & $n$ & 5 & 5 & 5 & 5 & 5 & 5 & 5 \\
\hline Wisconsin & 5 & $\%$ & 100,00 & 100,00 & 100,00 & 100,00 & 100,00 & 100,00 & 100,00 \\
\hline & & média & 179,30 & 176,90 & 103,90 & 146,80 & 122,40 & 135,00 & 111,80 \\
\hline & & $n$ & 3 & 3 & 3 & 3 & 3 & 3 & 3 \\
\hline Wyoming & 3 & $\%$ & 100,00 & 100,00 & 100,00 & 100,00 & 100,00 & 100,00 & 100,00 \\
\hline & & média & 180,00 & 178,00 & 100,00 & 142,67 & 115,00 & 130,83 & 110,50 \\
\hline
\end{tabular}




\begin{tabular}{|c|c|c|c|c|c|c|c|c|c|c|}
\hline série & & $\mathrm{BBH}$ & FRC & PAC & OCC & $\mathrm{BPL}$ & ZYB & $\mathrm{NPH}$ & DKB & $\mathrm{OBH}$ \\
\hline \multirow{3}{*}{ Aleuta 1} & $n$ & 77 & 78 & 79 & 80 & 74 & 67 & 77 & 79 & 80 \\
\hline & $\%$ & 93,90 & 95,12 & 96,34 & 97,56 & 90,24 & 81,71 & 93,90 & 96,34 & 97,56 \\
\hline & média & 130,06 & 111,74 & 106,61 & 98,15 & 103,17 & 143,72 & 72,47 & 21,44 & 36,06 \\
\hline \multirow{3}{*}{ Aleuta 2} & $\mathrm{n}$ & 45 & 45 & 45 & 45 & 44 & 43 & 44 & 45 & 45 \\
\hline & $\%$ & 100,00 & 100,00 & 100,00 & 100,00 & 97,78 & 95,56 & 97,78 & 100,00 & 100,00 \\
\hline & média & 130,20 & 113,24 & 105,29 & 96,58 & 104,07 & 144,23 & 73,85 & 21,42 & 37,19 \\
\hline \multirow{3}{*}{ Aleuta 3} & $\mathrm{n}$ & 13 & 13 & 13 & 12 & 12 & 11 & 12 & 13 & 13 \\
\hline & $\%$ & 100,00 & 100,00 & 100,00 & 92,31 & 92,31 & 84,62 & 92,31 & 100,00 & 100,00 \\
\hline & média & 129,54 & 110,88 & 105,88 & 98,42 & 101,63 & 141,14 & 71,04 & 21,27 & 35,88 \\
\hline \multirow{3}{*}{ Aleuta 4} & $\mathrm{n}$ & 17 & 18 & 18 & 17 & 17 & 14 & 18 & 17 & 18 \\
\hline & $\%$ & 94,44 & 100,00 & 100,00 & 94,44 & 94,44 & 77,78 & 100,00 & 94,44 & 100,00 \\
\hline & média & 128,06 & 109,89 & 106,72 & 97,29 & 102,00 & 143,46 & 70,83 & 21,68 & 34,92 \\
\hline \multirow{3}{*}{ Aleuta 5} & $n$ & 5 & 5 & 5 & 5 & 5 & 3 & 5 & 5 & 5 \\
\hline & $\%$ & 100,00 & 100,00 & 100,00 & 100,00 & 100,00 & 60,00 & 166,67 & 100,00 & "100,00 \\
\hline & média & 127,50 & 110,80 & 108,40 & 97,60 & 98,00 & 143,67 & 72,80 & 22,20 & 35,20 \\
\hline \multirow{3}{*}{ Aleuta 6} & $\mathrm{n}$ & 16 & 16 & 16 & 16 & 13 & 13 & 14 & 15 & 14 \\
\hline & $\%$ & 100,00 & 100,00 & 100,00 & 100,00 & 81,25 & 81,25 & 87,50 & 93,75 & 87,50 \\
\hline & média & 128,56 & 112,25 & 104,31 & 98,44 & 103,62 & 142,54 & 71,93 & 21,20 & 36,43 \\
\hline \multirow{3}{*}{$\begin{array}{l}\text { Austrália - } \\
\text { Murray River }\end{array}$} & $\mathrm{n}$ & 17 & 38 & 46 & 24 & 16 & 23 & 27 & 14 & 40 \\
\hline & $\%$ & 32,08 & " 71,70 & 86,79 & 45,28 & 30,19 & 43,40 & 50,94 & 26,42 & 75,47 \\
\hline & média & 128,65 & 111,24 & 117,04 & 92,96 & 104,88 & 133,61 & 64,30 & 23,00 & 33,68 \\
\hline \multirow{3}{*}{$\begin{array}{c}\text { Austrália- } \\
\text { New South } \\
\text { Walles }\end{array}$} & $\mathrm{n}$ & 57 & 61 & 61 & 57 & $\overline{54}$ & 46 & 57 & 60 & 58 \\
\hline & $\%$ & 86,36 & "92,42 & 92,42 & 86,36 & 81,82 & 69,70 & 86,36 & 90,91 & 87,88 \\
\hline & média & 135,18 & 113,95 & 117,21 & 95,95 & 103,09 & 133,28 & 65,79 & 22,58 & 33,77 \\
\hline \multirow{3}{*}{$\begin{array}{l}\text { Austrália- } \\
\text { Território do } \\
\text { Norte }\end{array}$} & $\mathrm{n}$ & 12 & 12 & 12 & 12 & 11 & 11 & 11 & 11 & 11 \\
\hline & $\%$ & 100,00 & 100,00 & 100,00 & 100,00 & 91,67 & 91,67 & 91,67 & 91,67 & 91,67 \\
\hline & média & 133,58 & 112,50 & 115,92 & 93,42 & 103,82 & 133,73 & 65,45 & 21,36 & 32,73 \\
\hline \multirow{3}{*}{$\begin{array}{l}\text { Austrália - } \\
\text { Queensland }\end{array}$} & $\mathrm{n}$ & 21 & 22 & 22 & 20 & 20 & 20 & 21 & 21 & 21 \\
\hline & $\%$ & 95,45 & 100,00 & 100,00 & 90,91 & 90,91 & 90,91 & 95,45 & 95,45 & 95,45 \\
\hline & média & 133,52 & 112,23 & 116,09 & 93,95 & 101,35 & 133,00 & 64,10 & 23,52 & 32,93 \\
\hline \multirow{3}{*}{ Austrália - Sul } & $\bar{n}$ & 102 & 134 & 135 & 116 & 88 & 82 & 102 & 99 & 110 \\
\hline & $\%$ & 69,39 & 91,16 & 91,84 & 78,91 & 59,86 & 55,78 & 69,39 & 67,35 & 74,83 \\
\hline & média & 129,58 & 111,72 & 113,20 & 93,27 & 106,30 & 131,17 & 65,71 & 22,71 & 33,49 \\
\hline \multirow{3}{*}{$\begin{array}{l}\text { Austrália - } \\
\text { Tasmânia }\end{array}$} & $\mathrm{n}$ & 15 & 17 & 16 & 14 & 15 & 14 & 15 & 15 & 15 \\
\hline & $\%$ & 88,24 & 100,00 & 94,12 & 82,35 & 88,24 & 82,35 & 88,24 & 88,24 & 88,24 \\
\hline & média & 132,87 & 110,53 & 115,63 & 95,71 & 105,33 & 134,50 & 62,37 & 22,80 & 31,40 \\
\hline \multirow{3}{*}{$\begin{array}{c}\text { Austrália - } \\
\text { Victoria State }\end{array}$} & $n$ & 9 & 10 & 10 & 10 & $\overline{9}$ & 7 & 10 & 10 & 10 \\
\hline & $\%$ & 90,00 & 100,00 & 100,00 & 100,00 & 90,00 & 70,00 & 100,00 & 100,00 & 100,00 \\
\hline & média & 132,89 & 110,85 & 115,35 & 92,00 & 103,89 & 134,29 & 64,70 & 22,00 & 32,30 \\
\hline & $n$ & 26 & 28 & 28 & 27 & 24 & 22 & 26 & 28 & 28 \\
\hline A & $\%$ & 92,86 & 100,00 & 100,00 & 96,43 & 85,71 & 78,57 & 92,86 & 100,00 & 100,00 \\
\hline & média & 130,85 & 111,64 & 114,43 & 94,30 & 101,79 & 131,18 & 65,46 & 22,29 & 33,98 \\
\hline Canadá - & $\mathrm{n}$ & 60 & 59 & 52 & 52 & 72 & 71 & 72 & 76 & 74 \\
\hline Columbia & $\%$ & 76,92 & 75,64 & 66,67 & 66,67 & 92,31 & 91,03 & 92,31 & 97,44 & 94,87 \\
\hline Britânica & média & 133,72 & 113,97 & 106,30 & 97,54 & 100,01 & 141,27 & 71,52 & 22,82 & 36,96 \\
\hline & $n$ & 3 & 2 & 3 & 2 & 2 & 3 & 3 & 3 & 3 \\
\hline Central & $\%$ & 100,00 & 66,67 & 100,00 & 66,67 & 66,67 & 100,00 & 100,00 & 100,00 & 100,00 \\
\hline & média & 134,33 & 110,50 & 109,33 & 94,50 & 97,50 & 137,67 & 67,00 & 22,67 & 34,67 \\
\hline Canadá - & $\mathrm{n}$ & 36 & 37 & 36 & 35 & 30 & 28 & 31 & 31 & 33 \\
\hline Ontário & $\%$ & 90,00 & "92,50" & 90,00 & 87,50 & 75,00 & 70,00 & 77,50 & 77,50 & 82,50 \\
\hline (Iroque) & média & 136,25 & 113,57 & 110,36 & 98,54 & 102,07 & 140,68 & 70,94 & 22,77 & 35,29 \\
\hline América & $\mathrm{n}$ & 9 & 9 & 9 & 9 & $\overline{9}$ & 8 & 9 & 9 & 9 \\
\hline Central e do & $\%$ & 100,00 & 100,00 & 100,00 & 100,00 & 100,00 & 88,89 & 100,00 & 100,00 & "100,00 \\
\hline Sul-Bolívia & média & 131,22 & 110,44 & 107,94 & 98,83 & 95,89 & 130,00 & 68,44 & 22,22 & 35,39 \\
\hline América & $\mathrm{n}$ & 9 & 11 & 11 & 11 & 11 & 8 & 12 & 12 & 12 \\
\hline Central e do & $\%$ & 69,23 & 84,62 & 84,62 & 84,62 & 84,62 & 61,54 & 92,31 & 92,31 & 92,31 \\
\hline Sul - Caribe & média & 136,33 & 111,45 & 113,05 & 97,82 & 97,55 & 138,50 & 71,00 & 23,00 & 36,50 \\
\hline América & $n$ & 20 & 20 & 20 & 19 & 19 & 18 & 19 & 20 & 20 \\
\hline Central e do & $\%$ & 100,00 & 100,00 & 100,00 & 95,00 & 95,00 & 90,00 & 95,00 & 100,00 & 100,00 \\
\hline Sul - Chile & média & 136,70 & 111,05 & 111,03 & 98,05 & 100,26 & 138,53 & 68,47 & 22,00 & 34,60 \\
\hline & $\mathrm{n}$ & 12 & 14 & 12 & 11 & $\overline{13}$ & 10 & 17 & 18 & 19 \\
\hline
\end{tabular}




\begin{tabular}{|c|c|c|c|c|c|c|c|c|c|c|}
\hline & $\mathrm{n}$ & 12 & 14 & 12 & 11 & 13 & 10 & 17 & 18 & 19 \\
\hline América & mógia & 60,00 & 70,00 & 60,00 & 55,00 & 65,00 & 50,00 & 85,00 & 90,00 & 95,00 \\
\hline Central e do & & 134,50 & 109,50 & 109,17 & 97,45 & 96,62 & 140,30 & 67,29 & 23,44 & 34,82 \\
\hline \multirow{3}{*}{$\begin{array}{l}\text { Sul Ancééliấanbia } \\
\text { Central e do } \\
\text { Sul - Equador }\end{array}$} & $\mathrm{n}$ & 5 & 7 & 7 & 4 & 5 & 3 & 7 & 7 & 7 \\
\hline & $\%$ & 71,43 & 100,00 & 100,00 & 57,14 & 71,43 & 42,86 & 100,00 & 100,00 & 100,00 \\
\hline & média & 127,20 & 109,14 & 109,14 & 94,50 & 95,00 & 133,67 & 68,14 & 21,29 & 34,57 \\
\hline \multirow{3}{*}{$\begin{array}{c}\text { América Central e } \\
\text { do Sul - Fueguinos } \\
\text { (Patagônia) }\end{array}$} & $\mathrm{n}$ & 55 & 57 & 54 & 53 & 53 & 53 & 55 & 55 & 55 \\
\hline & $\%$ & 96,49 & 100,00 & 94,74 & 92,98 & 92,98 & 92,98 & 96,49 & 96,49 & 96,49 \\
\hline & média & 139,05 & ' 115,28 & 113,26 & 98,99 & 102,11 & 143,47 & 73,75 & 22,17 & 35,79 \\
\hline \multirow{3}{*}{$\begin{array}{c}\text { América } \\
\text { Central e do } \\
\text { Sul - Guiana }\end{array}$} & $\mathrm{n}$ & 5 & 5 & 5 & 5 & 4 & 5 & 4 & 4 & 4 \\
\hline & $\%$ & 71,43 & 71,43 & 71,43 & 71,43 & 57,14 & 71,43 & 57,14 & 57,14 & 57,14 \\
\hline & média & 129,80 & 108,40 & 109,00 & 96,20 & 101,25 & 135,80 & 69,50 & 22,75 & 36,50 \\
\hline \multirow{3}{*}{$\begin{array}{c}\text { América } \\
\text { Central e do } \\
\text { Sul - México }\end{array}$} & $\mathrm{n}$ & 68 & 71 & 67 & 64 & 69 & 60 & 70 & 72 & 72 \\
\hline & $\%$ & 93,15 & 97,26 & 91,78 & 87,67 & 94,52 & 82,19 & 95,89 & 98,63 & 98,63 \\
\hline & média & 136,15 & 110,06 & 110,07 & 97,72 & 99,25 & 135,65 & 69,53 & 22,38 & 34,44 \\
\hline \multirow{3}{*}{$\begin{array}{c}\text { América } \\
\text { Central e do } \\
\text { Sul - Panamá }\end{array}$} & $\mathrm{n}$ & 1 & 1 & 1 & 1 & 1 & 1 & 1 & 1 & 1 \\
\hline & $\%$ & 100,00 & 100,00 & 100,00 & 100,00 & 100,00 & 100,00 & 100,00 & 100,00 & 100,00 \\
\hline & média & 133,00 & 108,00 & 108,00 & 95,00 & 97,00 & 148,00 & 72,00 & 23,00 & 36,00 \\
\hline \multirow{3}{*}{$\begin{array}{c}\text { América } \\
\text { Central e do } \\
\text { Sul - Peru }\end{array}$} & $\mathrm{n}$ & 221 & 222 & 222 & 223 & 221 & 218 & 222 & 222 & 223 \\
\hline & $\%$ & 99,10 & 99,55 & 99,55 & 100,00 & 99,10 & 97,76 & 99,55 & 99,55 & 100,00 \\
\hline & média & 132,60 & 109,03 & 108,55 & 97,98 & 97,25 & 135,36 & 68,09 & 20,94 & 34,40 \\
\hline \multirow{3}{*}{$\begin{array}{c}\text { América } \\
\text { Central e do } \\
\text { Sul - } \\
\text { Venezuela } \\
\end{array}$} & $n$ & 12 & 12 & 12 & 12 & 12 & 12 & 12 & 12 & 12 \\
\hline & $\%$ & 100,00 & 100,00 & 100,00 & 100,00 & 100,00 & 100,00 & 100,00 & 100,00 & 100,00 \\
\hline & média & 131,13 & 111,21 & 107,29 & 96,50 & 100,08 & 137,21 & 71,92 & 21,92 & 36,38 \\
\hline \multirow{3}{*}{$\begin{array}{c}\text { Leste Asiático } \\
\text { - Ainu } \\
\text { Hokkaido }\end{array}$} & $n$ & 34 & 35 & 35 & 33 & 32 & 31 & 35 & 35 & 35 \\
\hline & $\%$ & 97,14 & 100,00 & 100,00 & 94,29 & 91,43 & 88,57 & 100,00 & 100,00 & 100,00 \\
\hline & média & 137,41 & "113,06 & 113,20 & 99,36 & 102,94 & 138,77 & 66,31 & 21,37 & 33,86 \\
\hline \multirow{3}{*}{$\begin{array}{c}\text { Leste Asiático } \\
\text { - Ainu } \\
\text { Sakhalin }\end{array}$} & $\mathrm{n}$ & 5 & 5 & 5 & 4 & 5 & 5 & 5 & 5 & 5 \\
\hline & $\%$ & 100,00 & 100,00 & 100,00 & 80,00 & 100,00 & 100,00 & 100,00 & 100,00 & 100,00 \\
\hline & média & 141,00 & 111,80 & 114,80 & 103,25 & 108,00 & 140,20 & 68,80 & 20,00 & 34,40 \\
\hline Leste Asiático & $\mathrm{n}$ & 61 & 62 & 61 & 61 & 60 & 60 & 61 & 62 & 62 \\
\hline - Norte da & $\%$ & 98,39 & 100,00 & 98,39 & 98,39 & 96,77 & 96,77 & 98,39 & 100,00 & "100,00 \\
\hline China (Han) & média & 136,84 & 112,18 & 114,14 & 98,34 & 95,04 & 133,44 & 70,52 & 22,42 & 34,29 \\
\hline Leste Asiático - & $\mathrm{n}$ & 48 & 50 & 49 & 49 & 48 & 45 & 49 & 56 & 50 \\
\hline Norte & $\%$ & 85,71 & 89,29 & 87,50 & 87,50 & 85,71 & 80,36 & 87,50 & 100,00 & 89,29 \\
\hline & média & 137,23 & 112,70 & 115,47 & 98,47 & 96,73 & 134,53 & 74,51 & 20,95 & 35,54 \\
\hline Leste Asiático & $\mathrm{n}$ & 65 & 67 & 66 & 66 & 65 & 62 & 66 & 67 & 67 \\
\hline - Sul da China & $\%$ & 97,01 & 100,00 & 98,51 & 98,51 & 97,01 & 92,54 & 98,51 & 100,00 & 100,00 \\
\hline & média & 136,68 & 111,37 & 115,07 & 98,26 & 96,00 & 134,23 & 69,64 & 21,57 & "34,02 \\
\hline iático- & $n$ & 27 & 36 & 37 & 27 & 27 & 14 & 33 & 28 & 39 \\
\hline Jar & $\%$ & 54,00 & 72,00 & 74,00 & 54,00 & 54,00 & 28,00 & 66,00 & 56,00 & 78,00 \\
\hline & média & 138,63 & 111,17 & 114,54 & 99,81 & 101,74 & 142,86 & 64,03 & 23,25 & 32,90 \\
\hline Leste Asiático & $n$ & 97 & 97 & 97 & 97 & 97 & 92 & 98 & 107 & 107 \\
\hline - Japão & $\%$ & 90,65 & 90,65 & 90,65 & 90,65 & 90,65 & 85,98 & 91,59 & 100,00 & 100,00 \\
\hline Tohoku & média & 136,76 & 110,61 & 113,66 & 99,41 & 96,90 & 133,47 & 69,82 & 21,36 & 34,86 \\
\hline Leste Asiático & $n$ & 43 & 43 & 43 & 43 & 43 & 43 & 43 & 43 & 43 \\
\hline$-J$ & $\%$ & 100,00 & 100,00 & 100,00 & 100,00 & 100,00 & 100,00 & 100,00 & 100,00 & 100,00 \\
\hline Tóquio & média & 137,86 & 112,03 & 113,93 & 100,70 & 97,55 & 134,05 & 70,21 & 20,95 & 34,80 \\
\hline & $n$ & 30 & 31 & 28 & 25 & 31 & 29 & 32 & 30 & 32 \\
\hline Leste & $\%$ & 90,91 & 93,94 & 84,85 & 75,76 & 93,94 & 87,88 & 96,97 & 90,91 & 96,97 \\
\hline & média & 137,70 & ' & 112,39 & 99,18 & 94,84 & 134,69 & 70,98 & 20,98 & 34,45 \\
\hline & $\mathrm{n}$ & 34 & 35 & 34 & 33 & 32 & 29 & 34 & 35 & 35 \\
\hline Leste Aslatico & $\%$ & 94,44 & 97,22 & 94,44 & 91,67 & 88,89 & 80,56 & 94,44 & 97,22 & 97,22 \\
\hline & média & 131,06 & 109,40 & 114,59 & 92,53 & 95,44 & 127,41 & 64,03 & 22,06 & 33,31 \\
\hline & $\mathrm{n}$ & 11 & 11 & 11 & 10 & 11 & 11 & 11 & 11 & 11 \\
\hline Leste $\mathrm{A}$ & $\%$ & 100,00 & 100,00 & 100,00 & 90,91 & 100,00 & 100,00 & 100,00 & 100,00 & 100,00 \\
\hline & média & 138,64 & 113,73 & 114,64 & 99,10 & 96,91 & 134,45 & 69,73 & 21,45 & 34,82 \\
\hline & $\mathrm{n}$ & 56 & 57 & 57 & 56 & 56 & 53 & 57 & 56 & 57 \\
\hline Leste Aslatico & $\%$ & 87,50 & 89,06 & 89,06 & 87,50 & 87,50 & 82,81 & 89,06 & 87,50 & 89,06 \\
\hline & média & 131,95 & 109,91 & 113,86 & 95,29 & 94,36 & 131,28 & 66,75 & 22,48 & 34,70 \\
\hline Esquimó - & $n$ & 135 & 135 & 135 & 133 & 122 & 118 & 124 & 133 & 135 \\
\hline Alaska 1 & $\%$ & 100,00 & 100,00 & 100,00 & 98,52 & 90,37 & 87,41 & 91,85 & 98,52 & 100,00 \\
\hline & média & 136,43 & '112,52 & 107,81 & 96,79 & 100,10 & 140,55 & 74,19 & 21,00 & 36,32 \\
\hline & $\mathrm{n}$ & 105 & 107 & 107 & 107 & 103 & 100 & 105 & 106 & 107 \\
\hline Alaska? & $\%$ & 98,13 & 100,00 & 100,00 & 100,00 & 96,26 & 93,46 & 98,13 & 99,07 & 100,00 \\
\hline & média & 138,26 & 113,52 & 109,59 & 97,98 & 103,21 & 140,74 & 73,68 & 19,84 & 36,75 \\
\hline & $\mathrm{n}$ & 68 & 70 & 70 & 67 & 60 & 59 & 64 & 68 & 70 \\
\hline Esquimo - & $\%$ & 97,14 & 100,00 & 100,00 & 95,71 & 85,71 & 84,29 & 91,43 & 97,14 & "' 100,00 \\
\hline & média & 137,52 & 113,99 & 112,26 & 99,03 & 102,52 & 141,49 & 74,34 & 19,84 & 36,35 \\
\hline & $\bar{n}$ & 21 & 22 & 22 & 22 & 20 & 22 & 22 & 22 & 22 \\
\hline
\end{tabular}




\begin{tabular}{|c|c|c|c|c|c|c|c|c|c|c|}
\hline \multirow[b]{2}{*}{ Esquimó - } & $\mathrm{n}$ & 21 & 22 & 22 & 22 & 20 & 22 & 22 & 22 & 22 \\
\hline & média & 196,45 & 100,00 & $10 \theta, \theta \theta$ & 100,00 & $100, \theta 8$ & 100,00 & 100,00 & 100,00 & 100,00 \\
\hline \multirow{3}{*}{$\begin{array}{l}\text { Asiaia } \\
\text { Esquimó - } \\
\text { Canadá }\end{array}$} & $\mathrm{n}$ & 30 & 30 & 30 & 30 & 28 & 27 & 28 & 29 & 29 \\
\hline & $\%$ & 100,00 & 100,00 & 100,00 & 100,00 & 93,33 & 90,00 & 93,33 & 96,67 & 96,67 \\
\hline & média & 138,72 & 112,93 & 114,83 & 99,97 & 102,82 & 139,50 & 71,64 & 19,91 & 36,24 \\
\hline \multirow{3}{*}{$\begin{array}{l}\text { Esquimó - } \\
\text { Groelândia }\end{array}$} & $\mathrm{n}$ & 104 & 104 & 103 & 103 & 103 & 94 & 102 & 104 & 104 \\
\hline & $\%$ & 97,20 & 97,20 & 96,26 & 96,26 & 96,26 & 87,85 & 95,33 & 97,20 & 97,20 \\
\hline & média & 139,85 & 113,95 & 115,04 & 99,44 & 104,03 & 141,60 & 72,81 & 19,86 & 36,33 \\
\hline \multirow{3}{*}{$\begin{array}{l}\text { Esquimó - } \\
\text { "desconhecido" }\end{array}$} & $\mathrm{n}$ & 10 & 10 & 10 & 10 & 10 & 10 & $\overline{9}$ & 10 & 10 \\
\hline & $\%$ & 100,00 & 100,00 & 100,00 & 100,00 & 100,00 & 100,00 & 90,00 & 100,00 & 100,00 \\
\hline & média & 136,80 & 112,50 & 115,10 & 100,10 & 100,30 & 141,00 & 72,89 & 20,20 & 37,30 \\
\hline \multirow{3}{*}{$\begin{array}{l}\text { Europa - } \\
\text { Albânia }\end{array}$} & $\mathrm{n}$ & 3 & 3 & 3 & 3 & 3 & 3 & 3 & 3 & 3 \\
\hline & $\%$ & 100,00 & 100,00 & 100,00 & 100,00 & 100,00 & 100,00 & 100,00 & 100,00 & 100,00 \\
\hline & média & 138,00 & 113,17 & 107,67 & 94,00 & 96,00 & 133,00 & 65,33 & 20,33 & 33,33 \\
\hline \multirow{3}{*}{$\begin{array}{l}\text { Europa - } \\
\text { Áustria }\end{array}$} & $n$ & 80 & 80 & 80 & 80 & 77 & 79 & 77 & 80 & 80 \\
\hline & $\%$ & 100,00 & 100,00 & 100,00 & 100,00 & 96,25 & 98,75 & 96,25 & 100,00 & 100,00 \\
\hline & média & 132,01 & 110,94 & 111,33 & 94,11 & 96,58 & 133,04 & 67,37 & 22,88 & 33,04 \\
\hline \multirow{3}{*}{$\begin{array}{c}\text { Europa - } \\
\text { Áustria (Idade } \\
\text { do Ferro) }\end{array}$} & $n$ & 1 & 2 & 2 & 1 & 1 & 1 & 1 & 1 & 1 \\
\hline & $\%$ & 50,00 & 100,00 & 100,00 & 50,00 & 50,00 & 50,00 & 50,00 & 50,00 & 50,00 \\
\hline & média & 134,00 & 112,50 & 109,00 & 94,00 & 89,00 & 135,00 & 67,00 & 21,00 & 34,50 \\
\hline \multirow{3}{*}{$\begin{array}{l}\text { Europa - } \\
\text { Bélgica }\end{array}$} & $n$ & 4 & 4 & 4 & 4 & 4 & 4 & 4 & 4 & 4 \\
\hline & $\%$ & 100,00 & 100,00 & 100,00 & 100,00 & 100,00 & 100,00 & 100,00 & 100,00 & 100,00 \\
\hline & média & 128,50 & 108,63 & 115,00 & 93,88 & 95,00 & 134,50 & 64,75 & 22,25 & 33,00 \\
\hline \multirow{3}{*}{$\begin{array}{l}\text { Europa - } \\
\text { Bulgária }\end{array}$} & $n$ & 18 & 17 & 18 & 18 & 17 & 17 & 16 & 17 & 17 \\
\hline & $\%$ & 100,00 & 94,44 & 100,00 & 100,00 & 94,44 & 94,44 & 88,89 & 94,44 & 94,44 \\
\hline & média & 133,25 & 111,32 & 111,75 & 97,42 & 96,18 & 130,00 & 66,22 & 22,21 & 33,53 \\
\hline Europa - & $\mathrm{n}$ & 94 & 95 & 95 & 95 & 85 & 91 & 85 & 95 & 95 \\
\hline "Republica & $\%$ & 98,95 & 100,00 & 100,00 & 100,00 & 89,47 & 95,79 & 89,47 & 100,00 & 100,00 \\
\hline Tcheca" & média & 133,24 & 110,44 & 109,56 & 92,99 & 94,04 & 132,31 & 67,91 & 22,59 & 32,51 \\
\hline Europa - & $n$ & 4 & 5 & 5 & 4 & 4 & 4 & 5 & 5 & 5 \\
\hline "Republica & $\%$ & 80,00 & 100,00 & 100,00 & 80,00 & 80,00 & 80,00 & 100,00 & 100,00 & 100,00 \\
\hline Tcheca" Neolítico & média & 139,50 & 116,40 & 114,00 & 100,00 & 94,25 & 125,75 & 64,20 & 21,70 & 31,50 \\
\hline & $\mathrm{n}$ & 7 & 7 & 7 & 7 & 7 & 6 & 7 & 7 & 7 \\
\hline Dinam & $\%$ & 100,00 & 100,00 & 100,00 & 100,00 & 100,00 & 85,71 & 100,00 & 100,00 & 100,00 \\
\hline & média & 131,71 & 113,00 & 113,00 & 95,29 & 95,71 & 135,67 & 69,43 & 22,71 & 34,14 \\
\hline & $\mathrm{n}$ & 25 & 25 & 25 & 25 & 25 & 25 & 25 & 25 & 25 \\
\hline Finlân & $\%$ & 100,00 & 100,00 & 100,00 & 100,00 & 100,00 & 100,00 & 100,00 & 100,00 & 100,00 \\
\hline & média & 135,26 & 114,80 & 114,32 & 97,52 & 97,34 & 136,60 & 69,48 & 23,84 & 33,04 \\
\hline & $n$ & 58 & 63 & 63 & 62 & 58 & 51 & 60 & 60 & 62 \\
\hline Franca 1 & $\%$ & 92,06 & 100,00 & 100,00 & 98,41 & 92,06 & 80,95 & 95,24 & 95,24 & 98,41 \\
\hline & média & 131,38 & 111,54 & 111,92 & 94,02 & 93,36 & 130,43 & 68,30 & 22,62 & 33,81 \\
\hline & $n$ & 15 & 23 & 22 & 13 & 13 & 15 & 21 & 21 & 22 \\
\hline Franca ? & $\%$ & 65,22 & 100,00 & 95,65 & 56,52 & 56,52 & 65,22 & 91,30 & 91,30 & 95,65 \\
\hline & média & 133,40 & 112,52 & 114,50 & 98,46 & 96,38 & 135,53 & 68,38 & 23,52 & 33,30 \\
\hline & $\mathrm{n}$ & 77 & 78 & 77 & 77 & 80 & 78 & 79 & 82 & 82 \\
\hline Alem & $\%$ & 93,90 & 95,12 & 93,90 & 93,90 & 97,56 & 95,12 & 96,34 & 100,00 & 100,00 \\
\hline & média & 131,34 & 113,24 & 113,54 & 95,11 & 94,24 & 133,53 & 70,06 & 22,70 & 34,00 \\
\hline & $\mathrm{n}$ & 31 & 33 & 31 & 28 & 28 & 30 & 30 & 32 & 32 \\
\hline Grécia 1 & $\%$ & 91,18 & 97,06 & 91,18 & 82,35 & 82,35 & 88,24 & 88,24 & 94,12 & 94,12 \\
\hline & média & 134,35 & 110,39 & 111,94 & 94,68 & 95,93 & 131,17 & 67,80 & 21,52 & 34,19 \\
\hline & $n$ & 18 & 19 & 19 & 18 & 15 & 11 & 16 & 17 & 17 \\
\hline & $\%$ & 90,00 & 95,00 & 95,00 & 90,00 & 75,00 & 55,00 & 80,00 & 85,00 & 85,00 \\
\hline & média & 134,00 & 111,63 & 112,84 & 97,22 & 93,87 & 130,27 & 65,25 & 21,29 & 33,88 \\
\hline & $\mathrm{n}$ & 49 & 52 & 50 & 46 & 43 & 41 & 46 & 49 & 49 \\
\hline Euró & $\%$ & 90,74 & 96,30 & 92,59 & 85,19 & 79,63 & 75,93 & 85,19 & 90,74 & 90,74 \\
\hline & média & 134,22 & 110,85 & 112,28 & 95,67 & 95,21 & 130,93 & 66,91 & 21,44 & 34,08 \\
\hline & $n$ & 5 & 5 & 6 & 6 & 4 & 4 & 4 & 4 & 5 \\
\hline Herzegovinia & $\%$ & 83,33 & 83,33 & 100,00 & 100,00 & 66,67 & 66,67 & 66,67 & 66,67 & 83,33 \\
\hline & média & 136,20 & 117,40 & 113,17 & 96,17 & 96,75 & 136,75 & 67,50 & 25,25 & 33,80 \\
\hline & $\mathrm{n}$ & 32 & 33 & 33 & 33 & 31 & 32 & 31 & 33 & 33 \\
\hline Holanda & $\%$ & 96,97 & 100,00 & 100,00 & 100,00 & 93,94 & 96,97 & 93,94 & 100,00 & 100,00 \\
\hline & média & 129,97 & 111,86 & 111,88 & 94,27 & 93,74 & 132,19 & 68,11 & 21,83 & "34,38 \\
\hline & $n$ & 91 & 93 & 92 & 90 & 90 & 90 & 92 & 93 & 93 \\
\hline Hungria & $\%$ & 97,85 & 100,00 & 98,92 & 96,77 & 96,77 & 96,77 & 98,92 & 100,00 & 100,00 \\
\hline & média & 133,18 & 111,31 & 111,48 & 94,31 & 95,84 & 132,72 & 67,84 & 22,49 & 32,90 \\
\hline & $\mathrm{n}$ & 98 & 101 & 99 & 97 & 94 & 92 & 94 & 99 & 101 \\
\hline Europa- Ilalda & $\%$ & 97,03 & 100,00 & 98,02 & 96,04 & 93,07 & 91,09 & 93,07 & 98,02 & 100,00 \\
\hline & média & 133,24 & 110,94 & 111,73 & 95,82 & 96,17 & 133,17 & 68,07 & 22,35 & 33,83 \\
\hline & $\mathrm{n}$ & 27 & 38 & 38 & 30 & 27 & 26 & 34 & 35 & 35 \\
\hline & $\%$ & 67,50 & 95,00 & 95,00 & 75,00 & 67,50 & 65,00 & 85,00 & 87,50 & 87,50 \\
\hline
\end{tabular}




\begin{tabular}{|c|c|c|c|c|c|c|c|c|c|c|}
\hline & média & 136,41 & 112,32 & 115,08 & 97,53 & 94,52 & 133,42 & 69,41 & 21,79 & 34,27 \\
\hline \multirow{3}{*}{$\begin{array}{l}\text { Europa - } \\
\text { Lapônia }\end{array}$} & $n$ & 31 & 34 & 33 & 30 & 32 & 28 & 34 & 31 & 34 \\
\hline & $\%$ & 91,18 & 100,00 & 97,06 & 88,24 & 94,12 & 82,35 & 100,00 & 91,18 & 100,00 \\
\hline & média & 129,31 & 110,71 & 108,03 & 93,05 & 94,41 & 133,63 & 65,53 & 21,69 & 33,37 \\
\hline \multirow{3}{*}{$\begin{array}{l}\text { Europa - } \\
\text { Noruega }\end{array}$} & $\mathrm{n}$ & 19 & 19 & 19 & 19 & 20 & 19 & 20 & 20 & 20 \\
\hline & $\%$ & 95,00 & 95,00 & 95,00 & 95,00 & 100,00 & 95,00 & 100,00 & 100,00 & 100,00 \\
\hline & média & 132,42 & 113,53 & 110,37 & 96,53 & 95,10 & 132,58 & 70,20 & 21,73 & 34,48 \\
\hline \multirow{3}{*}{$\begin{array}{l}\text { Europa - } \\
\text { Polônia }\end{array}$} & $n$ & 11 & 11 & 11 & 11 & 11 & 11 & $\overline{11}$ & 11 & 11 \\
\hline & $\%$ & 100,00 & 100,00 & 100,00 & 100,00 & 100,00 & 100,00 & 100,00 & 100,00 & 100,00 \\
\hline & média & 135,45 & 113,18 & 110,82 & 93,77 & 97,55 & 133,18 & 69,45 & 22,41 & 32,68 \\
\hline \multirow{3}{*}{$\begin{array}{l}\text { Europa - } \\
\text { Portugal }\end{array}$} & $n$ & 7 & 7 & 7 & 7 & 7 & 7 & 7 & 7 & 7 \\
\hline & $\%$ & 100,00 & 100,00 & 100,00 & 100,00 & 100,00 & 100,00 & 100,00 & 100,00 & 100,00 \\
\hline & média & 134,43 & 116,86 & 112,71 & 99,14 & 95,14 & 129,86 & 69,14 & 21,71 & 33,36 \\
\hline \multirow{3}{*}{$\begin{array}{l}\text { Europa - } \\
\text { Romênia }\end{array}$} & $\mathrm{n}$ & 12 & 12 & 11 & 11 & 12 & 11 & 12 & 12 & 12 \\
\hline & $\%$ & 100,00 & 100,00 & 91,67 & 91,67 & 100,00 & 91,67 & 100,00 & 100,00 & 100,00 \\
\hline & média & 133,67 & 111,17 & 110,91 & 93,91 & 95,00 & 131,91 & 69,83 & 22,08 & 34,75 \\
\hline \multirow{3}{*}{$\begin{array}{l}\text { Europa - } \\
\text { Rússia }\end{array}$} & $n$ & 43 & 43 & 43 & 43 & 40 & 43 & 42 & 43 & 43 \\
\hline & $\%$ & 97,73 & 97,73 & 97,73 & 97,73 & 90,91 & 97,73 & 95,45 & 97,73 & 97,73 \\
\hline & média & 134,26 & 113,26 & 113,47 & 95,14 & 96,83 & 134,33 & 68,86 & 22,49 & 33,53 \\
\hline \multirow{3}{*}{$\begin{array}{l}\text { Europa - } \\
\text { Espanha } 1\end{array}$} & $n$ & 14 & 14 & 14 & 13 & 13 & 13 & 13 & 14 & 14 \\
\hline & $\%$ & 100,00 & 100,00 & 100,00 & 92,86 & 92,86 & 92,86 & 92,86 & 100,00 & 100,00 \\
\hline & média & 134,29 & 113,86 & 113,86 & 98,85 & 98,23 & 128,69 & 68,85 & 22,43 & "'33,61 \\
\hline \multirow{3}{*}{$\begin{array}{l}\text { Europa - } \\
\text { Espanha } 2\end{array}$} & $n$ & 4 & 7 & 7 & 5 & 4 & 4 & 5 & 5 & 5 \\
\hline & $\%$ & 57,14 & 100,00 & 100,00 & 71,43 & 57,14 & 57,14 & 71,43 & 71,43 & 71,43 \\
\hline & média & 136,00 & 110,43 & 114,86 & 98,00 & 96,75 & 126,75 & 67,80 & 22,40 & 31,60 \\
\hline \multirow{3}{*}{$\begin{array}{l}\text { Europa - } \\
\text { Suécia }\end{array}$} & $n$ & 31 & 31 & 31 & 31 & 30 & 29 & 30 & 30 & 30 \\
\hline & $\%$ & 100,00 & 100,00 & 100,00 & 100,00 & 96,77 & 93,55 & 96,77 & 96,77 & 96,77 \\
\hline & média & 133,23 & 115,87 & 114,26 & 97,26 & 95,87 & 133,76 & 70,27 & 23,17 & 34,17 \\
\hline & $\mathrm{n}$ & 37 & 37 & 37 & 37 & 36 & 36 & 36 & 37 & 37 \\
\hline Sú́ca & $\%$ & 100,00 & 100,00 & 100,00 & 100,00 & 97,30 & 97,30 & 97,30 & 100,00 & 100,00 \\
\hline & média & 129,34 & 112,38 & 109,58 & 93,35 & 93,11 & 132,08 & 69,22 & 23,07 & 33,12 \\
\hline & $n$ & 25 & 25 & 25 & 25 & 25 & 19 & 26 & 26 & 26 \\
\hline Ucrânia & $\%$ & 96,15 & "96,15 & 96,15 & 96,15 & 96,15 & 73,08 & 100,00 & 100,00 & 100,00 \\
\hline & média & 130,96 & 109,76 & 107,30 & 94,10 & 93,92 & 134,03 & 67,27 & 23,19 & 32,13 \\
\hline & $\mathrm{n}$ & 30 & 34 & 32 & 23 & 29 & 27 & 33 & 33 & 34 \\
\hline$y_{1}$ & $\%$ & 88,24 & 100,00 & 94,12 & 67,65 & 85,29 & 79,41 & 97,06 & 97,06 & 100,00 \\
\hline & média & 133,53 & 111,62 & 111,11 & 95,57 & 94,64 & 131,98 & 65,20 & 22,89 & 32,72 \\
\hline & $\mathrm{n}$ & 14 & 14 & 12 & 13 & 15 & 14 & 15 & 15 & 15 \\
\hline Índia - Assam & $\%$ & 93,33 & 93,33 & 80,00 & 86,67 & 100,00 & 93,33 & 100,00 & 100,00 & 100,00 \\
\hline & média & 133,86 & 109,07 & 114,42 & 95,92 & 94,87 & 131,14 & 65,87 & 21,73 & 33,67 \\
\hline & $n$ & 50 & 50 & 49 & 49 & 50 & 49 & 50 & 50 & 50 \\
\hline & $\%$ & 98,04 & 98,04 & 96,08 & 96,08 & 98,04 & 96,08 & 98,04 & 98,04 & 98,04 \\
\hline & média & 131,89 & 109,90 & 112,73 & 91,63 & 94,60 & 125,81 & 63,02 & 21,71 & 32,52 \\
\hline & $\mathrm{n}$ & 21 & 21 & 20 & 20 & 18 & 21 & 21 & 21 & 21 \\
\hline Índia - Bihar & $\%$ & 100,00 & 100,00 & 95,24 & 95,24 & 85,71 & 100,00 & 100,00 & 100,00 & 100,00 \\
\hline & média & 131,10 & 109,57 & 113,60 & 92,70 & 94,17 & 123,95 & 62,14 & 20,29 & 32,33 \\
\hline & $n$ & 7 & 7 & 7 & 6 & $\overline{6}$ & 7 & 7 & 7 & 7 \\
\hline Bomb & $\%$ & 100,00 & 100,00 & 100,00 & 85,71 & 85,71 & 100,00 & 100,00 & 100,00 & 100,00 \\
\hline & média & 133,14 & 112,29 & 113,86 & 95,83 & 95,67 & 127,86 & 65,14 & 22,14 & 33,50 \\
\hline & $n$ & 16 & 17 & 17 & 17 & 16 & 16 & 17 & 17 & 17 \\
\hline Índia - Calcutá & $\%$ & 94,12 & 100,00 & 100,00 & 100,00 & 94,12 & 94,12 & 100,00 & 100,00 & 100,00 \\
\hline & média & 134,88 & 111,47 & 113,29 & 94,47 & 95,06 & 126,56 & 66,12 & 20,71 & 33,91 \\
\hline & $\mathrm{n}$ & 4 & 4 & 4 & 4 & 3 & 4 & 3 & 4 & 4 \\
\hline Índia - Central & $\%$ & 100,00 & 100,00 & 100,00 & 100,00 & 75,00 & 100,00 & 75,00 & 100,00 & 100,00 \\
\hline & média & 129,50 & 111,25 & 115,00 & 94,25 & 101,33 & 126,00 & 68,33 & 21,75 & 34,00 \\
\hline & $\mathrm{n}$ & 4 & 5 & 5 & 5 & 1 & 4 & 3 & $\overline{4}$ & 4 \\
\hline Índia - Delhi & $\%$ & 80,00 & 100,00 & 100,00 & 100,00 & 20,00 & 80,00 & 60,00 & 80,00 & 80,00 \\
\hline & média & 129,25 & 109,80 & 114,20 & 89,60 & 96,00 & 125,75 & 63,33 & 20,50 & 34,00 \\
\hline & $\mathrm{n}$ & 100 & 100 & 98 & 98 & 97 & 95 & 99 & 100 & 100 \\
\hline Índia - Madras & $\%$ & 100,00 & 100,00 & 98,00 & 98,00 & 97,00 & 95,00 & 99,00 & 100,00 & 100,00 \\
\hline & média & 131,91 & 110,37 & 111,36 & 92,46 & 95,58 & 124,88 & 62,69 & 21,42 & 31,87 \\
\hline & $n$ & 1 & 1 & 1 & 1 & 1 & 1 & 1 & 1 & 1 \\
\hline Índia - Mahalls & $\%$ & 100,00 & 100,00 & 100,00 & 100,00 & 100,00 & 100,00 & 100,00 & 100,00 & 100,00 \\
\hline & média & 137,00 & 113,00 & 119,00 & 85,00 & 99,00 & 127,00 & 68,00 & 22,00 & 30,50 \\
\hline & $\mathrm{n}$ & 10 & 10 & 10 & 10 & $\overline{9}$ & 10 & 10 & 10 & 10 \\
\hline Mala - & $\%$ & 100,00 & 100,00 & 100,00 & 100,00 & 90,00 & 100,00 & 100,00 & 100,00 & 100,00 \\
\hline & média & 132,90 & 110,30 & 112,50 & 94,90 & 95,56 & 122,90 & 62,30 & 21,20 & 32,00 \\
\hline & $\mathrm{n}$ & 11 & 11 & 9 & 9 & 11 & 11 & 11 & 11 & 11 \\
\hline Índia - Mysore & $\%$ & 100,00 & "100,00 & 81,82 & 81,82 & 100,00 & 100,00 & 100,00 & 100,00 & 100,00 \\
\hline & média & 129,91 & 107,73 & 109,22 & 92,33 & 97,50 & 122,36 & 61,23 & 22,27 & 31,82 \\
\hline
\end{tabular}




\begin{tabular}{|c|c|c|c|c|c|c|c|c|c|c|}
\hline \multirow{3}{*}{$\begin{array}{l}\text { Índia - } \\
\text { Noroeste }\end{array}$} & $\mathrm{n}$ & 29 & 29 & 28 & 28 & 24 & 27 & 26 & 27 & 27 \\
\hline & $\%$ & 100,00 & 100,00 & 96,55 & 96,55 & 82,76 & 93,10 & 89,66 & 93,10 & 93,10 \\
\hline & média & 129,24 & 108,17 & 111,96 & 91,68 & 94,83 & 126,41 & 62,54 & 21,89 & 32,61 \\
\hline \multirow{3}{*}{ Índia - Orissa } & $\mathrm{n}$ & 9 & 9 & 9 & $\overline{9}$ & 8 & 9 & $\overline{9}$ & $\overline{9}$ & 9 \\
\hline & $\%$ & 100,00 & 100,00 & 100,00 & 100,00 & 88,89 & 100,00 & 100,00 & 100,00 & 100,00 \\
\hline & média & 132,11 & 110,06 & 111,44 & 91,11 & 94,31 & 126,56 & 65,39 & 20,89 & 33,22 \\
\hline \multirow{3}{*}{ Índia - Pujab } & $\mathrm{n}$ & 73 & 73 & 73 & 72 & 65 & 72 & 70 & 72 & 72 \\
\hline & $\%$ & 100,00 & 100,00 & 100,00 & 98,63 & 89,04 & 98,63 & 95,89 & 98,63 & 98,63 \\
\hline & média & 132,12 & 110,85 & 114,40 & 94,10 & 97,06 & 128,17 & 66,59 & 21,92 & 33,65 \\
\hline \multirow{3}{*}{ Índia - Sikkim } & $\mathrm{n}$ & 25 & 25 & 24 & 24 & 25 & 25 & 25 & 25 & 25 \\
\hline & $\%$ & 100,00 & 100,00 & 96,00 & 96,00 & 100,00 & 100,00 & 100,00 & 100,00 & 100,00 \\
\hline & média & 132,96 & 109,44 & 112,42 & 94,58 & 95,12 & 130,96 & 65,20 & 22,72 & 33,52 \\
\hline \multirow{3}{*}{ Índia - Veddah } & $\mathrm{n}$ & 17 & 17 & 17 & 17 & 15 & 15 & 15 & 17 & 17 \\
\hline & $\%$ & 94,44 & "'94,44" & 94,44 & 94,44 & 83,33 & 83,33 & 83,33 & 94,44 & 94,44 \\
\hline & média & 131,18 & 110,00 & 112,12 & 92,00 & 94,80 & 122,87 & 59,33 & 20,59 & 32,24 \\
\hline \multirow{3}{*}{$\begin{array}{l}\text { Melanésia - } \\
\text { Bismarck }\end{array}$} & $\mathrm{n}$ & 15 & 15 & 15 & 15 & 15 & 14 & 15 & 15 & 15 \\
\hline & $\%$ & 100,00 & 100,00 & 100,00 & 100,00 & 100,00 & 93,33 & 100,00 & 100,00 & 100,00 \\
\hline & média & 133,67 & 108,73 & 114,27 & 97,27 & 103,23 & 130,46 & 65,17 & 22,13 & 33,20 \\
\hline \multirow{3}{*}{$\begin{array}{c}\text { Melanésia - } \\
\text { Fiji }\end{array}$} & $\mathrm{n}$ & 40 & 45 & 46 & 43 & 33 & 39 & 39 & 32 & 42 \\
\hline & $\%$ & 85,11 & 95,74 & 97,87 & 91,49 & 70,21 & 82,98 & 82,98 & 68,09 & 89,36 \\
\hline & média & 138,05 & 113,51 & 119,07 & 98,74 & 103,24 & 131,74 & 66,26 & 21,72 & 34,32 \\
\hline \multirow{3}{*}{$\begin{array}{l}\text { Melanésia - } \\
\text { Nova Bretanha }\end{array}$} & $\mathrm{n}$ & 70 & 71 & 71 & $\overline{71}$ & 65 & 64 & 67 & $\overline{71}$ & 71 \\
\hline & $\%$ & 94,59 & 95,95 & 95,95 & 95,95 & 87,84 & 86,49 & 90,54 & 95,95 & 95,95 \\
\hline & média & 136,46 & 109,70 & 116,99 & 96,89 & 105,45 & 135,34 & 65,22 & 22,92 & 32,70 \\
\hline \multirow{3}{*}{$\begin{array}{c}\text { Melanésia - } \\
\text { Nova } \\
\text { Caledônia } \\
\end{array}$} & $\mathrm{n}$ & 47 & 49 & 47 & 46 & 42 & 45 & $\overline{44}$ & $\overline{45}$ & 47 \\
\hline & $\%$ & 92,16 & 96,08 & 92,16 & 90,20 & 82,35 & 88,24 & 86,27 & 88,24 & 92,16 \\
\hline & média & 136,74 & 113,80 & 116,43 & 97,92 & 106,19 & 134,93 & 64,08 & 23,23 & 32,85 \\
\hline Melanésia - & $\mathrm{n}$ & 50 & 51 & 51 & 51 & 47 & 43 & 48 & 50 & 50 \\
\hline "Now & $\%$ & 96,15 & 98,08 & 98,08 & 98,08 & 90,38 & 82,69 & 92,31 & 96,15 & 96,15 \\
\hline Hebrides" & média & 131,56 & 110,66 & 118,09 & 95,00 & 105,23 & 134,80 & 65,96 & 22,54 & 32,69 \\
\hline & $n$ & 33 & 34 & 34 & 32 & 31 & 29 & 31 & 33 & 33 \\
\hline & $\%$ & 94,29 & 97,14 & 97,14 & 91,43 & 88,57 & 82,86 & 88,57 & 94,29 & 94,29 \\
\hline & média & 134,74 & 109,72 & 116,81 & 95,03 & 102,50 & 132,41 & 67,79 & 22,17 & 34,08 \\
\hline & $\mathrm{n}$ & 16 & 16 & 16 & 16 & 12 & 15 & $\overline{13}$ & $\overline{16}$ & 16 \\
\hline Me & $\%$ & 100,00 & "100,00" & 100,00 & 100,00 & 75,00 & 93,75 & 81,25 & 100,00 & 100,00 \\
\hline & média & 133,00 & 110,88 & 119,38 & 94,88 & 103,58 & 130,00 & 63,92 & 21,88 & 33,28 \\
\hline & $\mathrm{n}$ & 65 & 71 & 70 & 66 & 58 & 63 & 63 & 69 & 71 \\
\hline Melanesia - & $\%$ & 91,55 & 100,00 & 98,59 & 92,96 & 81,69 & 88,73 & 88,73 & 97,18 & 100,00 \\
\hline & média & 134,95 & 110,04 & 115,26 & 95,98 & 101,11 & 132,70 & 65,34 & 21,90 & 33,50 \\
\hline & $n$ & 57 & 61 & 55 & 50 & 57 & 52 & 61 & 61 & 61 \\
\hline lanesia - & $\%$ & 93,44 & "'to0,00 & 90,16 & 81,97 & 93,44 & 85,25 & 100,00 & 100,00 & 100,00 \\
\hline & média & 134,28 & 111,41 & 115,84 & 96,92 & 106,28 & 134,46 & 67,15 & 22,80 & 32,94 \\
\hline & $\mathrm{n}$ & 22 & 22 & 22 & 21 & 22 & 20 & 22 & 21 & 22 \\
\hline & $\%$ & 100,00 & 100,00 & 100,00 & 95,45 & 100,00 & 90,91 & 100,00 & 95,45 & 100,00 \\
\hline & média & 138,73 & "'111,93 & 117,11 & 97,12 & 101,73 & 132,93 & 66,61 & 21,76 & 33,95 \\
\hline Micrn & $n$ & 22 & 26 & 23 & 20 & 20 & 21 & $\overline{24}$ & 25 & 24 \\
\hline IVICrol & $\%$ & 84,62 & 100,00 & 88,46 & 76,92 & 76,92 & 80,77 & 92,31 & 96,15 & 92,31 \\
\hline & média & 141,27 & 114,19 & 112,98 & 98,43 & 99,35 & 140,24 & 65,58 & 21,86 & 34,69 \\
\hline & $n$ & 89 & 89 & 89 & 88 & 89 & 78 & $\overline{89}$ & $\overline{86}$ & 89 \\
\hline - Egito 1 & $\%$ & 100,00 & 100,00 & 100,00 & 98,88 & 100,00 & 87,64 & 100,00 & 96,63 & 100,00 \\
\hline & média & 135,64 & 112,85 & 115,56 & 98,80 & 97,36 & 127,87 & 69,47 & 22,04 & 33,44 \\
\hline & $n$ & 14 & 14 & 14 & 14 & 14 & 12 & 14 & $\overline{13}$ & 14 \\
\hline Norte & $\%$ & 100,00 & 100,00 & 100,00 & 100,00 & 100,00 & 85,71 & 100,00 & 92,86 & 100,00 \\
\hline & média & 130,89 & 109,50 & 115,14 & 96,96 & 96,00 & 127,50 & 67,21 & 22,46 & 32,71 \\
\hline & $\mathrm{n}$ & 17 & 18 & 18 & 18 & 17 & 17 & 18 & 18 & 18 \\
\hline Norte a & $\%$ & 94,44 & 100,00 & 100,00 & 100,00 & 94,44 & 94,44 & 100,00 & 100,00 & 100,00 \\
\hline & média & 133,79 & 113,61 & 114,97 & 97,19 & 95,06 & - 131,12 & 69,22 & 21,78 & 33,61 \\
\hline & $\mathrm{n}$ & 39 & 40 & 41 & 37 & 36 & 35 & 37 & 34 & 37 \\
\hline - Faito Badari & $\%$ & 95,12 & 97,56 & 100,00 & 90,24 & 87,80 & 85,37 & 90,24 & 82,93 & 90,24 \\
\hline & média & 132,13 & "'110,40 & 114,68 & 96,41 & 96,61 & "123,69 & 63,70 & 23,07 & 32,00 \\
\hline & $n$ & 100 & 100 & 100 & 100 & 100 & 100 & 100 & 100 & 100 \\
\hline & $\%$ & 100,00 & 100,00 & 100,00 & 100,00 & 100,00 & 100,00 & 100,00 & 100,00 & 100,00 \\
\hline & média & 134,46 & 113,55 & 115,22 & 97,23 & 95,41 & 129,18 & 68,49 & 22,17 & 33,83 \\
\hline Norte da África & $\mathrm{n}$ & 80 & 80 & 80 & 76 & 77 & 69 & 78 & 79 & 79 \\
\hline & $\%$ & 100,00 & 100,00 & 100,00 & 95,00 & 96,25 & 86,25 & 97,50 & 98,75 & 98,75 \\
\hline Naqada & média & 133,43 & 111,20 & 115,89 & 95,66 & 97,61 & 127,80 & 66,15 & 22,66 & 32,49 \\
\hline & $\mathrm{n}$ & 29 & 30 & 30 & 29 & 28 & 27 & 29 & 29 & 29 \\
\hline Norle ua Alnica & $\%$ & 96,67 & 100,00 & 100,00 & 96,67 & 93,33 & 90,00 & 96,67 & 96,67 & 96,67 \\
\hline & média & 132,29 & 111,37 & 113,20 & 96,33 & 94,27 & 130,43 & 64,41 & 22,98 & 31,78 \\
\hline & $\mathrm{n}$ & 42 & 44 & 45 & 42 & 39 & 36 & 41 & 44 & 44 \\
\hline
\end{tabular}




\begin{tabular}{|c|c|c|c|c|c|c|c|c|c|c|}
\hline \multirow[b]{2}{*}{ Norte da África } & $\mathrm{n}$ & 42 & 44 & 45 & 42 & 39 & 36 & 41 & 44 & 44 \\
\hline & média & 194,60 & 198,65 & 196,83 & 97,00 & $18 \theta, 28$ & 128,96 & $8 \theta, 88$ & 23,66 & 98,68 \\
\hline \multirow{3}{*}{$\begin{array}{c}\text { Norte Nábia Africa } \\
\text { - Núbia } 2\end{array}$} & $n$ & 77 & 78 & $\overline{78}$ & 75 & 75 & 68 & $\overline{76}$ & 77 & 77 \\
\hline & $\%$ & 98,72 & 100,00 & 100,00 & 96,15 & 96,15 & 87,18 & 97,44 & 98,72 & 98,72 \\
\hline & média & 131,78 & ' & 115,13 & 95,16 & 95,56 & 127,59 & 66,30 & 22,39 & 34,57 \\
\hline \multirow{3}{*}{$\begin{array}{l}\text { Norte da África } \\
\text { - Kerma }\end{array}$} & $\mathrm{n}$ & 82 & 86 & 86 & 80 & 81 & 81 & 85 & 86 & 86 \\
\hline & $\%$ & 95,35 & 100,00 & 100,00 & 93,02 & 94,19 & 94,19 & 98,84 & 100,00 & 100,00 \\
\hline & média & 134,26 & 112,86 & 116,40 & 96,89 & 98,35 & 128,40 & 65,78 & 23,40 & 32,61 \\
\hline \multirow{3}{*}{$\begin{array}{l}\text { Nordeste } \\
\text { Asiático - } \\
\text { Amur }\end{array}$} & $\mathrm{n}$ & 9 & 10 & 10 & 9 & 10 & 9 & 10 & 10 & 10 \\
\hline & $\%$ & 81,82 & 90,91 & 90,91 & 81,82 & 90,91 & 81,82 & 90,91 & 90,91 & 90,91 \\
\hline & média & 129,33 & 111,70 & 105,70 & 95,11 & 99,80 & 136,44 & 72,50 & 21,50 & 34,95 \\
\hline \multirow{3}{*}{$\begin{array}{l}\text { Nordeste } \\
\text { Asiático - } \\
\text { Buriat }\end{array}$} & $\mathrm{n}$ & 26 & 26 & 27 & 27 & 23 & 25 & 23 & 26 & 25 \\
\hline & $\%$ & 96,30 & 96,30 & 100,00 & 100,00 & 85,19 & 92,59 & 85,19 & 96,30 & 92,59 \\
\hline & média & 130,87 & 111,08 & 108,74 & 96,11 & 96,26 & 138,02 & 73,54 & 21,65 & 35,28 \\
\hline \multirow{3}{*}{$\begin{array}{l}\text { Nordeste } \\
\text { Asiático - } \\
\text { Chukchi }\end{array}$} & $\mathrm{n}$ & 21 & 21 & 21 & 21 & 21 & 19 & 21 & 21 & 21 \\
\hline & $\%$ & 100,00 & 100,00 & 100,00 & 100,00 & 100,00 & 90,48 & 100,00 & 100,00 & 100,00 \\
\hline & média & 133,86 & 112,14 & 111,43 & 96,67 & 101,81 & 139,95 & 75,48 & 19,64 & 36,57 \\
\hline \multirow{3}{*}{$\begin{array}{l}\text { Nordeste } \\
\text { Asiático - } \\
\text { Evenki } \\
\end{array}$} & $\mathrm{n}$ & 2 & 2 & 2 & 2 & 2 & 2 & 2 & 2 & 2 \\
\hline & $\%$ & 100,00 & 100,00 & 100,00 & 100,00 & 100,00 & 100,00 & 100,00 & 100,00 & 100,00 \\
\hline & média & 126,50 & 110,50 & 107,00 & 89,00 & 100,00 & 136,50 & 70,50 & 24,00 & 34,00 \\
\hline \multirow{3}{*}{$\begin{array}{l}\text { Nordeste } \\
\text { Asiático - } \\
\text { Mongóis }\end{array}$} & $\mathrm{n}$ & 144 & 146 & 143 & 143 & 142 & 137 & 145 & 149 & 148 \\
\hline & $\%$ & 95,36 & 96,69 & 94,70 & 94,70 & 94,04 & 90,73 & 96,03 & 98,68 & 98,01 \\
\hline & média & 131,25 & 112,82 & 110,39 & 95,43 & 97,31 & 141,25 & 74,53 & 21,59 & 36,22 \\
\hline \multirow{3}{*}{$\begin{array}{l}\text { Nordeste } \\
\text { Asiático - } \\
\text { Neolítico } \\
\end{array}$} & $\mathrm{n}$ & 1 & 1 & 1 & 1 & 1 & 1 & $\overline{1}$ & 1 & $\overline{1}$ \\
\hline & $\%$ & 100,00 & 100,00 & 100,00 & 100,00 & 100,00 & 100,00 & 100,00 & 100,00 & 100,00 \\
\hline & média & 126,00 & 117,00 & 109,00 & 96,00 & 104,00 & 137,00 & 77,00 & 19,00 & 36,00 \\
\hline \multirow{3}{*}{$\begin{array}{l}\text { Nordeste } \\
\text { Asiático - } \\
\text { Nivkh }\end{array}$} & $\mathrm{n}$ & 4 & 4 & $\overline{4}$ & $\overline{4}$ & $\overline{4}$ & 4 & 4 & $\overline{4}$ & $\overline{4}$ \\
\hline & $\%$ & 100,00 & 100,00 & 100,00 & 100,00 & 100,00 & 100,00 & 100,00 & 100,00 & 100,00 \\
\hline & média & 127,25 & 111,00 & 102,50 & 96,00 & 101,00 & 137,00 & 72,50 & 21,25 & 35,13 \\
\hline \multirow{3}{*}{$\begin{array}{l}\text { Nordeste } \\
\text { Asiático - } \\
\text { Yakut }\end{array}$} & $\mathrm{n}$ & 4 & 4 & 4 & 4 & 4 & 4 & 4 & 4 & 4 \\
\hline & $\%$ & 100,00 & 100,00 & 100,00 & 100,00 & 100,00 & 100,00 & 100,00 & 100,00 & 100,00 \\
\hline & média & 135,00 & 114,50 & 111,25 & 95,25 & 98,50 & 137,25 & 70,75 & 21,50 & 32,50 \\
\hline \multirow{3}{*}{$\begin{array}{l}\text { Papua Nova } \\
\text { Guiné - } \\
\text { Província } \\
\text { Central }\end{array}$} & $\mathrm{n}$ & 9 & 9 & 8 & 8 & 8 & 9 & 8 & 9 & 9 \\
\hline & $\%$ & 100,00 & 100,00 & 88,89 & 88,89 & 88,89 & 100,00 & 88,89 & 100,00 & 100,00 \\
\hline & média & 130,00 & 107,22 & 110,13 & 94,38 & 98,00 & 130,89 & 64,50 & 22,67 & 33,50 \\
\hline Papua Nova & $n$ & 19 & 20 & 20 & 19 & 17 & 19 & 18 & 20 & 20 \\
\hline Guiné - & $\%$ & 90,48 & 95,24 & 95,24 & 90,48 & 80,95 & 90,48 & 85,71 & 95,24 & 95,24 \\
\hline Eastern Is & média & 134,84 & 110,10 & 113,45 & 95,00 & 103,94 & 135,42 & 65,61 & 22,70 & 32,98 \\
\hline Papua Nova & $\mathrm{n}$ & 32 & 32 & 30 & 28 & 30 & 28 & 31 & 31 & 32 \\
\hline Guiné - & $\%$ & 96,97 & 96,97 & 90,91 & 84,85 & 90,91 & 84,85 & 93,94 & 93,94 & 96,97 \\
\hline Golfo & média & 132,16 & 109,72 & 116,17 & 95,64 & 102,27 & 127,50 & 66,81 & 22,10 & 33,88 \\
\hline Papua Nova & $\mathrm{n}$ & 31 & 33 & 33 & 32 & $\overline{31}$ & 30 & 33 & $\overline{33}$ & $\overline{33}$ \\
\hline Guiné - & $\%$ & 93,94 & 100,00 & 100,00 & 96,97 & 93,94 & 90,91 & 100,00 & 100,00 & 100,00 \\
\hline Madang & média & 131,82 & 109,74 & 111,12 & 94,67 & 100,32 & 131,42 & 64,67 & 22,09 & 32,95 \\
\hline Papua Nova & $\mathrm{n}$ & 3 & 3 & $\overline{3}$ & 3 & $\overline{3}$ & 3 & $\overline{3}$ & $\overline{3}$ & $\overline{3}$ \\
\hline Guiné - & $\%$ & 100,00 & 100,00 & 100,00 & 100,00 & 100,00 & 100,00 & 100,00 & 100,00 & 100,00 \\
\hline $\begin{array}{l}\text { Bay } \\
\text { B. }\end{array}$ & média & 131,67 & 111,00 & 111,67 & 94,67 & 100,00 & 134,33 & 69,00 & 23,67 & 34,67 \\
\hline Papua Nova & $\mathrm{n}$ & 27 & 26 & 27 & 29 & 26 & 26 & 26 & 26 & 26 \\
\hline Guiné - & $\%$ & 93,10 & 89,66 & 93,10 & 100,00 & 89,66 & 89,66 & 89,66 & 89,66 & 89,66 \\
\hline Sepik Oriental & média & 133,33 & 108,40 & 114,00 & 94,09 & 105,04 & 130,10 & 66,71 & 22,31 & 33,31 \\
\hline Papua Nova & $\mathrm{n}$ & 24 & 24 & 24 & 24 & 24 & 24 & 24 & 24 & 24 \\
\hline Guiné - & $\%$ & 100,00 & 100,00 & 100,00 & 100,00 & 100,00 & 100,00 & 100,00 & 100,00 & 100,00 \\
\hline Sepik & média & & & & & & & & & \\
\hline Ocidental & & 132,06 & 110,50 & 114,92 & 94,75 & 100,90 & 128,98 & 64,44 & 22,71 & 32,81 \\
\hline Papua Nova & $\mathrm{n}$ & 17 & 17 & 16 & $\overline{14}$ & 17 & 17 & 18 & 18 & 18 \\
\hline Guiné - & $\%$ & 94,44 & "94,44" & 88,89 & 77,78 & 94,44 & 94,44 & 100,00 & 100,00 & 100,00 \\
\hline "desconhecido" & média & 133,47 & 110,24 & 113,44 & 96,43 & 101,18 & 129,35 & 65,94 & 21,39 & 34,67 \\
\hline Papua Nova & $\mathrm{n}$ & 14 & 15 & 14 & 13 & 11 & 11 & 13 & 14 & 14 \\
\hline Guiné - & $\%$ & 93,33 & 100,00 & 93,33 & 86,67 & 73,33 & 73,33 & 86,67 & 93,33 & 93,33 \\
\hline Ocidental 1 & média & 130,64 & 108,53 & 115,79 & 97,00 & 102,45 & 130,36 & 66,92 & 21,36 & 34,50 \\
\hline Papua Nova & $\mathrm{n}$ & 10 & 14 & 14 & 6 & 10 & 13 & 14 & 14 & 14 \\
\hline Guiné - & $\%$ & 71,43 & 100,00 & 100,00 & 42,86 & 71,43 & 92,86 & 100,00 & 100,00 & 100,00 \\
\hline Ocidental 2 & média & 133,10 & 108,21 & 114,36 & 94,00 & 104,40 & 127,92 & 66,00 & 21,64 & 32,86 \\
\hline & $\mathrm{n}$ & 73 & 74 & 75 & $\overline{74}$ & $\overline{71}$ & 71 & $\overline{71}$ & $\overline{72}$ & $\overline{73}$ \\
\hline
\end{tabular}




\begin{tabular}{|c|c|c|c|c|c|c|c|c|c|c|}
\hline \multirow[b]{2}{*}{$\begin{array}{l}\text { Polinésia - } \\
\text { Moriori (llhas }\end{array}$} & $n$ & 73 & 74 & 75 & 74 & 71 & 71 & 71 & 72 & 73 \\
\hline & média & $\begin{array}{r}96,05 \\
135,48\end{array}$ & $\begin{array}{r}97,37 \\
113,95\end{array}$ & $\begin{array}{r}98,68 \\
110,42\end{array}$ & $\begin{array}{r}97,37 \\
101,50\end{array}$ & $\begin{array}{r}93,42 \\
101,70\end{array}$ & $\begin{array}{r}93,42 \\
137,77\end{array}$ & $\begin{array}{l}93,42 \\
71,96\end{array}$ & $\begin{array}{l}94,74 \\
20,35\end{array}$ & $\begin{array}{l}96,05 \\
37,07\end{array}$ \\
\hline \multirow{3}{*}{$\begin{array}{l}\text { Pollinataña } \\
\text { llhas Cook }\end{array}$} & $n$ & 13 & 15 & 13 & 12 & 11 & 12 & 13 & 12 & 14 \\
\hline & $\%$ & 86,67 & 100,00 & 86,67 & 80,00 & 73,33 & 80,00 & 86,67 & 80,00 & 93,33 \\
\hline & média & 140,92 & 114,40 & 112,85 & 99,92 & 100,73 & 137,08 & 68,00 & 22,75 & 34,64 \\
\hline \multirow{3}{*}{$\begin{array}{l}\text { Polinésia - } \\
\text { Ilhas Easter }\end{array}$} & $\mathrm{n}$ & 61 & 69 & 67 & 60 & 56 & 52 & 59 & 65 & 65 \\
\hline & $\%$ & 75,31 & 85,19 & 82,72 & 74,07 & 69,14 & 64,20 & 72,84 & 80,25 & 80,25 \\
\hline & média & 144,33 & 116,68 & 116,15 & 99,84 & 106,03 & 136,06 & 66,97 & 22,78 & 34,28 \\
\hline \multirow{3}{*}{$\begin{array}{l}\text { Polinésia - } \\
\text { Havaí }\end{array}$} & $\mathrm{n}$ & 72 & 72 & 72 & 71 & 71 & 68 & 70 & 72 & 72 \\
\hline & $\%$ & 100,00 & 100,00 & 100,00 & 98,61 & 98,61 & 94,44 & 97,22 & 100,00 & 100,00 \\
\hline & média & 140,82 & 116,08 & 110,43 & 99,99 & 101,83 & 135,31 & 67,86 & 21,79 & 34,85 \\
\hline \multirow{3}{*}{$\begin{array}{l}\begin{array}{l}\text { Polinésia - } \\
\text { Ilhas } \\
\text { Marquesas }\end{array} \\
\end{array}$} & $n$ & 61 & 66 & 66 & 64 & 61 & 66 & 65 & 66 & 66 \\
\hline & $\%$ & 92,42 & 100,00 & 100,00 & 96,97 & 92,42 & 100,00 & 98,48 & 100,00 & 100,00 \\
\hline & média & 137,80 & 116,20 & 110,33 & 100,46 & 102,65 & 135,86 & 69,74 & 20,85 & 35,57 \\
\hline \multirow{3}{*}{$\begin{array}{l}\text { Polinésia- } \\
\text { Maori Nova } \\
\text { Zelândia } \\
\end{array}$} & $n$ & 117 & 120 & 119 & 115 & 114 & 112 & 117 & 119 & 119 \\
\hline & $\%$ & 97,50 & 100,00 & 99,17 & 95,83 & 95,00 & 93,33 & 97,50 & 99,17 & 99,17 \\
\hline & média & 137,95 & 114,78 & 111,86 & 100,29 & 100,95 & 138,21 & 68,47 & 20,89 & 35,11 \\
\hline \multirow{3}{*}{$\begin{array}{l}\text { Polinésia - } \\
\text { Ilhas Society }\end{array}$} & $n$ & 45 & 49 & 49 & 47 & 44 & 44 & 48 & 48 & 48 \\
\hline & $\%$ & 91,84 & 100,00 & 100,00 & 95,92 & 89,80 & 89,80 & 97,96 & 97,96 & 97,96 \\
\hline & média & 140,10 & 114,88 & 112,80 & 99,76 & 102,16 & 133,31 & 68,58 & 20,74 & 35,41 \\
\hline \multirow{3}{*}{$\begin{array}{l}\text { Polinésia - } \\
\text { Samoa Tonga }\end{array}$} & $\mathrm{n}$ & 20 & 21 & 20 & 19 & 17 & 16 & 17 & 15 & 19 \\
\hline & $\%$ & 90,91 & 95,45 & 90,91 & 86,36 & 77,27 & 72,73 & 77,27 & 68,18 & 86,36 \\
\hline & média & 142,10 & 114,79 & 109,00 & 98,37 & 100,65 & 140,44 & 69,06 & 21,73 & 35,97 \\
\hline \multirow{3}{*}{$\begin{array}{c}\text { Sudeste } \\
\text { Asiático - Ilhas } \\
\text { Andaman } \\
\end{array}$} & $n$ & 52 & 53 & 53 & 53 & 48 & 52 & 50 & 51 & 52 \\
\hline & $\%$ & 98,11 & 100,00 & 100,00 & 100,00 & 90,57 & 98,11 & 94,34 & 96,23 & 98,11 \\
\hline & média & 129,33 & 107,42 & 108,06 & 91,60 & 93,28 & 124,52 & 61,14 & 22,47 & 33,13 \\
\hline Sudeste & $\mathrm{n}$ & 5 & 5 & 4 & 3 & 5 & 5 & 5 & 5 & 5 \\
\hline & $\%$ & 100,00 & 100,00 & 80,00 & 60,00 & 100,00 & 100,00 & 100,00 & 100,00 & 100,00 \\
\hline & média & 134,80 & 108,80 & 110,50 & 94,67 & 97,40 & 133,20 & 65,40 & 21,20 & 33,20 \\
\hline Sudeste & $\mathrm{n}$ & 14 & 15 & 14 & 12 & 13 & 16 & 16 & 16 & 16 \\
\hline Asiático - & $\%$ & 82,35 & 88,24 & 82,35 & 70,59 & 76,47 & 94,12 & 94,12 & 94,12 & 94,12 \\
\hline Borneo 1 & média & 134,50 & 110,73 & 113,79 & 93,25 & 97,46 & 133,06 & 67,25 & 23,00 & 33,72 \\
\hline Sudeste & $n$ & 70 & 78 & 72 & 65 & 65 & 72 & 74 & 76 & 78 \\
\hline Asiático - & $\%$ & 88,61 & 98,73 & 91,14 & 82,28 & 82,28 & 91,14 & 93,67 & 96,20 & 98,73 \\
\hline Bor & média & 136,23 & 111,13 & 115,57 & 97,68 & 97,46 & 132,01 & 64,95 & 23,02 & 33,24 \\
\hline Sudeste & $\mathrm{n}$ & 10 & 11 & 5 & 5 & 10 & 10 & 11 & 11 & 11 \\
\hline Asiático - & $\%$ & 90,91 & 100,00 & 45,45 & 45,45 & 90,91 & 90,91 & 100,00 & 100,00 & 100,00 \\
\hline Camboja & média & 137,20 & 111,36 & 110,20 & 94,00 & 97,00 & 134,00 & 66,09 & 22,09 & 33,05 \\
\hline Sudeste & $\mathrm{n}$ & 19 & 19 & 19 & 19 & 19 & 17 & 19 & 18 & 19 \\
\hline Asiático - & $\%$ & 100,00 & 100,00 & 100,00 & 100,00 & 100,00 & 89,47 & 100,00 & 94,74 & 100,00 \\
\hline Celebes & média & 134,95 & 109,89 & 109,79 & 97,11 & 98,11 & 133,29 & 66,89 & 22,00 & 33,87 \\
\hline Sudeste & $\mathrm{n}$ & 1 & 0 & 1 & 1 & 1 & 0 & 0 & 0 & 0 \\
\hline Asiático - Laos & $\%$ & 100,00 & 0,00 & 100,00 & 100,00 & 100,00 & 0,00 & 0,00 & 0,00 & 0,00 \\
\hline (early) & média & 141,00 & 0,00 & 110,00 & 102,00 & 90,00 & 0,00 & 0,00 & 0,00 & 0,00 \\
\hline Sudeste & $n$ & 1 & 2 & 3 & 2 & 0 & 1 & 3 & 2 & 3 \\
\hline Asiático - & $\%$ & 12,50 & 25,00 & 37,50 & 25,00 & 0,00 & 12,50 & 37,50 & 25,00 & 37,50 \\
\hline Malásia (early) & média & 136,00 & 111,50 & 118,67 & 100,50 & 0,00 & 137,00 & 62,00 & 24,00 & 31,00 \\
\hline Sudeste & $n$ & 8 & 19 & 17 & 9 & 6 & 4 & 11 & 9 & 10 \\
\hline Asiático - & $\%$ & 34,78 & 82,61 & 73,91 & 39,13 & 26,09 & 17,39 & 47,83 & 39,13 & 43,48 \\
\hline Vietnam (early) & média & 137,38 & 113,26 & 118,76 & 99,00 & 98,50 & 137,50 & 63,82 & 22,78 & 33,05 \\
\hline Sudeste & $n$ & 4 & 4 & 4 & 4 & 4 & 4 & 4 & 4 & 4 \\
\hline Asiático - & $\%$ & 100,00 & 100,00 & 100,00 & 100,00 & 100,00 & 100,00 & 100,00 & 100,00 & 100,00 \\
\hline Flores & média & 135,00 & 111,25 & 112,00 & 92,25 & 94,75 & 135,00 & 63,00 & 21,25 & 33,88 \\
\hline & $n$ & 62 & 62 & 62 & 62 & 60 & 56 & 60 & 61 & 62 \\
\hline Aciáti & $\%$ & 100,00 & 100,00 & 100,00 & 100,00 & 96,77 & 90,32 & 96,77 & 98,39 & 100,00 \\
\hline & média & 136,13 & 111,81 & 111,26 & 96,89 & 99,08 & 134,61 & 67,02 & 23,07 & 33,96 \\
\hline & $n$ & 31 & 32 & 18 & 18 & 32 & 30 & 32 & 32 & 32 \\
\hline Asiático & $\%$ & 96,88 & 100,00 & 56,25 & 56,25 & 100,00 & 93,75 & 100,00 & 100,00 & 100,00 \\
\hline & média & 134,00 & 109,22 & 109,94 & 94,89 & 95,47 & 133,30 & 66,31 & 21,63 & 33,64 \\
\hline Sudeste & $\mathrm{n}$ & 53 & 53 & 48 & 46 & 48 & 52 & 51 & 54 & 54 \\
\hline Asiático - & $\%$ & 94,64 & 94,64 & 85,71 & 82,14 & 85,71 & 92,86 & 91,07 & 96,43 & 96,43 \\
\hline Malásia & média & 134,50 & 111,42 & 110,90 & 95,48 & 97,56 & 131,89 & 66,51 & 21,80 & 33,65 \\
\hline Sudeste & $n$ & 22 & 22 & 19 & 19 & 21 & 21 & 21 & 22 & 22 \\
\hline Asiático - & $\%$ & 100,00 & 100,00 & 86,36 & 86,36 & 95,45 & 95,45 & 95,45 & 100,00 & 100,00 \\
\hline Molucca & média & 132,23 & 110,32 & 109,61 & 97,29 & 98,98 & 131,36 & 66,62 & 22,57 & 33,98 \\
\hline Sudeste & $n$ & 101 & 103 & 88 & 87 & 98 & 94 & 98 & 102 & 103 \\
\hline Asiático - & $\%$ & 98,06 & 100,00 & 85,44 & 84,47 & 95,15 & 91,26 & 95,15 & 99,03 & 100,00 \\
\hline Myanmar & média & 134,77 & 111,62 & 111,90 & 95,93 & 96,72 & 131,63 & 67,40 & 22,28 & 33,75 \\
\hline & $n$ & 22 & 22 & 21 & 21 & 22 & 22 & 22 & 22 & 22 \\
\hline & $\%$ & 100,00 & 100,00 & 95,45 & 95,45 & 100,00 & 100,00 & 100,00 & 100,00 & 100,00 \\
\hline
\end{tabular}




\begin{tabular}{|c|c|c|c|c|c|c|c|c|c|c|}
\hline $\begin{array}{l}\text { Filipinas } \\
\text { (negrito) }\end{array}$ & média & 129,59 & 107,95 & 108,76 & 91,00 & 92,91 & 129,05 & 62,36 & 21,77 & 32,57 \\
\hline \multirow{3}{*}{$\begin{array}{l}\text { Sudeste } \\
\text { Asiático - } \\
\text { Semang } \\
\text { (negrito) }\end{array}$} & $n$ & 1 & 1 & 1 & 1 & 1 & 1 & 1 & 1 & 1 \\
\hline & $\%$ & 100,00 & 100,00 & 100,00 & 100,00 & 100,00 & 100,00 & 100,00 & 100,00 & 100,00 \\
\hline & média & 127,00 & 106,00 & 104,00 & 85,00 & 95,00 & 131,00 & 62,00 & 20,00 & 34,00 \\
\hline \multirow{3}{*}{$\begin{array}{l}\text { Sudeste } \\
\text { Asiático - Is } \\
\text { Nicobar }\end{array}$} & $\mathrm{n}$ & 21 & 20 & 21 & 20 & 15 & 17 & 14 & 19 & 19 \\
\hline & $\%$ & 100,00 & 95,24 & 100,00 & 95,24 & 71,43 & 80,95 & 66,67 & 90,48 & 90,48 \\
\hline & média & 134,64 & 110,18 & 117,48 & 94,65 & 98,60 & 128,82 & 64,00 & 22,16 & 32,50 \\
\hline \multirow{3}{*}{$\begin{array}{l}\text { Sudeste } \\
\text { Asiático - } \\
\text { Filipinas }\end{array}$} & $\mathrm{n}$ & 120 & 122 & 116 & 111 & 111 & 113 & 113 & 120 & 122 \\
\hline & $\%$ & 98,36 & 100,00 & 95,08 & 90,98 & 90,98 & 92,62 & 92,62 & 98,36 & 100,00 \\
\hline & média & 135,50 & 111,99 & 111,91 & 97,10 & 98,02 & 133,85 & 65,79 & 22,38 & 33,50 \\
\hline \multirow{3}{*}{$\begin{array}{c}\text { Sudeste } \\
\text { Asiático - } \\
\text { Singapura }\end{array}$} & $n$ & 43 & 43 & 43 & 43 & 43 & 43 & 43 & 43 & 43 \\
\hline & $\%$ & 100,00 & 100,00 & 100,00 & 100,00 & 100,00 & 100,00 & 100,00 & 100,00 & 100,00 \\
\hline & média & 136,92 & 111,33 & 110,64 & 96,50 & 95,93 & 133,36 & 67,59 & 22,35 & 33,17 \\
\hline \multirow{3}{*}{$\begin{array}{c}\text { Sudeste } \\
\text { Asiático - Sulu }\end{array}$} & $n$ & 5 & 5 & 5 & 5 & 5 & 4 & 4 & 4 & 5 \\
\hline & $\%$ & 100,00 & 100,00 & 100,00 & 100,00 & 100,00 & 80,00 & 80,00 & 80,00 & 100,00 \\
\hline & média & 131,00 & 110,80 & 108,40 & 96,20 & 97,00 & 131,00 & 65,00 & 22,25 & 34,40 \\
\hline \multirow{3}{*}{$\begin{array}{c}\text { Sudeste } \\
\text { Asiático - } \\
\text { Sumatra }\end{array}$} & $\mathrm{n}$ & 26 & 27 & 26 & 25 & 26 & 27 & 27 & 27 & 27 \\
\hline & $\%$ & 96,30 & 100,00 & 96,30 & 92.59 & 96,30 & 100,00 & 100,00 & 100.00 & 100,00 \\
\hline & média & 133,54 & 108,74 & 110,19 & 96,44 & 98,46 & 131,63 & 66,81 & 21,78 & 33,52 \\
\hline \multirow{3}{*}{$\begin{array}{l}\text { Sudeste } \\
\text { Asiático - } \\
\text { Sumbawa }\end{array}$} & $\mathrm{n}$ & 1 & 1 & 1 & 1 & 1 & 1 & 1 & 1 & 1 \\
\hline & $\%$ & 100,00 & 100,00 & 100,00 & 100,00 & 100,00 & 100,00 & 100,00 & 100,00 & 100,00 \\
\hline & média & 138,00 & 117,00 & 115,00 & 105,00 & 101,00 & 130,00 & 73,00 & 24,00 & 34,00 \\
\hline \multirow{3}{*}{$\begin{array}{l}\text { Sudeste } \\
\text { Asiático - } \\
\text { Tailândia }\end{array}$} & $\mathrm{n}$ & 45 & 47 & 30 & 30 & 47 & 47 & 47 & 47 & 47 \\
\hline & $\%$ & 95,74 & 100,00 & 63,83 & 63,83 & 100,00 & 100,00 & 100,00 & 100,00 & 100,00 \\
\hline & média & 137,11 & 111,65 & 111,27 & 96,13 & 96,68 & 133,96 & 67,95 & 22,01 & 33,77 \\
\hline \multirow{3}{*}{$\begin{array}{c}\text { Sudeste } \\
\text { Asiático - } \\
\text { Timor }\end{array}$} & $\mathrm{n}$ & 4 & 5 & 3 & 2 & 4 & 3 & 5 & 5 & 5 \\
\hline & $\%$ & 80,00 & "'100,00 & 60,00 & 40,00 & 80,00 & 60,00 & 100,00 & 100,00 & 100,00 \\
\hline & média & 132,50 & 109,40 & 109,33 & 101,00 & 96,50 & 129,33 & 68,00 & 21,60 & 34,60 \\
\hline \multirow{3}{*}{$\begin{array}{l}\text { Sudeste } \\
\text { Asiático - } \\
\text { Vietnam }\end{array}$} & $n$ & 22 & 23 & 23 & 22 & 22 & 22 & 23 & 24 & 24 \\
\hline & $\%$ & 91,67 & "95,83" & 95,83 & 91,67 & 91,67 & 91,67 & 95,83 & 100,00 & 100,00 \\
\hline & média & 137,86 & 112,48 & 113,78 & 95,55 & 97,23 & 134,95 & 66,70 & 22,67 & 33,13 \\
\hline & $\mathrm{n}$ & 33 & 33 & 33 & 31 & 33 & 33 & 33 & 33 & 33 \\
\hline Saariana - & $\%$ & 100,00 & 100,00 & 100,00 & 93,94 & 100,00 & 100,00 & 100,00 & 100,00 & 100,00 \\
\hline & média & 136,24 & 112,47 & 115,08 & 97,82 & 103,62 & 133,47 & 66,83 & 26,11 & 34,79 \\
\hline África Sub- & $\mathrm{n}$ & 14 & 18 & 18 & 15 & 14 & 15 & 16 & 16 & 16 \\
\hline Saariana - & $\%$ & 77,78 & "'100,00" & 100,00 & 83,33 & 77,78 & 83,33 & 88,89 & 88,89 & 88,89 \\
\hline Congo & média & 131,29 & 108,75 & 110,64 & 93,93 & 103,61 & 126,57 & 62,94 & 23,75 & 32,84 \\
\hline África Sub- & $n$ & 6 & 7 & 7 & 7 & 7 & 7 & 8 & 8 & 8 \\
\hline Saariana - & $\%$ & 75,00 & 87,50 & 87,50 & 87,50 & 87,50 & 87,50 & 100,00 & 100,00 & 100,00 \\
\hline África Oriental & média & 129,83 & " & 110,71 & 93,14 & 104,71 & 129,86 & 64,50 & 23,25 & 33,06 \\
\hline África Sub- & $n$ & 1 & 1 & 1 & 1 & $\overline{1}$ & $\overline{1}$ & 1 & 1 & $\overline{1}$ \\
\hline Saariana - & $\%$ & 100,00 & 100,00 & 100,00 & 100,00 & 100,00 & 100,00 & 100,00 & 100,00 & 100,00 \\
\hline $\begin{array}{c}\text { Africa } \\
\text { Equatorial }\end{array}$ & média & 143,50 & 115,00 & 116,00 & 95,00 & 111,00 & 146,00 & 71,00 & 25,00 & 35,00 \\
\hline África Sub- & $n$ & 8 & 8 & 8 & 8 & 8 & 8 & 8 & 8 & 8 \\
\hline Saariana - & $\%$ & 100,00 & "100,00" & 100,00 & 100,00 & 100,00 & 100,00 & 100,00 & 100,00 & 100,00 \\
\hline Etiópia & média & 132,38 & 113,63 & 113,69 & 95,81 & 105,00 & 130,69 & 69,25 & 24,44 & 34,31 \\
\hline África Sub- & $\mathrm{n}$ & 76 & 76 & 76 & 76 & 69 & 74 & 70 & 75 & 76 \\
\hline Saariana - & $\%$ & 100,00 & 100,00 & 100,00 & 100,00 & 90,79 & 97,37 & 92,11 & 98,68 & 100,00 \\
\hline Gabão & média & 135,03 & 111,66 & 112,74 & 96,79 & 101,43 & 128,61 & 65,49 & 24,09 & 34,07 \\
\hline África Sub- & $\mathrm{n}$ & 1 & 1 & 1 & 1 & 1 & 1 & 1 & 1 & 1 \\
\hline Saariana - & $\%$ & 100,00 & 100,00 & 100,00 & 100,00 & 100,00 & 100,00 & 100,00 & 100,00 & 100,00 \\
\hline Gâmbia & média & 130,00 & 105,00 & 121,00 & 93,00 & 97,00 & 123,00 & 65,00 & 21,00 & 32,50 \\
\hline África Sub- & $\mathrm{n}$ & 50 & 50 & 51 & 51 & 50 & 49 & 50 & 51 & 51 \\
\hline Saariana - & $\%$ & 98,04 & 98,04 & 100,00 & 100,00 & 98,04 & 96,08 & 98,04 & 100,00 & 100,00 \\
\hline Ashanti Gana & média & 134,67 & 111,24 & 115,91 & 97,08 & 104,12 & 128,90 & 65,95 & 24,05 & 33,84 \\
\hline África Sub- & $n$ & 3 & 3 & 3 & 3 & 3 & 3 & 3 & 3 & 3 \\
\hline Saariana - & $\%$ & 100,00 & 100,00 & 100,00 & 100,00 & 100,00 & 100,00 & 100,00 & 100,00 & 100,00 \\
\hline Guinea & média & 134,67 & "' 114,83 & 119,67 & 97,00 & 111,33 & 138,33 & 65,67 & 28,33 & 35,33 \\
\hline África Sub- & $n$ & 27 & 27 & 26 & 25 & 25 & 25 & 27 & 27 & 27 \\
\hline Saariana - & $\%$ & 100,00 & 100,00 & 96,30 & 92,59 & 92,59 & 92,59 & 100,00 & 100,00 & 100,00 \\
\hline $\begin{array}{l}\text { Costa do } \\
\text { Marfin }\end{array}$ & média & 135,93 & 111,04 & 115,92 & 96,60 & 103,88 & 130,96 & 66,11 & 24,93 & 33,76 \\
\hline África Sub- & $\bar{n}$ & 89 & 94 & 95 & 90 & 76 & 70 & 85 & 90 & 91 \\
\hline Saariana - & $\%$ & 93,68 & 98,95 & 100,00 & 94,74 & 80,00 & 73,68 & 89,47 & 94,74 & 95,79 \\
\hline Quênia & média & 130,29 & 112,14 & 113,39 & 94,09 & 101,24 & 130,53 & 65,79 & 24,88 & 33,27 \\
\hline África Sub- & $n$ & 7 & 7 & 7 & 7 & 7 & 7 & 7 & 7 & 7 \\
\hline Saariana - & $\%$ & 100,00 & 100,00 & 100,00 & 100,00 & 100,00 & 100,00 & 100,00 & 100,00 & 100,00 \\
\hline Libéria & média & 138,00 & 112,57 & 121,79 & 95,93 & 105,71 & 132,50 & 67,14 & 25,86 & 34,07 \\
\hline
\end{tabular}




\begin{tabular}{|c|c|c|c|c|c|c|c|c|c|c|}
\hline \multirow{3}{*}{$\begin{array}{l}\text { África Sub- } \\
\text { Saariana - } \\
\text { Malawi }\end{array}$} & $\mathrm{n}$ & 26 & 26 & 26 & 25 & 26 & 12 & 25 & 26 & 26 \\
\hline & $\%$ & 100,00 & 100,00 & 100,00 & 96,15 & 100,00 & 46,15 & 96,15 & 100,00 & 100,00 \\
\hline & média & 136,15 & 114,31 & 114,98 & 94,04 & 103,46 & 129,67 & 67,52 & 25,15 & 33,54 \\
\hline \multirow{3}{*}{$\begin{array}{c}\text { África Sub- } \\
\text { Saariana - } \\
\text { Moçambique }\end{array}$} & $n$ & 4 & 5 & 5 & 5 & 4 & 4 & 5 & 5 & 5 \\
\hline & $\%$ & 80,00 & 100,00 & 100,00 & 100,00 & 80,00 & 80,00 & 100,00 & 100,00 & 100,00 \\
\hline & média & 131,00 & 111,80 & 116,50 & 93,60 & 99,38 & 131,00 & 68,40 & 24,60 & 34,20 \\
\hline \multirow{3}{*}{$\begin{array}{c}\text { África Sub- } \\
\text { Saariana - Ibo } \\
\text { Nigéria }\end{array}$} & $\mathrm{n}$ & 75 & 79 & 78 & 73 & 60 & 71 & 68 & 76 & 78 \\
\hline & $\%$ & 94,94 & 100,00 & 98,73 & 92,41 & 75,95 & 89,87 & 86,08 & 96,20 & 98,73 \\
\hline & média & 134,51 & 112,86 & 115,26 & 95,90 & 101,05 & 133,56 & 65,57 & 25,53 & 34,10 \\
\hline \multirow{3}{*}{$\begin{array}{c}\text { África Sub- } \\
\text { Saariana - } \\
\text { Nigéria } \\
\text { (outros) } \\
\end{array}$} & $\mathrm{n}$ & 41 & 43 & 45 & 42 & 36 & 33 & 39 & 42 & 43 \\
\hline & $\%$ & 91,11 & 95,56 & 100,00 & 93,33 & 80,00 & 73,33 & 86,67 & 93,33 & 95,56 \\
\hline & média & 132,46 & 110,28 & 112,96 & 94,62 & 103,28 & 131,74 & 66,27 & 24,54 & 33,57 \\
\hline \multirow{3}{*}{$\begin{array}{l}\text { África Sub- } \\
\text { Saariana - } \\
\text { Pigmeus }\end{array}$} & $n$ & 8 & 8 & 8 & 8 & 7 & 6 & 7 & 7 & 7 \\
\hline & $\%$ & 100,00 & 100,00 & 100,00 & 100,00 & 87,50 & 75,00 & 87,50 & 87,50 & 87,50 \\
\hline & média & 122,75 & 104,88 & 109,63 & 90,50 & 99,29 & 123,83 & 60,43 & 22,71 & 31,36 \\
\hline \multirow{3}{*}{$\begin{array}{l}\text { África Sub- } \\
\text { Saariana - } \\
\text { Ruanda }\end{array}$} & $n$ & 1 & 1 & 1 & 1 & 1 & 1 & 1 & 1 & 1 \\
\hline & $\%$ & 100,00 & 100,00 & 100,00 & 100,00 & 100,00 & 100,00 & 100,00 & 100,00 & 100,00 \\
\hline & média & 126,00 & 108,00 & 105,00 & 97,00 & 94,00 & 132,00 & 72,00 & 23,00 & "'34,00" \\
\hline \multirow{3}{*}{$\begin{array}{l}\text { Africa Sub- } \\
\text { Saariana - } \\
\text { Senegal } \\
\end{array}$} & $\mathrm{n}$ & 0 & 1 & 1 & 1 & 0 & 0 & 1 & 1 & 1 \\
\hline & $\%$ & 0,00 & 100,00 & 100,00 & 100,00 & 0,00 & 0,00 & 100,00 & 100,00 & 100,00 \\
\hline & média & 0,00 & 106,00 & 118,00 & 104,00 & 0,00 & 0,00 & 67,00 & 29,00 & 30,00 \\
\hline \multirow{3}{*}{$\begin{array}{l}\text { África Sub- } \\
\text { Saariana - } \\
\text { Serra Leoa } \\
\end{array}$} & $\mathrm{n}$ & 4 & 5 & 5 & 4 & 4 & 5 & 5 & 5 & 5 \\
\hline & $\%$ & 80,00 & 100,00 & 100,00 & 80,00 & 80,00 & 100,00 & 100,00 & 100,00 & 100,00 \\
\hline & média & 134,88 & 108,90 & 115,80 & 97,00 & 105,00 & 127,40 & 64,80 & 27,20 & 32,70 \\
\hline \multirow{3}{*}{$\begin{array}{l}\text { África Sub- } \\
\text { Saariana - } \\
\text { Somália }\end{array}$} & $\mathrm{n}$ & 59 & 63 & 62 & 58 & 57 & 49 & 60 & 60 & 61 \\
\hline & $\%$ & 92,19 & 98,44 & 96,88 & 90,63 & 89,06 & 76,56 & 93,75 & 93,75 & 95,31 \\
\hline & média & 136,14 & 113,76 & 114,84 & 97,37 & 96,07 & 126,43 & 67,98 & 22,06 & 33,60 \\
\hline \multirow{3}{*}{$\begin{array}{c}\text { África Sub- } \\
\text { Saariana - } \\
\text { África do Sul }\end{array}$} & $\mathrm{n}$ & 24 & 24 & 24 & 24 & 24 & 24 & 24 & 24 & 24 \\
\hline & $\%$ & 100,00 & 100,00 & 100,00 & 100,00 & 100,00 & 100,00 & 100,00 & 100,00 & 100,00 \\
\hline & média & 131,88 & 113,15 & 114,00 & 93,50 & 100,98 & 129,19 & 65,60 & 24,81 & 32,98 \\
\hline \multirow{3}{*}{$\begin{array}{l}\text { África Sub- } \\
\text { Saariana - } \\
\text { Bushman } \\
\text { África do Sul }\end{array}$} & $\mathrm{n}$ & 31 & 32 & 32 & 32 & 29 & 27 & 28 & 32 & 32 \\
\hline & $\%$ & 96,88 & 100,00 & 100,00 & 100,00 & 90,63 & 84,38 & 87,50 & 100,00 & 100,00 \\
\hline & média & 126,92 & 111,06 & 108,83 & 92,17 & 95,76 & 123,33 & 60,25 & 22,91 & 31,22 \\
\hline África Sub- & $\mathrm{n}$ & 17 & 18 & 18 & 18 & 17 & 16 & 18 & 18 & 18 \\
\hline Saariana - & $\%$ & 94,44 & 100,00 & 100,00 & 100,00 & 94,44 & 88,89 & 100,00 & 100,00 & - 100,00 \\
\hline África do Sul & média & 129,94 & 111,67 & 112,22 & 92,33 & 98,71 & 124,88 & 64,22 & 23,78 & 32,47 \\
\hline África Sub- & $\mathrm{n}$ & 43 & 43 & 43 & 43 & 42 & 39 & 42 & 43 & 42 \\
\hline Saariana - & $\%$ & 100,00 & 100,00 & 100,00 & 100,00 & 97,67 & 90,70 & 97,67 & 100,00 & 97,67 \\
\hline Sul & média & 136,43 & 114,56 & 116,15 & 97,99 & 104,26 & 133,64 & 66,45 & 25,24 & 33,73 \\
\hline África Sub- & $n$ & 28 & 29 & 29 & 28 & 28 & 26 & 30 & 30 & 30 \\
\hline Saariana - & $\%$ & 93,33 & 96,67 & 96,67 & 93,33 & 93,33 & 86,67 & 100,00 & 100,00 & 100,00 \\
\hline Zulu & média & 134,75 & 113,45 & 115,69 & 95,93 & 103,07 & 130,69 & 66,47 & 24,67 & 33,48 \\
\hline África Sub- & $\mathrm{n}$ & 85 & 88 & 87 & 84 & 84 & 75 & 85 & 85 & 87 \\
\hline Saariana - & $\%$ & 95,51 & 98,88 & 97,75 & 94,38 & 94,38 & 84,27 & 95,51 & 95,51 & 97,75 \\
\hline Tanzânia & média & 131,74 & 111,53 & 113,21 & 95,04 & 104,42 & 131,68 & 66,24 & 24,57 & 34,01 \\
\hline África Sub- & $\mathrm{n}$ & 11 & 12 & 11 & 10 & 11 & 10 & 12 & 11 & 12 \\
\hline Saariana - & $\%$ & 91,67 & 100,00 & 91,67 & 83,33 & 91,67 & 83,33 & 100,00 & 91,67 & 100,00 \\
\hline Uganda & média & 130,82 & 112,17 & 119,45 & 93,20 & 102,55 & 127,20 & 65,25 & 23,95 & 33,71 \\
\hline África Sub- & $\mathrm{n}$ & 2 & 2 & 2 & 2 & 2 & 2 & 2 & 2 & 2 \\
\hline Saariana - & $\%$ & 100,00 & 100,00 & 100,00 & 100,00 & 100,00 & 100,00 & 100,00 & 100,00 & 100,00 \\
\hline Ocidental & média & 128,50 & 108,25 & 107,50 & 90,00 & 103,50 & 126,00 & 62,50 & 23,50 & 32,25 \\
\hline África Sub- & $n$ & 1 & 1 & 1 & 1 & 1 & 0 & 1 & 1 & 1 \\
\hline Saariana - & $\%$ & 100,00 & 100,00 & 100,00 & 100,00 & 100,00 & 0,00 & 100,00 & 100,00 & 100,00 \\
\hline Zaire & média & 138,00 & 110,00 & 116,00 & 94,00 & 107,00 & 0,00 & 68,00 & 25,00 & "34,00" \\
\hline África Sub- & $\mathrm{n}$ & 3 & 3 & 3 & 3 & 3 & 3 & 3 & 3 & 3 \\
\hline Saariana - & $\%$ & 100,00 & 100,00 & 100,00 & 100,00 & 100,00 & 100,00 & 100,00 & 100,00 & 100,00 \\
\hline Zâmbia & média & 139,83 & 115,83 & 114,50 & 101,00 & 106,00 & 130,50 & 73,17 & 25,67 & 37,00 \\
\hline África Sub- & $\mathrm{n}$ & 1 & 1 & 1 & 1 & 1 & 1 & 1 & 1 & 1 \\
\hline Saariana - & $\%$ & 100,00 & 100,00 & 100,00 & 100,00 & 100,00 & 100,00 & 100,00 & 100,00 & 100,00 \\
\hline Zimbaue & média & 139,00 & 113,00 & 119,00 & 101,00 & 111,00 & 134,00 & 64,00 & 27,00 & 32,00 \\
\hline Sudoeste & $\mathrm{n}$ & 39 & 40 & 31 & 29 & 36 & 37 & 39 & 39 & 40 \\
\hline Asiático - & $\%$ & 97,50 & 100,00 & 77,50 & 72,50 & 90,00 & 92,50 & 97,50 & 97,50 & 100,00 \\
\hline Afeganistão & média & 131,60 & 111,15 & 111,16 & 95,17 & 100,18 & 130,24 & 67,00 & 22,35 & 33,74 \\
\hline Sudoeste & $n$ & 22 & 25 & 25 & 24 & 19 & 25 & 25 & 25 & 25 \\
\hline Asia & $\%$ & 88,00 & 100,00 & 100,00 & 96,00 & 76,00 & 100,00 & 100,00 & 100,00 & 100,00 \\
\hline Bangladesh & média & 131,86 & 111,36 & 111,16 & 93,63 & 94,00 & 124,84 & 64,04 & 21,00 & 33,78 \\
\hline
\end{tabular}




\begin{tabular}{|c|c|c|c|c|c|c|c|c|c|c|}
\hline \multirow{3}{*}{$\begin{array}{l}\text { Sudoeste } \\
\text { Asiático - } \\
\text { Beduíno }\end{array}$} & $\mathrm{n}$ & 11 & 11 & 11 & $\overline{11}$ & 9 & 10 & $\overline{9}$ & $\overline{8}$ & $\overline{9}$ \\
\hline & $\%$ & 100,00 & 100,00 & 100,00 & 100,00 & 81,82 & 90,91 & 81,82 & 72,73 & 81,82 \\
\hline & média & 128,86 & 111,05 & 115,59 & 95,23 & 95,17 & 127,30 & 70,78 & 22,25 & 34,56 \\
\hline \multirow{3}{*}{$\begin{array}{c}\text { Sudoeste } \\
\text { Asiático - } \\
\text { Butão } \\
\end{array}$} & $\mathrm{n}$ & 2 & 2 & 1 & 1 & 1 & 2 & 2 & $\overline{2}$ & 2 \\
\hline & $\%$ & 100,00 & 100,00 & 50,00 & 50,00 & 50,00 & 100,00 & 100,00 & 100,00 & 100,00 \\
\hline & média & 132,00 & 112,50 & 118,00 & 92,00 & 98,00 & 127,50 & 62,50 & 24,00 & 32,50 \\
\hline \multirow{3}{*}{$\begin{array}{c}\text { Sudoeste } \\
\text { Asiático - } \\
\text { Chipre } \\
\end{array}$} & $\mathrm{n}$ & 19 & 22 & 21 & 19 & 18 & 16 & 19 & 19 & 22 \\
\hline & $\%$ & 86,36 & 100,00 & 95,45 & 86,36 & 81,82 & 72,73 & 86,36 & 86,36 & 100,00 \\
\hline & média & 134,66 & 112,98 & 114,90 & 97,16 & 94,78 & 132,88 & 67,00 & 21,58 & 33,68 \\
\hline \multirow{3}{*}{$\begin{array}{c}\text { Sudoeste } \\
\text { Asiático - Irã } 1\end{array}$} & $n$ & 3 & 5 & 7 & 6 & 1 & 2 & 2 & 5 & 3 \\
\hline & $\%$ & 23,08 & 38,46 & 53,85 & 46,15 & 7,69 & 15,38 & 15,38 & 38,46 & 23,08 \\
\hline & média & 134,67 & 112,60 & 108,00 & 99,50 & 100,00 & 133,50 & 69,50 & 22,20 & 34,00 \\
\hline \multirow{3}{*}{$\begin{array}{c}\text { Sudoeste } \\
\text { Asiático - Irã } 2\end{array}$} & $n$ & 2 & 9 & 9 & 5 & 1 & 0 & 5 & 3 & 5 \\
\hline & $\%$ & 16,67 & 75,00 & 75,00 & 41,67 & 8,33 & 0,00 & 41,67 & 25,00 & 41,67 \\
\hline & média & 142,00 & 117,00 & 114,78 & 97,60 & 94,00 & - & 73,00 & 22,33 & 33,00 \\
\hline \multirow{3}{*}{$\begin{array}{c}\text { Sudoeste } \\
\text { Asiático - Irã } 3\end{array}$} & $n$ & 9 & 13 & 14 & 12 & 7 & 10 & 9 & 9 & 11 \\
\hline & $\%$ & 52,94 & 76,47 & 82,35 & 70,59 & 41,18 & 58,82 & 52,94 & 52,94 & 64,71 \\
\hline & média & 135,78 & 115,62 & 117,29 & 95,17 & 102,29 & 127,80 & 70,22 & 21,00 & 33,82 \\
\hline \multirow{3}{*}{$\begin{array}{c}\text { Sudoeste } \\
\text { Asiático - Irã } 4\end{array}$} & $n$ & 2 & 3 & 4 & 4 & 3 & $\overline{4}$ & 5 & 8 & 5 \\
\hline & $\%$ & 25,00 & 37,50 & 50,00 & 50,00 & 37,50 & 50,00 & 62,50 & 100,00 & 62,50 \\
\hline & média & 139,00 & 111,67 & 109,00 & 98,50 & 98,33 & 132,00 & 70,20 & 21,00 & 33,20 \\
\hline \multirow{3}{*}{$\begin{array}{l}\text { Sudoeste } \\
\text { Asiático - } \\
\text { Iraque }\end{array}$} & $\mathrm{n}$ & 16 & 16 & 16 & 16 & 16 & 16 & 16 & 16 & 16 \\
\hline & $\%$ & 100,00 & 100,00 & 100,00 & 100,00 & 100,00 & 100,00 & 100,00 & 100,00 & 100,00 \\
\hline & média & 136,44 & 114,47 & 112,69 & 98,25 & 96,88 & 128,94 & 69,03 & 21,84 & 33,44 \\
\hline \multirow{3}{*}{$\begin{array}{c}\text { Sudoeste } \\
\text { Asiático - } \\
\text { Iraque (early) }\end{array}$} & $n$ & 13 & 14 & 13 & 14 & 13 & 10 & 14 & 14 & 14 \\
\hline & $\%$ & 92,86 & 100,00 & 92,86 & 100,00 & 92,86 & 71,43 & 100,00 & 100,00 & 100,00 \\
\hline & média & 134,46 & 112,68 & 118,23 & 98,25 & 96,31 & 128,25 & 68,07 & 22,61 & 32,82 \\
\hline Sudoeste & $\mathrm{n}$ & 76 & 78 & 77 & 75 & 74 & 55 & 77 & 77 & 78 \\
\hline Asiático - & $\%$ & 97,44 & 100,00 & 98,72 & 96,15 & 94,87 & 70,51 & 98,72 & 98,72 & 100,00 \\
\hline Israel 1 & média & 134,89 & 112,50 & 116,55 & 96,29 & 97,23 & 130,00 & 67,64 & 22,42 & 32,79 \\
\hline Sudoeste & $\mathrm{n}$ & 12 & 13 & 13 & 9 & 9 & 7 & 9 & 11 & 11 \\
\hline Asiático - & $\%$ & 92,31 & 100,00 & 100,00 & 69,23 & 69,23 & 53,85 & 69,23 & 84,62 & 84,62 \\
\hline Israel 2 & média & 134,42 & 113,23 & 114,69 & 93,00 & 96,78 & 130,71 & 67,67 & 21,45 & 33,27 \\
\hline Sudoeste & $\mathrm{n}$ & 88 & 91 & 90 & $\overline{84}$ & 83 & $\overline{62}$ & $\overline{86}$ & $\overline{88}$ & 89 \\
\hline Asiático - & $\%$ & 96,70 & 100,00 & 98,90 & 92,31 & 91,21 & 68,13 & 94,51 & 96,70 & 97,80 \\
\hline Israel 3 & média & 134,83 & 112,60 & 116,28 & 95,94 & 97,18 & 130,08 & 67,64 & 22,30 & 32,85 \\
\hline Sudoeste & $\mathrm{n}$ & 11 & 11 & 11 & 10 & 10 & 10 & 10 & 10 & 11 \\
\hline Asiático - & $\%$ & 100,00 & 100,00 & 100,00 & 90,91 & 90,91 & 90,91 & 90,91 & 90,91 & 100,00 \\
\hline Palestina & média & 133,82 & 111,68 & 112,91 & 96,25 & 94,70 & 128,90 & 69,05 & 21,70 & 34,09 \\
\hline & $\mathrm{n}$ & 16 & 16 & 16 & 16 & 16 & 16 & 16 & 16 & 16 \\
\hline - Síria & $\%$ & 100,00 & 100,00 & 100,00 & 100,00 & 100,00 & 100,00 & 100,00 & 100,00 & 100,00 \\
\hline & média & 136,34 & 114,88 & 112,41 & 94,78 & 95,97 & 132,84 & 72,19 & 22,09 & 35,00 \\
\hline Sudoeste & $\mathrm{n}$ & 49 & 52 & 48 & 45 & 48 & 49 & 50 & 51 & 51 \\
\hline Asiático - & $\%$ & 94,23 & 100,00 & 92,31 & 86,54 & 92,31 & 94,23 & 96,15 & 98,08 & 98,08 \\
\hline Turquia & média & 133,33 & 112,83 & 111,15 & 95,11 & 96,79 & 132,69 & 68,98 & 22,26 & 34,67 \\
\hline & $\mathrm{n}$ & 63 & 66 & 66 & 66 & 62 & 59 & 65 & 63 & 66 \\
\hline$y$ & $\%$ & 94,03 & 98,51 & 98,51 & 98,51 & 92,54 & 88,06 & 97,01 & 94,03 & 98,51 \\
\hline & média & 130,54 & 111,64 & 113,98 & 96,52 & 93,85 & 131,53 & 68,63 & 22,62 & 33,61 \\
\hline & $\mathrm{n}$ & 15 & 22 & 23 & 20 & 13 & 8 & 17 & 17 & 20 \\
\hline - Neolítico & $\%$ & 60,00 & 88,00 & 92,00 & 80,00 & 52,00 & 32,00 & 68,00 & 68,00 & 80,00 \\
\hline & média & 140,13 & 115,41 & 121,13 & 102,95 & 100,31 & 131,00 & 66,29 & 22,76 & 31,30 \\
\hline & $n$ & 100 & 102 & 102 & 100 & 93 & 87 & 96 & 100 & 102 \\
\hline & $\%$ & 98,04 & 100,00 & 100,00 & 98,04 & 91,18 & 85,29 & 94,12 & 98,04 & 100,00 \\
\hline & média & 133,39 & 112,83 & 116,28 & 97,79 & 94,87 & 134,68 & 69,19 & 22,95 & 34,03 \\
\hline & $\mathrm{n}$ & 35 & 43 & 43 & 37 & 28 & 24 & 37 & 34 & 38 \\
\hline -Bretanna & $\%$ & 81,40 & 100,00 & 100,00 & 86,05 & 65,12 & 55,81 & 86,05 & 79,07 & 88,37 \\
\hline & média & 133,29 & 111,58 & 115,98 & 96,46 & 97,54 & 132,00 & 68,86 & 22,38 & 34,01 \\
\hline Grã-Bretanha & $\mathrm{n}$ & 57 & 57 & 57 & 57 & 57 & 57 & 57 & 57 & 57 \\
\hline - Spitafields & $\%$ & 100,00 & 100,00 & 100,00 & 100,00 & 100,00 & 100,00 & 100,00 & 100,00 & 100,00 \\
\hline CAM & média & 133,56 & ' & 110,51 & 96,60 & 96,44 & 133,14 & 65,93 & 23,35 & 32,65 \\
\hline Grã-Bretanha & $\mathrm{n}$ & 79 & 82 & 79 & $\overline{76}$ & 64 & 65 & 65 & $\overline{76}$ & $\overline{78}$ \\
\hline - Spitafields & $\%$ & 91,86 & 95,35 & 91,86 & 88,37 & 74,42 & 75,58 & 75,58 & 88,37 & 90,70 \\
\hline $\mathrm{NHM}$ & média & 130,65 & 112,73 & 113,95 & 94,51 & 91,55 & 127,75 & 67,91 & 21,41 & 34,54 \\
\hline & $n$ & 5 & 5 & 5 & 5 & 4 & 4 & 4 & 4 & 5 \\
\hline EUA - & $\%$ & 100,00 & 100,00 & 100,00 & 100,00 & 80,00 & 80,00 & 80,00 & 80,00 & 100,00 \\
\hline & média & 140,40 & 114,20 & 108,80 & 97,40 & 100,88 & 139,50 & 68,00 & 22,25 & 35,50 \\
\hline & $\mathrm{n}$ & 36 & 36 & 36 & 36 & 35 & 35 & 35 & 35 & 35 \\
\hline do Alaska & $\%$ & 100,00 & 100,00 & 100,00 & 100,00 & 97,22 & 97,22 & 97,22 & 97,22 & 97,22 \\
\hline & média & 135,29 & 113,61 & 107,86 & 97,56 & 99,94 & 138,29 & 73,46 & 21,61 & 36,27 \\
\hline & $\mathrm{n}$ & 15 & 15 & 15 & 15 & 14 & 14 & 14 & 15 & 15 \\
\hline
\end{tabular}




\begin{tabular}{|c|c|c|c|c|c|c|c|c|c|c|}
\hline \multirow[b]{2}{*}{ EUA - Alaska } & $\mathrm{n}$ & 15 & 15 & 15 & 15 & $\overline{14}$ & 14 & 14 & 15 & 15 \\
\hline & média & $10 \theta, 00$ & 100,60 & 100,00 & $10 \theta, 00$ & 99,33 & 198,33 & 93,03 & 100,00 & $10 \theta, \theta 0$ \\
\hline \multirow{3}{*}{$\begin{array}{l}\text { EU(Kodjakk }{ }^{\text {Kolska }} \\
\text { (Tlingit) }\end{array}$} & $\mathrm{n}$ & 28 & 32 & 29 & 26 & 32 & 32 & 35 & 35 & 35 \\
\hline & $\%$ & 80,00 & 91,43 & 82,86 & 74,29 & 91,43 & 91,43 & 100,00 & 100,00 & 100,00 \\
\hline & média & 134,77 & 113,78 & 109,83 & 98,08 & 102,13 & 144,00 & 73,01 & 22,43 & 36,30 \\
\hline \multirow{3}{*}{ EUA - Arizona } & $\mathrm{n}$ & 41 & 41 & 40 & 40 & 41 & 38 & 41 & 41 & 41 \\
\hline & $\%$ & 100,00 & 100,00 & 97,56 & 97,56 & 100,00 & 92,68 & 100,00 & 100,00 & 100,00 \\
\hline & média & 133,83 & 110,91 & 110,48 & 96,39 & 97,96 & 137,55 & 70,55 & 23,12 & 34,78 \\
\hline \multirow{3}{*}{$\begin{array}{c}\text { EUA - } \\
\text { Arkansas }\end{array}$} & $n$ & 27 & 29 & 29 & 26 & 27 & 25 & 29 & 29 & 29 \\
\hline & $\%$ & 93,10 & 100,00 & 100,00 & 89,66 & 93,10 & 86,21 & 100,00 & 100,00 & 100,00 \\
\hline & média & 141,31 & 112,81 & 110,64 & 99,69 & 98,87 & 136,42 & 71,57 & 21,41 & 35,19 \\
\hline \multirow{3}{*}{$\begin{array}{c}\text { EUA - } \\
\text { Califórnia } 1\end{array}$} & $n$ & 58 & 59 & 59 & 55 & 58 & 53 & 59 & 58 & 60 \\
\hline & $\%$ & 95,08 & 96,72 & 96,72 & 90,16 & 95,08 & 86,89 & 96,72 & 95,08 & 98,36 \\
\hline & média & 139,24 & 113,36 & 110,40 & 100,49 & 100,09 & 140,49 & 71,08 & 23,18 & 35,14 \\
\hline \multirow{3}{*}{$\begin{array}{c}\text { EUA - } \\
\text { Califórnia } 2\end{array}$} & $n$ & 162 & 163 & 163 & 160 & 161 & 145 & 163 & 163 & 163 \\
\hline & $\%$ & 99,39 & 100,00 & 100,00 & 98,16 & 98,77 & 88,96 & 100,00 & 100,00 & 100,00 \\
\hline & média & 130,46 & 110,77 & 107,29 & 98,64 & 98,98 & 135,85 & 68,69 & 21,69 & 34,70 \\
\hline \multirow{3}{*}{$\begin{array}{c}\text { EUA - } \\
\text { Califórnia } 3\end{array}$} & $\mathrm{n}$ & 5 & 5 & 4 & 4 & 4 & 5 & 4 & 4 & 4 \\
\hline & $\%$ & 100,00 & 100,00 & 80,00 & 80,00 & 80,00 & 100,00 & 80,00 & 80,00 & 80,00 \\
\hline & média & 136,80 & 112,60 & 111,25 & 100,25 & 98,00 & 139,00 & 68,75 & 23,50 & 35,00 \\
\hline \multirow{3}{*}{$\begin{array}{c}\text { EUA - } \\
\text { Carolina do } \\
\text { Norte }\end{array}$} & $n$ & 1 & 1 & 1 & 1 & 1 & 1 & 1 & 1 & 1 \\
\hline & $\%$ & 100,00 & 100,00 & 100,00 & 100,00 & 100,00 & 100,00 & 100,00 & 100,00 & 100,00 \\
\hline & média & 131,00 & 116,00 & 109,00 & 93,00 & 97,00 & 125,00 & 65,00 & 21,00 & 34,00 \\
\hline \multirow{3}{*}{$\begin{array}{l}\text { EUA - } \\
\text { Carolina do Sul }\end{array}$} & $n$ & 1 & 1 & 1 & 1 & 1 & 1 & $\overline{1}$ & 1 & 1 \\
\hline & $\%$ & 100,00 & 100,00 & 100,00 & 100,00 & 100,00 & 100,00 & 100,00 & 100,00 & 100,00 \\
\hline & média & 142,00 & 118,00 & 114,00 & 108,00 & 98,00 & 148,00 & 66,00 & 23,00 & 36,00 \\
\hline & $n$ & 5 & 6 & 6 & 6 & 5 & 5 & 6 & 6 & 6 \\
\hline Color & $\%$ & 83,33 & 100,00 & 100,00 & 100,00 & 83,33 & 83,33 & 100,00 & 100,00 & 100,00 \\
\hline & média & 130,20 & 110,67 & 111,42 & 94,08 & 101,40 & 137,40 & 71,17 & 23,00 & 34,75 \\
\hline & $n$ & 1 & 1 & 1 & 1 & 1 & 1 & 1 & 1 & 1 \\
\hline$U A$ & $\%$ & 100,00 & 100,00 & 100,00 & 100,00 & 100,00 & 100,00 & 100,00 & 100,00 & 100,00 \\
\hline & média & 139,00 & 119,00 & 114,00 & 105,00 & 92,00 & 139,00 & 61,00 & 22,00 & 32,00 \\
\hline & $\mathrm{n}$ & 14 & 15 & 15 & 12 & 14 & 14 & 15 & 15 & 15 \\
\hline EUA - Lakota & $\%$ & 93,33 & 100,00 & 100,00 & 80,00 & 93,33 & 93,33 & 100,00 & 100,00 & 100,00 \\
\hline & média & 135,96 & 116,20 & 111,93 & 95,58 & 102,29 & 142,86 & 73,20 & 22,57 & 35,93 \\
\hline FUA - Dakota & $n$ & 117 & 119 & 119 & 117 & 114 & 114 & 116 & 119 & 119 \\
\hline Euld & $\%$ & 98,32 & 100,00 & 100,00 & 98,32 & 95,80 & 95,80 & 97,48 & 100,00 & 100,00 \\
\hline & média & 133,75 & 111,29 & 107,59 & 94,92 & 98,86 & 140,76 & 73,17 & 21,76 & 35,82 \\
\hline & $n$ & 6 & 6 & 6 & 6 & 6 & 6 & 6 & 6 & 6 \\
\hline do Sul? & $\%$ & 100,00 & 100,00 & 100,00 & 100,00 & 100,00 & 100,00 & 100,00 & 100,00 & 100,00 \\
\hline & média & 132,33 & 114,67 & 111,08 & 93,00 & 100,25 & 144,17 & 73,67 & 22,33 & 36,83 \\
\hline & $\mathrm{n}$ & 9 & 10 & 10 & 10 & 9 & 9 & 10 & $\overline{9}$ & 10 \\
\hline Delawa & $\%$ & 90,00 & 100,00 & 100,00 & 100,00 & 90,00 & 90,00 & 100,00 & 90,00 & 100,00 \\
\hline & média & 142,56 & 115,75 & 111,10 & 102,25 & 100,17 & 140,56 & 71,15 & 22,56 & 34,05 \\
\hline & $\mathrm{n}$ & 95 & 96 & 96 & 94 & 89 & 78 & 92 & 94 & 95 \\
\hline EUA - Flórida & $\%$ & 98,96 & 100,00 & 100,00 & 97,92 & 92,71 & 81,25 & 95,83 & 97,92 & 98,96 \\
\hline & média & 142,59 & 117,06 & 108,42 & 102,26 & 102,43 & 144,93 & 72,69 & 23,04 & 35,63 \\
\hline & $\mathrm{n}$ & 14 & 19 & 19 & 16 & 14 & 16 & 19 & 19 & 19 \\
\hline EUA - Geórgia & $\%$ & 73,68 & 100,00 & 100,00 & 84,21 & 73,68 & 84,21 & 100,00 & 100,00 & 100,00 \\
\hline & média & 136,89 & 113,29 & 109,58 & 98,72 & 101,00 & 135,50 & 70,71 & 21,97 & 35,11 \\
\hline & $\mathrm{n}$ & 0 & 1 & 1 & 0 & 0 & 1 & 1 & 0 & 1 \\
\hline Shelte & $\%$ & 0,00 & 100,00 & 100,00 & 0,00 & 0,00 & 100,00 & 100,00 & 0,00 & 100,00 \\
\hline & média & 0,00 & 114,00 & 114,00 & 0,00 & 0,00 & 146,00 & 70,00 & 0,00 & 32,00 \\
\hline & $\mathrm{n}$ & 118 & 118 & 118 & $\overline{114}$ & 115 & 111 & 116 & 117 & 118 \\
\hline EUA - Illinois & $\%$ & 100,00 & 100,00 & 100,00 & 96,61 & 97,46 & 94,07 & 98,31 & 99,15 & 100,00 \\
\hline & média & 141,25 & 113,41 & 109,88 & 100,55 & 99,57 & 138,37 & 71,91 & 22,22 & 34,59 \\
\hline & $\mathrm{n}$ & 3 & 4 & 4 & 4 & $\overline{3}$ & 3 & $\overline{4}$ & $\overline{4}$ & 4 \\
\hline EUA - Indiana & $\%$ & 75,00 & 100,00 & 100,00 & 100,00 & 75,00 & 75,00 & 100,00 & 100,00 & 100,00 \\
\hline & média & 140,33 & 114,13 & 112,75 & 100,00 & 98,67 & 133,67 & 67,25 & 23,63 & 32,63 \\
\hline & $\mathrm{n}$ & 1 & 1. & 1 & 1 & 1 & 1 & 1 & 1 & 1 \\
\hline EUA - lowa & $\%$ & 100,00 & 100,00 & 100,00 & 100,00 & 100,00 & 100,00 & 100,00 & 100,00 & 100,00 \\
\hline & média & 140,00 & 119,00 & 115,00 & 92,00 & 97,50 & 137,00 & 71,00 & 21,50 & 31,00 \\
\hline & $\mathrm{n}$ & 10 & 10 & 10 & 10 & 9 & 7 & 9 & 10 & 10 \\
\hline EUA - Kansas & $\%$ & 100,00 & 100,00 & 100,00 & 100,00 & 90,00 & 70,00 & 90,00 & 100,00 & 100,00 \\
\hline & média & 132,20 & 109,90 & 104,70 & 94,30 & 98,89 & 140,00 & 72,89 & 21,55 & 35,60 \\
\hline & $\mathrm{n}$ & 35 & 37 & 37 & 36 & 35 & 32 & 37 & 37 & 37 \\
\hline Kentuck & $\%$ & 94,59 & 100,00 & 100,00 & 97,30 & 94,59 & 86,49 & 100,00 & 100,00 & 100,00 \\
\hline & média & 139,03 & 110,84 & 109,78 & 98,32 & 96,20 & 136,88 & 68,86 & 21,05 & 33,20 \\
\hline & $\mathrm{n}$ & 7 & 8 & 8 & 7 & 7 & 8 & 6 & 5 & 8 \\
\hline & $\%$ & 87,50 & 100,00 & 100,00 & 87,50 & 87,50 & 100,00 & 75,00 & 62,50 & 100,00 \\
\hline
\end{tabular}




\begin{tabular}{|c|c|c|c|c|c|c|c|c|c|c|}
\hline & média & 142,36 & 114,69 & 107,69 & 99,43 & 100,93 & 141,88 & 70,17 & 22,20 & 34,94 \\
\hline \multirow{3}{*}{$\begin{array}{l}\text { EUA - } \\
\text { Maryland }\end{array}$} & $\mathrm{n}$ & 49 & 54 & 54 & 47 & 43 & 41 & 50 & 47 & 54 \\
\hline & $\%$ & 90,74 & 100,00 & 100,00 & 87,04 & 79,63 & 75,93 & 92,59 & 87,04 & 100,00 \\
\hline & média & 139,33 & 115,16 & 113,60 & 98,67 & 102,93 & 140,57 & 69,21 & 22,44 & 34,22 \\
\hline \multirow{3}{*}{$\begin{array}{c}\text { EUA - } \\
\text { Massachusetts }\end{array}$} & $n$ & 1 & 1 & 1 & 1 & 1 & 1 & 1 & 1 & $\overline{1}$ \\
\hline & $\%$ & 100,00 & 100,00 & 100,00 & 100,00 & 100,00 & 100,00 & 100,00 & 100,00 & 100,00 \\
\hline & média & 140,00 & 112,00 & 108,00 & 96,00 & 109,00 & 137,00 & 72,00 & 20,00 & 32,00 \\
\hline \multirow{3}{*}{$\begin{array}{l}\text { EUA - } \\
\text { Michigan }\end{array}$} & $\mathrm{n}$ & 12 & 12 & 12 & 12 & 12 & 8 & 12 & 12 & 12 \\
\hline & $\%$ & 100,00 & 100,00 & 100,00 & 100,00 & 100,00 & 66,67 & 100,00 & 100,00 & 100,00 \\
\hline & média & 134,33 & 112,29 & 109,29 & 94,42 & 98,42 & 142,19 & 68,83 & 22,21 & 34,63 \\
\hline \multirow{3}{*}{$\begin{array}{l}\text { EUA - } \\
\text { Mississipi }\end{array}$} & $n$ & 2 & 3 & 3 & 2 & 2 & 3 & 3 & 3 & 3 \\
\hline & $\%$ & 66,67 & 100,00 & 100,00 & 66,67 & 66,67 & 100,00 & 100,00 & 100,00 & 100,00 \\
\hline & média & 140,50 & 108,67 & 105,33 & 99,00 & 103,00 & 135,00 & 66,17 & 21,00 & 33,33 \\
\hline \multirow{3}{*}{$\begin{array}{l}\text { EUA - } \\
\text { Missouri }\end{array}$} & $\mathrm{n}$ & 9 & 10 & 10 & 10 & 7 & 8 & 8 & 10 & 10 \\
\hline & $\%$ & 90,00 & 100,00 & 100,00 & 100,00 & 70,00 & 80,00 & 80,00 & 100,00 & 100,00 \\
\hline & média & 139,44 & 113,45 & 111,25 & 96,70 & 100,79 & 137,38 & 70,88 & 21,25 & 35,00 \\
\hline \multirow{3}{*}{$\begin{array}{l}\text { EUA - } \\
\text { Montana }\end{array}$} & $\mathrm{n}$ & 15 & 15 & 15 & 15 & 14 & 13 & 14 & 15 & 15 \\
\hline & $\%$ & 100,00 & 100,00 & 100,00 & 100,00 & 93,33 & 86,67 & 93,33 & 100,00 & 100,00 \\
\hline & média & 132,60 & 112,77 & 107,33 & 95,10 & 99,29 & 141,12 & 72,43 & 22,10 & 35,93 \\
\hline \multirow{3}{*}{$\begin{array}{l}\text { EUA - } \\
\text { Nebraska }\end{array}$} & $n$ & 17 & 17 & 17 & 17 & 16 & 17 & 16 & 17 & 17 \\
\hline & $\%$ & 100,00 & 100,00 & 100,00 & 100,00 & 94,12 & 100,00 & 94,12 & 100,00 & 100,00 \\
\hline & média & 129,65 & 111,62 & 107,59 & 94,50 & 100,06 & 138,26 & 72,50 & 21,79 & 36,09 \\
\hline \multirow{3}{*}{ EUA - Nevada } & $n$ & 2 & 2 & 2 & 2 & 2 & 2 & 2 & 2 & 2 \\
\hline & $\%$ & 100,00 & 100,00 & 100,00 & 100,00 & 100,00 & 100,00 & 100,00 & 100,00 & 100,00 \\
\hline & média & 138,00 & 112,00 & 113,00 & 96,50 & 107,50 & 143,50 & 74,00 & 24,00 & 36,00 \\
\hline \multirow{3}{*}{$\begin{array}{l}\text { EUA - New } \\
\text { Jersey }\end{array}$} & $n$ & 8 & 8 & 8 & 8 & 8 & 6 & 8 & 8 & 8 \\
\hline & $\%$ & 100,00 & 100,00 & 100,00 & 100,00 & 100,00 & 75,00 & 100,00 & 100,00 & 100,00 \\
\hline & média & 140,88 & 116,94 & 111,31 & 100,06 & 101,38 & 141,08 & 69,50 & 22,19 & 33,25 \\
\hline & $n$ & 54 & 61 & 51 & 46 & 55 & 57 & 63 & 62 & 63 \\
\hline EUA - INOVO & $\%$ & 85,71 & 96,83 & 80,95 & 73,02 & 87,30 & 90,48 & 100,00 & 98,41 & 100,00 \\
\hline & média & 135,70 & 109,93 & 109,45 & 94,59 & 96,01 & 134,33 & 69,73 & 22,23 & 35,06 \\
\hline & $\mathrm{n}$ & 26 & 27 & 27 & 25 & 25 & 23 & 27 & 26 & 27 \\
\hline $\begin{array}{l}\text { EUA - Nova } \\
\text { York }\end{array}$ & $\%$ & 96,30 & 100,00 & 100,00 & 92,59 & 92,59 & 85,19 & 100,00 & 96,30 & 100,00 \\
\hline & média & 137,73 & 114,76 & 111,19 & 98,72 & 100,90 & 140,83 & 69,44 & 23,94 & 33,81 \\
\hline EUA - & $\mathrm{n}$ & 9 & 9 & 9 & 8 & 9 & 7 & 9 & 9 & $\overline{9}$ \\
\hline Nordeste & $\%$ & 100,00 & 100,00 & 100,00 & 88,89 & 100,00 & 77,78 & 100,00 & 100,00 & 100,00 \\
\hline americano & média & 131,67 & 112,56 & 111,11 & 96,63 & 101,33 & 141,00 & 71,44 & 21,83 & 36,11 \\
\hline & $\mathrm{n}$ & 0 & 2 & 2 & 1 & 0 & 0 & 0 & 0 & 0 \\
\hline EUA - Ohio & $\%$ & 0,00 & 100,00 & 100,00 & 50,00 & 0,00 & 0,00 & 0,00 & 0,00 & 0,00 \\
\hline & média & 0,00 & 114,50 & 109,50 & 101,00 & 0,00 & 0,00 & 0,00 & 0,00 & 0,00 \\
\hline & $n$ & $\overline{9}$ & 12 & 10 & 9 & 12 & 10 & 12 & 12 & 13 \\
\hline EUA - Oregon & $\%$ & 69,23 & 92,31 & 76,92 & 69,23 & 92,31 & 76,92 & 92,31 & 92,31 & 100,00 \\
\hline & média & 132,06 & ' & 105,20 & 95,39 & 100,08 & 136,90 & 69,92 & 21,46 & 35,81 \\
\hline & $\mathrm{n}$ & 4 & 4 & 4 & 3 & 3 & 0 & 3 & 2 & 3 \\
\hline Pen & $\%$ & 100,00 & 100,00 & 100,00 & 75,00 & 75,00 & 0,00 & 75,00 & 50,00 & 75,00 \\
\hline & média & 138,75 & 116,25 & 111,50 & 102,50 & 103,67 & -- & 72,00 & 20,00 & 34,67 \\
\hline & $\mathrm{n}$ & 5 & 9 & 7 & 5 & 6 & 8 & 7 & 10 & 10 \\
\hline Tennesse & $\%$ & 50,00 & 90,00 & 70,00 & 50,00 & 60,00 & 80,00 & 70,00 & 100,00 & 100,00 \\
\hline & média & 142,20 & 112,17 & 112,14 & 100,80 & 96,50 & 138,63 & 69,29 & 22,55 & 33,25 \\
\hline & $\mathrm{n}$ & 15 & 17 & 17 & 16 & 15 & 14 & 16 & 16 & 16 \\
\hline EUA - Texas & $\%$ & 88,24 & 100,00 & 100,00 & 94,12 & 88,24 & 82,35 & 94,12 & 94,12 & 94,12 \\
\hline & média & 132,87 & 111,97 & 108,06 & 93,47 & 97,57 & 140,21 & 70,38 & 21,56 & 34,84 \\
\hline & $\mathrm{n}$ & 58 & 58 & 58 & 58 & 58 & 58 & 58 & 58 & 58 \\
\hline EUA - Utah & $\%$ & 100,00 & 100,00 & 100,00 & 100,00 & 100,00 & 100,00 & 100,00 & 100,00 & 100,00 \\
\hline & média & 132,91 & 111,48 & 108,61 & 96,37 & 98,51 & 133,15 & 70,63 & 22,61 & 34,55 \\
\hline & $\mathrm{n}$ & 54 & 57 & 58 & 51 & 49 & 50 & 52 & 48 & 58 \\
\hline EUA - Virginia & $\%$ & 93,10 & 98,28 & 100,00 & 87,93 & 84,48 & 86,21 & 89,66 & 82,76 & 100,00 \\
\hline & média & 141,32 & ' & 111,34 & 100,10 & 101,23 & 139,38 & 70,92 & 22,13 & 34,38 \\
\hline & $n$ & 1 & 1 & 1 & 0 & 1 & 1 & 1 & 1 & 1 \\
\hline Ocidental & $\%$ & 100,00 & 100,00 & 100,00 & 0,00 & 100,00 & 100,00 & 100,00 & 100,00 & 100,00 \\
\hline & média & 133,00 & 113,50 & 105,00 & 0,00 & 94,00 & 133,00 & 79,00 & 20,00 & 34,00 \\
\hline & $n$ & 2 & 2 & 1 & 1 & 2 & 2 & 2 & 2 & 2 \\
\hline Washin & $\%$ & 100,00 & 100,00 & 50,00 & 50,00 & 100,00 & 100,00 & 100,00 & 100,00 & 100,00 \\
\hline & média & 127,00 & 109,00 & 106,00 & 91,00 & 102,50 & 136,50 & 66,50 & 22,00 & 34,00 \\
\hline & $n$ & 5 & 5 & 5 & 5 & 5 & 5 & 5 & 5 & 5 \\
\hline Wiscon & $\%$ & 100,00 & 100,00 & 100,00 & 100,00 & 100,00 & 100,00 & 100,00 & 100,00 & 100,00 \\
\hline & média & 132,20 & 115,30 & 107,30 & 93,40 & 103,40 & 144,80 & 72,40 & 23,20 & 35,50 \\
\hline & $n$ & 3 & 3 & 3 & 3 & 3 & 3 & 3 & 3 & 3 \\
\hline W & $\%$ & 100,00 & 100,00 & 100,00 & 100,00 & 100,00 & 100,00 & 100,00 & 100,00 & 100,00 \\
\hline & média & 125,33 & 111,33 & 107,00 & 93,33 & 100,33 & 140,83 & 68,00 & 21,50 & 35,17 \\
\hline
\end{tabular}




\begin{tabular}{|c|c|c|c|c|c|c|c|c|c|c|}
\hline série & & NLB & $\mathrm{NLH}$ & MAB & $\mathrm{MDH}$ & MDB & WNB & SIS & ZMB & SSS \\
\hline \multirow{3}{*}{ Aleuta 1} & $n$ & 81 & 79 & 80 & 80 & 80 & 79 & 79 & 78 & 78 \\
\hline & $\%$ & 98,78 & 96,34 & 97,56 & 97,56 & 97,56 & 96,34 & 96,34 & 95,12 & 95,12 \\
\hline & média & 25,80 & 54,11 & 66,16 & 25,70 & 17,81 & 7,65 & 2,76 & 102,73 & 22,04 \\
\hline \multirow{3}{*}{ Aleuta 2} & $\mathrm{n}$ & 44 & 44 & 44 & 45 & 45 & 45 & 45 & 44 & 44 \\
\hline & $\%$ & 97,78 & 97,78 & 97,78 & 100,00 & 100,00 & 100,00 & 100,00 & 97,78 & 97,78 \\
\hline & média & 25,45 & 53,66 & 65,49 & 25,09 & 18,18 & 7,93 & 3,10 & 101,95 & 21,52 \\
\hline \multirow{3}{*}{ Aleuta 3} & $\mathrm{n}$ & 13 & 13 & 12 & 13 & 13 & 13 & 13 & 13 & 13 \\
\hline & $\%$ & 100,00 & 100,00 & 92,31 & 100,00 & 100,00 & 100,00 & 100,00 & 100,00 & 100,00 \\
\hline & média & 26,15 & 51,88 & 65,75 & 24,85 & 16,69 & 8,34 & 2,75 & 102,98 & 21,77 \\
\hline \multirow{3}{*}{ Aleuta 4} & $\mathrm{n}$ & 18 & 18 & 18 & 17 & 17 & 18 & 18 & 17 & 17 \\
\hline & $\%$ & 100,00 & 100,00 & 100,00 & "94,44 & 94,44 & 100,00 & 100,00 & "94,44 & 94,44 \\
\hline & média & 25,39 & 52,06 & 67,36 & 26,59 & 17,41 & 8,46 & 2,94 & 102,12 & 21,13 \\
\hline \multirow{3}{*}{ Aleuta 5} & $\mathrm{n}$ & 5 & 5 & 5 & 5 & 5 & 5 & 5 & 5 & 5 \\
\hline & $\%$ & 100,00 & 100,00 & 100,00 & 100,00 & 100,00 & 100,00 & 100,00 & 100,00 & "100,00 \\
\hline & média & 24,60 & 53,00 & 64,80 & 24,40 & 18,00 & 7,50 & 2,81 & 104,38 & 23,39 \\
\hline \multirow{3}{*}{ Aleuta 6} & $\mathrm{n}$ & 15 & 15 & 15 & 16 & 16 & 15 & 15 & 12 & 12 \\
\hline & $\%$ & 93,75 & 93,75 & 93,75 & 100,00 & 100,00 & 93,75 & 93,75 & 75,00 & 75,00 \\
\hline & média & 26,20 & 53,67 & 65,93 & 26,69 & 18,69 & 7,85 & 2,65 & 101,78 & 20,18 \\
\hline \multirow{3}{*}{$\begin{array}{l}\text { Austrália - } \\
\text { Murray River }\end{array}$} & $\mathrm{n}$ & 34 & 26 & 35 & 42 & 42 & 18 & 18 & 24 & 23 \\
\hline & $\%$ & 64,15 & 49,06 & 66,04 & 79,25 & 79,25 & 33,96 & 33,96 & 45,28 & 43,40 \\
\hline & média & 27,99 & 50,04 & 67,34 & 29,83 & 19,81 & 9,50 & 3,52 & 95,51 & 24,40 \\
\hline \multirow{3}{*}{$\begin{array}{c}\text { Austrália- } \\
\text { New South } \\
\text { Walles }\end{array}$} & $\mathrm{n}$ & 59 & 58 & 60 & 59 & 60 & 57 & 57 & 53 & 53 \\
\hline & $\%$ & 89,39 & 87,88 & 90,91 & 89,39 & 90,91 & 86,36 & 86,36 & 80,30 & 80,30 \\
\hline & média & 27,64 & 50,93 & 67,57 & 29,92 & 19,18 & 9,17 & 3,79 & 95,11 & 25,21 \\
\hline \multirow{3}{*}{$\begin{array}{l}\text { Austrália- } \\
\text { Território do } \\
\text { Norte }\end{array}$} & $\mathrm{n}$ & 11 & 11 & 11 & 12 & 12 & 11 & 11 & 11 & 11 \\
\hline & $\%$ & 91,67 & 91,67 & 91,67 & 100,00 & 100,00 & 91,67 & 91,67 & 91,67 & 91,67 \\
\hline & média & 28,86 & 49,86 & 65,45 & 27,67 & 19,42 & 8,31 & 3,18 & 94,59 & 25,84 \\
\hline \multirow{3}{*}{$\begin{array}{l}\text { Austrália - } \\
\text { Queensland }\end{array}$} & $\mathrm{n}$ & 21 & 21 & 20 & 22 & 22 & 21 & 21 & 21 & 21 \\
\hline & $\%$ & 95,45 & 95,45 & 90,91 & 100,00 & 100,00 & 95,45 & 95,45 & 95,45 & 95,45 \\
\hline & média & 28,05 & 49,67 & 66,50 & 28,50 & 17,64 & 9,92 & 3,64 & 94,83 & 23,50 \\
\hline \multirow{3}{*}{ Austrália - Sul } & $\mathrm{n}$ & 103 & 104 & 104 & 126 & 130 & 103 & 101 & 97 & 95 \\
\hline & $\%$ & 70,07 & 70,75 & 70,75 & 85,71 & 88,44 & 70,07 & 68,71 & 65,99 & 64,63 \\
\hline & média & 27,26 & 50,41 & 67,15 & 29,64 & 20,52 & 9,89 & 4,07 & 96,60 & 26,06 \\
\hline \multirow{3}{*}{$\begin{array}{l}\text { Austrália - } \\
\text { Tasmânia }\end{array}$} & $\mathrm{n}$ & 15 & 15 & 15 & 14 & 17 & 17 & 17 & 15 & 15 \\
\hline & $\%$ & 88,24 & 88,24 & 88,24 & 82,35 & 100,00 & 100,00 & 100,00 & 88,24 & 88,24 \\
\hline & média & 27,07 & 48,20 & 66,73 & 28,43 & 18,26 & 8,65 & 3,70 & 96,02 & 27,37 \\
\hline \multirow{3}{*}{$\begin{array}{c}\text { Austrália - } \\
\text { Victoria State }\end{array}$} & $n$ & 10 & 10 & 10 & 10 & 10 & 9 & 9 & 9 & 9 \\
\hline & $\%$ & 100,00 & 100,00 & 100,00 & 100,00 & 100,00 & 90,00 & 90,00 & 90,00 & 90,00 \\
\hline & média & 27,60 & 48,55 & 66,30 & 27,50 & 17,50 & 9,49 & 3,62 & 94,06 & 23,85 \\
\hline & $\mathrm{n}$ & 28 & 28 & 26 & 27 & 27 & 27 & 27 & 25 & 25 \\
\hline Austr & $\%$ & 100,00 & 100,00 & 92,86 & 96,43 & 96,43 & 96,43 & 96,43 & 89,29 & 89,29 \\
\hline & média & 28,61 & 50,98 & 66,46 & 27,93 & 17,56 & 9,37 & 4,01 & 95,15 & 26,04 \\
\hline Canadá - & $\mathrm{n}$ & 75 & 75 & 73 & 75 & 77 & 76 & 75 & 73 & 73 \\
\hline Columbia & $\%$ & 96,15 & 96,15 & 93,59 & 96,15 & 98,72 & 97,44 & 96,15 & 93,59 & 93,59 \\
\hline Britânica & média & 24,75 & 53,87 & 65,58 & 26,17 & 17,47 & 8,61 & 3,10 & 101,04 & 23,26 \\
\hline & $\mathrm{n}$ & 3 & 3 & 3 & 3 & 3 & 3 & 3 & 3 & 3 \\
\hline Central & $\%$ & 100,00 & 100,00 & 100,00 & 100,00 & 100,00 & 100,00 & 100,00 & 100,00 & 100,00 \\
\hline & média & 23,33 & 50,33 & 67,33 & 26,67 & 17,67 & 7,19 & 4,14 & 99,43 & 24,00 \\
\hline Canadá - & $\mathrm{n}$ & 31 & 31 & 31 & 37 & 37 & 36 & 36 & 28 & 28 \\
\hline Ontário & $\%$ & 77,50 & 77,50 & 77,50 & 92,50 & 92,50 & 90,00 & 90,00 & 70,00 & 70,00 \\
\hline (Iroque) & média & 27,34 & 54,47 & 67,19 & 27,41 & 18,38 & 9,14 & 3,90 & 100,78 & 24,69 \\
\hline América & $\mathrm{n}$ & $\overline{9}$ & 9 & 9 & 9 & 9 & 9 & 9 & 8 & 8 \\
\hline Central e do & $\%$ & 100,00 & 100,00 & 100,00 & 100,00 & 100,00 & 100,00 & 100,00 & 88,89 & 88,89 \\
\hline Sul - Bolívia & média & 24,00 & 49,39 & 62,89 & 27,22 & 16,44 & 9,25 & 3,33 & 96,98 & 24,71 \\
\hline América & $\mathrm{n}$ & 12 & 12 & 11 & 12 & 12 & 12 & 12 & 11 & 11 \\
\hline Central e do & $\%$ & 92,31 & 92,31 & 84,62 & 92,31 & 92,31 & 92,31 & 92,31 & 84,62 & 84,62 \\
\hline Sul - Caribe & média & 25,92 & 54,04 & 65,27 & 29,00 & 17,83 & 9,57 & 4,11 & 103,37 & 25,46 \\
\hline América & $n$ & 20 & 20 & 19 & 20 & 20 & 20 & 20 & 20 & 20 \\
\hline Central e do & $\%$ & 100,00 & 100,00 & 95,00 & 100,00 & 100,00 & 100,00 & 100,00 & 100,00 & 100,00 \\
\hline Sul - Chile & média & 24,90 & 51,35 & 64,71 & 26,93 & 17,20 & 9,07 & 3,98 & "99,74 & 24,15 \\
\hline & $\mathrm{n}$ & 19 & 19 & 17 & 18 & 19 & 20 & 20 & 17 & 17 \\
\hline
\end{tabular}




\begin{tabular}{|c|c|c|c|c|c|c|c|c|c|c|}
\hline \multirow{3}{*}{$\begin{array}{c}\text { América } \\
\text { Central e do }\end{array}$} & $n$ & 19 & 19 & 17 & 18 & 19 & 20 & 20 & 17 & 17 \\
\hline & $\%$ & 95,00 & 95,00 & 85,00 & 90,00 & 95,00 & 100,00 & 100,00 & 85,00 & 85,00 \\
\hline & & 25,79 & 50,26 & 65,71 & 29,39 & 18,74 & 9,16 & 3,22 & 101,10 & 22,38 \\
\hline \multirow{3}{*}{$\begin{array}{l}\text { Sul Ancééliấanbia } \\
\text { Central e do } \\
\text { Sul - Equador }\end{array}$} & $\mathrm{n}$ & $\overline{7}$ & 7 & 7 & 6 & 7 & 7 & $\overline{7}$ & 6 & 6 \\
\hline & $\%$ & 100,00 & 100,00 & 100,00 & 85,71 & 100,00 & 100,00 & 100,00 & 85,71 & 85,71 \\
\hline & média & 24,36 & 51,07 & 66,00 & 27,33 & 17,86 & 9,53 & 4,19 & 99,02 & 25,23 \\
\hline \multirow{3}{*}{$\begin{array}{l}\text { América Central e } \\
\text { do Sul - Fueguinos } \\
\text { (Patagônia) }\end{array}$} & $\mathrm{n}$ & 55 & 55 & 54 & 56 & 56 & 55 & 55 & 55 & 55 \\
\hline & $\%$ & 96,49 & 96,49 & 94,74 & 98,25 & 98,25 & 96,49 & 96,49 & 96,49 & 96,49 \\
\hline & média & 25,27 & 54,25 & 66,38 & 27,59 & 17,44 & 8,12 & 3,75 & 103,26 & 24,71 \\
\hline \multirow{3}{*}{$\begin{array}{c}\text { América } \\
\text { Central e do } \\
\text { Sul - Guiana }\end{array}$} & $\mathrm{n}$ & 4 & 4 & 4 & 5 & 5 & 4 & 4 & 4 & 4 \\
\hline & $\%$ & 57,14 & 57,14 & 57,14 & 71,43 & 71,43 & 57,14 & 57,14 & 57,14 & 57,14 \\
\hline & média & 27,88 & 53,50 & 68,00 & 28,20 & 18,00 & 10,01 & 3,86 & 103,10 & 25,11 \\
\hline \multirow{3}{*}{$\begin{array}{c}\text { América } \\
\text { Central e do } \\
\text { Sul - México }\end{array}$} & $\mathrm{n}$ & 72 & 72 & 70 & 69 & 71 & 72 & 72 & 69 & 69 \\
\hline & $\%$ & 98,63 & 98,63 & 95,89 & 94,52 & 97,26 & 98,63 & 98,63 & 94,52 & 94,52 \\
\hline & média & 26,08 & 52,10 & 66,26 & 28,64 & 17,86 & 10,05 & 4,06 & 101,79 & 24,70 \\
\hline \multirow{3}{*}{$\begin{array}{c}\text { América } \\
\text { Central e do } \\
\text { Sul - Panamá }\end{array}$} & $\mathrm{n}$ & $\overline{1}$ & 1 & 1 & 1 & 1 & 1 & $\overline{1}$ & $\overline{1}$ & 1 \\
\hline & $\%$ & 100,00 & 100,00 & 100,00 & 100,00 & 100,00 & 100,00 & 100,00 & 100,00 & 100,00 \\
\hline & média & 26,00 & 54,00 & 68,00 & 28,00 & 21,00 & 10,16 & 5,84 & 99,20 & 26,09 \\
\hline \multirow{3}{*}{$\begin{array}{c}\text { América } \\
\text { Central e do } \\
\text { Sul - Peru }\end{array}$} & $\mathrm{n}$ & 222 & 223 & 220 & 221 & 223 & 222 & 222 & 222 & 222 \\
\hline & $\%$ & 99,55 & 100,00 & 98,65 & 99,10 & 100,00 & 99,55 & 99,55 & 99,55 & 99,55 \\
\hline & média & 24,39 & 50,71 & 64,38 & 27,71 & 17,46 & 8,98 & 4,00 & 99,49 & 23,83 \\
\hline \multirow{3}{*}{$\begin{array}{c}\text { América } \\
\text { Central e do } \\
\text { Sul - } \\
\text { Venezuela } \\
\end{array}$} & $\mathrm{n}$ & 12 & 12 & 12 & 12 & 12 & 12 & 12 & 12 & 12 \\
\hline & $\%$ & 100,00 & 100,00 & 100,00 & 100,00 & 100,00 & 100,00 & 100,00 & 100,00 & 100,00 \\
\hline & média & 26,38 & 54,33 & 66,88 & 26,67 & 18,17 & 9,02 & 3,30 & 102,30 & 25,47 \\
\hline \multirow{3}{*}{$\begin{array}{c}\text { Leste Asiático } \\
\text { - Ainu } \\
\text { Hokkaido }\end{array}$} & $n$ & 35 & 35 & 30 & 34 & 34 & 34 & 34 & 35 & 35 \\
\hline & $\%$ & 100,00 & 100,00 & 85,71 & 97,14 & 97,14 & 97,14 & 97,14 & 100,00 & 100,00 \\
\hline & média & 26,57 & 51,14 & 65,73 & 29,76 & 18,53 & 8,47 & 3,75 & 101,85 & 22,52 \\
\hline Leste Asiático & $n$ & 5 & 5 & 5 & 5 & 5 & 5 & 5 & 5 & 5 \\
\hline - Ainu & $\%$ & 100,00 & 100,00 & 100,00 & 100,00 & 100,00 & 100,00 & 100,00 & 100,00 & 100,00 \\
\hline Sakhalin & média & 25,30 & 49,80 & 65,80 & 31,00 & 17,40 & 6,60 & 3,02 & 97,36 & 23,29 \\
\hline Leste Asiático & $n$ & 62 & 62 & 61 & 62 & 62 & 62 & 62 & 61 & 61 \\
\hline - Norte da & $\%$ & 100,00 & 100,00 & 98,39 & 100,00 & 100,00 & 100,00 & 100,00 & 98,39 & 98,39 \\
\hline China (Han) & média & 26,49 & 53,50 & 64,42 & 27,77 & 17,79 & 8,06 & 2,51 & 98,24 & 21,68 \\
\hline Leste Asiático - & $n$ & 50 & 50 & 48 & 55 & 56 & 55 & 55 & 55 & 54 \\
\hline Norte & $\%$ & 89,29 & 89,29 & 85,71 & 98,21 & 100,00 & 98,21 & 98,21 & 98,21 & 96,43 \\
\hline (Man & média & 24,90 & 56,12 & 65,17 & 31,13 & 17,88 & 7,20 & 2,52 & 98,06 & 22,04 \\
\hline Leste Asiático & $\mathrm{n}$ & 67 & 67 & 66 & 65 & 67 & 67 & 66 & 64 & 63 \\
\hline - Sul da China & $\%$ & 100,00 & 100,00 & 98,51 & 97,01 & 100,00 & 100,00 & 98,51 & 95,52 & 94,03 \\
\hline$(\mathrm{H}$ & média & 26,42 & 53,07 & 64,70 & 27,40 & 16,39 & 7,51 & 2,12 & 98,71 & 21,22 \\
\hline Leste Asiático - & $n$ & 32 & 33 & 30 & 33 & 38 & 30 & 29 & 24 & 24 \\
\hline Japão & $\%$ & 64,00 & 66,00 & 60,00 & 66,00 & 76,00 & 60,00 & 58,00 & 48,00 & 48,00 \\
\hline & média & 26,47 & 48,18 & 64,13 & 28,85 & 18,95 & 9,74 & 3,96 & 100,23 & 22,22 \\
\hline Leste Asiático & $\mathrm{n}$ & 107 & 107 & 101 & 106 & 107 & 106 & 106 & 102 & 102 \\
\hline - Japão & $\%$ & 100,00 & 100,00 & 94,39 & 99,07 & 100,00 & 99,07 & 99,07 & 95,33 & 95,33 \\
\hline Tohoku & média & 25,18 & 52,51 & 65,55 & 28,68 & 16,78 & 6,77 & 2,19 & 97,92 & 22,65 \\
\hline Leste Asiático & $n$ & 43 & 43 & 42 & 43 & 43 & 41 & 41 & 43 & 43 \\
\hline - Japão & $\%$ & 100,00 & 100,00 & 97,67 & 100,00 & 100,00 & 95,35 & 95,35 & 100,00 & 100,00 \\
\hline Tóquio & média & 25,15 & 52,30 & 65,48 & 29,56 & 18,58 & 7,41 & 2,54 & 98,87 & 23,39 \\
\hline & $n$ & 32 & 32 & 31 & 31 & 31 & 31 & 31 & 30 & 30 \\
\hline - Coréia & $\%$ & 96,97 & 96,97 & 93,94 & 93,94 & 93,94 & 93,94 & 93,94 & 90,91 & 90,91 \\
\hline & média & 26,02 & 53,67 & 65,26 & 29,45 & 17,97 & 7,54 & 2,27 & 99,26 & 20,33 \\
\hline & $n$ & 35 & 35 & 34 & 34 & 35 & 35 & 35 & 35 & 35 \\
\hline Lesste Malatico & $\%$ & 97,22 & 97,22 & 94,44 & 94,44 & 97,22 & 97,22 & 97,22 & 97,22 & 97,22 \\
\hline & média & 25,27 & 49,59 & 64,81 & 28,79 & 17,97 & 8,49 & 3,68 & 95,77 & 22,67 \\
\hline e Asiático & $\mathrm{n}$ & 11 & 11 & 11 & 11 & 11 & 11 & 11 & 11 & 11 \\
\hline - Tajiwan & $\%$ & 100,00 & 100,00 & 100,00 & 100,00 & 100,00 & 100,00 & 100,00 & 100,00 & 100,00 \\
\hline & média & 26,36 & 53,82 & 64,27 & 28,45 & 17,82 & 7,41 & 2,30 & 98,81 & 24,09 \\
\hline & $\mathrm{n}$ & 56 & 57 & 56 & 57 & 58 & 56 & 56 & 56 & 56 \\
\hline - Tibet & $\%$ & 87,50 & 89,06 & 87,50 & 89,06 & 90,63 & 87,50 & 87,50 & 87,50 & 87,50 \\
\hline & média & 26,04 & 51,79 & 64,52 & 29,28 & 17,60 & 7,32 & 2,73 & 97,87 & 21,35 \\
\hline & $n$ & 134 & 134 & 131 & 132 & 134 & 135 & 133 & 124 & 123 \\
\hline Esqui & $\%$ & 99,26 & 99,26 & 97,04 & 97,78 & 99,26 & 100,00 & 98,52 & 91,85 & 91,11 \\
\hline & média & 24,10 & 55,13 & 65,90 & 26,27 & 17,39 & 5,76 & 2,49 & 102,64 & 20,51 \\
\hline & $\mathrm{n}$ & 107 & 107 & 106 & 106 & 107 & 105 & 103 & 104 & 104 \\
\hline Alaska? & $\%$ & 100,00 & 100,00 & 99,07 & 99,07 & 100,00 & 98,13 & 96,26 & 97,20 & 97,20 \\
\hline & média & 24,04 & 55,10 & 67,19 & 27,72 & 18,24 & 5,81 & 2,49 & 103,75 & 21,14 \\
\hline & $n$ & 65 & 66 & 63 & 66 & 68 & 70 & 70 & 59 & 58 \\
\hline Alaska 3 & $\%$ & 92,86 & 94,29 & 90,00 & 94,29 & 97,14 & 100,00 & 100,00 & 84,29 & 82,86 \\
\hline & média & 24,28 & 56,03 & 65,11 & 26,04 & 17,79 & 5,70 & 2,35 & 101,99 & 22,09 \\
\hline & $\mathrm{n}$ & 22 & 22 & 22 & 21 & 22 & 22 & 22 & 20 & 19 \\
\hline
\end{tabular}




\begin{tabular}{|c|c|c|c|c|c|c|c|c|c|c|}
\hline \multirow[b]{2}{*}{ Esquimó - } & $\mathrm{n}$ & 22 & 22 & 22 & 21 & 22 & 22 & 22 & 20 & 19 \\
\hline & média & 106,00 & $16 \theta, \theta 0$ & $10 \theta, 00$ & 83,45 & 100,60 & $100,0 \varnothing$ & 100,00 & 100,96 & 86,66 \\
\hline \multirow{3}{*}{$\begin{array}{l}\text { Asiaia } \\
\text { Esquimó - } \\
\text { Canadá }\end{array}$} & $\mathrm{n}$ & 29 & 29 & 28 & 28 & 30 & 29 & 29 & 29 & 29 \\
\hline & $\%$ & 96,67 & 96,67 & 93,33 & "93,33 & 100,00 & 96,67 & 96,67 & 96,67 & 96,67 \\
\hline & média & 23,24 & 53,93 & 65,02 & 27,39 & 17,90 & 5,35 & 2,61 & 99,77 & 20,50 \\
\hline \multirow{3}{*}{$\begin{array}{l}\text { Esquimó - } \\
\text { Groelândia }\end{array}$} & $\mathrm{n}$ & 103 & 104 & 101 & 101 & 104 & 102 & 100 & 101 & 101 \\
\hline & $\%$ & 96,26 & 97,20 & 94,39 & 94,39 & 97,20 & 95,33 & 93,46 & 94,39 & 94,39 \\
\hline & média & 23,59 & 54,77 & 66,28 & 26,22 & 17,62 & 5,24 & 2,45 & 100,92 & 19,25 \\
\hline \multirow{3}{*}{$\begin{array}{l}\text { Esquimó - } \\
\text { "desconhecido" }\end{array}$} & $\mathrm{n}$ & 10 & 10 & 9 & 10 & 10 & 10 & 10 & 10 & 10 \\
\hline & $\%$ & 100,00 & 100,00 & 90,00 & 100,00 & 100,00 & 100,00 & 100,00 & 100,00 & 100,00 \\
\hline & média & 23,50 & 55,40 & 66,00 & 28,20 & 18,40 & 6,97 & 2,86 & 102,14 & 21,15 \\
\hline \multirow{3}{*}{$\begin{array}{l}\text { Europa - } \\
\text { Albânia }\end{array}$} & $n$ & 3 & 3 & 3 & 3 & 3 & 3 & 3 & 3 & 3 \\
\hline & $\%$ & 100,00 & 100,00 & 100,00 & 100,00 & 100,00 & 100,00 & 100,00 & 100,00 & 100,00 \\
\hline & média & 23,50 & 49,17 & 59,67 & 24,00 & 16,67 & 7,54 & 4,19 & 89,35 & 22,40 \\
\hline \multirow{3}{*}{$\begin{array}{l}\text { Europa - } \\
\text { Áustria }\end{array}$} & $n$ & 80 & 80 & 76 & 80 & 80 & 80 & 80 & 79 & 79 \\
\hline & $\%$ & 100,00 & 100,00 & 95,00 & 100,00 & 100,00 & 100,00 & 100,00 & 98,75 & 98,75 \\
\hline & média & 24,53 & 51,06 & 62,70 & 26,08 & 16,67 & 9,52 & 4,42 & 94,69 & 23,01 \\
\hline \multirow{3}{*}{$\begin{array}{c}\text { Europa - } \\
\text { Áustria (Idade } \\
\text { do Ferro) }\end{array}$} & $\mathrm{n}$ & 1 & 1 & 1 & 2 & 2 & 1 & 1 & 1 & 1 \\
\hline & $\%$ & 50,00 & 50,00 & 50,00 & 100,00 & 100,00 & 50,00 & 50,00 & 50,00 & 50,00 \\
\hline & média & 26,50 & 49,00 & 59,00 & 26,50 & 17,50 & 9,07 & 3,34 & 93,60 & 20,06 \\
\hline \multirow{3}{*}{$\begin{array}{l}\text { Europa - } \\
\text { Bélgica }\end{array}$} & $n$ & 3 & 4 & 3 & 4 & 4 & 3 & 3 & 3 & 3 \\
\hline & $\%$ & 75,00 & 100,00 & 75,00 & 100,00 & 100,00 & 75,00 & 75,00 & 75,00 & 75,00 \\
\hline & média & 22,67 & 51,50 & 61,00 & 26,75 & 16,75 & 7,54 & 4,08 & 95,70 & 22,75 \\
\hline \multirow{3}{*}{$\begin{array}{l}\text { Europa - } \\
\text { Bulgária }\end{array}$} & $\mathrm{n}$ & 17 & 17 & 17 & 18 & 18 & 16 & 16 & 17 & 17 \\
\hline & $\%$ & 94,44 & 94,44 & 94,44 & 100,00 & 100,00 & 88,89 & 88,89 & 94,44 & 94,44 \\
\hline & média & 24,94 & 51,15 & 62,12 & 26,67 & 16,56 & 9,78 & 4,76 & 93,54 & 23,73 \\
\hline Europa - & $n$ & 94 & 95 & 84 & 92 & 95 & 94 & 93 & 95 & 95 \\
\hline "Republica & $\%$ & 98,95 & 100,00 & 88,42 & 96,84 & 100,00 & 98,95 & 97,89 & 100,00 & 100,00 \\
\hline Tcheca" & média & 24,63 & 50,46 & 61,81 & 26,54 & 17,56 & 9,78 & 4,37 & 93,69 & 22,83 \\
\hline Europa - & $n$ & 5 & 5 & 5 & 5 & 5 & 5 & 5 & 5 & 5 \\
\hline "Republica & $\%$ & 100,00 & 100,00 & 100,00 & 100,00 & 100,00 & 100,00 & 100,00 & 100,00 & 100,00 \\
\hline Tcheca" Neolítico & média & 24,10 & 47,30 & 63,20 & 26,20 & 17,00 & 9,82 & 4,03 & 92,62 & 24,21 \\
\hline & $n$ & 7 & 7 & 7 & 7 & 7 & 7 & $\overline{7}$ & 6 & 6 \\
\hline Dinamar & $\%$ & 100,00 & 100,00 & 100,00 & 100,00 & 100,00 & 100,00 & 100,00 & 85,71 & 85,71 \\
\hline & média & 23,86 & 53,00 & 62,00 & 25,29 & 16,57 & 8,20 & 3,65 & 94,80 & 24,64 \\
\hline & $\mathrm{n}$ & 25 & 25 & 25 & 25 & 25 & 25 & 25 & 25 & 25 \\
\hline Finlând & $\%$ & 100,00 & 100,00 & 100,00 & 100,00 & 100,00 & 100,00 & 100,00 & 100,00 & 100,00 \\
\hline & média & 24,66 & 52,98 & 63,76 & 27,52 & 15,80 & 10,10 & 4,36 & 97,78 & 23,48 \\
\hline & $\mathrm{n}$ & 60 & 61 & 56 & 63 & 63 & 61 & 59 & 58 & 58 \\
\hline Franca 1 & $\%$ & 95,24 & 96,83 & 88,89 & 100,00 & 100,00 & 96,83 & 93,65 & 92,06 & 92,06 \\
\hline & média & 23,99 & 51,46 & 61,69 & 26,48 & 16,33 & 9,13 & 4,37 & 92,13 & 22,88 \\
\hline & $n$ & 22 & 21 & 20 & 22 & 22 & 21 & 21 & 18 & 18 \\
\hline Franca ? & $\%$ & 95,65 & 91,30 & 86,96 & 95,65 & 95,65 & 91,30 & 91,30 & 78,26 & 78,26 \\
\hline & média & 24,68 & 51,36 & 63,25 & 27,95 & 17,00 & 9,28 & 4,43 & 96,52 & 22,67 \\
\hline & $\mathrm{n}$ & 80 & 80 & 78 & 82 & 82 & 82 & 82 & 81 & 80 \\
\hline Alem & $\%$ & 97,56 & 97,56 & 95,12 & 100,00 & 100,00 & 100,00 & 100,00 & 98,78 & 97,56 \\
\hline & média & 24,34 & 52,63 & 61,81 & 26,98 & 17,30 & 9,08 & 4,46 & 93,07 & 23,77 \\
\hline & $\mathrm{n}$ & 31 & 32 & 29 & 33 & 34 & 32 & 31 & 30 & 30 \\
\hline Grécia 1 & $\%$ & 91,18 & 94,12 & 85,29 & 97,06 & 100,00 & 94,12 & 91,18 & 88,24 & 88,24 \\
\hline & média & 24,79 & 52,30 & 62,45 & 27,33 & 15,56 & 9,45 & 4,28 & 93,93 & 23,64 \\
\hline & $n$ & 17 & 17 & 17 & 19 & 19 & 17 & 15 & 16 & 16 \\
\hline Grécia 2 & $\%$ & 85,00 & 85,00 & 85,00 & 95,00 & 95,00 & 85,00 & 75,00 & 80,00 & 80,00 \\
\hline & média & 24,44 & 50,56 & 63,00 & 25,47 & 14,74 & 9,53 & 4,82 & 94,66 & 22,37 \\
\hline & $n$ & 48 & 49 & 46 & 52 & 53 & 49 & 46 & 46 & 46 \\
\hline Europa - & $\%$ & 88,89 & 90,74 & 85,19 & 96,30 & 98,15 & 90,74 & 85,19 & 85,19 & 85,19 \\
\hline & média & 24,67 & 51,69 & 62,65 & 26,65 & 15,26 & 9,48 & 4,46 & 94,18 & 23,20 \\
\hline & $\mathrm{n}$ & 4 & 4 & 4 & 6 & 6 & 4 & 3 & 4 & 4 \\
\hline Herzegovinia & $\%$ & 66,67 & 66,67 & 66,67 & 100,00 & 100,00 & 66,67 & 50,00 & 66,67 & 66,67 \\
\hline & média & 26,50 & 53,25 & 65,25 & 26,67 & 17,50 & 10,26 & 4,76 & 101,08 & 23,22 \\
\hline & $\mathrm{n}$ & 32 & 32 & 31 & 33 & 33 & 33 & 33 & 32 & 32 \\
\hline Holanda & $\%$ & 96,97 & 96,97 & 93,94 & 100,00 & 100,00 & 100,00 & 100,00 & 96,97 & 96,97 \\
\hline & média & 23,28 & 51,03 & 61,73 & 25,73 & 16,21 & 8,93 & 4,24 & 91,62 & 22,69 \\
\hline Europa - & $\mathrm{n}$ & 93 & 93 & 91 & 92 & 93 & 93 & 93 & 92 & 92 \\
\hline Hungria & $\%$ & 100,00 & 100,00 & 97,85 & 98,92 & 100,00 & 100,00 & 100,00 & 98,92 & 98,92 \\
\hline & média & 24,92 & 50,94 & 62,91 & 25,69 & 16,23 & 9,58 & 4,43 & 94,28 & 23,22 \\
\hline & $n$ & 100 & 100 & 92 & 101 & 101 & 101 & 100 & 99 & 99 \\
\hline Europa- Ilallid & $\%$ & 99,01 & 99,01 & 91,09 & 100,00 & 100,00 & 100,00 & 99,01 & 98,02 & 98,02 \\
\hline & média & 24,43 & 52,49 & 62,79 & 27,14 & 16,56 & 9,37 & 4,19 & 93,67 & 23,93 \\
\hline & $\mathrm{n}$ & 35 & 35 & 34 & 36 & 37 & 36 & 36 & 33 & 32 \\
\hline & $\%$ & 87,50 & 87,50 & 85,00 & 90,00 & 92,50 & 90,00 & 90,00 & 82,50 & 80,00 \\
\hline
\end{tabular}




\begin{tabular}{|c|c|c|c|c|c|c|c|c|c|c|}
\hline & média & 24,20 & 52,57 & 64,09 & 26,89 & 17,24 & 9,70 & 4,89 & 94,16 & 22,76 \\
\hline \multirow{3}{*}{$\begin{array}{l}\text { Europa - } \\
\text { Lapônia }\end{array}$} & $n$ & 33 & 34 & 32 & 33 & 34 & 32 & 32 & 31 & 31 \\
\hline & $\%$ & 97,06 & 100,00 & 94,12 & 97,06 & 100,00 & 94,12 & 94,12 & 91,18 & 91,18 \\
\hline & média & 23,77 & 50,57 & 61,17 & 24,94 & 16,06 & 8,64 & 3,61 & 94,21 & 21,46 \\
\hline \multirow{3}{*}{$\begin{array}{l}\text { Europa - } \\
\text { Noruega }\end{array}$} & $n$ & 19 & 20 & 18 & 20 & 20 & 20 & 20 & 18 & 18 \\
\hline & $\%$ & 95,00 & 100,00 & 90,00 & $" 100,00$ & 100,00 & 100,00 & 100,00 & 90,00 & 90,00 \\
\hline & média & 22,87 & 53,00 & 63,22 & 27,25 & 16,60 & 9,02 & 4,68 & 93,58 & 24,76 \\
\hline \multirow{3}{*}{$\begin{array}{l}\text { Europa - } \\
\text { Polônia }\end{array}$} & $n$ & 11 & 11 & 11 & 11 & 11 & 10 & 10 & 11 & 11 \\
\hline & $\%$ & 100,00 & 100,00 & 100,00 & 100,00 & 100,00 & 90,91 & 90,91 & 100,00 & 100,00 \\
\hline & média & 24,68 & 52,09 & 61,77 & 26,36 & 16,82 & 8,27 & 3,93 & 96,02 & 25,71 \\
\hline \multirow{3}{*}{$\begin{array}{l}\text { Europa - } \\
\text { Portugal }\end{array}$} & $n$ & 7 & 7 & 5 & 7 & 7 & 7 & 7 & 7 & 7 \\
\hline & $\%$ & 100,00 & 100,00 & 71,43 & 100,00 & 100,00 & 100,00 & 100,00 & 100,00 & 100,00 \\
\hline & média & 25,00 & 52,57 & 63,80 & 27,29 & 16,57 & 9,40 & 4,77 & 95,56 & 26,22 \\
\hline \multirow{3}{*}{$\begin{array}{l}\text { Europa - } \\
\text { Romênia }\end{array}$} & $n$ & 12 & 12 & 11 & 12 & 12 & 12 & 12 & 12 & 12 \\
\hline & $\%$ & 100,00 & 100,00 & 91,67 & 100,00 & 100,00 & 100,00 & 100,00 & 100,00 & 100,00 \\
\hline & média & 24,42 & 53,58 & 63,27 & 26,25 & 15,25 & 9,39 & 4,02 & 92,32 & 24,70 \\
\hline \multirow{3}{*}{$\begin{array}{c}\text { Europa - } \\
\text { Rússia }\end{array}$} & $n$ & 43 & 42 & 40 & 44 & 44 & 44 & 44 & 42 & 42 \\
\hline & $\%$ & 97,73 & 95,45 & 90,91 & 100,00 & 100,00 & 100,00 & 100,00 & 95,45 & 95,45 \\
\hline & média & 24,65 & 51,99 & 63,30 & 28,07 & 17,43 & 9,30 & 4,52 & 94,11 & 23,30 \\
\hline \multirow{3}{*}{$\begin{array}{c}\text { Europa - } \\
\text { Espanha } 1\end{array}$} & $n$ & 14 & 14 & 12 & 14 & 14 & 14 & 14 & 12 & 12 \\
\hline & $\%$ & 100,00 & 100,00 & 85,71 & $" 100,00$ & 100,00 & 100,00 & 100,00 & 85,71 & 85,71 \\
\hline & média & 23,54 & 52,36 & 61,25 & 27,50 & 16,50 & 9,98 & 4,71 & 92,05 & 23,93 \\
\hline \multirow{3}{*}{$\begin{array}{c}\text { Europa - } \\
\text { Espanha } 2\end{array}$} & $n$ & 5 & 5 & 4 & 6 & 6 & 6 & 6 & 4 & 4 \\
\hline & $\%$ & 71,43 & 71,43 & 57,14 & 85,71 & 85,71 & 85,71 & 85,71 & 57,14 & 57,14 \\
\hline & média & 22,20 & 49,80 & 64,25 & 26,83 & 17,17 & 9,31 & 4,00 & 97,90 & 24,94 \\
\hline \multirow{3}{*}{$\begin{array}{c}\text { Europa - } \\
\text { Suécia }\end{array}$} & $n$ & 29 & 30 & 27 & 31 & 31 & 30 & 30 & 29 & 29 \\
\hline & $\%$ & 93,55 & 96,77 & 87,10 & 100,00 & 100,00 & 96,77 & 96,77 & 93,55 & 93,55 \\
\hline & média & 24,00 & 53,42 & 63,48 & 26,90 & 17,03 & 8,75 & 4,20 & "94,90" & '23,29" \\
\hline & $n$ & 37 & 37 & 37 & 37 & 37 & 37 & 36 & 36 & 36 \\
\hline Súca & $\%$ & 100,00 & 100,00 & 100,00 & 100,00 & 100,00 & 100,00 & 97,30 & 97,30 & 97,30 \\
\hline & média & 24,80 & 51,34 & 61,54 & 25,66 & 16,97 & 9,69 & 4,44 & 93,59 & 23,11 \\
\hline & $n$ & 25 & 26 & 25 & 26 & 26 & 26 & 26 & 24 & 24 \\
\hline Ucrânia & $\%$ & 96,15 & 100,00 & 96,15 & 100,00 & 100,00 & 100,00 & 100,00 & 92,31 & 92,31 \\
\hline & média & 24,68 & 50,71 & 62,12 & 26,69 & 17,88 & 9,38 & 4,02 & 95,71 & 22,12 \\
\hline & $n$ & 34 & 34 & 32 & 33 & 34 & 33 & 33 & 33 & 33 \\
\hline Europ & $\%$ & 100,00 & 100,00 & 94,12 & 97,06 & 100,00 & 97,06 & 97,06 & 97,06 & 97,06 \\
\hline & média & 24,87 & 50,28 & 61,34 & 26,09 & 17,24 & 9,60 & 4,83 & 92,76 & 22,82 \\
\hline & $n$ & 15 & 15 & 15 & 15 & 15 & 14 & 14 & 15 & 15 \\
\hline Índia - Assam & $\%$ & 100,00 & 100,00 & 100,00 & 100,00 & 100,00 & 93,33 & 93,33 & 100,00 & 100,00 \\
\hline & média & 26,53 & 50,10 & 65,27 & 28,07 & 16,80 & 7,58 & 2,45 & 97,99 & 22,27 \\
\hline & $n$ & 49 & 50 & 47 & 50 & 50 & 50 & 50 & 49 & 49 \\
\hline did - & $\%$ & 96,08 & 98,04 & 92,16 & 98,04 & 98,04 & 98,04 & 98,04 & 96,08 & 96,08 \\
\hline & média & 25,06 & 48,75 & 62,48 & 26,32 & 16,54 & 8,66 & 3,65 & "94,26 & 23,75 \\
\hline & $n$ & 21 & 21 & 20 & 21 & 21 & 20 & 19 & 21 & 21 \\
\hline Índia - Bihar & $\%$ & 100,00 & 100,00 & 95,24 & "' 100,00 & 100,00 & 95,24 & 90,48 & 100,00 & "' 100,00 \\
\hline & média & 25,19 & 48,14 & 61,60 & 27,52 & 16,14 & 8,77 & 3,75 & 93,00 & 23,07 \\
\hline & $\mathrm{n}$ & 7 & 7 & 7 & 7 & 7 & 7 & 7 & 7 & 7 \\
\hline Bomb & $\%$ & 100,00 & 100,00 & 100,00 & 100,00 & 100,00 & 100,00 & 100,00 & 100,00 & 100,00 \\
\hline & média & 26,29 & 50,71 & 63,86 & 29,86 & 17,71 & 9,71 & 4,03 & 96,53 & '24,99 \\
\hline & $n$ & 17 & 17 & 16 & 17 & 17 & 17 & 17 & 16 & 16 \\
\hline Índia - Calcutá & $\%$ & 100,00 & 100,00 & 94,12 & 100,00 & 100,00 & 100,00 & 100,00 & 94,12 & 94,12 \\
\hline & média & 24,50 & 51,65 & 62,81 & 27,76 & 18,00 & 7,86 & 3,70 & "94,53" & "' 25,41" \\
\hline & $n$ & 4 & 4 & 2 & 4 & 4 & 3 & 3 & 3 & 3 \\
\hline Índia - Central & $\%$ & 100,00 & 100,00 & 50,00 & 100,00 & 100,00 & 75,00 & 75,00 & 75,00 & 75,00 \\
\hline & média & 24,13 & 50,50 & 60,50 & 27,25 & 16,25 & 8,81 & 4,14 & 90,17 & 22,80 \\
\hline & $n$ & 4 & 4 & 2 & 4 & 5 & 4 & 4 & 4 & 4 \\
\hline Índia - Delhi & $\%$ & 80,00 & 80,00 & 40,00 & 80,00 & 100,00 & 80,00 & 80,00 & 80,00 & 80,00 \\
\hline & média & 25,25 & 50,13 & 63,50 & 29,50 & 17,00 & 7,36 & 3,46 & 92,10 & 22,55 \\
\hline & $n$ & 100 & 100 & 96 & 100 & 100 & 100 & 100 & 96 & 96 \\
\hline Índia - Madras & $\%$ & 100,00 & 100,00 & 96,00 & "' 100,00 & 100,00 & 100,00 & 100,00 & 96,00 & " 96,00 \\
\hline & média & 25,11 & 47,89 & 62,18 & 27,35 & 16,47 & 8,57 & 3,45 & 93,79 & 23,32 \\
\hline & $\mathrm{n}$ & 1 & 1 & 1 & 1 & 1 & 1 & 1 & 1 & 1 \\
\hline Índia - Mahalls & $\%$ & 100,00 & 100,00 & 100,00 & 100,00 & 100,00 & 100,00 & 100,00 & 100,00 & 100,00 \\
\hline & média & 26,00 & 51,00 & 63,00 & 24,00 & 17,00 & 7,45 & 5,06 & 92,85 & 26,69 \\
\hline & $\mathrm{n}$ & 10 & 10 & 10 & 10 & 10 & 10 & 10 & 10 & 10 \\
\hline India - & $\%$ & 100,00 & 100,00 & 100,00 & 100,00 & 100,00 & 100,00 & 100,00 & 100,00 & 100,00 \\
\hline & média & 23,90 & 48,80 & 62,80 & 27,50 & 16,90 & 8,40 & 3,21 & 93,88 & 23,42 \\
\hline & $n$ & 11 & 11 & 11 & 11 & 11 & 11 & 11 & 11 & 11 \\
\hline Índia - Mysore & $\%$ & 100,00 & 100,00 & 100,00 & 100,00 & 100,00 & 100,00 & 100,00 & 100,00 & 100,00 \\
\hline & média & 25,09 & 47,32 & 61,86 & 26,18 & 16,23 & 8,72 & 3,66 & 93,58 & 22,68 \\
\hline
\end{tabular}




\begin{tabular}{|c|c|c|c|c|c|c|c|c|c|c|}
\hline \multirow{3}{*}{$\begin{array}{l}\text { Índia - } \\
\text { Noroeste }\end{array}$} & $\mathrm{n}$ & 26 & 27 & 22 & 29 & 29 & 28 & 27 & 27 & 27 \\
\hline & $\%$ & 89,66 & 93,10 & 75,86 & 100,00 & 100,00 & 96,55 & 93,10 & 93,10 & 93,10 \\
\hline & média & 25,46 & 48,48 & 62,55 & 27,24 & 16,24 & 8,67 & 3,53 & 94,54 & 22,72 \\
\hline \multirow{3}{*}{ Índia - Orissa } & $\mathrm{n}$ & 9 & 9 & 9 & 9 & 9 & 9 & 8 & $\overline{9}$ & 9 \\
\hline & $\%$ & 100,00 & 100,00 & 100,00 & 100,00 & 100,00 & 100,00 & 88,89 & 100,00 & 100,00 \\
\hline & média & 25,56 & 49,56 & 63,00 & 28,89 & 17,39 & 8,69 & 3,23 & 94,27 & 23,64 \\
\hline \multirow{3}{*}{ Índia - Pujab } & $\mathrm{n}$ & 71 & 72 & 65 & 73 & 73 & 72 & 71 & $\overline{72}$ & 72 \\
\hline & $\%$ & 97,26 & 98,63 & 89,04 & 100,00 & 100,00 & 98,63 & 97,26 & 98,63 & 98,63 \\
\hline & média & 25,65 & 51,74 & 62,37 & 28,34 & 16,62 & 8,96 & 4,01 & 94,38 & 24,68 \\
\hline \multirow{3}{*}{ Índia - Sikkim } & $\mathrm{n}$ & 25 & 25 & 25 & 25 & 25 & 25 & 24 & 25 & 25 \\
\hline & $\%$ & 100,00 & 100,00 & 100,00 & 100,00 & 100,00 & 100,00 & 96,00 & 100,00 & 100,00 \\
\hline & média & 25,58 & 50,54 & 65,16 & 28,52 & 16,40 & 7,54 & 2,50 & 97,64 & 22,41 \\
\hline \multirow{3}{*}{ Índia - Veddah } & $\mathrm{n}$ & 17 & 17 & 15 & 17 & 17 & 17 & 16 & 16 & 16 \\
\hline & $\%$ & 94,44 & 94,44 & 83,33 & 94,44 & 94,44 & 94,44 & 88,89 & 88,89 & 88,89 \\
\hline & média & 24,26 & 47,00 & 60,40 & 25,53 & 17,06 & 8,05 & 3,17 & 90,38 & 22,82 \\
\hline \multirow{3}{*}{$\begin{array}{l}\text { Melanésia - } \\
\text { Bismarck }\end{array}$} & $\mathrm{n}$ & 15 & 15 & 15 & 15 & 15 & 15 & 15 & 15 & 15 \\
\hline & $\%$ & 100,00 & 100,00 & 100,00 & 100,00 & 100,00 & 100,00 & 100,00 & 100,00 & 100,00 \\
\hline & média & 25,53 & 49,80 & 64,43 & 26,07 & 17,37 & 8,19 & 3,48 & 95,93 & 26,85 \\
\hline \multirow{3}{*}{$\begin{array}{c}\text { Melanésia - } \\
\text { Fiji }\end{array}$} & $n$ & 42 & 41 & 42 & 34 & 34 & 33 & 33 & 31 & 30 \\
\hline & $\%$ & 89,36 & 87,23 & 89,36 & 72,34 & 72,34 & 70,21 & 70,21 & 65,96 & 63,83 \\
\hline & média & 26,02 & 51,29 & 64,43 & 29,12 & 19,18 & 7,86 & 3,35 & 96,58 & 26,23 \\
\hline \multirow{3}{*}{$\begin{array}{l}\text { Melanésia - } \\
\text { Nova Bretanha }\end{array}$} & $n$ & 70 & 68 & 67 & 70 & 70 & 71 & $\overline{70}$ & $\overline{69}$ & 69 \\
\hline & $\%$ & 94,59 & 91,89 & 90,54 & 94,59 & 94,59 & 95,95 & 94,59 & 93,24 & 93,24 \\
\hline & média & 27,12 & 49,40 & 66,29 & 28,66 & 19,13 & 8,21 & 2,80 & 96,98 & 25,56 \\
\hline \multirow{3}{*}{$\begin{array}{c}\text { Melanésia - } \\
\text { Nova } \\
\text { Caledônia } \\
\end{array}$} & $\mathrm{n}$ & 46 & 46 & 43 & 47 & 47 & 42 & 42 & 44 & 43 \\
\hline & $\%$ & 90,20 & 90,20 & 84,31 & 92,16 & 92,16 & 82,35 & 82,35 & 86,27 & 84,31 \\
\hline & média & 27,07 & 49,28 & 64,35 & 29,35 & 18,62 & 8,81 & 5,48 & 96,93 & 25,65 \\
\hline Melanésia - & $\mathrm{n}$ & 50 & 50 & 46 & 48 & 51 & 49 & 49 & 50 & 50 \\
\hline "New & $\%$ & 96,15 & 96,15 & 88,46 & 92,31 & 98,08 & 94,23 & 94,23 & 96,15 & 96,15 \\
\hline Hebrides" & média & 27,09 & 49,88 & 66,39 & 29,14 & 19,95 & 8,53 & 3,42 & 96,95 & 26,14 \\
\hline & $n$ & 33 & 32 & 31 & 32 & 32 & 33 & 33 & 31 & 31 \\
\hline & $\%$ & 94,29 & 91,43 & 88,57 & 91,43 & 91,43 & 94,29 & 94,29 & 88,57 & 88,57 \\
\hline & média & 25,83 & 51,84 & 64,79 & 28,61 & 20,06 & 7,69 & 3,24 & 95,81 & 26,76 \\
\hline & $\bar{n}$ & 16 & 16 & 10 & 16 & 16 & 16 & $\overline{16}$ & $\overline{16}$ & 16 \\
\hline Melc & $\%$ & 100,00 & 100,00 & 62,50 & 100,00 & 100,00 & 100,00 & 100,00 & 100,00 & 100,00 \\
\hline & média & 26,69 & 49,31 & 64,70 & 28,69 & 19,13 & 8,06 & 3,36 & 96,03 & 29,01 \\
\hline Melanócia - & $n$ & 69 & 68 & 61 & 69 & 70 & 70 & 68 & 66 & 65 \\
\hline Tol. & $\%$ & 97,18 & 95,77 & 85,92 & 97,18 & 98,59 & 98,59 & 95,77 & 92,96 & 91,55 \\
\hline & média & 25,77 & 50,90 & 63,88 & 29,67 & 19,49 & 7,96 & 3,37 & 96,60 & 25,78 \\
\hline & $n$ & 61 & 61 & 59 & 59 & 61 & 60 & 60 & 59 & 59 \\
\hline la - & $\%$ & 100,00 & 100,00 & 96,72 & 96,72 & 100,00 & 98,36 & 98,36 & 96,72 & 96,72 \\
\hline & média & 25,34 & 50,26 & 66,65 & 30,28 & 17,89 & 8,90 & 3,65 & 97,34 & 26,59 \\
\hline & $n$ & 22 & 22 & 22 & 22 & 22 & 20 & 20 & 22 & 22 \\
\hline Nilcro & $\%$ & 100,00 & 100,00 & 100,00 & 100,00 & 100,00 & 90,91 & 90,91 & 100,00 & 100,00 \\
\hline & média & 25,61 & 51,84 & 64,66 & 28,36 & 18,23 & 8,01 & 2,90 & 99,49 & 24,83 \\
\hline Mirrn & $\mathrm{n}$ & 24 & 24 & 24 & 26 & 26 & 24 & 24 & 22 & 22 \\
\hline IVICron & $\%$ & 92,31 & 92,31 & 92,31 & 100,00 & 100,00 & 92,31 & 92,31 & 84,62 & 84,62 \\
\hline & média & 26,38 & 52,63 & 66,13 & 29,08 & 17,77 & 8,95 & 2,84 & 100,45 & 20,84 \\
\hline & $n$ & 88 & 89 & 87 & 89 & 89 & 88 & 87 & $\overline{86}$ & 86 \\
\hline - Egito 1 & $\%$ & 98,88 & 100,00 & 97,75 & 100,00 & 100,00 & 98,88 & 97,75 & 96,63 & 96,63 \\
\hline & média & 25,56 & 52,34 & 63,47 & 26,65 & 16,90 & 9,80 & 4,15 & 95,34 & 25,10 \\
\hline Norte da África & $n$ & 14 & 14 & 13 & 14 & 14 & 14 & 13 & $\overline{13}$ & 13 \\
\hline 4Imca & $\%$ & 100,00 & 100,00 & 92,86 & 100,00 & 100,00 & 100,00 & 92,86 & 92,86 & 92,86 \\
\hline & média & 24,82 & 52,36 & 60,69 & 27,75 & 17,29 & 10,31 & 4,13 & 93,71 & 24,12 \\
\hline & $\mathrm{n}$ & 18 & 18 & 18 & 17 & 17 & 18 & 18 & 18 & 18 \\
\hline Norte da & $\%$ & 100,00 & 100,00 & 100,00 & 94,44 & 94,44 & 100,00 & 100,00 & 100,00 & 100,00 \\
\hline & média & 25,61 & 52,08 & 63,36 & 26,29 & 16,88 & 10,53 & 4,74 & 93,99 & 24,34 \\
\hline & $\mathrm{n}$ & 37 & 37 & 36 & 41 & 41 & 36 & 36 & 36 & 36 \\
\hline - Faito Badari & $\%$ & 90,24 & 90,24 & 87,80 & 100,00 & 100,00 & 87,80 & 87,80 & 87,80 & 87,80 \\
\hline & média & 24,66 & 48,11 & 61,72 & 25,27 & 15,46 & 10,56 & 3,79 & 93,33 & 22,91 \\
\hline & $\mathrm{n}$ & 100 & 100 & 100 & 100 & 100 & 100 & 100 & 100 & 100 \\
\hline - Eqito Gizeh & $\%$ & 100,00 & 100,00 & 100,00 & 100,00 & 100,00 & 100,00 & 100,00 & 100,00 & 100,00 \\
\hline & média & 24,69 & 52,42 & 61,09 & 27,29 & 16,13 & 10,28 & 4,38 & 93,81 & 23,25 \\
\hline Norte da África & $\mathrm{n}$ & 78 & 79 & 78 & 80 & 80 & 79 & 75 & 76 & 76 \\
\hline & $\%$ & 97,50 & 98,75 & 97,50 & 100,00 & 100,00 & 98,75 & 93,75 & 95,00 & 95,00 \\
\hline Naqada & média & 25,77 & 50,25 & 62,91 & 27,48 & 16,45 & 10,02 & 3,86 & 94,67 & 23,20 \\
\hline$N$ & $n$ & 29 & 29 & 26 & 28 & 30 & 30 & 29 & 29 & 29 \\
\hline INome da Alrica & $\%$ & 96,67 & 96,67 & 86,67 & 93,33 & 100,00 & 100,00 & 96,67 & 96,67 & 96,67 \\
\hline & média & 23,95 & 48,78 & 62,77 & 27,04 & 15,77 & 9,49 & 4,35 & 94,27 & 21,99 \\
\hline & $\mathrm{n}$ & 46 & 43 & 37 & 45 & 45 & 44 & 42 & 37 & 37 \\
\hline
\end{tabular}




\begin{tabular}{|c|c|c|c|c|c|c|c|c|c|c|}
\hline \multirow[b]{2}{*}{ Norte da África } & $n$ & 46 & 43 & 37 & 45 & 45 & 44 & 42 & 37 & 37 \\
\hline & média & 100,00 & 90,68 & $8 \theta, 63$ & 98,68 & 97,89 & 96,63 & 93,60 & 89,49 & $8 \theta, 03$ \\
\hline \multirow{3}{*}{$\begin{array}{c}\text { Norte Nábia Africa } \\
\text { - Núbia } 2\end{array}$} & $\mathrm{n}$ & 77 & 76 & 76 & 78 & 78 & 77 & 73 & 76 & 75 \\
\hline & $\%$ & 98,72 & 97,44 & 97,44 & 100,00 & 100,00 & 98,72 & 93,59 & 97,44 & 96,15 \\
\hline & média & 25,68 & 51,25 & 62,46 & 26,69 & 16,53 & 9,83 & 4,09 & 93,94 & 23,00 \\
\hline \multirow{3}{*}{$\begin{array}{l}\text { Norte da África } \\
\text { - Kerma }\end{array}$} & $n$ & 85 & 86 & 85 & 85 & 86 & 83 & 82 & 83 & 82 \\
\hline & $\%$ & 98,84 & 100,00 & 98,84 & 98,84 & 100,00 & 96,51 & 95,35 & 96,51 & 95,35 \\
\hline & média & 26,45 & 49,72 & 63,14 & 26,94 & 17,10 & 10,30 & 3,66 & 95,68 & 21,27 \\
\hline \multirow{3}{*}{$\begin{array}{l}\text { Nordeste } \\
\text { Asiático - } \\
\text { Amur }\end{array}$} & $n$ & 10 & 10 & 10 & 10 & 10 & 10 & 10 & 9 & $\overline{9}$ \\
\hline & $\%$ & 90,91 & 90,91 & 90,91 & 90,91 & 90,91 & 90,91 & 90,91 & 81,82 & 81,82 \\
\hline & média & 25,15 & 55,10 & 66,30 & 26,60 & 16,80 & 6,96 & 1,79 & 98,71 & 19,12 \\
\hline \multirow{3}{*}{$\begin{array}{l}\text { Nordeste } \\
\text { Asiático - } \\
\text { Buriat }\end{array}$} & $\mathrm{n}$ & 25 & 25 & 23 & 27 & 27 & 26 & 25 & 24 & 24 \\
\hline & $\%$ & 92,59 & 92,59 & 85,19 & 100,00 & 100,00 & 96,30 & 92,59 & 88,89 & 88,89 \\
\hline & média & 26,68 & 55,12 & 65,52 & 26,37 & 17,15 & 7,26 & 2,44 & 98,50 & 18,71 \\
\hline \multirow{3}{*}{$\begin{array}{l}\text { Nordeste } \\
\text { Asiático - } \\
\text { Chukchi }\end{array}$} & $\mathrm{n}$ & 21 & 21 & 21 & 20 & 21 & 21 & 21 & 21 & 21 \\
\hline & $\%$ & 100,00 & 100,00 & 100,00 & 95,24 & 100,00 & 100,00 & 100,00 & 100,00 & 100,00 \\
\hline & média & 24,74 & 56,95 & 65,60 & 26,10 & 16,95 & 6,58 & 2,60 & 99,75 & 19,87 \\
\hline \multirow{3}{*}{$\begin{array}{l}\text { Nordeste } \\
\text { Asiático - } \\
\text { Evenki }\end{array}$} & $\mathrm{n}$ & 2 & 2 & 2 & 2 & 2 & 2 & 2 & 2 & 2 \\
\hline & $\%$ & 100,00 & 100,00 & 100,00 & 100,00 & 100,00 & 100,00 & 100,00 & 100,00 & 100,00 \\
\hline & média & 26,50 & 54,00 & 65,00 & 28,50 & 16,50 & 9,56 & 2,73 & 99,05 & 23,71 \\
\hline \multirow{3}{*}{$\begin{array}{l}\text { Nordeste } \\
\text { Asiático - } \\
\text { Mongóis }\end{array}$} & $\mathrm{n}$ & 147 & 147 & 142 & 145 & 147 & 148 & 148 & 141 & 141 \\
\hline & $\%$ & 97,35 & 97,35 & 94,04 & 96,03 & 97,35 & 98,01 & 98,01 & 93,38 & 93,38 \\
\hline & média & 27,39 & 56,58 & 66,46 & 27,48 & 17,61 & 6,99 & 2,55 & 102,41 & 19,12 \\
\hline \multirow{3}{*}{$\begin{array}{l}\text { Nordeste } \\
\text { Asiático - } \\
\text { Neolítico } \\
\end{array}$} & $\mathrm{n}$ & 1 & 1 & 1 & 1 & 1 & 1 & $\overline{1}$ & $\overline{1}$ & $\overline{1}$ \\
\hline & $\%$ & 100,00 & 100,00 & 100,00 & 100,00 & 100,00 & 100,00 & 100,00 & 100,00 & 100,00 \\
\hline & média & 28,00 & 57,00 & 64,00 & 28,00 & 18,00 & 6,02 & 3,41 & 104,30 & 23,62 \\
\hline \multirow{3}{*}{$\begin{array}{l}\text { Nordeste } \\
\text { Asiático - } \\
\text { Nivkh }\end{array}$} & $n$ & $\overline{4}$ & $\overline{4}$ & $\overline{4}$ & 4 & 4 & 4 & 4 & $\overline{4}$ & $\overline{4}$ \\
\hline & $\%$ & 100,00 & 100,00 & 100,00 & 100,00 & 100,00 & 100,00 & 100,00 & 100,00 & 100,00 \\
\hline & média & 24,38 & 55,50 & 66,50 & 24,25 & 16,50 & 5,84 & 0,98 & 98,75 & 16,98 \\
\hline \multirow{3}{*}{$\begin{array}{l}\text { Nordeste } \\
\text { Asiático - } \\
\text { Yakut }\end{array}$} & $n$ & 4 & 4 & 4 & 4 & 4 & 4 & 4 & 4 & 4 \\
\hline & $\%$ & 100,00 & 100,00 & 100,00 & 100,00 & 100,00 & 100,00 & 100,00 & 100,00 & 100,00 \\
\hline & média & 26,00 & 53,25 & 63,75 & 27,75 & 16,00 & 7,16 & 1,76 & 97,48 & 19,39 \\
\hline \multirow{3}{*}{$\begin{array}{l}\text { Papua Nova } \\
\text { Guiné - } \\
\text { Província } \\
\text { Central }\end{array}$} & $\mathrm{n}$ & 9 & $\overline{9}$ & 8 & 9 & 9 & 9 & $\overline{9}$ & 8 & 8 \\
\hline & $\%$ & 100,00 & 100,00 & 88,89 & 100,00 & 100,00 & 100,00 & 100,00 & 88,89 & 88,89 \\
\hline & média & 25,56 & 49,44 & 62,25 & 27,78 & 18,00 & 9,70 & 3,38 & 95,94 & 23,42 \\
\hline Papua Nova & $\mathrm{n}$ & 20 & 19 & 17 & 20 & 20 & 20 & 20 & 20 & 19 \\
\hline Guiné - & $\%$ & 95,24 & 90,48 & 80,95 & 95,24 & 95,24 & 95,24 & 95,24 & 95,24 & 90,48 \\
\hline Eastern Is & média & 26,85 & 51,42 & 64,82 & 27,70 & 19,10 & 8,57 & 3,46 & 99,59 & 24,18 \\
\hline Papua Nova & $n$ & 32 & 29 & 31 & 32 & 32 & 31 & 30 & 30 & 28 \\
\hline Guiné - & $\%$ & 96,97 & 87,88 & 93,94 & 96,97 & 96,97 & 93,94 & 90,91 & 90,91 & 84,85 \\
\hline $\begin{array}{l}\text { Frovincla do } \\
\text { Golfo }\end{array}$ & média & 25,81 & 51,07 & 64,94 & 29,69 & 18,66 & 8,74 & 4,23 & 96,17 & 29,90 \\
\hline Papua Nova & $\mathrm{n}$ & 33 & 33 & 33 & 33 & 33 & 33 & $\overline{33}$ & 33 & $\overline{33}$ \\
\hline Guiné - & $\%$ & 100,00 & 100,00 & 100,00 & 100,00 & 100,00 & 100,00 & 100,00 & 100,00 & 100,00 \\
\hline Madang & média & 25,82 & 50,18 & 64,76 & 26,45 & 15,74 & 7,79 & 2,98 & 97,44 & 26,16 \\
\hline Papua Nova & $n$ & 3 & 3 & 3 & 3 & 3 & 3 & $\overline{3}$ & $\overline{3}$ & $\overline{3}$ \\
\hline Guiné - & $\%$ & 100,00 & 100,00 & 100,00 & 100,00 & 100,00 & 100,00 & 100,00 & 100,00 & 100,00 \\
\hline Bay & média & 26,67 & 54,67 & 67,00 & 30,67 & 20,67 & 10,12 & 3,76 & 100,67 & 26,39 \\
\hline Papua Nova & $\mathrm{n}$ & 26 & 26 & 26 & 26 & 26 & 26 & 26 & 26 & 26 \\
\hline Guiné - & $\%$ & 89,66 & 89,66 & 89,66 & 89,66 & 89,66 & 89,66 & 89,66 & 89,66 & 89,66 \\
\hline $\begin{array}{l}\text { Provincia } \\
\text { Sepik Oriental }\end{array}$ & média & 26.00 & 50.81 & 65,10 & 28,87 & 19.15 & 8.94 & 3.72 & 95,86 & 27.71 \\
\hline Papua Nova & $\mathrm{n}$ & 24 & 24 & 24 & 24 & 24 & 24 & 24 & 24 & 24 \\
\hline Guiné - & $\%$ & 100,00 & 100,00 & 100,00 & 100,00 & 100,00 & 100,00 & 100,00 & 100,00 & 100,00 \\
\hline Sepik & média & & & & & & & & & \\
\hline Ocidental & & 26,42 & 49,73 & 62,27 & 27,63 & 18,63 & 8,73 & 3,58 & 95,94 & 25,71 \\
\hline Papua Nova & $\bar{n}$ & 18 & 18 & 18 & 18 & 18 & 18 & 18 & 18 & 17 \\
\hline Guiné - & $\%$ & 100,00 & 100,00 & 100,00 & 100,00 & 100,00 & 100,00 & 100,00 & 100,00 & 94,44 \\
\hline "desconhecido" & média & 25,72 & 50,78 & 64,44 & 30,17 & 19,22 & 8,22 & 3,18 & 93,89 & 25,84 \\
\hline Papua Nova & $\mathrm{n}$ & 14 & 11 & 14 & 14 & 14 & 13 & 13 & 12 & 12 \\
\hline Guiné - & $\%$ & 93,33 & 73,33 & 93,33 & 93,33 & 93,33 & 86,67 & 86,67 & 80,00 & 80,00 \\
\hline Ocidental 1 & média & 25,50 & 51,64 & 64,29 & 30,00 & 19,29 & 8,39 & 3,62 & 96,92 & 27,94 \\
\hline Papua Nova & $\bar{n}$ & 14 & 14 & 14 & 14 & 14 & 14 & 14 & 14 & 14 \\
\hline Guiné - & $\%$ & 100,00 & 100,00 & 100,00 & 100,00 & 100,00 & 100,00 & 100,00 & 100,00 & 100,00 \\
\hline $\begin{array}{l}\text { Provincia } \\
\text { Ocidental } 2\end{array}$ & média & 27,21 & 50,36 & 63,57 & 25,71 & 15,00 & 7,51 & 3,17 & 92,54 & 25,56 \\
\hline & $\bar{n}$ & 72 & $\overline{71}$ & $\overline{71}$ & 73 & 73 & 73 & $\overline{73}$ & 71 & $\overline{70}$ \\
\hline
\end{tabular}




\begin{tabular}{|c|c|c|c|c|c|c|c|c|c|c|}
\hline \multirow[b]{2}{*}{$\begin{array}{l}\text { Polinésia - } \\
\text { Moriori (llhas }\end{array}$} & $n$ & 72 & 71 & 71 & 73 & 73 & 73 & 73 & 71 & 70 \\
\hline & média & $\begin{array}{l}94,74 \\
25,87 \\
\end{array}$ & $\begin{array}{l}93,42 \\
55,91\end{array}$ & $\begin{array}{l}93,42 \\
64,57 \\
\end{array}$ & $\begin{array}{l}96,05 \\
29,33 \\
\end{array}$ & $\begin{array}{l}96,05 \\
17,74 \\
\end{array}$ & $\begin{array}{r}96,05 \\
6,71 \\
\end{array}$ & $\begin{array}{r}96,05 \\
2,57 \\
\end{array}$ & $\begin{array}{l}93,42 \\
97,32\end{array}$ & $\begin{array}{l}92,11 \\
26,69\end{array}$ \\
\hline \multirow{3}{*}{$\begin{array}{l}\text { Pohatan) } \\
\text { Polnesia - } \\
\text { llhas Cook }\end{array}$} & $\mathrm{n}$ & 13 & 13 & 13 & 13 & 15 & 12 & 12 & 13 & 13 \\
\hline & $\%$ & 86,67 & 86,67 & 86,67 & 86,67 & 100,00 & 80,00 & 80,00 & 86,67 & 86,67 \\
\hline & média & 27,46 & 53,77 & 65,77 & 31,46 & 20,53 & 8,10 & 3,13 & 98,89 & 23,57 \\
\hline \multirow{3}{*}{$\begin{array}{l}\text { Polinésia - } \\
\text { Ilhas Easter }\end{array}$} & $n$ & 62 & 62 & 49 & 65 & 68 & 68 & 68 & 57 & 57 \\
\hline & $\%$ & 76,54 & 76,54 & 60,49 & 80,25 & 83,95 & 83,95 & 83,95 & 70,37 & 70,37 \\
\hline & média & 27,36 & 53,37 & 63,65 & 30,25 & 19,30 & 7,59 & 3,14 & 97,53 & 25,32 \\
\hline \multirow{3}{*}{$\begin{array}{l}\text { Polinésia - } \\
\text { Havaí }\end{array}$} & $\mathrm{n}$ & 71 & 72 & 69 & 72 & 72 & 71 & 69 & 72 & 72 \\
\hline & $\%$ & 98,61 & 100,00 & 95,83 & 100,00 & 100,00 & 98,61 & 95,83 & 100,00 & 100,00 \\
\hline & média & 26,13 & 53,01 & 64,30 & 27,33 & 17,17 & 7,24 & 2,47 & 96,53 & 24,17 \\
\hline \multirow{3}{*}{$\begin{array}{l}\text { Polinésia - } \\
\text { Ilhas } \\
\text { Marquesas }\end{array}$} & $n$ & 66 & 66 & 66 & 66 & 66 & 66 & 66 & 66 & 66 \\
\hline & $\%$ & 100,00 & 100,00 & 100,00 & 100,00 & 100,00 & 100,00 & 100,00 & 100,00 & 100,00 \\
\hline & média & 25,85 & 54,03 & 64,89 & 30,56 & 18,44 & 7,07 & 2,94 & 98,76 & 25,14 \\
\hline \multirow{3}{*}{$\begin{array}{c}\text { Polinésia - } \\
\text { Maori Nova } \\
\text { Zelândia } \\
\end{array}$} & $n$ & 118 & 120 & 120 & 119 & 119 & 118 & 115 & 117 & 117 \\
\hline & $\%$ & 98,33 & 100,00 & 100,00 & 99,17 & 99,17 & 98,33 & 95,83 & 97,50 & 97,50 \\
\hline & média & 26,24 & 53,78 & 64,06 & 29,38 & 18,50 & 6,93 & 2,84 & 97,37 & 25,70 \\
\hline \multirow{3}{*}{$\begin{array}{l}\text { Polinésia - } \\
\text { Ilhas Society }\end{array}$} & $n$ & 48 & 48 & 48 & 48 & 49 & 47 & 46 & 45 & 45 \\
\hline & $\%$ & 97,96 & 97,96 & 97,96 & 97,96 & 100,00 & 95,92 & 93,88 & 91,84 & 91,84 \\
\hline & média & 25,61 & 53,07 & 64,04 & 29,06 & 18,08 & 7,66 & 3,12 & 95,78 & 24,80 \\
\hline \multirow{3}{*}{$\begin{array}{l}\text { Polinésia - } \\
\text { Samoa Tonga }\end{array}$} & $\mathrm{n}$ & 19 & 18 & 16 & 16 & 16 & 15 & 15 & 14 & 14 \\
\hline & $\%$ & 86,36 & 81,82 & 72,73 & 72,73 & 72,73 & 68,18 & 68,18 & 63,64 & 63,64 \\
\hline & média & 26,16 & 55,31 & 64,31 & 30,44 & 19,31 & 7,99 & 3,54 & 101,62 & 24,91 \\
\hline \multirow{3}{*}{$\begin{array}{c}\text { Sudeste } \\
\text { Asiático - Ilhas } \\
\text { Andaman } \\
\end{array}$} & $n$ & 51 & 51 & 51 & 53 & 53 & 50 & 49 & 51 & 49 \\
\hline & $\%$ & 96,23 & 96,23 & 96,23 & 100,00 & 100,00 & 94,34 & 92,45 & 96,23 & 92,45 \\
\hline & média & 24,28 & 47,93 & 60,83 & 25,73 & 16,28 & 9,01 & 2,54 & 95,15 & 23,85 \\
\hline Sudeste & $n$ & 5 & 5 & 5 & 5 & 5 & 5 & 5 & 5 & 5 \\
\hline sucieste & $\%$ & 100,00 & 100,00 & 100,00 & 100,00 & 100,00 & 100,00 & 100,00 & 100,00 & 100,00 \\
\hline & média & 25,90 & 50,80 & 63,70 & 29,00 & 18,40 & 7,89 & 2,73 & 97,60 & 20,28 \\
\hline Sudeste & $\mathrm{n}$ & 16 & 16 & 14 & 16 & 16 & 16 & 16 & 16 & 16 \\
\hline Asiático - & $\%$ & 94,12 & 94,12 & 82,35 & 94,12 & 94,12 & 94,12 & 94,12 & 94,12 & 94,12 \\
\hline Borneo 1 & média & 26,94 & 52,25 & 65,86 & 29,38 & 19,06 & 7,91 & 2,54 & 101,48 & 22,35 \\
\hline Sudeste & $n$ & 76 & 77 & 72 & 78 & 79 & 76 & 76 & 72 & 71 \\
\hline Asiático - & $\%$ & 96,20 & 97,47 & 91,14 & 98,73 & 100,00 & 96,20 & 96,20 & 91,14 & 89,87 \\
\hline Bor & média & 26,42 & 50,47 & 63,94 & 27,40 & 17,03 & 7,98 & 2,27 & 99,17 & 22,50 \\
\hline Sudeste & $n$ & 11 & 11 & 10 & 11 & 11 & 11 & 11 & 11 & 11 \\
\hline Asiático - & $\%$ & 100,00 & 100,00 & 90,91 & 100,00 & 100,00 & 100,00 & 100,00 & 100,00 & 100,00 \\
\hline Camboja & média & 27,14 & 51,68 & 65,70 & 29,00 & 16,91 & 8,03 & 2,51 & 99,75 & 21,61 \\
\hline Sudeste & $n$ & 18 & 19 & 18 & 19 & 19 & 18 & 18 & 17 & 17 \\
\hline Asiático - & $\%$ & 94,74 & 100,00 & 94,74 & 100,00 & 100,00 & 94,74 & 94,74 & 89,47 & 89,47 \\
\hline Celebes & média & 26,75 & 52,03 & 66,61 & 30,53 & 17,79 & 8,13 & 2,67 & 100,24 & 21,48 \\
\hline Sudeste & $\mathrm{n}$ & 0 & 0 & 1 & 1 & 1 & 0 & 0 & 0 & 0 \\
\hline Asiático - Laos & $\%$ & 0,00 & 0,00 & 100,00 & 100,00 & 100,00 & 0,00 & 0,00 & 0,00 & 0,00 \\
\hline (early) & média & 0,00 & 0,00 & 68,00 & 28,00 & 18,00 & 0,00 & 0,00 & 0,00 & 0,00 \\
\hline Sudeste & $n$ & 6 & 3 & 6 & 2 & 3 & 2 & 2 & 3 & 3 \\
\hline Asiático - & $\%$ & 75,00 & 37,50 & 75,00 & 25,00 & 37,50 & 25,00 & 25,00 & 37,50 & 37,50 \\
\hline Malásia (early) & média & 29,08 & 48,33 & 64,67 & 24,00 & 17,00 & 7,02 & 1,93 & 98,67 & 23,50 \\
\hline Sudeste & $n$ & 9 & 11 & 9 & 18 & 18 & 12 & 12 & 7 & 7 \\
\hline Asiático - & $\%$ & 39,13 & 47,83 & 39,13 & 78,26 & 78,26 & 52,17 & 52,17 & 30,43 & 30,43 \\
\hline Vietnam (early) & média & 26,17 & 49,36 & 64,22 & 25,17 & 16,17 & 9,20 & 2,63 & 99,41 & 20,30 \\
\hline Sudeste & $n$ & 4 & 4 & 4 & 4 & 4 & 4 & 4 & 4 & 4 \\
\hline Asiático - & $\%$ & 100,00 & 100,00 & 100,00 & 100,00 & 100,00 & 100,00 & 100,00 & 100,00 & 100,00 \\
\hline Flores & média & 25,63 & 50,00 & 62,75 & 26,00 & 16,25 & 9,55 & 3,48 & 98,85 & 22,38 \\
\hline & $n$ & 61 & 60 & 60 & 62 & 62 & 61 & 61 & 59 & 58 \\
\hline Asiático - Java & $\%$ & 98,39 & 96,77 & 96,77 & 100,00 & 100,00 & 98,39 & 98,39 & 95,16 & 93,55 \\
\hline & média & 27,32 & 52,66 & 66,68 & 29,73 & 18,32 & 8,46 & 2,83 & 100,91 & 22,28 \\
\hline & $\mathrm{n}$ & 32 & 32 & 32 & 32 & 32 & 31 & 31 & 32 & 32 \\
\hline Asiático- & $\%$ & 100,00 & 100,00 & 100,00 & 100,00 & 100,00 & 96,88 & 96,88 & 100,00 & 100,00 \\
\hline & média & 26,83 & 51,45 & 64,78 & 27,97 & 16,75 & 8,07 & 2,15 & 99,77 & 21,69 \\
\hline Sudeste & $\mathrm{n}$ & 53 & 53 & 49 & 55 & 56 & 54 & 54 & 52 & 52 \\
\hline Asiático - & $\%$ & 94,64 & 94,64 & 87,50 & 98,21 & 100,00 & 96,43 & 96,43 & 92,86 & 92,86 \\
\hline Malásia & média & 26,48 & 51,67 & 65,82 & 28,98 & 18,66 & 7,84 & 2,85 & 98,14 & 22,64 \\
\hline Sudeste & $n$ & 22 & 22 & 22 & 22 & 22 & 22 & 22 & 22 & 22 \\
\hline Asiático - & $\%$ & 100,00 & 100,00 & 100,00 & 100,00 & 100,00 & 100,00 & 100,00 & 100,00 & 100,00 \\
\hline Molucca & média & 26,45 & 51,57 & 64,14 & 27,86 & 18,00 & 8,84 & 2,78 & 99,15 & 22,22 \\
\hline Sudeste & $n$ & 103 & 103 & 99 & 102 & 103 & 102 & 101 & 97 & 97 \\
\hline Asiático - & $\%$ & 100,00 & 100,00 & 96,12 & 99,03 & 100,00 & 99,03 & 98,06 & 94,17 & 94,17 \\
\hline Myanmar & média & 27,00 & 51,87 & 65,89 & 29,10 & 17,77 & 8,49 & 3,00 & 99,44 & 22,24 \\
\hline & $n$ & 22 & 22 & 22 & 22 & 22 & 22 & 21 & 22 & 22 \\
\hline & $\%$ & 100,00 & 100,00 & 100,00 & 100,00 & 100,00 & 100,00 & 95,45 & 100,00 & 100,00 \\
\hline
\end{tabular}




\begin{tabular}{|c|c|c|c|c|c|c|c|c|c|c|}
\hline $\begin{array}{l}\text { Filipinas } \\
\text { (negrito) }\end{array}$ & média & 26,84 & 48,09 & 60,91 & 24,27 & 16,32 & 7,89 & 2,25 & 94,89 & 19,12 \\
\hline \multirow{3}{*}{$\begin{array}{l}\text { Sudeste } \\
\text { Asiático - } \\
\text { Semang } \\
\text { (negrito) }\end{array}$} & $n$ & 1 & 1 & 0 & 1 & 1 & 1 & 1 & 1 & 1 \\
\hline & $\%$ & 100,00 & 100,00 & 0,00 & 100,00 & 100,00 & 100,00 & 100,00 & 100,00 & 100,00 \\
\hline & média & 27,00 & 51,00 & 0,00 & 27,00 & 16,00 & 4,17 & 1,23 & 95,08 & 21,36 \\
\hline \multirow{3}{*}{$\begin{array}{l}\text { Sudeste } \\
\text { Asiático - Is } \\
\text { Nicobar }\end{array}$} & $n$ & 19 & 19 & 14 & 20 & 20 & 18 & 18 & 18 & 18 \\
\hline & $\%$ & 90,48 & 90,48 & 66,67 & 95,24 & 95,24 & 85,71 & 85,71 & 85,71 & 85,71 \\
\hline & média & 27,68 & 50,63 & 64,50 & 26,95 & 17,45 & 9,04 & 2,79 & 99,63 & 22,39 \\
\hline \multirow{3}{*}{$\begin{array}{l}\text { Sudeste } \\
\text { Asiático - } \\
\text { Filipinas }\end{array}$} & $\mathrm{n}$ & 120 & 121 & 117 & 122 & 122 & 120 & 120 & 116 & 115 \\
\hline & $\%$ & 98,36 & 99,18 & 95,90 & 100,00 & 100,00 & 98,36 & 98,36 & 95,08 & 94,26 \\
\hline & média & 27,19 & 51,34 & 64,74 & 27,64 & 17,49 & 8,38 & 2,80 & 98,94 & 21,55 \\
\hline \multirow{3}{*}{$\begin{array}{l}\text { Sudeste } \\
\text { Asiático - } \\
\text { Singapura }\end{array}$} & $\mathrm{n}$ & 43 & 43 & 43 & 43 & 43 & 43 & 43 & 43 & 43 \\
\hline & $\%$ & 100,00 & 100,00 & 100,00 & 100,00 & 100,00 & 100,00 & 100,00 & 100,00 & 100,00 \\
\hline & média & 27,06 & 52,62 & 65,29 & 26,92 & 16,58 & 7,89 & 2,34 & 100,76 & 22,19 \\
\hline \multirow{3}{*}{$\begin{array}{c}\text { Sudeste } \\
\text { Asiático - Sulu }\end{array}$} & $\mathrm{n}$ & 4 & 5 & 4 & 5 & 5 & 4 & 4 & 4 & 4 \\
\hline & $\%$ & 80,00 & 100,00 & 80,00 & $" 100,00$ & 100,00 & 80,00 & 80,00 & 80,00 & 80,00 \\
\hline & média & 27,50 & 50,80 & 64,25 & 26,40 & 18,00 & 7,91 & 2,80 & 98,70 & 21,80 \\
\hline \multirow{3}{*}{$\begin{array}{c}\text { Sudeste } \\
\text { Asiático- } \\
\text { Sumatra } \\
\end{array}$} & $\mathrm{n}$ & 26 & 27 & 26 & 27 & 27 & 26 & 26 & 26 & 26 \\
\hline & $\%$ & 96,30 & 100,00 & 96,30 & 100,00 & 100,00 & 96,30 & 96,30 & 96,30 & 96,30 \\
\hline & média & 26,29 & 50,91 & 64,63 & 28,48 & 18,48 & 8,65 & 2,73 & 98,01 & 21,81 \\
\hline \multirow{3}{*}{$\begin{array}{l}\text { Sudeste } \\
\text { Asiático - } \\
\text { Sumbawa }\end{array}$} & $\mathrm{n}$ & 1 & 1 & 1 & $\overline{1}$ & 1 & 1 & 1 & 1 & 1 \\
\hline & $\%$ & 100,00 & 100,00 & 100,00 & 100,00 & 100,00 & 100,00 & 100,00 & 100,00 & 100,00 \\
\hline & média & 28,00 & 58,00 & 65,00 & 34,00 & 20,00 & 6,97 & 3,37 & 95,56 & 23,91 \\
\hline \multirow{3}{*}{$\begin{array}{l}\text { Sudeste } \\
\text { Asiático - } \\
\text { Tailândia }\end{array}$} & $\mathrm{n}$ & 47 & 47 & 47 & 47 & 47 & 47 & 47 & 47 & 47 \\
\hline & $\%$ & 100,00 & 100,00 & 100,00 & 100,00 & 100,00 & 100,00 & 100,00 & 100,00 & 100,00 \\
\hline & média & 26,44 & 52,35 & 65,85 & 28,81 & 17,49 & 8,10 & 2,61 & 100,45 & 21,99 \\
\hline \multirow{3}{*}{$\begin{array}{c}\text { Sudeste } \\
\text { Asiático - } \\
\text { Timor } \\
\end{array}$} & $n$ & 5 & 5 & 5 & 4 & 4 & 5 & 5 & 5 & 5 \\
\hline & $\%$ & 100,00 & 100,00 & 100,00 & 80,00 & 80,00 & 100,00 & 100,00 & 100,00 & 100,00 \\
\hline & média & 26,70 & 52,40 & 68,60 & 30,75 & 19,00 & 8,31 & 3,21 & 96,11 & 22,85 \\
\hline \multirow{3}{*}{$\begin{array}{l}\text { Sudeste } \\
\text { Asiático - } \\
\text { Vietnam }\end{array}$} & $\mathrm{n}$ & 24 & 24 & 23 & 24 & 24 & 24 & 24 & 22 & 22 \\
\hline & $\%$ & 100,00 & 100,00 & 95,83 & 100,00 & 100,00 & 100,00 & 100,00 & 91,67 & 91,67 \\
\hline & média & 26,69 & 51,58 & 64,87 & 27,79 & 16,58 & 8,09 & 2,28 & 100,48 & 21,95 \\
\hline & $n$ & 33 & 33 & 33 & 33 & 33 & 33 & 33 & 32 & 32 \\
\hline Saariana - & $\%$ & 100,00 & 100,00 & 100,00 & 100,00 & 100,00 & 100,00 & 100,00 & 96,97 & 96,97 \\
\hline & média & 28,39 & 49,15 & 64,73 & 26,53 & 17,59 & 9,65 & 2,59 & 98,42 & 22,44 \\
\hline África Sub- & $\mathrm{n}$ & 16 & 16 & 16 & 17 & 18 & 15 & 13 & 16 & 16 \\
\hline Saariana - & $\%$ & 88,89 & 88,89 & 88,89 & ' 94,44 & 100,00 & 83,33 & 72,22 & 88,89 & 88,89 \\
\hline Congo & média & 26,41 & 46,84 & 61,88 & 25,74 & 16,78 & 9,07 & 2,85 & 96,35 & 24,45 \\
\hline África Sub- & $\mathrm{n}$ & 8 & 8 & 8 & $\overline{7}$ & 7 & 8 & 8 & $\overline{7}$ & $\overline{7}$ \\
\hline Saariana - & $\%$ & 100,00 & 100,00 & 100,00 & 87,50 & 87,50 & 100,00 & 100,00 & 87,50 & 87,50 \\
\hline África Oriental & média & 27,00 & 47,56 & 63,25 & 26,43 & 16,29 & 9,18 & 2,48 & 95,94 & 24,11 \\
\hline Africa Sub- & $\mathrm{n}$ & 1 & 1 & $\overline{1}$ & 1 & 1 & 1 & 1 & 1 & $\overline{1}$ \\
\hline Saariana - & $\%$ & 100,00 & 100,00 & 100,00 & "100,00 & 100,00 & 100,00 & 100,00 & 100,00 & 100,00 \\
\hline $\begin{array}{l}\text { Africa } \\
\text { Equatorial }\end{array}$ & média & 28,50 & 52,00 & 73,50 & 22,00 & 19,00 & 9,61 & 2,18 & 101,90 & 21,36 \\
\hline África Sub- & $n$ & 8 & 8 & 8 & 8 & 8 & 8 & 8 & 8 & 8 \\
\hline Saariana - & $\%$ & 100,00 & 100,00 & 100,00 & 100,00 & 100,00 & 100,00 & 100,00 & 100,00 & 100,00 \\
\hline Etiópia & média & 27,81 & 51,94 & 64,81 & 28,13 & 17,25 & 8,96 & 2,58 & 97,86 & 24,51 \\
\hline África Sub- & $\mathrm{n}$ & 76 & 76 & 67 & $\overline{76}$ & 76 & 74 & 74 & 75 & 75 \\
\hline Saariana - & $\%$ & 100,00 & 100,00 & 88,16 & 100,00 & 100,00 & 97,37 & 97,37 & 98,68 & 98,68 \\
\hline Gabão & média & 27,47 & 49,28 & 64,72 & 26,86 & 16,64 & 8,86 & 2,66 & 96,57 & 24,52 \\
\hline África Sub- & $\mathrm{n}$ & 1 & 1 & 1 & 1 & 1 & 1 & 1 & 1 & 1 \\
\hline Saariana - & $\%$ & 100,00 & 100,00 & 100,00 & 100,00 & 100,00 & 100,00 & 100,00 & 100,00 & 100,00 \\
\hline Gâmbia & média & 29,00 & 50,00 & 61,00 & 25,00 & 15,00 & 5,90 & 2,49 & 97,70 & 20,03 \\
\hline África Sub- & $\mathrm{n}$ & 51 & 51 & 50 & 51 & 51 & 51 & 51 & 50 & 50 \\
\hline na - & $\%$ & 100,00 & 100,00 & 98,04 & 100,00 & 100,00 & 100,00 & 100,00 & 98,04 & 98,04 \\
\hline Ashanti Gana & média & 28,05 & 49,15 & 65,63 & 27,55 & 17,45 & 8,56 & 2,75 & 96,65 & 22,61 \\
\hline África Sub- & $n$ & 3 & 3 & 3 & 3 & 3 & 3 & 3 & 3 & $\overline{3}$ \\
\hline Saariana - & $\%$ & 100,00 & 100,00 & 100,00 & 100,00 & 100,00 & 100,00 & 100,00 & 100,00 & 100,00 \\
\hline Guinea & média & 28,50 & 49,00 & 68,50 & 28,17 & 18,33 & 9,04 & 1,49 & 99,90 & 21,41 \\
\hline África Sub- & $\mathrm{n}$ & 26 & 27 & 26 & 26 & 26 & 25 & 25 & 26 & 26 \\
\hline Saariana - & $\%$ & 96,30 & 100,00 & 96,30 & 96,30 & 96,30 & 92,59 & 92,59 & 96,30 & "' 96,30 \\
\hline Marfin & média & 27,75 & 49,80 & 64,54 & 28,50 & 17,54 & 9,28 & 3,09 & 98,02 & 23,68 \\
\hline África Sub- & $\mathrm{n}$ & 86 & 88 & $\overline{79}$ & 90 & 94 & 89 & 89 & 81 & 81 \\
\hline Saariana - & $\%$ & 90,53 & 92,63 & 83,16 & 94,74 & 98,95 & 93,68 & 93,68 & 85,26 & 85,26 \\
\hline Quênia & média & 27,18 & 49,43 & 63,39 & 26,68 & 16,77 & 9,35 & 2,31 & 97,03 & 21,81 \\
\hline África Sub- & $n$ & 7 & 7 & 7 & 7 & 7 & 7 & 7 & 7 & 7 \\
\hline Saariana - & $\%$ & 100,00 & 100,00 & 100,00 & 100,00 & 100,00 & 100,00 & 100,00 & 100,00 & 100,00 \\
\hline Libéria & média & 27,79 & 49,79 & 65,71 & 27,14 & 16,43 & 9,09 & 2,88 & 97,54 & 24,30 \\
\hline
\end{tabular}




\begin{tabular}{|c|c|c|c|c|c|c|c|c|c|c|}
\hline \multirow{3}{*}{$\begin{array}{l}\text { África Sub- } \\
\text { Saariana - } \\
\text { Malawi }\end{array}$} & $n$ & 26 & 26 & 26 & 26 & 26 & 25 & 25 & 17 & 17 \\
\hline & $\%$ & 100,00 & 100,00 & 100,00 & 100,00 & 100,00 & 96,15 & 96,15 & 65,38 & 65,38 \\
\hline & média & 28,12 & 49,92 & 66,15 & 28,42 & 17,00 & 8,97 & 2,62 & 97,00 & 23,74 \\
\hline \multirow{3}{*}{$\begin{array}{c}\text { África Sub- } \\
\text { Saariana - } \\
\text { Moçambique }\end{array}$} & $n$ & 4 & 5 & $\overline{4}$ & 5 & 5 & 5 & 5 & 4 & 4 \\
\hline & $\%$ & 80,00 & 100,00 & 80,00 & 100,00 & 100,00 & 100,00 & 100,00 & 80,00 & 80,00 \\
\hline & média & 28,63 & 51,30 & 64,63 & 27,00 & 16,30 & 9,10 & 3,12 & 93,70 & 22,29 \\
\hline \multirow{3}{*}{$\begin{array}{c}\text { África Sub- } \\
\text { Saariana - Ibo } \\
\text { Nigéria } \\
\end{array}$} & $\mathrm{n}$ & 74 & 75 & 69 & 77 & 79 & 72 & 72 & 69 & 68 \\
\hline & $\%$ & 93,67 & 94,94 & 87,34 & 97,47 & 100,00 & 91,14 & 91,14 & 87,34 & 86,08 \\
\hline & média & 28,82 & 50,15 & 65,65 & 28,26 & 18,47 & 9,68 & 3,07 & 98,49 & 21,40 \\
\hline \multirow{3}{*}{$\begin{array}{c}\text { África Sub- } \\
\text { Saariana - } \\
\text { Nigéria } \\
\text { (outros) } \\
\end{array}$} & $\mathrm{n}$ & 42 & 41 & 39 & 41 & 45 & 41 & 40 & 40 & 39 \\
\hline & $\%$ & 93,33 & 91,11 & 86,67 & 91,11 & 100,00 & 91,11 & 88,89 & 88,89 & 86,67 \\
\hline & média & 27,83 & 49,13 & 64,81 & 27,51 & 16,90 & 9,50 & 2,53 & 96,61 & 23,15 \\
\hline \multirow{3}{*}{$\begin{array}{l}\text { África Sub- } \\
\text { Saariana - } \\
\text { Pigmeus }\end{array}$} & $\mathrm{n}$ & 6 & 7 & 7 & 8 & 8 & 7 & 7 & 6 & 6 \\
\hline & $\%$ & 75,00 & 87,50 & 87,50 & 100,00 & 100,00 & 87,50 & 87,50 & 75,00 & 75,00 \\
\hline & média & 26,25 & 45,43 & 60,71 & 23,13 & 14,63 & 7,95 & 1,72 & 91,62 & 22,85 \\
\hline \multirow{3}{*}{$\begin{array}{l}\text { África Sub- } \\
\text { Saariana - } \\
\text { Ruanda }\end{array}$} & $n$ & 1 & 1 & 1 & 1 & 1 & 1 & 1 & 1 & 1 \\
\hline & $\%$ & 100,00 & 100,00 & 100,00 & 100,00 & 100,00 & 100,00 & 100,00 & 100,00 & 100,00 \\
\hline & média & 26,50 & 52,00 & 63,50 & 28,00 & 15,00 & 12,53 & 4,36 & 92,90 & 23,59 \\
\hline \multirow{3}{*}{$\begin{array}{l}\text { Africa Sub- } \\
\text { Saariana - } \\
\text { Senegal } \\
\end{array}$} & $n$ & 1 & 1 & 1 & 1 & 1 & 1 & 1 & 1 & 1 \\
\hline & $\%$ & 100,00 & 100,00 & 100,00 & 100,00 & 100,00 & 100,00 & 100,00 & 100,00 & 100,00 \\
\hline & média & 26,00 & 50,00 & 58,00 & 27,00 & 15,00 & 14,67 & 3,10 & 95,20 & 25,61 \\
\hline \multirow{3}{*}{$\begin{array}{l}\text { África Sub- } \\
\text { Saariana - } \\
\text { Serra Leoa } \\
\end{array}$} & $\mathrm{n}$ & 5 & 5 & 5 & 5 & 5 & 5 & 5 & 5 & 5 \\
\hline & $\%$ & 100,00 & 100,00 & 100,00 & 100,00 & 100,00 & 100,00 & 100,00 & 100,00 & 100,00 \\
\hline & média & 27,40 & 49,20 & 64,60 & 27,60 & 17,40 & 8,27 & 2,58 & 97,56 & 23,49 \\
\hline \multirow{3}{*}{$\begin{array}{l}\text { África Sub- } \\
\text { Saariana - } \\
\text { Somália }\end{array}$} & $\mathrm{n}$ & 60 & 60 & 59 & 62 & 62 & 62 & 61 & 52 & 52 \\
\hline & $\%$ & 93,75 & 93,75 & 92,19 & 96,88 & 96,88 & 96,88 & 95,31 & 81,25 & 81,25 \\
\hline & média & 24,93 & 51,62 & 62,22 & 27,03 & 15,81 & 9,72 & 3,42 & 93,00 & 22,27 \\
\hline \multirow{3}{*}{$\begin{array}{c}\text { África Sub- } \\
\text { Saariana - } \\
\text { África do Sul }\end{array}$} & $\mathrm{n}$ & 24 & 24 & 24 & 23 & 24 & 24 & 24 & 24 & 24 \\
\hline & $\%$ & 100,00 & 100,00 & 100,00 & 95,83 & 100,00 & 100,00 & 100,00 & 100,00 & 100,00 \\
\hline & média & 27,10 & 48,71 & 64,10 & 26,39 & 16,54 & 9,10 & 2,38 & 98,66 & 22,78 \\
\hline \multirow{3}{*}{$\begin{array}{l}\text { África Sub- } \\
\text { Saariana - } \\
\text { Bushman } \\
\text { África do Sul }\end{array}$} & $\mathrm{n}$ & 31 & 30 & 29 & 31 & 32 & 30 & 29 & 31 & 31 \\
\hline & $\%$ & 96,88 & 93,75 & 90,63 & 96,88 & 100,00 & 93,75 & 90,63 & 96,88 & 96,88 \\
\hline & média & 26,66 & 45,28 & 61,69 & 24,90 & 15,66 & 7,05 & 1,07 & 92,17 & 20,03 \\
\hline África Sub- & $\mathrm{n}$ & 18 & 18 & 18 & 18 & 18 & 18 & 18 & 17 & 17 \\
\hline Saariana - & $\%$ & 100,00 & 100,00 & 100,00 & 100,00 & 100,00 & 100,00 & 100,00 & 94,44 & 94,44 \\
\hline África do Sul & média & 27,03 & 48,17 & 63,56 & 26,94 & 17,03 & 8,37 & 2,18 & 94,99 & 22,11 \\
\hline África Sub- & $\mathrm{n}$ & 42 & 42 & 42 & 43 & 43 & 42 & 42 & 41 & 41 \\
\hline Saariana - & $\%$ & 97,67 & 97,67 & 97,67 & 100,00 & 100,00 & 97,67 & 97,67 & 95,35 & 95,35 \\
\hline Sul & média & 27,67 & 49,86 & 65,27 & 26,44 & 17,02 & 8,84 & 2,83 & 97,83 & 23,60 \\
\hline África Sub- & $n$ & 29 & 30 & 29 & 27 & 29 & 30 & 30 & 28 & 28 \\
\hline Saariana - & $\%$ & 96,67 & 100,00 & 96,67 & 90,00 & 96,67 & 100,00 & 100,00 & 93,33 & 93,33 \\
\hline Zulu & média & 27,91 & 50,13 & 65,83 & 28,41 & 18,38 & 8,78 & 2,60 & 97,76 & 23,95 \\
\hline África Sub- & $\mathrm{n}$ & 85 & 86 & 83 & 87 & 87 & 86 & 86 & 79 & 79 \\
\hline Saariana - & $\%$ & 95,51 & 96,63 & 93,26 & 97,75 & 97,75 & 96,63 & 96,63 & 88,76 & 88,76 \\
\hline Tanzânia & média & 27,95 & 48,78 & 65,39 & 26,18 & 16,41 & 9,33 & 2,56 & 97,23 & 24,00 \\
\hline Africa Sub- & $\mathrm{n}$ & 11 & 12 & 12 & 12 & 12 & 12 & 12 & 10 & 10 \\
\hline Saariana - & $\%$ & 91,67 & 100,00 & 100,00 & 100,00 & 100,00 & 100,00 & 100,00 & 83,33 & 83,33 \\
\hline Uganda & média & 27,41 & 48,17 & 64,50 & 27,83 & 16,33 & 8,87 & 2,09 & 95,77 & 22,49 \\
\hline África Sub- & $\mathrm{n}$ & 2 & 2 & 2 & 2 & 2 & 2 & 2 & 2 & 2 \\
\hline Saariana - & $\%$ & 100,00 & 100,00 & 100,00 & 100,00 & 100,00 & 100,00 & 100,00 & 100,00 & 100,00 \\
\hline Ocidental & média & 27,00 & 45,00 & 62,25 & 23,00 & 17,00 & 8,31 & 0,94 & 93,70 & 24,88 \\
\hline África Sub- & $\mathrm{n}$ & $\overline{1}$ & $\overline{1}$ & $\overline{1}$ & 1 & 1 & 1 & $\overline{1}$ & $\overline{1}$ & $\overline{1}$ \\
\hline Saariana - & $\%$ & 100,00 & 100,00 & 100,00 & 100,00 & 100,00 & 100,00 & 100,00 & 100,00 & 100,00 \\
\hline Zaire & média & 28,00 & 50,00 & 68,00 & 28,00 & 17,00 & 9,18 & 2,76 & 100,20 & 22,33 \\
\hline África Sub- & $\mathrm{n}$ & 3 & 3 & 3 & 3 & 3 & 3 & 3 & 3 & 3 \\
\hline Saariana - & $\%$ & 100,00 & 100,00 & 100,00 & 100,00 & 100,00 & 100,00 & 100,00 & 100,00 & 100,00 \\
\hline Zâmbia & média & 29,50 & 55,17 & 65,33 & 24,50 & 17,33 & 9,90 & 2,72 & 103,05 & 25,22 \\
\hline África Sub- & $\mathrm{n}$ & 1 & 1 & 1 & 1 & 1 & 1 & 1 & 1 & 1 \\
\hline Saariana - & $\%$ & 100,00 & 100,00 & 100,00 & 100,00 & 100,00 & 100,00 & 100,00 & 100,00 & 100,00 \\
\hline Zimbaue & média & 30,00 & 48,00 & 70,00 & 30,00 & 16,00 & 12,95 & 3,76 & 99,00 & 21,70 \\
\hline Sudoeste & $\mathrm{n}$ & 40 & 40 & 37 & 40 & 40 & 39 & 38 & 40 & 40 \\
\hline Asiático - & $\%$ & 100,00 & 100,00 & 92,50 & 100,00 & 100,00 & 97,50 & 95,00 & 100,00 & 100,00 \\
\hline Afeganistão & média & 25,14 & 51,23 & 65,00 & 27,65 & 16,70 & 9,55 & 4,34 & 94,90 & 24,56 \\
\hline Sudoeste & $n$ & 25 & 25 & 23 & 25 & 25 & 25 & 25 & 25 & 25 \\
\hline Asiáti & $\%$ & 100,00 & 100,00 & 92,00 & 100,00 & 100,00 & 100,00 & 100,00 & 100,00 & 100,00 \\
\hline Bangladesh & média & 25,24 & 50,00 & 62,57 & 27,60 & 16,32 & 8,59 & 3,66 & 94,17 & 24,14 \\
\hline
\end{tabular}




\begin{tabular}{|c|c|c|c|c|c|c|c|c|c|c|}
\hline Sudoeste & $\mathrm{n}$ & 9 & 9 & 9 & 11 & 11 & 10 & 10 & $\overline{9}$ & $\overline{9}$ \\
\hline \multirow{2}{*}{$\begin{array}{l}\text { Asiático - } \\
\text { Beduíno }\end{array}$} & $\%$ & 81,82 & 81,82 & 81,82 & 100,00 & 100,00 & 90,91 & 90,91 & 81,82 & 81,82 \\
\hline & média & 24,67 & 53,39 & 60,61 & 26,73 & 16,73 & 9,72 & 4,78 & 91,30 & 25,08 \\
\hline \multirow{3}{*}{$\begin{array}{l}\text { Sudoeste } \\
\text { Asiático - } \\
\text { Butão }\end{array}$} & $\mathrm{n}$ & 2 & 2 & 2 & 2 & 2 & 2 & 2 & 2 & 2 \\
\hline & $\%$ & 100,00 & 100,00 & 100,00 & 100,00 & 100,00 & 100,00 & 100,00 & 100,00 & 100,00 \\
\hline & média & 24,00 & 46,00 & 61,50 & 25,50 & 15,00 & 8,47 & 2,93 & 92,90 & 21,54 \\
\hline \multirow{3}{*}{$\begin{array}{l}\text { Sudoeste } \\
\text { Asiático - } \\
\text { Chipre } \\
\end{array}$} & $n$ & 20 & 21 & 20 & 21 & 22 & 19 & 19 & 19 & 19 \\
\hline & $\%$ & 90,91 & 95,45 & 90,91 & 95,45 & 100,00 & 86,36 & 86,36 & 86,36 & 86,36 \\
\hline & média & 24,05 & 51,60 & 62,05 & 26,90 & 16,68 & 9,74 & 4,57 & 95,03 & 22,91 \\
\hline \multirow{3}{*}{$\begin{array}{c}\text { Sudoeste } \\
\text { Asiático - Irã } 1\end{array}$} & $n$ & 4 & 3 & 3 & 8 & 9 & 6 & 6 & 4 & 4 \\
\hline & $\%$ & 30,77 & 23,08 & 23,08 & 61,54 & 69,23 & 46,15 & 46,15 & 30,77 & 30,77 \\
\hline & média & 25,75 & 53,33 & 62,33 & 31,50 & 19,22 & 9,35 & 4,49 & 97,00 & 25,33 \\
\hline \multirow{3}{*}{$\begin{array}{c}\text { Sudoeste } \\
\text { Asiático - Irã } 2\end{array}$} & $n$ & 6 & 5 & 4 & 8 & 9 & 5 & 5 & 2 & 2 \\
\hline & $\%$ & 50,00 & 41,67 & 33,33 & 66,67 & 75,00 & 41,67 & 41,67 & 16,67 & 16,67 \\
\hline & média & 24,83 & 56,00 & 66,00 & 28,75 & 19,33 & 9,30 & 4,84 & 99,00 & 27,19 \\
\hline \multirow{3}{*}{$\begin{array}{c}\text { Sudoeste } \\
\text { Asiático - Irã } 3\end{array}$} & $n$ & 9 & 10 & 8 & 13 & 13 & 12 & 12 & 9 & 9 \\
\hline & $\%$ & 52,94 & 58,82 & 47,06 & 76,47 & 76,47 & 70,59 & 70,59 & 52,94 & 52,94 \\
\hline & média & 25,11 & 53,70 & 62,50 & 30,92 & 17,31 & 9,90 & 4,82 & 97,00 & 26,57 \\
\hline \multirow{3}{*}{$\begin{array}{c}\text { Sudoeste } \\
\text { Asiático - Irã } 4\end{array}$} & $n$ & 4 & 5 & 4 & 8 & 8 & 8 & 8 & 8 & 8 \\
\hline & $\%$ & 50,00 & 62,50 & 50,00 & 100,00 & 100,00 & 100,00 & 100,00 & 100,00 & 100,00 \\
\hline & média & 24,50 & 53,00 & 61,75 & 28,75 & 17,75 & 8,29 & 4,19 & 95,88 & 22,38 \\
\hline \multirow{3}{*}{$\begin{array}{l}\text { Sudoeste } \\
\text { Asiático - } \\
\text { Iraque }\end{array}$} & $\mathrm{n}$ & 16 & 16 & 16 & 16 & 16 & 16 & 15 & 16 & 16 \\
\hline & $\%$ & 100,00 & 100,00 & 100,00 & 100,00 & 100,00 & 100,00 & 93,75 & 100,00 & 100,00 \\
\hline & média & 24,56 & 52,50 & 62,00 & 27,16 & 17,91 & 8,71 & 4,68 & 93,99 & 24,73 \\
\hline \multirow{3}{*}{$\begin{array}{c}\text { Sudoeste } \\
\text { Asiático - } \\
\text { Iraque (early) }\end{array}$} & $\mathrm{n}$ & 14 & 14 & 14 & 14 & 14 & 14 & 12 & $\overline{12}$ & $\overline{12}$ \\
\hline & $\%$ & 100,00 & 100,00 & 100,00 & 100,00 & 100,00 & 100,00 & 85,71 & 85,71 & 85,71 \\
\hline & média & 24,86 & 51,46 & 61,18 & 26,71 & 17,64 & 10,29 & 4,70 & 93,86 & 25,06 \\
\hline Sudoeste & $\mathrm{n}$ & 78 & 78 & 75 & 74 & 78 & 78 & 71 & 75 & 75 \\
\hline Asiático - & $\%$ & 100,00 & 100,00 & 96,15 & 94,87 & 100,00 & 100,00 & 91,03 & 96,15 & 96,15 \\
\hline Israel 1 & média & 24,94 & 51,44 & 62,87 & 27,64 & 16,81 & 10,23 & 4,72 & 94,89 & 23,70 \\
\hline Sudoeste & $\mathrm{n}$ & 10 & 10 & 8 & 12 & 12 & 12 & 12 & 8 & 7 \\
\hline Asiático - & $\%$ & 76,92 & 76,92 & 61,54 & 92,31 & 92,31 & 92,31 & 92,31 & 61,54 & 53,85 \\
\hline Israel 2 & média & 23,80 & 52,10 & 62,25 & 27,33 & 17,00 & 10,43 & 4,85 & 93,53 & 24,48 \\
\hline Sudoeste & $\mathrm{n}$ & 88 & 88 & 83 & 86 & 90 & 90 & $\overline{83}$ & $\overline{83}$ & $\overline{82}$ \\
\hline Asiático - & $\%$ & 96,70 & 96,70 & 91,21 & 94,51 & 98,90 & 98,90 & 91,21 & 91,21 & 90,11 \\
\hline Israel 3 & média & 24,81 & 51,52 & 62,81 & 27,59 & 16,83 & 10,26 & 4,74 & 94,76 & 23,77 \\
\hline Sudoeste & $\mathrm{n}$ & 11 & 11 & 10 & 11 & 11 & 11 & 11 & 9 & 8 \\
\hline Asiático - & $\%$ & 100,00 & 100,00 & 90,91 & ' & 100,00 & 100,00 & 100,00 & 81,82 & 72,73 \\
\hline Palestina & média & 25,41 & 52,91 & 62,20 & 26,55 & 17,00 & 9,60 & 4,62 & 94,58 & 24,26 \\
\hline & $n$ & 16 & 16 & 16 & 16 & 16 & 16 & 16 & 16 & 16 \\
\hline Assático - Síria & $\%$ & 100,00 & 100,00 & 100,00 & 100,00 & 100,00 & 100,00 & 100,00 & 100,00 & 100,00 \\
\hline & média & 25,53 & 53,41 & 64,72 & 28,72 & 16,81 & 9,43 & 4,85 & 96,72 & 24,52 \\
\hline Sudoeste & $n$ & 49 & 50 & 50 & 51 & 51 & 51 & 50 & 49 & 49 \\
\hline Asiático - & $\%$ & 94,23 & 96,15 & 96,15 & 98,08 & 98,08 & 98,08 & 96,15 & 94,23 & 94,23 \\
\hline Turquia & média & 24,89 & 52,40 & 63,09 & 27,10 & 16,35 & 9,90 & 4,51 & 94,60 & 23,91 \\
\hline & $\mathrm{n}$ & 65 & 65 & 61 & 65 & 65 & 63 & 60 & 64 & 64 \\
\hline Gra-Bretanna & $\%$ & 97,01 & 97,01 & 91,04 & 97,01 & 97,01 & 94,03 & 89,55 & 95,52 & 95,52 \\
\hline & média & 23,85 & 51,25 & 61,30 & 25,74 & 15,71 & 9,03 & 3,85 & 92,90 & 23,23 \\
\hline & $\mathrm{n}$ & 19 & 18 & 18 & 22 & 23 & 20 & 20 & 12 & 11 \\
\hline Gra- & $\%$ & 76,00 & 72,00 & 72,00 & 88,00 & 92,00 & 80,00 & 80,00 & 48,00 & 44,00 \\
\hline & média & 23,55 & 50,44 & 62,83 & 26,27 & 16,70 & 9,61 & 4,56 & 92,68 & 23,57 \\
\hline & $\mathrm{n}$ & 99 & 101 & 91 & 101 & 101 & 102 & 101 & 94 & 93 \\
\hline - Poundbury & $\%$ & 97,06 & 99,02 & 89,22 & 99,02 & 99,02 & 100,00 & 99,02 & 92,16 & 91,18 \\
\hline & média & 24,52 & 52,41 & 62,19 & 27,00 & 16,39 & 9,31 & 4,20 & 94,31 & 23,29 \\
\hline & $n$ & 36 & 38 & 35 & 38 & 40 & 35 & 35 & 30 & 30 \\
\hline - Repton & $\%$ & 83,72 & 88,37 & 81,40 & 88,37 & 93,02 & 81,40 & 81,40 & 69,77 & 69,77 \\
\hline & média & 24,43 & 51,93 & 63,69 & 25,68 & 16,75 & 8,93 & 4,35 & 93,97 & 23,58 \\
\hline Grã-Bretanha & $\mathrm{n}$ & 57 & 57 & 57 & 57 & 57 & 57 & 57 & 57 & 57 \\
\hline - Spitafields & $\%$ & 100,00 & 100,00 & 100,00 & 100,00 & 100,00 & 100,00 & 100,00 & 100,00 & 100,00 \\
\hline CAM & média & 24,95 & 50,32 & 62,68 & 26,30 & 16,46 & 8,81 & 3,92 & 94,33 & 22,70 \\
\hline Grã-Bretanha & $\mathrm{n}$ & 76 & 78 & 59 & 84 & 84 & 77 & 77 & 72 & 72 \\
\hline - Spitafields & $\%$ & 88,37 & 90,70 & 68,60 & 97,67 & 97,67 & 89,53 & 89,53 & 83,72 & 83,72 \\
\hline NHM & média & 23,33 & 51,22 & 58,85 & 26,21 & 15,51 & 8,39 & 4,46 & 88,36 & 22,35 \\
\hline & $n$ & 4 & 4 & 4 & 5 & 5 & 5 & 5 & 4 & 4 \\
\hline Alabama & $\%$ & 80,00 & 80,00 & 80,00 & 100,00 & 100,00 & 100,00 & 100,00 & 80,00 & 80,00 \\
\hline & média & 25,75 & 51,25 & 66,88 & 26,60 & 17,80 & 9,32 & 4,15 & 102,95 & 23,66 \\
\hline & $\mathrm{n}$ & 35 & 35 & 35 & 36 & 36 & 36 & 36 & 35 & 35 \\
\hline EUA - nativos & $\%$ & 97,22 & 97,22 & 97,22 & 100,00 & 100,00 & 100,00 & 100,00 & 97,22 & - 97,22 \\
\hline & média & 25,29 & 54,20 & 65,04 & 27,47 & 18,36 & 7,10 & 2,77 & 101,31 & 21,63 \\
\hline & $\mathrm{n}$ & 15 & 15 & 15 & 15 & 15 & 15 & 15 & 15 & 15 \\
\hline
\end{tabular}




\begin{tabular}{|c|c|c|c|c|c|c|c|c|c|c|}
\hline \multirow[b]{2}{*}{ EUA - Alaska } & $\mathrm{n}$ & 15 & 15 & 15 & 15 & 15 & 15 & 15 & 15 & 15 \\
\hline & média & 106,00 & $10 \theta, \theta 0$ & $100,0 \theta$ & 100,00 & $10 \theta, 00$ & $10 \theta, \theta \theta$ & 100,00 & 100,00 & 100,00 \\
\hline \multirow{3}{*}{$\begin{array}{l}\text { EU(Kodjakk }{ }^{\text {Kolska }} \\
\text { (Tlingit) }\end{array}$} & $\bar{n}$ & 35 & 35 & 34 & 33 & 34 & 35 & 35 & 35 & 35 \\
\hline & $\%$ & 100,00 & 100,00 & 97,14 & "94,29" & 97,14 & 100,00 & 100,00 & 100,00 & 100,00 \\
\hline & média & 26,59 & 55,07 & 67,53 & 27,33 & 18,26 & 8,43 & 3,45 & 102,14 & 23,28 \\
\hline \multirow{3}{*}{ EUA - Arizona } & $\mathrm{n}$ & 41 & 41 & 41 & 41 & 41 & 41 & 41 & 41 & 41 \\
\hline & $\%$ & 100,00 & 100,00 & 100,00 & 100,00 & 100,00 & 100,00 & 100,00 & 100,00 & 100,00 \\
\hline & média & 26,71 & 51,80 & 66,63 & 27,21 & 17,76 & 10,48 & 3,85 & 102,87 & 22,65 \\
\hline \multirow{3}{*}{$\begin{array}{c}\text { EUA - } \\
\text { Arkansas }\end{array}$} & $n$ & 29 & 29 & 29 & 29 & 29 & 28 & 28 & 28 & 28 \\
\hline & $\%$ & 100,00 & 100,00 & 100,00 & 100,00 & 100,00 & 96,55 & 96,55 & 96,55 & 96,55 \\
\hline & média & 26,19 & 53,26 & 66,36 & 25,69 & 17,48 & 9,32 & 3,56 & 100,40 & 26,92 \\
\hline \multirow{3}{*}{$\begin{array}{c}\text { EUA - } \\
\text { Califórnia } 1\end{array}$} & $n$ & 58 & 60 & 57 & 60 & 60 & 61 & 61 & 56 & 56 \\
\hline & $\%$ & 95,08 & 98,36 & 93,44 & 98,36 & 98,36 & 100,00 & 100,00 & 91,80 & 91,80 \\
\hline & média & 25,21 & 51,67 & 65,26 & 27,20 & 17,62 & 9,58 & 3,45 & 102,02 & 23,49 \\
\hline \multirow{3}{*}{$\begin{array}{c}\text { EUA - } \\
\text { Califórnia } 2\end{array}$} & $n$ & 163 & 163 & 161 & 163 & 163 & 162 & 162 & 157 & 157 \\
\hline & $\%$ & 100,00 & 100,00 & 98,77 & 100,00 & 100,00 & 99,39 & 99,39 & 96,32 & 96,32 \\
\hline & média & 24,43 & 50,32 & 65,83 & 26,24 & 17,45 & 7,75 & 3,44 & 99,60 & 24,28 \\
\hline \multirow{3}{*}{$\begin{array}{c}\text { EUA - } \\
\text { Califórnia } 3\end{array}$} & $\mathrm{n}$ & 4 & 4 & 3 & 5 & 5 & 4 & 4 & 4 & 4 \\
\hline & $\%$ & 80,00 & 80,00 & 60,00 & 100,00 & 100,00 & 80,00 & 80,00 & 80,00 & 80,00 \\
\hline & média & 25,75 & 52,00 & 65,33 & 31,40 & 20,00 & 8,99 & 3,21 & 105,33 & 25,67 \\
\hline \multirow{3}{*}{$\begin{array}{l}\text { EUA - } \\
\text { Carolina do } \\
\text { Norte }\end{array}$} & $\mathrm{n}$ & 1 & 1 & 1 & 1 & 1 & 1 & $\overline{1}$ & 1 & 1 \\
\hline & $\%$ & 100,00 & 100,00 & 100,00 & 100,00 & 100,00 & 100,00 & 100,00 & 100,00 & 100,00 \\
\hline & média & 24,50 & 47,00 & 58,00 & 26,00 & 18,00 & 10,43 & 5,51 & 91,60 & 21,04 \\
\hline \multirow{3}{*}{$\begin{array}{l}\text { EUA - } \\
\text { Carolina do Sul }\end{array}$} & $n$ & 1 & 1 & 1 & 1 & 1 & 1 & 1 & 1 & 1 \\
\hline & $\%$ & 100,00 & 100,00 & 100,00 & 100,00 & 100,00 & 100,00 & 100,00 & 100,00 & 100,00 \\
\hline & média & 28,00 & 50,00 & 67,00 & 28,00 & 17,00 & 12,68 & 6,56 & 106,50 & 28,50 \\
\hline & $n$ & 6 & 6 & 6 & 6 & 6 & 6 & $\overline{6}$ & $\overline{6}$ & 6 \\
\hline Color & $\%$ & 100,00 & 100,00 & 100,00 & 100,00 & 100,00 & 100,00 & 100,00 & 100,00 & 100,00 \\
\hline & média & 26,92 & 52,50 & 66,83 & 26,50 & 17,83 & 9,33 & 3,59 & 100,57 & "'24,01" \\
\hline & $n$ & 1 & 1 & 1 & 1 & 1 & 1 & 1 & 1 & 1 \\
\hline ut & $\%$ & 100,00 & 100,00 & 100,00 & 100,00 & 100,00 & 100,00 & 100,00 & 100,00 & 100,00 \\
\hline & média & 25,00 & 47,00 & 64,00 & 21,00 & 17,00 & 8,18 & 2,85 & 100,60 & 26,38 \\
\hline & $\mathrm{n}$ & 14 & 15 & 14 & 15 & 15 & 15 & 15 & 15 & 15 \\
\hline EUA - DakUla & $\%$ & 93,33 & 100,00 & 93,33 & 100,00 & 100,00 & 100,00 & 100,00 & 100,00 & 100,00 \\
\hline & média & 27,00 & 55,63 & 66,21 & 25,80 & 17,67 & 9,36 & 4,55 & 104,25 & 24,94 \\
\hline EUA - Dakota & $\mathrm{n}$ & 117 & 118 & 117 & 119 & 119 & 117 & 117 & 116 & 115 \\
\hline EUA 1 & $\%$ & 98,32 & 99,16 & 98,32 & 100,00 & 100,00 & 98,32 & 98,32 & 97,48 & 96,64 \\
\hline & média & 26,12 & 54,93 & 65,71 & 26,13 & 17,54 & 8,45 & 4,11 & 102,53 & 25,62 \\
\hline & $n$ & 6 & 6 & 6 & 6 & 6 & 6 & 6 & 6 & 6 \\
\hline do Sul? & $\%$ & 100,00 & 100,00 & 100,00 & 100,00 & 100,00 & 100,00 & 100,00 & 100,00 & 100,00 \\
\hline & média & 27,17 & 55,83 & 67,92 & 26,83 & 16,83 & 8,08 & 4,09 & 106,30 & 25,09 \\
\hline & $n$ & 10 & 10 & 10 & 10 & 10 & 9 & 9 & 10 & 10 \\
\hline Delaw & $\%$ & 100,00 & 100,00 & 100,00 & 100,00 & 100,00 & 90,00 & 90,00 & 100,00 & 100,00 \\
\hline & média & 25,85 & 52,55 & 68,20 & 27,00 & 18,40 & 8,88 & 3,79 & 102,09 & 28,13 \\
\hline & $\mathrm{n}$ & 95 & 95 & 92 & 96 & 96 & 94 & 93 & 91 & 91 \\
\hline EUA - Flórida & $\%$ & 98,96 & 98,96 & 95,83 & 100,00 & 100,00 & 97,92 & 96,88 & 94,79 & 94,79 \\
\hline & média & 25,72 & 53,69 & 66,40 & 27,26 & 18,61 & 9,21 & 3,92 & 106,35 & 26,27 \\
\hline & $\mathrm{n}$ & 19 & 19 & 18 & 19 & 19 & 18 & 18 & 19 & 19 \\
\hline EUA - Geórgia & $\%$ & 100,00 & 100,00 & 94,74 & 100,00 & 100,00 & 94,74 & 94,74 & 100,00 & 100,00 \\
\hline & média & 25,21 & 52,61 & 66,31 & 26,95 & 17,79 & 9,03 & 4,01 & 98,63 & 25,94 \\
\hline & $n$ & 1 & 1 & 1 & 1 & 1 & 0 & 0 & 1 & 1 \\
\hline Shelter & $\%$ & 100,00 & 100,00 & 100,00 & 100,00 & 100,00 & 0,00 & 0,00 & 100,00 & 100,00 \\
\hline & média & 28,50 & 52,00 & 63,00 & 23,00 & 15,00 & 0,00 & 0,00 & 103,90 & 28,58 \\
\hline & $\mathrm{n}$ & 117 & 117 & 117 & 118 & 118 & 118 & 117 & 116 & 116 \\
\hline EUA - Illinois & $\%$ & 99,15 & 99,15 & 99,15 & 100,00 & 100,00 & 100,00 & 99,15 & 98,31 & 98,31 \\
\hline & média & 26,18 & 53,13 & 66,96 & 26,63 & 17,61 & 8,86 & 3,64 & 101,96 & 26,47 \\
\hline & $\mathrm{n}$ & 4 & 4 & 4 & 4 & 4 & 4 & 4 & 3 & 3 \\
\hline EUA - Indiana & $\%$ & 100,00 & 100,00 & 100,00 & 100,00 & 100,00 & 100,00 & 100,00 & 75,00 & 75,00 \\
\hline & média & 27,63 & 50,88 & 66,88 & 25,25 & 18,25 & 9,41 & 3,51 & 98,57 & 23,69 \\
\hline & $\mathrm{n}$ & 1 & 1 & 1 & 1. & 1 & 1 & 1 & 1 & 1 \\
\hline EUA - lowa & $\%$ & 100,00 & 100,00 & 100,00 & 100,00 & 100,00 & 100,00 & 100,00 & 100,00 & 100,00 \\
\hline & média & 27,00 & 52,00 & 67,00 & 25,00 & 18,00 & 9,48 & 3,95 & 104,00 & 30,43 \\
\hline & $\mathrm{n}$ & 10 & 10 & 9 & 9 & 9 & 10 & 10 & 10 & 9 \\
\hline EUA - Kansas & $\%$ & 100,00 & 100,00 & 90,00 & 90,00 & 90,00 & 100,00 & 100,00 & 100,00 & 90,00 \\
\hline & média & 26,95 & 54,45 & 65,22 & 24,00 & 16,56 & 8,80 & 3,95 & 101,26 & 23,56 \\
\hline & $\mathrm{n}$ & 37 & 37 & 37 & 37 & 37 & 37 & 36 & 36 & 36 \\
\hline Kentuckv & $\%$ & 100,00 & 100,00 & 100,00 & 100,00 & 100,00 & 100,00 & 97,30 & 97,30 & 97,30 \\
\hline & média & 24,49 & 51,85 & 64,16 & 25,47 & 17,68 & 8,51 & 3,12 & 98,42 & 24,58 \\
\hline & $\mathrm{n}$ & 7 & 8 & 7 & 8 & 8 & 7 & 7 & 8 & 7 \\
\hline & $\%$ & 87,50 & 100,00 & 87,50 & 100,00 & 100,00 & 87,50 & 87,50 & 100,00 & 87,50 \\
\hline
\end{tabular}




\begin{tabular}{|c|c|c|c|c|c|c|c|c|c|c|}
\hline & média & 26,50 & 52,50 & 66,57 & 25,63 & 18,75 & 9,79 & 3,78 & 101,71 & 24,98 \\
\hline \multirow{3}{*}{$\begin{array}{l}\text { EUA - } \\
\text { Maryland }\end{array}$} & $\mathrm{n}$ & 53 & 53 & 49 & 54 & 54 & 52 & 51 & 48 & 48 \\
\hline & $\%$ & 98,15 & 98,15 & 90,74 & 100,00 & 100,00 & 96,30 & 94,44 & 88,89 & 88,89 \\
\hline & média & 27,35 & 52,68 & 67,85 & 25,26 & 17,70 & 9,02 & 3,69 & 101,79 & 27,00 \\
\hline \multirow{3}{*}{$\begin{array}{c}\text { EUA - } \\
\text { Massachusetts }\end{array}$} & $\mathrm{n}$ & 1 & 1 & 1 & 1 & 1 & 1 & 1 & 1 & 1 \\
\hline & $\%$ & 100,00 & 100,00 & 100,00 & - & 100,00 & 100,00 & 100,00 & 100,00 & 100,00 \\
\hline & média & 26,50 & 54,00 & 70,00 & 26,00 & 18,00 & 4,71 & 2,94 & 95,30 & 30,55 \\
\hline \multirow{3}{*}{$\begin{array}{l}\text { EUA - } \\
\text { Michigan }\end{array}$} & $\mathrm{n}$ & 12 & 12 & 11 & 12 & 12 & 12 & 12 & 10 & 10 \\
\hline & $\%$ & 100,00 & 100,00 & 91,67 & 100,00 & 100,00 & 100,00 & 100,00 & 83,33 & 83,33 \\
\hline & média & 26,96 & 52,54 & 66,64 & 25,88 & 17,42 & 8,54 & 3,80 & 100,15 & 22,74 \\
\hline \multirow{3}{*}{$\begin{array}{l}\text { EUA - } \\
\text { Mississipi }\end{array}$} & $\mathrm{n}$ & 3 & 3 & 3 & 3 & 3 & 3 & 3 & 3 & 3 \\
\hline & $\%$ & 100,00 & 100,00 & 100,00 & 100,00 & 100,00 & 100,00 & 100,00 & 100,00 & 100,00 \\
\hline & média & 25,00 & 49,67 & 63,00 & 26,33 & 16,67 & 7,94 & 3,56 & 99,93 & 24,75 \\
\hline \multirow{3}{*}{$\begin{array}{l}\text { EUA - } \\
\text { Missouri }\end{array}$} & $n$ & 10 & 10 & 10 & 9 & 10 & 10 & 10 & 9 & 8 \\
\hline & $\%$ & 100,00 & 100,00 & 100,00 & 90,00 & 100,00 & 100,00 & 100,00 & 90,00 & 80,00 \\
\hline & média & 25,15 & 52,25 & 66,60 & 27,11 & 17,30 & 8,76 & 3,42 & 101,01 & 25,21 \\
\hline \multirow{3}{*}{$\begin{array}{l}\text { EUA - } \\
\text { Montana }\end{array}$} & $\mathrm{n}$ & 15 & 15 & 15 & 13 & 15 & 15 & 15 & 14 & 14 \\
\hline & $\%$ & 100,00 & 100,00 & 100,00 & 86,67 & 100,00 & 100,00 & 100,00 & 93,33 & 93,33 \\
\hline & média & 26,83 & 54,10 & 65,90 & 26,31 & 17,13 & 8,40 & 3,85 & 100,81 & 23,96 \\
\hline \multirow{3}{*}{$\begin{array}{l}\text { EUA - } \\
\text { Nebraska }\end{array}$} & $n$ & 17 & 17 & 17 & 17 & 17 & 17 & 17 & 17 & 17 \\
\hline & $\%$ & 100,00 & 100,00 & 100,00 & 100,00 & 100,00 & 100,00 & 100,00 & 100,00 & 100,00 \\
\hline & média & 26,21 & 54,15 & 66,91 & 26,35 & 17,35 & 8,14 & 3,77 & 103,39 & 24,35 \\
\hline \multirow{3}{*}{ EUA - Nevada } & $n$ & 2 & 2 & 2 & 2 & 2 & 2 & 2 & 2 & 2 \\
\hline & $\%$ & 100,00 & 100,00 & 100,00 & 100,00 & 100,00 & 100,00 & 100,00 & 100,00 & 100,00 \\
\hline & média & 29,50 & 54,25 & 70,50 & 26,50 & 16,50 & 10,30 & 3,92 & 112,35 & 23,64 \\
\hline \multirow{3}{*}{$\begin{array}{c}\text { EUA - New } \\
\text { Jersey }\end{array}$} & $n$ & 8 & 8 & 8 & 8 & 8 & 8 & 8 & 7 & 7 \\
\hline & $\%$ & 100,00 & 100,00 & 100,00 & 100,00 & 100,00 & 100,00 & 100,00 & 87,50 & 87,50 \\
\hline & média & 26,69 & 52,75 & 67,50 & 25,63 & 18,25 & 9,40 & 4,17 & 102,71 & 27,99 \\
\hline & $n$ & 63 & 63 & 57 & 63 & 63 & 63 & 63 & 61 & 61 \\
\hline México & $\%$ & 100,00 & 100,00 & 90,48 & 100,00 & 100,00 & 100,00 & 100,00 & 96,83 & 96,83 \\
\hline & média & 25,85 & 51,15 & 64,58 & 26,36 & 16,89 & 9,66 & 3,41 & 100,23 & 22,94 \\
\hline & $\mathrm{n}$ & 27 & 27 & 27 & 27 & 27 & 27 & 27 & 25 & 25 \\
\hline CUA York & $\%$ & 100,00 & 100,00 & 100,00 & 100,00 & 100,00 & 100,00 & 100,00 & 92,59 & 92,59 \\
\hline & média & 27,19 & 52,61 & 67,09 & 25,98 & 17,59 & 9,41 & 3,82 & 100,35 & 25,95 \\
\hline EUA - & $\mathrm{n}$ & 9 & 9 & 9 & 9 & 9 & 9 & 9 & 9 & $\overline{9}$ \\
\hline Nordeste & $\%$ & 100,00 & 100,00 & 100,00 & 100,00 & 100,00 & 100,00 & 100,00 & 100,00 & 100,00 \\
\hline americano & média & 25,56 & 54,33 & 66,00 & 28,33 & 18,22 & 8,49 & 4,11 & 100,58 & 24,18 \\
\hline & $n$ & 0 & 0 & 1 & 1 & 1 & 1 & 1 & 0 & $\overline{0}$ \\
\hline EUA - Ohio & $\%$ & 0,00 & 0,00 & 50,00 & 50,00 & 50,00 & 50,00 & 50,00 & 0,00 & 0,00 \\
\hline & média & 0,00 & 0,00 & 70,00 & 30,00 & 20,00 & 10,22 & 4,89 & 0,00 & 0,00 \\
\hline & $n$ & 13 & 13 & 12 & 12 & 12 & 12 & 12 & 12 & 12 \\
\hline EUA - Oregon & $\%$ & 100,00 & 100,00 & 92,31 & 92,31 & 92,31 & 92,31 & 92,31 & 92,31 & 92,31 \\
\hline & média & 23,88 & 51,08 & 64,83 & 25,92 & 17,25 & 8,56 & 3,78 & 99,23 & 24,98 \\
\hline & $n$ & 2 & 3 & 2 & 4 & 4 & 4 & 4 & 2 & 2 \\
\hline P & $\%$ & 50,00 & 75,00 & 50,00 & 100,00 & 100,00 & 100,00 & 100,00 & 50,00 & 50,00 \\
\hline & média & 27,00 & 54,50 & 71,50 & 27,00 & 17,50 & 10,18 & 4,51 & 101,55 & 29,51 \\
\hline & $\mathrm{n}$ & 8 & 9 & 8 & 10 & 10 & 10 & 10 & 8 & 8 \\
\hline Tenn & $\%$ & 80,00 & 90,00 & 80,00 & 100,00 & 100,00 & 100,00 & 100,00 & 80,00 & 80,00 \\
\hline & média & 26,00 & 51,28 & 68,25 & 28,00 & 19,50 & 8,70 & 3,72 & 100,50 & 24,23 \\
\hline & $n$ & 16 & 16 & 17 & 17 & 17 & 16 & 16 & 16 & 16 \\
\hline EUA - Texas & $\%$ & 94,12 & 94,12 & 100,00 & 100,00 & 100,00 & 94,12 & 94,12 & 94,12 & 94,12 \\
\hline & média & 27,41 & 53,63 & 65,38 & 25,94 & 17,06 & 9,61 & 4,35 & 101,94 & 22,58 \\
\hline & $\mathrm{n}$ & 58 & 58 & 58 & 58 & 58 & 58 & 58 & 58 & 58 \\
\hline EUA - Utah & $\%$ & 100,00 & 100,00 & 100,00 & 100,00 & 100,00 & 100,00 & 100,00 & 100,00 & 100,00 \\
\hline & média & 25,65 & 51,65 & 65,53 & 26,48 & 17,67 & 9,93 & 3,87 & 101,77 & 23,06 \\
\hline & $n$ & 56 & 57 & 53 & 58 & 58 & 54 & 53 & 52 & 51 \\
\hline EUA - Virginia & $\%$ & 96,55 & 98,28 & 91,38 & 100,00 & 100,00 & 93,10 & 91,38 & 89,66 & 87,93 \\
\hline & média & 26,71 & 52,85 & 66,84 & 26,79 & 17,86 & 8,79 & 3,76 & 101,34 & 27,18 \\
\hline & $n$ & 1 & 1 & 1 & 1 & 1 & 1 & 1 & 1 & 1 \\
\hline Ocidental & $\%$ & 100,00 & 100,00 & 100,00 & 100,00 & 100,00 & 100,00 & 100,00 & 100,00 & 100,00 \\
\hline & média & 25,00 & 57,00 & 71,00 & 28,00 & 16,00 & 6,87 & 3,90 & 103,40 & 24,94 \\
\hline & $n$ & 2 & 2 & 2 & 2 & 2 & 2 & 2 & 2 & 2 \\
\hline Washin & $\%$ & 100,00 & 100,00 & 100,00 & 100,00 & 100,00 & 100,00 & 100,00 & 100,00 & 100,00 \\
\hline & média & 24,50 & 50,00 & 64,50 & 25,50 & 18,00 & 11,18 & 3,80 & 95,95 & 20,65 \\
\hline & $\mathrm{n}$ & 5 & 5 & 5 & 5 & 5 & 5 & 5 & 5 & 5 \\
\hline Visconsin & $\%$ & 100,00 & 100,00 & 100,00 & 100,00 & 100,00 & 100,00 & 100,00 & 100,00 & 100,00 \\
\hline & média & 26,40 & 54,30 & 67,80 & 26,20 & 17,00 & 9,02 & 4,62 & 103,62 & 26,20 \\
\hline & $n$ & 3 & 3 & 3 & 3 & 3 & 3 & 3 & 3 & 3 \\
\hline Ec & $\%$ & 100,00 & 100,00 & 100,00 & 100,00 & 100,00 & 100,00 & 100,00 & 100,00 & 100,00 \\
\hline & média & 26,00 & 52,33 & 67,00 & 25,67 & 15,67 & 8,62 & 3,22 & 105,90 & 25,34 \\
\hline
\end{tabular}




\section{Apêndice 2}

Esquema de posicionamento das páginas do Apêndice 2:

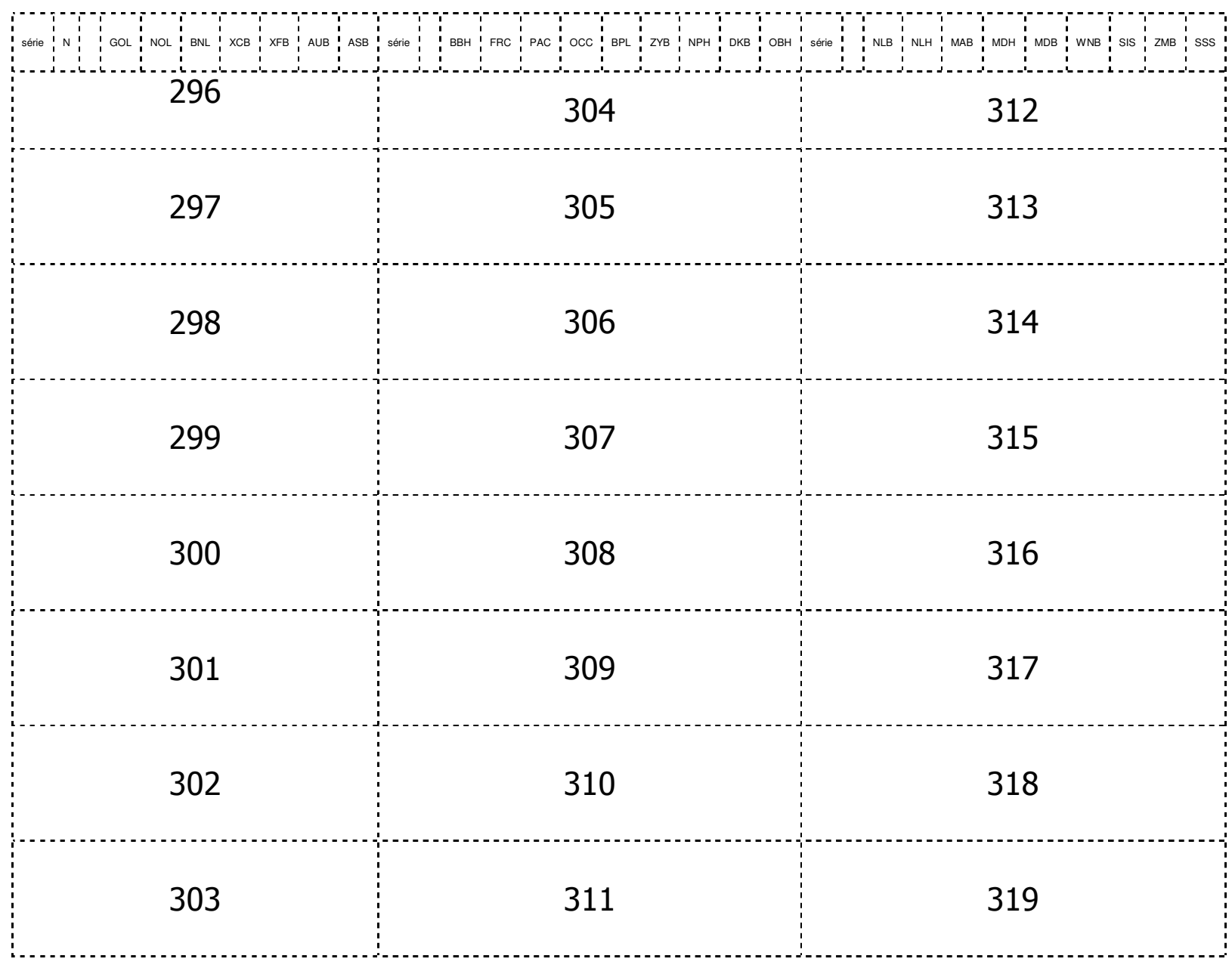


Apêndice 2 - Número de Indivíduos, número de medidas tomadas (absoluta e relativa) e média de cada uma das variáveis utilizáveis do Banco Hanihara - Parcela Feminina.

\begin{tabular}{|c|c|c|c|c|c|c|c|c|c|}
\hline série & $\mathrm{N}$ & & GOL & NOL & BNL & XCB & XFB & AUB & ASB \\
\hline \multirow{3}{*}{ Aleuta 1} & \multirow{3}{*}{57} & $n$ & 56 & 56 & 55 & 57 & 55 & 56 & 56 \\
\hline & & $\%$ & 98,25 & 98,25 & 96,49 & 100,00 & 96,49 & 98,25 & 98,25 \\
\hline & & média & 175,79 & 175,08 & 96,92 & 142,61 & 112,67 & 127,69 & 112,06 \\
\hline \multirow{3}{*}{ Aleuta 2} & \multirow{3}{*}{42} & $\mathrm{n}$ & 42 & 42 & 42 & 42 & 42 & 42 & 42 \\
\hline & & $\%$ & 100,00 & 100,00 & 100,00 & 100,00 & 100,00 & 100,00 & 100,00 \\
\hline & & média & 173,88 & 173,02 & 95,10 & 144,32 & 114,20 & 128,88 & 112,57 \\
\hline \multirow{3}{*}{ Aleuta 3} & \multirow{3}{*}{13} & $\mathrm{n}$ & 13 & 13 & 13 & 11 & 10 & 12 & 13 \\
\hline & & $\%$ & 100,00 & 100,00 & 100,00 & 84,62 & 76,92 & 92,31 & 100,00 \\
\hline & & média & 171,81 & 170,81 & 95,27 & 140,45 & 112,20 & 125,21 & 111,58 \\
\hline \multirow{3}{*}{ Aleuta 4} & \multirow{3}{*}{7} & $\mathrm{n}$ & 7 & 7 & 7 & 6 & 7 & 6 & 6 \\
\hline & & $\%$ & 100,00 & 100,00 & 100,00 & 85,71 & 100,00 & 85,71 & 85,71 \\
\hline & & média & 171,00 & 170,14 & 93,93 & 140,17 & 113,50 & 124,58 & 110,92 \\
\hline \multirow{3}{*}{ Aleuta 5} & \multirow{3}{*}{7} & $\mathrm{n}$ & 7 & 7 & 7 & 7 & 6 & 7 & 7 \\
\hline & & $\%$ & 100,00 & 100,00 & 100,00 & 100,00 & 85,71 & 100,00 & 100,00 \\
\hline & & média & 173,00 & 172,57 & 93,21 & 143,14 & 111,75 & 126,50 & 109,29 \\
\hline \multirow{3}{*}{ Aleuta 6} & & $\mathrm{n}$ & 5 & 5 & 5 & 5 & 5 & 5 & 5 \\
\hline & 5 & $\%$ & 100,00 & 100,00 & 100,00 & 100,00 & 100,00 & 100,00 & 100,00 \\
\hline & & média & 171,20 & 170,40 & 95,20 & 144,00 & 111,80 & 128,20 & 109,00 \\
\hline & & $\mathrm{n}$ & 14 & 13 & 6 & 15 & 13 & 10 & 11 \\
\hline Murray River & 18 & $\%$ & 77,78 & 72,22 & 33,33 & 83,33 & 72,22 & 55,56 & 61,11 \\
\hline & & média & 182,29 & 177,85 & 102,50 & 124,20 & 105,38 & 110,40 & 101,91 \\
\hline Austrália - & & $\mathrm{n}$ & 10 & 10 & 7 & 9 & 8 & 7 & 9 \\
\hline New South & 12 & $\%$ & 83,33 & 83,33 & 58,33 & 75,00 & 66,67 & 58,33 & 75,00 \\
\hline Walles & & média & 179,20 & 175,10 & 95,29 & 128,22 & 109,38 & 110,29 & 99,67 \\
\hline Austrália - & & $\mathrm{n}$ & 2 & 2 & 2 & 2 & 2 & 2 & 2 \\
\hline Território do & 2 & $\%$ & 100,00 & 100,00 & 100,00 & 100,00 & 100,00 & 100,00 & 100,00 \\
\hline & & média & 183,00 & 178,50 & 99,00 & 124,50 & 105,50 & 114,50 & 103,50 \\
\hline & & $n$ & 67 & 64 & 42 & 65 & 64 & 54 & 63 \\
\hline Austrália - Sul & 71 & $\%$ & 94,37 & 90,14 & 59,15 & 91,55 & 90,14 & 76,06 & 88,73 \\
\hline & & média & 180,87 & 176,69 & 96,14 & 126,02 & 106,09 & 110,76 & 103,11 \\
\hline & & $\mathrm{n}$ & 7 & 7 & 6 & 7 & 7 & 7 & 7 \\
\hline Tasmânia & 7 & $\%$ & 100,00 & 100,00 & 85,71 & 100,00 & 100,00 & 100,00 & 100,00 \\
\hline & & média & 176,79 & 171,71 & 95,67 & 135,86 & 109,86 & 116,43 & 104,57 \\
\hline Canadá - & & $\mathrm{n}$ & 22 & 22 & 22 & 22 & 22 & 22 & 22 \\
\hline Columbia & 22 & $\%$ & 100,00 & 100,00 & 100,00 & 100,00 & 100,00 & 100,00 & 100,00 \\
\hline Britânica & & média & 173,59 & 172,64 & 97,61 & 136,82 & 111,11 & 122,91 & 107,16 \\
\hline & & $n$ & 1 & 1 & 1 & 1 & 1 & 1 & 1 \\
\hline & 1 & $\%$ & 100,00 & 100,00 & 100,00 & 100,00 & 100,00 & 100,00 & 100,00 \\
\hline & & média & 171,00 & 168,00 & 95,00 & 136,00 & 110,00 & 123,00 & 107,00 \\
\hline Canadá - & & $\mathrm{n}$ & 6 & 6 & 6 & 6 & 6 & 6 & 6 \\
\hline Ontário & 6 & $\%$ & 100,00 & 100,00 & 100,00 & 100,00 & 100,00 & 100,00 & 100,00 \\
\hline (Iroque) & & média & 174,17 & 173,17 & 98,83 & 135,33 & 113,00 & 120,17 & 104,67 \\
\hline América Central & & $\mathrm{n}$ & 2 & 2 & 2 & 2 & 2 & 2 & 2 \\
\hline e do Sul- & 2 & $\%$ & 100,00 & 100,00 & 100,00 & 100,00 & 100,00 & 100,00 & 100,00 \\
\hline Argentina & & média & 171,00 & 168,00 & 93,50 & 130,00 & 109,00 & 117,25 & 103,00 \\
\hline América & & $n$ & 6 & 6 & 6 & 6 & 6 & 6 & 6 \\
\hline Central e do & 6 & $\%$ & 100,00 & 100,00 & 100,00 & 100,00 & 100,00 & 100,00 & 100,00 \\
\hline Sul - Bolívia & & média & 164,92 & 164,58 & 91,08 & 131,75 & 110,33 & 115,08 & 103,42 \\
\hline América & & $\mathrm{n}$ & 20 & 20 & 20 & 20 & 20 & 20 & 20 \\
\hline Central e do & 20 & $\%$ & 100,00 & 100,00 & 100,00 & 100,00 & 100,00 & 100,00 & 100,00 \\
\hline Sul - Chile & & média & 171,68 & 169,75 & 94,10 & 135,95 & 110,88 & 115,63 & 104,15 \\
\hline América & & $\mathrm{n}$ & 1 & 1 & 1 & 1 & 1 & 1 & 1 \\
\hline Central e do & 1 & $\%$ & 100,00 & 100,00 & 100,00 & 100,00 & 100,00 & 100,00 & 100,00 \\
\hline Sul - Colômbia & & média & 162,00 & 161,00 & 90,00 & 125,00 & 109,00 & 114,00 & 101,00 \\
\hline América & & $\mathrm{n}$ & 2 & 2 & 1 & 2 & 2 & 2 & 2 \\
\hline Central e do & 2 & $\%$ & 100,00 & 100,00 & 50,00 & 100,00 & 100,00 & 100,00 & 100,00 \\
\hline Sul - Equador & & média & 169,00 & 168,25 & 92,00 & 142,50 & 116,00 & 126,50 & 106,00 \\
\hline América Central e & & $n$ & 14 & 14 & 12 & 14 & 14 & 14 & 14 \\
\hline do Sul - Fueguinos & 14 & $\%$ & 100,00 & 100,00 & 85,71 & 100,00 & 100,00 & 100,00 & 100,00 \\
\hline (Patagônia) & & média & 178,14 & 176,50 & 97,71 & 136,93 & 112,29 & 124,14 & 107,43 \\
\hline América & & $\mathrm{n}$ & 43 & 43 & 42 & 43 & 41 & 43 & 42 \\
\hline Central e do & 43 & $\%$ & 100,00 & 100,00 & 97,67 & 100,00 & 95,35 & 100,00 & 97,67 \\
\hline Sul - México & & média & 169,07 & 166,95 & 94,95 & 133,17 & 110,87 & 117,97 & 103,68 \\
\hline América & & $n$ & 143 & 143 & 143 & 143 & 143 & 143 & 143 \\
\hline Central e do & 143 & $\%$ & 100,00 & 100,00 & 100,00 & 100,00 & 100,00 & 100,00 & 100,00 \\
\hline Sul - Peru & & média & 169,50 & 167,85 & 92,55 & 134,67 & 111,07 & 118,47 & 106,04 \\
\hline
\end{tabular}




\begin{tabular}{|c|c|c|c|c|c|c|c|c|c|}
\hline \multirow{3}{*}{$\begin{array}{c}\text { América } \\
\text { Central e do } \\
\text { Sul - } \\
\text { Venezuela }\end{array}$} & \multirow{3}{*}{2} & $n$ & 2 & 2 & 2 & 2 & 2 & 2 & 2 \\
\hline & & $\%$ & 100,00 & 100,00 & 100,00 & 100,00 & 100,00 & 100,00 & 100,00 \\
\hline & & média & 176,00 & 174,50 & 96,50 & 139,50 & 113,00 & 124,00 & 106,50 \\
\hline \multirow{3}{*}{$\begin{array}{l}\text { Leste Asiático } \\
\text { - Norte da } \\
\text { China (Han) }\end{array}$} & \multirow{3}{*}{12} & $n$ & 12 & 12 & 12 & 12 & 12 & 12 & 12 \\
\hline & & $\%$ & 100,00 & 100,00 & 100,00 & 100,00 & 100,00 & 100,00 & 100,00 \\
\hline & & média & 176,50 & 174,00 & 95,00 & 139,67 & 113,92 & 121,79 & 108,58 \\
\hline \multirow{3}{*}{$\begin{array}{c}\text { Leste Asiático } \\
\text { - Japão } \\
\text { Tohoku }\end{array}$} & \multirow{3}{*}{68} & $n$ & 63 & 63 & 67 & 63 & 63 & 68 & 68 \\
\hline & & $\%$ & 92,65 & 92,65 & 98,53 & 92,65 & 92,65 & 100,00 & 100,00 \\
\hline & & média & 173,17 & 170,94 & 96,81 & 134,25 & 110,29 & 117,31 & 104,67 \\
\hline \multirow{3}{*}{$\begin{array}{l}\text { Leste Asiático } \\
\text { - Japão } \\
\text { Período Jomon } \\
\end{array}$} & \multirow{3}{*}{9} & $n$ & 9 & 7 & 5 & 9 & 9 & 8 & 7 \\
\hline & & $\%$ & 100,00 & 77,78 & 55,56 & 100,00 & 100,00 & 88,89 & 77,78 \\
\hline & & média & 182,22 & 179,57 & 102,40 & 138,56 & 116,67 & 119,75 & 108,14 \\
\hline \multirow{3}{*}{$\begin{array}{l}\text { Leste Asiático } \\
\text { - Nepal }\end{array}$} & & $n$ & 7 & 7 & 7 & 7 & 7 & 7 & 7 \\
\hline & 7 & $\%$ & 100,00 & 100,00 & 100,00 & 100,00 & 100,00 & 100,00 & 100,00 \\
\hline & & média & 171,86 & 169,71 & 93,50 & 128,29 & 106,43 & 114,00 & 101,57 \\
\hline & & $n$ & 1 & 1 & 1 & 1 & 1 & 1 & 1 \\
\hline - Taiwan & 1 & $\%$ & 100,00 & 100,00 & 100,00 & 100,00 & 100,00 & 100,00 & 100,00 \\
\hline & & média & 181,00 & 179,00 & 98,00 & 140,00 & 109,00 & 120,00 & 107,00 \\
\hline Leste Asiático & & $n$ & 14 & 14 & 16 & 13 & 15 & 15 & 14 \\
\hline - Tibet & 16 & $\%$ & 87,50 & 87,50 & 100,00 & 81,25 & 93,75 & 93,75 & 87,50 \\
\hline & & média & 170,71 & 168,50 & 93,25 & 136,15 & 112,53 & 116,60 & 103,36 \\
\hline & & $n$ & 130 & 130 & 129 & 128 & 126 & 130 & 130 \\
\hline Alacka 1 & 130 & $\%$ & 100,00 & 100,00 & 99,23 & 98,46 & 96,92 & 100,00 & 100,00 \\
\hline & & média & 173,37 & 172,02 & 98,45 & 136,50 & 112,30 & 122,63 & 107,43 \\
\hline & & $n$ & 104 & 104 & 104 & 104 & 101 & 102 & 104 \\
\hline Alaska? & 104 & $\%$ & 100,00 & 100,00 & 100,00 & 100,00 & 97,12 & 98,08 & 100,00 \\
\hline & & média & 178,76 & 176,51 & 101,20 & 134,26 & 111,65 & 123,03 & 107,86 \\
\hline & & $n$ & 60 & 59 & 57 & 59 & 55 & 57 & 58 \\
\hline Alaska 3 & 60 & $\%$ & 100,00 & 98,33 & 95,00 & 98,33 & 91,67 & 95,00 & 96,67 \\
\hline & & média & 178,84 & 176,54 & 100,62 & 131,53 & 108,99 & 121,28 & 105,46 \\
\hline & & $n$ & 16 & 16 & 16 & 15 & 15 & 16 & 16 \\
\hline Esqúmo - & 16 & $\%$ & 100,00 & 100,00 & 100,00 & 93,75 & 93,75 & 100,00 & 100,00 \\
\hline & & média & 174,22 & 172,72 & 98,44 & 136,43 & 111,67 & 122,81 & 104,50 \\
\hline & & $n$ & 25 & 25 & 25 & 22 & 23 & 24 & 25 \\
\hline Canadá & 25 & $\%$ & 100,00 & 100,00 & 100,00 & 88,00 & 92,00 & 96,00 & 100,00 \\
\hline & & média & 180,52 & 177,64 & 99,56 & 132,66 & 112,13 & 120,19 & 104,26 \\
\hline & & $n$ & 56 & 56 & 55 & 56 & 56 & 56 & 55 \\
\hline Groelândia & 57 & $\%$ & 98,25 & 98,25 & 96,49 & 98,25 & 98,25 & 98,25 & 96,49 \\
\hline & & média & 181,29 & 178,49 & 100,55 & 130,66 & 109,30 & 120,26 & 105,71 \\
\hline & & $n$ & 3 & 3 & 3 & 3 & 3 & 3 & 3 \\
\hline esconhecido" & 3 & $\%$ & 100,00 & 100,00 & 100,00 & 100,00 & 100,00 & 100,00 & 100,00 \\
\hline & & média & 187,00 & 183,67 & 101,67 & 131,67 & 110,00 & 120,00 & 106,00 \\
\hline & & $\mathrm{n}$ & 55 & 55 & 55 & 55 & 55 & 55 & 55 \\
\hline Áustria & 55 & $\%$ & 100,00 & 100,00 & 100,00 & 100,00 & 100,00 & 100,00 & 100,00 \\
\hline & & média & 171,56 & 169,09 & 95,59 & 138,89 & 118,62 & 118,07 & 107,52 \\
\hline Europa - & & $n$ & 1 & 1 & 1 & 1 & 1 & 1 & 1 \\
\hline Áustria (Idade & 1 & $\%$ & 100,00 & 100,00 & 100,00 & 100,00 & 100,00 & 100,00 & 100,00 \\
\hline do Ferro) & & média & 174,00 & 171,00 & 94,00 & 132,00 & 115,00 & 112,00 & 109,00 \\
\hline & & $n$ & 6 & 6 & 6 & 6 & 6 & 6 & 6 \\
\hline Bélgica & 6 & $\%$ & 100,00 & 100,00 & 100,00 & 100,00 & 100,00 & 100,00 & 100,00 \\
\hline & & média & 171,58 & 169,92 & 91,33 & 136,00 & 114,83 & 114,67 & 103,92 \\
\hline Europa - & & $n$ & 36 & 36 & 35 & 36 & 36 & 36 & 36 \\
\hline "Republica & 36 & $\%$ & 100,00 & 100,00 & 97,22 & 100,00 & 100,00 & 100,00 & 100,00 \\
\hline Tcheca" & & média & 169,35 & 166,88 & 95,26 & 139,42 & 118,72 & 118,24 & 107,64 \\
\hline & & $n$ & 10 & 10 & 10 & 10 & 10 & 10 & 10 \\
\hline Alemanha & 10 & $\%$ & 100,00 & 100,00 & 100,00 & 100,00 & 100,00 & 100,00 & 100,00 \\
\hline & & média & 172,10 & 170,15 & 92,05 & 141,30 & 118,10 & 118,95 & 108,90 \\
\hline & & $n$ & 2 & 2 & 2 & 2 & 2 & 2 & 2 \\
\hline Holanda & 2 & $\%$ & 100,00 & 100,00 & 100,00 & 100,00 & 100,00 & 100,00 & 100,00 \\
\hline & & média & 173,75 & 172,25 & 94,25 & 140,75 & 115,00 & 118,25 & 110,00 \\
\hline & & $n$ & 51 & 51 & 51 & 51 & 51 & 51 & 51 \\
\hline Europa - & 51 & $\%$ & 100,00 & 100,00 & 100,00 & 100,00 & 100,00 & 100,00 & 100,00 \\
\hline & & média & 171,64 & 169,36 & 95,25 & 135,80 & 115,27 & 117,07 & 106,88 \\
\hline & & $n$ & 3 & 3 & 3 & 3 & 3 & 3 & 3 \\
\hline Luropa - & 3 & $\%$ & 100,00 & 100,00 & 100,00 & 100,00 & 100,00 & 100,00 & 100,00 \\
\hline & & média & 168,33 & 167,00 & 92,67 & 140,33 & 117,67 & 118,17 & 110,33 \\
\hline & & $n$ & 6 & 6 & 6 & 6 & 6 & 6 & 6 \\
\hline Polônia & 6 & $\%$ & 100,00 & 100,00 & 100,00 & 100,00 & 100,00 & 100,00 & 100,00 \\
\hline & & média & 169,00 & 166,42 & 97,83 & 138,25 & 120,67 & 118,67 & 104,67 \\
\hline & & $\mathrm{n}$ & 23 & 23 & 23 & 23 & 23 & 23 & 23 \\
\hline
\end{tabular}




\begin{tabular}{|c|c|c|c|c|c|c|c|c|c|}
\hline \multirow{5}{*}{$\begin{array}{l}\text { Europa - } \\
\text { Eúíca } \\
\text { Europa - } \\
\text { Ucrânia }\end{array}$} & \multirow[b]{2}{*}{23} & $\mathrm{n}$ & 23 & 23 & 23 & 23 & 23 & 23 & 23 \\
\hline & & média & 100,00 & $10 \theta, 00$ & $100,0 \theta$ & $1 \theta \theta, \theta 0$ & $10 \theta, 00$ & 100,00 & 100,60 \\
\hline & \multirow{3}{*}{4} & $\mathrm{n}$ & 4 & $\overline{4}$ & $\overline{4}$ & 2 & 3 & 4 & 4 \\
\hline & & $\%$ & 100,00 & 100,00 & 100,00 & 50,00 & 75,00 & 100,00 & 100,00 \\
\hline & & média & 168,25 & 166,75 & 93,13 & 140,50 & 115,00 & 118,63 & 108,00 \\
\hline \multirow{3}{*}{$\begin{array}{l}\text { Europa - } \\
\text { Yuguslavia }\end{array}$} & \multirow{3}{*}{14} & $\mathrm{n}$ & 13 & 13 & 10 & 13 & 14 & 11 & 12 \\
\hline & & $\%$ & 92,86 & 92,86 & 71,43 & 92,86 & 100,00 & 78,57 & 85,71 \\
\hline & & média & 172,19 & 169,77 & 96,65 & 141,04 & 119,82 & 117,77 & 107,33 \\
\hline \multirow{3}{*}{$\begin{array}{l}\text { Índia- } \\
\text { Bengala }\end{array}$} & \multirow{3}{*}{24} & $\mathrm{n}$ & 24 & 24 & 24 & 24 & 24 & 24 & 24 \\
\hline & & $\%$ & 100,00 & 100,00 & 100,00 & 100,00 & 100,00 & 100,00 & 100,00 \\
\hline & & média & 172,96 & 170,88 & 96,48 & 127,71 & 109,04 & 111,38 & 100,69 \\
\hline \multirow{3}{*}{ Índia - Mahalls } & \multirow{3}{*}{2} & $\mathrm{n}$ & 2 & 2 & 2 & 2 & 2 & 2 & 2 \\
\hline & & $\%$ & 100,00 & 100,00 & 100,00 & 100,00 & 100,00 & 100,00 & 100,00 \\
\hline & & média & 169,00 & 166,50 & 92,25 & 126,75 & 108,00 & 105,25 & 102,00 \\
\hline & & $\mathrm{n}$ & 3 & 3 & 3 & 3 & 3 & 3 & 3 \\
\hline Índia - Mysore & 3 & $\%$ & 100,00 & 100,00 & 100,00 & 100,00 & 100,00 & 100,00 & 100,00 \\
\hline & & média & 167,67 & 164,33 & 94,33 & 127,67 & 106,33 & 108,17 & 100,17 \\
\hline & & $\mathrm{n}$ & 1 & 1 & 1 & 1 & 1 & 1 & 1 \\
\hline Índia - Nagpur & 1 & $\%$ & 100,00 & 100,00 & 100,00 & 100,00 & 100,00 & 100,00 & 100,00 \\
\hline & & média & 181,00 & 177,00 & 99,00 & 116,00 & 103,00 & 104,00 & 97,00 \\
\hline & & $\mathrm{n}$ & 3 & 3 & 3 & 3 & 3 & 3 & 3 \\
\hline Índia - Orissa & 3 & $\%$ & 100,00 & 100,00 & 100,00 & 100,00 & 100,00 & 100,00 & 100,00 \\
\hline & & média & 169,00 & 167,33 & 97,50 & 125,83 & 103,50 & 110,00 & 97,17 \\
\hline & & $\mathrm{n}$ & 2 & 2 & 2 & 2 & 2 & 2 & 2 \\
\hline Índia - Sikkim & 2 & $\%$ & 100,00 & 100,00 & 100,00 & 100,00 & 100,00 & 100,00 & 100,00 \\
\hline & & média & 170,50 & 163,50 & 92,50 & 131,50 & 115,50 & 121,00 & 98,75 \\
\hline & & $\mathrm{n}$ & 4 & $\overline{4}$ & $\overline{4}$ & 4 & 4 & 4 & 4 \\
\hline Índia - Sul & 4 & $\%$ & 100,00 & 100,00 & 100,00 & 100,00 & 100,00 & 100,00 & 100,00 \\
\hline & & média & 170,00 & 167,00 & 92,25 & 127,00 & 110,25 & 109,63 & 100,13 \\
\hline & & $n$ & 2 & 2 & 2 & 2 & 2 & 2 & 2 \\
\hline Índia - Tamil & 2 & $\%$ & 100,00 & 100,00 & 100,00 & 100,00 & 100,00 & 100,00 & 100,00 \\
\hline & & média & 173,50 & 170,50 & 96,75 & 126,50 & 107,00 & 112,00 & 102,50 \\
\hline & & $\mathrm{n}$ & 6 & 6 & 6 & 6 & 6 & 6 & 6 \\
\hline "India - & 6 & $\%$ & 100,00 & 100,00 & 100,00 & 100,00 & 100,00 & 100,00 & 100,00 \\
\hline & & média & 171,50 & 169,42 & 96,25 & 129,33 & 111,33 & 112,42 & 102,17 \\
\hline & & $\mathrm{n}$ & 6 & 6 & $\overline{6}$ & $\overline{6}$ & 6 & 6 & 6 \\
\hline Índia - Veddah & 6 & $\%$ & 100,00 & 100,00 & 100,00 & 100,00 & 100,00 & 100,00 & 100,00 \\
\hline & & média & 173,17 & 170,83 & 93,83 & 123,17 & 106,17 & 106,33 & 99,50 \\
\hline & & $n$ & 13 & 13 & 12 & 12 & 13 & 13 & 13 \\
\hline Bis & 13 & $\%$ & 100,00 & 100,00 & 92,31 & 92,31 & 100,00 & 100,00 & 100,00 \\
\hline & & média & 175,81 & 173,81 & 96,21 & 131,21 & 108,31 & 113,19 & 104,08 \\
\hline & & $\mathrm{n}$ & 4 & 4 & 4 & 4 & 4 & 4 & 4 \\
\hline Melanesia - & 5 & $\%$ & 80,00 & 80,00 & 80,00 & 80,00 & 80,00 & 80,00 & 80,00 \\
\hline & & média & 181,50 & 178,25 & 100,13 & 125,75 & 107,50 & 110,00 & 101,50 \\
\hline Molanócia & & $n$ & 23 & 23 & 24 & 23 & 24 & 24 & 23 \\
\hline Neratan- & 24 & $\%$ & 95,83 & 95,83 & 100,00 & 95,83 & 100,00 & 100,00 & 95,83 \\
\hline & & média & 175,17 & 172,04 & 95,88 & 128,52 & 107,38 & 115,52 & 103,43 \\
\hline Melanésia - & & $\mathrm{n}$ & 11 & 11 & 11 & 11 & 11 & 11 & 11 \\
\hline Nova & 11 & $\%$ & 100,00 & 100,00 & 100,00 & 100,00 & 100,00 & 100,00 & 100,00 \\
\hline Caledônia & & média & 180,14 & 176,91 & 98,32 & 124,77 & 107,50 & 113,09 & 103,05 \\
\hline Melanésia - & & $n$ & 29 & 29 & 28 & 29 & 29 & 29 & 29 \\
\hline "New & 29 & $\%$ & 100,00 & 100,00 & 96,55 & 100,00 & 100,00 & 100,00 & 100,00 \\
\hline Hebrides" & & média & 174,03 & 171,60 & 93,77 & 128,83 & 108,24 & 114,10 & 102,69 \\
\hline Melanésia - & & $\mathrm{n}$ & 24 & 24 & 25 & 24 & 24 & 25 & 24 \\
\hline Velanesla - & 25 & $\%$ & 96,00 & 96,00 & 100,00 & 96,00 & 96,00 & 100,00 & 96,00 \\
\hline & & média & 173,90 & 171,21 & 95,26 & 130,83 & 109,06 & 113,82 & 104,60 \\
\hline & & $\mathrm{n}$ & 2 & $\overline{2}$ & $\overline{2}$ & 2 & 2 & 2 & 2 \\
\hline Santa Cruz & 2 & $\%$ & 100,00 & 100,00 & 100,00 & 100,00 & 100,00 & 100,00 & 100,00 \\
\hline & & média & 174,00 & 169,50 & 92,50 & 123,00 & 101,00 & 107,50 & 103,50 \\
\hline & & $n$ & 28 & 28 & 28 & 30 & 31 & 30 & 28 \\
\hline Solomon - & 31 & $\%$ & 90,32 & 90,32 & 90,32 & 96,77 & 100,00 & 96,77 & 90,32 \\
\hline & & média & 173,82 & 170,86 & 94,82 & 128,48 & 106,61 & 114,30 & 102,93 \\
\hline & & $n$ & 6 & 6 & 6 & 6 & 6 & 6 & 6 \\
\hline Fstroito Torrec & 6 & $\%$ & 100,00 & 100,00 & 100,00 & 100,00 & 100,00 & 100,00 & 100,00 \\
\hline & & média & 175,08 & 172,42 & 99,00 & 125,83 & 105,17 & 112,33 & 104,00 \\
\hline & & $n$ & 10 & 10 & 11 & 11 & 11 & 11 & 11 \\
\hline Micronesia - & 11 & $\%$ & 90,91 & 90,91 & 100,00 & 100,00 & 100,00 & 100,00 & 100,00 \\
\hline & & média & 173,15 & 170,45 & 95,82 & 129,41 & 109,00 & 115,73 & 101,41 \\
\hline & & $n$ & 2 & 2 & 2 & 2 & 2 & 2 & 2 \\
\hline & & $\%$ & 100,00 & 100,00 & 100,00 & 100,00 & 100,00 & 100,00 & 100,00 \\
\hline
\end{tabular}




\begin{tabular}{|c|c|c|c|c|c|c|c|c|c|}
\hline & & média & 168,50 & 166,00 & 96,50 & 130,00 & 105,00 & 118,75 & 103,75 \\
\hline \multirow{3}{*}{$\begin{array}{l}\text { Norte da África } \\
\text { - Egito } 1\end{array}$} & \multirow{3}{*}{83} & $n$ & 83 & 83 & 82 & 81 & 81 & 83 & 83 \\
\hline & & $\%$ & 100,00 & 100,00 & 98,80 & 97,59 & 97,59 & 100,00 & 100,00 \\
\hline & & média & 175,17 & 174,18 & 96,85 & 133,44 & 111,88 & 111,27 & 103,13 \\
\hline \multirow{3}{*}{$\begin{array}{l}\text { Norte da África } \\
\text { - Egito } 2\end{array}$} & \multirow{3}{*}{14} & $n$ & 14 & 14 & 14 & 14 & 14 & 14 & 14 \\
\hline & & $\%$ & 100,00 & 100,00 & 100,00 & 100,00 & 100,00 & 100,00 & 100,00 \\
\hline & & média & 171,36 & 170,21 & 93,43 & 132,93 & 110,79 & 110,07 & 101,07 \\
\hline \multirow{3}{*}{$\begin{array}{c}\text { Norte da África } \\
\text { - Egito } 3\end{array}$} & \multirow{3}{*}{8} & $n$ & 8 & 8 & 8 & 8 & 8 & 8 & 8 \\
\hline & & $\%$ & 100,00 & 100,00 & 100,00 & 100,00 & 100,00 & 100,00 & 100,00 \\
\hline & & média & 172,50 & 172,00 & 95,19 & 133,31 & 115,25 & 116,19 & 101,38 \\
\hline \multirow{3}{*}{$\begin{array}{c}\text { Nordeste } \\
\text { Asiático - } \\
\text { Amur }\end{array}$} & \multirow{3}{*}{1} & $n$ & 0 & 0 & 1 & 0 & 0 & 0 & 0 \\
\hline & & $\%$ & 0,00 & 0,00 & 100,00 & 0,00 & 0,00 & 0,00 & 0,00 \\
\hline & & média & - & 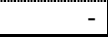 & 91,00 & - & - & - & 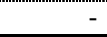 \\
\hline \multirow{3}{*}{$\begin{array}{c}\text { Nordeste } \\
\text { Asiático - } \\
\text { Buriat }\end{array}$} & & $\mathrm{n}$ & 12 & 12 & 12 & 12 & 12 & 12 & 12 \\
\hline & 12 & $\%$ & 100,00 & 100,00 & 100,00 & 100,00 & 100,00 & 100,00 & 100,00 \\
\hline & & média & 173,08 & 171,83 & 95,92 & 144,17 & 115,92 & 127,58 & 112,33 \\
\hline Nordeste & & $\mathrm{n}$ & 4 & 4 & 4 & 4 & 4 & 4 & 4 \\
\hline Asiático - & 4 & $\%$ & 100,00 & 100,00 & 100,00 & 100,00 & 100,00 & 100,00 & 100,00 \\
\hline Chukchi & & média & 177,50 & 174,75 & 98,75 & 136,75 & 115,75 & 121,75 & 105,25 \\
\hline Nordeste & & $n$ & 64 & 64 & 64 & 63 & 64 & 64 & 64 \\
\hline Asiático - & 65 & $\%$ & 98,46 & 98,46 & 98,46 & 96,92 & 98,46 & 98,46 & 98,46 \\
\hline & & média & 173,41 & 171,42 & 94,63 & 143,24 & 117,47 & 126,09 & 110,63 \\
\hline & & $n$ & 4 & 4 & 3 & 4 & 4 & 3 & 4 \\
\hline $\begin{array}{l}\text { Papua Nova Gune } \\
\text { - Província Central }\end{array}$ & 4 & $\%$ & 100,00 & 100,00 & 75,00 & 100,00 & 100,00 & 75,00 & 100,00 \\
\hline & & média & 173,75 & 171,00 & 97,33 & 129,50 & 110,50 & 114,33 & 102,25 \\
\hline & & $n$ & 5 & 5 & 4 & 4 & 5 & 4 & 5 \\
\hline $\begin{array}{l}\text { Papua Nova Giune } \\
\text { - Eastern Is }\end{array}$ & 5 & $\%$ & 100,00 & 100,00 & 80,00 & 80,00 & 100,00 & 80,00 & 100,00 \\
\hline & & média & 170,00 & 167,60 & 92,00 & 131,00 & 105,80 & 118,25 & 104,20 \\
\hline & & $\mathrm{n}$ & 37 & 37 & 37 & 38 & 37 & 38 & 38 \\
\hline $\begin{array}{l}\text { Papua Nova Guiné } \\
\text { - Província do Golfo }\end{array}$ & 42 & $\%$ & 88,10 & 88,10 & 88,10 & 90,48 & 88,10 & 90,48 & 90,48 \\
\hline & & média & 176,64 & 173,95 & 95,86 & 125,83 & 105,76 & 109,13 & 101,97 \\
\hline & & $n$ & 4 & 4 & 4 & 4 & $\overline{4}$ & 4 & 4 \\
\hline $\begin{array}{l}\text { Papua Nova Guine } \\
\text { - Província Madang }\end{array}$ & 4 & $\%$ & 100,00 & 100,00 & 100,00 & 100,00 & 100,00 & 100,00 & 100,00 \\
\hline & & média & 167,13 & 165,38 & 94,50 & 128,63 & 106,25 & 111,75 & 102,38 \\
\hline Papua Nova Guiné & & $\mathrm{n}$ & 4 & 4 & 4 & 4 & 4 & 4 & 4 \\
\hline - Província Milne & 4 & $\%$ & 100,00 & 100,00 & 100,00 & 100,00 & 100,00 & 100,00 & 100,00 \\
\hline & & média & 170,75 & 168,25 & 95,00 & 129,75 & 109,75 & 113,75 & 104,00 \\
\hline Papua Nova Guiné & & $\mathrm{n}$ & 26 & 25 & 24 & 26 & 25 & 25 & 24 \\
\hline - Província Sepik & 27 & $\%$ & 96,30 & 92,59 & 88,89 & 96,30 & 92,59 & 92,59 & 88,89 \\
\hline & & média & 173,25 & 170,50 & 95,23 & 127,35 & 106,88 & 110,88 & 102,29 \\
\hline Papua Nova Guiné & & $n$ & 33 & 33 & 33 & 33 & 33 & 33 & 33 \\
\hline - Província Sepik & 33 & $\%$ & 100,00 & 100,00 & 100,00 & 100,00 & 100,00 & 100,00 & 100,00 \\
\hline Ocidental & & média & 170,71 & 168,50 & 97,39 & 128,47 & 107,14 & 112,42 & 101,73 \\
\hline Papua Nova & & $\mathrm{n}$ & 7 & 7 & 8 & 6 & 7 & 8 & 6 \\
\hline Guiné - & 9 & $\%$ & 77,78 & 77,78 & 88,89 & 66,67 & 77,78 & 88,89 & 66,67 \\
\hline "desconhecido" & & média & 170,43 & 167,29 & 94,00 & 126,50 & 106,71 & 113,88 & 101,50 \\
\hline & & $\mathrm{n}$ & 12 & 12 & 8 & 12 & 12 & 11 & 12 \\
\hline - Província & 12 & $\%$ & 100,00 & 100,00 & 66,67 & 100,00 & 100,00 & 91,67 & 100,00 \\
\hline & & média & 171,33 & 169,75 & 95,13 & 127,17 & 105,25 & 108,64 & 99,67 \\
\hline Polinésia - & & $n$ & 5 & 6 & 6 & 5 & 5 & 6 & 6 \\
\hline Moriori (Ilhas & 6 & $\%$ & 83,33 & 100,00 & 100,00 & 83,33 & 83,33 & 100,00 & 100,00 \\
\hline Chatan) & & média & 182,40 & 178,33 & 100,25 & 138,20 & 113,00 & 119,08 & 107,08 \\
\hline & & $n$ & 4 & 4 & 3 & 3 & 3 & 3 & 4 \\
\hline llhas Cook & 4 & $\%$ & 100,00 & 100,00 & 75,00 & 75,00 & 75,00 & 75,00 & 100,00 \\
\hline & & média & 178,25 & 174,75 & 98,67 & 139,33 & 113,33 & 122,33 & 107,50 \\
\hline & & $\mathrm{n}$ & 31 & 31 & 30 & 29 & 27 & 29 & 30 \\
\hline llhas Faster & 39 & $\%$ & 79,49 & 79,49 & 76,92 & 74,36 & 69,23 & 74,36 & 76,92 \\
\hline & & média & 181,48 & 177,92 & 103,93 & 127,84 & 106,37 & 116,03 & 101,30 \\
\hline Polinésia - & & $\mathrm{n}$ & 20 & 20 & 20 & 20 & 20 & 20 & 20 \\
\hline Ilhas & 20 & $\%$ & 100,00 & 100,00 & 100,00 & 100,00 & 100,00 & 100,00 & 100,00 \\
\hline Marquesas & & média & 176,40 & 174,50 & 98,00 & 138,00 & 109,73 & 118,53 & 104,20 \\
\hline Polinésia - & & $n$ & 22 & 22 & 22 & 22 & 22 & 22 & 22 \\
\hline Maori Nova & 23 & $\%$ & 95,65 & 95,65 & 95,65 & 95,65 & 95,65 & 95,65 & 95,65 \\
\hline Zelândia & & média & 179,64 & 176,80 & 98,09 & 133,34 & 109,16 & 119,55 & 105,55 \\
\hline & & $n$ & 1 & 1 & 1 & 1 & 1 & 1 & 1 \\
\hline Samoa Tonga & 1 & $\%$ & 100,00 & 100,00 & 100,00 & 100,00 & 100,00 & 100,00 & 100,00 \\
\hline & & média & 175,00 & 171,00 & 96,00 & 131,00 & 111,00 & 119,50 & 97,50 \\
\hline Sudeste & & $\mathrm{n}$ & 23 & 23 & 22 & 23 & 22 & 23 & 23 \\
\hline Asiático - Ilhas & 24 & $\%$ & 95,83 & 95,83 & 91,67 & 95,83 & 91,67 & 95,83 & 95,83 \\
\hline Andaman & & média & 162,22 & 161,15 & 89,50 & 131,52 & 106,27 & 108,52 & 96,22 \\
\hline
\end{tabular}




\begin{tabular}{|c|c|c|c|c|c|c|c|c|c|}
\hline \multirow{3}{*}{$\begin{array}{c}\text { Sudeste } \\
\text { Asiático - } \\
\text { Borneo } 1\end{array}$} & \multirow{3}{*}{5} & $\mathrm{n}$ & 4 & 4 & 5 & 5 & 5 & 5 & 5 \\
\hline & & $\%$ & 80,00 & 80,00 & 100,00 & 100,00 & 100,00 & 100,00 & 100,00 \\
\hline & & média & 172,25 & 168,75 & 93,40 & 131,40 & 109,20 & 113,40 & 100,60 \\
\hline \multirow{3}{*}{$\begin{array}{c}\text { Sudeste } \\
\text { Asiático - } \\
\text { Borneo } 2 \\
\end{array}$} & \multirow{3}{*}{5} & $\mathrm{n}$ & 5 & 5 & 5 & 5 & 5 & 4 & 5 \\
\hline & & $\%$ & 100,00 & 100,00 & 100,00 & 100,00 & 100,00 & 80,00 & 100,00 \\
\hline & & média & 173,20 & 171,00 & 94,60 & 133,20 & 109,00 & 117,50 & 102,60 \\
\hline Sudeste & \multirow{3}{*}{2} & $\mathrm{n}$ & 2 & 2 & 2 & 2 & 2 & 2 & 2 \\
\hline \multirow{2}{*}{$\begin{array}{l}\text { Asiático - } \\
\text { Celebes }\end{array}$} & & $\%$ & 100,00 & 100,00 & 100,00 & 100,00 & 100,00 & 100,00 & 100,00 \\
\hline & & média & 173,50 & 171,25 & 95,50 & 133,50 & 111,00 & 117,00 & 101,75 \\
\hline \multirow{3}{*}{$\begin{array}{c}\text { Sudeste } \\
\text { Asiático - Java }\end{array}$} & \multirow{3}{*}{8} & $\mathrm{n}$ & 8 & 8 & 8 & 8 & 8 & 8 & 7 \\
\hline & & $\%$ & 100,00 & 100,00 & 100,00 & 100,00 & 100,00 & 100,00 & 87,50 \\
\hline & & média & 167,38 & 165,63 & 94,75 & 136,00 & 111,63 & 116,50 & 102,57 \\
\hline Sudeste & \multirow{3}{*}{5} & $\mathrm{n}$ & 4 & 4 & 4 & 4 & 5 & 4 & 4 \\
\hline Asiático - & & $\%$ & 80,00 & 80,00 & 80,00 & 80,00 & 100,00 & 80,00 & 80,00 \\
\hline Malásia & & média & 169,00 & 166,50 & 94,75 & 129,00 & 111,00 & 114,75 & 99,25 \\
\hline Sudeste & & $n$ & 5 & 5 & 5 & 5 & 5 & 5 & 5 \\
\hline Asiático - & 5 & $\%$ & 100,00 & 100,00 & 100,00 & 100,00 & 100,00 & 100,00 & 100,00 \\
\hline Molucca & & média & 168,00 & 167,00 & 92,20 & 135,40 & 109,60 & 113,00 & 99,80 \\
\hline Sudeste & & $n$ & 3 & 3 & 3 & 3 & 3 & 3 & 3 \\
\hline Asiático - & 3 & $\%$ & 100,00 & 100,00 & 100,00 & 100,00 & 100,00 & 100,00 & 100,00 \\
\hline Myanmar & & média & 170,67 & 168,67 & 94,00 & 133,67 & 113,67 & 118,33 & 105,00 \\
\hline Sudeste & & $n$ & 8 & 8 & 8 & 8 & 9 & 9 & 8 \\
\hline Asiático - & 9 & $\%$ & 88,89 & 88,89 & 88,89 & 88,89 & 100,00 & 100,00 & 88,89 \\
\hline (negrito) & & média & 162,00 & 160,25 & 90,63 & 131,00 & 110,44 & 112,56 & 99,75 \\
\hline Sudeste & & $\mathrm{n}$ & 2 & 2 & 2 & 2 & 2 & 2 & 2 \\
\hline Asiático - Is & 2 & $\%$ & 100,00 & 100,00 & 100,00 & 100,00 & 100,00 & 100,00 & 100,00 \\
\hline Nicobar & & média & 175,50 & 172,50 & 95,50 & 133,00 & 110,00 & 113,00 & 101,50 \\
\hline Sudeste & & $n$ & 37 & 37 & 38 & 37 & 38 & 38 & 37 \\
\hline Asiático - & 38 & $\%$ & 97,37 & 97,37 & 100,00 & 97,37 & 100,00 & 100,00 & 97,37 \\
\hline Filipinas & & média & 168,34 & 166,14 & 94,01 & 134,69 & 110,96 & 117,50 & 102,23 \\
\hline Sudeste & & $\mathrm{n}$ & 15 & 15 & 15 & 15 & 15 & 15 & 15 \\
\hline Asiático - & 15 & $\%$ & 100,00 & 100,00 & 100,00 & 100,00 & 100,00 & 100,00 & 100,00 \\
\hline Singapura & & média & 167,57 & 165,37 & 94,27 & 136,67 & 113,80 & 119,17 & 104,97 \\
\hline & & $\mathrm{n}$ & 3 & 3 & 3 & 3 & 3 & 3 & 3 \\
\hline Asiático - Sulu & 3 & $\%$ & 100,00 & 100,00 & 100,00 & 100,00 & 100,00 & 100,00 & 100,00 \\
\hline & & média & 172,67 & 170,67 & 91,33 & 137,33 & 114,67 & 112,00 & 101,67 \\
\hline Sudeste & & $\mathrm{n}$ & 3 & 3 & 3 & 3 & 3 & 3 & 3 \\
\hline Asiático - & 3 & $\%$ & 100,00 & 100,00 & 100,00 & 100,00 & 100,00 & 100,00 & 100,00 \\
\hline Sumatra & & média & 173,00 & 171,33 & 93,67 & 136,67 & 108,67 & 116,00 & 105,67 \\
\hline Sudeste & & $\mathrm{n}$ & 10 & 10 & 11 & 10 & 11 & 11 & 10 \\
\hline Asiático - & 11 & $\%$ & 90,91 & 90,91 & 100,00 & 90,91 & 100,00 & 100,00 & 90,91 \\
\hline Tailândia & & média & 166,70 & 164,30 & 94,00 & 138,10 & 112,45 & 117,41 & 104,45 \\
\hline Sudeste & & $\mathrm{n}$ & 2 & 2 & 2 & 2 & 2 & 2 & 2 \\
\hline Asiático - & 2 & $\%$ & 100,00 & 100,00 & 100,00 & 100,00 & 100,00 & 100,00 & 100,00 \\
\hline Timor & & média & 170,50 & 169,50 & 94,50 & 134,50 & 110,50 & 110,50 & 101,50 \\
\hline África Sub- & & $n$ & 16 & 16 & 16 & 16 & 16 & 16 & 16 \\
\hline Saariana - & 16 & $\%$ & 100,00 & 100,00 & 100,00 & 100,00 & 100,00 & 100,00 & 100,00 \\
\hline Camarões & & média & 177,84 & 176,44 & 97,66 & 132,28 & 112,50 & 112,84 & 102,75 \\
\hline África Sub- & & $\mathrm{n}$ & 3 & 3 & 3 & 3 & 3 & 3 & 3 \\
\hline Saariana - & 3 & $\%$ & 100,00 & 100,00 & 100,00 & 100,00 & 100,00 & 100,00 & 100,00 \\
\hline Congo & & média & 177,67 & 176,33 & 98,33 & 136,50 & 117,33 & 112,50 & 104,50 \\
\hline África Sub- & & $\mathrm{n}$ & 1 & 1 & 1 & 1 & 1 & 1 & 1 \\
\hline Saariana - & 1 & $\%$ & 100,00 & 100,00 & 100,00 & 100,00 & 100,00 & 100,00 & 100,00 \\
\hline Etiópia & & média & 183,00 & 182,00 & 98,00 & 140,00 & 120,00 & 114,00 & 107,00 \\
\hline África Sub- & & $n$ & 5 & 5 & 5 & 5 & 4 & 5 & 5 \\
\hline Saariana - & 5 & $\%$ & 100,00 & 100,00 & 100,00 & 100,00 & 80,00 & 100,00 & 100,00 \\
\hline Gabão & & média & 169,90 & 169,00 & 94,40 & 130,40 & 108,50 & 111,80 & 99,60 \\
\hline África Sub- & & $n$ & 40 & 40 & 40 & 40 & 40 & 40 & 40 \\
\hline Saariana - & 40 & $\%$ & 100,00 & 100,00 & 100,00 & 100,00 & 100,00 & 100,00 & 100,00 \\
\hline Ashanti Gana & & média & 174,28 & 172,89 & 97,25 & 127,46 & 108,23 & 108,99 & 100,64 \\
\hline África Sub- & & $n$ & 29 & 29 & 29 & 29 & 29 & 29 & 29 \\
\hline Saariana - & 29 & $\%$ & 100,00 & 100,00 & 100,00 & 100,00 & 100,00 & 100,00 & 100,00 \\
\hline Quênia & & média & 176,38 & 174,48 & 96,83 & 130,09 & 108,69 & 112,76 & 103,47 \\
\hline África Sub- & & $\mathrm{n}$ & 5 & 5 & 4 & 5 & 5 & 5 & 5 \\
\hline Saariana - & 5 & $\%$ & 100,00 & 100,00 & 80,00 & 100,00 & 100,00 & 100,00 & 100,00 \\
\hline Libéria & & média & 175,90 & 174,80 & 101,38 & 129,30 & 109,40 & 114,20 & 99,40 \\
\hline África Sub- & & $n$ & 1 & 1 & 1 & 1 & 1 & 1 & 1 \\
\hline Saariana - & 1 & $\%$ & 100,00 & 100,00 & 100,00 & 100,00 & 100,00 & 100,00 & 100,00 \\
\hline Moçambique & & média & 165,50 & 165,00 & 94,00 & 133,00 & 118,00 & 114,00 & 103,00 \\
\hline & & $\mathrm{n}$ & 24 & 24 & 24 & 24 & 24 & 24 & 24 \\
\hline
\end{tabular}




\begin{tabular}{|c|c|c|c|c|c|c|c|c|c|}
\hline \multirow[b]{2}{*}{$\begin{array}{c}\text { África Sub- } \\
\text { Saariana - lbo }\end{array}$} & \multirow[b]{2}{*}{24} & $\mathrm{n}$ & 24 & 24 & 24 & 24 & 24 & 24 & 24 \\
\hline & & média & $\begin{array}{l}100,00 \\
175,17\end{array}$ & $\begin{array}{l}100,00 \\
173,63\end{array}$ & $\begin{array}{r}100,00 \\
96,29\end{array}$ & $\begin{array}{l}100,00 \\
132,50\end{array}$ & $\begin{array}{l}100,00 \\
112,79\end{array}$ & $\begin{array}{l}100,00 \\
113,83\end{array}$ & $\begin{array}{l}100,00 \\
103,25\end{array}$ \\
\hline \multirow{3}{*}{$\begin{array}{l}\text { Affilogéé8ab- } \\
\text { Saariana - } \\
\text { Nigéria } \\
\text { (outros) }\end{array}$} & \multirow{3}{*}{1} & $n$ & 1 & 1 & 1 & 1 & 1 & 1 & 1 \\
\hline & & $\%$ & 100,00 & 100,00 & 100,00 & 100,00 & 100,00 & 100,00 & 100,00 \\
\hline & & média & 182,00 & 179,00 & 96,00 & 131,00 & 113,00 & 107,00 & 96,00 \\
\hline \multirow{3}{*}{$\begin{array}{l}\text { África Sub- } \\
\text { Saariana - } \\
\text { Ruanda }\end{array}$} & \multirow{3}{*}{1} & $\mathrm{n}$ & 1 & 1 & 1 & 1 & 1 & 1 & 1 \\
\hline & & $\%$ & 100,00 & 100,00 & 100,00 & 100,00 & 100,00 & 100,00 & 100,00 \\
\hline & & média & 182,00 & 179,00 & 94,00 & 128,00 & 108,00 & 115,00 & 102,00 \\
\hline \multirow{3}{*}{$\begin{array}{l}\text { África Sub- } \\
\text { Saariana - } \\
\text { Somália }\end{array}$} & \multirow{3}{*}{3} & $n$ & 3 & 3 & 3 & 3 & 3 & 3 & 3 \\
\hline & & $\%$ & 100,00 & 100,00 & 100,00 & 100,00 & 100,00 & 100,00 & 100,00 \\
\hline & & média & 170,67 & 168,00 & 94,33 & 133,33 & 108,67 & 112,00 & 104,67 \\
\hline \multirow{3}{*}{$\begin{array}{c}\text { África Sub- } \\
\text { Saariana - } \\
\text { África do Sul }\end{array}$} & \multirow{3}{*}{8} & $n$ & 8 & 8 & 8 & 8 & 8 & 8 & 8 \\
\hline & & $\%$ & 100,00 & 100,00 & 100,00 & 100,00 & 100,00 & 100,00 & 100,00 \\
\hline & & média & 180,31 & 178,88 & 97,06 & 131,56 & 110,94 & 112,44 & 105,50 \\
\hline \multirow{3}{*}{$\begin{array}{l}\text { África Sub- } \\
\text { Saariana - } \\
\text { Bushman } \\
\text { África do Sul }\end{array}$} & & $n$ & 5 & 5 & 5 & 5 & 5 & 5 & 5 \\
\hline & 5 & $\%$ & 100,00 & 100,00 & 100,00 & 100,00 & 100,00 & 100,00 & 100,00 \\
\hline & & média & 173,00 & 171,00 & 92,70 & 133,40 & 109,40 & 109,10 & 104,00 \\
\hline África Sub- & & $n$ & 1 & 1 & 1 & 1 & 1 & 1 & 1 \\
\hline Saariana - & 1 & $\%$ & 100,00 & 100,00 & 100,00 & 100,00 & 100,00 & 100,00 & 100,00 \\
\hline $\begin{array}{l}\text { Hottentot } \\
\text { África do Sul }\end{array}$ & & média & 182,00 & 179,00 & 100,00 & 126,00 & 105,00 & 109,00 & 103,00 \\
\hline África Sub- & & $n$ & 1 & 1 & 1 & 1 & 1 & 1 & 1 \\
\hline Saariana - & 1 & $\%$ & 100,00 & 100,00 & 100,00 & 100,00 & 100,00 & 100,00 & 100,00 \\
\hline $\begin{array}{l}\text { Kafir Africa do } \\
\text { Sul }\end{array}$ & & média & 181,00 & 180,00 & 93,00 & 143,00 & 115,00 & 112,00 & 106,00 \\
\hline África Sub- & & $n$ & 1 & 1 & 1 & 1 & 1 & 1 & 1 \\
\hline Saariana - & 1 & $\%$ & 100,00 & 100,00 & 100,00 & 100,00 & 100,00 & 100,00 & 100,00 \\
\hline Zulu & & média & 183,00 & 181,00 & 98,00 & 128,00 & 117,50 & 115,00 & 99,50 \\
\hline África Sub- & & $\mathrm{n}$ & 27 & 27 & 26 & 27 & 27 & 27 & 27 \\
\hline Saariana - & 27 & $\%$ & 100,00 & 100,00 & 96,30 & 100,00 & 100,00 & 100,00 & 100,00 \\
\hline Tanzânia & & média & 175,56 & 174,06 & 96,67 & 129,30 & 110,26 & 113,50 & 103,24 \\
\hline África Sub- & & $n$ & 4 & 4 & 4 & 4 & 4 & 4 & 4 \\
\hline Saariana - & 4 & $\%$ & 100,00 & 100,00 & 100,00 & 100,00 & 100,00 & 100,00 & 100,00 \\
\hline $\begin{array}{c}\text { Africa } \\
\text { Ocidental }\end{array}$ & & média & 163,38 & 162,25 & 91,50 & 126,25 & 105,50 & 106,13 & 96,75 \\
\hline África Sub- & & $n$ & 1 & 1 & 1 & 1 & 1 & 1 & 1 \\
\hline Saariana - & 1 & $\%$ & 100,00 & 100,00 & 100,00 & 100,00 & 100,00 & 100,00 & 100,00 \\
\hline Zâmbia & & média & 177,00 & 175,00 & 96,00 & 130,00 & 102,00 & 113,00 & 109,00 \\
\hline Sudoeste & & $n$ & 8 & 8 & 8 & 8 & 8 & 8 & 8 \\
\hline Asiático - & 8 & $\%$ & 100,00 & 100,00 & 100,00 & 100,00 & 100,00 & 100,00 & 100,00 \\
\hline Beduíno & & média & 171,81 & 170,75 & 94,00 & 130,13 & 110,75 & 111,88 & 102,00 \\
\hline Sudoeste & & $\mathrm{n}$ & 4 & 4 & 4 & 4 & 4 & 4 & 4 \\
\hline Asiático - & 4 & $\%$ & 100,00 & 100,00 & 100,00 & 100,00 & 100,00 & 100,00 & 100,00 \\
\hline Iraque & & média & 174,75 & 173,13 & 97,25 & 134,00 & 114,25 & 112,50 & 103,63 \\
\hline Sudoeste & & $n$ & 7 & 7 & 7 & 6 & 6 & 5 & 5 \\
\hline Asiático - & 7 & $\%$ & 100,00 & 100,00 & 100,00 & 85,71 & 85,71 & 71,43 & 71,43 \\
\hline Iraque (early) & & média & 174,43 & 172,86 & 98,43 & 130,58 & 109,92 & 111,40 & 104,40 \\
\hline Sudoeste & & $\mathrm{n}$ & 1 & 1 & 1 & 1 & 1 & 1 & 1 \\
\hline Asiático - & 1 & $\%$ & 100,00 & 100,00 & 100,00 & 100,00 & 100,00 & 100,00 & 100,00 \\
\hline Líbano & & média & 171,00 & 169,00 & 98,00 & 133,00 & 115,00 & 112,00 & 99,00 \\
\hline Sudoeste & & $n$ & 5 & 5 & 5 & 5 & 5 & 5 & 5 \\
\hline Asiático - & 5 & $\%$ & 100,00 & 100,00 & 100,00 & 100,00 & 100,00 & 100,00 & 100,00 \\
\hline Palestina & & média & 173,10 & 171,40 & 97,40 & 135,30 & 116,00 & 116,60 & 106,40 \\
\hline & & $n$ & 5 & 5 & 5 & 5 & 5 & 5 & 5 \\
\hline $\begin{array}{l}\text { Sudoeste } \\
\text { Asiático - Síria }\end{array}$ & 5 & $\%$ & 100,00 & 100,00 & 100,00 & 100,00 & 100,00 & 100,00 & 100,00 \\
\hline & & média & 167,70 & 166,70 & 93,10 & 133,50 & 114,40 & 110,80 & 104,30 \\
\hline Sudoeste & & $\mathrm{n}$ & 17 & 17 & 17 & 17 & 17 & 17 & 17 \\
\hline Asiático - & 17 & $\%$ & 100,00 & 100,00 & 100,00 & 100,00 & 100,00 & 100,00 & 100,00 \\
\hline Turquia & & média & 172,41 & 171,76 & 97,03 & 132,56 & 111,74 & 113,82 & 103,44 \\
\hline & & $n$ & 5 & 5 & 5 & 5 & 5 & 5 & 5 \\
\hline - Poundbury & 5 & $\%$ & 100,00 & 100,00 & 100,00 & 100,00 & 100,00 & 100,00 & 100,00 \\
\hline & & média & 178,80 & 176,80 & 94,00 & 137,40 & 118,00 & 120,00 & 107,00 \\
\hline Grã-Bretanha & & $\mathrm{n}$ & 16 & 16 & 15 & 16 & 16 & 14 & 16 \\
\hline - Spitafields & 16 & $\%$ & 100,00 & 100,00 & 93,75 & 100,00 & 100,00 & 87,50 & 100,00 \\
\hline CAM & & média & 170,06 & 168,38 & 95,07 & 137,06 & 117,50 & 116,71 & 105,25 \\
\hline Grã-Bretanha & & $n$ & 86 & 84 & 85 & 84 & 86 & 84 & 82 \\
\hline - Spitafields & 88 & $\%$ & 97,73 & 95,45 & 96,59 & 95,45 & 97,73 & 95,45 & 93,18 \\
\hline $\mathrm{NHM}$ & & média & 177,50 & 175,98 & 93,78 & 136,00 & 116,20 & 113,87 & 106,65 \\
\hline
\end{tabular}




\begin{tabular}{|c|c|c|c|c|c|c|c|c|c|}
\hline \multirow{3}{*}{$\begin{array}{c}\text { EUA - } \\
\text { Alabama }\end{array}$} & \multirow{3}{*}{7} & $n$ & 7 & 7 & 6 & 7 & 7 & 7 & 7 \\
\hline & & $\%$ & 100,00 & 100,00 & 85,71 & 100,00 & 100,00 & 100,00 & 100,00 \\
\hline & & média & 166,43 & 164,86 & 99,58 & 137,50 & 111,14 & 119,71 & 105,86 \\
\hline \multirow{3}{*}{$\begin{array}{c}\text { EUA - nativos } \\
\text { do Alaska }\end{array}$} & \multirow{3}{*}{29} & $\mathrm{n}$ & 28 & 28 & 28 & 27 & 26 & 28 & 28 \\
\hline & & $\%$ & 96,55 & 96,55 & 96,55 & 93,10 & 89,66 & 96,55 & 96,55 \\
\hline & & média & 174,61 & 172,79 & 97,46 & 133,87 & 112,27 & 120,82 & 105,79 \\
\hline \multirow{3}{*}{$\begin{array}{c}\text { EUA - Alaska } \\
\text { (Kodiak) }\end{array}$} & \multirow{3}{*}{14} & $\mathrm{n}$ & 14 & 14 & 14 & 13 & 13 & 14 & 13 \\
\hline & & $\%$ & 100,00 & 100,00 & 100,00 & 92,86 & 92,86 & 100,00 & 92,86 \\
\hline & & média & 168,36 & 167,46 & 95,86 & 142,81 & 115,85 & 125,93 & 109,54 \\
\hline \multirow{3}{*}{$\begin{array}{c}\text { EUA - Alaska } \\
\text { (Tlingit) }\end{array}$} & \multirow{3}{*}{11} & $\mathrm{n}$ & 11 & 11 & 11 & 11 & 11 & 11 & 11 \\
\hline & & $\%$ & 100,00 & 100,00 & 100,00 & 100,00 & 100,00 & 100,00 & 100,00 \\
\hline & & média & 174,14 & 172,05 & 96,05 & 142,32 & 113,18 & 125,41 & 110,82 \\
\hline \multirow{3}{*}{ EUA - Arizona } & & $n$ & 1 & 0 & 0 & 1 & 1 & 1 & 1 \\
\hline & 35 & $\%$ & 100,00 & 0,00 & 0,00 & 100,00 & 100,00 & 100,00 & 100,00 \\
\hline & & média & 163,00 & - & - & 147,00 & 132,00 & 128,00 & 116,00 \\
\hline & & $\mathrm{n}$ & 35 & 35 & 35 & 35 & 35 & 34 & 35 \\
\hline EuA - & 12 & $\%$ & 100,00 & 100,00 & 100,00 & 100,00 & 100,00 & 97,14 & 100,00 \\
\hline & & média & 170,19 & 168,61 & 96,00 & 132,76 & 111,16 & 119,60 & 103,47 \\
\hline & & $n$ & 12 & 12 & 12 & 12 & 12 & 12 & 12 \\
\hline Califórnia 1 & 50 & $\%$ & 100,00 & 100,00 & 100,00 & 100,00 & 100,00 & 100,00 & 100,00 \\
\hline & & média & 165,83 & 165,00 & 98,13 & 136,54 & 112,75 & 117,25 & 104,29 \\
\hline & & $\mathrm{n}$ & 50 & 50 & 47 & 50 & 49 & 50 & 50 \\
\hline Califórn & 156 & $\%$ & 100,00 & 100,00 & 94,00 & 100,00 & 98,00 & 100,00 & 100,00 \\
\hline & & média & 173,61 & 171,20 & 97,29 & 137,91 & 113,45 & 120,08 & 107,67 \\
\hline EUA - & & $\mathrm{n}$ & 156 & 156 & 155 & 156 & 154 & 156 & 156 \\
\hline Carolina do & 1 & $\%$ & 100,00 & 100,00 & 99,36 & 100,00 & 98,72 & 100,00 & 100,00 \\
\hline Norte & & média & 172,50 & 170,36 & 93,30 & 135,42 & 110,07 & 119,15 & 106,08 \\
\hline & & $n$ & 1 & 1 & 1 & 1 & 1 & 1 & 1 \\
\hline Colorado & 2 & $\%$ & 100,00 & 100,00 & 100,00 & 100,00 & 100,00 & 100,00 & 100,00 \\
\hline & & média & 178,00 & 178,00 & 100,00 & 135,00 & 112,00 & 120,00 & 104,50 \\
\hline & & $n$ & 2 & 2 & 2 & 2 & 2 & 2 & 2 \\
\hline do $\mathrm{N}$ & 11 & $\%$ & 100,00 & 100,00 & 100,00 & 100,00 & 100,00 & 100,00 & 100,00 \\
\hline & & média & 170,50 & 167,25 & 98,75 & 139,50 & 119,50 & 123,00 & 105,75 \\
\hline & & $n$ & 11 & 11 & 11 & 11 & 10 & 11 & 11 \\
\hline CUH Suld & 76 & $\%$ & 100,00 & 100,00 & 100,00 & 100,00 & 90,91 & 100,00 & 100,00 \\
\hline & & média & 177,18 & 175,77 & 99,05 & 138,36 & 112,40 & 126,45 & 108,55 \\
\hline & & $\mathrm{n}$ & 76 & 76 & 76 & 74 & 74 & 75 & 75 \\
\hline Delaware & 10 & $\%$ & 100,00 & 100,00 & 100,00 & 97,37 & 97,37 & 98,68 & 98,68 \\
\hline & & média & 172,12 & 171,02 & 98,03 & 135,86 & 112,86 & 123,30 & 105,86 \\
\hline & & $\mathrm{n}$ & 10 & 10 & 10 & 10 & 10 & 10 & 10 \\
\hline EUA - Flórida & 62 & $\%$ & 100,00 & 100,00 & 100,00 & 100,00 & 100,00 & 100,00 & 100,00 \\
\hline & & média & 180,50 & 179,10 & 102,40 & 133,20 & 111,70 & 122,00 & 108,30 \\
\hline & & $n$ & 62 & 62 & 62 & 62 & 62 & 62 & 62 \\
\hline EUA - Geórgia & 10 & $\%$ & 100,00 & 100,00 & 100,00 & 100,00 & 100,00 & 100,00 & 100,00 \\
\hline & & média & 173,48 & 172,47 & 99,44 & 139,27 & 113,88 & 125,56 & 108,23 \\
\hline & & $n$ & 10 & 10 & 8 & 9 & 9 & 10 & 10 \\
\hline Shelte & 1 & $\%$ & 100,00 & 100,00 & 80,00 & 90,00 & 90,00 & 100,00 & 100,00 \\
\hline & & média & 172,65 & 170,85 & 98,56 & 135,89 & 113,56 & 120,80 & 104,80 \\
\hline & & $\mathrm{n}$ & 0 & 0 & 0 & 0 & 0 & 0 & 0 \\
\hline EUA - Illinois & 88 & $\%$ & 0,00 & 0,00 & 0,00 & 0,00 & 0,00 & 0,00 & 0,00 \\
\hline & & média & & & & -1 & & - & \\
\hline & & $\mathrm{n}$ & 88 & 88 & 88 & 88 & 87 & 88 & 88 \\
\hline EUA - Indiana & 2 & $\%$ & 100,00 & 100,00 & 100,00 & 100,00 & 98,86 & 100,00 & 100,00 \\
\hline & & média & 172,47 & 170,93 & 99,17 & 132,48 & 110,52 & 117,86 & 104,45 \\
\hline & & $\mathrm{n}$ & 2 & 2 & 2 & 2 & 2 & 2 & 2 \\
\hline EUA - Kansas & 11 & $\%$ & 100,00 & 100,00 & 100,00 & 100,00 & 100,00 & 100,00 & 100,00 \\
\hline & & média & 170,75 & 167,50 & 100,00 & 136,50 & 111,00 & 124,00 & 108,00 \\
\hline & & $\mathrm{n}$ & 11 & 11 & 11 & 11 & 11 & 10 & 11 \\
\hline Kentucky & 25 & $\%$ & 100,00 & 100,00 & 100,00 & 100,00 & 100,00 & 90,91 & 100,00 \\
\hline & & média & 169,91 & 168,50 & 97,23 & 138,73 & 112,82 & 124,55 & 107,77 \\
\hline & & $n$ & 25 & 25 & 25 & 24 & 25 & 25 & 25 \\
\hline Luisiana & 2 & $\%$ & 100,00 & 100,00 & 100,00 & 96,00 & 100,00 & 100,00 & 100,00 \\
\hline & & média & 169,48 & 167,94 & 96,36 & 131,40 & 109,72 & 115,84 & 103,68 \\
\hline & & $n$ & 2 & 2 & 2 & 2 & 2 & 2 & 2 \\
\hline EUA - & 42 & $\%$ & 100,00 & 100,00 & 100,00 & 100,00 & 100,00 & 100,00 & 100,00 \\
\hline & & média & 172,50 & 171,50 & 104,00 & 137,00 & 111,00 & 123,00 & 107,50 \\
\hline EUA - & & $n$ & 42 & 42 & 40 & 42 & 41 & 42 & 42 \\
\hline Massachusetts & 3 & $\%$ & 100,00 & 100,00 & 95,24 & 100,00 & 97,62 & 100,00 & 100,00 \\
\hline & & média & 175,96 & 174,24 & 100,68 & 136,33 & 113,80 & 122,11 & 106,71 \\
\hline & & $n$ & 3 & 3 & 3 & 3 & 3 & 3 & 3 \\
\hline
\end{tabular}




\begin{tabular}{|c|c|c|c|c|c|c|c|c|c|}
\hline \multirow{5}{*}{$\begin{array}{l}\text { EUA - } \\
\text { Michjigan } \\
\text { Mississipi }\end{array}$} & \multirow[b]{2}{*}{6} & $n$ & 3 & 3 & 3 & 3 & 3 & 3 & 3 \\
\hline & & média & $100, \theta 0$ & $10 Q, \theta 0$ & $10 \theta, 00$ & $10 Q, \theta \theta$ & $10 \emptyset, \theta \emptyset$ & 100,00 & 100,00 \\
\hline & \multirow{3}{*}{1} & $n$ & 6 & 6 & 5 & 6 & 6 & 6 & 6 \\
\hline & & $\%$ & 100,00 & 100,00 & 83,33 & 100,00 & 100,00 & 100,00 & 100,00 \\
\hline & & média & 172,67 & 170,92 & 96,60 & 136,33 & 113,50 & 121,08 & 106,67 \\
\hline \multirow{3}{*}{$\begin{array}{l}\text { EUA - } \\
\text { Missouri }\end{array}$} & \multirow{3}{*}{4} & $\mathrm{n}$ & 1 & 1 & 1 & 1 & 1 & 1 & 1 \\
\hline & & $\%$ & 100,00 & 100,00 & 100,00 & 100,00 & 100,00 & 100,00 & 100,00 \\
\hline & & média & 165,00 & 162,50 & 99,00 & 130,00 & 105,00 & 118,00 & 103,00 \\
\hline \multirow{3}{*}{$\begin{array}{l}\text { EUA - } \\
\text { Montana }\end{array}$} & \multirow{3}{*}{7} & $n$ & 4 & 4 & 3 & 4 & 3 & 4 & 4 \\
\hline & & $\%$ & 100,00 & 100,00 & 75,00 & 100,00 & 75,00 & 100,00 & 100,00 \\
\hline & & média & 172,75 & 171,00 & 99,83 & 132,00 & 107,67 & 117,50 & 101,50 \\
\hline \multirow{3}{*}{$\begin{array}{l}\text { EUA - } \\
\text { Nebraska }\end{array}$} & \multirow{3}{*}{9} & $n$ & 7 & 7 & 7 & 7 & 7 & 7 & 7 \\
\hline & & $\%$ & 100,00 & 100,00 & 100,00 & 100,00 & 100,00 & 100,00 & 100,00 \\
\hline & & média & 174,00 & 172,36 & 96,36 & 138,29 & 112,43 & 125,86 & 109,71 \\
\hline \multirow{3}{*}{$\begin{array}{l}\text { EUA - New } \\
\text { Jersey }\end{array}$} & \multirow{3}{*}{7} & $n$ & 9 & 9 & 9 & 9 & 9 & 9 & 9 \\
\hline & & $\%$ & 100,00 & 100,00 & 100,00 & 100,00 & 100,00 & 100,00 & 100,00 \\
\hline & & média & 176,00 & 174,56 & 95,11 & 137,39 & 111,56 & 123,44 & 107,50 \\
\hline \multirow{3}{*}{$\begin{array}{l}\text { EUA - Novo } \\
\text { México }\end{array}$} & \multirow{3}{*}{50} & $n$ & 7 & 7 & 7 & 7 & 7 & 7 & 7 \\
\hline & & $\%$ & 100,00 & 100,00 & 100,00 & 100,00 & 100,00 & 100,00 & 100,00 \\
\hline & & média & 171,00 & 170,07 & 99,14 & 134,29 & 111,00 & 120,71 & 103,29 \\
\hline \multirow{3}{*}{$\begin{array}{c}\text { EUA - Nova } \\
\text { York }\end{array}$} & \multirow{3}{*}{24} & $n$ & 50 & 50 & 50 & 50 & 49 & 50 & 50 \\
\hline & & $\%$ & 100,00 & 100,00 & 100,00 & 100,00 & 98,00 & 100,00 & 100,00 \\
\hline & & média & 167,18 & 164,98 & 95,08 & 132,33 & 111,67 & 120,18 & 102,87 \\
\hline \multirow{3}{*}{$\begin{array}{c}\text { EUA - } \\
\text { Oklahoma }\end{array}$} & \multirow{3}{*}{3} & $n$ & 24 & 24 & 24 & 24 & 24 & 24 & 24 \\
\hline & & $\%$ & 100,00 & 100,00 & 100,00 & 100,00 & 100,00 & 100,00 & 100,00 \\
\hline & & média & 176,96 & 175,31 & 100,98 & 132,60 & 110,96 & 119,96 & 105,69 \\
\hline \multirow{3}{*}{ EUA - Oregon } & & $\mathrm{n}$ & 3 & 3 & 3 & 3 & 3 & 3 & 3 \\
\hline & 3 & $\%$ & 100,00 & 100,00 & 100,00 & 100,00 & 100,00 & 100,00 & 100,00 \\
\hline & & média & 164,50 & 164,00 & 95,17 & 138,33 & 111,33 & 124,33 & 108,00 \\
\hline & & $\mathrm{n}$ & 3 & 3 & 3 & 3 & 3 & 3 & 3 \\
\hline Pensilvânia & 2 & $\%$ & 100,00 & 100,00 & 100,00 & 100,00 & 100,00 & 100,00 & 100,00 \\
\hline & & média & 165,67 & 164,67 & 95,00 & 132,00 & 108,00 & 119,33 & 102,67 \\
\hline & & $n$ & 2 & 2 & 2 & 2 & 2 & 2 & 2 \\
\hline Tennecce & 13 & $\%$ & 100,00 & 100,00 & 100,00 & 100,00 & 100,00 & 100,00 & 100,00 \\
\hline & & média & 170,00 & 168,00 & 99,50 & 133,50 & 109,00 & 120,00 & 106,00 \\
\hline & & $n$ & 13 & 13 & 13 & 13 & 13 & 12 & 13 \\
\hline EUA - Texas & 10 & $\%$ & 100,00 & 100,00 & 100,00 & 100,00 & 100,00 & 92,31 & 100,00 \\
\hline & & média & 169,69 & 168,19 & 99,77 & 134,31 & 111,92 & 115,42 & 106,65 \\
\hline & & $\mathrm{n}$ & 10 & 10 & 9 & 10 & 9 & 10 & 10 \\
\hline EUA - Utah & 40 & $\%$ & 100,00 & 100,00 & 90,00 & 100,00 & 90,00 & 100,00 & 100,00 \\
\hline & & média & 173,85 & 172,05 & 96,72 & 132,55 & 110,33 & 122,65 & 106,95 \\
\hline & & $\mathrm{n}$ & 40 & 40 & 40 & 40 & 40 & 39 & 40 \\
\hline EUA - Virginia & 33 & $\%$ & 100,00 & 100,00 & 100,00 & 100,00 & 100,00 & 97,50 & 100,00 \\
\hline & & média & 173,46 & 171,50 & 96,40 & 130,58 & 109,21 & 119,46 & 103,81 \\
\hline & & $n$ & 33 & 33 & 30 & 33 & 32 & 33 & 31 \\
\hline Ocidental & 1 & $\%$ & 100,00 & 100,00 & 90,91 & 100,00 & 96,97 & 100,00 & 93,94 \\
\hline & & média & 171,68 & 170,52 & 100,67 & 135,29 & 112,81 & 120,39 & 104,63 \\
\hline & & $n$ & 1 & 1 & 1 & 1 & 1 & 1 & 1 \\
\hline WUA - & 2 & $\%$ & 100,00 & 100,00 & 100,00 & 100,00 & 100,00 & 100,00 & 100,00 \\
\hline & & média & 180,00 & 179,00 & 101,00 & 132,00 & 109,00 & 114,00 & 105,00 \\
\hline & & $\mathrm{N}$ & 2 & 2 & 2 & 2 & 2 & 2 & 2 \\
\hline & & $\%$ & 100,00 & 100,00 & 100,00 & 100,00 & 100,00 & 100,00 & 100,00 \\
\hline & & média & 170,00 & 168,75 & 96,00 & 140,00 & 114,00 & 124,00 & 109,50 \\
\hline
\end{tabular}




\begin{tabular}{|c|c|c|c|c|c|c|c|c|c|c|}
\hline série & & $\mathrm{BBH}$ & FRC & PAC & OCC & BPL & ZYB & $\mathrm{NPH}$ & DKB & $\mathrm{OBH}$ \\
\hline \multirow{3}{*}{ Aleuta 1} & $n$ & 56 & 56 & 56 & 55 & 50 & 45 & 53 & 55 & 54 \\
\hline & $\%$ & 98,25 & 98,25 & 98,25 & 96,49 & 87,72 & 78,95 & 92,98 & 96,49 & 94,74 \\
\hline & média & 125,18 & 108,33 & 104,05 & 96,92 & 98,39 & 133,96 & 69,76 & 20,33 & 36,09 \\
\hline \multirow{3}{*}{ Aleuta 2} & $\mathrm{n}$ & 42 & 42 & 42 & 42 & 40 & 38 & 40 & 42 & 42 \\
\hline & $\%$ & 100,00 & 100,00 & 100,00 & 100,00 & 95,24 & 90,48 & 95,24 & 100,00 & 100,00 \\
\hline & média & 124,06 & 108,54 & 102,85 & 95,58 & 99,20 & 134,87 & 68,73 & 20,25 & 36,25 \\
\hline \multirow{3}{*}{ Aleuta 3} & $\mathrm{n}$ & 13 & 13 & 13 & 13 & 12 & 7 & 12 & 13 & 13 \\
\hline & $\%$ & 100,00 & 100,00 & 100,00 & 100,00 & 92,31 & 53,85 & 92,31 & 100,00 & 100,00 \\
\hline & média & 127,15 & 108,00 & 102,85 & 96,54 & 97,17 & 131,43 & 68,63 & 20,73 & 34,92 \\
\hline \multirow{3}{*}{ Aleuta 4} & $\mathrm{n}$ & 7 & 7 & 7 & 7 & 7 & 6 & 7 & 7 & 7 \\
\hline & $\%$ & 100,00 & 100,00 & 100,00 & 100,00 & 100,00 & 85,71 & 100,00 & 100,00 & 100,00 \\
\hline & média & 125,50 & 108,14 & 99,64 & 97,93 & 93,79 & 131,50 & 67,50 & 19,21 & 35,43 \\
\hline \multirow{3}{*}{ Aleuta 5} & $\mathrm{n}$ & 7 & 7 & 7 & 7 & 7 & 5 & 7 & 7 & 7 \\
\hline & $\%$ & 100,00 & 100,00 & 100,00 & 100,00 & 100,00 & 71,43 & 100,00 & 100,00 & 100,00 \\
\hline & média & 124,14 & 107,00 & 103,14 & 97,14 & 94,43 & 133,40 & 67,57 & 22,29 & 33,57 \\
\hline \multirow{3}{*}{ Aleuta 6} & $\mathrm{n}$ & 5 & 5 & 5 & 5 & 5 & 5 & 5 & 5 & 5 \\
\hline & $\%$ & 100,00 & 100,00 & 100,00 & 100,00 & 100,00 & "' & 100,00 & 100,00 & 100,00 \\
\hline & média & 122,20 & 105,40 & 100,40 & 92,80 & 97,40 & 134,80 & 70,40 & 19,20 & 36,00 \\
\hline \multirow{3}{*}{$\begin{array}{l}\text { Austrália - } \\
\text { Murray River }\end{array}$} & $n$ & 6 & 14 & 16 & 8 & 4 & 5 & 9 & 5 & 12 \\
\hline & $\%$ & 33,33 & 77,78 & 88,89 & 44,44 & 22,22 & 27,78 & 50,00 & 27,78 & 66,67 \\
\hline & média & 128,17 & 107,50 & 112,69 & 91,63 & 104,50 & 124,00 & 63,11 & 21,20 & 34,00 \\
\hline \multirow{3}{*}{$\begin{array}{l}\text { Austrália- } \\
\text { New South } \\
\text { Walles }\end{array}$} & $n$ & 7 & 10 & 10 & 9 & 7 & 4 & 9 & 9 & 9 \\
\hline & $\%$ & 58,33 & 83,33 & 83,33 & 75,00 & 58,33 & 33,33 & 75,00 & 75,00 & 75,00 \\
\hline & média & 130,29 & 110,10 & 117,50 & 94,78 & 97,71 & 122,00 & 62,33 & 21,11 & 33,56 \\
\hline \multirow{3}{*}{$\begin{array}{l}\text { Austrália - } \\
\text { Território do } \\
\text { Norte }\end{array}$} & $\mathrm{n}$ & 2 & 2 & 2 & 2 & 2 & 2 & 2 & 2 & 2 \\
\hline & $\%$ & 100,00 & 100,00 & 100,00 & 100,00 & 100,00 & "' & 100,00 & 100,00 & 100,00 \\
\hline & média & 129,00 & 109,00 & 115,50 & 89,00 & 104,50 & ' 129,50 & 67,00 & 20,50 & 34,50 \\
\hline & $\mathrm{n}$ & 41 & 64 & 69 & 56 & 32 & 29 & 38 & 38 & 42 \\
\hline Austrália - Sul & $\%$ & 57,75 & 90,14 & 97,18 & 78,87 & 45,07 & 40,85 & 53,52 & 53,52 & 59,15 \\
\hline & média & 124,12 & 107,44 & 110,09 & 90,96 & 100,69 & 121,31 & 62,45 & 21,00 & 33,26 \\
\hline & $\mathrm{n}$ & 6 & 7 & 7 & 6 & 6 & 6 & 7 & 7 & 7 \\
\hline & $\%$ & 85,71 & 100,00 & 100,00 & 85,71 & 85,71 & 85,71 & 100,00 & 100,00 & 100,00 \\
\hline & média & 126,50 & 106,57 & 110,36 & 93,00 & 98,83 & 124,33 & 57,14 & 22,43 & 29,71 \\
\hline Canadá - & $\mathrm{n}$ & 22 & 22 & 22 & 22 & 22 & 21 & 22 & 22 & 22 \\
\hline Columbia & $\%$ & 100,00 & 100,00 & 100,00 & 100,00 & 100,00 & 95,45 & 100,00 & 100,00 & 100,00 \\
\hline ânica & média & 128,89 & 110,30 & 101,43 & 97,20 & 99,27 & '"'-130,52 & 68,89 & 21,52 & 35,50 \\
\hline & $n$ & 1 & 1 & 1 & 1 & 1 & 1 & 1 & 1 & 1 \\
\hline & $\%$ & 100,00 & 100,00 & 100,00 & 100,00 & 100,00 & 100,00 & 100,00 & 100,00 & 100,00 \\
\hline & média & 132,00 & 104,00 & 109,00 & 93,00 & 97,00 & 126,00 & 67,00 & 22,00 & 31,50 \\
\hline Canadá - & $\mathrm{n}$ & 6 & 6 & 6 & 6 & 5 & 3 & 5 & 6 & 6 \\
\hline Ontário & $\%$ & 100,00 & 100,00 & 100,00 & 100,00 & 83,33 & 50,00 & 83,33 & 100,00 & 100,00 \\
\hline e) & média & 131,00 & 107,00 & 106,17 & 96,17 & 97,20 & 129,33 & 67,00 & 21,83 & 34,17 \\
\hline América Central & $n$ & 2 & 2 & 2 & 2 & 2 & 2 & 2 & 2 & 2 \\
\hline 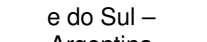 & $\%$ & 100,00 & 100,00 & 100,00 & 100,00 & 100,00 & 100,00 & 100,00 & 100,00 & 100,00 \\
\hline gentina & média & 127,50 & 106,00 & 107,50 & 89,50 & 96,00 & 127,50 & 64,50 & 21,00 & 33,50 \\
\hline América & $\mathrm{n}$ & 6 & 6 & 6 & 6 & 6 & 6 & 6 & 6 & 6 \\
\hline Central e do & $\%$ & 100,00 & 100,00 & 100,00 & 100,00 & 100,00 & 100,00 & 100,00 & 100,00 & 100,00 \\
\hline Sul - Bolívia & média & 126,50 & 105,42 & 100,83 & 95,75 & 91,83 & 125,00 & 62,67 & 22,50 & 34,00 \\
\hline América & $\mathrm{n}$ & 20 & 20 & 20 & 20 & 18 & 17 & 18 & 18 & 20 \\
\hline Central e do & $\%$ & 100,00 & 100,00 & 100,00 & 100,00 & 90,00 & 85,00 & 90,00 & 90,00 & 100,00 \\
\hline Sul - & média & 129,18 & 105,78 & 106,78 & 94,83 & 92,14 & 123,62 & 64,75 & 20,08 & 34,15 \\
\hline América & $\mathrm{n}$ & 1 & 1 & 1 & 1 & 1 & 1 & $\overline{1}$ & $\overline{1}$ & $\overline{1}$ \\
\hline Central e do & $\%$ & 100,00 & 100,00 & 100,00 & 100,00 & 100,00 & 100,00 & 100,00 & 100,00 & 100,00 \\
\hline Sul - Colômbia & média & 119,00 & 101,00 & 100,00 & 92,00 & 93,00 & 122,00 & 63,00 & 23,00 & 33,00 \\
\hline América & $\mathrm{n}$ & 1 & 2 & 2 & 1 & 1 & 1 & 2 & 2 & 2 \\
\hline Central e do & $\%$ & 50,00 & 100,00 & 100,00 & 50,00 & 50,00 & 50,00 & 100,00 & 100,00 & 100,00 \\
\hline Sul - Equador & média & 130,00 & 109,50 & 101,00 & 100,00 & 96,00 & 131,00 & 64,50 & 20,50 & 33,00 \\
\hline & $n$ & 12 & 14 & 14 & 13 & 12 & 13 & 14 & 14 & 14 \\
\hline do Sul & $\%$ & 85,71 & 100,00 & 100,00 & 92,86 & 85,71 & 92,86 & 100,00 & 100,00 & 100,00 \\
\hline$(\mathrm{Pa}$ & média & 133,13 & 112,11 & 107,71 & 98,62 & 96,29 & 133,65 & 68,86 & 20,86 & 34,71 \\
\hline América & $\mathrm{n}$ & 42 & 43 & 43 & 43 & 39 & 42 & 40 & 43 & 43 \\
\hline Central e do & $\%$ & 97,67 & 100,00 & 100,00 & 100,00 & 90,70 & 97,67 & 93,02 & 100,00 & 100,00 \\
\hline Sul - México & média & 129,81 & 105,73 & 105,40 & 94,40 & 95,14 & '126,49 & 62,71 & 20,55 & 33,16 \\
\hline América & $\mathrm{n}$ & 143 & 143 & 143 & 143 & 143 & 140 & 143 & 143 & 143 \\
\hline Central e do & $\%$ & 100,00 & 100,00 & 100,00 & 100,00 & 100,00 & 97,90 & 100,00 & 100,00 & 100,00 \\
\hline Sul - Peru & média & 125,87 & 104,68 & 104,88 & 95,42 & 91,61 & ' & 63,31 & 20,06 & 33,67 \\
\hline América & $n$ & 2 & 2 & 2 & 2 & 2 & 2 & 2 & 2 & 2 \\
\hline Central e do & $\%$ & 100,00 & 100,00 & 100,00 & 100,00 & 100,00 & 100,00 & 100,00 & 100,00 & 100,00 \\
\hline
\end{tabular}




\begin{tabular}{|c|c|c|c|c|c|c|c|c|c|c|}
\hline $\begin{array}{c}\text { Sul- } \\
\text { Venezuela }\end{array}$ & média & 127,00 & 102,50 & 107,00 & 92,50 & 98,50 & 132,50 & 66,00 & 20,50 & 33,00 \\
\hline \multirow{3}{*}{$\begin{array}{l}\text { Leste Asiático } \\
\text { - Norte da } \\
\text { China (Han) } \\
\end{array}$} & $\mathrm{n}$ & 12 & 12 & 12 & 12 & 12 & 12 & 12 & 12 & 12 \\
\hline & $\%$ & 100,00 & 100,00 & 100,00 & 100,00 & 100,00 & 100,00 & 100,00 & 100,00 & 100,00 \\
\hline & média & 134,00 & 110,50 & 112,21 & 97,42 & 91,50 & 130,17 & 69,21 & 21,33 & 34,29 \\
\hline \multirow{3}{*}{$\begin{array}{l}\text { Leste Asiático } \\
\text { - Japão } \\
\text { Tohoku }\end{array}$} & $n$ & 63 & 62 & 63 & 63 & 51 & 63 & 52 & 68 & 68 \\
\hline & $\%$ & 92,65 & 91,18 & 92,65 & 92,65 & 75,00 & 92,65 & 76,47 & 100,00 & 100,00 \\
\hline & média & 131,08 & 105,79 & 108,81 & 96,21 & 93,55 & 124,97 & 66,17 & 20,10 & 34,48 \\
\hline \multirow{3}{*}{$\begin{array}{l}\text { Leste Asiático } \\
\text { - Japão } \\
\text { Período Jomon } \\
\end{array}$} & $n$ & 6 & 8 & 9 & 7 & 5 & 3 & 7 & 6 & 8 \\
\hline & $\%$ & 66,67 & 88,89 & 100,00 & 77,78 & 55,56 & 33,33 & 77,78 & 66,67 & 88,89 \\
\hline & média & 134,17 & 110,75 & 114,89 & 100,86 & 99,40 & 133,67 & 64,29 & 23,00 & 34,63 \\
\hline \multirow{3}{*}{$\begin{array}{l}\text { Leste Asiático } \\
\text { - Nepal }\end{array}$} & $n$ & 7 & 7 & 7 & 7 & 5 & 7 & 5 & 7 & 7 \\
\hline & $\%$ & 100,00 & 100,00 & 100,00 & 100,00 & 71,43 & 100,00 & 71,43 & 100,00 & 100,00 \\
\hline & média & 126,86 & 108,29 & 107,86 & 91,00 & 90,80 & 121,00 & 59,40 & 20,29 & 32,79 \\
\hline \multirow{3}{*}{$\begin{array}{l}\text { Leste Asiático } \\
\text { - Taiwan }\end{array}$} & $n$ & 1 & 1 & 1 & 1 & 1 & 1 & 1 & 1 & 1 \\
\hline & $\%$ & 100,00 & 100,00 & 100,00 & 100,00 & 100,00 & 100,00 & 100,00 & 100,00 & 100,00 \\
\hline & média & 140,00 & 108,00 & 115,00 & 109,00 & 101,00 & 127,00 & 70,00 & 18,00 & 34,00 \\
\hline \multirow{3}{*}{$\begin{array}{l}\text { Leste Asiático } \\
\text { - Tibet }\end{array}$} & $n$ & 16 & 16 & 15 & 14 & 16 & 13 & 16 & 16 & 16 \\
\hline & $\%$ & 100,00 & 100,00 & 93,75 & 87,50 & 100,00 & 81,25 & 100,00 & 100,00 & 100,00 \\
\hline & média & 127,41 & 106,88 & 108,00 & 91,71 & 93,19 & 124,62 & 63,38 & 21,31 & 33,19 \\
\hline \multirow{3}{*}{$\begin{array}{l}\text { Esquimó - } \\
\text { Alaska } 1\end{array}$} & $n$ & 129 & 130 & 130 & 130 & 116 & 114 & 119 & 129 & 128 \\
\hline & $\%$ & 99,23 & 100,00 & 100,00 & 100,00 & 89,23 & 87,69 & 91,54 & 99,23 & 98,46 \\
\hline & média & 129,67 & 108,13 & 103,66 & 94,00 & 97,03 & 130,51 & 69,14 & 20,38 & 35,54 \\
\hline \multirow{3}{*}{$\begin{array}{l}\text { Esquimó - } \\
\text { Alaska } 2\end{array}$} & $n$ & 104 & 104 & 104 & 103 & 97 & 92 & 99 & 104 & 104 \\
\hline & $\%$ & 100,00 & 100,00 & 100,00 & 99,04 & 93,27 & 88,46 & 95,19 & 100,00 & 100,00 \\
\hline & média & 132,24 & 109,84 & 106,22 & 95,96 & 99,42 & 131,71 & 69,71 & 19,40 & 35,77 \\
\hline \multirow{3}{*}{$\begin{array}{c}\text { Esquimó - } \\
\text { Alaska } 3\end{array}$} & $n$ & 57 & 59 & 60 & 60 & 53 & 43 & 53 & 58 & 57 \\
\hline & $\%$ & 95,00 & 98,33 & 100,00 & 100,00 & 88,33 & 71,67 & 88,33 & 96,67 & 95,00 \\
\hline & média & 131,29 & 109,36 & 106,74 & 94,82 & 97,10 & 129,66 & 68,03 & 19,39 & 35,61 \\
\hline & $n$ & 16 & 16 & 16 & 16 & 15 & 15 & 15 & 16 & 16 \\
\hline Ásia & $\%$ & 100,00 & 100,00 & 100,00 & 100,00 & 93,75 & 93,75 & 93,75 & 100,00 & 100,00 \\
\hline & média & 132,38 & 110,41 & 107,44 & 95,00 & 96,60 & 131,23 & 69,50 & 18,97 & 35,78 \\
\hline & $n$ & 25 & 24 & 24 & 25 & 25 & 19 & 25 & 25 & 25 \\
\hline Canadá & $\%$ & 100,00 & 96,00 & 96,00 & 100,00 & 100,00 & 76,00 & 100,00 & 100,00 & 100,00 \\
\hline & média & 132,98 & 110,92 & 109,06 & 96,48 & 97,02 & 129,18 & 68,06 & 19,00 & 35,38 \\
\hline $\mathrm{F}$ & $n$ & 55 & 56 & 56 & 56 & 54 & 48 & 54 & 56 & 56 \\
\hline Groe & $\%$ & 96,49 & 98,25 & 98,25 & 98,25 & 94,74 & 84,21 & 94,74 & 98,25 & 98,25 \\
\hline & média & 132,84 & 109,95 & 110,65 & 96,42 & 99,41 & 129,38 & 67,91 & 18,63 & 35,87 \\
\hline & $n$ & 3 & 3 & 3 & 3 & 3 & 1 & 3 & 3 & 3 \\
\hline "descon & $\%$ & 100,00 & 100,00 & 100,00 & 100,00 & 100,00 & 33,33 & 100,00 & 100,00 & 100,00 \\
\hline & média & 130,00 & 111,00 & 116,67 & 95,00 & 105,33 & 130,00 & 66,67 & 21,33 & 33,67 \\
\hline & $n$ & 55 & 55 & 55 & 55 & 55 & 55 & 55 & 55 & 55 \\
\hline Lúu & $\%$ & 100,00 & 100,00 & 100,00 & 100,00 & 100,00 & 100,00 & 100,00 & 100,00 & 100,00 \\
\hline & média & 128,03 & 106,63 & 107,49 & 91,52 & 90,41 & 124,04 & 63,91 & 21,82 & 32,54 \\
\hline Europa - & $n$ & 1 & 1 & 1 & 1 & 1 & 1 & 1 & 1 & 1 \\
\hline Áustria (Idade & $\%$ & 100,00 & 100,00 & 100,00 & 100,00 & 100,00 & 100,00 & 100,00 & 100,00 & 100,00 \\
\hline ) & média & 127,50 & 106,00 & 108,00 & 96,00 & 86,00 & 119,00 & 61,00 & 18,00 & 32,00 \\
\hline & $n$ & 6 & 6 & 6 & 6 & 6 & 6 & 6 & 6 & 6 \\
\hline Bélaica & $\%$ & 100,00 & 100,00 & 100,00 & 100,00 & 100,00 & 100,00 & 100,00 & 100,00 & 100,00 \\
\hline & média & 125,17 & 108,83 & 108,67 & 92,58 & 86,17 & 122,50 & 65,17 & 20,17 & 33,67 \\
\hline Europa - & $n$ & 35 & 36 & 36 & 36 & 33 & 35 & 33 & 36 & 36 \\
\hline "Republica & $\%$ & 97,22 & 100,00 & 100,00 & 100,00 & 91,67 & 97,22 & 91,67 & 100,00 & 100,00 \\
\hline Tcheca" & média & 128,41 & 105,67 & 106,93 & 90,54 & 90,42 & 124,37 & 63,03 & 20,83 & 31,99 \\
\hline & $n$ & 10 & 10 & 10 & 10 & 10 & 10 & 10 & 10 & 10 \\
\hline $\mathrm{Al}$ & $\%$ & 100,00 & 100,00 & 100,00 & 100,00 & 100,00 & 100,00 & 100,00 & 100,00 & 100,00 \\
\hline & média & 125,50 & 107,55 & 108,40 & 91,15 & 87,10 & 124,35 & 63,90 & 19,30 & 34,15 \\
\hline & $\mathrm{n}$ & 2 & 2 & 2 & 2 & 2 & 2 & 2 & 2 & 2 \\
\hline Holanda & $\%$ & 100,00 & 100,00 & 100,00 & 100,00 & 100,00 & 100,00 & 100,00 & 100,00 & 100,00 \\
\hline & média & 124,00 & 104,50 & 107,50 & 92,50 & 95,50 & 124,00 & 63,50 & 19,75 & 33,00 \\
\hline & $n$ & 51 & 51 & 51 & 51 & 51 & 51 & 51 & 51 & 51 \\
\hline Hungria & $\%$ & 100,00 & 100,00 & 100,00 & 100,00 & 100,00 & 100,00 & 100,00 & 100,00 & 100,00 \\
\hline & média & 126,74 & 105,08 & 107,34 & 92,10 & 91,35 & 123,41 & 63,03 & 21,77 & 31,70 \\
\hline & $n$ & 3 & 3 & 3 & 3 & 3 & 3 & 3 & 3 & 3 \\
\hline lanônia & $\%$ & 100,00 & 100,00 & 100,00 & 100,00 & 100,00 & 100,00 & 100,00 & 100,00 & 100,00 \\
\hline & média & 121,17 & 109,83 & 97,50 & 88,67 & 90,33 & 123,33 & 59,67 & 19,00 & 34,50 \\
\hline & $n$ & 6 & 6 & 6 & 6 & 6 & 6 & 6 & 6 & 6 \\
\hline Curupa - & $\%$ & 100,00 & 100,00 & 100,00 & 100,00 & 100,00 & 100,00 & 100,00 & 100,00 & 100,00 \\
\hline & média & 128,83 & 105,17 & 106,08 & 88,50 & 91,75 & 126,75 & 64,42 & 22,50 & 32,83 \\
\hline Europa - & $\mathrm{n}$ & 23 & 23 & 23 & 23 & 21 & 23 & 21 & 23 & 23 \\
\hline Suíça & $\%$ & 100,00 & 100,00 & 100,00 & 100,00 & 91,30 & 100,00 & 91,30 & 100,00 & 100,00 \\
\hline
\end{tabular}




\begin{tabular}{|c|c|c|c|c|c|c|c|c|c|c|}
\hline & média & 124,87 & 107,35 & 104,54 & 90,00 & 86,38 & 124,20 & 64,90 & 21,74 & 33,59 \\
\hline \multirow{3}{*}{$\begin{array}{l}\text { Europa - } \\
\text { Ucrânia }\end{array}$} & $\mathrm{n}$ & 4 & 4 & 4 & 3 & 2 & 2 & 2 & 3 & $\overline{4}$ \\
\hline & $\%$ & 100,00 & 100,00 & 100,00 & 75,00 & 50,00 & 50,00 & 50,00 & 75,00 & 100,00 \\
\hline & média & 124,25 & 104,00 & 105,50 & 90,50 & 88,00 & 126,50 & 62,00 & 19,00 & 32,38 \\
\hline \multirow{3}{*}{$\begin{array}{l}\text { Europa - } \\
\text { Yuguslavia }\end{array}$} & $\mathrm{n}$ & 9 & 14 & 14 & 7 & 10 & 6 & 14 & 14 & $\overline{14}$ \\
\hline & $\%$ & 64,29 & 100,00 & 100,00 & 50,00 & 71,43 & 42,86 & 100,00 & 100,00 & 100,00 \\
\hline & média & 131,44 & 107,89 & 107,04 & 93,86 & 89,35 & 124,75 & 63,11 & 22,14 & 31,96 \\
\hline \multirow{3}{*}{$\begin{array}{l}\text { Índia - } \\
\text { Bengala }\end{array}$} & $\mathrm{n}$ & 24 & 24 & 24 & 24 & 24 & 23 & 24 & 24 & 24 \\
\hline & $\%$ & 100,00 & 100,00 & 100,00 & 100,00 & 100,00 & 95,83 & 100,00 & 100,00 & 100,00 \\
\hline & média & 127,83 & 106,94 & 108,25 & 92,31 & 92,69 & 118,61 & 60,94 & 20,38 & 32,60 \\
\hline \multirow{3}{*}{ Índia - Mahalls } & $\mathrm{n}$ & 2 & 2 & 2 & 2 & 2 & 2 & 2 & 2 & 2 \\
\hline & $\%$ & 100,00 & 100,00 & 100,00 & 100,00 & 100,00 & 100,00 & 100,00 & 100,00 & 100,00 \\
\hline & média & 126,50 & 106,00 & 107,00 & 89,50 & 88,25 & 114,50 & 59,00 & 22,00 & 31,50 \\
\hline \multirow{3}{*}{ Índia - Mysore } & $\mathrm{n}$ & 3 & 3 & 3 & 3 & 3 & 3 & 3 & 3 & $\overline{3}$ \\
\hline & $\%$ & 100,00 & 100,00 & 100,00 & 100,00 & 100,00 & 100,00 & 100,00 & 100,00 & 100,00 \\
\hline & média & 127,33 & 108,00 & 101,67 & 91,00 & 94,00 & 118,67 & 57,33 & 21,83 & 31,50 \\
\hline \multirow{3}{*}{ Índia - Nagpur } & $\mathrm{n}$ & 1 & 1 & 1 & 1 & 1 & 1 & 1 & 1 & 1 \\
\hline & $\%$ & 100,00 & 100,00 & 100,00 & 100,00 & 100,00 & 100,00 & 100,00 & 100,00 & 100,00 \\
\hline & média & 126,50 & 107,00 & 109,50 & 95,00 & 93,00 & 113,00 & 60,00 & 20,00 & 33,00 \\
\hline \multirow{3}{*}{ Índia - Orissa } & $n$ & 3 & 3 & 3 & 3 & 3 & 3 & 3 & 3 & 3 \\
\hline & $\%$ & 100,00 & 100,00 & 100,00 & 100,00 & 100,00 & 100,00 & 100,00 & 100,00 & 100,00 \\
\hline & média & 124,67 & 103,00 & 104,83 & 88,00 & 96,00 & 117,83 & 59,50 & 20,67 & 31,50 \\
\hline \multirow{3}{*}{ Índia - Sikkim } & $\mathrm{n}$ & 2 & 2 & 2 & 2 & 2 & 2 & 2 & 2 & 2 \\
\hline & $\%$ & 100,00 & 100,00 & 100,00 & 100,00 & 100,00 & 100,00 & 100,00 & 100,00 & 100,00 \\
\hline & média & 121,00 & 106,50 & 103,00 & 84,50 & 90,00 & 125,00 & 63,00 & 24,00 & 33,75 \\
\hline \multirow{3}{*}{ Índia - Sul } & $\mathrm{n}$ & 4 & 4 & 4 & 4 & 4 & 4 & 4 & 4 & 4 \\
\hline & $\%$ & 100,00 & 100,00 & 100,00 & 100,00 & 100,00 & 100,00 & 100,00 & 100,00 & 100,00 \\
\hline & média & 124,75 & 106,25 & 107,88 & 89,25 & 90,13 & 118,63 & 64,00 & 19,75 & 32,13 \\
\hline & $n$ & 2 & 2 & 2 & 2 & 2 & 2 & 2 & 2 & 2 \\
\hline Índia - Tamil & $\%$ & 100,00 & 100,00 & 100,00 & 100,00 & 100,00 & 100,00 & 100,00 & 100,00 & 100,00 \\
\hline & média & 123,50 & 102,50 & 109,00 & 89,00 & 92,50 & 125,50 & 57,00 & 22,00 & 32,00 \\
\hline & $n$ & 6 & 6 & 6 & 6 & 6 & 6 & 6 & 6 & 6 \\
\hline "don & $\%$ & 100,00 & 100,00 & 100,00 & 100,00 & 100,00 & 100,00 & 100,00 & 100,00 & 100,00 \\
\hline & média & 131,42 & 107,08 & 107,33 & 94,58 & 91,75 & 120,33 & 63,58 & 19,75 & 33,25 \\
\hline & $n$ & 6 & 6 & 6 & 6 & 5 & 5 & 5 & 6 & 6 \\
\hline Índia - Veddah & $\%$ & 100,00 & 100,00 & 100,00 & 100,00 & 83,33 & 83,33 & 83,33 & 100,00 & 100,00 \\
\hline & média & 127,58 & 106,00 & 109,00 & 91,17 & 88,80 & 115,00 & 58,40 & 19,17 & 32,83 \\
\hline & $\mathrm{n}$ & 12 & 13 & 13 & 12 & 12 & 12 & 13 & 13 & 13 \\
\hline Mielanesla - & $\%$ & 92,31 & 100,00 & 100,00 & 92,31 & 92,31 & 92,31 & 100,00 & 100,00 & 100,00 \\
\hline & média & 131,04 & 108,54 & 112,23 & 96,50 & 97,25 & 123,13 & 64,58 & 20,96 & 33,00 \\
\hline & $n$ & 4 & 4 & 4 & 4 & 4 & 3 & 4 & 4 & 4 \\
\hline Fiii & $\%$ & 80,00 & 80,00 & 80,00 & 80,00 & 80,00 & 60,00 & 80,00 & 80,00 & 80,00 \\
\hline & média & 130,50 & 110,50 & 114,00 & 96,50 & 101,25 & 120,50 & 65,75 & 21,00 & 34,38 \\
\hline & $\mathrm{n}$ & 24 & 24 & 24 & 24 & 24 & 22 & 24 & 24 & $\overline{24}$ \\
\hline Nova Rretanha & $\%$ & 100,00 & 100,00 & 100,00 & 100,00 & 100,00 & 91,67 & 100,00 & 100,00 & 100,00 \\
\hline & média & 128,42 & 104,88 & 113,15 & 94,04 & 100,29 & 126,66 & 62,33 & 21,71 & 32,77 \\
\hline Melanésia - & $\mathrm{n}$ & 11 & 11 & 11 & 11 & 10 & 9 & 10 & 11 & 11 \\
\hline & $\%$ & 100,00 & 100,00 & 100,00 & 100,00 & 90,91 & 81,82 & 90,91 & 100,00 & 100,00 \\
\hline Cale & média & 130,50 & 108,73 & 116,73 & 93,82 & 103,45 & 125,50 & 61,90 & 23,50 & 32,73 \\
\hline Melanésia - & $n$ & 28 & 29 & 29 & 28 & 22 & 25 & 22 & 29 & 29 \\
\hline $\mathrm{NNy}$ & $\%$ & 96,55 & 100,00 & 100,00 & 96,55 & 75,86 & 86,21 & 75,86 & 100,00 & 100,00 \\
\hline Hebrides" & média & 127,95 & 106,76 & 113,88 & 92,48 & 98,95 & "'-124,66 & 62,41 & 21,10 & 32,55 \\
\hline & $n$ & 24 & 24 & 24 & 23 & 24 & 21 & 24 & 24 & 24 \\
\hline Mela & $\%$ & 96,00 & 96,00 & 96,00 & 92,00 & 96,00 & 84,00 & 96,00 & 96,00 & 96,00 \\
\hline & média & 128,96 & 107,02 & 109,21 & 94,78 & 97,46 & 124,33 & 62,85 & 21,38 & 32,56 \\
\hline & $n$ & 2 & 2 & 2 & 2 & 2 & 1 & 2 & 2 & 2 \\
\hline Thanta Cruz- & $\%$ & 100,00 & 100,00 & 100,00 & 100,00 & 100,00 & 50,00 & 100,00 & 100,00 & 100,00 \\
\hline & média & 126,50 & 106,00 & 112,50 & 90,50 & 100,50 & "114,00 & 55,00 & 22,00 & 30,50 \\
\hline & $n$ & 28 & 31 & 30 & 29 & 25 & 27 & 26 & 30 & 31 \\
\hline Solomon & $\%$ & 90,32 & 100,00 & 96,77 & 93,55 & 80,65 & 87,10 & 83,87 & 96,77 & 100,00 \\
\hline & média & 130,13 & 106,74 & 110,77 & 94,33 & 97,86 & 125,09 & 61,87 & 20,33 & 32,89 \\
\hline & $n$ & 6 & 6 & 6 & 6 & 6 & 6 & 6 & 6 & 6 \\
\hline Ectroit & $\%$ & 100,00 & 100,00 & 100,00 & 100,00 & 100,00 & "'to0,00 & 100,00 & 100,00 & 100,00 \\
\hline & média & 128,58 & 107,17 & 105,75 & 95,83 & 105,08 & 123,83 & 65,42 & 22,25 & 33,50 \\
\hline & $\mathrm{n}$ & 11 & 11 & 11 & 11 & 11 & 11 & 11 & 11 & 11 \\
\hline lhas Carolina & $\%$ & 100,00 & 100,00 & 100,00 & 100,00 & 100,00 & 100,00 & 100,00 & 100,00 & 100,00 \\
\hline & média & 133,05 & 107,41 & 111,95 & 92,91 & 95,77 & 126,18 & 63,64 & 20,05 & 33,18 \\
\hline & $\mathrm{n}$ & 2 & 2 & 2 & 2 & 1 & 2 & $\overline{1}$ & 1 & $\overline{1}$ \\
\hline $\begin{array}{l}\text { IVIcronesta - } \\
\text { llhas Mariana }\end{array}$ & $\%$ & 100,00 & 100,00 & 100,00 & 100,00 & 50,00 & 100,00 & 50,00 & 50,00 & 50,00 \\
\hline & média & 136,00 & 109,00 & 107,50 & 94,00 & 90,00 & "' 129,00 & 72,00 & 20,00 & 38,00 \\
\hline
\end{tabular}




\begin{tabular}{|c|c|c|c|c|c|c|c|c|c|c|}
\hline \multirow{3}{*}{$\begin{array}{l}\text { Norte da África } \\
\text { - Egito } 1\end{array}$} & $n$ & 82 & 83 & 83 & 76 & 80 & 71 & 81 & 83 & 83 \\
\hline & $\%$ & 98,80 & 100,00 & 100,00 & 91,57 & 96,39 & 85,54 & 97,59 & 100,00 & 100,00 \\
\hline & média & 130,71 & 108,75 & 111,96 & 95,64 & 92,81 & 119,62 & 65,51 & 21,25 & 32,97 \\
\hline \multirow{3}{*}{$\begin{array}{l}\text { Norte da África } \\
\text { - Egito } 2\end{array}$} & $\mathrm{n}$ & 14 & 14 & 14 & 14 & 14 & 14 & 14 & 12 & 14 \\
\hline & $\%$ & 100,00 & 100,00 & 100,00 & 100,00 & 100,00 & 100,00 & 100,00 & 85,71 & 100,00 \\
\hline & média & 128,36 & 107,04 & 109,57 & 93,46 & 88,71 & 117,07 & 64,75 & 21,67 & 33,21 \\
\hline \multirow{3}{*}{$\begin{array}{c}\text { Norte da África } \\
\text { - Egito } 3\end{array}$} & $\mathrm{n}$ & 8 & 8 & 8 & 8 & 8 & 6 & 8 & 8 & 8 \\
\hline & $\%$ & 100,00 & 100,00 & 100,00 & 100,00 & 100,00 & 75,00 & 100,00 & 100,00 & 100,00 \\
\hline & média & 127,38 & 109,31 & 110,38 & 91,00 & 90,00 & 124,92 & 64,63 & 22,94 & 34,19 \\
\hline \multirow{3}{*}{$\begin{array}{l}\text { Nordeste } \\
\text { Asiático - } \\
\text { Amur }\end{array}$} & $\mathrm{n}$ & 1 & 1 & 0 & 0 & 1 & 0 & 1 & 1 & 1 \\
\hline & $\%$ & 100,00 & 100,00 & 0,00 & 0,00 & 100,00 & 0,00 & 100,00 & 100,00 & 100,00 \\
\hline & média & 125,00 & 103,00 & & & 84,00 & & 62,00 & 18,00 & 35,00 \\
\hline \multirow{3}{*}{$\begin{array}{l}\text { Nordeste } \\
\text { Asiático - } \\
\text { Buriat } \\
\end{array}$} & $\mathrm{n}$ & 12 & 12 & 12 & 12 & 11 & 11 & 11 & 12 & 12 \\
\hline & $\%$ & 100,00 & 100,00 & 100,00 & 100,00 & 91,67 & 91,67 & 91,67 & 100,00 & 100,00 \\
\hline & média & 125,92 & 108,25 & 104,58 & 95,00 & 93,45 & 134,18 & 71,09 & 20,75 & 35,29 \\
\hline \multirow{3}{*}{$\begin{array}{l}\text { Nordeste } \\
\text { Asiático - } \\
\text { Chukchi }\end{array}$} & $\mathrm{n}$ & 4 & 4 & 4 & 4 & 4 & 3 & 4 & 4 & 4 \\
\hline & $\%$ & 100,00 & 100,00 & 100,00 & 100,00 & 100,00 & 75,00 & 100,00 & 100,00 & 100,00 \\
\hline & média & 134,50 & 111,00 & 107,75 & 96,50 & 97,75 & 134,00 & 69,00 & 20,25 & 35,38 \\
\hline \multirow{3}{*}{$\begin{array}{l}\text { Nordeste } \\
\text { Asiático - } \\
\text { Mongóis }\end{array}$} & $\mathrm{n}$ & 63 & 64 & 64 & 64 & 61 & 55 & 62 & 64 & 64 \\
\hline & $\%$ & 96,92 & 98,46 & 98,46 & 98,46 & 93,85 & 84,62 & 95,38 & 98,46 & 98,46 \\
\hline & média & 125,70 & 108,13 & 106,20 & 92,70 & 92,68 & 131,53 & 68,51 & 20,56 & 35,11 \\
\hline \multirow{3}{*}{$\begin{array}{l}\text { Papua Nova Guiné } \\
\text { - Província Central }\end{array}$} & $\mathrm{n}$ & 3 & 4 & $\overline{4}$ & 4 & 3 & 3 & 3 & 4 & 4 \\
\hline & $\%$ & 75,00 & 100,00 & 100,00 & 100,00 & 75,00 & 75,00 & 75,00 & 100,00 & 100,00 \\
\hline & média & 130,33 & 107,50 & 112,00 & 92,50 & 102,00 & 127,67 & 63,00 & 21,75 & 33,50 \\
\hline \multirow{3}{*}{$\begin{array}{l}\text { Papua Nova Guiné } \\
\text { - Eastern Is }\end{array}$} & $\mathrm{n}$ & 4 & 5 & 5 & 5 & 4 & 4 & 5 & 5 & 5 \\
\hline & $\%$ & 80,00 & 100,00 & 100,00 & 100,00 & 80,00 & 80,00 & 100,00 & 100,00 & 100,00 \\
\hline & média & 125,25 & 107,60 & 107,00 & 91,80 & 95,25 & 126,75 & 64,00 & 20,20 & 33,20 \\
\hline & $n$ & 37 & 37 & 38 & 34 & 36 & 29 & 37 & 37 & 38 \\
\hline $\begin{array}{l}\text { Papua Nova Guiné } \\
\text { - Provincia do Golfo }\end{array}$ & $\%$ & 88,10 & 88,10 & 90,48 & 80,95 & 85,71 & 69,05 & 88,10 & 88,10 & 90,48 \\
\hline & média & 128,54 & 107,14 & 113,03 & 94,40 & 99,28 & 120,03 & 64,00 & 21,70 & 33,16 \\
\hline & $\mathrm{n}$ & 4 & 4 & 4 & 4 & 4 & 4 & 4 & 4 & 4 \\
\hline $\begin{array}{l}\text { ova Guiné } \\
\text { ia Madang }\end{array}$ & $\%$ & 100,00 & 100,00 & 100,00 & 100,00 & 100,00 & 100,00 & 100,00 & 100,00 & 100,00 \\
\hline & média & 126,38 & 101,75 & 110,63 & 91,75 & 98,25 & 121,13 & 61,75 & 21,50 & 31,63 \\
\hline iné & $\mathrm{n}$ & 4 & 4 & 4 & 4 & 4 & 4 & 4 & 4 & 4 \\
\hline - Provín & $\%$ & 100,00 & 100,00 & 100,00 & 100,00 & 100,00 & 100,00 & 100,00 & 100,00 & 100,00 \\
\hline & média & 129,50 & 104,75 & 108,25 & 96,50 & 96,75 & '"'-125,75 & 63,25 & 22,75 & 31,00 \\
\hline Guiné & $\mathrm{n}$ & 25 & 25 & 26 & 26 & 24 & 23 & 24 & 24 & 24 \\
\hline- & $\%$ & 92,59 & 92,59 & 96,30 & 96,30 & 88,89 & 85,19 & 88,89 & 88,89 & 88,89 \\
\hline & média & 128,92 & 106,62 & 112,94 & 92,38 & 97,94 & 121,46 & 61,21 & 21,35 & 32,31 \\
\hline Papua I & $\mathrm{n}$ & 33 & 33 & 33 & 33 & 33 & 33 & 33 & 33 & 33 \\
\hline - Pro & $\%$ & 100,00 & 100,00 & 100,00 & 100,00 & 100,00 & "'t" & 100,00 & 100,00 & 100,00 \\
\hline Oc & média & 129,98 & 106,48 & 109,26 & 92,32 & 99,42 & 124,52 & 61,65 & 21,61 & 32,08 \\
\hline Papua Nova & $\mathrm{n}$ & 7 & 7 & 7 & 7 & 8 & 6 & 8 & 8 & 8 \\
\hline Guiné - & $\%$ & 77,78 & 77,78 & 77,78 & 77,78 & 88,89 & 66,67 & 88,89 & 88,89 & 88,89 \\
\hline "desconhecido" & média & 129,00 & 105,00 & 108,57 & 91,43 & 97,00 & "' 124,00 & 62,13 & 20,50 & 33,25 \\
\hline Papua & $\bar{n}$ & 8 & 12 & 12 & 10 & 7 & 10 & 9 & 11 & 12 \\
\hline & $\%$ & 66,67 & 100,00 & 100,00 & 83,33 & 58,33 & 83,33 & 75,00 & 91,67 & 100,00 \\
\hline & média & 125,75 & 104,75 & 109,83 & 91,50 & 98,71 & 120,30 & 64,89 & 20,36 & 33,58 \\
\hline Polinésia - & $\mathrm{n}$ & 6 & 6 & 6 & 6 & 5 & 4 & 5 & 5 & 5 \\
\hline Morior & $\%$ & 100,00 & 100,00 & 100,00 & 100,00 & 83,33 & 66,67 & 83,33 & 83,33 & 83,33 \\
\hline Chatan) & média & 134,00 & 111,50 & 112,17 & 95,67 & 100,30 & 130,25 & 65,00 & 21,10 & 35,30 \\
\hline & $n$ & 3 & 4 & 4 & 3 & 2 & 2 & 3 & 4 & 4 \\
\hline $1 \mathrm{a}-$ & $\%$ & 75,00 & 100,00 & 100,00 & 75,00 & 50,00 & 50,00 & 75,00 & 100,00 & 100,00 \\
\hline & média & 137,33 & 110,00 & 113,25 & 96,67 & 98,00 & 131,00 & 63,67 & 21,00 & 32,00 \\
\hline & $\mathrm{n}$ & 30 & 31 & 31 & 29 & 25 & 23 & 26 & 31 & 31 \\
\hline rolin & $\%$ & 76,92 & 79,49 & 79,49 & 74,36 & 64,10 & 58,97 & 66,67 & 79,49 & 79,49 \\
\hline & média & 136,57 & 111,16 & 110,39 & 96,45 & 100,44 & 125,43 & 62,15 & 22,19 & 33,87 \\
\hline Polinésia - & $\mathrm{n}$ & 20 & 20 & 20 & 20 & 20 & 20 & 20 & 20 & 20 \\
\hline & $\%$ & 100,00 & 100,00 & 100,00 & 100,00 & 100,00 & 100,00 & 100,00 & 100,00 & 100,00 \\
\hline Marquesas & média & 134,05 & 112,43 & 105,38 & 99,10 & 98,15 & "' & 64,45 & 19,43 & 34,20 \\
\hline Polinésia - & $\bar{n}$ & 22 & 22 & 22 & 22 & 22 & 20 & 22 & 22 & 22 \\
\hline ova & $\%$ & 95,65 & 95,65 & 95,65 & 95,65 & 95,65 & 86,96 & 95,65 & 95,65 & 95,65 \\
\hline Zelândia & média & 132,20 & 111,32 & 109,27 & 98,66 & 97,84 & "'t"' & 62,41 & 19,48 & 34,23 \\
\hline & $\mathrm{n}$ & A & 4 & 1 & $\overline{1}$ & 1 & 1 & 1 & 1 & 1 \\
\hline rollin & $\%$ & 100,00 & 100,00 & 100,00 & 100,00 & 100,00 & "'t" & 100,00 & 100,00 & 100,00 \\
\hline & média & 130,00 & 107,00 & 103,50 & 98,50 & 97,00 & 126,00 & 60,50 & 21,00 & 33,00 \\
\hline Sudeste & $\mathrm{n}$ & 22 & 22 & 22 & 23 & 20 & 22 & 20 & 22 & 22 \\
\hline Asiático - Ilhas & $\%$ & 91,67 & 91,67 & 91,67 & 95,83 & 83,33 & 91,67 & 83,33 & 91,67 & 91,67 \\
\hline Andaman & média & 123,64 & 102,91 & 102,55 & 89,48 & 90,05 & "' & 57,05 & 21,68 & 32,73 \\
\hline & $\mathrm{n}$ & 5 & 5 & 5 & 5 & 5 & 4 & 5 & 4 & 5 \\
\hline
\end{tabular}




\begin{tabular}{|c|c|c|c|c|c|c|c|c|c|c|}
\hline \multirow{3}{*}{$\begin{array}{c}\text { Sudeste } \\
\text { Asiático - }\end{array}$} & $n$ & 5 & 5 & 5 & 5 & 5 & 4 & 5 & 4 & 5 \\
\hline & $\%$ & 100,00 & 100,00 & 100,00 & 100,00 & 100,00 & 80,00 & 100,00 & 80,00 & 100,00 \\
\hline & meara & 128,00 & 106,20 & 106,00 & 92,00 & 94,20 & 119,75 & 60,60 & 20,50 & 30,80 \\
\hline \multirow{3}{*}{$\begin{array}{l}\text { Boretested } \\
\text { Asiático - } \\
\text { Borneo } 2\end{array}$} & $n$ & 5 & 5 & 5 & 5 & 4 & 4 & 5 & 5 & 5 \\
\hline & $\%$ & 100,00 & 100,00 & 100,00 & 100,00 & 80,00 & 80,00 & 100,00 & 100,00 & 100,00 \\
\hline & média & 131,00 & 107,60 & 112,40 & 94,60 & 95,25 & 124,50 & 61,20 & 21,00 & 32,40 \\
\hline \multirow{3}{*}{$\begin{array}{l}\text { Sudeste } \\
\text { Asiático - } \\
\text { Celebes }\end{array}$} & $\mathrm{n}$ & 2 & 2 & 2 & 2 & $\overline{1}$ & $\overline{2}$ & 1 & 2 & 2 \\
\hline & $\%$ & 100,00 & 100,00 & 100,00 & 100,00 & 50,00 & 100,00 & 50,00 & 100,00 & 100,00 \\
\hline & média & 132,50 & 113,00 & 109,50 & 93,00 & 92,00 & $" 125,50$ & 64,00 & 21,50 & 34,00 \\
\hline \multirow{3}{*}{$\begin{array}{c}\text { Sudeste } \\
\text { Asiático - Java }\end{array}$} & $n$ & 8 & 8 & 8 & 8 & 7 & 7 & 7 & 7 & 8 \\
\hline & $\%$ & 100,00 & 100,00 & 100,00 & 100,00 & 87,50 & 87,50 & 87,50 & 87,50 & 100,00 \\
\hline & média & 130,00 & 106,13 & 104,88 & 95,38 & 96,29 & 125,29 & 62,14 & 20,86 & 34,13 \\
\hline \multirow{3}{*}{$\begin{array}{l}\text { Sudeste } \\
\text { Asiático - } \\
\text { Malásia }\end{array}$} & $\mathrm{n}$ & 4 & 5 & 4 & 4 & 3 & 2 & 3 & 3 & 4 \\
\hline & $\%$ & 80,00 & 100,00 & 80,00 & 80,00 & 60,00 & 40,00 & 60,00 & 60,00 & 80,00 \\
\hline & média & 128,50 & 105,80 & 104,00 & 95,50 & 95,00 & 126,00 & 62,67 & 20,67 & 33,00 \\
\hline \multirow{3}{*}{$\begin{array}{l}\text { Sudeste } \\
\text { Asiático - } \\
\text { Molucca }\end{array}$} & $n$ & 5 & 5 & 5 & 5 & 4 & 5 & 4 & 4 & 5 \\
\hline & $\%$ & 100,00 & 100,00 & 100,00 & 100,00 & 80,00 & 100,00 & 80,00 & 80,00 & 100,00 \\
\hline & média & 125,00 & 106,00 & 102,80 & 95,20 & 94,50 & 120,20 & 62,75 & 20,00 & 32,70 \\
\hline \multirow{3}{*}{$\begin{array}{c}\text { Sudeste } \\
\text { Asiático - } \\
\text { Myanmar } \\
\end{array}$} & $\mathrm{n}$ & 3 & 3 & 3 & 3 & $\overline{3}$ & $\overline{3}$ & 3 & 3 & 3 \\
\hline & $\%$ & 100,00 & 100,00 & 100,00 & 100,00 & 100,00 & 100,00 & 100,00 & 100,00 & 100,00 \\
\hline & média & 127,33 & 106,00 & 110,00 & 91,33 & 91,67 & 126,67 & 64,67 & 23,00 & 33,33 \\
\hline \multirow{3}{*}{$\begin{array}{c}\text { Sudeste } \\
\text { Asiático - } \\
\text { Filipinas } \\
\text { (negrito) }\end{array}$} & $\mathrm{n}$ & 8 & 9 & 8 & 8 & 8 & 9 & 9 & 9 & 9 \\
\hline & $\%$ & 88,89 & 100,00 & 88,89 & 88,89 & 88,89 & 100,00 & 100,00 & 100,00 & 100,00 \\
\hline & média & 122,00 & 103,33 & 101,25 & 87,00 & 88,13 & 120,00 & 59,06 & 20,56 & 33,11 \\
\hline \multirow{3}{*}{$\begin{array}{l}\text { Sudeste } \\
\text { Asiático - Is } \\
\text { Nicobar }\end{array}$} & $n$ & 2 & 2 & 2 & 2 & $\overline{2}$ & 2 & 2 & 2 & 2 \\
\hline & $\%$ & 100,00 & 100,00 & 100,00 & 100,00 & 100,00 & 100,00 & 100,00 & 100,00 & 100,00 \\
\hline & média & 130,00 & 109,50 & 112,50 & 96,50 & 102,00 & 122,00 & 61,50 & 23,00 & 30,50 \\
\hline Sudeste & $\mathrm{n}$ & 38 & 38 & 37 & 36 & 36 & 35 & 37 & 38 & 38 \\
\hline Asiático - & $\%$ & 100,00 & 100,00 & 97,37 & 94,74 & 94,74 & 92,11 & 97,37 & 100,00 & 100,00 \\
\hline Filipinas & média & 128,67 & 106,30 & 107,66 & 93,75 & 91,46 & 123,36 & 62,78 & 21,26 & 33,63 \\
\hline Sudeste & $\mathrm{n}$ & 15 & 15 & 15 & 15 & 15 & 15 & 15 & 15 & 15 \\
\hline Asiático - & $\%$ & 100,00 & 100,00 & 100,00 & 100,00 & 100,00 & 100,00 & 100,00 & 100,00 & 100,00 \\
\hline Singapura & média & 131,37 & 109,73 & 105,80 & 95,10 & 93,57 & 126,33 & 63,70 & 20,60 & 33,23 \\
\hline & $\mathrm{n}$ & 3 & 3 & 3 & 3 & 2 & 3 & 2 & 3 & 3 \\
\hline suc & $\%$ & 100,00 & 100,00 & 100,00 & 100,00 & 66,67 & 100,00 & 66,67 & 100,00 & 100,00 \\
\hline Astal & média & 127,33 & 108,00 & 111,00 & 98,67 & 95,50 & 117,00 & 63,50 & 18,00 & 34,00 \\
\hline Sudeste & $\mathrm{n}$ & 3 & 3 & 3 & 3 & $\overline{3}$ & $\overline{3}$ & 2 & 3 & 3 \\
\hline Asiático - & $\%$ & 100,00 & 100,00 & 100,00 & 100,00 & 100,00 & 100,00 & 66,67 & 100,00 & 100,00 \\
\hline Sumatra & média & 127,00 & 107,00 & 104,67 & 100,67 & 92,67 & 122,67 & 62,00 & 21,00 & 31,00 \\
\hline Sudeste & $n$ & 11 & 11 & 10 & 10 & 11 & 11 & 11 & 11 & 11 \\
\hline Asiático - & $\%$ & 100,00 & 100,00 & 90,91 & 90,91 & 100,00 & 100,00 & 100,00 & 100,00 & 100,00 \\
\hline Tailândia & média & 130,36 & 107,18 & 105,05 & 94,00 & 92,27 & 123,68 & 61,45 & 20,18 & 32,00 \\
\hline Sudeste & $\mathrm{n}$ & 2 & 2 & 2 & 2 & 2 & 2 & 2 & 2 & 2 \\
\hline Asiático - & $\%$ & 100,00 & 100,00 & 100,00 & 100,00 & 100,00 & 100,00 & 100,00 & 100,00 & 100,00 \\
\hline Timor & média & 127,00 & 110,00 & 105,00 & 93,00 & 100,00 & 122,00 & 64,00 & 19,50 & 33,50 \\
\hline África Sub- & $\mathrm{n}$ & 16 & 16 & 16 & 15 & 16 & 16 & 16 & 16 & 16 \\
\hline Saariana - & $\%$ & 100,00 & 100,00 & 100,00 & 93,75 & 100,00 & 100,00 & 100,00 & 100,00 & 100,00 \\
\hline Camarões & média & 130,50 & 110,63 & 111,41 & 93,57 & 98,03 & 127,66 & 64,19 & 23,44 & 35,00 \\
\hline África Sub- & $\mathrm{n}$ & 3 & 3 & 3 & 3 & 3 & 3 & 3 & 3 & 3 \\
\hline Saariana - & $\%$ & 100,00 & 100,00 & 100,00 & 100,00 & 100,00 & 100,00 & 100,00 & 100,00 & 100,00 \\
\hline Congo & média & 133,67 & 110,00 & 110,33 & 95,00 & 99,17 & "125,83 & 64,33 & 23,17 & 35,67 \\
\hline África Sub- & $n$ & 1 & 1 & 1 & 1 & $\overline{1}$ & $\overline{1}$ & 1 & 1 & 1 \\
\hline Saariana - & $\%$ & 100,00 & 100,00 & 100,00 & 100,00 & 100,00 & $" 100,00$ & 100,00 & 100,00 & 100,00 \\
\hline Etiópia & média & 141,00 & 117,00 & 123,00 & 101,00 & 92,00 & 119,00 & 68,00 & 20,00 & 32,00 \\
\hline África Sub- & $\mathrm{n}$ & 5 & 5 & 5 & 5 & 5 & $\overline{4}$ & 5 & 5 & 5 \\
\hline Saariana - & $\%$ & 100,00 & 100,00 & 100,00 & 100,00 & 100,00 & 80,00 & 100,00 & 100,00 & 100,00 \\
\hline Gabão & média & 127,80 & 106,60 & 105,00 & 95,50 & 96,60 & 119,25 & 61,20 & 22,20 & 32,50 \\
\hline África Sub- & $\mathrm{n}$ & 40 & 40 & 40 & 40 & 39 & 39 & 40 & 40 & 40 \\
\hline Saariana - & $\%$ & 100,00 & 100,00 & 100,00 & 100,00 & 97,50 & 97,50 & 100,00 & 100,00 & 100,00 \\
\hline Ashanti Gana & média & 130,20 & 106,36 & 112,15 & 93,40 & 99,58 & 120,83 & 61,93 & 22,93 & 32,90 \\
\hline África Sub- & $n$ & 29 & 29 & 29 & 29 & 28 & 23 & 29 & 29 & 29 \\
\hline Saariana - & $\%$ & 100,00 & 100,00 & 100,00 & 100,00 & 96,55 & 79,31 & 100,00 & 100,00 & 100,00 \\
\hline Quênia & média & 124,93 & 107,79 & 108,83 & 90,55 & 98,46 & 122,41 & 62,29 & 24,24 & 33,14 \\
\hline África Sub- & $\mathrm{n}$ & 4 & 5 & 5 & 4 & 4 & 5 & 5 & 5 & 5 \\
\hline Saariana - & $\%$ & 80,00 & 100,00 & 100,00 & 80,00 & 80,00 & $" 100,00$ & 100,00 & 100,00 & 100,00 \\
\hline Libéria & média & 133,50 & 105,90 & 113,80 & 93,38 & 100,38 & 126,90 & 61,40 & 24,40 & 33,70 \\
\hline África Sub- & $\mathrm{n}$ & 1 & 1 & 1 & 1 & 1 & 1 & 1 & 1 & 1 \\
\hline Saariana - & $\%$ & 100,00 & 100,00 & 100,00 & 100,00 & 100,00 & 100,00 & 100,00 & 100,00 & 100,00 \\
\hline Moçambique & média & 130,50 & 106,00 & 105,50 & 86,50 & 95,00 & 132,00 & 64,00 & 25,00 & 35,00 \\
\hline & $n$ & 24 & 24 & 24 & 24 & 23 & 24 & 24 & 24 & 24 \\
\hline
\end{tabular}




\begin{tabular}{|c|c|c|c|c|c|c|c|c|c|c|}
\hline \multirow[b]{2}{*}{$\begin{array}{c}\text { África Sub- } \\
\text { Saariana - lbo }\end{array}$} & $\mathrm{n}$ & 24 & 24 & 24 & 24 & 23 & 24 & 24 & 24 & 24 \\
\hline & média & $\begin{array}{l}100,00 \\
130,67\end{array}$ & $\begin{array}{l}100,00 \\
109,42\end{array}$ & $\begin{array}{l}100,00 \\
111,21\end{array}$ & $\begin{array}{r}100,00 \\
92,29\end{array}$ & $\begin{array}{l}95,83 \\
96,65\end{array}$ & $\begin{array}{l}100,00 \\
126,88\end{array}$ & $\begin{array}{r}100,00 \\
62,58 \\
\end{array}$ & $\begin{array}{r}100,00 \\
24,46\end{array}$ & $\begin{array}{r}100,00 \\
34,17\end{array}$ \\
\hline \multirow{3}{*}{$\begin{array}{c}\text { Áfkilogé8ab- } \\
\text { Saariana - } \\
\text { Nigéria } \\
\text { (outros) }\end{array}$} & $n$ & 1 & 1 & 1 & 1 & 1 & 1 & 1 & 1 & 1 \\
\hline & $\%$ & 100,00 & 100,00 & 100,00 & 100,00 & 100,00 & 100,00 & 100,00 & 100,00 & 100,00 \\
\hline & média & 135,00 & 108,00 & 116,00 & 103,00 & 96,00 & 120,00 & 66,00 & 24,00 & 35,00 \\
\hline \multirow{3}{*}{$\begin{array}{l}\text { África Sub- } \\
\text { Saariana - } \\
\text { Ruanda }\end{array}$} & $\mathrm{n}$ & 1 & 1 & 1 & 1 & 1 & 1 & 1 & 1 & 1 \\
\hline & $\%$ & 100,00 & 100,00 & 100,00 & 100,00 & 100,00 & 100,00 & 100,00 & 100,00 & 100,00 \\
\hline & média & 127,00 & 106,00 & 123,50 & 95,00 & 102,00 & 130,00 & 60,50 & 25,00 & 32,00 \\
\hline \multirow{3}{*}{$\begin{array}{l}\text { África Sub- } \\
\text { Saariana - } \\
\text { Somália }\end{array}$} & $n$ & 3 & 3 & 3 & 3 & 3 & 3 & 3 & 3 & 3 \\
\hline & $\%$ & 100,00 & 100,00 & 100,00 & 100,00 & 100,00 & 100,00 & 100,00 & 100,00 & 100,00 \\
\hline & média & 131,00 & 108,67 & 109,67 & 92,67 & 94,00 & "121,33 & 57,00 & 23,00 & 32,67 \\
\hline \multirow{3}{*}{$\begin{array}{c}\text { África Sub- } \\
\text { Saariana - } \\
\text { África do Sul }\end{array}$} & $\mathrm{n}$ & 8 & 8 & 8 & 8 & 8 & 8 & 8 & 8 & 8 \\
\hline & $\%$ & 100,00 & 100,00 & 100,00 & 100,00 & 100,00 & 100,00 & 100,00 & 100,00 & 100,00 \\
\hline & média & 127,25 & 109,69 & 113,19 & 91,38 & 96,50 & 122,88 & 62,31 & 23,94 & 32,63 \\
\hline \multirow{3}{*}{$\begin{array}{l}\text { África Sub- } \\
\text { Saariana - } \\
\text { Bushman } \\
\text { África do Sul }\end{array}$} & $\mathrm{n}$ & 5 & 5 & 5 & 5 & 5 & 5 & 5 & 4 & 5 \\
\hline & $\%$ & 100,00 & 100,00 & 100,00 & 100,00 & 100,00 & 100,00 & 100,00 & 80,00 & 100,00 \\
\hline & média & 122,80 & 109,30 & 107,00 & 86,40 & 91,00 & 118,50 & 60,70 & 22,38 & 30,20 \\
\hline \multirow{3}{*}{$\begin{array}{c}\text { África Sub- } \\
\text { Saariana - } \\
\text { Hottentot } \\
\text { África do Sul }\end{array}$} & $\mathrm{n}$ & 1 & 1 & 1 & 1 & 1 & 1 & 1 & 1 & 1 \\
\hline & $\%$ & 100,00 & 100,00 & 100,00 & 100,00 & 100,00 & 100,00 & 100,00 & 100,00 & 100,00 \\
\hline & média & 133,00 & 109,00 & 115,00 & 93,00 & 103,00 & 117,00 & 64,00 & 22,00 & 35,00 \\
\hline \multirow{3}{*}{$\begin{array}{c}\text { África Sub- } \\
\text { Saariana - } \\
\text { Kafir África do } \\
\text { Sul }\end{array}$} & $n$ & 1 & 1 & 1 & 1 & 1 & 1 & 1 & 1 & 1 \\
\hline & $\%$ & 100,00 & 100,00 & 100,00 & 100,00 & 100,00 & 100,00 & 100,00 & 100,00 & 100,00 \\
\hline & média & 126,00 & 116,00 & 116,00 & 86,00 & 92,00 & 122,00 & 53,00 & 25,00 & 32,00 \\
\hline \multirow{3}{*}{$\begin{array}{l}\text { África Sub- } \\
\text { Saariana - } \\
\text { Zulu }\end{array}$} & $n$ & 1 & 1 & 1 & 1 & 1 & 1 & 1 & 1 & 1 \\
\hline & $\%$ & 100,00 & 100,00 & 100,00 & 100,00 & 100,00 & 100,00 & 100,00 & 100,00 & 100,00 \\
\hline & média & 124,00 & 105,50 & 125,00 & 81,00 & 94,00 & 126,00 & 65,00 & 31,00 & 34,50 \\
\hline \multirow{3}{*}{$\begin{array}{c}\text { África Sub- } \\
\text { Saariana - } \\
\text { Tanzânia } \\
\end{array}$} & $\mathrm{n}$ & 26 & 27 & 27 & 26 & 26 & 24 & 27 & 27 & 27 \\
\hline & $\%$ & 96,30 & 100,00 & 100,00 & 96,30 & 96,30 & 88,89 & 100,00 & 100,00 & 100,00 \\
\hline & média & 125,98 & 107,81 & 108,80 & 91,92 & 98,31 & 124,42 & 63,31 & 23,09 & 33,31 \\
\hline \multirow{3}{*}{$\begin{array}{l}\text { África Sub- } \\
\text { Saariana - } \\
\text { África } \\
\text { Ocidental } \\
\end{array}$} & $\mathrm{n}$ & 4 & 4 & 4 & 4 & 4 & 4 & 4 & 4 & 4 \\
\hline & $\%$ & 100,00 & 100,00 & 100,00 & 100,00 & 100,00 & 100,00 & 100,00 & 100,00 & 100,00 \\
\hline & média & 123,63 & 100,00 & 105,75 & 90,88 & 94,00 & 119,00 & 62,75 & 21,13 & 33,63 \\
\hline & $n$ & 1 & 1 & 1 & 1 & 1 & 1 & 1 & 1 & 1 \\
\hline Saariana - & $\%$ & 100,00 & 100,00 & 100,00 & 100,00 & 100,00 & 100,00 & 100,00 & 100,00 & 100,00 \\
\hline & média & 131,00 & 113,00 & 108,00 & 90,00 & 100,00 & 122,00 & 74,00 & 21,00 & 36,00 \\
\hline Sudoeste & $\mathrm{n}$ & 8 & 8 & 8 & 8 & 8 & 7 & 8 & 8 & 8 \\
\hline Asiático - & $\%$ & 100,00 & 100,00 & 100,00 & 100,00 & 100,00 & 87,50 & 100,00 & 100,00 & 100,00 \\
\hline Beduíno & média & 126,63 & 107,06 & 108,13 & 90,94 & 93,38 & 122,21 & 65,06 & 21,31 & 33,25 \\
\hline Sudoeste & $\mathrm{n}$ & 4 & 4 & 4 & 4 & 4 & 4 & 4 & 4 & 4 \\
\hline Asiático - & $\%$ & 100,00 & 100,00 & 100,00 & 100,00 & 100,00 & "' 100,00 & 100,00 & 100,00 & 100,00 \\
\hline Iraque & média & 134,50 & 110,50 & 112,00 & 95,13 & 92,88 & 119,25 & 64,13 & 21,13 & 32,38 \\
\hline Sudoeste & $n$ & 7 & 7 & 6 & 6 & 7 & 5 & 7 & 7 & 7 \\
\hline Asiático - & $\%$ & 100,00 & 100,00 & 85,71 & 85,71 & 100,00 & 71,43 & 100,00 & 100,00 & 100,00 \\
\hline Iraque (early) & média & 130,50 & 108,36 & 110,25 & 94,58 & 94,50 & 119,50 & 65,29 & 20,43 & 33,07 \\
\hline Sudoeste & $n$ & 1 & 1 & 1 & 1 & 1 & 1 & 1 & 1 & 1 \\
\hline Asiático - & $\%$ & 100,00 & 100,00 & 100,00 & 100,00 & 100,00 & 100,00 & 100,00 & 100,00 & 100,00 \\
\hline Líbano & média & 135,00 & 106,00 & 112,50 & 97,50 & 96,50 & 120,00 & 66,00 & 21,00 & 32,00 \\
\hline Sudoeste & $\mathrm{n}$ & 5 & 5 & 5 & 5 & 5 & 5 & 5 & 5 & 5 \\
\hline Asiático - & $\%$ & 100,00 & 100,00 & 100,00 & 100,00 & 100,00 & 100,00 & 100,00 & 100,00 & 100,00 \\
\hline Palestina & média & 133,30 & 109,40 & 107,20 & 95,00 & 90,40 & "'t25,50 & 65,30 & 21,00 & 32,60 \\
\hline & $n$ & 5 & 5 & 5 & 5 & 5 & 5 & 5 & 5 & 5 \\
\hline Síria & $\%$ & 100,00 & 100,00 & 100,00 & 100,00 & 100,00 & 100,00 & 100,00 & 100,00 & 100,00 \\
\hline & média & 126,00 & 106,40 & 105,50 & 90,50 & 88,80 & 118,80 & 64,00 & 19,60 & 33,60 \\
\hline Sudoeste & $\mathrm{n}$ & 17 & 17 & 17 & 17 & 17 & 17 & 17 & 17 & 17 \\
\hline Asiático - & $\%$ & 100,00 & 100,00 & 100,00 & 100,00 & 100,00 & 100,00 & 100,00 & 100,00 & 100,00 \\
\hline Turquia & média & 126,24 & 107,24 & 107,62 & 93,15 & 93,82 & 122,94 & 66,03 & 21,26 & 33,82 \\
\hline & $n$ & 5 & 5 & 5 & 5 & 5 & 5 & 5 & 5 & 5 \\
\hline dbury & $\%$ & 100,00 & 100,00 & 100,00 & 100,00 & 100,00 & 100,00 & 100,00 & 100,00 & 100,00 \\
\hline & média & 124,60 & 106,00 & 110,60 & 94,00 & 89,60 & 125,20 & 67,60 & 20,80 & 34,80 \\
\hline Grã-Bretanha & $\mathrm{n}$ & 15 & 15 & 15 & 16 & 15 & 16 & 16 & 16 & 16 \\
\hline - Spitafields & $\%$ & 93,75 & 93,75 & 93,75 & 100,00 & 93,75 & 100,00 & 100,00 & 100,00 & 100,00 \\
\hline CAM & média & 126,67 & 105,67 & 105,13 & 93,81 & 92,13 & 122,69 & 61,75 & 22,00 & 32,16 \\
\hline Grã-Bretanha & $\mathrm{n}$ & 86 & 87 & 86 & 85 & 68 & 74 & 71 & 84 & 86 \\
\hline - Spitafields & $\%$ & 97,73 & 98,86 & 97,73 & 96,59 & 77,27 & 84,09 & 80,68 & 95,45 & 97,73 \\
\hline $\mathrm{NHM}$ & média & 123,48 & 108,56 & 108,80 & 93,92 & 88,32 & (119,03' & 64,01 & 20,15 & 34,13 \\
\hline
\end{tabular}




\begin{tabular}{|c|c|c|c|c|c|c|c|c|c|c|}
\hline \multirow{3}{*}{$\begin{array}{l}\text { EUA - } \\
\text { Alabama }\end{array}$} & $n$ & 6 & 7 & 7 & 7 & 5 & 6 & 6 & 7 & 7 \\
\hline & $\%$ & 85,71 & 100,00 & 100,00 & 100,00 & 71,43 & 85,71 & 85,71 & 100,00 & 100,00 \\
\hline & média & 135,00 & 107,50 & 103,14 & 95,14 & 95,50 & 127,25 & 69,00 & 21,14 & 35,21 \\
\hline \multirow{3}{*}{$\begin{array}{c}\text { EUA - nativos } \\
\text { do Alaska }\end{array}$} & $n$ & 28 & 28 & 28 & 28 & 28 & 24 & 28 & 28 & 28 \\
\hline & $\%$ & 96,55 & 96,55 & 96,55 & 96,55 & 96,55 & 82,76 & 96,55 & 96,55 & 96,55 \\
\hline & média & 131,71 & 108,64 & 106,66 & 94,36 & 95,71 & 129,67 & 69,80 & 21,57 & 35,63 \\
\hline \multirow{3}{*}{$\begin{array}{c}\text { EUA - Alaska } \\
\text { (Kodiak) }\end{array}$} & $n$ & 14 & 14 & 14 & 14 & 13 & 8 & 13 & 14 & 14 \\
\hline & $\%$ & 100,00 & 100,00 & 100,00 & 100,00 & 92,86 & 57,14 & 92,86 & 100,00 & 100,00 \\
\hline & média & 127,93 & 109,32 & 99,54 & 93,21 & 95,85 & 131,63 & 69,69 & 20,54 & 36,21 \\
\hline \multirow{3}{*}{$\begin{array}{c}\text { EUA - Alaska } \\
\text { (Tlingit) }\end{array}$} & $\mathrm{n}$ & 11 & 11 & 11 & 11 & 11 & 10 & 11 & 11 & 11 \\
\hline & $\%$ & 100,00 & 100,00 & 100,00 & 100,00 & 100,00 & 90,91 & 100,00 & 100,00 & 100,00 \\
\hline & média & 129,09 & 108,41 & 102,55 & 96,09 & 94,82 & 132,60 & 67,18 & 21,00 & 35,55 \\
\hline \multirow{3}{*}{ EUA - Arizona } & $\mathrm{n}$ & 1 & 0 & 1 & 1 & 1 & 0 & 0 & 1 & 1 \\
\hline & $\%$ & 100,00 & 0,00 & 100,00 & 100,00 & 100,00 & 0,00 & 0,00 & 100,00 & 100,00 \\
\hline & média & 127,00 & & 109,00 & 97,00 & 84,00 & & & 20,00 & 28,00 \\
\hline \multirow{3}{*}{$\begin{array}{c}\text { EUA - } \\
\text { Arkansas }\end{array}$} & $n$ & 35 & 35 & 35 & 32 & 35 & 31 & 35 & 35 & 35 \\
\hline & $\%$ & 100,00 & 100,00 & 100,00 & 91,43 & 100,00 & 88,57 & 100,00 & 100,00 & 100,00 \\
\hline & média & 129,07 & 106,16 & 105,47 & 94,09 & 94,20 & 128,76 & 65,76 & 21,99 & 34,03 \\
\hline \multirow{3}{*}{$\begin{array}{c}\text { EUA - } \\
\text { Califórnia } 1\end{array}$} & $n$ & 12 & 12 & 12 & 11 & 12 & 11 & 12 & 11 & 12 \\
\hline & $\%$ & 100,00 & 100,00 & 100,00 & 91,67 & 100,00 & 91,67 & 100,00 & 91,67 & 100,00 \\
\hline & média & 135,83 & 108,54 & 105,79 & 94,05 & 96,75 & 126,59 & 68,67 & 20,09 & 35,13 \\
\hline \multirow{3}{*}{$\begin{array}{c}\text { EUA - } \\
\text { Califórnia } 2\end{array}$} & $n$ & 47 & 50 & 50 & 49 & 44 & 47 & 48 & 50 & 50 \\
\hline & $\%$ & 94,00 & 100,00 & 100,00 & 98,00 & 88,00 & 94,00 & 96,00 & 100,00 & 100,00 \\
\hline & média & 134,27 & 108,09 & 106,63 & 100,42 & 96,39 & 130,03 & 64,80 & 22,12 & 34,04 \\
\hline \multirow{3}{*}{$\begin{array}{c}\text { EUA - } \\
\text { Carolina do } \\
\text { Norte }\end{array}$} & $n$ & 155 & 156 & 156 & 151 & 153 & 137 & 153 & 156 & 156 \\
\hline & $\%$ & 99,36 & 100,00 & 100,00 & 96,79 & 98,08 & 87,82 & 98,08 & 100,00 & 100,00 \\
\hline & média & 124,79 & 106,01 & 103,19 & 95,48 & 95,37 & 127,28 & 64,63 & 20,65 & 34,02 \\
\hline & $\mathrm{n}$ & 1 & 1 & 1 & $\overline{1}$ & 1 & 1 & 1 & 1 & 1 \\
\hline EUA & $\%$ & 100,00 & 100,00 & 100,00 & 100,00 & 100,00 & 100,00 & 100,00 & 100,00 & 100,00 \\
\hline & média & 142,00 & 115,00 & 108,00 & 108,00 & 97,00 & 131,00 & 71,00 & 20,00 & 36,00 \\
\hline & $n$ & 2 & 2 & 2 & 2 & 2 & 2 & 2 & 2 & 2 \\
\hline$E U A$ & $\%$ & 100,00 & 100,00 & 100,00 & 100,00 & 100,00 & 100,00 & 100,00 & 100,00 & 100,00 \\
\hline & média & 129,00 & 105,50 & 105,50 & 90,00 & 93,50 & 130,50 & 65,00 & 23,00 & 35,00 \\
\hline & $n$ & 11 & 11 & 11 & 11 & 11 & 10 & 11 & 10 & 11 \\
\hline EUA - Dak & $\%$ & 100,00 & 100,00 & 100,00 & 100,00 & 100,00 & 90,91 & 100,00 & 90,91 & 100,00 \\
\hline & média & 127,50 & 109,95 & 105,68 & 92,36 & 96,00 & "'t"'t32,60" & 69,00 & 20,75 & 35,05 \\
\hline & $\mathrm{n}$ & 76 & 76 & 76 & 76 & 75 & 74 & 75 & 76 & 76 \\
\hline Delaware & $\%$ & 100,00 & 100,00 & 100,00 & 100,00 & 98,68 & 97,37 & 98,68 & 100,00 & 100,00 \\
\hline & média & 127,96 & 107,45 & 104,03 & 91,84 & 95,34 & 129,79 & 68,59 & 20,77 & 34,78 \\
\hline & $n$ & 10 & 10 & 10 & 9 & 9 & 5 & 9 & 9 & 10 \\
\hline EUA - Flórida & $\%$ & 100,00 & 100,00 & 100,00 & 90,00 & 90,00 & 50,00 & 90,00 & 90,00 & 100,00 \\
\hline & média & 136,80 & 112,90 & 110,70 & 98,17 & 98,39 & 130,00 & 66,67 & 21,06 & 34,10 \\
\hline & $\mathrm{n}$ & 62 & 62 & 62 & 61 & 57 & 47 & 59 & 62 & 62 \\
\hline EUA - Geórgia & $\%$ & 100,00 & 100,00 & 100,00 & 98,39 & 91,94 & 75,81 & 95,16 & 100,00 & 100,00 \\
\hline & média & 136,43 & 111,78 & 104,40 & 100,61 & 98,68 & "'t34,76 & 68,73 & 22,26 & 34,82 \\
\hline & $\mathrm{n}$ & 8 & 10 & 10 & $\overline{8}$ & 8 & 7 & 10 & 9 & 10 \\
\hline She & $\%$ & 80,00 & 100,00 & 100,00 & 80,00 & 80,00 & 70,00 & 100,00 & 90,00 & 100,00 \\
\hline & média & 130,81 & 107,20 & 105,05 & 96,63 & 95,13 & 128,64 & 65,85 & 21,94 & 34,45 \\
\hline & $\mathrm{n}$ & 0 & 0 & 1 & 0 & 0 & 0 & 0 & 0 & 0 \\
\hline EUA - Illinois & $\%$ & 0,00 & 0,00 & 100,00 & 0,00 & 0,00 & 0,00 & 0,00 & 0,00 & 0,00 \\
\hline & média & - & - & 123,00 & - & - & - & - & - & - \\
\hline & $\mathrm{n}$ & 88 & 88 & 88 & 88 & 85 & 86 & 86 & 88 & 88 \\
\hline EUA - Indiana & $\%$ & 100,00 & 100,00 & 100,00 & 100,00 & 96,59 & 97,73 & 97,73 & 100,00 & 100,00 \\
\hline & média & 135,69 & 108,98 & 106,39 & 98,00 & 96,73 & 127,53 & 67,81 & 21,10 & 34,11 \\
\hline & $\mathrm{n}$ & 2 & 2 & 2 & 2 & 2 & 2 & 2 & 2 & 2 \\
\hline EUA - Kansas & $\%$ & 100,00 & 100,00 & 100,00 & 100,00 & 100,00 & 100,00 & 100,00 & 100,00 & 100,00 \\
\hline & média & 133,00 & 105,50 & 104,25 & 93,25 & 93,00 & "'-"129,00 & 62,00 & 19,00 & 34,00 \\
\hline & $\mathrm{n}$ & 11 & 11 & 11 & 11 & 11 & 10 & 11 & 11 & 11 \\
\hline KUA - & $\%$ & 100,00 & 100,00 & 100,00 & 100,00 & 100,00 & 90,91 & 100,00 & 100,00 & 100,00 \\
\hline & média & 125,73 & 106,95 & 103,59 & 91,09 & 96,32 & "'130,80" & 65,82 & 20,95 & 35,00 \\
\hline & $n$ & 25 & 25 & 25 & 25 & 24 & 24 & 24 & 25 & 25 \\
\hline Louisiana & $\%$ & 100,00 & 100,00 & 100,00 & 100,00 & 96,00 & 96,00 & 96,00 & 100,00 & 100,00 \\
\hline & média & 131,36 & 106,52 & 105,06 & 95,90 & 93,29 & 125,10 & 63,67 & 20,08 & 33,04 \\
\hline & $n$ & 2 & 2 & 2 & 2 & 2 & 2 & 2 & 2 & 2 \\
\hline EUA & $\%$ & 100,00 & 100,00 & 100,00 & 100,00 & 100,00 & "'t" & 100,00 & 100,00 & 100,00 \\
\hline & média & 144,00 & 112,50 & 106,00 & 104,50 & 99,00 & 133,00 & 66,00 & 21,50 & 33,00 \\
\hline & $\mathrm{n}$ & 40 & 42 & 42 & 40 & 37 & 30 & 40 & 40 & 42 \\
\hline Macsachu- & $\%$ & 95,24 & 100,00 & 100,00 & 95,24 & 88,10 & 71,43 & 95,24 & 95,24 & 100,00 \\
\hline & média & 133,01 & 109,75 & 106,75 & 96,74 & 97,03 & "' & 64,65 & 21,53 & 33,40 \\
\hline & $\mathrm{n}$ & 3 & 3 & 3 & 2 & $\overline{3}$ & 3 & 3 & 3 & 3 \\
\hline
\end{tabular}




\begin{tabular}{|c|c|c|c|c|c|c|c|c|c|c|}
\hline \multirow{5}{*}{$\begin{array}{l}\text { EUA - } \\
\text { Michjigan } \\
\text { Mississipi }\end{array}$} & $n$ & 3 & 3 & 3 & 2 & 3 & 3 & 3 & 3 & 3 \\
\hline & média & 100,00 & $10 \theta, 00$ & $10 \theta, \theta 0$ & $\theta 6, \theta \emptyset$ & $1 \theta \emptyset, \theta \emptyset$ & $10 \theta, \theta 0$ & $10 \theta, 00$ & $10 \theta, 00$ & 109,00 \\
\hline & $n$ & 5 & 6 & 6 & 5 & 5 & 4 & 6 & 6 & 6 \\
\hline & $\%$ & 83,33 & 100,00 & 100,00 & 83,33 & 83,33 & 66,67 & 100,00 & 100,00 & 100,00 \\
\hline & média & 125,40 & 107,33 & 102,00 & 93,80 & 97,20 & 129,75 & 63,83 & 20,67 & 33,83 \\
\hline \multirow{3}{*}{$\begin{array}{l}\text { EUA - } \\
\text { Missouri }\end{array}$} & $\mathrm{n}$ & 1 & 1 & 1 & 1 & $\overline{1}$ & 1 & 1 & 1 & 1 \\
\hline & $\%$ & 100,00 & 100,00 & 100,00 & 100,00 & 100,00 & '"' & 100,00 & 100,00 & 100,00 \\
\hline & média & 133,00 & 102,00 & 108,00 & 90,00 & 97,00 & 126,00 & 63,00 & 19,00 & 33,00 \\
\hline \multirow{3}{*}{$\begin{array}{l}\text { EUA - } \\
\text { Montana }\end{array}$} & $n$ & 3 & 4 & 4 & 4 & 3 & 4 & 4 & 4 & 4 \\
\hline & $\%$ & 75,00 & 100,00 & 100,00 & 100,00 & 75,00 & 100,00 & 100,00 & 100,00 & 100,00 \\
\hline & média & 139,00 & 107,38 & 109,25 & 97,63 & 96,00 & 126,50 & 65,88 & 20,38 & 33,75 \\
\hline \multirow{3}{*}{$\begin{array}{l}\text { EUA - } \\
\text { Nebraska }\end{array}$} & $\mathrm{n}$ & 7 & 7 & 7 & 7 & 7 & 7 & 7 & 7 & 7 \\
\hline & $\%$ & 100,00 & 100,00 & 100,00 & 100,00 & 100,00 & 100,00 & 100,00 & 100,00 & 100,00 \\
\hline & média & 126,21 & 108,57 & 104,93 & 89,07 & 93,50 & "131,64 & 68,86 & 20,64 & 35,21 \\
\hline \multirow{3}{*}{$\begin{array}{c}\text { EUA - New } \\
\text { Jersey }\end{array}$} & $n$ & 9 & 9 & 9 & 9 & 9 & 9 & 9 & 9 & 9 \\
\hline & $\%$ & 100,00 & 100,00 & 100,00 & 100,00 & 100,00 & 100,00 & 100,00 & 100,00 & 100,00 \\
\hline & média & 126,50 & 110,33 & 103,94 & 95,56 & 94,11 & 129,72 & 68,89 & 20,50 & 35,28 \\
\hline \multirow{3}{*}{$\begin{array}{l}\text { EUA - Novo } \\
\text { México }\end{array}$} & $\mathrm{n}$ & 7 & 7 & 7 & 7 & 5 & 4 & 5 & 7 & 7 \\
\hline & $\%$ & 100,00 & 100,00 & 100,00 & 100,00 & 71,43 & 57,14 & 71,43 & 100,00 & 100,00 \\
\hline & média & 131,86 & 107,64 & 102,71 & 94,93 & 94,70 & 129,00 & 65,60 & 20,64 & 34,14 \\
\hline \multirow{3}{*}{$\begin{array}{l}\text { EUA - Nova } \\
\text { York }\end{array}$} & $n$ & 50 & 50 & 50 & 45 & 50 & 42 & 50 & 50 & 50 \\
\hline & $\%$ & 100,00 & 100,00 & 100,00 & 90,00 & 100,00 & 84,00 & 100,00 & 100,00 & 100,00 \\
\hline & média & 128,68 & 104,91 & 104,01 & 92,78 & 93,15 & 127,99 & 65,78 & 21,85 & 34,25 \\
\hline \multirow{3}{*}{$\begin{array}{l}\text { EUA - } \\
\text { Oklahoma }\end{array}$} & $n$ & 24 & 24 & 24 & 23 & 23 & 19 & 24 & 24 & 24 \\
\hline & $\%$ & 100,00 & 100,00 & 100,00 & 95,83 & 95,83 & 79,17 & 100,00 & 100,00 & 100,00 \\
\hline & média & 132,17 & 108,85 & 106,40 & 96,04 & 96,48 & 128,18 & 65,04 & 22,08 & 33,73 \\
\hline \multirow{3}{*}{ EUA - Oregon } & $\mathrm{n}$ & 3 & 3 & 3 & 3 & 3 & 2 & 3 & 3 & 3 \\
\hline & $\%$ & 100,00 & 100,00 & 100,00 & 100,00 & 100,00 & 66,67 & 100,00 & 100,00 & 100,00 \\
\hline & média & 126,17 & 105,33 & 106,50 & 90,00 & 96,33 & 131,75 & 66,67 & 20,67 & 33,83 \\
\hline \multirow{3}{*}{$\begin{array}{l}\text { EUA - } \\
\text { Pensilvânia }\end{array}$} & $\mathrm{n}$ & 3 & 3 & 3 & 3 & 3 & 3 & 3 & 3 & 3 \\
\hline & $\%$ & 100,00 & 100,00 & 100,00 & 100,00 & 100,00 & 100,00 & 100,00 & 100,00 & 100,00 \\
\hline & média & 123,33 & 101,67 & 99,67 & 91,33 & 92,50 & 128,00 & 66,00 & 19,83 & 35,00 \\
\hline \multirow{3}{*}{$\begin{array}{l}\text { EUA - } \\
\text { Tennesse }\end{array}$} & $n$ & 2 & 2 & 2 & 2 & 2 & 2 & 2 & 2 & 2 \\
\hline & $\%$ & 100,00 & 100,00 & 100,00 & 100,00 & 100,00 & 100,00 & 100,00 & 100,00 & 100,00 \\
\hline & média & 135,50 & 107,00 & 105,00 & 92,25 & 97,00 & 124,50 & 65,00 & 20,50 & 32,50 \\
\hline \multirow{3}{*}{ EUA - Texas } & $\mathrm{n}$ & 13 & 13 & 13 & 13 & 13 & 10 & 13 & 13 & 13 \\
\hline & $\%$ & 100,00 & 100,00 & 100,00 & 100,00 & 100,00 & 76,92 & 100,00 & 100,00 & 100,00 \\
\hline & média & 138,38 & 110,23 & 106,42 & 96,54 & 95,12 & 125,10 & 67,08 & 21,04 & 34,42 \\
\hline \multirow{3}{*}{ EUA - Utah } & $\mathrm{n}$ & 9 & 10 & 10 & 9 & 8 & 10 & 10 & 10 & 10 \\
\hline & $\%$ & 90,00 & 100,00 & 100,00 & 90,00 & 80,00 & 100,00 & 100,00 & 100,00 & 100,00 \\
\hline & média & 126,94 & 107,40 & 105,25 & 92,28 & 97,00 & 130,75 & 65,20 & 21,20 & 33,25 \\
\hline \multirow{3}{*}{ EUA - Virginia } & $\mathrm{n}$ & 40 & 40 & 40 & 40 & 40 & 39 & 39 & 40 & 40 \\
\hline & $\%$ & 100,00 & 100,00 & 100,00 & 100,00 & 100,00 & 97,50 & 97,50 & 100,00 & 100,00 \\
\hline & média & 128,54 & 107,10 & 105,63 & 94,15 & 94,63 & 127,35 & 65,95 & 21,56 & 34,13 \\
\hline \multirow{3}{*}{$\begin{array}{c}\text { EUA - Virginia } \\
\text { Ocidental }\end{array}$} & $n$ & 30 & 33 & 33 & 30 & 28 & 26 & 33 & 30 & 33 \\
\hline & $\%$ & 90,91 & 100,00 & 100,00 & 90,91 & 84,85 & 78,79 & 100,00 & 90,91 & 100,00 \\
\hline & média & 134,37 & 108,68 & 106,52 & 94,98 & 98,55 & 128,40 & 64,38 & 21,70 & 34,03 \\
\hline \multirow{6}{*}{$\begin{array}{c}\text { EUA - } \\
\text { Washington }\end{array}$} & $n$ & 1 & 1 & 1 & 1 & 1 & 0 & 1 & 0 & 1 \\
\hline & $\%$ & 100,00 & 100,00 & 100,00 & 100,00 & 100,00 & 0,00 & 100,00 & 0,00 & 100,00 \\
\hline & média & 132,00 & 105,00 & 100,00 & 108,00 & 102,00 & & 70,00 & - & 32,00 \\
\hline & $\mathrm{N}$ & 2 & 2 & 2 & 2 & 2 & 2 & 2 & 2 & 2 \\
\hline & $\%$ & 100,00 & 100,00 & 100,00 & 100,00 & 100,00 & 100,00 & 100,00 & 100,00 & 100,00 \\
\hline & média & 126,50 & 103,50 & 104,50 & 96,50 & 93,25 & 133,75 & 63,50 & 21,50 & 34,75 \\
\hline
\end{tabular}




\begin{tabular}{|c|c|c|c|c|c|c|c|c|c|c|}
\hline série & & NLB & $\mathrm{NLH}$ & MAB & $\mathrm{MDH}$ & MDB & WNB & SIS & ZMB & SSS \\
\hline \multirow{3}{*}{ Aleuta 1} & $\mathrm{n}$ & 55 & 55 & 55 & 55 & 56 & 54 & 54 & 51 & 51 \\
\hline & $\%$ & 96,49 & 96,49 & 96,49 & 96,49 & 98,25 & 94,74 & 94,74 & 89,47 & 89,47 \\
\hline & média & 25,18 & 51,78 & 62,97 & 22,24 & 15,38 & 7,76 & 2,73 & 96,87 & 21,45 \\
\hline \multirow{3}{*}{ Aleuta 2} & $\mathrm{n}$ & 42 & 42 & 41 & 41 & 41 & 40 & 40 & 41 & 41 \\
\hline & $\%$ & 100,00 & 100,00 & 97,62 & 97,62 & 97,62 & 95,24 & 95,24 & 97,62 & 97,62 \\
\hline & média & 24,96 & 49,79 & 62,57 & 21,54 & 15,68 & 7,58 & 2,53 & 96,00 & 20,44 \\
\hline \multirow{3}{*}{ Aleuta 3} & $\mathrm{n}$ & 13 & 13 & 12 & 13 & 13 & 13 & 12 & 10 & 10 \\
\hline & $\%$ & 100,00 & 100,00 & 92,31 & 100,00 & 100,00 & 100,00 & 92,31 & 76,92 & 76,92 \\
\hline & média & 24,96 & 49,96 & 62,67 & 22,31 & 15,23 & 7,86 & 2,57 & 95,95 & 23,27 \\
\hline \multirow{3}{*}{ Aleuta 4} & $\mathrm{n}$ & 7 & 7 & 7 & 7 & 7 & 7 & 7 & 7 & 7 \\
\hline & $\%$ & 100,00 & 100,00 & 100,00 & 100,00 & 100,00 & 100,00 & 100,00 & 100,00 & 100,00 \\
\hline & média & 24,93 & 49,86 & 61,71 & 22,00 & 14,86 & "'7,24 & 2,70 & 92,39 & 19,56 \\
\hline \multirow{3}{*}{ Aleuta 5} & $\mathrm{n}$ & 7 & 7 & 7 & 7 & 7 & 7 & 7 & 6 & 6 \\
\hline & $\%$ & 100,00 & 100,00 & 100,00 & 100,00 & 100,00 & 100,00 & 100,00 & 85,71 & 85,71 \\
\hline & média & 23,86 & 49,64 & 61,57 & 22,29 & 14,43 & 9,44 & 2,60 & 96,15 & 21,00 \\
\hline \multirow{3}{*}{ Aleuta 6} & $\mathrm{n}$ & 5 & 5 & 4 & 5 & 5 & 5 & 5 & 5 & 5 \\
\hline & $\%$ & 100,00 & 100,00 & 80,00 & 100,00 & 100,00 & 100,00 & 100,00 & 100,00 & 100,00 \\
\hline & média & 24,00 & 52,60 & 62,50 & 22,80 & 14,60 & 6,56 & 2,20 & 97,06 & 20,88 \\
\hline \multirow{3}{*}{$\begin{array}{l}\text { Austrália - } \\
\text { Murray River }\end{array}$} & $n$ & 11 & 11 & 12 & 15 & 15 & 5 & 4 & 8 & 8 \\
\hline & $\%$ & 61,11 & 61,11 & 66,67 & 83,33 & 83,33 & 27,78 & 22,22 & 44,44 & 44,44 \\
\hline & média & 25,55 & 48,91 & 61,17 & 27,33 & 18,13 & 10,45 & 3,34 & 90,38 & 24,15 \\
\hline \multirow{3}{*}{$\begin{array}{l}\text { Austrália- } \\
\text { New South } \\
\text { Walles }\end{array}$} & $n$ & 10 & 8 & 9 & 7 & 7 & 10 & 9 & 8 & 8 \\
\hline & $\%$ & 83,33 & 66,67 & 75,00 & 58,33 & 58,33 & 83,33 & 75,00 & 66,67 & 66,67 \\
\hline & média & 25,50 & 48,38 & 62,89 & 25,14 & 17,14 & 9,35 & 3,24 & 88,50 & 22,23 \\
\hline \multirow{3}{*}{$\begin{array}{c}\text { Austrália - } \\
\text { Território do } \\
\text { Norte }\end{array}$} & $\mathrm{n}$ & 2 & 2 & 2 & 2 & 2 & 2 & 2 & 2 & 2 \\
\hline & $\%$ & 100,00 & 100,00 & 100,00 & 100,00 & 100,00 & "' & 100,00 & 100,00 & 100,00 \\
\hline & média & 26,25 & 49,25 & 67,00 & 25,00 & 17,00 & 5,70 & 1,82 & 95,00 & 24,43 \\
\hline & $\mathrm{n}$ & 39 & 41 & 37 & 57 & 58 & 41 & 41 & 36 & 35 \\
\hline Austrália - Sul & $\%$ & 54,93 & 57,75 & 52,11 & 80,28 & 81,69 & 57,75 & 57,75 & 50,70 & 49,30 \\
\hline & média & 25,28 & 47,71 & 61,73 & 25,58 & 18,48 & 9,29 & 3,41 & 89,92 & 24,76 \\
\hline & $\mathrm{n}$ & 7 & 7 & 7 & 7 & 7 & 7 & 7 & 7 & 7 \\
\hline & $\%$ & 100,00 & 100,00 & 100,00 & 100,00 & 100,00 & ' & 100,00 & 100,00 & 100,00 \\
\hline & média & 26,71 & 45,21 & 61,64 & 22,29 & 15,00 & 8,32 & 2,82 & 88,64 & 25,48 \\
\hline Canadá - & $\mathrm{n}$ & 22 & 22 & 22 & 22 & 22 & 22 & 22 & 21 & 21 \\
\hline Columbia & $\%$ & 100,00 & 100,00 & 100,00 & 100,00 & 100,00 & 100,00 & 100,00 & 95,45 & 95,45 \\
\hline ânica & média & 24,59 & 50,70 & 62,82 & 21,52 & 14,61 & 8,09 & 2,38 & 95,66 & 21,56 \\
\hline & $\mathrm{n}$ & 1 & 1 & 1 & 1 & 1 & 4 & 0 & 1 & 1 \\
\hline & $\%$ & 100,00 & 100,00 & 100,00 & 100,00 & 100,00 & 100,00 & 0,00 & 100,00 & 100,00 \\
\hline & média & 25,50 & 48,00 & 62,00 & 25,00 & 17,00 & 8,15 & & 90,90 & 24,21 \\
\hline Canadá - & $\mathrm{n}$ & 6 & 6 & 6 & 6 & 6 & 6 & 6 & 4 & 4 \\
\hline Ontário & $\%$ & 100,00 & 100,00 & 100,00 & 100,00 & 100,00 & "' & 100,00 & 66,67 & 66,67 \\
\hline (Iroc & média & 26,50 & 50,83 & 62,50 & 23,33 & 17,33 & '9,59 & 3,46 & 91,98 & 26,59 \\
\hline América Central & $n$ & 2 & 2 & 2 & 2 & 2 & 2 & 2 & 2 & 2 \\
\hline Sul & $\%$ & 100,00 & 100,00 & 100,00 & 100,00 & 100,00 & 100,00 & 100,00 & 100,00 & 100,00 \\
\hline Argentina & média & 25,50 & 45,00 & 60,50 & 19,50 & 14,50 & 8,21 & 2,12 & 94,40 & 20,64 \\
\hline América & $\mathrm{n}$ & 6 & 6 & 6 & 6 & 6 & 6 & 6 & 6 & 6 \\
\hline Central e do & $\%$ & 100,00 & 100,00 & 100,00 & 100,00 & 100,00 & 100,00 & 100,00 & 100,00 & 100,00 \\
\hline Sul - Bolívia & média & 24,42 & 47,17 & 59,17 & 22,17 & 14,00 & 10,29 & 3,14 & 92,78 & 21,93 \\
\hline América & $\mathrm{n}$ & 20 & 20 & 17 & 20 & 20 & 19 & 18 & 20 & 20 \\
\hline Central e do & $\%$ & 100,00 & 100,00 & 85,00 & 100,00 & 100,00 & 95,00 & 90,00 & 100,00 & 100,00 \\
\hline Sul-Chile & média & 23,35 & 48,30 & 59,15 & 22,30 & 15,03 & 8,81 & 3,27 & 89,87 & 21,80 \\
\hline América & $\mathrm{n}$ & 1 & 1 & 1 & 1 & 1 & 1 & 1 & 1 & $\overline{1}$ \\
\hline Central e do & $\%$ & 100,00 & 100,00 & 100,00 & 100,00 & 100,00 & 100,00 & 100,00 & 100,00 & 100,00 \\
\hline Sul - Colômbia & média & 22,00 & 45,00 & 59,00 & 20,00 & 14,00 & 8,81 & 1,72 & 88,50 & 20,57 \\
\hline América & $\mathrm{n}$ & 2 & 2 & 2 & 2 & 2 & 2 & 2 & 2 & 2 \\
\hline Central e do & $\%$ & 100,00 & 100,00 & 100,00 & 100,00 & 100,00 & "' & 100,00 & 100,00 & 100,00 \\
\hline Sul - Equador & média & 23,25 & 48,25 & 64,00 & 21,50 & 14,00 & 6,91 & 2,93 & 91,75 & 22,40 \\
\hline & $\mathrm{n}$ & $\overline{13}$ & 14 & 13 & 14 & 14 & 14 & 14 & 13 & 13 \\
\hline do Sul - & $\%$ & 92,86 & 100,00 & 92,86 & 100,00 & 100,00 & 100,00 & 100,00 & 92,86 & 92,86 \\
\hline$(\mathrm{Pa}$ & média & 24,00 & 49,82 & 62,62 & 24,14 & 16,36 & 8,65 & 3,36 & 95,43 & 23,72 \\
\hline América & $\mathrm{n}$ & 43 & 43 & 40 & 42 & 43 & 43 & 43 & 41 & 41 \\
\hline Central e do & $\%$ & 100,00 & 100,00 & 93,02 & 97,67 & 100,00 & 100,00 & 100,00 & 95,35 & 95,35 \\
\hline Sul - México & média & 25,35 & 47,31 & 62,46 & 23,74 & 16,29 & 8,62 & 3,11 & 94,18 & 22,06 \\
\hline América & $\mathrm{n}$ & 143 & 143 & 143 & 143 & 143 & 143 & 143 & 143 & 143 \\
\hline Central e do & $\%$ & 100,00 & 100,00 & 100,00 & 100,00 & 100,00 & 100,00 & 100,00 & 100,00 & 100,00 \\
\hline Sul - Peru & média & 23,90 & 47,33 & 60,49 & 22,95 & 15,10 & 8,75 & 3,62 & 92,96 & 21,80 \\
\hline América & $n$ & 2 & 2 & 2 & 2 & 2 & 2 & 2 & 2 & 2 \\
\hline Central e do & $\%$ & 100,00 & 100,00 & 100,00 & 100,00 & 100,00 & 100,00 & 100,00 & 100,00 & 100,00 \\
\hline
\end{tabular}




\begin{tabular}{|c|c|c|c|c|c|c|c|c|c|c|}
\hline $\begin{array}{c}\text { Sul- } \\
\text { Venezuela }\end{array}$ & média & 25,50 & 51,50 & 65,50 & 25,50 & 18,50 & 9,97 & 2,82 & 101,25 & 25,16 \\
\hline \multirow{3}{*}{$\begin{array}{l}\text { Leste Asiático } \\
\text { - Norte da } \\
\text { China (Han) } \\
\end{array}$} & $\mathrm{n}$ & 12 & 12 & 11 & 12 & 12 & 12 & 12 & 12 & 12 \\
\hline & $\%$ & 100,00 & 100,00 & 91,67 & 100,00 & 100,00 & 100,00 & 100,00 & 100,00 & 100,00 \\
\hline & média & 25,50 & 52,63 & 64,05 & 25,67 & 16,75 & 7,63 & 2,02 & 94,96 & 20,53 \\
\hline \multirow{3}{*}{$\begin{array}{l}\text { Leste Asiático } \\
\text { - Japão } \\
\text { Tohoku }\end{array}$} & $n$ & 67 & 66 & 47 & 68 & 68 & 67 & 67 & 65 & 64 \\
\hline & $\%$ & 98,53 & 97,06 & 69,12 & 100,00 & 100,00 & 98,53 & 98,53 & 95,59 & 94,12 \\
\hline & média & 24,63 & 49,62 & 61,07 & 24,88 & 14,90 & 6,73 & 1,82 & 91,98 & 21,59 \\
\hline \multirow{3}{*}{$\begin{array}{l}\text { Leste Asiático } \\
\text { - Japão } \\
\text { Período Jomon } \\
\end{array}$} & $n$ & 7 & 6 & 6 & 9 & 9 & 6 & 6 & 6 & 5 \\
\hline & $\%$ & 77,78 & 66,67 & 66,67 & 100,00 & 100,00 & 66,67 & 66,67 & 66,67 & 55,56 \\
\hline & média & 25,86 & 47,83 & 61,50 & 29,33 & 18,89 & 9,99 & 3,69 & 97,17 & 21,37 \\
\hline \multirow{3}{*}{$\begin{array}{l}\text { Leste Asiático } \\
\text { - Nepal }\end{array}$} & $\mathrm{n}$ & 7 & 7 & 6 & 7 & 7 & 6 & 6 & 7 & 7 \\
\hline & $\%$ & 100,00 & 100,00 & 85,71 & 100,00 & 100,00 & 85,71 & 85,71 & 100,00 & 100,00 \\
\hline & média & 25,00 & 47,14 & 61,67 & 25,57 & 15,14 & 7,25 & 2,46 & 91,73 & 21,07 \\
\hline \multirow{3}{*}{$\begin{array}{l}\text { Leste Asiático } \\
\text { - Taiwan }\end{array}$} & $n$ & 1 & 1 & 1 & 1 & 1 & 1 & 1 & 1 & 1 \\
\hline & $\%$ & 100,00 & 100,00 & 100,00 & 100,00 & 100,00 & 100,00 & 100,00 & 100,00 & 100,00 \\
\hline & média & 25,00 & 51,00 & 66,00 & 27,00 & 14,00 & 6,13 & 2,42 & 94,10 & 23,29 \\
\hline \multirow{3}{*}{$\begin{array}{l}\text { Leste Asiático } \\
\text { - Tibet }\end{array}$} & $n$ & 16 & 16 & 16 & 16 & 16 & 16 & 16 & 16 & 16 \\
\hline & $\%$ & 100,00 & 100,00 & 100,00 & 100,00 & 100,00 & 100,00 & 100,00 & 100,00 & 100,00 \\
\hline & média & 25,88 & 48,50 & 61,78 & 26,69 & 17,22 & 7,84 & 2,50 & 96,00 & 21,18 \\
\hline \multirow{3}{*}{$\begin{array}{l}\text { Esquimó - } \\
\text { Alaska } 1\end{array}$} & $n$ & 128 & 130 & 121 & 128 & 128 & 129 & 125 & 122 & 122 \\
\hline & $\%$ & 98,46 & 100,00 & 93,08 & 98,46 & 98,46 & 99,23 & 96,15 & 93,85 & 93,85 \\
\hline & média & 23,84 & 51,07 & 61,83 & 22,41 & 15,13 & 5,98 & 2,06 & 96,22 & 19,12 \\
\hline \multirow{3}{*}{$\begin{array}{l}\text { Esquimó - } \\
\text { Alaska } 2\end{array}$} & $n$ & 102 & 103 & 98 & 104 & 104 & 104 & 103 & 99 & 98 \\
\hline & $\%$ & 98,08 & 99,04 & 94,23 & 100,00 & 100,00 & 100,00 & 99,04 & 95,19 & 94,23 \\
\hline & média & 23,23 & 51,45 & 63,37 & 23,56 & 15,60 & 5,98 & 2,14 & 96,91 & 20,41 \\
\hline \multirow{3}{*}{$\begin{array}{c}\text { Esquimó - } \\
\text { Alaska } 3\end{array}$} & $n$ & 55 & 54 & 51 & 57 & 57 & 57 & 55 & 43 & 43 \\
\hline & $\%$ & 91,67 & 90,00 & 85,00 & 95,00 & 95,00 & 95,00 & 91,67 & 71,67 & 71,67 \\
\hline & média & 22,97 & 51,70 & 60,72 & 21,91 & 14,93 & 5,29 & 2,05 & 94,95 & 21,05 \\
\hline & $n$ & 15 & 15 & 15 & 16 & 16 & 16 & 15 & 14 & 14 \\
\hline Ásia & $\%$ & 93,75 & 93,75 & 93,75 & 100,00 & 100,00 & 100,00 & 93,75 & 87,50 & 87,50 \\
\hline & média & 24,43 & 51,50 & 62,17 & 20,75 & 14,25 & 5,76 & 2,21 & 93,99 & 19,38 \\
\hline & $n$ & 25 & 25 & 25 & 22 & 24 & 25 & 24 & 23 & 23 \\
\hline Canadá & $\%$ & 100,00 & 100,00 & 100,00 & 88,00 & 96,00 & 100,00 & 96,00 & 92,00 & 92,00 \\
\hline & média & 22,46 & 50,66 & 60,90 & 22,59 & 15,00 & 5,63 & 2,37 & 92,52 & 18,92 \\
\hline Fsau & $n$ & 56 & 56 & 53 & 54 & 55 & 56 & 56 & 52 & 50 \\
\hline Groe & $\%$ & 98,25 & 98,25 & 92,98 & 94,74 & 96,49 & 98,25 & 98,25 & 91,23 & 87,72 \\
\hline & média & 22,21 & 50,64 & 61,69 & 22,08 & 15,79 & 5,59 & 2,32 & 93,48 & 18,27 \\
\hline & $n$ & 3 & 3 & 3 & 2 & 3 & 3 & 3 & 3 & 3 \\
\hline "descon & $\%$ & 100,00 & 100,00 & 100,00 & 66,67 & 100,00 & 100,00 & 100,00 & 100,00 & 100,00 \\
\hline & média & 22,00 & 50,00 & 62,00 & 22,00 & 15,00 & 5,99 & 2,17 & 98,73 & 17,88 \\
\hline & $\mathrm{n}$ & 55 & 55 & 55 & 55 & 55 & 55 & 55 & 55 & 55 \\
\hline Áus & $\%$ & 100,00 & 100,00 & 100,00 & 100,00 & 100,00 & 100,00 & 100,00 & 100,00 & 100,00 \\
\hline & média & 23,77 & 48,44 & 60,02 & 22,24 & 13,74 & 9,23 & 4,02 & 89,63 & 21,92 \\
\hline Europa - & $n$ & 1 & 1 & 1 & 1 & 1 & 1 & 1 & 1 & 1 \\
\hline Áustria (Idade & $\%$ & 100,00 & 100,00 & 100,00 & 100,00 & 100,00 & 100,00 & 100,00 & 100,00 & 100,00 \\
\hline 1 & média & 20,00 & 47,00 & 52,00 & 23,50 & 13,50 & 7,09 & 4,20 & 86,40 & 18,00 \\
\hline & $n$ & 6 & 6 & 6 & 6 & 6 & 6 & 6 & 5 & 5 \\
\hline Bélgica & $\%$ & 100,00 & 100,00 & 100,00 & 100,00 & 100,00 & 100,00 & 100,00 & 83,33 & 83,33 \\
\hline & média & 22,25 & 49,25 & 58,67 & 22,83 & 13,42 & 9,83 & 4,41 & 86,96 & 20,96 \\
\hline Europa - & $n$ & 35 & 36 & 34 & 36 & 36 & 36 & 35 & 35 & 35 \\
\hline "Republica & $\%$ & 97,22 & 100,00 & 94,44 & 100,00 & 100,00 & 100,00 & 97,22 & 97,22 & 97,22 \\
\hline Tcheca" & média & 23,67 & 47,89 & 59,66 & 22,75 & 15,86 & 8,77 & 3,80 & 89,05 & 21,25 \\
\hline & $n$ & 10 & 10 & 10 & 10 & 10 & 10 & 10 & 10 & 10 \\
\hline Alem & $\%$ & 100,00 & 100,00 & 100,00 & 100,00 & 100,00 & 100,00 & 100,00 & 100,00 & 100,00 \\
\hline & média & 23,00 & 49,60 & 57,60 & 23,80 & 14,70 & 7,83 & 3,74 & 85,32 & 21,62 \\
\hline & $n$ & 2 & 2 & 2 & 2 & 2 & 2 & 2 & 2 & 2 \\
\hline Hola & $\%$ & 100,00 & 100,00 & 100,00 & 100,00 & 100,00 & 100,00 & 100,00 & 100,00 & 100,00 \\
\hline & média & 21,25 & 46,50 & 62,75 & 22,00 & 15,00 & 5,22 & 2,21 & 87,60 & 21,60 \\
\hline & $n$ & 51 & 51 & 51 & 51 & 51 & 51 & 50 & 51 & 51 \\
\hline Hungria & $\%$ & 100,00 & 100,00 & 100,00 & 100,00 & 100,00 & 100,00 & 98,04 & 100,00 & 100,00 \\
\hline & média & 24,31 & 47,08 & 60,49 & 22,21 & 13,95 & 9,17 & 3,63 & 89,31 & 21,62 \\
\hline & $n$ & 3 & 3 & 3 & 3 & 3 & 3 & 3 & 3 & 3 \\
\hline Lapônia & $\%$ & 100,00 & 100,00 & 100,00 & 100,00 & 100,00 & 100,00 & 100,00 & 100,00 & 100,00 \\
\hline & média & 22,33 & 46,33 & 59,50 & 22,33 & 15,00 & 8,23 & 3,48 & 89,87 & 20,28 \\
\hline$F_{1}$ & $n$ & 6 & 6 & 6 & 6 & 6 & 6 & 6 & 6 & 6 \\
\hline Luropa - & $\%$ & 100,00 & 100,00 & 100,00 & 100,00 & 100,00 & 100,00 & 100,00 & 100,00 & 100,00 \\
\hline & média & 24,25 & 48,25 & 59,33 & 22,50 & 14,33 & 10,40 & 3,62 & 91,60 & 22,00 \\
\hline Europa - & $\mathrm{n}$ & 23 & 23 & 21 & 23 & 23 & 23 & 23 & 23 & 23 \\
\hline Suíça & $\%$ & 100,00 & 100,00 & 91,30 & 100,00 & 100,00 & 100,00 & 100,00 & 100,00 & 100,00 \\
\hline
\end{tabular}




\begin{tabular}{|c|c|c|c|c|c|c|c|c|c|c|}
\hline & média & 23,09 & 48,24 & 57,84 & 23,52 & 14,83 & 9,13 & 3,95 & 87,22 & 21,40 \\
\hline \multirow{3}{*}{$\begin{array}{l}\text { Europa - } \\
\text { Ucrânia }\end{array}$} & $n$ & 4 & 4 & 4 & 4 & 4 & 3 & 2 & 2 & 2 \\
\hline & $\%$ & 100,00 & 100,00 & 100,00 & 100,00 & 100,00 & 75,00 & 50,00 & 50,00 & 50,00 \\
\hline & média & 24,00 & 47,75 & 59,00 & 24,25 & 15,00 & 7,89 & 2,73 & 93,60 & 18,16 \\
\hline \multirow{3}{*}{$\begin{array}{l}\text { Europa - } \\
\text { Yuguslavia }\end{array}$} & $\mathrm{n}$ & 14 & 14 & 13 & 14 & 14 & 14 & 14 & 12 & 12 \\
\hline & $\%$ & 100,00 & 100,00 & 92,86 & 100,00 & 100,00 & 100,00 & 100,00 & 85,71 & 85,71 \\
\hline & média & 23,82 & 49,64 & 59,15 & 23,04 & 14,36 & 9,03 & 4,21 & 90,75 & 22,02 \\
\hline \multirow{3}{*}{$\begin{array}{l}\text { Índia - } \\
\text { Bengala }\end{array}$} & $n$ & 24 & 24 & 24 & 24 & 24 & 24 & 23 & 24 & 24 \\
\hline & $\%$ & 100,00 & 100,00 & 100,00 & 100,00 & 100,00 & 100,00 & 95,83 & 100,00 & 100,00 \\
\hline & média & 23,56 & 47,23 & 59,98 & 22,75 & 13,77 & 8,20 & 3,64 & 90,95 & 23,30 \\
\hline \multirow{3}{*}{ Índia - Mahalls } & $n$ & 2 & 2 & 2 & 2 & 2 & 2 & 2 & 2 & 2 \\
\hline & $\%$ & 100,00 & 100,00 & 100,00 & 100,00 & 100,00 & 100,00 & 100,00 & 100,00 & 100,00 \\
\hline & média & 23,75 & 44,00 & 55,25 & 23,75 & 15,50 & 9,37 & 3,15 & 85,85 & 22,35 \\
\hline \multirow{3}{*}{ Índia - Mysore } & $n$ & 3 & 3 & 3 & 3 & 3 & 3 & 3 & 3 & 3 \\
\hline & $\%$ & 100,00 & 100,00 & 100,00 & 100,00 & 100,00 & 100,00 & 100,00 & 100,00 & 100,00 \\
\hline & média & 24,17 & 41,67 & 56,50 & 19,67 & 12,33 & 7,73 & 2,66 & 90,03 & 21,11 \\
\hline \multirow{3}{*}{ Índia - Nagpur } & $n$ & 1 & 1 & 1 & 1 & 1 & 1 & 0 & 1 & 1 \\
\hline & $\%$ & 100,00 & 100,00 & 100,00 & 100,00 & 100,00 & 100,00 & 0,00 & 100,00 & 100,00 \\
\hline & média & 23,50 & 44,00 & 59,00 & 21,00 & 14,00 & 7,88 & - & 91,90 & 23,13 \\
\hline \multirow{3}{*}{ Índia - Orissa } & $n$ & 3 & 3 & 2 & 3 & 3 & 3 & 3 & 2 & 2 \\
\hline & $\%$ & 100,00 & 100,00 & 66,67 & 100,00 & 100,00 & 100,00 & 100,00 & 66,67 & 66,67 \\
\hline & média & 24,50 & 45,67 & 57,75 & 21,83 & 14,67 & 8,65 & 3,69 & 88,90 & 19,45 \\
\hline \multirow{3}{*}{ Îndia - Sikkim } & $\mathrm{n}$ & 2 & 2 & 2 & 2 & 2 & 2 & 2 & 2 & 2 \\
\hline & $\%$ & 100,00 & 100,00 & 100,00 & 100,00 & 100,00 & 100,00 & 100,00 & 100,00 & 100,00 \\
\hline & média & 23,50 & 47,25 & 61,00 & 23,50 & 15,50 & 10,37 & 2,70 & 92,95 & 21,89 \\
\hline \multirow{3}{*}{ Índia - Sul } & $\mathrm{n}$ & 4 & 4 & 4 & 4 & 4 & 4 & 4 & 4 & 4 \\
\hline & $\%$ & 100,00 & 100,00 & 100,00 & 100,00 & 100,00 & 100,00 & 100,00 & 100,00 & 100,00 \\
\hline & média & 24,75 & 48,50 & 59,75 & 22,25 & 13,63 & 7,22 & 3,16 & 91,93 & 24,16 \\
\hline & $\mathrm{n}$ & 2 & 2 & 2 & 2 & 2 & 2 & 2 & 2 & 2 \\
\hline İndia - Tamil & $\%$ & 100,00 & 100,00 & 100,00 & 100,00 & 100,00 & 100,00 & 100,00 & 100,00 & 100,00 \\
\hline & média & 27,75 & 44,50 & 63,00 & 21,50 & 13,50 & 10,54 & 3,53 & 92,70 & 22,30 \\
\hline & $n$ & 6 & 6 & 6 & 6 & 6 & 6 & 6 & 6 & 6 \\
\hline & $\%$ & 100,00 & 100,00 & 100,00 & 100,00 & 100,00 & 100,00 & 100,00 & 100,00 & 100,00 \\
\hline & média & 22,75 & 47,83 & 59,50 & 21,67 & 12,50 & 8,08 & 3,46 & 90,73 & 23,07 \\
\hline & $n$ & 6 & 6 & 6 & 6 & 5 & 5 & 5 & 6 & 6 \\
\hline Índia - Veddah & $\%$ & 100,00 & 100,00 & 100,00 & 100,00 & 83,33 & 83,33 & 83,33 & 100,00 & 100,00 \\
\hline & média & 23,83 & 47,17 & 56,17 & 22,50 & 16,20 & 8,07 & 3,27 & 88,03 & 23,53 \\
\hline & $\mathrm{n}$ & 13 & 13 & 13 & 13 & 13 & 13 & 13 & 13 & 13 \\
\hline Bisn & $\%$ & 100,00 & 100,00 & 100,00 & 100,00 & 100,00 & 100,00 & 100,00 & 100,00 & 100,00 \\
\hline & média & 25,12 & 49,77 & 61,38 & 23,65 & 14,85 & 8,11 & 2,48 & 93,10 & 25,35 \\
\hline & $\mathrm{n}$ & 4 & 4 & 4 & 4 & 4 & 4 & 4 & 4 & 4 \\
\hline Fiij & $\%$ & 80,00 & 80,00 & 80,00 & 80,00 & 80,00 & 80,00 & 80,00 & 80,00 & 80,00 \\
\hline & média & 25,00 & 50,50 & 60,50 & 26,50 & 16,25 & 7,82 & 2,83 & 90,83 & 24,75 \\
\hline & $n$ & 24 & 21 & 24 & 24 & 24 & 24 & 24 & 24 & 24 \\
\hline Nova $\mathrm{E}$ & $\%$ & 100,00 & 87,50 & 100,00 & 100,00 & 100,00 & 100,00 & 100,00 & 100,00 & 100,00 \\
\hline & média & 25,50 & 47,83 & 62,60 & 25,54 & 17,25 & 8,70 & 2,69 & 92,50 & 24,92 \\
\hline Melanésia - & $n$ & 10 & 10 & 10 & 11 & 11 & 11 & 11 & 9 & $\overline{9}$ \\
\hline Nova & $\%$ & 90,91 & 90,91 & 90,91 & 100,00 & 100,00 & 100,00 & 100,00 & 81,82 & 81,82 \\
\hline Caledônia & média & 25,25 & 46,85 & 61,95 & 24,18 & 15,59 & 8,91 & 2,79 & 93,10 & 25,24 \\
\hline Melanésia - & $n$ & 29 & 29 & 26 & 29 & 29 & 29 & 28 & 29 & 29 \\
\hline "N/2 & $\%$ & 100,00 & 100,00 & 89,66 & 100,00 & 100,00 & 100,00 & 96,55 & 100,00 & 100,00 \\
\hline Hebrides" & média & 25,98 & 46,79 & 62,52 & 23,97 & 16,14 & 8,04 & 2,87 & 89,57 & 23,59 \\
\hline & $n$ & 24 & 24 & 24 & 25 & 25 & 24 & 23 & 24 & 24 \\
\hline Nova Irlanda & $\%$ & 96,00 & 96,00 & 96,00 & 100,00 & 100,00 & 96,00 & 92,00 & 96,00 & 96,00 \\
\hline & média & 24,90 & 48,21 & 60,48 & 25,44 & 17,30 & 7,49 & 2,79 & 91,08 & 24,56 \\
\hline & $n$ & 2 & 2 & 2 & 2 & 2 & 2 & 2 & 2 & 2 \\
\hline Sant & $\%$ & 100,00 & 100,00 & 100,00 & 100,00 & 100,00 & 100,00 & 100,00 & 100,00 & 100,00 \\
\hline & média & 23,50 & 41,00 & 58,50 & 26,50 & 17,00 & 7,72 & 2,50 & 87,00 & 22,55 \\
\hline & $\mathrm{n}$ & 31 & 31 & 27 & 30 & 30 & 30 & 30 & 31 & 31 \\
\hline Solomon - & $\%$ & 100,00 & 100,00 & 87,10 & 96,77 & 96,77 & 96,77 & 96,77 & 100,00 & 100,00 \\
\hline & média & 25,19 & 47,98 & 60,76 & 25,98 & 17,80 & 7,03 & 2,67 & 91,91 & 24,96 \\
\hline & $n$ & 6 & 6 & 6 & 5 & 6 & 6 & 6 & 6 & 6 \\
\hline Fstreito Torres & $\%$ & 100,00 & 100,00 & 100,00 & 83,33 & 100,00 & 100,00 & 100,00 & 100,00 & 100,00 \\
\hline & média & 23,83 & 47,50 & 61,25 & 24,30 & 15,83 & 8,97 & 3,29 & 91,38 & 26,75 \\
\hline & $\mathrm{n}$ & 11 & 11 & 11 & 11 & 11 & 11 & 10 & 11 & 11 \\
\hline Uhas Carolina & $\%$ & 100,00 & 100,00 & 100,00 & 100,00 & 100,00 & 100,00 & 90,91 & 100,00 & 100,00 \\
\hline & média & 24,09 & 49,64 & 62,32 & 24,64 & 15,91 & 7,63 & 2,05 & 93,28 & 22,73 \\
\hline & $n$ & 1 & 1 & 1 & 2 & 2 & 1 & 1 & 1 & 1 \\
\hline llhas Mariana & $\%$ & 50,00 & 50,00 & 50,00 & 100,00 & 100,00 & 50,00 & 50,00 & 50,00 & 50,00 \\
\hline & média & 27,00 & 54,00 & 66,50 & 24,00 & 16,50 & 7,87 & 3,37 & 96,70 & 20,65 \\
\hline
\end{tabular}




\begin{tabular}{|c|c|c|c|c|c|c|c|c|c|c|}
\hline \multirow{3}{*}{$\begin{array}{l}\text { Norte da África } \\
\text { - Egito } 1\end{array}$} & $n$ & 83 & 83 & 81 & 83 & 83 & 82 & 76 & 81 & 81 \\
\hline & $\%$ & 100,00 & 100,00 & 97,59 & 100,00 & 100,00 & 98,80 & 91,57 & 97,59 & 97,59 \\
\hline & média & 24,14 & 49,49 & 60,06 & 23,78 & 14,87 & 9,61 & 3,80 & 90,63 & 23,37 \\
\hline \multirow{3}{*}{$\begin{array}{c}\text { Norte da África } \\
\text { - Egito } 2\end{array}$} & $\mathrm{n}$ & 14 & 14 & 14 & 14 & 14 & 11 & 11 & 14 & 14 \\
\hline & $\%$ & 100,00 & 100,00 & 100,00 & 100,00 & 100,00 & 78,57 & 78,57 & 100,00 & 100,00 \\
\hline & média & 23,61 & 48,79 & 59,00 & 23,79 & 14,86 & 9,70 & 3,52 & 88,43 & 23,29 \\
\hline \multirow{3}{*}{$\begin{array}{c}\text { Norte da África } \\
\text { - Egito } 3\end{array}$} & $\mathrm{n}$ & 8 & 8 & 8 & 8 & 8 & 8 & 8 & 7 & 7 \\
\hline & $\%$ & 100,00 & 100,00 & 100,00 & 100,00 & 100,00 & 100,00 & 100,00 & 87,50 & 87,50 \\
\hline & média & 25,38 & 49,25 & 59,50 & 22,13 & 14,38 & 10,86 & 3,71 & 90,60 & 22,25 \\
\hline \multirow{3}{*}{$\begin{array}{l}\text { Nordeste } \\
\text { Asiático - } \\
\text { Amur }\end{array}$} & $\mathrm{n}$ & 1 & 1 & 1 & 0 & 0 & 1 & 1 & 0 & 0 \\
\hline & $\%$ & 100,00 & 100,00 & 100,00 & 0,00 & 0,00 & '"' & 100,00 & 0,00 & 0,00 \\
\hline & média & 23,00 & 48,00 & 60,00 & & & 5,93 & 1,90 & & \\
\hline \multirow{3}{*}{$\begin{array}{l}\text { Nordeste } \\
\text { Asiático - } \\
\text { Buriat } \\
\end{array}$} & $\mathrm{n}$ & 12 & 12 & 12 & 11 & 12 & 12 & 12 & 12 & 12 \\
\hline & $\%$ & 100,00 & 100,00 & 100,00 & 91,67 & 100,00 & 100,00 & 100,00 & 100,00 & 100,00 \\
\hline & média & 26,25 & 53,92 & 62,42 & 24,00 & 15,42 & 7,03 & 2,14 & 97,71 & 17,79 \\
\hline \multirow{3}{*}{$\begin{array}{l}\text { Nordeste } \\
\text { Asiático - } \\
\text { Chukchi }\end{array}$} & $\mathrm{n}$ & 4 & 4 & 3 & 4 & 4 & 4 & 4 & 4 & 4 \\
\hline & $\%$ & 100,00 & 100,00 & 75,00 & 100,00 & 100,00 & 100,00 & 100,00 & 100,00 & 100,00 \\
\hline & média & 26,38 & 52,00 & 63,67 & 24,25 & 16,50 & 6,84 & 2,28 & 97,23 & 18,62 \\
\hline \multirow{3}{*}{$\begin{array}{l}\text { Nordeste } \\
\text { Asiático - } \\
\text { Mongóis }\end{array}$} & $\mathrm{n}$ & 64 & 64 & 63 & 64 & 64 & 64 & 64 & 62 & 61 \\
\hline & $\%$ & 98,46 & 98,46 & 96,92 & 98,46 & 98,46 & 98,46 & 98,46 & 95,38 & 93,85 \\
\hline & média & 26,09 & 52,49 & 62,52 & 23,67 & 15,53 & 6,50 & 1,96 & 95,90 & 17,89 \\
\hline \multirow{3}{*}{$\begin{array}{l}\text { Papua Nova Guiné } \\
\text { - Província Central }\end{array}$} & $\mathrm{n}$ & 4 & 4 & 4 & 4 & 4 & 4 & 4 & 4 & 4 \\
\hline & $\%$ & 100,00 & 100,00 & 100,00 & 100,00 & 100,00 & 100,00 & 100,00 & 100,00 & 100,00 \\
\hline & média & 24,75 & 47,25 & 62,00 & 24,50 & 17,00 & 7,35 & 2,75 & 93,75 & 23,31 \\
\hline \multirow{3}{*}{$\begin{array}{l}\text { Papua Nova Guiné } \\
\text { - Eastern Is }\end{array}$} & $\mathrm{n}$ & 5 & 5 & 5 & 5 & 5 & 4 & 4 & 5 & 5 \\
\hline & $\%$ & 100,00 & 100,00 & 100,00 & 100,00 & 100,00 & 80,00 & 80,00 & 100,00 & 100,00 \\
\hline & média & 23,20 & 47,60 & 59,40 & 25,40 & 18,80 & 7,02 & 2,07 & 92,20 & 25,29 \\
\hline & $n$ & 37 & 28 & 37 & 37 & 38 & 37 & 33 & 37 & 36 \\
\hline $\begin{array}{l}\text { Papua Nova Guiné } \\
\text { - Provincia do Golfo }\end{array}$ & $\%$ & 88,10 & 66,67 & 88,10 & 88,10 & 90,48 & 88,10 & 78,57 & 88,10 & 85,71 \\
\hline & média & 25,57 & 49,21 & 62,69 & 25,35 & 16,84 & 8,71 & 3,33 & 92,29 & 28,02 \\
\hline & $\mathrm{n}$ & 4 & 4 & 4 & 4 & 4 & 4 & 4 & 4 & 4 \\
\hline $\begin{array}{l}\text { nè } \\
\text { ng }\end{array}$ & $\%$ & 100,00 & 100,00 & 100,00 & 100,00 & 100,00 & 100,00 & 100,00 & 100,00 & 100,00 \\
\hline & média & 25,00 & 46,00 & 59,88 & 23,75 & 15,13 & 7,65 & 3,14 & 89,03 & 25,12 \\
\hline uné & $\mathrm{n}$ & 4 & 4 & 4 & 4 & 4 & 4 & 4 & 4 & 4 \\
\hline - Provín & $\%$ & 100,00 & 100,00 & 100,00 & 100,00 & 100,00 & 100,00 & 100,00 & 100,00 & 100,00 \\
\hline & média & 25,50 & 49,50 & 61,50 & 24,25 & 17,75 & 9,77 & 2,81 & 94,75 & 25,82 \\
\hline Guiné & $\mathrm{n}$ & 24 & 24 & 23 & 25 & 25 & 24 & 23 & 24 & 24 \\
\hline- & $\%$ & 88,89 & 88,89 & 85,19 & 92,59 & 92,59 & 88,89 & 85,19 & 88,89 & 88,89 \\
\hline & média & 25,10 & 47,17 & 60,91 & 24,20 & 16,24 & 8,19 & 3,08 & 91,96 & 25,43 \\
\hline Papua No & $\mathrm{n}$ & 33 & 33 & 33 & 33 & 33 & 33 & 33 & 33 & 33 \\
\hline - Prov & $\%$ & 100,00 & 100,00 & 100,00 & 100,00 & 100,00 & "'t" & 100,00 & 100,00 & 100,00 \\
\hline Ocider & média & 25,38 & 47,45 & 60,70 & 25,12 & 15,88 & 8,70 & 3,29 & 93,49 & 24,86 \\
\hline Papua Nova & $\mathrm{n}$ & 8 & 8 & 5 & 8 & 8 & 8 & 8 & 7 & 7 \\
\hline Guiné - & $\%$ & 88,89 & 88,89 & 55,56 & 88,89 & 88,89 & 88,89 & 88,89 & 77,78 & 77,78 \\
\hline "desconhecido" & média & 25,75 & 48,13 & 60,20 & 24,75 & 18,63 & 7,82 & 2,86 & 89,14 & 27,31 \\
\hline Papua & $\bar{n}$ & 11 & 9 & 10 & 11 & 12 & 12 & 12 & 11 & 10 \\
\hline$-\operatorname{PrC}$ & $\%$ & 91,67 & 75,00 & 83,33 & 91,67 & 100,00 & 100,00 & 100,00 & 91,67 & 83,33 \\
\hline & média & 25,09 & 48,67 & 63,00 & 25,18 & 15,67 & 8,95 & 3,25 & 93,36 & 26,00 \\
\hline Polinésia - & $\mathrm{n}$ & 5 & 4 & 5 & 6 & 6 & 5 & 5 & 5 & 5 \\
\hline Moriori & $\%$ & 83,33 & 66,67 & 83,33 & 100,00 & 100,00 & 83,33 & 83,33 & 83,33 & 83,33 \\
\hline Chatan) & média & 25,40 & 49,75 & 61,50 & 26,17 & 17,17 & 7,69 & 2,48 & 91,44 & 26,61 \\
\hline & $n$ & 4 & 4 & 3 & 4 & 4 & 4 & 4 & 3 & 3 \\
\hline Pollinesia - & $\%$ & 100,00 & 100,00 & 75,00 & 100,00 & 100,00 & 100,00 & 100,00 & 75,00 & 75,00 \\
\hline & média & 27,00 & 50,00 & 60,00 & 28,75 & 18,50 & 8,17 & 3,05 & 92,67 & 22,09 \\
\hline & $\mathrm{n}$ & 28 & 28 & 26 & 28 & 31 & 31 & 31 & 25 & 25 \\
\hline rollnesia - & $\%$ & 71,79 & 71,79 & 66,67 & 71,79 & 79,49 & 79,49 & 79,49 & 64,10 & 64,10 \\
\hline & média & 25,64 & 49,46 & 58,62 & 26,23 & 18,18 & 7,44 & 2,50 & 91,70 & 22,52 \\
\hline Polinésia - & $\mathrm{n}$ & 20 & 20 & 20 & 20 & 20 & 20 & 20 & 20 & 20 \\
\hline & $\%$ & 100,00 & 100,00 & 100,00 & 100,00 & 100,00 & 100,00 & 100,00 & 100,00 & 100,00 \\
\hline Marquesas & média & 24,85 & 49,65 & 62,18 & 24,40 & 15,98 & 6,71 & 2,42 & 93,23 & 22,96 \\
\hline Polinésia - & $\bar{n}$ & 22 & 22 & 22 & 21 & 22 & 22 & 22 & 22 & 22 \\
\hline Maori Nova & $\%$ & 95,65 & 95,65 & 95,65 & 91,30 & 95,65 & 95,65 & 95,65 & 95,65 & 95,65 \\
\hline Zelândia & média & 24,95 & 48,84 & 61,89 & 25,43 & 17,14 & 6,27 & 2,03 & 92,11 & 24,25 \\
\hline & $\mathrm{n}$ & 1 & 1 & 1 & 1 & 1 & 1 & 1 & 1 & 1 \\
\hline Polinesia - & $\%$ & 100,00 & 100,00 & 100,00 & 100,00 & 100,00 & "'t" & 100,00 & 100,00 & 100,00 \\
\hline & média & 25,50 & 46,50 & 58,50 & 20,00 & 15,00 & 7,44 & 2,95 & 91,60 & 23,22 \\
\hline Sudeste & $\mathrm{n}$ & 22 & 22 & 20 & 22 & 23 & 22 & 22 & 22 & 21 \\
\hline Asiático - Ilhas & $\%$ & 91,67 & 91,67 & 83,33 & 91,67 & 95,83 & 91,67 & 91,67 & 91,67 & 87,50 \\
\hline Andaman & média & 23,70 & 45,36 & 59,30 & 23,36 & 15,04 & 8,75 & 2,29 & 91,25 & 23,05 \\
\hline & $n$ & 4 & 5 & 4 & 5 & 5 & 3 & 3 & 4 & 4 \\
\hline
\end{tabular}




\begin{tabular}{|c|c|c|c|c|c|c|c|c|c|c|}
\hline \multirow[b]{2}{*}{$\begin{array}{l}\text { Sudeste } \\
\text { Asiático - }\end{array}$} & $n$ & 4 & 5 & 4 & 5 & 5 & 3 & 3 & 4 & 4 \\
\hline & média & $\begin{array}{l}80,00 \\
24,75\end{array}$ & $\begin{array}{r}100,00 \\
47,00\end{array}$ & $\begin{array}{l}80,00 \\
58,75\end{array}$ & $\begin{array}{r}100,00 \\
25,40\end{array}$ & $\begin{array}{r}100,00 \\
18,60\end{array}$ & $\begin{array}{r}60,00 \\
6,45\end{array}$ & $\begin{array}{r}60,00 \\
1,86\end{array}$ & $\begin{array}{l}80,00 \\
95,25\end{array}$ & $\begin{array}{l}80,00 \\
23,98\end{array}$ \\
\hline \multirow{3}{*}{$\begin{array}{l}\text { Bordested } \\
\text { Asiático - } \\
\text { Borneo } 2\end{array}$} & $n$ & 5 & 5 & 5 & 5 & 5 & 4 & 4 & 5 & 5 \\
\hline & $\%$ & 100,00 & 100,00 & 100,00 & 100,00 & 100,00 & 80,00 & 80,00 & 100,00 & 100,00 \\
\hline & média & 25,30 & 47,00 & 59,00 & 25,00 & 16,40 & 6,69 & 1,63 & 93,60 & 20,60 \\
\hline \multirow{3}{*}{$\begin{array}{l}\text { Sudeste } \\
\text { Asiático - } \\
\text { Celebes }\end{array}$} & $n$ & 2 & 2 & 2 & 2 & 2 & 2 & 2 & 2 & 2 \\
\hline & $\%$ & 100,00 & 100,00 & 100,00 & 100,00 & 100,00 & 100,00 & 100,00 & 100,00 & 100,00 \\
\hline & média & 26,75 & 50,00 & 60,50 & 24,50 & 16,50 & 8,19 & 3,30 & 93,12 & 19,26 \\
\hline \multirow{3}{*}{$\begin{array}{c}\text { Sudeste } \\
\text { Asiático - Java }\end{array}$} & $\mathrm{n}$ & 7 & 7 & 6 & 8 & 8 & 8 & 8 & 7 & 7 \\
\hline & $\%$ & 87,50 & 87,50 & 75,00 & 100,00 & 100,00 & 100,00 & 100,00 & 87,50 & 87,50 \\
\hline & média & 26,71 & 50,00 & 61,33 & 27,75 & 16,63 & 8,17 & 2,84 & 94,56 & 22,62 \\
\hline \multirow{3}{*}{$\begin{array}{c}\text { Sudeste } \\
\text { Asiático - } \\
\text { Malásia } \\
\end{array}$} & $\mathrm{n}$ & 4 & 4 & 3 & 5 & 5 & 4 & 4 & 3 & 3 \\
\hline & $\%$ & 80,00 & 80,00 & 60,00 & 100,00 & 100,00 & 80,00 & 80,00 & 60,00 & 60,00 \\
\hline & média & 24,25 & 49,00 & 62,00 & 23,00 & 15,60 & 9,16 & 2,41 & 90,53 & 21,25 \\
\hline \multirow{3}{*}{$\begin{array}{l}\text { Sudeste } \\
\text { Asiático - } \\
\text { Molucca }\end{array}$} & $n$ & 5 & 5 & 5 & 5 & 5 & 4 & 4 & 5 & 4 \\
\hline & $\%$ & 100,00 & 100,00 & 100,00 & 100,00 & 100,00 & 80,00 & 80,00 & 100,00 & 80,00 \\
\hline & média & 25,40 & 48,40 & 59,80 & 22,20 & 14,60 & 8,67 & 2,11 & 87,92 & 20,09 \\
\hline \multirow{3}{*}{$\begin{array}{c}\text { Sudeste } \\
\text { Asiático - } \\
\text { Myanmar }\end{array}$} & $\mathrm{n}$ & 3 & 3 & 3 & $\overline{3}$ & 3 & 3 & 3 & 3 & 3 \\
\hline & $\%$ & 100,00 & 100,00 & 100,00 & 100,00 & 100,00 & 100,00 & 100,00 & 100,00 & 100,00 \\
\hline & média & 26,00 & 48,33 & 61,00 & 26,33 & 16,33 & 7,53 & 2,40 & 98,03 & 22,36 \\
\hline \multirow{3}{*}{$\begin{array}{l}\text { Sudeste } \\
\text { Asiático - } \\
\text { Filipinas } \\
\text { (negrito) }\end{array}$} & $\mathrm{n}$ & 9 & 9 & 9 & $\overline{9}$ & 9 & 8 & 8 & 9 & 9 \\
\hline & $\%$ & 100,00 & 100,00 & 100,00 & 100,00 & 100,00 & 88,89 & 88,89 & 100,00 & 100,00 \\
\hline & média & 25,39 & 46,33 & 59,89 & 22,89 & 15,11 & 8,67 & 2,11 & 91,31 & 18,69 \\
\hline \multirow{3}{*}{$\begin{array}{c}\text { Sudeste } \\
\text { Asiático - Is } \\
\text { Nicobar }\end{array}$} & $\mathrm{n}$ & 2 & 2 & 2 & $\overline{2}$ & 2 & 2 & 2 & $\overline{2}$ & 2 \\
\hline & $\%$ & 100,00 & 100,00 & 100,00 & 100,00 & 100,00 & 100,00 & 100,00 & 100,00 & 100,00 \\
\hline & média & 28,50 & 47,50 & 60,00 & 26,00 & 18,00 & 12,51 & 2,88 & 100,00 & 25,15 \\
\hline & $\mathrm{n}$ & 37 & 37 & 35 & 38 & 38 & 38 & 38 & 36 & 35 \\
\hline Asi & $\%$ & 97,37 & 97,37 & 92,11 & 100,00 & 100,00 & 100,00 & 100,00 & 94,74 & 92,11 \\
\hline & média & 26,14 & 48,59 & 61,17 & 23,67 & 15,97 & 8,57 & 2,49 & 92,90 & 20,25 \\
\hline Sudeste & $\mathrm{n}$ & 15 & 15 & 15 & 15 & 15 & 15 & 15 & 15 & 15 \\
\hline Asiático - & $\%$ & 100,00 & 100,00 & 100,00 & 100,00 & 100,00 & 100,00 & 100,00 & 100,00 & 100,00 \\
\hline Singapura & média & 25,23 & 49,10 & 63,37 & 24,23 & 14,90 & 6,80 & 2,10 & 94,38 & 21,18 \\
\hline & $\mathrm{n}$ & 3 & 3 & 3 & 3 & 3 & 3 & 3 & 3 & 3 \\
\hline Sudeste & $\%$ & 100,00 & 100,00 & 100,00 & 100,00 & 100,00 & 100,00 & 100,00 & 100,00 & 100,00 \\
\hline suru & média & 22,67 & 49,00 & 61,00 & 21,33 & 15,33 & 5,96 & 1,80 & 90,43 & 19,83 \\
\hline Sudeste & $\mathrm{n}$ & 3 & 3 & 3 & $\overline{3}$ & 3 & 3 & 3 & $\overline{3}$ & 3 \\
\hline Asiático - & $\%$ & 100,00 & 100,00 & 100,00 & 100,00 & 100,00 & 100,00 & 100,00 & 100,00 & 100,00 \\
\hline Sumatra & média & 26,33 & 47,00 & 61,67 & 24,33 & 17,00 & 8,43 & 1,58 & 92,16 & 17,40 \\
\hline Sudeste & $n$ & 11 & 11 & 11 & 11 & 11 & 11 & 11 & 11 & 11 \\
\hline Asiático - & $\%$ & 100,00 & 100,00 & 100,00 & 100,00 & 100,00 & 100,00 & 100,00 & 100,00 & 100,00 \\
\hline Tailândia & média & 25,77 & 47,32 & 59,68 & 22,41 & 14,73 & 8,20 & 2,24 & 91,74 & 20,44 \\
\hline Sudeste & $\mathrm{n}$ & 2 & 2 & 1 & 2 & 2 & 2 & 2 & 2 & 2 \\
\hline Asiático - & $\%$ & 100,00 & 100,00 & 50,00 & 100,00 & 100,00 & 100,00 & 100,00 & 100,00 & 100,00 \\
\hline Timor & média & 27,00 & 49,00 & 61,00 & 24,00 & 14,00 & 8,41 & 2,71 & 91,39 & 23,14 \\
\hline África Sub- & $\mathrm{n}$ & 16 & 16 & 16 & 16 & 16 & 16 & 16 & 16 & 16 \\
\hline Saariana - & $\%$ & 100,00 & 100,00 & 100,00 & 100,00 & 100,00 & 100,00 & 100,00 & 100,00 & 100,00 \\
\hline Camarões & média & 25,94 & 48,16 & 61,72 & 23,53 & 14,50 & 8,87 & 2,71 & 94,66 & 21,95 \\
\hline África Sub- & $\mathrm{n}$ & 3 & 3 & 3 & 3 & 3 & 3 & 1 & 3 & 3 \\
\hline Saariana - & $\%$ & 100,00 & 100,00 & 100,00 & 100,00 & 100,00 & 100,00 & 33,33 & 100,00 & 100,00 \\
\hline Congo & média & 26,17 & 46,67 & 64,83 & 26,17 & 18,00 & "6,50 & 0,60 & 92,87 & 22,39 \\
\hline África Sub- & $n$ & 1 & 1 & 1 & 1 & 1 & 1 & 1 & 1 & 1 \\
\hline Saariana - & $\%$ & 100,00 & 100,00 & 100,00 & 100,00 & 100,00 & "' & 100,00 & 100,00 & 100,00 \\
\hline Etiópia & média & 27,00 & 53,00 & 62,00 & 28,00 & 17,00 & 6,58 & 3,00 & 86,00 & 25,12 \\
\hline África Sub- & $\mathrm{n}$ & 5 & 5 & 5 & 5 & 5 & 5 & 5 & 5 & 5 \\
\hline Saariana - & $\%$ & 100,00 & 100,00 & 100,00 & 100,00 & 100,00 & 100,00 & 100,00 & 100,00 & 100,00 \\
\hline Gabão & média & 26,60 & 46,60 & 59,80 & 23,40 & 15,20 & 7,78 & 1,81 & 92,88 & 22,73 \\
\hline África Sub- & $\mathrm{n}$ & 40 & 40 & 40 & 40 & 40 & 38 & 37 & 39 & 39 \\
\hline Saariana - & $\%$ & 100,00 & 100,00 & 100,00 & 100,00 & 100,00 & 95,00 & 92,50 & 97,50 & 97,50 \\
\hline Ashanti Gana & média & 26,40 & 46,09 & 60,91 & 23,66 & 14,83 & 8,88 & 2,51 & 91,67 & 21,33 \\
\hline África Sub- & $n$ & 29 & 29 & 29 & 28 & 29 & 29 & 27 & 26 & 26 \\
\hline Saariana - & $\%$ & 100,00 & 100,00 & 100,00 & 96,55 & 100,00 & 100,00 & 93,10 & 89,66 & 89,66 \\
\hline Quênia & média & 26,10 & 46,14 & 60,90 & 23,61 & 15,76 & 8,78 & 1,80 & 92,18 & 22,70 \\
\hline África Sub- & $\mathrm{n}$ & 5 & 5 & 5 & $\overline{5}$ & 5 & 5 & 5 & $\overline{5}$ & 5 \\
\hline Saariana - & $\%$ & 100,00 & 100,00 & 100,00 & 100,00 & 100,00 & 100,00 & 100,00 & 100,00 & 100,00 \\
\hline Libéria & média & 28,20 & 47,50 & 64,20 & 23,40 & 15,80 & 9,93 & 2,57 & 94,44 & 22,99 \\
\hline África Sub- & $n$ & 1 & 1 & 1 & $\overline{1}$ & 1 & 1 & 1 & 1 & 1 \\
\hline Saariana - & $\%$ & 100,00 & 100,00 & 100,00 & 100,00 & 100,00 & 100,00 & 100,00 & 100,00 & 100,00 \\
\hline Moçambique & média & 26,00 & 45,00 & 62,00 & 25,00 & 14,50 & 3,61 & 0,67 & 98,30 & 19,83 \\
\hline & $n$ & 24 & 24 & 24 & 24 & 24 & 24 & 23 & 24 & 24 \\
\hline
\end{tabular}




\begin{tabular}{|c|c|c|c|c|c|c|c|c|c|c|}
\hline \multirow[b]{2}{*}{$\begin{array}{c}\text { África Sub- } \\
\text { Saariana - lbo }\end{array}$} & $\mathrm{n}$ & 24 & 24 & 24 & 24 & 24 & 24 & 23 & 24 & 24 \\
\hline & média & $\begin{array}{r}100,00 \\
27,73 \\
\end{array}$ & $\begin{array}{r}100,00 \\
47,96 \\
\end{array}$ & $\begin{array}{r}100,00 \\
61,38 \\
\end{array}$ & $\begin{array}{r}100,00 \\
25,54 \\
\end{array}$ & $\begin{array}{r}100,00 \\
16,50 \\
\end{array}$ & $\begin{array}{r}100,00 \\
9,86 \\
\end{array}$ & $\begin{array}{r}95,83 \\
3,07 \\
\end{array}$ & $\begin{array}{r}100,00 \\
93,93 \\
\end{array}$ & $\begin{array}{r}100,00 \\
20,83 \\
\end{array}$ \\
\hline \multirow{3}{*}{$\begin{array}{l}\text { ÁfNilogé8ab- } \\
\text { Saariana - } \\
\text { Nigéria } \\
\text { (outros) }\end{array}$} & $\mathrm{n}$ & 1 & 1 & 1 & 1 & 1 & 1 & 1 & 1 & 1 \\
\hline & $\%$ & 100,00 & 100,00 & 100,00 & 100,00 & 100,00 & 100,00 & 100,00 & 100,00 & 100,00 \\
\hline & média & 28,00 & 48,00 & 61,00 & 24,00 & 15,00 & 8,33 & 2,34 & 92,00 & 20,22 \\
\hline \multirow{3}{*}{$\begin{array}{c}\text { África Sub- } \\
\text { Saariana - } \\
\text { Ruanda }\end{array}$} & $n$ & 1 & 1 & 1 & 1 & 1 & 1 & 1 & 1 & 1 \\
\hline & $\%$ & 100,00 & 100,00 & 100,00 & 100,00 & 100,00 & 100,00 & 100,00 & 100,00 & 100,00 \\
\hline & média & 25,50 & 42,00 & 63,00 & 19,00 & 11,00 & 10,45 & 0,95 & 93,10 & 19,83 \\
\hline \multirow{3}{*}{$\begin{array}{l}\text { África Sub- } \\
\text { Saariana - } \\
\text { Somália }\end{array}$} & $n$ & 3 & 3 & 3 & 3 & 3 & 3 & 3 & 3 & 3 \\
\hline & $\%$ & 100,00 & 100,00 & 100,00 & 100,00 & 100,00 & 100,00 & 100,00 & 100,00 & 100,00 \\
\hline & média & 25,50 & 44,00 & 59,50 & 23,33 & 16,00 & "'10,33 & 2,20 & 88,52 & 20,04 \\
\hline \multirow{3}{*}{$\begin{array}{c}\text { África Sub- } \\
\text { Saariana - } \\
\text { África do Sul }\end{array}$} & $\mathrm{n}$ & 8 & 8 & 8 & 8 & 8 & 8 & 7 & 7 & 7 \\
\hline & $\%$ & 100,00 & 100,00 & 100,00 & 100,00 & 100,00 & '" & 87,50 & 87,50 & 87,50 \\
\hline & média & 26,75 & 45,56 & 60,81 & 22,25 & 14,25 & 8,81 & 1,97 & 93,71 & 20,59 \\
\hline \multirow{3}{*}{$\begin{array}{l}\text { África Sub- } \\
\text { Saariana - } \\
\text { Bushman } \\
\text { África do Sul }\end{array}$} & $\mathrm{n}$ & 5 & 5 & 5 & 5 & 5 & 4 & 3 & 5 & 5 \\
\hline & $\%$ & 100,00 & 100,00 & 100,00 & 100,00 & 100,00 & 80,00 & 60,00 & 100,00 & 100,00 \\
\hline & média & 26,20 & 44,00 & 60,40 & 20,50 & 12,40 & 5,96 & 1,31 & 90,22 & 18,97 \\
\hline \multirow{3}{*}{$\begin{array}{l}\text { África Sub- } \\
\text { Saariana - } \\
\text { Hottentot } \\
\text { África do Sul }\end{array}$} & $\mathrm{n}$ & 1 & 1 & 1 & 1 & 1 & 1 & 1 & 1 & 1 \\
\hline & $\%$ & 100,00 & 100,00 & 100,00 & 100,00 & 100,00 & 100,00 & 100,00 & 100,00 & 100,00 \\
\hline & média & 27,00 & 48,00 & 59,00 & 24,00 & 14,00 & 7,95 & 2,28 & 91,80 & 20,57 \\
\hline \multirow{3}{*}{$\begin{array}{c}\text { África Sub- } \\
\text { Saariana - } \\
\text { Kafir África do } \\
\text { Sul }\end{array}$} & $n$ & 1 & 1 & 1 & 1 & 1 & 1 & 1 & 1 & 1 \\
\hline & $\%$ & 100,00 & 100,00 & 100,00 & 100,00 & 100,00 & 100,00 & 100,00 & 100,00 & 100,00 \\
\hline & média & 27,00 & 43,00 & 60,00 & 21,00 & 15,00 & 8,38 & 3,17 & 87,30 & 20,78 \\
\hline \multirow{3}{*}{$\begin{array}{l}\text { África Sub- } \\
\text { Saariana - } \\
\text { Zulu }\end{array}$} & $n$ & 1 & 1 & 1 & 1 & 1 & 1 & 1 & 1 & 1 \\
\hline & $\%$ & 100,00 & 100,00 & 100,00 & 100,00 & 100,00 & 100,00 & 100,00 & 100,00 & 100,00 \\
\hline & média & 31,00 & 51,50 & 61,50 & 20,00 & 13,00 & 15,97 & 0,89 & 93,30 & 20,49 \\
\hline \multirow{3}{*}{$\begin{array}{c}\text { África Sub- } \\
\text { Saariana - } \\
\text { Tanzânia } \\
\end{array}$} & $\mathrm{n}$ & 27 & 27 & 27 & 27 & 27 & 27 & 27 & 24 & 24 \\
\hline & $\%$ & 100,00 & 100,00 & 100,00 & 100,00 & 100,00 & 100,00 & 100,00 & 88,89 & 88,89 \\
\hline & média & 26,09 & 47,19 & 61,54 & 22,70 & 14,26 & 9,08 & 1,88 & 94,31 & 21,41 \\
\hline \multirow{3}{*}{$\begin{array}{l}\text { África Sub- } \\
\text { Saariana - } \\
\text { África } \\
\text { Ocidental } \\
\end{array}$} & $\mathrm{n}$ & 4 & 4 & 4 & 4 & 4 & 4 & 4 & 4 & 4 \\
\hline & $\%$ & 100,00 & 100,00 & 100,00 & 100,00 & 100,00 & 100,00 & 100,00 & 100,00 & 100,00 \\
\hline & média & 24,75 & 45,75 & 57,63 & 21,25 & 13,25 & 8,29 & 2,30 & 89,55 & 22,66 \\
\hline & $n$ & 1 & 1 & 1 & 1 & 1 & 1 & 1 & 1 & 1 \\
\hline Saariana - & $\%$ & 100,00 & 100,00 & 100,00 & 100,00 & 100,00 & 100,00 & 100,00 & 100,00 & 100,00 \\
\hline Zâmbia & média & 26,00 & 49,00 & 65,00 & 23,00 & 15,00 & 11,04 & 3,44 & 93,10 & 27,27 \\
\hline Sudoeste & $n$ & 8 & 8 & 8 & 8 & 8 & 8 & 8 & 8 & 8 \\
\hline Asiático - & $\%$ & 100,00 & 100,00 & 100,00 & 100,00 & 100,00 & 100,00 & 100,00 & 100,00 & 100,00 \\
\hline Beduíno & média & 23,81 & 46,44 & 61,19 & 23,44 & 14,88 & 8,98 & 3,46 & 88,23 & 21,49 \\
\hline Sudoeste & $\mathrm{n}$ & 4 & 4 & 4 & 4 & 4 & 4 & 4 & 4 & 4 \\
\hline Asiático - & $\%$ & 100,00 & 100,00 & 100,00 & 100,00 & 100,00 & "' 100,00 & 100,00 & 100,00 & 100,00 \\
\hline Iraque & média & 22,88 & 46,88 & 60,00 & 26,50 & 15,00 & 8,11 & 4,62 & 85,39 & 21,82 \\
\hline Sudoeste & $n$ & 7 & 7 & 7 & 7 & 7 & 7 & 6 & 7 & 7 \\
\hline Asiático - & $\%$ & 100,00 & 100,00 & 100,00 & 100,00 & 100,00 & 100,00 & 85,71 & 100,00 & 100,00 \\
\hline Iraque (early) & média & 24,36 & 48,50 & 57,79 & 23,36 & 15,43 & 9,97 & 4,92 & 88,65 & 24,61 \\
\hline Sudoeste & $n$ & 1 & 1 & 1 & 1 & 1 & 1 & 1 & 1 & 1 \\
\hline Asiático - & $\%$ & 100,00 & 100,00 & 100,00 & 100,00 & 100,00 & 100,00 & 100,00 & 100,00 & 100,00 \\
\hline Líbano & média & 23,00 & 45,50 & 59,50 & 23,00 & 15,00 & 8,54 & 3,77 & 87,20 & 23,01 \\
\hline Sudoeste & $n$ & 5 & 5 & 5 & 5 & 5 & 5 & 5 & 5 & 5 \\
\hline Asiático - & $\%$ & 100,00 & 100,00 & 100,00 & 100,00 & 100,00 & "' & 100,00 & 100,00 & 100,00 \\
\hline Palestina & média & 24,90 & 49,90 & 60,40 & 22,40 & 14,00 & 9,94 & 4,26 & 90,14 & 21,99 \\
\hline & $n$ & 5 & 5 & 5 & 5 & 5 & 5 & 4 & 5 & 5 \\
\hline Súria & $\%$ & 100,00 & 100,00 & 100,00 & 100,00 & 100,00 & 100,00 & 80,00 & 100,00 & 100,00 \\
\hline & média & 23,90 & 49,10 & 58,30 & 22,50 & 13,40 & 8,28 & 3,85 & 88,52 & 22,15 \\
\hline Sudoeste & $\mathrm{n}$ & 17 & 17 & 17 & 17 & 17 & 17 & 17 & 17 & 17 \\
\hline Asiático - & $\%$ & 100,00 & 100,00 & 100,00 & 100,00 & 100,00 & 100,00 & 100,00 & 100,00 & 100,00 \\
\hline Turquia & média & 23,53 & 50,26 & 59,59 & 25,15 & 14,65 & 10,13 & 4,55 & 90,11 & 23,34 \\
\hline & $n$ & 5 & 5 & 3 & 5 & 5 & 5 & 5 & 5 & 5 \\
\hline $\begin{array}{l}\text { Gol } \\
- \text { Pol }\end{array}$ & $\%$ & 100,00 & 100,00 & 60,00 & 100,00 & 100,00 & 100,00 & 100,00 & 100,00 & 100,00 \\
\hline & média & 23,40 & 50,90 & 60,00 & 25,00 & 14,80 & 8,42 & 3,63 & 90,96 & 22,06 \\
\hline Grã-Bretanha & $n$ & 16 & 16 & 16 & 15 & 15 & 16 & 15 & 16 & 16 \\
\hline - Spitafields & $\%$ & 100,00 & 100,00 & 100,00 & 93,75 & 93,75 & 100,00 & 93,75 & 100,00 & 100,00 \\
\hline CAM & média & 23,75 & 46,69 & 59,50 & 24,40 & 14,47 & 9,56 & 3,92 & 87,61 & 21,39 \\
\hline Grã-Bretanha & $\mathrm{n}$ & 83 & 84 & 61 & 88 & 88 & 87 & 87 & 79 & 79 \\
\hline - Spitafields & $\%$ & 94,32 & 95,45 & 69,32 & 100,00 & 100,00 & 98,86 & 98,86 & 89,77 & 89,77 \\
\hline $\mathrm{NHM}$ & média & 22,73 & 48,30 & 56,54 & 22,84 & 13,81 & 8,18 & 3,73 & 83,96 & 22,00 \\
\hline
\end{tabular}




\begin{tabular}{|c|c|c|c|c|c|c|c|c|c|c|}
\hline \multirow{3}{*}{$\begin{array}{c}\text { EUA - } \\
\text { Alabama }\end{array}$} & $n$ & 7 & 7 & 6 & 7 & 7 & 7 & 7 & 7 & 7 \\
\hline & $\%$ & 100,00 & 100,00 & 85,71 & 100,00 & 100,00 & 100,00 & 100,00 & 100,00 & 100,00 \\
\hline & média & 25,43 & 51,36 & 64,50 & 23,14 & 15,43 & 9,19 & 3,42 & 96,46 & 24,45 \\
\hline \multirow{3}{*}{$\begin{array}{c}\text { EUA - nativos } \\
\text { do Alaska }\end{array}$} & $\mathrm{n}$ & 28 & 28 & 28 & 27 & 28 & 28 & 28 & 26 & 26 \\
\hline & $\%$ & 96,55 & 96,55 & 96,55 & 93,10 & 96,55 & 96,55 & 96,55 & 89,66 & 89,66 \\
\hline & média & 24,30 & 51,36 & 62,27 & 23,00 & 15,21 & 7,60 & 2,73 & 95,15 & 20,70 \\
\hline \multirow{3}{*}{$\begin{array}{c}\text { EUA - Alaska } \\
\text { (Kodiak) }\end{array}$} & $n$ & 14 & 14 & 13 & 13 & 13 & 14 & 14 & 12 & 10 \\
\hline & $\%$ & 100,00 & 100,00 & 92,86 & 92,86 & 92,86 & 100,00 & 100,00 & 85,71 & 71,43 \\
\hline & média & 23,93 & 51,11 & 63,50 & 21,92 & 15,85 & 7,14 & 2,31 & 95,20 & 20,79 \\
\hline \multirow{3}{*}{$\begin{array}{c}\text { EUA - Alaska } \\
\text { (Tlingit) }\end{array}$} & $\mathrm{n}$ & 11 & 11 & 11 & 11 & 11 & 11 & 11 & 11 & 11 \\
\hline & $\%$ & 100,00 & 100,00 & 100,00 & 100,00 & 100,00 & 100,00 & 100,00 & 100,00 & 100,00 \\
\hline & média & 24,64 & 50,59 & 61,09 & 22,00 & 16,45 & 8,20 & 2,51 & 94,79 & 18,90 \\
\hline \multirow{3}{*}{ EUA - Arizona } & $\mathrm{n}$ & 0 & 0 & 1 & 0 & 0 & 0 & 0 & 0 & 0 \\
\hline & $\%$ & 0,00 & 0,00 & 100,00 & 0,00 & 0,00 & 0,00 & 0,00 & 0,00 & 0,00 \\
\hline & média & - & $=$ & 64,00 & - & - & . & - & $\cdots$ & - \\
\hline \multirow{3}{*}{$\begin{array}{c}\text { EUA - } \\
\text { Arkansas }\end{array}$} & $n$ & 35 & 35 & 35 & 35 & 35 & 35 & 35 & 34 & 34 \\
\hline & $\%$ & 100,00 & 100,00 & 100,00 & 100,00 & 100,00 & 100,00 & 100,00 & 97,14 & 97,14 \\
\hline & média & 25,31 & 48,51 & 63,17 & 23,04 & 14,90 & 9,86 & 2,98 & 96,06 & 21,44 \\
\hline \multirow{3}{*}{$\begin{array}{c}\text { EUA - } \\
\text { Califórnia } 1\end{array}$} & $n$ & 12 & 12 & 12 & 12 & 12 & 11 & 11 & 12 & 12 \\
\hline & $\%$ & 100,00 & 100,00 & 100,00 & 100,00 & 100,00 & 91,67 & 91,67 & 100,00 & 100,00 \\
\hline & média & 25,42 & 52,04 & 63,25 & 22,33 & 15,33 & 8,99 & 3,10 & 95,26 & 24,31 \\
\hline \multirow{3}{*}{$\begin{array}{c}\text { EUA - } \\
\text { Califórnia } 2\end{array}$} & $n$ & 50 & 50 & 48 & 50 & 50 & 50 & 50 & 50 & 49 \\
\hline & $\%$ & 100,00 & 100,00 & 96,00 & 100,00 & 100,00 & 100,00 & 100,00 & 100,00 & 98,00 \\
\hline & média & 24,78 & 47,26 & 60,63 & 23,98 & 16,26 & 9,21 & 2,73 & 95,96 & 21,64 \\
\hline \multirow{3}{*}{$\begin{array}{c}\text { EUA - } \\
\text { Carolina do } \\
\text { Norte }\end{array}$} & $\mathrm{n}$ & 156 & 156 & 155 & 156 & 156 & 156 & 155 & 152 & 152 \\
\hline & $\%$ & 100,00 & 100,00 & 99,36 & 100,00 & 100,00 & 100,00 & 99,36 & 97,44 & 97,44 \\
\hline & média & 23,50 & 47,12 & 61,73 & 22,76 & 15,60 & 7,25 & 2,87 & 93,30 & 22,66 \\
\hline & $\mathrm{n}$ & 1 & 1 & 1 & 1 & 1 & 1 & 1 & 1 & 1 \\
\hline Color & $\%$ & 100,00 & 100,00 & 100,00 & 100,00 & 100,00 & 100,00 & 100,00 & 100,00 & 100,00 \\
\hline & média & 25,00 & 53,00 & 58,00 & 23,00 & 16,00 & 6,56 & 2,71 & 86,50 & 21,95 \\
\hline & $n$ & 2 & 2 & 1 & 2 & 2 & 2 & 2 & 2 & 2 \\
\hline EUA & $\%$ & 100,00 & 100,00 & 50,00 & 100,00 & 100,00 & 100,00 & 100,00 & 100,00 & 100,00 \\
\hline & média & 25,75 & 50,50 & 68,00 & 24,00 & 15,50 & '"10,56 & 2,39 & 94,25 & 21,12 \\
\hline & $n$ & 11 & 11 & 11 & 11 & 11 & 11 & 11 & 10 & 10 \\
\hline EUA - Lakota & $\%$ & 100,00 & 100,00 & 100,00 & 100,00 & 100,00 & 100,00 & 100,00 & 90,91 & 90,91 \\
\hline & média & 25,68 & 52,09 & 62,73 & 22,91 & 15,00 & 8,10 & 3,79 & 97,11 & 22,92 \\
\hline & $n$ & 76 & 76 & 76 & 76 & 76 & 76 & 76 & 74 & 74 \\
\hline Delav & $\%$ & 100,00 & 100,00 & 100,00 & 100,00 & 100,00 & 100,00 & 100,00 & 97,37 & 97,37 \\
\hline & média & 24,91 & 51,14 & 62,86 & 22,68 & 15,16 & 8,64 & 3,57 & 96,19 & 24,20 \\
\hline & $\mathrm{n}$ & 10 & 10 & 9 & 10 & 10 & 9 & 7 & 9 & 9 \\
\hline EUA - Flórida & $\%$ & 100,00 & 100,00 & 90,00 & 100,00 & 100,00 & 90,00 & 70,00 & 90,00 & 90,00 \\
\hline & média & 24,90 & 50,75 & 63,00 & 22,60 & 15,10 & 8,46 & 3,27 & 97,19 & 25,83 \\
\hline & $\mathrm{n}$ & 62 & 62 & 60 & 62 & 62 & 62 & 59 & 60 & 60 \\
\hline EUA - Geórgia & $\%$ & 100,00 & 100,00 & 96,77 & 100,00 & 100,00 & "'-"'-100,00 & 95,16 & 96,77 & 96,77 \\
\hline & média & 25,31 & 50,82 & 63,76 & 23,56 & 16,27 & 8,98 & 3,11 & 100,90 & 24,30 \\
\hline & $n$ & 10 & 10 & 9 & 10 & 10 & 9 & 8 & 8 & 8 \\
\hline She & $\%$ & 100,00 & 100,00 & 90,00 & 100,00 & 100,00 & 90,00 & 80,00 & 80,00 & 80,00 \\
\hline & média & 25,05 & 50,25 & 62,33 & 22,40 & 15,40 & 8,24 & 2,91 & 95,19 & 23,26 \\
\hline & $\mathrm{n}$ & 0 & 0 & 0 & 1 & 1 & 0 & 0 & 0 & 0 \\
\hline EUA - Illinois & $\%$ & 0,00 & 0,00 & 0,00 & 100,00 & 100,00 & 0,00 & 0,00 & 0,00 & 0,00 \\
\hline & média & & & & 19,00 & 13,00 & & & & \\
\hline & $\mathrm{n}$ & 88 & 88 & 88 & 88 & 88 & 88 & 87 & 88 & 88 \\
\hline EUA - Indiana & $\%$ & 100,00 & 100,00 & 100,00 & 100,00 & 100,00 & 100,00 & 98,86 & 100,00 & 100,00 \\
\hline & média & 25,52 & 50,16 & 62,98 & 23,07 & 15,50 & 8,65 & 2,94 & 96,12 & 24,66 \\
\hline & $\mathrm{n}$ & 2 & 2 & 2 & 2 & 2 & 2 & 2 & 1 & 1 \\
\hline EUA - Kansas & $\%$ & 100,00 & 100,00 & 100,00 & 100,00 & 100,00 & 100,00 & 100,00 & 50,00 & 50,00 \\
\hline & média & 25,00 & 49,00 & 63,00 & 20,00 & 15,50 & 5,23 & 1,79 & 91,70 & 20,68 \\
\hline $\mathrm{F}$ & $n$ & 11 & 11 & 11 & 11 & 11 & 11 & 11 & 11 & 11 \\
\hline Kentu & $\%$ & 100,00 & 100,00 & 100,00 & 100,00 & 100,00 & 100,00 & 100,00 & 100,00 & 100,00 \\
\hline & média & 26,23 & 49,82 & 62,95 & 21,82 & 15,18 & 8,75 & 3,28 & 98,12 & 23,78 \\
\hline & $n$ & 25 & 25 & 23 & 25 & 25 & 25 & 25 & 25 & 25 \\
\hline Lusiana & $\%$ & 100,00 & 100,00 & 92,00 & 100,00 & 100,00 & 100,00 & 100,00 & 100,00 & 100,00 \\
\hline & média & 23,66 & 47,70 & 59,96 & 21,20 & 15,48 & 8,30 & 2,70 & 91,21 & 22,09 \\
\hline & $n$ & 2 & 2 & 2 & 2 & 2 & 2 & 2 & 2 & 2 \\
\hline EUA - & $\%$ & 100,00 & 100,00 & 100,00 & 100,00 & 100,00 & "' 100,00 & 100,00 & 100,00 & 100,00 \\
\hline & média & 24,75 & 50,00 & 62,50 & 21,50 & 17,00 & 9,95 & 4,06 & 99,40 & 23,20 \\
\hline & $n$ & 42 & 42 & 36 & 42 & 42 & 41 & 36 & 36 & 36 \\
\hline scachusetts & $\%$ & 100,00 & 100,00 & 85,71 & 100,00 & 100,00 & 97,62 & 85,71 & 85,71 & 85,71 \\
\hline & média & 26,20 & 49,13 & 63,11 & 21,50 & 15,10 & 8,22 & 2,67 & 94,34 & 24,39 \\
\hline & $n$ & 3 & 3 & 3 & 3 & 3 & 3 & 3 & 3 & 3 \\
\hline
\end{tabular}




\begin{tabular}{|c|c|c|c|c|c|c|c|c|c|c|}
\hline \multirow{5}{*}{$\begin{array}{l}\text { EUA - } \\
\text { Michjigan } \\
\text { Mississipi }\end{array}$} & $n$ & 3 & 3 & 3 & 3 & 3 & 3 & 3 & 3 & 3 \\
\hline & média & $10 \theta, 00$ & 160,00 & $16 \theta, 00$ & 100,00 & $100, \theta 0$ & 100,00 & $10 Q, 0 \theta$ & $10 \theta, 00$ & 100,00 \\
\hline & $n$ & 6 & 6 & 6 & 6 & 6 & 6 & 6 & 5 & 5 \\
\hline & $\%$ & 100,00 & 100,00 & 100,00 & 100,00 & 100,00 & 100,00 & 100,00 & 83,33 & 83,33 \\
\hline & média & 26,50 & 49,75 & 61,67 & 21,00 & 15,50 & 8,03 & 3,57 & 93,42 & 24,52 \\
\hline \multirow{3}{*}{$\begin{array}{l}\text { EUA - } \\
\text { Missouri }\end{array}$} & $\mathrm{n}$ & 1 & 1 & 1 & 1 & 1 & 1 & 1 & 1 & 1 \\
\hline & $\%$ & 100,00 & 100,00 & 100,00 & 100,00 & 100,00 & 100,00 & 100,00 & 100,00 & 100,00 \\
\hline & média & 25,00 & 48,00 & 65,50 & 25,00 & 17,00 & 9,09 & 3,03 & 99,30 & 25,90 \\
\hline \multirow{3}{*}{$\begin{array}{l}\text { EUA - } \\
\text { Montana }\end{array}$} & $\mathrm{n}$ & 4 & 4 & 3 & 4 & 4 & 4 & 4 & 4 & 4 \\
\hline & $\%$ & 100,00 & 100,00 & 75,00 & 100,00 & 100,00 & 100,00 & 100,00 & 100,00 & 100,00 \\
\hline & média & 26,00 & 50,50 & 64,00 & 22,75 & 16,00 & 8,96 & 4,47 & 92,10 & 23,73 \\
\hline \multirow{3}{*}{$\begin{array}{l}\text { EUA - } \\
\text { Nebraska }\end{array}$} & $n$ & 7 & 7 & 7 & 7 & 7 & 7 & 7 & 6 & 6 \\
\hline & $\%$ & 100,00 & 100,00 & 100,00 & 100,00 & 100,00 & 100,00 & 100,00 & 85,71 & 85,71 \\
\hline & média & 25,71 & 51,57 & 62,64 & 21,57 & 14,57 & 8,61 & 2,82 & 97,32 & 21,29 \\
\hline \multirow{3}{*}{$\begin{array}{c}\text { EUA - New } \\
\text { Jersey }\end{array}$} & $n$ & 9 & 9 & 9 & 9 & 9 & 9 & 9 & $\overline{9}$ & $\overline{9}$ \\
\hline & $\%$ & 100,00 & 100,00 & 100,00 & 100,00 & 100,00 & 100,00 & 100,00 & 100,00 & 100,00 \\
\hline & média & 24,39 & 50,89 & 62,39 & 23,22 & 15,00 & 8,42 & 3,62 & 97,16 & 23,55 \\
\hline \multirow{3}{*}{$\begin{array}{l}\text { EUA - Novo } \\
\text { México }\end{array}$} & $\mathrm{n}$ & 7 & 7 & 6 & 7 & 7 & 7 & 7 & 5 & 5 \\
\hline & $\%$ & 100,00 & 100,00 & 85,71 & 100,00 & 100,00 & 100,00 & 100,00 & 71,43 & 71,43 \\
\hline & média & 26,14 & 48,43 & 62,67 & 23,00 & 15,43 & 8,61 & 3,08 & 91,94 & 23,09 \\
\hline \multirow{3}{*}{$\begin{array}{c}\text { EUA - Nova } \\
\text { York }\end{array}$} & $n$ & 50 & 50 & 48 & 50 & 50 & 50 & 50 & 49 & 49 \\
\hline & $\%$ & 100,00 & 100,00 & 96,00 & 100,00 & 100,00 & 100,00 & 100,00 & 98,00 & 98,00 \\
\hline & média & 25,66 & 48,87 & 61,67 & 23,40 & 15,56 & 9,95 & 2,97 & 96,38 & 22,23 \\
\hline \multirow{3}{*}{$\begin{array}{l}\text { EUA - } \\
\text { Oklahoma }\end{array}$} & $\mathrm{n}$ & 24 & 24 & 24 & 24 & 23 & 23 & 23 & 22 & 22 \\
\hline & $\%$ & 100,00 & 100,00 & 100,00 & 100,00 & 95,83 & 95,83 & 95,83 & 91,67 & 91,67 \\
\hline & média & 26,25 & 49,67 & 62,40 & 21,06 & 14,91 & 8,73 & 3,06 & 93,25 & 24,25 \\
\hline \multirow{3}{*}{ EUA - Oregon } & $n$ & 3 & 3 & 3 & 3 & 3 & 3 & 3 & 3 & $\overline{3}$ \\
\hline & $\%$ & 100,00 & 100,00 & 100,00 & 100,00 & 100,00 & 100,00 & 100,00 & 100,00 & 100,00 \\
\hline & média & 24,67 & 51,17 & 62,00 & 22,00 & 14,67 & 8,25 & 2,78 & 97,93 & 23,35 \\
\hline \multirow{3}{*}{$\begin{array}{c}\text { EUA - } \\
\text { Pensilvânia }\end{array}$} & $n$ & 3 & 3 & 3 & 3 & 3 & 3 & 3 & 3 & 3 \\
\hline & $\%$ & 100,00 & 100,00 & 100,00 & 100,00 & 100,00 & 100,00 & 100,00 & 100,00 & 100,00 \\
\hline & média & 22,67 & 48,33 & 56,67 & 21,67 & 14,33 & 9,12 & 3,31 & 91,80 & 22,76 \\
\hline \multirow{3}{*}{$\begin{array}{c}\text { EUA - } \\
\text { Tennesse }\end{array}$} & $\mathrm{n}$ & 2 & 2 & 2 & 2 & 2 & 2 & 2 & 2 & 2 \\
\hline & $\%$ & 100,00 & 100,00 & 100,00 & 100,00 & 100,00 & 100,00 & 100,00 & 100,00 & 100,00 \\
\hline & média & 25,50 & 50,00 & 65,00 & 22,00 & 16,00 & 7,33 & 2,57 & 92,55 & 25,06 \\
\hline \multirow{3}{*}{ EUA - Texas } & $\mathrm{n}$ & 13 & 13 & 13 & 13 & 13 & 13 & 13 & 13 & 13 \\
\hline & $\%$ & 100,00 & 100,00 & 100,00 & 100,00 & 100,00 & 100,00 & 100,00 & 100,00 & 100,00 \\
\hline & média & 25,65 & 50,19 & 62,31 & 23,00 & 15,69 & 8,65 & 3,30 & 94,79 & 23,00 \\
\hline \multirow{3}{*}{ EUA - Utah } & $\mathrm{n}$ & 10 & 10 & 10 & 10 & 10 & 10 & 10 & 10 & 10 \\
\hline & $\%$ & 100,00 & 100,00 & 100,00 & 100,00 & 100,00 & 100,00 & 100,00 & 100,00 & 100,00 \\
\hline & média & 26,45 & 49,30 & 62,85 & 22,50 & 15,40 & 8,31 & 3,48 & 97,73 & 23,41 \\
\hline \multirow{3}{*}{ EUA - Virginia } & $n$ & 40 & 40 & 40 & 39 & 40 & 40 & 40 & 40 & 40 \\
\hline & $\%$ & 100,00 & 100,00 & 100,00 & 97,50 & 100,00 & 100,00 & 100,00 & 100,00 & 100,00 \\
\hline & média & 24,85 & 48,29 & 62,15 & 23,37 & 15,51 & 9,16 & 2,89 & 95,67 & 20,92 \\
\hline \multirow{3}{*}{$\begin{array}{c}\text { EUA - Virginia } \\
\text { Ocidental }\end{array}$} & $n$ & 32 & 33 & 32 & 33 & 33 & 29 & 29 & 31 & 30 \\
\hline & $\%$ & 96,97 & 100,00 & 96,97 & 100,00 & 100,00 & 87,88 & 87,88 & 93,94 & 90,91 \\
\hline & média & 26,66 & 50,06 & 61,14 & 22,23 & 18,35 & 8,57 & 6,05 & 91,70 & 24,39 \\
\hline \multirow{6}{*}{$\begin{array}{c}\text { EUA - } \\
\text { Washington }\end{array}$} & $n$ & 1 & 1 & 1 & 1 & 1 & 0 & 0 & $\overline{0}$ & 0 \\
\hline & $\%$ & 100,00 & 100,00 & 100,00 & 100,00 & 100,00 & 0,00 & 0,00 & 0,00 & 0,00 \\
\hline & média & 26,00 & 50,00 & 65,00 & 23,00 & 16,00 & - & 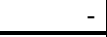 & - & - \\
\hline & $n$ & 2 & 2 & 2 & 2 & 2 & 2 & 2 & 2 & 2 \\
\hline & $\%$ & 100,00 & 100,00 & 100,00 & 100,00 & 100,00 & 100,00 & 100,00 & 100,00 & 100,00 \\
\hline & média & 24,00 & 46,50 & 60,50 & 22,50 & 15,50 & 7,24 & 1,68 & 93,10 & 19,92 \\
\hline
\end{tabular}

